Prepared for the U.S. Department of Energy under Contract DE-AC05-76RL01830

\title{
Characterization of Vadose Zone Sediments Below the TX Tank Farm: Boreholes C3830, C3831, C3832 and RCRA Borehole 299-W10-27
}
RJ Serne
BN Bjornstad
DG Horton
DC Lanigan
CW Lindenmeier

September 2008
MJ Lindberg

RE Clayton

VL LeGore

RD Orr

IV Kutnyakov
SR Baum

KN Geiszler

MM Valenta

TS Vickerman

r




\title{
DISCLAIMER
}

This report was prepared as an account of work sponsored by an agency of the United States Government. Neither the United States Government nor any agency thereof, nor Battelle Memorial Institute, nor any of their employees, makes any warranty, express or implied, or assumes any legal liability or responsibility for the accuracy, completeness, or usefulness of any information, apparatus, product, or process disclosed, or represents that its use would not infringe privately owned rights. Reference herein to any specific commercial product, process, or service by trade name, trademark, manufacturer, or otherwise does not necessarily constitute or imply its endorsement, recommendation, or favoring by the United States Government or any agency thereof, or Battelle Memorial Institute. The views and opinions of authors expressed herein do not necessarily state or reflect those of the United States Government or any agency thereof.

\author{
PACIFIC NORTHWEST NATIONAL LABORATORY \\ operated by \\ BATTELLE \\ for the \\ UNITED STATES DEPARTMENT OF ENERGY \\ under Contract DE-AC05-76RL01830
}

Printed in the United States of America
Available to DOE and DOE contractors from the Office of Scientific and Technical Information,
P.O. Box 62, Oak Ridge, TN 37831-0062;
ph: (865) 576-8401
fax: (865) 576-5728
email: reports@adonis.osti.gov

\author{
Available to the public from the National Technical Information Service, \\ U.S. Department of Commerce, 5285 Port Royal Rd., Springfield, VA 22161 \\ ph: (800) 553-6847 \\ fax: $(703) 605-6900$ \\ email: orders@ntis.fedworld.gov \\ online ordering: http://www.ntis.gov/ordering.htm
}

This document was printed on recycled paper. 
PNNL-14594, Rev. 1

\section{Characterization of Vadose Zone Sediments Below the TX Tank Farm: Boreholes C3830, C3831, and C3832 and RCRA Borehole 299-W10-27}
R. J. Serne
M. J. Lindberg
S. R. Baum
B. N. Bjornstad
R. E. Clayton
K. N. Geiszler
D.G. Horton
V. L. LeGore
M. M. Valenta
D. C. Lanigan
R. D. Orr
T. S. Vickerman
C. W. Lindenmeier
I. V. Kutnyakov

September 2008

Prepared for CH2M HILL Hanford Group, Inc. and the U.S. Department of Energy

under Contract DE-AC05-76RL01830

Pacific Northwest National Laboratory

Richland, Washington 99352 


\section{Executive Summary}

This report was revised in September 2008 to remove acid-extractable sodium data from Tables 4.8, 4.28,4.43, and 4.59. The sodium data was removed due to potential contamination introduced during the acid extraction process. The rest of the text remains unchanged from the original report issued in April 2004.

The overall goal of the Tank Farm Vadose Zone Project, led by CH2M HILL Hanford Group, Inc., is to define risks from past and future single-shell tank farm activities at Hanford. To meet this goal, CH2M HILL Hanford Group, Inc. tasked scientists from Pacific Northwest National Laboratory to perform detailed analyses on vadose zone sediments from within Waste Management Area (WMA) T-TX-TY. This report is the first of two reports written to present the results of these analyses. Specifically, this report contains all the geologic, geochemical, and selected physical characterization data collected on vadose zone sediment recovered from boreholes C3830, C3831, and C3832 in the TX Tank Farm, and from borehole 299-W-10-27 installed northeast of the TY Tank Farm.

Sediments from borehole 299-W-10-27 were considered to be background uncontaminated sediments against which to compare contaminated sediments for the TX characterization effort. This report also presents our interpretation of the data in the context of sediment types, the vertical extent of contamination, the migration potential of the contaminants, and the likely source of the contamination in the vadose zone and groundwater below the TX Tank Farm. The information presented in this report supports the T-TX-TY Waste Management Area field investigation report ${ }^{\text {(a) }}$ in preparation by CH2M HILL Hanford Group, Inc.

Sediment samples from the boreholes were analyzed and characterized in the laboratory for the following parameters: moisture content, gamma-emitting radionuclides, one-to-one water extracts (which provide soil $\mathrm{pH}$, electrical conductivity, cation, trace metal, and anion data), total carbon and inorganic carbon content, and $8 \mathrm{M}$ nitric acid extracts (which provide a measure of the total leachable sediment content of contaminants). Two key radiocontaminants, technetium-99 and uranium-238, along with other trace metals were determined in acid and water extracts by inductively coupled plasma mass spectrometry.

Overall, our analyses showed that common ion exchange is a key mechanism that influences the distribution of contaminants within that portion of the vadose zone affected by tank liquor. Past characterization at WMA BBX-BY did not show significant indications of caustic alteration of the sediment mineralogy or porosity, but did show slightly elevated $\mathrm{pH}$ values between the depths of 79 and $141 \mathrm{feet}(\mathrm{ft})$ below ground surface (bgs). At WMA S-SX, some indication of mineral alteration was found directly below tank SX-108, and elevated $\mathrm{pH}$ zones were found in the vadose zone sediments at two boreholes near SX-108 and SX-109 tanks. Unlike the vadose zone sediments at the SX and BX Tank Farms, we did not observe significant indications of caustic alteration of the sediment mineralogy or porosity, or significant zones of elevated $\mathrm{pH}$ values in samples from the three boreholes (C3830, C3831, and C3832) at WMA T-TX-TY.

Sediments from the three TX tank farm boreholes show that sodium-, nitrate-, and sulfate-dominated fluids are present below tanks TX-104, TX-105, and TX-107 and have formed three salt plumes. The fluids are more dilute than tank fluids observed below tanks at the SX and BX Tank Farms. Most of the chemical data for contaminants intercepted by boreholes C3831 and C3832 suggest that fluid leaked from Tank TX-107 and may have percolated deeper into the sediments and traveled southwest to C3832.

(a) Field Investigation Report for Waste Management Areas T and TX-TY, by FJ Anderson (CH2M HILL Hanford Group, Inc., Richland, Washington), under preparation. 
However, more uranium is present in the sediments and water extracts at C3832. This confounds the hypothesis that TX-107 is the sole source of fluids that were intercepted by both boreholes. Therefore, we hypothesize that a small-volume leak with elevated uranium also occurred from TX-104. Borehole C3830 suggests another small-volume leak occurred from TX-105.

The conceptual model of the geology between core samples is based on our interpretation of the geophysical log and blow-count data. Three primary stratigraphic units were encountered in each of the three boreholes: 1) backfill material, 2) the Hanford formation, and 3) the Cold Creek unit. At C3830, we infer that there are four thin fine-grained layers in the Hanford formation $\mathrm{H} 2$ stratigraphic unit. At C3831, we infer that there are at least eight fine-grained layers in the $\mathrm{H} 2$ unit. Also at C3831, a clastic dike was observed within the Hanford formation $\mathrm{H} 2$ unit at about $60 \mathrm{ft}$ bgs. Contamination at this borehole starts at the depth where the clastic dike was intercepted, suggesting that the dike may represent a preferred pathway for fluids that leaked from Tank TX-107. There are at least eight thin, fine-grained interbeds in the Hanford formation $\mathrm{H} 2$ unit at C3832. These thin fine-grained lenses within sands of the Hanford formation $\mathrm{H} 2$ unit may impact the flow of leaked fluids and affect irregular and horizontal flow.

The boreholes could not penetrate below the calcium-carbonate-rich strata of the Cold Creek lower subunit $\left(\mathrm{CCU}_{1}\right)$ (refusal was met at about $115 \mathrm{ft}$ bgs at all three holes); therefore, we did not identify the maximum vertical penetration of the tank-related plumes. However, the more elevated portions of the electrical conductivity (EC) profile at C3830 currently reside at the bottom of a fine-grained thin lens in the Hanford formation $\mathrm{H} 2$ unit at $87 \mathrm{ft}$ bgs. At C3831, we lack good sample coverage in the fine-grained $\mathrm{CCU}_{\mathrm{u}}$ subunit and the caliche unit to ascertain whether the salt plume has significantly descended into the Cold Creek unit sediments. There is strong indication that at C3832 the saline plume has descended into the Cold Creek unit to the bottom of the borehole. The EC, nitrate, and technetium-99 profiles versus depth do not identify the leading edge of the plume with any certainty. The profiles do collectively suggest that the deepest penetration of tank-related fluids is found in C3832 and that the plume has reached the caliche material in the Cold Creek lower subunit at least to a depth of $116 \mathrm{ft}$ bgs.

Despite the evidence that elevated EC values may be present in all three boreholes to their depth of refusal, the concentrations are not large. For example, the maximum dilution-corrected $\mathrm{EC}$ at $\mathrm{C} 3832$ is 6.27 milliSieverts per centimeter $(\mathrm{mS} / \mathrm{cm})$. At C3830, the maximum is $12.5 \mathrm{mS} / \mathrm{cm}$, and at $\mathrm{C} 3831$ the maximum is $43.3 \mathrm{mS} / \mathrm{cm}$. The leaks near the SX108-109 and BX-102 tanks had peak vadose zone porewater concentrations that were much more concentrated waste fluids: 524 to 1774 and $77 \mathrm{mS} / \mathrm{cm}$, respectively.

The water potential data from 299-W10-27's Hanford formation H2 unit, the unit where most of the contaminants reside in the TX boreholes, are consistent with a draining profile. The inventories as a function of depth of potential contaminants of concern (nitrate, technetium-99, uranium, and chromium) are provided. In addition, in situ desorption $\mathrm{K}_{\mathrm{d}}$ (distribution coefficient or sorption partition coefficient) values for these potential contaminants are provided based on the difference between acid and water extracts of the contaminated sediments. For conservative modeling purposes, we recommend using $\mathrm{K}_{\mathrm{d}}$ values of 0 milliliters/gram (mL/g) for nitrate and technetium-99, a value of $1 \mathrm{~mL} / \mathrm{g}$ for uranium, and $10 \mathrm{~mL} / \mathrm{g}$ for chromium to represent the entire vadose zone profile from the bottoms of the tanks to the water table. These conservative $\mathrm{K}_{\mathrm{d}}$ values, along with the provided inventories in the vadose zone sediments obtained from the three boreholes, can be used in long-term risk projections that rely on estimates of water recharge and vadose zone and aquifer transport calculations. 
In summary, there is no current similarity between the present or past groundwater contamination and current porewater compositions from the contaminated borehole sediments. Therefore, we cannot link the contaminants in the groundwater, currently or during the era of contaminant introduction into the vadose zone, to the porewaters currently in the borehole sediments, which are known to be derived from liquids that leaked from tank TX-107. Thus, we cannot identify the TX tank leaks as the sole source of the contamination present in the groundwater in the past or currently. 


\section{Acknowledgments}

This work was conducted as part of the Tank Farm Vadose Zone Project led by CH2M HILL Hanford Group, Inc. in support of the U.S. Department of Energy's Office of River Protection. The authors wish to thank Frank J. Anderson, Anthony J. Knepp, Fredrick M. Mann, David A. Myers, Thomas E. Jones, and Harold A. Sydnor with CH2M HILL Hanford Group, Inc. for their support of this work, and Raziuddin Khaleel with Fluor Government Group, Marcus I. Wood with Fluor Hanford, Inc. and Dwayne Crumpler with Columbia Energy \& Environmental Services, Inc. for their technical review. We would also like to express our gratitude to Robert Yasek with the Department of Energy Office of River Protection.

We would especially like to thank Kent D. Reynolds (Duratek Federal Services, Inc.) for his efforts in selecting depths to sample and executing the field work that obtained the samples, and Victoria Johnson and Kevin A. Lindsey (Kennedy/Jenks Consultants, Inc.) for their insights on the geologic nature of the materials penetrated by the boreholes.

Finally, we would like to thank Chris Brown and Bill Deutsch for their technical review of this document, and Alexandra Amonette (Technical Writer's Ink Corp.) and David Payson and Rose Urbina (both with Pacific Northwest National Laboratory) for their editorial and document production support. 


\section{Acronyms and Abbreviations}

\begin{tabular}{|c|c|}
\hline ASA & American Society of Agronomy \\
\hline ASTM & American Society for Testing and Materials \\
\hline bgs & below ground surface \\
\hline $\mathrm{CCU}_{\mathrm{u}}$ & Cold Creek unit, upper subunit \\
\hline $\mathrm{CCU}_{1}$ & Cold Creek unit, lower subunit; also referred to as Cold Creek caliche subunit \\
\hline $\mathrm{EC}$ & electrical conductivity \\
\hline EPA & United States Environmental Protection Agency \\
\hline FIR & Field Investigation Report \\
\hline $\mathrm{g}$ & gram \\
\hline GEA & gamma energy analysis \\
\hline GPS & global positioning system \\
\hline $\mathrm{H} 1$ & Hanford formation $-\mathrm{H} 1$ unit \\
\hline $\mathrm{H} 2$ & Hanford formation $-\mathrm{H} 2$ unit \\
\hline HPGe & High-Purity Germanium \\
\hline IC & ion chromatography \\
\hline $\mathrm{ICP}$ & $\begin{array}{l}\text { inductively coupled plasma (also called inductively coupled plasma - optical emission } \\
\text { spectroscopy }\end{array}$ \\
\hline ICP-MS & inductively coupled plasma mass spectrometer \\
\hline ICP-OES & inductively coupled plasma - optical emission spectroscopy \\
\hline $\mathrm{K}_{\mathrm{d}}$ & distribution coefficient, or sorption partition coefficient, in units of $\mathrm{mL} / \mathrm{g}$ \\
\hline KUT & potassium, uranium, and thorium \\
\hline $\mathrm{MPa}$ & megapascal \\
\hline $\mathrm{mS}$ & millisiemen \\
\hline MSL & mean sea level \\
\hline PNNL & Pacific Northwest National Laboratory \\
\hline QA & quality assurance \\
\hline QC & quality control \\
\hline RCRA & Resource Conservation and Recovery Act \\
\hline REDOX & $\begin{array}{l}\text { Reduction Oxidation Process (the second fuel reprocessing process used at the Hanford Site } \\
\text { to extract plutonium) }\end{array}$ \\
\hline $\mathrm{R}_{\mathrm{tf}}$ & Ringold Formation - Member of Taylor Flat \\
\hline $\mathrm{R}_{\mathrm{wi}}$ & Ringold Formation - Member of Wooded Island \\
\hline SEM & scanning electron microscope \\
\hline TEM & transmission electron microscopy \\
\hline UFA & unsaturated flow apparatus (ultracentrifuge for squeezing porewater out of sediment) \\
\hline UV & ultraviolet \\
\hline WMA & Waste Management Area \\
\hline $\mathrm{wt} \%$ & weight percent \\
\hline XRD & $\mathrm{X}$-ray diffraction \\
\hline $\mathrm{XRF}$ & X-ray fluorescence (a technique to measure total element mass in solids) \\
\hline
\end{tabular}




\section{Contents}

Executive Summary ................................................................................................ ii

Acknowledgments............................................................................................... v

Acronyms and Abbreviations ..................................................................................... vii

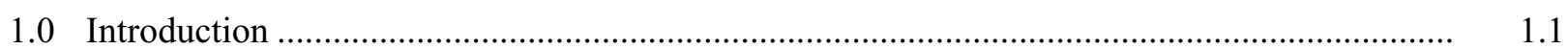

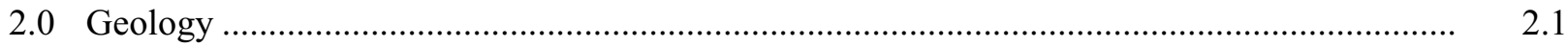

$2.1 \quad$ Regional Geologic Setting................................................................................... 2.1

2.1.1 Ringold Formation ................................................................................... 2.3

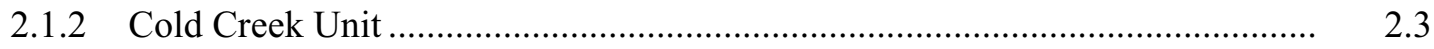

2.1.3 Hanford Formation......................................................................................... 2.3

2.2 Geologic Setting of the TX Tank Farm..................................................................... 2.6

2.2.1 Stratigraphy and Lithology …………………………………………….... 2.6

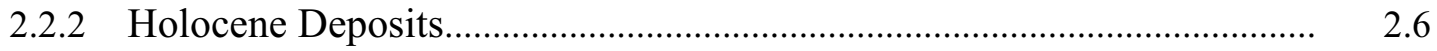

2.2.3 Clastic Dikes ....................................................................................... 2.16

2.3 Summary of Recent Characterization Activities Within TX Tank Farm ...................... 2.17

2.3.1 Hydrogeologic Characterization .................................................................... 2.17

2.3.2 Hydrogeology of Borehole 299-W10-27 (Background Well) ........................... 2.21

2.3.3 Borehole C3830 (TX-105) ....................................................................... 2.29

2.3.4 Borehole C3831 (TX-107) ……………………………………………….. 2.36

2.3.5 Hydrogeology of Borehole C3832 (TX-104) ................................................. 2.45

$2.4 \quad$ Discussion of Increased Moisture Zones.......................................................................... 2.53

3.0 Geochemical Methods and Materials ……………………............................................. 3.1

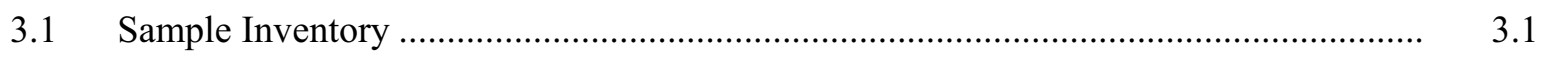

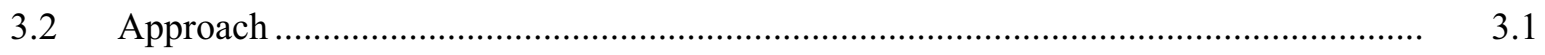

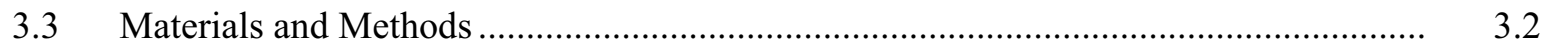

3.3.1 Moisture Content..................................................................................... 3.2

3.3.2 1:1 Sediment:Water Extracts …………………………………………..... 3.2

3.3.3 Radioanalytical Analysis................................................................................ 3.4

3.3.4 Carbon Content of Sediment............................................................................ 3.4

3.3.5 $\quad 8$ M Nitric Acid Extract …………………………………………………..... 3.5

3.3.6 Elemental Analysis .................................................................................... 3.5

3.3.7 Particle Size Distribution .......................................................................... 3.6

3.3.8 Particle Density …………………………………………………….... 3.6

3.3.9 Water Potential (Suction) Measurements.............................................................. 3.6

4.0 Results and Discussion ...............................................................................................

4.1 Vadose Zone Sediment from Borehole 299-W10-27 ............................................... 4.1

4.1.1 Moisture Content...................................................................................... 4.1

4.1.2 1:1 Sediment:Water Extracts for Borehole 299-W10-27 ................................. 4.1

4.1.3 8 M Nitric Acid-Extractable Amounts of Selected Elements ............................ $\quad 4.16$

4.1.4 Bulk Chemical Composition of Sediment from 299-W10-27 .......................... 4.16 
4.1.5 Radionuclide Content in Vadose Zone Sediment from 299-W10-27

4.1.6 Total Carbon, Calcium Carbonate, and Organic Carbon Content of Vadose Zone Sediment from Borehole 299-W10-27 ....................................... 4.17

4.1.7 Particle Size Measurements on Vadose Zone Sediment ................................... 4.17

4.1.8 Matric Suction Potential Measurements ......................................................... 4.33

4.2 Vadose Zone Sediment from Borehole C3830 ........................................................ 4.40

4.2.1 Moisture Content................................................................................. $\quad 4.40$

4.2.2 1:1 Sediment:Water Extracts for Borehole C3830 ...................................... 4.42

4.2.3 Derivation of Vadose Zone Porewater Chemical Composition ....................... 4.48

4.2.4 8 M Nitric Acid-Extractable Amounts of Selected Elements in C3830

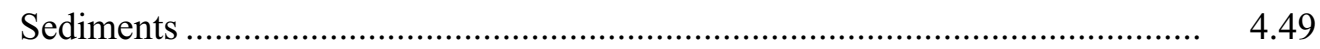

4.2.5 Radionuclide Content in Vadose Zone Sediment from C3830 ........................ 4.73

4.2.6 Total Carbon, Calcium Carbonate, and Organic Carbon Content of Vadose Zone Sediment from Borehole C3830 ........................................... 4.73

4.3 Vadose Zone Sediment from Borehole C3831 …................................................. 4.76

4.3.1 Moisture Content................................................................................ 4.76

4.3.2 1:1 Sediment:Water Extracts for Borehole C3831 ........................................ 4.77

4.3.3 Derivation of Vadose Zone Porewater Chemical Composition ........................ 4.93

4.3.4 8 M Nitric Acid-Extractable Amounts of Selected Elements in C3831

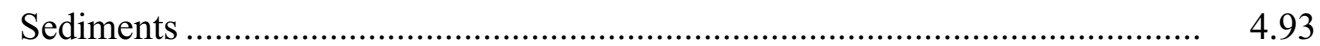

4.3.5 Radionuclide Content in Vadose Zone Sediment from C3831 ........................ 4.109

4.3.6 Total Carbon, Calcium Carbonate, and Organic Carbon Content of Vadose Zone Sediment from Borehole C3831 .............................................. 4.109

$4.4 \quad$ Vadose Zone Sediment from Borehole C3832 …...................................................... 4.116

4.4.1 Moisture Content............................................................................... 4.116

4.4.2 1:1 Sediment:Water Extracts for Borehole C3832 ........................................ 4.116

4.4.3 Derivation of Vadose Zone Porewater Chemical Composition ........................ 4.133

4.4.4 8 M Nitric Acid-Extractable Amounts of Selected Elements in C3832 Sediments ..................................................................................... 4.142

4.4.5 Radionuclide Content in Vadose Zone Sediment from C3832 ........................ 4.151

4.4.6 Total Carbon, Calcium Carbonate, and Organic Carbon Content of Vadose Zone Sediment from Borehole C3832 ........................................... 4.151

5.0 Groundwater Status Below the TX Tank Farm ........................................................ 5.1

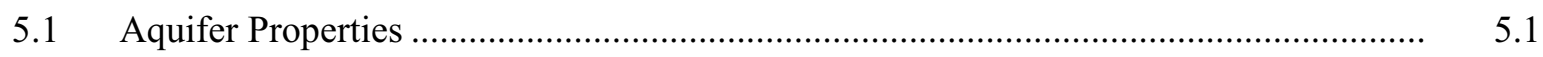

5.2 Existing Groundwater Contamination ................................................................ 5.11

5.2.1 Extent of Contamination - Depth Distribution .......................................... $\quad 5.12$

5.2.2 Geographical Distribution of Contaminants ................................................. 5.25

5.3 Comparison of Groundwater Vadose Zone Porewater Compositions at the

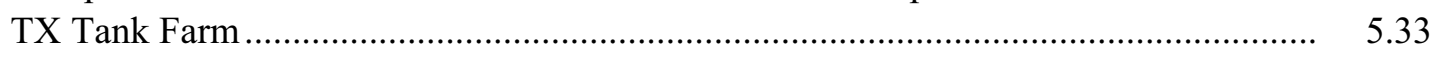

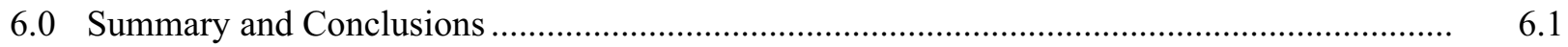

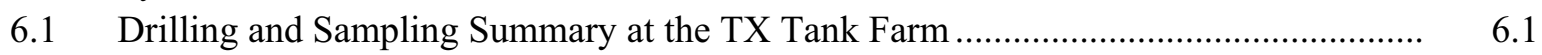

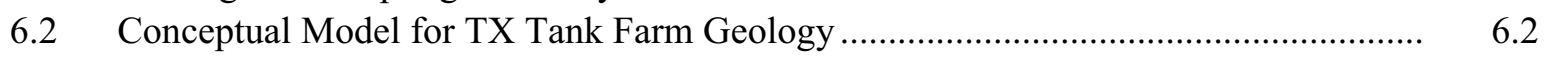

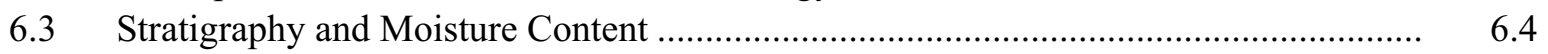

6.4 Vertical Extent of Contamination............................................................................... 6.5 
6.5 Detailed Characterization to Elucidate Controlling Geochemical Processes ................ 6.7

6.6 Estimates of Contaminant Inventory and Sorption-Desorption Values ........................ 6.11

6.7 Other Geochemical Characterization Observations .............................................. 6.18

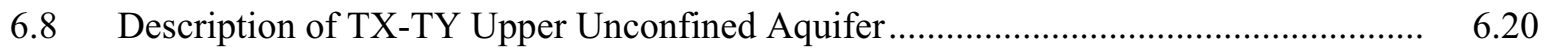

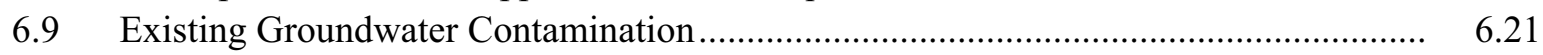

6.10 Complexities in Groundwater Data (Vertical and Temporal Variations)...................... 6.23

6.11 Vadose Zone Porewater and Groundwater Chemical Ratio Comparisons .................... $\quad 6.24$

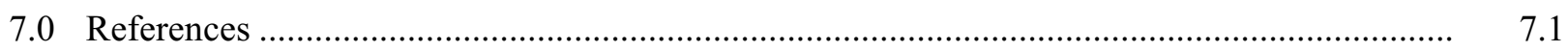

Appendix A.1-A.4 Core Photographs ............................................................................... A.1

Appendix B.1-B.3 Geologic Description of Cores Obtained During Opening in Laboratory ......... B. 1 


\section{Figures}

2.1 Stratigraphic Cross Section of the Vadose Zone Within the Central Pasco Basin ...............

2.2 Thickness and Distribution of Cataclysmic Flood Deposits (i.e., Hanford Formation)

Within the Central Pasco Basin

Generalized, Composite Stratigraphy for the Late-Cenozoic Sediments Overlying the

Selected Borehole Location Map for the TX Tank Farm

2.8 Sediment Textural Classification [Modified After Folk (1968) and Wentworth (1922)].....

2.9 Summary Hydrogeologic Log for Borehole 299-W10-27.

2.10 Hanford Formation H2 Unit in Borehole 299-W10-27.

2.14 Fine to Medium Sand Recovered from the Hanford Formation H2 Unit in Borehole C3830

2.15 Interbedded Sand and Silty Sand Within the Hanford Formation H2 Unit ...

Soft-Sediment Deformation Within the Hanford Formation H2 Unit ....

4.1 $\mathrm{pH}$ and Electrical Conductivity Calculated (from sediment:water extracts) for

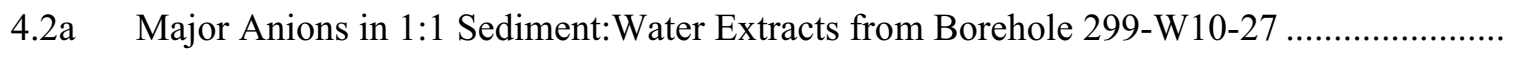

4.2b 1:1 Sediment:Water Extract Carbonate and Alkalinity (as Carbonate) Contents from Borehole 299-W10-27....

4.2c 1:1 Sediment:Water Extract Small Organic Molecule Contents from Borehole 299-W10-27.

4.3 Cations in 1:1 Sediment:Water Extracts for Borehole 299-W10-27 
4.4 Aluminum, Barium, Iron, Manganese, Silicon, and Zinc in 1:1 Sediment:Water

Extracts from Borehole 299-W10-27.

4.14

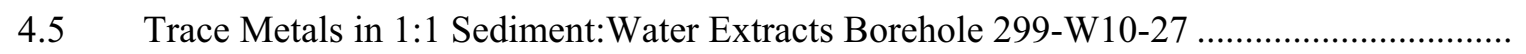

4.6 Acid-Extractable Concentrations of Major Cations in Borehole 299-W10-27 Sediment.....

4.15

4.21

4.7 Acid-Extractable Concentrations of Aluminum, Barium, Iron, Manganese, Silicon and Zinc from Borehole 299-W10-27 Sediments ....

4.8 Concentration of Uranium-238, Chromium, and Molybdenum in 299-W10-27 Borehole

Sediment that is Acid-Extractable ....

4.9 Comparison between Acid-and Water-Extractable Sulfate and Phosphate in Vadose

Zone Sediments from Borehole 299-W10-27

4.10 Particle Size Distribution of Hanford Formation H2 Unit Subsamples from

Borehole 299-W10-27 ....

4.11 Particle Size Distribution of Cold Creek Unit Subsamples from Borehole 299-W10-27.....

4.12 Particle Size Distribution of Ringold Formation Subsamples-Borehole 299-W10-27 .........

4.13 Matric Water Potential Measured by Filter Paper Technique on Core Samples from

Borehole 299-W10-27

4.14 Borehole 3830 Sediment:Water Extract pH and Calculated Porewater Electrical

Conductivity, Sodium, and Nitrate

4.15 Borehole C3830 Water-Extractable Anions ( $\mu \mathrm{g} / \mathrm{g}$ dry sediment).....

4.34

4.35

4.36

4.39

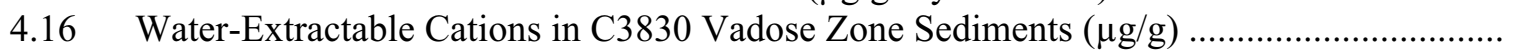

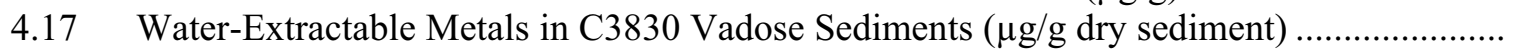

4.18 Distribution of Mobile Metals in Water Extracts of C3830 Vadose Zone Sediments ...........

4.19 Derived Porewater Composition of Major Cations in C3830 Vadose Zone Sediments .......

4.20

4.21

Derived Porewater Anion Composition in C3830 Vadose Zone Sediments ....

Derived Porewater Composition for Selected Metals in C3830 Vadose Zone Sediments ...

4.22

4.23

Derived Porewater Composition of Mobile Metals in C3830 Vadose Zone Sediments.......

Acid-Extractable Cations in C3830 Vadose Zone Sediments ( $\mu \mathrm{g} / \mathrm{g}$ dry sediment)...

4.24

4.25

Acid-Extractable Metals in C3830 Vadose Zone Sediments ( $\mu \mathrm{g} / \mathrm{g}$ dry sediment)....

Acid-Extractable Trace Metals in C3830 Vadose Zone Sediments (units vary)....

4.26 Water- versus Acid-Extractable Sulfate and Phosphate in C3830 Vadose Zone

Sediments.

4.27 Comparison of Lab Gamma Energy Analysis (GEA) and Field Log for Natural

Gamma Emitters

4.28

Lab and Field Data for Common Gamma Emitters in C3830 Vadose Zone Sediments.......

4.29

Borehole C3831 Sediment-to-Water Extract pH and Calculated Porewater EC,

Sodium, and Nitrate

4.30

C3831 Borehole Water-Extractable Anions ( $\mu \mathrm{g} / \mathrm{g}$ dry sediment).

4.31

4.32

4.33

4.34

4.35

4.36

4.37

Water-Extractable Cations in Borehole C3831 Vadose Zone Sediments $(\mu \mathrm{g} / \mathrm{g})$......

Water-Extractable Metals in Borehole C3831 Vadose Sediments ( $\mu \mathrm{g} / \mathrm{g}$ dry sediment).....

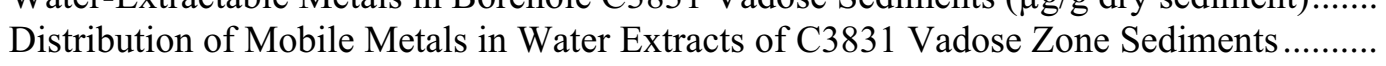

Derived Porewater Composition of Major Cations in C3831 Vadose Zone Sediments ........

Derived Porewater Anion Composition in C3831 Vadose Zone Sediments

Derived Porewater Composition for Selected Metals in C3831 Vadose Zone Sediments ...

Calculated Porewater Composition of Mobile Metals in C3831 Vadose Zone Sediments ..

4.38

Acid-Extractable Cations in C3831 Vadose Zone Sediments ( $\mu \mathrm{g} / \mathrm{g}$ dry sediment).

4.39

Acid-Extractable Metals in C3831 Vadose Zone Sediments ( $\mu \mathrm{g} / \mathrm{g}$ dry sediment).....

4.40

Acid-Extractable Trace Metals in C3831 Vadose Zone Sediments (units vary) .....

4.41

Water versus Acid-Extractable Sulfate and Phosphate in C3831 Vadose Zone

Sediments.

4.42 Comparison of Lab Gamma Energy Analysis (GEA) and Field Log for Natural

Gamma Emitters 
4.43 Lab and Field Data for Common Gamma Emitters in C3831 Vadose Zone Sediments.......

4.44 Lab Data for Cobalt-60 Extracts of C3831 Vadose Zone Sediments

Borehole 3832 Sediment-to-Water Extract pH and Calculated Porewater EC, Sodium, and Nitrate.....

4.46 C3832 Borehole Water-Extractable Anions ( $\mu \mathrm{g} / \mathrm{g}$ dry sediment)....

4.48 Water-Extractable Metals in C3832 Borehole Vadose Sediments ( $\mu \mathrm{g} / \mathrm{g}$ dry sediment)........

4.49 Distribution of Mobile Metals in Water Extracts of C3832 Vadose Zone Sediments ...........

4.50 Calculated Porewater Composition of Major Cations in C3832 Vadose Zone Sediments...

4.51 Calculated Porewater Anion Composition in C3832 Vadose Zone Sediments ...................

4.52 Calculated Porewater Composition for Selected Metals in C3832 Vadose Zone

Sediments.

4.132

4.138

4.139

4.53 Calculated Porewater Composition of Mobile Metals in C3832 Vadose Zone Sediments ..

4.54 Acid-Extractable Cations in C3832 Vadose Zone Sediments ( $\mu \mathrm{g} / \mathrm{g}$ dry sediment)..............

4.55 Acid-Extractable Metals in C3832 Vadose Zone Sediments ( $\mu \mathrm{g} / \mathrm{g}$ dry sediment) ................

4.56 Acid-Extractable Trace Metals in C3832 Vadose Zone Sediments (units vary) ..................

4.57 Water- versus Acid-Extractable Phosphate in C3832 Vadose Zone Sediments

4.58 Comparison of Lab Gamma Energy Analysis (GEA) and Field Log for Natural Gamma Emitters

4.59 Lab and Field Data for Common Gamma Emitters in C3832 Vadose Zone Sediments......

5.1 Well Location Map for WMA TX-TY 


\section{Tables}

2.1 Stratigraphic Terminology for the Vadose Zone Beneath the TX Tank Farm..................... 2.8

2.2 Four Borings Used for Recent Geochemical Characterization in the Vicinity of TX Tank Farm

2.3 Core Samples Collected from 299-W10-27 for Paleomagnetic Analysis - May 16, 2001 ...

2.4 Splitspoon Samples Selected for Physical and Chemical Characterization from the Vadose Zone in 299-W10-27

2.5 Gravimetric Moisture Content Measured in Core Samples. Units are Wt\% Water.............

4.1 Gravimetric Moisture Content of Core Samples Obtained Between 50 and $125 \mathrm{ft}$ bgs in Borehole 299-W10-27

4.3 Anion Composition of Water Extracts of 299-W10-27 Sediment (units $\mu \mathrm{g} / \mathrm{g}$ dry sediment).....

4.4 Small Molecular Weight Organic Content of Water Extracts of 299-W10-27 Sediment (units $\mu \mathrm{g} / \mathrm{g}$ dry sediment).

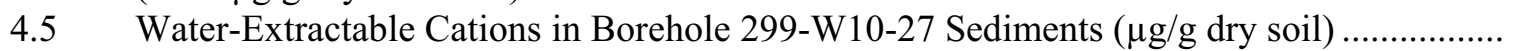

4.6 Other Water-Extractable Cations in Borehole 299-W10-27 Sediments ( $\mu \mathrm{g} / \mathrm{g}$ dry soil) .......

4.7 Water-Extractable Mobile Trace Contaminants in Borehole 299-W10-27 Sediments ( $\mu$ g per gram dry soil)

4.8 Acid-Extractable Major Cations in Borehole 299-W10-27 Sediments ( $\mu \mathrm{g} / \mathrm{g}$ dry sediment).....

4.9 Acid-Extractable Content for Major Constituents in Borehole 299-W10-27 Sediments ( $\mu \mathrm{g} / \mathrm{g}$ dry sediment).....

4.10 Acid-Extractable Mobile Trace Metals in Borehole 299-W10-27 Sediments ( $\mu \mathrm{g}$ per gram dry sediment)

4.11 Total Chemical Composition of Borehole 299-W10-27 Sediments (as Weight \% Oxides)

4.12 Trace Element Composition of Borehole 299-W10-27 Sediments (as $\mu \mathrm{g}$ per g dry sediment)

4.13 Total, Inorganic, and Organic Carbon Content of Vadose Zone Sediments from Borehole 299-W10-27.

4.14 Wet Sieve Particle Size Results for Borehole 299-W10-27 Sediments...

4.16 Matric Potential as Measured by Filter Paper Method for Borehole 299-W10-27

Core Sediments

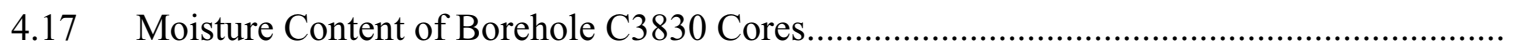

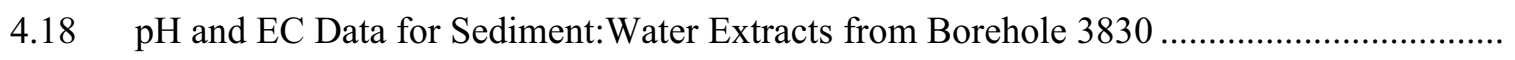

4.19 Water-Extractable Anions in Borehole C3830 Vadose Zone Sediments ( $\mu \mathrm{g} / \mathrm{g}$ dry sediment).....

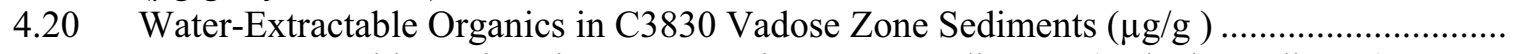

4.21 Water-Extractable Cations in C3830 Vadose Zone Sediments ( $\mu \mathrm{g} / \mathrm{g}$ dry sediment).............

4.22 Water-Extractable Concentrations of Other Metals in C3830 Vadose Zone Sediments ( $\mu \mathrm{g} / \mathrm{g}$ dry sediment).....

4.23 Water-Extractable Concentrations of Mobile Metals in C3830 Vadose Sediments $(\mu \mathrm{g} / \mathrm{g}$ dry sediment). 
4.24 Calculated Porewater Cation Concentrations in C3830 Vadose Zone Sediments....

4.25 Calculated Porewater Anion Concentrations in C3830 Vadose Zone Sediments.

4.26 Calculated Porewater Concentrations of Selected Constituents in C3830 Vadose

Zone Sediments.

4.27 Calculated Porewater Concentrations of Potentially Mobile Constituents in C3830

Vadose Sediments.

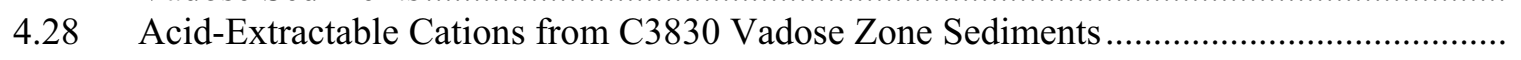

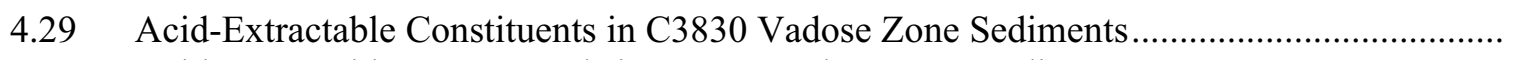

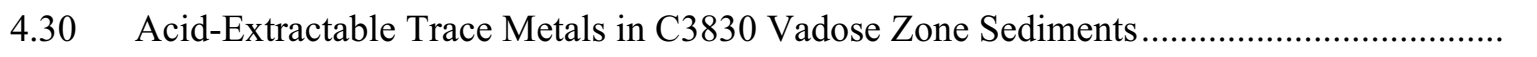

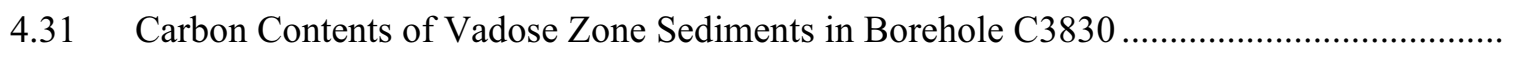

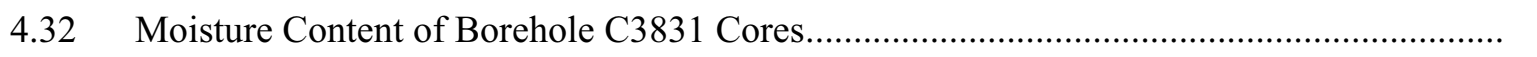

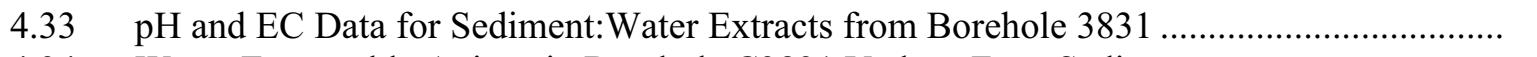

4.34 Water-Extractable Anions in Borehole C3831 Vadose Zone Sediments.............................

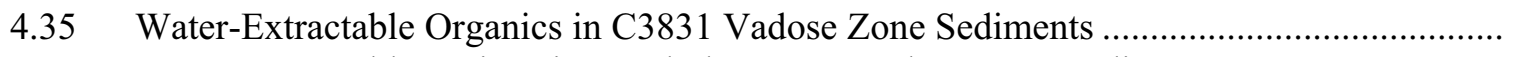

4.36 Water-Extractable Cations in Borehole C3831 Vadose Zone Sediments .............................

4.37 Water-Extractable Concentrations of Other Metals in C3831 Vadose Zone Sediments ......

4.38 Water-Extractable Concentrations of Mobile Metals in C3831 Vadose Sediments ..............

4.39 Calculated Porewater Cation Concentrations in C3831 Vadose Zone Sediments ................

4.40 Calculated Porewater Anion Concentrations in C3831 Vadose Zone Sediments..................

4.41 Calculated Porewater Concentrations of Selected Constituents in C3831 Vadose Zone Sediments.

4.58 Calculated Porewater Concentrations of Potentially Mobile Constituents in C3832

Vadose Sediments.

4.61 Acid-Extractable Trace Metals in C3832 Vadose Zone Sediments. 
5.3 Results from Tracer-Dilution and Tracer-Pumpback Tests in Wells at WMA TX-TY ........

5.4 Hydraulic Properties from Slug and Constant Rate Pumping Tests and Calculated Darcy Velocities at New Wells at WMA TX-TY....

5.5 Initial and Final Specific Conductance Values from Four Routine Quarterly Sampling Events During Calendar Year 2003 at 299-W14-13 ....

5.6 Nitrate Concentration in Groundwater Collected During Drilling of New RCRA Wells ....

5.7 Average Concentration of Mobile Contaminants in Groundwater in the Vicinity of the TX-TY WMA for the Time Period August 2002 to August 2003 ...

5.8 Contaminant Concentration Ratios for Vadose Zone Porewater from Borehole C3831 as a Function of Depth and From Tank TX-107 Fluids

5.9 Contaminant Concentration Ratios for Groundwater Samples from Well 299-W14-12 ......

5.10 Contaminant Concentration Ratios for Vadose Zone Porewater from Borehole C3831 as a Function of Depth and From Tank TX-107 Fluids

5.11 Contaminant Concentration Ratios for Groundwater Samples from Well 299-W14-12 ......

6.1 Stratigraphic Units and Contacts ( $\mathrm{ft}$ bgs)....

6.2 Maximum Pore Water Concentrations in Sediments from Hanford and Cold Creek Units....

6.3 Inventory Estimates for Potential Contaminants of Concern in Borehole C3830 Sediments.

6.4 Inventory Estimates for Potential Contaminants of Concern in Borehole C3831 Sediments.

6.5 Inventory Estimates for Potential Contaminants of Concern in Borehole C3832 Sediments. 


\subsection{Introduction}

The overall goals of the of the Tank Farm Vadose Zone Project, led by CH2M HILL Hanford Group, Inc., are 1) to define risks from past and future single-shell tank farm activities, 2) to identify and evaluate the efficacy of interim measures, and 3) to aid, via collection of geotechnical information and data, the future decisions that must be made by the Department of Energy (DOE) regarding the near-term operations, future waste retrieval, and final closure activities for the single-shell tank Waste Management Areas (WMA). For a more complete discussion of the goals of the Tank Farm Vadose Zone Project, see the overall work plan, Phase 1 RCRA Facility Investigation/Corrective Measures Study Work Plan for the Single-Shell Tank Waste Management Areas (DOE 1999). Specific details on the rationale for activities performed at WMA T-TX-TY are found in Crumpler (2002). To meet these goals, CH2M HILL Hanford Group, Inc. tasked scientists from Pacific Northwest National Laboratory (PNNL) to perform detailed analyses of vadose zone sediment, both uncontaminated and contaminated, in the vicinity of WMA T-TX-TY.

Specifically, this report contains all the geologic, geochemical, and selected physical characterization data collected on vadose zone sediment recovered from two sources: 1) a new RCRA monitoring well, 299-W10-27, located just outside the WMA fenceline to the east and in the northern quadrant of tank TY tank farm, and 2) three boreholes that extended from ground surface down to refusal in the Cold Creek unit caliche. Drill locations for the boreholes were selected to evaluate possible leaks from tanks 241TX-105 (C3830), TX-107 (C3831), and TX-104 (C3832), respectively. Location maps are presented in Section 2. We have also provided our interpretation of the data in the context of determining the appropriate hydrogeologic model, the vertical extent of contamination, the migration potential of the contaminants that still reside in the vadose zone, and the correspondence of the contaminant distribution in the borehole sediment to groundwater plumes in the aquifer proximate and downgradient from the TX tank farm.

This report is the first of two reports written to present recent data collected on vadose zone sediments, both uncontaminated and contaminated, from within WMA T-TX-TY. The second PNNL report will discuss the characterization of 1) uncontaminated sediment from a Resource Conservation and Recovery Act (RCRA) borehole (299-W11-39) that provides baseline against information from contaminated sediment, and 2) contaminated sediment obtained from two boreholes near tank T-106, a confirmed leaker ( $\sim 115,000$ gallons $)$ in 1973 . The two documents contain preliminary interpretations to identify the distribution of key contaminants within the vadose zone and to determine what their future migration potential could be. The two PNNL reports will be incorporated into Appendix B of the WMA T-TX-TY field investigation report (FIR) (scheduled for publication in 2005).

This document describes the characterization data collected and interpretations assembled by the Applied Geology and Geochemistry Group within the PNNL Environmental Technology Division. Based on a review of all available historical information on tank farm operations and vadose zone gross and spectral gamma monitoring of dry wells around the TX tanks (see Crumpler 2002 and Wood et al. 2001), three areas of interests were identified. The historical data analysis did not uncover any explicit documentation that there were fluid losses at the TX tank farm, which was quite active during the early 1970s during the bismuth phosphate metals waste recovery activity, used to obtain uranium for reuse in 
making fuel. However, vadose zone monitoring data show a uranium plume between tanks TX-101 and TX-105 with the higher concentrations closer to tank TX-105. Therefore, borehole C3830 was drilled to the southwest of Tank TX-105.

The second area of interest is the region between tanks TX-107 and TX-103 where historical vadose zone spectral gamma monitoring data indicate there is cobalt-60 and europium-152/154 in the vadose zone below the tanks. There are about six drywells concentrated in the area between these two tanks but no paper trail was found as to why these holes were drilled. These signs suggest that there was a loss of tank fluids from one of these tanks. Further, tank TX-107 was used for transferring wastes to the $\mathrm{T}$ Evaporator and thus there were very large volumes of fluids moved through this tank. For these reasons, borehole C3831 was drilled to the southwest of tank TX-107 in the region between tanks TX-107/103. The third borehole, C3832, was placed to the southeast of tank TX-104 in the hopes that it would capture the migration of more mobile contaminants in the down dip direction from a tank leak at TX-107 and to evaluate whether there were separate and distinct leaks from TX-107 and TX-104. If the mobile contaminant profile at C3832 differed significantly from the nature of the profile at C3831, two distinct leaks, one from TX-107 and one from TX-104, would be a more plausible explanation. It is also possible that the two leaks might have commingled.

This report is divided into sections that describe the geology, geochemical characterization methods employed, geochemical results and contaminant migration potential, and correlation between the existing vadose zone porewater with current and past groundwater contamination characteristics, as well as summary and conclusions, references, and appendixes with additional geology details and sediment photographs.

English units are used in this report for descriptions and discussions of drilling activities and samples because that is the system of units used by drillers to measure and report depths and well construction details. To convert feet to meters, multiply by 0.3048 ; to convert inches to centimeters, multiply by 2.54 . The metric system is used in this report for all other purposes. 


\subsection{Geology}

The geology of the vadose zone underlying the 241-TX Tank Farm (TX Tank Farm) forms the framework through which contaminants that leaked from the single-shell tanks or their ancillary piping and junction boxes move, and is fundamental to the understanding of migration and distribution of the contamination in the vadose zone. Of particular interest are the interrelationships between the coarser and finer-grained strata, and the degree of contrast in their physical and geochemical properties.

This section presents a discussion of the regional geologic setting and the geology of the TX Tank Farm, followed by a discussion of the geohydrologic characterization methods and background information on four recently completed boreholes sampled for physical and geochemical characterization.

\subsection{Regional Geologic Setting}

The Hanford Site is located within the Columbia Plateau of southeastern Washington State. This broad plain, situated between the Cascade Mountains to the west and the Rocky Mountains to the east, is underlain by a thick sequence of Miocene age tholeiitic basalt flows (the Columbia River Basalt Group). The Columbia River Basalt Group (composed of approximately 50 basalt flows) is more than 3,000-m thick and forms the bedrock beneath southeastern Washington. Sedimentary interbeds are sandwiched between the basalt flows, particularly in the uppermost Saddle Mountains Basalt. These interbeds along with the porous basalt flow tops and flow bottoms form confined aquifers that extend across the Pasco Basin (DOE 1988).

The basalt flows have been folded and faulted creating broad structural and topographic basins, separated by asymmetric anticlinal ridges. Sediments of late Miocene, Pliocene, and Pleistocene age have accumulated up to 520-m thick in some of these basins. The Hanford Site lies within one of the larger of these basins, the Pasco Basin. This basin is partially bisected by the Umtanum-Gable Mountain anticline creating two subordinate synclinal basins. The largest of these is the Cold Creek syncline, which is further subdivided into two basins, the Wye Barricade depression and the Cold Creek depression. The Cold Creek depression underlies the principal waste management areas (200 East and 200 West Areas) of the Hanford Site, including the TX Tank Farm.

The generalized stratigraphy beneath the Hanford Site consists of, in ascending order, the Columbia River Basalt Group, the Ringold Formation, the Cold Creek unit (CCU) (formerly called the PlioPleistocene unit), and the Hanford formation. A geologic cross section showing the stratigraphic relationships of these units in the western Pasco Basin is presented in Figure 2.1. Thin veneers of Holocene alluvium, colluvium, and/or eolian sediments discontinuously overlie these principal geologic units. The regional suprabasalt stratigraphy is described in more detail elsewhere (Lindsey 1995; DOE 1988; DOE 2002a). 


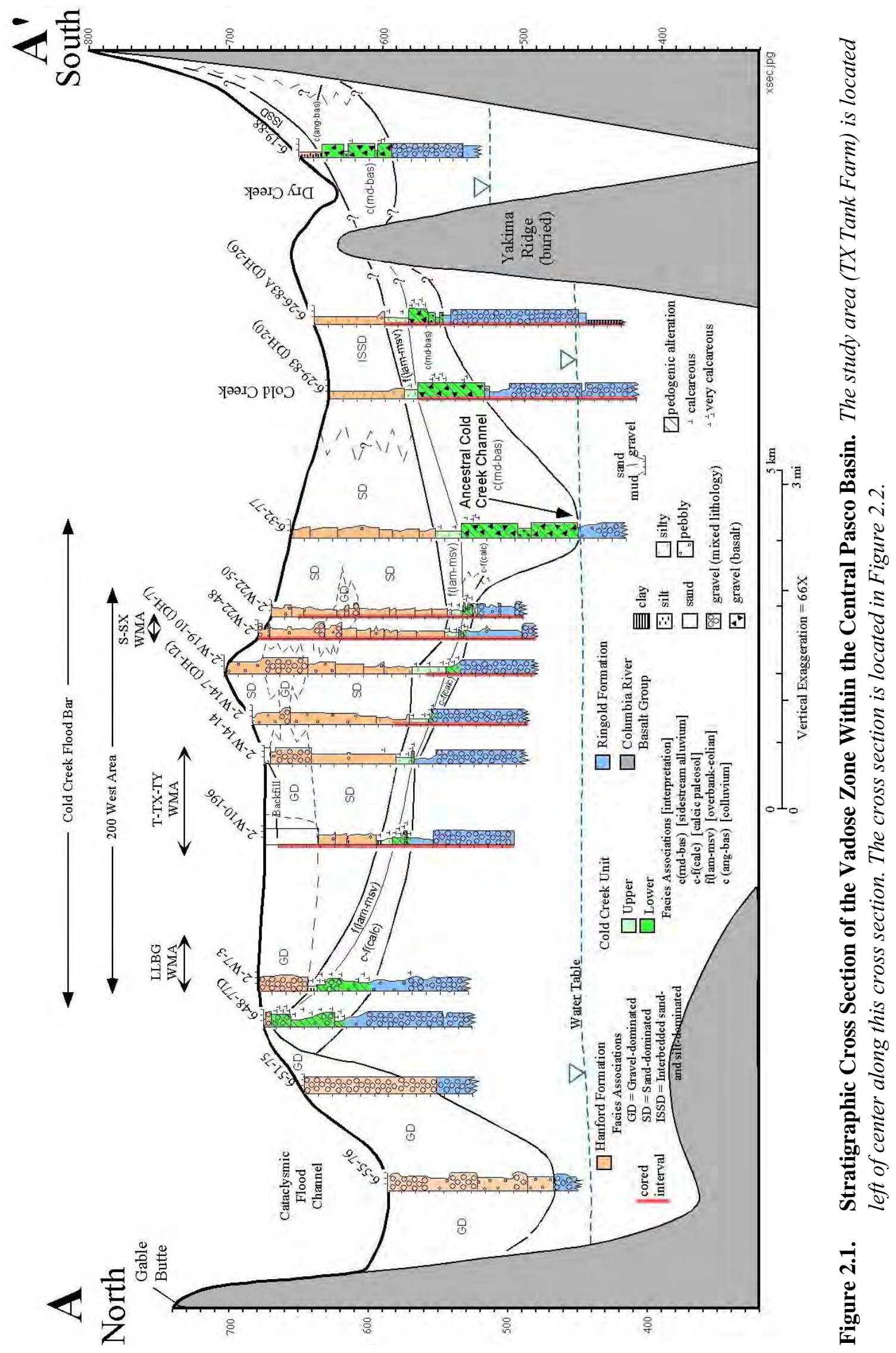




\subsubsection{Ringold Formation}

The Ringold Formation records fluvial-lacustrine deposition associated with the ancestral Columbia River drainage system, following the last eruption of basalt at the Hanford Site about 10.5 million years (m.y.) ago (Tallman et al. 1981; DOE 1988; Lindsey et al. 1994a, Lindsey 1996). Deformation of the Yakima folds, which began in the middle Miocene Epoch, concurrent with the Columbia River basalt volcanism, continued into Ringold Formation time so the centers of downwarped basins received more sediments than the margins. The Ringold Formation is up to $185-\mathrm{m}(600 \mathrm{ft})$ thick in the center of the basin and pinches out against the basin-bounding basalt ridges.

The Ringold Formation consists of semi-indurated clay, silt, fine- to coarse-grained sand, and variably cemented granule to cobble gravel. Ringold Formation sediments have been classified into five sediment facies associations: 1) fluvial gravel, 2) fluvial sand, 3) overbank deposits, 4) lacustrine deposits, and 5) alluvial fan deposits. See Lindsey (1996) and Lindsey et al. (2001) for more detailed descriptions of these facies.

\subsubsection{Cold Creek Unit}

After a period of post-Ringold Formation incision, the eroded surface of the Ringold Formation was locally weathered and/or covered with deposits of the Cold Creek unit (CCU). These deposits consist of fluvial, eolian and/or colluvial deposits, often pedogenically altered (DOE 2002a). The Cold Creek unit includes those deposits formerly referred to as the "Plio-Pleistocene unit" and "pre-Missoula Gravels," as well as the "early Palouse soil" and "caliche layer" within the 200 West Area. The new name, Cold Creek unit, was given to these deposits because recent studies suggest this unit is all of late Pliocene age. The Cold Creek unit is a more appropriate name choice since it is independent of age and geographically better describes the unit, which is generally confined to the boundaries of the Cold Creek syncline within the west central Pasco Basin (DOE 2002a).

Five different facies of the CCU have been differentiated based on grain size, sedimentary structure, sorting, roundness, fabric, and mineralogic composition (DOE 2002a). These facies include: 1) fluvialoverbank and/or eolian, 2) calcic paleosol, 3) mainstream alluvium, 4) colluvium, and 5) sidestream alluvium.

\subsubsection{Hanford Formation}

The Hanford formation is an informal name used within the Pasco Basin to describe Pleistocene catacylsmic flood deposits (Tallman et al. 1979, 1981; DOE 1988, 2002a). Ice Age floods originated from outbursts of glacial Lake Missoula, as well as other ice-dammed lakes (Baker and Bunker 1985), pluvial lake Bonneville (O’Connor 1993), or possible sub-glacial floods (Shaw et al. 1999) associated with the Cordilleran Ice Sheet. The Hanford formation may include some minor fluvial, colluvial, and/or eolian deposits interbedded with flood deposits.

Recently, the possibility of converting the Hanford formation into a formalized stratigraphic unit was investigated (Bjornstad et al. 2002; DOE 2002a). However, the consensus is that the Hanford formation cannot be formalized as a stratigraphic unit at this time, even though it is a mappable unit, for several reasons as specified in the International Stratigraphic Guide (Salvador 1994). These include 1) the Hanford formation, as defined, is based on a common time period and depositional environment, which 
are invalid formalization criteria; 2) the Hanford formation is very diverse lithologically (i.e., facies range from bouldery gravels to silts); geologic formations, as defined in the stratigraphic code, should have similar lithologic properties; and 3) there is lack of complete reference sections with which to define and characterize the Hanford formation. For example, the range of internal variability within the Hanford formation often exceeds that between adjacent stratigraphic units (e.g., CCU and Ringold Formation). Therefore, for the present, the Hanford formation should continue to be used informally to describe cataclysmic flood deposits within the Pasco Basin.

As mentioned above, the Hanford formation consists predominantly of unconsolidated sediments that cover a wide range in grain size, from boulder-size gravel to sand, silty sand, and silt. The sorting ranges from poorly sorted (for gravel facies) to well-sorted (for fine sand to silt facies). Traditionally the Hanford formation has been subdivided into three lithofacies (gravel-, sand-, and silt-dominated), which grade into one another, both vertically and laterally (DOE 1988; Baker et al. 1991; Lindsey et al. 1994a). These lithofacies may interfinger with or grade from gravel-dominated to sand-dominated facies, or sanddominated to silt-dominated facies, but rarely from gravel-dominated to silt-dominated facies.

An interbedded sand- and silt-dominated facies (DOE 2002a) is stratigraphically equivalent to Touchet Beds, which were first formally recognized by R. F. Flint in 1938 (Flint 1938). Beginning in the late 1980 s, these deposits were called by a variety of other informal names, including slackwater facies (Moody 1987; Lindsey et al. 1992b; Connelly et al. 1992a; Last et al. 1989; Smith 1993), silt-dominated facies (Lindsey et al. 1992a, 1994b; Connelly et al. 1992b), silty facies (Lindsey et al. 1994a), and rhythmite facies (Baker et al. 1991). Interbedded sand- and silt-dominated facies occur as sequences of rhythmic, graded beds that range from 0.1 to $1 \mathrm{~m}(0.3$ to $3.3 \mathrm{ft})$ in thickness and are characterized by loose, horizontal- to ripple-laminated, coarse to medium sand, grading up into cohesive fine sand to silt. The silt-sized fractions consist predominantly of quartz, feldspar, and mica (Tallman et al. 1979).

Sand-dominated facies of the Hanford formation (Lindsey et al. 1992a, 1992b, 1994a, 1994b; Connelly et al. 1992a, 1992b) consist of relatively thick ( $\geq 1 \mathrm{~m})$, predominantly horizontally laminated, loose, basalt-rich, fine- to coarse-grained sand, sometimes grading upward into a thinner sequence of ripple-laminated fine sand to silt. The sand-dominated facies have also been referred to as the transitional sand facies (Reidel et al. 1992; Fecht and Weekes 1996) and the plane-laminated sand facies (Baker et al. 1991). Typically, sand-dominated facies average about 50\% mafic rock fragments (i.e., basalt) and 50\% quartz-feldspar (Tallman et al. 1979). This composition gives the Hanford formation its characteristic "salt and pepper" appearance that is frequently noted in drillers' and geologists' logs.

The gravel-dominated facies have been variously named Pasco gravels (Brown 1970; Myers and Price 1979; Tallman et al. 1979, 1981; DOE 1984), Missoula flood gravels (Webster and Crosby 1982), coarse-grained main-channel facies (DOE 1988; Last et al. 1989), coarse-grained flood gravels (Moody 1987; Baker et al. 1991), and gravel-dominated facies (Lindsey et al. 1992a, 1992b, 1994b; Connelly et al. 1992a, 1992b). The gravel-dominated facies of the Hanford formation consist of loose, massive, horizontal and large-scale, planar-tabular cross-bedded, poorly sorted mixtures of gravel, sand, and silt. Gravel clasts in flood gravels generally consist of $50 \%$ to $75 \%$ subangular to subrounded basalt (DOE 2002a).

Below an elevation of approximately $300 \mathrm{~m}(1,000 \mathrm{ft})$ within the Pasco Basin, the Hanford formation unconformably overlies the Cold Creek unit and, where the CCU is eroded, lies directly on the Ringold Formation or Columbia River basalt. Within the central Pasco Basin up to $100 \mathrm{~m}$ of flood deposits 
accumulated along Priest Rapids, Cold Creek and Gable Mountain bars, which developed downstream of constrictions or obstructions in floodwater flow through the basin (Figure 2.2).

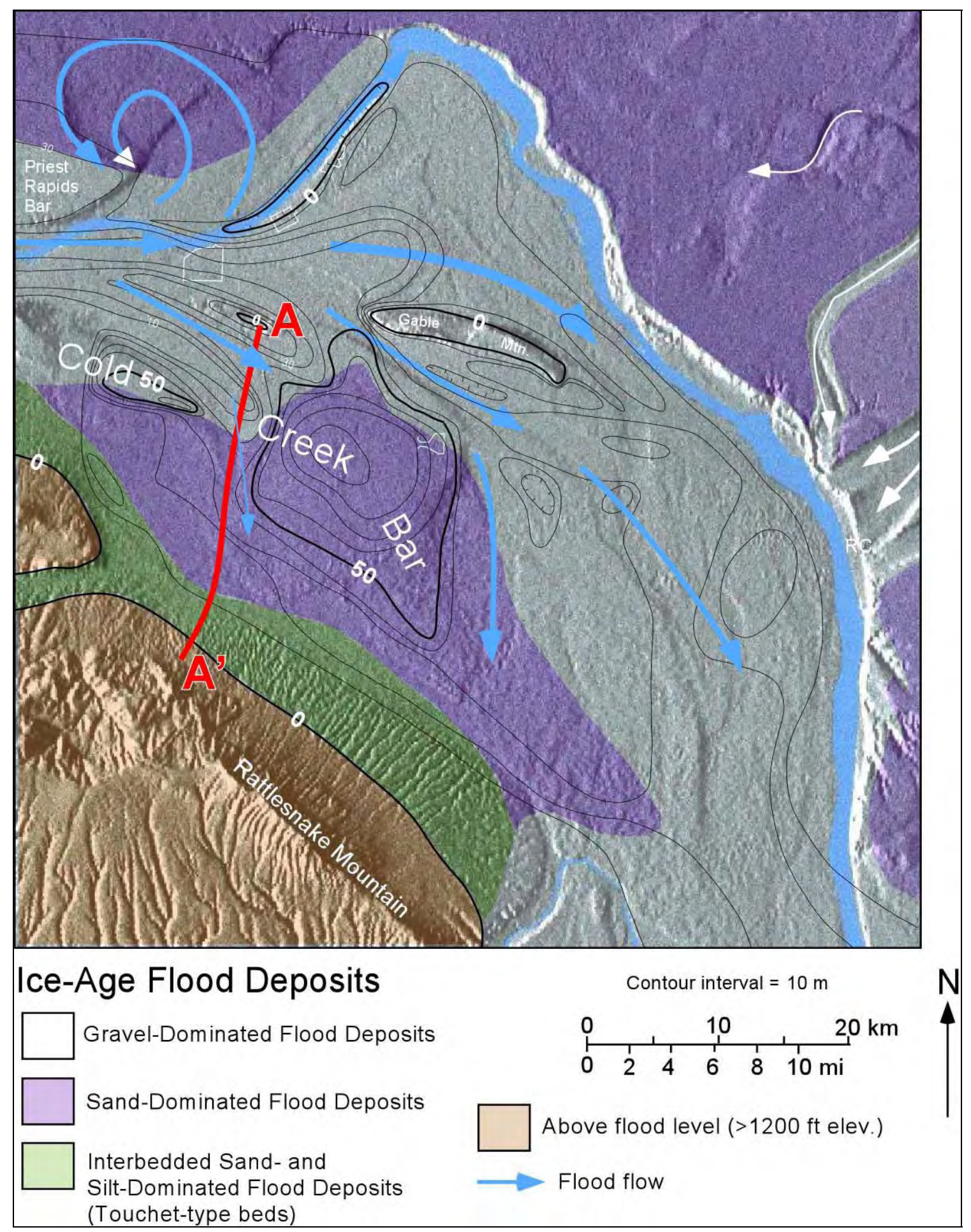

Figure 2.2. Thickness and Distribution of Cataclysmic Flood Deposits (i.e., Hanford formation) Within the Central Pasco Basin. Cross section A-A' is shown in Figure 2.1. 


\subsection{Geologic Setting of the TX Tank Farm}

The geology in the vicinity of the TX Tank Farm has been described in numerous reports (Price and Fecht 1976; Tallman et al. 1979; Last et al. 1989; Bjornstad 1990; Connelly et al. 1992a; DOE-GJO 1997; Lindsey et al. 2001; Wood et al. 2001). A generalized stratigraphic column for the TX Tank Farm is presented in Figure 2.3.

More detailed descriptions of the vadose zone units, the focus of this report, are presented in Table 2.1. The stratigraphic terminology for the post-Ringold-Formation units used in this report may be different than that used in previous reports but reflects the standardized stratigraphic nomenclature recommended by DOE (2002a).

The subsurface geology of the TX Tank Farm is interpreted from dozens of boreholes drilled in the area. A total of 94 dry wells were constructed between 1952 and 1978 to monitor for leaks from the 18 single-shell tanks of the TX Tank Farm (DOE-GJO 1997). These shallow vadose-zone holes served as primary and secondary leak-detection devices. In addition, 9 deeper groundwater monitoring wells are located around the perimeter of the TX Tank Farm. The key boreholes used in this study are shown in Figure 2.4.

\subsubsection{Stratigraphy and Lithology}

Stratigraphic terminology of the vadose zone used in this report is presented in Table 2.1. The tank farm was excavated into the Pleistocene-age Hanford formation and Holocene eolian deposits that mantle the central portion of the Cold Creek flood bar. The depth to groundwater in the vicinity of the TX Tank Farm is about $220 \mathrm{ft}(67 \mathrm{~m})$. Stratigraphic units that make up the vadose-zone units beneath the tank farm include (in descending order) 1) recent deposits, 2) Hanford formation, 3) Cold Creek unit, and 4) Ringold Formation.

Two additional detailed cross sections are presented in Figures 2.5 and 2.6 for the TX Tank Farm. Additional information on the stratigraphic and facies relationships among the different stratigraphic units in the vicinity of the TX Tank Farm is presented in Wood et al. (2001) and Lindsey et al. (2001).

\subsubsection{Holocene Deposits}

Holocene deposits within the TX Tank Farm consist of backfill material emplaced around the tanks. This backfill material is composed of mostly gravel-dominated $\mathrm{H} 1$ unit of the Hanford formation perhaps mixed with eolian materials, which blanketed the area with 1-2 $\mathrm{m}$ of windblown sand and silt prior to construction of TX Tank Farm. Up to $52 \mathrm{ft}$ of the Hanford formation H1 unit, perhaps extending down into the Hanford formation $\mathrm{H} 2$ unit, were removed during construction of the tank farm and stockpiled for placement later around and over the underground storage tanks. The backfill has been described as poorly sorted gravelly sand to sandy gravel (Price and Fecht 1976; Caggiano and Goodwin 1991). Finegrained sand and silt was occasionally placed at and toward the base of the backfill within the TX Tank Farm, apparently to improve traction for construction vehicles (DOE-GJO 1997). 


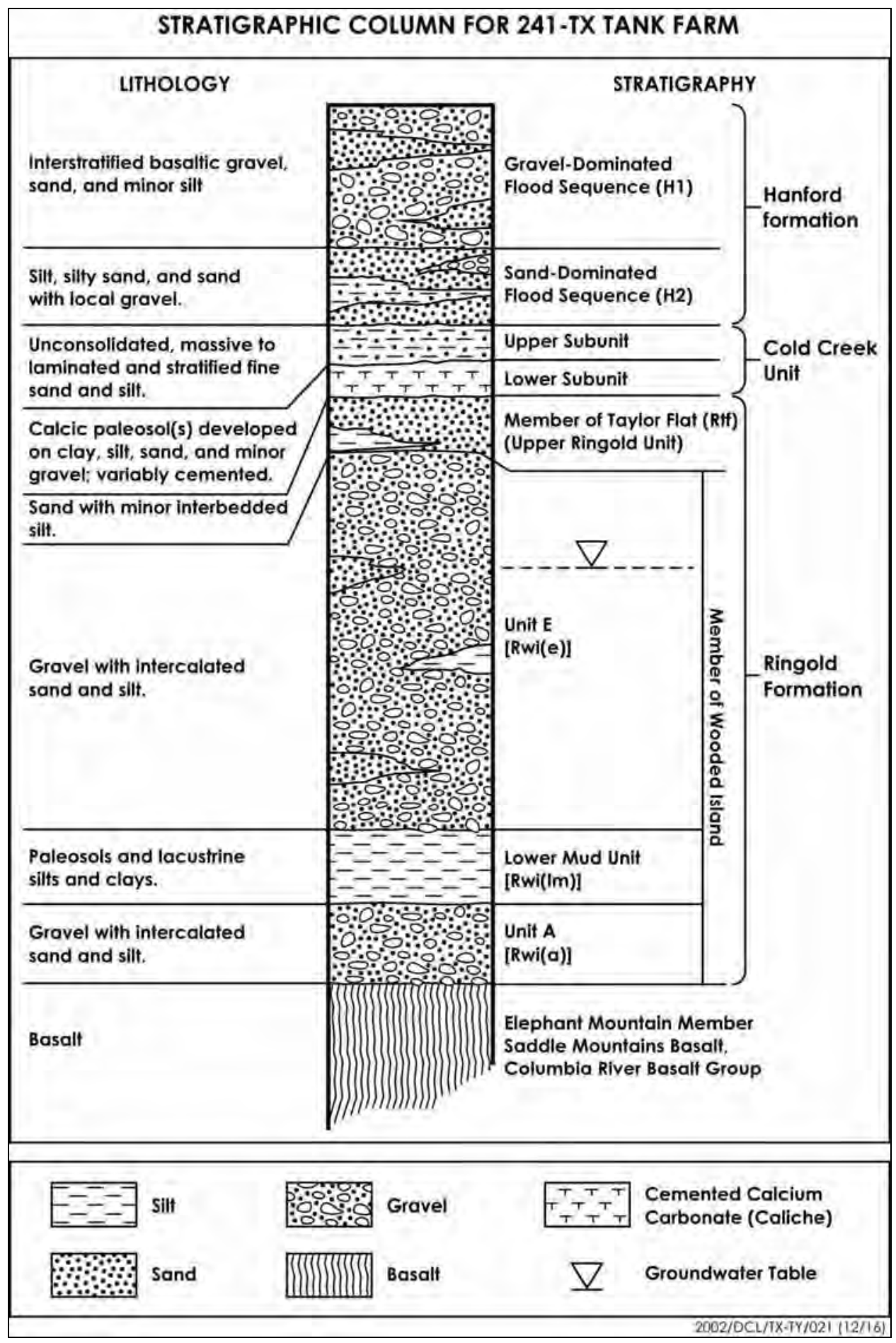

Figure 2.3. Generalized, Composite Stratigraphy for the Late-Cenozoic Sediments Overlying the Columbia River Basalt Group at the TX Tank Farm (Modified After Wood et al. 2001) 
Table 2.1. Stratigraphic Terminology for the Vadose Zone Beneath the TX Tank Farm

\begin{tabular}{|c|c|c|c|c|}
\hline $\begin{array}{c}\text { Stratigraphic } \\
\text { Symbol }\end{array}$ & Formation & $\begin{array}{l}\text { Facies / } \\
\text { Subunit }\end{array}$ & Description & Genesis \\
\hline Backfill & NA & Backfill & $\begin{array}{l}\text { Gravel-dominated sequence consisting of poorly to } \\
\text { moderately sorted cobbles, pebbles, and coarse to } \\
\text { medium sand with some silt derived from coarse-grained } \\
\text { Hanford formation (H1 Unit) excavated around tanks } \\
\text { (Price and Fecht 1976; Wood et al. 2001); occasional } \\
\text { layers of sand to silty sand occur near the base of the } \\
\text { backfill sequence. }\end{array}$ & Anthropogenic \\
\hline $\mathrm{H} 1$ & \multirow{2}{*}{$\begin{array}{l}\text { Hanford } \\
\text { formation }\end{array}$} & $\begin{array}{l}\text { Unit H1 } \\
\text { (Gravel- } \\
\text { dominated } \\
\text { facies } \\
\text { association) }\end{array}$ & $\begin{array}{l}\text { Gravel-dominated flood sequence composed of mostly } \\
\text { poorly sorted, basaltic, sandy gravel to silty sandy } \\
\text { gravel. Equivalent to the upper gravel sequence } \\
\text { discussed by Last et al. (1989), the Qfg documented by } \\
\text { Reidel and Fecht (1994), Hanford Gravel Unit A of } \\
\text { Johnson et al. (1999), coarse-grained sequence (H1 unit) } \\
\text { of Wood et al. (2001) and gravel facies of unit H1 of } \\
\text { Lindsey et al. (2001), and gravel-dominated facies } \\
\text { association of DOE (2002a). The majority of this unit } \\
\text { was excavated out and is missing from beneath TX Tank } \\
\text { Farm. }\end{array}$ & $\begin{array}{l}\text { Cataclysmic } \\
\text { flood deposits } \\
\text { (high-energy) }\end{array}$ \\
\hline $\mathrm{H} 2$ & & $\begin{array}{l}\text { Unit H2 } \\
\text { (Sand- } \\
\text { dominated } \\
\text { facies } \\
\text { association) }\end{array}$ & $\begin{array}{l}\text { Sand-dominated flood sequence composed of mostly } \\
\text { horizontal to tabular cross-bedded sand to gravelly sand. } \\
\text { Some sand beds capped with thin layers of silty sand to } \\
\text { sandy silt. Equivalent to Hanford Sands of Johnson } \\
\text { et al. (1999), Fine-Grained Sequence (H2 unit) of Wood } \\
\text { et al. (2001) and unit H2 of Lindsey et al. (2001), the } \\
\text { sandy sequence of Last et al. (1989) and Lindsey et al. } \\
\text { (1992a), and to Qfs documented by Reidel and Fecht } \\
\text { (1994), and sand-dominated facies association of DOE } \\
\text { (2002a). }\end{array}$ & $\begin{array}{l}\text { Cataclysmic } \\
\text { flood deposits } \\
\text { (moderate } \\
\text { energy) }\end{array}$ \\
\hline $\mathrm{CCU}_{\mathrm{u}}$ & $\begin{array}{c}\text { Cold Creek } \\
\text { unit }\end{array}$ & $\begin{array}{l}\text { Upper } \\
\text { subunit }\end{array}$ & $\begin{array}{l}\text { Silty sequence consisting of interstratified well-sorted } \\
\text { silt and fine sand. Uncemented but may be moderately } \\
\text { to strongly calcareous from detrital } \mathrm{CaCO}_{3} \text {. Equivalent } \\
\text { to the "early Palouse soil" (Brown 1970; Tallman et al. } \\
\text { 1979; DOE 1988; and DOE-GJO 1997) and the Hanford } \\
\text { Formation(?)/Plio-Pleistocene (?) deposits (H/PP) of } \\
\text { Wood et al. (2001). Also equivalent to the upper Plio- } \\
\text { Pleistocene unit in Lindsey et al. (2001) and the fine- } \\
\text { grained, laminated to massive [CCUf (lam-msv)] } \\
\text { lithofacies of the Cold Creek unit DOE (2002a). }\end{array}$ & $\begin{array}{l}\text { Post-Ringold } \\
\text { Fm. eolian } \\
\text { and/or overbank } \\
\text { alluvial deposits }\end{array}$ \\
\hline $\mathrm{CCU}_{1}$ & & $\begin{array}{l}\text { Lower } \\
\text { subunit }\end{array}$ & $\begin{array}{l}\text { Calcic paleosol sequence, consisting of interbedded } \\
\text { layers of pedogenically altered to unaltered gravel, sand, } \\
\text { silt, and/or clay, cemented together with one or more } \\
\text { layers of secondary } \mathrm{CaCO}_{3} \text {, originally referred to as } \\
\text { "caliche" (Brown 1959). Since then the name has } \\
\text { evolved from the Plio-Pleistocene unit (Bjornstad 1984; } \\
\text { DOE 1988; DOE-GJO 1997; Slate 2000), the Plio- } \\
\text { Pleistocene calcrete facies (DOE 1988; Wood et al. } \\
\text { 2001), the lower Plio-Pleistocene unit (Lindsey et al. } \\
\text { 2001), and the coarse- to fine-grained, CaCO } \mathrm{CO}_{3} \text {-cemented } \\
\text { lithofacies [CCUc-f(calc)] of the Cold Creek unit (DOE } \\
\text { 2002a). }\end{array}$ & $\begin{array}{l}\text { Calcic paleosols } \\
\text { developed on } \\
\text { eroded Ringold } \\
\text { Fm. or post- } \\
\text { Ringold Fm. } \\
\text { eolian and/or } \\
\text { fluvial deposits }\end{array}$ \\
\hline
\end{tabular}


Table 2.1. (contd)

\begin{tabular}{|c|c|c|c|c|}
\hline $\begin{array}{c}\text { Stratigraphic } \\
\text { Symbol }\end{array}$ & Formation & $\begin{array}{l}\text { Facies / } \\
\text { Subunit }\end{array}$ & Description & Genesis \\
\hline $\mathrm{R}_{\mathrm{tf}}$ & \multirow{2}{*}{$\begin{array}{l}\text { Ringold } \\
\text { Formation }\end{array}$} & $\begin{array}{l}\text { Member } \\
\text { of Taylor } \\
\text { Flat }\end{array}$ & $\begin{array}{l}\text { Fine-grained Ringold Formation sequence consisting } \\
\text { of interstratified, well bedded fine to coarse sand to silt. } \\
\text { Equivalent to the upper Ringold Formation unit (DOE } \\
\text { 1988). This unit is not present beneath most of the TX } \\
\text { Tank Farm. }\end{array}$ & $\begin{array}{l}\text { Ancestral } \\
\text { Columbia River } \\
\text { System fluvial } \\
\text { channel, crevasse } \\
\text { splay, and } \\
\text { overbank deposits }\end{array}$ \\
\hline $\mathrm{R}_{\mathrm{wi}}$ & & $\begin{array}{l}\text { Member } \\
\text { of } \\
\text { Wooded } \\
\text { Island }\end{array}$ & $\begin{array}{l}\text { Coarse-grained Ringold Formation sequence } \\
\text { consisting of mostly moderately sorted, quartzitic sandy } \\
\text { gravel to silty sandy gravel. Equivalent to middle } \\
\text { Ringold Formation unit (DOE 1988) and the Ringold } \\
\text { Formation Unit E gravels (Wood et al. 2001; } \\
\text { Lindsey et al. 2001). }\end{array}$ & $\begin{array}{l}\text { Ancestral } \\
\text { Columbia River } \\
\text { System braided- } \\
\text { stream deposits }\end{array}$ \\
\hline
\end{tabular}




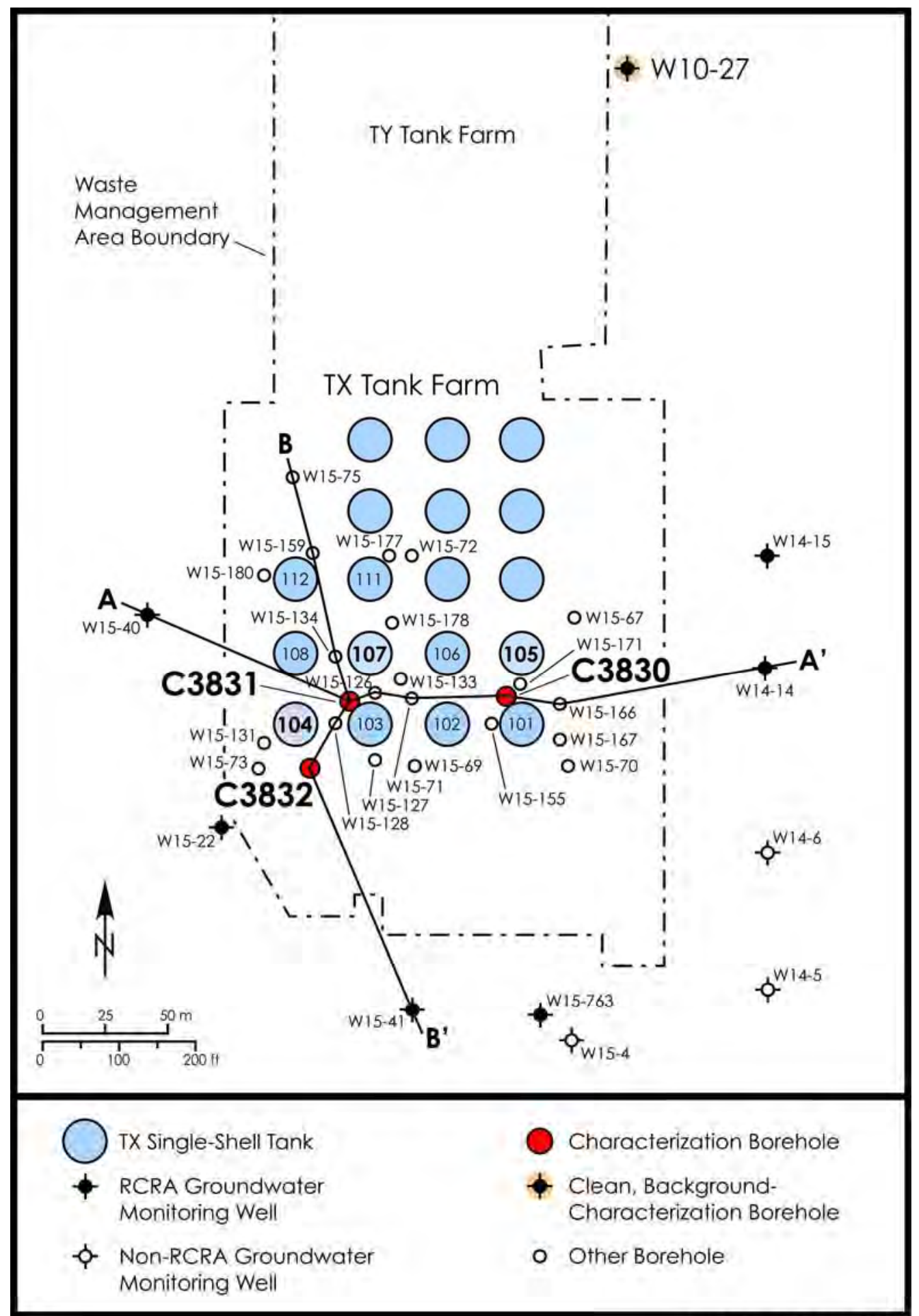

2003/DCL/TX-TY/001 (06/20)

Figure 2.4. Selected Borehole Location Map for the TX Tank Farm. Cross sections $A-A$ ' and $B-B$ ' are shown in Figures 2.5 and 2.6, respectively. 


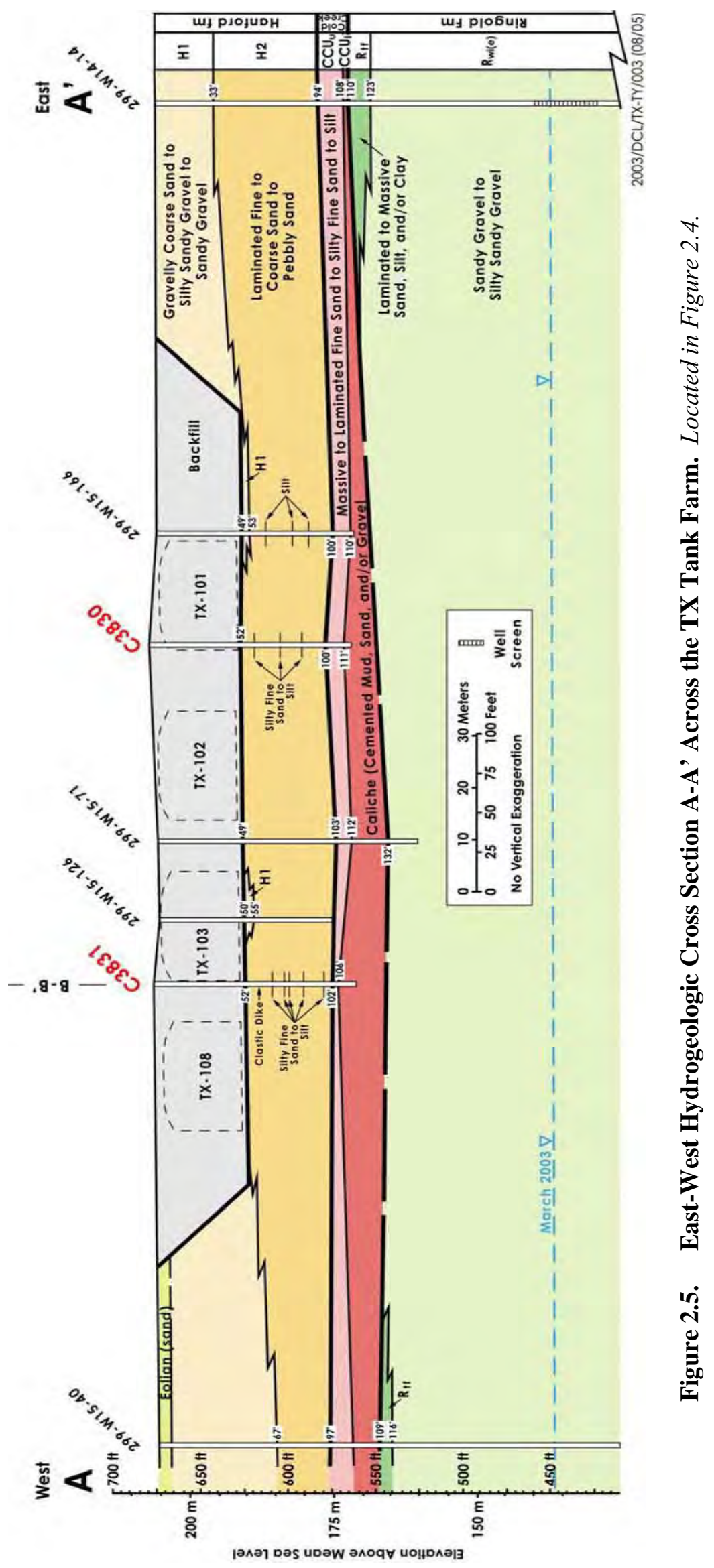




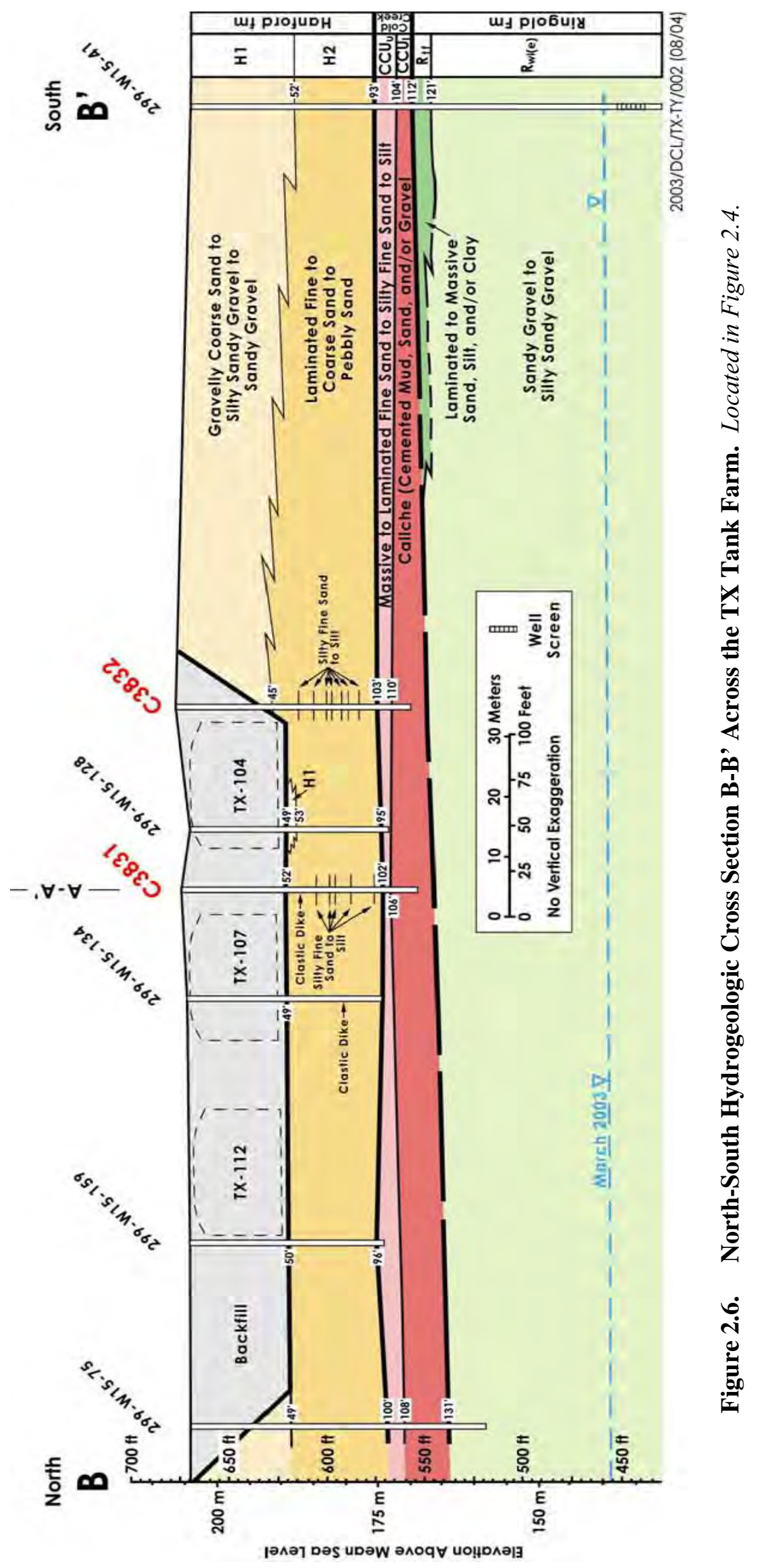




\subsubsection{Hanford Formation}

The Hanford formation in the TX Tank Farm consists of two informal subunits: the H1 and H2 units. The $\mathrm{H} 2$ unit belongs to the sand-dominated facies association, while the $\mathrm{H} 1$ is gravel-dominated (DOE 2002a). However, during excavation of the TX Tank Farm, most of the Hanford formation H1 unit was removed so that only the $\mathrm{H} 2$ unit occurs beneath backfill material emplaced around the tanks.

\subsection{Gravel-Dominated Sequence (H1 Unit).}

The gravel-dominated Hanford formation H1 unit is generally not present in the TX Tank Farm, having been completely removed during tank-farm excavation. However, much of the material used for backfill around the tanks consists of the Hanford formation $\mathrm{H} 1$ unit.

\subsection{Sand-Dominated Sequence (H2 Unit)}

The $\mathrm{H} 2$ unit consists of predominantly sand-dominated facies of the Hanford formation. Cementation is very minor or absent, and total calcium carbonate- $\left(\mathrm{CaCO}_{3}\right)$ content is generally only a few weight percent $(\mathrm{wt} \%)$ or less.

The Hanford formation H2 unit is continuous beneath the TX Tank Farm; the base is well-defined by a change from well-stratified fine-coarse-grained "salt and pepper"-like sands to silt-dominated facies of the upper CCU. There is also usually an increase in total natural gamma activity and moisture along this contact.

\subsubsection{Cold Creek Unit}

The Cold Creek unit lies unconformably on the tilted and truncated Ringold Formation that formed following incision and downcutting by the ancestral Columbia River toward the end of the Pliocene Epoch about 2.5 to 3.4 m.y. ago. Two distinctive subunits of the Cold Creek unit are present beneath the TX Tank Farm and most of the 200 West Area (DOE 2002a). The lower subunit consists of a variably cemented calcic paleosol sequence, while the upper subunit consists of unconsolidated, fine-grained, fluvial-overbank and/or eolian facies sediments.

\subsection{Upper Cold Creek Subunit}

The unconsolidated, silt-rich sediments of the upper Cold Creek unit consist of cohesive, compact, massive to laminated and stratified, fine-grained sand and silt. This brown- to yellow-colored unit is also characterized as micaceous, very well sorted, and moderately to strongly calcareous, with relatively high natural background-gamma activity (DOE 2002a). It is equivalent to the "early Palouse soil" (Brown 1960; Tallman et al. 1979, 1981; Bjornstad 1984, 1990; DOE 1988, Last et al. 1989; Lindsey et al. 1992b, Delaney et al. 1991; DOE-GJO 1997) and the "Hanford Formation (?)/Plio-Pleistocene (?) deposits" of Wood et al. (2001), and most recently identified as the CCUf(lam-msv) facies of the Cold Creek unit by DOE (2002a). Similar to the lower CCU, the upper CCU ranges from 10-15-ft thick and dips to the southwest beneath the TX Tank Farm (Wood et al. 2001).

While the upper CCU was originally interpreted as an eolian deposit, which was derived from the reworking of the underlying Ringold Formation and/or caliche (Brown 1960), more recent investigations indicate this facies may contain other fine-grained deposits besides eolian silt and fine sand (Lindsey et al. 
1994b, 2000; Slate 1996). For example, recent studies in the S-SX WMA (Lindsey et al. 2000;

Serne et al. 2002a) indicate that the upper CCU is composed of mostly intercalated layers of fine sand and silt, with some weakly developed paleosols, which is more characteristic of overbank-type alluvial deposits than eolian deposits (Lindsey et al. 2000). Regardless of its exact stratigraphic relationship and origin, the upper $\mathrm{CCU}$ is a distinctive lithostratigraphic unit has a significant influence on the moisture and contaminant distribution within the vadose zone.

\subsection{Lower Cold Creek Subunit}

Diagnostic features of the lower CCU include 1) advanced induration with pedogenic calcium carbonate, 2) white color, 3) presence of pedogenic structures (e.g., root traces, animal burrows, or soil horizonation), as well as an erratic geophysical log (i.e., natural gamma and neutron moisture) response (DOE 1988; Bjornstad 1990; DOE 2002a).

The upper boundary is usually sharp and distinct in contrast to the lower boundary, which is commonly gradational and overprinted onto the underlying Ringold Formation within the west central Pasco Basin. The upper CCU is easily distinguished from the lower CCU based on a contrast in color, degree of cementation (Figure 2.7), as well as natural-gamma activity. Furthermore, while the upper $\mathrm{CCU}$ may be compact and cohesive, it is generally uncemented, in contrast to the underlying pedogenically altered lower CCU. Even though the upper CCU may contain moderate to high concentrations of calcium carbonate, the carbonate is evenly disseminated as detrital grains. The bulk of the detrital calcium carbonate in the upper CCU is likely derived from the disintegration and mechanical reworking/redeposition of the underlying lower CCU, where discrete calcium carbonate-rich zones developed diagenetically as a result of pedogenesis. The top of the lower CCU is well defined by a coincident significant increase in calcium-carbonate content and decrease in mud content and sorting, accompanied by a sudden drop in total gamma activity (i.e., potassium-40 [K-40]) on borehole geophysical logs (Bjornstad 1990; DOE-GJO 1997). 


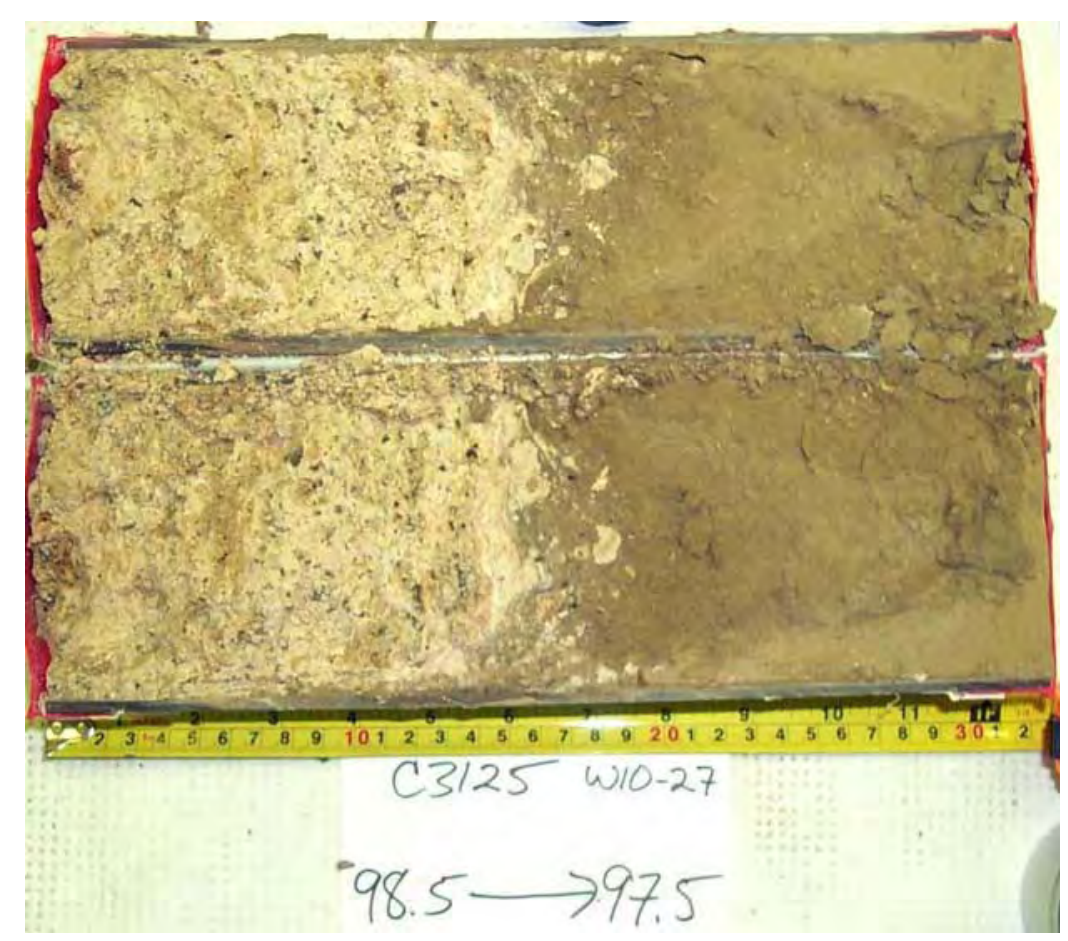

Figure 2.7. Sharp Contact Between the Upper and Lower Cold Creek Subunits in Borehole 299-W10-27. The upper unit consists of unconsolidated, yellowish-brown, silt and fine sand $(\mathrm{mS})$, in sharp contrast to the white, $\mathrm{CaCO}_{3}$-cemented lower unit. The top of this 1-foot core is to the right.

The lower CCU represents a highly weathered paleosurface that developed unconformably on top of the Ringold Formation (Brown 1959, 1960) following a period of downcutting and degradation within the central Pasco Basin. Other names used to describe this facies have included "caliche" (Brown 1959) and "calcrete" (DOE 1988). The lower CCU consist of basaltic to quartzitic gravels, sands, silt, and clay that are cemented with one or more layers of secondary, pedogenic calcium carbonate. The concentration of calcium carbonate within the lower CCU is generally 20 to $30 \mathrm{wt} \%$ but can range from 5 to $70 \mathrm{wt} \%$. The overall thickness of the lower CCU beneath the TX Tank Farm is generally 10 to $20 \mathrm{ft}$ and dips to the southwest about one degree (Wood et al. 2001).

Considerable variability may exist internally within the lower CCU because of natural heterogeneity inherent in soils and soil-forming processes, which vary under different physical, chemical, and biological conditions (e.g., moisture, grain size, aspect, mineralogy, bioturbation, and microbial activity). An additional complicating factor is that the land surface during late Pliocene time was locally undergoing changes via fluvial and eolian activity, which resulted in variable rates of aggradation, degradation, and soil development (Bjornstad 1984, 1990; DOE 1988; Slate 1996, 2000; Wood et al. 2001). The calciumcarbonate overprint is superimposed onto a variety of rock types, including silt, quartz-feldpsar-rich sand and gravel, and locally derived basaltic sand and gravel (Slate 1996, 2000; Lindsey et al. 2000). In the vicinity of the TX Tank Farm, multiple, calcic-rich zones may be separated by relatively noncalcareous, uncemented material indicating some rapid accumulations occurred periodically between periods of soil development. 


\subsubsection{Ringold Formation}

Generally, only fluvial gravel and sand facies are represented in the Ringold Formation vadose zone beneath the TX Tank Farm. A thick sequence of fluvial gravel facies occurs in the vadose zone beneath the TX Tank Farm; these belong to the Ringold Formation member of Wooded Island, Unit E. Fluvial sands, which locally overlie Unit E adjacent to the TX Tank Farm, are considered part of Ringold Formation member of Taylor Flat (Lindsey et al. 2001).

\subsection{Member of Taylor Flat $\left(\mathbf{R}_{\mathrm{tf}}\right)$}

The Ringold Formation member of Taylor Flat within the T-TX-TY WMA (previously referred to as the upper Ringold Formation unit) consists of interstratified, well-bedded fine to coarse sand to silt belonging to a mixture of fluvial-sand and overbank facies associations. Post-Ringold Formation erosion has locally stripped away this member, including all the area beneath TX Tank Farm. In areas adjacent to the TX Tank Farm, up to $10 \mathrm{~m}(30 \mathrm{ft})$ of $\mathrm{R}_{\mathrm{tf}}$ lies sandwiched between the Cold Creek unit and gravels of the Ringold Formation member of Wooded Island (Wood et al. 2001).

Weathering and soil development associated with the overlying Cold Creek unit is often overprinted onto the member of Taylor Flat and/or the member of Wooded Island, Unit E. Because the degree of post-Ringold Formation pedogenesis decreases with depth, the contact with the overlying Cold Creek unit is gradational and generally defined by an upward decrease in natural-gamma activity, increase in calcium carbonate content, and/or decrease in mud content (indicative of more cementation).

\subsection{Member of Wooded Island $\left(\mathbf{R}_{\text {wi }}\right.$, Unit $\left.\mathbf{E}\right)$}

Unit E consists predominantly of the fluvial-gravel facies association with occasional thin beds of the fluvial-sand and/or the overbank facies associations. Unit E within the TX Tank Farm averages about $85 \mathrm{~m}(275 \mathrm{ft})$ thick and the top of the unit dips very gently to the southwest (Wood et al. 2001), consistent with the top of basalt and underlying Ringold Formation units. There exists about $10 \mathrm{ft}(3 \mathrm{~m})$ of structural relief on top of the Ringold Formation Unit E beneath the TX Tank Farm. The water table lies within Unit E gravels at about $220-\mathrm{ft}(67 \mathrm{~m})$ depth, about half-way between basalt bedrock and the ground surface.

\subsubsection{Clastic Dikes}

Clastic dikes are vertical to sub-vertical sedimentary structures that crosscut normal sedimentary layering that are common to ice-age flood deposits, especially in the sand- and silt-dominated facies of the Hanford formation (Black 1979; Fecht and Weekes 1996; Fecht et al. 1999). Some clastic dikes were noted during excavation of the T-TX-TY Tank Farms (Price and Fecht 1976) and clastic dikes were previously reported for two boreholes (299-W15-134 and 299-W15-180) within the TX Tank Farm (Wood et al. 2001). Of the four new boreholes documented here, two of boreholes intersected clastic dikes. One of the boreholes (C3831) intersected a dike in the Hanford formation $\mathrm{H} 2$ unit; the other borehole (299-W10-27) appears to have intersected two dikes, one in the Hanford formation H2 unit and another in the Ringold Formation member of Taylor Flat. These dikes are discussed further in subsequent sections of this report. 
Where clastic dikes intersect the ground surface and are not covered with younger deposits, a feature known as "patterned ground" can be observed (Fecht et al. 1999). Well-developed "patterned ground" exists just south of the 200 West Area. Within the 200 West Area and the T-TX-TY WMA, however, "patterned ground" is scarce due to the many man-made surface disturbances and/or because it is buried under a thin cover of recent eolian sand. Clastic dikes occur in swarms and form four types of networks: 1) regular-shaped polygonal-patterns, 2) irregular-shaped, polygonal-patterns, 3) pre-existing fissure fillings, and 4) random occurrences. Clastic dikes in the T-TX-TY Tank Farm area probably occur randomly in the gravel-dominated facies of the Hanford formation (H1 unit) and as regular-shaped polygons in the finer-grained facies (H2 unit). Regular polygonal networks resemble 4- to 8-sided polygons and typically range from $3 \mathrm{~cm}$ to $1 \mathrm{~m}$ in width, from $2 \mathrm{~m}$ to greater than $20 \mathrm{~m}$ in depth and from 1.5 to $100 \mathrm{~m}$ along strike. Smaller dikelets, sills, and small-scale faults and shears are commonly associated with master dikes that form the polygons.

\subsection{Summary of Recent Characterization Activities Within TX Tank Farm}

Four boreholes were recently drilled and sampled within or near the TX Tank Farm (Table 2.2). Boreholes C3830, C3831, and C3832 were drilled via the closed-end probe method within the TX Tank Farm for the specific purpose of collecting core samples for physical and chemical characterization as outlined in Crumpler (2002). Core samples, 1.25-ft-long by 2.5-in.-diameter, were collected at predetermined intervals within these boreholes (Gardner et al 2002a, 2002b; Reynolds 2003). Drill locations were selected to evaluate possible leaks from tanks 241-TX-105 (C3830), TX-107 (C3831), and TX-104 (C3832), respectively.

In addition, almost continuous, 2.5 -ft-long by 4-in.-diameter splitspoon core samples were collected in well 299-W10-27 (C3125) from 50 to $132 \mathrm{ft}$ bgs. Well 299-W10-27 is a RCRA groundwater monitoring well about $200 \mathrm{~m}$ northeast of the TX Tank Farm (Figure 2.4). Located outside of the tank farm, this well is considered generally free of contamination and was chosen as a background control for the other three boreholes suspected of having possible chemical and radiological contamination. A geologic and hydrologic summary, based on the information collected from these boreholes, is presented below.

\subsubsection{Hydrogeologic Characterization}

Field hydrogeologic characterization for the four new boreholes in Table 2.2 included geophysical logging and penetration resistance measured via hammer blow counts. Additional hydrogeologic characterization was performed in the laboratory, including photography as well as geologic logging and gravimetric moisture measurements on the splitspoon core samples. 


\begin{tabular}{|c|c|c|c|c|c|}
\hline \multicolumn{2}{|c|}{ 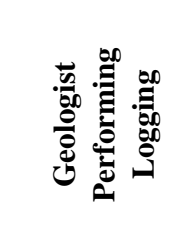 } & 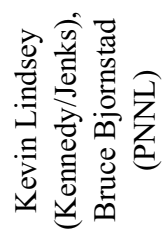 & 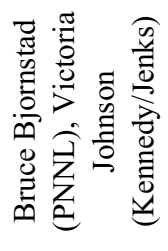 & 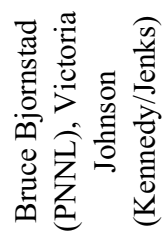 & 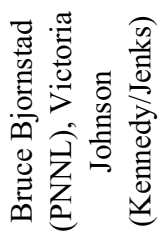 \\
\hline \multicolumn{2}{|c|}{ 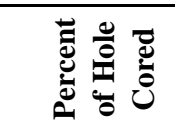 } & 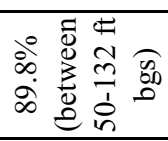 & ڤें & $\stackrel{\text { ेे }}{\text { ते }}$ & ஸें \\
\hline \multicolumn{2}{|c|}{ 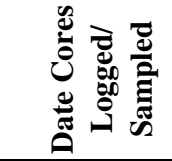 } & 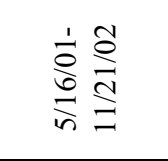 & $\begin{array}{l}\frac{0}{0} \\
\frac{1}{0}\end{array}$ & $\frac{1}{\infty} \frac{\widetilde{d}}{\frac{n}{n}}$ & 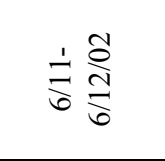 \\
\hline \multicolumn{2}{|c|}{ 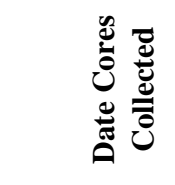 } & 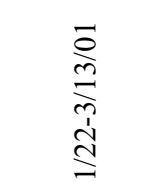 & $\begin{array}{l}\frac{\delta}{2} \\
\frac{n}{\hat{a}} \\
\frac{\hat{1}}{\infty}\end{array}$ & 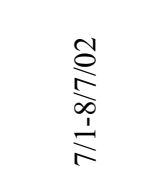 & \begin{tabular}{l} 
है \\
m \\
$\stackrel{1}{1}$ \\
\multirow{n}{n}{}
\end{tabular} \\
\hline \multicolumn{2}{|c|}{ 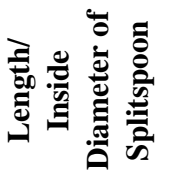 } & $\begin{array}{ll}\vec{Z} & \dot{\Xi} \\
\stackrel{n}{n} & \forall\end{array}$ & $\begin{array}{ll}\rightleftarrows & \dot{ } \\
& \stackrel{n}{\sim}\end{array}$ & 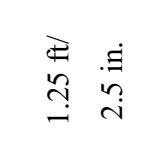 & 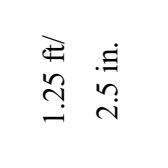 \\
\hline \multicolumn{2}{|c|}{ 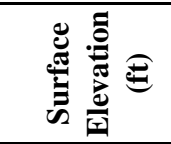 } & 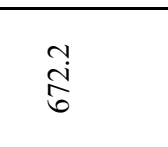 & in & $\begin{array}{l}0 \\
\stackrel{+}{t}\end{array}$ & $\begin{array}{l}0 \\
0 \\
6\end{array}$ \\
\hline \multicolumn{2}{|c|}{ 串 } & $\begin{array}{l}\overline{8} \\
\stackrel{0}{0} \\
\frac{0}{2} \\
0 \\
0\end{array}$ & $\begin{array}{l}0 \\
0 \\
0 \\
0 \\
0 \\
\overline{0} \\
2 \\
2\end{array}$ & $\begin{array}{l}0 \\
0 \\
0 \\
2 \\
0 \\
5 \\
2 \\
2\end{array}$ & $\begin{array}{l}0 \\
0 \\
0 \\
0 \\
0 \\
0 \\
0 \\
0 \\
0\end{array}$ \\
\hline \multicolumn{2}{|r|}{ 苙 } & 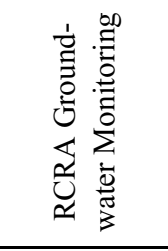 & 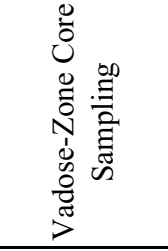 & 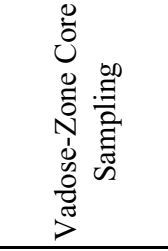 & 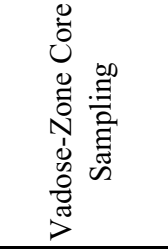 \\
\hline \multicolumn{2}{|c|}{ 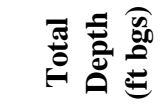 } & $\begin{array}{l}\text { id } \\
\text { id }\end{array}$ & $\stackrel{\infty}{\stackrel{\infty}{\emptyset}}$ & $\stackrel{+}{a}$ & $\stackrel{a}{=}$ \\
\hline \multirow{2}{*}{ 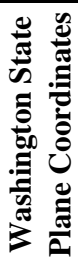 } & 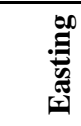 & 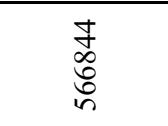 & $\begin{array}{l}2 \\
2 \\
\delta \\
\llcorner \\
n\end{array}$ & 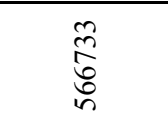 & $\begin{array}{l}\infty \\
\stackrel{\infty}{*} \\
\stackrel{0}{0} \\
n\end{array}$ \\
\hline & 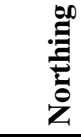 & 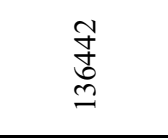 & $\begin{array}{l}\hat{\sigma} \\
0 \\
0\end{array}$ & $\begin{array}{l}\hat{\sigma} \\
0 \\
\end{array}$ & $\frac{n}{n}$ \\
\hline \multicolumn{2}{|c|}{ 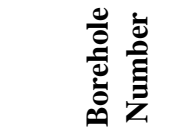 } & $\frac{2}{3}$ & $\begin{array}{l}\infty \\
\infty \\
\infty \\
ల\end{array}$ & $\begin{array}{l}\vec{\infty} \\
\infty \\
\tilde{0}\end{array}$ & $\begin{array}{l}\tilde{D} \\
\infty \\
\tilde{U}\end{array}$ \\
\hline \multicolumn{2}{|c|}{ 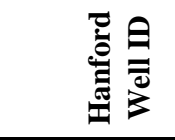 } & $\begin{array}{l}\hat{N} \\
0 \\
\vdots \\
1 \\
\vdots \\
\end{array}$ & & & \\
\hline
\end{tabular}




\subsubsection{Geophysical Logging}

Geophysical logging was performed by Duratek Federal Services on all four boreholes using highpurity germanium (HPGe) spectral gamma and neutron-moisture tools (Lindsey et al. 2001; Gardner et al. 2002a, 2002b; Reynolds 2003). The neutron-moisture log is generally used to depict the relative moisture content within a 20-30-cm (8-12 in.) radius around the borehole. However, the neutron-moisture logging tool was not calibrated for the casing conditions; therefore, absolute moisture values cannot be obtained directly from the neutron-moisture log. Generally, where there is no radiological contamination, the total gamma count rate increases in finer-grained sediments with a corresponding increase in moisture content due the moisture-retaining properties of these sediments.

Processing of the spectral gamma log data allows the identification of gamma-emitting man-made radionuclides (if present) and the naturally occurring radionuclides potassium, uranium, and thorium (KUT) that are present in earth materials (Lindsey et al. 2001). As expected, man-made radiological contaminants were detected in the three boreholes within the TX Tank Farm, while no man-made contaminants were detected outside the tank farm in borehole 299-W10-27. More detailed descriptions of the logging tools and data analysis for 299-W10-27 are presented in Lindsey et al. (2001). Additional information on the geophysical logging results on the three TX boreholes is presented below under the more detailed discussions for these holes, as well as in Gardner et al. (2002a, 2002b) and Reynolds (2003).

\subsubsection{Sample Handling}

Because there was no man-made contamination in 299-W10-27, sample handling was slightly different for this clean background borehole compared to the three boreholes sampled within the TX Tank Farm. Two, 4-in.-diameter, 1-ft-long, lexan-lined core samples were recovered from each 2.5-ft splitspoon in 299-W10-27. Upon recovery, any open spaces in the ends of the liners were stuffed with aluminum foil in the field and plastic end caps were secured with duct tape. The outside of the liner was labeled with the borehole number, depth interval, and an "up" arrow. Alternatively, potentially contaminated core samples from the three TX boreholes were collected in two, 2.5-in.-diameter, 0.5 -ft long stainless-steel liners (Gardner et al. 2002a, 2002b; Reynolds 2003). The liners were sealed with plastic end caps and the outsides labeled with chain-of-custody or borehole ID number, an "up" arrow, and the letter " $A$ " or "B". The letter "A" was assigned to the deeper of the two cores in the core run.

Once received at the PNNL 3720 Building, the core samples were stored in a refrigerator to maintain the sample temperatures between 2 and $4^{\circ} \mathrm{C}$. Core samples from the clean 299-W10-27 borehole were opened, sampled, and described within a non-radiologically controlled PNNL laboratory (Lindsey et al. 2001). Because of the potential for radiological contamination, more precautions were taken processing the cores from within the tank farms.

Within a month of collection, the core samples from the boreholes were sequentially taken to a fume hood for sample processing. Initially, the liner end caps were removed and the contents of the liner were placed in a plastic tray, one plastic tray per liner. Material within the plastic tray was then subsampled for physical and geochemical analysis, photographed, and described geologically. A complete set of core photographs for all four boreholes documented in this report are presented in Appendixes A.1 through A.4. Sediment within the sample liners was extracted using either a hammer to tap out the contents of the

liner or a specially constructed hydraulic "extruder." Efforts were made to keep the sample materials as 
intact as possible. In the coarser-grained facies however, the internal sedimentary structures could generally not be preserved because of the unconsolidated, friable nature of these materials.

\subsubsection{Subsampling and Geologic Description}

Geologic description for the 299-W10-27 borehole was performed in May 2001 by Kevin Lindsey of Kennedy / Jenks Consultants, Inc. Geologic descriptions and logs for this hole are presented in Lindsey et al. (2001).

Moisture samples were collected immediately upon extracting material from the core liner within the three TX Tank Farm boreholes. An attempt was made to sample the finer-grained and/or wetter materials as well as any distinct hydrogeologic units, while at the same time trying to avoid slough and/or other unrepresentative portions. The remaining sample was used for a brief visual geologic evaluation. Geologic logs of the opened cores from the three boreholes (C3830, C3831, and C3832) are presented in Appendixes B.1, B.2, and B.3, respectively.

A visual geologic evaluation of cores from the TX Tank Farm boreholes was conducted in accordance with the following procedures: ASTM D2488 (ASTM 1993), PNL-DO-1 (PNL 1990a), and PNL-D9T81-99-GVL-1 (PNNL 1999). Throughout the subsampling and geologic evaluation activities, the PNNL geologist made continual visual observations regarding the mineralogy, structure, grain-size distribution (and sorting), maximum particle size, grain-shape (e.g., roundness), color, moisture, consolidation, and reaction to dilute hydrochloric acid $[\mathrm{HCl}]$ (used to test for the presence of calcium carbonate). Particular attention was given to visually estimate the percentage (by weight) of gravel, sand, and mud (silt+clay), and to visually classify the samples based on the modified Folk (1968)-Wentworth (1922) classification scheme historically used at the Hanford Site. This sediment classification scheme uses a ternary diagram to categorize the sediment into one of 19 textural classes based on the relative proportions of gravel, sand, and mud (Figure 2.8).

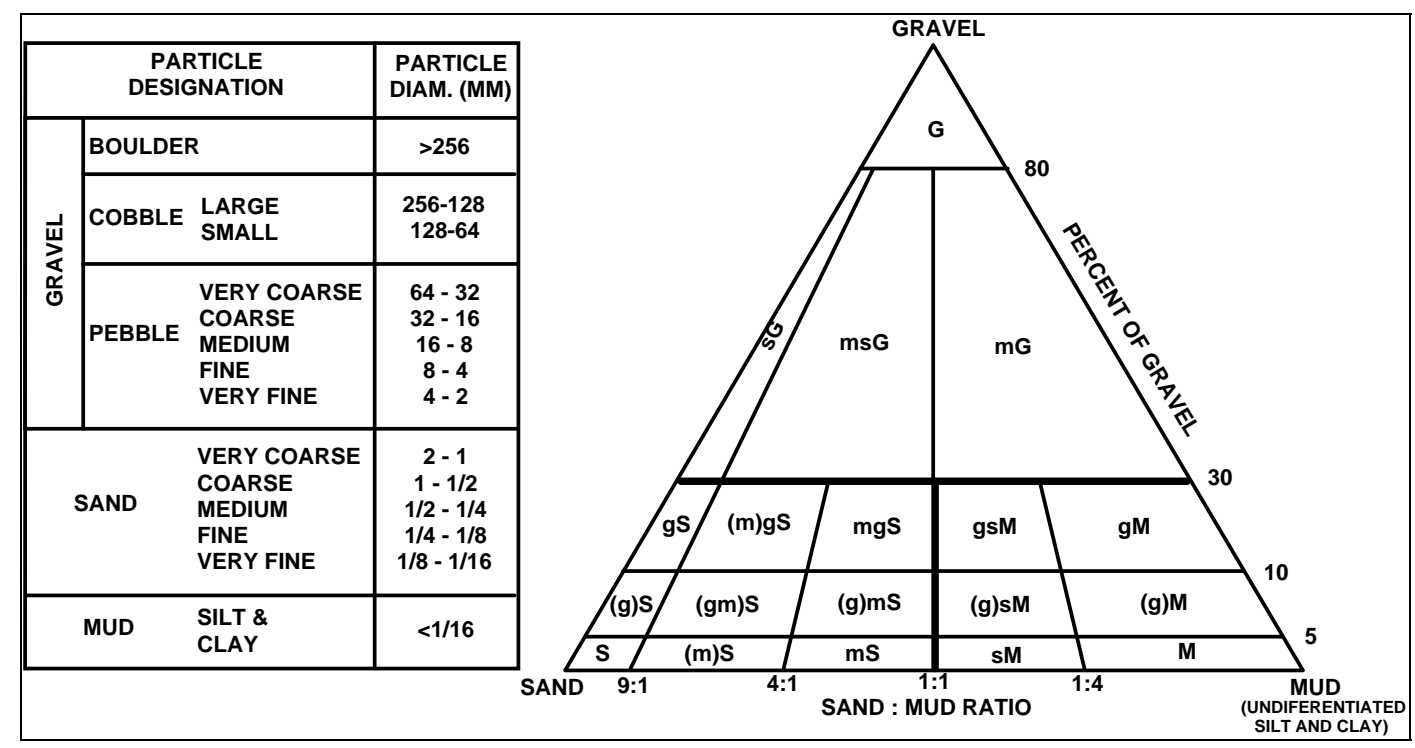

Figure 2.8. Sediment Textural Classification [modified after Folk (1968) and Wentworth (1922)] 
The tops of some cores contained several inches or more of sloughed material in the core liners. Slough is recognizable by its loose, darker, more massive, and poorly sorted nature, and is always at the top of the core. The sloughed material represents sediment that either fell back into the hole or was not completely removed between core runs. Re-coring of sloughed materials was more common in coarser and looser sediments found in backfill and the Hanford formations; it was generally not a problem in the finer-grained and/or higher moisture intervals, which have a greater tendency to hold together between core runs. Whenever possible, sampling of sloughed material was intentionally avoided during the collection of physical- and chemical-characterization samples in the laboratory.

\subsubsection{Hydrogeology of Borehole 299-W10-27 (Background Well)}

Borehole 299-W10-27 (C3125) was drilled using the cable-tool method between January 22 and March 13, 2001. The borehole is located approximately $650 \mathrm{ft}(200 \mathrm{~m})$ northeast of TX Tank Farm (Figure 2.4). The total depth of the borehole is $268.7 \mathrm{ft}(81.9 \mathrm{~m}) \mathrm{bgs}$; the hole terminated within the Ringold Formation Unit E gravels at $81 \mathrm{ft}(25 \mathrm{~m})$ below the groundwater table.

Near continuous core sampling was performed between 50 to $132 \mathrm{ft}$ bgs (Lindsey et al. 2001), for a total of 33 splitspoon core runs. Two, 1.0-ft-long plastic (i.e., lexan) core liners were collected for each 2.5 -ft-splitspoon run. The extra $0.5 \mathrm{ft}$ collected in the shoe of the splitspoon was used for geologic description in the field geologist's log. Generally, after performing a geologic description, the core material in the shoe was discarded. Accounting for the loss of the $0.5-\mathrm{ft}$ shoe samples and slough atop many of the cores, the total recovery for the 50 to $132 \mathrm{ft}$ interval in $299-\mathrm{W} 10-27$ is estimated at $89.8 \%$ (Lindsey et al. 2001). Sampling above $50 \mathrm{ft}$ was limited to core-barrel grab samples every $5 \mathrm{ft}$, while below $132 \mathrm{ft}$ bgs grab samples were collected every $5 \mathrm{ft}$ from the hard-tool drill cuttings. An additional three splitspoon cores were collected between hard-tooled intervals from the saturated zone within Ringold Formation Unit E gravels.

Core logging was performed by K.A. Lindsey of Kennedy / Jenks Consultants, Inc. at PNNL's 3720 Building laboratory on May 16, 2001. Core logs are presented in Lindsey et al. (2001

[Appendix A]). Geologic logging and sampling for gravimetric moisture occurred after each core segment was cut and split open, logged, and photographed. During logging, PNNL staff also collected 20 samples for paleomagnetic analysis (Table 2.3). Core photos taken during logging of this hole are presented in Appendix A.1 of this report. After geologic logging, moisture sampling, and photographing, the plastic-lined cores were resealed with duct tape and placed into cold storage for archival purposes.

Selected cores from 299-W10-27 were reopened 20 months later and nine subsamples were collected for physical and chemical characterization (Table 2.4). 
Table 2.3. Core Samples Collected from 299-W10-27 for Paleomagnetic Analysis - May 16, 2001

\begin{tabular}{|c|c|l||}
\hline $\begin{array}{c}\text { Depth } \\
\text { (ft bgs) }\end{array}$ & $\begin{array}{c}\text { Stratigraphic } \\
\text { Unit }\end{array}$ & \multicolumn{1}{|c||}{ Sample Description } \\
\hline 50.8 & $\mathrm{H} 2$ & Medium sand, loose, well-sorted \\
\hline 53.3 & $\mathrm{H} 2$ & Fine sand, compact, v. well-sorted, moist \\
\hline 54.0 & $\mathrm{H} 2$ & Fine to medium sand, laminated \\
\hline 58.0 & $\mathrm{H} 2$ & Medium to coarse sand, loose, well-sorted \\
\hline 61.2 & $\mathrm{H} 2$ & Fine to medium sand, compact, moderately sorted \\
\hline 64.0 & $\mathrm{H} 2$ & Fine to coarse sand, loose, moderately sorted \\
\hline 68.3 & $\mathrm{H} 2$ & Fine to coarse sand, compact, moderately sorted \\
\hline 70.7 & $\mathrm{H} 2$ & Silty fine sand, weak lamination, compact, dipping $\geq 45^{\circ}$ (clastic dike) \\
\hline 74.0 & $\mathrm{H} 2$ & Fine to coarse sand, compact, moderately sorted \\
\hline 78.0 & $\mathrm{H} 2$ & Fine to medium sand, moderately sorted, weakly laminated \\
\hline 80.8 & $\mathrm{H} 2$ & Fine to medium sand, moderately sorted, weakly laminated \\
\hline 83.0 & $\mathrm{H} 2$ & Silty fine to medium sand, compact, poorly sorted, laminated \\
\hline 85.7 & $\mathrm{H} 2$ & Silty fine to medium sand, compact, poorly sorted, laminated \\
\hline 88.3 & $\mathrm{H} 2$ & Silty v. fine sand, well laminated, well-sorted \\
\hline 90.7 & $\mathrm{CCU}$ & Fine sandy silt, compact, laminated, v. well-sorted \\
\hline 93.3 & $\mathrm{CCU}$ & Silty v. fine sand, weakly laminated, compact, v. well-sorted \\
\hline 95.5 & $\mathrm{CCU}$ & Silty v. fine sand, massive to weakly mottled, well-sorted \\
\hline 97.8 & $\mathrm{CCU}$ & Silty fine sand, massive, few CaCO 3 nodules (just above caliche) \\
\hline 105.6 & $\mathrm{CCU}$ & Fine pebbly silty sand, massive, v. poorly sorted, crumbly, mottled \\
\hline 108.1 & $\mathrm{CCU} \mathrm{u}_{1}$ & Fine pebbly silty sand, massive, v. poorly sorted, crumbly, mottled \\
\hline \hline
\end{tabular}


Table 2.4. Splitspoon Samples Selected for Physical and Chemical Characterization from the Vadose Zone in 299-W10-27. One physical and chemical characterization sample was collected from each of the depths indicated.

\begin{tabular}{||c|c|c|c|c||}
\hline $\begin{array}{c}\text { Core Sample } \\
\text { ID }\end{array}$ & $\begin{array}{c}\text { Discrete } \\
\text { Sample } \\
\text { Depth (ft) }\end{array}$ & Lithology & $\begin{array}{c}\text { Stratigraphic } \\
\text { Unit }\end{array}$ & Comments \\
\hline C3125-52.5 & 53.3 & Silty fine sand & $\mathrm{H} 2$ & \\
\hline C3125-53.5 & 54.2 & $\begin{array}{c}\text { Silty fine- } \\
\text { medium sand }\end{array}$ & $\mathrm{H} 2$ & \\
\hline C3125-61 & 61.2 & $\begin{array}{c}\text { Silty fine- } \\
\text { coarse sand }\end{array}$ & $\mathrm{H} 2$ & \\
\hline C3125-87.5 & 88.2 & Silty fine sand & $\mathrm{H} 2$ & \\
\hline C3125-92.5 & 93.0 & Silty fine sand & $\mathrm{CCU}_{\mathrm{u}}$ & \\
\hline C3125-100 & 100.5 & Sandy caliche & $\mathrm{CCU}_{1}$ & \\
\hline C3125-113.5 & 114.0 & $\begin{array}{c}\text { Fine-medium } \\
\text { sand }\end{array}$ & $\mathrm{R}_{\mathrm{tf}}$ & \\
\hline C3125-117.5 & 118.5 & Silt and sand & $\mathrm{R}_{\mathrm{tf}}$ & Clastic dike within $\mathrm{R}_{\mathrm{tf}}$ \\
\hline C3125-130 & 130.2 & $\begin{array}{c}\text { Muddy sandy } \\
\text { gravel }\end{array}$ & $\mathrm{R}_{\mathrm{wi}}$ & \\
\hline \hline
\end{tabular}

Figure 2.9 presents a summary geologic log for borehole 299-W10-27 based on a compilation of field geologists' logs, core log notes (Lindsey et al. 2001 [Appendix A]), geophysical logs (PNNL 2004), gravimetric moisture measurements, and core photographs (Appendix A.1 of this report). Four primary stratigraphic units were encountered in this borehole: 1) recent backfill/eolian materials, 2) the Hanford formation, 3) the Cold Creek unit, and 4) the Ringold Formation. A brief description of the sampled materials from each of these major stratigraphic units is presented below.

Based on the results of geophysical logging, no man-made contaminants were detected in borehole 299-W10-27 (Lindsey et al. 2001). Geophysical logging (Figure 2.9) shows a sharp increase in total gamma and neutron-moisture activity at a depth of $56 \mathrm{ft}$ where the casing telescopes down from a double to a single string of temporary steel casing. These casings were advanced during drilling of the hole and used to keep it open for geophysical logging and subsequent well installation. At depth, the total gamma count rate increases again between 90-96 ft bgs within the silts and fine sands of the upper CCU before dropping very sharply at the contact with the lower CCU (i.e., top of the calcic paleosol sequence).

Zones of elevated moisture occur within the CCU and $\mathrm{R}_{\mathrm{tf}}$ units between 90-120 ft bgs in 299-W10-27 (Figure 2.9). Moisture ranged from as low as $2.2 \mathrm{wt} \%$ in pebbly sand facies of the Hanford formation $\mathrm{H} 2$ unit up to $23.7 \mathrm{wt} \%$ in fine-grained facies of the lower CCU (Table 2.5). 


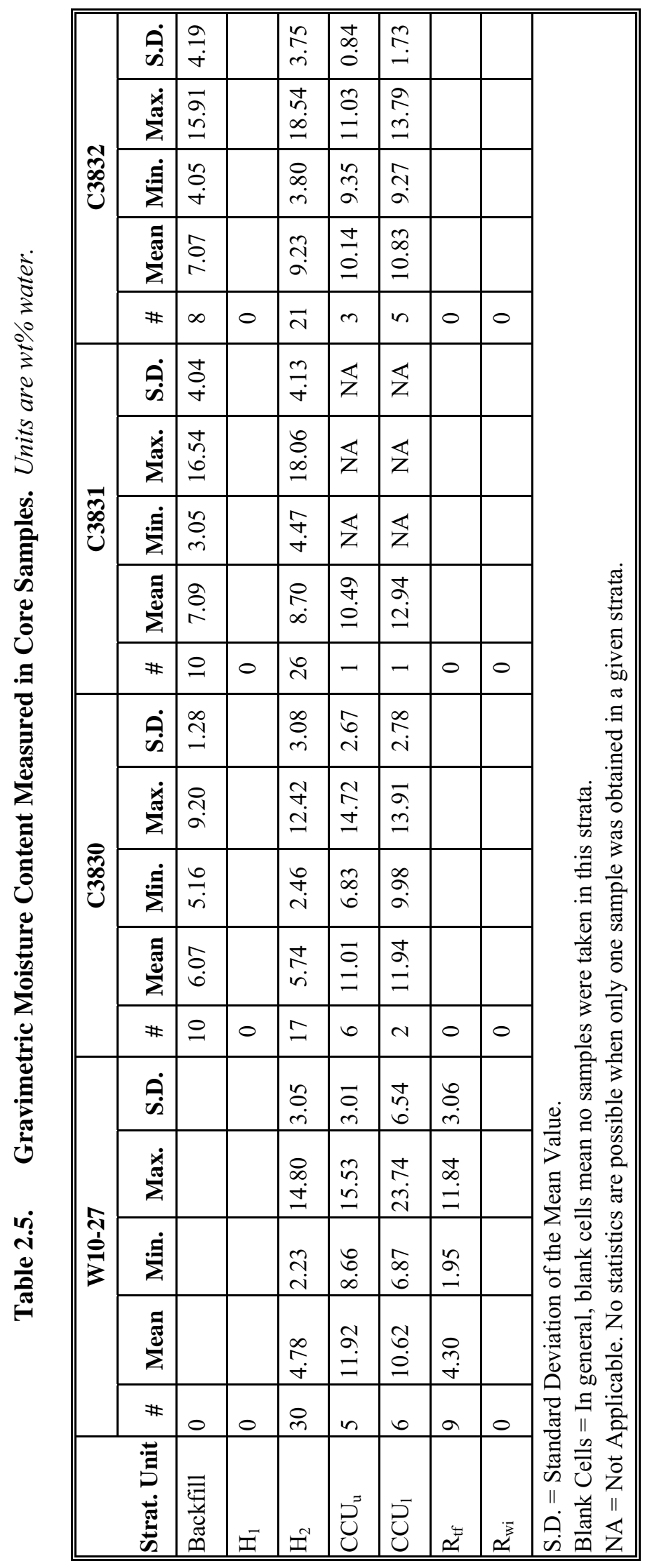


More specifically, highest moisture occurs 1) toward the top of the upper CCU between 90-95 ft, 2) along the contact between the upper and lower CCU at $\sim 98 \mathrm{ft}, 3$ ) at the base of the lower CCU at $\sim 110 \mathrm{ft}$, and 4) within a fine-grained clastic dike at $120 \mathrm{ft}$.

\subsubsection{Recent Backfill/Eolian Materials}

Less than $2 \mathrm{ft}$ of sandy gravel surface-construction material covers the surface at 299-W10-27. This material lies over about $3 \mathrm{ft}$ of eolian silty sand that exists to a depth of $4.5 \mathrm{ft}$ bgs.

\subsubsection{Hanford Formation}

Pleistocene cataclysmic flood deposits of the Hanford formation underlie the recent sediments to a depth of $89.4 \mathrm{ft}$ in borehole 299-W10-27. Both units of the Hanford formation in the area (Wood et al. 2001) are represented, including a coarse-grained, gravel-dominated sequence (H1 unit) and an underlying finer, sand-dominated sequence (H2 unit). The $\mathrm{H} 1$ unit, which extends from 4.5 to $41.5 \mathrm{ft}$ bgs, consists of mostly poorly sorted, clast-supported sandy gravel to silty sandy gravel. The H2 unit, on the other hand, is predominantly medium- to coarse-grained sand to slightly pebbly sand, which extends to a depth of $89.4 \mathrm{ft}$ bgs. The term "salt and pepper" is often used to describe sands of the H2 unit on geologic $\operatorname{logs}$ due to the roughly equal amounts of dark- (basaltic) and light-colored (quartz and feldspar) grains. These beds show occasional weak horizontal laminations and are generally non-calcareous to weakly calcareous. A few, relatively thin, low permeability, well-sorted, fine-grained layers of laminated fine to silty fine sand are interspersed within the $\mathrm{H} 2$ unit (Figure 2.10).

No samples were analyzed for physical and chemical characterization from the Hanford formation H1 unit since no splitspoon samples were collected from this unit. Four characterization samples were obtained from the Hanford formation $\mathrm{H} 2$ unit, however (Table 2.4, see Figure 2.10 for example). These were selected from finer-grained lenses within the $\mathrm{H} 2$ unit, since these typically contain more moisture (Bjornstad et al. 2003), and thus may have a higher probability for carrying contaminants. The clastic dike showed relatively high moisture ( $15 \mathrm{wt} \%$ ) compared to adjacent strata (Figure 2.9 ).

A thin zone of steeply dipping $\left(>45^{\circ}\right)$ beds (Table 2.3 ) of silty fine sand, which occurs between 70-71 ft, is suggestive of a clastic dike within the H2 unit in 299-W10-27. A clastic dike at this depth was reported in association with sampling for paleomagnetism (Table 2.3). 


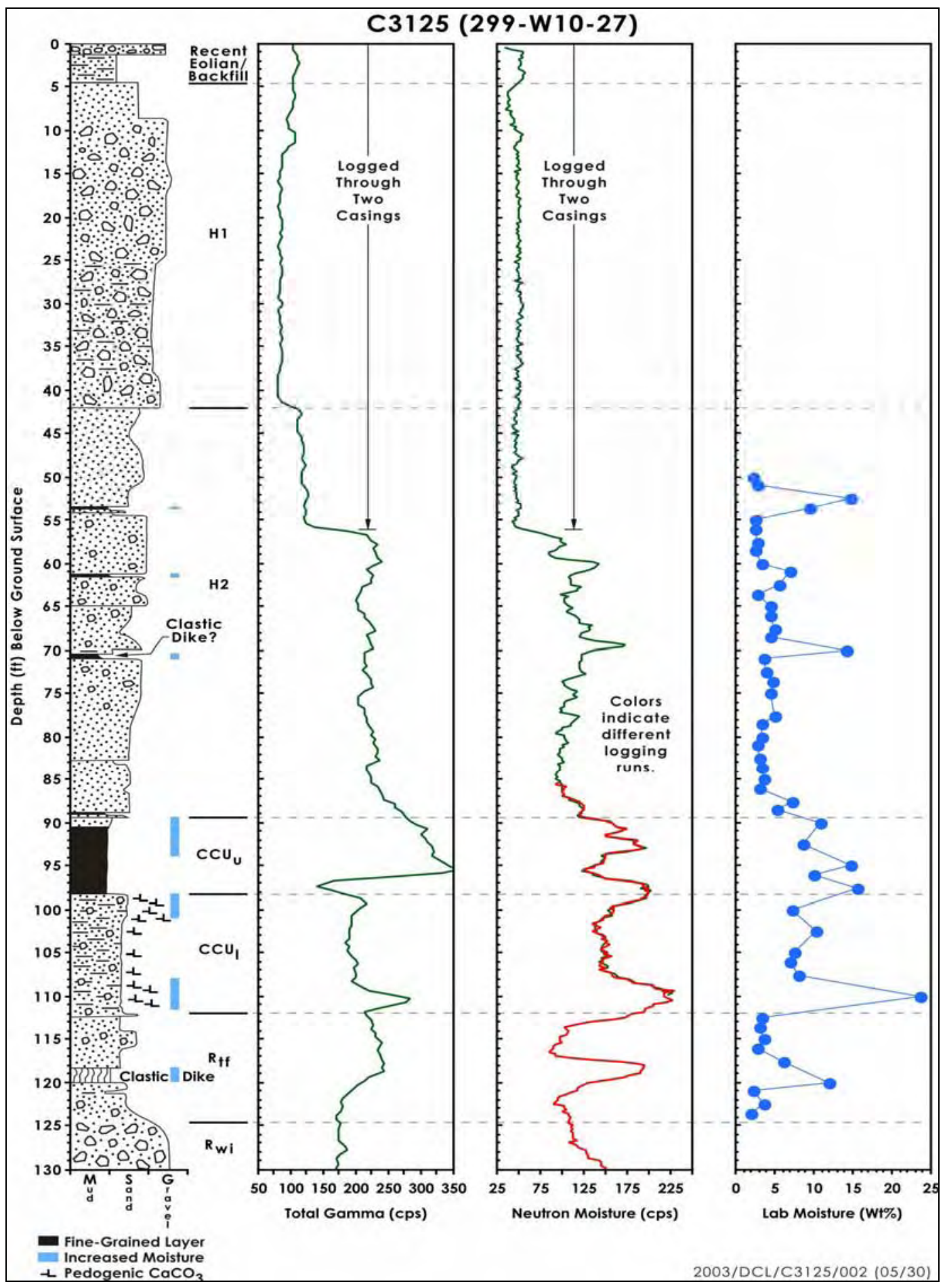

Figure 2.9. Summary Hydrogeologic Log for Borehole 299-W10-27. Zones of increased moisture are indicated as those with $>15 \mathrm{wt} \%$ water in core samples and/or show as distinct spikes on neutron-moisture log. Fine-grained layers are defined as those consisting predominantly of particles $\leq 0.25 \mathrm{~mm}$ in diameter (i.e., fine sand and smaller). 


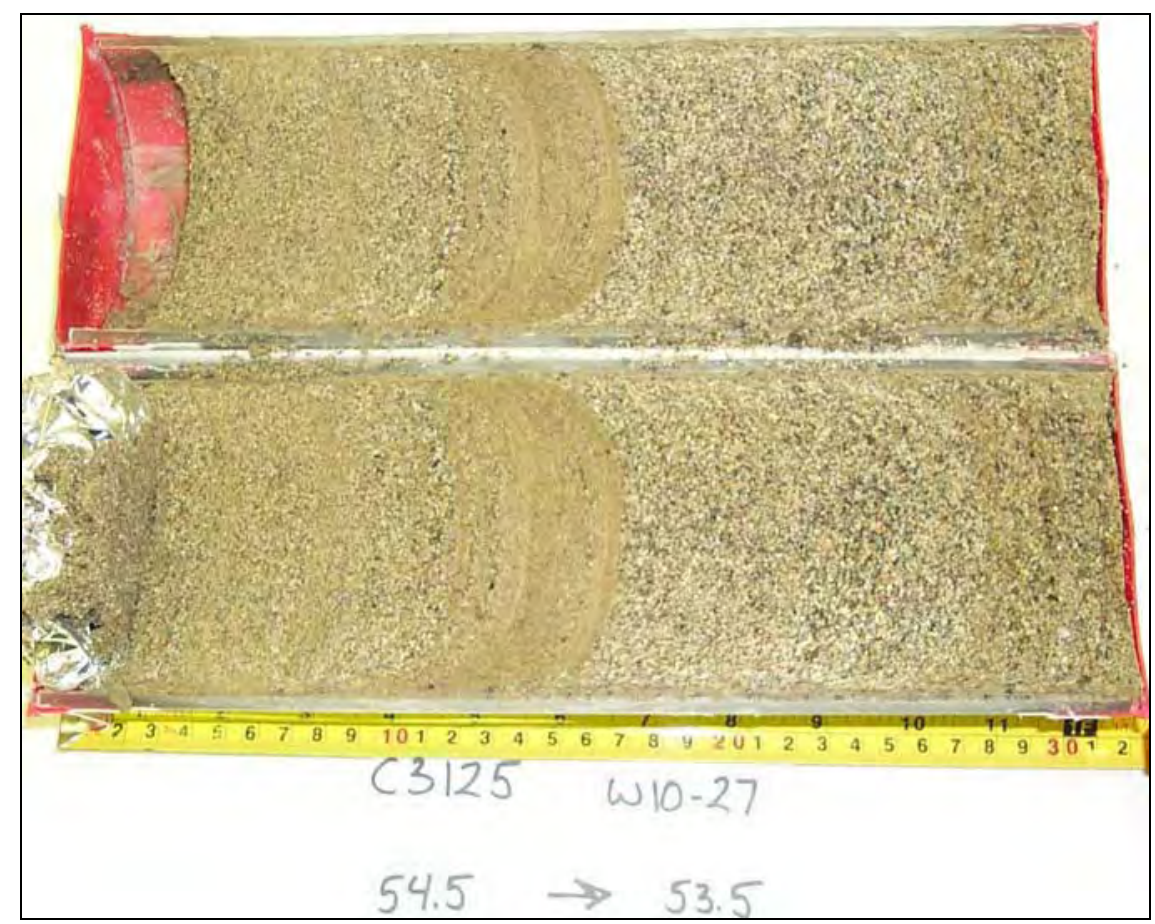

Figure 2.10. Hanford Formation H2 Unit in Borehole 299-W10-27. A thin (0.2 ft) layer of well-laminated silty very fine sand $(\mathrm{mS})$ lies between beds of medium-to coarse-grained "salt and pepper" sand (S). One of the nine characterization samples from this borehole was collected from the silty sand layer at $54.2 \mathrm{ft}$. The top of the core is to the right. Notice the drilling-induced drag folding along the sides of the core.

\subsubsection{Cold Creek Unit}

The Cold Creek unit is subdivided into the upper and lower subunits within the TX Tank Farm as well as the greater 200 West Area (DOE 2002a). The upper Cold Creek subunit consists of a brownish, well-sorted, unconsolidated fine-grained unit, which sharply overlies the lower subunit, characterized as a whitish calcic paleosol or sequence of paleosols. A distinct contact occurs between these two highly contrasting units (Figure 2.7).

\subsection{Upper Cold Creek Subunit $\left(\mathrm{CCU}_{\mathrm{u}}\right)$}

The upper CCU, 2.6-m (8.6 ft) thick, underlies the basalt-rich, "salt and pepper" sands of the Hanford formation in borehole 299-W10-27 between $27.2 \mathrm{~m}(89.4 \mathrm{ft})$ and $29.9 \mathrm{~m}(98 \mathrm{ft})$ bgs. This unit consists of a brownish, laminated to massive, compacted and very well sorted, silty fine sand to fine sandy silt. This unit is also relatively unconsolidated and moderately to strongly calcareous. The uncemented nature of this unit suggests the calcium carbonate is probably of detrital origin instead of that forming pedogenically in situ, as did carbonate in the underlying lower Cold Creek unit. Also characteristic of this unit is its relatively high natural-gamma activity and increased moisture on the neutron-moisture log, compared to adjacent units. Core photographs (Appendix A.1) show the upper half of this unit to be mostly laminated, while the lower half is mostly massive. The average moisture content $(\sim 12 \mathrm{wt} \%)$ for the upper $\mathrm{CCU}$ is significantly greater than that of the overlying Hanford formation (Table 2.5). 
A single sample was collected for laboratory characterization from near the top of the upper CCU at $100.5 \mathrm{ft}$ bgs (Table 2.4, Figure 2.9).

\subsection{Lower Cold Creek Subunit $\left(\mathrm{CCU}_{1}\right)$}

The lower Cold Creek unit, also referred to as "caliche," "calcrete," or "calcic paleosol" (Table 2.1), extends from 98 to $112 \mathrm{ft}$ bgs in 299-W10-27. Characteristics of the lower CCU are the abundance of white, secondary calcium carbonate cement, massive to mottled structures with evidence for bioturbation, and low to erratic natural-gamma activity on geophysical logs (DOE 1988; Bjornstad 1990; Wood et al. 2001). Two highly cemented calcic horizons are present within the 14-ft-thick calcic paleosol sequence in 299-W10-27 (Lindsey et al. 2001). One highly cemented zone (Stage III-IV as described in DOE [2002a]) occurs from the top at $98 \mathrm{ft}$ (Figure 2.7) to $112 \mathrm{ft} \mathrm{bgs}$; the other lies at the base of lower Cold Creek unit between 109.3 to $111 \mathrm{ft}$ bgs. In between these two zones are more weakly developed Stage I-II calcic horizons (Figure 2.11).

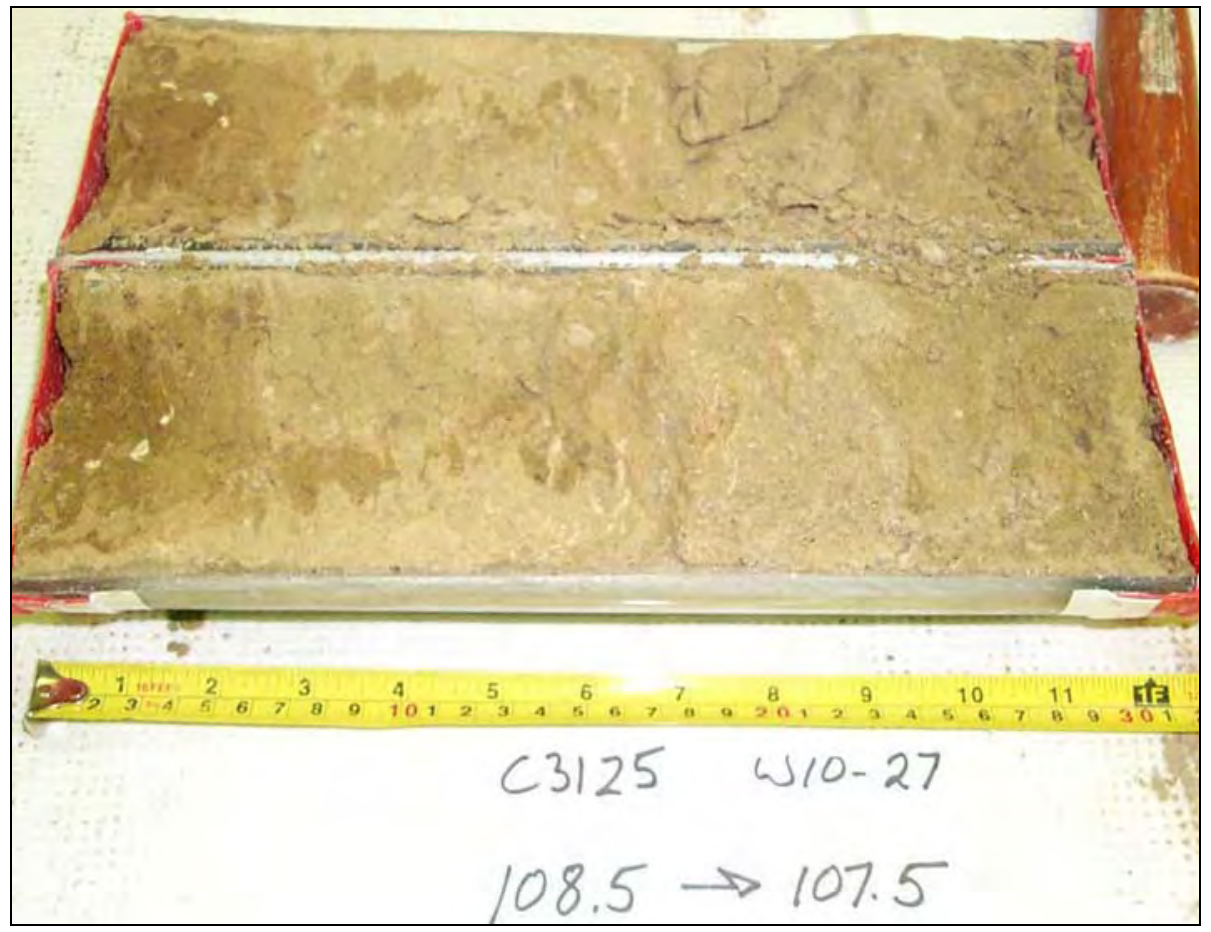

Figure 2.11. Lower Cold Creek Subunit $\left(\mathbf{C C U}_{1}\right)$ in 299-W10-27. Massive to mottled, poorly sorted, sand and silt $[(\mathrm{g}) \mathrm{mS}]$ with white stringers and nodules of secondary, pedogenic, calcium carbonate. The top of the core is to the right.

A single sample, near the top of the lower CCU (100.5 ft bgs), was collected from the lower Cold Creek unit in 299-W10-27 for laboratory characterization (Table 2.4). Moisture content within the upper CCU is relatively high, similar to the upper CCU, but is more variable (Table 2.5). 


\subsubsection{Ringold Formation}

The Ringold Formation is present from about $112 \mathrm{ft} \mathrm{bgs}$ to the bottom of 299-W10-27 (268.7 ft bgs). Predominantly sand to pebbly sand makes up the upper $12 \mathrm{ft}$ of the Ringold Formation, which is considered part of the Ringold Formation member of Taylor Flat $\left(\mathrm{R}_{\mathrm{tf}}\right)$, or upper Ringold (Table 2.1). The remaining $144 \mathrm{ft}$ of 299-W10-27 is predominantly clast-supported sandy gravel to silty sandy gravel, considered part of the member of Wooded Island $\left(\mathrm{R}_{\mathrm{wi}}\right)$, unit $\mathrm{E}$ (Lindsey et al. 2001).

Three characterization samples were collected from the Ringold Formation. These included one each from the $\mathrm{R}_{\mathrm{tf}}$ member (114.0 ft bgs), a clastic dike within the $\mathrm{R}_{\mathrm{tf}}$ member (118.5 ft bgs), and the $\mathrm{R}_{\mathrm{wi}}$ member (130.2 ft bgs) (Table 2.4, Figure 2.9). Except for the clastic dike, moisture content within the $\mathrm{R}_{\mathrm{tf}}$ member is relatively low, averaging about $4 \mathrm{wt} \%$ (Table 2.5 ).

\subsubsection{Borehole C3830 (TX-105)}

Borehole C3830 was drilled and sampled using a driven-probe technique between August 20 and September 5, 2002 (Table 2.2). The borehole is located approximately $40 \mathrm{ft}(12.2 \mathrm{~m})$ southwest of singleshell tank 241-TX-105 (Figure 2.4). The total depth of the borehole was $116.75 \mathrm{ft}(35.6 \mathrm{~m}) \mathrm{bgs}$; the hole was terminated when refusal was encountered near the top of the caliche within the lower Cold Creek unit. Borehole C3830 was decommissioned on September 19, 2002 by back-pulling the casing while filling the annulus with dry bentonite. During decommissioning, four sets of in situ tensiometers were placed within the hole at depths of $96.25 \mathrm{ft}, 49.95 \mathrm{ft}, 7.45 \mathrm{ft}$, and $2.9 \mathrm{ft}$ bgs. The surface elevation of the boring was $675.9 \mathrm{ft}$ (206 m) and geographic coordinates were N136167 and E566795 (Reynolds 2003).

During drilling, a total of 18,1.25-ft long, 2.5-inch-diameter splitspoon core samples were collected intermittently starting at a depth of $15 \mathrm{ft}$ bgs (Table 2.6, Figure 2.12). Two, 0.5 -ft-long stainless-steel core liners were collected during each core run. A separate sample was collected in the laboratory from each of the two liners for physical and chemical characterization, making a total of 36 characterization samples collected from this hole. In all, about $25 \mathrm{ft}$ of core was obtained from C3830, or about $22 \%$ of the total length of the hole (Table 2.2). No samples or drill cuttings were collected between the 18 core runs since the hole was advanced in a closed configuration using a solid, removable tip (Reynolds 2003).

All cores were extracted, sampled, photographed, and geologically logged on October 16, 2002 in a radiologically controlled PNNL laboratory. Geologic logs of the material within the core liners were generated by geologists Victoria Johnson (Kennedy / Jenks Consultants, Inc.) and Bruce Bjornstad (PNNL); the core logs for these two geologists are presented in Reynolds (2003) and Appendix B.1 of this report, respectively. Geologic logging occurred after the contents of each 0.5 -ft stainless-steel core liner was emptied into an open plastic container, followed by photographing and subsampling for physical and chemical characterization. Upon completion of these activities, the contents in the plastic containers were sealed shut and placed into cold storage for archival purposes.

The hole was advanced using a solid probe such that no grab samples were collected between core runs; thus no near-continuous geologic field log is available for this hole unlike the background hole (299-W10-27). Figure 2.12 presents a summary log for C3830 based on available geologic descriptions, core photographs, geophysical logs, laboratory derived gravimetric moisture and blow-count data. The geology between core runs is inferred and interpreted based on the geophysical log and blow-count data. Four primary stratigraphic units were encountered by this borehole: 1) recent backfill material, 2) the 
Hanford formation, 3) the Cold Creek unit, and 4) the Ringold Formation. A brief description of the sampled materials from each of these major stratigraphic units is presented below.

Table 2.6. Splitspoon Core Samples from C3830. Two characterization samples, labeled "A" and " $B$ " were collected from each of the cores for a total of 36 samples.

\begin{tabular}{|c|c|c|c|c|c|c|c|}
\hline $\begin{array}{c}\text { Core } \\
\text { Sample ID }\end{array}$ & $\begin{array}{c}\text { Top } \\
\text { Depth } \\
\text { (ft) }\end{array}$ & $\begin{array}{c}\text { Bottom } \\
\text { Depth } \\
\text { (ft) }\end{array}$ & $\begin{array}{c}\text { Mid } \\
\text { Depth (ft) }\end{array}$ & $\begin{array}{c}\text { Sampled } \\
\text { Interval } \\
\text { Thickness (ft) }\end{array}$ & Lithology & $\begin{array}{c}\text { Stratigraphic } \\
\text { Unit }\end{array}$ & Comments \\
\hline C3830-14.96 & 14.96 & 16.31 & 15.64 & 1.35 & Sand & backfill & \\
\hline C3830-27.91 & 27.91 & 29.25 & 28.58 & 1.34 & Gravelly sand & backfill & \\
\hline C3830-40.93 & 40.93 & 42.49 & 41.71 & 1.56 & Gravelly sand & backfill & \\
\hline C3830-46.2 & 46.20 & 47.50 & 46.85 & 1.30 & Gravelly sand & backfill & \\
\hline C3830-47.5 & 47.50 & 49.00 & 48.25 & 1.50 & $\begin{array}{c}\text { Slightly } \\
\text { gravelly sand }\end{array}$ & backfill & \\
\hline C3830-52.98 & 52.98 & 54.36 & 53.67 & 1.38 & Sand & $\mathrm{H} 2$ & \\
\hline C3830-56.99 & 56.99 & 58.37 & 57.68 & 1.38 & Sand & $\mathrm{H} 2$ & \\
\hline C $3830-58.29$ & 58.29 & 59.70 & 59.00 & 1.41 & $\begin{array}{l}\text { Sand to silty } \\
\text { sand }\end{array}$ & $\mathrm{H} 2$ & $\begin{array}{c}0.08 \mathrm{ft} \text { of } \\
\text { overlap with } \\
\text { sample above }\end{array}$ \\
\hline C3830-66.06 & 66.06 & 67.46 & 66.76 & 1.40 & Sand & $\mathrm{H} 2$ & \\
\hline C3830-71.95 & 71.95 & 73.30 & 72.63 & 1.35 & Sand & $\mathrm{H} 2$ & \\
\hline C3830-76.98 & 76.98 & 78.35 & 77.67 & 1.37 & Sand & $\mathrm{H} 2$ & \\
\hline C3830-80.91 & 80.91 & 82.21 & 81.56 & 1.30 & Sand & $\mathrm{H} 2$ & \\
\hline C3830-86.11 & 86.11 & 87.41 & 86.76 & 1.30 & $\begin{array}{l}\text { Sand to silty } \\
\text { sand }\end{array}$ & $\mathrm{H} 2$ & \\
\hline C3830-98.97 & 98.97 & 100.36 & 99.67 & 1.39 & Sand & $\mathrm{H} 2$ & \\
\hline C3830-100.32 & 100.32 & 101.72 & 101.02 & 1.40 & $\begin{array}{l}\text { Silty sand to } \\
\text { sandy silt and } \\
\text { silt }\end{array}$ & $\mathrm{CCU}_{\mathrm{u}}$ & $\begin{array}{c}0.04 \mathrm{ft} \text { of } \\
\text { overlap with } \\
\text { sample above }\end{array}$ \\
\hline C3830-102.99 & 102.99 & 104.44 & 103.72 & 1.45 & Sandy silt & $\mathrm{CCU}_{\mathrm{u}}$ & \\
\hline C3830-107.89 & 107.89 & 109.19 & 108.54 & 1.30 & Sandy silt & $\mathrm{CCU}_{\mathrm{u}}$ & \\
\hline C3830-113.55 & 113.55 & 115.00 & 114.28 & 1.45 & $\begin{array}{l}\text { Calcareous, } \\
\text { pebbly sand } \\
\text { and mud }\end{array}$ & $\mathrm{CCU}_{1}$ & $\begin{array}{l}\text { Cemented } \\
\text { caliche }\end{array}$ \\
\hline
\end{tabular}




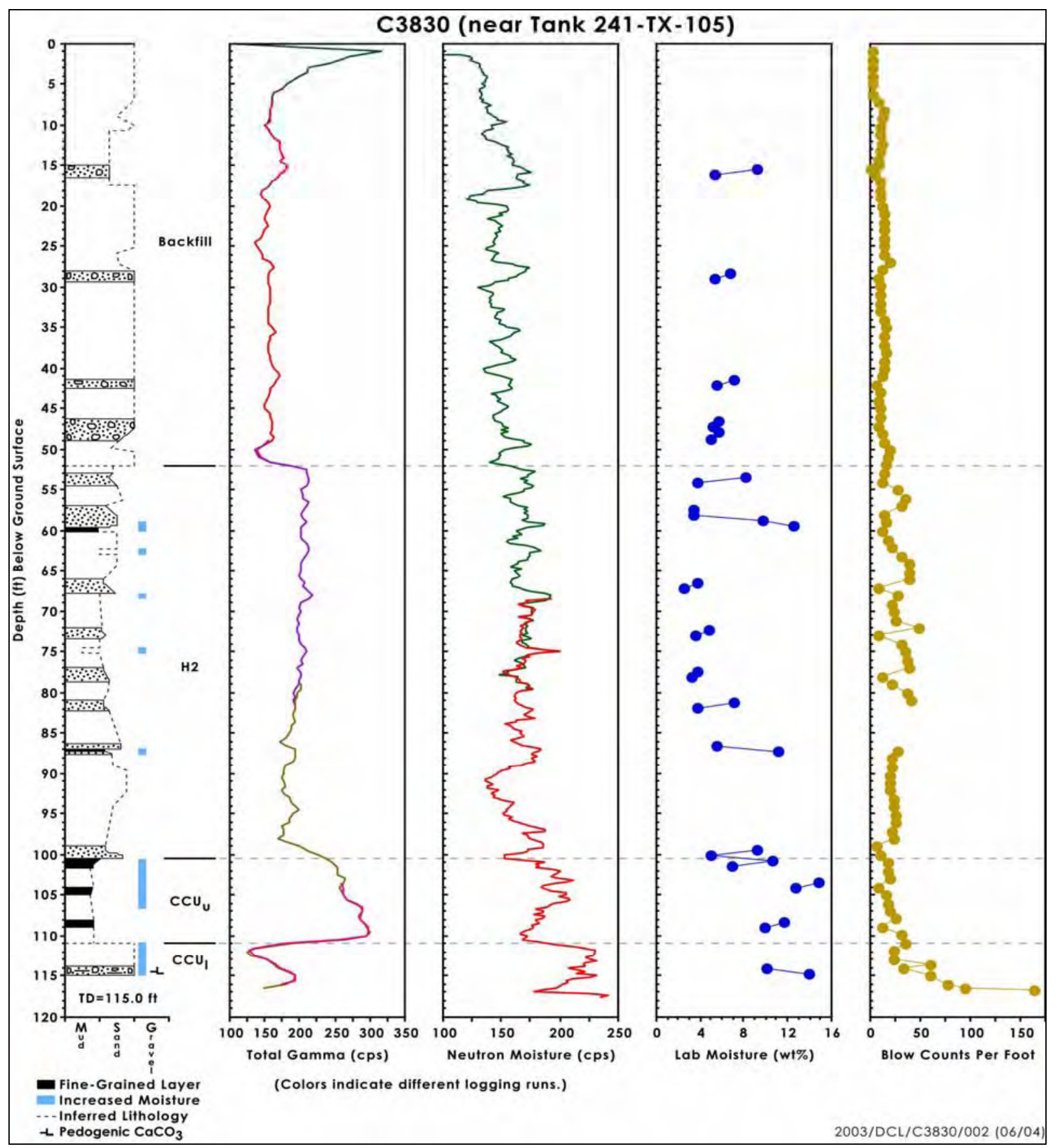

Figure 2.12. Summary Hydrogeologic Log for Borehole C3830. Zones of increased moisture are indicated as those with $>15 \mathrm{wt} \%$ water in core samples and/or show as distinct spikes on neutron-moisture log. Fine-grained layers are defined as those consisting predominantly of particles $\leq 0.25 \mathrm{~mm}$ in diameter (i.e., fine sand and smaller). 


\subsubsection{Backfill}

The backfill extends from the ground surface to a depth of $15.8 \mathrm{~m}(52 \mathrm{ft})$ where it lies in contact with the Hanford formation (Figure 2.12). This depth is consistent with a minimum depth of $45 \mathrm{ft}$ required to completely bury tanks used at TX Tank Farm (Crumpler 2002). A total of 10 physical/chemical characterization samples were collected in backfill material (Table 2.6). Backfill material (Figure 2.13) consists of predominantly grayish brown, poorly to moderately sorted, massive, gravelly sand to slightly gravelly sand, which is unconsolidated and weakly to strongly calcareous (see Appendix B.1 for more detailed descriptions). A sharp increase in total gamma activity in the upper few feet of this hole is associated with near-surface cesium-137 contamination at this location (Reynolds 2003). This unit appears to be rather homogeneous and lacks lithologic variation suggested by relatively uniform geophysical logs and blow-count data (Figure 2.12). Moisture content is also relatively low, averaging about $6 \mathrm{wt} \%$ (Table 2.5).

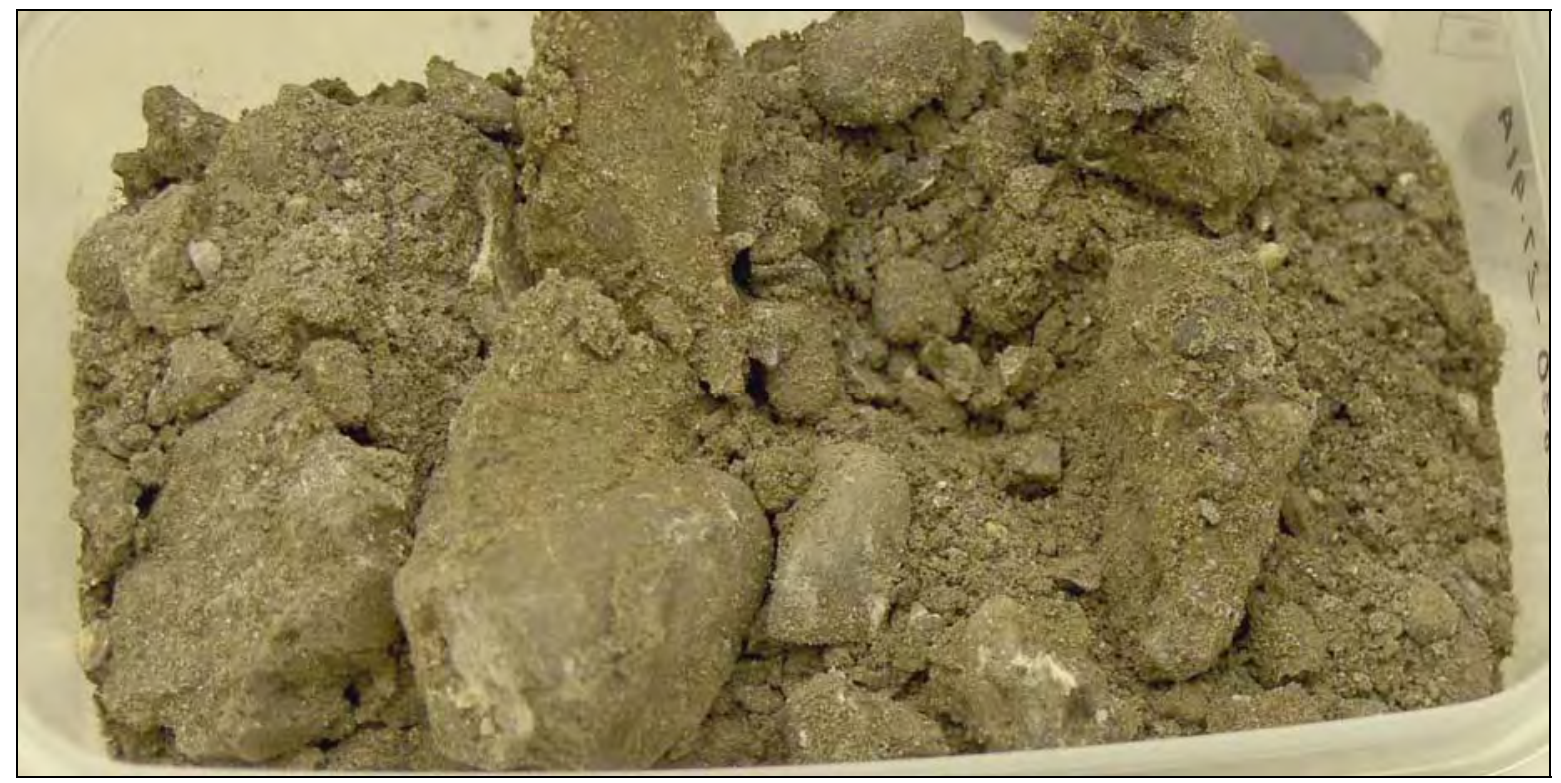

Figure 2.13. Typical Backfill from Borehole C3830. Core sample C3830-27.91A, described as a slightly moist, dark grayish brown, poorly sorted, pebbly, fine to coarse sand (gS), weakly to moderately calcareous. The top of the 0.5-ft core is to the right. Considerable pulverization of the sample occurred during drilling, as indicated by the abundance of angular gravel clasts.

\subsubsection{Hanford Formation}

Pleistocene cataclysmic flood deposits of the Hanford formation underlie backfill materials to a depth of $100.4 \mathrm{ft}$ in borehole C3830. Only the sand-dominated Hanford formation H2 unit is represented; all of the coarse-grained Hanford formation $\mathrm{H} 1$ unit was removed during tank-farm construction, to be used later as backfill around the tanks. 


\subsection{Hanford Formation H2 Unit}

The Hanford formation $\mathrm{H} 2$ unit is present between 52.0 to $100.4 \mathrm{ft}$ bgs. The $\mathrm{H} 2$ unit consists of predominantly fine-to-coarse-grained, gray to brownish-gray "salt and pepper" sand (Figure 2.14). $\mathrm{H} 2$ unit strata show occasional weak horizontal laminations and are weakly to strongly calcareous. Dispersed within the Hanford formation $\mathrm{H} 2$ unit are at least two separate, relatively thin $(\leq 0.5 \mathrm{ft})$, brown to yellow, compact, well-sorted, silty fine sand beds (Figure 2.15). These occur at depths starting at 59.3 and $86.8 \mathrm{ft}$ bgs (Figure 2.12). Other coincident peaks in total gamma and neutron moisture logs suggest additional fine-grained beds are probably present between cored intervals. Zones with increased moisture, both within the sampled cores as well as those interpreted from the geophysical logs, are illustrated together on Figure 2.12. There appears to be a significant increase in penetration resistance (i.e., blow counts) within portions of the Hanford formation $\mathrm{H} 2$ unit, relative to the overlying backfill material.

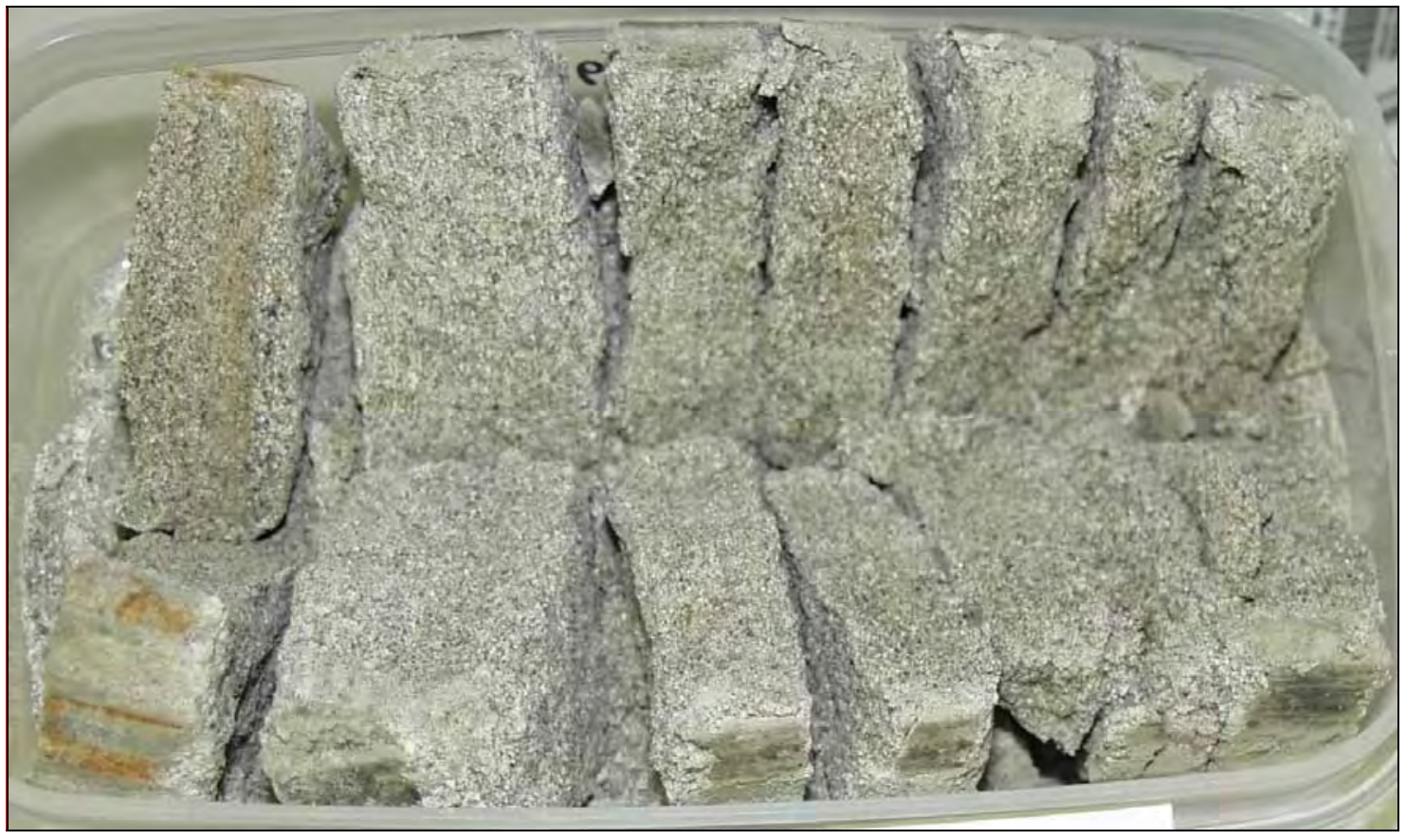

Figure 2.14. Fine to Medium Sand Recovered from the Hanford Formation H2 Unit in Borehole C3830. Core C3830-76.98A, described as slightly moist, light gray, well-sorted, fine to medium sand (S), moderately calcareous. The core separated along natural, well-developed laminations. The top of the 0.5-ft core is to the right. 


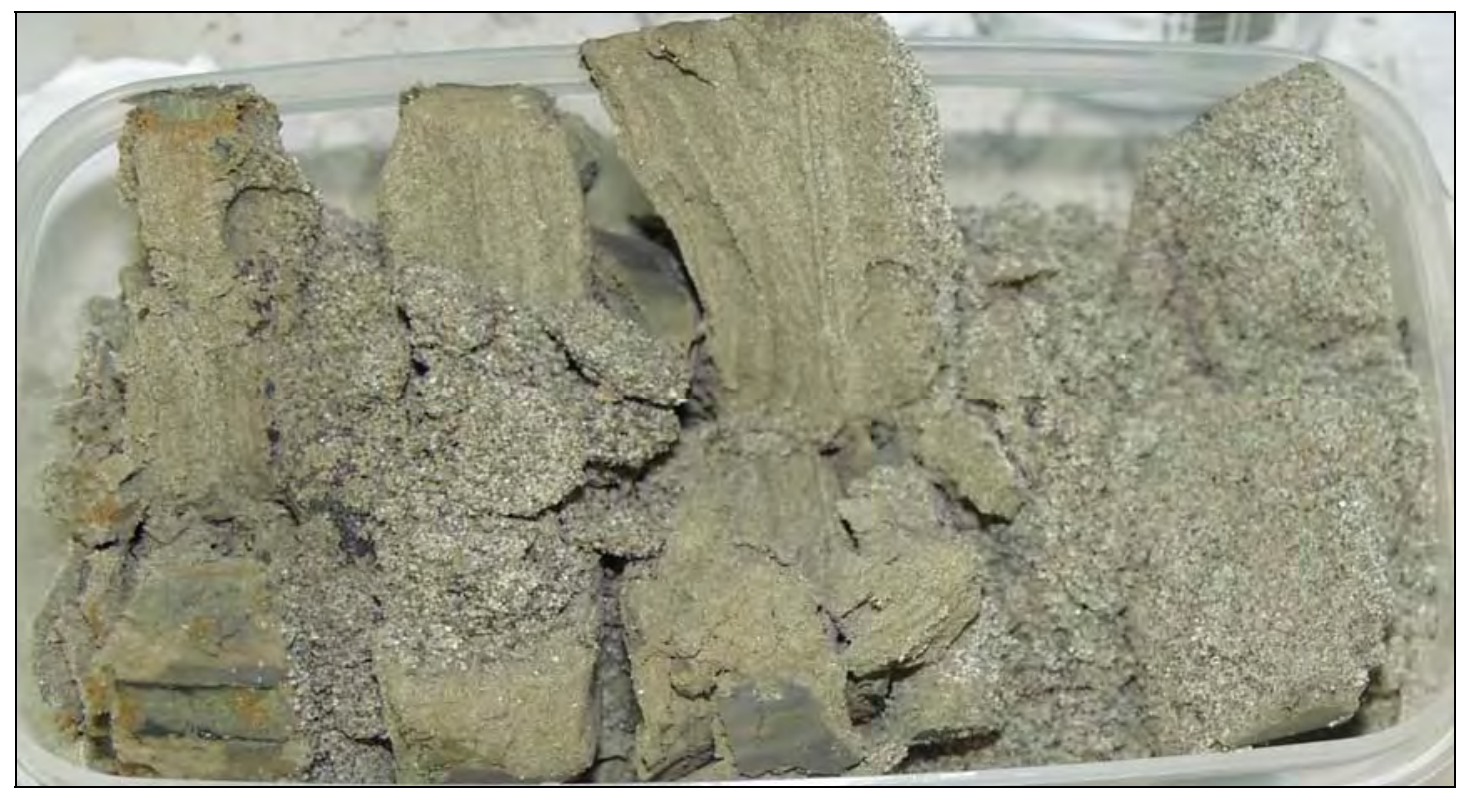

Figure 2.15. Interbedded Sand and Silty Sand Within the Hanford Formation H2 Unit. Core C3830-58.29A, described as two lenses of slightly moist, cohesive, brown, well-sorted and laminated silty fine sand $(\mathrm{mS})$, interbedded with loose, grayish-brown, medium-grained sand (S). The top of the 0.5-ft core is to the right.

A total of 18 characterization samples were obtained from the Hanford formation $\mathrm{H} 2$ unit (Table 2.5). Most of the samples are composed of medium- to coarse-grained sand while two of the samples are silty fine sand.

\subsubsection{Cold Creek Unit}

The top of the CCU in C3830 lies at $100.4 \mathrm{ft}$ bgs; the bottom of the hole terminates within the lower CCU. A total of eight characterization samples were collected from the CCU, six from the upper and two from the lower Cold Creek subunits (Table 2.6). The average moisture content (Table 2.5) is significantly greater in the $\mathrm{CCU}$, compared to other stratigraphic units.

\subsection{Upper Cold Creek Unit $\left(\mathrm{CCU}_{\mathrm{u}}\right)$}

The contact between the Cold Creek unit and the overlying Hanford formation $\mathrm{H} 2$ unit is at $100.4 \mathrm{ft}$ bgs (Figure 2.16). The upper CCU is 10.6-ft thick. 


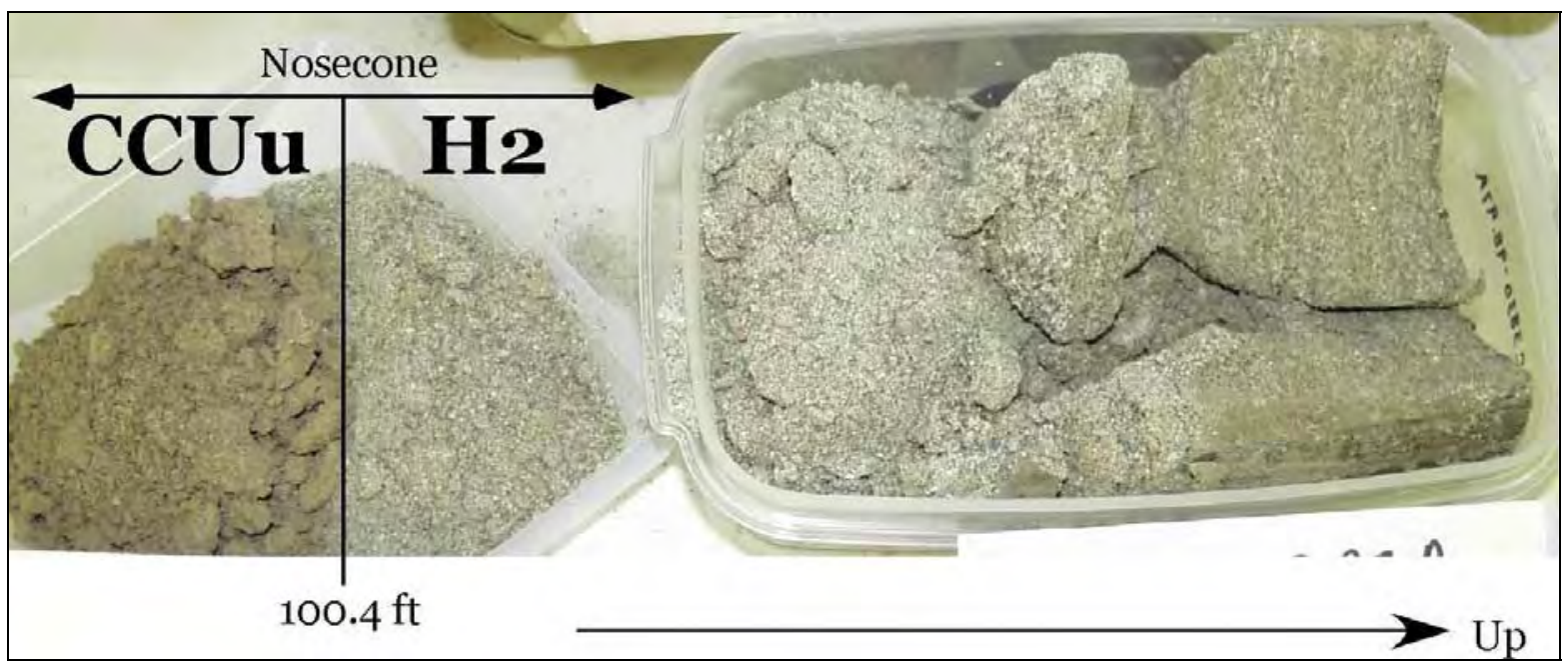

Figure 2.16. Contact Between Hanford Formation $\mathbf{H} 2$ and Cold Creek Units. Contact was encountered in the nose cone of the splitspoon sampler in core \#3830-98.7. The contact is well-defined based on the sudden textural, color, and moisture change at $100.4 \mathrm{ft}$ bgs. The Hanford formation $\mathrm{H} 2$ unit is described as slightly moist, laminated, moderately sorted, light brownish-gray, fine to coarse sand (S). The underlying $C C U_{u}$ unit is described as moist, well-sorted, yellowish-brown, silty fine sand $(\mathrm{mS})$. The top of the core is to the right.

Six samples of the upper CCU were collected for physical and chemical characterization at three different depths within the upper CCU (Table 2.6). Sediments from this unit are compact and well-sorted silt to silty fine sand, which range from laminated to massive and moderately to strongly calcareous. An example of one of the cores is shown in Figure 2.17.

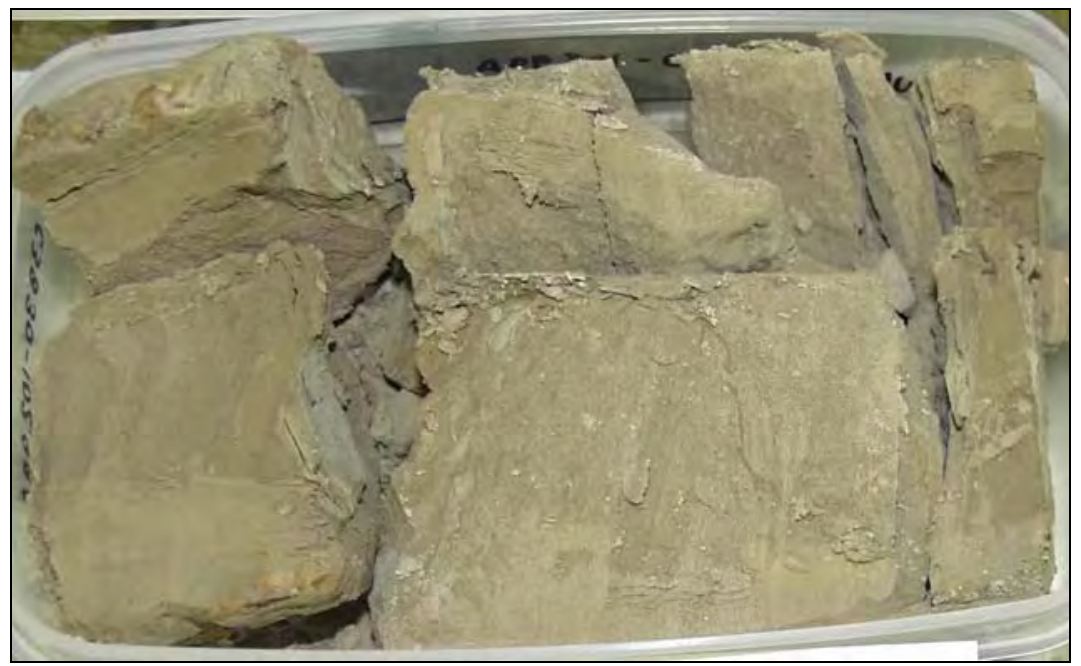

Figure 2.17. Upper Cold Creek Unit $\left(\mathbf{C C U}_{\mathbf{u}}\right)$ in C3830. Core C3830-102.99A, described as moist, laminated to massive, compact, yellowish-brown, fine sandy silt (sM), moderately to strongly calcareous. The top of the 0.5-ft core is to the right. 


\subsection{Lower Cold Creek Unit $\left(\mathrm{CCU}_{\mathrm{l}}\right)$}

Only a single core was obtained from a caliche layer within the lower CCU (Figure 2.18). The hole was abandoned at $115 \mathrm{ft}$ depth after this core sample was collected. Two characterization samples were collected, one from the lower "A" liner and another from the " $\mathrm{B}$ " liner.

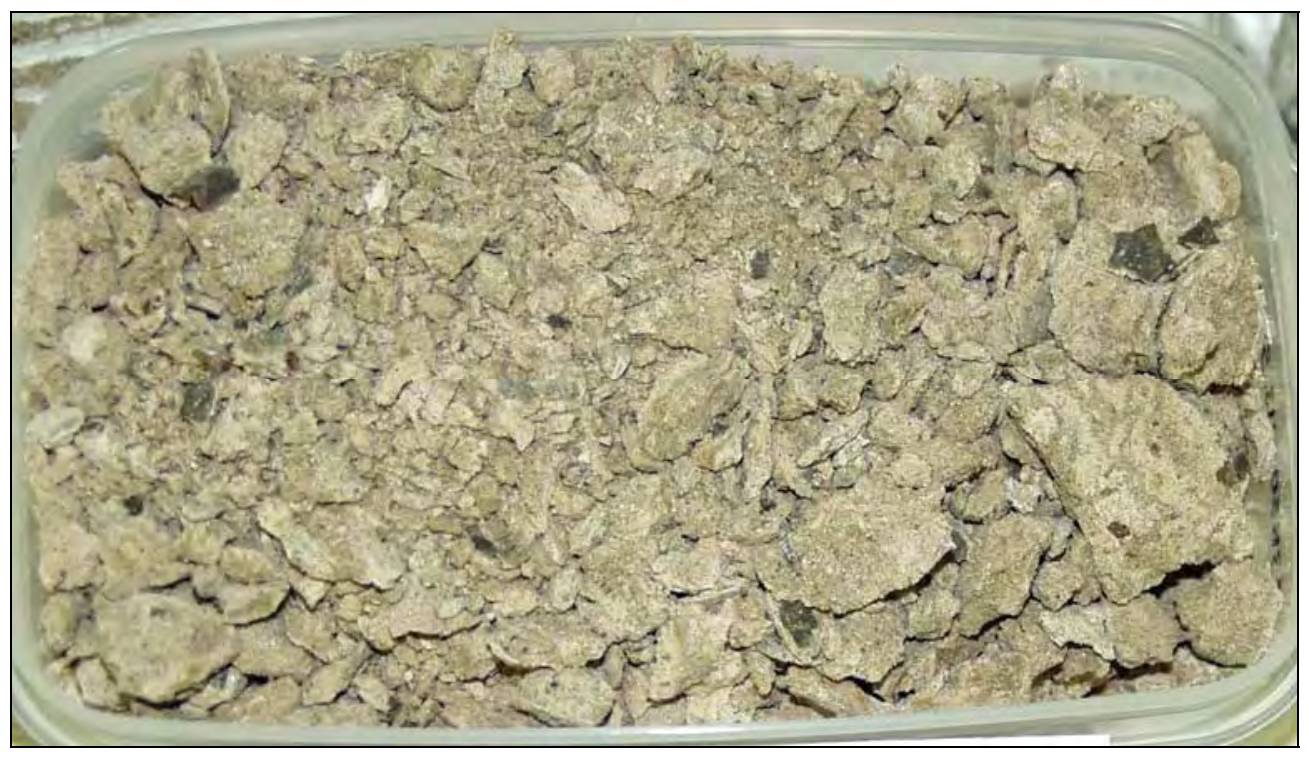

Figure 2.18. Lower Cold Creek Unit $(\mathbf{C C U})$ in C3830. Core C3830-113.55A, described as slightly moist, mottled and cemented, pinkish-gray, very poorly sorted sand, silt, and clay, with a few small pebbles of angular basalt $([\mathrm{g}] \mathrm{mS})$, and very strongly calcareous. Material in this photo is highly fragmented because it had to be manually broken apart to be removed from the core liner. The top of the 0.5-ft core is to the right.

\subsubsection{Borehole C3831 (TX-107)}

Borehole C3831 was drilled and sampled using a driven-probe technique between July 1 and August 7, 2002 (Gardner et al. 2002a). The borehole is located approximately $40 \mathrm{ft}$ (12 m) southwest of single-shell tank 241-TX-107 (Figure 2.4). Total depth of the borehole was $115.37 \mathrm{ft}(35.2 \mathrm{~m}) \mathrm{bgs}$; the hole terminated within the vadose zone about $100 \mathrm{ft}(30 \mathrm{~m})$ above the groundwater table. During drilling, a total of 20,1.25-ft long by 2.5-in.-diameter splitspoon core samples were collected intermittently starting at a depth of $15 \mathrm{ft} \mathrm{bgs}$ (Table 2.7, Figure 2.19). Many of the samples were overdriven beyond the $1.25-\mathrm{ft}$ length of the splitspoon, which resulted in over-compaction of some samples. In all, $26.74 \mathrm{ft}$ of core was drilled in C3831, which accounts for about $23 \%$ of the total length of the hole. No samples or drill cuttings were collected between the 20 core runs because the hole was advanced in a closed configuration using a solid, removable tip. The surface elevation of the since abandoned borehole was $674.63 \mathrm{ft}$ above mean sea level and geographic coordinates were N136167.19 m and E566732.93 m (Gardner et al. 2002a). Borehole C3831 was decommissioned on August 13-14, 2002 by back-pulling the casing while filling the annulus with dry bentonite (Gardner et al. 2002a). 
The same as the other boreholes documented in this report, each splitspoon contained two 0.5 -ft-long stainless-steel core liners. A separate subsample was collected from each of the two liners for physical and chemical characterization, making a total of 40 characterization samples collected within this borehole. All but three of the 40 liners were completely full (Gardner et al. 2002a).

All cores were extracted, sampled, photographed, and geologically logged on August 14-15, 2002 in a radiologically controlled PNNL laboratory. Geologic logs of the material within the core liners were generated by geologists Victoria Johnson (Kennedy / Jenks) and Bruce Bjornstad (PNNL); the core logs for these two geologists are presented in Gardner et al. (2002a) and Appendix B.2 of this report, respectively. Geologic logging occurred after the contents of each 0.5 -ft stainless-steel core liner was emptied into an open plastic container, followed by photographing and subsampling for physical and chemical characterization. Upon completion of these activities the contents in the plastic containers were sealed shut and placed into cold storage for archival purposes.

No radiological contamination was detected with field instrumentation during the driving and sampling of borehole C3831; however, HPGe spectral logging did detect cobalt-60 from $52 \mathrm{ft}$ (near the base of the backfill and tanks) to total depth (Gardner et al. 2002a). Because of contamination with radionuclides, the total gamma signal is significantly greater than natural background and therefore not useful for interpreting lithology, especially between 52-77 ft bgs (Figure 2.19). 
Table 2.7. Splitspoon Core Samples from C3831. Two characterization samples (labeled "A" and "B") were collected from each of the cores for a total of 40 samples.

\begin{tabular}{|c|c|c|c|c|c|c|c|c|}
\hline $\begin{array}{c}\text { Core } \\
\text { Sample ID }\end{array}$ & COC\# & $\begin{array}{c}\text { Top } \\
\text { Depth } \\
\text { (ft) }\end{array}$ & $\begin{array}{l}\text { Bottom } \\
\text { Depth } \\
\text { (ft) }\end{array}$ & $\begin{array}{c}\text { Mid } \\
\text { Depth } \\
(\mathbf{f t})\end{array}$ & $\begin{array}{c}\text { Sampled } \\
\text { Interval } \\
\text { Thickness } \\
\text { (ft) }\end{array}$ & Lithology & $\begin{array}{l}\text { Strati- } \\
\text { graphic } \\
\text { Unit }\end{array}$ & Comments \\
\hline C3831-15 & S02057-01 & 14.93 & 16.31 & 15.62 & 1.38 & Silty sandy gravel & backfill & \\
\hline C3831-21 & S02057-02 & 20.80 & 22.30 & 21.55 & 1.50 & Silty sandy gravel & backfill & \\
\hline C3831-28 & S02057-03 & 27.96 & 29.21 & 28.59 & 1.25 & Silty sandy gravel & backfill & \\
\hline C3831-45 & S02057-04 & 45.06 & 46.39 & 45.73 & 1.33 & $\begin{array}{l}\text { Silty sand to } \\
\text { gravelly sand }\end{array}$ & backfill & \\
\hline C3831-51 & S02057-05 & 51.01 & 52.36 & 51.69 & 1.35 & $\begin{array}{l}\text { Silty gravelly } \\
\text { sand to silty sandy } \\
\text { gravel to silty } \\
\text { sand }\end{array}$ & backfill/H2 & $\begin{array}{l}\text { Contact between } \\
\text { backfill and } \mathrm{H} 2 \text { at } \\
52.3 \mathrm{ft} \text { bgs }\end{array}$ \\
\hline C3831-52 & S02057-06 & 52.16 & 53.51 & 52.84 & 1.35 & Sand & $\mathrm{H} 2$ & \\
\hline C3831-59 & $\mathrm{S} 02057-07$ & 59.04 & 60.24 & 59.64 & 1.20 & Sand to silty sand & $\mathrm{H} 2$ & \\
\hline C3831-60 & S02057-08 & 60.08 & 61.50 & 60.79 & 1.42 & $\begin{array}{l}\text { Sand, silt and clay } \\
\text { (clastic dike) to } \\
\text { sand }\end{array}$ & $\mathrm{H} 2$ & \begin{tabular}{l|} 
Excess free water \\
observed while \\
sampling; ${ }^{60} \mathrm{Co}$ \\
contamination \\
(Gardner et al. \\
2002a); upper half \\
of this core is a \\
clastic dike; 0.16 \\
$\mathrm{ft}$ of overlap with \\
sample above
\end{tabular} \\
\hline C3831-67 & $\mathrm{S} 02057-09$ & 67.19 & 68.54 & 67.87 & 1.35 & Sand to silty sand & $\mathrm{H} 2$ & \\
\hline C3831-69 & S02057-10 & 68.43 & 69.98 & 69.21 & 1.55 & Sand to silty sand & $\mathrm{H} 2$ & \begin{tabular}{|l||}
${ }^{60} \mathrm{Co}$ \\
contamination \\
$($ Gardner et al. \\
2002a); $0.11 \mathrm{ft}$ of \\
overlap with \\
sample above
\end{tabular} \\
\hline C3831-74 & S02057-11 & 74.04 & 75.30 & 74.67 & 1.26 & Sand to silty sand & $\mathrm{H} 2$ & \\
\hline C3831-77 & S02057-12 & 76.73 & 77.98 & 77.36 & 1.25 & Sand to silty sand & $\mathrm{H} 2$ & \\
\hline
\end{tabular}


Table 2.7. (contd)

\begin{tabular}{|c|c|c|c|c|c|c|c|c|}
\hline $\begin{array}{c}\text { Core } \\
\text { Sample ID }\end{array}$ & COC\# & $\begin{array}{c}\text { Top } \\
\text { Depth } \\
\text { (ft) }\end{array}$ & $\begin{array}{c}\text { Bottom } \\
\text { Depth } \\
(\mathbf{f t})\end{array}$ & $\begin{array}{l}\text { Mid } \\
\text { Depth } \\
\text { (ft) }\end{array}$ & $\begin{array}{c}\text { Sampled } \\
\text { Interval } \\
\text { Thickness } \\
\text { (ft) }\end{array}$ & Lithology & $\begin{array}{l}\text { Strati- } \\
\text { graphic } \\
\text { Unit }\end{array}$ & Comments \\
\hline C3831-78 & S02057-13 & 77.76 & 79.04 & 78.40 & 1.28 & $\begin{array}{l}\text { Sand to silty } \\
\text { sand }\end{array}$ & $\mathrm{H} 2$ & $\begin{array}{l}0.22 \mathrm{ft} \text { of overlap } \\
\text { with sample above }\end{array}$ \\
\hline C3831-85 & S02057-14 & 85.05 & 86.30 & 85.68 & 1.25 & $\begin{array}{l}\text { Sand to silty } \\
\text { sand to sandy } \\
\text { silt }\end{array}$ & $\mathrm{H} 2$ & \\
\hline C3831-88 & S02057-15 & 88.30 & 89.75 & 89.03 & 1.45 & Sand & $\mathrm{H} 2$ & \\
\hline C3831-93 & S02057-16 & 93.05 & 94.30 & 93.68 & 1.25 & Sand & $\mathrm{H} 2$ & \\
\hline C3831-97 & S02057-17 & 97.11 & 98.38 & 97.75 & 1.27 & $\begin{array}{l}\text { Sand to silty } \\
\text { sand and silt }\end{array}$ & $\mathrm{H} 2$ & \\
\hline C3831-100 & S02057-18 & 100.20 & 101.65 & 100.93 & 1.45 & $\begin{array}{l}\text { Sand to silty } \\
\text { sand }\end{array}$ & $\mathrm{H} 2$ & \\
\hline C3831-102 & S02057-19 & 101.63 & 102.98 & 102.31 & 1.35 & Silty sand & $\mathrm{CCU}_{\mathrm{u}}$ & $\begin{array}{l}0.02 \mathrm{ft} \text { of overlap } \\
\text { with sample above }\end{array}$ \\
\hline C3831-114 & S02057-20 & 114.12 & 115.37 & 114.75 & 1.25 & $\begin{array}{l}\text { Slightly } \\
\text { gravelly } \\
\text { muddy sand }\end{array}$ & $\mathrm{CCU}_{1}$ & $\begin{array}{l}\text { Borehole refuses to } \\
\text { advance through } \\
\text { cemented caliche }\end{array}$ \\
\hline
\end{tabular}

The hole was advanced via a solid probe so no grab samples were collected between core runs; thus no geologic field $\log$ is available for this hole. Figure 2.19 presents a summary log for C3831 based on available geologic descriptions, core photographs, geophysical logs, laboratory measured gravimetric moisture, and blow-count data. The geology between core runs is inferred and interpreted based on these data. Four primary stratigraphic units were encountered by this borehole: 1) recent backfill materials, 2) the Hanford formation, 3) the Cold Creek unit, and 4) the Ringold Formation. A brief description of the sampled materials from each of these stratigraphic intervals is presented in Sections 2.3.4.1-2.3.4.3.2. 


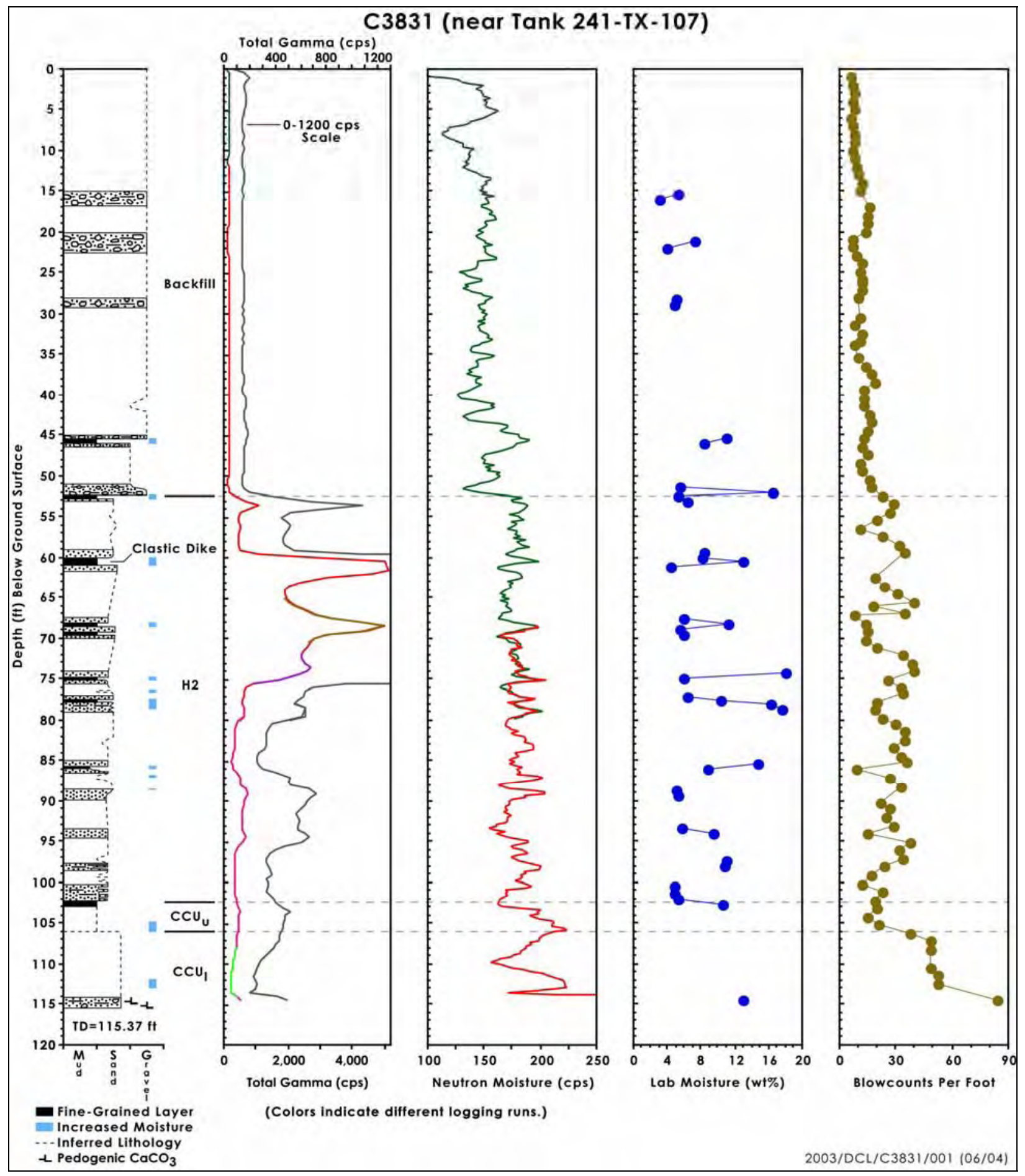

Figure 2.19. Summary Hydrogeologic Log for Borehole C3831. Penetration resistance

(i.e., blow-count) data is from Gardner et al. (2002a). Zones of increased moisture are indicated as those with $>15 \mathrm{wt} \%$ water in core samples and/or show as distinct spikes on neutron-moisture log. Fine-grained layers are defined as those consisting predominantly of particles $\leq 0.25 \mathrm{~mm}$ in diameter (i.e., fine sand and smaller). 


\subsubsection{Backfill}

The backfill extends from the ground surface to a depth of $15.9 \mathrm{~m}(52.3 \mathrm{ft})$ where it lies in contact with the Hanford formation (Figure 2.19). This depth is consistent with a minimum depth of $45 \mathrm{ft}$ required to completely bury tanks used at the TX Tank Farm (Crumpler 2002). Five of the 20 splitspoons contained backfill materials. The backfill material consisted of predominantly dark gray to brown, poorly to very poorly sorted, silty sandy gravel, which was unconsolidated and moderately calcareous. A finer-grained layer of laminated silty sand, about one $\mathrm{ft}$ thick, occurred within the backfill at about $46 \mathrm{ft}$ bgs (Figure 2.20). Rust-coated fragments of metal (nails?) at the base of this layer prove a backfill origin.

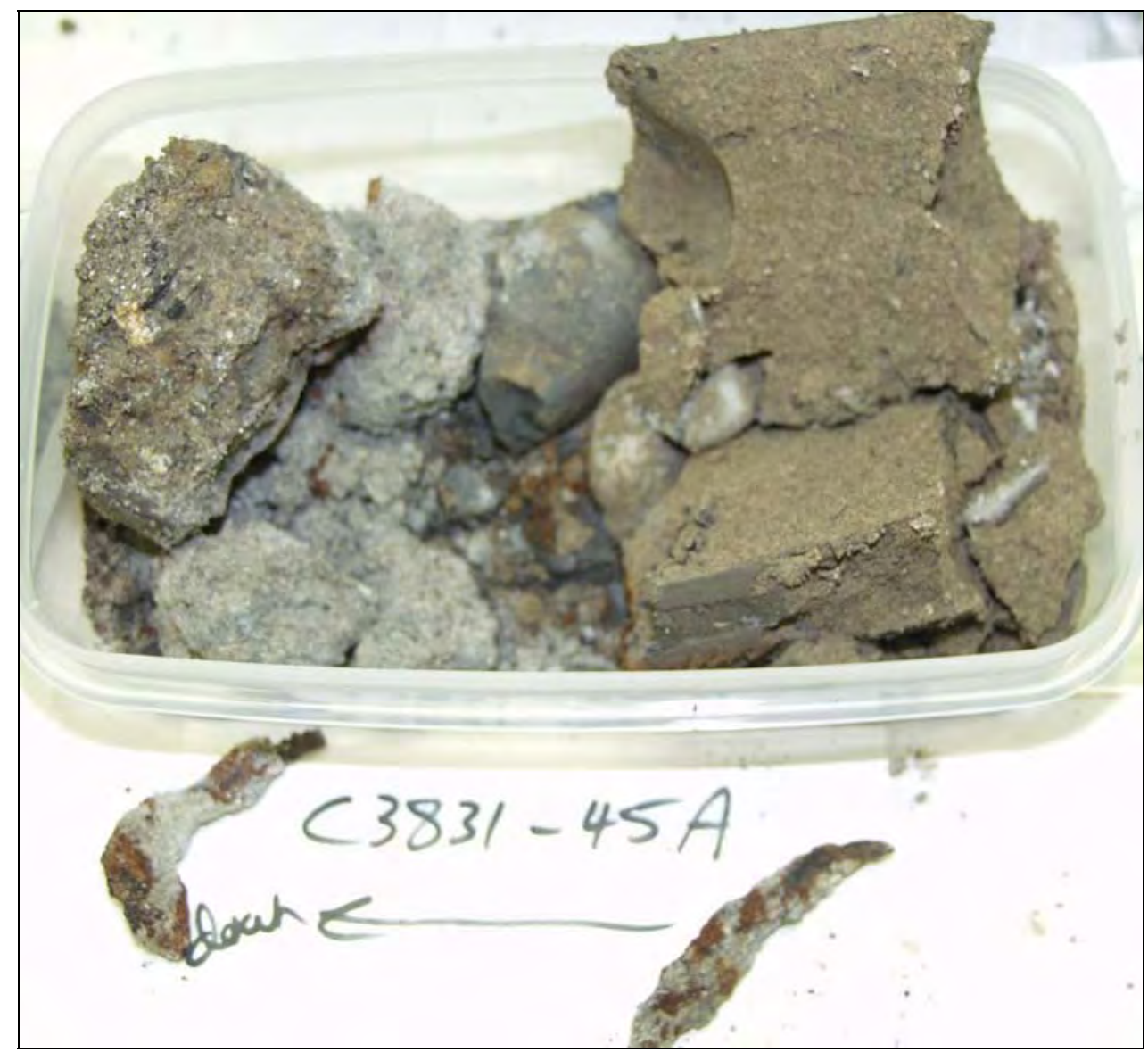

Figure 2.20. Rusted Metal Fragments from Backfill Material in C3831. Metal fragments came from $46 \mathrm{ft}$ depth. The top of the 0.5-ft core is to the right.

The total gamma and neutron-moisture activity is generally low in the backfill materials. Blow counts are also lower in the backfill, compared to the underlying Hanford formation (Figure 2.19). Because of subsurface contamination with radionuclides below the backfill, background gamma activity appears washed out through the backfill in Figure 2.19 and therefore not very useful for interpreting lithology. 


\subsubsection{Hanford Formation}

About $50 \mathrm{ft}$ of Pleistocene cataclysmic flood deposits of the Hanford formation underlie backfill materials in C3831. Only the sand-dominated Hanford formation $\mathrm{H} 2$ is represented; all of the coarsergrained Hanford formation H1 unit was removed during tank-farm construction and later used as backfill around the tanks.

\subsection{Hanford Formation H2 Unit}

The Hanford formation $\mathrm{H} 2$ unit is present between 52.3 to $102.2 \mathrm{ft}$ bgs. A total of 27 physical and chemical characterization samples were collected from within this unit (Table 2.7). The Hanford formation $\mathrm{H} 2$ sediments consist of mostly fine to coarse sand, sometimes capped or interbedded with thin beds of silty fine sand to silt (Figures 2.21 and 2.22). The fine to coarse sand beds are loose, massive to laminated, brownish-gray to olive-brown, moderately to well-sorted, and weakly to moderately calcareous. Finer-grained beds are generally very well sorted, cohesive, massive to laminated, yellowishto olive-brown, and moderately to strongly calcareous.

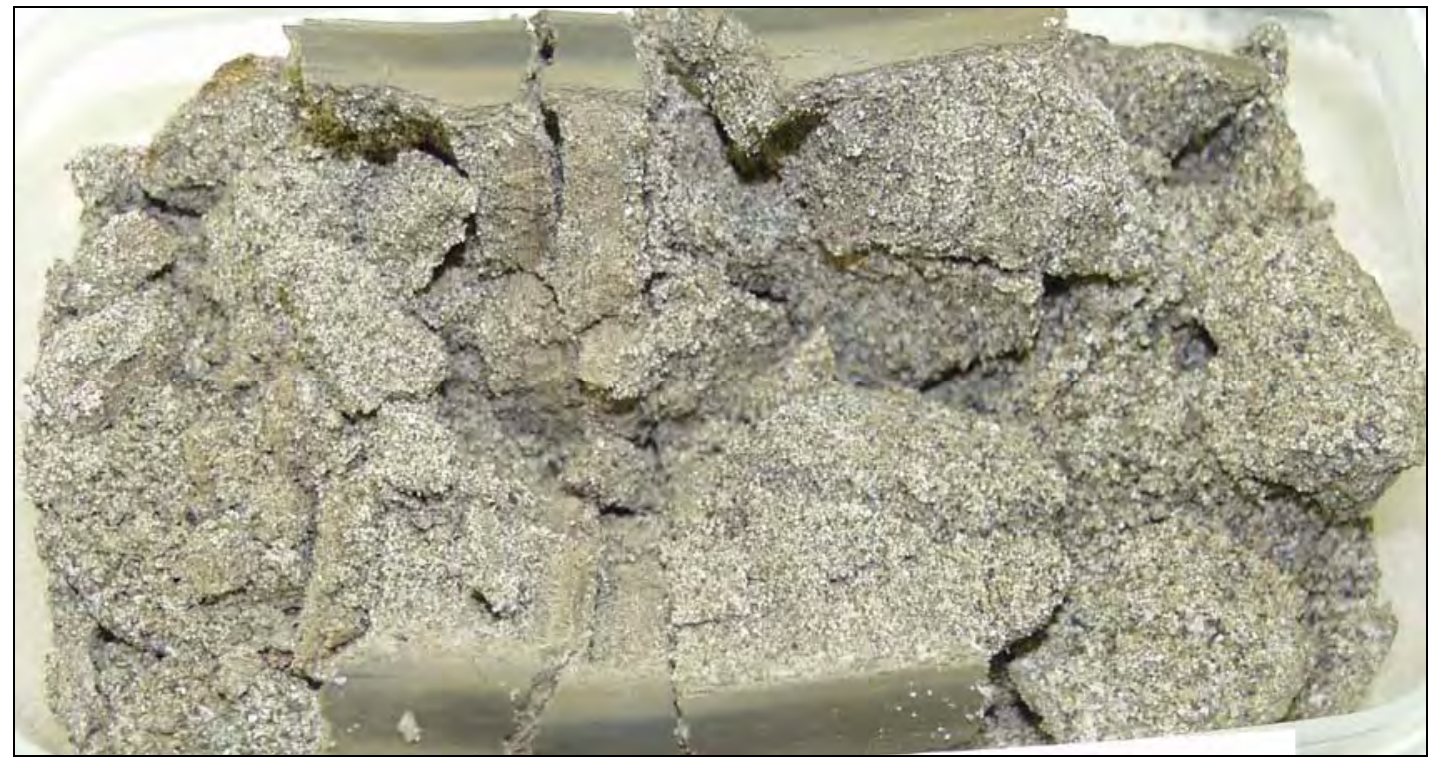

Figure 2.21. Hanford Formation H2 Unit in C3831 - Core C3831-69A. Mostly a slightly moist, loose, well-sorted, laminated, moderately calcareous, medium to coarse, "salt and pepper"-like, grayish-brown sand (S). A few thin lenses of brownish, silty fine sand ( $\mathrm{mS}$ ) are interspersed. The top of the 0.5-ft-long core is to the right.

The base of the Hanford formation in C3831 contains a number of fine-grained layers of silty fine sand to silt interbedded with coarser sands (Figure 2.22). Two types of soft-sediment deformation were observed within the Hanford formation $\mathrm{H} 2$ unit of C3831: 1) a clastic dike, and 2) load structures (Figure 2.23). A single clastic dike was observed within the Hanford formation $\mathrm{H} 2$ unit at about $60 \mathrm{ft}$ bgs. The clastic dike is characterized by compact and cohesive, sub-vertically laminated, grayish brown sand to dark gray silt and clay. A few small pebbles are also present within the dike, which is moderately calcareous. The clastic dike shows a higher moisture content compared to adjacent strata, probably as a 


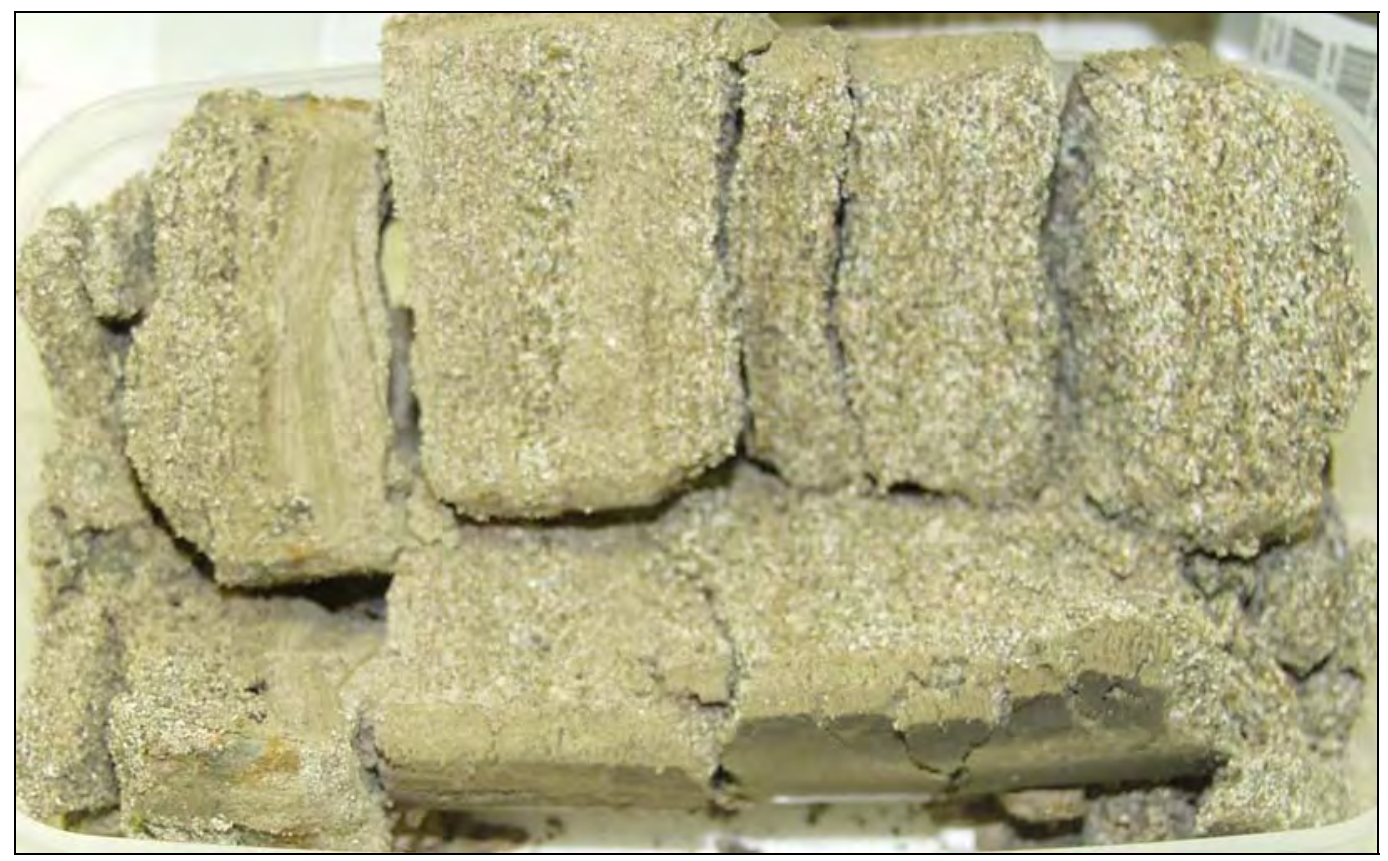

Figure 2.22. Interbedded, Laminated Sand and Silt Near Base of the Hanford Formation H2 Unit

- Core 3831-97A. Slightly moist, loose, fine to medium sand $(S)$ is interbedded with more cohesive silty fine sand $(\mathrm{mS})$ to silt (M) layers.

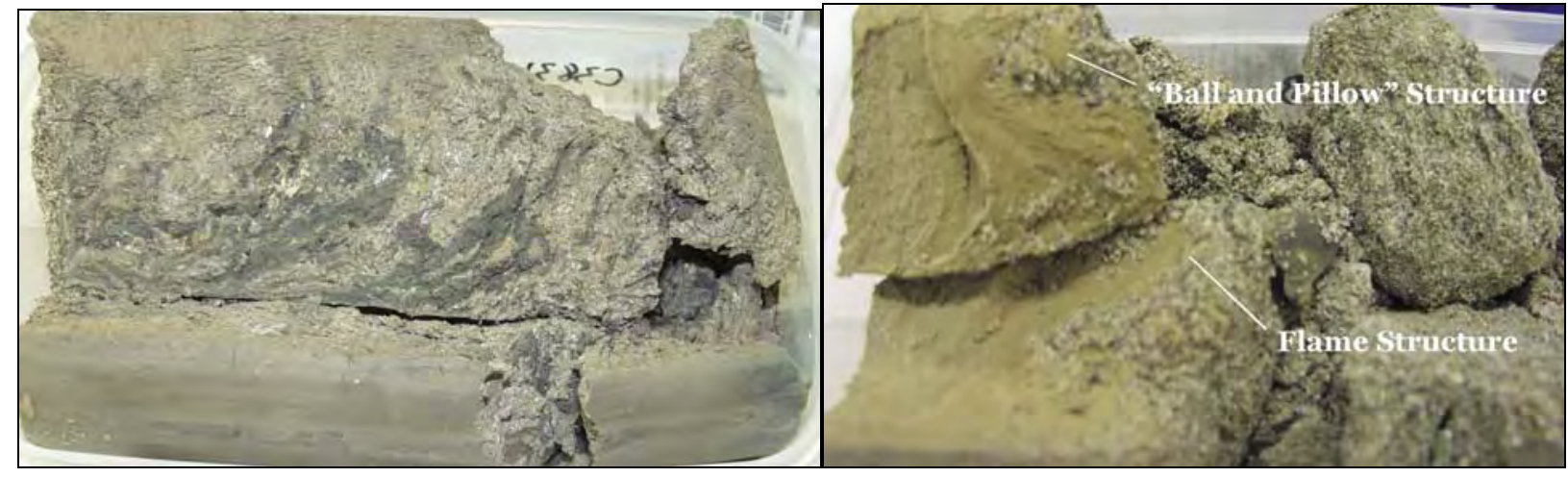

Figure 2.23. Soft-Sediment Deformation Within the Hanford Formation H2 Unit. Left Photo: Core C3831-60B, 0.5-ft long. Moist clastic dike, with alternating sub-vertical layers of sand, silt, and clay. Right Photo: C3831-85B, 0.3-ft long. Syndepositional loading and deformation occurred along the contact between slightly moist, fine to medium sand (above) and moist silt (below). The tops of the cores are to the right.

result of the presence of more fine-grained material, which tends to retain more moisture. Discordant clastic dikes, which are common to the Hanford formation, probably formed during or soon after Ice-Age flood episodes (Fecht et al. 1999). 
"Ball and pillow" and flame structures (right photo in Figure 2.23) are a type of soft sediment deformation related to the differential loading of rapidly deposited sediment (Reineck and Singh, 1975). The mechanism involves rapid flood deposition onto a saturated and fine-grained substrate, which is unable to support the sudden added weight and loading of the overlying bed. As a result, material from the underlying bed is squeezed upward and protrudes into the overlying bed, creating flame structures. Where the underlying fine-grained material became completly enveloped within the coarser overlying material, "ball and pillow" structures formed.

\subsubsection{Cold Creek Unit}

The contact between the Cold Creek unit and the overlying Hanford formation $\mathrm{H} 2$ unit lies at about 102.2 $\mathrm{ft}$ bgs (Figure 2.19). Two samples each were collected for characterization from the upper and lower Cold Creek units, respectively.

\subsection{Upper Cold Creek Unit $\left(\mathrm{CCU}_{\mathrm{u}}\right)$}

Sediments from this unit are compact and well-sorted silt to silty fine sand, which range from laminated to massive and moderately to strongly calcareous. An image of one of the cores collected from the top of the upper CCU in C3831 is shown in Figure 2.24. The upper CCU in C3831 is relatively thin (only $3.8 \mathrm{ft}$-thick) compared to other nearby boreholes. As in most other holes through the upper CCU, the neutron moisture and total gamma activity are slightly elevated on geophysical logs (Figure 2.19).

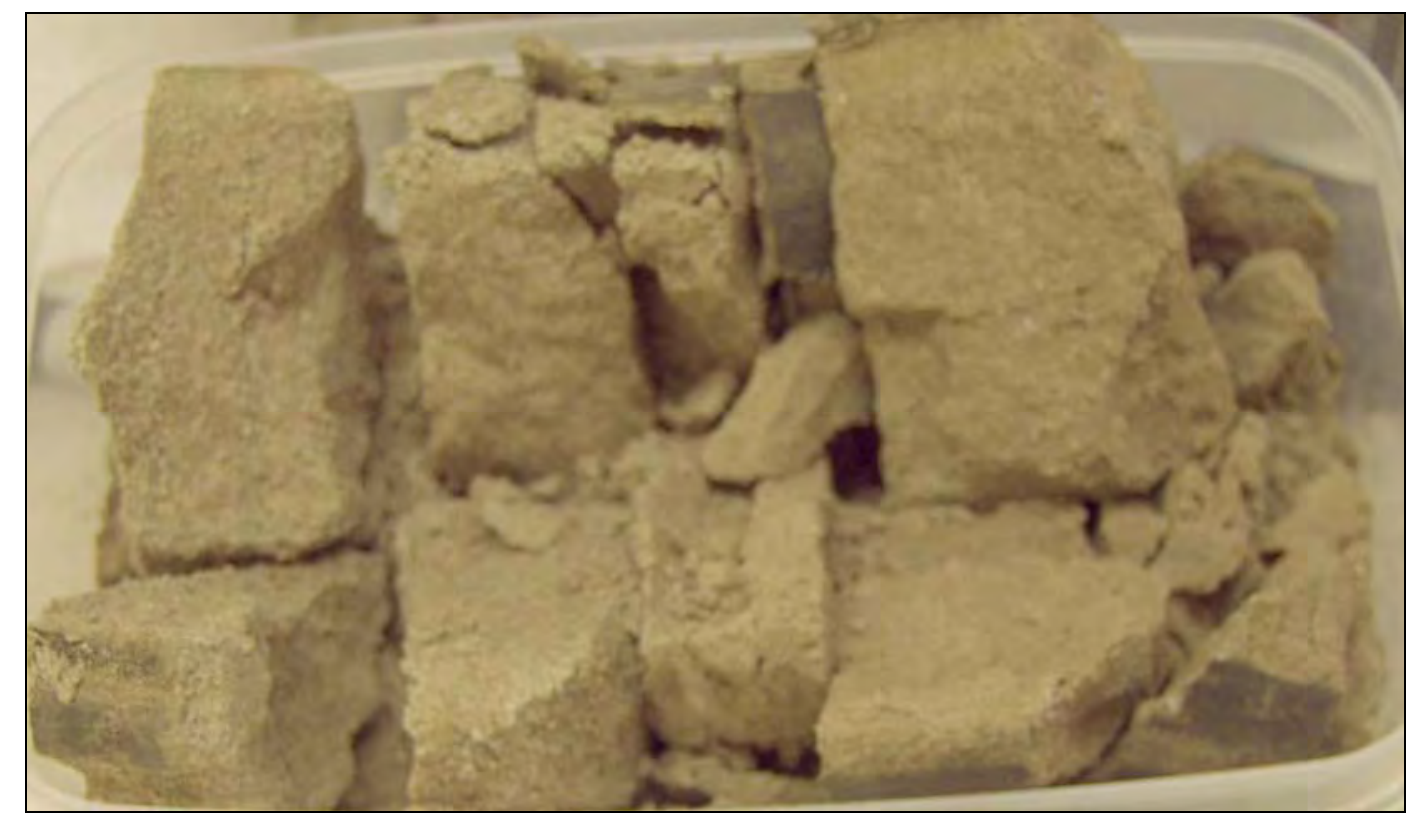

Figure 2.24. Upper Cold Creek Unit in C3831 - Core 3831-102A. Described as slightly moist, weakly laminated, well-sorted, strongly calcareous, yellowish-brown, silty fine sand (mS). The top of the 0.5-ft core is to the right. 


\subsection{Lower Cold Creek Unit $\left(\mathrm{CCU}_{1}\right)$.}

The top of the lower CCU lies at a depth of about $106 \mathrm{ft}$, where there is a sudden increase in penetration resistance (Figure 2.19) and extends to the bottom of the hole at $115.37 \mathrm{ft}$. The casing met refusal between 113.9 and $114.1 \mathrm{ft}$ bgs. The hard, cemented nature of the formation was corroborated by the permanent damage to the shoe, as observed upon removal of the casing (Gardner et al. 2002a). Only a single core was obtained from the lower $\mathrm{CCU}$; this came from the bottom of the borehole (Figure 2.25).

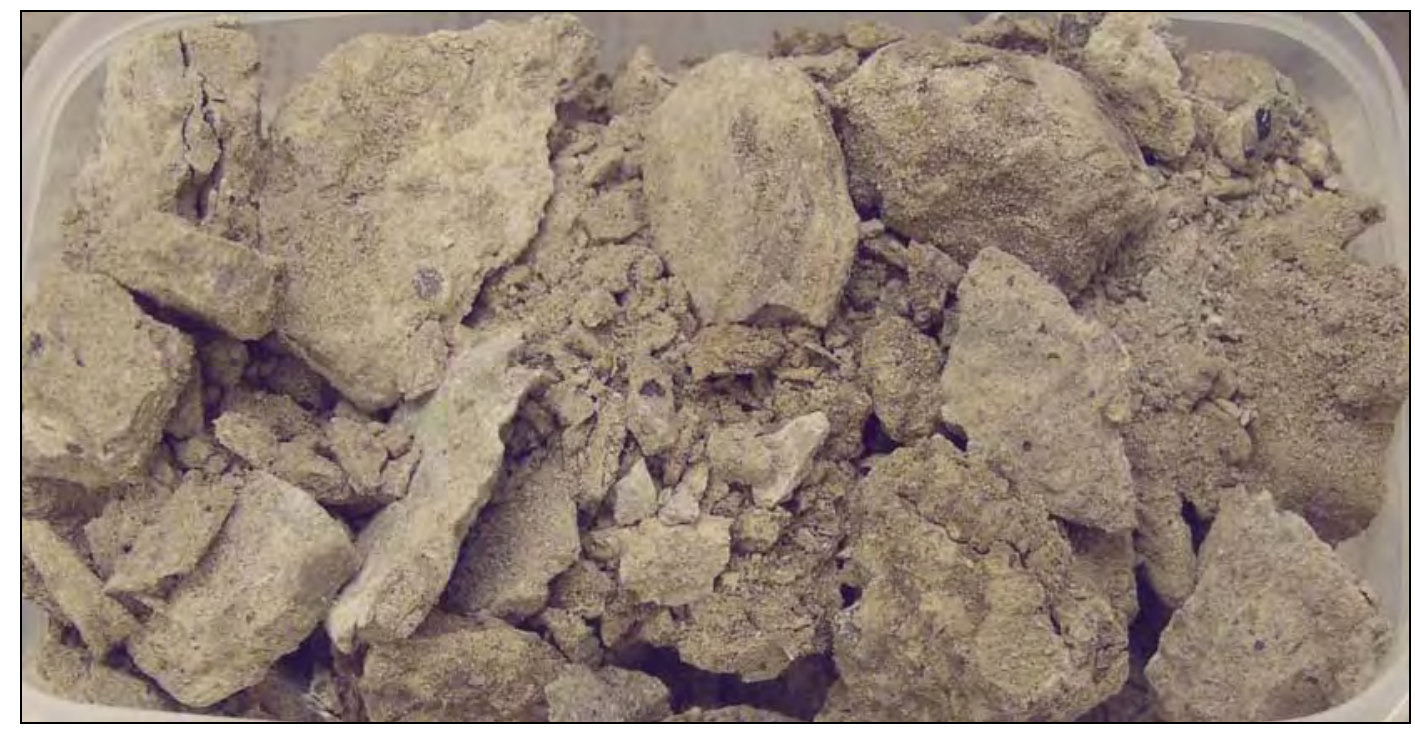

Figure 2.25. Lower Cold Creek Unit Within C3831 - Core 3831-114A. Described as slightly moist, poorly sorted, strongly to very strongly calcareous, moderately to strongly consolidated, yellowish brown, slightly gravelly silty sand ( $[\mathrm{g}] \mathrm{zS})$, mottled with gray to brownish-gray, pedogenic, calcium-carbonate cemented caliche nodules and stringers. Includes about 5\% small, angular, matrix-supported basalt pebbles. The sample in the tray had to be broken up in order to be removed from the core liner. The top of the 0.5-ft core is to the right.

\subsubsection{Hydrogeology of Borehole C3832 (TX-104)}

Borehole C3832 was drilled and sampled using a driven-probe technique between May 2 and June 3, 2002 (Gardner et al. 2002b). The borehole is located about $20 \mathrm{ft}(6 \mathrm{~m})$ south-southeast of single-shell tank 241-TX-104 (Figure 2.4). Total depth of the borehole was $115.89 \mathrm{ft}(35.3 \mathrm{~m}) \mathrm{bgs}$; casing refusal (blow counts in excess of 120 blows per foot) occurred at $113.77 \mathrm{ft} \mathrm{bgs} \mathrm{(Gardner} \mathrm{et} \mathrm{al.}$ $2002 \mathrm{~b}$ ). Soon afterwards, the hole was terminated about $100 \mathrm{ft}(30 \mathrm{~m})$ above the groundwater table.

During drilling, a total of 19, 1.25-ft-long by 2.5-in.-diameter splitspoon core samples were collected intermittently starting at a depth of about $16 \mathrm{ft}$ bgs (Table 2.8, Figure 2.26). Two, 0.5-ft-long stainless-steel core liners were collected during each core run. One characterization sample was obtained from each 0.5 - $\mathrm{ft}$ liner, for a total of 38 characterization samples. In all, $27.09 \mathrm{ft}$ of core was drilled, which accounts for about $23 \%$ of the total length of the hole (Table 2.2). Most of the samples were driven beyond the 1.25 -ft length of the splitspoon, suggesting most cores were over-compacted during drilling. While over-compaction can destroy the sedimentary structure and alter hydraulic properties (i.e., density and porosity), it does not adversely affect chemical or radiological analysis. No samples or drill cuttings 
were collected between the 19 core runs since the hole was advanced in a closed configuration using a solid, removable tip. Borehole C3832 was decommissioned on June 12-13, 2002 by back-pulling the casing while filling the hole with dry bentonite. The surface elevation of the abandoned borehole was $676.57 \mathrm{ft}$ above mean sea level and the geographic coordinates were N136137.32 m and E566717.68 m (Gardner et al. 2002b).

Core extraction, logging and sampling were performed later in a radiologically controlled PNNL laboratory between June 11-12, 2002. A geologic log of the material within the core liners was compiled by geologists Victoria Johnson (Kennedy / Jenks Consultants, Inc.) and Bruce Bjornstad (PNNL); the core $\log$ s for these two geologists are presented in Gardner et al. (2002b) and, for Bjornstad, in Appendix B.3 of this report, respectively. Geologic logging occurred after each 0.5 -ft core segment was emptied into an open plastic container, followed by photographing and subsampling for physical and chemical characterization. Upon completion of these activities, the contents in the plastic containers were sealed shut and placed into cold storage for archival purposes.

Between core runs, the hole was advanced using a closed-end probe so no grab samples were collected between core runs; thus no geologic field log is available for this hole. Figure 2.26 presents a summary log for $\mathrm{C} 3832$ based on geologic descriptions, core photographs, laboratory-derived gravimetric moisture, blow counts, and geophysical logs. The geology between core runs is inferred and interpreted based on the geophysical log and blow-count data. Four primary stratigraphic units were encountered in this borehole: 1) recent backfill material, 2) the Hanford formation, 3) the Cold Creek unit, and 4) the Ringold Formation. The description and photographs of the sampled materials from each of these major stratigraphic units is presented below. 
Table 2.8. Splitspoon Core Samples from C3832. Two characterization samples, labeled "A" and " $B$ " were collected from each of the cores for a total of 38 samples.

\begin{tabular}{|c|c|c|c|c|c|c|c|c|}
\hline $\begin{array}{c}\text { Core } \\
\text { Sample } \\
\text { ID }\end{array}$ & COC\# & \begin{tabular}{|c|} 
Top \\
Depth \\
(ft)
\end{tabular} & $\begin{array}{c}\text { Bottom } \\
\text { Depth } \\
(\mathbf{f t})\end{array}$ & $\begin{array}{l}\text { Mid } \\
\text { Depth } \\
\text { (ft) }\end{array}$ & $\begin{array}{c}\text { Sampled } \\
\text { Interval } \\
\text { Thickness } \\
\text { (ft) }\end{array}$ & Lithology & $\begin{array}{l}\text { Strati- } \\
\text { graphic } \\
\text { Unit }\end{array}$ & Comments \\
\hline C3832-15 & S02046-02 & 16.21 & 17.61 & 16.91 & 1.40 & $\begin{array}{l}\text { Silty sandy } \\
\text { gravel }\end{array}$ & backfill & \\
\hline C3832-28 & S02046-03 & 28.09 & 29.49 & 28.79 & 1.40 & $\begin{array}{l}\text { Silty sandy } \\
\text { gravel }\end{array}$ & backfill & \\
\hline C3832-37 & S02046-04 & 36.09 & 37.49 & 36.79 & 1.40 & Sandy gravel & backfill & \\
\hline C3832-44 & S02046-05 & 44.14 & 45.54 & 44.84 & 1.40 & Silty sand & backfill & $\begin{array}{l}\text { Free water present during } \\
\text { sampling }\end{array}$ \\
\hline C3832-52 & S02046-06 & 51.18 & 52.28 & 51.73 & 1.10 & Sand & $\mathrm{H} 2$ & \\
\hline C3832-53 & S02046-07 & 53.08 & 54.43 & 53.76 & 1.35 & $\begin{array}{l}\text { Sand to silty } \\
\text { sand }\end{array}$ & $\mathrm{H} 2$ & \\
\hline C3832-61 & S02046-08 & 60.12 & 61.52 & 60.82 & 1.40 & Sand & $\mathrm{H} 2$ & \\
\hline C3832-62 & S02046-09 & 61.76 & 63.36 & 62.56 & 1.60 & $\begin{array}{l}\text { Silty sand to } \\
\text { sand }\end{array}$ & $\mathrm{H} 2$ & \\
\hline C3832-69 & S02046-10 & 69.01 & 70.31 & 69.66 & 1.30 & $\begin{array}{l}\text { Sand to silty } \\
\text { sand }\end{array}$ & $\mathrm{H} 2$ & \\
\hline C3832-76 & S02046-11 & 75.99 & 77.39 & 76.69 & 1.40 & $\begin{array}{l}\text { Sand to silty } \\
\text { sand }\end{array}$ & $\mathrm{H} 2$ & \\
\hline C3832-79 & S02046-12 & 78.29 & 80.31 & 79.30 & 2.02 & $\begin{array}{c}\text { Sand to silty } \\
\text { sand/sandy silt }\end{array}$ & $\mathrm{H} 2$ & \\
\hline C3832-83 & S02046-13 & 82.99 & 84.34 & 83.67 & 1.35 & $\begin{array}{l}\text { Sand to silty } \\
\text { sand }\end{array}$ & $\mathrm{H} 2$ & $\begin{array}{l}{ }^{60} \text { Co contamination along } \\
\text { contact between sand/silt } \\
\text { (Gardner et al. 2002c) }\end{array}$ \\
\hline C3832-87 & S02046-14 & 86.99 & 88.41 & 87.70 & 1.42 & $\begin{array}{l}\text { Sand to silty } \\
\text { sand }\end{array}$ & $\mathrm{H} 2$ & \\
\hline C3832-93 & S02046-15 & 92.99 & 94.40 & 93.70 & 1.41 & $\begin{array}{l}\text { Sand to silty } \\
\text { sand }\end{array}$ & $\mathrm{H} 2$ & \\
\hline C3832-96 & S02046-16 & 95.64 & 97.04 & 96.34 & 1.40 & Sand & $\mathrm{H} 2$ & \\
\hline C3832-104 & S02046-17 & 103.94 & 105.36 & 104.65 & 1.42 & Silty sand to silt & $\mathrm{CCU}_{\mathrm{u}}$ & \\
\hline C3832-110 & S02046-18 & 109.91 & 111.38 & 110.65 & 1.47 & $\begin{array}{l}\text { Silty sand to } \\
\text { calcic pebbly } \\
\text { muddy sand }\end{array}$ & $\mathrm{CCU}_{\mathrm{u}} / \mathrm{CCU}_{1}$ & $\begin{array}{c}\text { Contact between upper and } \\
\text { lower Cold Creek unit } \\
\text { at } 110.4 \mathrm{ft}\end{array}$ \\
\hline C3832-114 & S02046-19 & 113.77 & 115.20 & 114.49 & 1.43 & $\begin{array}{l}\text { Pebbly sandy } \\
\text { mud }\end{array}$ & $\mathrm{CCU}_{1}$ & \\
\hline C3832-121 & S02046-20 & 114.47 & 115.89 & 115.18 & 1.42 & $\begin{array}{l}\text { Pebbly sandy } \\
\text { mud }\end{array}$ & $\mathrm{CCU}_{1}$ & $\begin{array}{c}0.73 \mathrm{ft} \text { of overlap with sample } \\
\text { above }\end{array}$ \\
\hline
\end{tabular}




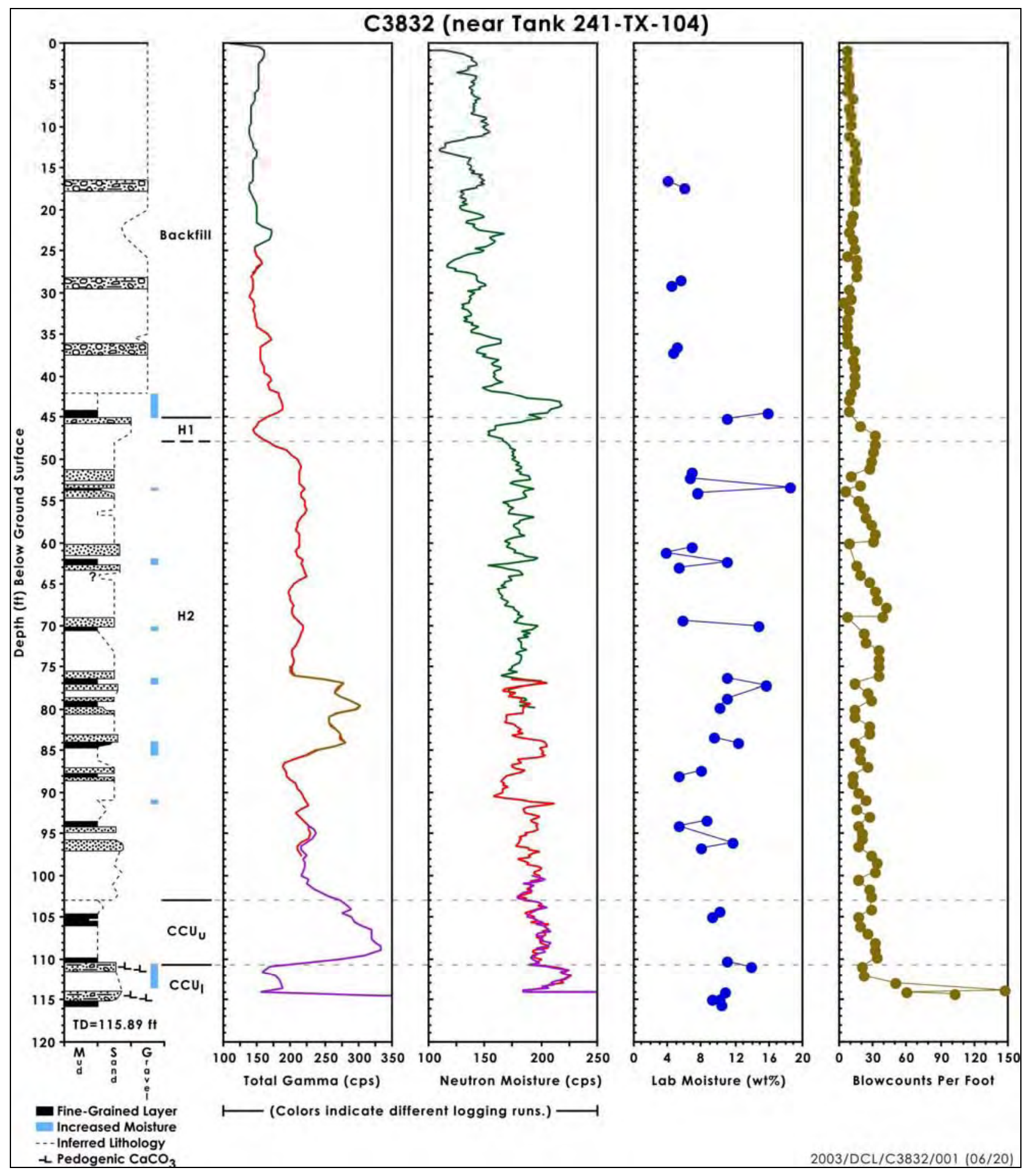

Figure 2.26. Summary Hydrogeologic Log for Borehole C3832. Penetration resistance

(i.e., blow-count) data is from Gardner et al. (2002b). Zones of increased moisture are indicated as those with $>15 \mathrm{wt} \%$ water in core samples and/or show as distinct spikes on the neutron-moisture log. Fine-grained layers are defined as those consisting predominantly of particles $\leq 0.25 \mathrm{~mm}$ in diameter (i.e., fine sand and smaller). 


\subsubsection{Backfill}

The backfill extends from the ground surface to a depth of $45 \mathrm{ft}(13.7 \mathrm{~m})$ where it lies in contact with the Hanford formation (Figure 2.26). This depth is exactly the height of the tanks buried in the TX Tank Farm (Crumpler 2002). Four of the 19 splitspoons contained backfill materials. The backfill material consisted of mostly loose, dark gray to brown, very poorly sorted, sandy gravel to silty sandy gravel, which was slightly moist and weakly to moderately calcareous (Figure 2.27). Several feet or more of wet to moist, cohesive, well-sorted, strongly calcareous, dark grayish-brown, silty fine sand is present at the base of the backfill sequence (Figure 2.28). This material appears to be from a compacted zone at the bottom of the tank-farm excavation; free water was reported in this material during core sampling (Gardner et al. 2002b). Fine-grained sand and silt was occasionally placed at and toward the base of the backfill within the TX Tank Farm, apparently to improve traction for construction vehicles (DOE-GJO 1997).

The total gamma and neutron-moisture activity is generally low in the backfill materials of C3832. Blow counts are also uniformly lower in the backfill, compared to the underlying Hanford formation (Figure 2.26).

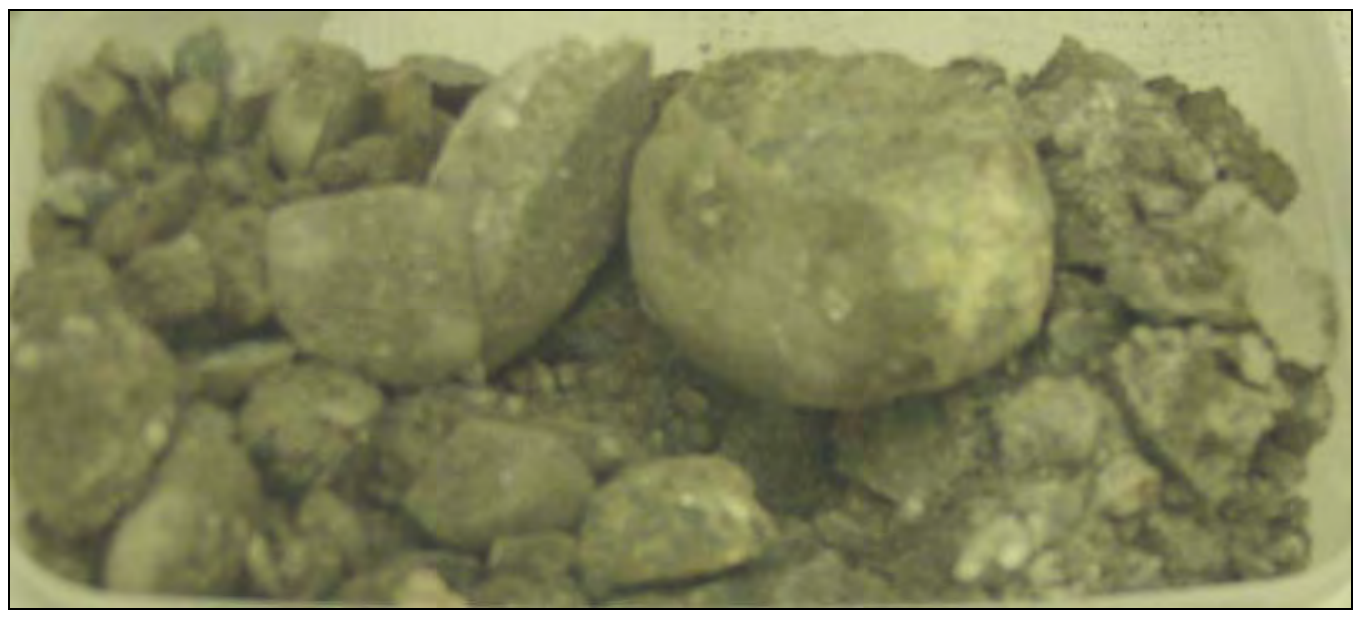

Figure 2.27. Backfill from C3832 - Core C3832-28A. Described as slightly moist, loose, very poorly sorted, weakly to moderately calcareous, dark grayish-brown, silty sandy gravel (msG). The top of the 0.5-ft core is to the right. 


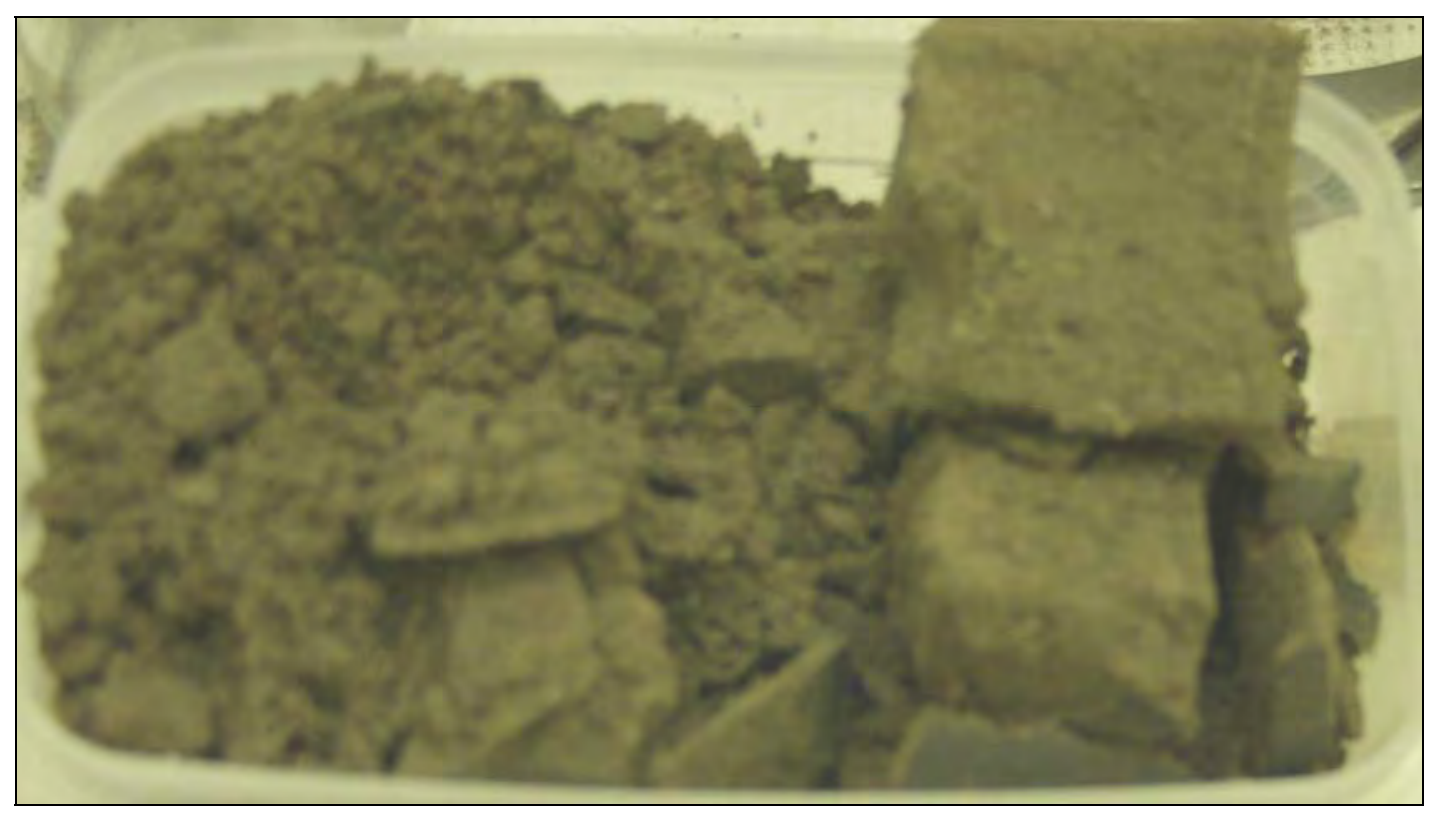

Figure 2.28. Fine-Grained Sediments at Base of Backfill Sequence - Core C3832-44A. Described as a moist, consolidated, well-sorted, strongly calcareous, dark grayish-brown, felsic, silty fine to very fine sand $(\mathrm{mS})$. The top of the 0.5-ft core is to the right.

\subsubsection{Hanford Formation}

A total of $58 \mathrm{ft}$ of Pleistocene cataclysmic flood deposits of the Hanford formation underlie backfill materials in $\mathrm{C} 3832$. Only the sand-dominated Hanford formation $\mathrm{H} 2$ is represented; all of the coarsergrained Hanford formation H1 unit was removed during tank-farm construction.

\subsection{Hanford Formation H2 Unit}

The Hanford formation $\mathrm{H} 2$ unit is present between 45 to $103 \mathrm{ft}$ bgs. A total of 22 physical and chemical characterization samples were collected from within this unit (Table 2.8). The Hanford formation $\mathrm{H} 2$ sediments consist of mostly fine to coarse sand, sometimes capped or interbedded with thin beds of silty fine sand to silt (Figure 2.29). The fine to coarse sand beds are loose, massive to laminated, brownish-gray to olive-brown, moderately to well-sorted, and weakly to moderately calcareous. Finer grained beds are generally well-sorted, cohesive, massive to laminated, yellowish- to olive-brown, and moderately to strongly calcareous. 


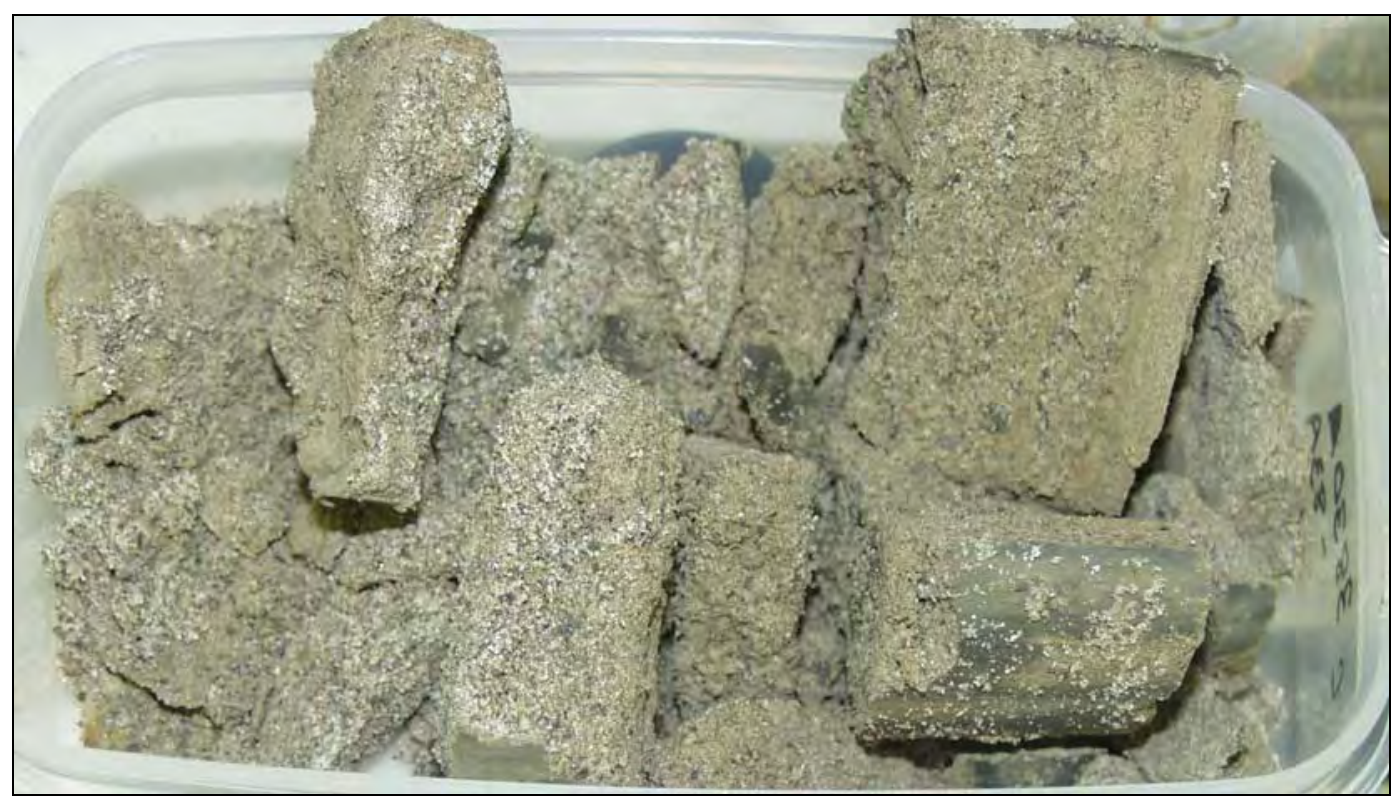

Figure 2.29. Hanford Formation H2 Unit in C3832 - Core C3832-83A. Alternating layers of slightly moist, well laminated, moderately to well-sorted, loose, grayish-brown, medium sand (S), and moist, compact, strongly calcareous, light olive-brown, silty fine sand (mS). The top of the 0.5-ft-long core is to the right.

\subsubsection{Cold Creek Unit}

The contact between the Cold Creek unit and the overlying Hanford formation $\mathrm{H} 2$ unit lies at about $103 \mathrm{ft}$ bgs (Figure 2.26). Three characterization samples were collected from the upper CCU while five came from the calcic paleosol sequence of the lower CCU (Table 2.8).

\subsection{Upper Cold Creek Subunit $\left(\mathrm{CCU}_{\mathrm{u}}\right)$}

The upper CCU in C3832 is $7.4 \mathrm{ft}$-thick and consists of compacted and well-sorted, mottled to laminated, moderately to strongly calcareous, yellowish-brown to olive-brown, silt to silty fine sand (Figure 2.30). The top of the upper CCU is defined by a dramatic decrease in grain size and an increase in the total gamma activity, as demonstrated in Figure 2.26. The base of the upper CCU lies in sharp contact with the caliche of the underlying lower CCU. 


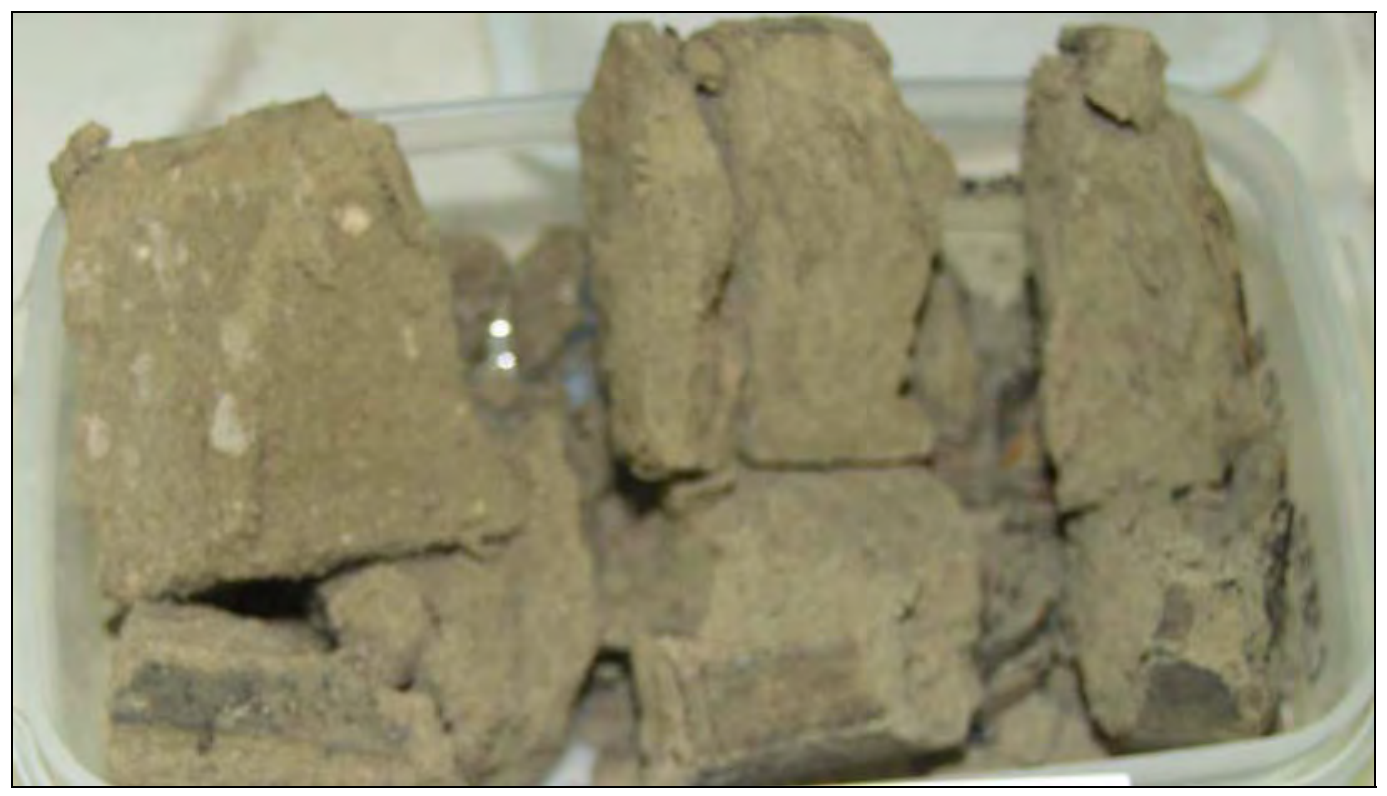

Figure 2.30. Upper Cold Creek Unit in C3832 - Core 3832-110B. Described as slightly moist, laminated, well-sorted, strongly calcareous, olive-brown, silty fine sand (mS). Whitish $\mathrm{CaCO}_{3}$-cemented nodules to the left are associated with the underlying caliche of the lower $C C U$. The top of the 0.5-ft core is to the right.

\subsection{Lower Cold Creek Unit $\left(\mathrm{CCU}_{1}\right)$.}

The lower CCU extends from a depth of $100.4 \mathrm{ft}$ to the bottom of hole at $115.89 \mathrm{ft}$ bgs. The uppermost few feet of the lower CCU are relatively soft compared to deeper depths where there is a sharp increase in penetration resistance (Figure 2.26). The casing met refusal at $114.29 \mathrm{ft}$ bgs. The resistant bottom of the borehole consisted of mostly olive-colored clay and silt mottled with pedogenic calcium carbonate stringers and nodules (Figure 2.31). 


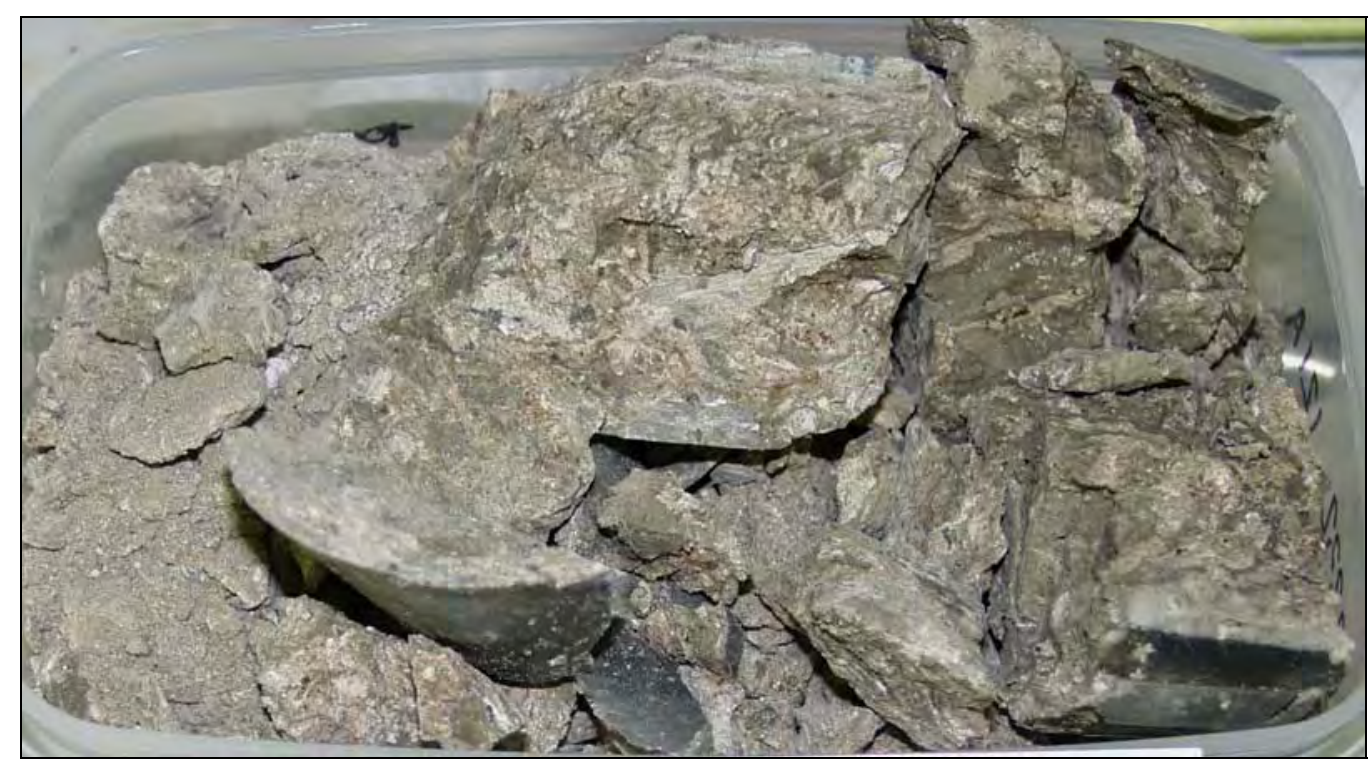

Figure 2.31. Lower Cold Creek Unit Within C3832 - Core C3832-121A. Described as slightly moist, very poorly sorted, mottled to massive, strongly to very strongly calcareous, strongly consolidated, olive, pebbly sandy mud (gsM), mottled with gray to brownish-gray, pedogenic, calcium-carbonate-cemented caliche nodules and stringers. Includes about $10 \%$ small pebbles. The sample in the tray was broken apart during removal from the core liner. The top of the 0.5-ft core is to the right.

\subsection{Discussion of Increased Moisture Zones}

Zones of increased moisture in the vadose zone may be determined indirectly using the downhole, neutron moisture geophysical log and/or, when available, gravimetric moisture may be measured directly from core samples in the laboratory. As discussed previously, borehole 299-W10-27 (Figure 2.9) was continuously cored and sampled between 50-125 ft bgs. Lab moisture results in Figure 2.9 show a close correlation with the neutron moisture log. Therefore, the neutron moisture log appears to accurately reflect the relative moisture content, and can confidently be used as a substitute to estimate relative moisture conditions when core samples are unavailable.

The moisture distribution for three boreholes C3830, C3831, and C3832 are shown in Figures 2.12, 2.19 , and 2.26, respectively. Similarly, moisture distribution for the background well (299-W10-27) is shown in Figure 2.9. Zones with relatively high moisture $(>15 \mathrm{wt} \%)$ are illustrated via a light blue bar immediately to the right of the lithologic log in these diagrams.

Increased moisture appears to be associated with the boundary between sudden, large contrasts in grain size. Commonly, a lower-permeability fine-grained silty layer may be present along the boundary, but is not required for a high-moisture zone to develop. Depending on the flux rate, moisture may collect and move laterally 1) within finer-grained layers, 2) along interfaces between highly contrasting facies, or 3) along primary sedimentary structures (Bjornstad et al. 2003). Moisture may also move vertically along discordant clastic dikes. During high flux rates moisture moves preferentially within the coarser units in contrast to fine-grained layers, which transmit relatively more moisture under a low flux rate. 
Generally $<10 \mathrm{wt} \%$ moisture content is associated with backfill materials, except where fine-grained sand and/or silt occurs within backfill deposits, such as near the base of the backfill sequence in C3831 (Figure 2.19) and C3832 (Figure 2.26). Figure 2.32 shows a statistical analysis of moisture conditions at different stratigraphic levels for each of the four borings documented in this report. Conclusions that can be drawn from this table include:

There is relatively higher moisture for the Cold Creek unit in all holes, especially for the lower CCU (i.e., caliche), although it is variable.

- Gravelly backfill materials have relatively little moisture, generally $<10 \mathrm{wt} \%$, except for fine-grained zones that occasionally occur at the base of this unit.

- Average moisture content for the Hanford formation $\mathrm{H} 2$ unit in the background hole is significantly less than C3830, C3831, and C3832. This may be attributed to either:

1. sample bias. Moisture samples from 299-W10-27 were collected at regular 1-ft intervals, whereas the C3830, C3831, and C3832 borehole intervals were pre-selected based on suspected contamination (i.e., high moisture), or

2. higher natural recharge beneath the tank farms due to the removal of surface vegetation. In exchange for vegetation, a cover of gravel was placed, which significantly reduces or eliminates near-surface transpiration of moisture back to the atmosphere.

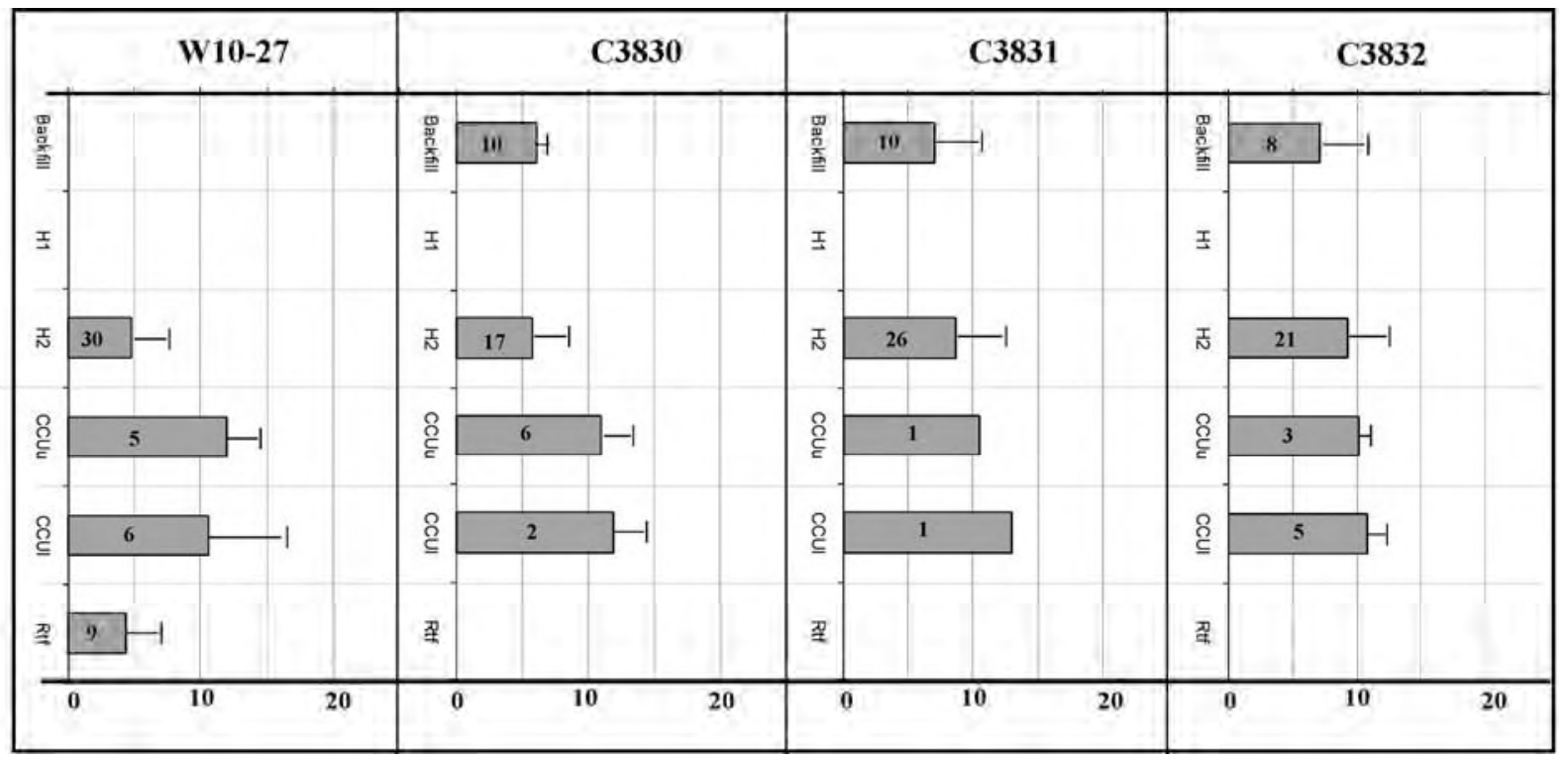

Figure 2.32. Average Moisture Content (wt\% water) from Different Stratigraphic Units in the Vicinity of the TX Tank Farm. Numbers in shaded boxes are the number of analyses; lines to the right of the boxes are one standard deviation from the mean. 


\subsection{Geochemical Methods and Materials}

This section discusses the methods and philosophy used to determine which borehole samples would be characterized and the parameters that would be measured and analyzed in the laboratory. It also describes the materials and methods used to conduct analyses of the physical, geochemical, and radioanalytical properties of the sediments, and the water potential (suction) measurements of the core liners in each sequential splitspoon sample from borehole 299-W10-27.

\subsection{Sample Inventory}

Samples were identified using a project-specific prefix, in this case, C3125 (for the background borehole 299-W10-27), C3830 (for the borehole southwest of TX-105), C3831 (for the borehole southwest of TX-107), and C3832 (for the borehole south of TX-104), followed by a specific sample identification suffix such as -01 , for each splitspoon. As noted in Section 2.3, the cores contained two liners identified by the letters A and B, where the A Liner was always in the deeper position closest to the drive shoe (i.e., the protective end attached to the bottom of the drive casing).

\subsection{Approach}

During a past investigation at WMA SX, a significant finding was that changes in sediment type and contaminant concentrations occurred within a distance of a few inches within a given liner. It was concluded that a more methodical scoping approach would be necessary to provide the technical justification for selecting samples for detailed characterization as defined in the data quality objectives process (DOE 1999). Subsequently, a method was developed that considered depth, geology (e.g., lithology, grain-size composition, and carbonate content, etc.), individual liner contaminant concentration (e.g., radionuclides, nitrate), moisture content, and overall sample quality. Inexpensive analyses and certain key parameters (i.e., moisture content, gamma energy analysis) were performed on sediment from each liner. More complicated and costly analyses were performed on sediment from selected depths.

The objective of the TX characterization was to quantify the extent of penetration of mobile contaminants into the vadose zone sediment. Because of the potential for slough material in the upper liner, only the sediment from the A Liner was analyzed for most constituents except moisture and gamma energy. Measurable or significant drag-down effects (i.e., the process of moving contaminants down through the sediment column via pushing the casing) for contaminants were not noted, perhaps because the borehole was installed by pile driving closed end casing with periodic sampling through the retractable nose cone, and the main contaminants (i.e., uranium-238 and technetium-99) are associated mainly with the porewater (technetium-99) or not exclusively concentrated on the sediment particles (uranium-238). Because drag-down is dominated by highly contaminated sediment particles, the contaminants in these boreholes had less chance of concentrating on particles.

During the geologic examination, the liner contents were subsampled for moisture content, gammaemission radiocounting, 1:1 water extracts (which provide soil $\mathrm{pH}$, electrical conductivity (EC), cation, and anion data), total carbon and inorganic carbon content, and $8 \mathrm{M}$ nitric acid extracts (which provide a measure of the total leachable sediment content of contaminants). The remaining sediment from each 
liner was then sealed and placed in cold storage. Later, additional aliquots of selected liners from clean borehole 299-W10-27 were removed to measure particle size distribution and total chemical composition.

\subsection{Materials and Methods}

During subsampling of the selected core liner, every effort was made to minimize moisture loss and prevent cross contamination between samples. Depending on the sample matrix, very coarse pebble and larger material (i.e., $>32$ millimeter $[\mathrm{mm}]$ ) was avoided during subsampling. Larger substrate was excluded to provide moisture contents representative of counting and 1:1 sediment:water extract samples. Therefore, the results from the subsample measurements may contain a possible bias toward higher concentrations for some analytes that would be preferentially associated with the smaller sized sediment fractions. The sediment in the lower Cold Creek unit (silt-dominated facies) contained no large pebbles or cobbles.

Procedures ASTM D2488-93 (1993) and PNL-MA-567-DO-1 (PNL 1990a) were followed for visual descriptions and geologic description of all splitspoon samples. The sediment classification scheme used for geologic identification of the sediment types is based on the modified Folk/Wentworth classification scheme described earlier (Section 2.3.1.3 and Figure 2.8). However, the particle size distribution for samples from the background well was also performed where further separation of the mud into discrete silt and clay size fractions was performed.

\subsubsection{Moisture Content}

Gravimetric water contents of the sediment samples from each liner were determined using PNNL procedure PNL-MA-567-DO-1 (PNL 1990a). This procedure is based on the American Society for Testing and Materials procedure Test Method for Laboratory Determination of Water (Moisture) Content of Soil and Rock by Mass (ASTM D2216-98 [ASTM 1998]). One representative subsample of at least 15 to 70 grams (g) was taken from each liner. Sediment samples were placed in tared containers, weighed, and dried in an oven at $105^{\circ} \mathrm{C}\left(221^{\circ} \mathrm{F}\right)$ until constant weight was achieved, which took at least 24 hours. The containers then were removed from the oven, sealed, cooled, and weighed. At least two weighings, each after a 24-hour heating, were performed to ensure that all moisture was removed. All weighings were performed using a calibrated balance. A calibrated weight set was used to verify balance performance before weighing samples. The gravimetric water content was computed as the percentage change in soil weight before and after oven drying.

\subsubsection{1:1 Sediment:Water Extracts}

The water-soluble inorganic constituents were determined using a 1:1 sediment:deionized-water extract method. This method was chosen because the sediment was too dry to easily extract vadose zone porewater. The extracts were prepared by adding an exact weight of deionized water to approximately 60 to $80 \mathrm{~g}$ of sediment subsampled from each liner. The weight of deionized water needed was calculated based on the weight of the field-moist samples and their previously determined moisture contents. The sum of the existing moisture (porewater) and the deionized water was fixed at the mass of the dry sediment. The appropriate amount of deionized water was added to screw cap jars containing the sediment samples. The jars were sealed and briefly shaken by hand, then placed on a mechanical orbital shaker for one hour. The samples were allowed to settle until the supernatant liquid was fairly clear. The supernatant was carefully decanted and separated into unfiltered aliquots for conductivity and $\mathrm{pH}$ 
determinations, and filtered aliquots (passed through $0.45 \mu \mathrm{m}$ membranes) for anion, cation, carbon, and radionuclide analyses. More details can be found in Rhoades (1996) and within Methods of Soils Analysis - Part 3 (ASA 1996a).

\subsubsection{1 pH and Conductivity}

Two approximately 3-mL aliquots of the unfiltered 1:1 sediment:water extract supernatant were used for $\mathrm{pH}$ and conductivity measurements. The $\mathrm{pHs}$ for the extracts were measured with a solid-state $\mathrm{pH}$ electrode and a pH meter calibrated with buffers 4, 7, and 10. Electrical conductivity was measured and compared to potassium chloride standards with a range of $0.001 \mathrm{M}$ to $1.0 \mathrm{M}$.

\subsubsection{Anions and Small Organic Acids}

The 1:1 sediment:water extracts were analyzed for anions using an ion chromatograph. Fluoride, acetate, formate, chloride, nitrite, bromide, nitrate, carbonate, phosphate, sulfate, and oxalate were separated on a Dionex AS17 column with a gradient elution of $1 \mathrm{mM}$ to $35 \mathrm{mM}$ sodium hydroxide and measured using a conductivity detector. This methodology is based on U.S. Environmental Protection Agency (EPA) Method 300.0A (EPA 1984) with the exception of using the gradient elution of sodium hydroxide. Only small carbon chained organic acids elute with the inorganic anions using this procedure, and no attempts were made to measure other soluble organic components. Water extract chromatograms were visually scanned to assure there were no unidentified peaks caused by other constituents. No unexpected peaks were found in the water extracts from the background or contaminated sediments.

\subsubsection{Cations and Trace Metals}

Major cation analysis was performed using an inductively coupled plasma-optical emission spectrometry (ICP-OES) unit using high-purity calibration standards to generate calibration curves and verify continuing calibration during the analysis run. Dilutions of 100x, 50x, 10x, and 5x were made of each 1:1 water extract for analysis to investigate and correct for matrix interferences. Details of this method are found in EPA Method 6010B (EPA 2000b). The second instrument used to analyze trace metals, including technetium-99 and uranium-238, was an inductively coupled plasma-mass spectrometer (ICP-MS) using PNNL-AGG-415 method (PNNL 1998). This method is quite similar to EPA Method 6020 (EPA 2000c).

\subsubsection{Alkalinity and Carbon}

The alkalinity and inorganic/organic carbon content of several of the 1:1 sediment:water extracts were measured using standard titration with acid and a carbon analyzer, respectively. The alkalinity procedure is equivalent to the U.S. Geological Survey (USGS) National Field Manual (USGS 2001) method. Inorganic and organic carbon in the water extracts were determined using a carbon analyzer and ASTM Method D4129-88 (ASTM 1988), Standard Test Method for Total and Organic Carbon in Water by High Temperature Oxidation and by Coulometric Detection. 


\subsubsection{Radioanalytical Analysis}

\subsubsection{Gamma Energy Analysis}

Gamma energy analysis (GEA) was performed on sediment from either the A or the B core liners for the three TX boreholes. For C3831, sediment from both the A and the B liners was counted. All samples for gamma energy analysis were analyzed using 60\%-efficient intrinsic germanium gamma detectors. All germanium counters were efficiency calibrated for distinct geometries using mixed gamma standards traceable to the National Institute of Standards and Technology. Field-moist samples were placed in $150-\mathrm{cm}^{3}$ counting containers and analyzed for 100 minutes in a fixed geometry. All spectra were background-subtracted. Spectral analysis was conducted using libraries containing most mixed fission products, activation products, and natural decay products. Control samples were run throughout the analysis to ensure correct operation of the detectors. The controls contained isotopes with photo peaks spanning the full detector range and were monitored for peak position, counting rate, and full-width half-maximum. Details are found in Gamma Energy Analysis, Operation, and Instrument Verification using Genie2000' ${ }^{\mathrm{TM}}$ Support Software (PNNL 1997).

\subsubsection{Total Beta and Total Alpha Measurements on Water and Acid Extracts}

Gross alpha and beta measurement were made on both the water and acid extracts. For each extract, an $\sim 1$-mL sample volume was placed in a $20-\mathrm{mL}$ tared liquid scintillation and weighed. Fifteen $\mathrm{mL}$ of scintillation cocktail were then added and the samples were mixed and counted on a Wallac Model 1415 Liquid Scintillation Counter as prescribed in procedure AGG-RRL-002, Liquid Scintillation Counting and Instrument Verification Using the 1400 DSA ${ }^{\mathrm{TM}}$ Support Software (PNNL 2000). Results were converted to picocuries ( $\mathrm{pCi}$ ) per gram of dry sediment by using the known solution-to-solid ratios used to extract aliquots of the sediment.

\subsubsection{Carbon Content of Sediment}

The carbon content of borehole sediment samples was determined using ASTM Method D4129-88, Standard Methods for Total and Organic Carbon in Water by High Temperature Oxidation and by Coulometric Detection (ASTM 1988). Total carbon in all samples was determined using a Coulometrics, Inc. Model 5051 Carbon Dioxide Coulometer with combustion at approximately $980^{\circ} \mathrm{C}\left(1796^{\circ} \mathrm{F}\right)$. Ultrapure oxygen was used to sweep the combustion products through a barium chromate catalyst tube for conversion to carbon dioxide. Evolved carbon dioxide was quantified through coulometric titration following absorption in a solution containing ethanolamine. Equipment output reported carbon content values in micrograms per sample. Soil samples for determining total carbon content were placed into precombusted, tared platinum combustion boats and weighed on a four-place analytical balance. After the combustion boats were placed into the furnace introduction tube, a one-minute waiting period was allowed so that the ultrapure oxygen carrier gas could remove (i.e., sparge) any carbon dioxide introduced to the coulometric system from the atmosphere during sample placement. After this system sparge, the sample was moved into the combustion furnace and the titration was begun. Sample titration readings were performed at 3 minutes after combustion began and again once stability was reached, usually within the next 2 minutes. The system background was determined by performing the entire process using an empty, pre-combusted platinum boat. Adequate system performance was confirmed by analyzing for known quantities of a calcium carbonate standard. 
Inorganic carbon contents for borehole sediment samples were determined using a Coulometrics, Inc., Model 5051 Carbon Dioxide Coulometer. Soil samples were weighed on a four-place analytical balance, and then placed into acid-treated glass tubes. Following placement of sample tubes into the system, a one-minute waiting period allowed the ultrapure oxygen carrier gas to remove any carbon dioxide introduced to the system from the atmosphere. Inorganic carbon was released through acid-assisted evolution $\left(50 \%\right.$ hydrochloric acid) with heating to $200^{\circ} \mathrm{C}\left(392^{\circ} \mathrm{F}\right)$. Samples were completely covered by the acid to allow full reaction to occur. Ultrapure oxygen gas swept the resultant carbon dioxide through the equipment to determine inorganic carbon content by coulometric titration. Sample titration readings were performed 5 minutes following acid addition and again once stability was reached, usually within 10 minutes. Known quantities of calcium carbonate standards were analyzed to verify that the equipment was operating properly. Background values were determined. Inorganic carbon content was determined through calculations performed using the microgram per-sample output data and sample weights. Organic carbon was calculated by subtracting inorganic carbon from total carbon and using the remainder.

\subsubsection{M Nitric Acid Extract}

Approximately $20 \mathrm{~g}$ of oven-dried sediment was contacted with $8 \mathrm{M}$ nitric acid at a ratio of $\sim 5$ parts acid to one part sediment. The slurries were heated to about $80^{\circ} \mathrm{C}\left(176^{\circ} \mathrm{F}\right)$ for several hours and then the fluid was separated by centrifugation and filtration through $0.2 \mu \mathrm{m}$ membranes. The acid extracts were analyzed for major cations and trace metals using ICP and ICP-MS techniques, respectively. The acid digestion procedure is based on EPA SW-846 Method 3050B (EPA 2000a).

\subsubsection{Elemental Analysis}

The elemental composition of the bulk sediment from nine liners from the clean borehole, 299-W10-27, was determined by a commercial analytical laboratory using total fusion (using lithium metaborate/tetraborate) and inductively coupled plasma (ICP) and ICP-MS. The commercial lab used was ACTLAB-Skyline in Tucson, Arizona. Sample preparation involved grinding and mixing the sample in a Coors high-density alumina $\left(\mathrm{Al}_{2} \mathrm{O}_{3}\right)$ mortar and pestle. Fifty-six elements (i.e., beryllium, sodium through phosphorous, potassium through arsenic, rubidium through molybdenum, silver, indium through antimony, cesium through tungsten, thallium, lead, bismuth, thorium, and uranium) were analyzed on each sample. Nine geologic material standards that represent a wide range of geologic materials were fused and run along with the unknown sediments. Results for each element for the nine standards were reported along with the certified values from NIST, USGS, and other institutions that provide certified standards. We were satisfied with the accuracy on reported results for the standards and also found that the total oxide composition of the sediments from 299-W10-27 summed to close to $100 \%$, suggesting that the results were acceptable.

No elemental analyses were performed on the three contaminated borehole sediments because the commercial laboratory cannot test radioactive samples. We also have found that bulk elemental analysis of moderately radionuclide-contaminated sediments, such as the three TX borehole samples, do not vary significantly from uncontaminated samples. 


\subsubsection{Particle Size Distribution}

The wet sieving/hydrometer method was used to determine the particle size distribution of selected samples from the background borehole, 299-W10-27. No particle size measurements were made on samples from C3830, C3831, and C3832. The technique is described in ASA (1986a), Part 1, Method 15-5, "Hydrometer Method." It concentrates on quantifying the relative amounts of silt and clay. The silt and clay separates were saved for later mineralogical analyses. Samples from the borehole that were used for the hydrometer method were never air- or oven-dried to minimize the effects of particle aggregation that can affect the separation of clay grains from the coarser material.

\subsubsection{Particle Density}

The particle density of bulk grains from the background borehole are usually determined using pychnometers as described in ASA (1986b) Part 1, Method 14-3, "Pychnometer Method," and oven-dried material. The particle density is an input needed to determine the particle size when using the hydrometer method. For the 299-W10-27 particle size analyses reported in this document, the quartz default value of $2.65 \mathrm{~g} / \mathrm{cm}^{3}$ was assumed and no direct particle density measurements were performed.

\subsubsection{Water Potential (Suction) Measurements}

Suction measurements were made on the core liners in each splitspoon sampler from borehole 299-W10-27 using the filter paper method PNL-MA-567-SFA-2 (PNL 1990b), which is essentially the same as ASTM (2002). This method relies on three filter papers folded together into a small sandwich that rapidly equilibrates with the sediment sample. The middle filter paper does not contact sediment that might stick to the paper and bias the mass measurements. At equilibrium, the matric suction in the filter paper is the same as the matric suction of the sediment sample. The dry filter paper sandwiches were placed in the liners while still filled with the sediment and remained there for three weeks to allow sufficient time for the matric suction in the sediment to equilibrate with the matric suction in the filter paper. The mass of the wetted middle filter paper that has had no direct contact with the sediment was subsequently determined, and the suction of the sediment was determined from a calibration relationship between filter paper water content and matric suction. The filter paper method provides a good estimate of water potentials over the range from -0.01 to $-2 \mathrm{MPa}$ ( 1 to $200 \mathrm{~m}$ [3.3 to $656 \mathrm{ft}$ ] suction head) (Deka et al. 1995).

The relationships used for converting the water content of filter paper to matric suction for Whatman \#42 filter paper have been determined by Deka et al. (1995) and can be expressed as:

$$
\begin{aligned}
& \mathrm{Sm}=10^{(5.144-6.699 \mathrm{w})} / 10 \text { for } \mathrm{w}<0.5 \\
& \mathrm{Sm}=10^{(2.383-1.309 \mathrm{w})} / 10 \text { for } \mathrm{w}>0.5
\end{aligned}
$$

where

$\mathrm{Sm}$ is the matric suction $(\mathrm{m})$ and

$\mathrm{w}$ is the gravimetric water content $(\mathrm{g} / \mathrm{g})$.

Fifty-one core liner samples from borehole 299-W10-27 were analyzed for soil matric suction. The matric potential samples covered the borehole profile from 50 to $123.5 \mathrm{ft}$ bgs ( 15.2 to $37.6 \mathrm{~m}$ ). 


\subsection{Results and Discussion}

This section presents the geochemical and physical characterization data collected on sediment from the background borehole 299-W10-27 and the three boreholes C3830 (near tank TX105), C3831 (near tank TX107), and C3832 (near tank TX104). The results for 299-W10-27 are presented in Section 4.1, and those for C3830, C3831, and C3832 are given in Sections 4.2, 4.3, and 4.4, respectively.

The first activities emphasized tests that were inexpensive or that were key to determining the vertical distribution of mobile contaminants in the vadose zone sediments. Information on the borehole sediments presented in this section includes moisture content and total and inorganic carbon content of the sediments, $\mathrm{pH}$, and electrical conductivity (EC) of 1:1 sediment:water extracts, and measurements of major cations, anions, trace metals, and radionuclides in both the sediment and 1:1 sediment:water extracts. A gamma energy analysis (GEA) of the sediments was also performed to search for any detectable man-made gamma emitting radionuclides. The particle size and bulk chemical composition of selected sediment samples were measured in the second phase of characterization to aid in selecting contacts between major geologic units and to attempt to better define the background composition of the uncontaminated sediments with the intent of aiding in determining the vertical extent of mobile contaminants in the other boreholes.

\subsection{Vadose Zone Sediment from Borehole 299-W10-27}

\subsubsection{Moisture Content}

The moisture content of the sediment from the sleeves from the section of borehole 299-W10-27 that was continuously cored (50 to $132 \mathrm{ft}$ bgs) is listed in Table 4.1 and presented as a graph in Section 2.0 Geology (see Figure 2.9). Figure 2.9 shows both the field volumetric moisture obtained via neutron logging and the gravimetric moisture content of small aliquots of sediment taken during the geologic description activities. The moisture content profile correlates with the lithology described in Section 2.3.2 and shown in Figure 2.9. The first region with elevated moisture in the Hanford formation $\mathrm{H} 2$ unit is the thin mud lens at 52 to $54 \mathrm{ft}$ bgs. There is one other elevated moisture content spot in the Hanford formation $\mathrm{H} 2$ unit that appears to be a clastic dike at $70 \mathrm{ft}$ bgs. The rest of the Hanford formation $\mathrm{H} 2$ unit is rather dry, with a mean gravimetric moisture content of $3.9 \mathrm{wt} \%$. Both the Cold Creek upper (finegrained) and the lower (carbonate-rich) units are wetter than the Hanford formation unit and the Ringold Formation units that lie below the Cold Creek unit. Both Cold Creek subunits have moisture contents that average between 11 and $12 \mathrm{wt} \%$. The wettest sediment is found at the bottom of the Cold Creek lower subunit at $110 \mathrm{ft}$ bgs with $23.74 \mathrm{wt} \%$ water (Table 2.5). As discussed in Section 2, there appears to be a deep clastic dike manifesting itself in the Ringold Formation - Member of Taylor Flat $\left(\mathrm{R}_{\mathrm{tf}}\right)$ at $120 \mathrm{ft}$ bgs with a moisture content of $12 \mathrm{wt} \%$. Excluding this wet sample, the $\mathrm{R}_{\mathrm{tf}}$ unit has an average moisture content of $3.4 \mathrm{wt} \%$.

\subsubsection{1:1 Sediment:Water Extracts for Borehole 299-W10-27}

No subsampling of the background sediment from borehole 299-W10-27 - aside from moisture content determination - was performed immediately after core opening. When cores were selected for geochemical characterization several months later, it was found that the samples had dried significantly. 
Table 4.1. Gravimetric Moisture Content of Core Samples Obtained Between 50 and $125 \mathrm{ft}$ bgs in Borehole 299-W10-27

\begin{tabular}{|c|c|c|c|c|c|}
\hline $\begin{array}{l}\text { Depth } \\
\text { (ft bgs) }\end{array}$ & $\begin{array}{c}\text { Stratigraphic } \\
\text { Unit }\end{array}$ & $\begin{array}{c}\text { MC } \\
\% \mathrm{Wt}\end{array}$ & $\begin{array}{c}\text { Depth } \\
\text { (ft bgs) }\end{array}$ & $\begin{array}{l}\text { Stratigraphic } \\
\text { Unit }\end{array}$ & $\begin{array}{c}\mathrm{MC} \\
\% \mathrm{Wt}\end{array}$ \\
\hline & H1 & no samples & 83.5 & H2 & 3.41 \\
\hline 50 & H2 & 2.23 & 85 & H2 & 3.67 \\
\hline 51 & H2 & 2.75 & 86 & H2 & 3.07 \\
\hline 52.5 & $\mathbf{H 2}$ & 14.80 & 87.5 & $\mathbf{H} 2$ & 7.35 \\
\hline 53.5 & H2 & 9.61 & 88.5 & H2 & 5.31 \\
\hline 55 & $\mathrm{H} 2$ & 2.52 & 90 & $\mathbf{C C U}_{\mathbf{u}}$ & 10.81 \\
\hline 56 & H2 & 2.43 & 92.5 & $\mathrm{CCU}_{\mathbf{u}}$ & 8.66 \\
\hline 57.5 & $\mathrm{H} 2$ & 2.92 & 95 & $\mathrm{CCU}_{\mathrm{u}}$ & 14.66 \\
\hline 58.5 & $\mathbf{H} 2$ & 2.44 & 96 & $\mathrm{CCU}_{\mathrm{u}}$ & 9.94 \\
\hline 60 & H2 & 3.27 & 97.5 & $\mathrm{CCU}_{\mathbf{u}}$ & 15.53 \\
\hline 61 & $\mathrm{H} 2$ & 6.88 & 100 & $\mathrm{CCU}_{\mathrm{I}}$ & 7.25 \\
\hline 62.5 & $\mathbf{H} 2$ & 5.60 & 102.5 & $\mathbf{C C U}_{\mathbf{l}}$ & 10.27 \\
\hline 63.5 & H2 & 2.83 & 105 & $\mathbf{C C U}_{\mathbf{l}}$ & 7.48 \\
\hline 65 & H2 & 4.58 & 106 & $\mathrm{CCU}_{\mathrm{I}}$ & 6.87 \\
\hline 66 & H2 & 4.61 & 107.5 & $\mathbf{C C U}_{\mathbf{l}}$ & 8.09 \\
\hline 67.5 & $\mathbf{H 2}$ & 5.05 & 110 & $\mathrm{CCU}_{1}$ & 23.74 \\
\hline 68.5 & $\mathbf{H} 2$ & 4.48 & 112.5 & $\mathbf{R}_{\mathbf{t f}}$ & 3.40 \\
\hline 70 & H2 & $14.12^{a}$ & 113.5 & $\mathbf{R}_{\mathrm{tf}}$ & 3.08 \\
\hline 71 & $\mathbf{H} 2$ & 3.52 & 115 & $\mathbf{R}_{\mathbf{t f}}$ & 3.63 \\
\hline 72.5 & $\mathbf{H 2}$ & 3.78 & 116 & $\mathbf{R}_{\mathrm{tf}}$ & 2.71 \\
\hline 73.5 & $\mathrm{H} 2$ & 4.67 & 117.5 & $\mathbf{R}_{\mathbf{t f}}$ & 6.05 \\
\hline 75 & H2 & 4.57 & 120 & $\mathbf{R}_{\mathbf{t f}}$ & $11.84^{(\mathrm{a})}$ \\
\hline 77.5 & H2 & 5.00 & 121 & $\mathbf{R}_{\mathbf{t f}}$ & 2.37 \\
\hline 78.5 & $\mathbf{H 2}$ & 3.34 & 122.5 & $\mathbf{R}_{\mathbf{t f}}$ & 3.66 \\
\hline 80 & H2 & 3.37 & 123.5 & $\mathbf{R}_{\mathrm{tf}}$ & 1.95 \\
\hline 81 & H2 & 2.93 & & $\mathbf{R}_{\mathrm{wi}}$ & no samples \\
\hline 82.5 & $\mathbf{H} 2$ & 3.12 & & & \\
\hline \multicolumn{6}{|c|}{$\begin{array}{l}\text { Italics connote wet sediment. } \\
\text { (a) Designates samples where clastic dikes appear to be intercepted. } \\
\text { MC = moisture content. }\end{array}$} \\
\hline
\end{tabular}


Unlike past comparisons between background and contaminated sediments at the S-SX and B-BX-BY waste management areas (WMA), no attempt is made to estimate the chemical composition of uncontaminated vadose zone porewater from the 1:1 sediment:water extracts. Instead, the data from the 1:1 water extracts for the background borehole (299-W10-27) and the three boreholes around suspected leaking tanks in the TX Tank Farm were compared on a per gram of dry soil basis. The following sections discuss the results of the analyses for the 1:1 sediment:water extracts on the background sediment.

\subsubsection{1 $\quad \mathrm{pH}$ and Electrical Conductivity}

The $\mathrm{pH}$ and $\mathrm{EC}$ for the water extracts are shown in Table 4.2 and Figure 4.1. The $\mathrm{pH}$ is plotted as measured in the 1:1 sediment:water extracts but the EC is corrected for dilution and plotted as if it was actual porewater.

The $\mathrm{pH}$ profile shows the highest values [ 7.5] at the bottom of the lower Cold Creek subunit (caliche) and in the gravel facies of the Ringold Formation-Member of Wooden Island $\left(\mathrm{R}_{\mathrm{wi}}\right)$. These two water extracts also show the highest values for EC. The sample in the $\mathrm{R}_{\mathrm{tf}}$ at $113 \mathrm{ft}$ bgs shows the lowest $\mathrm{pH}$ and EC values. During the SX Tank Farm characterization two uncontaminated boreholes, 299-W22-48 and 299-W22-50, were cored and fully characterized. The $\mathrm{pH}$ and EC data for 299-W10-27 sediments agree more closely with the data for 299-W22-48 than 299-W22-50 (see Tables 5.15 and 5.38 in Serne et al. 2002a). The $\mathrm{R}_{\mathrm{wi}}$ unit 1:1 sediment:water extract at 299-W10-27 (only one sample characterized) has a higher EC $(0.227 \mathrm{mS} / \mathrm{cm})$ than the uncontaminated samples characterized at the SX Tank Farm (EC ranges from 0.08 to $0.12 \mathrm{mS} / \mathrm{cm}$ ). This may suggest that there is more leachable salts in the $\mathrm{R}_{\mathrm{wi}}$ unit further north in the T-TX-TY WMA.

Table 4.2. $\quad$ pH and EC Values for 1:1 Sediment:Water Extracts from 299-W10-27

\begin{tabular}{||c|c|c|c||}
\hline $\begin{array}{c}\text { Depth } \\
\text { (ft) }\end{array}$ & $\begin{array}{c}\text { Stratigraphic } \\
\text { Unit }\end{array}$ & $\mathbf{p H}$ & $\begin{array}{c}\text { Conductivity } \\
\mathbf{m S} / \mathbf{c m}\end{array}$ \\
\hline 53.3 & $\mathrm{H} 2$ & 7.18 & 0.156 \\
\hline 53.5 & $\mathrm{H} 2$ & 7.08 & 0.137 \\
\hline 61 & $\mathrm{H} 2$ & 7.16 & 0.149 \\
\hline 88.3 & $\mathrm{H} 2$ & 7.27 & 0.165 \\
\hline 92.5 & $\mathrm{CCU}_{\mathrm{u}}$ & 7.33 & 0.154 \\
\hline 100 & $\mathrm{CCU}_{1}$ & 7.47 & 0.184 \\
\hline 113.5 & $\mathrm{R}_{\mathrm{tf}}$ & 6.82 & 0.066 \\
\hline $113.5(\mathrm{dup})$ & $\mathrm{R}_{\mathrm{tf}}$ & 6.95 & 0.084 \\
\hline 117.5 & $\mathrm{R}_{\mathrm{tf}}$ & 7.37 & 0.170 \\
\hline 130 & $\mathrm{R}_{\mathrm{wi}}$ & 7.40 & 0.227 \\
\hline
\end{tabular}




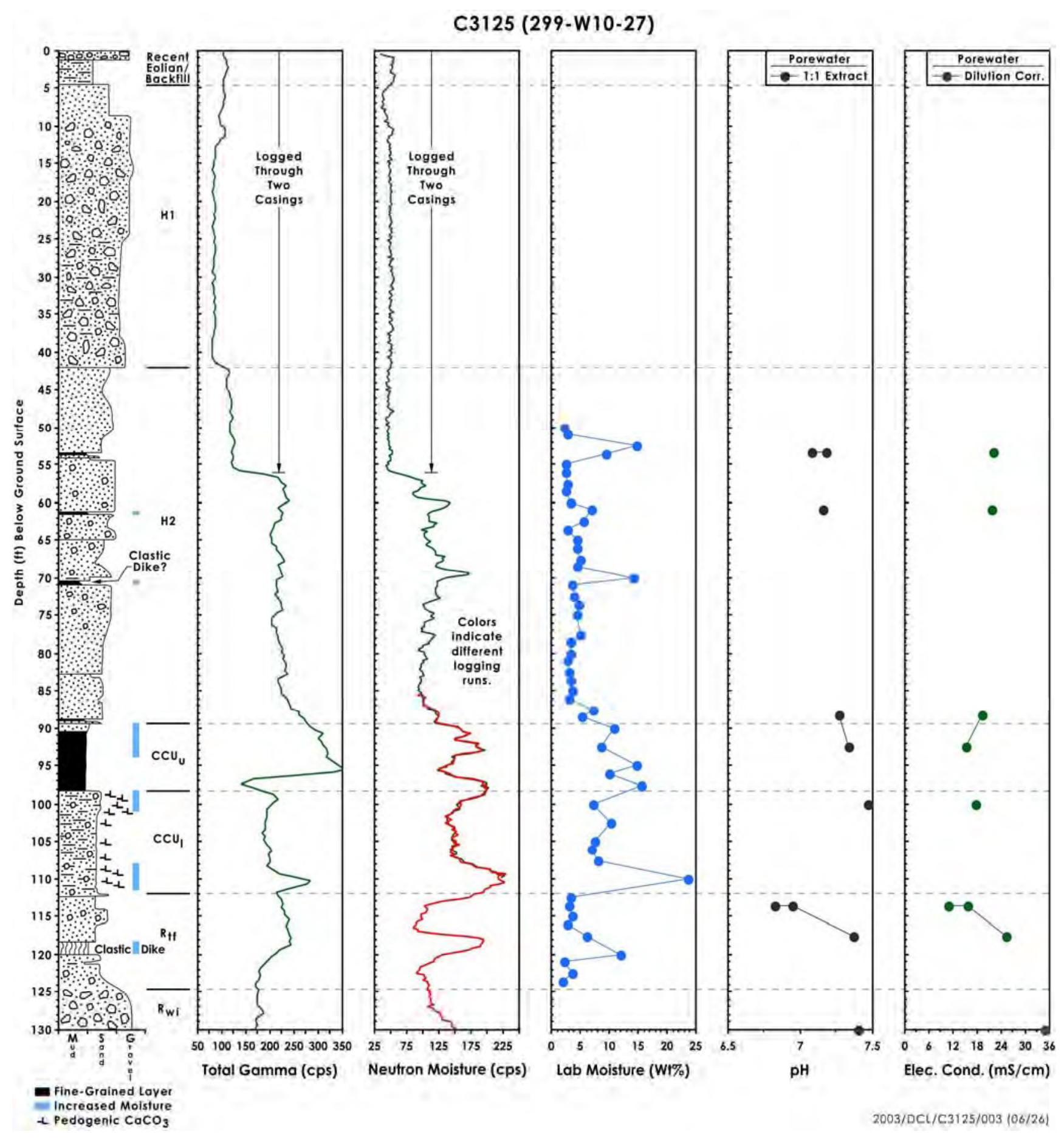

Figure 4.1. $\quad \mathrm{pH}$ and Electrical Conductivity Calculated (from Sediment:Water Extracts) for Borehole 299-W10-27 


\subsubsection{Water Extract Composition or the 1:1 Sediment:Water Extract for 299-W10-27}

The 1:1 sediment:water extract anion composition from 299-W10-27 samples, in units of $\mu \mathrm{g}$ per $\mathrm{g}$ of dry sediment, is shown in Table 4.3 and Figure 4.2a and Figure 4.2b. We are assuming that the values represent background values that can be compared to values for water extracts from the three boreholes near TX tanks that were suspected as having leaked in the past. Values in Table 4.3 that appear to be elevated compared to the others are shown in bold type and values that are low compared to the others are shown in italics. Two samples show high water-leachable fluoride, the calcium-carbonate-rich $\mathrm{CCU}_{1}$ sediment at $100 \mathrm{ft}$ bgs and the $\mathrm{R}_{\text {wi }}$ gravel at $130 \mathrm{ft}$ bgs. At the $\mathrm{SX}$ tank farm we also observed sediments enriched in calcium carbonate contained numerous other water-leachable solutes (see Serne et al. 2002a). The $\mathrm{CCU}_{1}$ stratum is an old near-surface soil zone that translocated solutes during periods of active precipitation-evaporation. Thus, this stratum would be expected to contain larger quantities of leachable salts. We have no explanation as to why the $\mathrm{R}_{\mathrm{wi}}$ gravel sample should contain high water-leachable fluoride. This sample also contains high water-leachable chloride and sulfate compared to all the other sediment samples that were water-leached. In general, the water extracts for both Cold Creek unit samples show slightly elevated concentrations of water-leachable carbonates, likely signifying the higher calcium carbonate contents in sediments in these two units. Figure $4.2 \mathrm{~b}$ shows two measurements of inorganic carbon (IC) in the 1:1 sediment:water extracts. We find that the IC values reported as carbonate are biased high compared to the values measured by standard alkalinity titration. None of the water extracts contain measurable amounts of phosphate, nitrite, or bromide.

Table 4.4 and Figure 4.2c show the water-leachable composition for small organic molecules. In general, the Hanford formation sediments geologically have slightly lower water-leachable concentrations of formate, acetate, and oxalate than the Cold Creek unit and Ringold Formation sediments. One possible cause for the differing concentrations of water-leachable organic molecules is the fact that the Hanford formation was deposited very rapidly and large volumes of sediment diluted any near surface organic matter that was present.

Table 4.5 shows the water-leachable concentrations of divalent and monovalent cations, in units of $\mu \mathrm{g}$ per gram of dry sediment for the background borehole 299-W10-27. Table 4.6 shows the water-leachable concentrations of aluminum (Al), silicon $(\mathrm{Si})$, iron $(\mathrm{Fe})$, manganese $(\mathrm{Mn})$, zinc $(\mathrm{Zn})$, and phosphorous $(\mathrm{P})$ and sulfur (S). The latter two were converted to their respective anions, phosphate and sulfate, and the data are compared to the ion chromatograph measured anion data in Figure 4.2a. The comparison is quite good. The distributions of several of the major cations versus depth are shown in Figure 4.3. The depth profiles for the divalent alkaline earth cations magnesium $(\mathrm{Mg})$, barium $(\mathrm{Ba})$, and strontium $(\mathrm{Sr})$ show higher values leach from the carbonate-rich $\mathrm{CCU}_{1}$ sediment. This is to be expected as these cations form moderately soluble carbonates. The Ringold Formation sediments from both the deeper $\mathrm{R}_{\mathrm{tf}}$ and $\mathrm{R}_{\mathrm{wi}}$ units show slightly elevated water-leachable divalent cations with the exception of calcium, suggesting that carbonate coatings on the grains or detrital carbonates are present in these older sediments. The shallow $\mathrm{R}_{\mathrm{tf}}$ sample shows the lowest water-leachable divalent and monovalent cations but the highest waterleachable iron and manganese, suggesting that this sample may contain $\mathrm{Fe}$ - and $\mathrm{Mn}$-oxide coatings instead of carbonates. The fine-grained upper Cold Creek subunit at $92.5 \mathrm{ft}$ bgs appears to contain some water-leachable phosphorous and the $\mathrm{R}_{\mathrm{wi}}$ contains elevated levels of soluble sulfate, perhaps indicating the presence of gypsum. 


\begin{tabular}{|c|c|c|c|c|c|c|c|c|c|c|c|}
\hline & $\stackrel{\vec{D}}{\vec{\nabla}}$ & $\begin{array}{l} \pm \\
\dot{\vec{V}}\end{array}$ & $\stackrel{\Xi}{\dot{D}}$ & $\stackrel{ \pm}{\dot{\theta}}$ & $\frac{\dot{I}}{\dot{\theta}}$ & $\frac{\Xi}{\dot{\nabla}}$ & $\frac{\dot{\theta}}{\dot{Q}}$ & $\frac{\vec{D}}{\dot{\nabla}}$ & $\stackrel{\vec{D}}{\vec{v}}$ & $\frac{\dot{\Xi}}{\dot{\nabla}}$ & \\
\hline 苾 & $\stackrel{\infty}{\stackrel{0}{0}}$ & $\begin{array}{l}\infty \\
0 \\
\dot{p} \\
\nabla\end{array}$ & $\begin{array}{l}\infty \\
0 \\
0 \\
\dot{v} \\
\end{array}$ & $\begin{array}{l}\infty \\
0 \\
\dot{\nabla} \\
\nabla\end{array}$ & $\begin{array}{l}\infty \\
\stackrel{0}{0} \\
\dot{0}\end{array}$ & $\stackrel{\infty}{\stackrel{0}{0}}$ & $\begin{array}{l}\infty \\
\stackrel{0}{0} \\
\stackrel{\nabla}{V}\end{array}$ & $\stackrel{\infty}{\stackrel{\infty}{0}}$ & $\stackrel{\infty}{\stackrel{\infty}{\dot{\theta}}}$ & $\stackrel{\infty}{\stackrel{\infty}{0}}$ & \\
\hline 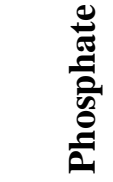 & 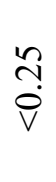 & 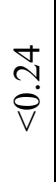 & $\begin{array}{l}\stackrel{\nabla}{c} \\
\stackrel{Q}{v}\end{array}$ & $\begin{array}{c}\tilde{n} \\
\stackrel{2}{v}\end{array}$ & $\stackrel{\vartheta}{+}$ & $\stackrel{+}{\grave{Q}}$ & 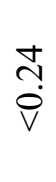 & 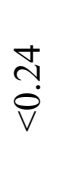 & $\stackrel{\stackrel{\sim}{~}}{\stackrel{\nabla}{V}}$ & $\stackrel{\stackrel{\sim}{~}}{\stackrel{\nabla}{v}}$ & \\
\hline & $\begin{array}{l}\hat{0} \\
\dot{n}\end{array}$ & $\begin{array}{l}\stackrel{0}{+} \\
0\end{array}$ & $\begin{array}{l}\mathscr{0} \\
\stackrel{n}{=}\end{array}$ & $\begin{array}{c}0 \\
m \\
\infty\end{array}$ & $\underset{\infty}{ \pm}$ & $\stackrel{?}{\circ}$ & $\underset{\forall}{\stackrel{P}{f}}$ & ले & $\begin{array}{l}\text { के } \\
\text { ri }\end{array}$ & $\begin{array}{l}\hat{b} \\
\text { ले }\end{array}$ & \\
\hline 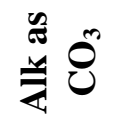 & à & 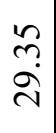 & $\begin{array}{c} \pm \\
0 \\
\infty \\
\sim \\
\sim\end{array}$ & $\begin{array}{l}\hat{0} \\
\dot{q}\end{array}$ & $\begin{array}{l}0 \\
\dot{\theta} \\
\dot{\gamma}\end{array}$ & $\frac{n}{\infty}$ & $\begin{array}{l}\hat{\partial} \\
\infty \\
\stackrel{n}{n} \\
\end{array}$ & 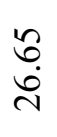 & $\begin{array}{l}n \\
\tilde{n} \\
\tilde{\gamma}\end{array}$ & 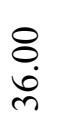 & \\
\hline 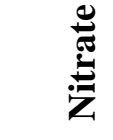 & $\begin{array}{l}\text { ळे } \\
\text { 入i }\end{array}$ & $\begin{array}{c}0 \\
\frac{0}{i}\end{array}$ & $\begin{array}{l}\sim \\
\sim \\
\sim\end{array}$ & $\bar{m}$ & $\stackrel{0}{\stackrel{0}{\rightleftarrows}}$ & $\begin{array}{l}0 \\
\stackrel{0}{0} \\
0\end{array}$ & $\underset{-}{8}$ & $\stackrel{\hat{N}}{0}$ & $\stackrel{m}{n}$ & $\stackrel{m}{\sim}$ & 苞 \\
\hline & $\begin{array}{l}\mathbb{U} \\
0\end{array}$ & $\stackrel{\circ}{\circ}$ & $\begin{array}{l}8 \\
\vdots \\
0\end{array}$ & ְٕ. & $\stackrel{\infty}{+}$ & $\hat{n}$ & $\begin{array}{l}0 \\
n \\
n\end{array}$ & $\begin{array}{l}\tilde{n} \\
\dot{0} \\
0\end{array}$ & $\underset{0}{\tilde{0}}$ & in & 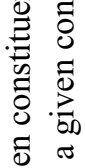 \\
\hline & $\stackrel{\nabla}{\stackrel{*}{0}}$ & 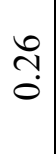 & 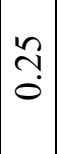 & $\hat{n}$ & $\overline{0}$ & 递 & $\stackrel{n}{\stackrel{0}{0}}$ & $\tilde{n}$ & $\stackrel{t}{\mathbb{U}}$ & $\stackrel{10}{\stackrel{10}{+}}$ & 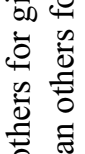 \\
\hline 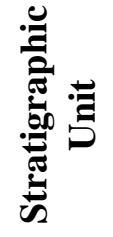 & $\cong$ & $\underline{I}$ & $\cong$ & $\stackrel{I}{I}$ & $e_{0}^{z}$ & $\underbrace{\supset}$ & $\tilde{2}$ & $\approx$ & $\widetilde{z}$ & $\sqrt{2}$ & 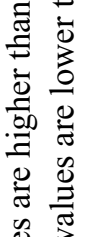 \\
\hline 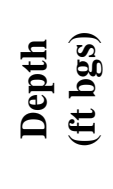 & $\begin{array}{l}m \\
\tilde{n}\end{array}$ & $\begin{array}{l}n \\
n \\
n\end{array}$ & $\overrightarrow{6}$ & $\begin{array}{l}m \\
\infty \\
\infty\end{array}$ & ๙n & 8 & $\stackrel{n}{=}$ & 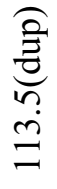 & $\stackrel{n}{\beth}$ & હ & 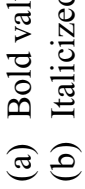 \\
\hline
\end{tabular}


Table 4.4. Small Molecular Weight Organic Content of Water Extracts of 299-W10-27 Sediment (units $\mu \mathrm{g} / \mathrm{g}$ dry sediment)

\begin{tabular}{||c|c|c|c|c||}
\hline Depth (ft) & $\begin{array}{c}\text { Stratigraphic } \\
\text { Unit }\end{array}$ & Formate & Acetate & Oxalate \\
\hline 53.3 & $\mathrm{H} 2$ & 0.12 & 0.29 & 0.54 \\
\hline 53.5 & $\mathrm{H} 2$ & $<0.13^{(\mathrm{b})}$ & 0.43 & 0.60 \\
\hline 61 & $\mathrm{H} 2$ & $<0.11$ & $<0.16$ & 0.53 \\
\hline 88.3 & $\mathrm{H} 2$ & 0.28 & 0.41 & 0.48 \\
\hline 92.5 & $\mathrm{CCU}_{\mathrm{u}}$ & 0.18 & 0.54 & 0.68 \\
\hline 100 & $\mathrm{CCU}_{1}$ & 0.14 & 0.51 & 0.76 \\
\hline 113.5 & $\mathrm{R}_{\mathrm{tf}}$ & 0.39 & 0.47 & 0.58 \\
\hline $113.5(\mathrm{dup})$ & $\mathrm{R}_{\mathrm{tf}}$ & 0.48 & 0.68 & 0.55 \\
\hline 117.5 & $\mathrm{R}_{\mathrm{tf}}$ & $\mathbf{0 . 8 0}^{(\mathrm{a})}$ & $\mathbf{0 . 8 5}$ & 0.66 \\
\hline 130 & $\mathrm{R}_{\mathrm{wi}}$ & 0.42 & 0.61 & $\mathbf{0 . 9 4}$ \\
\hline
\end{tabular}

(a) Bold values are higher than others for given constituent.

(b) Italicized values are lower than others for a given constituent.

Table 4.7 and Figures 4.4 and 4.5 show the water-leachable concentrations of some metals that are present in tank leak fluids and, in the case of Figure 4.5, metals that have been found to be relatively mobile under some tanks in the S-SX and B-BX-BY WMAs (see Serne et al. 2002b, 2002c, 2002d, 2002e, 2002f for more discussion). The lower Cold Creek subunit $\left(\mathrm{CCU}_{1}\right)$ contains the highest water-leachable chromium $(\mathrm{Cr})$ in this background borehole and the $\mathrm{R}_{\mathrm{wi}}$ sample contains the highest concentration water-leachable molybdenum (Mo) (Figure 4.5). The technetium-99 (Tc-99) data are all below or very near to our detection limit as expected for a background borehole (Table 4.7).

The values presented in Tables 4.2 through Table 4.7 will be compared to similar data for the three TX boreholes C3830, C3831, and C3832, to evaluate whether significantly higher values are found in any borehole that would suggest tank fluids had percolated into the vadose zone where the boreholes were pushed. 


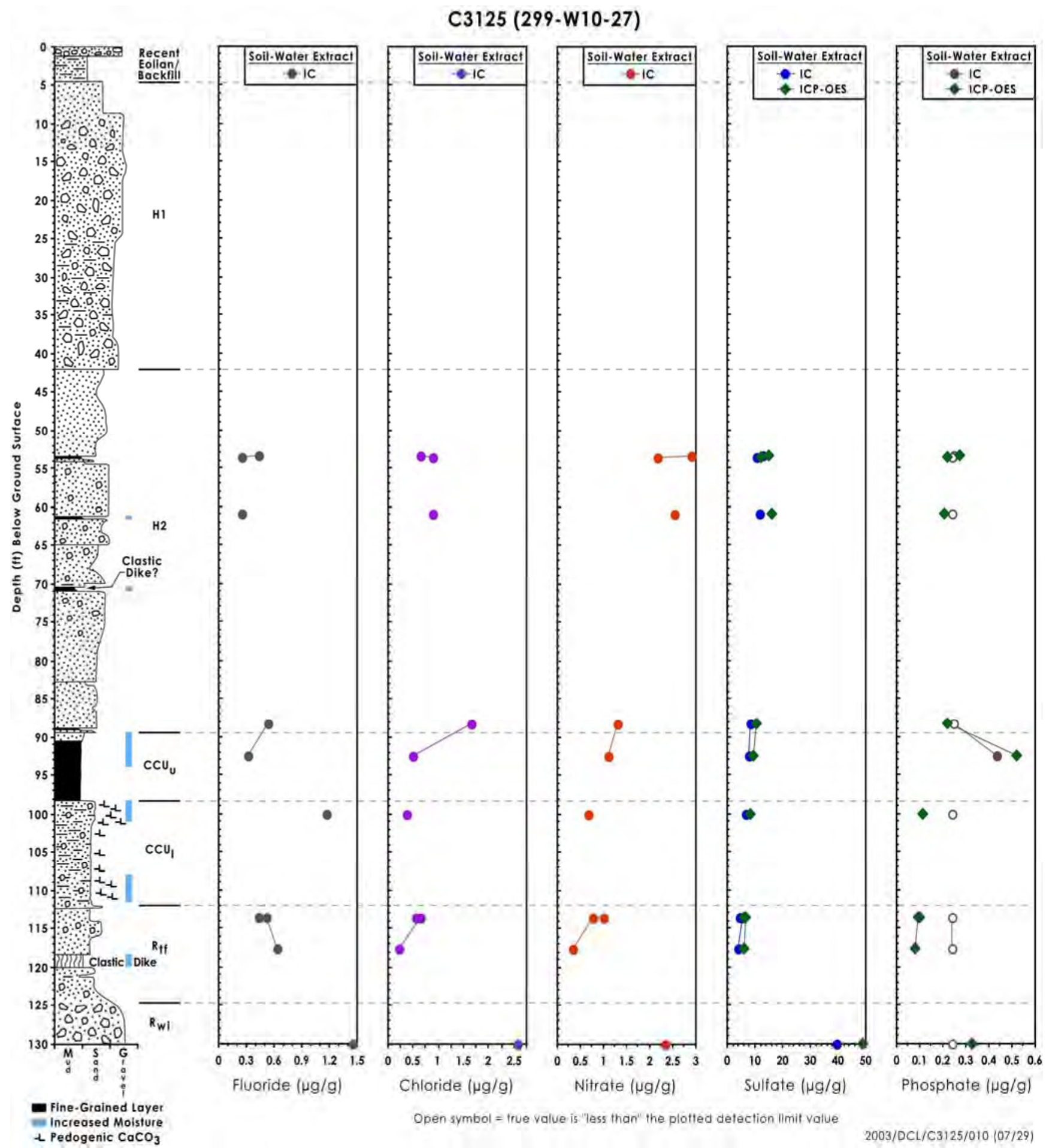

Figure 4.2a. Major Anions in 1:1 Sediment:Water Extracts from Borehole 299-W10-27 


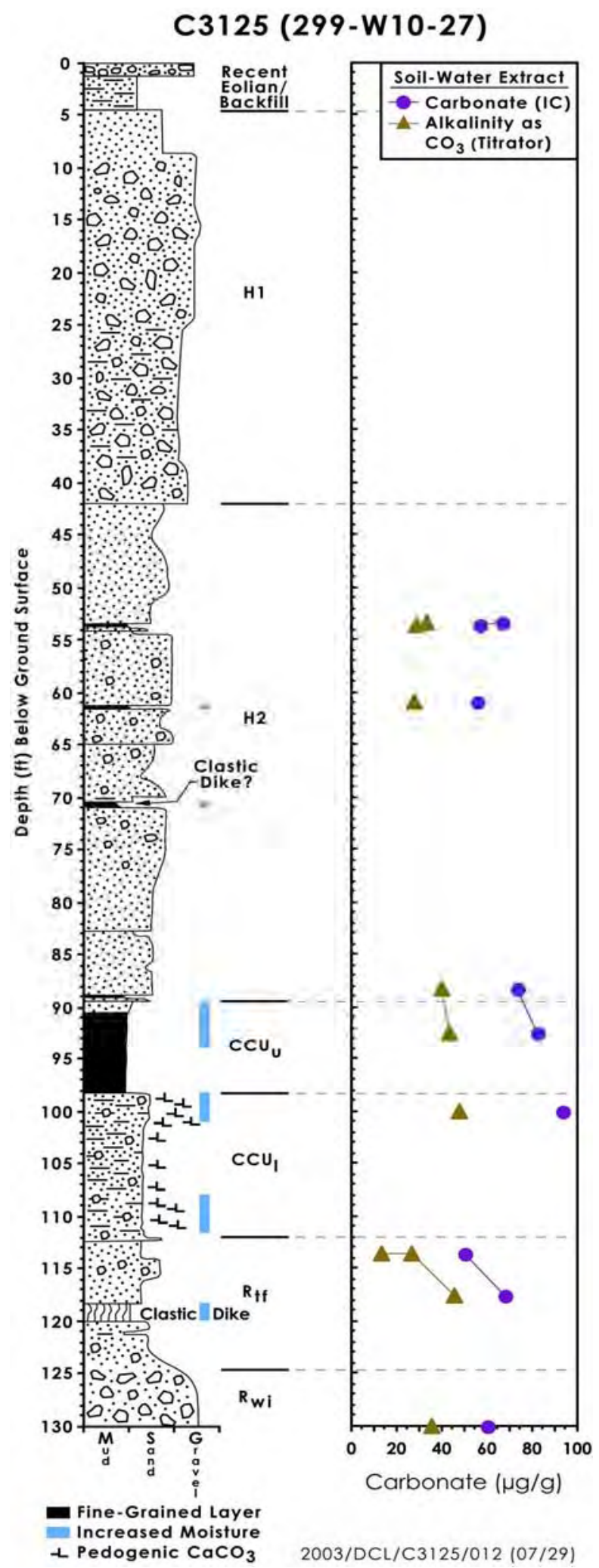

Figure 4.2b. 1:1 Sediment:Water Extract Carbonate and Alkalinity (as Carbonate) Contents from Borehole 299-W10-27 (units $\mu$ g per g dry sediment) 


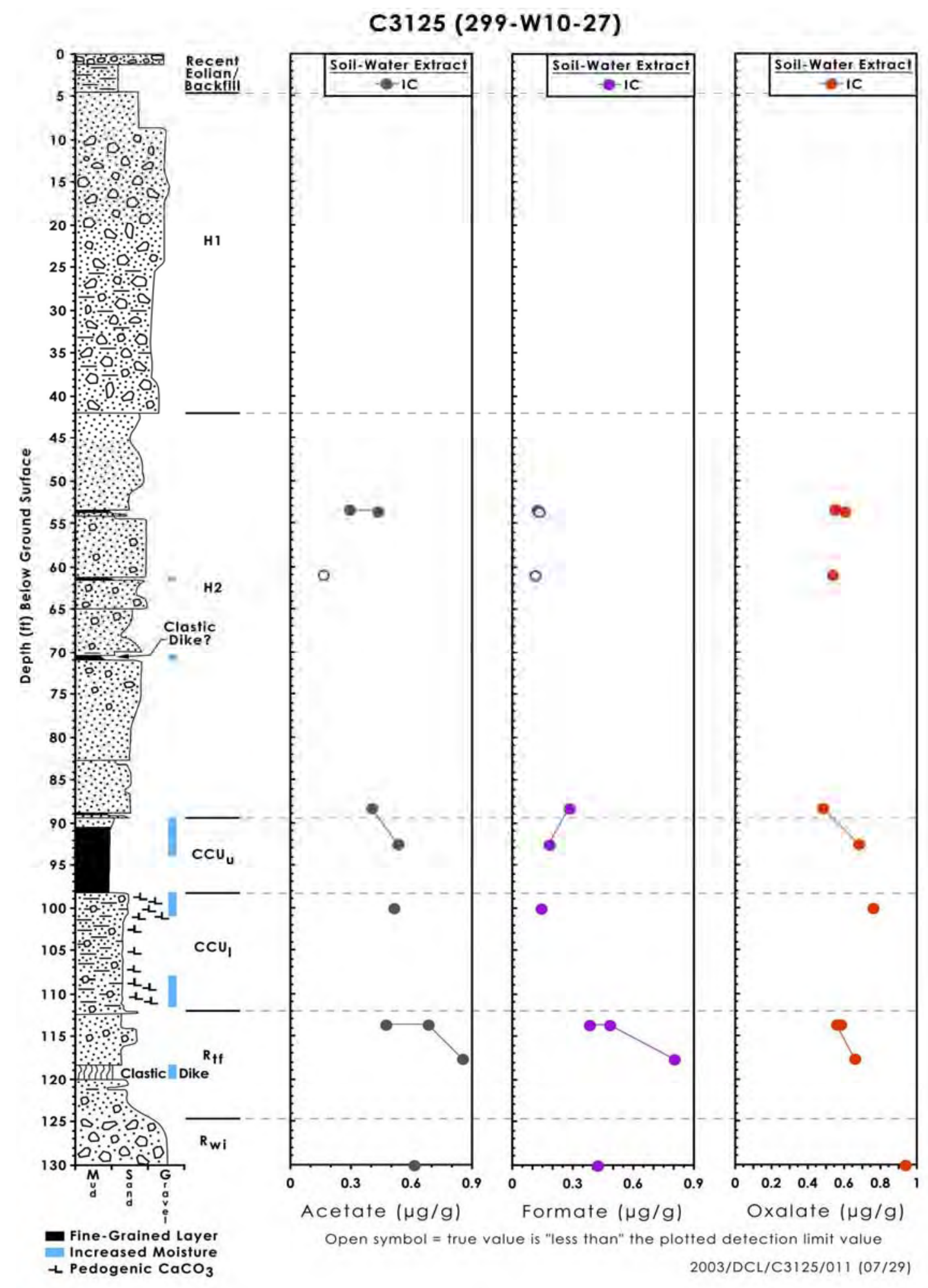

Figure 4.2c. 1:1 Sediment:Water Extract Small Organic Molecule Contents from Borehole 299-W10-27 (units $\mu$ g per g dry sediment) 
Table 4.5. Water-Extractable Cations in Borehole 299-W10-27 Sediments ( $\mu \mathrm{g} / \mathrm{g}$ dry soil)

\begin{tabular}{|c|c|c|c|c|c|c|c|}
\hline $\begin{array}{l}\text { Depth } \\
\text { (ft bgs) }\end{array}$ & $\begin{array}{c}\text { Stratigraphic } \\
\text { Unit }\end{array}$ & Mg & Ca & $\mathbf{S r}$ & $\mathbf{B a}$ & $\mathbf{N a}$ & $\mathbf{K}$ \\
\hline 53.3 & $\mathrm{H} 2$ & $3.11 \mathrm{E}+00$ & $1.38 \mathrm{E}+01$ & $6.11 \mathrm{E}-02$ & $1.79 \mathrm{E}-02$ & $7.29 \mathrm{E}+00$ & $3.44 \mathrm{E}+00$ \\
\hline 53.5 & $\mathrm{H} 2$ & $2.35 \mathrm{E}+00$ & $1.09 \mathrm{E}+01$ & $5.57 \mathrm{E}-02$ & $2.48 \mathrm{E}-02$ & $6.66 \mathrm{E}+00$ & $2.85 \mathrm{E}+00$ \\
\hline 61 & $\mathrm{H} 2$ & $2.80 \mathrm{E}+00$ & $1.26 \mathrm{E}+01$ & $6.28 \mathrm{E}-02$ & $1.78 \mathrm{E}-02$ & $7.25 \mathrm{E}+00$ & $4.18 \mathrm{E}+00$ \\
\hline 88.3 & $\mathrm{H} 2$ & $2.95 \mathrm{E}+00$ & $1.34 \mathrm{E}+01$ & $6.72 \mathrm{E}-02$ & $2.60 \mathrm{E}-02$ & $1.08 \mathrm{E}+01$ & $3.78 \mathrm{E}+00$ \\
\hline 92.5 & $\mathrm{CCU}_{\mathrm{u}}$ & $2.88 \mathrm{E}+00$ & $1.32 \mathrm{E}+01$ & $6.55 \mathrm{E}-02$ & $3.79 \mathrm{E}-02$ & $9.34 \mathrm{E}+00$ & $3.30 \mathrm{E}+00$ \\
\hline 100 & $\mathrm{CCU}_{1}$ & $6.71 \mathrm{E}+00^{(\mathrm{a})}$ & $1.36 \mathrm{E}+01$ & 1.06E-01 & 4.55E-02 & $9.19 \mathrm{E}+00$ & $2.46 \mathrm{E}+00$ \\
\hline 113.5 & $\mathrm{R}_{\mathrm{tf}}$ & $1.48 E+00^{(\mathrm{b})}$ & $2.46 E+00$ & $2.51 E-02$ & $1.60 \mathrm{E}-02$ & $4.32 E+00$ & $1.46 E+00$ \\
\hline 113.5 (dup) & $\mathrm{R}_{\mathrm{tf}}$ & $2.36 \mathrm{E}+00$ & $4.05 E+00$ & $3.95 E-02$ & $1.76 \mathrm{E}-02$ & $5.01 E+00$ & $1.87 E+00$ \\
\hline 117.5 & $\mathrm{R}_{\mathrm{tf}}$ & $6.54 \mathrm{E}+00$ & $1.25 \mathrm{E}+01$ & 1.09E-01 & $3.22 \mathrm{E}-02$ & $7.55 \mathrm{E}+00$ & $2.51 \mathrm{E}+00$ \\
\hline 130 & $\mathrm{R}_{\mathrm{wi}}$ & $4.26 \mathrm{E}+00$ & $1.08 \mathrm{E}+01$ & 1.06E-01 & 4.60E-02 & $2.53 \mathrm{E}+01$ & $6.13 E+00$ \\
\hline
\end{tabular}

Table 4.6. Other Water-Extractable Cations in Borehole 299-W10-27 Sediments ( $\mu \mathrm{g} / \mathrm{g}$ dry soil)

\begin{tabular}{|c|c|c|c|c|c|c|c|c|}
\hline $\begin{array}{c}\text { Depth } \\
\text { (ft bgs) }\end{array}$ & $\begin{array}{c}\text { Strati- } \\
\text { graphic } \\
\text { Unit }\end{array}$ & Al & $\mathbf{S i}$ & $\mathbf{F e}$ & Mn & $\mathbf{Z n}$ & $\mathrm{P}$ as $\mathrm{PO}_{4}$ & $\mathrm{~S}$ as $\mathrm{SO}_{4}$ \\
\hline 53.3 & $\mathrm{H} 2$ & $(1.29 \mathrm{E}-02)^{(\mathrm{c})}$ & $1.11 \mathrm{E}+01$ & $(9.62 \mathrm{E}-03)$ & $(8.13 \mathrm{E}-04)$ & $2.91 \mathrm{E}-02$ & $2.72 \mathrm{E}-01$ & $1.48 \mathrm{E}+01$ \\
\hline 53.5 & $\mathrm{H} 2$ & $2.64 \mathrm{E}-02$ & $1.13 \mathrm{E}+01$ & $(1.93 \mathrm{E}-02)$ & (5.82E-04) & $2.89 \mathrm{E}-02$ & $2.19 \mathrm{E}-01$ & $1.22 \mathrm{E}+01$ \\
\hline 61 & $\mathrm{H} 2$ & $(1.97 \mathrm{E}-02)$ & $1.31 \mathrm{E}+01$ & $(1.56 \mathrm{E}-02)$ & $(6.16 \mathrm{E}-04)$ & $(2.09 \mathrm{E}-02)$ & $2.05 \mathrm{E}-01$ & $1.60 \mathrm{E}+01$ \\
\hline 88.3 & $\mathrm{H} 2$ & $(1.30 \mathrm{E}-02)$ & $1.54 \mathrm{E}+01$ & (1.15E-02) & $(5.71 \mathrm{E}-04)$ & $3.41 \mathrm{E}-02$ & 2.22E-01 & $1.06 \mathrm{E}+01$ \\
\hline 92.5 & $\mathrm{CCU}_{\mathrm{u}}$ & $2.69 \mathrm{E}-02$ & $1.20 \mathrm{E}+01$ & (6.30E-03) & $<2.60 \mathrm{E}-03$ & $3.58 \mathrm{E}-02$ & 5.23E-01 & $9.38 \mathrm{E}+00$ \\
\hline 100 & $\mathrm{CCU}_{1}$ & $<1.27 E-02^{(\mathrm{b})}$ & $2.53 \mathrm{E}+01^{(\mathrm{a})}$ & $(5.42 E-03)$ & (5.72E-04) & $3.07 \mathrm{E}-02$ & $(1.15 \mathrm{E}-01)$ & $8.13 \mathrm{E}+00$ \\
\hline 113.5 & $\mathrm{R}_{\mathrm{tf}}$ & $3.24 \mathrm{E}-02$ & $1.95 \mathrm{E}+01$ & $5.29 \mathrm{E}-02$ & (3.53E-03) & $(2.30 \mathrm{E}-02)$ & $(9.75 \mathrm{E}-02)$ & $6.08 E+00$ \\
\hline $\begin{array}{l}113.5 \\
\text { (dup) }\end{array}$ & $\mathrm{R}_{\mathrm{tf}}$ & $2.89 \mathrm{E}-02$ & $1.92 \mathrm{E}+01$ & 5.03E-02 & $(3.43 \mathrm{E}-03)$ & $2.51 \mathrm{E}-02$ & $(9.34 \mathrm{E}-02)$ & $6.45 E+00$ \\
\hline 117.5 & $\mathrm{R}_{\mathrm{tf}}$ & $(2.51 \mathrm{E}-03)$ & $2.95 \mathrm{E}+01$ & $(9.94 \mathrm{E}-03)$ & (8.40E-04) & $3.08 \mathrm{E}-02$ & $(8.36 \mathrm{E}-02)$ & $6.41 E+00$ \\
\hline 130 & $\mathrm{R}_{\mathrm{wi}}$ & $5.82 \mathrm{E}-02$ & $1.44 \mathrm{E}+01$ & $(3.12 \mathrm{E}-02)$ & $(2.98 \mathrm{E}-03)$ & $(2.33 \mathrm{E}-02)$ & $3.27 \mathrm{E}-01$ & $4.88 \mathrm{E}+01$ \\
\hline $\begin{array}{ll}\text { (a) } & \text { Bol } \\
\text { (b) } & \text { Itali } \\
\text { (c) } & \text { Pare }\end{array}$ & 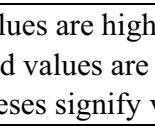 & $\begin{array}{l}\text { others for } \\
\text { han others } \\
\text { gelow leve }\end{array}$ & uantitation & $\begin{array}{l}\text { ent. } \\
\text { considered }\end{array}$ & & & & \\
\hline
\end{tabular}


Table 4.7. Water-Extractable Mobile Trace Contaminants in Borehole 299-W10-27 Sediments ( $\mu$ g per gram dry soil)

\begin{tabular}{|c|c|c|c|c|c|c|}
\hline $\begin{array}{c}\text { Depth } \\
\text { (ft bgs) }\end{array}$ & $\begin{array}{c}\text { Stratigraphic } \\
\text { Unit }\end{array}$ & Tc-99 & U-238 & $\mathrm{Cr}$ & $\begin{array}{c}\text { Mo } \\
\text { (ICP-MS) }\end{array}$ & $\begin{array}{c}\text { Mo } \\
\text { (ICP) }\end{array}$ \\
\hline 53.3 & $\mathrm{H} 2$ & $<4.39 \mathrm{E}+00$ & $1.07 \mathrm{E}-03$ & $8.19 \mathrm{E}-04$ & 7.99E-03 & $9.15 \mathrm{E}-03$ \\
\hline 53.5 & $\mathrm{H} 2$ & $(2.58 \mathrm{E}-01)$ & 4.98E-04 & $(4.65 \mathrm{E}-04)$ & $3.35 \mathrm{E}-03$ & $(4.30 \mathrm{E}-03)$ \\
\hline 61 & $\mathrm{H} 2$ & $<1.70 \mathrm{E}+00$ & $6.41 \mathrm{E}-04$ & $5.41 \mathrm{E}-04$ & 4.32E-03 & $4.57 \mathrm{E}-03$ \\
\hline 88.3 & $\mathrm{H} 2$ & $<4.36 \mathrm{E}+00$ & $1.46 \mathrm{E}-03$ & $1.01 \mathrm{E}-03$ & 4.37E-03 & $5.64 \mathrm{E}-03$ \\
\hline 92.5 & $\mathrm{CCU}_{\mathrm{u}}$ & $<1.77 \mathrm{E}+00$ & $9.58 \mathrm{E}-04$ & $1.60 \mathrm{E}-03^{(a)}$ & $8.62 \mathrm{E}-03$ & $1.05 \mathrm{E}-02$ \\
\hline 100 & $\mathrm{CCU}_{1}$ & $<1.72 \mathrm{E}+00$ & $2.89 \mathrm{E}-03$ & $(2.52 \mathrm{E}-04)$ & $9.05 E-04$ & $<2.53 E-03$ \\
\hline 113.5 & $\mathrm{R}_{\mathrm{tf}}$ & $<1.69 \mathrm{E}+00$ & $(4.39 E-05)^{(\mathrm{b})}$ & $(4.03 \mathrm{E}-04)$ & $1.76 \mathrm{E}-03$ & $(2.32 \mathrm{E}-03)$ \\
\hline $113.5(\mathrm{dup})$ & $\mathrm{R}_{\mathrm{tf}}$ & $<1.70 \mathrm{E}+00$ & $1.13 \mathrm{E}-04$ & $(3.86 \mathrm{E}-04)$ & $1.84 \mathrm{E}-03$ & $(8.46 \mathrm{E}-04)$ \\
\hline 117.5 & $\mathrm{R}_{\mathrm{tf}}$ & $(2.36 \mathrm{E}-01)^{(\mathrm{c})}$ & $1.60 \mathrm{E}-03$ & $5.90 \mathrm{E}-04$ & $9.49 \mathrm{E}-03$ & $9.66 \mathrm{E}-03$ \\
\hline 130 & $\mathrm{R}_{\mathrm{wi}}$ & $<1.69 \mathrm{E}+00$ & $6.86 \mathrm{E}-04$ & $(4.25 \mathrm{E}-04)$ & 1.05E-02 & 1.15E-02 \\
\hline \multicolumn{7}{|c|}{$\begin{array}{l}\text { (a) Bold values are higher than others for given constituent. } \\
\text { (b) Italicized values are lower than others for a given constituent. } \\
\text { (c) Parentheses signify values below level of quantitation but considered valid. }\end{array}$} \\
\hline
\end{tabular}




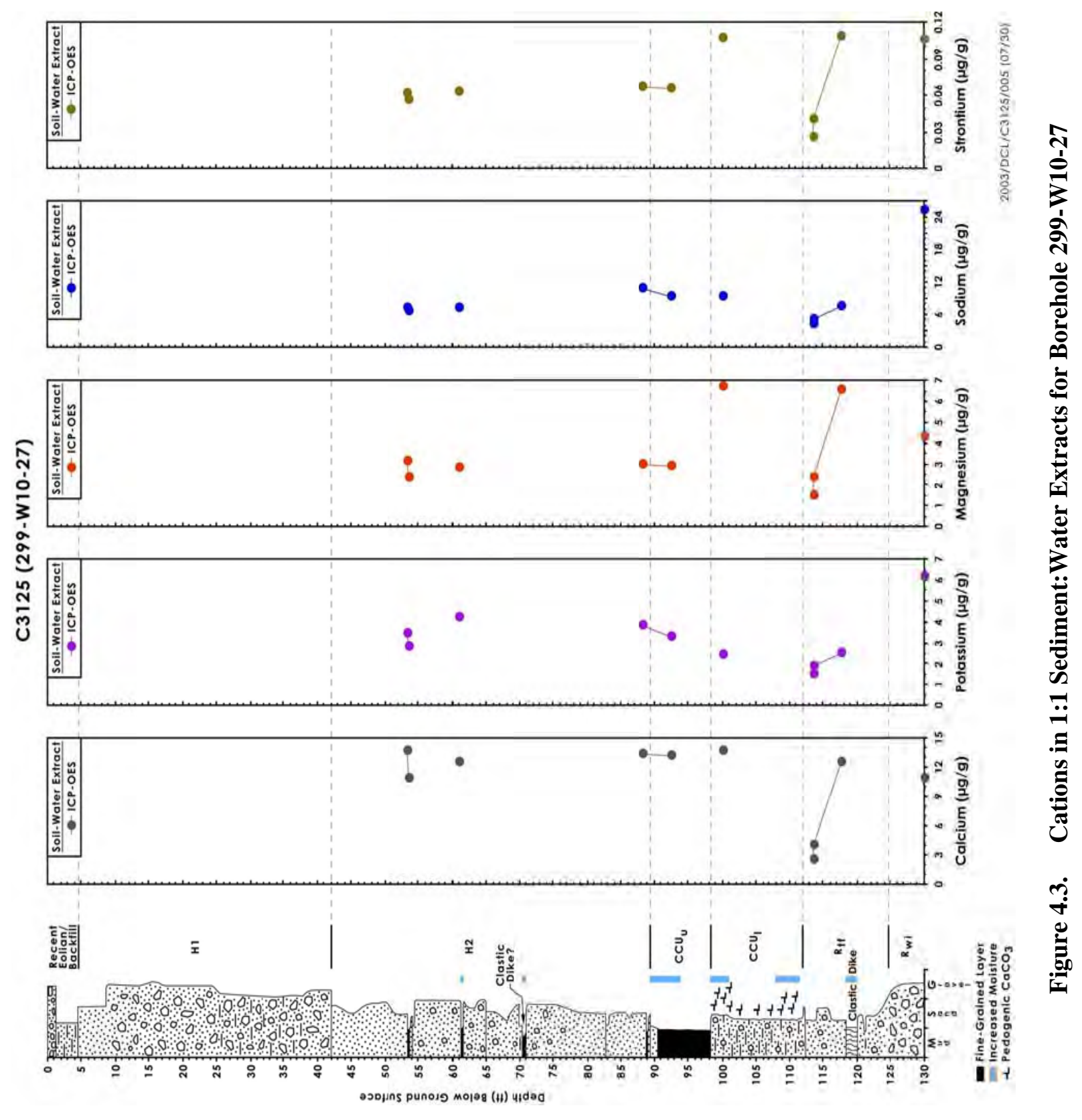




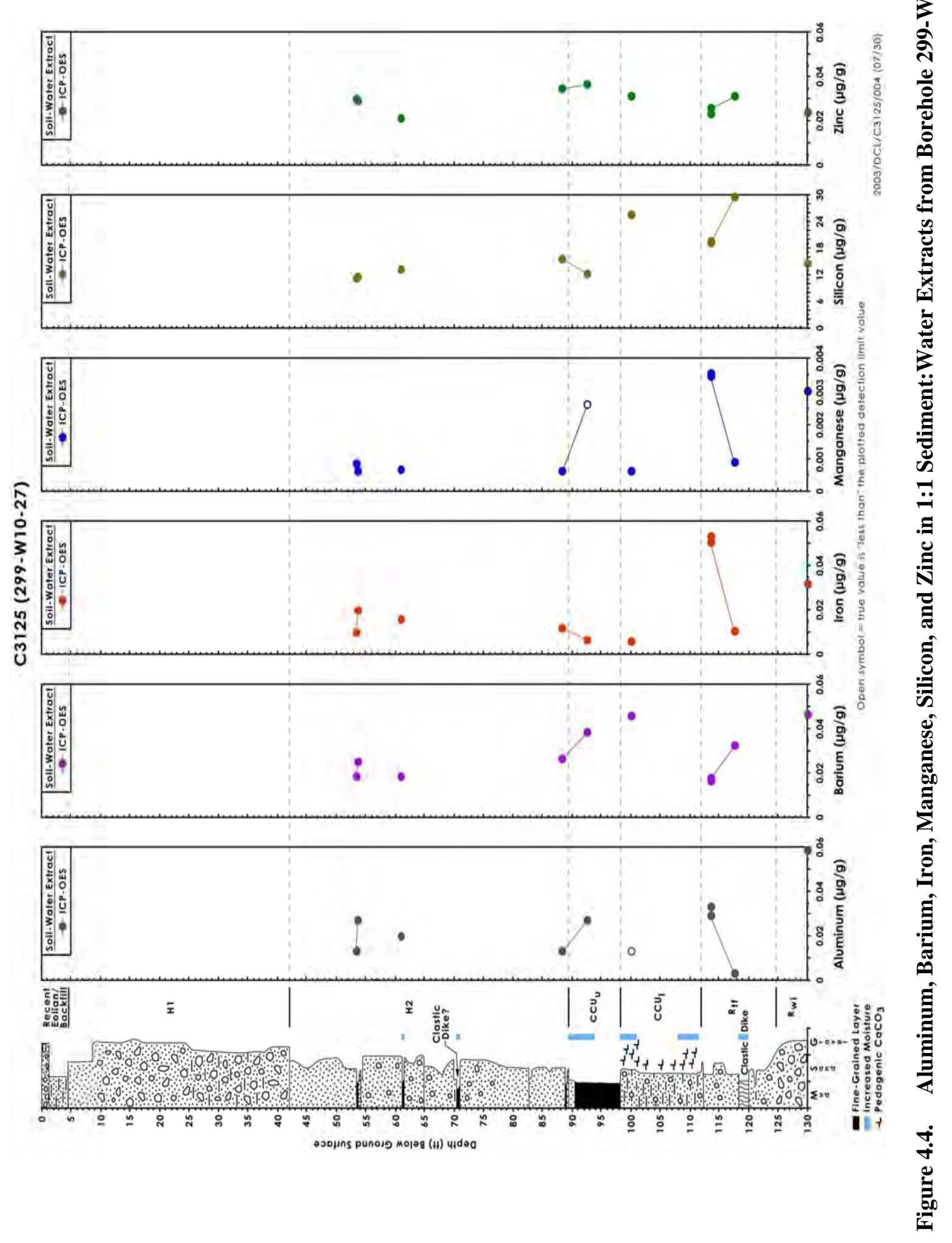




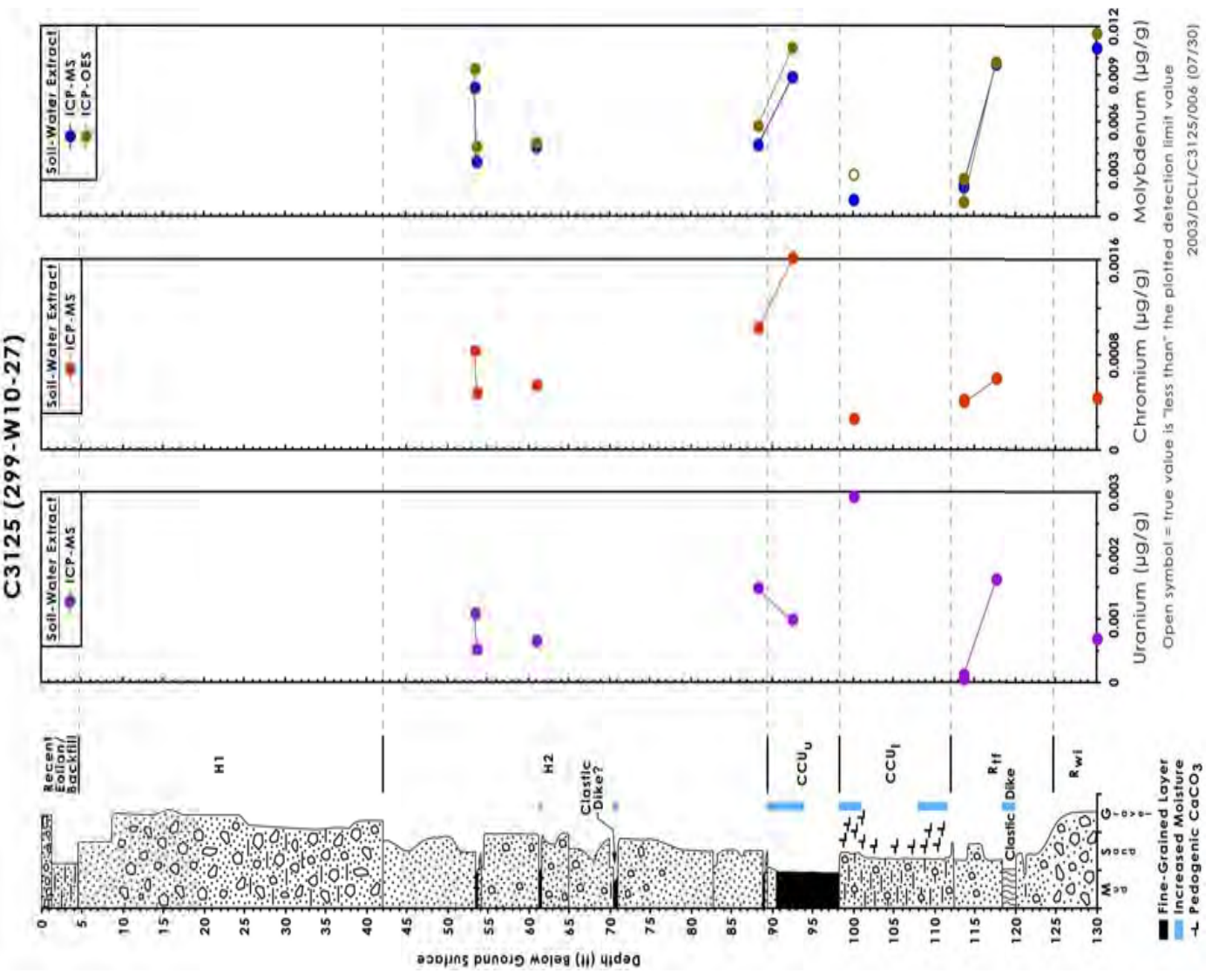

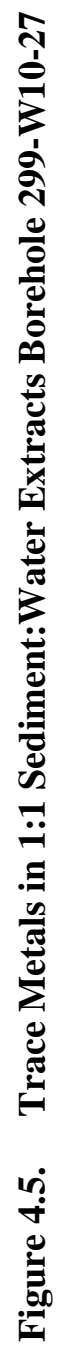




\subsection{3 $8 \mathrm{M}$ Nitric Acid-Extractable Amounts of Selected Elements}

The amount of material that could be extracted from the vadose zone sediment into $8 \mathrm{M}$ nitric acid is shown in Tables 4.8 through 4.10 and Figures 4.6 through 4.9. The $8 \mathrm{M}$ nitric acid extraction is a protocol used by the U.S. Environmental Protection Agency to estimate the maximum concentrations of regulated metals in contaminated sediment that would be biologically available. Aliquots of uncontaminated sediment from borehole 299-W10-27 were subjected to the acid extraction to establish baseline values to compare with acid extracts of potentially contaminated sediments from the three boreholes, C3830, C3831, and C3832.

The acid extract data show high values for barium in the fine-grained $\mathrm{CCU}_{\mathrm{u}}$ subunit, and high values for calcium $(\mathrm{Ca})$, strontium $(\mathrm{Sr})$, manganese $(\mathrm{Mn})$, sodium $(\mathrm{Na})$, uranium $(\mathrm{U})$ and sulfate $\left(\mathrm{SO}_{4}{ }^{2-}\right)$ in the two sediment types with high calcium-carbonate content, $\mathrm{CCU}_{1}$ at $100 \mathrm{ft}$ bgs and $\mathrm{R}_{\mathrm{tf}}$ at $117 \mathrm{ft}$ bgs. The acid-extractable magnesium content of the $\mathrm{R}_{\mathrm{tf}}$ sample at $117 \mathrm{ft}$ bgs is also high. All these high values suggest that these elements are associated with readily acid-soluble carbonates. Similar results were found for background sediments near the SX tank farm (Serne et al. 2002a). Conversely, the acidextractable chromium content of the caliche enriched sample at $100 \mathrm{ft}$ bgs is low compared to the other sediments. Chromium is also low but molybdenum and sulfur are relatively high in the acid extract from the gravelly $\mathrm{R}_{\mathrm{wi}}$ unit sample at $130 \mathrm{ft}$ bgs. Acid-leachable potassium $(\mathrm{K})$ is also low in this coarse sample as one might expect seeing as higher potassium is generally associated with certain clay and fine-grained materials.

A comparison of the water-leachable and acid-leachable contents of the uncontaminated sediments from borehole 299-W10-27 (see data shown in Tables 4.3 to 4.7 versus 4.8 to 4.10) shows that less than $0.1 \%$ of the acid-extractable quantities of the following elements are water leachable: $\mathrm{Al}, \mathrm{Ba}, \mathrm{Fe}, \mathrm{Mn}, \mathrm{Zn}$, $\mathrm{Cr}$, and $\mathrm{P}$ as phosphate. Less than $0.2 \%$ of the acid-extractable quantities of the following elements are water leachable: $\mathrm{Ca}, \mathrm{K}, \mathrm{Mg}, \mathrm{Sr}$, and $\mathrm{U}$. Less than $5 \%$ of the acid-extractable sodium and molybdenum are water soluble and less than $20 \%$ of the acid-extractable sulfur as sulfate is water extractable. The sulfur in the sediments may be predominately present as slightly soluble gypsum and the phosphorous may be present predominantly as rather insoluble apatite-like minerals. The comparison of water- to acid-soluble sulfur and phosphorous are shown in Figure 4.9.

\subsubsection{Bulk Chemical Composition of Sediment from 299-W10-27}

Nine core samples were selected from this borehole and sent to a commercial analytical lab for bulk chemical composition analyses using fusion, followed by dissolution of the fused beads and analysis by ICP and ICP-MS. The carbon content of the samples was determined with a carbon analyzer as discussed in Section 4.1.6. The total chemical composition of the samples is shown in Table 4.11 and total trace element compositions are shown in Table 4.12.

As found for most Hanford Site sediments, the bulk chemistry is dominated by silicon and aluminum oxides, with calcium and iron being next in abundance. Calcium from $\mathrm{CaCO}_{3}$ is evident in several of the samples (100 and $117.5 \mathrm{ft} \mathrm{bgs).} \mathrm{There} \mathrm{is} \mathrm{also} \mathrm{several} \mathrm{percent} \mathrm{of} \mathrm{sodium,} \mathrm{potassium,} \mathrm{and} \mathrm{magnesium}$ present in all the sediments. The relatively high iron-oxide contents in the $\mathrm{R}_{\mathrm{tf}}$ and $\mathrm{R}_{\mathrm{wi}}$ samples from 117.5 and $130 \mathrm{ft}$ bgs (see Table 4.11) likely are caused by ferric oxide coatings or cement. Trace metals are often used to differentiate different lithologic units but the data in Table 4.12 only suggest that the fine-grained Cold Creek upper subunit is distinguishable from all other units by the presence of elevated 
lanthanide series elements. The other elements do not show striking differences in trace element concentrations with lithology.

\subsubsection{Radionuclide Content in Vadose Zone Sediment from 299-W10-27}

The sediment cores from borehole 299-W10-27 did not contain any man-made gamma radioactivity. The radioanalytical analyses performed on the sediment included direct gamma energy analysis and technetium-99 and uranium-238 analysis of the 1:1 sediment:water extracts and the sediment:acid extracts. The uranium and technetium water-extractable contents of the background sediments that were characterized are shown in Table 4.7 and the acid-extractable amounts are shown in Table 4.10. Both data sets suggest no elevated amounts are present. As mentioned above, the sediments with high concentrations of calcium-carbonate-equivalent carbonate contain slightly higher concentrations of acidleachable uranium, one part per million ( $\mathrm{ppm}$ ). The gamma energy analysis data are not reported because there is nothing significant to report.

\subsubsection{Total Carbon, Calcium Carbonate, and Organic Carbon Content of Vadose Zone Sediment from Borehole 299-W10-27}

Table 4.13 shows the total carbon, inorganic carbon, and organic carbon contents of the vadose zone sediment at selected depths. The inorganic carbon was also converted to the equivalent calciumcarbonate content. The sediment in the Hanford formation $\mathrm{H} 2$ unit is relatively low in calcium carbonate $(<2 \mathrm{wt} \%)$ and organic carbon. The three shallow $\mathrm{H} 2$ unit samples show a fairly uniform distribution for inorganic carbon between 1.6 and $1.8 \%$ as calcium carbonate. At depth, the $\mathrm{H} 2$ unit shows slightly more calcium carbonate. The fine-grained $\mathrm{CCU}_{\mathrm{u}}$ sample contains $\sim 2.6 \mathrm{wt} \%$ calcium carbonate.

The coarser-grained $\mathrm{CCU}_{1}$ contains significant quantities ( $\left.25 \mathrm{wt} \%\right)$ of calcium carbonate and low organic carbon content. The $\mathrm{R}_{\mathrm{tf}}$ unit samples show highly variable calcium-carbonate contents as a function of depth. The coarse-grained $\mathrm{R}_{\mathrm{wi}}$ gravel has very little calcium carbonate and organic carbon. The calcium-carbonate content of the $\mathrm{CCU}_{1}$ unit at 299-W10-27 is less than at 299-W22-48 (contained 38 to $39 \mathrm{wt} \%$ ) but larger than sediments at 299-W22-50, which contained only 2 to $8 \mathrm{wt} \%$ (Serne et al. 2002a).

\subsubsection{Particle Size Measurements on Vadose Zone Sediment}

Both the hydrometer and wet sieving methods were used to determine the particle size distributions of the selected samples from borehole 299-W10-27. Wet sieving results are shown in Table 4.14. The four samples of the Hanford formation $\mathrm{H} 2$ unit that were chosen for particle-size characterization represent zones with atypically high contents of fines. Samples for geochemical characterization were biased in favor of the fine-grained strata since these tend to contain more moisture and are more likely to have contaminants associated with them. Therefore, the values in Table 4.14 should not be used as representative of the bulk of the Hanford $\mathrm{H} 2$ unit. The Cold Creek upper subunit is predominantly silt. In contrast, the Cold Creek lower subunit (caliche) is very poorly sorted and has a wide range of particle sizes from gravel to silt and clay, as has been described previously for sediments below the SX tank farm (Serne et al. 2002a, 2002b, 2002c, 2002d). The two grain size samples from the $\mathrm{R}_{\mathrm{tf}}$ unit show great variability as described in Section 2.3.2.4. One is a well-sorted sand; the other, a well-sorted silt. 


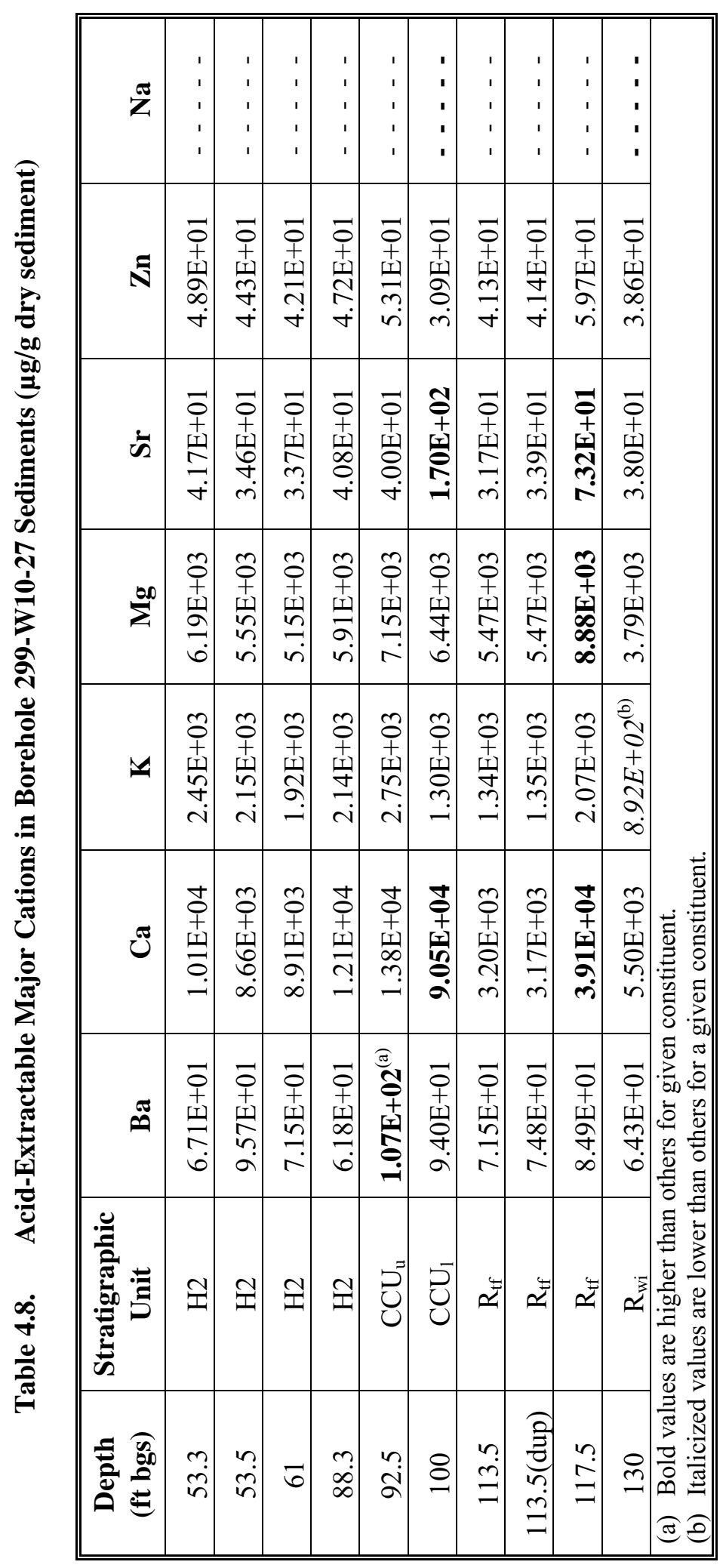




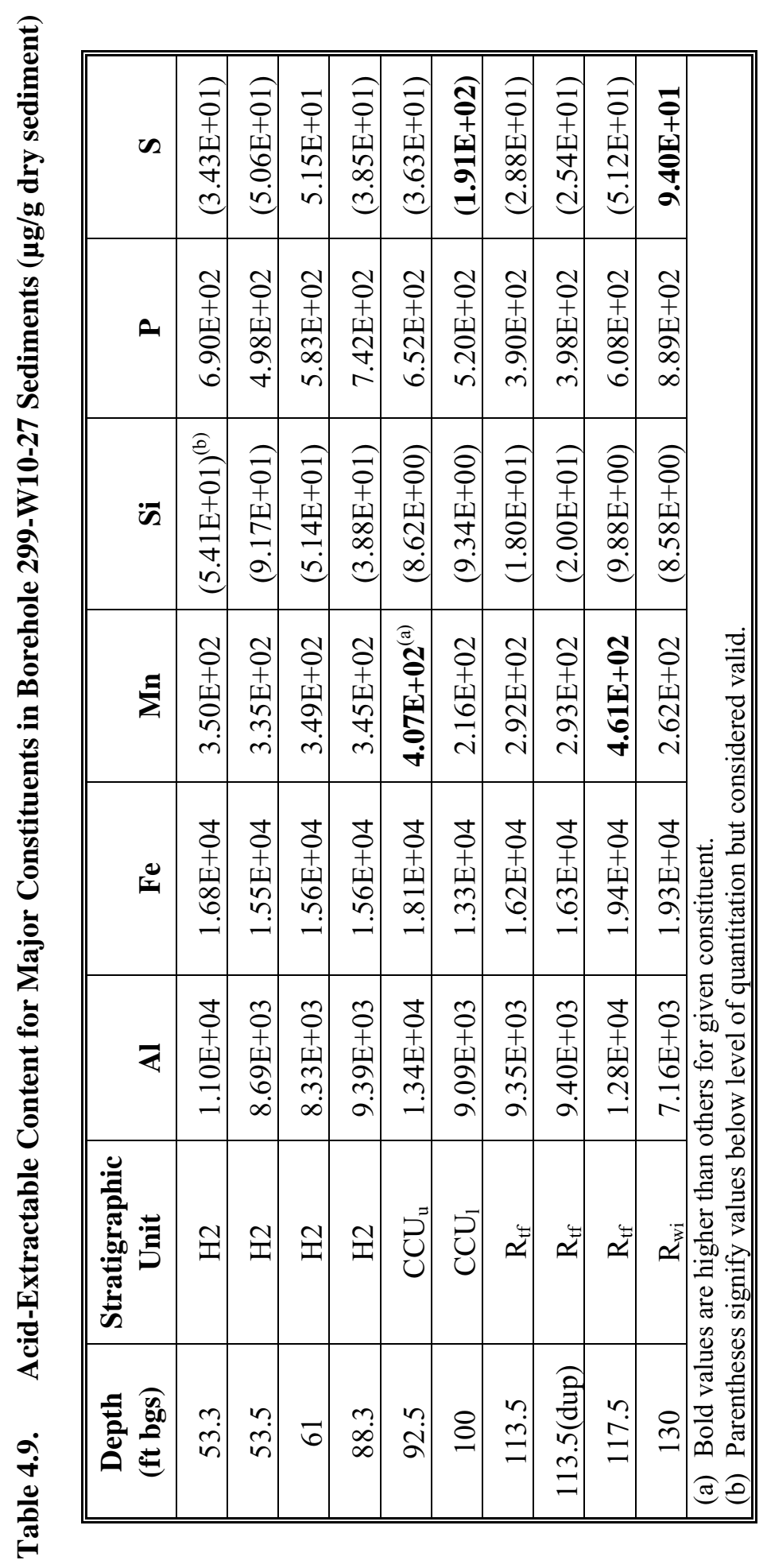




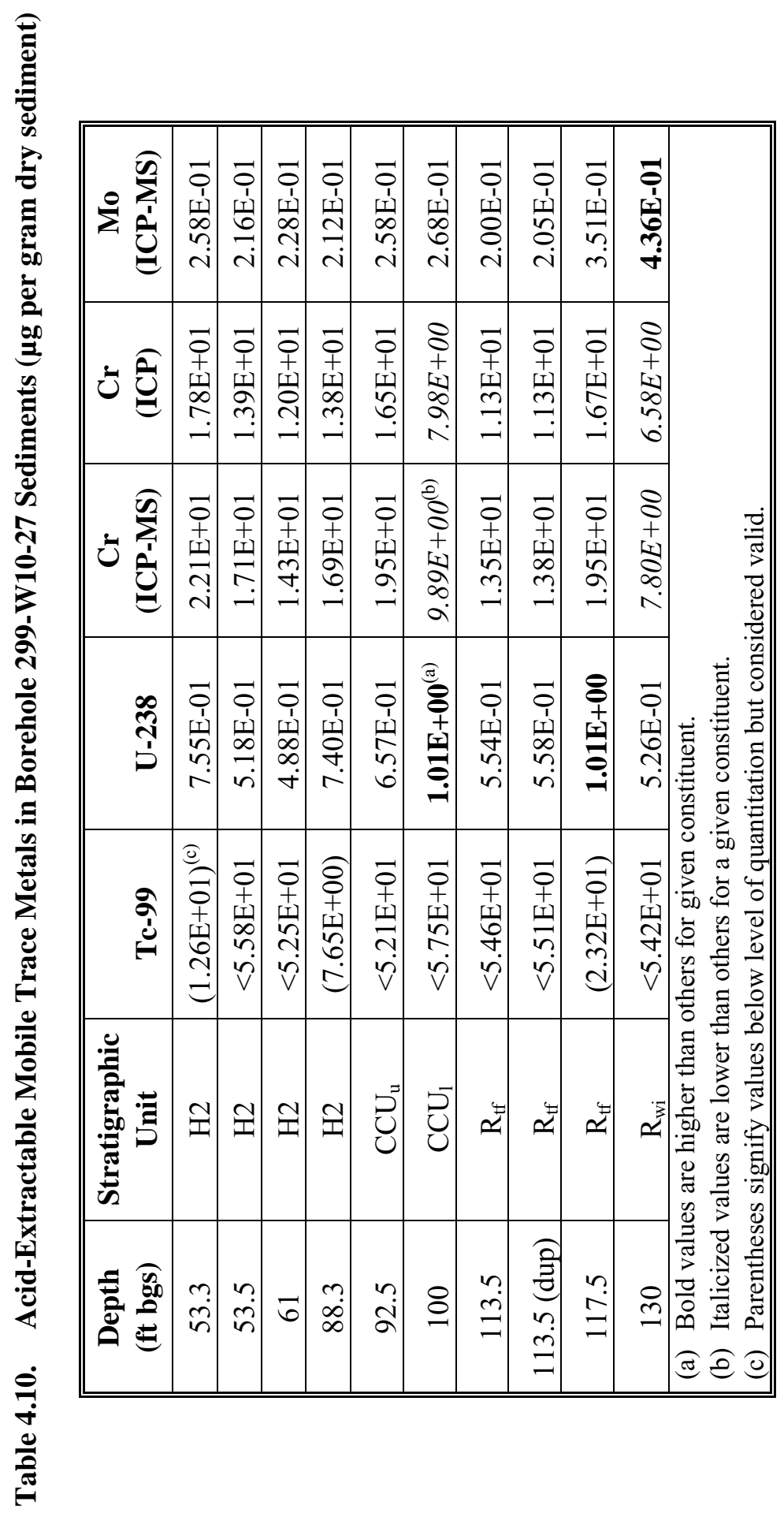




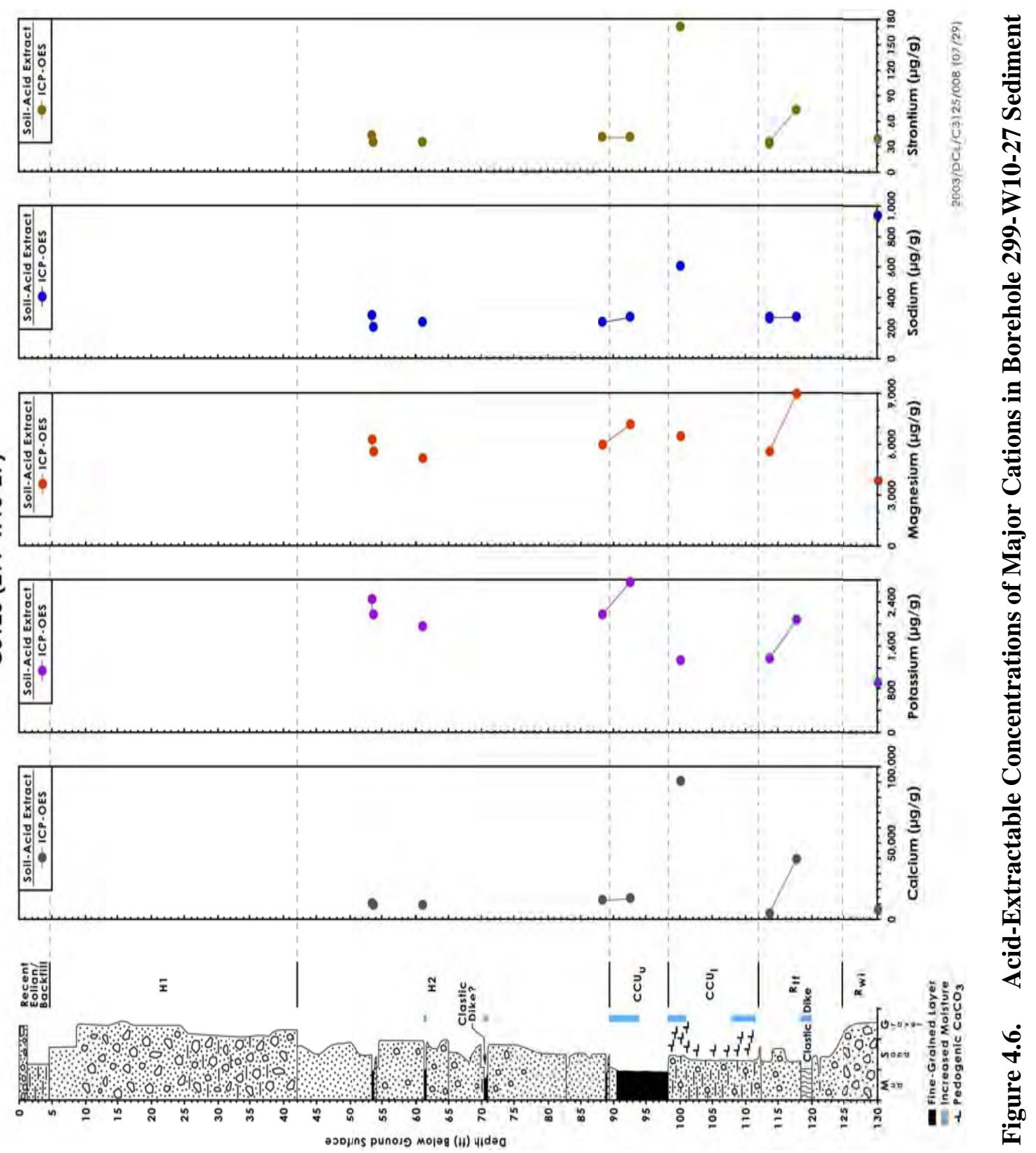




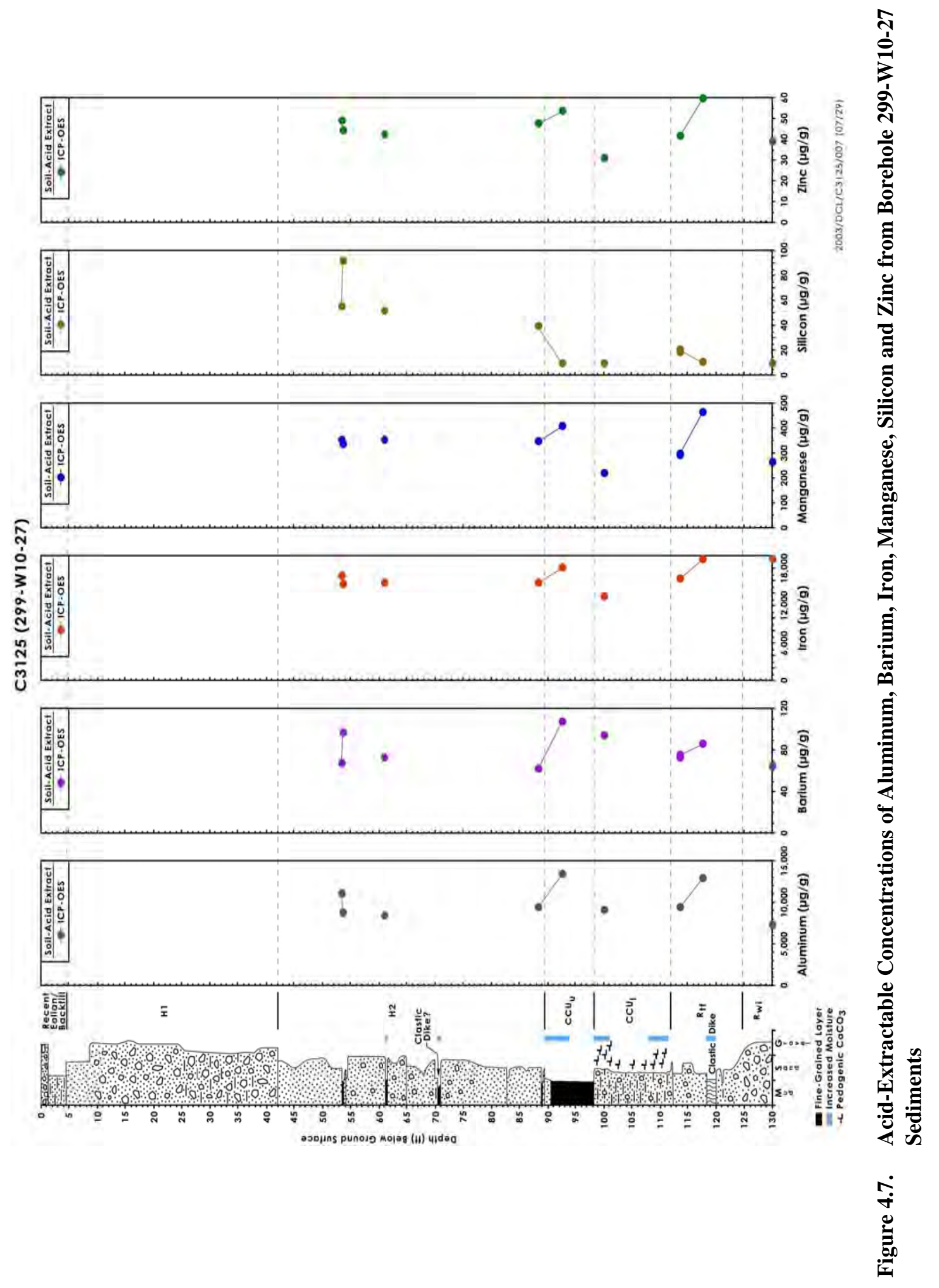


C3125 (299-W10-27)

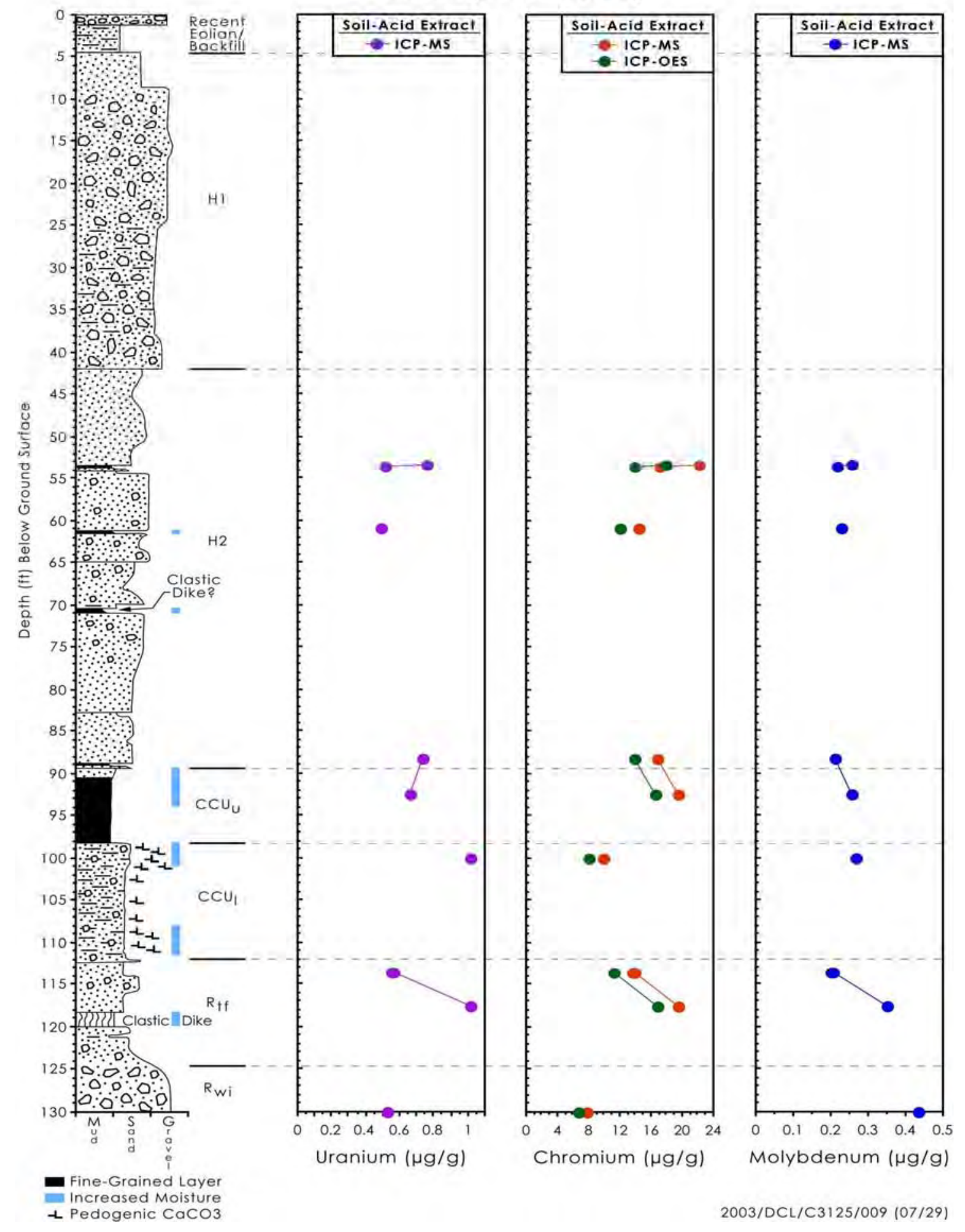

Figure 4.8. Concentration of Uranium-238, Chromium, and Molybdenum in 299-W10-27 Borehole Sediment that is Acid-Extractable. (Technetium-99 and Ruthenium were not detected in clean sediments; thus, they are not plotted). 


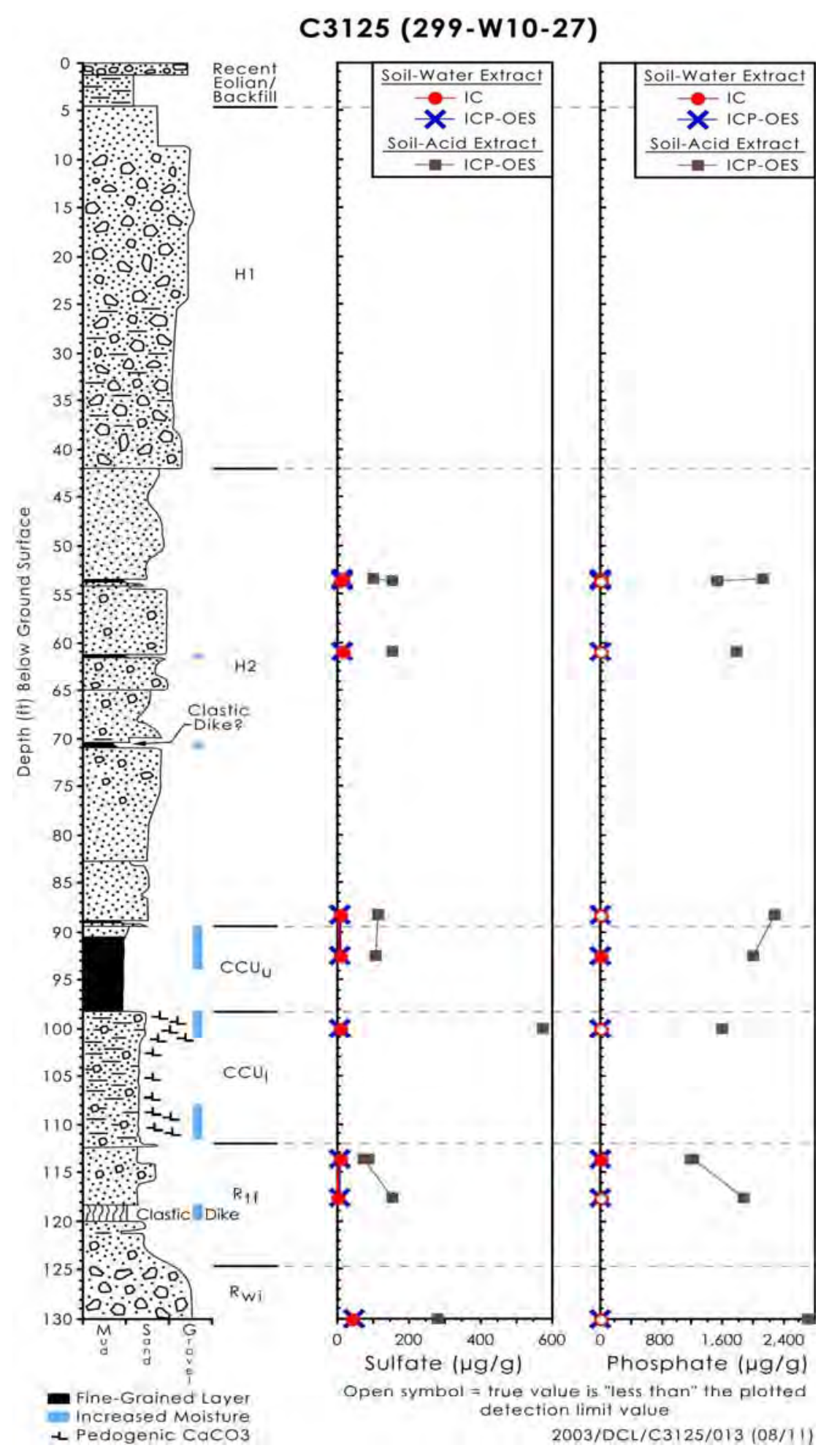

Figure 4.9. Comparison between Acid-and Water-Extractable Sulfate and Phosphate in Vadose Zone Sediments from Borehole 299-W10-27 


\begin{tabular}{|c|c|c|c|}
\hline 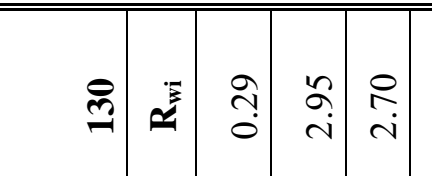 & 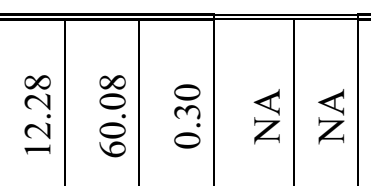 & $\Xi \because$ & : \\
\hline 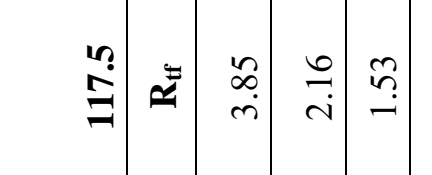 & $=\frac{m}{E}$ & 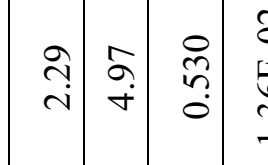 & 密: \\
\hline 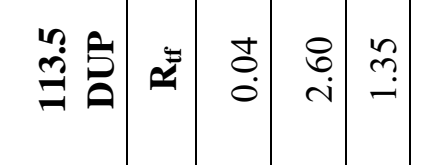 & 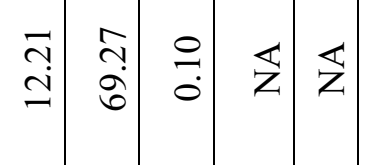 & 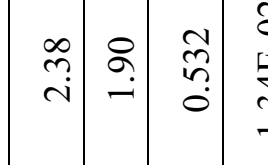 & 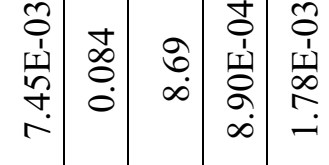 \\
\hline 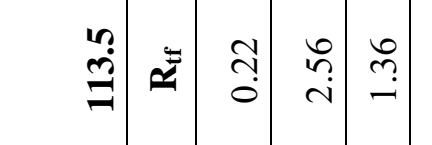 & 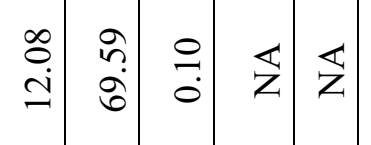 & $\bar{z}:$ & 鄯: \\
\hline 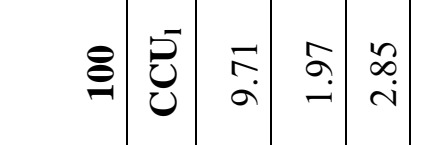 & 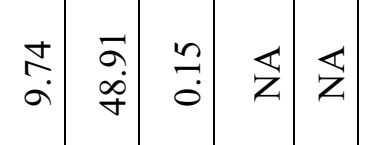 & $\because g$ & 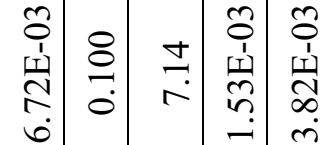 \\
\hline ำ & 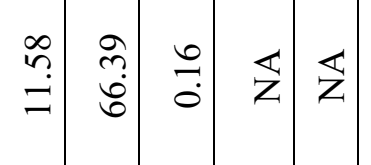 & aี & 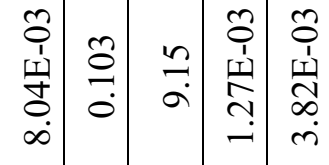 \\
\hline 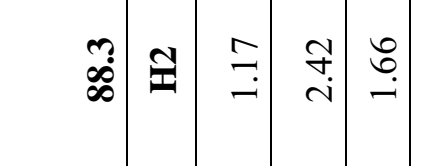 & $\stackrel{0}{=}=\frac{1}{b} \frac{n}{b}=\frac{1}{z}$ & 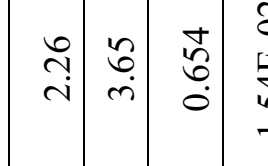 & 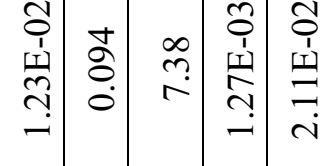 \\
\hline 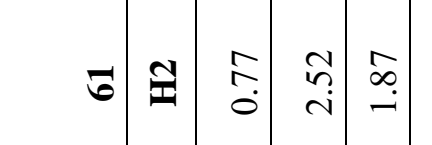 & 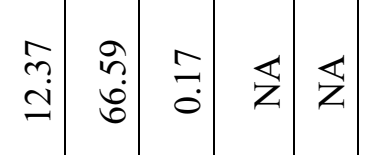 & 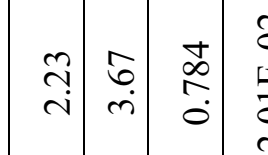 & 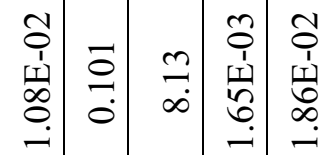 \\
\hline 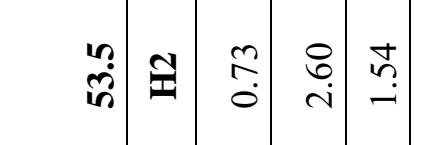 & 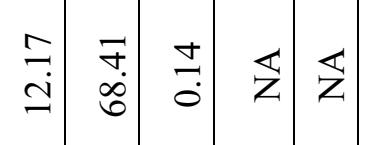 & $\frac{7}{2}=\frac{n}{2}$ & 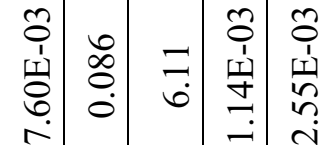 \\
\hline 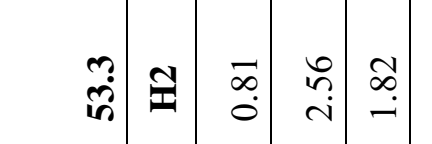 & $\frac{z}{2} \frac{7}{8}$ & $\because \xi$ & $=0$ \\
\hline 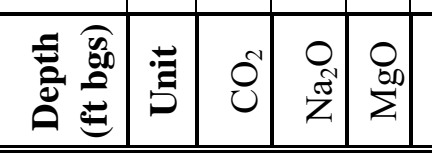 & 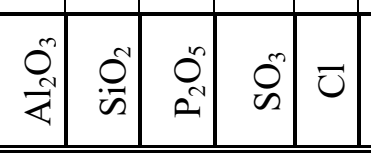 & \begin{tabular}{|l|l|l}
0 & 0 & 0
\end{tabular} & 彭高总 \\
\hline
\end{tabular}




\begin{tabular}{|c|c|c|c|c|c|c|c|c|c|c|c|}
\hline లి & $\tilde{\bar{z}}$ & 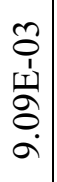 & $\begin{array}{c}0 \\
0 \\
1 \\
\stackrel{I}{1} \\
\infty \\
\dot{+}\end{array}$ & 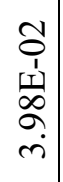 & $\begin{array}{l}n \\
\vdots \\
1 \\
\dot{1} \\
6 \\
\dot{n}\end{array}$ & 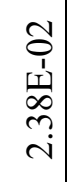 & $\begin{array}{l}\mathfrak{d} \\
1 \\
1 \\
\infty \\
\infty \\
\infty \\
\infty \\
\infty\end{array}$ & 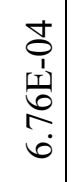 & 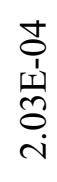 & $\begin{array}{c}m \\
\stackrel{8}{\sigma}\end{array}$ & \\
\hline$\frac{n}{2}$ & $\approx$ & 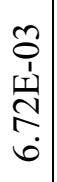 & $\begin{array}{c}m \\
0 \\
1 \\
\stackrel{\lrcorner}{\nabla} \\
\vec{\sigma}\end{array}$ & 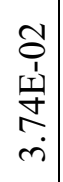 & 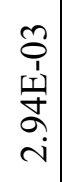 & 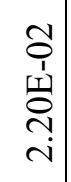 & 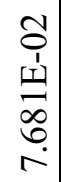 & $\begin{array}{c} \pm \\
0 \\
1 \\
\\
+ \\
\infty\end{array}$ & 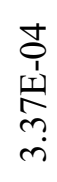 & $\begin{array}{l}n \\
\dot{0} \\
\dot{\theta}\end{array}$ & \\
\hline$\stackrel{n}{\stackrel{n}{g}}$ & $\approx$ & 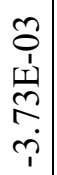 & $\begin{array}{c}m \\
0 \\
1 \\
n \\
n \\
\infty \\
\infty\end{array}$ & 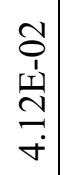 & $\begin{array}{c}n \\
0 \\
1 \\
\omega \\
n \\
i \\
i\end{array}$ & 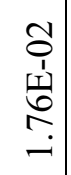 & 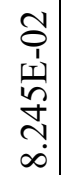 & $\begin{array}{c}+ \\
0 \\
1 \\
\dot{1} \\
0 \\
\dot{0}\end{array}$ & $\begin{array}{l}\mathbb{S} \\
1 \\
\stackrel{1}{N} \\
0 \\
\text { d }\end{array}$ & $\begin{array}{l}m \\
\stackrel{a}{a}\end{array}$ & \\
\hline$\stackrel{n}{m}$ & $\approx$ & \begin{tabular}{c}
0 \\
0 \\
1 \\
\multirow{1}{*}{} \\
$\infty$ \\
$\sim$ \\
$\sim$
\end{tabular} & $\begin{array}{c}m \\
0 \\
1 \\
1 \\
0 \\
0 \\
a\end{array}$ & 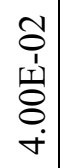 & $\begin{array}{l}n \\
0 \\
1 \\
0 \\
0 \\
n \\
i\end{array}$ & 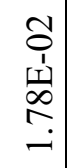 & 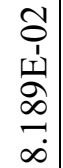 & 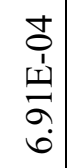 & 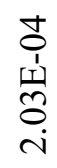 & $\begin{array}{l}\bar{\theta} \\
\dot{\Theta} \\
\end{array}$ & \\
\hline$\underline{8}$ & $\Xi$ & $\begin{array}{c}n \\
0 \\
1 \\
\\
\tilde{n} \\
\infty\end{array}$ & $\begin{array}{c}m \\
0 \\
1 \\
\underline{y} \\
\underline{I} \\
\dot{m}\end{array}$ & \begin{tabular}{c}
\multicolumn{2}{c}{} \\
$\stackrel{1}{1}$ \\
$\stackrel{1}{2}$ \\
$\partial$ \\
$\dot{+}$
\end{tabular} & 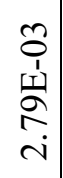 & 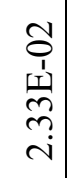 & 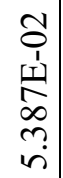 & $\begin{array}{c}+ \\
0 \\
1 \\
\omega \\
\infty \\
0 \\
r\end{array}$ & 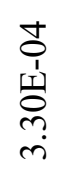 & $\begin{array}{c}\hat{N} \\
\stackrel{0}{a}\end{array}$ & \\
\hline గn & $\underbrace{z}$ & 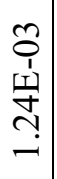 & $\begin{array}{c}m \\
0 \\
1 \\
\infty \\
0 \\
0 \\
a\end{array}$ & $\begin{array}{c}\widetilde{o} \\
0 \\
\underline{1} \\
\sigma \\
\vec{n} \\
\dot{m}\end{array}$ & $\begin{array}{l}0 \\
0 \\
1 \\
1 \\
1 \\
0 \\
\dot{n}\end{array}$ & 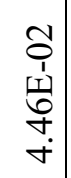 & 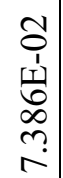 & $\begin{array}{c}m \\
0 \\
1 \\
n \\
\\
-1\end{array}$ & \begin{tabular}{l}
$\dot{J}$ \\
\multirow{1}{1}{} \\
$\stackrel{I}{d}$ \\
$\infty$ \\
$\dot{\infty}$
\end{tabular} & \begin{tabular}{c}
$\infty$ \\
$:$ \\
$\infty$ \\
\hdashline
\end{tabular} & \\
\hline $\begin{array}{c}m \\
\infty \\
\infty\end{array}$ & $\mathfrak{\Xi}$ & \begin{tabular}{c}
0 \\
0 \\
1 \\
\multicolumn{1}{|c}{} \\
$\infty$ \\
$\infty$ \\
\end{tabular} & $\begin{array}{c}m \\
0 \\
1 \\
n \\
n \\
\infty \\
\infty\end{array}$ & 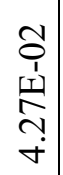 & $\begin{array}{c}n \\
0 \\
1 \\
1 \\
\infty \\
-1 \\
m\end{array}$ & 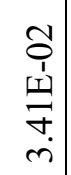 & 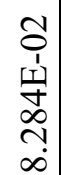 & $\begin{array}{c} \pm \\
0 \\
1 \\
\sigma \\
\sigma \\
a\end{array}$ & 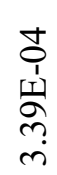 & $\begin{array}{c}0 \\
0 \\
\stackrel{0}{0}\end{array}$ & \\
\hline 6] & $\mathfrak{\Xi}$ & 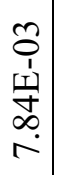 & $\begin{array}{c}m \\
0 \\
1 \\
n \\
n \\
\infty\end{array}$ & 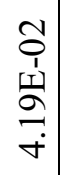 & $\begin{array}{l}\tilde{0} \\
0 \\
1 \\
1 \\
0 \\
\dot{n} \\
\dot{n}\end{array}$ & 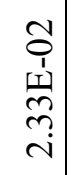 & $\begin{array}{l}2 \\
0 \\
1 \\
1 \\
\infty \\
n \\
n \\
\infty\end{array}$ & $\begin{array}{c} \pm \\
0 \\
1 \\
\\
\sigma\end{array}$ & 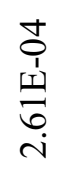 & $\begin{array}{l}\stackrel{0}{+} \\
\dot{a}\end{array}$ & \\
\hline $\begin{array}{l}n \\
\tilde{n} \\
0\end{array}$ & $\mathfrak{I}$ & 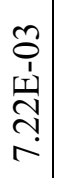 & $\begin{array}{c}m \\
0 \\
1 \\
\stackrel{1}{\sim} \\
\dot{f} \\
\infty\end{array}$ & 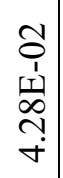 & $\begin{array}{l}n \\
0 \\
1 \\
\infty \\
\infty \\
n \\
i\end{array}$ & 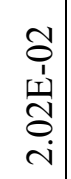 & 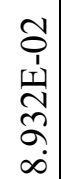 & 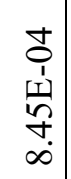 & 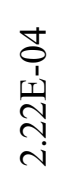 & $\begin{array}{c}\frac{1}{a} \\
\stackrel{0}{a}\end{array}$ & \\
\hline mై & $\mathfrak{I}$ & $\begin{array}{c}n \\
o \\
1 \\
\stackrel{1}{N} \\
\stackrel{N}{r}\end{array}$ & $\begin{array}{c}m \\
0 \\
1 \\
1 \\
n \\
n \\
\infty\end{array}$ & 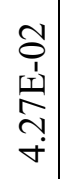 & 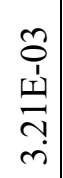 & 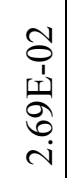 & 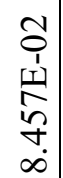 & 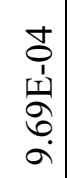 & $\begin{array}{l}\dot{J} \\
0 \\
\dot{1} \\
\dot{0} \\
\dot{0}\end{array}$ & $\begin{array}{l}8 \\
2 \\
2\end{array}$ & 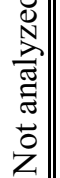 \\
\hline 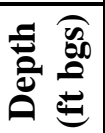 & $\stackrel{\Xi}{\Xi}$ & $\stackrel{\circ}{\stackrel{\bigcirc}{N}}$ & $\begin{array}{l}0 \\
\hat{N}^{\prime}\end{array}$ & 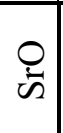 & $\overbrace{}^{N}$ & 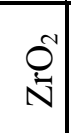 & $\begin{array}{l}0 \\
\mathscr{D} \\
0\end{array}$ & $\underset{\tilde{E}}{\stackrel{N}{N}}$ & $\stackrel{\text { }}{\Omega}$ & $\stackrel{\frac{\sigma}{0}}{0}$ & 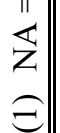 \\
\hline
\end{tabular}


Table 4.12. Trace Element Composition of Borehole 299-W10-27 Sediments (as $\mu \mathrm{g}$ per $\mathrm{g}$ dry sediment)

\begin{tabular}{|c|c|c|c|c|c|c|c|c|c|c|}
\hline Depth (ft bgs) & 53.3 & 53.5 & 61 & 88.3 & 92.5 & 100 & 113.5 & 113.5 DUP & 117.5 & 130 \\
\hline Unit & H2 & H2 & $\mathbf{H} 2$ & H2 & $\mathrm{CCU}_{\mathbf{u}}$ & $\mathrm{CCU}_{\mathrm{l}}$ & $\mathbf{R}_{\mathbf{t f}}$ & $\mathbf{R}_{\mathbf{t f}}$ & $\mathbf{R}_{\mathbf{t f}}$ & $\mathbf{R}_{\mathrm{wi}}$ \\
\hline Be & 2 & 2 & 2 & 2 & 2 & 1 & 2 & 2 & 2 & 2 \\
\hline Sc & 11 & 10 & 12 & 10 & 10 & 15 & 8 & 8 & 9 & 22 \\
\hline Ga & 15 & 14 & 16 & 15 & 15 & 12 & 14 & 13 & 14 & 17 \\
\hline Ge & 1.6 & 1.2 & 1.5 & 1.3 & 1.4 & 1 & 1.4 & 1.2 & 1.6 & 0.9 \\
\hline As & 9 & 6 & 8 & 7 & 7 & 6 & 7 & $<5$ & 10 & $<5$ \\
\hline Se & $\mathrm{NA}^{(1)}$ & NA & NA & NA & NA & NA & NA & NA & NA & NA \\
\hline $\mathbf{N b}$ & 11.5 & 8.8 & 10.1 & 11.3 & 12.6 & 9.4 & 7.7 & 7.7 & 9.1 & 11.9 \\
\hline Mo & 3 & $<2$ & 2 & 3 & $<2$ & $<2$ & 3 & $<2$ & 4 & 0 \\
\hline Ag & $<0.5$ & $<0.5$ & $<0.5$ & $<0.5$ & $<0.5$ & $<0.5$ & $<0.5$ & $<0.5$ & $<0.5$ & $<0.5$ \\
\hline In & $<0.1$ & $<0.1$ & $<0.1$ & $<0.1$ & $<0.1$ & $<0.1$ & $<0.1$ & $<0.1$ & $<0.1$ & $<0.1$ \\
\hline Sn & 4 & 3 & 4 & 4 & 3 & 2 & 5 & 4 & 5 & 3 \\
\hline Sb & 1.2 & 0.8 & 0.9 & 0.8 & 1 & 0.4 & 1.3 & 0.9 & 1.6 & 0.4 \\
\hline Cs & 3.3 & 3 & 3.3 & 3.2 & 4.1 & 1 & 3.4 & 3.3 & 3.9 & 1.1 \\
\hline La & 33.1 & 27.5 & 26.9 & 32.5 & 38.1 & 26.3 & 22.1 & 23.4 & 27.7 & 24.9 \\
\hline $\mathrm{Ce}$ & 61.8 & 53.9 & 51.9 & 62.1 & 74.4 & 49.3 & 45.3 & 45.2 & 53.2 & 49.9 \\
\hline Pr & 6.9 & 5.82 & 6.18 & 6.98 & 8.6 & 5.49 & 5.03 & 5.02 & 6.11 & 5.77 \\
\hline Nd & 27.8 & 22 & 24.9 & 28.1 & 33.3 & 22.2 & 18.9 & 19.6 & 24.4 & 23.4 \\
\hline Sm & 5.35 & 4.33 & 4.74 & 5.23 & 6.07 & 4.64 & 3.74 & 3.87 & 4.61 & 5.17 \\
\hline $\mathbf{E u}$ & 1.27 & 1.08 & 1.18 & 1.14 & 1.31 & 1.25 & 0.967 & 0.980 & 1.04 & 1.70 \\
\hline Gd & 3.98 & 3.23 & 3.98 & 3.97 & 5.33 & 3.54 & 3.04 & 3.18 & 3.66 & 4.60 \\
\hline $\mathbf{T b}$ & 0.75 & 0.54 & 0.72 & 0.74 & 0.88 & 0.62 & 0.53 & 0.55 & 0.66 & 0.80 \\
\hline Dy & 4.38 & 3.27 & 4.00 & 4.16 & 4.94 & 3.86 & 3.18 & 3.30 & 3.85 & 4.96 \\
\hline Нo & 0.83 & 0.65 & 0.78 & 0.80 & 0.97 & 0.74 & 0.65 & 0.63 & 0.79 & 1.00 \\
\hline $\mathbf{E r}$ & 2.52 & 1.87 & 2.44 & 2.54 & 2.98 & 2.08 & 1.92 & 1.89 & 2.35 & 2.86 \\
\hline $\mathbf{T m}$ & 0.373 & 0.275 & 0.353 & 0.374 & 0.457 & 0.306 & 0.282 & 0.281 & 0.356 & 0.419 \\
\hline $\mathbf{Y b}$ & 2.53 & 1.86 & 2.30 & 2.44 & 2.89 & 2.02 & 1.80 & 1.89 & 2.26 & 2.65 \\
\hline Lu & 0.373 & 0.289 & 0.350 & 0.371 & 0.460 & 0.304 & 0.288 & 0.282 & 0.335 & 0.407 \\
\hline
\end{tabular}


Table 4.12 (contd)

\begin{tabular}{||c|c|c|c|c|c|c|c|c|c|c||}
\hline Depth (ft bgs) & $\mathbf{5 3 . 3}$ & $\mathbf{5 3 . 5}$ & $\mathbf{6 1}$ & $\mathbf{8 8 . 3}$ & $\mathbf{9 2 . 5}$ & $\mathbf{1 0 0}$ & $\mathbf{1 1 3 . 5}$ & $\mathbf{1 1 3 . 5} \mathbf{D U P}$ & $\mathbf{1 1 7 . 5}$ & $\mathbf{1 3 0}$ \\
\hline Unit & $\mathbf{H 2}$ & $\mathbf{H 2}$ & $\mathbf{H 2}$ & $\mathbf{H 2}$ & $\mathbf{C C U}_{\mathbf{u}}$ & $\mathbf{C C U}_{\mathbf{l}}$ & $\mathbf{R}_{\mathbf{t f}}$ & $\mathbf{R}_{\mathbf{t f}}$ & $\mathbf{R}_{\mathbf{t f}}$ & $\mathbf{R}_{\mathbf{w i}}$ \\
\hline $\mathbf{H f}$ & 5.5 & 3.8 & 4.6 & 6.6 & 8.2 & 4.4 & 3.4 & 3.3 & 4.5 & 4.4 \\
\hline $\mathbf{T a}$ & 0.96 & 0.71 & 0.78 & 0.94 & 1.03 & 0.70 & 0.59 & 0.64 & 0.77 & 0.79 \\
\hline $\mathbf{W}$ & 1.5 & 1.0 & 1.1 & 1.9 & 1.6 & 0.6 & 1.2 & 1.2 & 1.6 & 0.1 \\
\hline $\mathbf{T l}$ & 0.48 & 0.46 & 0.42 & 0.46 & 0.32 & 0.19 & 0.49 & 0.29 & 0.51 & 0.26 \\
\hline $\mathbf{P b}$ & 13 & 13 & 11 & 12 & 2 & 8 & 10 & $<5$ & 13 & 0 \\
\hline $\mathbf{B i}$ & 0.3 & 0.2 & 0.2 & 0.3 & 0.1 & 0.1 & 0.3 & $<0.1$ & 0.4 & $<0.1$ \\
\hline (1) NA = Not analyzed. & \multicolumn{10}{|c|}{} \\
\hline
\end{tabular}




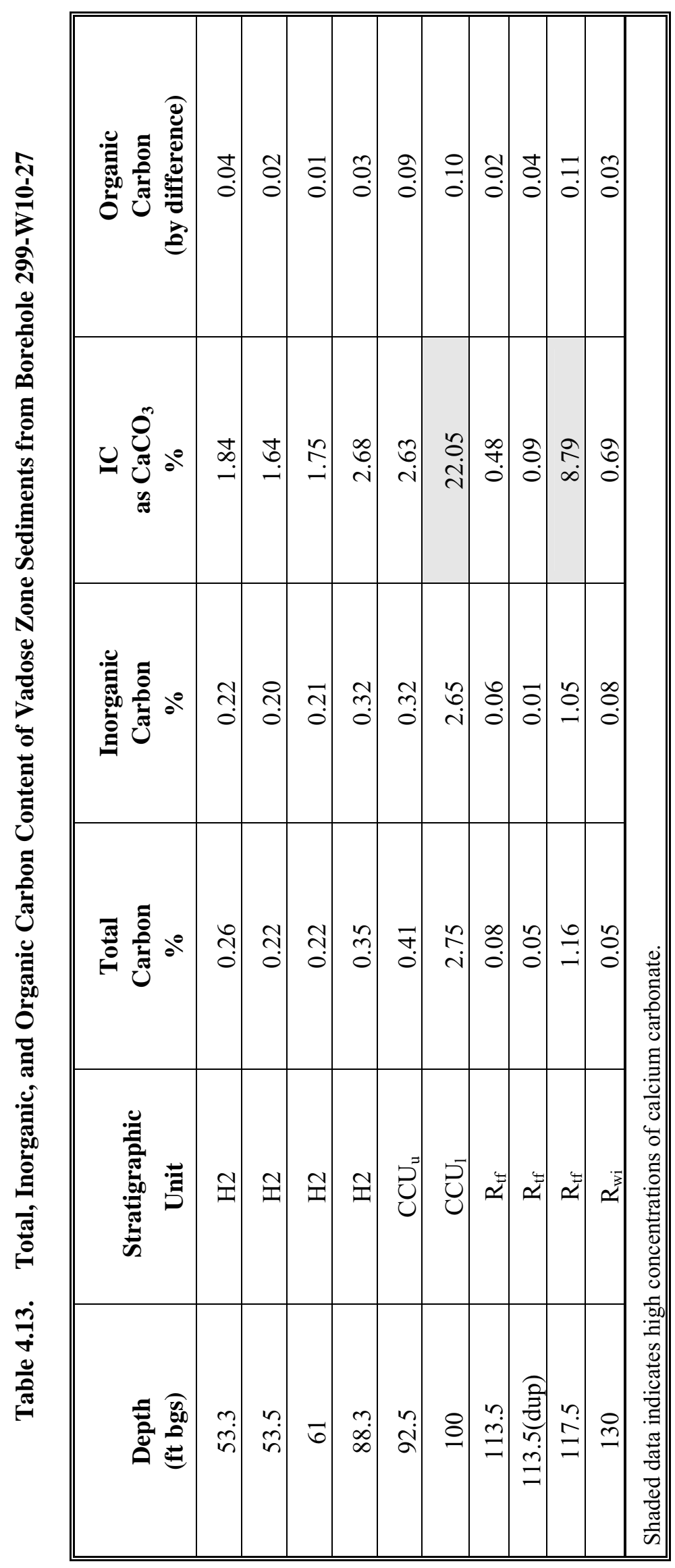


The sample from the $\mathrm{R}_{\mathrm{wi}}$ unit is a poorly sorted mixture of gravel, sand, and mud. The hydrometer results and wet sieving results are combined in Figures 4.10 through Figure 4.12 as plots of cumulative percent finer than versus particle size in microns. The data for the two particle size methods are shown in Table 4.15.

Within the Hanford formation $\mathrm{H} 2$ unit the samples from 53.3 and $88.3 \mathrm{ft}$ bgs are more fine-grained than the samples from 53.5 and $61 \mathrm{ft}$ bgs. The median grain size of these $\mathrm{H} 2$ unit samples are $\sim 150,260$, 250 , and 75 microns for the $53.3,53.5,61$, and $88.3 \mathrm{ft}$ bgs samples.

The sample from the Cold Creek upper subunit is well-sorted, based on the steep slope in Figure 4.11, and has a fine texture with the median grain size, $\sim 57$ microns. The sample from the Cold Creek lower subunit is less sorted and has a median grain size of $\sim 110$ microns. The two samples of $\mathrm{R}_{\mathrm{tf}}$ have significantly different particle size distributions with the $113.5 \mathrm{ft}$ bgs sample being medium sand (median particle size $\sim 300$ microns) but well-sorted, and the $117.5 \mathrm{ft}$ bgs sample being rather mostly silt (median particle size $\sim 45$ microns) but less well sorted. The $\mathrm{R}_{\mathrm{wi}}$ sample is poorly sorted with a median grain size of $\sim 200$ microns.

Table 4.14. Wet Sieve Particle Size Results for Borehole 299-W10-27 Sediments

\begin{tabular}{||c|c|c|c|c||}
\hline \multirow{2}{*}{$\begin{array}{c}\text { Depth } \\
\text { (ft bgs) }\end{array}$} & \multirow{2}{*}{$\begin{array}{c}\text { Stratigraphic } \\
\text { Unit }\end{array}$} & \multicolumn{3}{|c||}{ Weight Percent } \\
\cline { 3 - 5 } & Gravel & Sand & Silt/Clay \\
\hline 53.3 & $\mathrm{H} 2$ & 0.61 & 83.94 & 15.45 \\
\hline 53.5 & $\mathrm{H} 2$ & 0.39 & 88.58 & 11.03 \\
\hline 61 & $\mathrm{H} 2$ & 4.16 & 73.86 & 21.98 \\
\hline 88.3 & $\mathrm{H} 2$ & 0.14 & 52.28 & 47.58 \\
\hline 92.5 & $\mathrm{CCU}_{\mathrm{u}}$ & 0.00 & 27.11 & 72.89 \\
\hline 100 & $\mathrm{CCU}_{1}$ & 10.5 & 68.44 & 21.07 \\
\hline 113.5 & $\mathrm{R}_{\mathrm{tf}}$ & 0.00 & 88.78 & 11.22 \\
\hline 117.5 & $\mathrm{R}_{\mathrm{tf}}$ & 0.91 & 11.77 & 87.32 \\
\hline 130 & $\mathrm{R}_{\mathrm{wi}}$ & 15.68 & 48.23 & 36.09 \\
\hline
\end{tabular}




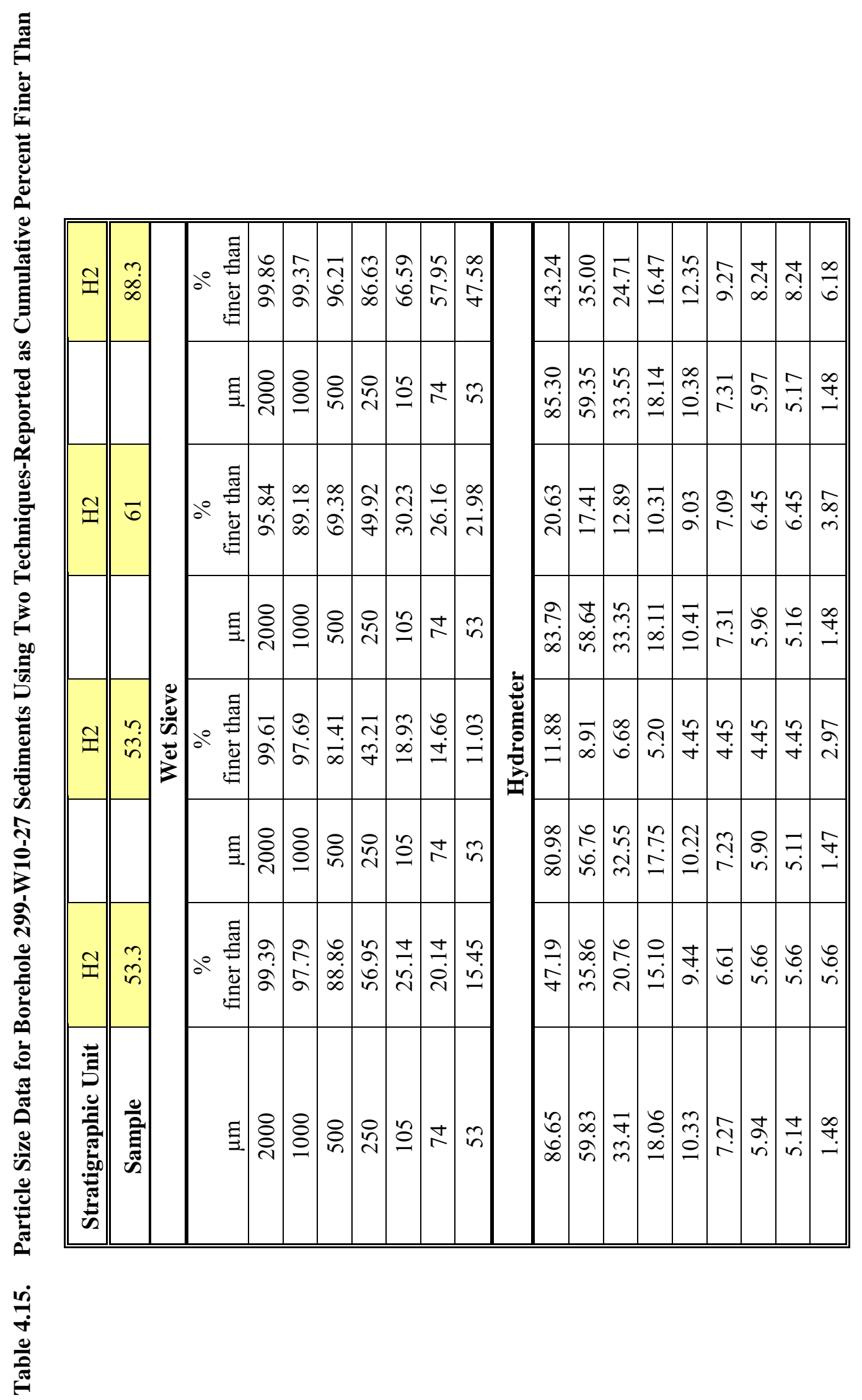




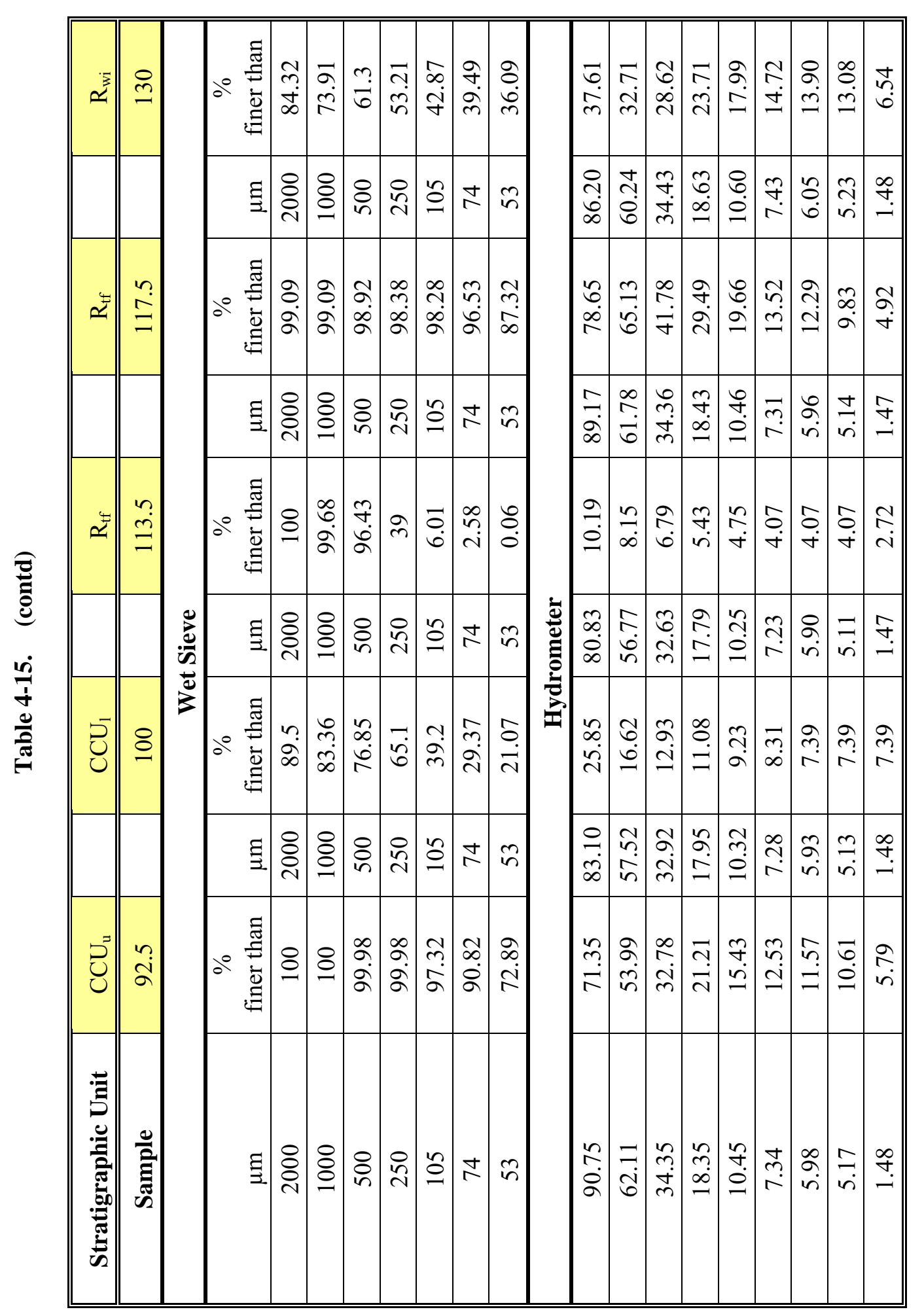




\subsubsection{Matric Suction Potential Measurements}

Water potential measurements have been included in the Hanford Tank Farm Vadose Zone Characterization Program to document the energy state of porewaters in the tank farm sediments. At the tank farms, vegetation is absent, surface soils are coarse-textured, and the potential for drainage (recharge) is high (Gee 1987; Gee et al. 1992). However, actual drainage rates are generally unknown. Attempts are currently being made to status the soil water matrix potential and use the analysis to confirm the occurrence of recharge within the Hanford Site tank farms.

The status of soil water can be defined by either the amount of water in the soil (water content) or by the force that holds water to the soil matrix (i.e., the matric potential or suction) (Or and Wraith 2002). In recent studies, Serne et al. (2002b, 2002d, 2002e, and 2002f) measured both water content (gravimetrically) and matric water potential (filter paper method, ASTM 2002) on core samples obtained from boreholes in the SX and B-BX tank farm environs. The same measurements were made at borehole 299-W10-27 near to the TX tank farm. All cores from the Hanford formation H2 unit that were obtained were analyzed. Unfortunately, at 299-W10-27 continuous coring was not performed all the way to the water table so that the entire profile of matric potential is not available.

Table 4.16 and Figure 4.13 show the matric potentials as a function of depth. Also plotted in Figure 4.13 is the gravity head expressed in pressure units (MPa). The gravity head is zero at the water table and increases linearly with height to the soil surface. For the core samples available from 299-W10-27, the water potentials are generally much less than the gravity potential from the shallowest core at $50 \mathrm{ft}$ bgs down to the deepest core taken at $123.5 \mathrm{ft}$ bgs all within the Hanford formation $\mathrm{H} 2$ unit. The last sample taken at $123.5 \mathrm{ft}$ bgs appears to have a matric potential larger than the theoretical line but all other measurements are lower than the theoretical line. The green line labeled "theoretical value" in Figure 4.13 is the theoretical line that represents the steady state unit gradient condition, which represents the profile for matric potential in a sediment profile that is neither draining nor drier than (actively evapotranspiring) equilibrium. Matric potential values to the left of the unit gradient line suggest a draining profile. The general trend for the data from $299-\mathrm{W} 10-27$ is that the water potentials are consistent with a draining profile. 


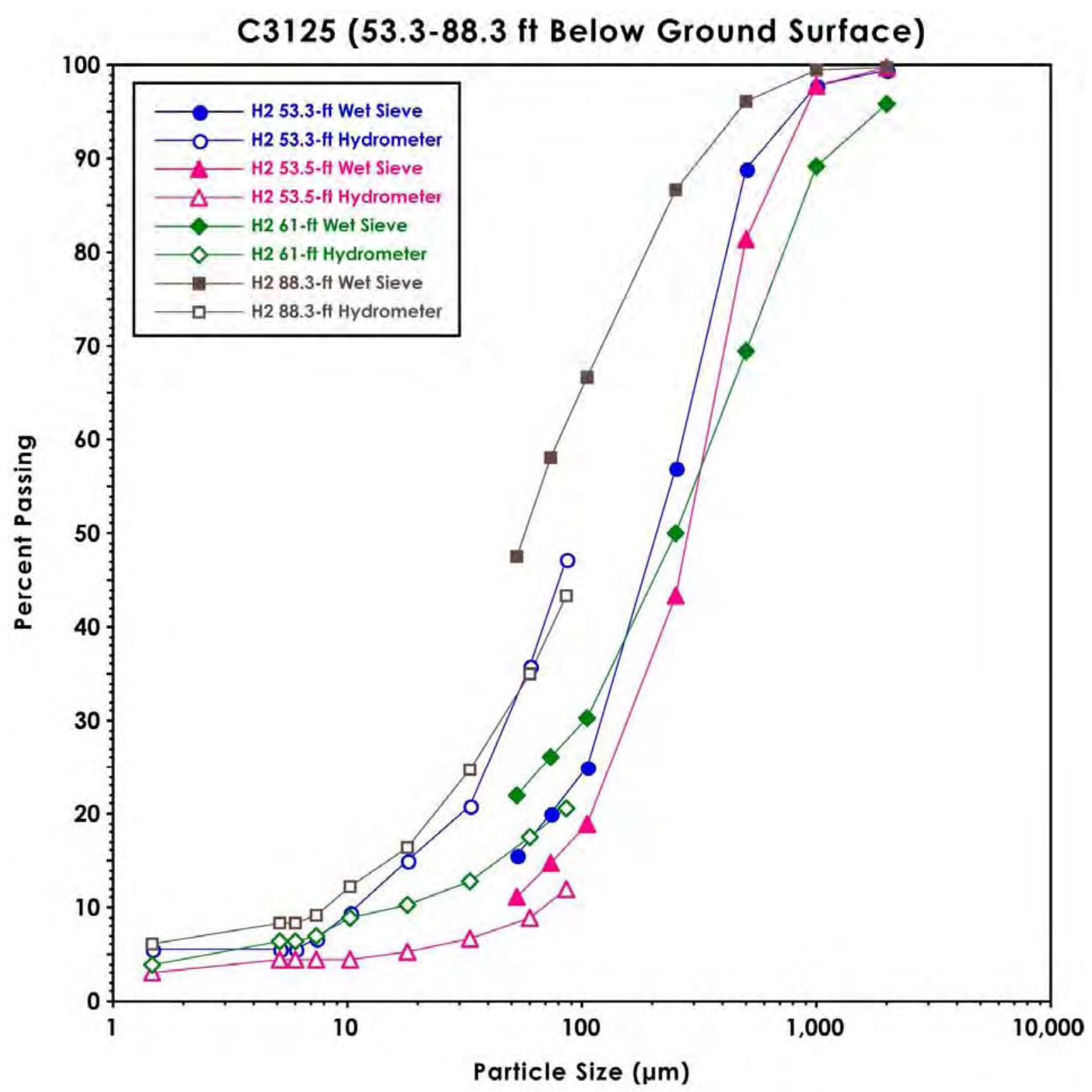

2003/DCL/C3125/014 (07/30)

Figure 4.10. Particle Size Distribution of Hanford Formation H2 Unit Subsamples from Borehole 299-W10-27 


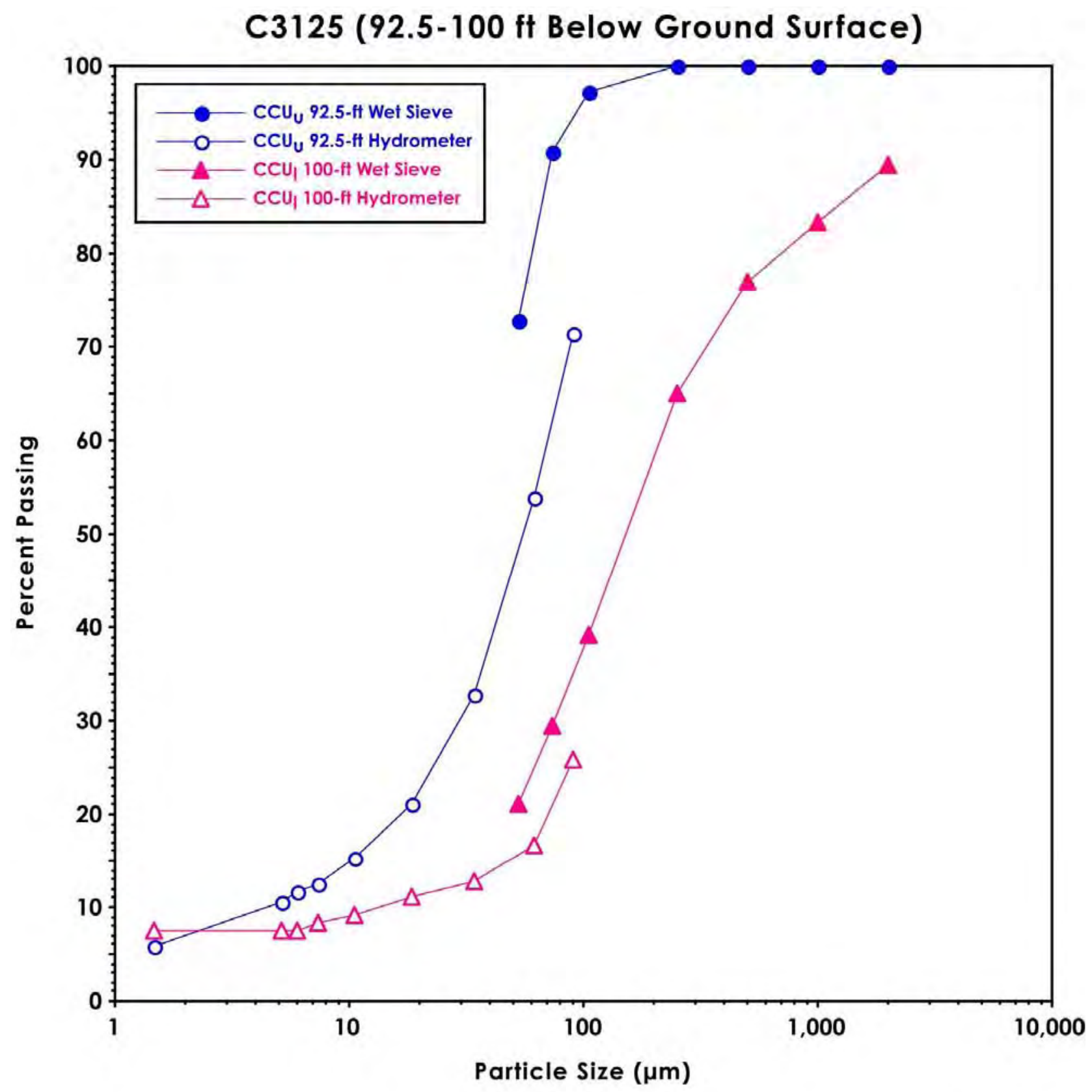

2003/DCL/C3125/015 (07/30)

Figure 4.11. Particle Size Distribution of Cold Creek Unit Subsamples from Borehole 299-W10-27 


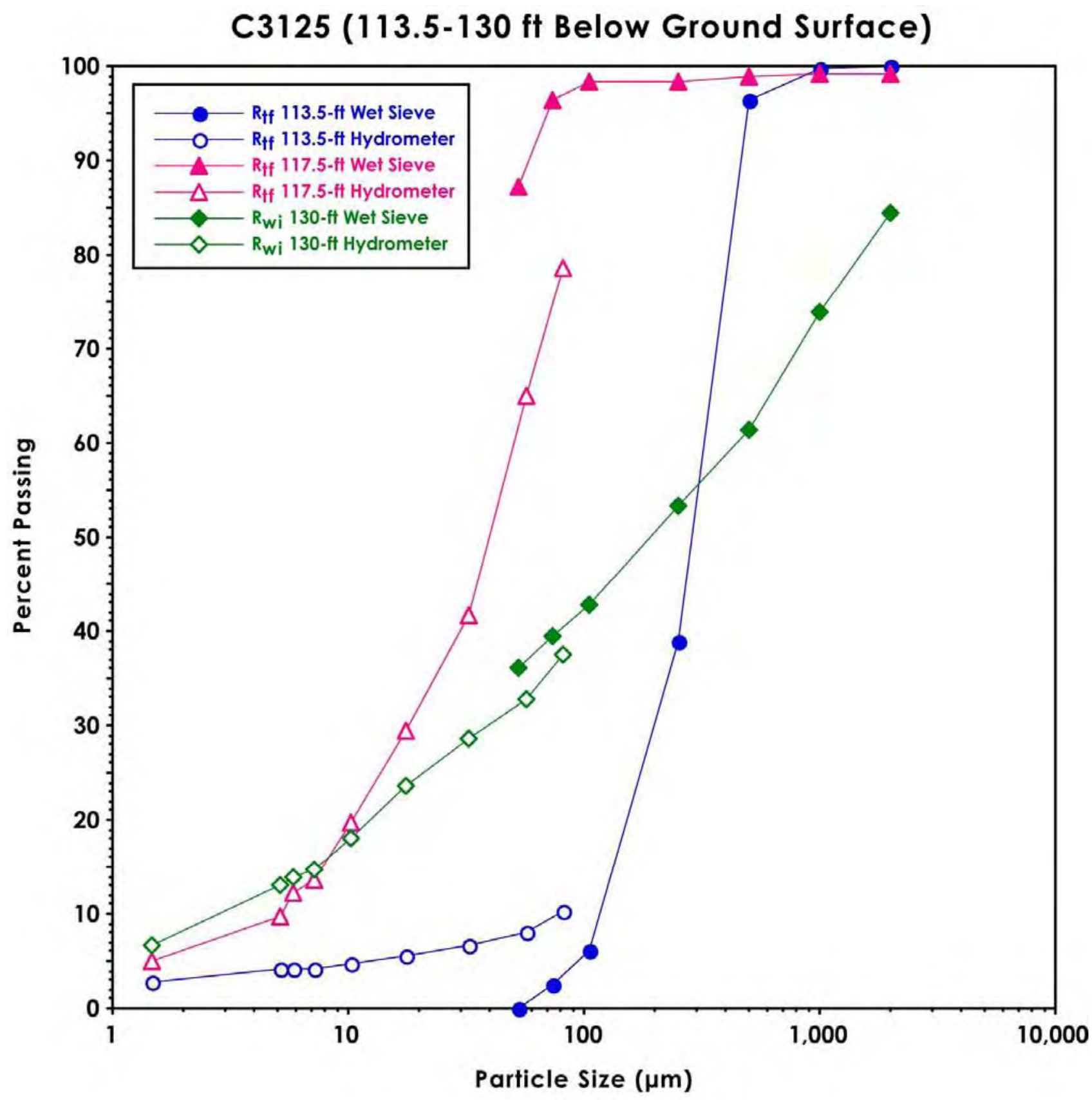

2003/DCL/C3125/016 (07/30)

Figure 4.12. Particle Size Distribution of Ringold Formation Subsamples from Borehole 299-W10-27 


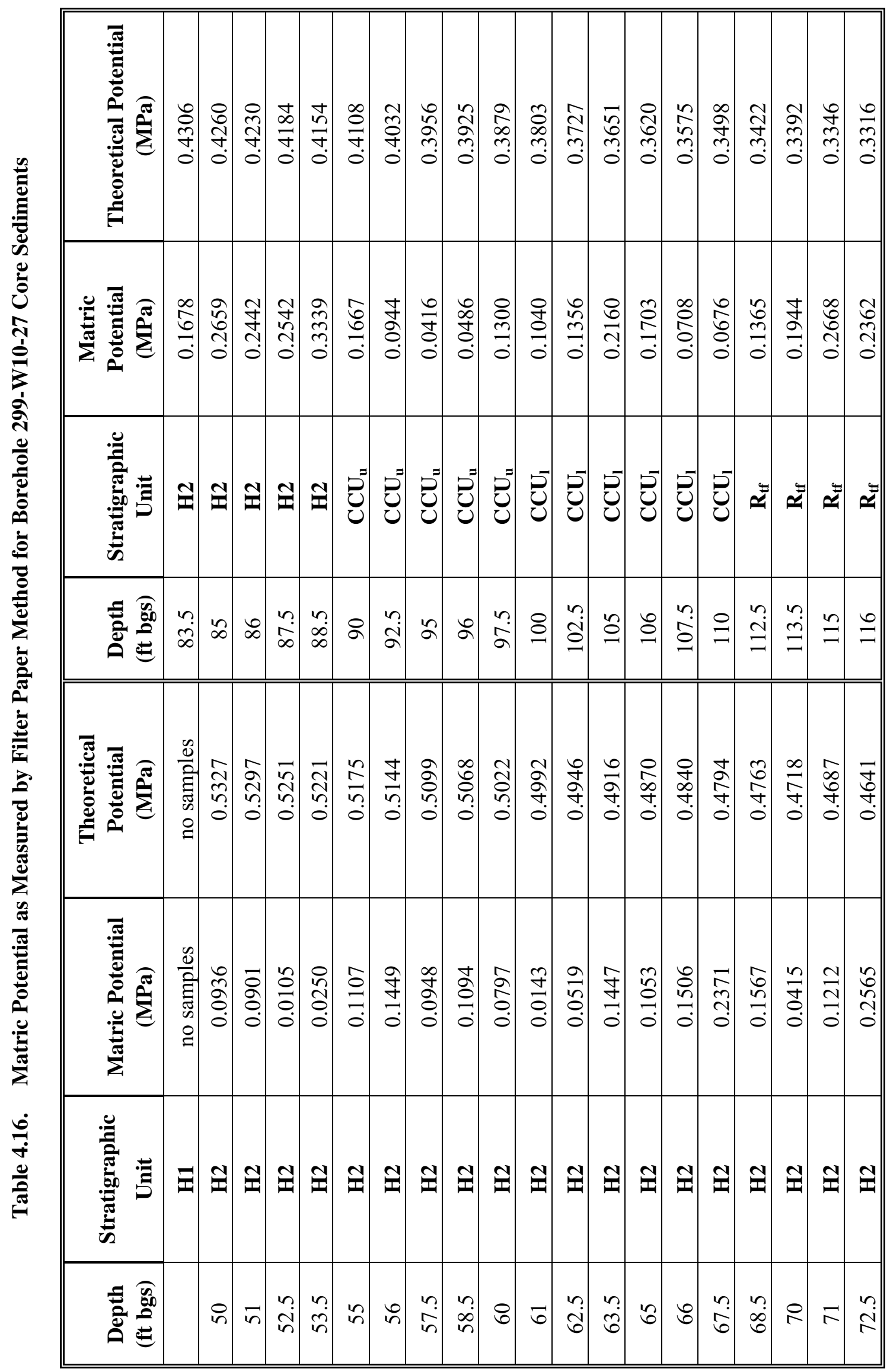




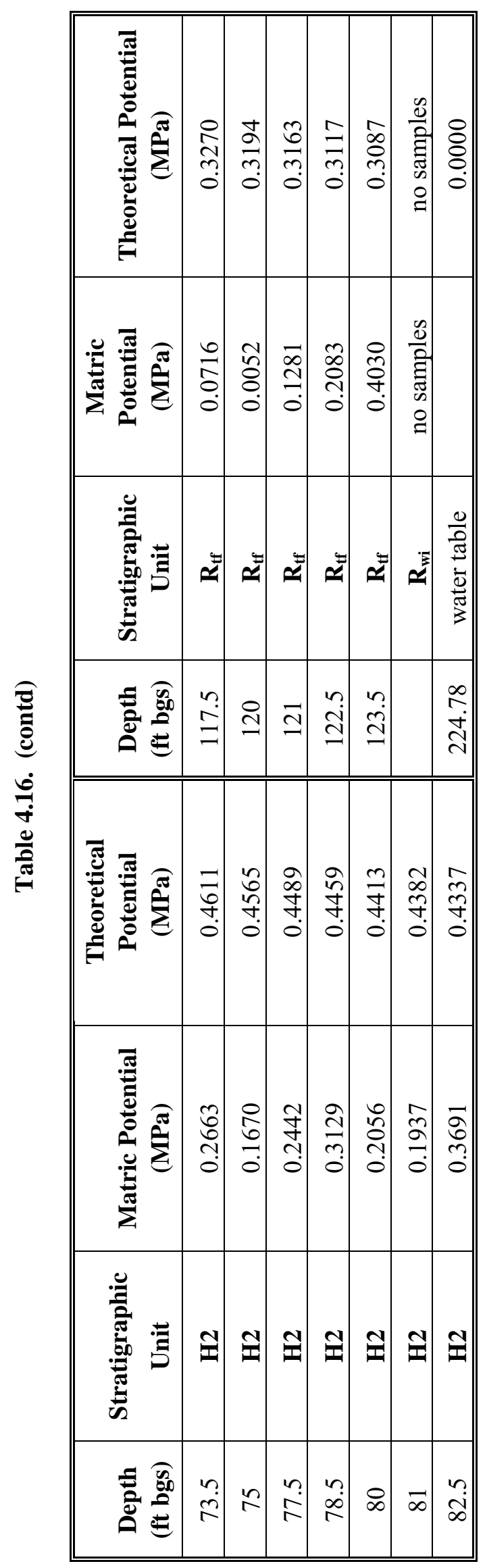




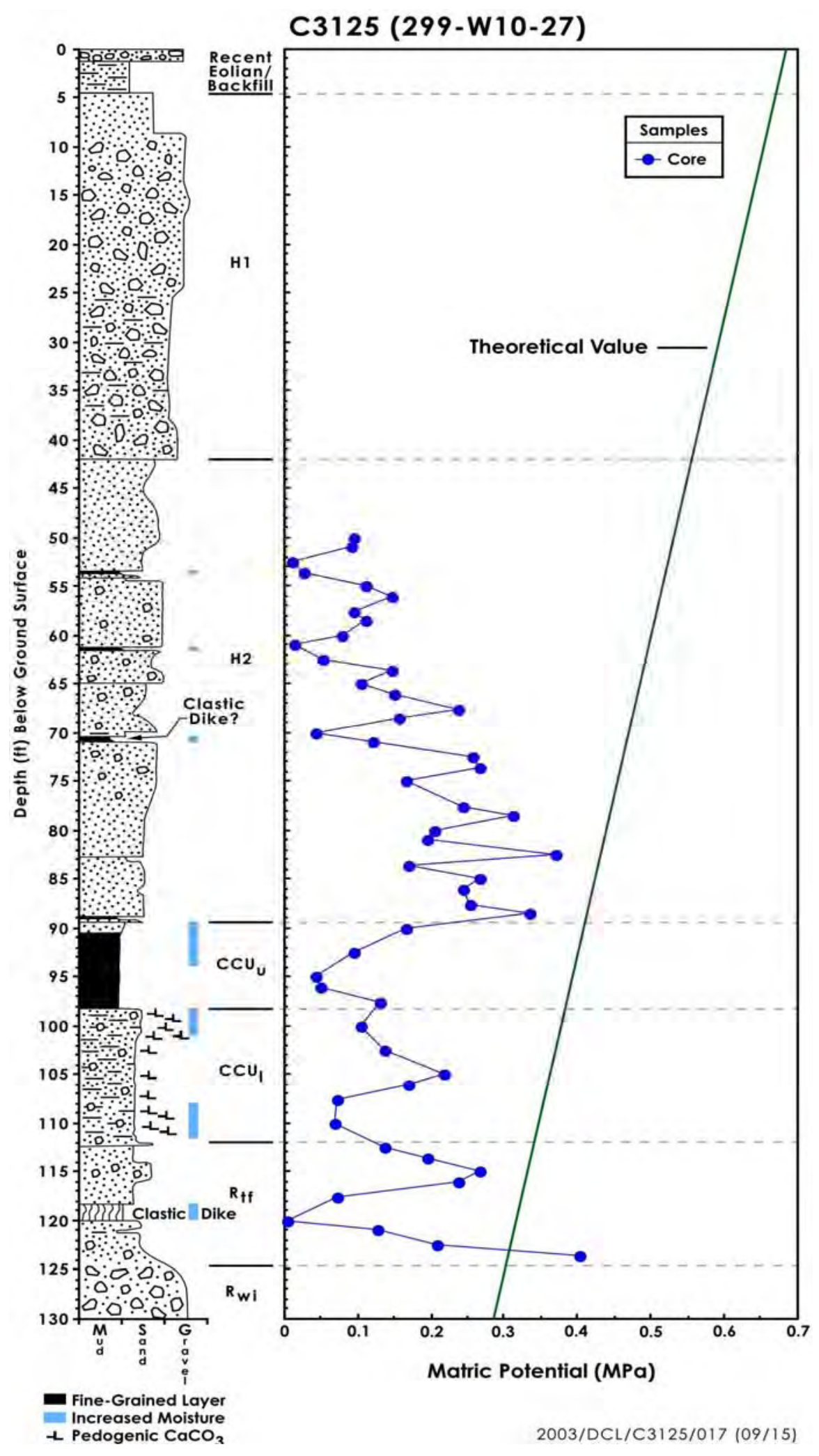

Figure 4.13. Matric Water Potential Measured by Filter Paper Technique on Core Samples from Borehole 299-W10-27 


\subsection{Vadose Zone Sediment from Borehole C3830}

Borehole C3830 was pushed into the vadose zone sediment approximately $40 \mathrm{ft}$ southwest of tank TX-105 to evaluate whether there is evidence to support designating tank TX-105 as having leaked in the past. The borehole reached a depth of $116.8 \mathrm{ft}$ bgs at which point it met refusal.

\subsubsection{Moisture Content}

The moisture content of the 36 core liners as a function of depth and lithology are shown in Table 4.17 and Figure 2.12. The backfill samples have a mean moisture content of $6.1 \%$ by weight with little variation. The Hanford formation $\mathrm{H} 2$ samples have a mean moisture content of $5.7 \%$ by weight with more variation that tracks variations in particle size (finer-grained samples have slightly higher moisture contents). The Cold Creek subunits have higher moisture with averages for the two subunits of $11.0 \%$ and $11.9 \%$ by weight. Both show about the same variability as the $\mathrm{H} 2$ unit. The average moisture content of the $\mathrm{H} 2$ unit samples measured in $\mathrm{C} 3830$ is about one percent by weight larger than the average for the same stratigraphic unit at the uncontaminated borehole 299-W10-27. Whether this is significant and an indication of the various tank farm operations that encourage higher moisture infiltration cannot be determined because of the small sample population obtained. The moisture content of the C3830 borehole and 299-W10-27 Cold Creek unit sediments is about the same, and this does not suggest any excess tank fluids in the Cold Creek unit sediments at C3830.

Table 4.17. Moisture Content of Borehole C3830 Cores

\begin{tabular}{|c|c|c|c|c|}
\hline Sample No. & $\begin{array}{l}\text { Depth } \\
\text { (ft bgs) }\end{array}$ & $\begin{array}{c}\text { Stratigraphic } \\
\text { Unit }\end{array}$ & Lithology & $\begin{array}{c}\text { Moisture } \\
\text { Content } \\
\% \mathbf{W t}\end{array}$ \\
\hline C3830-14.96B & 15.30 & Bkfl & \multirow{2}{*}{ Sand } & $9.20 \%$ \\
\hline C3830-14.96A & 15.98 & Bkfl & & $5.37 \%$ \\
\hline C3830-27.91B & 28.25 & Bkfl & \multirow{2}{*}{ Gravelly sand } & $6.74 \%$ \\
\hline C3830-27.91A & 28.92 & Bkfl & & $5.37 \%$ \\
\hline C3830-40.93B & 41.32 & Bkfl & \multirow{2}{*}{ Gravelly sand } & $6.97 \%$ \\
\hline C3830-40.93A & 42.10 & Bkfl & & $5.50 \%$ \\
\hline C3830-46.20B & 46.53 & $\mathrm{Bkfl}$ & \multirow{2}{*}{ Gravelly sand } & $5.71 \%$ \\
\hline C3830-46.20A & 47.18 & Bkfl & & $5.16 \%$ \\
\hline C3830-47.50B & 47.88 & Bkfl & \multirow{2}{*}{$\begin{array}{c}\text { Slightly gravelly } \\
\text { sand }\end{array}$} & $5.71 \%$ \\
\hline C3830-47.50A & 48.63 & $\mathrm{Bkfl}$ & & $4.96 \%$ \\
\hline C3830-52.98B & 53.33 & $\mathrm{H} 2$ & \multirow{2}{*}{ Sand } & $8.11 \%$ \\
\hline C3830-52.98B DUP & 53.33 & $\mathrm{H} 2$ & & $6.94 \%$ \\
\hline C3830-52.98A & 54.02 & $\mathrm{H} 2$ & \multirow{2}{*}{ Sand } & $3.70 \%$ \\
\hline C3830-52.98A DUP & 54.02 & $\mathrm{H} 2$ & & $4.36 \%$ \\
\hline
\end{tabular}


Table 4.17. (contd)

\begin{tabular}{|c|c|c|c|c|}
\hline Sample No. & $\begin{array}{c}\text { Depth } \\
\text { (ft bgs) }\end{array}$ & $\begin{array}{c}\text { Stratigraphic } \\
\text { Unit }\end{array}$ & Lithology & $\begin{array}{c}\text { Moisture } \\
\text { Content } \\
\% \mathbf{W t}\end{array}$ \\
\hline C3830-56.99B & 57.34 & $\mathrm{H} 2$ & Sand & $3.31 \%$ \\
\hline C3830-56.99A & 58.03 & $\mathrm{H} 2$ & & $3.41 \%$ \\
\hline C3830-58.29B & 58.65 & $\mathrm{H} 2$ & Sand to silty sand & $9.62 \%$ \\
\hline C3830-58.29A & 59.35 & $\mathrm{H} 2$ & & $12.42 \%$ \\
\hline C3830-66.06B & 66.41 & $\mathrm{H} 2$ & Sand & $3.63 \%$ \\
\hline C3830-66.06A & 67.11 & $\mathrm{H} 2$ & & $2.46 \%$ \\
\hline C3830-71.95B & 72.29 & $\mathrm{H} 2$ & Sand & $4.74 \%$ \\
\hline C3830-71.95A & 72.63 & $\mathrm{H} 2$ & & $3.45 \%$ \\
\hline C3830-76.98B & 77.33 & $\mathrm{H} 2$ & Sand & $3.63 \%$ \\
\hline C3830-76.98A & 78.01 & $\mathrm{H} 2$ & & $3.14 \%$ \\
\hline C3830-80.91B & 81.24 & $\mathrm{H} 2$ & Sand & $7.10 \%$ \\
\hline C3830-80.91A & 81.89 & $\mathrm{H} 2$ & & $3.70 \%$ \\
\hline C3830-86.11B & 86.44 & $\mathrm{H} 2$ & Sand to silty sand & $5.53 \%$ \\
\hline C3830-86.11A & 87.09 & $\mathrm{H} 2$ & & $11.18 \%$ \\
\hline C3830-98.97B & 99.32 & $\mathrm{H} 2$ & \multirow{2}{*}{ Sand } & $9.19 \%$ \\
\hline C3830-98.97A & 100.02 & $\mathrm{H} 2$ & & $4.95 \%$ \\
\hline C3830-100.32B & 100.67 & $\mathrm{CCU}_{\mathrm{u}}$ & \multirow{3}{*}{$\begin{array}{c}\text { Silty sand to } \\
\text { sandy silt and silt }\end{array}$} & $10.53 \%$ \\
\hline C3830-100.32A & 101.37 & $\mathrm{CCU}_{\mathrm{u}}$ & & $6.83 \%$ \\
\hline C3830-100.32A DUP & 101.37 & $\mathrm{CCU}_{\mathrm{u}}$ & & $7.08 \%$ \\
\hline C3830-102.99B & 103.36 & $\mathrm{CCU}_{\mathrm{u}}$ & \multirow{2}{*}{ Sandy silt } & $14.72 \%$ \\
\hline C3830-102.99A & 104.08 & $\mathrm{CCU}_{\mathrm{u}}$ & & $12.59 \%$ \\
\hline C3830-107.89B & 108.22 & $\mathrm{CCU}_{\mathrm{u}}$ & \multirow{2}{*}{ Sandy silt } & $11.57 \%$ \\
\hline C3830-107.89A & 108.87 & $\mathrm{CCU}_{\mathrm{u}}$ & & $9.80 \%$ \\
\hline C3830-113.55B & 113.92 & $\mathrm{CCU}_{1}$ & \multirow{2}{*}{$\begin{array}{c}\text { Calcareous, } \\
\text { pebbly sand and } \\
\text { mud }\end{array}$} & $9.98 \%$ \\
\hline C3830-113.55A & 114.64 & $\mathrm{CCU}_{1}$ & & $13.91 \%$ \\
\hline
\end{tabular}




\subsubsection{1:1 Sediment:Water Extracts for Borehole C3830}

The A liners (the deeper of two liners) from the 18 cores were characterized by performing 1:1 sediment:water extracts. The following tables present the mass of a given constituent leached per gram of sediment as measured in the water extracts to allow direct comparison to the same data for the background sediments from borehole 299-W10-27. Other figures show dilution-corrected values that represent concentrations in vadose zone porewater. As discussed in several other Vadose Zone Characterization Project reports, the dilution-corrected 1:1 sediment:water extracts are a reasonable estimate of the actual vadose zone porewater (see Serne et al. 2002b, 2002c, 2002e, 2002f).

\subsubsection{1 $\quad \mathrm{pH}$ and Electrical Conductivity}

The 1:1 sediment:water extract $\mathrm{pH}$ and $\mathrm{EC}$ data are shown in Table 4.18. Both the measured value and dilution-corrected EC values are shown. Figure 4.14 shows the 1:1 sediment:water extract $\mathrm{pH}$ value and dilution-corrected EC as a function of depth and stratigraphy. A comparison of the data in Table 4.18 with the $\mathrm{pH}$ and EC of the 299-W10-27 extracts suggests that there is slightly elevated EC in the C3830 borehole sediments from $59.4 \mathrm{ft}$ bgs to the bottom of the borehole samples. This suggests the presence of some higher than normal salinity fluids in the porewaters, such as tank liquors. Although the dilutioncorrected porewater EC is above the background values, the highest values between 67 and $87 \mathrm{ft}$ bgs are equivalent to a pore solution of $0.12 \mathrm{M} \mathrm{KCl}$, the salt solution used to calibrate the conductivity probe. The leaks near the SX108-109 and BX-102 tanks had peak vadose zone porewater concentrations that were equivalent to much more concentrated waste fluids, 7 to 17 and 0.7 to $1 \mathrm{M} \mathrm{KCl}$ solutions, respectively. The maximum dilution-corrected EC at C3830 is $12.5 \mathrm{mS} / \mathrm{cm}$, slightly lower than the dilution-corrected EC at 299-E33-46 near tank B-110 that contained $15.1 \mathrm{mS} / \mathrm{cm}$ (Serne et al. 2002f).

The slightly elevated electrical conductivities are evident in Figure 4.14 from about 65 to $87 \mathrm{ft}$ bgs. The figure also shows that there are elevated values for sodium and nitrate in this range. The sodium peak value occurs at $65 \mathrm{ft}$ bgs and the peak nitrate and $\mathrm{EC}$ value occurs at $\sim 77 \mathrm{ft}$ bgs. 
Table 4.18. $\quad$ pH and EC Data for Sediment:Water Extracts from Borehole 3830

\begin{tabular}{||c|c|c|c|c|c||}
\hline \hline Sample No. & $\begin{array}{c}\text { Depth } \\
\text { (ft bgs) }\end{array}$ & $\begin{array}{c}\text { Stratigraphic } \\
\text { Unit }\end{array}$ & $\mathbf{p H}$ & $\begin{array}{c}\text { Conductivity } \\
\mathbf{m S} / \mathbf{c m}\end{array}$ & $\begin{array}{c}\text { Dilution-Corrected } \\
\text { Conductivity } \\
\text { (mS/cm) }\end{array}$ \\
\hline C3830-14.96A & 15.98 & $\mathrm{Bkfl}$ & 7.93 & 0.171 & 3.19 \\
\hline C3830-27.91A & 28.92 & $\mathrm{Bkfl}$ & 8.39 & 0.166 & 3.09 \\
\hline C3830-40.93A & 42.10 & $\mathrm{Bkfl}$ & 8.02 & 0.163 & 3.01 \\
\hline C3830-46.20A & 47.18 & $\mathrm{Bkfl}$ & 8.15 & 0.158 & 3.14 \\
\hline C3830-47.50A & 48.63 & $\mathrm{Bkfl}$ & 8.09 & 0.218 & 4.40 \\
\hline C3830-52.98A & 54.02 & $\mathrm{H} 2$ & 8.03 & 0.178 & 4.81 \\
\hline C3830-52.98A DUP & 54.02 & $\mathrm{H} 2$ & 8.13 & 0.165 & 3.79 \\
\hline C3830-56.99A & 58.03 & $\mathrm{H} 2$ & 7.92 & 0.166 & 4.88 \\
\hline C3830-58.29A & 59.35 & $\mathrm{H} 2$ & 7.97 & 0.218 & 1.76 \\
\hline C3830-66.06A & 67.11 & $\mathrm{H} 2$ & 8.24 & 0.307 & 12.51 \\
\hline C3830-71.95A & 72.63 & $\mathrm{H} 2$ & 7.93 & 0.259 & 7.51 \\
\hline C3830-76.98A & 78.01 & $\mathrm{H} 2$ & 7.94 & 0.358 & 11.40 \\
\hline C3830-80.91A & 81.89 & $\mathrm{H} 2$ & 7.97 & 0.205 & 5.74 \\
\hline C3830-86.11A & 87.09 & $\mathrm{H} 2$ & 8.02 & 0.365 & 3.54 \\
\hline C3830-98.97A & 100.02 & $\mathrm{H} 2$ & 7.93 & 0.246 & 4.97 \\
\hline C3830-100.32A & 101.37 & $\mathrm{CCU}_{\mathrm{u}}$ & 8.00 & 0.243 & 3.56 \\
\hline C3830-100.32A DUP & 101.37 & $\mathrm{CCU}_{\mathrm{u}}$ & 7.98 & 0.256 & 3.62 \\
\hline C3830-102.99A & 104.08 & $\mathrm{CCU}_{\mathrm{u}}$ & 7.96 & 0.253 & 2.66 \\
\hline C3830-107.89A & 108.87 & $\mathrm{CCU}_{\mathrm{u}}$ & 8.07 & 0.205 & 2.09 \\
\hline C3830-113.55A & 114.64 & $\mathrm{CCU}_{1}$ & 8.00 & 0.332 & 2.39 \\
\hline \hline
\end{tabular}




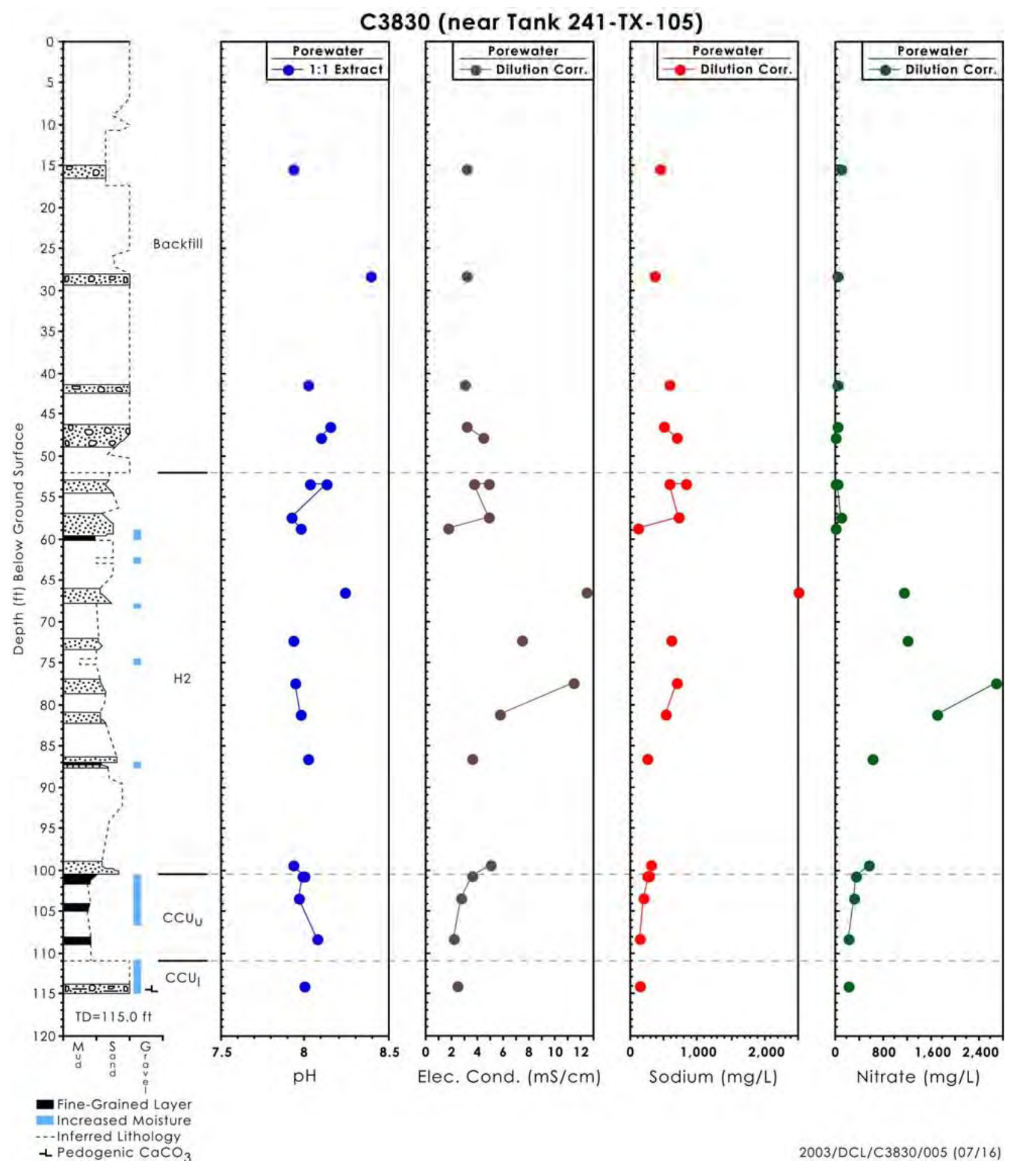

Figure 4.14. Borehole 3830 Sediment: Water Extract pH and Calculated Porewater Electrical Conductivity, Sodium, and Nitrate 


\subsubsection{Water Extract Composition or the 1:1 Sediment:Water Extract for C3830}

The water extract values for the major cations and anions and several trace constituents are discussed in this section. The anion data are tabulated in Tables 4.19 and 4.20 and Figure 4.15 in units of mass per gram of dry sediment. The data for the water extracts of borehole C3830 for fluoride, phosphate, nitrite, and bromide do not differ significantly from the same data for the uncontaminated sediments from borehole 299-W10-27. However, there are obvious signs of elevated chloride, nitrate, and sulfate in the water extracts of $\mathrm{C} 3830$ sediments. The chloride values from $78 \mathrm{ft}$ bgs to the deepest sample obtained at $114.6 \mathrm{ft}$ bgs are elevated by a factor of $\sim 8$ to 20 when compared to water extracts of uncontaminated sediment. The nitrate water extract values for the $\mathrm{C} 3830$ borehole are elevated from $67 \mathrm{ft}$ bgs to the deepest sample obtained. The nitrate water extract values are 10 to 50 times larger than for the background sediments in similar uncontaminated lithologies in borehole 299-W10-27. The sulfate water extracts from C3830 are elevated from about $59.4 \mathrm{ft} \mathrm{bgs} \mathrm{to} \mathrm{the} \mathrm{deepest} \mathrm{sample} \mathrm{obtained} \mathrm{and} \mathrm{the} \mathrm{values}$ exceed the background sediment values by a factor of 2 to 8 . There is one very large value for water-extractable carbonate in the Cold Creek upper subunit in the $\mathrm{C} 3830$ borehole sediments at $104 \mathrm{ft}$ bgs. As shown in Figure 4.15, a direct analysis of carbonate using the ion chromatograph does not show a similar very high value, however. So we attribute the very large alkalinity value to analytical vagaries and conclude that dissolvable carbonates in the C3830 sediments are not significantly different than values in the background borehole 299-W10-27. The agreement between measuring the water extracts for phosphate and sulfate directly with the ion chromatograph and indirectly by converting the ICP measurements for phosphorous and sulfur is very good. Besides validating the ion chromatography data, we can state that the water-extractable sulfur and phosphorous species are in fact sulfate and phosphate.

The water-extractable small organic molecules in the $\mathrm{C} 3830$ borehole sediments are shown in Table 4.20. The values are not significantly different than for the uncontaminated sediments from borehole 299-W10-27.

The water-extractable major cations in the $\mathrm{C} 3830$ borehole sediments are tabulated in Table 4.21 and the distribution with depth is shown in Figure 4.16. The distribution of the divalent alkaline earth cations ( $\mathrm{Mg}, \mathrm{Ca}$, and $\mathrm{Sr}$ but not $\mathrm{Ba}$ ) and the monovalent cation potassium, show low water-extractable quantities between 54 and $58 \mathrm{ft}$ bgs and the lowest values of all at $67 \mathrm{ft}$ bgs. The water-extractable mass of these cations at the $59.35 \mathrm{ft}$ bgs sample is very similar to uncontaminated background sediments. Conversely, the distribution of water-extractable sodium is higher than the mass that is water-leachable from uncontaminated sediments in the whole profile, excepting at the $59.35 \mathrm{ft}$ depth. These trends suggest that tank fluids that are high in sodium and nitrate did seep into the vadose zone near this borehole. The sodium pushed the natural divalent cations and some of the natural potassium off the sediment cation exchange sites in the sediments between 54 and at least $67 \mathrm{ft}$ bgs, excepting a zone near $59.35 \mathrm{ft}$ bgs. There is a fine-grained lens near this depth that may have forced tank fluids to percolate horizontally around this zone. We have observed the same cation distribution and ion exchange fronts where divalent cations and sometimes potassium are depleted in the shallow sediments and high levels of water-extractable sodium are present at both the SX and BX tank farms where tank fluids have been confirmed as being present (see Serne et al. 2002b, 2002c, 2002e, 2002f for details). Right below the leading edge of the sodium plume one finds elevated levels of the divalent cations that were displaced. We observe the high levels of divalent cations in the samples between 78 and $87 \mathrm{ft} \mathrm{bgs.} \mathrm{But} \mathrm{there} \mathrm{are} \mathrm{also}$ elevated masses of water-leachable calcium and strontium at 104.8 and $114.64 \mathrm{ft}$ bgs, both in the Cold Creek unit. 


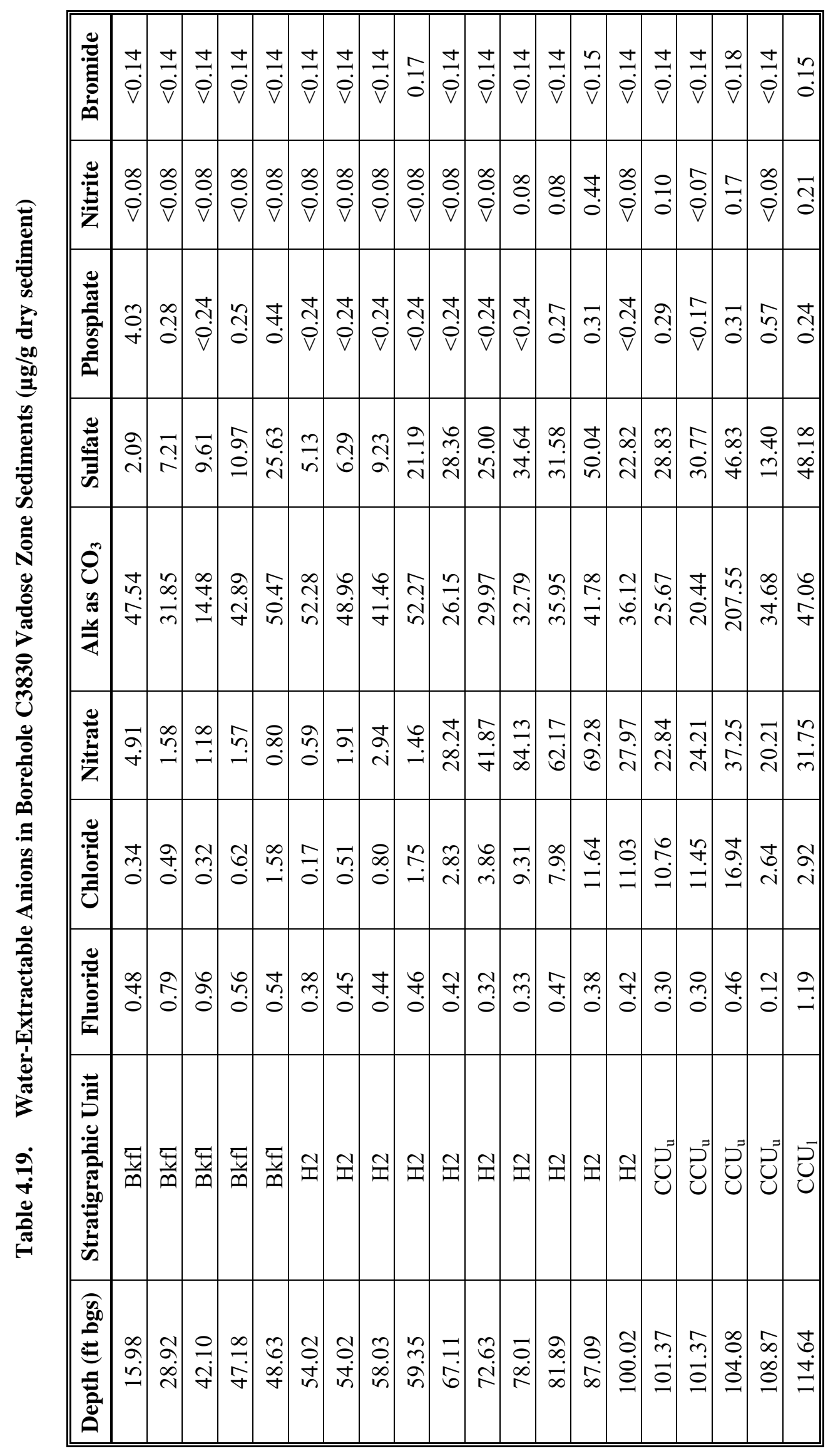



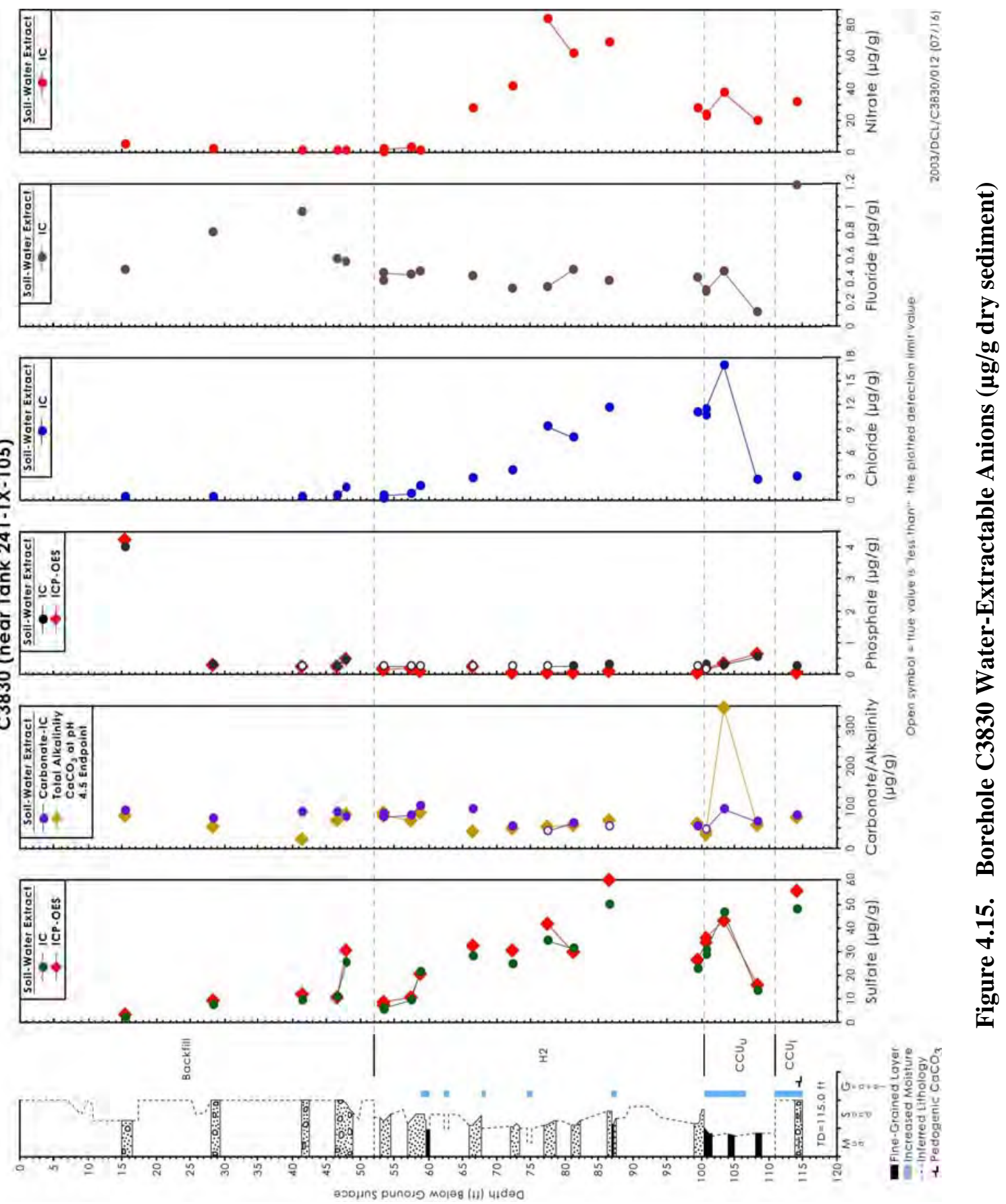
It is possible that some of the elevated divalent cations in these deeper samples reflect waterleachable carbonate minerals. The lowest values for water-leachable divalent cations occur at $67 \mathrm{ft}$ bgs and this depth is also the position of the highest water-leachable sodium.

The water-extractable aluminum, silicon, iron, manganese, zinc, phosphorous, and sulfur in the C3830 borehole sediments are shown in Table 4.22 and Figure 4.17. The phosphorous and sulfur data were converted to water-extractable phosphate and sulfate and plotted with the anion data in Figure 4.15. In general, the agreement between direct measurement of the two anions by ion chromatography and the converted ICP measurements is very good. The water-soluble aluminum and iron data show elevated values between the depths of 54 and 67 to $72 \mathrm{ft} \mathrm{bgs}$, excepting the sample at $59.35 \mathrm{ft} \mathrm{bgs}$. We speculate that these elevated values indicate some chemical reaction between alkaline tank fluids and native sediments that formed precipitates of aluminum and iron that are more water soluble than the native sediments. There are also elevated water-leachable aluminum and iron in the upper Cold Creek subunit. The water-extractable $\mathrm{S}$ values between the depths of $67 \mathrm{ft}$ bgs and the bottom of the borehole at $114.6 \mathrm{ft}$ bgs also appear to be elevated in comparison with the $\mathrm{S}$ that is water extractable from background sediments in borehole 299-W10-27.

The water-extractable data for potentially mobile metals such as technetium-99, uranium-238, chromium, molybdenum and ruthenium $(\mathrm{Ru})$ are shown in Table 4.23 and Figure 4.18. There appears to be some technetium- 99 present in the sediment in the zone between 67 and $87 \mathrm{ft}$ bgs and perhaps as shallow as $59 \mathrm{ft}$ bgs and as deep as $100 \mathrm{ft}$ bgs. There is only one indication of uranium-238 contamination in the sample at $67 \mathrm{ft}$ bgs. This sample also shows the highest value found in borehole C3830 sediments for chromium. The molybdenum and ruthenium data do not suggest any elevated values compared to uncontaminated sediments. The technetium-99 data suggest that tank fluids may have percolated down through the entire Hanford formation $\mathrm{H} 2$ unit and then stopped on top of the fine-grained $\mathrm{CCU}_{\mathrm{u}}$ mud contact at $100.4 \mathrm{ft}$ bgs.

\subsubsection{Derivation of Vadose Zone Porewater Chemical Composition}

The 1:1 water extract data was recalculated to derive the porewater composition of the vadose zone sediments. From knowledge of the moisture content of the sediment samples taken from the A liners of each core, we calculated the amount of deionized water that would be needed to make the water extract exactly one part water (total of native porewater and added deionized water) to one part by weight dry sediment. The ratio of the total volume of water in the extract to the native mass of porewater is the dilution factor. We assume that the deionized water acts solely as a diluent of the existing porewater and that the deionized water does not dissolve any of the solids in the sediments. Thus by correcting for the dilution, we can estimate the actual chemical composition of the native porewater in the partially saturated vadose zone sediments. The assumption that none of the solid is dissolved during the water extraction process is simplistic. In comparisons of actual porewater that was obtained via ultracentrifugation of vadose zone sediments to the dilution-corrected calculated porewaters from both contaminated and uncontaminated sediments from the SX and B-BX Tank Farms (see Serne et al. 2002b, 2002c, 2002d, 2002e, 2002f), we have found that for highly contaminated sediments that the comparison is quite good. For slightly contaminated or uncontaminated sediments the dilution-corrected water extract data is biased high by a factor of 2 to 7 for many constituents such that the true porewater is less saline.

Tables 4.24 through 4.27 and Figures 4.19 through 4.22 show the derived porewater composition of key constituents as a function of depth and stratigraphy. The most concentrated porewater - on a total 
dissolved salts basis — is found at $\sim 78 \mathrm{ft}$ bgs and has a total concentration of $102 \mathrm{meq} / \mathrm{L}$ cations and 102 $\mathrm{meq} / \mathrm{L}$ anions. The calculated most saline porewater composition consists of $42 \mathrm{meq} / \mathrm{L} \mathrm{Ca}, 32 \mathrm{meq} / \mathrm{L} \mathrm{Na}$, $18 \mathrm{meq} / \mathrm{L} \mathrm{Mg}$ and $10 \mathrm{meq} / \mathrm{L} \mathrm{K}$. The cation charge is compensated by the following mixture of anions: $40 \mathrm{meq} / \mathrm{L}$ nitrate, $34 \mathrm{meq} / \mathrm{L}$ bicarbonate, $20 \mathrm{meq} / \mathrm{L}$ sulfate and $8 \mathrm{meq} / \mathrm{L}$ chloride. This concentration is very dilute compared to the vadose zone porewaters found at the SX and BX tank farms where the total ionic strength of the porewaters were as high as 7,000 to 17,000 and $1,000 \mathrm{meq} / \mathrm{L}$, respectively. At the borehole emplaced near tank B-110 the most saline porewater was 150 to $160 \mathrm{meq} / \mathrm{L}$.

There appears to be a thin lens of technetium-99 in the porewaters between the depths of 67 and $87 \mathrm{ft}$ bgs that has maximum concentrations of 1 to $4 \times 10^{+05} \mathrm{pCi} / \mathrm{L}$. On a per gram of dry sediment basis, these porewater concentrations are 3 to $11 \mathrm{pCi} / \mathrm{g}$. Because the water content of the $\mathrm{H} 2$ unit sediments is so small, when equated to porewater concentrations this small mass of technetium- 99 reaches concentrations about 400 times larger than the drinking water standard in the thin zone where technetium-99 was found.

The calculated porewater uranium concentration for the sample at $67 \mathrm{ft}$ bgs is $0.1 \mathrm{~g} / \mathrm{L}$ and about 1000 times larger than any other measurements. As mentioned, this water extract also shows high values for technetium-99, chromium, silicon, aluminum, iron, and sulfate besides the uranium. Thus we conclude that there is tank-related contamination concentrated at this location.

\subsubsection{M Nitric Acid-Extractable Amounts of Selected Elements in C3830 Sediments}

The same cores that were characterized for water-extractable constituents were also characterized to see how much of various constituents could be leached with hot $8 \mathrm{M}$ nitric acid. A comparison between the quantities that were acid extractable with those that are water extractable often indicates the relative mobility of a given constituent and can sometimes differentiate man-disposed from naturally occurring constituents. Finally, a comparison of the acid-extractable quantities in suspected contaminated sediments with acid-extractable amounts in uncontaminated sediments can be used to delineate the presence of less mobile contaminants.

The quantities of various constituents in the $\mathrm{C} 3830$ vadose zone sediments that were acid extractable are shown in Tables 4.28 through 4.30 and Figures 4.23 through 4.26. Upon comparing the acid extract data for borehole C3830 with similar lithologies in the uncontaminated borehole 299-W10-27, most of the variation in mass leached per gram of sediment versus depth is found to be lithology-related. That is, for most constituents there is no sign of elevated values of acid-leachable constituents in borehole C3830 sediments with the exception of acid-extractable sulfur (assumed to represent sulfate) and technetium-99. The acid-extractable sulfate profile in borehole C3830 sediments averages about 4 to 7 times higher than in comparable uncontaminated sediments from borehole 299-W10-27. The acid-extractable technetium99 profile in the $\mathrm{C} 3830$ borehole sediments is elevated from $42 \mathrm{ft} \mathrm{bgs}$ to $109 \mathrm{ft}$ bgs by a factor of 4 over the distribution of acid-extractable technetium-99 in the background sediment, which was a measure of our detection limit. The deepest sample obtained in borehole C3830 within the lower Cold Creek (caliche) subunit does not have this slight elevated acid-extractable technetium-99. We are not sure how to interpret the acid-extractable data for technetium-99 in borehole C3830. If the differences are real, it would appear that some technetium-99 is present in the backfill at $42 \mathrm{ft} \mathrm{bgs,} \mathrm{which} \mathrm{is} \mathrm{above} \mathrm{the} \mathrm{base} \mathrm{of}$ 


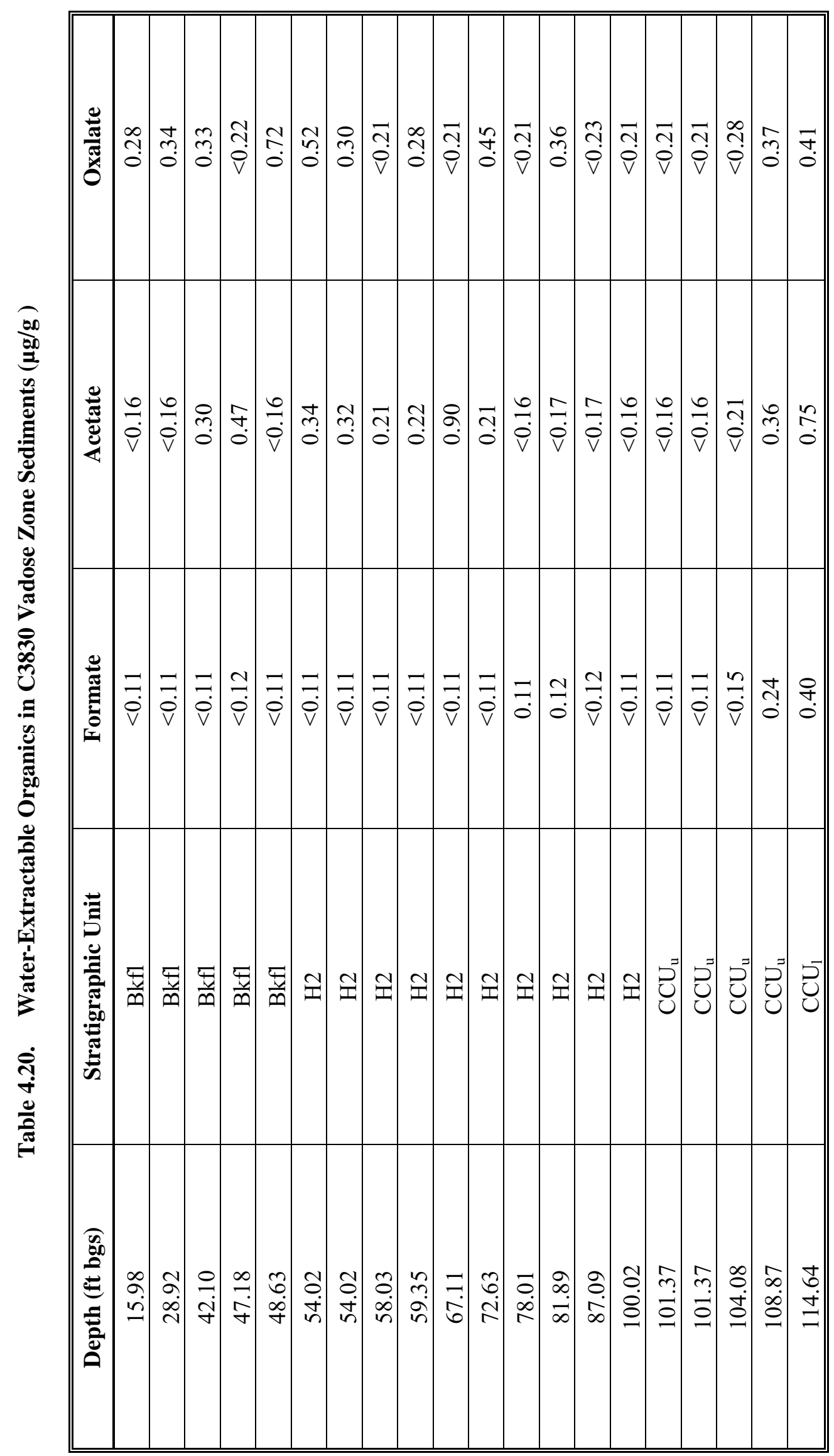




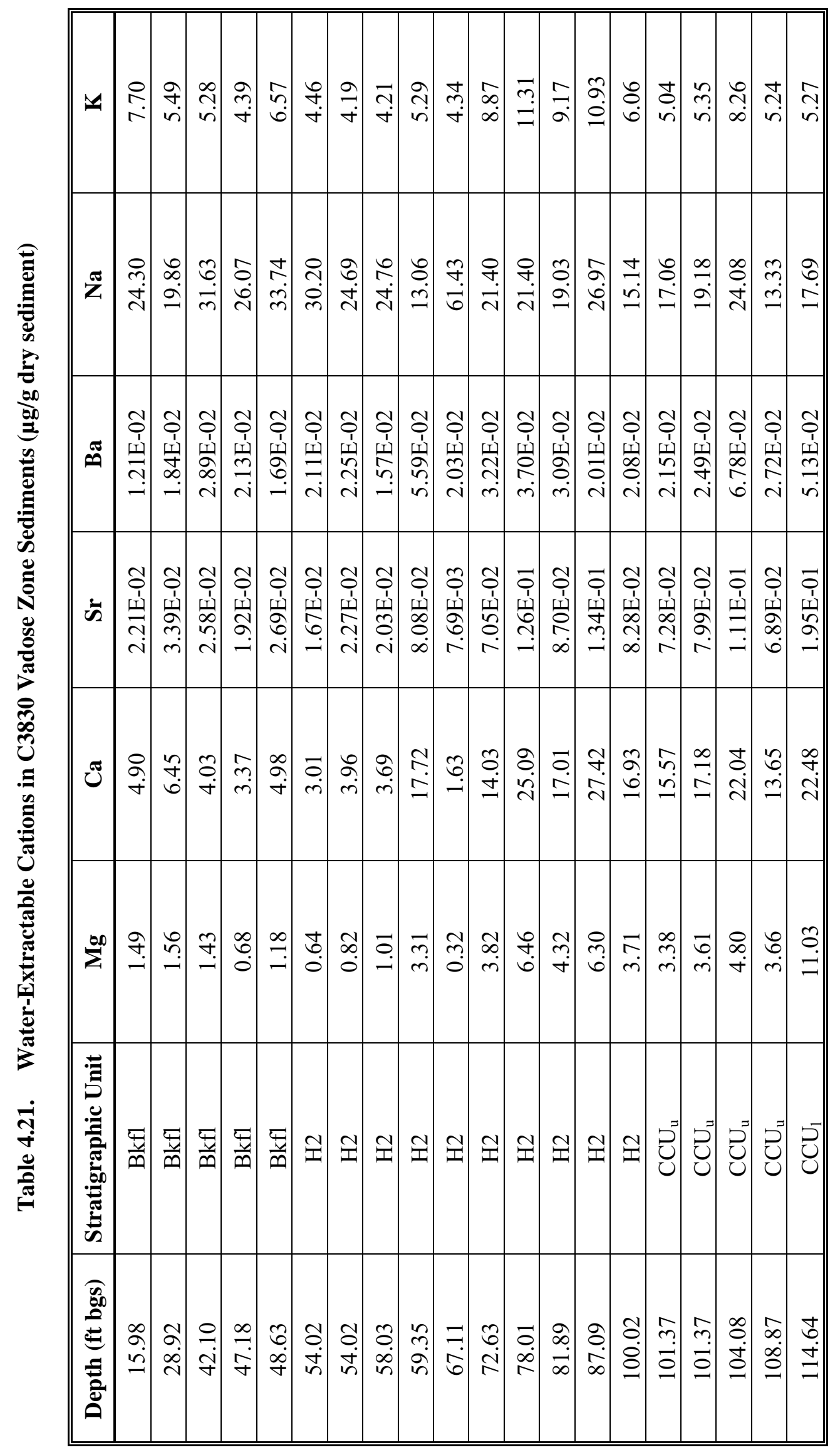




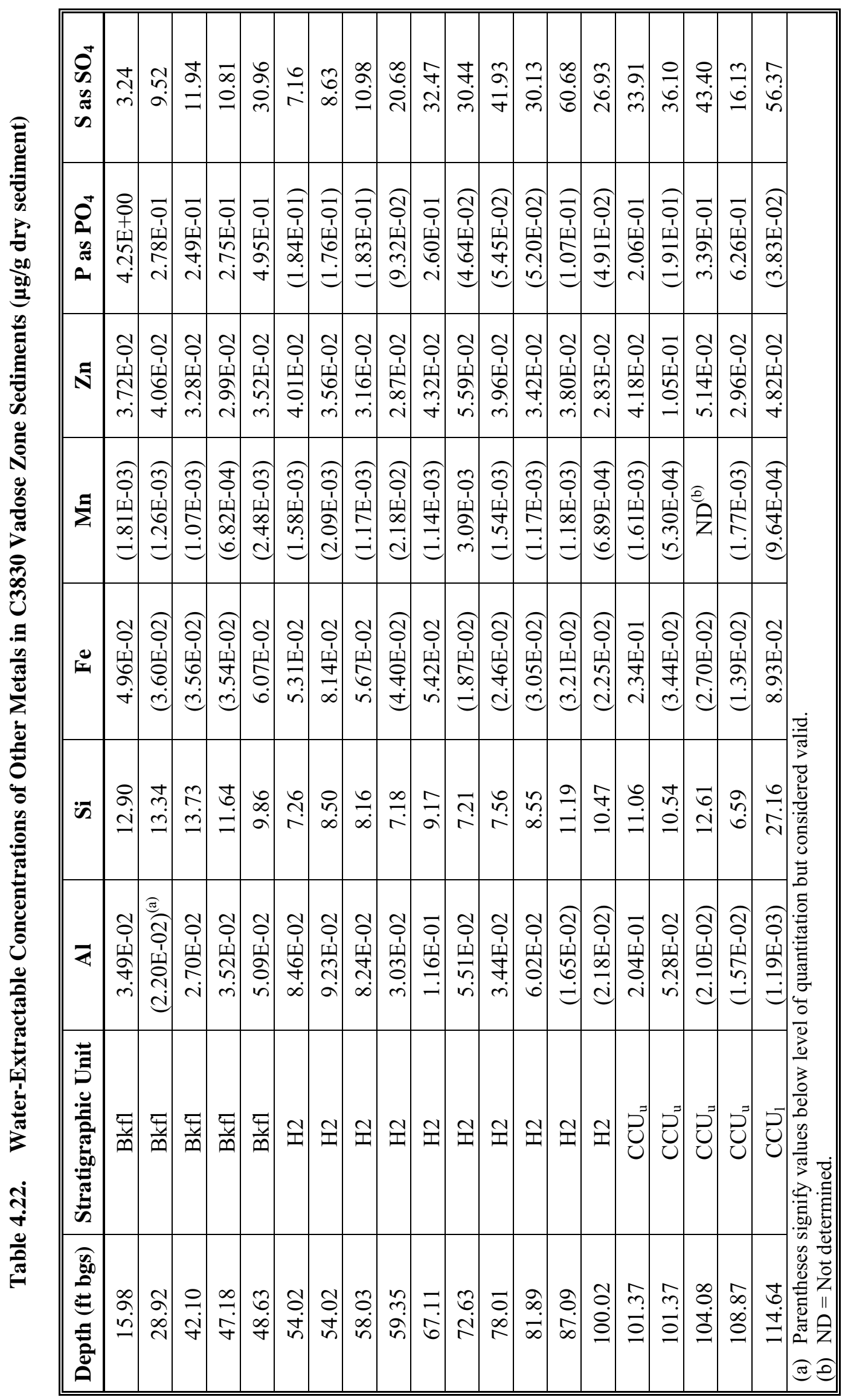




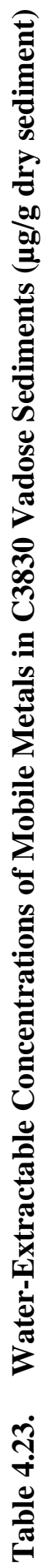

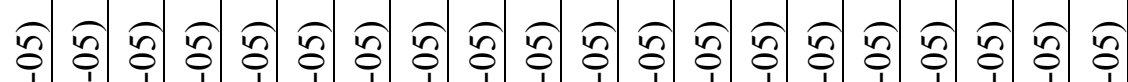

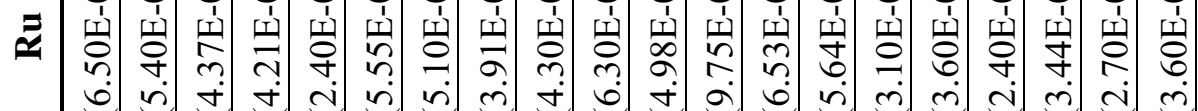

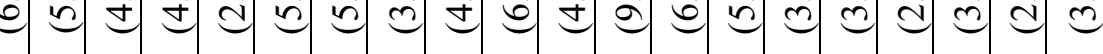

\begin{tabular}{|c|c|c|c|c|c|c|c|c|c|c|c|c|c|c|c|c|c|c|c|c|}
\hline$\stackrel{\Theta}{\Sigma}$ & $\begin{array}{l}\hat{0} \\
1 \\
1 \\
\infty \\
\infty \\
0\end{array}$ & 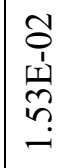 & $\begin{array}{c}2 \\
0 \\
1 \\
1 \\
\\
0 \\
\end{array}$ & $\begin{array}{c}m \\
0 \\
1 \\
\underline{1} \\
n \\
\infty \\
\infty\end{array}$ & $\begin{array}{l}0 \\
0 \\
1 \\
1 \\
0 \\
n \\
a \\
a\end{array}$ & 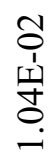 & 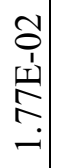 & 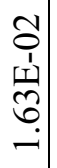 & $\begin{array}{c}c \\
0 \\
1 \\
\frac{1}{\sigma} \\
\sigma \\
v\end{array} \mid$ & 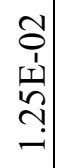 & 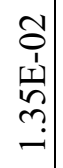 & 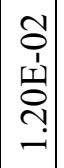 & 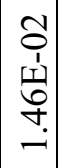 & 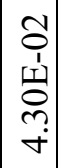 & 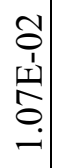 & $\begin{array}{c}\mathfrak{c} \\
0 \\
1 \\
\\
n \\
\end{array}$ & 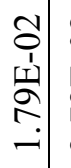 & 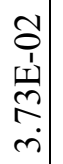 & 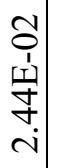 & \\
\hline
\end{tabular}

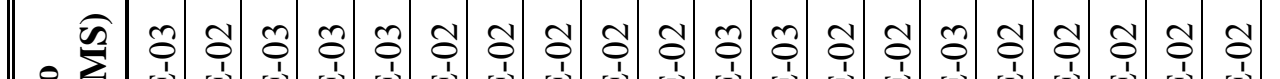

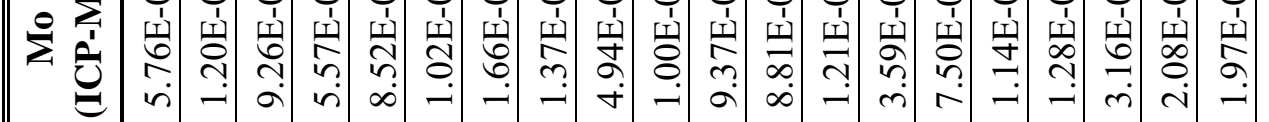

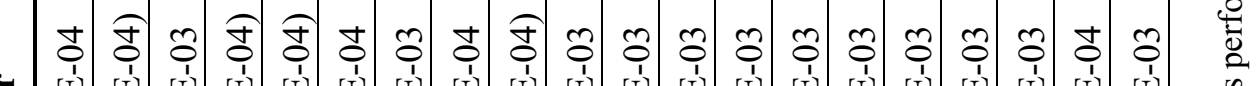

ப

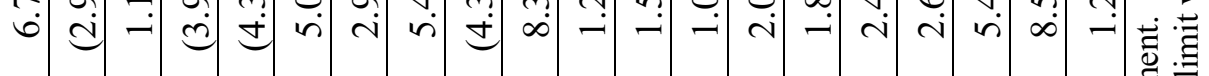

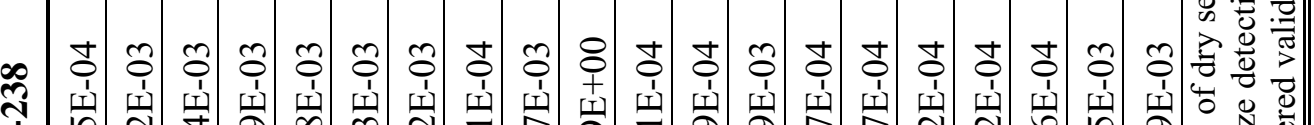

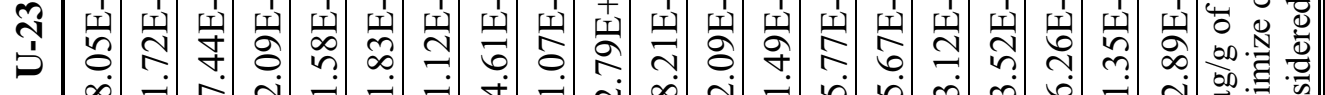

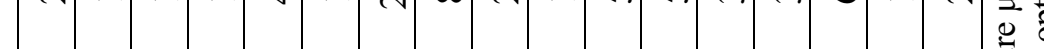
능

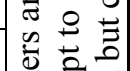

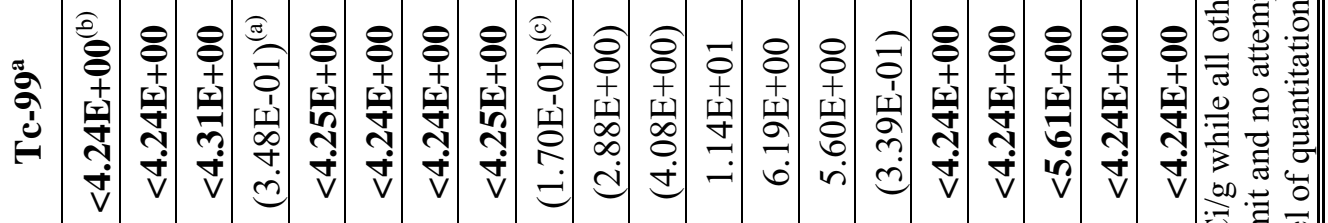

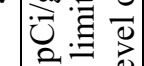

离.

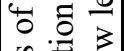

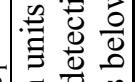

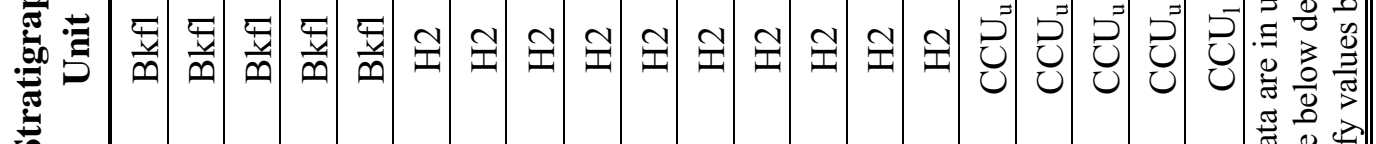

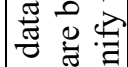

을 흥

它

₹

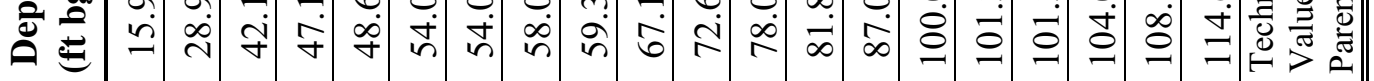
ฮิอ 


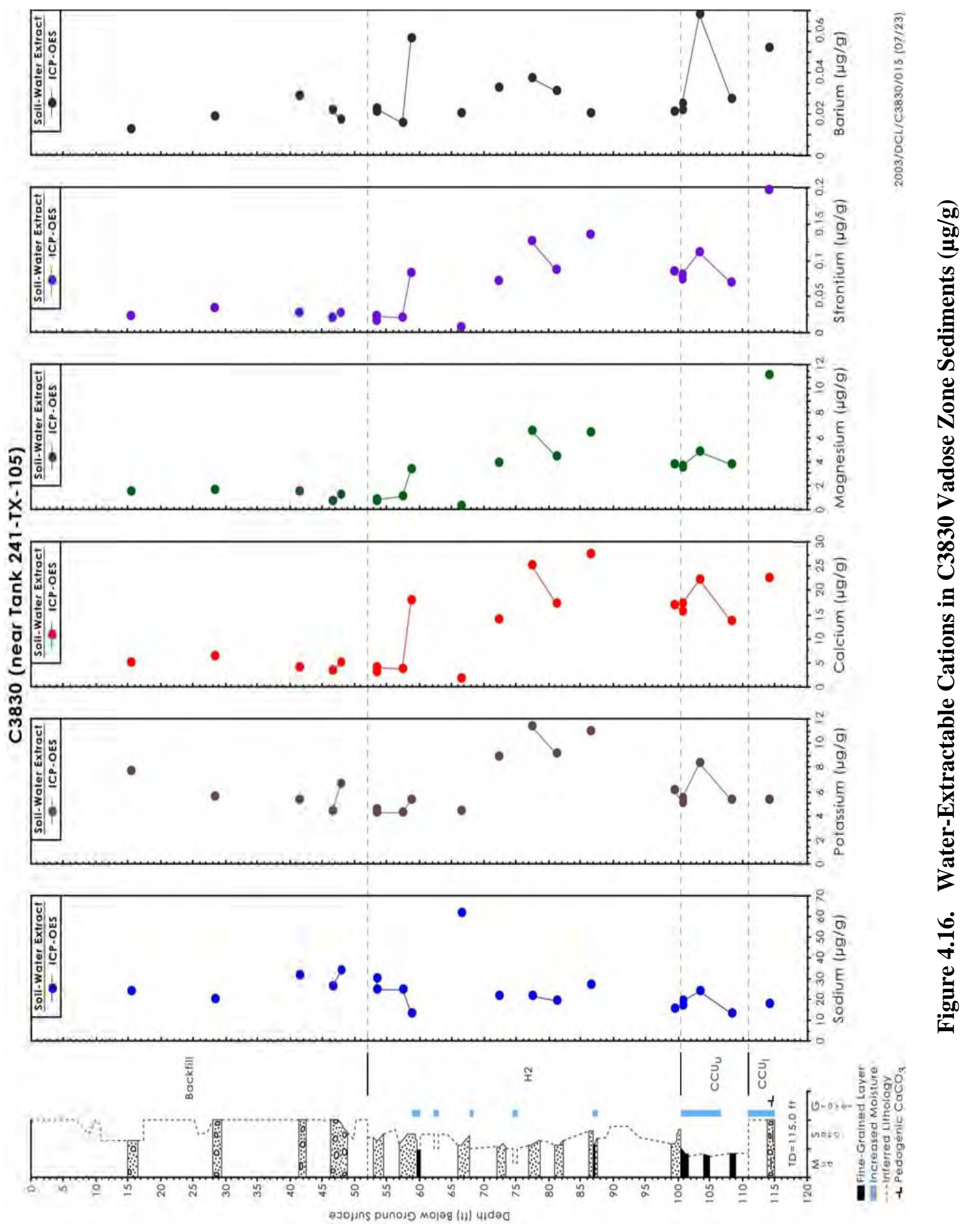




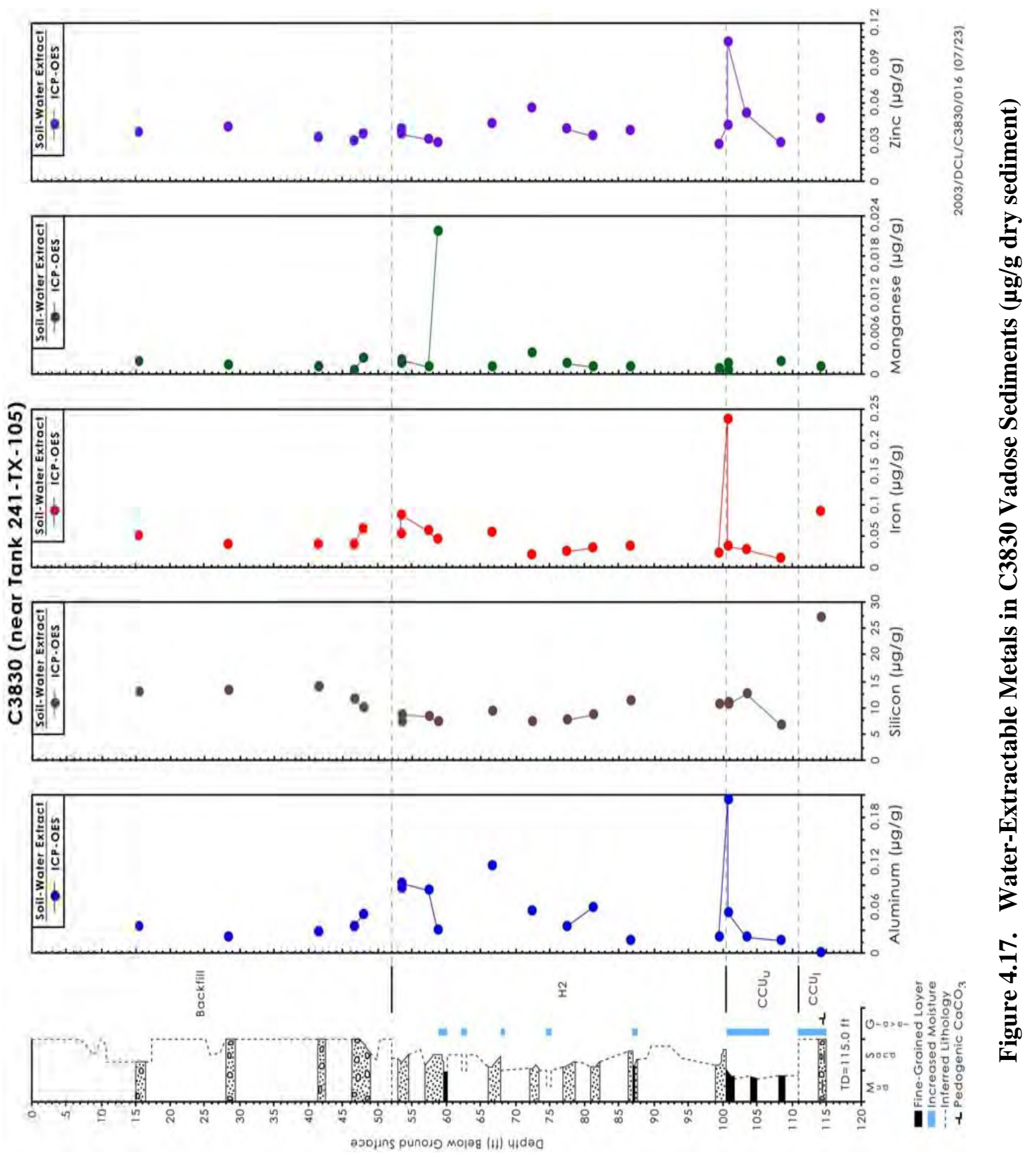



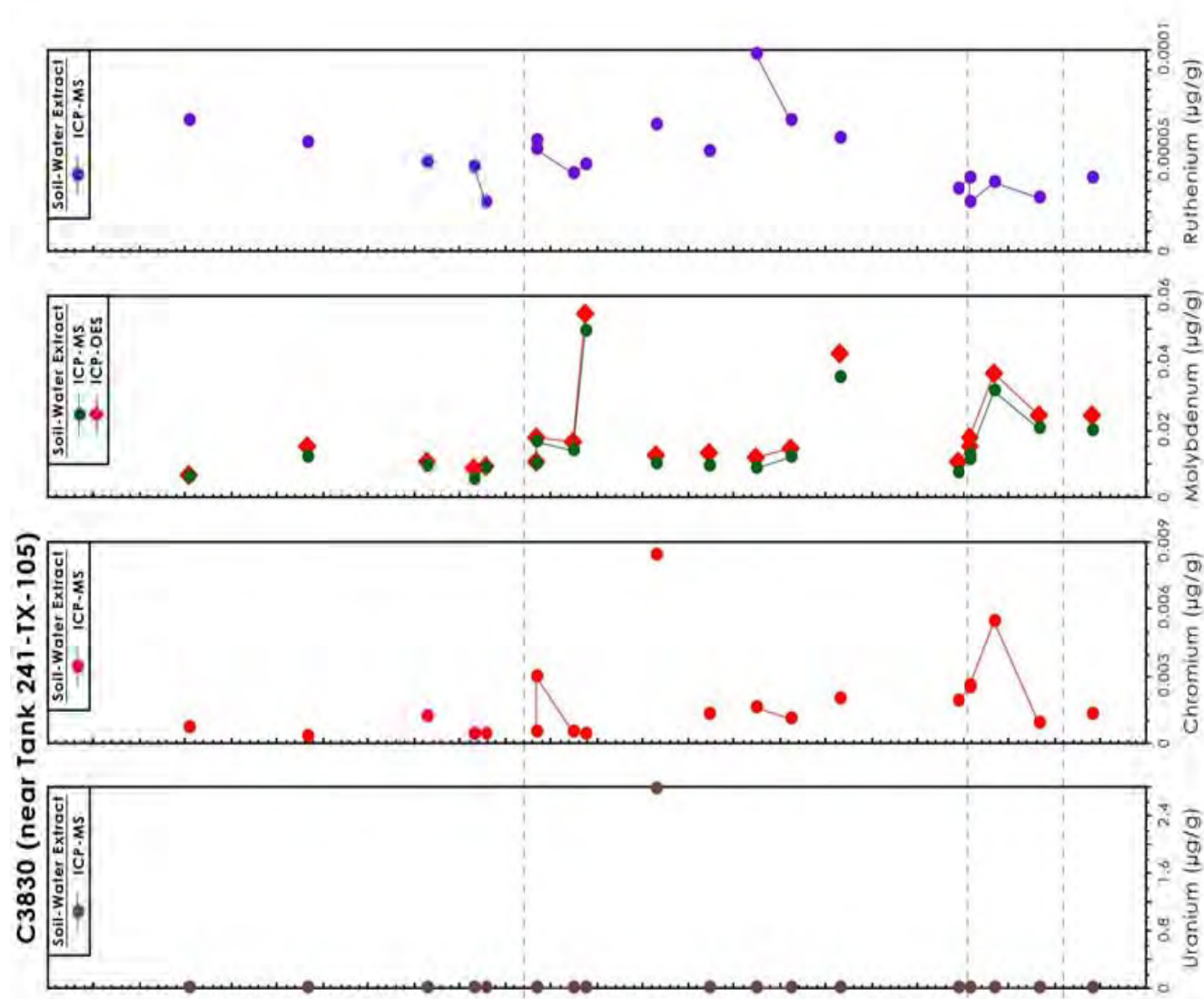

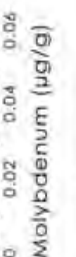
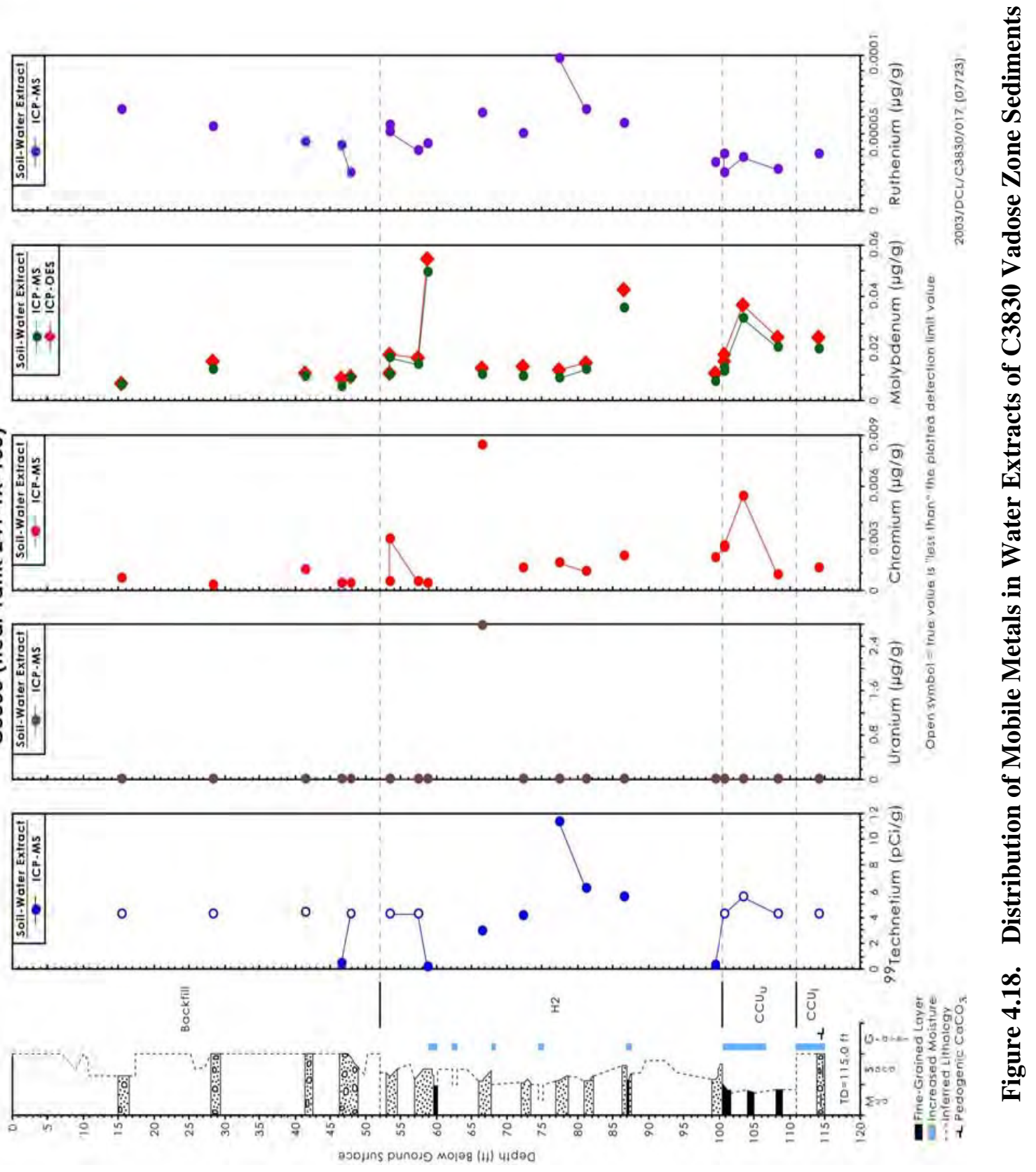


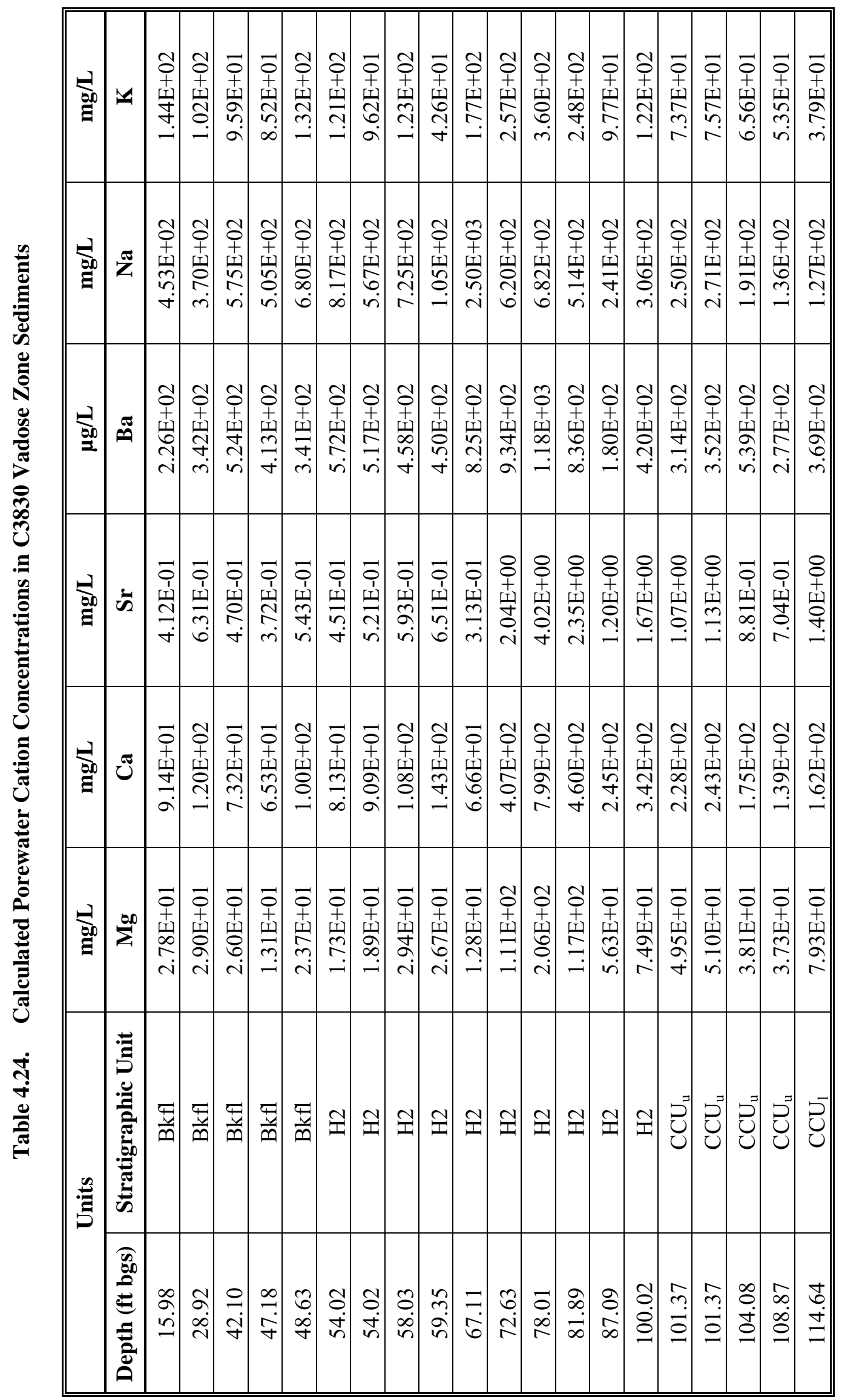




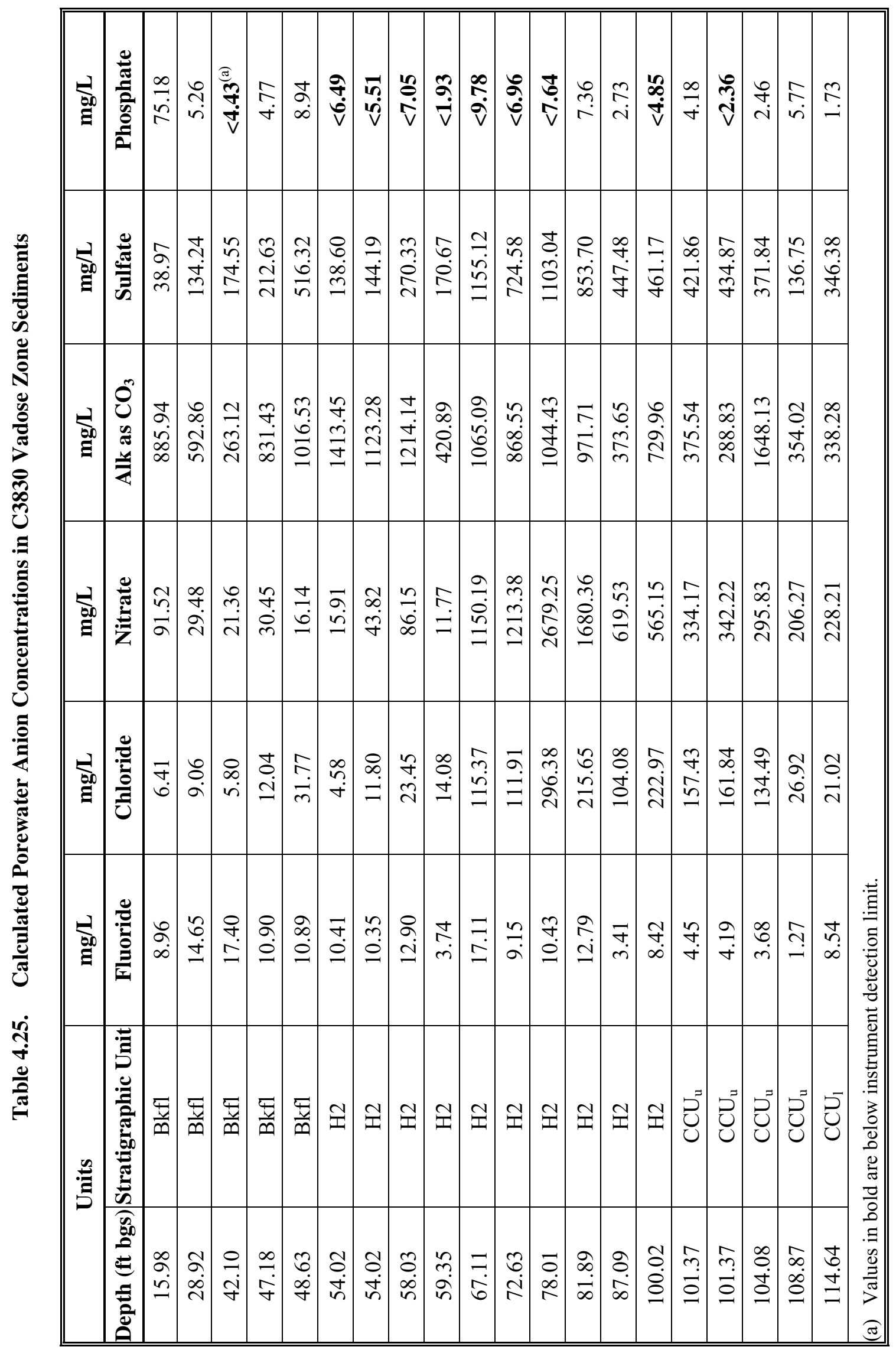




\begin{tabular}{|c|c|c|c|c|c|c|c|c|c|c|c|c|c|c|c|c|c|c|c|c|c|c|}
\hline$\stackrel{200}{a}$ & 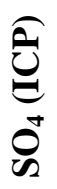 & \begin{tabular}{l}
$\mathbf{0}$ \\
+ \\
I \\
\multirow{0}{0}{} \\
0
\end{tabular} & $\begin{array}{c}\text { I } \\
+ \\
1 \\
\mathbb{1} \\
\\
-\end{array}$ & 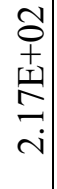 & 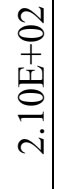 & 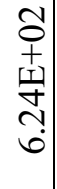 & 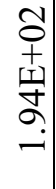 & 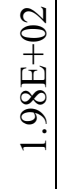 & 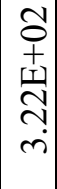 & 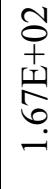 & 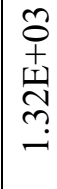 & $\begin{array}{c}\mathcal{N} \\
+ \\
+ \\
\\
\infty \\
\infty \\
\infty\end{array}$ & 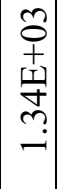 & 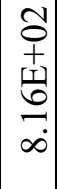 & 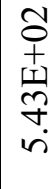 & \begin{tabular}{c} 
c \\
0 \\
+ \\
I \\
\multirow{2}{*}{} \\
n.
\end{tabular} & 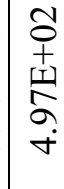 & 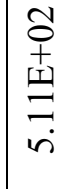 & 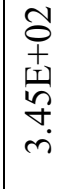 & 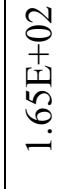 & 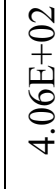 & \\
\hline 总 & 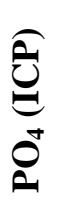 & $\begin{array}{l}\overline{0} \\
+ \\
\pm \\
\bar{\sigma} \\
\end{array}$ & 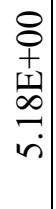 & 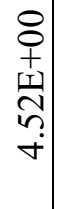 & \begin{tabular}{c}
8 \\
8 \\
+ \\
1 \\
\multirow{2}{*}{} \\
$i$ \\
$i$
\end{tabular} & $\begin{array}{l}8 \\
+ \\
1 \\
\\
\sigma \\
a\end{array}$ & $\begin{array}{c}8 \\
+ \\
+1 \\
\infty \\
0 \\
\dot{+}\end{array}$ & 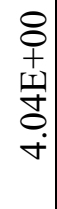 & $\begin{array}{c}8 \\
0 \\
+ \\
1 \\
0 \\
0 \\
i \\
i n\end{array}$ & $\begin{array}{c}\overline{0} \\
1 \\
1 \\
0 \\
i \\
r\end{array}$ & $\begin{array}{l}\overline{0} \\
+ \\
\text { 11 } \\
0 \\
0\end{array}$ & $\begin{array}{l}8 \\
0 \\
+ \\
\text { 年 } \\
\text { ? } \\
\end{array}$ & 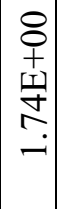 & 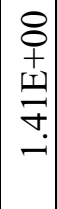 & $\begin{array}{c}\overline{0} \\
1 \\
1 \\
n \\
n \\
a\end{array}$ & 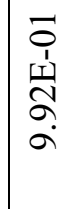 & $\begin{array}{c}8 \\
0 \\
+ \\
1 \\
0 \\
0 \\
\text { r }\end{array}$ & 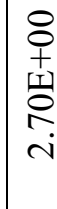 & $\begin{array}{l}8 \\
0 \\
+ \\
\text { 11 } \\
\text { bे } \\
\text { i }\end{array}$ & 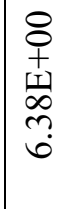 & 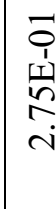 & \\
\hline$\underset{2}{20}$ & సี & $\begin{array}{l}\widetilde{\sigma} \\
+ \\
\pm \\
\widetilde{I} \\
\sigma \\
\sigma\end{array}$ & $\begin{array}{c}0 \\
0 \\
+ \\
\text { II } \\
0 \\
n \\
r\end{array}$ & $\begin{array}{c}1 \\
0 \\
+ \\
1 \\
\tilde{n} \\
\vdots \\
n\end{array}$ & $\begin{array}{c}\mathcal{1} \\
+ \\
+ \\
\text { I } \\
\infty \\
\dot{r} \\
\dot{0}\end{array}$ & $\begin{array}{c}2 \\
0 \\
+ \\
1 \\
2 \\
0 \\
-1\end{array}$ & $\begin{array}{l}0 \\
0 \\
+ \\
1 \\
0 \\
0 \\
0 \\
-\end{array}$ & $\mid \begin{array}{c}\tau \\
0 \\
+ \\
+1 \\
0 \\
\infty \\
\infty\end{array}$ & $\mid \begin{array}{c}\tau \\
0 \\
+ \\
1 \\
2 \\
\\
\vdots \\
0\end{array}$ & 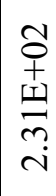 & 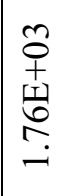 & 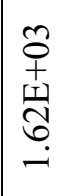 & 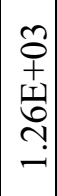 & 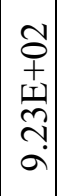 & 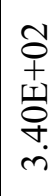 & $\begin{array}{c}\mathcal{O} \\
+ \\
\text { 1 } \\
\text { r } \\
\text { in }\end{array}$ & 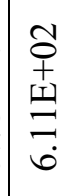 & $\begin{array}{c}\text { ô } \\
+ \\
\text { I } \\
\text { + } \\
-\end{array}$ & \begin{tabular}{c}
$\mathcal{O}$ \\
0 \\
+ \\
+1 \\
$\infty$ \\
0 \\
\multirow{+}{*}{}
\end{tabular} & 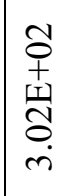 & 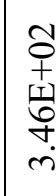 & \\
\hline 是o & $\sum$ & $\begin{array}{l}\overparen{7} \\
+ \\
\omega \\
\infty \\
\vdots \\
0 \\
0\end{array}$ & 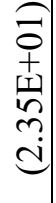 & 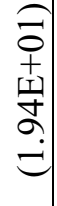 & 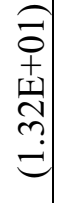 & $\begin{array}{l}\widehat{\vec{\sigma}} \\
+ \\
\text { 1 } \\
\stackrel{\sigma}{\sigma} \\
\dot{ \pm}\end{array}$ & 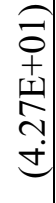 & 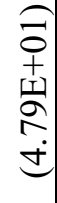 & $\begin{array}{c}\widehat{\overrightarrow{0}} \\
+ \\
\omega \\
\tilde{0} \\
\dot{v} \\
\tilde{v}\end{array}$ & 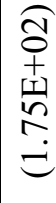 & 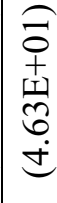 & $\begin{array}{c}\overline{0} \\
+ \\
\text { 11 } \\
0 \\
0 \\
\infty\end{array}$ & $\begin{array}{c}\widehat{\widehat{o}} \\
+ \\
\text { 1 } \\
8 \\
\dot{0}\end{array}$ & $\begin{array}{l}\widehat{-} \\
0 \\
1 \\
0 \\
0 \\
0 \\
0\end{array}$ & 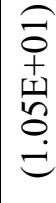 & 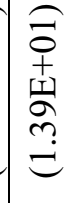 & 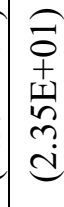 & 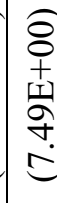 & $\stackrel{\hat{\partial}}{\hat{z}}$ & 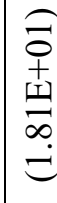 & $\begin{array}{l}\text { } \\
+ \\
1 \\
0 \\
0 \\
0\end{array}$ & \\
\hline$\underset{2}{20}$ & 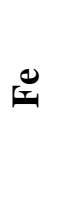 & 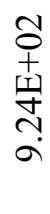 & 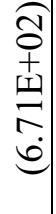 & $\begin{array}{l}\widehat{\imath} \\
0 \\
+ \\
1 \\
0 \\
+ \\
0 \\
0\end{array}$ & $\begin{array}{l}\widehat{\imath} \\
0 \\
+ \\
10 \\
0 \\
0 \\
0\end{array}$ & $\begin{array}{c}0 \\
0 \\
+ \\
\pm \\
\\
\end{array}$ & 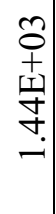 & $\begin{array}{c}0 \\
+ \\
+ \\
1 \\
0 \\
\infty \\
-1 \\
-1\end{array}$ & $\mid \begin{array}{c}0 \\
+ \\
+ \\
1 \\
0 \\
0 \\
0 \\
-1\end{array}$ & 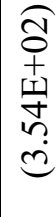 & $\begin{array}{c}\tilde{o} \\
+ \\
1 \\
\tilde{\nu} \\
\tilde{\gamma}\end{array}$ & તิ & 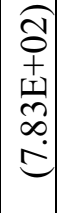 & 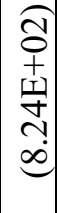 & 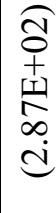 & $\begin{array}{l}\text { ชิ } \\
+ \\
\text { I } \\
n \\
n \\
\text { 巳 }\end{array}$ & \begin{tabular}{c}
$\tilde{o}$ \\
+ \\
\multicolumn{1}{c}{} \\
$\tilde{\sigma}$ \\
$\dot{r}$
\end{tabular} & శิ & حิ & તิ & 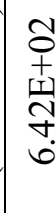 & \\
\hline & is & 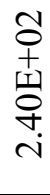 & $\begin{array}{l}\text { ô } \\
+ \\
+1 \\
\infty \\
+ \\
+ \\
ن\end{array}$ & 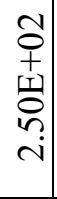 & 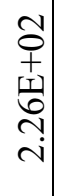 & $\begin{array}{l}\tilde{o} \\
+ \\
\pm \\
\sigma \\
\sigma \\
-\end{array}$ & 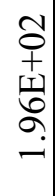 & 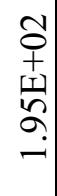 & 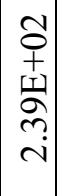 & 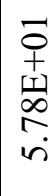 & \begin{tabular}{c}
$\mathcal{O}$ \\
+ \\
+1 \\
\multirow{\tau}{\tau}{} \\
$\dot{r}$
\end{tabular} & 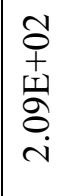 & 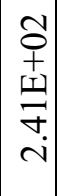 & 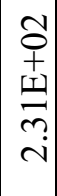 & $\begin{array}{l}\mathcal{O} \\
0 \\
+ \\
\text { 11 } \\
\delta \\
0 \\
\end{array}$ & 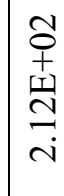 & 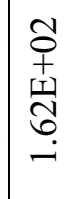 & 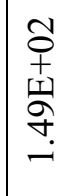 & 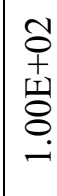 & 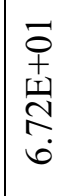 & 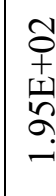 & 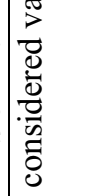 \\
\hline 是 & 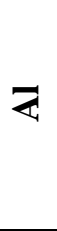 & 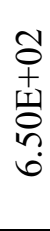 & $\begin{array}{l}\widehat{\Xi} \\
\widehat{0} \\
+ \\
\text { 1 } \\
0 \\
0 \\
\dot{ \pm}\end{array}$ & 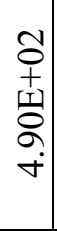 & $\begin{array}{c}2 \\
0 \\
+ \\
11 \\
-2 \\
0 \\
0\end{array}$ & $\begin{array}{l}0 \\
0 \\
+ \\
1 \\
\mathbb{V} \\
0 \\
-1\end{array}$ & 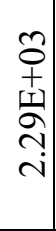 & 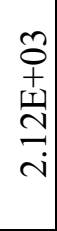 & $\mid \begin{array}{c}m \\
+ \\
+ \\
\pm \\
\gamma \\
\dot{\gamma} \\
c\end{array}$ & 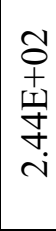 & 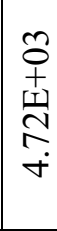 & $\begin{array}{c}0 \\
0 \\
+ \\
\text { 11 } \\
0 \\
0 \\
\end{array}$ & $\begin{array}{c}0 \\
0 \\
+ \\
\pm \\
\sigma \\
\delta \\
-1\end{array}$ & $\mid \begin{array}{c}0 \\
0 \\
+ \\
1 \\
\tilde{n} \\
0 \\
-1 \\
-\end{array}$ & 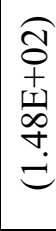 & $\begin{array}{l}\text { 고 } \\
+ \\
\text { I } \\
\text { + } \\
\dot{+}\end{array}$ & 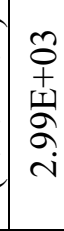 & 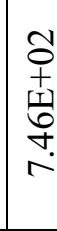 & 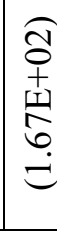 & 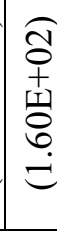 & $\begin{array}{l}\delta \\
8 \\
1 \\
\text { I } \\
\delta \\
n \\
\infty\end{array}$ & 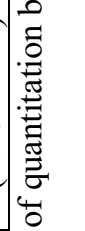 \\
\hline$\stackrel{\mathscr{Z}}{\mathscr{B}}$ & 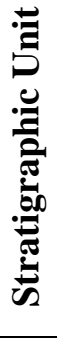 & $\frac{\bar{y}}{m}$ & $\frac{E}{\bar{m}}$ & $\frac{\vec{n}}{m}$ & $\frac{\bar{n}}{m}$ & $\frac{\bar{t}}{m}$ & $\tilde{I}$ & 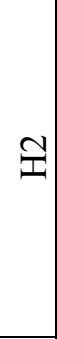 & $\mathbb{I}$ & $\mathbb{I}$ & I & I & $\mathbb{I}$ & 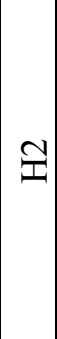 & $\tilde{I}$ & $\tilde{I}$ & نَ & ن & 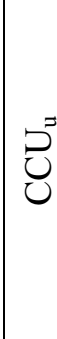 & e & 己 & 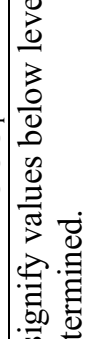 \\
\hline & 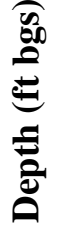 & $\stackrel{\Omega}{\Omega}$ & 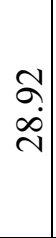 & & & $\begin{array}{l}\hat{b} \\
\dot{0} \\
+\end{array}$ & $\begin{array}{l}\text { Oै } \\
\dot{H} \\
n\end{array}$ & $\begin{array}{l}\tilde{O} \\
\dot{0} \\
i\end{array}$ & $\begin{array}{c}2 \\
0 \\
\dot{\infty} \\
n \\
n\end{array}$ & $\begin{array}{l}\text { ma } \\
\text { ñ } \\
\text { nn }\end{array}$ & $\underset{6}{6}$ & $\begin{array}{l}\widetilde{b} \\
\stackrel{i}{i}\end{array}$ & $\begin{array}{l}\overline{0} \\
\infty \\
\infty\end{array}$ & $\begin{array}{l}\infty \\
\infty \\
\dot{\infty}\end{array}$ & $\begin{array}{l}8 \\
\dot{\infty}\end{array}$ & : & $\stackrel{n}{0}$ & ñ & O. & $\begin{array}{l}\infty \\
\infty \\
\infty \\
0\end{array}$ & 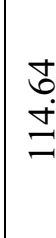 & 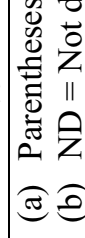 \\
\hline
\end{tabular}




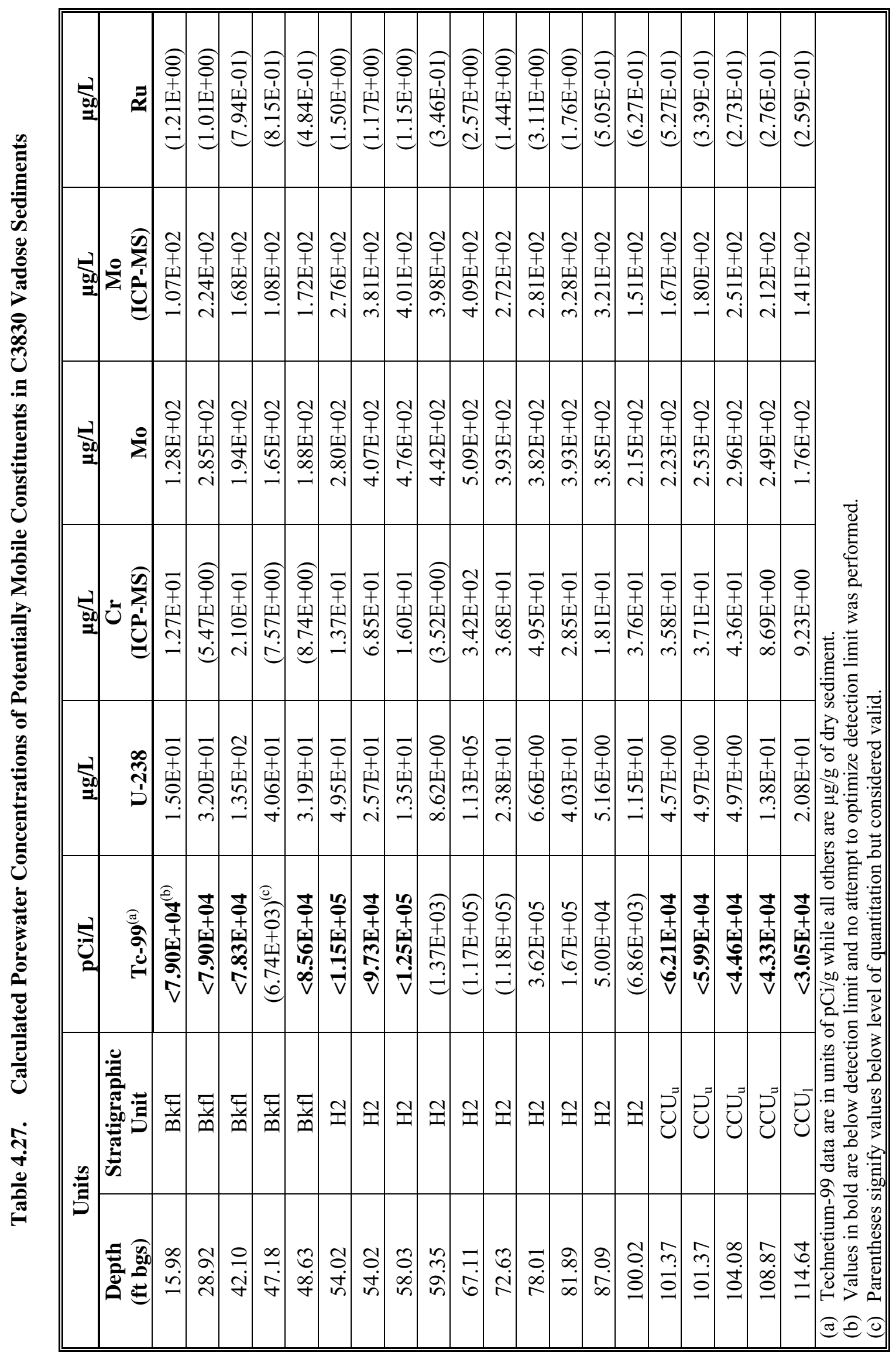



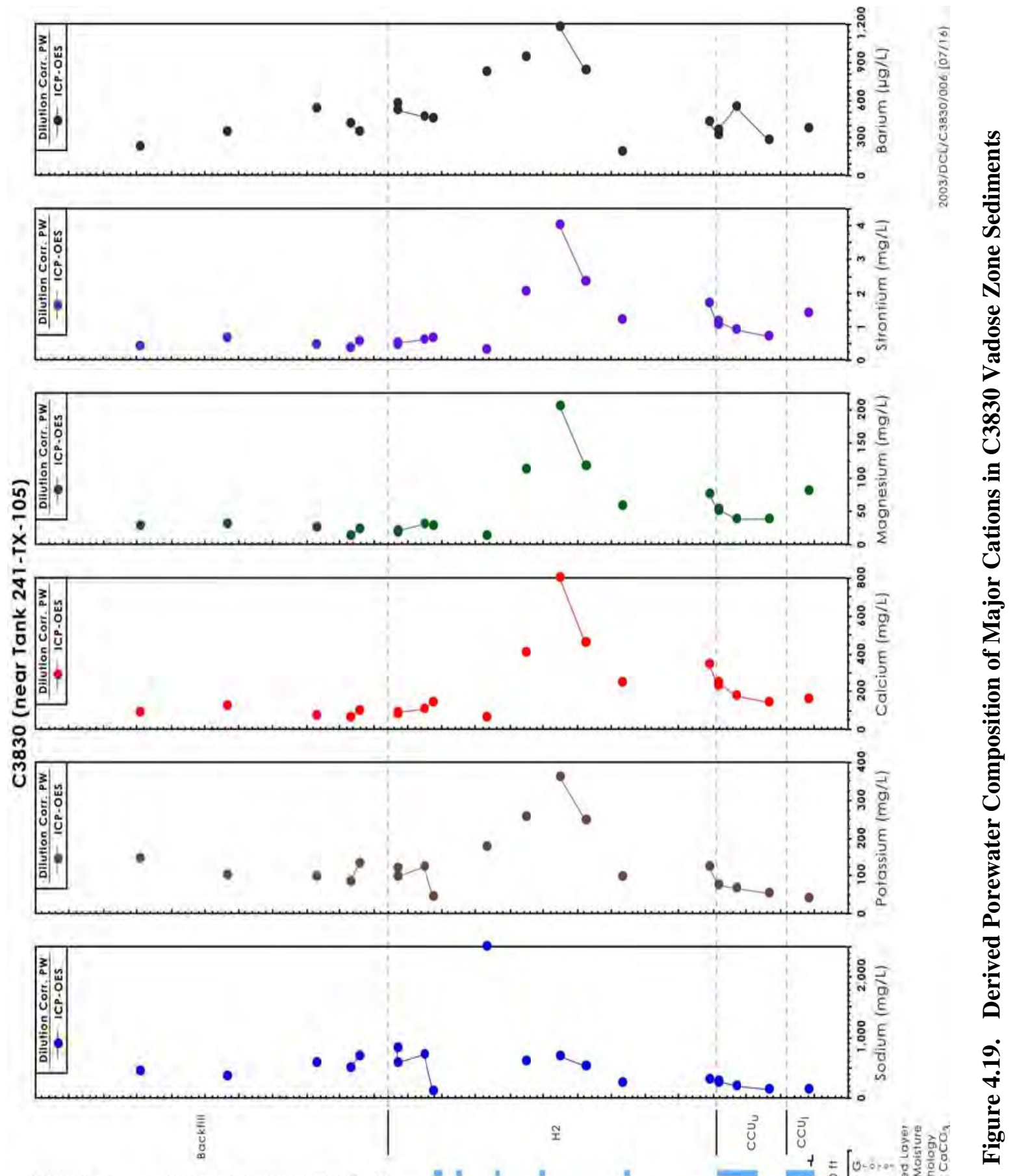


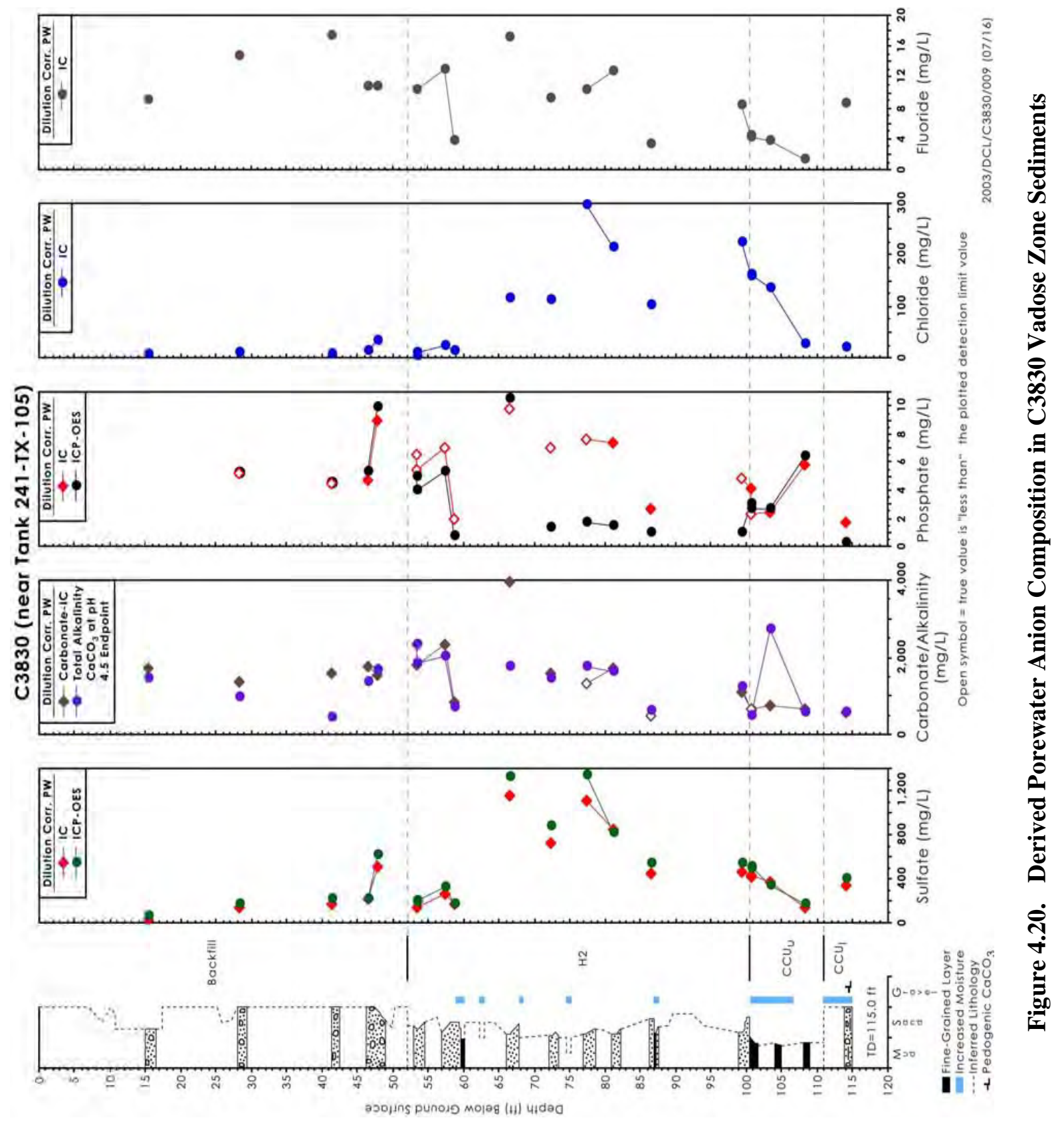




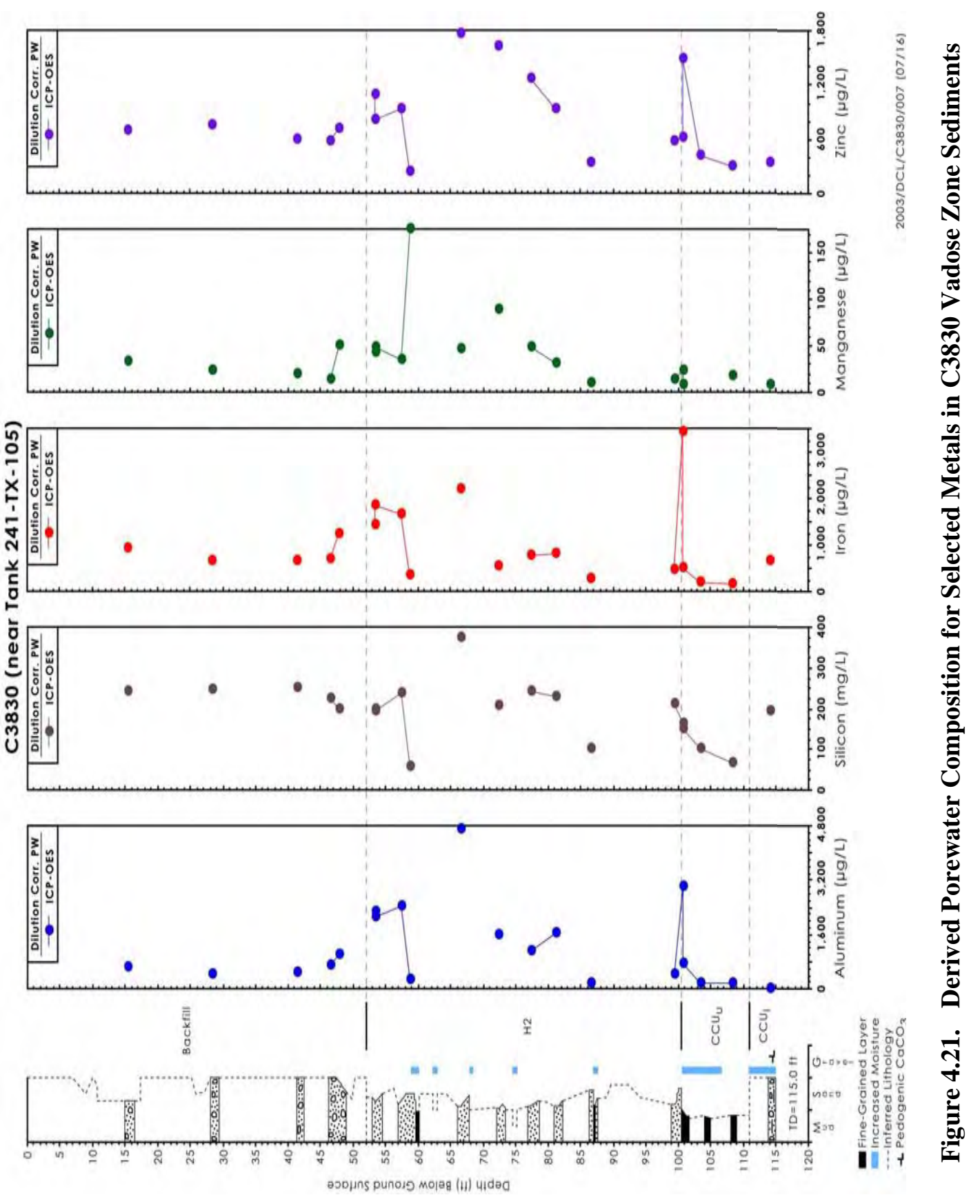



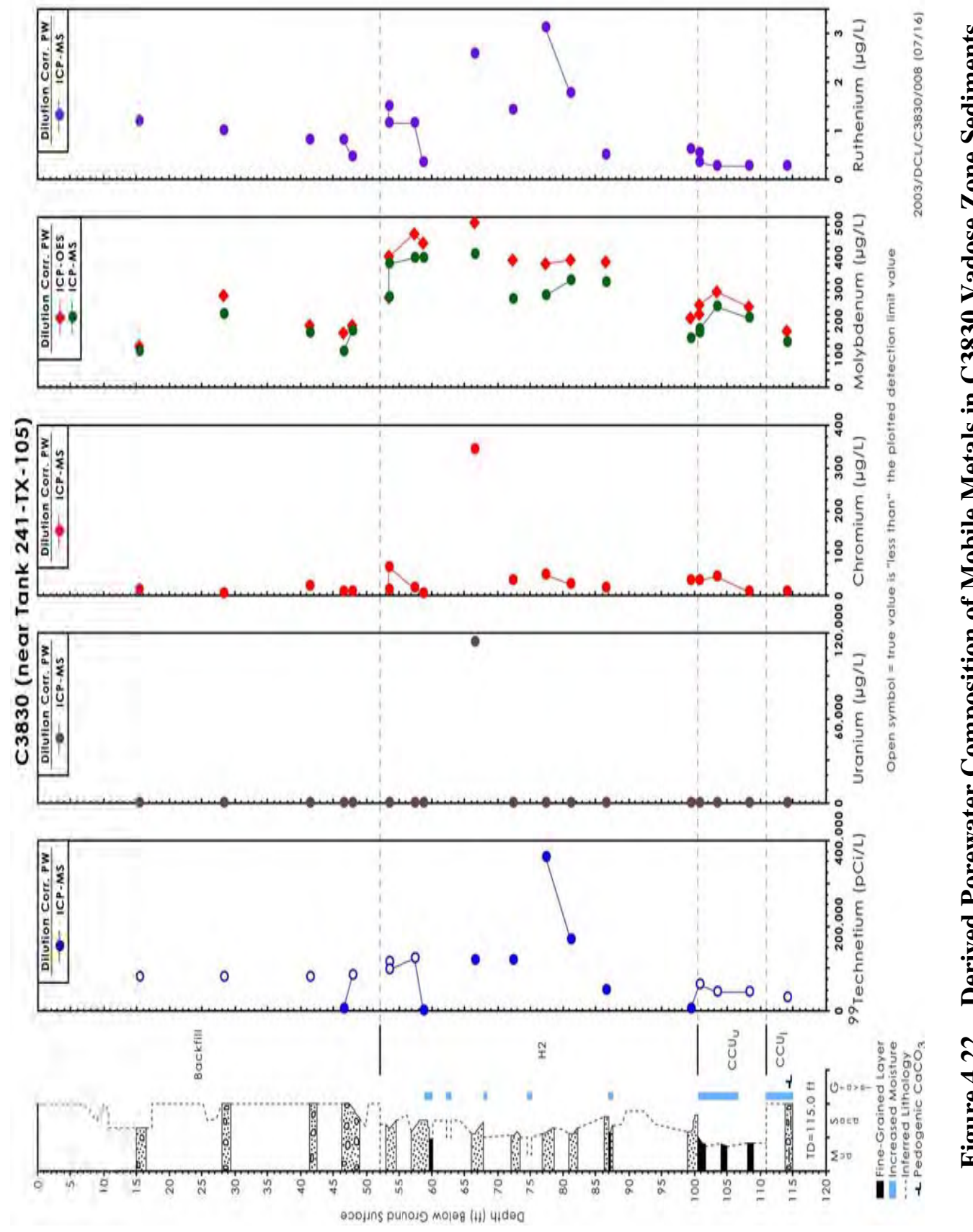

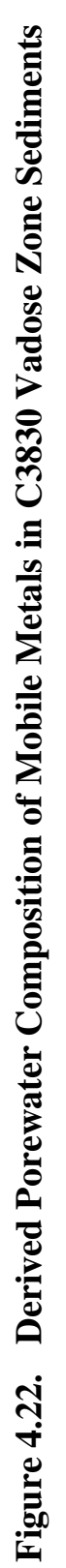




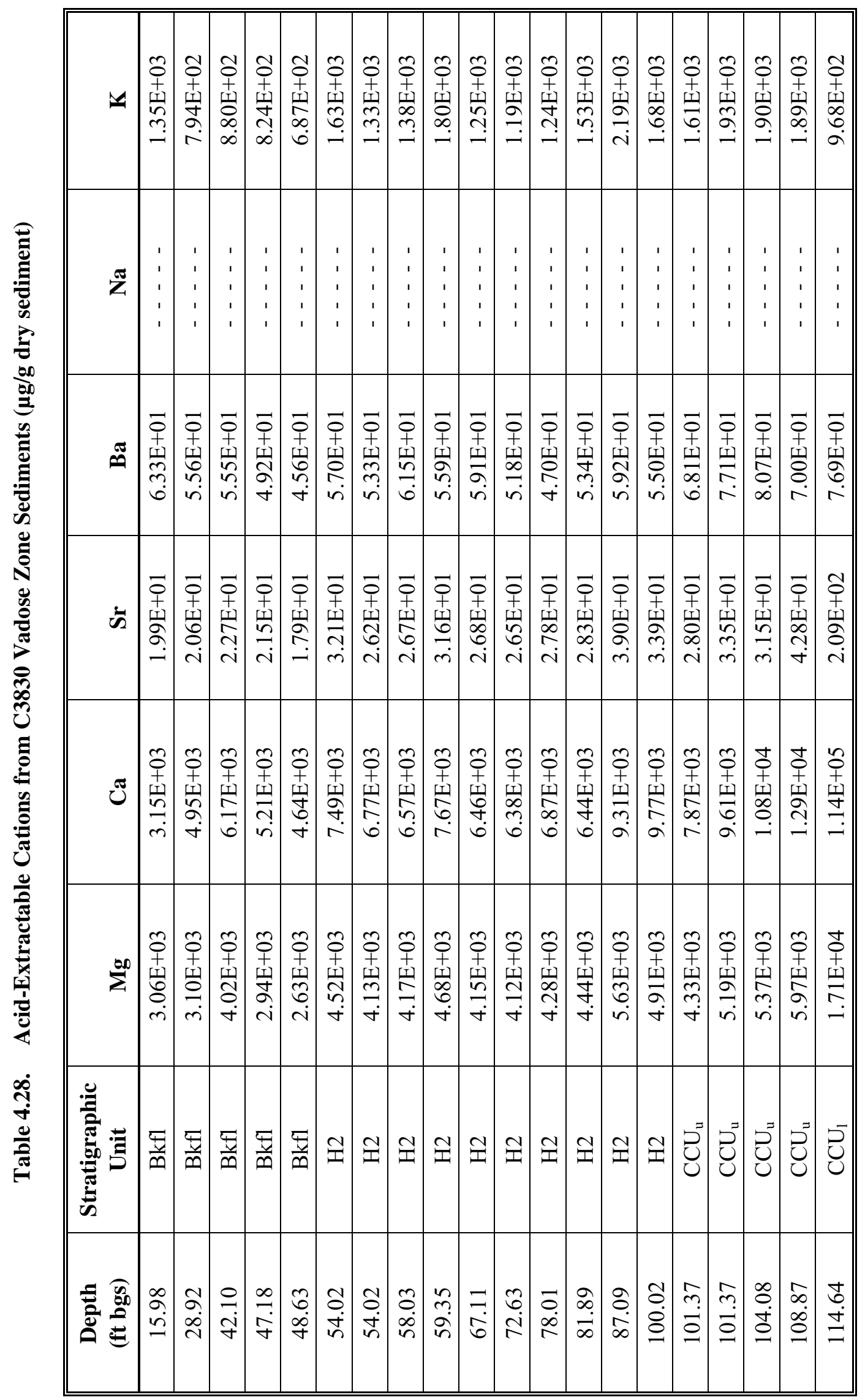




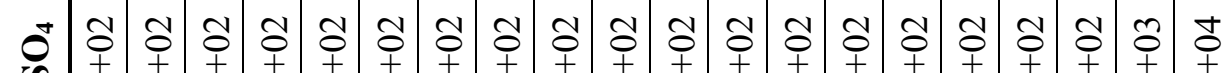

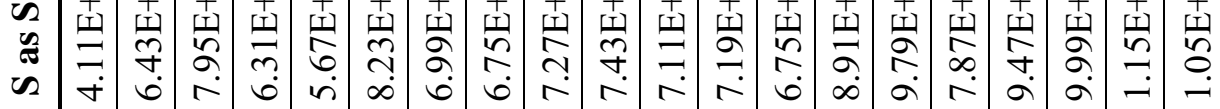

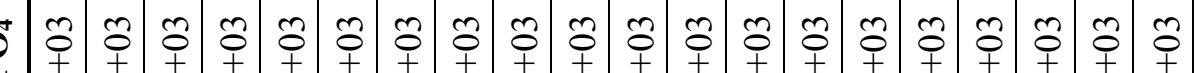

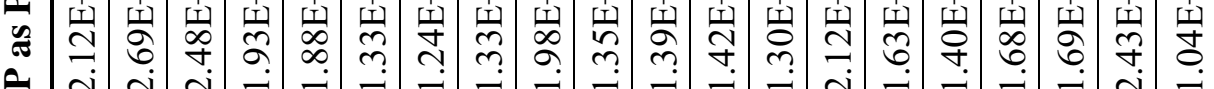

- v i v

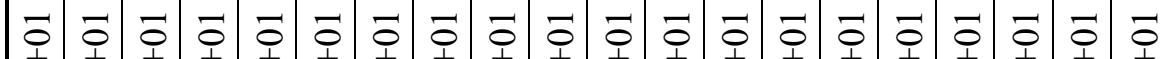

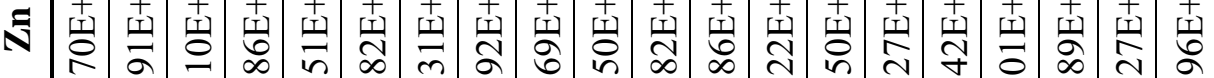

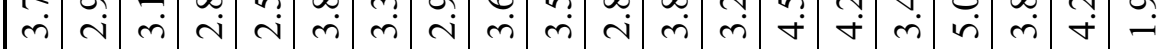

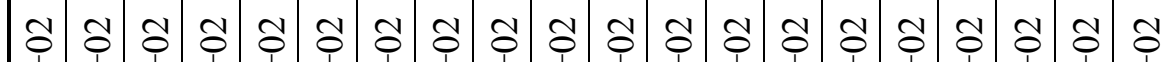

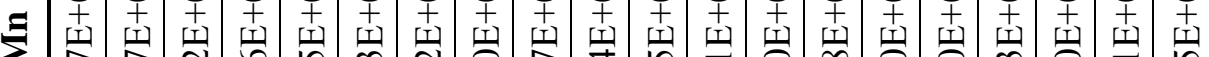

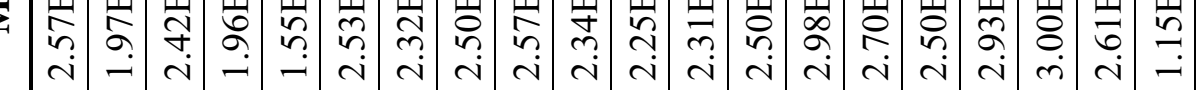

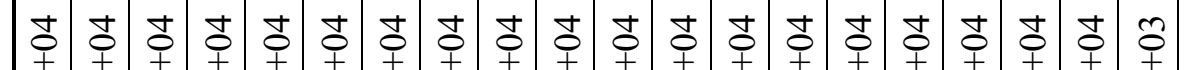

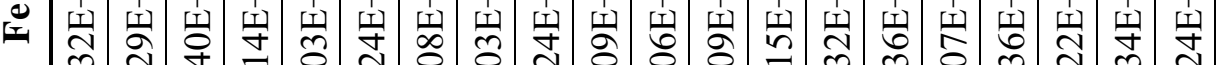

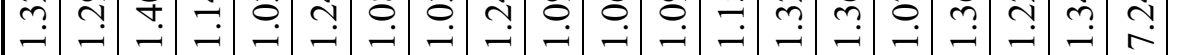

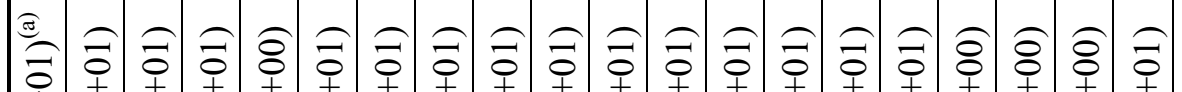

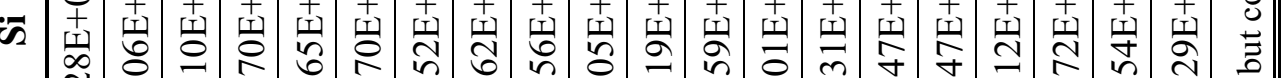

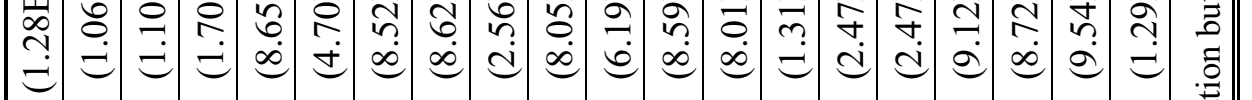

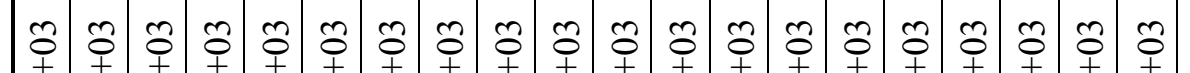

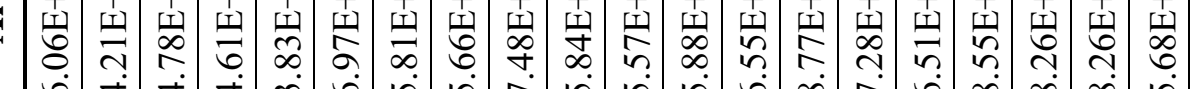




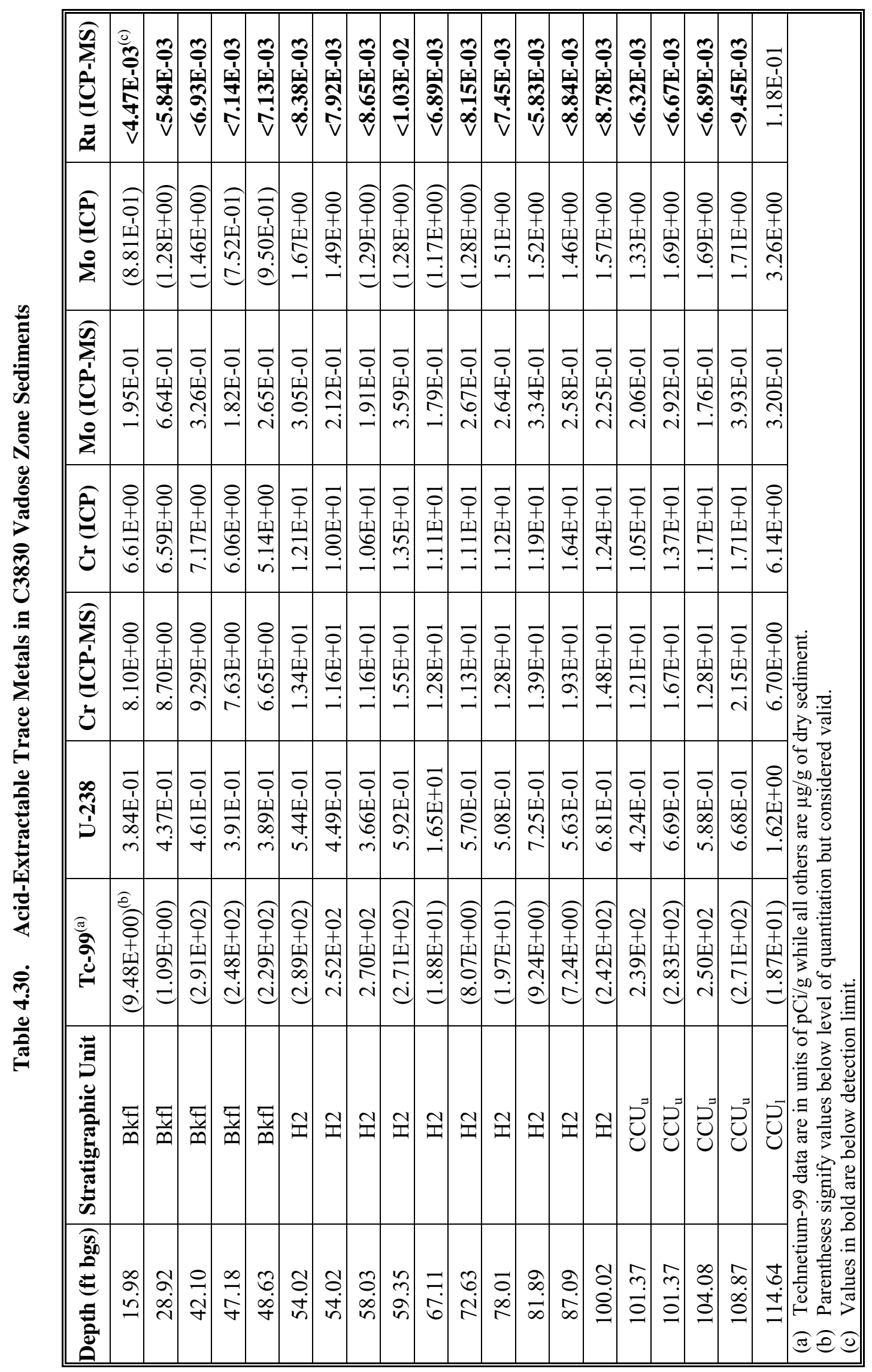




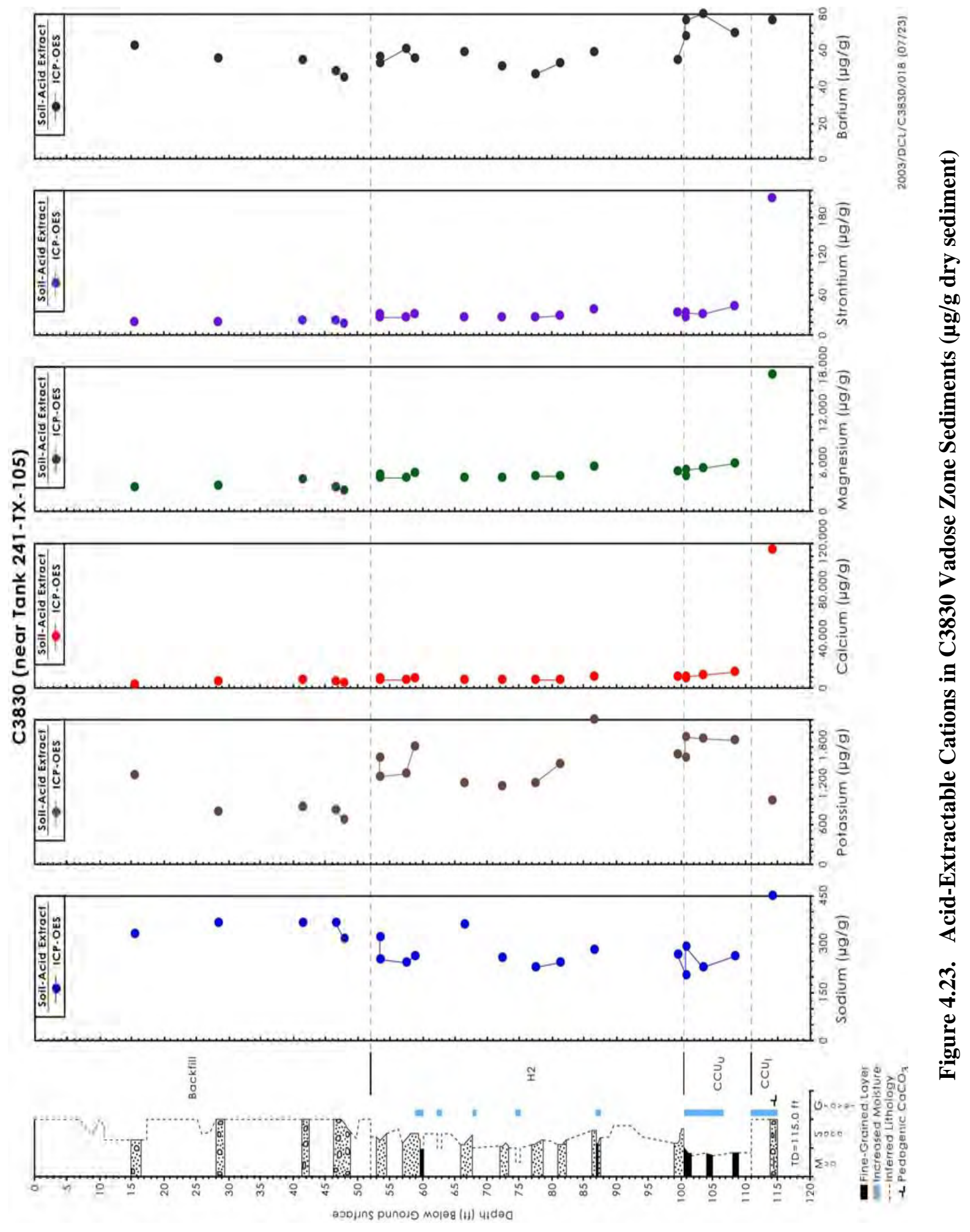




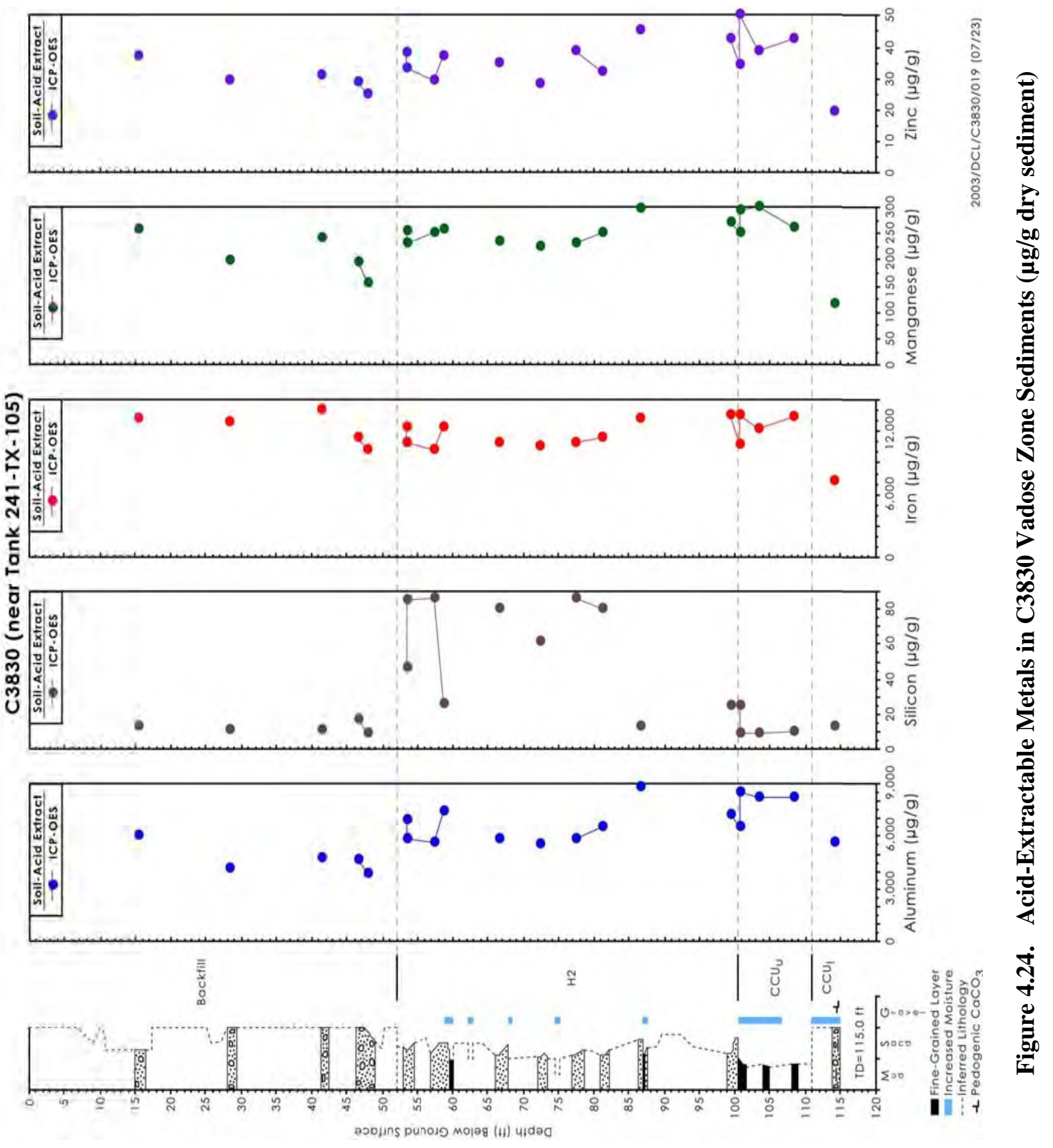



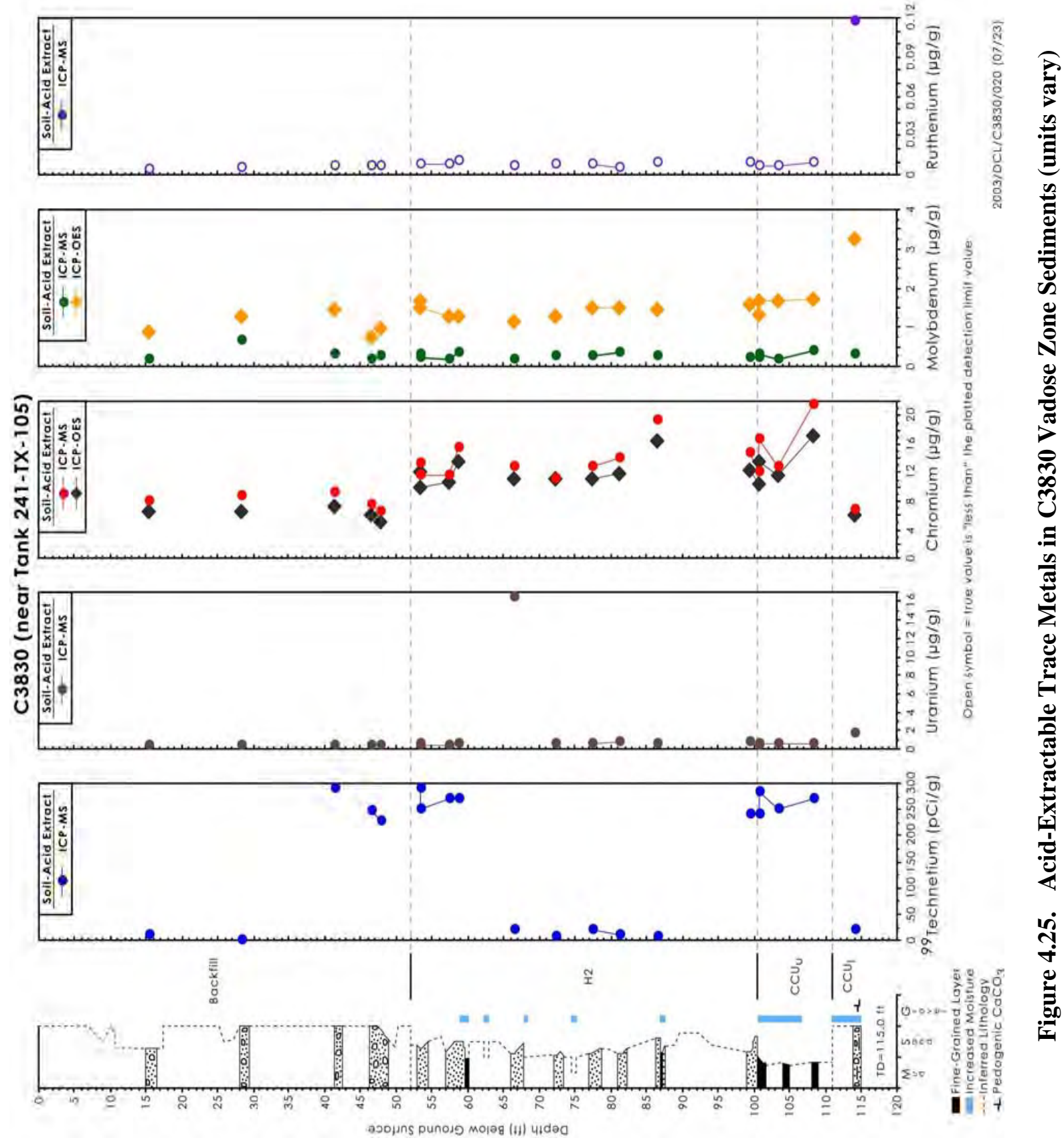


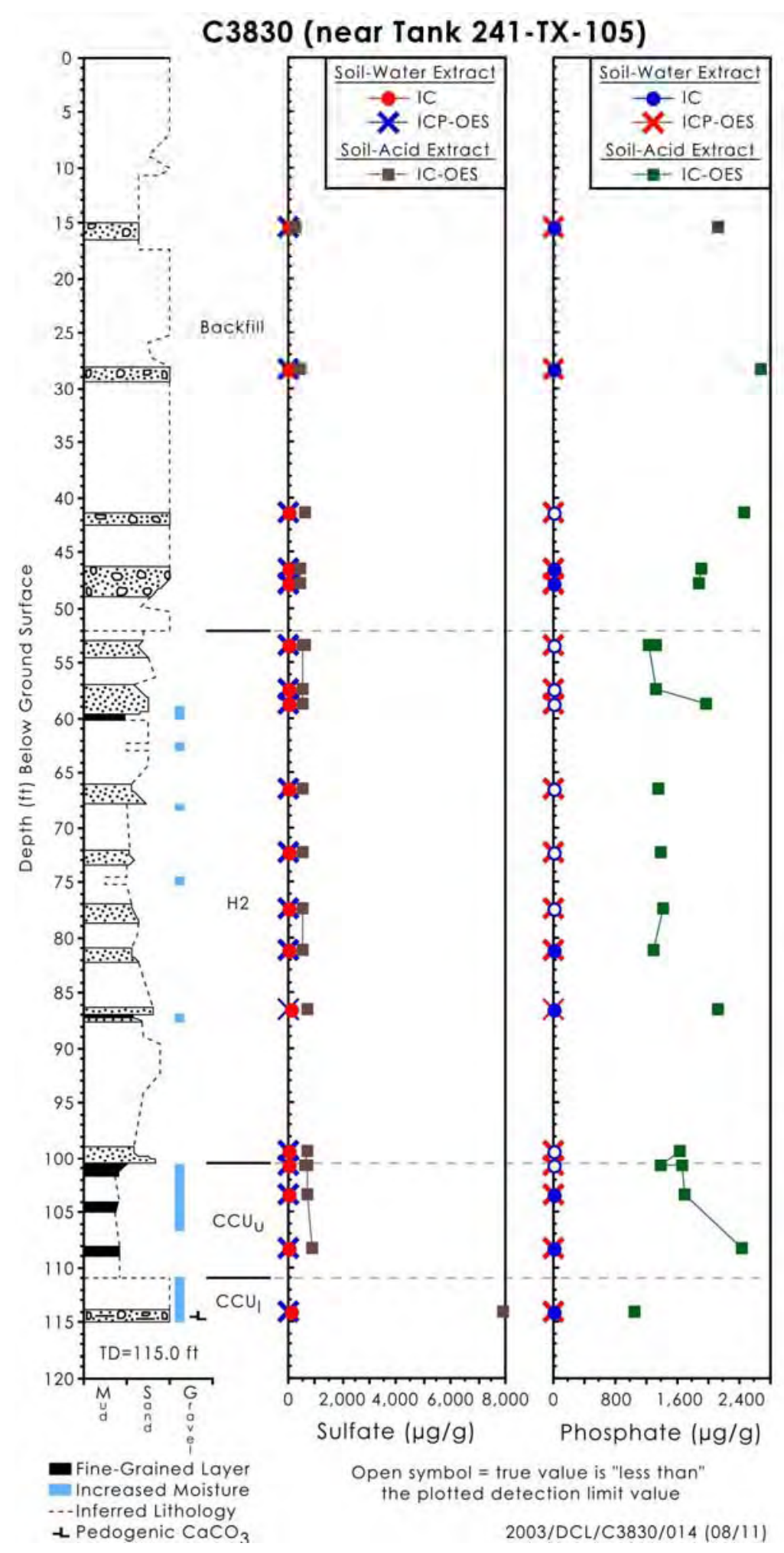

Figure 4.26. Water- versus Acid-Extractable Sulfate and Phosphate in C3830 Vadose Zone Sediments 
the TX tanks. This might reflect that tank fluids leaked from shallower positions than the tank bottoms. Alternatively, we may be seeing analytical vagaries in our ability to obtain the same detection limit for technetium-99 from sediment to sediment and month to month. The quantities of technetium-99 that are acid extractable per gram of sediment and the quantities that are water soluble differ. The acid extract data are variable and, as shown in Table 4.30, mostly qualified with parentheses that mean values below our level of quantification. As found in sediments at borehole 299-E33-46 (see Serne et al. 2002f), measuring technetium-99 at low levels by acid extraction yields results that are not as reliable as water extraction data. We thus place more confidence in the technetium-99 data shown in Table 4.23.

The comparison of the water to acid-extractable quantities of each constituent was performed by taking the data in Tables 4.21 to 4.23 and dividing by the data in Tables 4.28 through 4.30. The data are not presented herein but show the same trends as found for the uncontaminated borehole (299-W10-27), wherein less than $0.1 \%$ of the acid-extractable quantities of the following elements are water leachable: $\mathrm{Al}, \mathrm{Ba}, \mathrm{Fe}, \mathrm{Mn}, \mathrm{Cr}$, and $\mathrm{P}$ as phosphate. Less than $0.5 \%$ of the acid-extractable quantities of the following elements are water leachable: $\mathrm{Ca}, \mathrm{K}, \mathrm{Mg}, \mathrm{Sr}, \mathrm{Zn}$, and $\mathrm{U}$. Less than $20 \%$ of the acid-extractable sodium, sulfur, and molybdenum are water extractable excepting the following. The only indication of tank contamination is the high water and acid-extractable uranium value for the sample at $67.11 \mathrm{ft}$ bgs and the presence of technetium-99 in both acid and water extracts. The percentage of the acid-extractable uranium that is also water extractable for the sediment at $67.11 \mathrm{ft}$ bgs is $17 \%$ while all other water extracts for samples below the tank are less than $0.5 \%$. The water-extractable sodium percentage is also $17 \%$ of the sodium that is acid extractable for this sample. At other tank farms we have found that water extracts of highly contaminated sediments release larger percentages of most constituents than uncontaminated sediments. The water and acid-extractable uranium of the sample at $67.11 \mathrm{ft}$ bgs are 2.8 and $16.5 \mu \mathrm{g}$ of uranium per $g$ of sediment. These values are small compared to the values in contaminated sediments east of tank BX-102 from borehole 299-E33-45 that contained 300 to $1500 \mu \mathrm{g}$ of uranium per $\mathrm{g}$ of sediment acid-extractable uranium.

The borehole C3830 sediment from the Cold Creek lower subunit (caliche) has elevated acid-extractable levels of uranium, magnesium, calcium, sodium and low levels of acid-extractable potassium in comparison to other samples and the caliche from the uncontaminated 299-W10-27 borehole. The likely cause for these differences is the higher level of evaporites present as indicated by the higher amount of calcium carbonate found in this subunit at C3830 than at 299-W10-27. Caliche contains higher concentrations of acid-extractable uranium, magnesium, calcium, and sodium than other minerals and, when one caliche sample contains more calcium carbonate than another sample, higher amounts of these constituents are acid leachable. The ratio of water- to acid-extractable constituents in the caliche does not indicate significant man-made contamination is present.

Figure 4.25 shows that our acid-extractable molybdenum results from ICP analyses is biased high likely from an unaccounted for spectral interference. The molybdenum results from the ICP-MS are more accurate and detection limits are much lower. Figure 4.26 shows that there is some sulfate present in the sediments that is not readily water extractable and the vast majority of the sediment phosphate content is not water extractable in comparison with the amounts that are acid extractable. The same trend was observed for the uncontaminated sediments from borehole 299-W10-27. Alternatively, some of the acid-extractable phosphorous may be present in a form other than phosphate such that when we convert the acid-extractable phosphorous number to phosphate (essentially multiply by 3 ), we are inflating the acid-extractable value. 


\subsubsection{Radionuclide Content in Vadose Zone Sediment from C3830}

Aside from the technetium-99 data already presented and the uranium observed near $67 \mathrm{ft}$ bgs, no radionuclides above a few tenths of a $\mathrm{pCi} / \mathrm{g}$ were found in the core samples obtained from borehole C3830. Further, aside from a small amount of surface cesium-137 contamination, the field logging results of the entire borehole did not find any gamma-emitting contamination. Figures 4.27 and 4.28 show the field logs and results for natural potassium-40 and uranium-238 and for common gamma emitters, respectively. Where field-logging data were above detection limits, the log data are plotted also. The agreement between the field and lab-generated data for gamma emitters is excellent. There are no man-made gamma emitters in the sediment profile above concentrations of a few tenths of a $\mathrm{pCi} / \mathrm{g}$, excepting the near surface contamination that has a few $\mathrm{pCi} / \mathrm{g}$ cesium-137 in shallow backfill sediments.

Gross alpha and beta measurement were made on both the 1:1 sediment:water and sediment:acid extracts. With knowledge of the mass of dry sediment to extraction fluid used, the data were converted to activity of gross beta and alpha leached per gram of dry sediment. None of the water or acid extracts, of the 20 extracts (18 cores from selected depths and two duplicates), showed activities significantly greater than the detection limits for the procedures. For the total beta analyses, our detection limits for the water extracts were 10 to $20 \mathrm{pCi} / \mathrm{g}$ dry sediment and 5 to $10 \mathrm{pCi} / \mathrm{g}$ dry sediment for the acid extracts. For the total alpha analyses, the detection limit for both extracts was 3 to $5 \mathrm{pCi} / \mathrm{g}$ dry sediment. Note that the efficiency of the total beta technique for the low energy techetium-99 is poor such that the total beta analyses can indicate no beta above 10 to $20 \mathrm{pCi} / \mathrm{g}$, yet the ICP-MS measurements for the water and acid extracts show that there may be up to $200 \mathrm{pCi} / \mathrm{g}$ of technetium- 99 present.

\subsubsection{Total Carbon, Calcium Carbonate, and Organic Carbon Content of Vadose Zone Sediment from Borehole C3830}

The total, inorganic and organic carbon contents of the $\mathrm{C} 3830$ sediments are reported in Table 4.31. The only sample of lower Cold Creek subunit (caliche) obtained, at $114.6 \mathrm{ft} \mathrm{bgs,} \mathrm{contains} \mathrm{significant} \mathrm{amounts}$ of calcium-carbonate equivalent material calculated to be $38.25 \%$ by weight. We have found samples in 200 West near the SX Tank Farm with almost $50 \%$ by weight calcium-carbonate equivalent. The wide range in calcium-carbonate contents reflects the variability in weathering processes and time for paleosol horizon development. The deepest sediment from the upper Cold Creek subunit also contains some elevated calcium-carbonate content. As found in most vadose sediments from the Hanford Reservation there is very little $(<0.1 \%$ by weight $)$ organic carbon in the vadose zone sediments. 


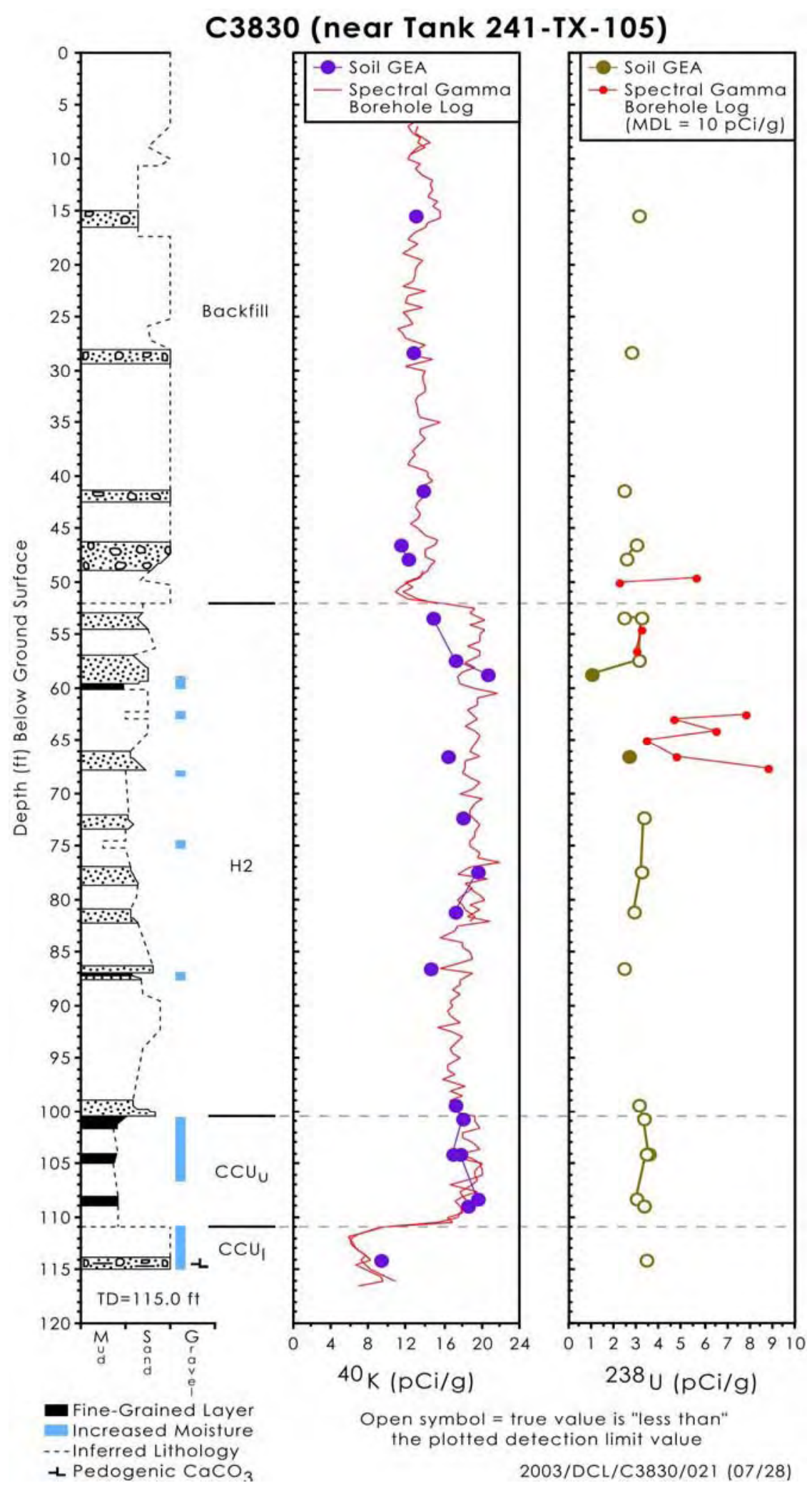

Figure 4.27. Comparison of Lab Gamma Energy Analysis (GEA) and Field Log for Natural Gamma Emitters 


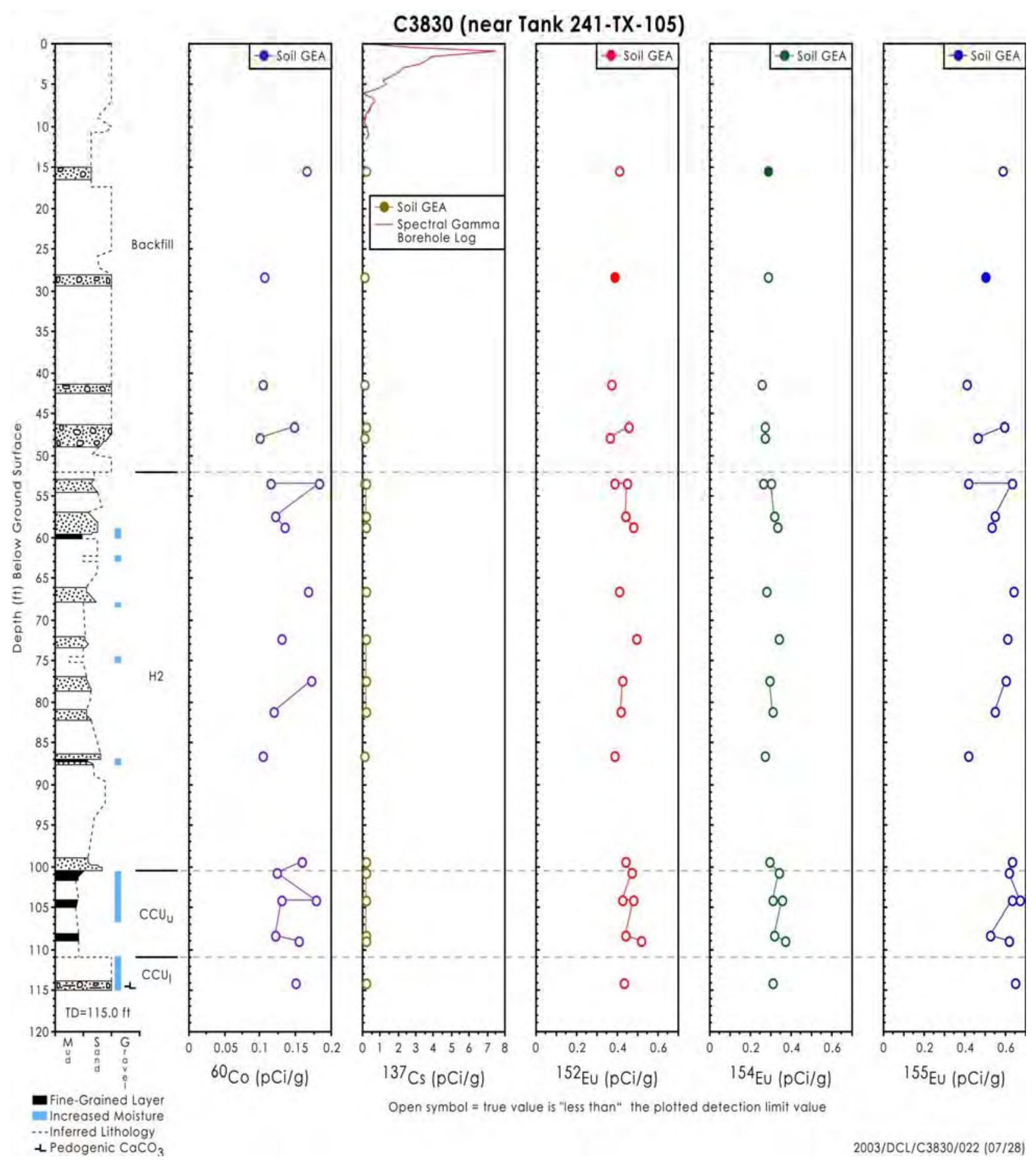

Figure 4.28. Lab and Field Data for Common Gamma Emitters in C3830 Vadose Zone Sediments 
Table 4.31. Carbon Contents of Vadose Zone Sediments in Borehole C3830

\begin{tabular}{||c|c|c|c|c|c||}
\hline $\begin{array}{c}\text { Stratigraphic } \\
\text { Unit }\end{array}$ & $\begin{array}{c}\text { Depth } \\
\text { (ft bgs) }\end{array}$ & $\begin{array}{c}\text { Total } \\
\text { Carbon } \\
\text { \% }\end{array}$ & $\begin{array}{c}\text { Inorganic } \\
\text { Carbon } \\
\text { \% }\end{array}$ & $\begin{array}{c}\text { IC as } \\
\text { CaCO } \\
\text { \% }\end{array}$ & $\begin{array}{c}\text { Organic } \\
\text { Carbon } \\
\text { \% } \\
\text { (by diff.) }\end{array}$ \\
\hline $\mathrm{Bkfl}$ & 15.98 & 0.11 & 0.03 & 0.25 & 0.08 \\
\hline $\mathrm{Bkfl}$ & 28.92 & 0.13 & 0.08 & 0.68 & 0.05 \\
\hline $\mathrm{Bkfl}$ & 42.10 & 0.21 & 0.14 & 1.19 & 0.07 \\
\hline $\mathrm{Bkfl}$ & 47.18 & 0.18 & 0.13 & 1.12 & 0.05 \\
\hline $\mathrm{Bkfl}$ & 48.63 & 0.25 & 0.19 & 1.62 & 0.06 \\
\hline $\mathrm{H} 2$ & 54.02 & 0.22 & 0.19 & 1.57 & 0.03 \\
\hline $\mathrm{H} 2$ & 54.02 & 0.25 & 0.2 & 1.69 & 0.05 \\
\hline $\mathrm{H} 2$ & 58.03 & 0.24 & 0.2 & 1.65 & 0.04 \\
\hline $\mathrm{H} 2$ & 59.35 & 0.25 & 0.21 & 1.75 & 0.04 \\
\hline $\mathrm{H} 2$ & 67.11 & 0.23 & 0.21 & 1.71 & 0.02 \\
\hline $\mathrm{H} 2$ & 72.63 & 0.28 & 0.23 & 1.89 & 0.05 \\
\hline $\mathrm{H} 2$ & 78.01 & 0.27 & 0.23 & 1.91 & 0.04 \\
\hline $\mathrm{H} 2$ & 81.89 & 0.2 & 0.17 & 1.42 & 0.03 \\
\hline $\mathrm{H} 2$ & 87.09 & 0.31 & 0.27 & 2.27 & 0.04 \\
\hline $\mathrm{H} 2$ & 100.02 & 0.35 & 0.32 & 2.67 & 0.03 \\
\hline $\mathrm{CCU}_{\mathrm{u}}$ & 101.37 & 0.34 & 0.29 & 2.45 & 0.05 \\
\hline $\mathrm{CCU}_{\mathrm{u}}$ & 101.37 & 0.34 & 0.3 & 2.49 & 0.04 \\
\hline $\mathrm{CCU}_{\mathrm{u}}$ & 104.08 & 0.45 & 0.4 & 3.33 & 0.05 \\
\hline $\mathrm{CCU}_{\mathrm{u}}$ & 108.87 & 0.61 & 0.53 & 4.42 & 0.08 \\
\hline $\mathrm{CCU}_{1}$ & 114.64 & 4.76 & 4.59 & 38.25 & 0.17 \\
\hline & & & & & \\
\hline
\end{tabular}

\subsection{Vadose Zone Sediment from Borehole C3831}

Borehole C3831 was pushed into the vadose zone sediment approximately $40 \mathrm{ft}$ southwest of tank TX-107 to evaluate whether there is evidence to support a past decision to designate tank TX-107 as having leaked. The borehole reached a depth of $115.4 \mathrm{ft} \mathrm{bgs}$ at which point driving the probe met refusal.

\subsubsection{Moisture Content}

The moisture content of the 36 cores liners as a function of depth and lithology are shown in Table 4.32 and Figure 2.19. The backfill samples have a mean moisture content of $7.1 \%$ by weight with significant variation and a wet zone at the very bottom, at $52 \mathrm{ft}$ bgs. The moisture in the backfill at C3831 is much more variable and on average one percent by weight wetter than the backfill sediments in borehole C3830 near tank TX-105. The Hanford formation H2 unit samples from borehole C3831 have a mean moisture content of $8.7 \%$ by weight with variation that tracks variations in particle size (finer-grained samples have slightly higher moisture contents). The Hanford formation $\mathrm{H} 2$ sediments in 
borehole $\mathrm{C} 3831$ are on average $3 \%$ by weight wetter than the $\mathrm{H} 2$ sediments at borehole $\mathrm{C} 3830$. At borehole C3831, the Cold Creek upper subunit has a rather low moisture content for a fine-grained sediment, 5.11\% wt. The Cold Creek lower subunit at C3831 has an average moisture content of $11.7 \% \mathrm{wt}$, which is very similar to the moisture content observed for the caliche at borehole C3830.

The average moisture content of the $\mathrm{H} 2$ unit samples measured in borehole $\mathrm{C} 3831$ is about $4 \%$ by weight greater than the average for the same stratigraphic unit at the uncontaminated borehole 299-W10-27 (Table 2.5). One could speculate that this wetter Hanford H2 sediment is significant and an indication of the various tank farm operations that encourage higher moisture infiltration.

\subsubsection{1:1 Sediment:Water Extracts for Borehole C3831}

Twenty A liner and two B liner (run in duplicate) cores were characterized after the geologic descriptions were completed. In total, 24 separate sediment samples were characterized using the 1:1 sediment:water procedure. The following tables and figures present the mass of a given constituent leached per gram of sediment as measured in the water extracts to allow direct comparison to the same data for the background borehole sediments from borehole 299-W10-27 and from the other two boreholes. Other figures show dilution-corrected values that represent concentrations in vadose zone porewater in borehole C3831. As discussed in several other Vadose Zone Characterization Project reports, the dilution-corrected 1:1 sediment:water extracts are a reasonable estimate of the actual vadose zone porewater (see Serne et al. 2002b, 2002c, 2002d, 2002e, 2002f).

Table 4.32. Moisture Content of Borehole C3831 Cores

\begin{tabular}{|c|c|c|c|c|}
\hline Sample No. & $\begin{array}{c}\text { Depth } \\
\text { (ft bgs) }\end{array}$ & Stratigraphic Unit & Lithology & $\begin{array}{c}\text { Moisture } \\
\text { Content } \\
\% \mathbf{W t}\end{array}$ \\
\hline $\mathrm{C} 383115 \mathrm{~B}$ & 15.28 & \multirow{2}{*}{ backfill } & \multirow{2}{*}{ Silty sandy gravel } & $5.34 \%$ \\
\hline $\mathrm{C} 383115 \mathrm{~A}$ & 15.97 & & & $3.05 \%$ \\
\hline $\mathrm{C} 383121 \mathrm{~B}$ & 21.18 & \multirow{2}{*}{ backfill } & \multirow{2}{*}{ Silty sandy gravel } & $7.30 \%$ \\
\hline $\mathrm{C} 383121 \mathrm{~A}$ & 21.93 & & & $3.89 \%$ \\
\hline $\mathrm{C} 383128 \mathrm{~B}$ & 28.28 & \multirow{2}{*}{ backfill } & \multirow{2}{*}{ Silty sandy gravel } & $5.17 \%$ \\
\hline $\mathrm{C} 383128 \mathrm{~A}$ & 28.90 & & & $4.82 \%$ \\
\hline $\mathrm{C} 383145 \mathrm{~B}$ & 45.40 & \multirow{2}{*}{ backfill } & \multirow{2}{*}{ Silty sand to gravelly sand } & $10.93 \%$ \\
\hline $\mathrm{C} 383145 \mathrm{~A}$ & 46.06 & & & $8.33 \%$ \\
\hline $\mathrm{C} 383151 \mathrm{~B}$ & 51.35 & \multirow{2}{*}{ backfill } & \multirow{2}{*}{$\begin{array}{l}\text { Silty gravelly sand to silty } \\
\text { sandy gravel to silty sand }\end{array}$} & $5.51 \%$ \\
\hline $\mathrm{C} 383151 \mathrm{~A}$ & 52.03 & & & $16.54 \%$ \\
\hline
\end{tabular}


Table 4.32. (contd)

\begin{tabular}{|c|c|c|c|c|}
\hline Sample No. & $\begin{array}{c}\text { Depth } \\
\text { (ft bgs) } \\
\end{array}$ & Stratigraphic Unit & Lithology & $\begin{array}{c}\text { Moisture } \\
\text { Content } \\
\% \mathrm{Wt} \\
\end{array}$ \\
\hline $\mathrm{C} 383152 \mathrm{~B}$ & 52.50 & \multirow{2}{*}{$\mathrm{H} 2$} & \multirow{2}{*}{ Sand } & $5.20 \%$ \\
\hline C3831 52A & 53.18 & & & $6.35 \%$ \\
\hline C3831 59B & 59.34 & \multirow{2}{*}{$\mathrm{H} 2$} & \multirow{2}{*}{ Sand to silty sand } & $8.43 \%$ \\
\hline C3831 59A & 59.94 & & & $8.10 \%$ \\
\hline $\mathrm{C} 383160 \mathrm{~B}$ & 60.44 & \multirow{2}{*}{$\mathrm{H} 2$} & \multirow{2}{*}{$\begin{array}{l}\text { Sand, silt and clay (clastic } \\
\text { dike) to sand }\end{array}$} & $13.00 \%$ \\
\hline $\mathrm{C} 383160 \mathrm{~A}$ & 61.15 & & & $4.47 \%$ \\
\hline $\mathrm{C} 383167 \mathrm{~B}$ & 67.53 & \multirow{2}{*}{$\mathrm{H} 2$} & \multirow{2}{*}{ Sand to silty sand } & $5.93 \%$ \\
\hline $\mathrm{C} 383167 \mathrm{~A}$ & 68.21 & & & $12.44 \%$ \\
\hline C3831 69B & 68.82 & \multirow{2}{*}{$\mathrm{H} 2$} & \multirow{2}{*}{ Sand to silty sand } & $11.30 \%$ \\
\hline C3831 69A & 69.60 & & & $5.49 \%$ \\
\hline $\mathrm{C} 383174 \mathrm{~B}$ & 74.36 & \multirow{2}{*}{$\mathrm{H} 2$} & \multirow{2}{*}{ Sand to silty sand } & $5.87 \%$ \\
\hline $\mathrm{C} 383174 \mathrm{~A}$ & 74.99 & & & $18.06 \%$ \\
\hline C3831 77B & 77.05 & \multirow{2}{*}{$\mathrm{H} 2$} & \multirow{2}{*}{ Sand to silty sand } & $5.98 \%$ \\
\hline C3831 77A & 77.67 & & & $6.40 \%$ \\
\hline C3831 78B & 78.08 & \multirow{2}{*}{$\mathrm{H} 2$} & \multirow{2}{*}{ Sand to silty sand } & $10.28 \%$ \\
\hline $\mathrm{C} 383178 \mathrm{~A}$ & 78.72 & & & $16.22 \%$ \\
\hline C3831 85B & 85.37 & \multirow{2}{*}{$\mathrm{H} 2$} & \multirow{2}{*}{$\begin{array}{l}\text { Sand to silty sand to sandy } \\
\text { silt }\end{array}$} & $17.53 \%$ \\
\hline $\mathrm{C} 383185 \mathrm{~A}$ & 85.99 & & & $14.66 \%$ \\
\hline C3831 88B & 88.67 & \multirow{2}{*}{$\mathrm{H} 2$} & \multirow{2}{*}{ Sand } & $8.85 \%$ \\
\hline C3831 88A & 89.39 & & & $5.13 \%$ \\
\hline C3831 93B & 93.37 & \multirow{2}{*}{$\mathrm{H} 2$} & \multirow{2}{*}{ Sand } & $5.20 \%$ \\
\hline $\mathrm{C} 383193 \mathrm{~A}$ & 93.99 & & & $5.79 \%$ \\
\hline C3831 97B & 97.43 & \multirow{2}{*}{$\mathrm{H} 2$} & \multirow{2}{*}{ Sand to silty sand and silt } & $9.56 \%$ \\
\hline C3831 97A & 98.07 & & & $10.98 \%$ \\
\hline $\mathrm{C} 3831$ 100B & 100.57 & \multirow{2}{*}{$\mathrm{H} 2$} & \multirow{2}{*}{ Sand to silty sand } & $10.89 \%$ \\
\hline $\mathrm{C} 3831100 \mathrm{~A}$ & 101.29 & & & $4.95 \%$ \\
\hline $\mathrm{C} 3831102 \mathrm{~B}$ & 101.97 & \multirow{2}{*}{$\mathrm{CCU}_{\mathrm{u}}$} & \multirow{2}{*}{ Silty sand } & $4.94 \%$ \\
\hline $\mathrm{C} 3831102 \mathrm{~A}$ & 102.65 & & & $5.28 \%$ \\
\hline $\mathrm{C} 3831114 \mathrm{~B}$ & 114.44 & \multirow{2}{*}{$\mathrm{CCU}_{1}$} & \multirow{2}{*}{ Slightly gravelly muddy sand } & $10.49 \%$ \\
\hline $\mathrm{C} 3831114 \mathrm{~A}$ & 115.06 & & & $12.94 \%$ \\
\hline
\end{tabular}




\subsubsection{1 $\quad \mathrm{pH}$ and Electrical Conductivity}

The 1:1 sediment:water extract $\mathrm{pH}$ and EC data are shown in Table 4.33. Both the measured value and dilution-corrected EC values are shown. Figure 4.29 shows the 1:1 sediment:water extract $\mathrm{pH}$ value and dilution-corrected EC as a function of depth and stratigraphy. A comparison of the data in Table 4.33 with the $\mathrm{pH}$ and $\mathrm{EC}$ of the 299-W10-27 extracts suggests that there is slightly elevated $\mathrm{pH}$ in borehole $\mathrm{C} 3831$ between 61 and $70 \mathrm{ft}$ bgs that is indicative of alkaline tank fluids interactions. There is also evidence of elevated EC starting at $60 \mathrm{ft}$ bgs all the way to the bottom of the borehole at C3831 when compared to the background sediment from 299-W10-27. Somewhere between the two samples at 53.2 and $59.9 \mathrm{ft}$ bgs, the EC of the 1:1 water extract increases to between 10 and 13 times the background sediment values. Between 67.5 and $78 \mathrm{ft} \mathrm{bgs,} \mathrm{the} \mathrm{EC}$ is about 5 times larger than background sediment extracts. At $\sim 86 \mathrm{ft}$ bgs there is a second peak of high EC at about 11 times the background sediment extract. Below $86 \mathrm{ft}$ bgs to the bottom of the borehole at $115 \mathrm{ft}$ bgs, the EC averages about 3 times higher than that in background sediments. When compared to the EC at borehole C3830 (see Table 4.18), the extract EC values at C3831 are unequivocally higher and indicative of the presence of saline tank-related fluids.

The highest dilution-corrected porewater EC value between 60-61 ft bgs is equivalent to a pore solution of $0.4 \mathrm{M} \mathrm{KCl}$, the salt solution used to calibrate the conductivity cell. As shown in Figure 4.29, the dissolved salts are high in sodium and nitrate. The sodium and nitrate peak values both occur at $61 \mathrm{ft}$ bgs, which is the depth where the borehole intercepted a clastic dike. One plausible cause for the abrupt appearance of high concentrations of sodium and nitrate at $61 \mathrm{ft} \mathrm{bgs}$ is that tank fluids moved preferentially along the clastic dike that was ruptured by the borehole drilling. The leaks near the SX-108, SX-109, and BX-102 tanks had peak vadose zone porewater concentrations that were equivalent to much more concentrated waste fluids, 7 to 17 and 0.7 to $1 \mathrm{M} \mathrm{KCl}$ solutions, respectively. The maximum dilution-corrected $\mathrm{EC}$ at borehole $\mathrm{C} 3831$ is $43.3 \mathrm{mS} / \mathrm{cm}$, higher than the dilution-corrected EC at 299-E33-46 (near tank B-110) that contained $15.1 \mathrm{mS} / \mathrm{cm}$ and borehole C3830 porewater that contained $12.5 \mathrm{mS} / \mathrm{cm}$. 
Table 4.33. pH and EC Data for Sediment:Water Extracts from Borehole 3831

\begin{tabular}{|c|c|c|c|c|c|}
\hline Sample No. & $\begin{array}{c}\text { Depth } \\
\text { (ft bgs) }\end{array}$ & $\begin{array}{c}\text { Stratigraphic } \\
\text { Unit }\end{array}$ & $\mathbf{p H}$ & $\begin{array}{c}\text { Conductivity } \\
\mathrm{mS} / \mathrm{cm}\end{array}$ & $\begin{array}{c}\text { Conductivity } \\
\text { (mS/cm) Dilution- } \\
\text { Corrected } \\
\text { Porewater }\end{array}$ \\
\hline C3831-14.93A & 15.97 & Bkfl & 7.70 & 0.169 & 5.578 \\
\hline C3831-20.8A & 21.93 & Bkfl & 7.87 & 0.212 & 5.453 \\
\hline C3831-28A & 28.90 & Bkfl & 7.76 & 0.227 & 4.720 \\
\hline C3831-45A & 46.06 & Bkfl & 7.82 & 0.376 & 4.516 \\
\hline C3831-51A & 52.03 & Bkfl & 7.81 & 0.175 & 1.060 \\
\hline C3831-52A & 53.18 & $\mathrm{H} 2$ & 7.80 & 0.264 & 4.159 \\
\hline C3831-59A & 59.94 & $\mathrm{H} 2$ & 8.15 & 1.526 & 18.829 \\
\hline C3831-60A & 61.15 & $\mathrm{H} 2$ & 8.96 & 1.932 & 43.259 \\
\hline C3831-67B & 67.53 & $\mathrm{H} 2$ & 8.47 & 0.701 & 11.843 \\
\hline C3831-67B Dup & 67.53 & $\mathrm{H} 2$ & 8.80 & 0.742 & 12.589 \\
\hline C3831-67A & 68.21 & $\mathrm{H} 2$ & 8.20 & 0.502 & 4.035 \\
\hline C3831-69A & 69.60 & $\mathrm{H} 2$ & 8.12 & 0.394 & 7.315 \\
\hline C3831-74A & 74.99 & $\mathrm{H} 2$ & 7.91 & 0.902 & 4.994 \\
\hline C3831-77A & 77.67 & $\mathrm{H} 2$ & 7.90 & 0.348 & 5.442 \\
\hline C3831-78A & 78.72 & $\mathrm{H} 2$ & 8.33 & 0.781 & 4.814 \\
\hline C3831-85A & 85.99 & $\mathrm{H} 2$ & 7.81 & 1.755 & 11.967 \\
\hline C3831-88A & 89.39 & $\mathrm{H} 2$ & 7.92 & 0.349 & 6.810 \\
\hline C3831-93A & 93.99 & $\mathrm{H} 2$ & 7.89 & 0.634 & 10.964 \\
\hline C3831-97A & 98.07 & $\mathrm{H} 2$ & 7.87 & 0.584 & 5.320 \\
\hline $\mathrm{C} 3831-100 \mathrm{~A}$ & 101.29 & $\mathrm{H} 2$ & 7.91 & 0.407 & 8.232 \\
\hline C3831-102A & 102.65 & $\mathrm{CCU}_{\mathrm{u}}$ & 7.95 & 0.506 & 9.660 \\
\hline C3831-114B & 114.44 & $\mathrm{CCU}_{1}$ & 7.80 & 0.607 & 5.813 \\
\hline C3831-114B Dup & 114.44 & $\mathrm{CCU}_{1}$ & 7.91 & 0.496 & 4.755 \\
\hline C3831-114A & 115.06 & $\mathrm{CCU}_{1}$ & 7.65 & 0.712 & 5.501 \\
\hline
\end{tabular}




\section{C3831 (near Tank 241-TX-107)}
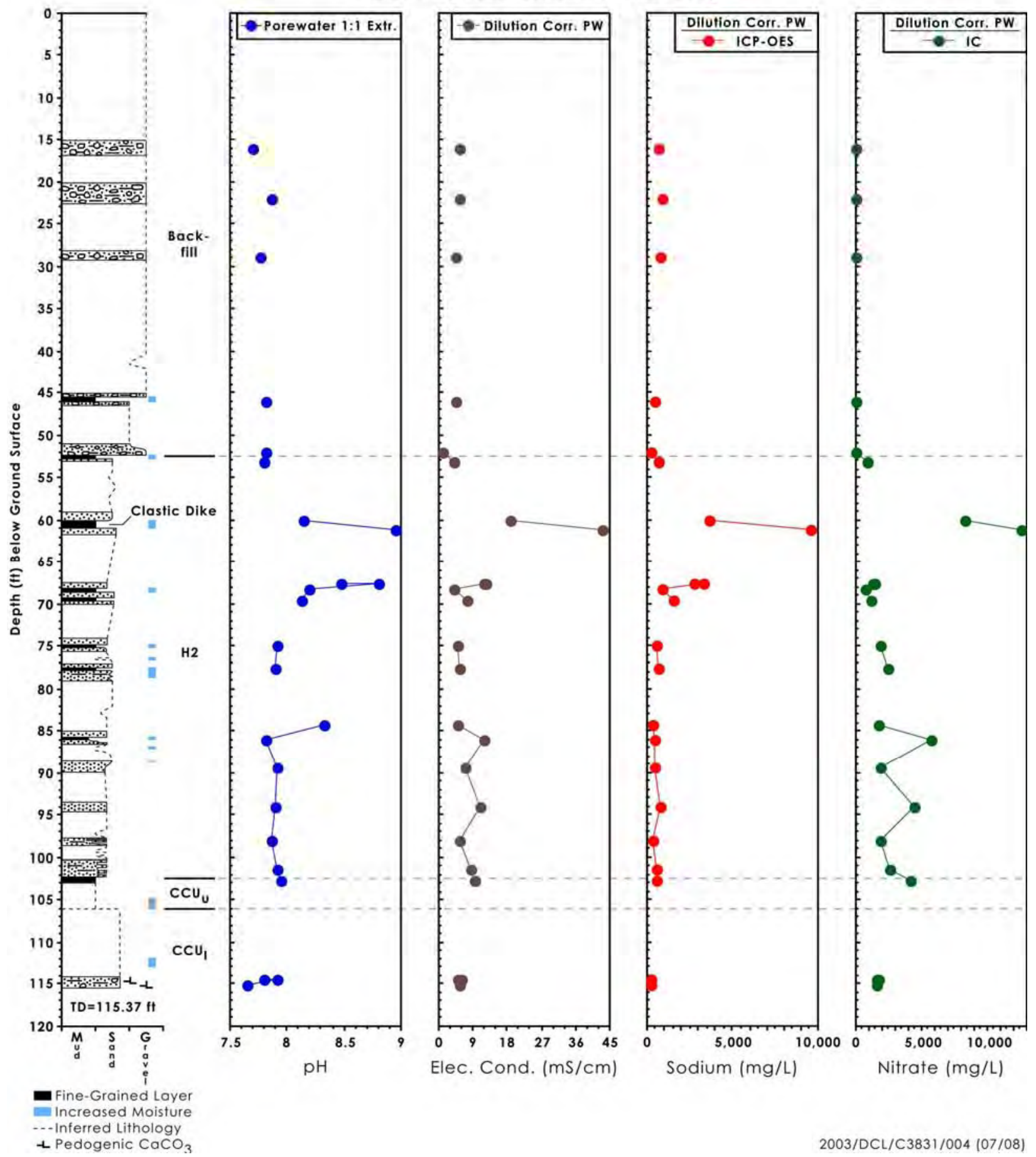

Figure 4.29. Borehole C3831 Sediment-to-Water Extract $\mathrm{pH}$ and Calculated Porewater EC, Sodium, and Nitrate 


\subsubsection{Water Extract Composition or the 1:1 Sediment:Water Extract for Borehole C3831}

The water extract values for the major cations and anions and several trace constituents are discussed in this section. The anion data are tabulated in Tables 4.34 and 4.35 and Figure 4.30 in units of mass per gram of dry sediment.

The data for the water extracts of borehole C3831 for fluoride and bromide do not differ significantly from the same data for the uncontaminated sediments from borehole 299-W10-27 or borehole C3830. However, there are obvious signs of elevated chloride, nitrate, bicarbonate, sulfate, phosphate, and nitrite in some of the water extracts from borehole C3831 sediments when compared to the uncontaminated sediments and borehole $\mathrm{C} 3830$. The chloride values in the $\mathrm{C} 3831$ sediments from 46, 60, and $61 \mathrm{ft}$ bgs are 10 to 20 times larger than the background sediment. The water-extractable chloride concentrations in borehole $\mathrm{C} 3831$ sediments from $68 \mathrm{ft}$ bgs to the deepest sample obtained at $115 \mathrm{ft}$ bgs are elevated by a factor of $\sim 5$ to 10 when compared to water extracts of uncontaminated sediment and by a factor of 2 compared to the water extracts from borehole $\mathrm{C} 3830$. The nitrate water extract values for borehole C3831 are elevated compared to the background sediments from $53 \mathrm{ft}$ bgs to the deepest sample obtained. The nitrate water extract values are 20 to 300 times larger than for the background sediments between the depths of 53 and $86 \mathrm{ft}$ bgs. The nitrate concentrations in borehole $\mathrm{C} 3831$ are also $\sim 5$ to 10 times greater than those at similar depths in borehole C3830. The sulfate water extracts from borehole C3831 are elevated from about $60 \mathrm{ft}$ bgs to the deepest sample obtained and the values exceed the background sediment values by a factor of 3 to 10 . The water-extractable sulfate values for sediments from borehole C3831 are in general about twice as high as for borehole C3830. There is one zone of large water-extractable bicarbonate in the $\mathrm{H} 2$ unit in the $\mathrm{C} 3831$ borehole sediments between 61 to $68 \mathrm{ft}$ bgs. There is also high water-extractable phosphate and nitrite in the $\mathrm{C} 3831$ borehole sediments at $61.15 \mathrm{ft}$ bgs and also slightly elevated values 60 to $70 \mathrm{ft}$ bgs for phosphate and 60 to $86 \mathrm{ft}$ bgs for nitrite. The agreement between measuring the water extracts for phosphate and sulfate directly with the ion chromatograph and indirectly by converting the ICP measurements for phosphorous and sulfur are very good (see Figure 4.30). Besides validating the ion chromatography data, we can state that the waterextractable sulfur and phosphorous species exist as primarily sulfate and phosphate.

The water-extractable small organic molecules in the $\mathrm{C} 3831$ borehole sediments are shown in Table 4.35. The values are not significantly different than for the uncontaminated sediments from borehole 299-W10-27 or the values at borehole C3830, excepting the sample at $61.15 \mathrm{ft}$ bgs that shows a few ppm of soluble acetate and oxalate. We do not know if these values are indicative of any tank fluid influence such as degradation products of some other man-introduced organics or natural variability.

The water-extractable major cations in the borehole C3831 sediments are tabulated in Table 4.36 and the distribution with depth is shown in Figure 4.31. The distribution of the divalent alkaline earth cations ( $\mathrm{Mg}, \mathrm{Ca}$, and $\mathrm{Sr}$ but not $\mathrm{Ba}$ ) shows low water-extractable quantities between 61 and $70 \mathrm{ft}$ bgs. High divalent cation water extracts are found in a single sample ( $86 \mathrm{ft} \mathrm{bgs})$. Conversely, the distribution of water-extractable sodium is very high between the depths of 60 and 75 bgs. The water-extractable sodium values in borehole $\mathrm{C} 3831$ sediments are higher than the values in the uncontaminated sediments from borehole 299-W10-27 over the whole borehole profile. These trends suggest that tank fluids that are high in sodium and nitrate did seep into the vadose zone near this borehole, probably along a clastic dike. The sodium in the tank fluids pushed the natural divalent cations and some of the natural potassium off the sediment cation exchange sites in the sediments between 53 and at least $70 \mathrm{ft}$ bgs. We have observed the same cation distribution and ion exchange fronts - where divalent cations, and sometimes potassium 


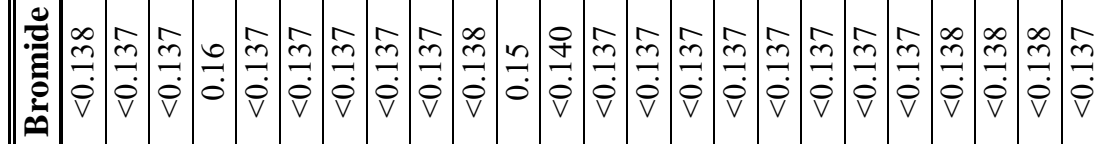

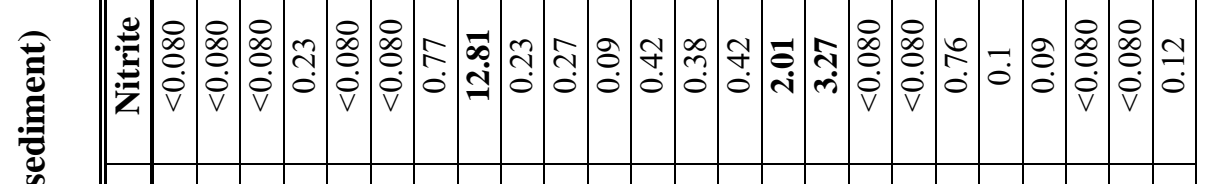

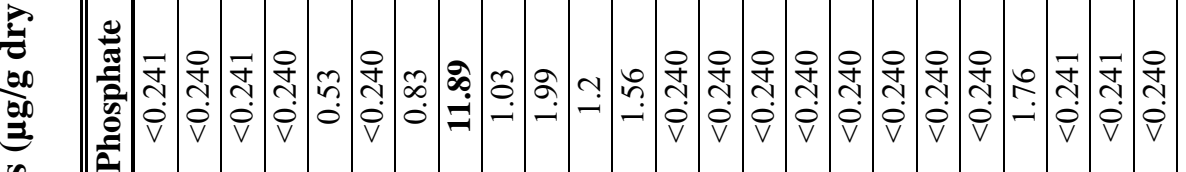

.

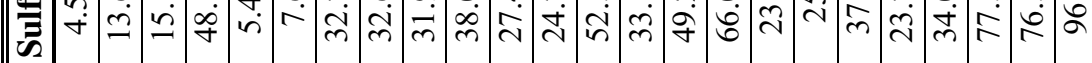

⿹勹巳

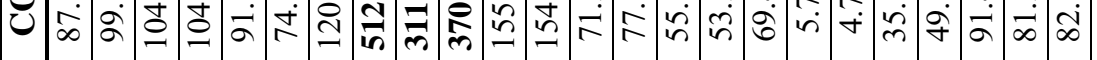

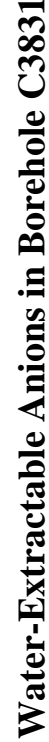

芦

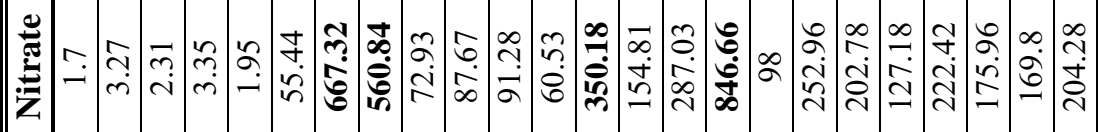

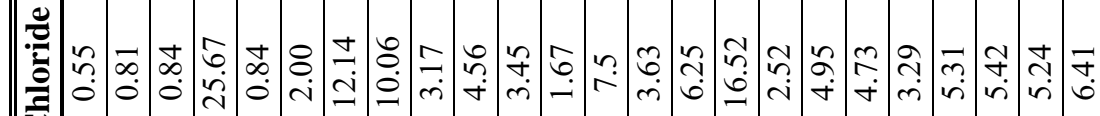

己

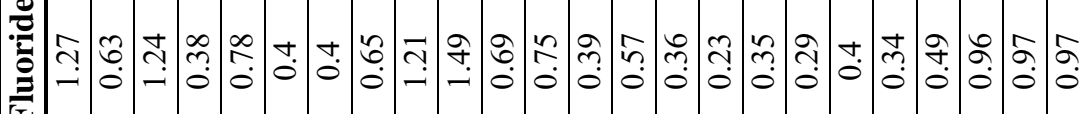

I

彦

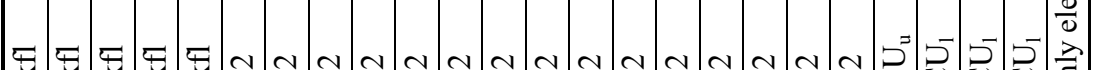

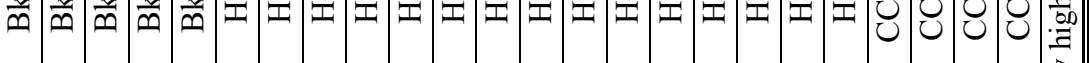

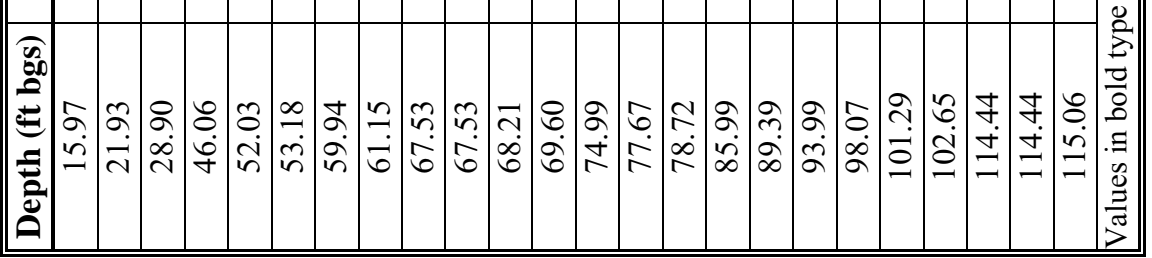



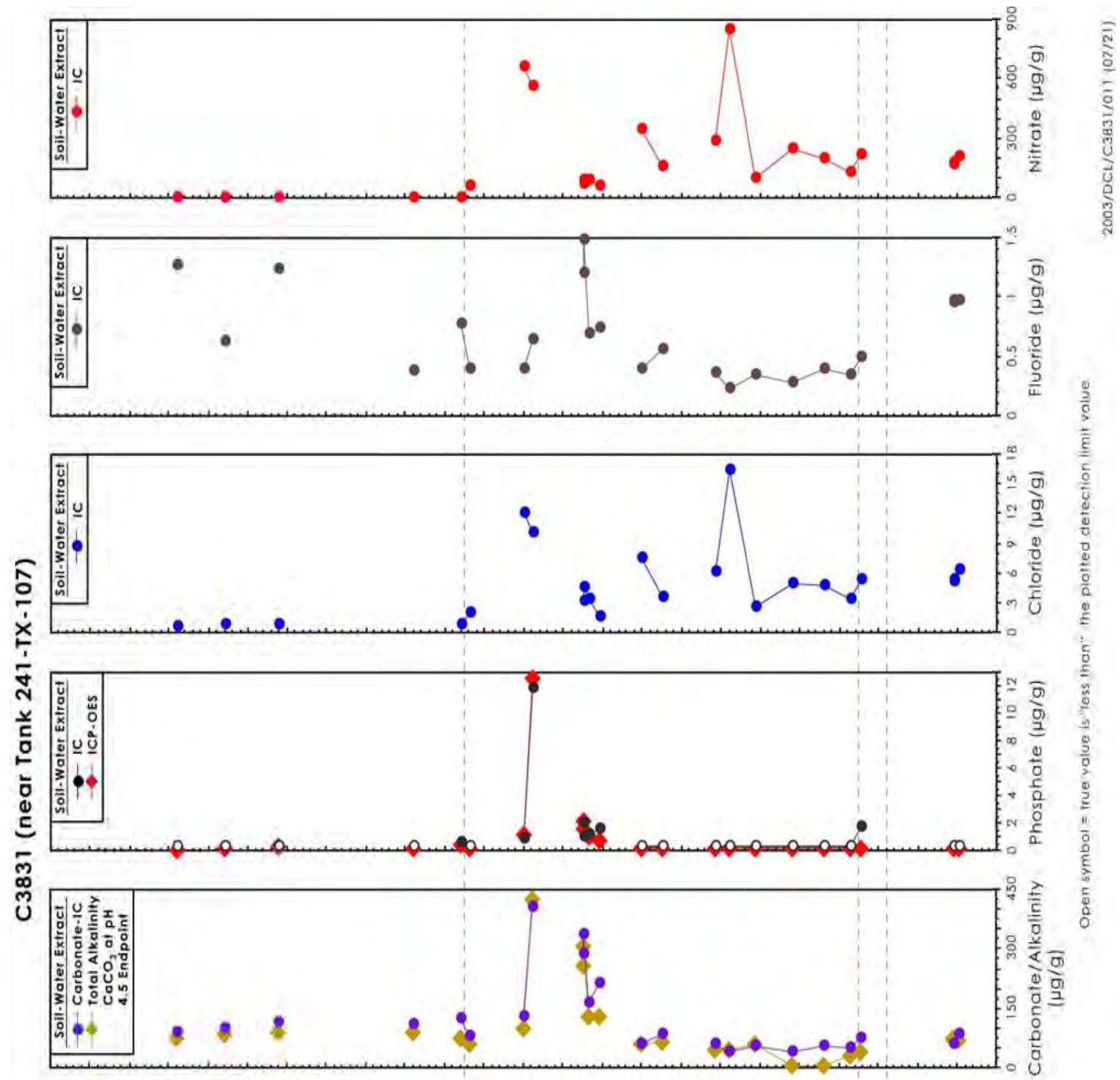

氖

릉

D.

3

D.
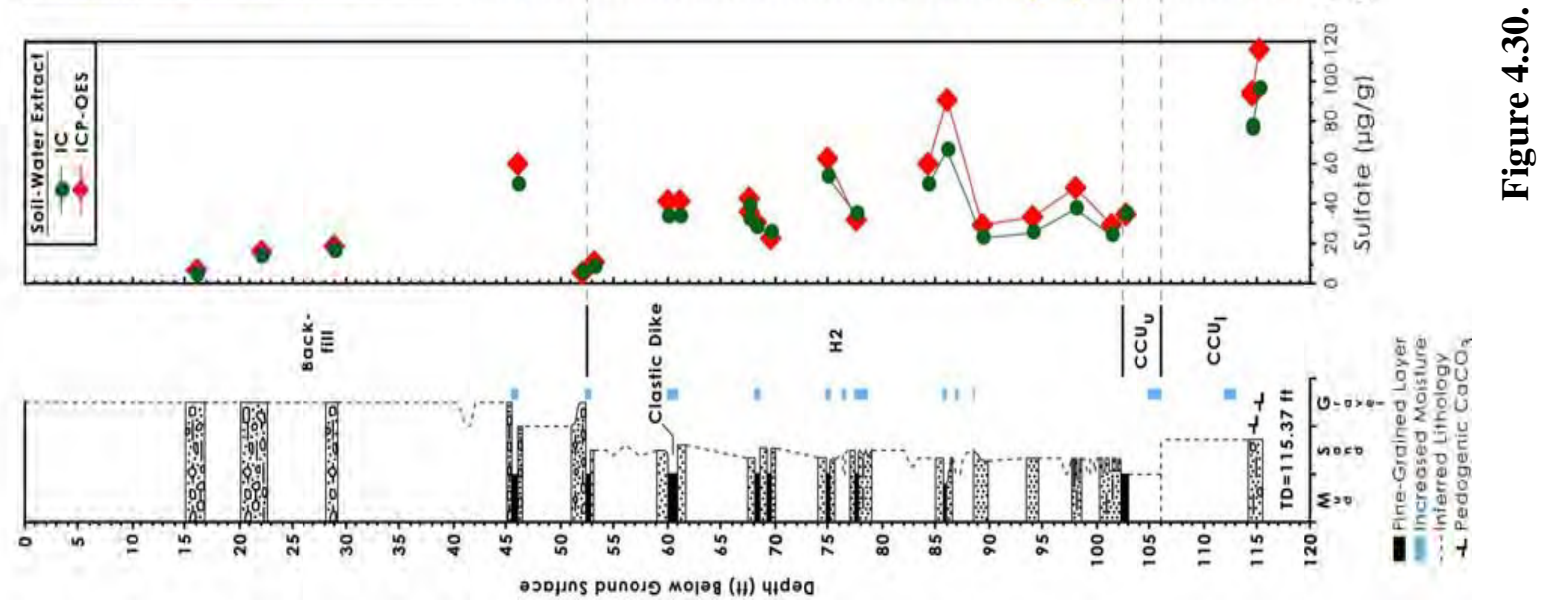
are depleted in the shallow sediments and high levels of water-extractable sodium are present - at both the SX and BX tank farms, where tank fluids have been confirmed as being present (for details, see Serne et al. 2002b, 2002c, 2002d, 2002e, 2002f). Just below the leading edge of the sodium plume one finds elevated levels of divalent cations that were displaced (e.g., $86 \mathrm{ft}$ in C3831). We observe the highest levels of water-extractable divalent cations in a single sample depth ( $86 \mathrm{ft} \mathrm{bgs})$. At borehole C3831, the water-extractable magnesium, calcium, strontium, barium, potassium, and sodium in the sediments from $75 \mathrm{ft}$ bgs to the bottom of the borehole are greater than for the background sediment in borehole 299-W10-27 by a factor of 3 to 5 and also borehole C3830 sediments by a factor of 2 . This likely is an indication of more concentrated leaked tank fluids being present in the $\mathrm{C} 3831$ sediments from $75 \mathrm{ft}$ bgs to the bottom of the borehole.

The water-extractable aluminum, silicon, iron, manganese, and zinc in the $\mathrm{C} 3831$ borehole sediments are shown in Table 4.37 and Figure 4.32. The water-soluble borehole C3831 aluminum, iron, and manganese data show elevated values between the depths of 60 and 67.5 to $68.2 \mathrm{ft}$ bgs. We speculate that these elevated values indicate some chemical reaction between alkaline tank fluids and native sediments that formed precipitates of aluminum, iron, and manganese that are more water soluble than solid phases present in native sediments. In the zone between 60 and $68.2 \mathrm{ft}$ bgs at borehole $\mathrm{C} 3831$ the water-extractable aluminum, iron, and manganese are 2 to 3 times larger than the same zone at borehole C3830.

The phosphorous and sulfur data were converted to water-extractable phosphate and sulfate and plotted with the anion data in Figure 4.30. In general, the agreement between direct measurement of the two anions by ion chromatography and the converted ICP measurements is very good. The water-extractable sulfur values in C3831 do not differ much from those at C3830 but both boreholes show elevated water-soluble sulfate in comparison to sulfur that is water extractable from background sediments. The water-extractable phosphorous at borehole $\mathrm{C} 3831$ between the depths of 60 and $69.6 \mathrm{ft}$ bgs is greater than at borehole C3830 and the background sediment by a factor of 2 to 5 .

The water-extractable data for potentially mobile metals such as technetium-99, uranium-238, chromium, molybdenum, and ruthenium in borehole C3831 sediments are shown in Table 4.38 and Figure 4.33. In borehole C3831 sediments, technetium- 99 and elevated water-soluble ruthenium is present between $53 \mathrm{ft}$ bgs and the bottom of the borehole at $115 \mathrm{ft}$ bgs. There is also elevated watersoluble uranium-238, molybdenum, and chromium in borehole C3831 sediment between 61 and $70 \mathrm{ft}$ bgs. The technetium-99 and ruthenium water extract data suggest that tank fluids may have percolated down through the entire Hanford $\mathrm{H} 2$ unit and Cold Creek unit to a depth at least as deep as the bottom of the borehole at $115 \mathrm{ft}$ bgs. However, the abrupt increases in ruthenium, technetium-99, and most other contaminants suggest that tank fluids descended preferentially along the clastic dike that was intercepted at $\sim 60 \mathrm{ft}$ bgs. The maximum technetium-99 concentrations between 59.9 and $61.2 \mathrm{ft}$ bgs are 80 to $140 \mathrm{pCi} / \mathrm{g}$. Between 75 and $94 \mathrm{ft}$ bgs, the technetium- 99 varies between 40 and $70 \mathrm{pCi} / \mathrm{g}$. Between 98 and $115 \mathrm{ft}$ bgs at borehole $\mathrm{C} 3831$, the technetium- 99 concentration is $\sim 35 \mathrm{pCi} / \mathrm{g}$. The technetium-99 values in borehole $\mathrm{C} 3831$ are at least 10 times larger than the values at borehole $\mathrm{C} 3830$.

The maximum water-soluble uranium concentration is $0.06 \mu \mathrm{g} / \mathrm{g}$ and the maximum water-soluble chromium concentration is $0.07 \mu \mathrm{g} / \mathrm{g}$. Both occur in the sediment between 61 and $70 \mathrm{ft}$ bgs. Above and below this zone both metals are present at concentrations at least 10 times smaller than in the more elevated but narrow zone between 61 and $70 \mathrm{ft}$ bgs. These water-soluble maxima are small compared to 
those at 299-E33-45 (BX-102 uranium overfill [Serne et al. 2002e]) and the SX boreholes where water-soluble chromium from the REDOX process was quite large (Serne et al. 2002b, 2002c, 2002d).

Table 4.35. Water-Extractable Organics in C3831 Vadose Zone Sediments $(\mu \mathrm{g} / \mathrm{g})$

\begin{tabular}{|c|c|c|c|c|}
\hline $\begin{array}{l}\text { Depth } \\
\text { (ft bgs) }\end{array}$ & $\begin{array}{c}\text { Stratigraphic } \\
\text { Unit }\end{array}$ & Formate & Acetate & Oxalate \\
\hline 15.97 & Bkfl & $<0.114$ & 0.62 & 0.44 \\
\hline 21.93 & Bkfl & 0.21 & 0.82 & 0.82 \\
\hline 28.90 & Bkfl & $<0.113$ & $<0.160$ & $<0.214$ \\
\hline 46.06 & Bkfl & $<0.113$ & $<0.160$ & $<0.214$ \\
\hline 52.03 & Bkfl & $<0.113$ & $<0.160$ & 0.41 \\
\hline 53.18 & $\mathrm{H} 2$ & 0.14 & 0.78 & 0.46 \\
\hline 59.94 & $\mathrm{H} 2$ & 0.16 & $<0.160$ & $<0.214$ \\
\hline 61.15 & $\mathrm{H} 2$ & 0.43 & 3.02 & 2.06 \\
\hline 67.53 & $\mathrm{H} 2$ & $<0.113$ & $<0.160$ & 0.4 \\
\hline 67.53 & $\mathrm{H} 2$ & 0.1 & $<0.161$ & 0.75 \\
\hline 68.21 & $\mathrm{H} 2$ & $<0.113$ & $<0.160$ & 0.24 \\
\hline 69.60 & $\mathrm{H} 2$ & $<0.115$ & 0.21 & $<0.218$ \\
\hline 74.99 & $\mathrm{H} 2$ & $<0.113$ & $<0.160$ & $<0.214$ \\
\hline 77.67 & $\mathrm{H} 2$ & $<0.113$ & $<0.160$ & $<0.214$ \\
\hline 78.72 & $\mathrm{H} 2$ & $<0.113$ & $<0.160$ & 0.33 \\
\hline 85.99 & $\mathrm{H} 2$ & $<0.113$ & $<0.160$ & $<0.214$ \\
\hline 89.39 & $\mathrm{H} 2$ & $<0.113$ & $<0.160$ & $<0.214$ \\
\hline 93.99 & $\mathrm{H} 2$ & $<0.113$ & $<0.160$ & 0.23 \\
\hline 98.07 & $\mathrm{H} 2$ & $<0.113$ & $<0.160$ & $<0.214$ \\
\hline 101.29 & $\mathrm{H} 2$ & $<0.113$ & $<0.160$ & $<0.214$ \\
\hline 102.65 & $\mathrm{CCU}_{\mathrm{u}}$ & 0.13 & 0.53 & 0.29 \\
\hline 114.44 & $\mathrm{CCU}_{1}$ & $<0.113$ & $<0.161$ & 0.5 \\
\hline 114.44 & $\mathrm{CCU}_{1}$ & 0.24 & 0.5 & 0.49 \\
\hline 115.06 & $\mathrm{CCU}_{1}$ & $<0.113$ & 0.53 & 0.54 \\
\hline
\end{tabular}


Table 4.36. Water-Extractable Cations in Borehole C3831 Vadose Zone Sediments ( $\mu \mathrm{g} / \mathrm{g}$ dry sediment)

\begin{tabular}{|c|c|c|c|c|c|c|c|}
\hline $\begin{array}{l}\text { Depth } \\
\text { (ft bgs) }\end{array}$ & $\begin{array}{c}\text { Stratigraphic } \\
\text { Unit }\end{array}$ & Mg & $\mathbf{C a}$ & $\mathrm{Sr}$ & $\mathbf{B a}$ & $\mathbf{N a}$ & $\mathbf{K}$ \\
\hline 15.97 & $\mathrm{Bkfl}$ & 2.40 & 6.87 & $3.14 \mathrm{E}-02$ & $2.23 \mathrm{E}-02$ & 21.48 & 5.56 \\
\hline 21.93 & Bkfl & 1.48 & 6.78 & 4.34E-02 & $1.90 \mathrm{E}-02$ & 32.94 & 5.88 \\
\hline 28.90 & $\mathrm{Bkfl}$ & 1.94 & 5.81 & $3.24 \mathrm{E}-02$ & $3.19 \mathrm{E}-02$ & 36.71 & 6.45 \\
\hline 46.06 & $\mathrm{Bkfl}$ & 4.64 & 23.11 & $1.06 \mathrm{E}-01$ & $3.54 \mathrm{E}-02$ & 38.37 & 12.90 \\
\hline 52.03 & Bkfl & 0.50 & 2.63 & $1.30 \mathrm{E}-02$ & $1.87 \mathrm{E}-02$ & 32.57 & 3.84 \\
\hline 53.18 & $\mathrm{H} 2$ & 1.47 & 7.00 & $4.12 \mathrm{E}-02$ & $3.61 \mathrm{E}-02$ & 40.94 & 6.44 \\
\hline 59.94 & $\mathrm{H} 2$ & 0.87 & 2.95 & $2.02 \mathrm{E}-02$ & $2.34 \mathrm{E}-02$ & 296.51 & 12.09 \\
\hline 61.15 & $\mathrm{H} 2$ & 0.08 & 1.04 & $5.87 \mathrm{E}-03$ & $2.97 \mathrm{E}-02$ & 430.12 & 8.43 \\
\hline 67.53 & $\mathrm{H} 2$ & 0.15 & 0.98 & $6.46 \mathrm{E}-03$ & $2.57 \mathrm{E}-02$ & 161.29 & 7.72 \\
\hline 67.53 & $\mathrm{H} 2$ & 0.13 & 0.77 & $5.20 \mathrm{E}-03$ & $1.55 \mathrm{E}-02$ & 193.85 & 8.83 \\
\hline 68.21 & $\mathrm{H} 2$ & 0.27 & 1.85 & $1.02 \mathrm{E}-02$ & $1.71 \mathrm{E}-02$ & 104.37 & 5.48 \\
\hline 69.60 & $\mathrm{H} 2$ & 0.18 & 1.25 & $6.77 \mathrm{E}-03$ & $2.49 \mathrm{E}-02$ & 86.93 & 4.13 \\
\hline 74.99 & $\mathrm{H} 2$ & 10.81 & 40.14 & $2.33 \mathrm{E}-01$ & $4.71 \mathrm{E}-02$ & 101.43 & 19.98 \\
\hline 77.67 & $\mathrm{H} 2$ & 5.47 & 19.13 & $1.18 \mathrm{E}-01$ & $4.72 \mathrm{E}-02$ & 42.39 & 12.31 \\
\hline 78.72 & $\mathrm{H} 2$ & 13.19 & 48.45 & $2.58 \mathrm{E}-01$ & $4.28 \mathrm{E}-02$ & 56.80 & 17.06 \\
\hline 85.99 & $\mathrm{H} 2$ & 41.37 & 173.67 & $8.86 \mathrm{E}-01$ & $1.16 \mathrm{E}-01$ & 58.54 & 29.63 \\
\hline 89.39 & $\mathrm{H} 2$ & 6.08 & 24.00 & $1.33 \mathrm{E}-01$ & 4.38E-02 & 24.99 & 9.83 \\
\hline 93.99 & $\mathrm{H} 2$ & 10.72 & 43.16 & $2.23 \mathrm{E}-01$ & $6.08 \mathrm{E}-02$ & 43.13 & 12.96 \\
\hline 98.07 & $\mathrm{H} 2$ & 10.19 & 43.68 & $2.41 \mathrm{E}-01$ & $7.50 \mathrm{E}-02$ & 39.59 & 13.76 \\
\hline 101.29 & $\mathrm{H} 2$ & 7.01 & 31.00 & $1.70 \mathrm{E}-01$ & $5.54 \mathrm{E}-02$ & 25.01 & 9.62 \\
\hline 102.65 & $\mathrm{CCU}_{\mathrm{u}}$ & 9.32 & 38.82 & $1.99 \mathrm{E}-01$ & $4.23 \mathrm{E}-02$ & 29.59 & 12.12 \\
\hline 114.44 & $\mathrm{CCU}_{1}$ & 21.64 & 48.51 & $3.68 \mathrm{E}-01$ & 8.04E-02 & 29.54 & 9.50 \\
\hline 114.44 & $\mathrm{CCU}_{1}$ & 20.52 & 48.32 & $3.69 \mathrm{E}-01$ & 8.19E-02 & 29.74 & 9.07 \\
\hline 115.06 & $\mathrm{CCU}_{1}$ & 25.40 & 55.47 & $4.27 \mathrm{E}-01$ & $8.48 \mathrm{E}-02$ & 31.06 & 10.18 \\
\hline
\end{tabular}




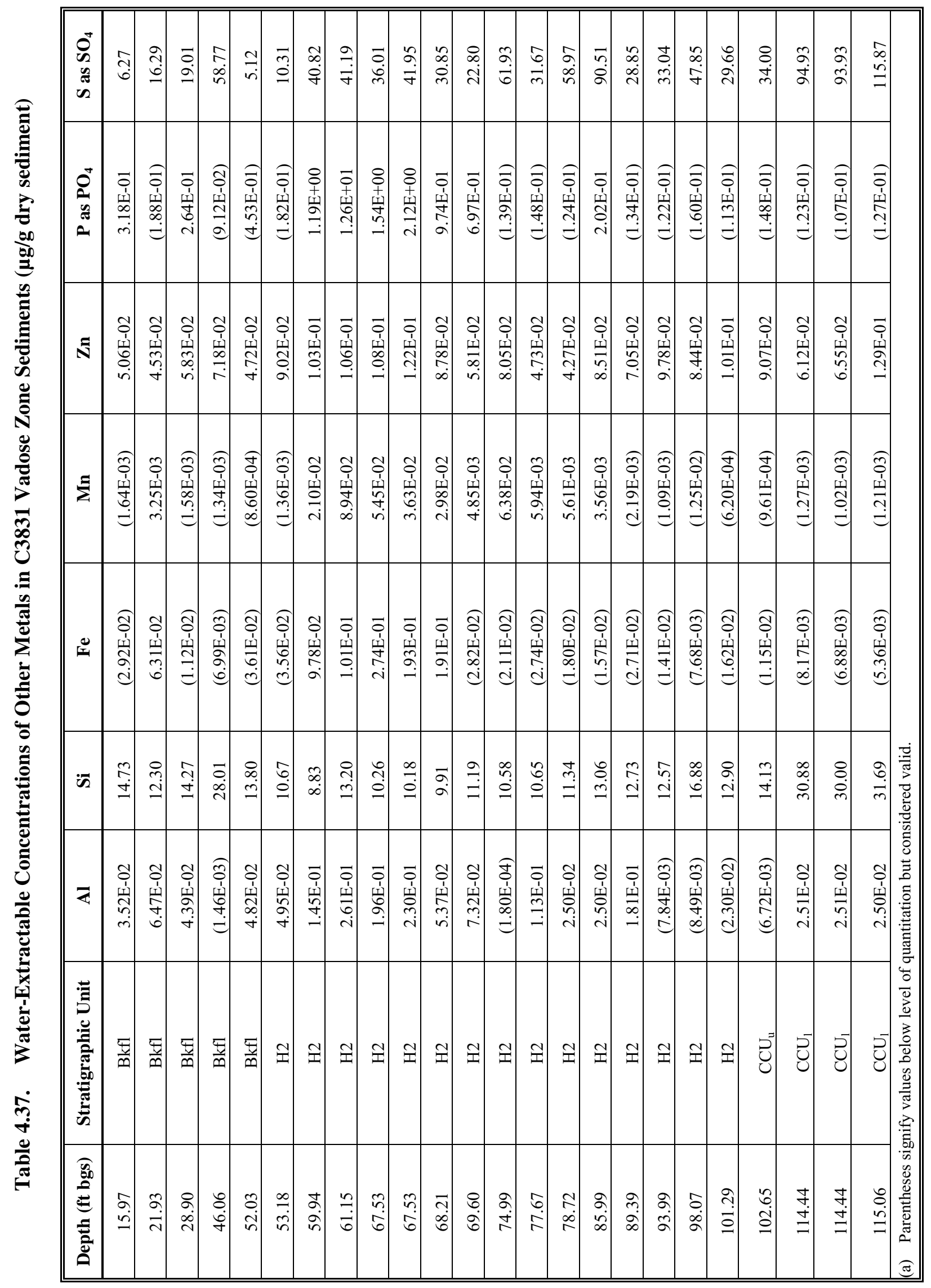




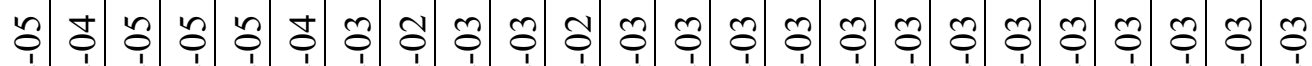
\#

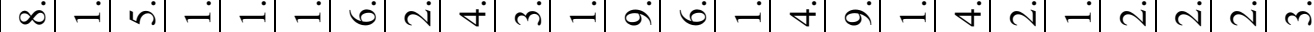

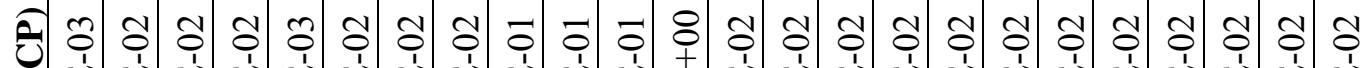

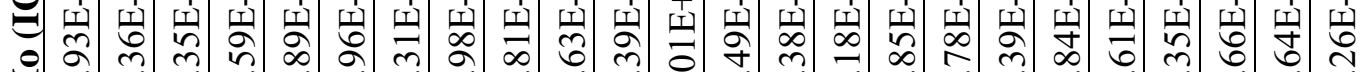

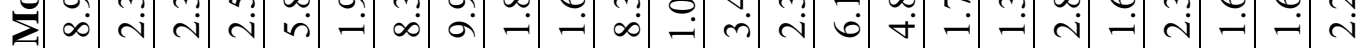

饣

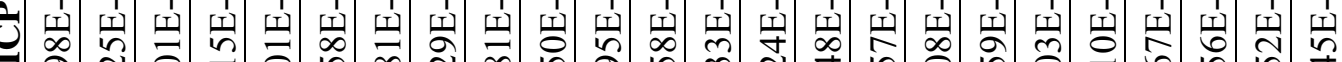

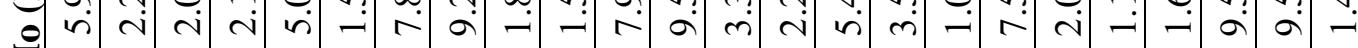
$\sum$

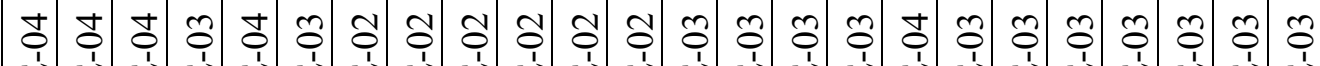

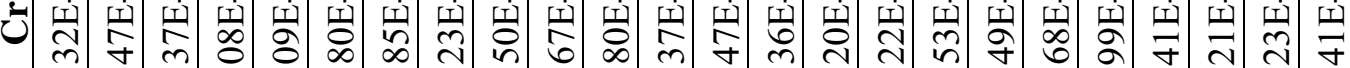

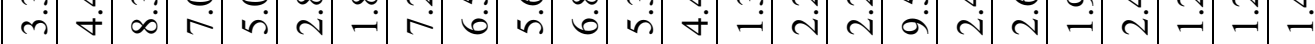

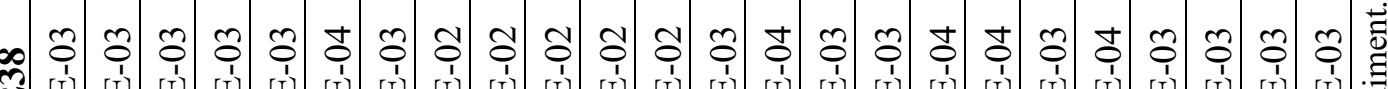

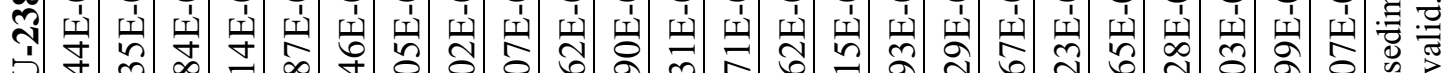

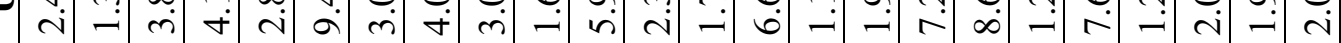
궁

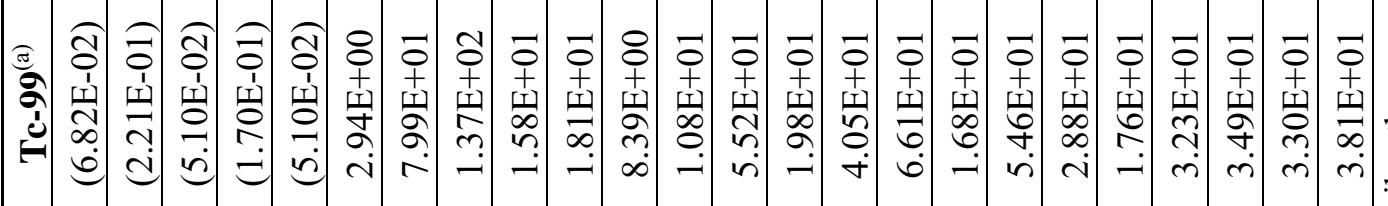
प.

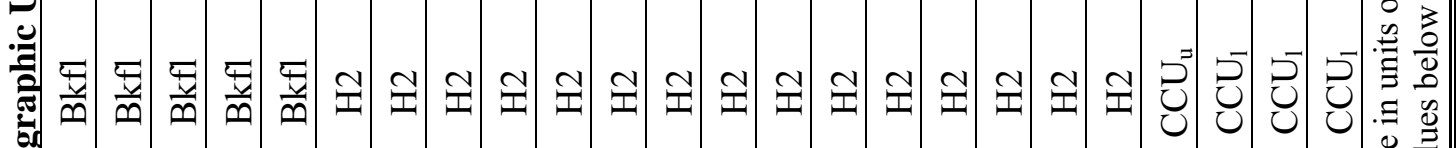
을

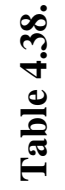

అ

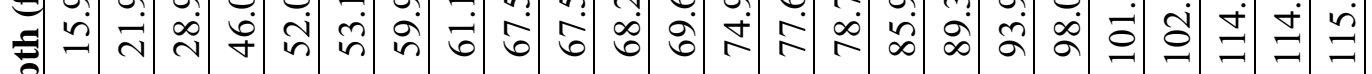




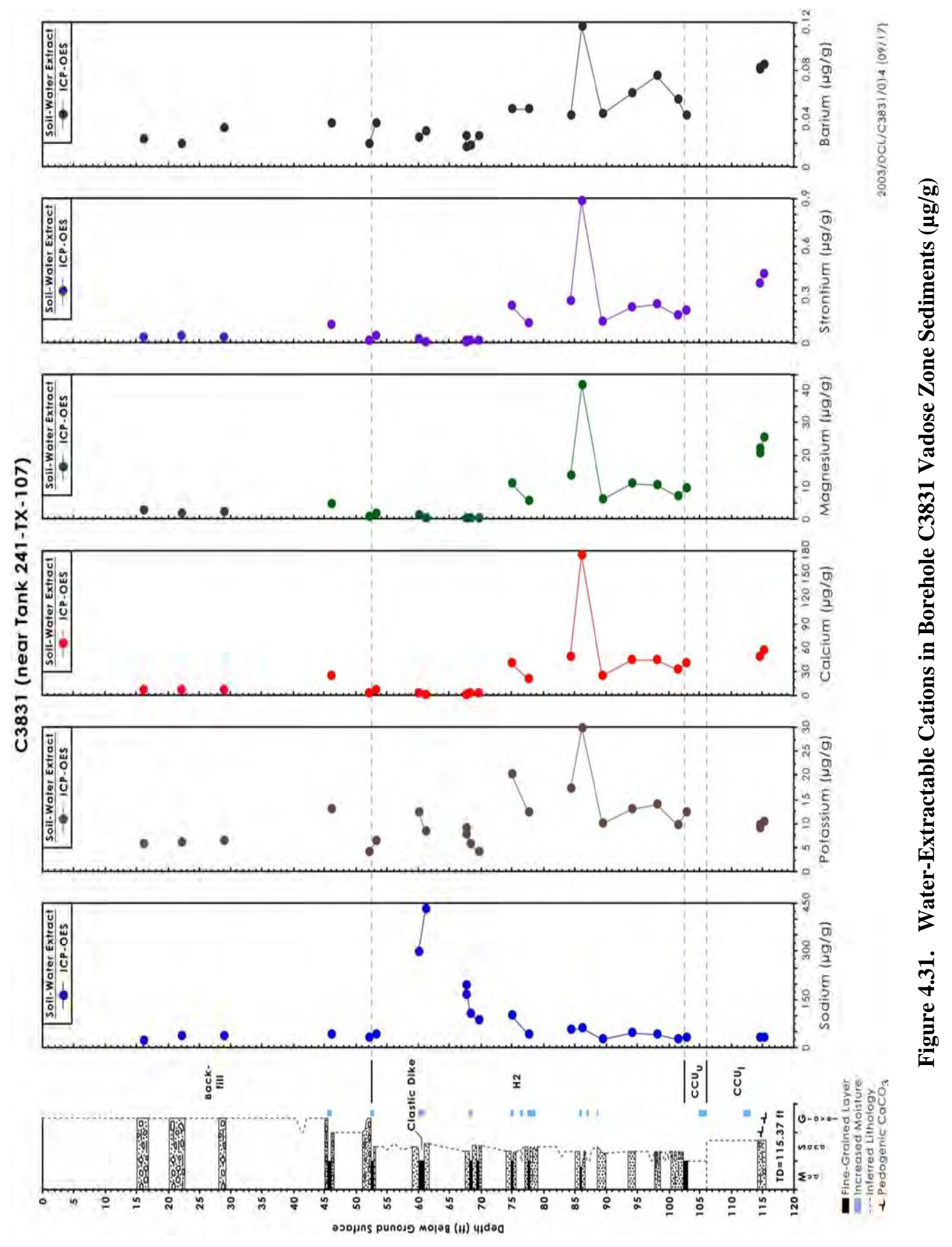




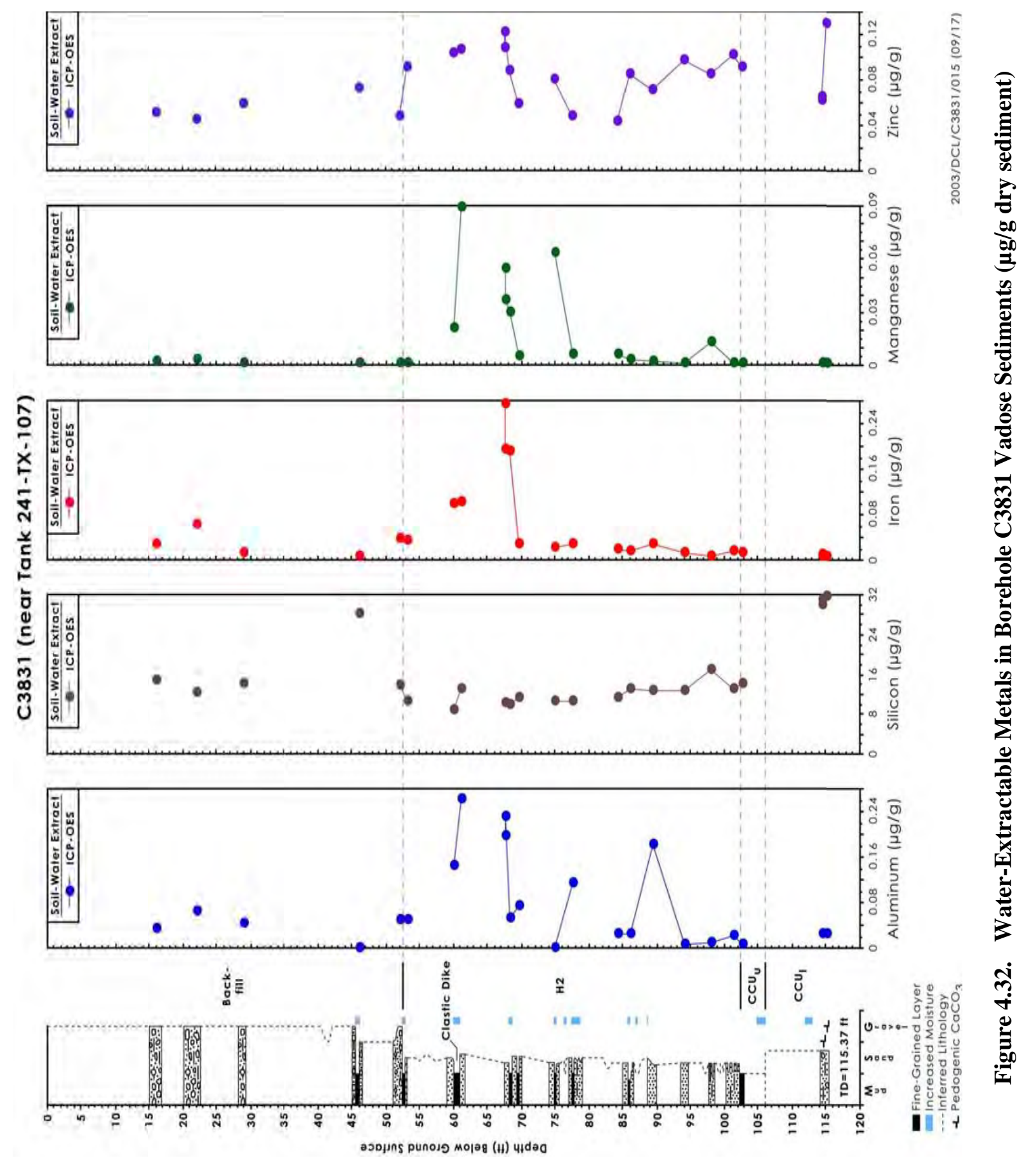




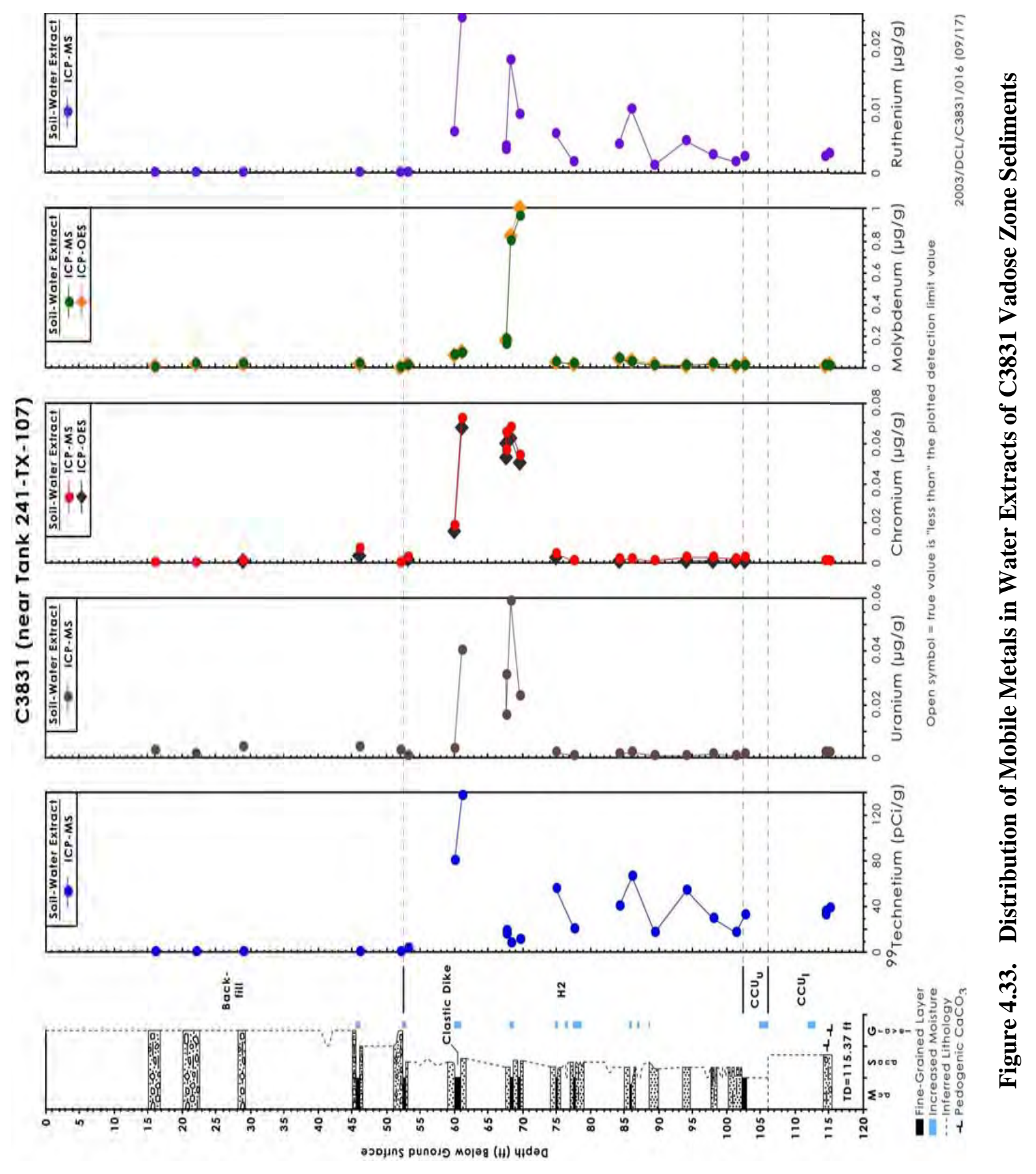




\subsubsection{Derivation of Vadose Zone Porewater Chemical Composition}

The 1:1 water extract data was recalculated to estimate the composition of the vadose zone porewater. From knowledge of the moisture content of the sediment samples taken from the liners of each core we calculated the amount of deionized water that would be needed to make the water extract exactly one part water (total of native porewater and added deionized water) to one part by weight dry sediment. The contaminated or uncontaminated sediments the dilution-corrected water extract data is biased high by a factor of 2 to 7 for many constituents such that the true porewater is less saline.

Tables 4.39 through 4.42 and Figures 4.34 through 4.37 show the calculated porewater composition of key constituents as a function of depth and stratigraphy. The most concentrated porewater is found at a clastic dike at $\sim 61 \mathrm{ft} \mathrm{bgs}$ and has a total concentration of $424 \mathrm{meq} / \mathrm{L}$ cations and anions. The calculated most saline porewater composition consists of $418.5 \mathrm{meq} / \mathrm{L} \mathrm{Na}, 1.2 \mathrm{meq} / \mathrm{L} \mathrm{Ca}, 0.2 \mathrm{meq} / \mathrm{L} \mathrm{Mg}$, and $4.7 \mathrm{meq} / \mathrm{L} \mathrm{K}$. These cations are neutralized by the following mixture of anions: $202.4 \mathrm{meq} / \mathrm{L}$ nitrate, $191.2 \mathrm{meq} / \mathrm{L}$ bicarbonate, $15.2 \mathrm{meq} / \mathrm{L}$ sulfate and $6.4 \mathrm{meq} / \mathrm{L}$ chloride, $0.8 \mathrm{meq} / \mathrm{L}$ fluoride, and $8.4 \mathrm{meq} / \mathrm{L}$ phosphate. This concentration is relatively dilute compared to the vadose zone porewaters found at the SX and BX tank farms (Serne et al. 2002b, 2002c, 2002d, 2002e) where the total ionic strength of the porewaters were as high as 7,000 to 17,000 and $1,000 \mathrm{meq} / \mathrm{L}$, respectively. At the borehole emplaced near tank B-110 the most saline porewater was 150 to $160 \mathrm{meq} / \mathrm{L}$. Thus the porewater maximum at borehole $\mathrm{C} 3831$ is $\sim 3$ and 4 times more concentrated than the vadose zone porewater at 299-E33-46 (Serne et al. 2002f) and at borehole C3830, respectively.

At $\sim 86 \mathrm{ft}$ bgs, where the divalent cations that were stripped from the shallower sediments by sodium reside, there is a second smaller peak in porewater salt content with about $110 \mathrm{meq} / \mathrm{L}$ of cations and anions with the following chemical composition: the cation distribution is $17.4 \mathrm{meq} / \mathrm{L} \mathrm{Na}, 59.2 \mathrm{meq} / \mathrm{L} \mathrm{Ca}$, $23.2 \mathrm{meq} / \mathrm{L} \mathrm{Mg}$, and $5.2 \mathrm{meq} / \mathrm{L} \mathrm{K}$; the anion distribution is $93.2 \mathrm{meq} / \mathrm{L}$ nitrate, $9.4 \mathrm{meq} / \mathrm{L}$ sulfate, $6.0 \mathrm{meq} / \mathrm{L}$ bicarbonate, $3.2 \mathrm{meq} / \mathrm{L}$ chloride, and $0.08 \mathrm{meq} / \mathrm{L}$ fluoride.

The technetium-99 in the porewaters between the depths of 53 to the bottom of the hole at $116 \mathrm{ft}$ bgs ranges from 50,000 to $10^{+6} \mathrm{pCi} / \mathrm{L}$. On a per gram of dry sediment basis, these porewater concentrations are 40 to $140 \mathrm{pCi} / \mathrm{g}$. Because the water content of the $\mathrm{H} 2$ unit sediments is so small when equated to porewater concentrations, this small mass of technetium-99 reaches concentrations about 500 to 1000 times larger than the drinking water standard.

The calculated porewater uranium, chromium, molybdenum, and ruthenium concentrations are significantly elevated between 61 and $70 \mathrm{ft}$ bgs and range from 300 to 900,600 to 1600,1000 to 17,000 and 60 to $2,000 \mu \mathrm{g} / \mathrm{L}$, respectively. Below these depths the porewater concentrations are 50 to 100 times lower. The porewaters in borehole $\mathrm{C} 3831$ are definitely more contaminated than the porewaters in borehole C3830 sediments.

\subsubsection{M Nitric Acid-Extractable Amounts of Selected Elements in C3831 Sediments}

The same cores that were characterized for water-extractable constituents were also characterized to see how much of various constituents could be leached with hot $8 \mathrm{M}$ nitric acid. A comparison between the quantities that were acid extractable with those that are water extractable often indicates the relative mobility of a given constituent and can sometimes differentiate man-disposed from naturally occurring constituents. Finally, a comparison of the acid-extractable quantities in suspected contaminated 
sediments with acid-extractable amounts in uncontaminated sediments can be used to delineate the presence of less mobile contaminants.

The quantities of various constituents in the $\mathrm{C} 3831$ vadose zone sediments that were acid extractable are shown in Tables 4.43 to 4.45 and Figures 4.38 through 4.40. Upon comparing the acid extract data for borehole C3831 with similar strata in the uncontaminated borehole 299-W10-27, most of the variation in mass leached per gram of sediment versus depth in found to be lithology-related. That is, for most constituents there are no signs of elevated values of acid-leachable constituents in borehole C3831 sediments excepting acid-extractable sulfur (assumed to represent sulfate), sodium (between the depths of 61 and $67.5 \mathrm{ft} \mathrm{bgs}$ ), molybdenum (between 67.5 and $70 \mathrm{ft} \mathrm{bgs}$ ), and ruthenium and technetium-99 throughout most of the depth profile. The acid-extractable sulfate profile in borehole C3831 sediments averages about 4 to 7 times higher than in comparable uncontaminated sediments from borehole 299-W10-27. The acid-extractable sulfur (measured as sulfate) for boreholes C3830 and C3831 are similar. Borehole C3831 shows high acid-leachable technetium-99 and ruthenium throughout the profile and larger acidextractable sodium and molybdenum in thin zones between 67.5 and 70 and 61 to $67.5 \mathrm{ft}$ bgs, respectively than borehole $\mathrm{C} 3830$. The acid-extractable technetium-99 ranges from 50 to $200 \mathrm{pCi} / \mathrm{g}$ from $60 \mathrm{ft}$ bgs to the bottom of the borehole. This range is slightly lower than the technetium-99 acid extracts at C3830.

As mentioned, the ratio of water-extractable to acid-extractable quantities of constituents can identify samples that may contain leaked fluids for Hanford waste disposals. The comparison of water to acid extracts suggests that there are unnaturally high percentages of water-leachable uranium, chromium, and molybdenum between the depths of 61 and $70 \mathrm{ft}$ bgs. There are unnaturally high percentages of waterleachable phosphate at the $61 \mathrm{ft}$ bgs depth. The water-extractable percentages versus acid-extractable divalent cations are high between 75 and $98 \mathrm{ft}$ bgs, especially at $86 \mathrm{ft}$ bgs suggesting the impacts of the sodium waste solution ion exchange reaction. The water to acid-extractable sodium percentage is unnaturally high between the depths of 53 and $86 \mathrm{ft} \mathrm{bgs,} \mathrm{suggesting} \mathrm{sodium-enriched} \mathrm{fluids} \mathrm{reside} \mathrm{in} \mathrm{the}$ pores of the vadose zone sediments in this zone. The presence of elevated water- and acid-extractable quantities of technetium-99 and ruthenium between $60 \mathrm{ft}$ bgs and the bottom of the borehole at $115 \mathrm{ft}$ bgs suggests the presence of Hanford Site waste fluids in the vadose zone at these depths in borehole C3831.

The borehole C3831 sediment from the Cold Creek lower subunit (caliche) has elevated acid-extractable levels of uranium, magnesium, calcium, strontium, sodium, and potassium and lower acid-extactable silicon, manganese, and zinc in comparison to other samples. The cause for these differences is the higher concentrations of pedogenic calcium carbonate found in this subunit at C3831 than at 299-W10-27. Caliche contains higher concentrations of acid-extractable uranium, magnesium, calcium, and sodium than other minerals and when one caliche sample contains more calcium carbonate than another sample higher amounts of these constituents are acid leachable.

Figure 4.40 shows that our acid-extractable molybdenum results from ICP analyses is biased high likely from an unaccounted for spectral interference. The molybdenum results from the ICP-MS are more accurate and the detection limits are much lower. Figure 4.41 shows that there is some sulfate present in the sediments that is not readily water extractable but the vast majority of the sediment phosphate content is not water extractable in comparison with the amounts that are acid extractable. The same trend was observed for the uncontaminated sediments from borehole 299-W10-27 and samples from borehole C3830. Alternatively, some of the acid-extractable phosphorous may be present in a form other than phosphate such that when we convert the acid-extractable phosphorous number to phosphate (essentially we multiply by 3 ), we are inflating the acid-extractable value. 


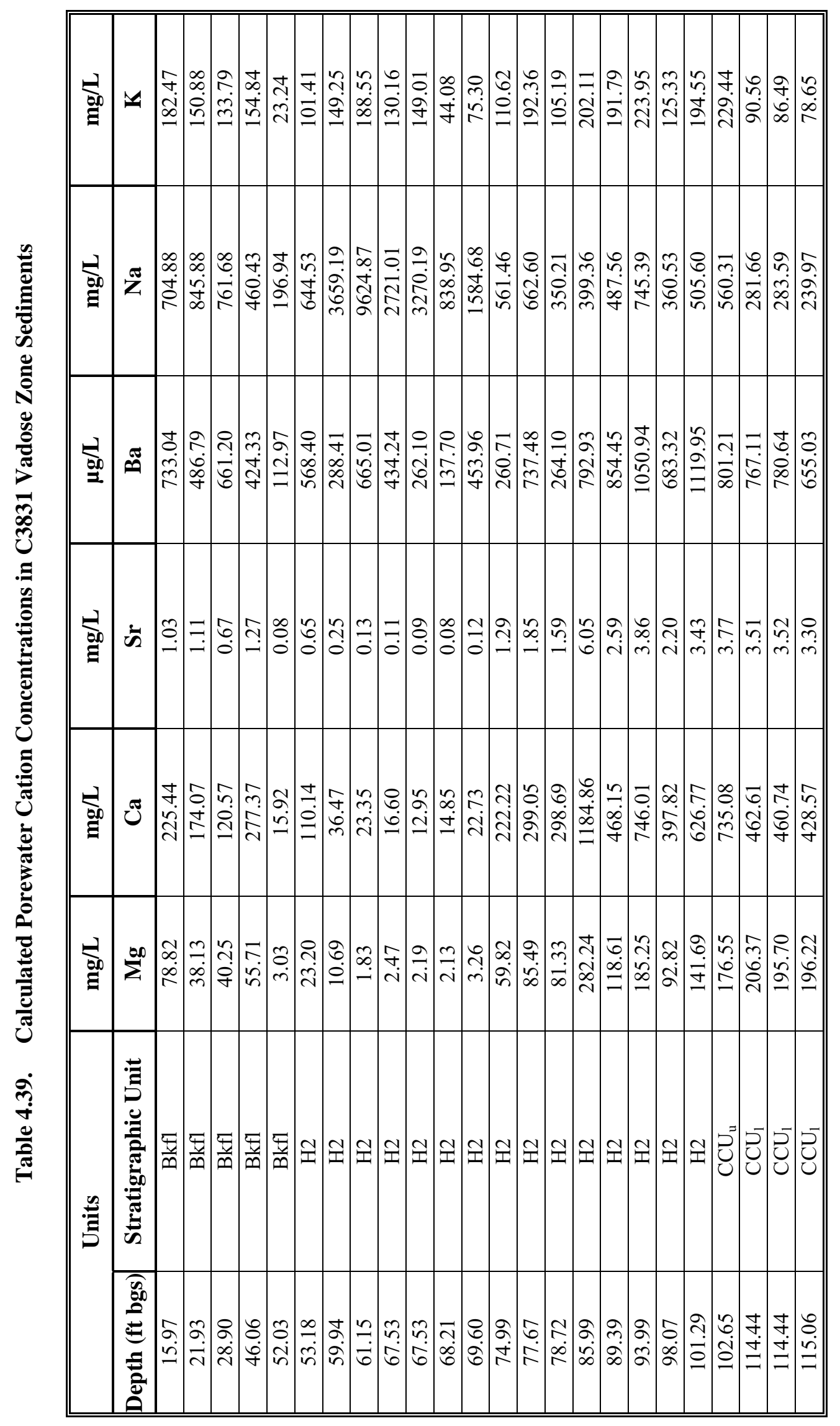




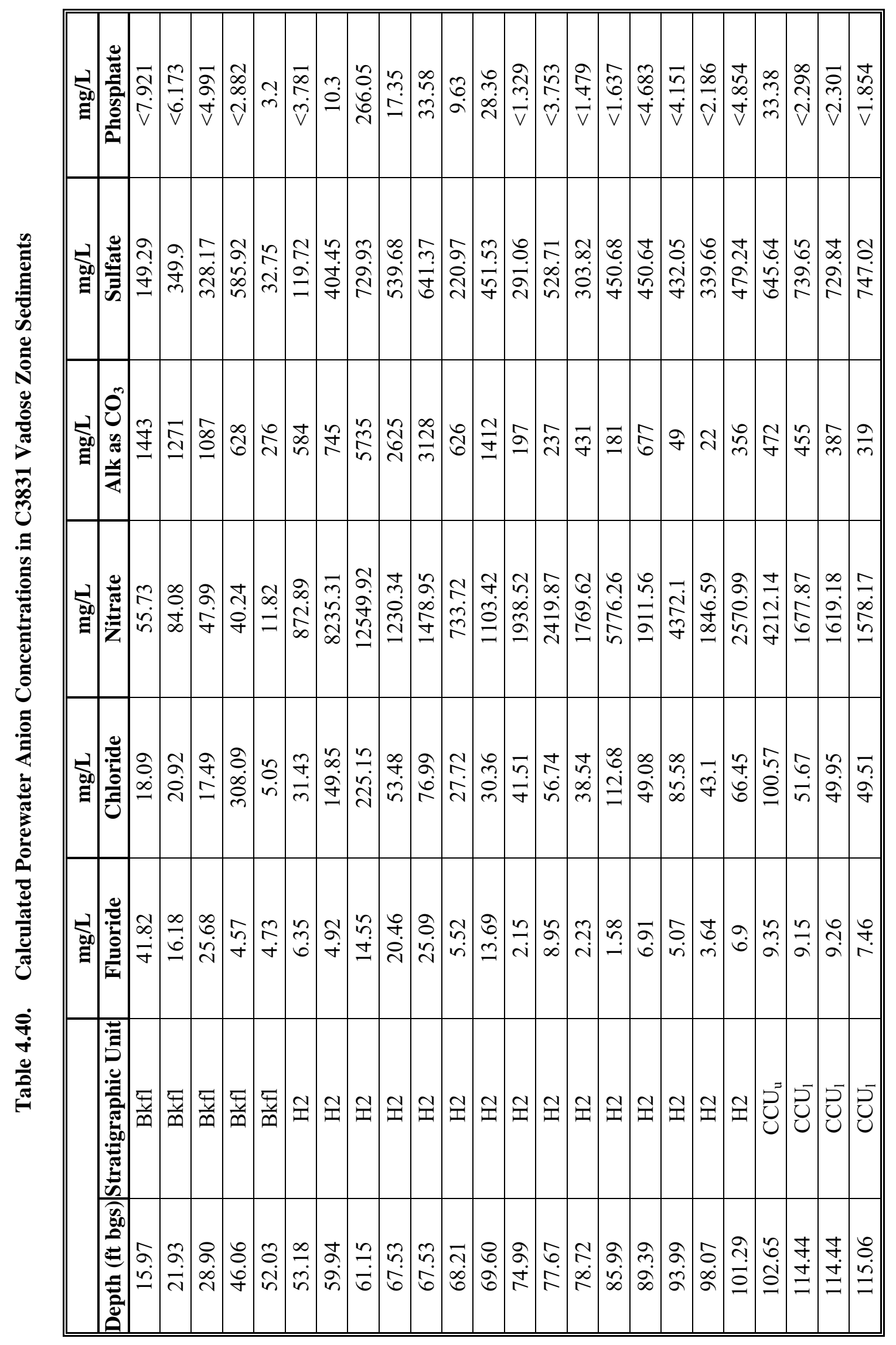




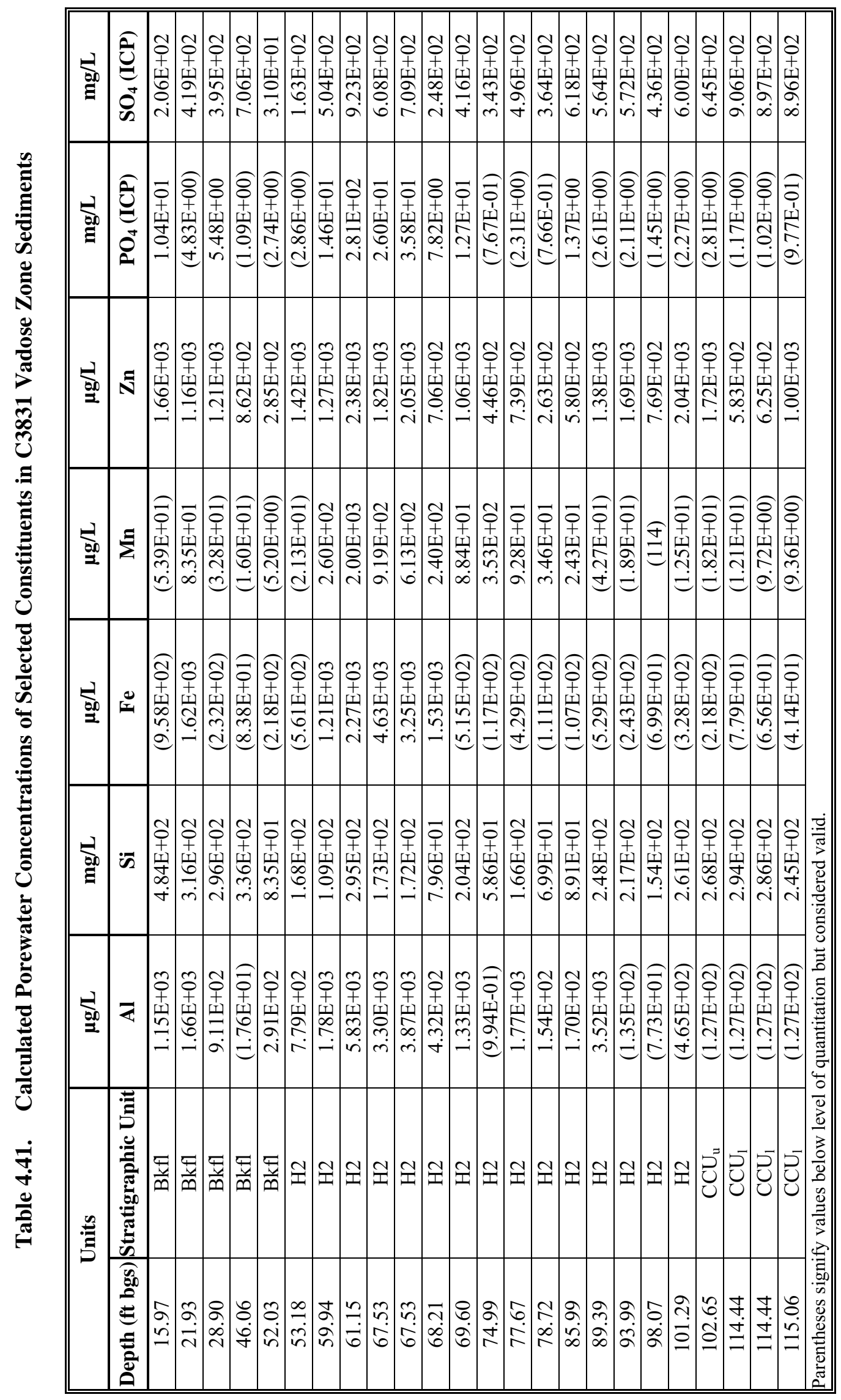




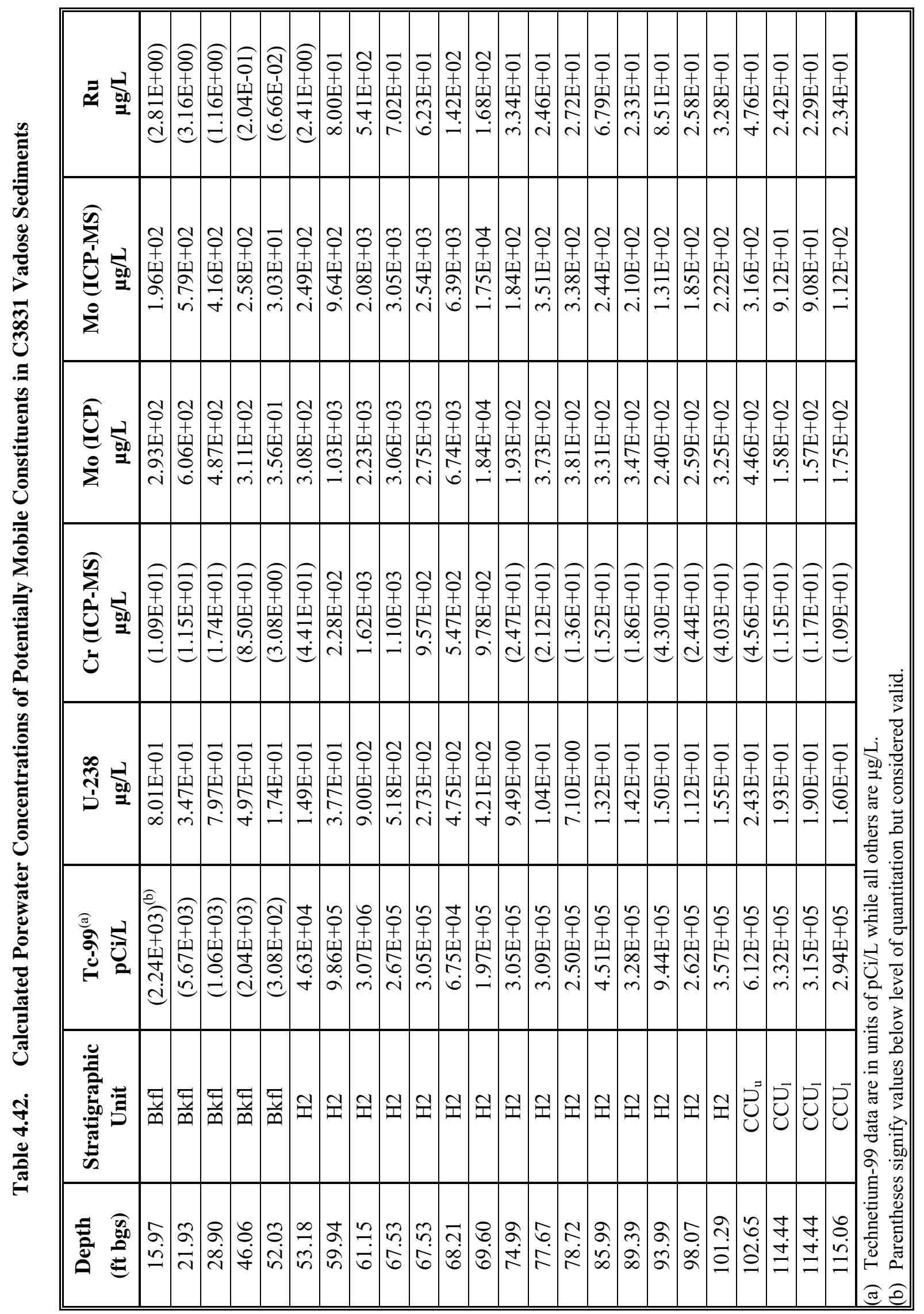



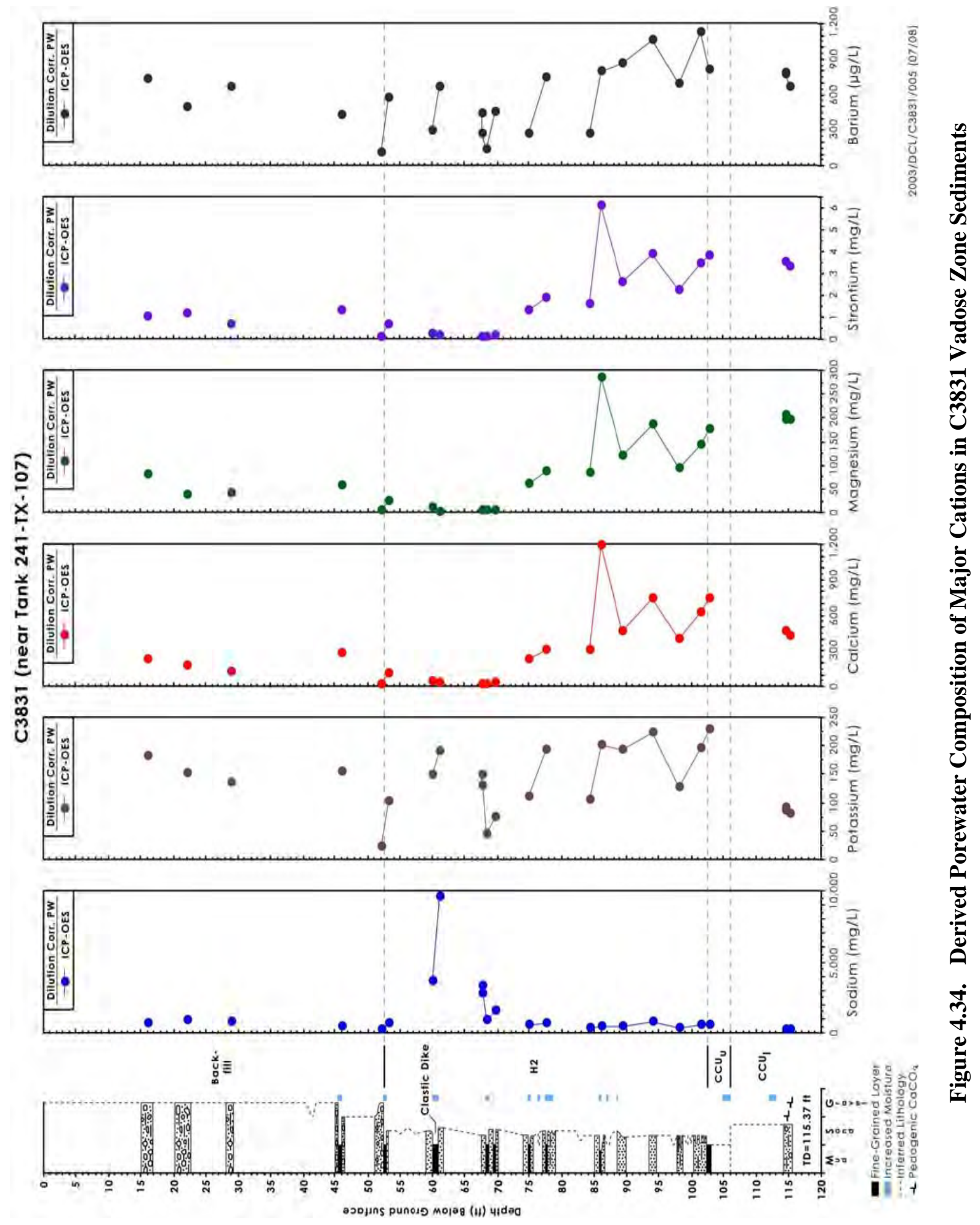

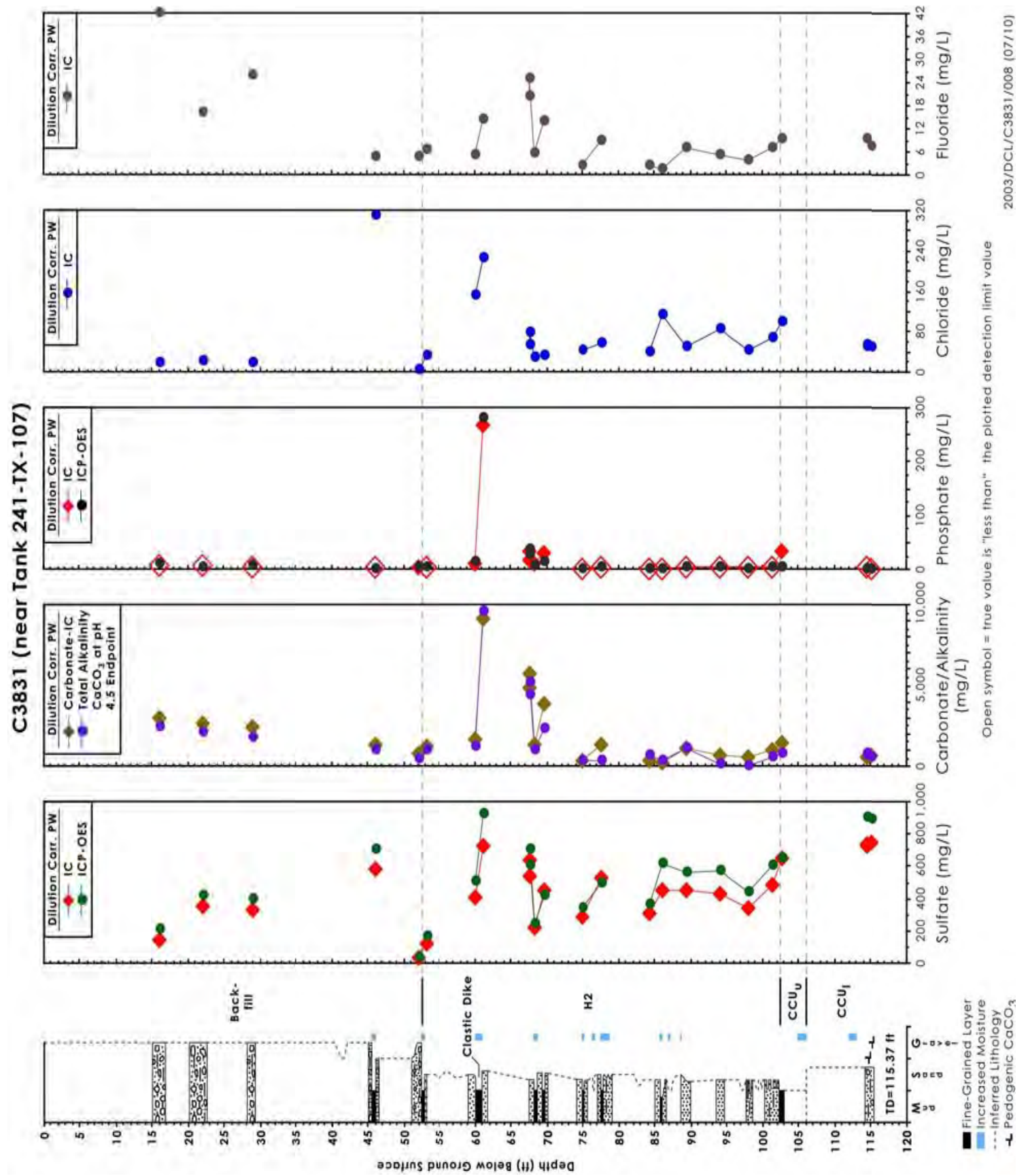

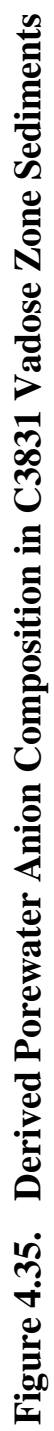




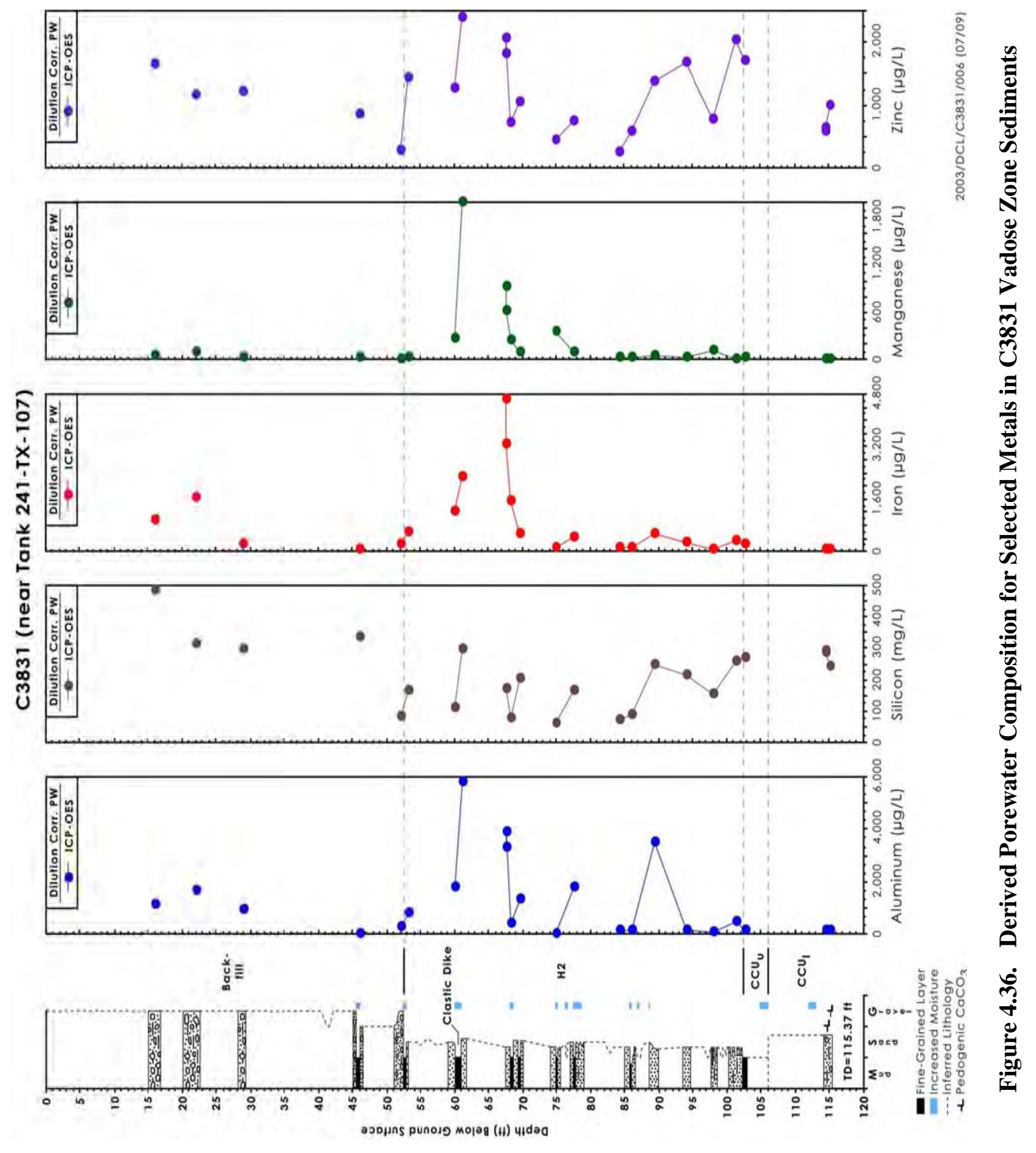




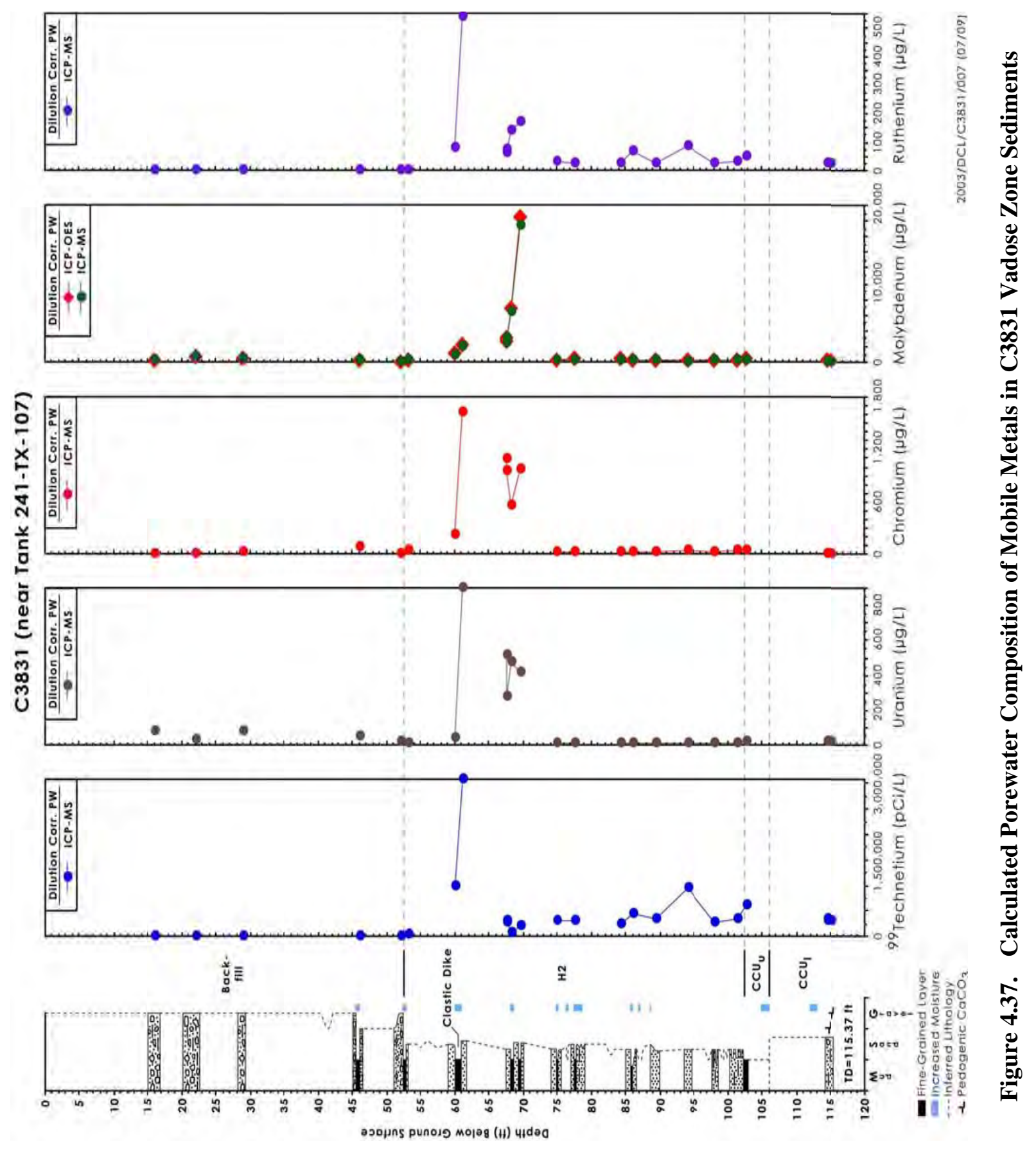




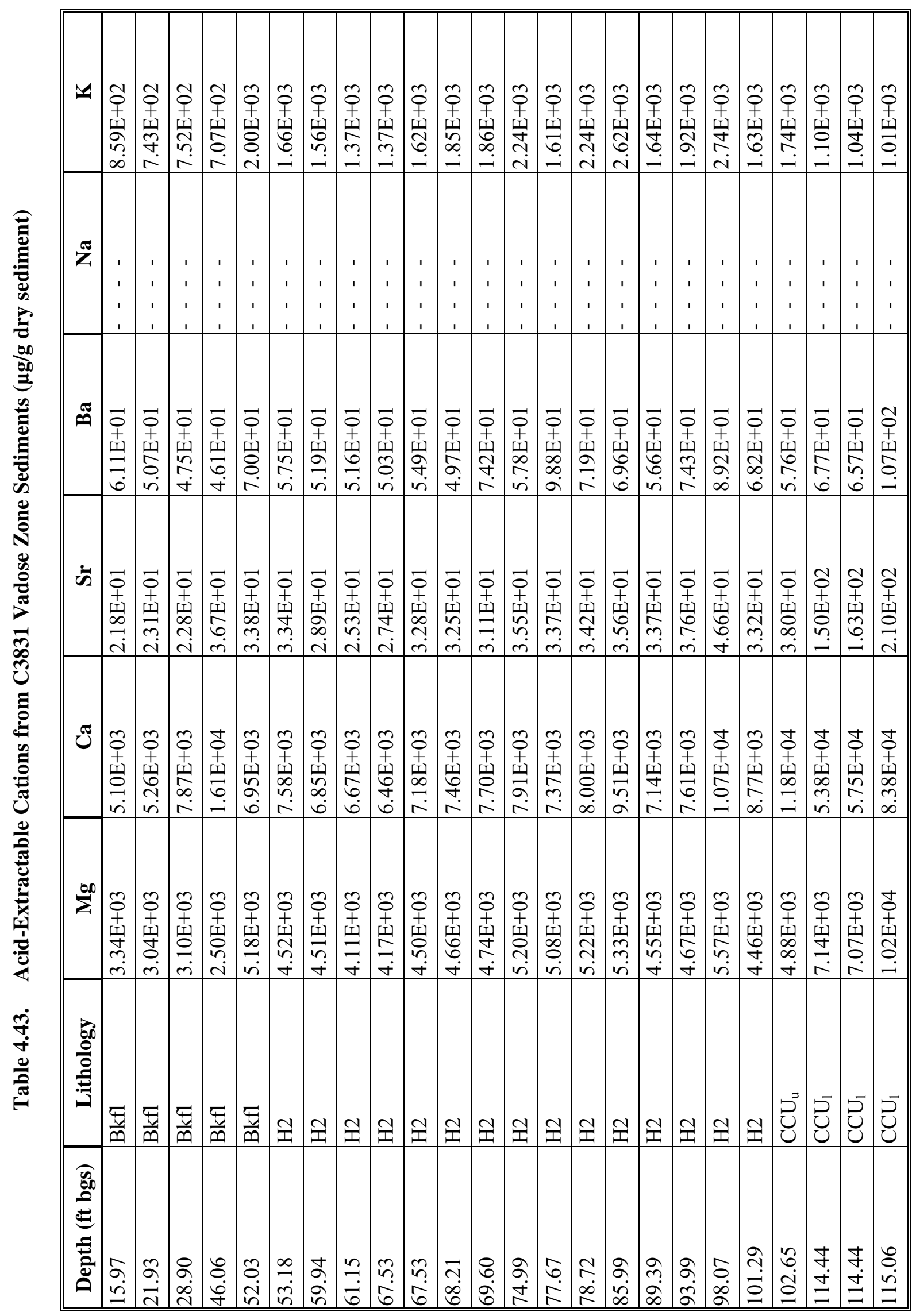




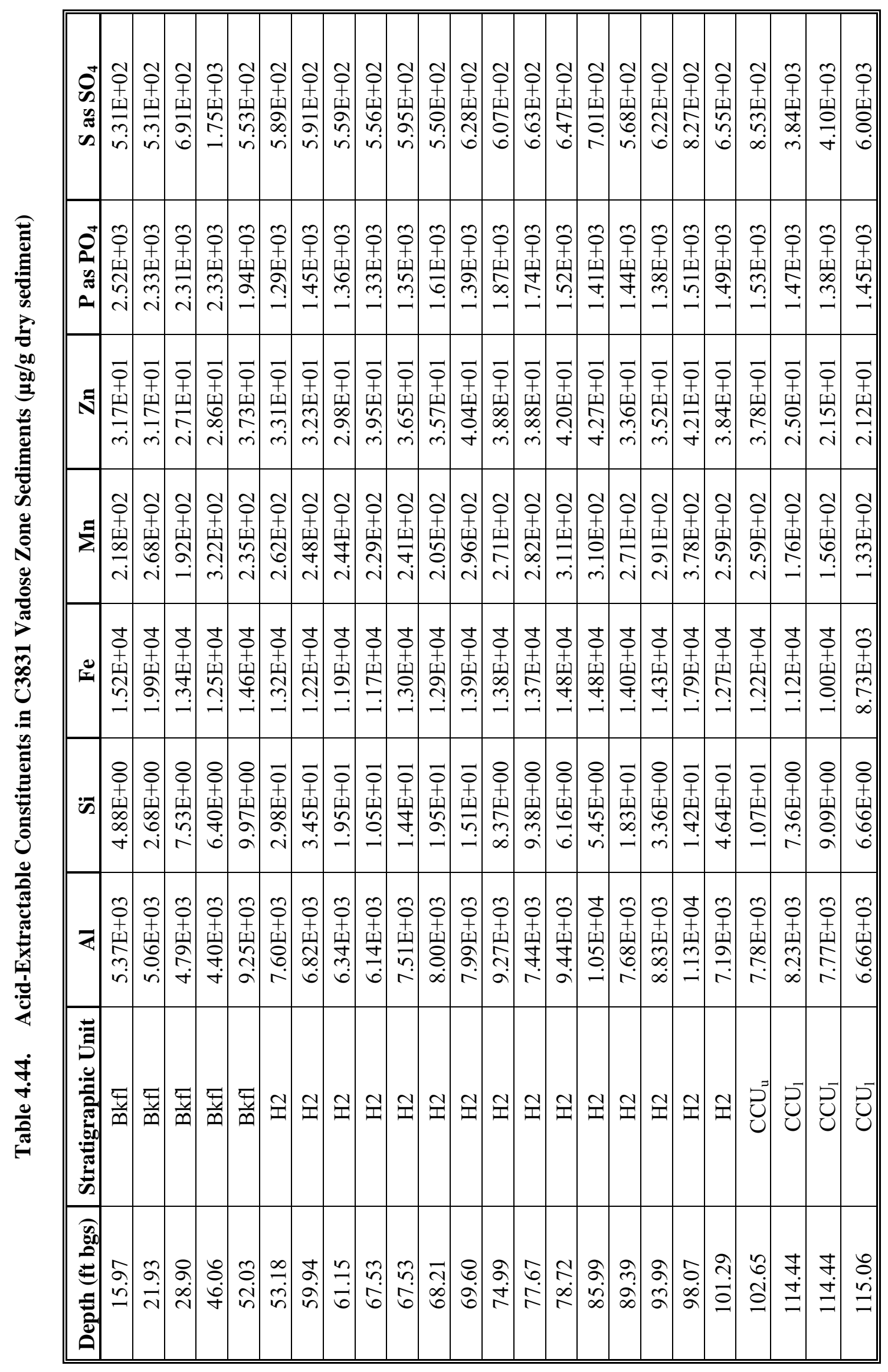




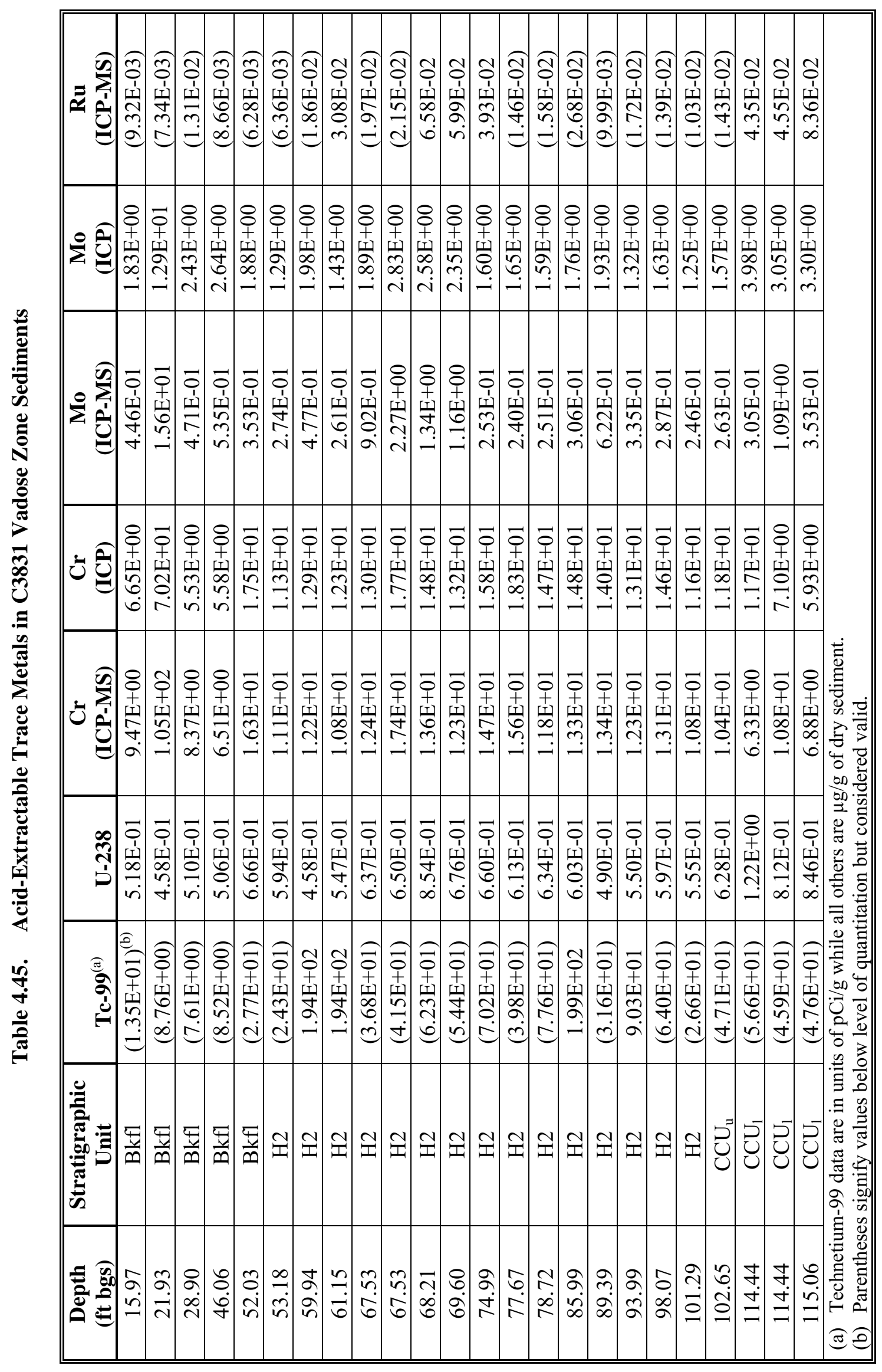




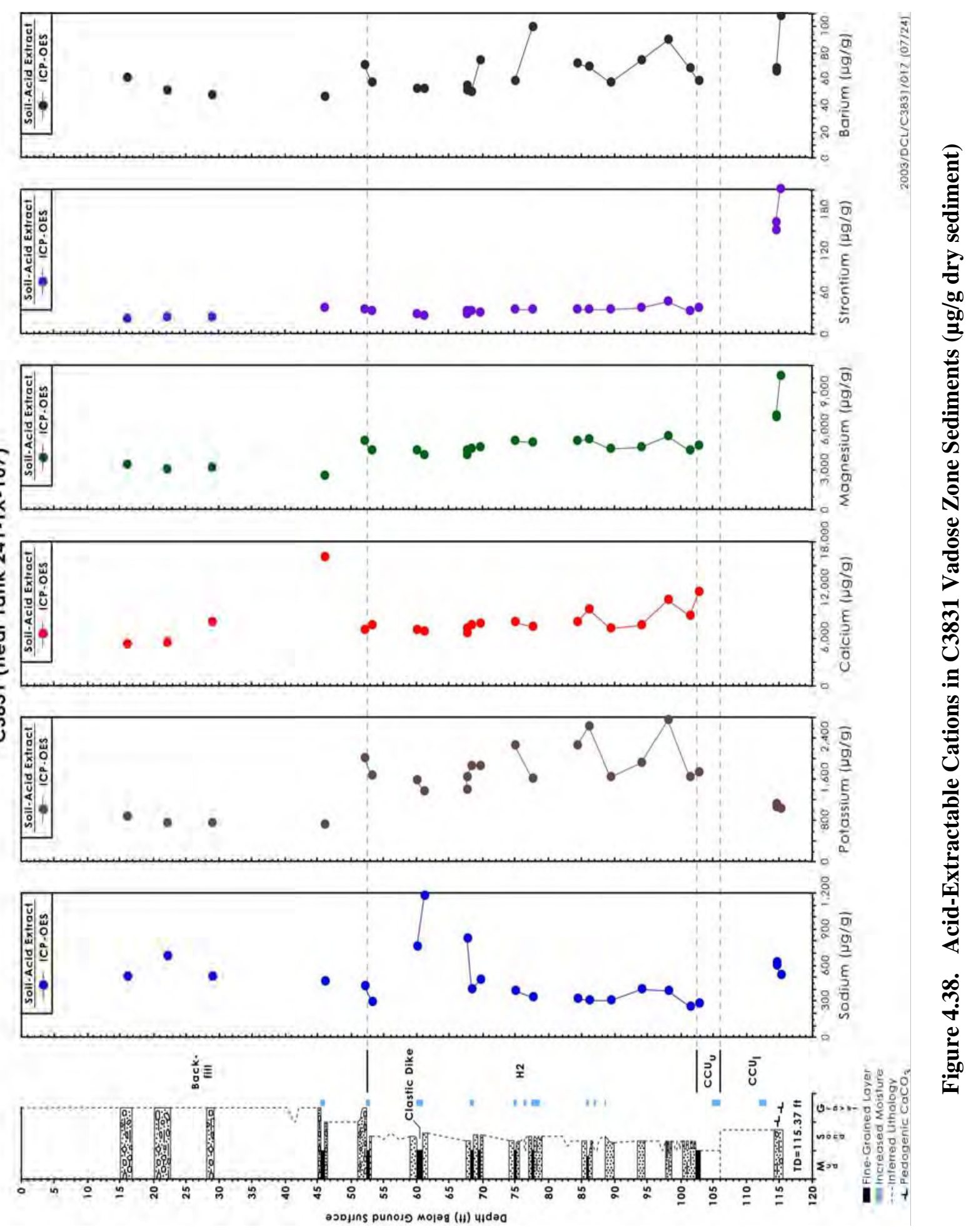



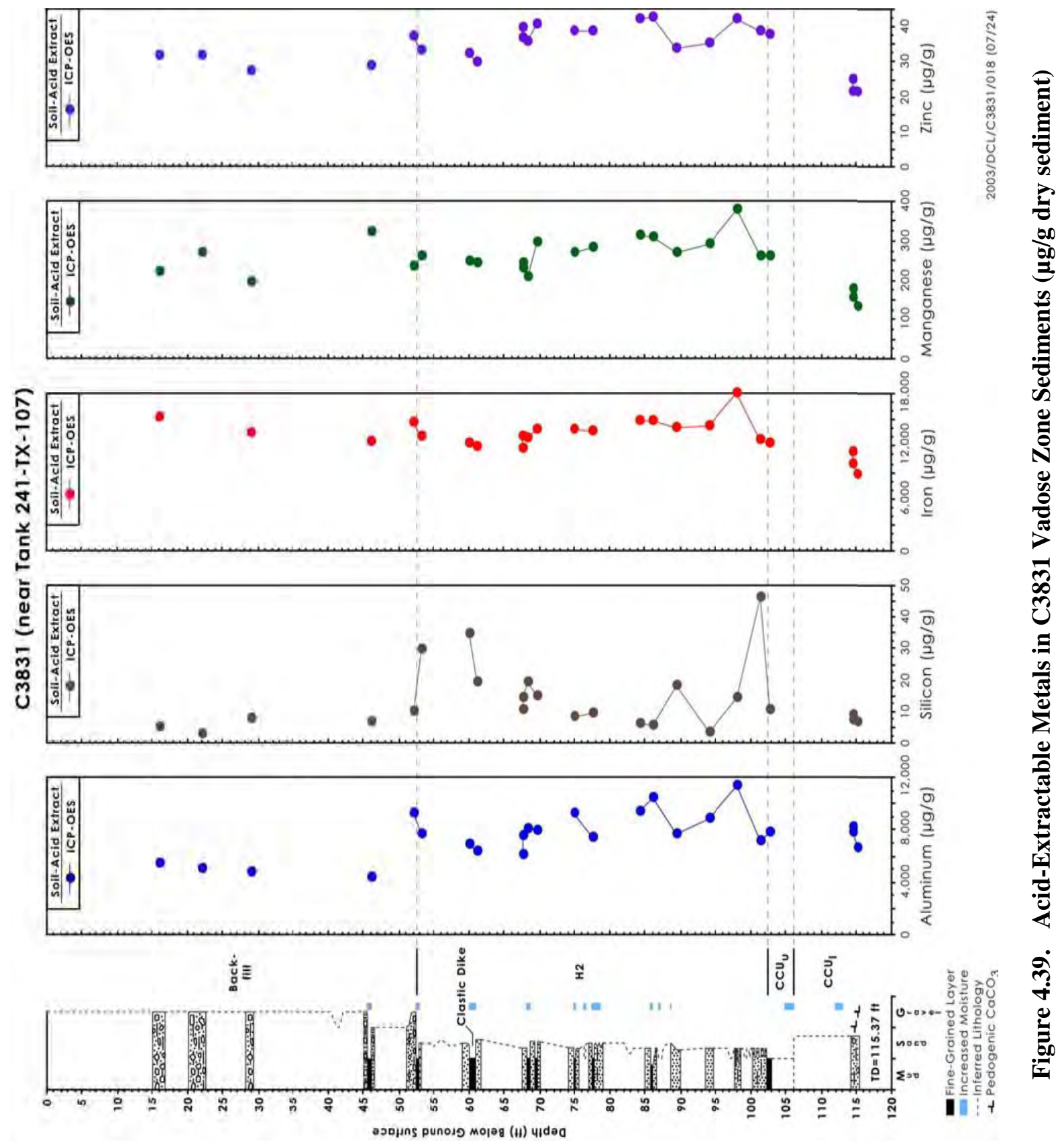

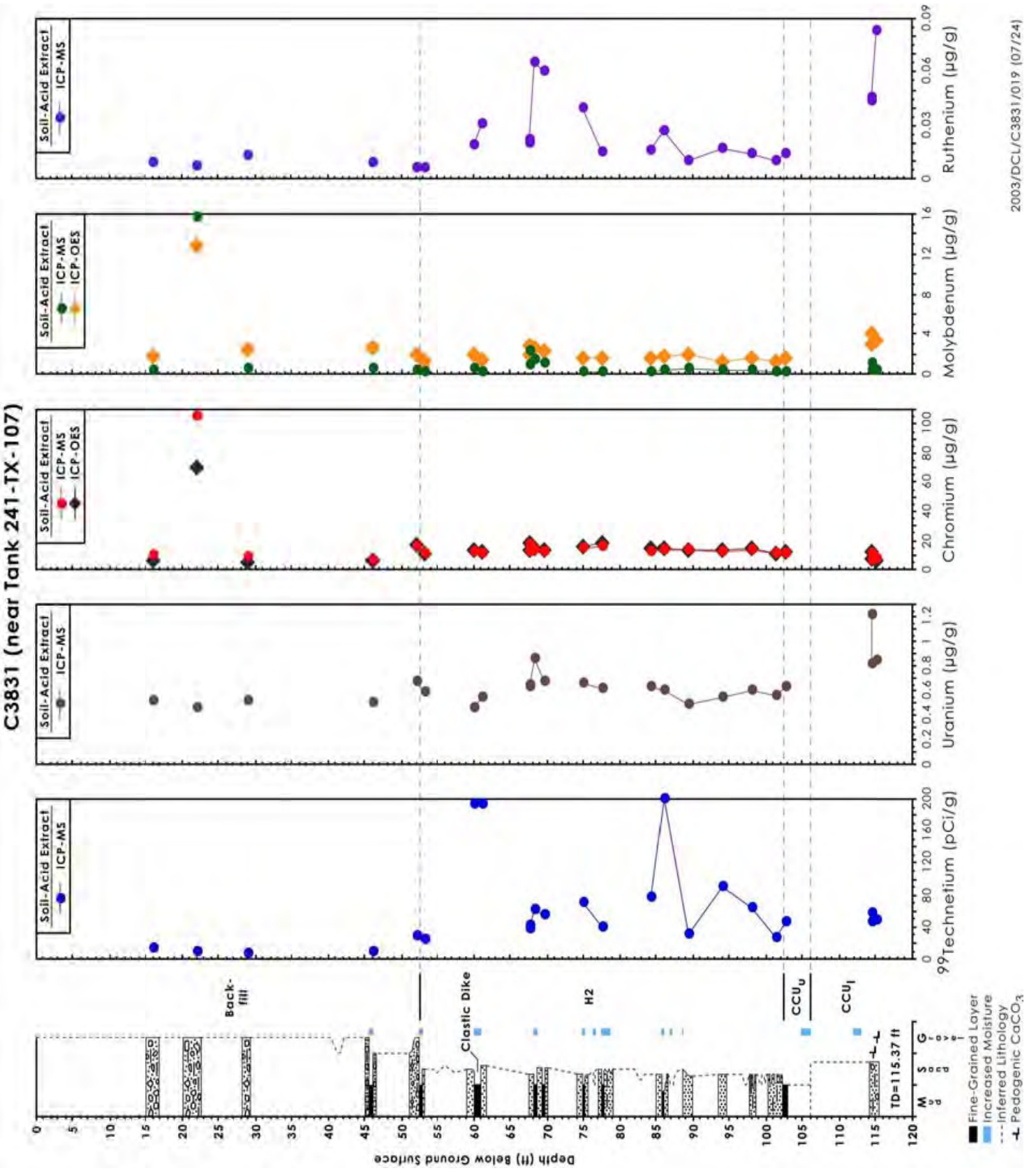

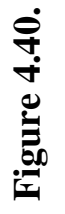




\subsubsection{Radionuclide Content in Vadose Zone Sediment from C3831}

Aside from the technetium-99 and uranium data already presented, the lab-measured gamma emitters (see Figures 4.42 and 4.43) show natural potassium-40, natural uranium, very sporadic hits of cesium-137 and a small elevated zone of cobalt- 60 between the depths of 60 and $85 \mathrm{ft} \mathrm{bgs}$ and perhaps down to the bottom of the borehole. The lab measurements of cobalt- 60 show activities ranging from approximately one to a few tens of $\mathrm{pCi} / \mathrm{g}$ while the continuous field log shows values of 40 to $60 \mathrm{pCi} / \mathrm{g}$ between 60 and $75 \mathrm{ft}$ bgs. The field log also shows a small amount of surface cesium-137 contamination. The agreement between the field and lab-generated data for gamma emitters is good. Aside from the thin zone of cobalt-60 there are no man-made gamma emitters in the sediment profile above concentrations of a few tenths of a $\mathrm{pCi} / \mathrm{g}$ excepting the near surface contamination of a few $\mathrm{pCi} / \mathrm{g}$ cesium-137.

Water and acid extracts of the sediments containing cobalt-60 were performed. The amounts of cobalt-60 that were extractable are compared with the total cobalt- 60 measured by direct gamma energy analysis of the sediment in Table 4.46 and Figure 4.44. In almost all cases the acid extract and direct measure of the cobalt- 60 in the sediments are similar, as one would expect. The water extract data show in general that some of the cobalt- 60 did not extract into the water over the $\sim 16$-hour time period allotted. However, as will be discussed in Section 6.5, the in situ desorption $\mathrm{K}_{\mathrm{d}}$ values that can be calculated from these data are quite small, $<1 \mathrm{~mL} / \mathrm{g}$, suggesting that the cobalt- 60 in borehole C3831 vadose zone sediments would be fairly mobile.

Gross alpha and beta measurement were made on both the 1:1 sediment:water and sediment:acid extracts following the procedure described in Section 3.3.3.2. With knowledge of the mass of dry sediment to extraction fluid used, the data were converted to activity of gross beta and alpha leached per gram of dry sediment. None of the water or acid extracts of the 24 extracts ( 22 cores from selected depths and two duplicates) showed any detectable alpha activities above the detection limit of 5 to $8 \mathrm{pCi} / \mathrm{g}$. Both the water and acid extracts contained measurable gross beta between 50 and $100 \mathrm{pCi} / \mathrm{g}$ in the sediment profile from $62 \mathrm{ft} \mathrm{bgs}$ to the bottom of the borehole. In the thin zone from 59 to $61 \mathrm{ft}$ bgs the gross beta is 300 to $400 \mathrm{pCi} / \mathrm{g}$ in both the water or acid extracts. These values likely reflect the presence of both technetium- 99 and cobalt- 60 contamination. The technetium- 99 is equally water or acid extractable. The ICP-MS measurements for both the water and acid extracts show technetium-99 concentrations between 40 and $140 \mathrm{pCi} / \mathrm{g}$, but the water extract ICP-MS data are considered most accurate. Thus we feel that the gross beta values (between 300 and $400 \mathrm{pCi} / \mathrm{g}$ ) are biased high and that $200 \mathrm{pCi} / \mathrm{g}$ is more accurate for a gross beta value in borehole $\mathrm{C} 3831$ vadose zone sediments.

\subsubsection{Total Carbon, Calcium Carbonate, and Organic Carbon Content of Vadose Zone Sediment from Borehole C3831}

The total, inorganic, and organic carbon contents of the C3831 sediments are reported in Table 4.47. The two samples of Cold Creek lower unit contain substantial amounts of caliche between 114.4 and $115.1 \mathrm{ft}$ bgs. The last sample obtained before the probe met refusal has $34 \mathrm{wt} \%$ calcium-carbonate equivalent, essentially the same as the bottom sample obtained at borehole C3830. As found in most vadose sediments from the Hanford Reservation, there is very little $(<0.1 \%$ by weight $)$ organic carbon in the borehole C3831vadose zone sediments. The borehole C3831 backfill sample at $46.1 \mathrm{ft}$ bgs also appears to have elevated inorganic carbon and some $(0.4 \mathrm{wt} \%)$ organic carbon. Aside from this backfill sample the borehole C3831 carbon values for total, inorganic, and organic are quite similar to those at borehole C3830. 


\section{C3831 (near Tank 241-TX-107)}

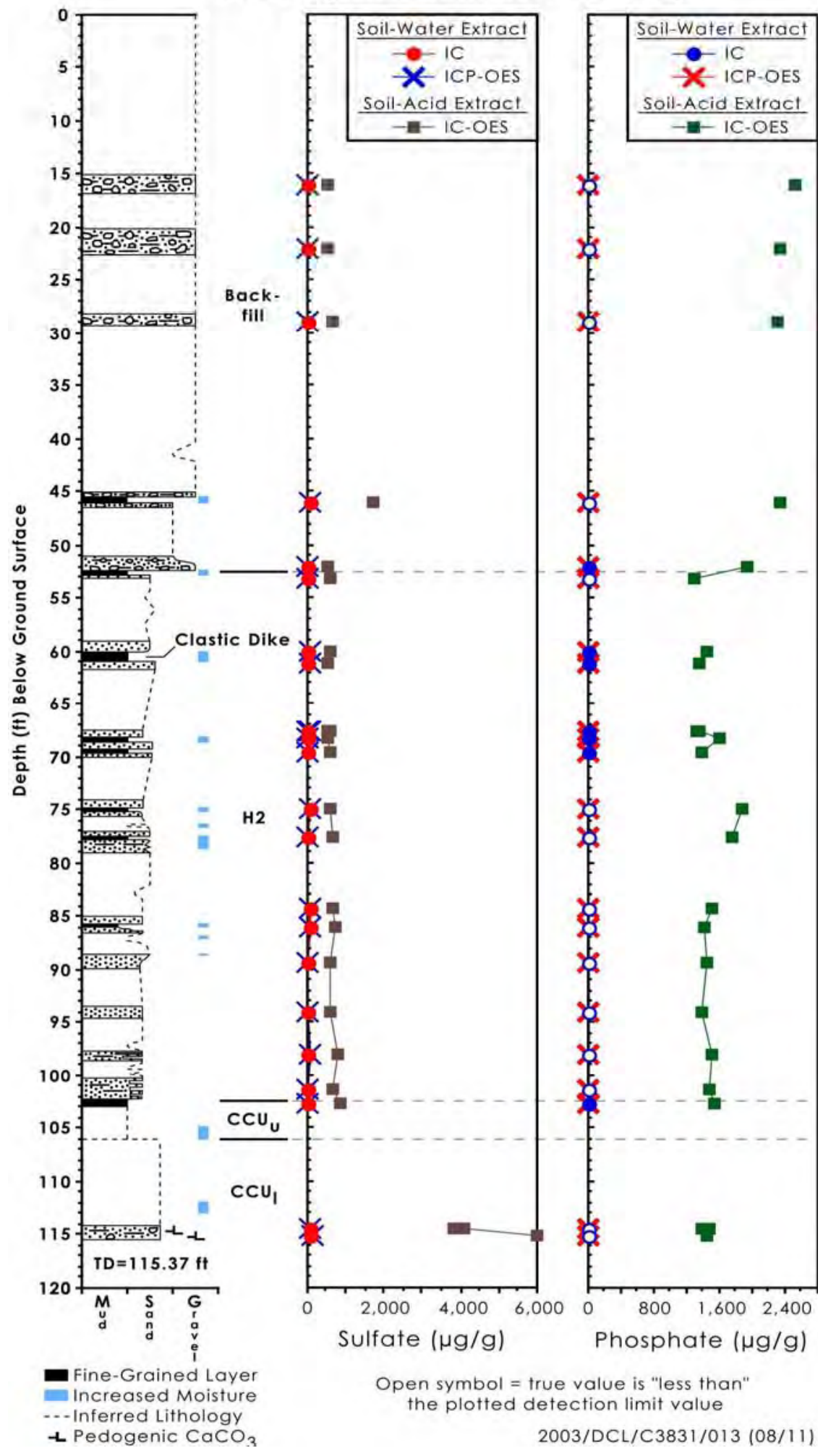

Figure 4.41. Water versus Acid-Extractable Sulfate and Phosphate in C3831 Vadose Zone Sediments 


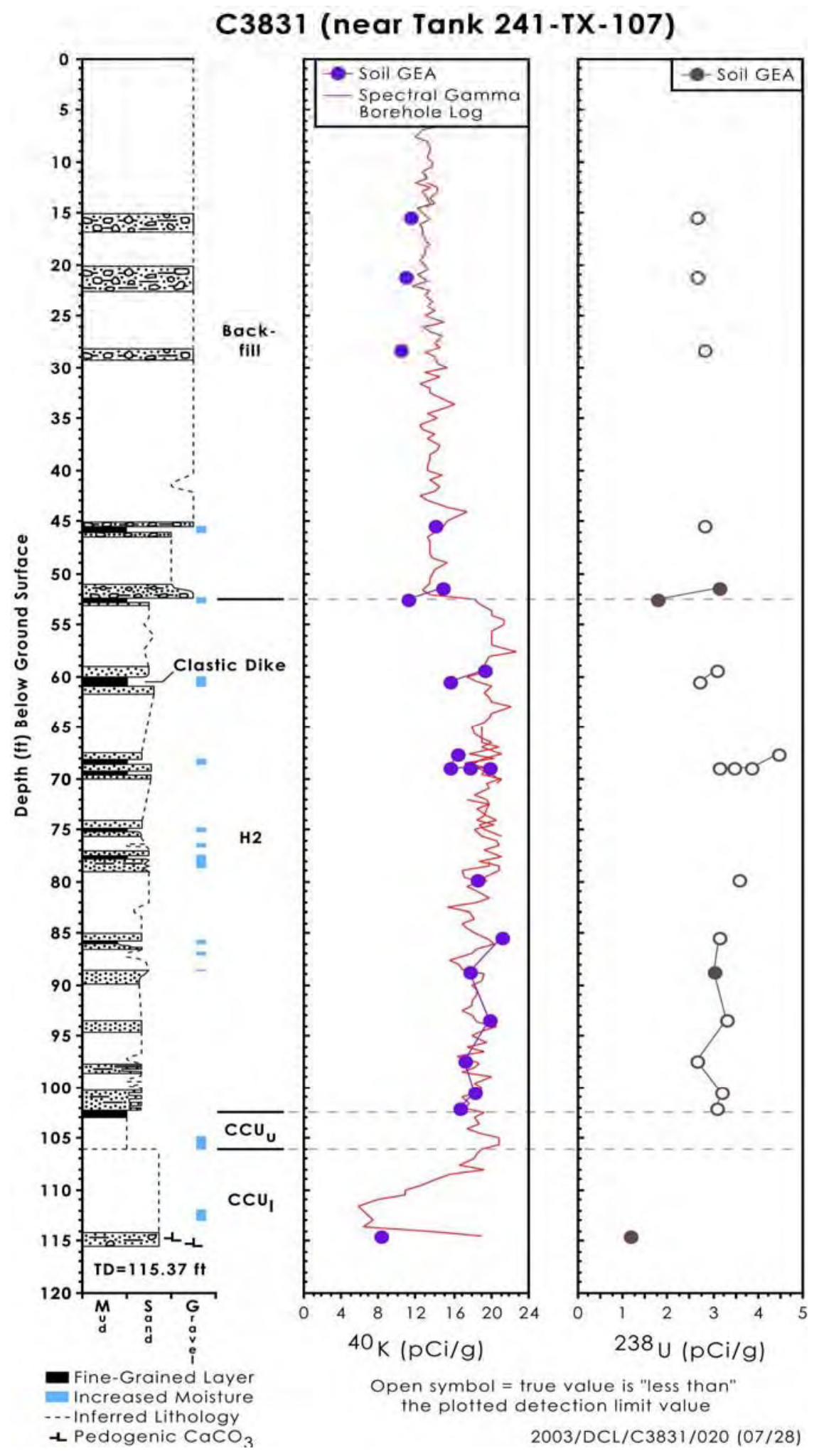

Figure 4.42. Comparison of Lab Gamma Energy Analysis (GEA) and Field Log for Natural Gamma Emitters 


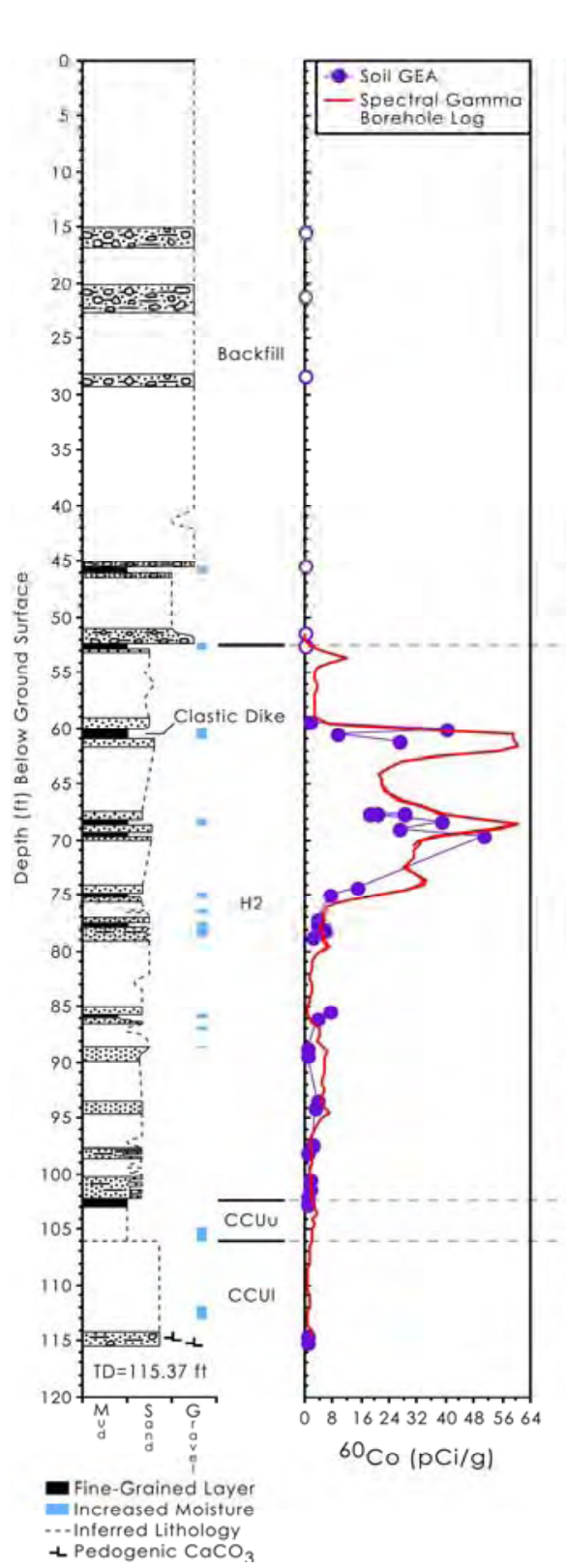

C3831 (near Tank 241-TX-107)

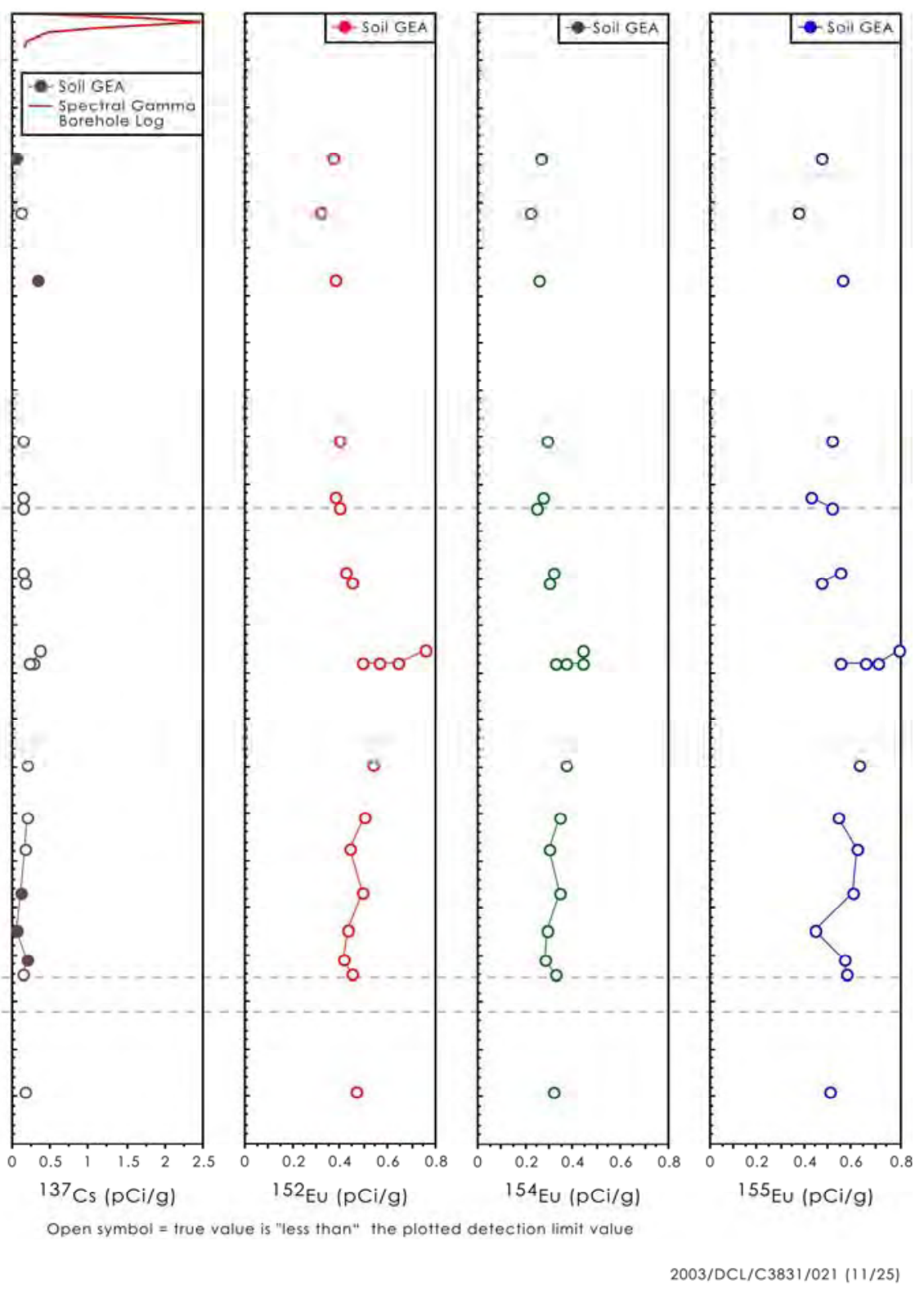

Figure 4.43. Lab and Field Data for Common Gamma Emitters in C3831 Vadose Zone Sediments 
Table 4.46. Cobalt-60 Content of Sediment and Extracts for Vadose Zone Sediments in Borehole C3831

\begin{tabular}{|c|c|c|c|c|c|c|c|c|}
\hline \multirow{3}{*}{$\begin{array}{c}\begin{array}{c}\text { Sample } \\
\text { No. }\end{array} \\
\text { C3831 15B }\end{array}$} & \multirow{3}{*}{$\begin{array}{c}\begin{array}{c}\text { Depth } \\
\text { (ft bgs) }\end{array} \\
15.28\end{array}$} & \multicolumn{7}{|c|}{ Co-60 pCi/g dry sediment } \\
\hline & & \multicolumn{3}{|c|}{ Direct Gamma Energy Analysis } & \multicolumn{2}{|c|}{ Acid Extract } & \multicolumn{2}{|c|}{ Water Extract } \\
\hline & & $<0.107$ & & & & & & \\
\hline C3831 15A & 15.97 & & & & $<3.313$ & & & \\
\hline C3831 21B & 21.18 & $<0.089$ & & & & & & \\
\hline C3831 21A & 21.93 & & & & $<2.185$ & & & \\
\hline C3831 28B & 28.28 & $<0.134$ & & & & & & \\
\hline C3831 28A & 28.90 & & & & $<2.541$ & & & \\
\hline $\mathrm{C} 383145 \mathrm{~B}$ & 45.40 & $<0.105$ & & & & & & \\
\hline $\mathrm{C} 383145 \mathrm{~A}$ & 46.06 & & & & $<3.653$ & & & \\
\hline C3831 51B & 51.35 & $<0.107$ & & & & & & \\
\hline $\mathrm{C} 3831$ 51A & 52.03 & & & & $<3.324$ & & & \\
\hline $\mathrm{C} 3831$ 52B & 52.50 & $<0.140$ & & & & & & \\
\hline $\mathrm{C} 383152 \mathrm{~A}$ & 53.18 & & & & $<2.660$ & & & \\
\hline C3831 59B & 59.34 & 1.521 & & & & & & \\
\hline C3831 59A & 59.94 & 40.120 & & & 10.418 & & 11.075 & \\
\hline C3831 60B & 60.44 & 9.356 & & & & & & \\
\hline $\mathrm{C} 383160 \mathrm{~A}$ & 61.15 & 26.713 & & & 31.288 & & 12.115 & \\
\hline C3831 67B & 67.53 & 28.124 & 20.230 & 18.618 & 27.398 & 24.499 & 7.690 & 6.269 \\
\hline C3831 67A & 68.21 & 38.557 & & & 48.508 & & 11.090 & \\
\hline C3831 69B & 68.82 & 26.562 & & & & & & \\
\hline C3831 69A & 69.60 & 50.877 & & & 44.751 & & 4.956 & \\
\hline C3831 74B & 74.36 & 15.064 & & & & & & \\
\hline C3831 74A & 74.99 & 7.337 & & & 10.519 & & 3.803 & \\
\hline C3831 77B & 77.05 & 3.569 & & & & & & \\
\hline C3831 77A & 77.67 & 3.693 & & & $<3.431$ & & 1.320 & \\
\hline C3831 78B & 78.08 & 5.631 & & & & & & \\
\hline C3831 78A & 78.72 & 2.068 & & & 4.347 & & 1.127 & \\
\hline $\mathrm{C} 383185 \mathrm{~B}$ & 85.37 & 7.165 & & & & & & \\
\hline C3831 85A & 85.99 & 3.647 & & & $<5.210$ & & 3.655 & \\
\hline C3831 88B & 88.67 & 0.731 & & & & & & \\
\hline C3831 88A & 89.39 & 0.452 & & & $<2.817$ & & $<0.903$ & \\
\hline C3831 93B & 93.37 & 3.267 & & & & & & \\
\hline C3831 93A & 93.99 & 2.708 & & & 4.189 & & 1.141 & \\
\hline C3831 97B & 97.43 & 2.363 & & & & & & \\
\hline C3831 97A & 98.07 & 1.005 & & & $<3.663$ & & $<1.98$ & \\
\hline C3831 100B & 100.57 & 1.152 & & & & & & \\
\hline C3831 100A & 101.29 & 1.408 & & & $<2.785$ & & 0.744 & \\
\hline C3831 102B & 101.97 & 0.916 & & & & & & \\
\hline C3831 102A & 102.65 & 0.582 & & & $<3.121$ & & 0.540 & \\
\hline C3831 114B & 114.44 & 0.875 & 0.694 & 0.579 & $<4.325$ & $<3.178$ & $<2.16$ & $<0.934$ \\
\hline $\mathrm{C} 3831114 \mathrm{~A}$ & 115.06 & 0.570 & & & $<2.450$ & & $<1.550$ & \\
\hline
\end{tabular}




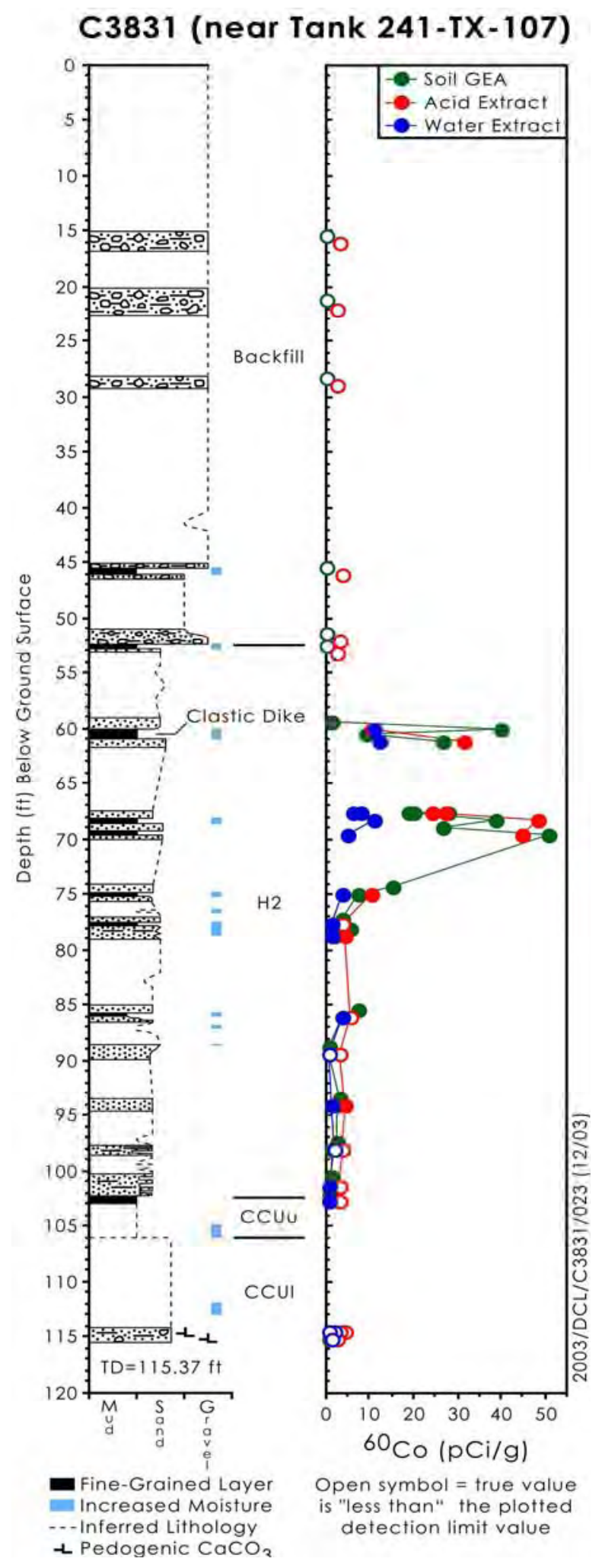

Figure 4.44. Lab Data for Cobalt-60 Extracts of C3831 Vadose Zone Sediments 
Table 4.47. Carbon Contents of Vadose Zone Sediments in Borehole C3831

\begin{tabular}{|c|c|c|c|c|c|}
\hline $\begin{array}{c}\text { Depth } \\
\text { (ft bgs) }\end{array}$ & $\begin{array}{c}\text { Stratigraphic } \\
\text { Unit }\end{array}$ & $\begin{array}{c}\text { Total } \\
\text { Carbon } \\
\% \\
\end{array}$ & $\begin{array}{c}\text { Inorganic } \\
\text { Carbon } \\
\% \\
\end{array}$ & $\begin{array}{c}\mathrm{IC} \text { as } \\
\mathrm{CaCO}_{3} \\
\% \\
\end{array}$ & $\begin{array}{c}\text { Organic } \\
\text { Carbon } \\
\% \\
\end{array}$ \\
\hline 15.97 & $\mathrm{Bkfl}$ & 0.11 & 0.07 & 0.59 & 0.04 \\
\hline 21.93 & $\mathrm{Bkfl}$ & 0.13 & 0.11 & 0.91 & 0.02 \\
\hline 28.90 & Bkfl & 0.13 & 0.14 & 1.13 & 0.01 \\
\hline 46.06 & $\mathrm{Bkfl}$ & 1.63 & 1.23 & 10.26 & 0.40 \\
\hline 52.03 & Bkfl & 0.23 & 0.18 & 1.46 & 0.05 \\
\hline 53.18 & $\mathrm{H} 2$ & 0.25 & 0.19 & 1.58 & 0.06 \\
\hline 59.94 & $\mathrm{H} 2$ & 0.23 & 0.19 & 1.58 & 0.04 \\
\hline 61.15 & $\mathrm{H} 2$ & 0.22 & 0.14 & 1.20 & 0.08 \\
\hline 67.53 & $\mathrm{H} 2$ & 0.25 & 0.20 & 1.63 & 0.05 \\
\hline 67.53 & $\mathrm{H} 2$ & 0.23 & 0.20 & 1.65 & 0.03 \\
\hline 68.21 & $\mathrm{H} 2$ & 0.25 & 0.18 & 1.51 & 0.07 \\
\hline 69.60 & $\mathrm{H} 2$ & 0.28 & 0.24 & 1.99 & 0.04 \\
\hline 74.99 & $\mathrm{H} 2$ & 0.26 & 0.21 & 1.71 & 0.05 \\
\hline 77.67 & $\mathrm{H} 2$ & 0.22 & 0.18 & 1.52 & 0.04 \\
\hline 78.72 & $\mathrm{H} 2$ & 0.25 & 0.21 & 1.73 & 0.04 \\
\hline 85.99 & $\mathrm{H} 2$ & 0.35 & 0.32 & 2.71 & 0.03 \\
\hline 89.39 & $\mathrm{H} 2$ & 0.24 & 0.20 & 1.63 & 0.04 \\
\hline 93.99 & $\mathrm{H} 2$ & 0.23 & 0.20 & 1.64 & 0.03 \\
\hline 98.07 & $\mathrm{H} 2$ & 0.30 & 0.24 & 2.00 & 0.06 \\
\hline 101.29 & $\mathrm{H} 2$ & 0.26 & 0.22 & 1.87 & 0.04 \\
\hline 102.65 & $\mathrm{CCU}_{\mathrm{u}}$ & 0.44 & 0.36 & 3.01 & 0.08 \\
\hline $114.44^{*}$ & $\mathrm{CCU}_{1}$ & 2.14 & 1.95 & 16.26 & 0.19 \\
\hline $114.44 *$ & $\mathrm{CCU}_{1}$ & 2.68 & 2.58 & 21.50 & 0.10 \\
\hline 115.06 & $\mathrm{CCU}_{1}$ & 4.34 & 4.10 & 34.17 & 0.23 \\
\hline
\end{tabular}




\subsection{Vadose Zone Sediment from Borehole C3832}

Borehole C3832 was pushed into the vadose zone sediment approximately $20 \mathrm{ft}$ south-southeast of tank TX-104 to evaluate whether there is evidence to support designating tank TX-104 as having leaked in the past. The borehole reached a depth of $115.9 \mathrm{ft}$ bgs at which point driving the probe met refusal.

\subsubsection{Moisture Content}

The moisture content of the 38 cores liners as a function of depth and lithology are shown in Table 4.48 and Figure 2.26. The backfill samples have a mean moisture content of $7.1 \%$ by weight with significant variation and a wet zone at the very bottom at $45 \mathrm{ft}$ bgs. The moisture in the backfill at C3832 is much more variable and, on average, one percent by weight wetter than the backfill sediments in borehole C3830 near tank TX-105, but is the same as the moisture content as borehole C3831 near tank TX-107 (Table 2.5). The Hanford formation H2 samples from borehole C3832 have a mean moisture content of $9.2 \%$ by weight with variation that tracks variations in particle size (finer grained samples have slightly higher moisture contents). The Hanford formation $\mathrm{H} 2$ sediments in borehole $\mathrm{C} 3832$ are on average $3.5 \%$ by weight wetter than the $\mathrm{H} 2$ sediments at borehole $\mathrm{C} 3830$ and $0.5 \%$ by weight wetter than the $\mathrm{H} 2$ sediments at borehole $\mathrm{C} 3831$. At borehole $\mathrm{C} 3832$, the Cold Creek upper subunit is $\sim 10 \%$ by weight, about typical for a fine-grained sediment in the vadose zone at Hanford. The Cold Creek lower subunit (caliche) at $\mathrm{C} 3832$ has an average moisture content of $\sim 11 \% \mathrm{wt}$, slightly less than the average for this unit at boreholes C3830 and C3831.

The average moisture content of the $\mathrm{H} 2$ unit samples measured in borehole $\mathrm{C} 3832$ is about $4.5 \%$ by weight greater than the average for the same stratigraphic unit at the uncontaminated borehole 299-W10-27. We speculate that this wetter Hanford H2 sediment is significant and an indication of the various tank farm operations (e.g., gravel cover) that encourage higher moisture infiltration.

\subsubsection{1:1 Sediment:Water Extracts for Borehole C3832}

The A liners from the 19 and two B liners (run in duplicate) cores were characterized after the geologic descriptions by performing 1:1 water:sediment extracts. In total, 23 separate sediment samples were characterized. The following tables and figures present the mass of a given constituent leached per gram of sediment as measured in the water extracts to allow direct comparison to the same data for the background borehole sediments from borehole 299-W10-27 and the other two boreholes. Other figures show dilution-corrected values that represent concentrations in vadose zone porewater in borehole C3832. As discussed in several other Vadose Zone Characterization Project reports, the dilution-corrected 1:1 water:sediment extracts are a reasonable derivation of the actual vadose zone porewater (see Serne et al. 2002b, 2002c, 2002d, 2002e, 2002f). 
Table 4.48. Moisture Content of Borehole C3832 Cores

\begin{tabular}{|c|c|c|c|c|}
\hline Sample No. & $\begin{array}{c}\text { Depth } \\
\text { (ft bgs) }\end{array}$ & $\begin{array}{c}\text { Stratigraphic } \\
\text { Unit }\end{array}$ & Lithology & $\begin{array}{c}\text { Moisture } \\
\text { Content }\end{array}$ \\
\hline $15 \mathrm{~B}$ & 16.56 & \multirow{2}{*}{ backfill } & \multirow{2}{*}{ Silty sandy gravel } & $4.10 \%$ \\
\hline $15 \mathrm{~A}$ & 17.26 & & & $5.87 \%$ \\
\hline $28 \mathrm{~B}$ & 28.44 & \multirow{2}{*}{ backfill } & \multirow{2}{*}{ Silty sandy gravel } & $5.22 \%$ \\
\hline $28 \mathrm{~A}$ & 29.14 & & & $4.47 \%$ \\
\hline $37 \mathrm{~B}$ & 36.44 & \multirow{2}{*}{ backfill } & \multirow{2}{*}{ Sandy gravel } & $5.07 \%$ \\
\hline $37 \mathrm{~A}$ & 37.14 & & & $4.62 \%$ \\
\hline $44 \mathrm{~B}$ & 44.49 & \multirow{2}{*}{ backfill } & \multirow{2}{*}{ Silty sand } & $15.67 \%$ \\
\hline $44 \mathrm{~A}$ & 45.19 & & & $10.96 \%$ \\
\hline $52 \mathrm{~B}$ & 51.46 & \multirow{2}{*}{$\mathrm{H} 2$} & \multirow{2}{*}{ Sand } & $6.77 \%$ \\
\hline $52 \mathrm{~A}$ & 52.01 & & & $6.57 \%$ \\
\hline $53 \mathrm{~B}$ & 53.42 & \multirow{2}{*}{$\mathrm{H} 2$} & \multirow{2}{*}{ Sand to silty sand } & $18.40 \%$ \\
\hline $53 \mathrm{~A}$ & 54.10 & & & $7.39 \%$ \\
\hline $61 \mathrm{~B}$ & 60.47 & \multirow{2}{*}{$\mathrm{H} 2$} & \multirow{2}{*}{ Sand } & $6.78 \%$ \\
\hline $61 \mathrm{~A}$ & 61.17 & & & $3.75 \%$ \\
\hline $62 \mathrm{~B}$ & 62.16 & \multirow{2}{*}{$\mathrm{H} 2$} & \multirow{2}{*}{ Silty sand to sand } & $10.87 \%$ \\
\hline $62 \mathrm{~A}$ & 62.96 & & & $5.19 \%$ \\
\hline $69 \mathrm{~B}$ & 69.34 & \multirow{2}{*}{$\mathrm{H} 2$} & \multirow{2}{*}{ Sand to silty sand } & $5.76 \%$ \\
\hline $69 \mathrm{~A}$ & 69.99 & & & $14.74 \%$ \\
\hline $76 \mathrm{~B}$ & 76.34 & \multirow{3}{*}{$\mathrm{H} 2$} & \multirow{3}{*}{ Sand to silty sand } & $10.14 \%$ \\
\hline 76B Dup & 76.34 & & & $11.00 \%$ \\
\hline $76 \mathrm{~A}$ & 77.04 & & & $15.47 \%$ \\
\hline $79 \mathrm{~B}$ & 78.80 & \multirow{2}{*}{$\mathrm{H} 2$} & \multirow{2}{*}{$\begin{array}{c}\text { Sand to silty } \\
\text { sand/sandy silt }\end{array}$} & $11.04 \%$ \\
\hline $79 \mathrm{~A}$ & 79.81 & & & $10.02 \%$ \\
\hline $83 \mathrm{~B}$ & 83.33 & \multirow{2}{*}{$\mathrm{H} 2$} & \multirow{2}{*}{ Sand to silty sand } & $9.57 \%$ \\
\hline $83 \mathrm{~A}$ & 84.01 & & & $12.33 \%$ \\
\hline $87 \mathrm{~B}$ & 87.35 & \multirow{2}{*}{$\mathrm{H} 2$} & \multirow{2}{*}{ Sand to silty sand } & $7.79 \%$ \\
\hline $87 \mathrm{~A}$ & 88.06 & & & $5.21 \%$ \\
\hline $93 \mathrm{~B}$ & 93.35 & \multirow{2}{*}{$\mathrm{H} 2$} & \multirow{2}{*}{ Sand to silty sand } & $8.56 \%$ \\
\hline $93 \mathrm{~A}$ & 94.05 & & & $5.25 \%$ \\
\hline $96 \mathrm{~B}$ & 95.99 & \multirow{2}{*}{$\mathrm{H} 2$} & \multirow{2}{*}{ Sand } & $11.74 \%$ \\
\hline $96 \mathrm{~A}$ & 96.69 & & & $7.81 \%$ \\
\hline
\end{tabular}


Table 4.48. (contd)

\begin{tabular}{|c|c|c|c|c|}
\hline Sample No. & $\begin{array}{l}\text { Depth } \\
\text { (ft bgs) }\end{array}$ & $\begin{array}{c}\text { Stratigraphic } \\
\text { Unit }\end{array}$ & Lithology & $\begin{array}{c}\text { Moisture } \\
\text { Content }\end{array}$ \\
\hline 104B & 104.30 & \multirow{2}{*}{$\mathrm{CCU}_{\mathrm{u}}$} & \multirow{2}{*}{ Silty sand to silt } & $9.89 \%$ \\
\hline $104 \mathrm{~A}$ & 105.01 & & & $9.28 \%$ \\
\hline 110B & 110.28 & \multirow{2}{*}{$\mathrm{CCU}_{\mathrm{u}}$} & \multirow{2}{*}{ Silty sand } & $10.81 \%$ \\
\hline 110B Dup & 110.28 & & & $11.03 \%$ \\
\hline $110 \mathrm{~A}$ & 111.02 & $\mathrm{CCU}_{1}$ & $\begin{array}{l}\text { Calcic pebbly muddy } \\
\text { sand }\end{array}$ & $13.67 \%$ \\
\hline 114B & 114.13 & \multirow{2}{*}{$\mathrm{CCU}_{1}$} & \multirow{2}{*}{ Pebbly sandy mud } & $10.74 \%$ \\
\hline $114 \mathrm{~A}$ & 114.85 & & & $9.21 \%$ \\
\hline $121 \mathrm{~B}$ & 114.83 & \multirow{2}{*}{$\mathrm{CCU}_{1}$} & \multirow{2}{*}{ Pebbly sandy mud } & $9.98 \%$ \\
\hline $121 \mathrm{~A}$ & 115.54 & & & $10.30 \%$ \\
\hline
\end{tabular}

\subsubsection{1 pH and Electrical Conductivity (EC)}

The 1:1 sediment:water extract $\mathrm{pH}$ and $\mathrm{EC}$ data are shown in Table 4.49. Both the extract and dilution-corrected EC values are shown. Figure 4.45 shows the 1:1 sediment:water extract $\mathrm{pH}$ value and dilution-corrected EC as a function of depth and stratigraphy. A comparison of the data in Table 4.49 with the $\mathrm{pH}$ and EC of the 299-W10-27 extracts suggests evidence of slightly elevated EC starting at 63 to $84 \mathrm{ft} \mathrm{bgs}$, and then from $97 \mathrm{ft}$ bgs all the way to the bottom of the borehole at $115.5 \mathrm{ft}$ bgs. In the shallower zone ( 63 to $83 \mathrm{ft}$ bgs) at $\mathrm{C} 3832$, the $\mathrm{EC}$ of the 1:1 water extract increases to between 1.6 and 2.6 times the background sediment. Between 67.5 and $78 \mathrm{ft}$ bgs, the EC is about 5 times larger than background sediment extracts. In the Cold Creek unit the EC at borehole C3832 is 2 to 4 times higher than that in background sediments. When compared to the EC at borehole C3830 (see Table 4.18) and borehole $\mathrm{C} 3831$ (see Table 4.33), the values at C3832 are lower in the $\mathrm{H} 2$ unit and slightly greater than those at C3830 in the Cold Creek units, and unequivocally lower than the EC values at borehole C3831 in both the $\mathrm{H} 2$ and $\mathrm{CCU}_{\mathrm{u}}$ units. The $\mathrm{EC}$ values at borehole $\mathrm{C} 3832$ are indicative of the presence of slightly saline tank-related fluids. The borehole $\mathrm{C} 3832$ water extract $\mathrm{pH}$ values are all below 8 , suggesting that the tank fluids were either not strongly alkaline or that the volume of alkaline tank fluids was relatively small and readily neutralized in the sediments.

The highest values of dilution-corrected porewater EC in borehole C3832 occur in two zones, between 61 to $63 \mathrm{ft}$ bgs and 110.3 to the bottom of the hole at $115.5 \mathrm{ft}$ bgs. The dilution-corrected EC values for these two zones are equivalent to a pore solution of 0.042 and $0.051 \mathrm{M} \mathrm{KCl}$, the salt solution used to calibrate the conductivity cell. The leaks near the SX108-109 and BX-102 tanks had peak vadose zone porewater concentrations that were equivalent to much more concentrated waste fluids, 7 to 17 and 0.7 to $1 \mathrm{M} \mathrm{KCl}$ solutions, respectively. The maximum dilution-corrected $\mathrm{EC}$ at borehole $\mathrm{C} 3832$ in the $\mathrm{H} 2$ unit is $4.54 \mathrm{mS} / \mathrm{cm}$, lower than the dilution-corrected EC at borehole C3830 $(12.5 \mathrm{mS} / \mathrm{cm})$ and 299-E33-46 near tank B-110 that contained $15.1 \mathrm{mS} / \mathrm{cm}$. The highest dilution-corrected EC at borehole $\mathrm{C} 3832$ occurs in the $\mathrm{CCU}_{1}$ unit with a value of $6.27 \mathrm{mS} / \mathrm{cm}$. 
As shown in Figure 4.45, the dissolved salts are locally high in sodium and nitrate. The sodium peak value occurs at $63 \mathrm{ft}$ bgs at a value of $0.04 \mathrm{M}$ and the nitrate peak value is at the contact (110.4 $\mathrm{ft}$ bgs) between the upper Cold Creek mud subunit and the lower Cold Creek (caliche) subunit with a value of $0.015 \mathrm{M}$.

Table 4.49. pH and EC Data for Sediment-Water Extracts from Borehole 3832

\begin{tabular}{|c|c|c|c|c|c|}
\hline Sample No. & $\begin{array}{c}\text { Depth } \\
\text { (ft bgs) }\end{array}$ & Stratigraphic Unit & pH & $\begin{array}{c}\text { Conductivity } \\
\mathrm{mS} / \mathrm{cm}\end{array}$ & \begin{tabular}{|c} 
Dilution-Corrected \\
Porewater \\
$(\mathrm{mS} / \mathrm{cm})$
\end{tabular} \\
\hline $15 \mathrm{~A}$ & 17.26 & backfill & 7.24 & 0.150 & 2.557 \\
\hline $28 \mathrm{~A}$ & 29.14 & backfill & 7.30 & 0.160 & 3.577 \\
\hline $37 \mathrm{~A}$ & 37.14 & backfill & 7.36 & 0.185 & 4.008 \\
\hline $44 \mathrm{~A}$ & 45.19 & backfill & 7.50 & 0.217 & 1.982 \\
\hline $52 \mathrm{~A}$ & 52.01 & $\mathrm{H} 2$ & 7.42 & 0.167 & 2.547 \\
\hline $53 \mathrm{~A}$ & 54.10 & $\mathrm{H} 2$ & 7.49 & 0.175 & 2.409 \\
\hline $61 \mathrm{~A}$ & 61.17 & $\mathrm{H} 2$ & 7.48 & 0.161 & 4.304 \\
\hline $62 \mathrm{~A}$ & 62.96 & $\mathrm{H} 2$ & 7.70 & 0.235 & 4.537 \\
\hline $69 \mathrm{~A}$ & 69.99 & $\mathrm{H} 2$ & 7.69 & 0.232 & 1.576 \\
\hline $76 \mathrm{~B}$ & 76.34 & $\mathrm{H} 2$ & 7.72 & 0.391 & 3.864 \\
\hline 76B Dup & 76.34 & $\mathrm{H} 2$ & 7.92 & 0.387 & 3.519 \\
\hline $76 \mathrm{~A}$ & 77.04 & $\mathrm{H} 2$ & 7.52 & 0.384 & 2.484 \\
\hline $79 \mathrm{~A}$ & 79.81 & $\mathrm{H} 2$ & 7.44 & 0.245 & 2.449 \\
\hline $83 \mathrm{~A}$ & 84.01 & $\mathrm{H} 2$ & 7.37 & 0.246 & 1.994 \\
\hline $87 \mathrm{~A}$ & 88.06 & $\mathrm{H} 2$ & 7.44 & 0.161 & 3.097 \\
\hline $93 \mathrm{~A}$ & 94.05 & $\mathrm{H} 2$ & 7.52 & 0.173 & 3.491 \\
\hline $96 \mathrm{~A}$ & 96.69 & $\mathrm{H} 2$ & 7.51 & 0.226 & 2.895 \\
\hline $104 \mathrm{~A}$ & 105.01 & $\mathrm{CCU}_{\mathrm{u}}$ & 7.46 & 0.289 & 3.346 \\
\hline $110 \mathrm{~B}$ & 110.28 & \multirow{2}{*}{$\mathrm{CCU}_{\mathrm{u}}$} & 7.55 & 0.478 & 4.422 \\
\hline 110B Dup & 110.28 & & 7.59 & 0.574 & 5.213 \\
\hline $110 \mathrm{~A}$ & 111.02 & $\mathrm{CCU}_{1}$ & 7.48 & 0.671 & 4.920 \\
\hline $114 \mathrm{~A}$ & 114.85 & $\mathrm{CCU}_{1}$ & 7.51 & 0.578 & 6.273 \\
\hline $121 \mathrm{~A}$ & 115.54 & $\mathrm{CCU}_{1}$ & 7.64 & 0.555 & 5.389 \\
\hline
\end{tabular}




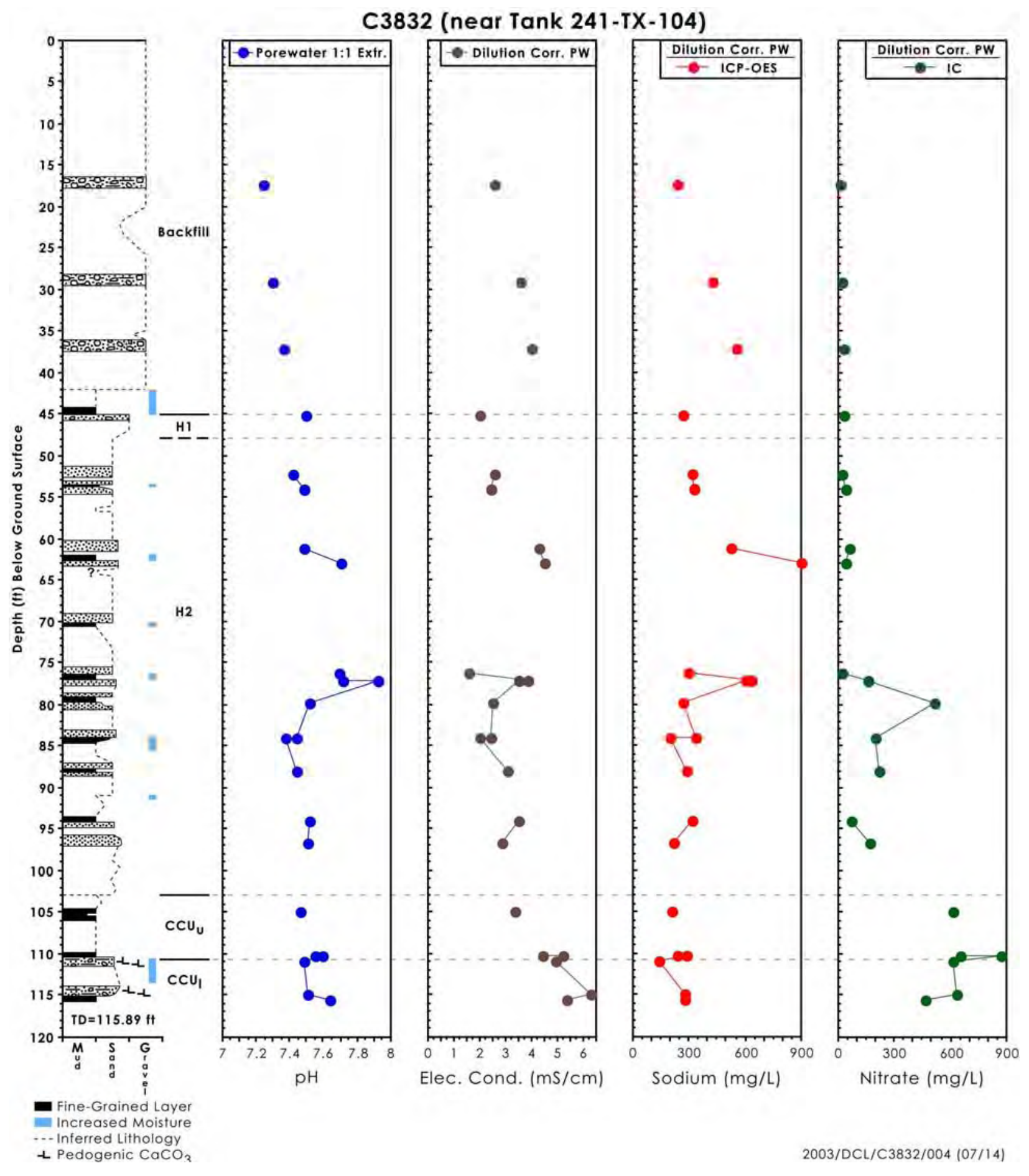

Figure 4.45. Borehole 3832 Sediment-to-Water Extract $\mathrm{pH}$ and Calculated Porewater EC, Sodium, and Nitrate 


\subsubsection{Water Extract Composition or the 1:1 Sediment:Water Extract for Borehole C3832}

The water extract values for the major cations and anions and several trace constituents are discussed in this section. The anion data are tabulated in Tables 4.50 and 4.51 and Figure 4.46 in units of mass per gram of dry sediment. The data for the water extracts of borehole C3832 for fluoride are elevated slightly in comparison to the background sediment at 299-W10-27 and borehole C3830 but almost a factor of 10 lower than at borehole $\mathrm{C} 3831$. The chloride concentrations in the borehole $\mathrm{C} 3832$ sediments are elevated in two zones, between 76 to 77 and 105 to $111 \mathrm{ft}$ bgs, by a factor of 10 to 20 times larger than the background sediment. The water-extractable chloride concentrations in C3832 are quite similar to the chloride in borehole $\mathrm{C} 3830$ sediments and both are significantly less than the water-extractable chloride in borehole C3831 sediments. The nitrate water extract values for borehole C3832 are elevated compared to the background sediments from $76 \mathrm{ft}$ bgs to the deepest sample obtained except the sample at $94 \mathrm{ft}$ bgs. The nitrate water extract values are 20 to 30 times larger than for the background sediments at $77 \mathrm{ft}$ bgs and between the depths of 105 and $111 \mathrm{ft}$ bgs. The nitrate concentrations in the borehole $\mathrm{C} 3832$ are the same as those at borehole $\mathrm{C} 3830$ in the $\mathrm{H} 2$ sediments down to $97 \mathrm{ft}$ bgs, but higher than the $\mathrm{C} 3830$ sediments below $97 \mathrm{ft}$ bgs. Both $\mathrm{C} 3832$ and $\mathrm{C} 3830$ sediments contain $\sim 5$ to 10 times less nitrate than those in borehole $\mathrm{C} 3831$. The sulfate water extracts from borehole $\mathrm{C} 3832$ are elevated from about $76 \mathrm{ft}$ bgs to the deepest sample obtained and the values exceed the background sediment values by a factor of 3 to 10 . The water-extractable sulfate values for sediments from borehole C3832 are similar to those in borehole $\mathrm{C} 3830$ in the shallow $\mathrm{H} 2$ impacted zone but slightly larger in the sediments below $97 \mathrm{ft}$ bgs than the water-extractable sulfate in borehole C3830. Borehole C3831 water-extractable sulfate values are $\sim 2$ times larger than those at the other two boreholes.

There is also above background water-extractable phosphate (at one depth $76.34 \mathrm{ft} \mathrm{bgs)}$ and nitrite (in two zones ( 77 to $84 \mathrm{ft}$ bgs and 110.3 to the bottom of the borehole at $115.5 \mathrm{ft}$ bgs) in borehole C3832. The agreement between measuring the water extracts for phosphate and sulfate directly with the ion chromatograph and indirectly by converting the ICP measurements for phosphorous and sulfur are very good (see Figure 4.46). Besides validating the ion chromatography data, we can state that the waterextractable sulfur and phosphorous species exist as sulfate and phosphate.

The water-extractable small organic molecules in the $\mathrm{C} 3832$ borehole sediments are shown in Table 4.51. Several samples have values that appear to be slightly elevated over background sediments and for sediments at the other two boreholes, excepting one sample at $61.15 \mathrm{bgs}$ at C3831. The values in C3832 sediments that appear elevated are noted in bold type in Table 4.51. None of the values are above $10 \mathrm{ppm}$ and we do not have enough data on water-extractable formate, acetate, or oxalate from Hanford Area sediments to form conclusions as to whether these values indicate that any organics were present in tank fluid and still persist today in the vadose zone. Note that one of the sample 76 replicates has significantly greater organic concentrations than its mate. Whether this signifies analytical vagaries or true sample heterogeneity is unknown.

The water-extractable major cations in the borehole C3832 sediments are tabulated in Table 4.52 and the distribution with depth is shown in Figure 4.47. The distribution of the divalent alkaline earth cations ( $\mathrm{Mg}, \mathrm{Ca}$, and $\mathrm{Sr}$ but not $\mathrm{Ba}$ ) shows low water-extractable quantities between 63 and $97 \mathrm{ft}$ bgs excepting the sample at $77 \mathrm{ft}$ bgs. High divalent cation water extracts are found below in the Cold Creek unit. Conversely, the distribution of water-extractable sodium is elevated between the depths of 63 and 77 bgs. The water-extractable sodium values in borehole C3832 sediments are higher than the values in the uncontaminated sediments from borehole $299-$ W10-27 over the whole borehole profile, even in the 
backfill above the tank. These trends suggest that tank fluids that contained sodium did seep into the vadose zone near this borehole. The sodium displaced the natural divalent cations and some of the natural potassium off the sediment cation exchange sites in the sediments between 63 and at least 76 if not all the way to the bottom of the $\mathrm{H} 2$ unit at $102 \mathrm{ft}$ bgs. We have observed the same cation distribution and ion exchange fronts where divalent cations and sometimes potassium are depleted and high levels of water-extractable sodium are present in the shallow sediments at both the SX and BX tank farms, where tank fluids have been confirmed as being present (for details, see Serne et al. 2002b, 2002c, 2002d, 2002e, 2002f). Right below the leading edge of the sodium plume one finds elevated levels of divalent cations that were displaced. We observe the highest levels of water-extractable divalent cations in the C3832 samples below the Hanford formation Cold Creek unit contact to the bottom of the borehole. At borehole $\mathrm{C} 3832$, the water-extractable magnesium, calcium, strontium, potassium, and sodium in the sediments in both Cold Creek units (from $105 \mathrm{ft}$ bgs to the bottom of the borehole) are larger than for the background sediment in borehole 299-W10-27 and also borehole C3830 sediments by a factor of 2 to 5 . This likely is an indication that a larger volume of tank fluids passed through the C3832 sediments from $75 \mathrm{ft}$ bgs to the bottom of the borehole than passed through the vadose zone at borehole 3830 . There is no clear indication that tank fluids descended vertically from the tank bottom to $75 \mathrm{ft}$ bgs at borehole C3832. The data for the available samples suggests that tank fluids migrated horizontally at $\sim 75 \mathrm{ft}$ into the sediments intercepted by borehole C3832 and then descended vertically.

It is odd that the water-extractable sodium values but not the water-extractable nitrate values are higher in the borehole C3830 and C3832 backfill sediments. Generally, Hanford waste streams are elevated in both constituents. The vadose zone sediment profiles for boreholes C3830 and C3832 may reflect that there were surface spills of waste that had the mobile nitrate pushed deeper by natural recharge. There is evidence of some surface spillage at these two boreholes based on the cesium-137 distribution measured by the field logging activities. The sediment water extract profiles also suggest that there were some tank-related fluids introduced at depths near 55 to $65 \mathrm{ft}$ bgs, somewhat below the depths of the tank bottoms. 


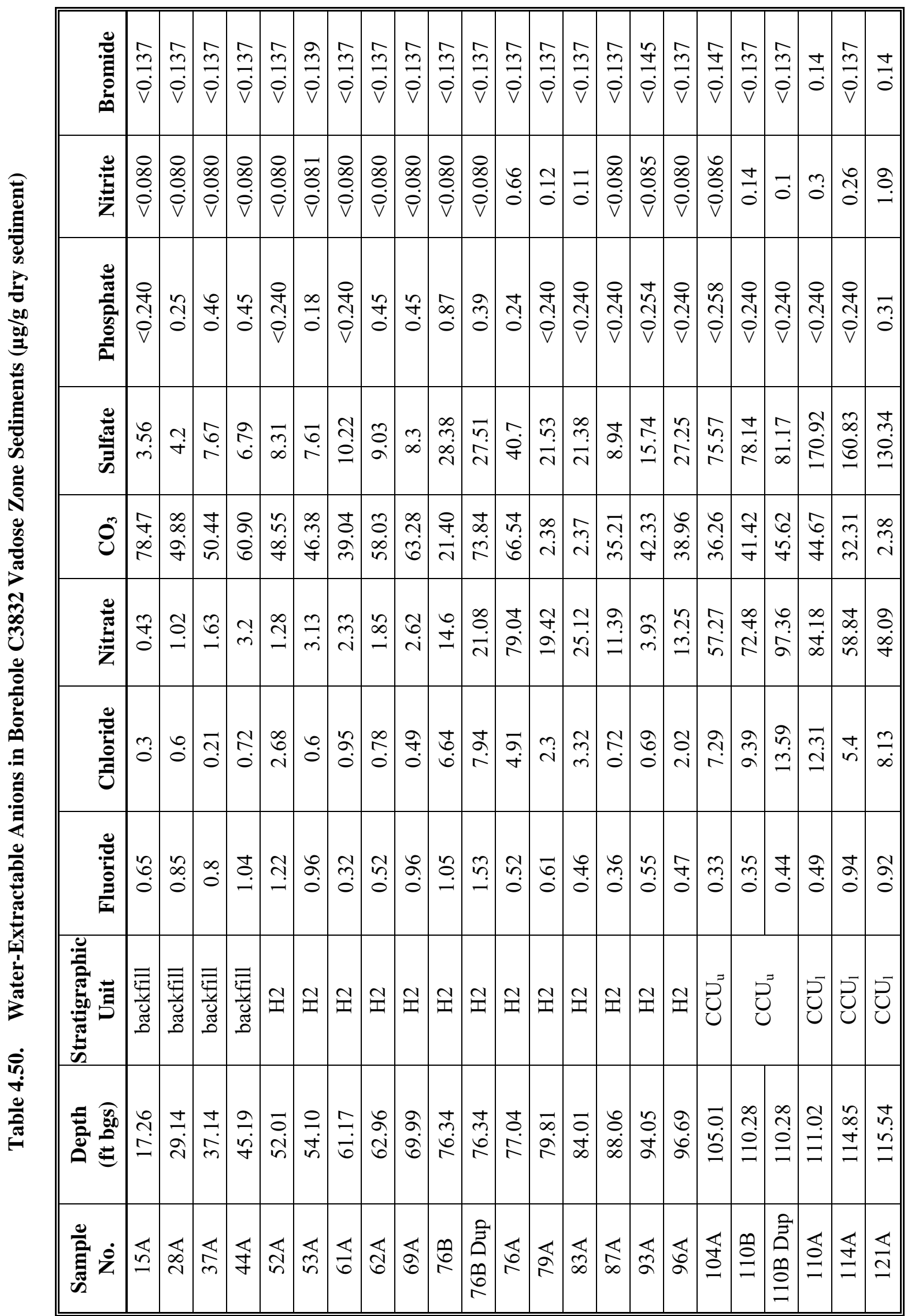



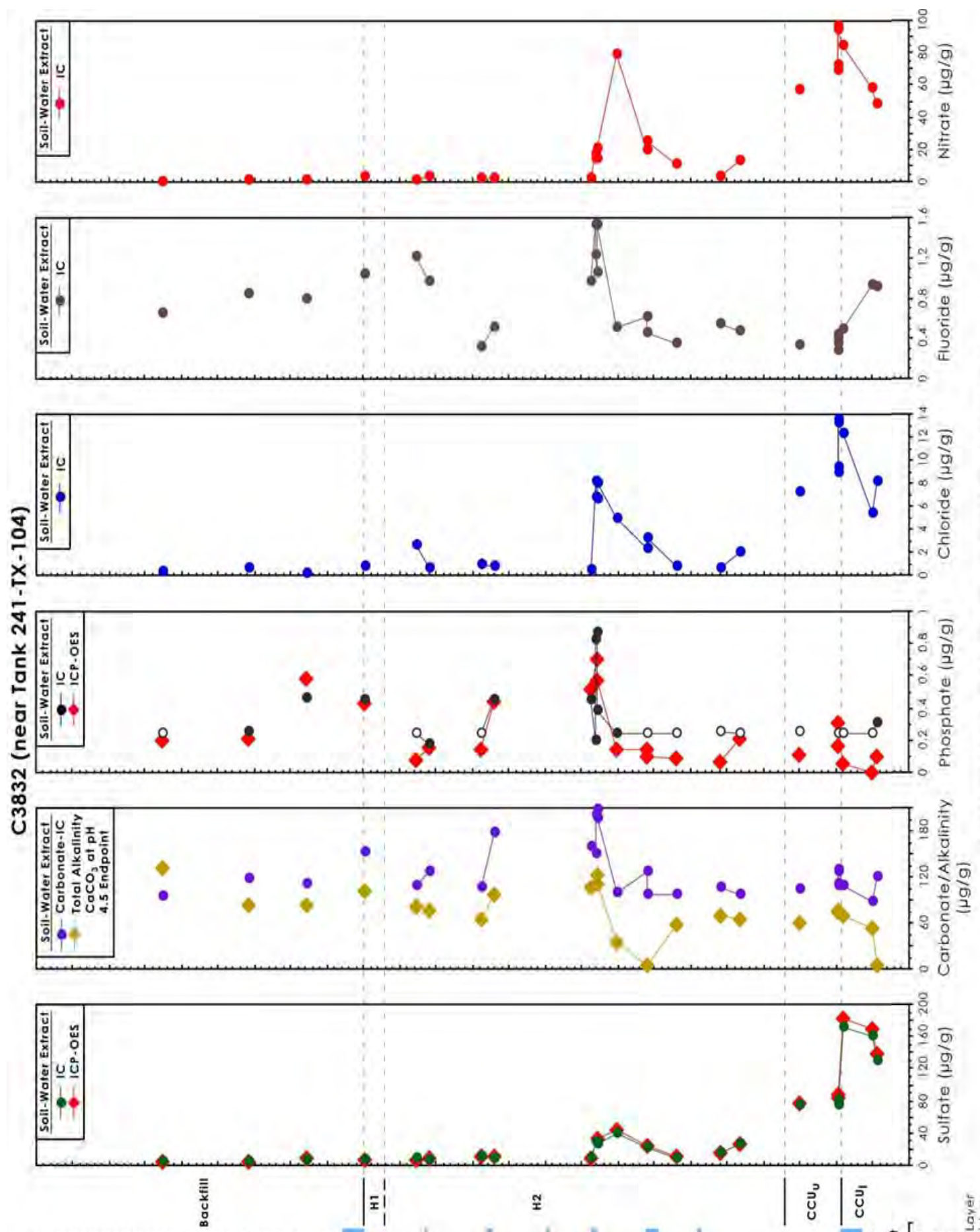



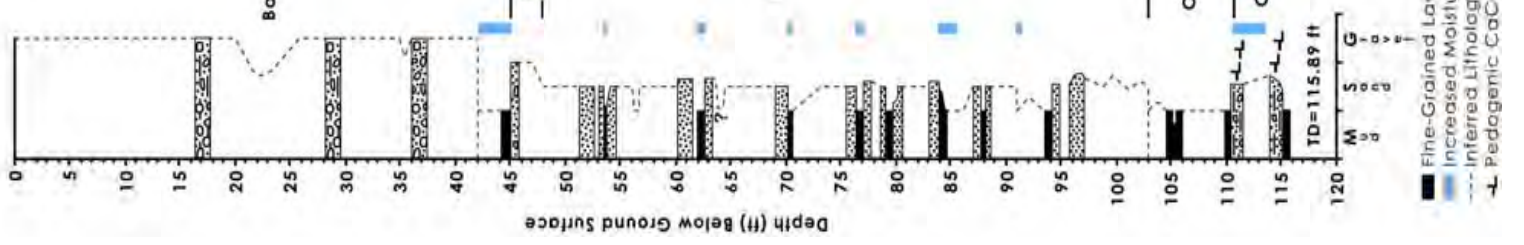


The water-extractable aluminum, silicon, iron, manganese, zinc, phosphorous, and sulfur in the C3832 borehole sediments are shown in Table 4.53 and Figure 4.48. The phosphorous and sulfur data were converted to water-extractable phosphate and sulfate and plotted with the anion data in Figure 4.46. In general, the agreement between direct measurement of the two anions by ion chromatography and the converted ICP measurements of water-extractable phosphorous and sulfur are very good. The borehole C3832 water-soluble aluminum data show elevated values between the depths of 63 and $76.3 \mathrm{ft}$ bgs and the water-soluble iron is high at $70 \mathrm{ft}$ bgs. We speculate that these elevated values indicate some chemical reaction between tank fluids and native sediments that formed precipitates of aluminum and iron that are more water soluble than the natural aluminum and iron phases present in the native sediments. In this zone at borehole $\mathrm{C} 3832$, the water-extractable aluminum is very similar to the values at borehole C3830 but both are significantly lower than the water-soluble aluminum concentrations at borehole C3831. The water-extractable iron at $70 \mathrm{ft}$ bgs in borehole C3832 is larger than at C3830 and both are lower than at borehole $\mathrm{C} 3831$. The water-extractable zinc values at $76.34 \mathrm{ft}$ bgs and from $105 \mathrm{ft}$ bgs to the bottom of borehole C3832 appear to be larger than at borehole C3830 and about the same as at borehole $\mathrm{C} 3831$. The water-extractable sulfur values in borehole $\mathrm{C} 3832$ in the 76 to $84 \mathrm{ft}$ bgs zone do not differ much from those at borehole $\mathrm{C} 3830$ but both boreholes show elevated water-soluble sulfate in comparison to sulfur that is water extractable from background sediments. At borehole C3832 the water-soluble sulfate from $97 \mathrm{ft}$ bgs to the bottom of the borehole is larger than at boreholes $\mathrm{C} 3830$ and C3831. This suggests that more sulfate-bearing waste leaked into the Cold Creek units at borehole C3832 than at borehole $\mathrm{C} 3830$. The water-extractable phosphorous at borehole $\mathrm{C} 3832$ between the depths of 63 and $76.3 \mathrm{ft}$ bgs is greater than at borehole $\mathrm{C} 3830$ and the background sediment by a factor of 5 and 10 , respectively.

The water-extractable data for potentially mobile metals such as technetium-99, uranium-238, chromium, molybdenum, and ruthenium in borehole C3832 sediments are shown in Table 4.54 and Figure 4.49. In borehole C3832 sediments, technetium-99 is present between $76.34 \mathrm{ft} \mathrm{bgs}$ and the bottom of the borehole at $115.54 \mathrm{ft}$ bgs. The concentrations are similar to those found at borehole C3830 and are in the range of 2 to $12 \mathrm{pCi} / \mathrm{g}$. The water-extractable technetium-99 data for borehole C3830 and C3832 sediments below $70 \mathrm{ft}$ bgs are about a factor five lower than for sediments at C3831. In borehole C3831 there is a thin zone along a clastic dike with $140 \mathrm{pCi} / \mathrm{g}$ water soluble technetium-99. The technetium-99 water extract data for boreholes C3831 and C3832 may have come from the same source, perhaps a leak from tank TX-107 that becomes diluted as the plume traveled towards borehole C3832. The cobalt-60 content of the sediments at these two boreholes (to be discussed below) also suggests that the vadose zone plume at boreholes C3831 and C3832 may be related.

There is also elevated water-soluble uranium-238 in borehole C3832 sediment between 75 and $110.3 \mathrm{ft}$ bgs, the contact between the Cold Creek mud and caliche units. The water-soluble uranium concentrations are significantly larger in the C3832 sediments than the $\mathrm{C} 3830$ and $\mathrm{C} 3831$ sediments, excepting the one elevated sample at borehole C3830 at depth $67 \mathrm{ft}$ bgs. The water-extractable uranium concentrations in borehole C3831 and C3832 do not follow the same trends (C3832 data appearing diluted compared to C3831 data) as found for water-extractable technetium-99 and total cobalt-60.

The water-extractable molybdenum values for borehole $\mathrm{C} 3832$ below the tank bottom are 2 to 3 times larger than at borehole $\mathrm{C} 3830$ but only half the values at borehole $\mathrm{C} 3831$. Water-leachable ruthenium values (mostly at the detection limit) are about a factor of 10 larger at borehole C3832 than at the other two boreholes. The reported detection limit, however, is about 10 times less sensitive than the detection limit for data on the other two boreholes so we suspect that the instrument was not operating at its optimal 
level. Higher concentrations of water-extractable molybdenum and ruthenium data for borehole C3832 are observed from the shallowest samples in the backfill to the bottom of the borehole. We suspect artifacts in the ICP-MS performance on the day these samples were analyzed compromised the data as opposed to suggesting that surface contamination was pushed throughout the backfill to comingle coincidently with a true tank leak fluids that migrated all the way to the bottom of the borehole.

In summary, the maximum water-soluble technetium-99 concentrations at borehole C3832 occur in the lower Cold Creek subunits between 110 and $115 \mathrm{ft} \mathrm{bgs}$ at 10 to $12 \mathrm{pCi} / \mathrm{g}$. Shallower, between 76 and $105 \mathrm{ft}$ bgs, the technetium- 99 varies between 2 to $7 \mathrm{pCi} / \mathrm{g}$. The maximum water-soluble uranium concentrations are in the Cold Creek subunit with a concentration of $3 \mu \mathrm{g} / \mathrm{g}$. The maximum water-soluble chromium concentration is $0.03 \mu \mathrm{g} / \mathrm{g}$ in the sediment between 77 and $84 \mathrm{ft} \mathrm{bgs}$. Above and below this zone, water-soluble chromium is present at concentrations at least 10 times less.

Table 4.51. Water-Extractable Organics in C3832 Vadose Zone Sediments $(\mu \mathrm{g} / \mathrm{g})$

\begin{tabular}{|c|c|c|c|c|}
\hline Depth (ft bgs) & Stratigraphic Unit & Formate & Acetate & Oxalate \\
\hline $15 \mathrm{~A}$ & 17.26 & $<0.113$ & 0.32 & 0.42 \\
\hline $28 \mathrm{~A}$ & 29.14 & 0.16 & 0.49 & 0.47 \\
\hline $37 \mathrm{~A}$ & 37.14 & $<0.113$ & 0.34 & 0.41 \\
\hline $44 \mathrm{~A}$ & 45.19 & 0.13 & 0.42 & 0.2 \\
\hline $52 \mathrm{~A}$ & 52.01 & 8.42 & 0.78 & 0.97 \\
\hline $53 \mathrm{~A}$ & 54.10 & $<0.115$ & 0.45 & 0.28 \\
\hline $61 \mathrm{~A}$ & 61.17 & 0.09 & 0.38 & 0.14 \\
\hline $62 \mathrm{~A}$ & 62.96 & 0.08 & 2.3 & 0.3 \\
\hline $69 \mathrm{~A}$ & 69.99 & $<0.113$ & 0.82 & 0.3 \\
\hline $76 \mathrm{~B}$ & 76.34 & $<0.113$ & $<0.160$ & 2.52 \\
\hline 76B Dup & 76.34 & 2.1 & 2.25 & 1.56 \\
\hline $76 \mathrm{~A}$ & 77.04 & $<0.113$ & 0.77 & 0.44 \\
\hline $79 \mathrm{~A}$ & 79.81 & $<0.113$ & 0.44 & $<0.214$ \\
\hline $83 \mathrm{~A}$ & 84.01 & $<0.113$ & 0.9 & $<0.214$ \\
\hline $87 \mathrm{~A}$ & 88.06 & $<0.113$ & 0.53 & $<0.214$ \\
\hline $93 \mathrm{~A}$ & 94.05 & 0.1 & 0.36 & $<0.227$ \\
\hline $96 \mathrm{~A}$ & 96.69 & $<0.113$ & 0.32 & 0.23 \\
\hline $104 \mathrm{~A}$ & 105.01 & $<0.121$ & $<0.172$ & 0.37 \\
\hline $110 \mathrm{~B}$ & 110.28 & 0.86 & 0.56 & 0.66 \\
\hline 110B Dup & 110.28 & 3.35 & 0.65 & 1 \\
\hline $110 \mathrm{~A}$ & 111.02 & 1.43 & 1.15 & 0.58 \\
\hline $114 \mathrm{~A}$ & 114.85 & 0.37 & 1.12 & 1.19 \\
\hline $121 \mathrm{~A}$ & 115.54 & $<0.113$ & 0.32 & 1.62 \\
\hline
\end{tabular}




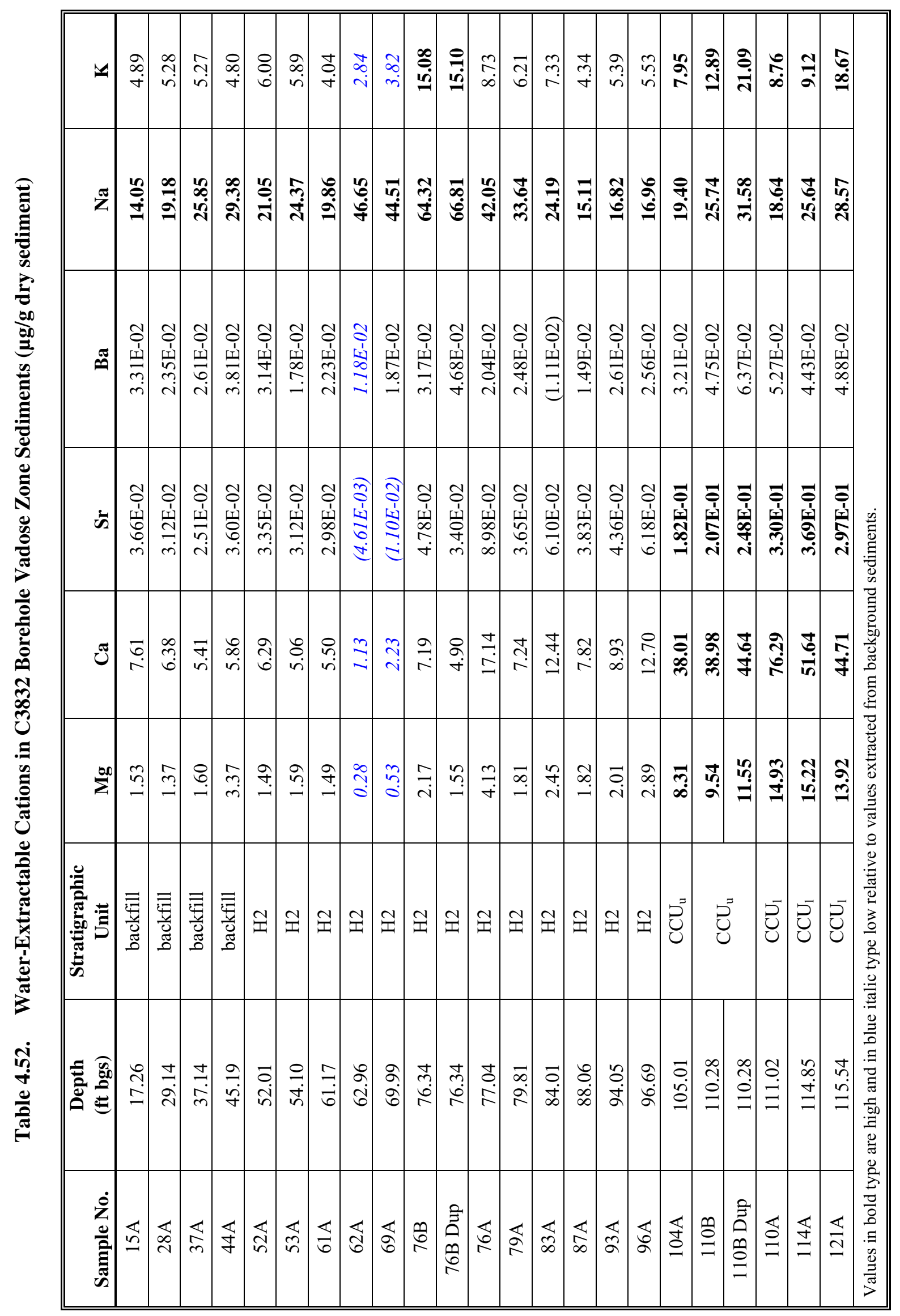




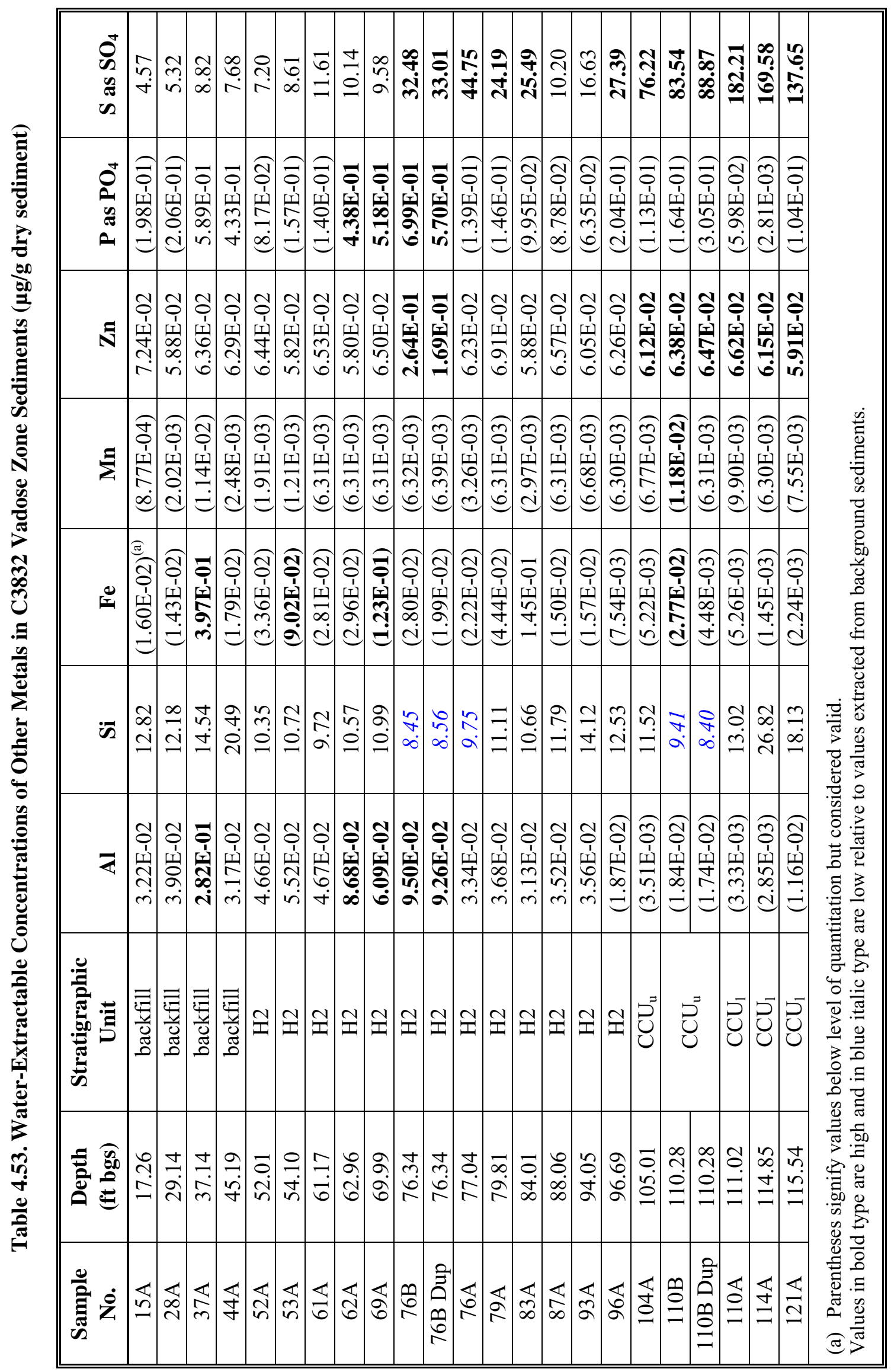




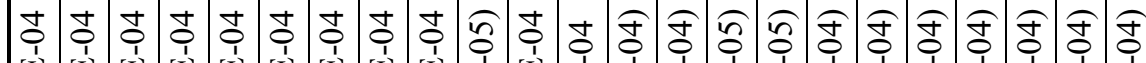

ב

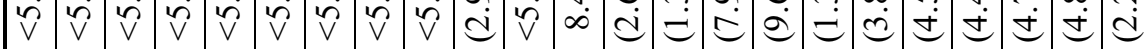

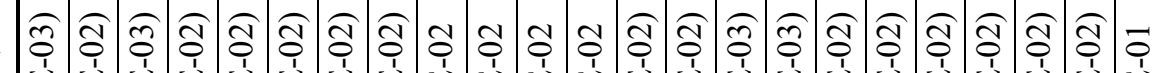

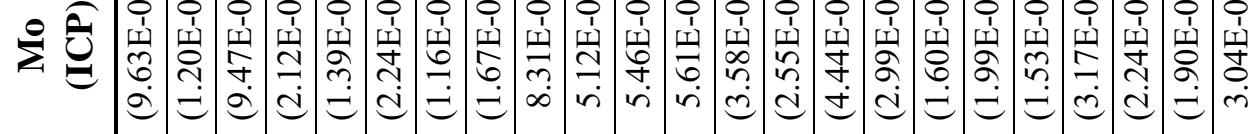

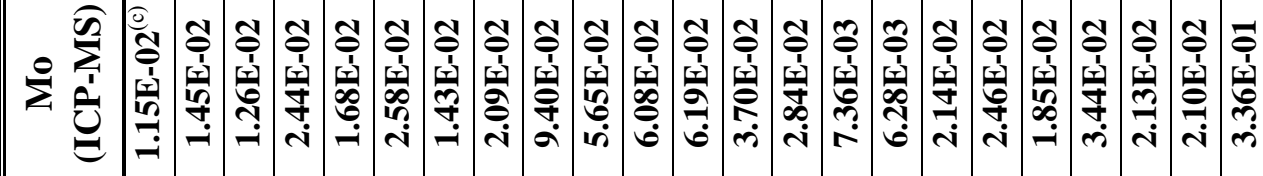

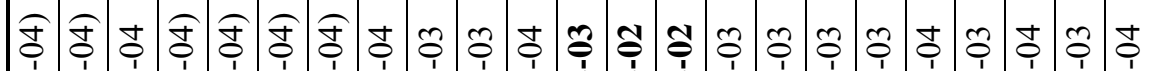

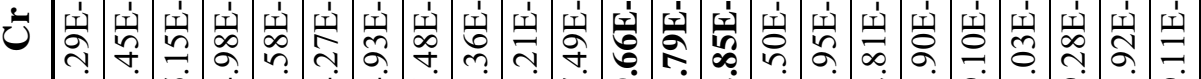

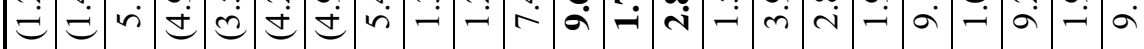

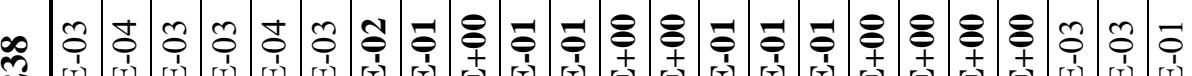

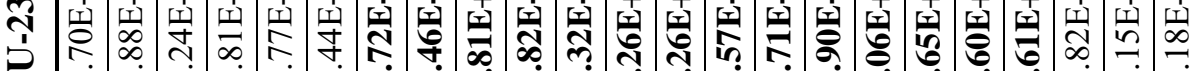

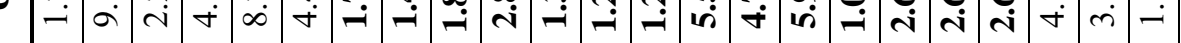

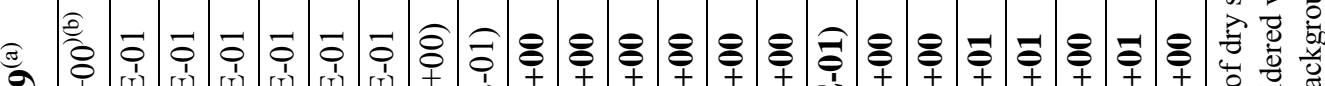

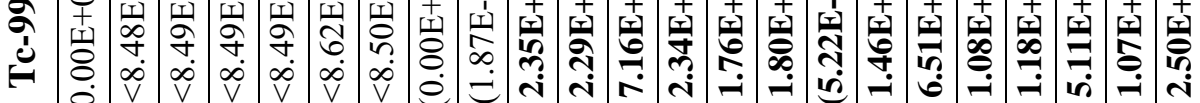

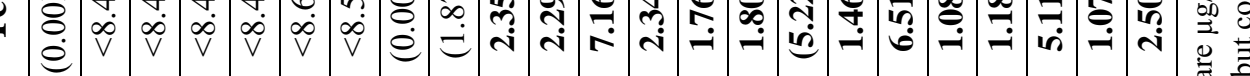

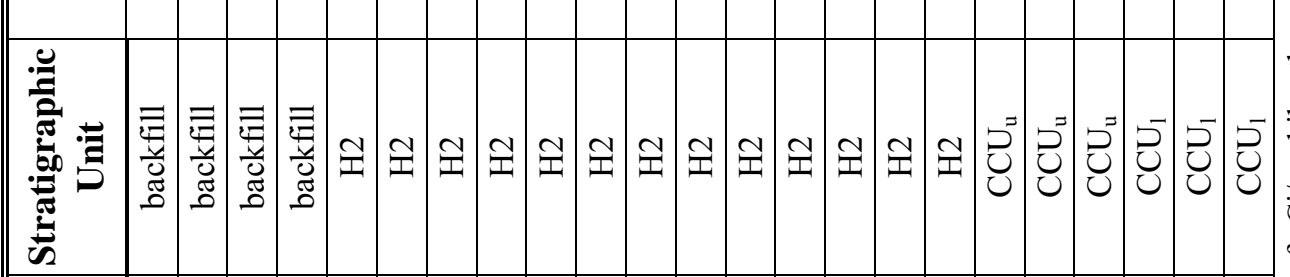

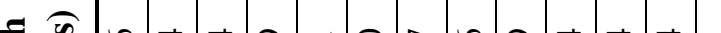

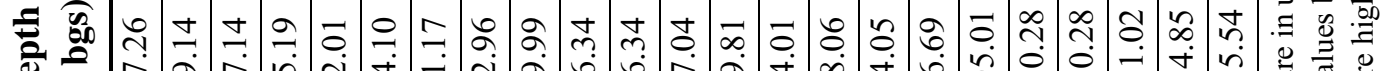

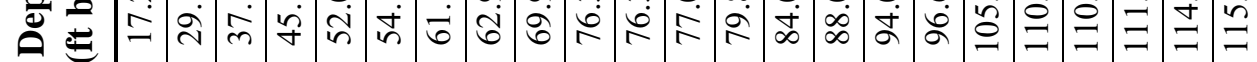

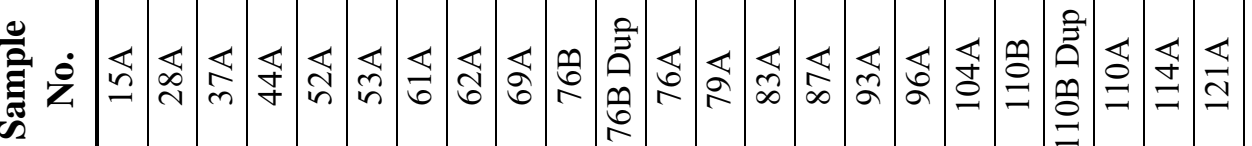




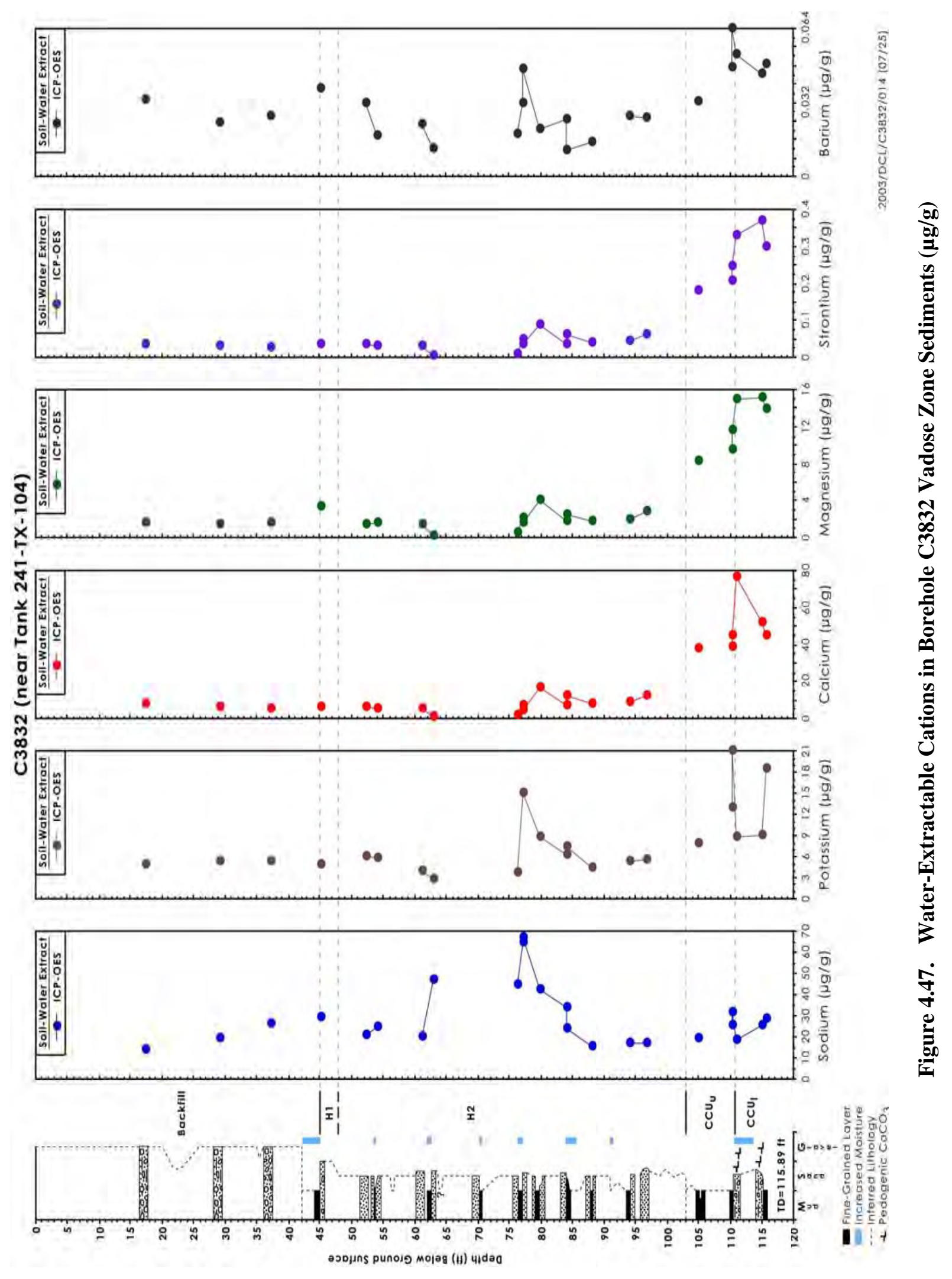




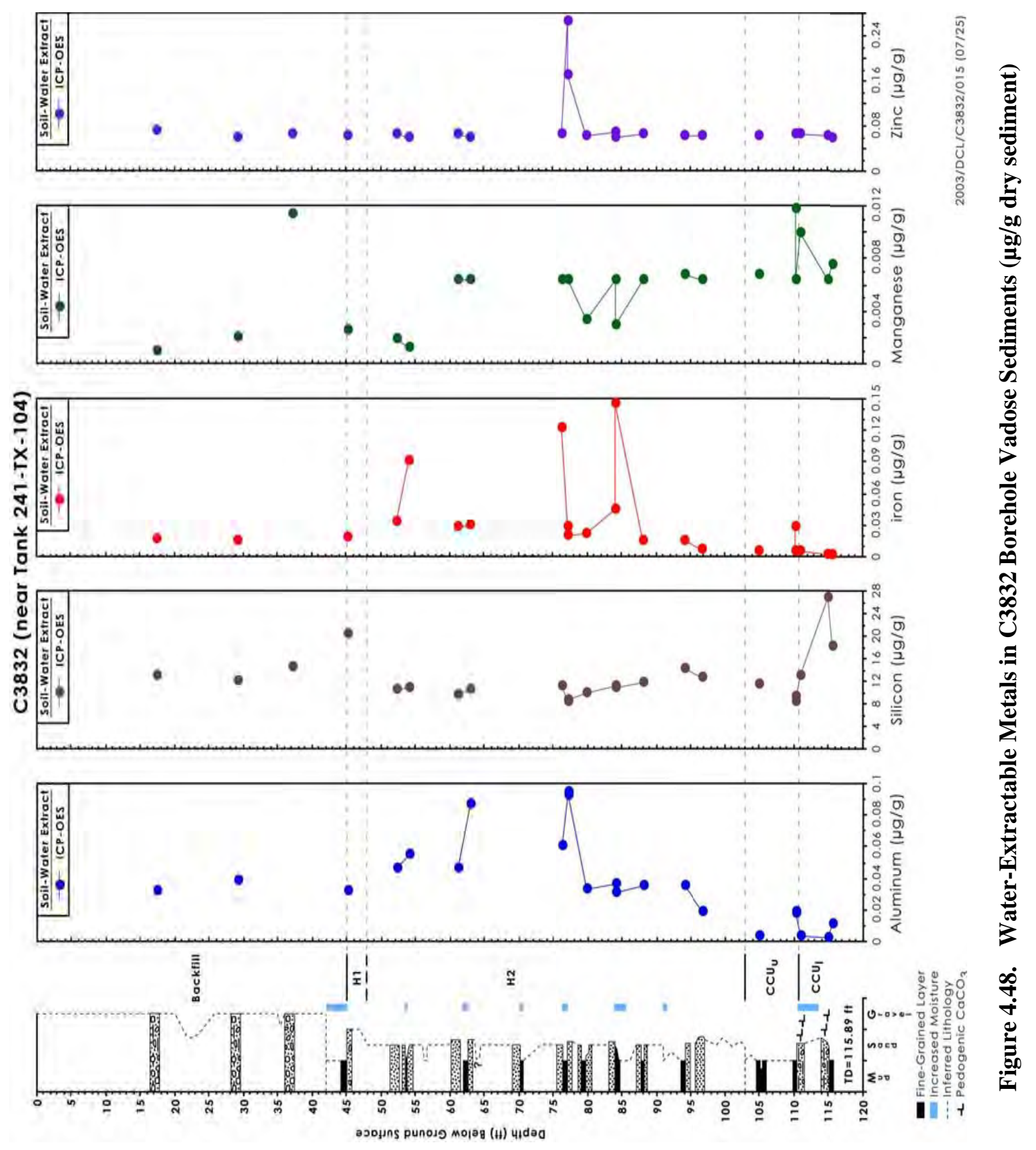



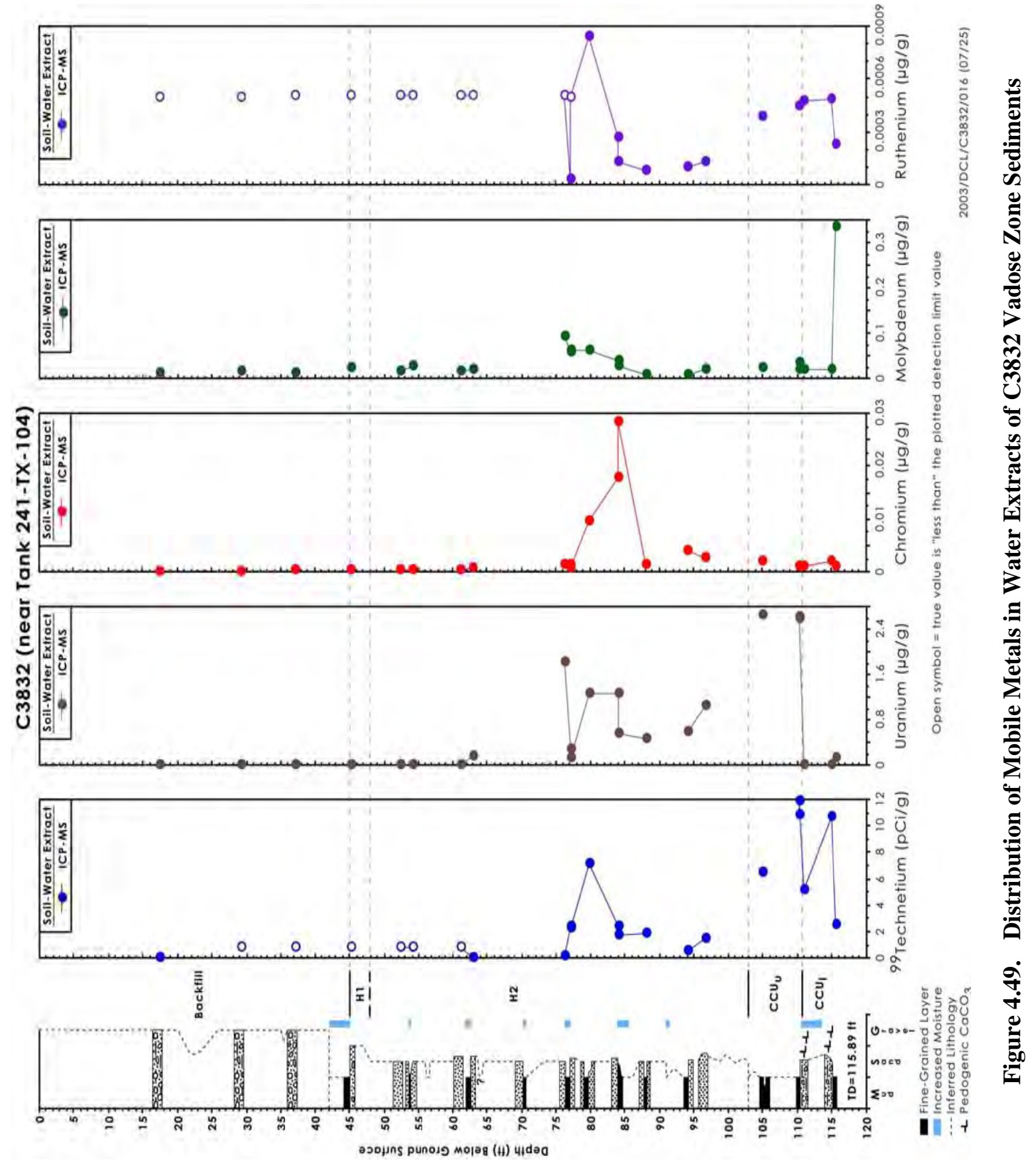


\subsubsection{Derivation of Vadose Zone Porewater Chemical Composition}

The 1:1 water extract data was recalculated to derive an estimate of the porewater composition of the vadose zone porewater. From knowledge of the moisture content of the sediment samples taken from the A liners of each core, we calculated the amount of deionized water that would be needed to make the water extract exactly one part water (total of native porewater and added deionized water) to one part by weight dry sediment. The contaminated or uncontaminated sediment dilution-corrected water extract data is biased high by a factor of 2 to 7 for many constituents such that the true porewater is less saline.

Tables 4.55 through 4.58 and Figures 4.50 through 4.53 show the derived porewater composition of key constituents as a function of depth and stratigraphy. There are two concentrated porewaters, one shallow at $63 \mathrm{ft}$ bgs and one deep at $\sim 115 \mathrm{ft}$ bgs. The shallow porewater has a total concentration of $\sim 42 \mathrm{meq} / \mathrm{L}$ of cations and anions consisting of $0.44 \mathrm{meq} / \mathrm{L} \mathrm{Mg}, 1.1 \mathrm{meq} / \mathrm{L} \mathrm{Ca}, 39.1 \mathrm{meq} / \mathrm{L} \mathrm{Na}$, $1.4 \mathrm{meq} / \mathrm{L} \mathrm{K}, 0.5 \mathrm{meq} / \mathrm{L} \mathrm{F}, 0.4 \mathrm{meq} / \mathrm{L} \mathrm{Cl}, 37.3 \mathrm{meq} / \mathrm{L}$ bicarbonate, $0.6 \mathrm{meq} / \mathrm{L}$ nitrate, and $0.3 \mathrm{meq} / \mathrm{L}$ phosphate. The deeper saline porewater contains $\sim 58 \mathrm{meq} / \mathrm{L}$ cations and anions consisting of $13.6 \mathrm{meq} / \mathrm{L}$ $\mathrm{Mg}, 30 \mathrm{meq} / \mathrm{L} \mathrm{Ca}, 12.1 \mathrm{meq} / \mathrm{L} \mathrm{Na}, 2.5 \mathrm{meq} / \mathrm{L} \mathrm{K}, 0.5 \mathrm{meq} / \mathrm{L} \mathrm{F}, 1.6 \mathrm{meq} / \mathrm{L} \mathrm{Cl}, 11 \mathrm{meq} / \mathrm{L}$ bicarbonate, $10 \mathrm{meq} / \mathrm{L}$ nitrate, and $36 \mathrm{meq} / \mathrm{L}$ sulfate.

These two calculated porewater concentrations are very dilute compared to the vadose zone porewaters found at the SX and BX tank farms where the total ionic strength of the porewaters were as high as 7,000 to 17,000 and1,000 meq/L, respectively (Serne et al. 2002c, 2002d, 2002e). At the borehole emplaced near tank B-110 the most saline porewater was 150 to $160 \mathrm{meq} / \mathrm{L}$. Thus the porewater maximum at borehole $\mathrm{C} 3831$ is $\sim 3$ and 4 times more concentrated than the vadose zone porewater at 299-E33-46 and at borehole C3830, respectively. The porewater concentration $\sim 10 \mathrm{ft}$ below the tank bottom at borehole $\mathrm{C} 3832$ has about one-half the concentration as that at borehole C3830 and is $\sim 10$ times more dilute than at borehole C3831. Deeper in the $\mathrm{C} 3832$ borehole in the Cold Creek upper unit the porewater is more saline than at borehole C3830, suggesting that at borehole C3832 tank fluids migrated to deeper depths than at borehole C3830 and may have come from a more distant source than Tank TX-104.

Technetium-99 in the $\mathrm{C} 3832$ porewaters between the depths of 76.3 and the bottom of the borehole at $115.5 \mathrm{ft}$ bgs contains about 20,000 to $40,000 \mathrm{pCi} / \mathrm{L}$ in the $\mathrm{H} 2$ unit and 50,000 to $110,000 \mathrm{pCi} / \mathrm{L}$ in the Cold Creek units. On a per gram of dry sediment basis, these porewater concentrations are 10 to $12 \mathrm{pCi} / \mathrm{g}$. Because the water content of the vadose sediments is so small when equated to porewater concentrations, this small mass of technetium-99 reaches concentrations about 50 to 100 times larger than the drinking water standard. The derived porewater uranium concentration for the $\mathrm{H} 2$ unit between 80 and $97 \mathrm{ft}$ bgs is $\sim 12,000 \mu \mathrm{g} / \mathrm{L}$ and increases to $25,000 \mu \mathrm{g} / \mathrm{L}$ in the upper Cold Creek subunit (mud). The chromium porewater concentrations between 77 and $84 \mathrm{ft}$ bgs are 200 to $300 \mu \mathrm{g} / \mathrm{L}$. 


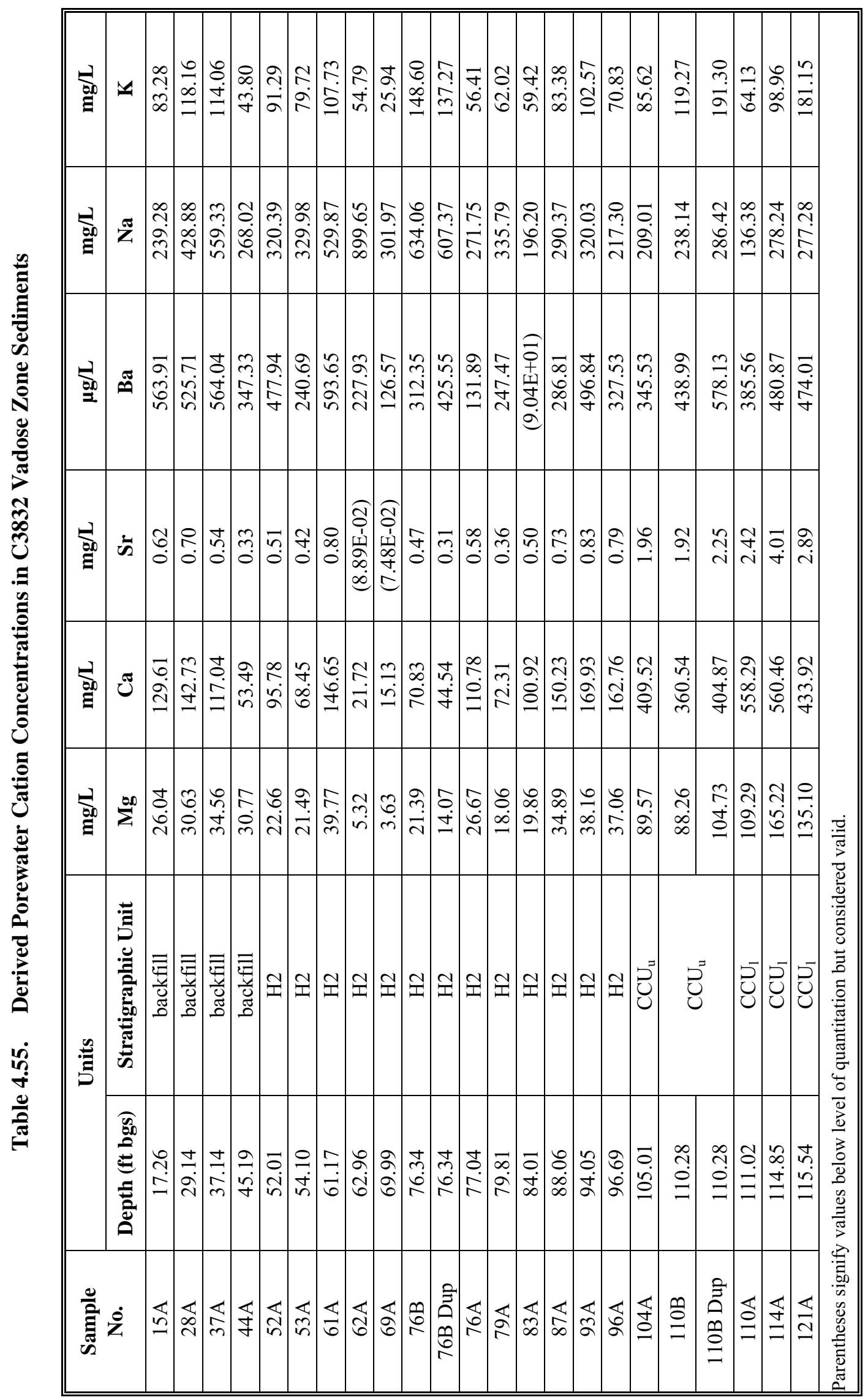




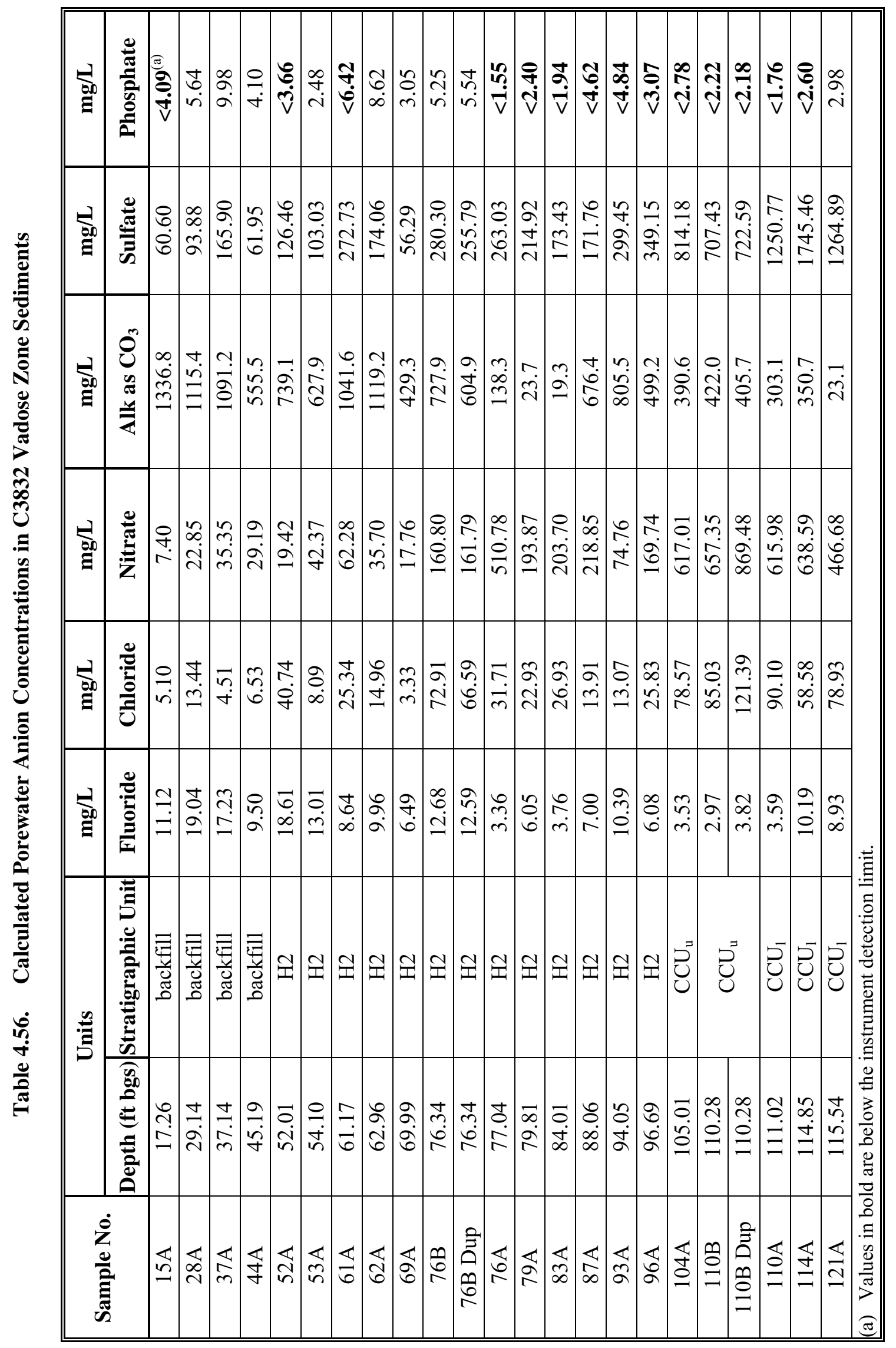




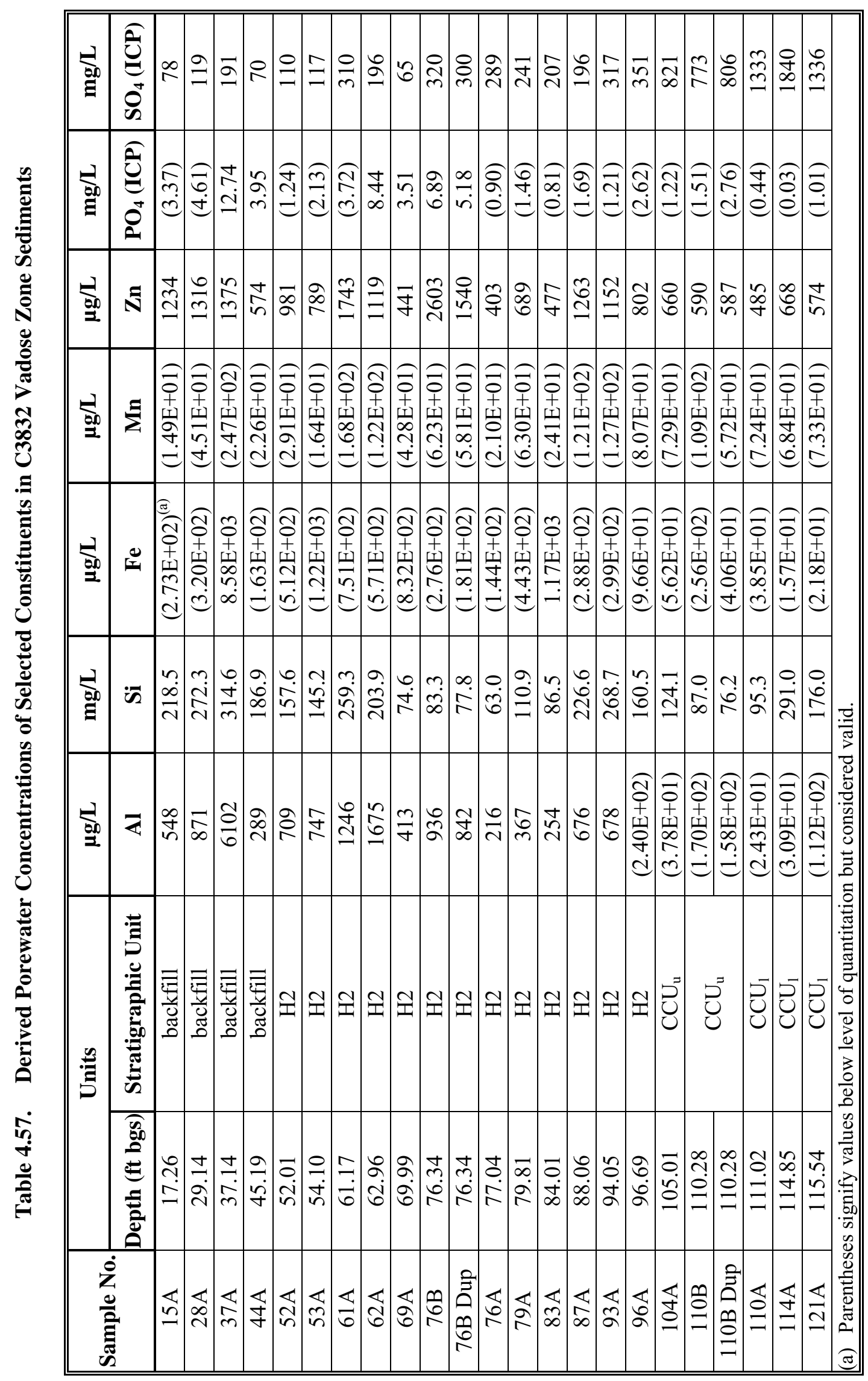




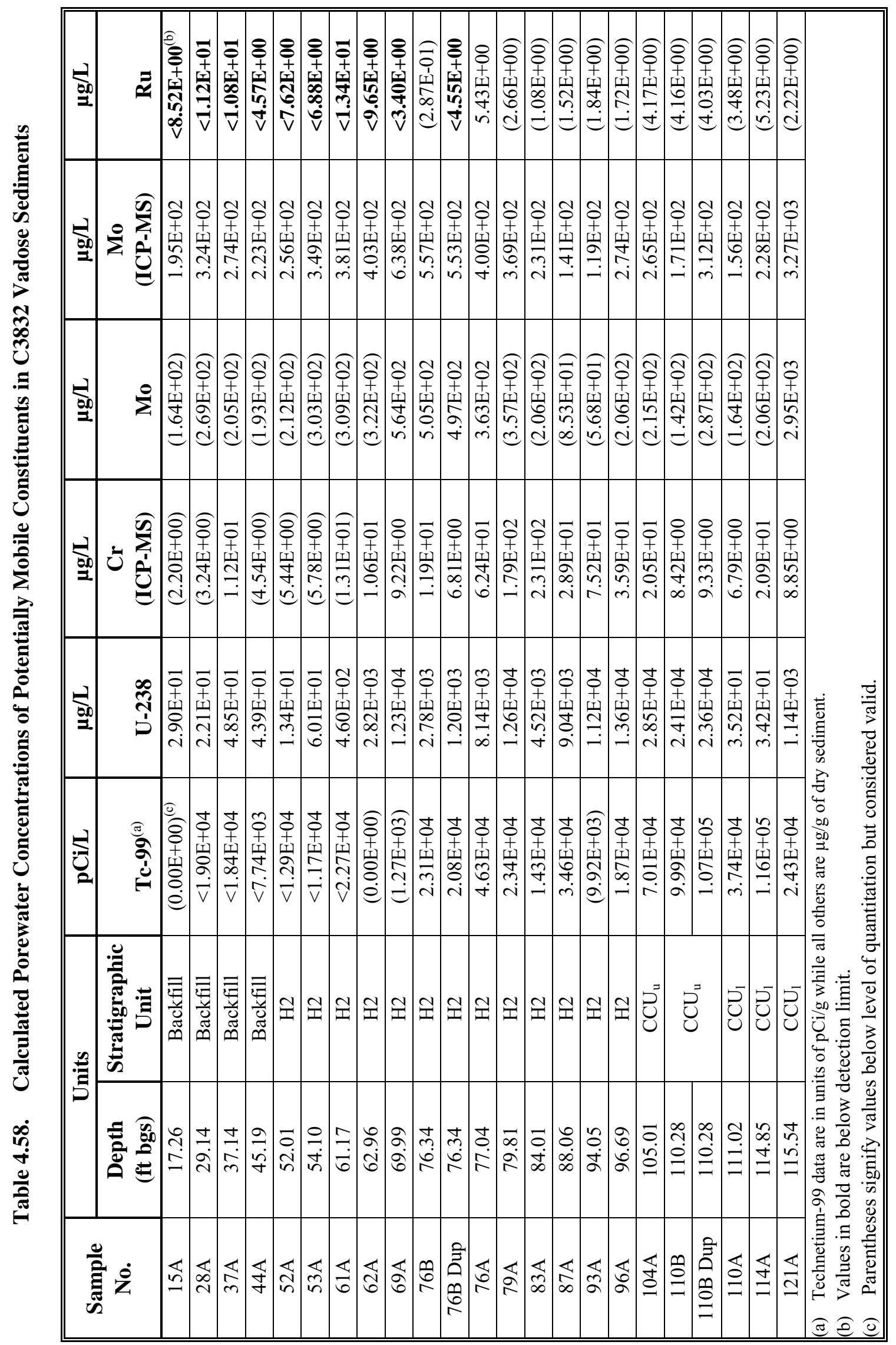



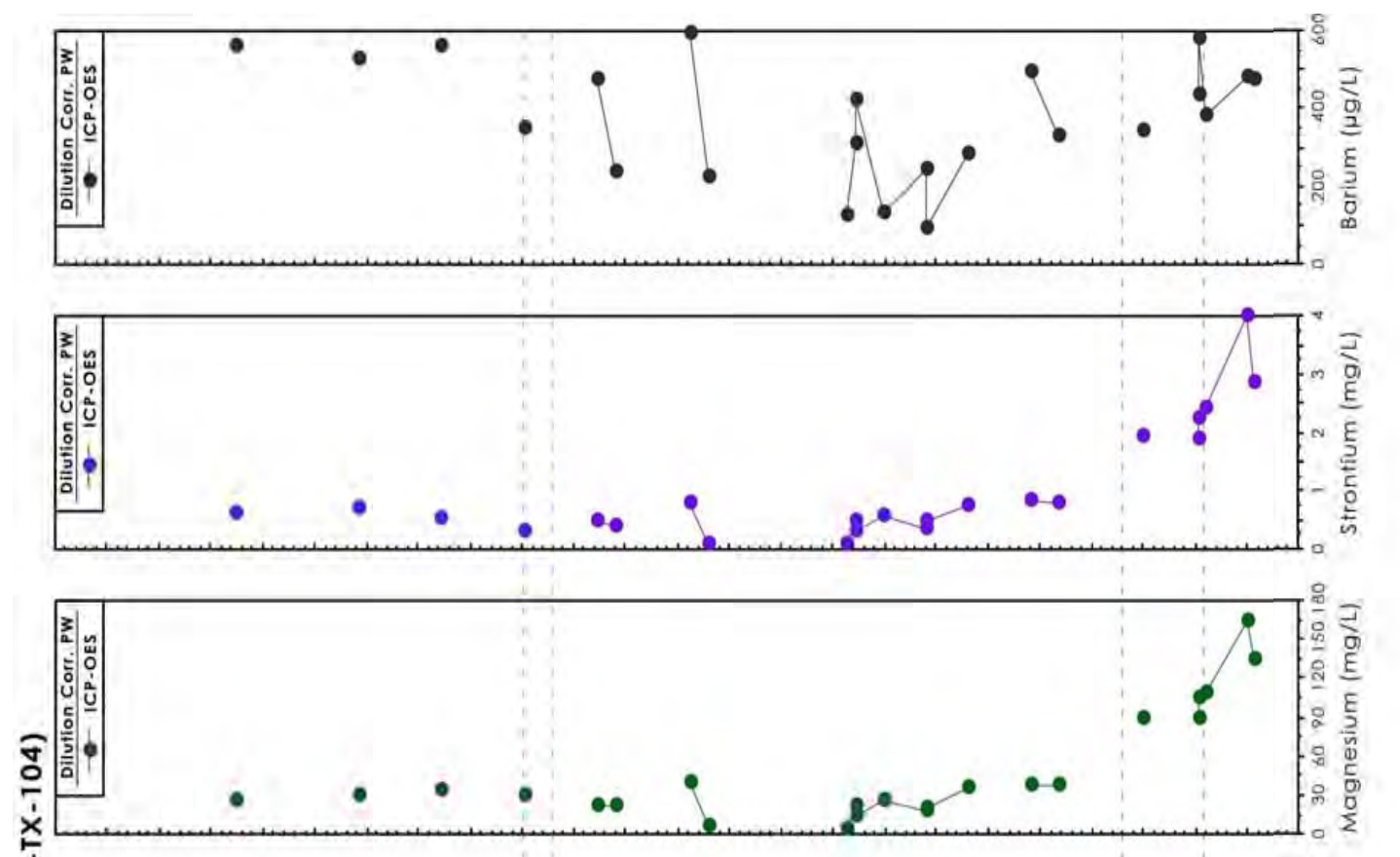

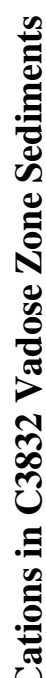
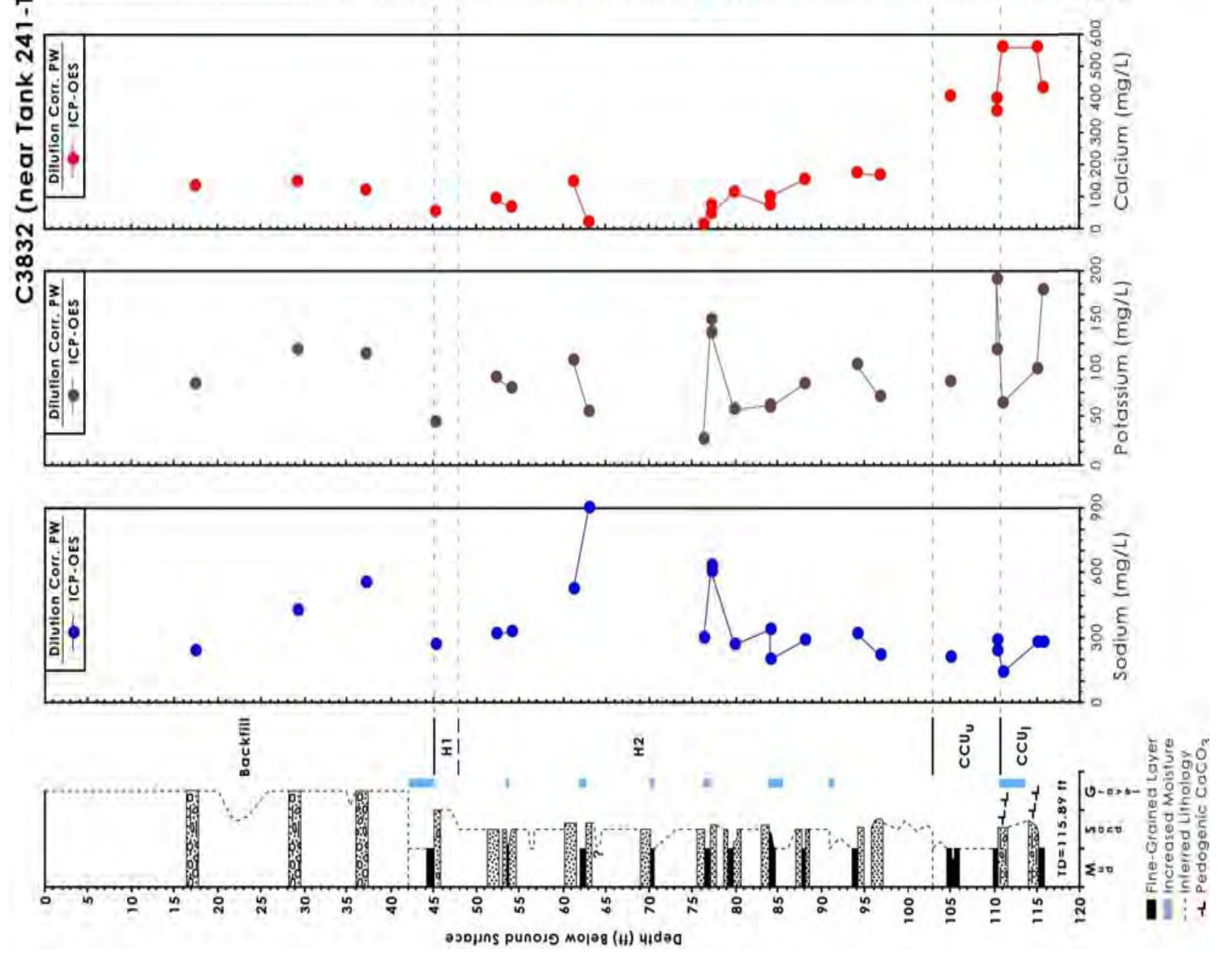

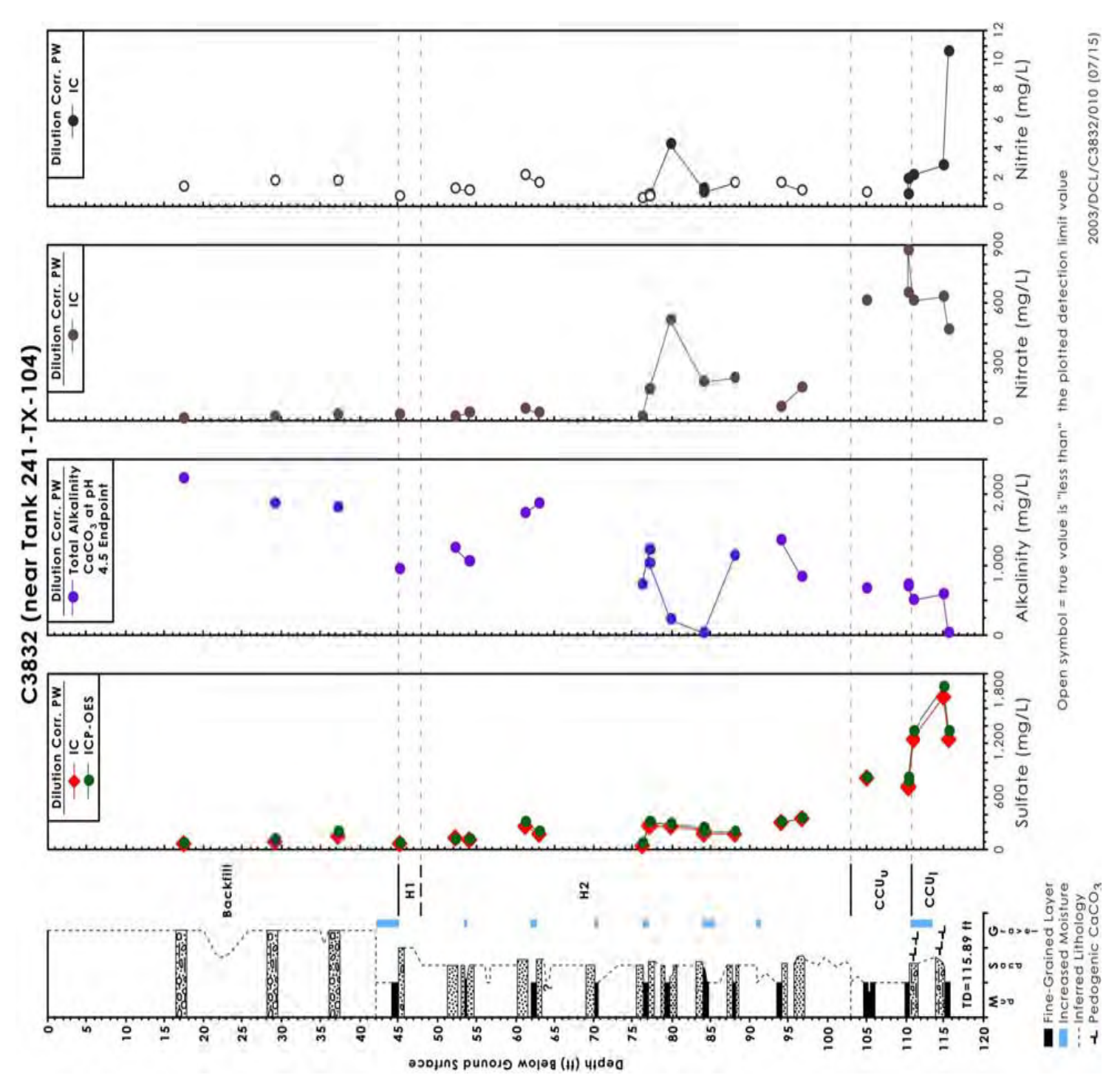

告 

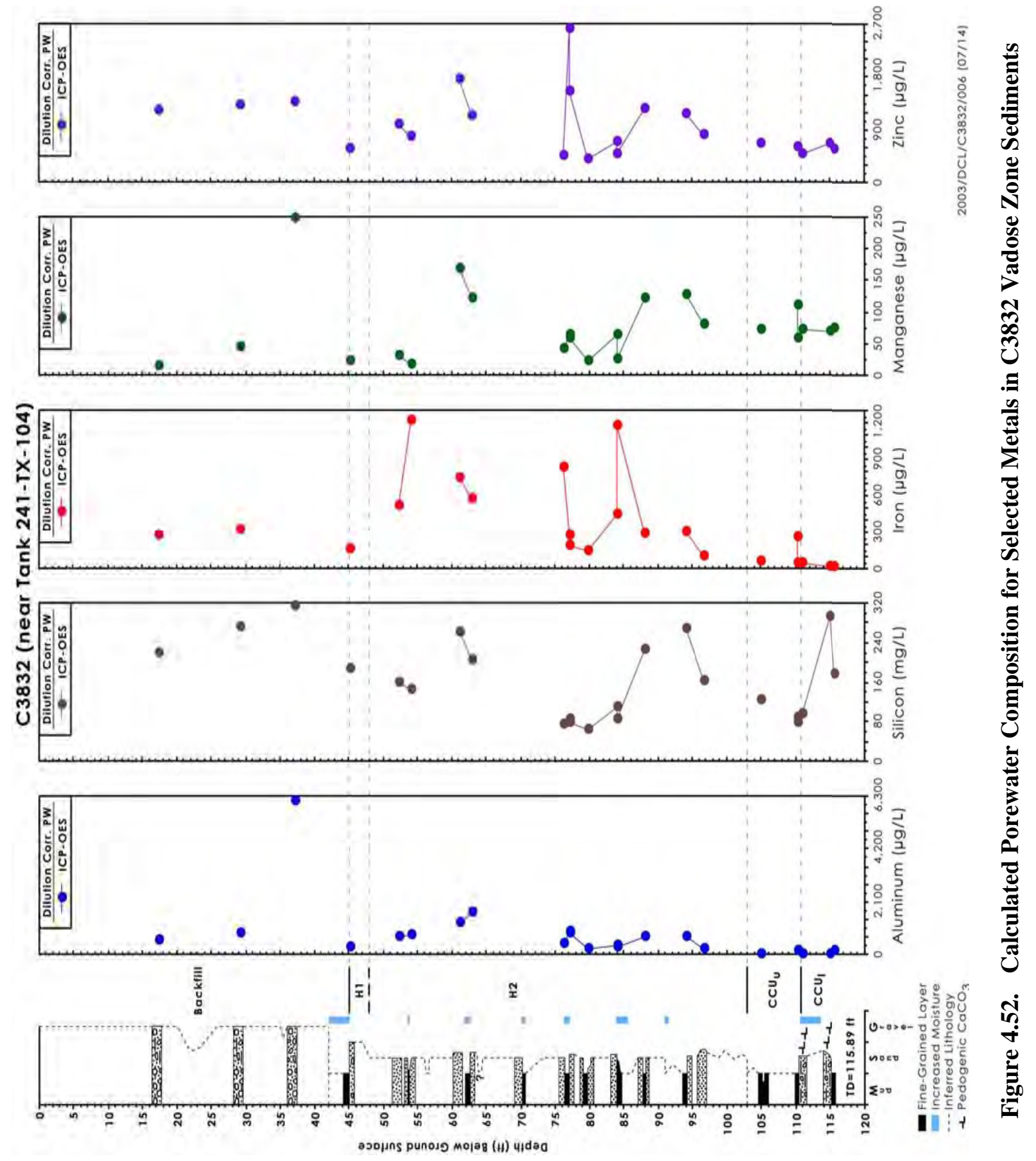


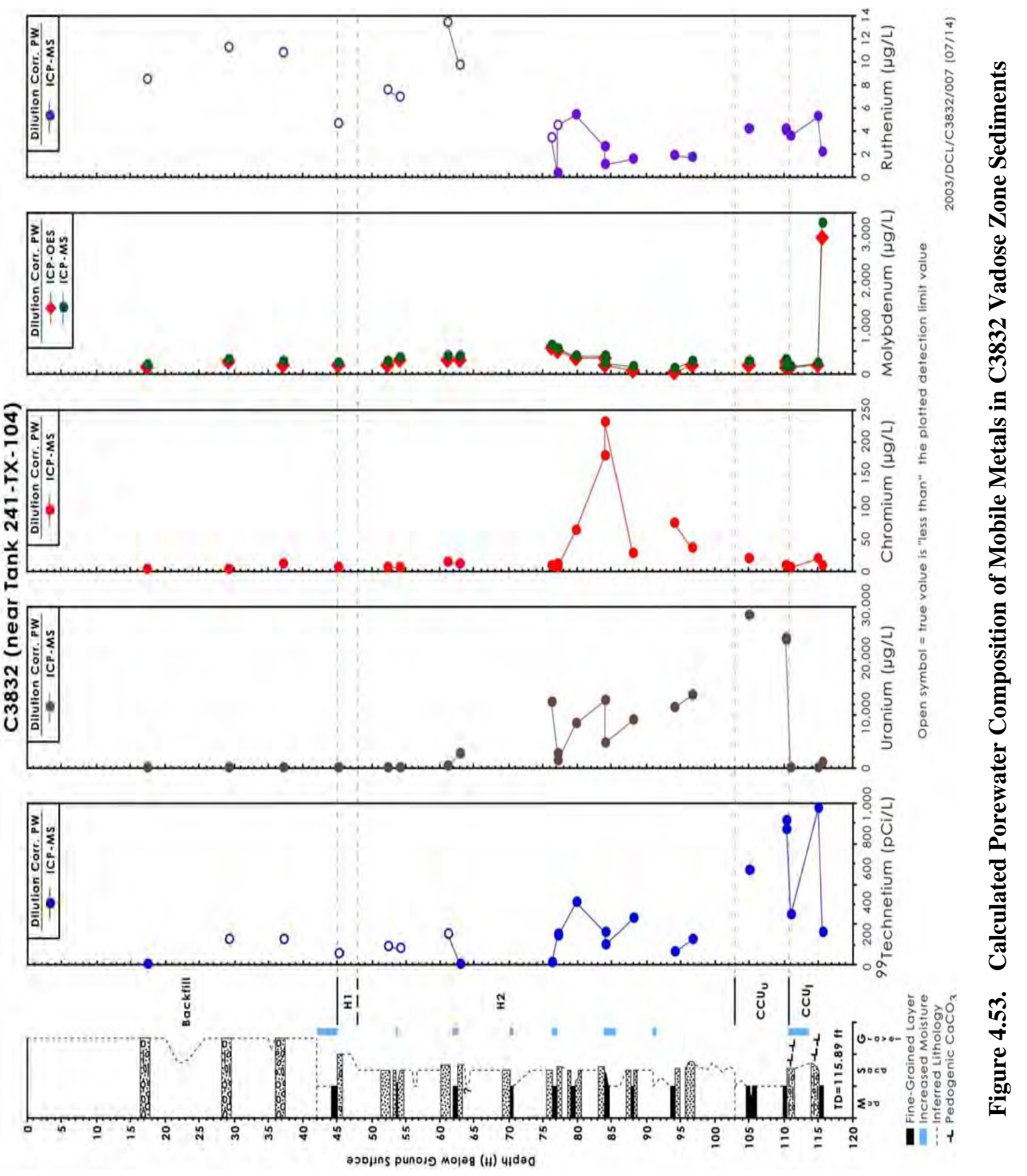




\subsubsection{M Nitric Acid-Extractable Amounts of Selected Elements in C3832 Sediments}

The same cores that were characterized for water-extractable constituents were also characterized to see how much of various constituents could be leached with hot $8 \mathrm{M}$ nitric acid. A comparison between the quantities that were acid extractable with those that are water extractable often indicates the relative mobility of a given constituent and can sometimes differentiate man-disposed from naturally occurring constituents. Finally, a comparison of the acid-extractable quantities in suspected contaminated sediments with acid-extractable amounts in uncontaminated sediments can be used to delineate the presence of less mobile contaminants.

The quantities of various constituents in the $\mathrm{C} 3832$ vadose zone sediments that were acid extractable are shown in Tables 4.59 to 4.61 and Figures 4.54 through 4.56. Upon comparing the acid extract data for borehole C3832 with similar lithologies in the uncontaminated borehole 299-W10-27, most of the variation in mass leached per gram of sediment versus depth in found to be lithology related. That is, for most constituents there are no signs of elevated values of acid-leachable constituents in borehole C3832 sediments excepting acid-extractable sodium in the backfill, and often in the $\mathrm{H} 2$ unit below the tank bottom. At C3832, we did not observe any elevated acid-extractable sulfur (assumed to represent sulfate) as was found in borehole C3831 sediments. Acid-extractable technetium-99 in borehole C3832 appears to be slightly above the background sediments but the same as in borehole C3831 and somewhat lower than acid-extractable technetium-99 in borehole C3830. There are greater acid-extractable concentrations of uranium at borehole $\mathrm{C} 3832$ from $70 \mathrm{ft}$ bgs all the way to the bottom of the borehole than at either of the other two boreholes. Acid-extractable uranium concentrations vary from 1 to $30 \mu \mathrm{g} / \mathrm{g}$ over this interval. There also appears to be a zone elevated acid-extractable chromium in borehole C3832 between 70 and $76 \mathrm{ft}$ bgs with a concentration of $25 \mu \mathrm{g} / \mathrm{g}$. Values of acid-extractable chromium at the other two boreholes never exceed $15 \mu \mathrm{g} / \mathrm{g}$. The acid-extractable molybdenum at borehole C3832 is larger than at C3830 but similar to acid-extractable molybdenum at borehole C3831. As mentioned below for alkaline earth cations, some of the differences in acid extract concentrations may reflect differences in the efficiency of the acid digestion.

The acid-extractable silicon at depths 61 to $63 \mathrm{ft} \mathrm{bgs}$ at borehole C3832 is elevated in comparison to background sediment and the other two boreholes suggesting some more soluble silicate phase may exist at this depth as a result of tank fluid (likely caustic) interaction with native sediments. The acid-extractable phosphate in the backfill between 17 and $45 \mathrm{ft}$ bgs appears elevated compared to the background sediment and other two boreholes. This suggests that some phosphate-bearing waste fluid may have been spilled near the surface and percolated into the backfill; however, phosphate is generally not very mobile/soluble in Hanford sediments and porewaters. Thus the elevated phosphate may be an analytical artifact or natural variability in the native sediments.

The acid-extractable magnesium, calcium, strontium, and barium at borehole C3832 is higher than at either of the other two boreholes but not the background sediment, suggesting that we may have some variation in efficiency of extraction by the technique. (Perhaps efficiency is dependent on temperature and time of extraction.) The acid-extractable sodium concentration profile at borehole $\mathrm{C} 3832$ is larger than at borehole $\mathrm{C} 3830$ but only one-half that at borehole $\mathrm{C} 3831$. This indicates that $\mathrm{C} 3831$ waste was more concentrated than the fluids that leaked near borehole $\mathrm{C} 3830$ and $\mathrm{C} 3832$, as corroborated by the pore water compositions. The clastic dike intercepted at borehole C3831 may have allowed tank fluids to "short-circuit" many of the sediment interactions, including dilution with native porewaters that would occur in more "homogeneously layered" porous media. 
Figure 4.57 shows that the vast majority of the sediment phosphate content is not water extractable in comparison with the amounts that are acid extractable. The same trend was observed for the uncontaminated sediments from borehole 299-W10-27 and other two boreholes. Alternatively, some of the acid-extractable phosphorous may be present in a form other than phosphate such that when we convert the acid-extractable phosphorous number to phosphate (essentially multiply by 3 ) we are inflating the acid-extractable value

As mentioned, the ratio of water-extractable to acid-extractable quantities of constituents can identify samples that may contain leaked fluids from Hanford waste disposals. The comparison of water to acid extracts for borehole C3832 sediments suggests that there are unnaturally high percentages of water-leachable technetium-99 and uranium-238 between 76 and 115 and 61 to $110.3 \mathrm{ft}$ bgs, respectively. There is also slightly high water-extractable sodium between 63 and $77 \mathrm{ft} \mathrm{bgs.} \mathrm{The} \mathrm{total} \mathrm{mass} \mathrm{of} \mathrm{tank}$ fluids that are present in $\mathrm{C} 3832$ borehole sediments and the percentages that are water leachable versus the concentrations that are acid leachable are lower than at borehole C3831. The two data sets suggest that the tank-related fluids in borehole C3832 may in fact be the leading edge of fluids that leaked from tank TX-107 that were intercepted by borehole C3831. It also appears that the vadose zone plume dips to the southwest between the two boreholes as does the stratigraphy (see discussion in Section 2). 


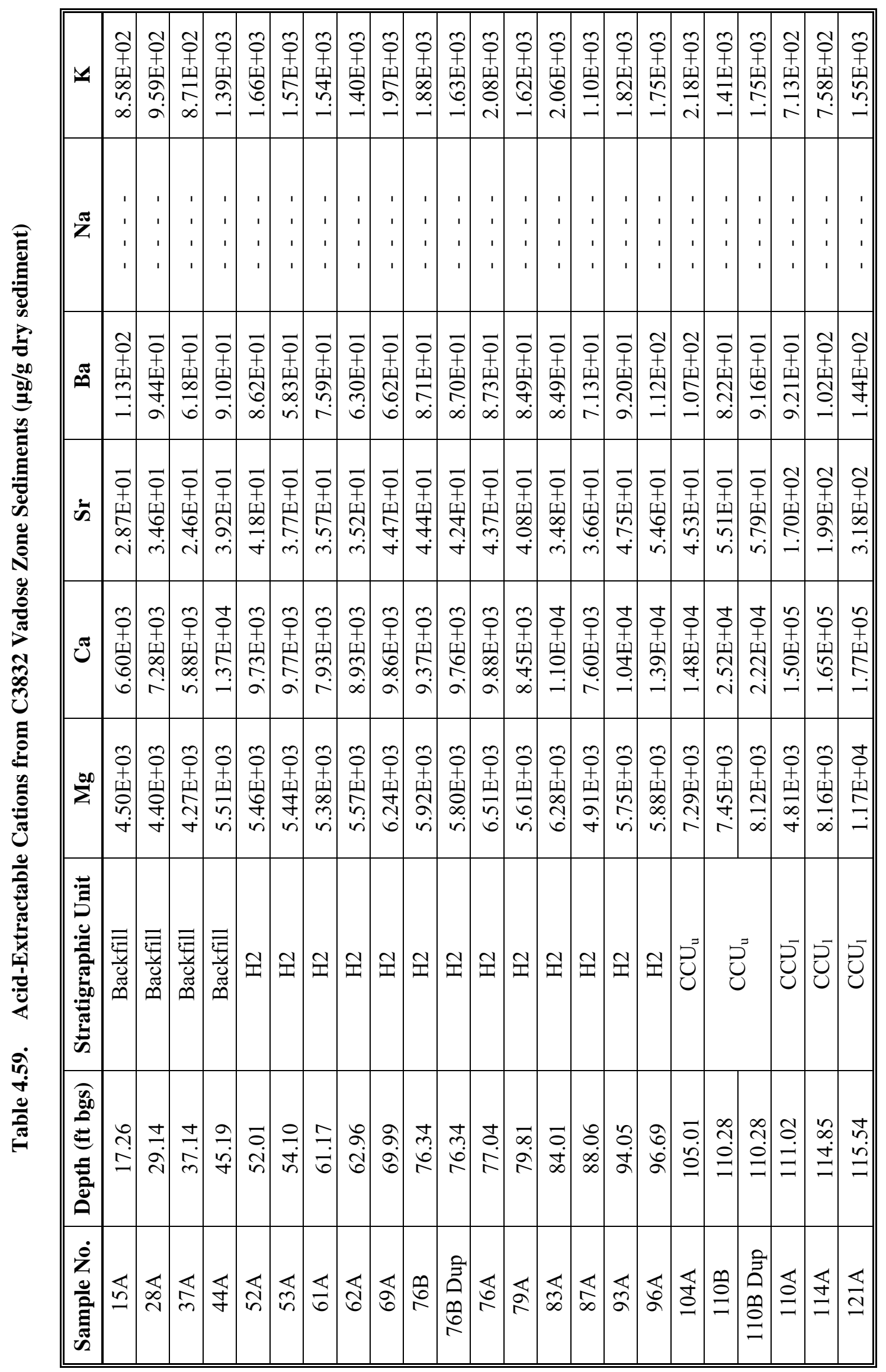




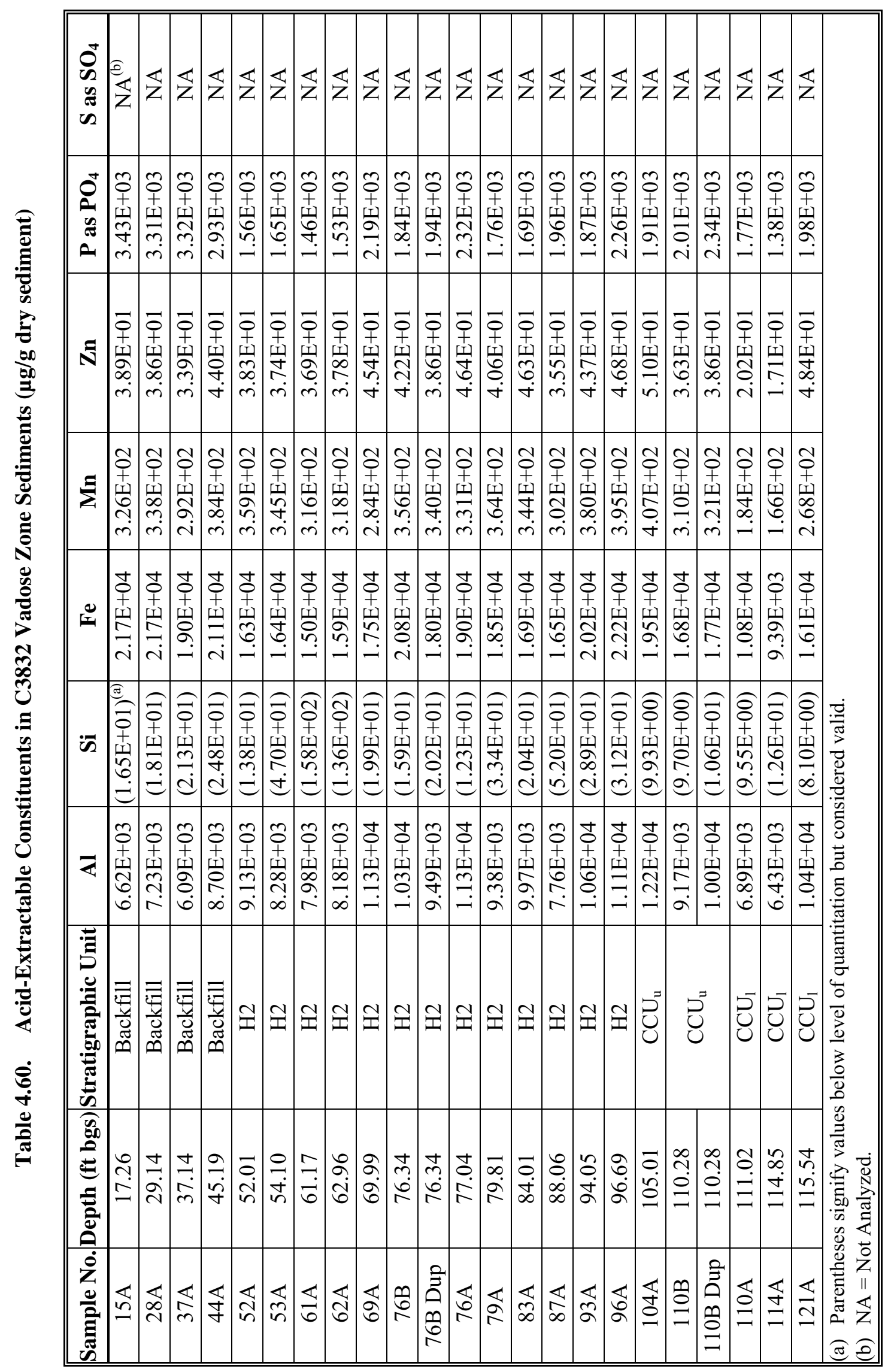




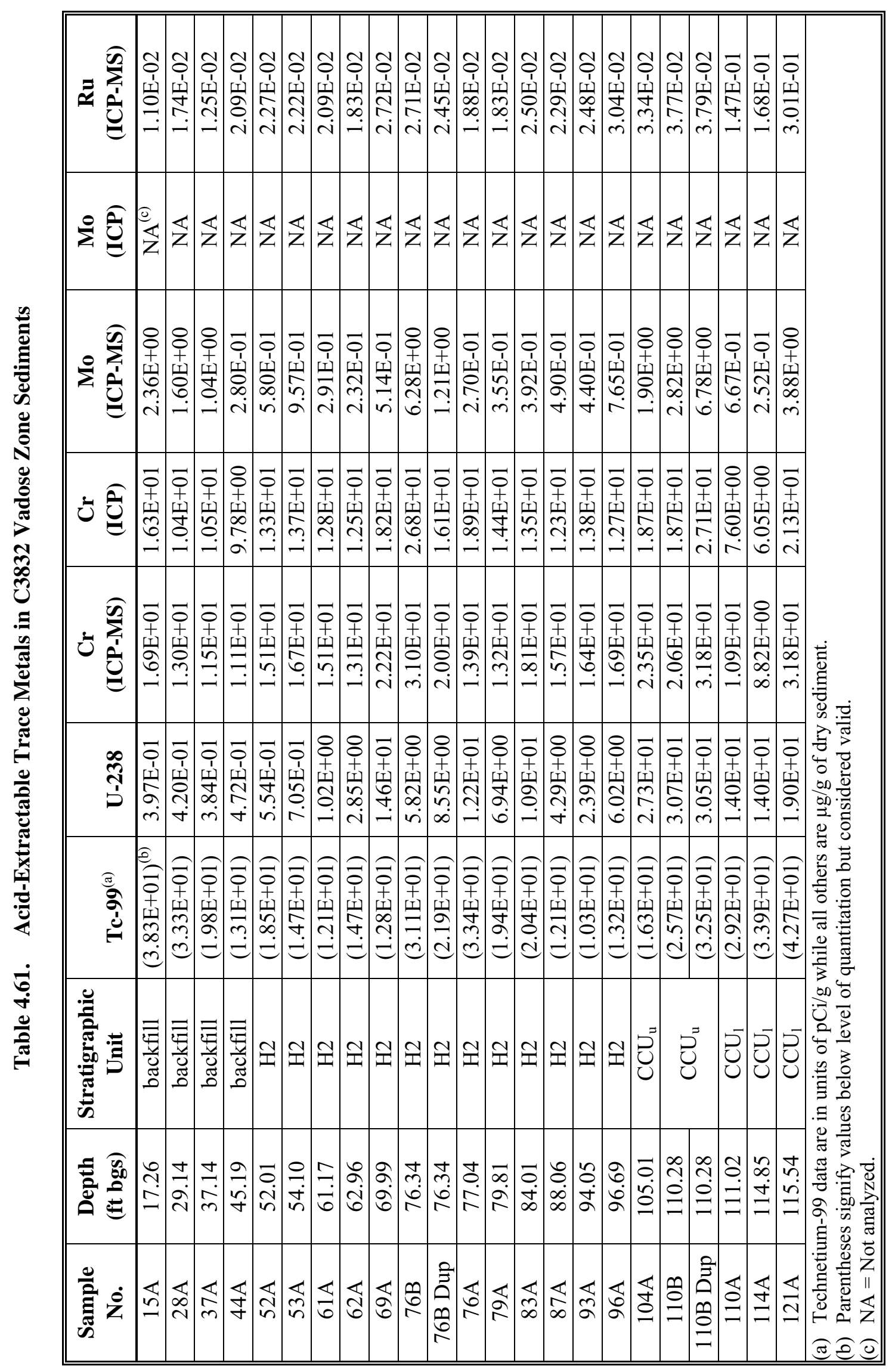




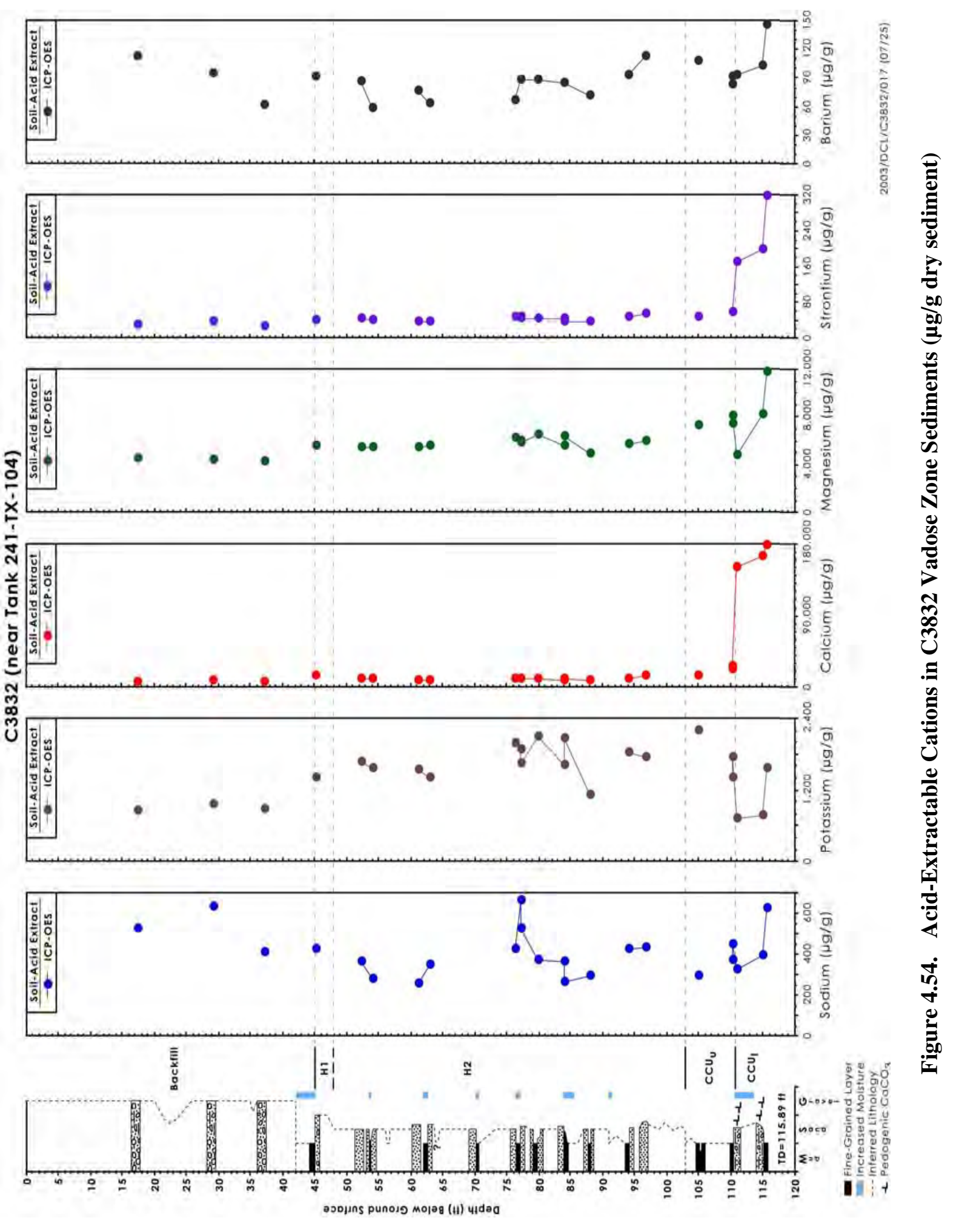




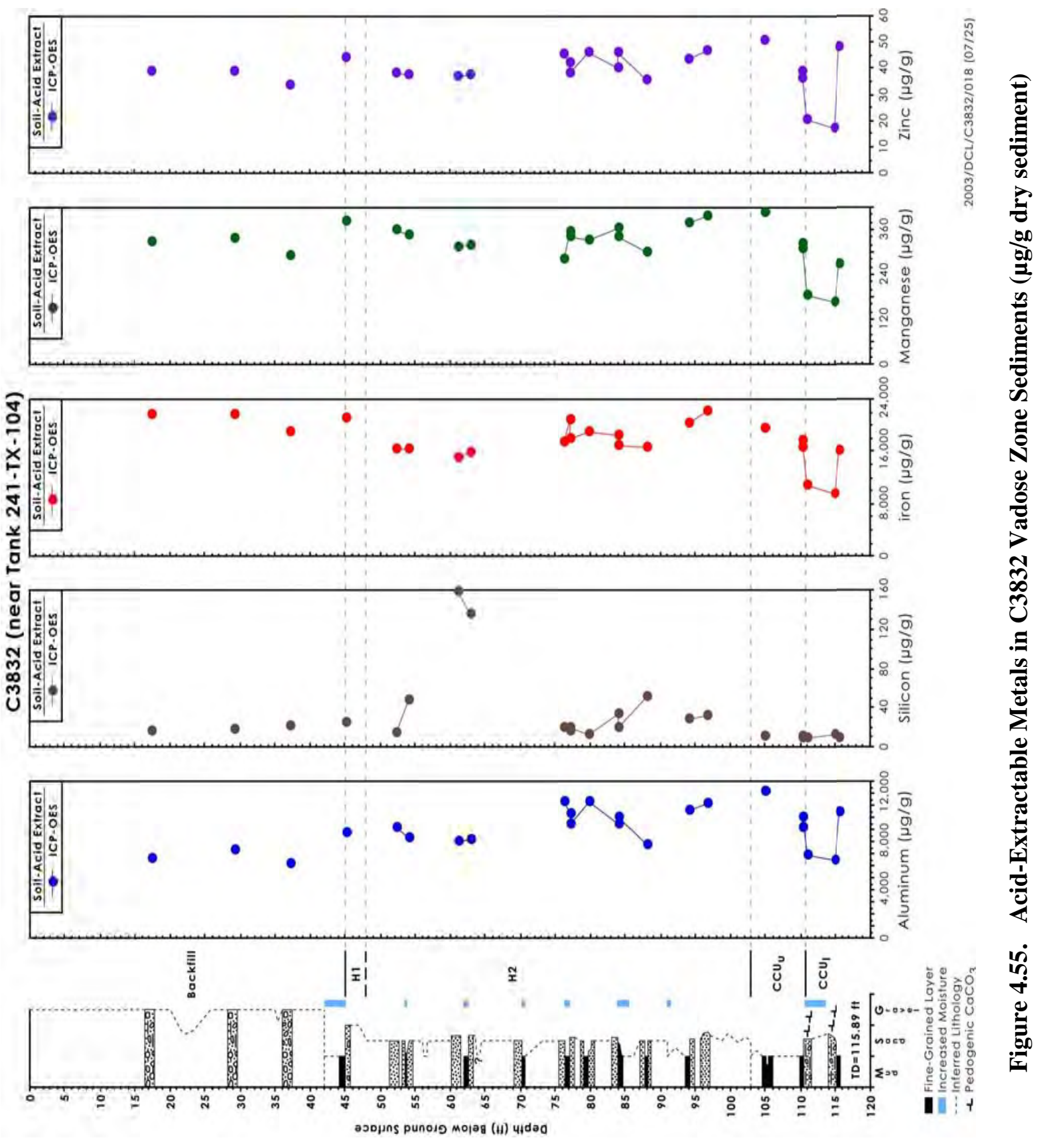




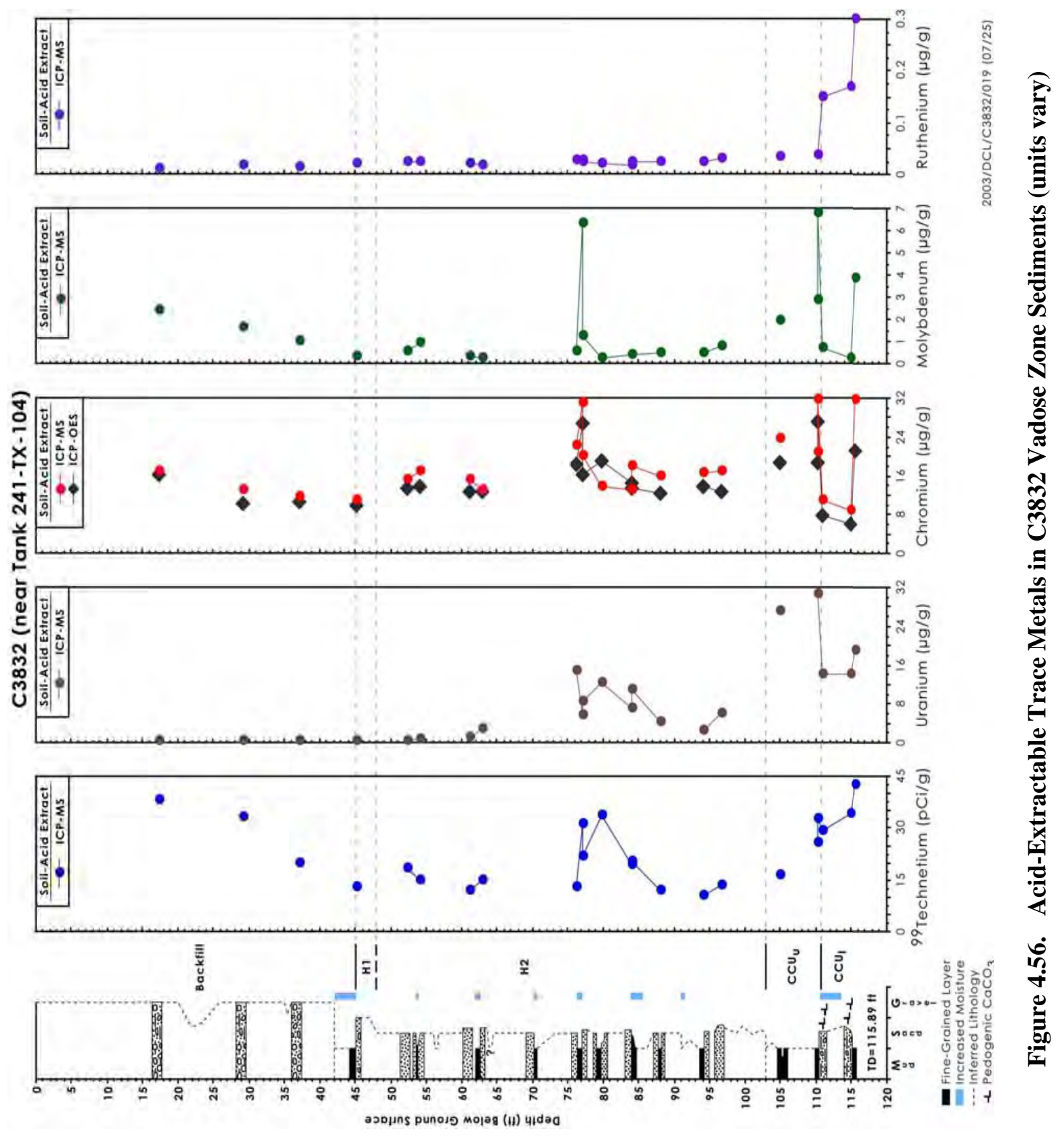




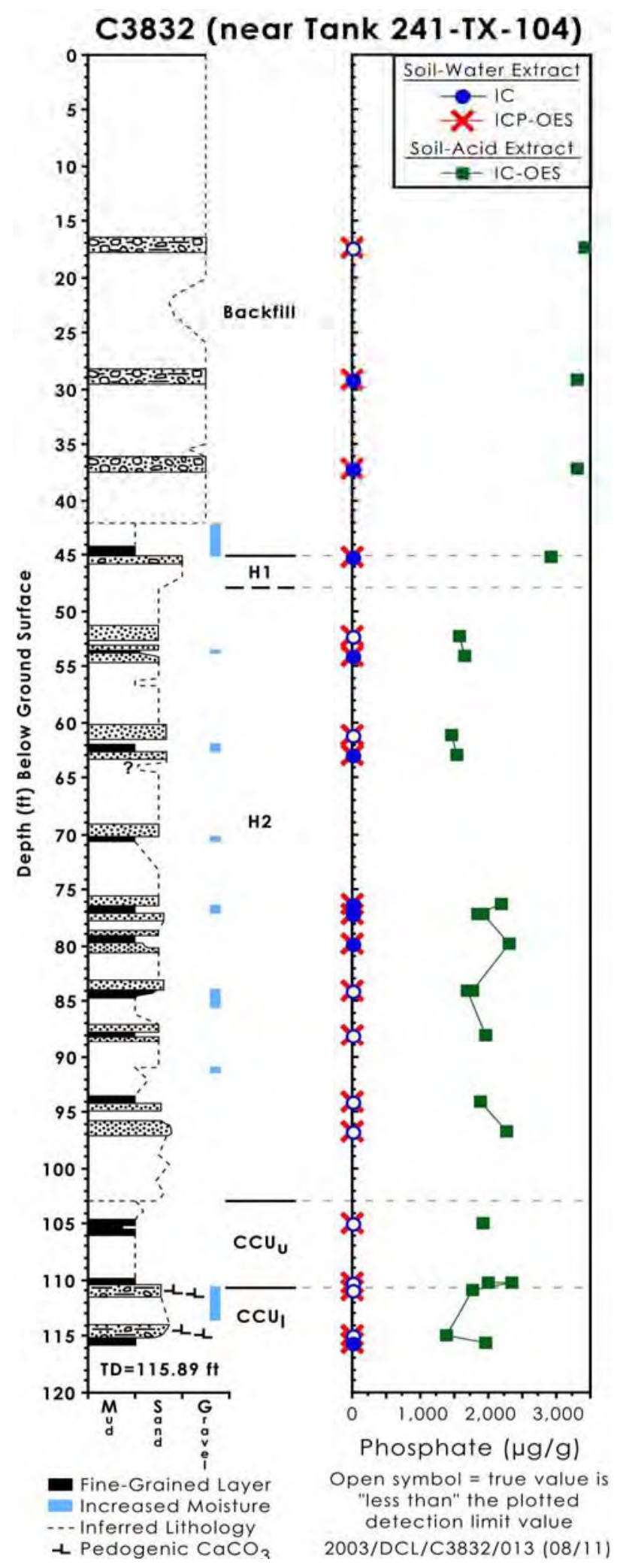

Figure 4.57. Water- versus Acid-Extractable Phosphate in C3832 Vadose Zone Sediments 


\subsubsection{Radionuclide Content in Vadose Zone Sediment from C3832}

Aside from the technetium-99 and uranium-238 data already presented, our gamma energy analyses of sediment from the B core liners found low concentrations of cobalt-60 and cesium-137 in the borehole C3832 sediments between the depths of 60 and $115 \mathrm{ft} \mathrm{bgs}$ (see Table 4.62). Aside from a small amount of surface cesium-137 contamination, the field logging results of the entire borehole casing did not find any other gamma emitting fission product contamination. Figures 4.58 and 4.59 show the laboratory results for natural potassium-40 and uranium-238 and the lab results for common gamma emitters, respectively. Where field-logging data was above detection limits, the log data are plotted also. The agreement between the field and lab generated data for gamma emitters is excellent. There are no manmade gamma emitters in the sediment profile above concentrations of a few tenths of a $\mathrm{pCi} / \mathrm{g}$ excepting the uranium that is several $\mathrm{pCi} / \mathrm{g}$. It is possible that the low concentrations of cobalt- 60 (between 0.5 and $1.2 \mathrm{pCi} / \mathrm{g}$ ) found in the borehole $\mathrm{C} 3832$ sediments between 77 and $115 \mathrm{ft}$ bgs are an extension of the tens of $\mathrm{pCi} / \mathrm{g}$ values found in borehole $\mathrm{C} 3831$ sediments between the depths of 60 and $80 \mathrm{ft}$ bgs. As shown in Figure 2.6, the bottom of the $\mathrm{H} 2$ strata does dip towards the southwest, which is the position of borehole C3832 in juxtaposition with borehole C3831. The uranium-238 concentrations in the sediment at borehole $\mathrm{C} 3832$ are greater than at borehole C3831, which suggests the plume at borehole C3832 is not an extension of the plume intercepted by borehole C 3831 .

Gross alpha and beta measurement were made on both the 1:1 sediment:water and sediment:acid extracts. With knowledge of the mass of dry sediment to extraction fluid used the data were converted to activity of gross beta and alpha leached per gram of dry sediment. None of the water or acid extracts of the 23 extracts ( 21 cores from selected depths and two duplicates) showed activities significantly greater than the detection limits for the procedures. For total beta analyses our detection limits for the water extracts were 10 to $20 \mathrm{pCi} / \mathrm{g}$ dry sediment and 5 to $10 \mathrm{pCi} / \mathrm{g}$ gram dry sediment for the acid extracts. For the total alpha analyses the detection limit for both extracts was 3 to $5 \mathrm{pCi} / \mathrm{g}$ dry sediment. Note that the efficiency of the total beta technique for the low energy technetium-99 is poor such that the total beta analyses can indicate no beta above 10 to $20 \mathrm{pCi} / \mathrm{g}$, yet the ICP-MS measurements for the water and acid extracts for technetium-99 show that there may be 5 to 10 and 10 to $50 \mathrm{pCi} / \mathrm{g}$ of technetium- 99 , respectively, in the borehole $\mathrm{C} 3832$ sediments. We have more confidence in the accuracy of the water extract technetium-99 data.

\subsubsection{Total Carbon, Calcium Carbonate, and Organic Carbon Content of Vadose Zone Sediment from Borehole C3832}

The total, inorganic and organic carbon contents of the C3832 sediments are reported in Table 4.63. The lower Cold Creek subunit (caliche) samples obtained between 111 and $115.54 \mathrm{ft} \mathrm{bgs} \mathrm{contain}$ significant amounts of calcium-carbonate equivalent material with 38 to $46 \%$ by weight. The deepest sediment from the upper Cold Creek subunit at $105 \mathrm{ft}$ bgs and a Hanford $\mathrm{H} 2$ sample at $84 \mathrm{ft}$ bgs also contains about $3 \%$ by weight calcium-carbonate content. As found in most vadose sediments from the Hanford Reservation, there is very little $(<0.1 \%$ by weight $)$ organic carbon in the vadose zone sediments.

The caliche at borehole C3832 has the most calcium-carbonate equivalent solid of all three boreholes and the uncontaminated background sediment from 299-W10-27 based on available samples. The calcium-carbonate content ranges from 20 to $34 \%$ at borehole $\mathrm{C} 3830,22 \%$ at $299-\mathrm{W} 10-27,38 \%$ at borehole C3831, and 38 to $46 \%$ at borehole C3832. Such variability is considered "normal" for paleosols at the Hanford Site. 
Table 4.62. Gamma Emitter Concentrations in Vadose Zone Sediments in Borehole C3832 (pCi/g)

\begin{tabular}{|c|c|c|c|c|c|}
\hline Sample No. & $\begin{array}{c}\text { Depth } \\
\text { (ft bgs) }\end{array}$ & $\begin{array}{c}\text { Stratigraphic } \\
\text { Unit }\end{array}$ & Co-60 & Cs-137 & U-238 \\
\hline $15 \mathrm{~B}$ & 16.56 & backfill & $<0.042$ & $<0.047$ & 1.12 \\
\hline $28 \mathrm{~B}$ & 28.44 & backfill & $<0.034$ & 0.081 & $<0.915$ \\
\hline $37 \mathrm{~B}$ & 36.44 & backfill & $<0.033$ & $<0.040$ & 3.71 \\
\hline $44 \mathrm{~B}$ & 44.49 & backfill & $<0.052$ & 0.099 & 3.28 \\
\hline $52 \mathrm{~B}$ & 51.46 & $\mathrm{H} 2$ & $<0.037$ & 0.061 & 1.65 \\
\hline $53 \mathrm{~B}$ & 53.42 & $\mathrm{H} 2$ & $<0.059$ & $<0.067$ & 3.16 \\
\hline $61 \mathrm{~B}$ & 60.47 & $\mathrm{H} 2$ & $<0.038$ & 0.091 & $<1.30$ \\
\hline $62 \mathrm{~B}$ & 62.16 & $\mathrm{H} 2$ & 0.037 & $<0.050$ & 8.67 \\
\hline $69 \mathrm{~B}$ & 69.34 & $\mathrm{H} 2$ & $<0.049$ & $<0.054$ & 6.12 \\
\hline $76 \mathrm{~B}$ & 76.34 & $\mathrm{H} 2$ & 0.15 & 0.052 & 5.55 \\
\hline 79B & 78.80 & $\mathrm{H} 2$ & 0.32 & $<0.017$ & 2.90 \\
\hline $83 \mathrm{~B}$ & 83.33 & $\mathrm{H} 2$ & 0.78 & $<0.060$ & 6.08 \\
\hline $87 \mathrm{~B}$ & 87.35 & $\mathrm{H} 2$ & 0.14 & 0.037 & 5.57 \\
\hline 93B & 93.35 & $\mathrm{H} 2$ & 0.26 & 0.078 & 7.67 \\
\hline $96 \mathrm{~B}$ & 95.99 & $\mathrm{H} 2$ & 0.31 & 0.043 & 9.35 \\
\hline $104 \mathrm{~B}$ & 104.30 & $\mathrm{CCU}_{\mathrm{u}}$ & 0.18 & 0.019 & $<1.33$ \\
\hline $110 \mathrm{~B}$ & 110.28 & $\mathrm{CCU}_{\mathrm{u}}$ & 0.22 & $<0.050$ & 18.29 \\
\hline $114 \mathrm{~B}$ & 114.13 & $\mathrm{CCU}_{1}$ & 0.25 & 0.058 & 3.14 \\
\hline $121 \mathrm{~B}$ & 114.83 & $\mathrm{CCU}_{1}$ & 0.22 & 0.044 & 4.83 \\
\hline
\end{tabular}




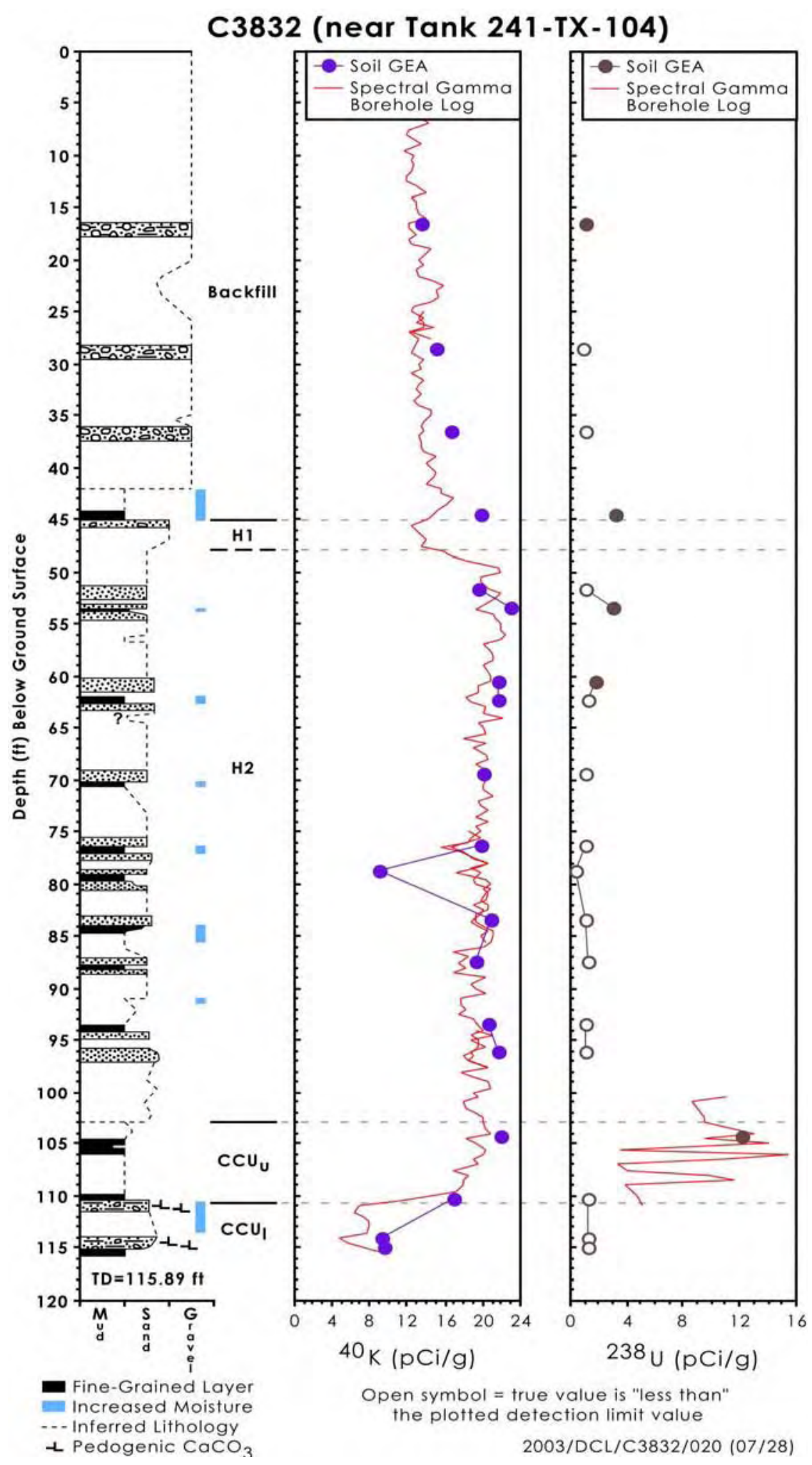

Figure 4.58. Comparison of Lab Gamma Energy Analysis (GEA) and Field Log for Natural Gamma Emitters 

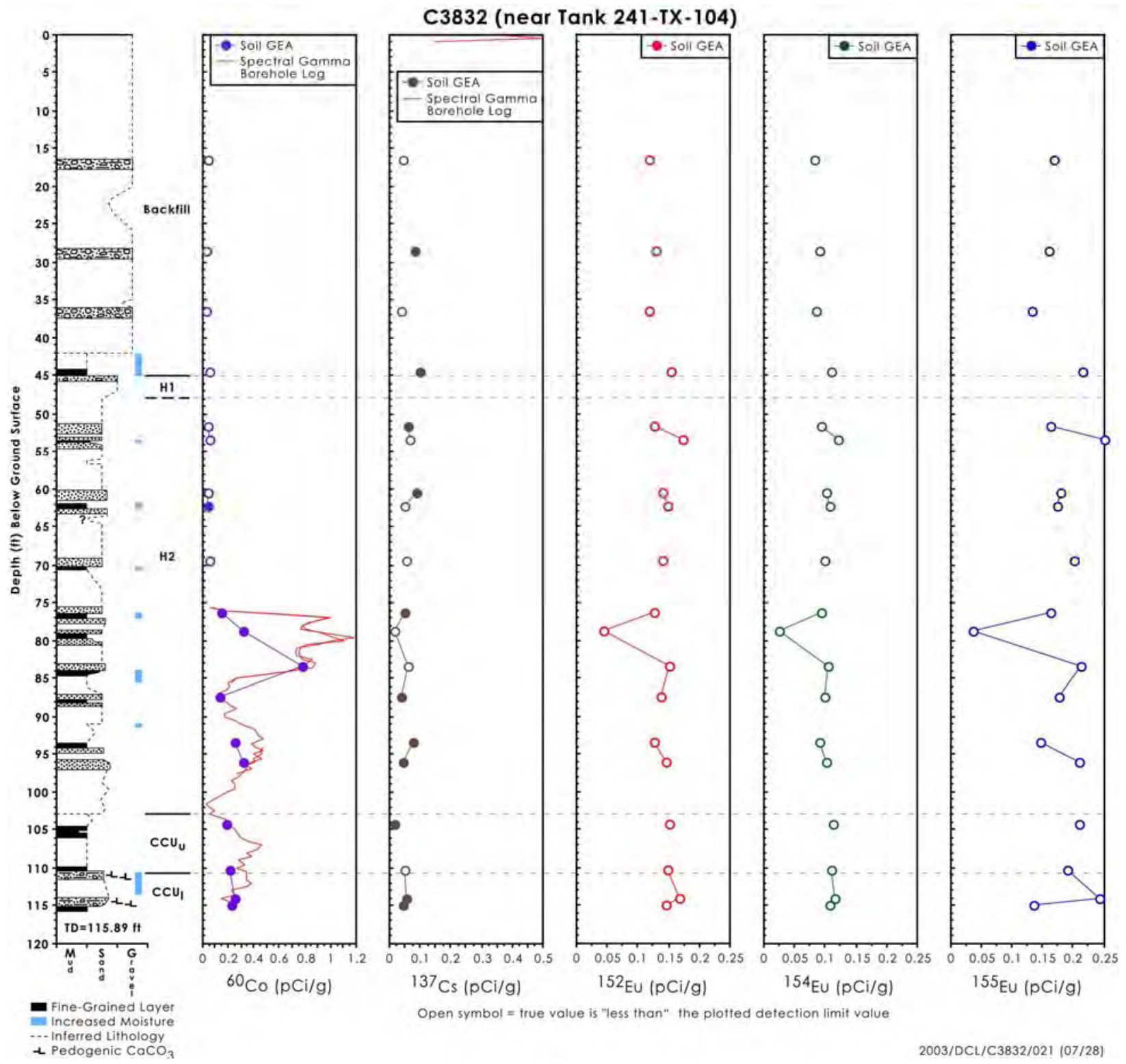

Figure 4.59. Lab and Field Data for Common Gamma Emitters in C3832 Vadose Zone Sediments 
Table 4.63. Carbon Contents of Vadose Zone Sediments in Borehole C3832

\begin{tabular}{||c|c|c|c|c|c|c||}
\hline $\begin{array}{c}\text { Sample } \\
\text { No. }\end{array}$ & $\begin{array}{c}\text { Depth } \\
\text { (ft bgs) }\end{array}$ & $\begin{array}{c}\text { Stratigraphic } \\
\text { Unit }\end{array}$ & $\begin{array}{c}\text { Total } \\
\text { Carbon } \\
\text { \% }\end{array}$ & $\begin{array}{c}\text { Inorganic } \\
\text { Carbon (IC) } \\
\text { \% }\end{array}$ & $\begin{array}{c}\text { IC as } \\
\text { CaCO3 } \\
\text { \% }\end{array}$ & $\begin{array}{c}\text { Organic } \\
\text { Carbon } \\
\text { \% (by diff.) }\end{array}$ \\
\hline 15A & 17.26 & Backfill & 0.17 & 0.06 & 0.51 & 0.11 \\
\hline 28A & 29.14 & Backfill & 0.17 & 0.07 & 0.56 & 0.11 \\
\hline 37A & 37.14 & Backfill & 0.15 & 0.06 & 0.54 & 0.08 \\
\hline 44A & 45.19 & Backfill & 0.34 & 0.24 & 2.00 & 0.10 \\
\hline 52A & 52.01 & H2 & 0.26 & 0.21 & 1.71 & 0.05 \\
\hline 53A & 54.10 & H2 & 0.23 & 0.18 & 1.52 & 0.05 \\
\hline 61A & 61.17 & H2 & 0.21 & 0.16 & 1.33 & 0.05 \\
\hline 62A & 62.96 & H2 & 0.24 & 0.19 & 1.59 & 0.05 \\
\hline 69A & 69.99 & H2 & 0.25 & 0.21 & 1.78 & 0.03 \\
\hline 76A & 77.04 & H2 & 0.24 & 0.17 & 1.45 & 0.07 \\
\hline 79A & 79.81 & H2 & 0.28 & 0.22 & 1.87 & 0.05 \\
\hline 83A & 84.01 & H2 & 0.36 & 0.32 & 2.65 & 0.05 \\
\hline 87A & 88.06 & H2 & 0.16 & 0.13 & 1.07 & 0.03 \\
\hline 93A & 94.05 & H2 & 0.20 & 0.17 & 1.41 & 0.04 \\
\hline 96A & 96.69 & H2 & 0.29 & 0.24 & 1.98 & 0.05 \\
\hline 104A & 105.01 & CCUu & 0.44 & 0.39 & 3.23 & 0.05 \\
\hline 110A & 111.02 & CCU1 & 4.95 & 4.69 & $\mathbf{3 9 . 1 0}$ & 0.26 \\
\hline 114A & 114.85 & CCU1 & 5.74 & 5.48 & $\mathbf{4 5 . 6 4}$ & 0.26 \\
\hline 121A & 115.54 & CCU1 & 4.63 & 4.52 & $\mathbf{3 7 . 6 6}$ & 0.11 \\
\hline Bold type represents samples with caliche present. & & & & \\
\hline \hline
\end{tabular}




\subsection{Groundwater Status Below the TX Tank Farm}

This section summarizes historical as well as recent groundwater data from the uppermost, unconfined aquifer in the vicinity of WMA TX-TY. The data then are used to describe the nature and extent of contamination in the area. The primary focus of this effort is to relate ambient groundwater contamination to releases from waste storage and disposal facilities within or near the Waste Management Area (WMA). Accordingly, historical water levels and flow directions, and contaminant histories in key wells near the WMA are reviewed as background information to better understand the current groundwater contaminant distribution patterns and their relationship to possible waste management area sources.

Selected ratios of mobile contaminants in 1) the vadose zone sediments sampled by the three boreholes, C3830, C3831, and C3832 (see Section 4), 2) the groundwater, and 3) specific single-shell tanks, cribs and trenches at the time of suspected leaks and disposal campaigns, respectively, are used to assess whether there are indications that the groundwater contamination is related to current vadose zone contamination below a specific facility or to chemistry in the tanks at the time of suspected leaks. Figure 5.1 shows the location of all wells discussed in this section.

\subsection{Aquifer Properties}

This section provides information on the properties of the uppermost, unconfined aquifer in the immediate region of WMA TX-TY. Aquifer properties were determined from stratigraphic interpretations, current water level elevations, and aquifer testing.

Beneath the 200 West Area, the suprabasalt aquifer system contains the uppermost, unconfined aquifer and the underlying Ringold confined aquifer. Deeper confined and semi-confined aquifer systems also exist beneath these sedimentary aquifers in the basalt flow tops, flow bottom zones, and sedimentary interbeds (DOE 1988). Groundwater flow, both vertically and horizontally, in the suprabasalt aquifers is less constrained than in the deeper basalt aquifers.

The suprabasalt aquifers below the Hanford Reservation have been impacted by past practice, liquid waste disposal operations, and unplanned releases, in some instances from single-shell tank leaks. In the area of WMA TX-TY, large volumes of waste water disposed to the ground between the 1940s and 1997 created large artificial groundwater mounds, particularly beneath the 216-T pond system, north of WMA TX-TY, and beneath the 216-U pond, southwest of WMA TX-TY. The disposed liquids contained many of the contaminants that now move through the upper unconfined aquifer. Water mounding has declined significantly since the 1997 cessation of non-permitted liquid waste disposal.

The following discussion focuses on the uppermost, suprabasalt aquifer system within the Ringold and Hanford formations. The suprabasalt aquifers are the uppermost regionally extensive aquifers beneath the WMA TX-TY. Groundwater within this aquifer system is contained within the fluvial-lacustrine sediments of the Ringold Formation.

Only one well, 299-W11-13, near WMA TX-TY extends to the top of basalt and has recent water level data. (Well 299-W11-13 is located about 275 m east of the 241-TY tank farm.) Based on the March 2003 water table elevation, the suprabasalt aquifer system is approximately $73-\mathrm{m}$ thick at this well. 


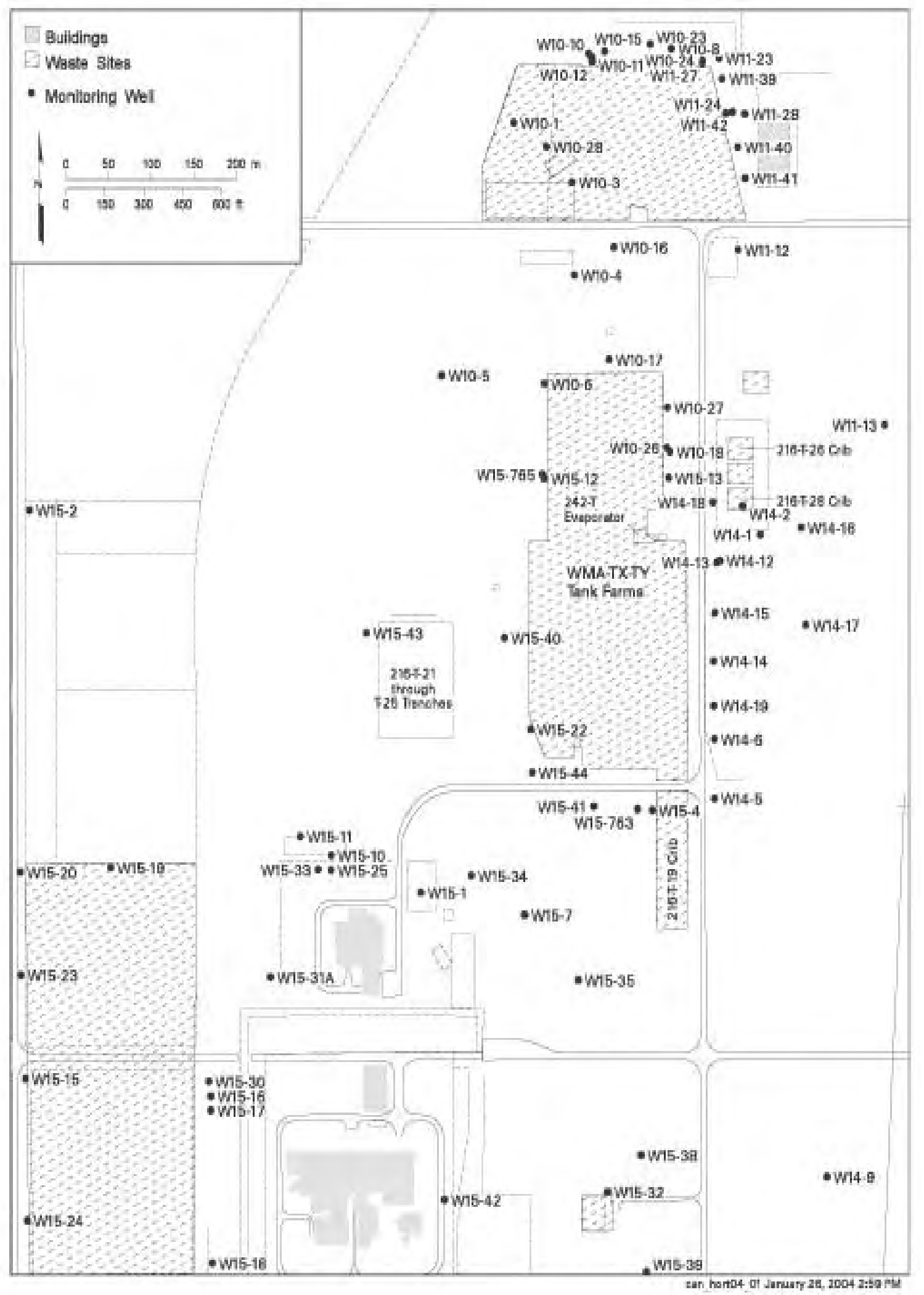

Figure 5.1. Well Location Map for WMA TX-TY 
The base of the uppermost, unconfined aquifer generally is regarded as the basalt surface and, where this is the case, the entire suprabasalt aquifer is unconfined. However, beneath WMA TX-TY (and beneath the entire 200 West Area), the silt and clay deposits of the Ringold Formation lower mud unit (hydrogeologic unit 8 of Williams et al. [2002]) form a confining layer that separates the suprabasalt aquifer into the uppermost, unconfined aquifer and the underlying, Ringold confined aquifer (Williams et al. 2002). Thus, the uppermost, unconfined aquifer in the area of interest extends from the water table down to the top of the lower mud unit. The unconfined aquifer is about 55-m thick at well 299-W14-14, east of WMA TX-TY, based on the August 2003 water level. The unconfined aquifer consists of sandy gravels and gravelly sands of the Ringold Formation member of Wooded Island unit E (hydrogeologic unit 5 of Williams et al. 2002). The Ringold confined aquifer is 18-m thick based on the 2003 data. All wells in the WMA TX-TY monitoring networks are screened in hydrogeologic unit 5. Currently, the water table at WMA TX-TY is 136 to $137 \mathrm{~m}$ above sea level.

Water levels in the uppermost, unconfined aquifer raised as much as $13.5 \mathrm{~m}$ (above the pre-Hanford natural water table) beneath WMA T and TX-TY because of artificial recharge from liquid waste disposal operations active since the mid-1940s. The largest volumes of discharge were to the 216-T pond system and the $216-\mathrm{U}-10$ pond. Figure 5.2 shows the liquid discharge history for the two ponds. The 216-T pond system is estimated to have received approximately 424 billion liters of effluent (Alexander et al. 1995) and the 216-U pond to have received about 158 billion liters of effluent (Last 1994). The large-volume disposals to the ponds (and lesser volumes to cribs and ditches) artificially recharged the uppermost unconfined aquifer, creating large water-table mounds. The increase in water-table elevation was most rapid from 1949 to 1956, and was somewhat stabilized between the late 1960s and the late 1980s. Water levels began to decline in the late 1980s beneath WMA T and TX-TY when wastewater discharges in the 200 West Area were reduced. The decline in water levels may have implications for the groundwater monitoring network at WMA TX-TY, as discussed later.

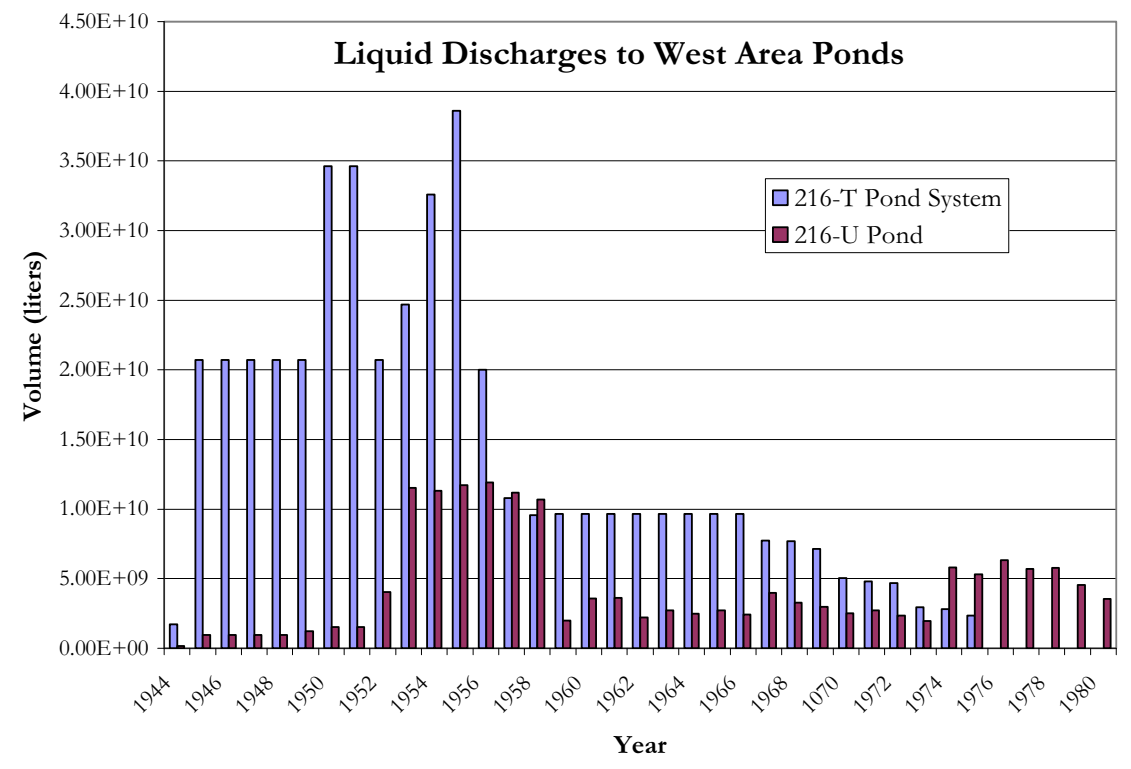

Figure 5.2. Discharge History for the 216-T Pond and the 216-U Pond. Data for the 216-T Pond are from Alexander et. al 1995 and Data for the 216-U Pond are from Last 1994 
Accompanying the changes in water level were changes in groundwater flow direction. Pre-Hanford Site groundwater flow direction was toward the east (Kipp and Mudd 1974). Figure 5.3 contains hydrographs that show that groundwater flow had changed toward the south in the area in the late 1940s and early 1950s. This shift resulted from disposal of large volumes of liquid to the 216-T pond system. In 1956, groundwater flow direction changed again and started flowing towards the north due to the increasing influence of the groundwater mound under 216-U pond and a decreasing influence of the mound under 216-T pond. Discharges to 216-T pond ended in 1976 but continued at 216-U pond until 1984. Consequently, the flow direction changed again in about 1996 when all non-permitted discharges to the ground ceased and the influence of the 216-U pond mound on the groundwater beneath the TX and TY tank farms diminished. Around 1996, the groundwater flow direction began to return toward the east or southeast.

\section{Hydrographs}

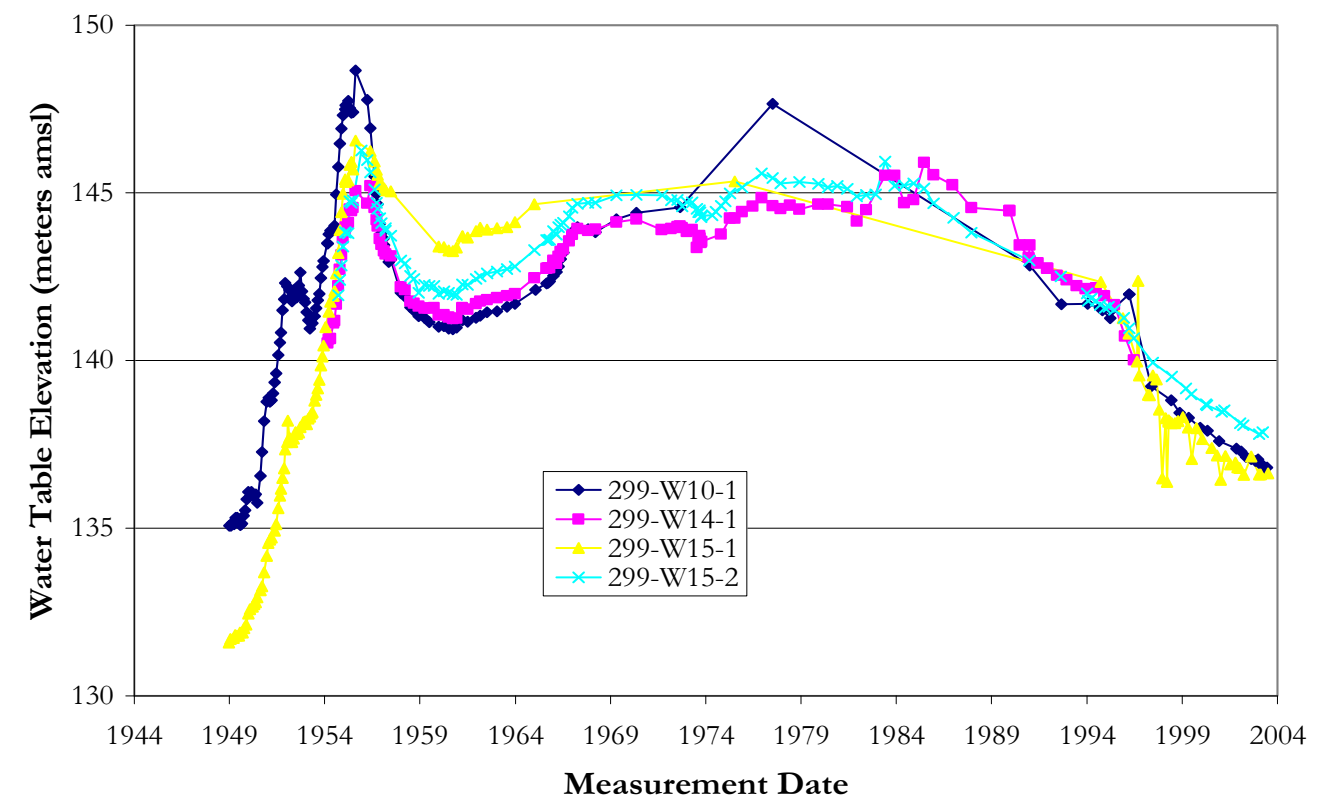

Figure 5.3. Hydrographs of Selected Wells in North 200 West Area. See Figure 5.1 for Locations of Wells

These large shifts in groundwater flow direction have large implications for contaminant distribution in the uppermost aquifer beneath WMA TX-TY. In the late 1940s and early 1950s, contamination was spread south in the aquifer. Then, in the late 1950s and until the mid-1990s, that same contamination returned to the north along with any new contamination that entered the aquifer after the 1950s. Today, groundwater contamination beneath the WMA and the surrounding area is generally migrating east.

Figure 5.4 and 5.5 show hydrographs for monitoring wells around the TX and TY tank farms. These hydrographs and the regional water table map (Figure 5.6) show that the groundwater flow direction beneath the TY tank farm and the northern and central parts of the TX tank farm is currently toward the southeast. Groundwater flow beneath the southern part of the TX tank farm, which is strongly influenced by the 200-ZP-1 pump-and-treat system, is toward the south, or possibly the south-southwest.

(The nearest 200-ZP-1 extraction wells to the TX tank farm are shown as open triangles on the water table map in Figure 5.6.) 


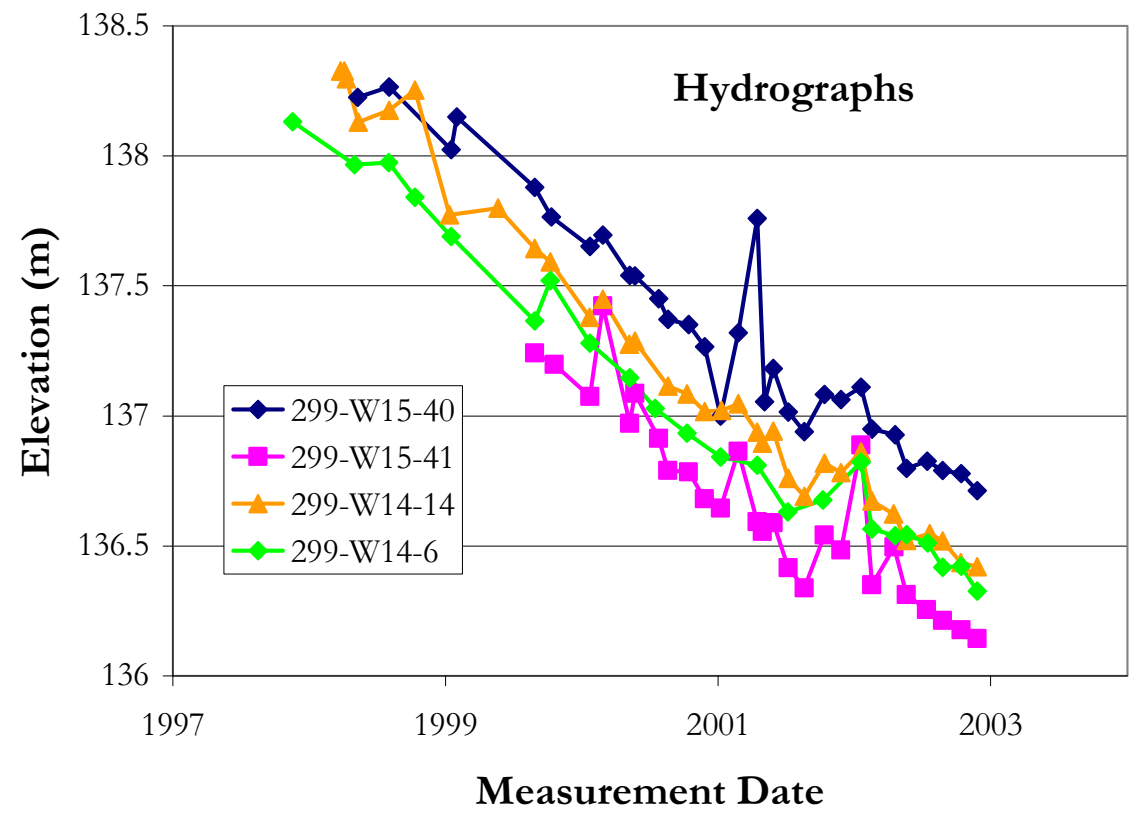

Figure 5.4. Water Levels in Selected Wells Around the TX Tank Farm. See Figure 5.1 for Well Locations

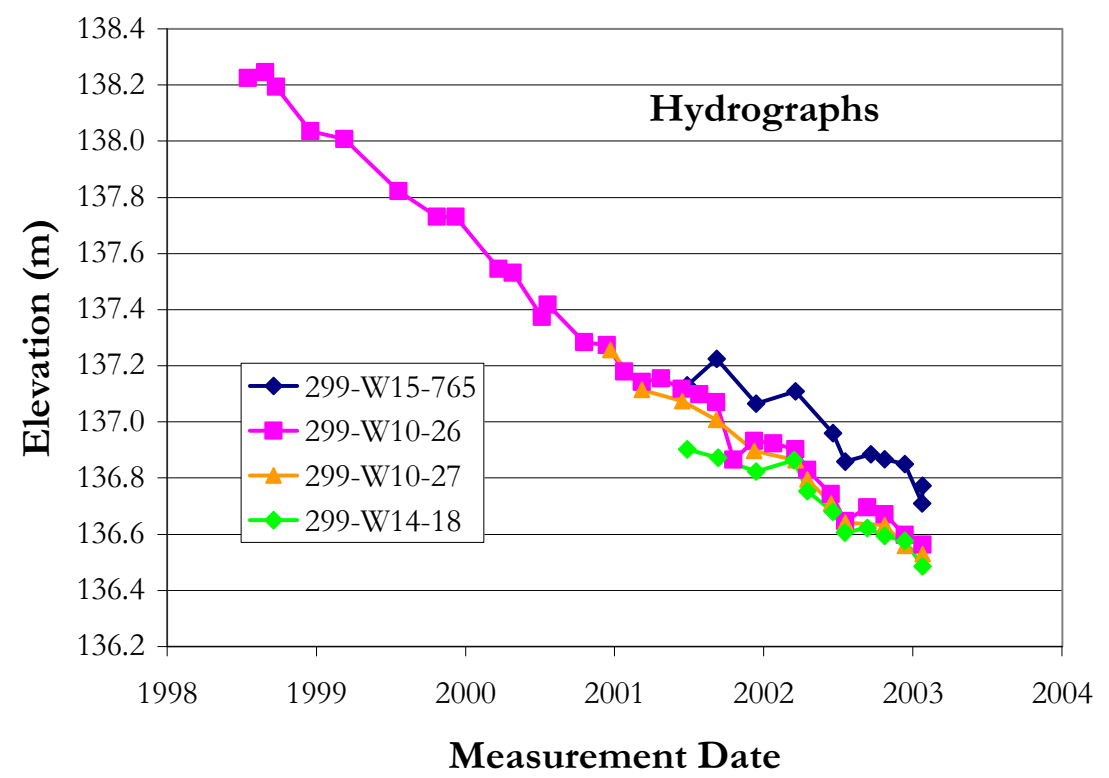

Figure 5.5. Water Levels in Selected Wells Around the TY Tank Farm. See Figure 5.1 for Well Locations 


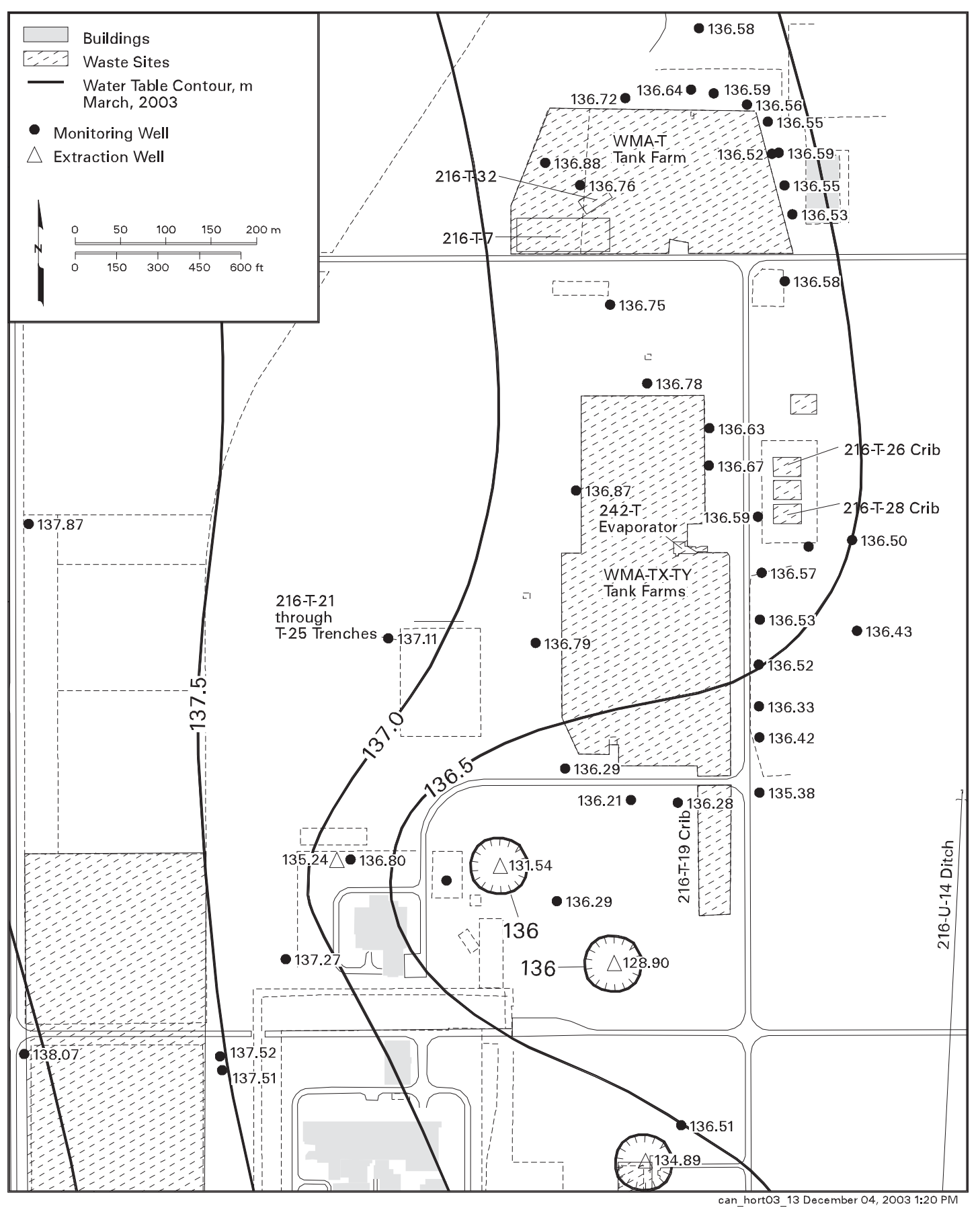

Figure 5.6. March 2003 Water Table Map for the WMA TX-TY Area

Four trend-surface analyses of the water table have been done at WMA TX-TY in recent years (Table 5.1). One trend-surface analysis of the water table was done at well 299-W10-26 east of the TY tank farm area using May 1999 water levels. The analysis yielded a flow direction 72 degrees east of south $\left(\mathrm{S} 72^{\circ} \mathrm{E}\right)$ and a gradient of 0.00073 (Spane et al. 2001a). The calculated flow direction is somewhat more southerly than the flow direction indicated by the latest water table map (Figure 5.6). 
The most northern analysis at the TX tank farm was done at well 29-W14-13 and gave the same flow direction $\left(\mathrm{S} \mathrm{72}{ }^{\circ} \mathrm{E}\right)$ and hydraulic gradient (0.00073) as obtained for the analysis of well 299-W10-26 at TY tank farm. (This is because the same data set, except for the subject well, was used in both analyses.) A flow direction of $\mathrm{S} 72^{\circ} \mathrm{E}$ at this well is in good agreement with the water table map.

Further south, along the downgradient side of the TX tank farm, groundwater flow direction changes from $\mathrm{S} 72^{\circ} \mathrm{E}$ at well 299-W14-13, to $\mathrm{S} 64^{\circ} \mathrm{E}$ to $\mathrm{S} 59^{\circ} \mathrm{E}$ at well 299-W-14-15 (Spane et al. 2001a, 2002). Still further south, at well 299-W14-14, a trend analysis indicates a flow direction of S $47^{\circ} \mathrm{E}$ (Spane et al. 2003). The flow directions from the trend surface analyses are in general agreement with the current water table map (Figure 5.6). These data show that the groundwater flow direction becomes increasingly more southerly toward the south. Groundwater beneath this part of the WMA is obviously influenced by the extraction wells of the 200-ZP-1 pump-and-treat system. Figure 5.6 shows the location of the nearest extraction wells for this pump-and-treat to WMA TX-TY.

Table 5.1. Groundwater Flow Characterization Results Based on Trend Surface Analyses. (Data are from Spane et al. 2001a, 2002, and 2003)

\begin{tabular}{|c|c|c|c|c|}
\hline Well & $\begin{array}{c}\text { Measurement } \\
\text { Date }\end{array}$ & $\begin{array}{l}\text { Groundwater } \\
\text { Flow Direction }\end{array}$ & $\begin{array}{c}\text { Hydraulic } \\
\text { Gradient }\end{array}$ & $\begin{array}{l}\text { Wells Used } \\
\text { in Analysis }\end{array}$ \\
\hline \multicolumn{5}{|c|}{ TX Tank Farm } \\
\hline 299-W14-13 & $5 / 3 / 99$ & $\mathrm{~S} 72^{\circ} \mathrm{E}$ & 0.00073 & \begin{tabular}{|l} 
299-W10-17 \\
299-W10-18 \\
299-W14-12 \\
299-W15-12 \\
299-W15-22
\end{tabular} \\
\hline 299-W14-14 & $\begin{array}{l}7 / 12 / 02 \\
7 / 22 / 02\end{array}$ & $\begin{array}{l}\mathrm{S} 47^{\circ} \mathrm{E} \\
\mathrm{S} 47^{\circ} \mathrm{E}\end{array}$ & $\begin{array}{l}0.00114 \\
0.00109\end{array}$ & $\begin{array}{l}\text { 299-W14-13 } \\
\text { 299-W14-15 } \\
\text { 299-W14-16 } \\
\text { 299-W14-17 }\end{array}$ \\
\hline 299-W14-15 & $\begin{array}{l}7 / 30 / 01 \\
8 / 2 / 01\end{array}$ & $\begin{array}{l}\mathrm{S} 59^{\circ} \mathrm{E} \\
\mathrm{S} 64^{\circ} \mathrm{E}\end{array}$ & $\begin{array}{l}0.00135 \\
0.00140\end{array}$ & $\begin{array}{l}\text { 299-W14-13 } \\
\text { 299-W14-14 } \\
\text { 299-W14-16 } \\
\text { 299-W14-17 }\end{array}$ \\
\hline \multicolumn{5}{|c|}{ TY Tank Farm } \\
\hline 299-W10-26 & $5 / 3 / 99$ & $\mathrm{~S} 72^{\circ} \mathrm{E}$ & 0.00073 & \begin{tabular}{|l}
$299-W 10-17$ \\
$299-W 10-18$ \\
$299-W 14-12$ \\
$299-W 15-12$ \\
$299-W 15-22$
\end{tabular} \\
\hline
\end{tabular}

Borehole tracer dilution and tracer pumpback tests were conducted in one new RCRA monitoring well at TY tank farm (299-W10-26) and two new RCRA wells (299-W14-13 and 299-W14-14) at TX tank farm between fiscal years 1999 and 2002. These tests permitted some inferences about flow rate as well as aquifer homogeneity. The tests allowed direct observation of the effect of lateral groundwater 
flow through the screened interval of the wells, and, thus, provided an indication of the variability of flow through the screened intervals. Details of the test methods, computations, and the results are included in Spane et al. 2001a, 2001b, 2002, and 2003.

A significant finding of the tracer dilution test results is evidence for downward, vertical hydraulic gradients within the upper portion of the aquifer in wells 299-W10-26, 299-W14-13, and 299-W14-14. Vertical flow within these wells was first indicated by tracer-dilution studies in 1999 and later confirmed, also in 1999 (for two of the wells), by vertical tracer tests specifically designed to detect vertical flow within a borehole (Spane et al. 2001a, 2003). Downward vertical flow in these two wells was subsequently confirmed by electromagnetic flow-meter surveys in 2000 (Waldrop and Pearson 2000). The electromagnetic flow-meter surveys found that the depth of maximum downward flow was at $4.9 \mathrm{~m}$ below the water table in well 299-W10-26 and at 5.6 m below the water table in well 299-W14-13. Hydrogeologic data from all three tests are shown in Table 5.2.

Table 5.2. In-Well, Downward Vertical, Flow-Velocity Summary for Wells 299-W10-26 and 299-W-14-13 at WMA TX-TY (Spane et al. 2001a; Spane et al. 2003)

\begin{tabular}{|c|c|c|c|c|c|c|}
\hline & \multicolumn{2}{|c|}{ Tracer-Dilution Profile } & \multicolumn{2}{|c|}{ Vertical Tracer Test $^{(\mathrm{a})}$} & \multicolumn{2}{|c|}{$\begin{array}{c}\text { Electromagnetic Flow- } \\
\text { Meter Survey }\end{array}$} \\
\hline Test Well & $\begin{array}{l}\text { Range } \\
(\mathrm{m} / \mathrm{min})\end{array}$ & $\begin{array}{l}\text { Average } \\
(\mathrm{m} / \mathrm{min})\end{array}$ & $\begin{array}{l}\text { Range } \\
(\mathrm{m} / \mathrm{min})\end{array}$ & $\begin{array}{l}\text { Average } \\
(\mathrm{m} / \mathrm{min})\end{array}$ & $\begin{array}{l}\text { Range } \\
(\mathrm{m} / \mathrm{min})\end{array}$ & $\begin{array}{l}\text { Average } \\
(\mathrm{m} / \mathrm{min})\end{array}$ \\
\hline \multicolumn{7}{|c|}{ TY Tank Farm } \\
\hline 299-W10-26 & $0.002-0.004$ & 0.003 & $0.004-0.008$ & 0.005 & $0.003-0.006$ & 0.004 \\
\hline \multicolumn{7}{|c|}{ TX Tank Farm } \\
\hline 299-W14-13 & $0.008-0.015$ & 0.011 & $0.013-0.014$ & 0.012 & $0.012-0.013$ & 0.012 \\
\hline 299-W14-14 & $0.0054-0.0058$ & 0.0056 & ND & ND & ND & ND \\
\hline \multicolumn{7}{|c|}{$\begin{array}{l}\text { (a) In-well, vertical, flow-velocity range calculated using tracer peak arrival method for selected sensor depth, while the } \\
\text { average was determined using the center-of-mass technique. } \\
\mathrm{ND}=\text { Not Determined }\end{array}$} \\
\hline
\end{tabular}

All three wells that show in-well, vertical flow have fairly homogeneous lithology throughout the screened interval and the well development drawdown data do not indicate substantial variations in hydraulic conductivity. The existence of vertical flow in a well does not necessarily reflect actual groundwater flow conditions within the surrounding aquifer, but its presence implies a vertical flow gradient and has implications pertaining to the representativeness of groundwater samples collected from the wells. The vertical gradient detected in some wells along the eastern edge of the TX and TY tank farms may have an impact on contaminant distribution patterns in the area. (See Section 5.2.1.4 for discussion of possible causes of vertical flow within these wells.)

A second finding of the hydrologic test data is the suggestion of higher hydraulic conductivity at certain depths within the screened interval of some wells relative to other depths. Aquifer tests in well 299-W15-41, located just south of the TX tank farm, indicate that the middle and lower parts of the screened interval have higher permeability than the upper part (Spane et al. 2001b). However, development pumping data (which is not as definitive as aquifer testing) indicate that the upper part of the 
screened interval in nearby well 299-W15-763 has higher permeability than the lower parts (Horton 2002). Thus, apparent differences in hydraulic conductivity do not appear to correlate from well to well.

For the WMA TX-TY groundwater assessment, new hydraulic conductivity data were obtained from slug tests and drawdown tests conducted in 11 new wells drilled since 1999. Effective porosities were determined from tracer drift and tracer pumpback tests. Hydraulic properties are discussed in detail by Spane et al. 2001a, 2001b, Spane 2002, and Spane et al. 2003 and are presented in Tables 5.3 and 5.4.

Table 5.3 shows horizontal groundwater flow velocities determined from tracer pumpback tests. These velocities are about an order of magnitude greater than the calculated velocities in Table 5.4 for wells 299-W10-26, 299-W14-13, and 299-W14-14, all of which have downward vertical flow in the well. The vertical flow in these wells probably resulted in overestimation of measured flow velocities. Both the measured and calculated velocities are about the same for well 299-W15-41, which has no vertical flow. The relatively high Darcy velocity in well 299-W15-41 is probably due to the relatively high gradient caused by the 200-ZP-1 pump-and-treat extraction wells.

The horizontal velocity in well 299-W14-15 is substantially greater than the velocity calculated for any other wells. Very rapid recovery during slug testing was noted, which suggests a fairly permeable formation (Spane et al. 2002). Pumping tests at well 299-W14-15 did not cause significant drawdown when the well was pumped at 73.2 liters per minute for 285 minutes, which also indicates a relatively permeable formation (Spane et al. 2002). However, there is nothing in the geologist's log to suggest that the formation in the screened interval of well 299-W14-15 is significantly different than the formation at nearby wells. Conversely, slug tests in well 299-W10-27 resulted in extremely long response recoveries indicating low permeability and, thus, a slow groundwater flow velocity. Overall, the calculated Darcy velocities from tests in new wells show approximately one order of magnitude variation in the data.

Taken as a whole, the geologist's logs, geophysical logs, development pumping data, and the hydrologic testing data all indicate heterogeneity in aquifer properties within the screened intervals of several individual wells and among wells at WMA TX-TY. No widespread trends have been identified.

The hydrographs in Figure 5.7 show that water levels have declined by about $6 \mathrm{~m}$ since 1991 beneath the TX and TY tank farms. This decline, resulting from decreasing effluent discharge in the $200 \mathrm{West}$ Area, became much steeper in 1995 with the effective cessation of discharge to all non-permitted facilities in this area. Between 1998 and 2003 the average rate of water table decline was between about 0.3 and $0.4 \mathrm{~m}$ per year in all monitoring wells at WMA TX-TY. The rapid decrease in water levels after 1995 has resulted in monitoring wells going dry more than previously predicted and has necessitated the drilling of 14 new monitoring wells since 2000 .

The pre-Manhattan Project water table was postulated to be at approximately $123 \mathrm{~m}$ above sea level by Kipp and Mudd (1974). More recently, Bergeron and Wurstner (2000) modeled the elevation of the water table beneath the Hanford Site for the Immobilized Low-Activity Waste Performance Assessment. Their results predict a water table elevation between about 130 and $132 \mathrm{~m}$ above sea level in the TX and TY tank farm area for post-Hanford Site influence. 
Table 5.3. Results from Tracer-Dilution and Tracer-Pumpback Tests in Wells at WMA TX-TY (Spane et al. 2001a, 2001b, Spane et al. 2002; Spane et al. 2003)

\begin{tabular}{||l|c|c|c||}
\hline Well & $\begin{array}{c}\text { Effective } \\
\text { Porosity }^{(a)}\end{array}$ & $\begin{array}{c}\text { Groundwater } \\
\text { Flow Velocity } \\
(\mathbf{m} / \mathbf{d})\end{array}$ & $\begin{array}{c}\text { Average In-Well } \\
\text { Flow Velocity }\end{array}$ \\
\hline \hline \multicolumn{3}{|c|}{ TY Tank Farm } \\
\hline \hline \multicolumn{3}{|c|}{ TX Tank Farm } \\
\hline \multicolumn{3}{|c||}{0.124} \\
\hline 299-W14-13
\end{tabular}

Table 5.4. Hydraulic Properties from Slug and Constant Rate Pumping Tests and Calculated Darcy Velocities at New Wells at WMA TX-TY

\begin{tabular}{|c|c|c|c|c|c|}
\hline Well & $\begin{array}{l}\text { Hydraulic }^{(\mathrm{a}, \mathrm{b})} \\
\text { Conductivity } \\
(\mathrm{m} / \mathrm{d})\end{array}$ & $\begin{array}{l}\text { Hydraulic }^{(\mathrm{a}, \mathrm{c})} \\
\text { Conductivity } \\
(\mathrm{m} / \mathrm{d})\end{array}$ & $\begin{array}{l}\text { Transmissivity }^{(\mathrm{a}, \mathrm{c})} \\
\qquad\left(\mathbf{m}^{2} / \mathbf{d}\right)\end{array}$ & $\begin{array}{l}\text { Specific }^{(\mathrm{a}, \mathrm{c})} \\
\text { Yield }\end{array}$ & $\begin{array}{l}\text { Calculated Flow } \\
\text { Velocity }(\mathrm{m} / \mathrm{d})\end{array}$ \\
\hline \multicolumn{6}{|c|}{ TY Tank Farm } \\
\hline 299-W10-26 & "1.39-1.95 & 1.49 & 82 & 0.14 & $0.014^{(\mathrm{d})}$ \\
\hline 299-W10-27 & "0.05-0.07 & ND & ND & ND & $0.0007^{(\mathrm{e})}$ \\
\hline \multicolumn{6}{|c|}{ TX Tank Farm } \\
\hline 299-W14-13 & $1.66-2.43$ & 2.45 & 135 & 0.12 & $0.020^{(\mathrm{d},)}$ \\
\hline 299-W14-14 & $2.31-3.22$ & 2.21 & 121 & 0.12 & $0.027^{(\mathrm{d})}$ \\
\hline 299-W14-15 & $3.52-4.92$ & 4.09 & 225 & 0.01 & $2.46^{(\mathrm{f})}$ \\
\hline 299-W14-16 & $3.90-5.08$ & ND & ND & ND & $0.051^{(\mathrm{e})}$ \\
\hline 299-W14-17 & $3.71-4.89$ & ND & ND & ND & $0.489^{(\mathrm{e})}$ \\
\hline 299-W14-18 & $0.39-0.54$ & ND & ND & ND & $0.005^{(\mathrm{e})}$ \\
\hline 299-W15-40 & $0.88-1.22$ & ND & ND & ND & $0.012^{(\mathrm{e})}$ \\
\hline 299-W15-41 & $14.2-19.9$ & 19.6 & 1130 & 0.12 & $0.29^{(\mathrm{f})}$ \\
\hline 299-W15-763 & $0.71-0.93$ & ND & ND & ND & $0.009^{(\mathrm{e})}$ \\
\hline \multicolumn{6}{|c|}{ (a) Data from Spane et al. 2001a,b, Spane et al. 2002, and Spane et al. 2003) } \\
\hline \multicolumn{6}{|c|}{ (b) Slug test data. } \\
\hline \multicolumn{6}{|c|}{ (c) Constant rate pumping test data. } \\
\hline \multicolumn{2}{|c|}{ Specific yield was used because downward flow in the well resulted in uncertain effective porosity. } & & & & \\
\hline \multicolumn{6}{|c|}{ (e) Estimated using maximum hydraulic conductivity value, a gradient of 0.001 and effective porosity values of 0.1 . } \\
\hline \multicolumn{6}{|c|}{$\begin{array}{l}\text { (f) Estimated using maximum hydraulic conductivity value, a gradient of } 0.001 \text {, and effective porosity value from } \\
\text { Table 5.3. }\end{array}$} \\
\hline \multicolumn{6}{|c|}{ (g) Indicates average hydraulic conductivity obtained from high-permeability, non-linear type-curve analysis method. } \\
\hline
\end{tabular}




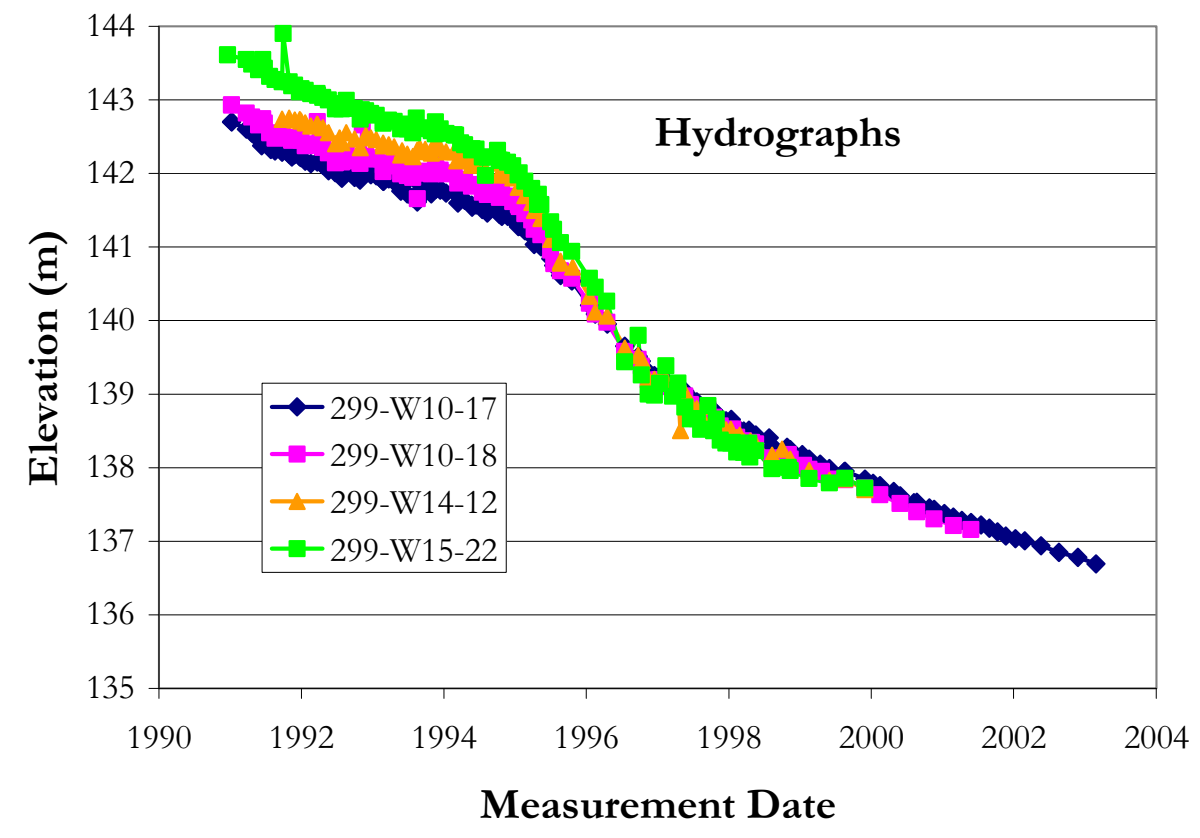

Figure 5.7. Historical Water Level Data from Wells at WMA TX-TY. All Wells Used in the Figure Are Now Dry

\subsection{Existing Groundwater Contamination}

This section discusses the current and historical groundwater contamination at WMA TX-TY. The evaluation of contamination includes descriptions of the types and concentrations of contaminants in the groundwater, the depth distribution of contaminants in the aquifer, and the areal extent of contamination in the area.

Monitoring results from new and existing wells, results of depth sampling during and after installation of new monitoring wells, and comparison of groundwater chemistry in old wells and their adjacent replacement wells, provide new insights into the occurrence and nature of groundwater contamination in the TX and TY tank farm area. The information given in this section is taken largely from Horton (2002) and is updated with more current groundwater data.

Groundwater at the TX and TY tank farms contains elevated concentrations of carbon tetrachloride $\left(\mathrm{CCl}_{4}\right)$, chromium $(\mathrm{Cr})$, iodine-129 (I-129), nitrate $\left(\mathrm{NO}_{3}{ }^{-}\right)$, technetium-99 $(\mathrm{Tc}-99)$, and tritium $\left({ }^{3} \mathrm{H}\right)$. This contamination is a result of mixing of wastes from a number of past waste-disposal activities, including the disposal of tank waste process water, and steam condensate at nearby cribs and trenches, disposal of plutonium processing waste at cribs and trenches associated with the Plutonium Finishing Plant, and leaks from single-shell tanks and transfer lines within the TX and TY tank farms. 


\subsubsection{Extent of Contamination - Depth Distribution}

Determining the vertical extent of contaminants within the uppermost aquifer is part of the RCRA groundwater quality assessment currently underway at WMA TX-TY. A variety of data including discrete depth sampling during drilling, comparison of adjacent wells that sample different parts of the aquifer, depth discrete sampling using dialysis sampling techniques, and detailed specific conductance profiling provide important information about the depth distribution of contaminants.

\subsubsection{Specific Conductance Profiling}

In September 2002, specific conductance measurements were taken at 0.5 - to $1-\mathrm{m}$ intervals throughout the screened intervals of three groundwater monitoring wells around the TX and TY tank farms. Significant differences in specific conductance with depth were found in one of these wells (299-W14-13). The remaining two wells (299-W15-41, and 299-W15-763) showed no variation of specific conductance with depth.

Specific conductance versus depth measured in the screened interval of well 299-W14-13, a downgradient well at WMA TX-TY, is shown in Figure 5.8. Specific conductance in this well decreases significantly with depth between 1 and $4 \mathrm{~m}$ below the water table and then stabilizes at deeper depths. There also appears to be a maximum value of $\sim 1635 \mu \mathrm{S} / \mathrm{cm}$ between 0.5 and $2 \mathrm{~m}$ above which specific conductance decreases with decreasing depth. Very near the surface, at $0.04 \mathrm{~m}$ below the water table, the specific conductance falls to about $1480 \mu \mathrm{S} / \mathrm{cm}$. (The sample from $0.04-\mathrm{m}$ depth was measured in the field with a conductivity meter from a bailed sample approximately six months after the conductivity profile was measured.)

Also shown on Figure 5.8 are four specific conductance values measured during routine quarterly sampling that occurred during fiscal year 2002 and prior to performing the depth profile measurements. All of the pumped specific conductance values range between 1203 and $1250 \mu \mathrm{S} / \mathrm{cm}$ and are less than the ambient values of the depth profile. This indicates that, after purging the well, the pumped samples are not representative of ambient conditions. During purging, the specific conductivity in well 299-W14-13 decreases with increasing purge time. Table 5.5 shows the initial and final specific conductance values after purging and sampling the quarterly samples in 2002. The initial specific conductance values are closer to, but still lower than, the profile values. Evidently, purging the well causes dilution of the samples.

Interpreting the contaminant distribution in well 299-W14-13 is very difficult because groundwater at the well contains high concentrations of several contaminants that show different vertical concentration profiles and probably come from several sources in the area. These variations are discussed later in Section 5.2.1.4. For now, the specific conductance indicates that there are concentration gradients in the screened interval of well 299-W14-13 and that the highest conductance, which probably reflects the highest nitrate concentration, occurs between 0.5 and $2 \mathrm{~m}$ beneath the water table. 


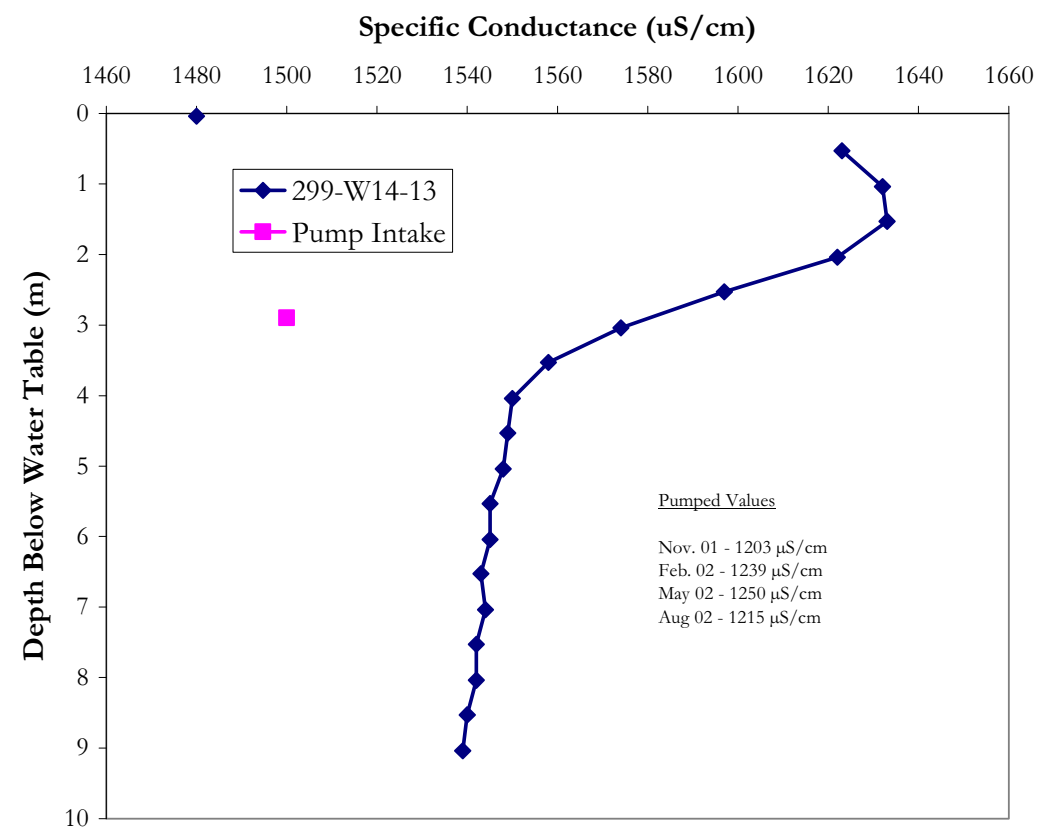

Figure 5.8. Specific Conductance versus Depth in Well 299-W14-13. The Red Box is at the Depth of the Sample Pump Intake. See text for discussion.

Table 5.5. Initial and Final Specific Conductance Values from Four Routine Quarterly Sampling Events During Calendar Year 2002 at 299-W14-13

\begin{tabular}{|c|c|c|}
\hline Sample Date & $\begin{array}{l}\text { Initial Specific Conductance } \\
(\mu \mathrm{S} / \mathrm{cm})\end{array}$ & $\begin{array}{l}\text { Final Specific Conductance } \\
(\mu \mathrm{S} / \mathrm{cm})\end{array}$ \\
\hline November 2001 & 1395 & 1203 \\
\hline February 2002 & 1354 & 1239 \\
\hline May 2002 & 1443 & 1250 \\
\hline August 2002 & 1476 & 1215 \\
\hline
\end{tabular}

\subsubsection{Comparison of Chemical Data from New and Replaced Wells}

Replacement wells, when located immediately adjacent to older wells, offer an opportunity to look for vertical variation within the upper part of the aquifer. Data from three well pairs at the TX and TY tank farms suggest vertical stratification of contaminants in the upper part of the aquifer. In each case, the old well and its replacement well are separated by only a few meters. In addition, in each case, the older well was last sampled when there was a fraction of a meter of water within the screened interval and the replacement well was sampled with a pump placed at least $3 \mathrm{~m}$ below the water table within a $10.7-\mathrm{m}$ screened interval. Thus, the last samples from the old well represent the top of the aquifer and the samples from the replacement well represent a composite of water pumped from the length of the screened interval that includes both the water from near the water table and water from deeper parts of the aquifer. 
Well 299-W14-13 is at the northeast corner of the TX tank farm on the downgradient side of WMA TX-TY (Figure 5.1). This well currently has the highest concentration of technetium-99, tritium, iodine-129, fluoride (F), nitrate, and chromium of any well in TX and TY tank farm monitoring network. Well 299-W14-13 is the replacement well for well 299-W14-12 that went dry in early 1999. The two wells are located $\sim 3 \mathrm{~m}$ apart. The last sampling of well 299-W14-12 took place in January 1999 and sampling of replacement well 299-W14-13 started in December 1998, allowing a sampling overlap between the two adjacent wells. The last samples collected from well 299-W14-12 represent the top of the aquifer. The samples collected from well 299-W14-13 represent water throughout the screened interval, which extends from the water table to $10 \mathrm{~m}$ below the water table. The pump intake is at $4.8 \mathrm{~m}$ below the water table.

Trend plots for several key constituents are shown in the series of Figures 5.9 to 5.12. The results for technetium-99 are particularly interesting (Figure 5.9). The concentration of technetium-99 in the last sample from well 299-W14-12 was $\sim 6,000 \mathrm{pCi} / \mathrm{L}$. This represented the concentration of technetium-99 at the top of the aquifer in January 1999. The sample from replacement well 299-W14-13, taken about the same time, contained $\sim 2,500 \mathrm{pCi} / \mathrm{L}$ technetium- 99 . That sample represented the technetium-99 concentration throughout much of the upper $10 \mathrm{~m}$ of the aquifer. The conclusion is that technetium-99 existed at the top of the aquifer at about $6,000 \mathrm{pCi} / \mathrm{L}$ and the concentration decreased deeper in the aquifer. The 2,500 pCi/L technetium-99 value from well 299-W14-13 is a mixture of the relatively concentrated technetium-99 near the water table with more dilute groundwater from deeper in the aquifer.

Technetium-99 in the area of well 299-W14-12 began decreasing from a maximum of $\sim 13,500 \mathrm{pCi} / \mathrm{L}$ in 1993 and continued to decrease until about January 1997. At that time, technetium-99 began to increase and reached $6,000 \mathrm{pCi} / \mathrm{L}$ in January 1999 when the well went dry. The increasing technetium-99 trend was continued in the replacement well (although offset to lower concentrations) until early 2000 when technetium- 99 concentrations climbed to $\sim 8,000 \mathrm{pCi} / \mathrm{L}$. In early 2000 , technetium- 99 began to decrease and dropped to about $3,300 \mathrm{pCi} / \mathrm{L}$ in early 2001 at which time the concentration began to increase again. The latest increase continued until February 2003 and reached 8,740 pCi/L.

The results for nitrate in wells 299-W14-12 and 299-W14-13 (Figure 5.10) show a trend similar to that seen for technetium-99. The concentration of nitrate in the last sample from well 299-W14-12 was about $600,000 \mu \mathrm{g} / \mathrm{L}$, and this represented the concentration of nitrate at the top of the aquifer. The sample from well 299-W14-13, taken at about the same time, contained only about $315,000 \mu \mathrm{g} / \mathrm{L}$ of nitrate. Just as for technetium-99, the conclusion is that nitrate existed at the water table at about $600,000 \mu \mathrm{g} / \mathrm{L}$ in January 1999, and the concentration decreased with depth in the aquifer. The 315,000 $\mu \mathrm{g} / \mathrm{L}$ nitrate value from well 299-W14-13 is a mixture of the high nitrate-bearing water at the top of the aquifer with lower nitrate-bearing water deeper in the aquifer.

The nitrate concentration trends through time are the similar to those seen for technetium-99 (compare Figures 5.9 and 5.10). Nitrate began to decrease from a maximum or about $540,000 \mu \mathrm{g} / \mathrm{L}$ in 1993 to about $200,000 \mu \mathrm{g} / \mathrm{L}$ in early 1997 . Nitrate then began to increase, reaching $580,000 \mu \mathrm{g} / \mathrm{L}$ in January 1999. The increasing nitrate trend was continued in the replacement well until early 2000 when concentrations reached $\sim 440,000 \mu \mathrm{g} / \mathrm{L}$. Nitrate began to decrease a second time until early 2001 , at which time it began a second increasing trend that lasted through the beginning of 2003. Since that time nitrate concentration has decreased somewhat. 
The analytical results for tritium in wells 299-W14-12 and 299-W14-13 (Figure 5.11) show a different trend than that seen for technetium-99 and nitrate. The concentration of tritium in the last sample from well 299-W14-12 was 1,170,000 pCi/L. The sample from well 299-W14-13, obtained about one month later, contained 1,160,000 pCi/L tritium. Following the same logic as used for technetium-99 and nitrate, the sample from well 299-W14-12 represents the tritium concentration at the top of the aquifer, whereas the sample from well 299-W14-13 represents the upper $10 \mathrm{~m}$ of the aquifer. Both results are the same, indicating little, if any, vertical concentration differences for tritium. Thus, unlike nitrate and technetium-99, the upper part of the aquifer at this location appears to be fairly homogeneous with respect to tritium concentration.

However, tritium concentrations in the groundwater show the same trends with time as shown by nitrate and technetium-99. Tritium began to decrease in concentration in 1993 and began to increase in early 1997 to a maximum of $2,940,000 \mathrm{pCi} / \mathrm{L}$ in early 2000 . At that time, tritium began to decrease until early 2001 when tritium concentrations began to increase again. The latest increase reached 2,170,000 pCi/L in February 2003 and concentrations have declined since that time.

The concentrations of chromium in filtered samples from wells 299-W14-12 and 299-W14-13 are shown in Figure 5.12. The data suggest a different distribution of chromium in the upper part of the aquifer than the distributions of nitrate, technetium-99, and tritium. The data from the well pair indicate that the concentration of chromium is low at the top of the aquifer and increases at some depth below the water table. Chromium concentrations in the upgradient well pair, 299-W15-12 and 299-W15-765, seem to support this distribution of chromium in the aquifer (Figure 5.13), although the concentration in both upgradient wells is much lower than at the 299-W14-12 and 299-W14-13 pair. As will be discussed later, detailed depth-discrete sampling in well 299-W14-13 suggests that the chromium concentration at the water table is slightly greater than the concentration throughout the rest of the screened interval. This is contrary to the conclusion drawn from comparing the chromium concentrations in well 299-W14-12 and 299-W14-13. In addition, the concentrations of technetium-99 and chromium in well 299-W14-13 track each other through time and the ratio of the two is fairly constant (Figure 5.14). This suggests that the two contaminants are from the same source and, if this is the case, they should not be fractionated differently in the aquifer versus depth or time. Thus, there is some discrepancy among the data as to the interpretation of the distribution of chromium in this well pair and its relation to technetium-99.

Two other well pairs were examined at the TY tank farm. No concentration differences versus water depth were noted for technetium-99, tritium, chromium or nitrate in well pair 299-W10-18 and 299-W10-26, located downgradient (east) of TY tank farm. Data from well pair 299-W15-12 and 299-W15-765, located upgradient of the TY tank farm and not in a high contamination area, suggest that technetium-99 concentrations are somewhat greater at the water table than at depth in the screened interval. 


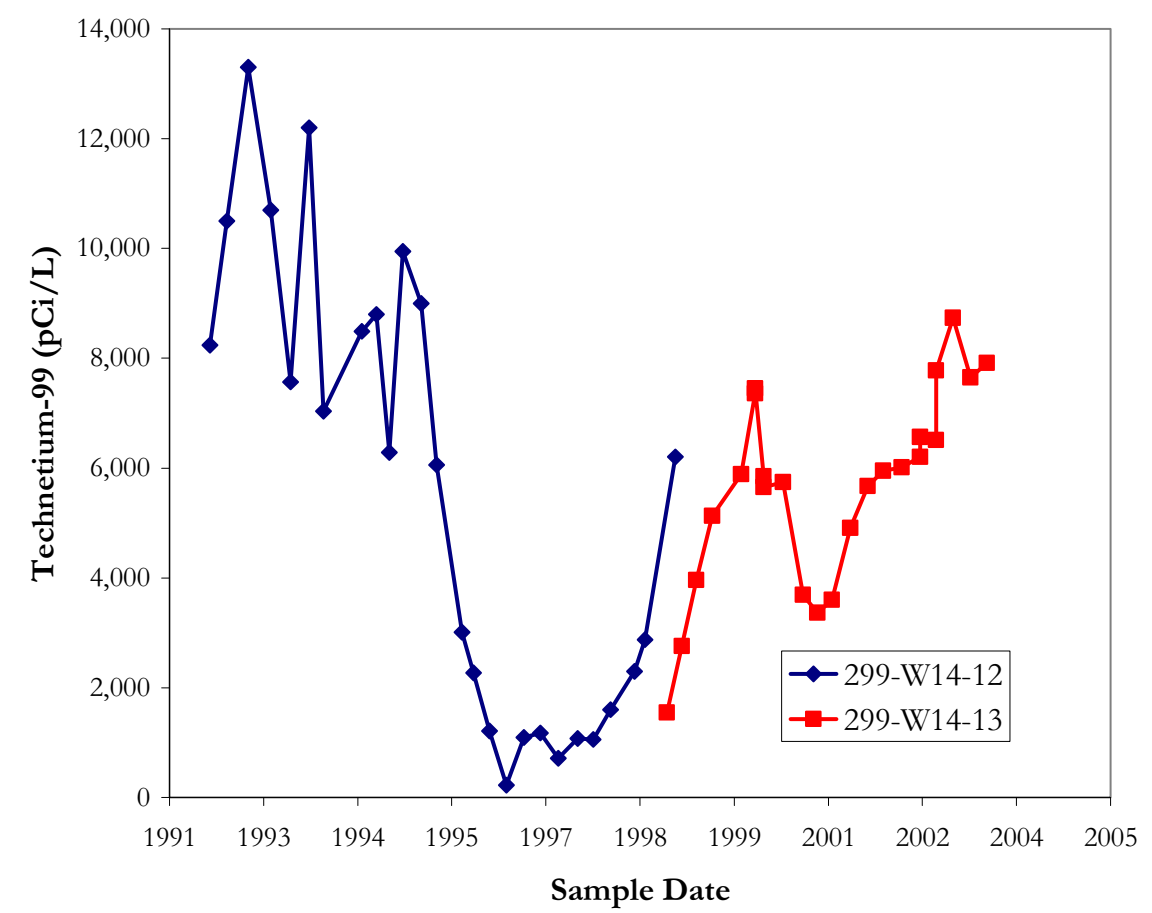

Figure 5.9. Technetium-99 Concentration in Wells 299-W14-12 and 299-W14-13 in WMA TX-TY

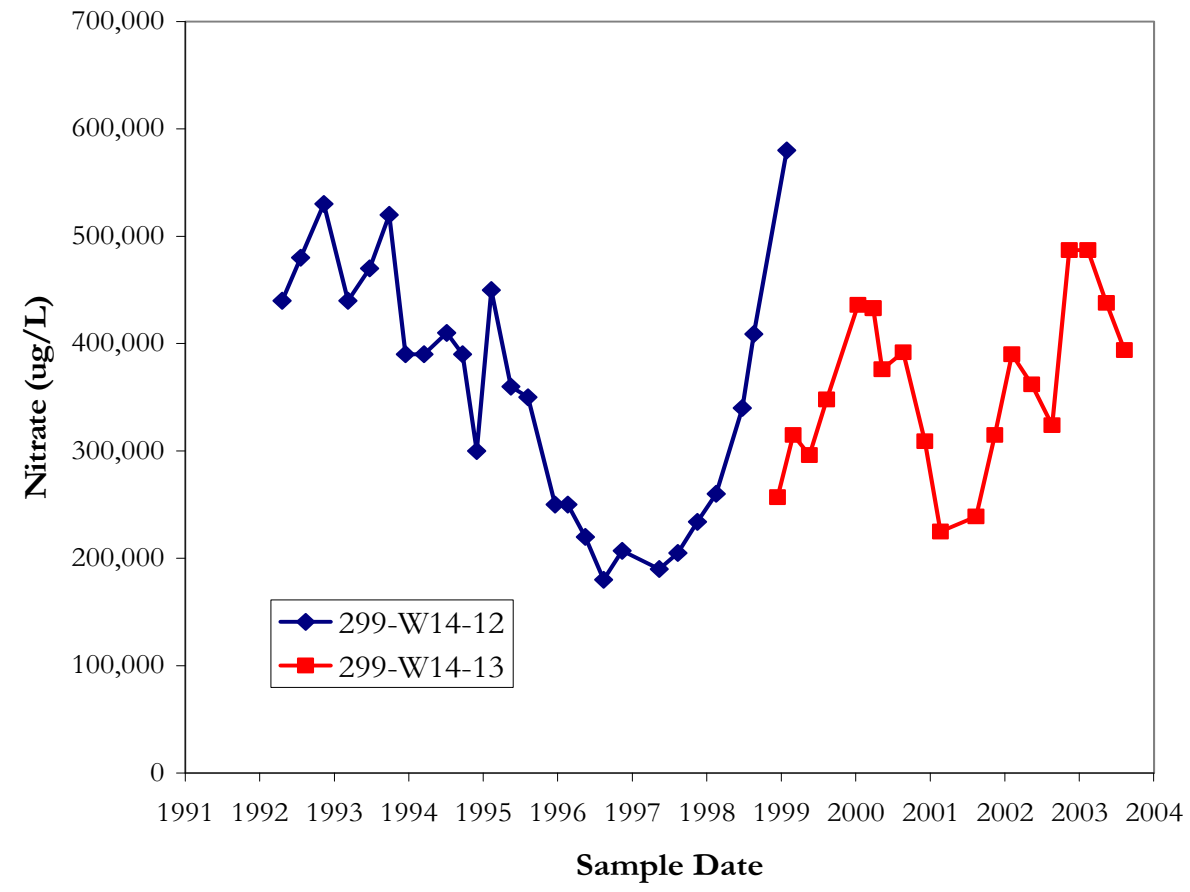

Figure 5.10. Nitrate Concentrations in Wells 299-W14-12 and 299-W14-13 at WMA TX-TY 


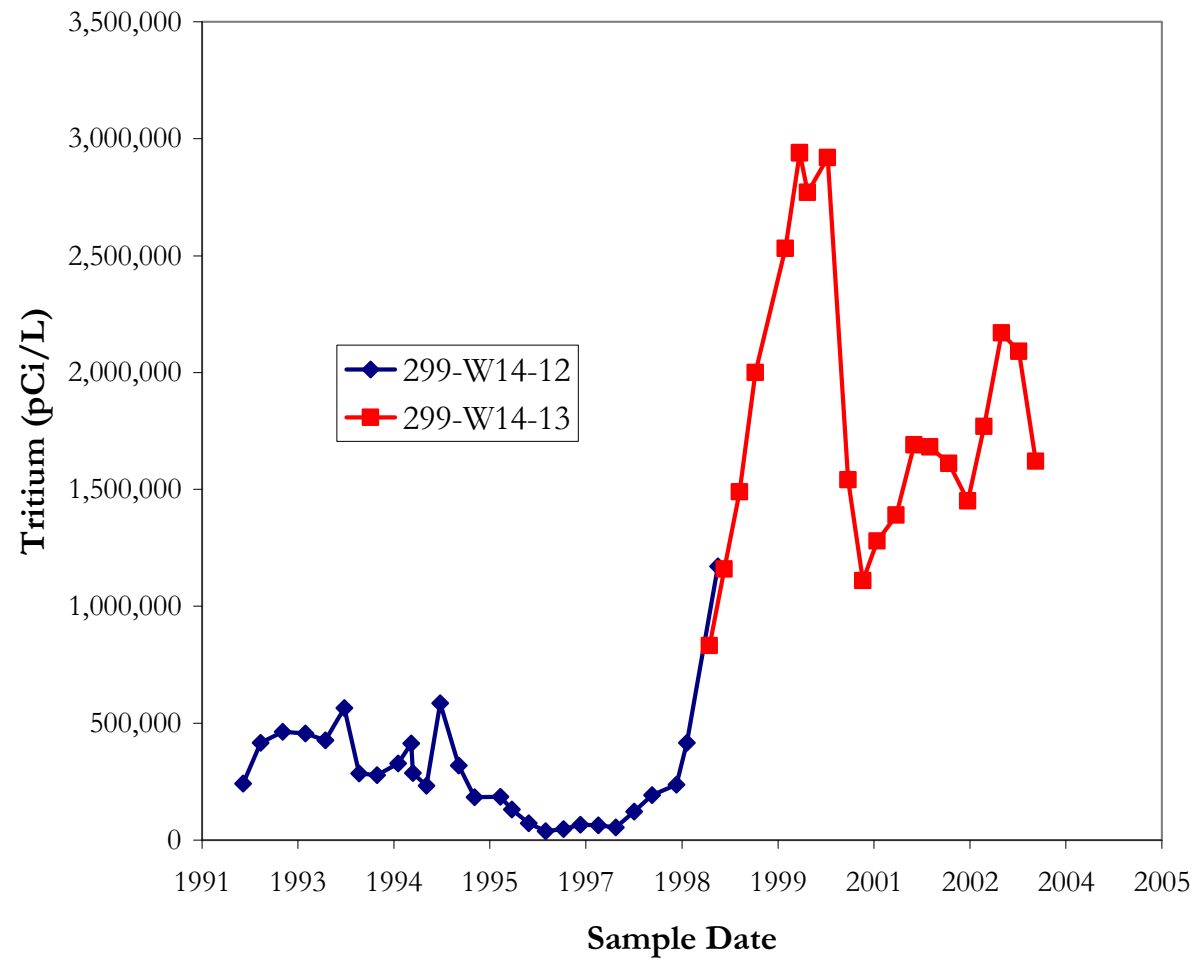

Figure 5.11. Tritium Concentrations in Wells 299-W14-12 and 299-W14-13 at WMA TX-TY

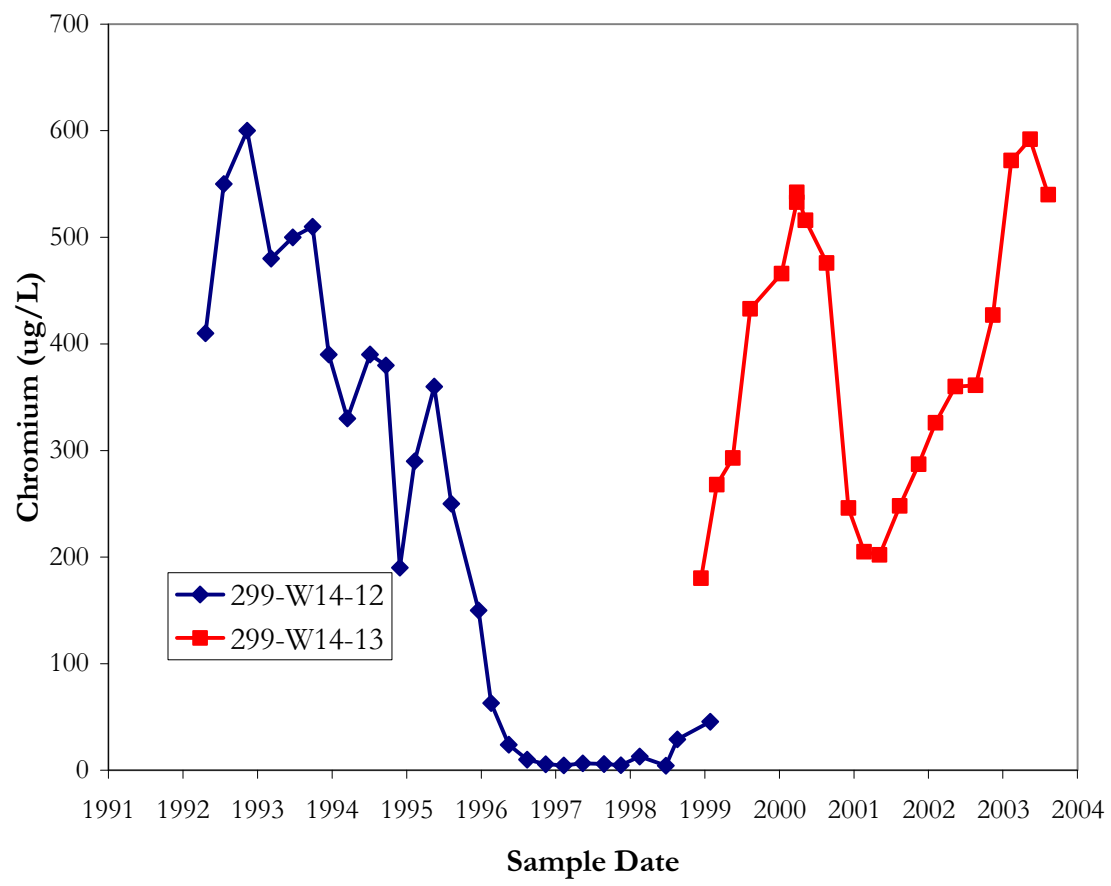

Figure 5.12. Chromium Concentrations in Wells 299-W14-12 and 299-W14-13 at WMA TX-TY 


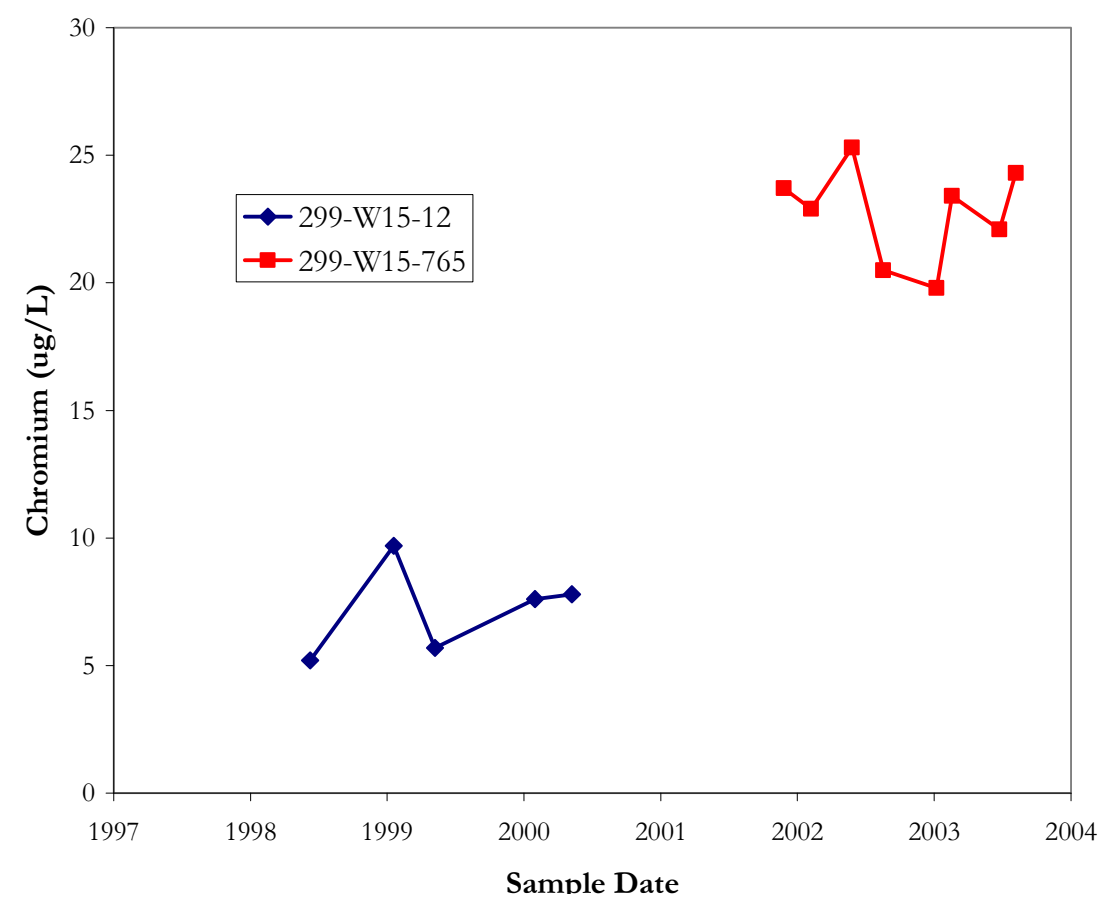

Figure 5.13. Chromium concentrations in well pair 299-W15-12 and 299-W15-765.

Well 299 W15-765 is the newer replacement well; well 299-W15-12 is now dry.

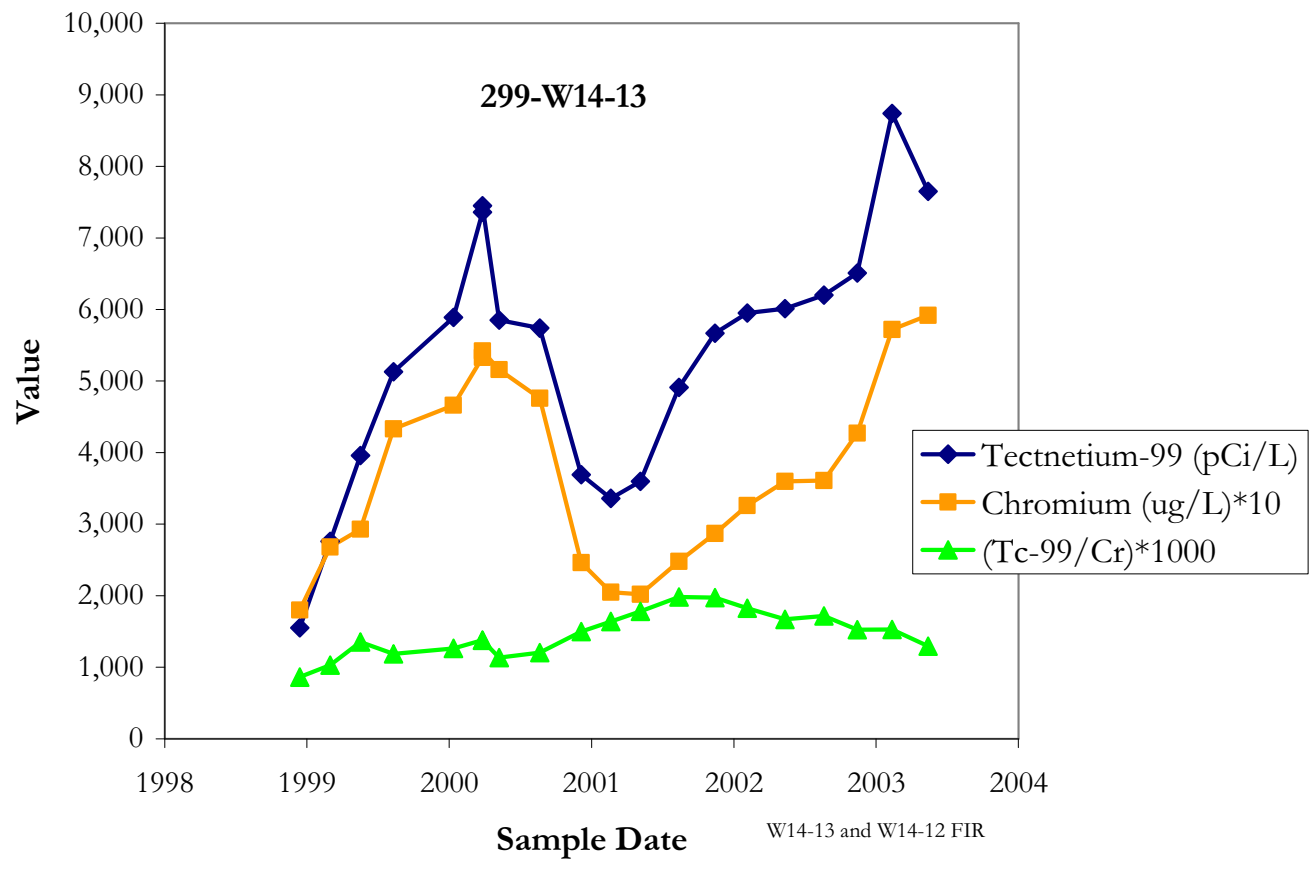

Figure 5.14. Tc-99 and $\mathrm{Cr}(* 10)$ Concentrations, and Tc-99/Cr $(* 1000)$ Ratios in Well 299-W14-13 


\subsubsection{Sampling During Drilling}

Groundwater and saturated sediments brought to the surface during drilling can give an indication of vertical chemical variations within the aquifer. Seven new wells have been sampled during drilling since 2000.

Groundwater samples were collected by pumping during drilling of well 299-W14-14 east of TX tank farm. Each sample interval was isolated by packers before sampling. Figure 5.15 shows the results of analysis of those samples for technetium-99, nitrate, tritium, and carbon tetrachloride. The uppermost sample on Figure 5.15 was collected by pumping from the screened interval after the well was completed.

The depth distribution of tritium and carbon tetrachloride showed maximums at about $40 \mathrm{~m}$ below the water table. The Ringold Formation lower mud unit (hydrogeologic unit 8) occurs between 56 and $67 \mathrm{~m}$ below the water table in well 299-W14-14. The largest concentrations of carbon tetrachloride $(920 \mu \mathrm{g} / \mathrm{L})$ and tritium $(9,010 \mathrm{pCi} / \mathrm{L})$ occur above this unit at $46 \mathrm{~m}$ below the water table. Concentrations of both constituents decrease near the top of, but within, the lower mud unit at $58 \mathrm{~m}$ depth and increase again near the bottom contact of the lower mud unit with the underlying Ringold Formation unit A (hydrogeologic unit 9). Concentrations of both constituents show increases in the deepest sample indicating that the deepest occurrence of these constituents was not encountered in the well and that significant concentrations exist in the confined Ringold Formation aquifer.

The maximum concentrations of technetium-99 $(556 \mathrm{pCi} / \mathrm{L})$ and nitrate $(226,000 \mu \mathrm{g} / \mathrm{L})$ occurred at $15.4 \mathrm{~m}$ below the water table. Concentrations decreased immediately below $15.4 \mathrm{~m}$ and remained constant throughout the remainder of the drilled depth. No concentration changes were noted across the lower mud unit. The maximum concentrations of technetium-99 and nitrate occur about $10 \mathrm{~m}$ below the current pump intake in well 299-W14-14.

Air lifted samples of groundwater and sediment cuttings were collected from wells 299-W14-19 and 299-W15-44 during drilling at TX tank farm. The samples were collected at 6-m intervals down to $36 \mathrm{~m}$ below the water table and analyzed for metals, anions, tritium, and technetium-99 (Horton 2003). No high levels of contamination were encountered. Several metals and anions, however, showed concentration variations with depth in the aquifer. The results from well 299-W14-19 are similar to those from well 299-W15-44.

Additional groundwater samples were collected from drilling slurries at well 299-W15-44 for analysis of nitrate in the field. The nitrate data from well 299-W15-44 are shown in Figure 5.16. Figure 5.16 shows that nitrate in well 299-W15-44 is relatively high at the water table and decreases with depth down to about $20 \mathrm{~m}$ below the water table. This is followed by an increase in concentration at about $60 \mathrm{~m}$ below the water table, below which the nitrate concentration remains constant to the bottom of the borehole. In all TX-TY wells that have been sampled during drilling, nitrate has been found to vary in concentration with depth in the aquifer (Table 5.6). In most wells with sufficient samples to define a trend, nitrate concentration is shown to increase with increasing depth.

The high nitrate concentrations near the water table in well 299-W15-44 are interpreted to be from a nearby source such that either the nitrate has not traveled far enough in the aquifer to become more highly dispersed, or has not resided long enough in the aquifer to descend deeper due, perhaps, to higher density in the contaminant plume. The nearby source for the nitrate is probably the TX tank farm. The deeper, 
relatively high nitrate concentrations in well 299-W15-44, and in other wells at WMA TX-TY, have been interpreted elsewhere to represent past-practice discharges, probably from the Plutonium Finishing Plant, that were disposed to U pond (Hodges and Chou 2001; Johnson and Chou 2001). The large groundwater mound from the pond probably drove contaminated pond water deep into the aquifer before it moved northward beneath WMA TX-TY. Thus, the deeper nitrate concentrations represent a widespread, regional plume.

\subsubsection{Multi-Level Dialysis Sampling In Well 299-W14-13}

Well 299-W14-13 is located on the east (downgradient) side of WMA TX-TY in an area of high chromium, nitrate, technetium-99, iodine-129, and tritium groundwater contamination. Previous interpretations of chromium and technetium-99 distributions in the well suggested that the two contaminants existed at different depths within the aquifer, implying two different sources for the technetium-99 and chromium. The concentrations of chromium and technetium-99 show the same increasing and decreasing trends through time, however, suggesting either a single source for both contaminants or dilution of the entire upper aquifer. Multi-level, depth-discrete sampling was done in the well to help determine the source or sources of chromium and technetium-99 and to refine the chromium distribution in the upper part of the aquifer. 

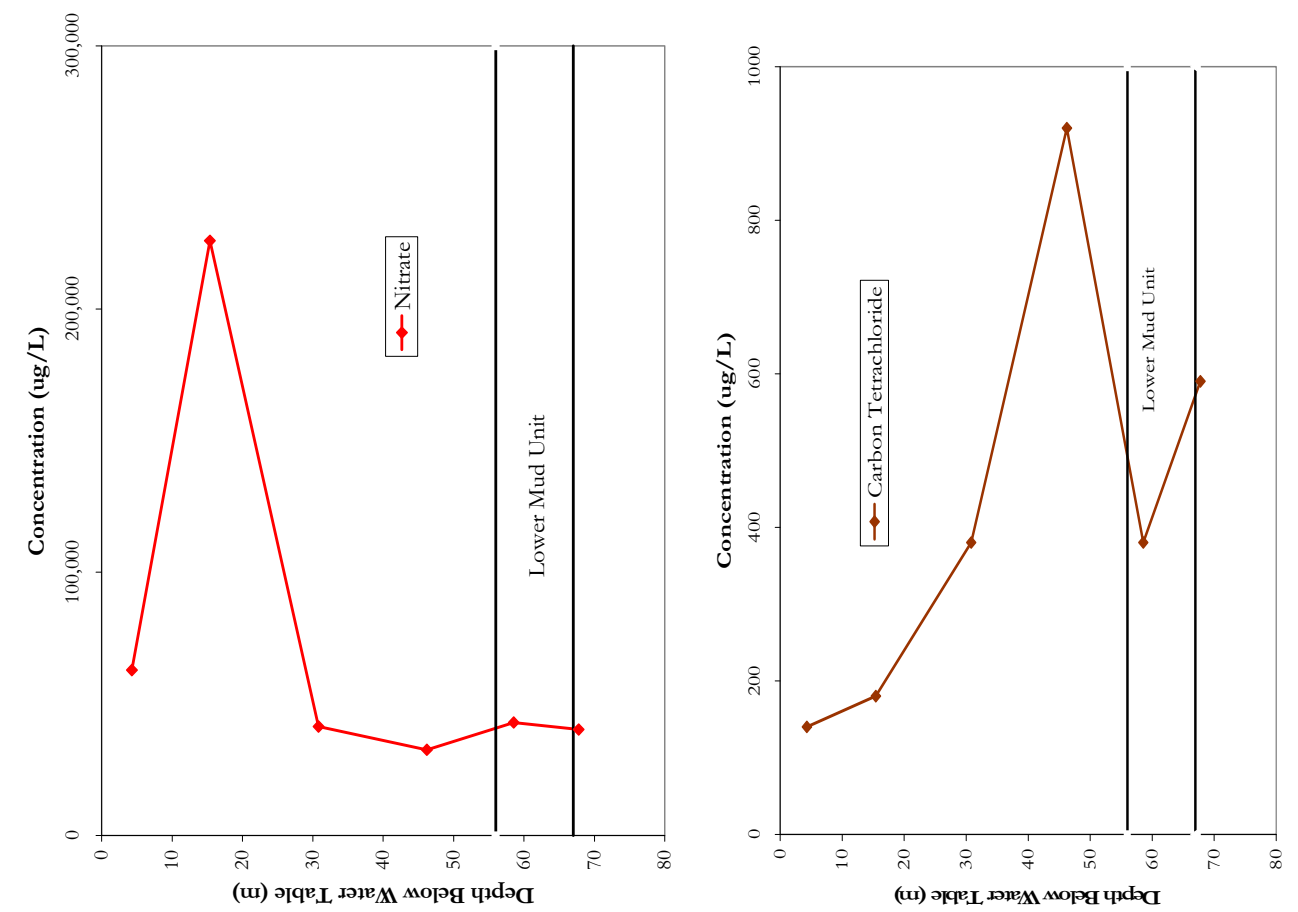

J
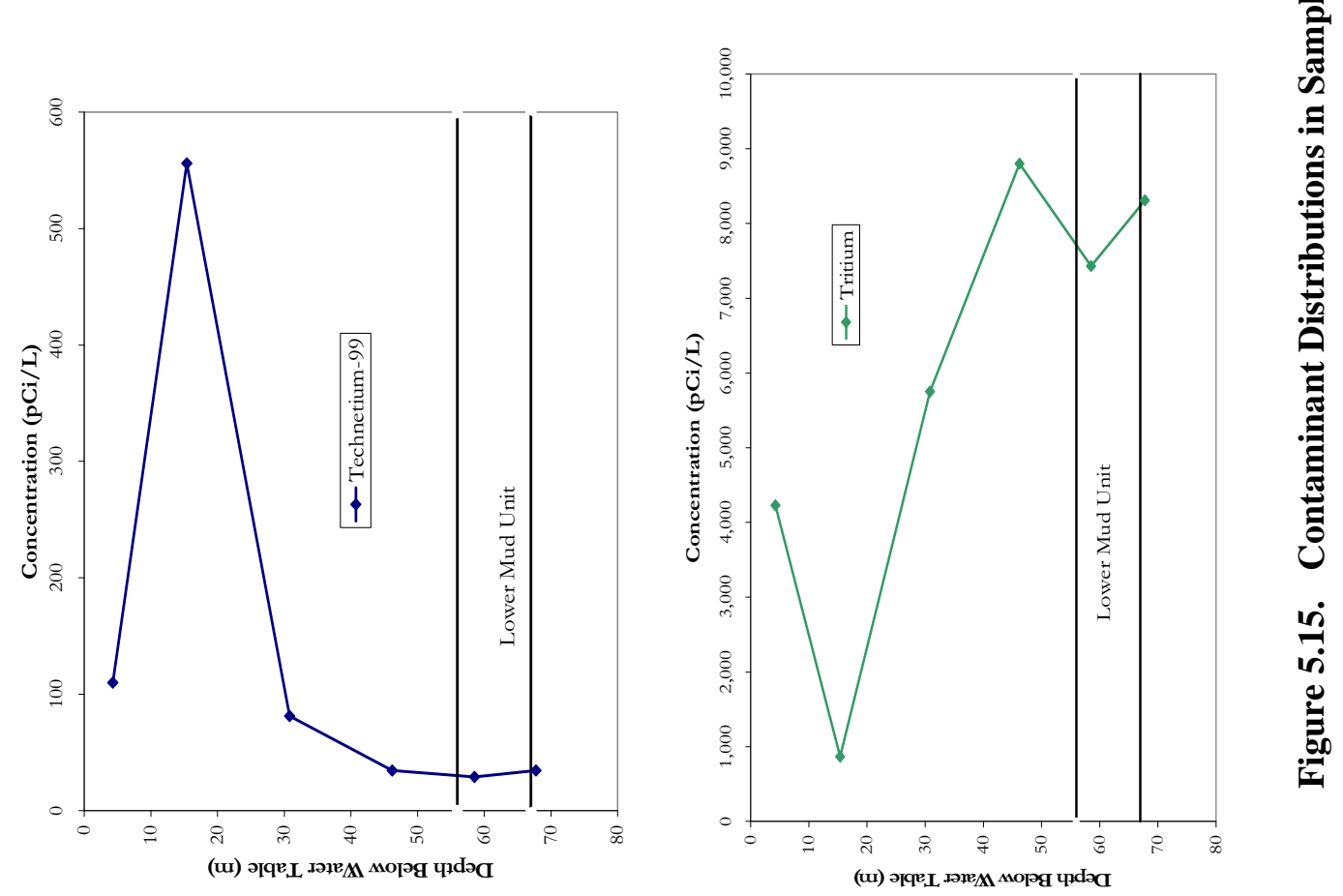


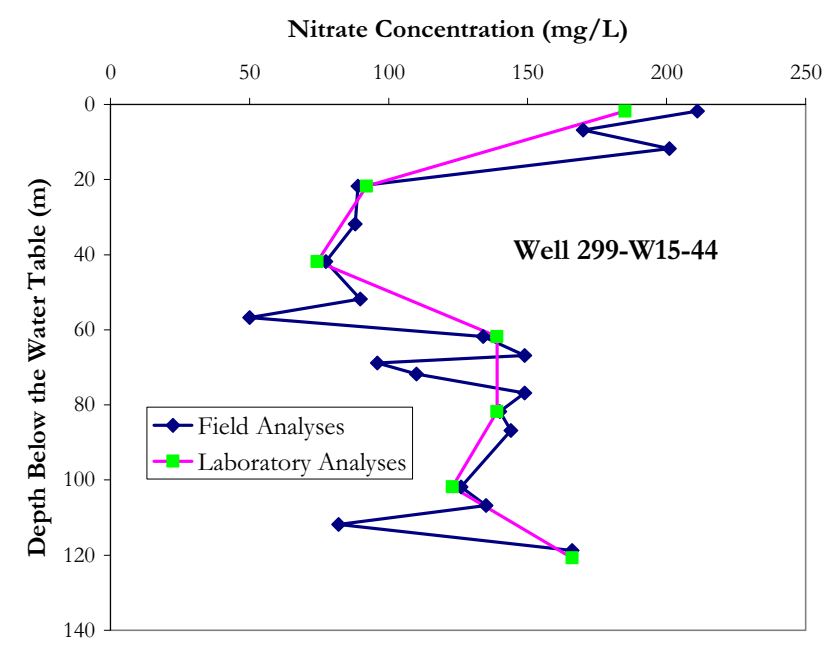

Figure 5.16. Nitrate Concentration in Groundwater versus Depth in Well 299-W15-44 During Drilling

Table 5.6. Nitrate Concentration in Groundwater Collected During Drilling of New RCRA Wells

\begin{tabular}{|c|c|c|c|}
\hline $\begin{array}{l}\text { Depth Below the } \\
\text { Water Table } \\
\text { (m) }\end{array}$ & $\begin{array}{c}\text { Nitrate } \\
\text { Concentration } \\
(\mu \mathrm{g} / \mathrm{L})\end{array}$ & $\begin{array}{l}\text { Depth Below the } \\
\text { Water Table } \\
\text { (m) }\end{array}$ & $\begin{array}{c}\text { Nitrate } \\
\text { Concentration } \\
(\mu \mathrm{g} / \mathrm{L})\end{array}$ \\
\hline \multicolumn{2}{|c|}{ 299-W14-15 ${ }^{(1)}$} & \multicolumn{2}{|c|}{$299-W 14-16^{(1)}$} \\
\hline 3.4 & 66,000 & 3.1 & 30,000 \\
\hline 5.1 & 94,000 & 6.1 & 46,000 \\
\hline 9.6 & 111,000 & 9.1 & 80,000 \\
\hline \multicolumn{2}{|c|}{$299-W 15-765^{(2)}$} & 13.1 & 149,000 \\
\hline 5.5 & 24,270 & \multicolumn{2}{|c|}{ 299-W14-18 } \\
\hline 13.8 & 52,111 & At the water table & 56,850 \\
\hline- & - & 12.6 & 3,260 \\
\hline \multicolumn{4}{|l|}{ (1) Field Analysis } \\
\hline
\end{tabular}

A multi-level, dialysis sampling device was deployed in well 299-W14-13 in September 2002. The sampling device was left in the well for about one month to allow equilibration of the water in the dialysis tubes with the groundwater. Samples were obtained every $1.5 \mathrm{~m}$ from about $1 \mathrm{~m}$ below the top of the aquifer to the bottom of the well screen at about $9 \mathrm{~m}$ below the water table. Samples were analyzed for major cations, anions, tritium, chromium, and technetium-99.

In addition, one sample was collected from about $4 \mathrm{~cm}$ below the water table using a mini-bailer. The bailed sample was analyzed for chromium and nitrate in the field and chromium and technetium-99 in the laboratory. 
The analytical results from both the multi-level dialysis and the bailed samples are shown in Figure 5.17. The results show that, except for a zone at about $2.5 \mathrm{~m}$ below the water table, the concentrations of most cations and anions are fairly constant throughout the screened interval of the aquifer. Neither the geology, the geophysical logs, nor aquifer testing results show any evidence of changes in the formation at $2.5 \mathrm{~m}$ below the water table, so the reason for the increased concentrations at this depth is unknown.

In contrast, nitrate and technetium-99 show increased concentrations with depth from the shallowest dialysis sample at $1 \mathrm{~m}$ below the water table to about 4 to $5 \mathrm{~m}$ below the water table. For nitrate, there is an extremely large increase in concentration between the shallowest dialysis sample and the bailed sample near the water table. For technetium-99, the mini-bailed sample has lower technetium-99 concentration than any the dialysis samples.

Contaminant concentrations in the upper meter of the aquifer at well 299-W14-13 are difficult to interpret. The dialysis and mini-bailer data indicate a large increase in nitrate concentration at the water table relative to deeper in the screened interval, a small increase in chromium concentration, and a decrease in technetium-99 concentration relative to concentrations deeper in the screened interval. (Technetium-99 concentration does increase with decreasing depth between about 4 and $1 \mathrm{~m}$, however.) Comparisons of samples from wells 299-W14-12 and 299-W14-13 support higher concentrations of nitrate at the water table but suggest lower chromium and higher technetium- 99 concentrations than supported by the dialysis sampling. Also, the specific conductance profile from well 299-W14-13 indicates fairly large changes in salinity within the upper meter of the aquifer.

The solid squares on Figure 5.17 represent the concentrations of the various constituents in routine quarterly, pumped samples collected the quarter before and the quarter after the dialysis samples were collected. The data show that for some cations and anions, the concentrations in the pumped samples are similar to the dialysis concentrations throughout the screened interval. Exceptions are calcium, chromium, nitrate, and technetium-99. The pumped concentrations of calcium, chromium, and technetium-99 are substantially less than the ambient concentrations measured from the dialysis samples. For nitrate the opposite is true.

Considering all available data, there are inconsistencies in the current understanding of contaminant distribution within the upper meter or so of the aquifer at well 299-W14-13. More detailed sampling within the upper $1 \mathrm{~m}$ of the aquifer may help resolve these inconsistencies. 

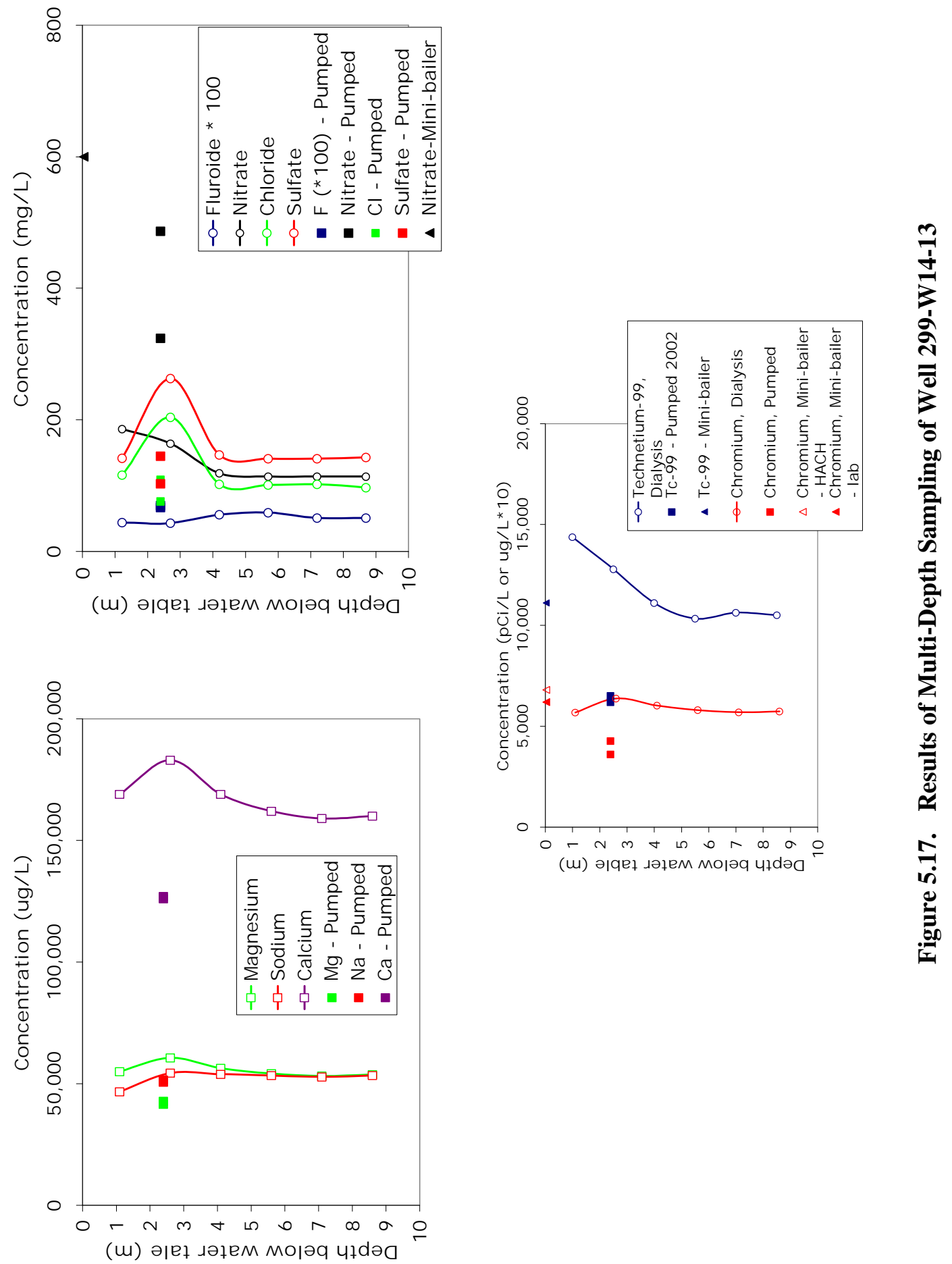
Despite a rigorous QA/QC program in the contract analytical laboratory and well-established sample collection and preservation protocols, it may be that sampling and analytical vagaries are the cause of some of these inconsistent trends in the results from samples collected at different depths and different times using different techniques. However, there are feasible explanations for the data variabilities.

Aquifer testing showed that well 299-W14-13 has a downward flow gradient within the well bore (see Section 5.1). This implies potential zones of different permeability in the screened interval. Alternatively, downward flow may, in part, be driven by differences in density. If the major cations and anion concentrations at $1-\mathrm{m}$ depth are increased proportionally to the nitrate concentration at 4-cm depth, the resulting salinity of the water at $4 \mathrm{~cm}$ is $2.3 \%$. This is in contrast to the estimated salinity from the deepest dialysis sample which is $0.63 \%$. The salinity difference between the top and bottom of the screened interval may be sufficient to cause a downward, density-driven flow within the well bore.

Regardless of the mechanism responsible for the downward flow, contaminants existing near the top of the aquifer will be transported downward in the well. If the contaminant concentrations are relatively high near the top of the aquifer, the highly contaminated water will be transported downward and diluted with less contaminated water at depth. This is important because the well itself is helping to spread contamination.

When well 299-W14-13 is purged, all the ambient water is removed. The resulting pumped samples consist of a mixture of the relatively high concentrations of contaminants from near the water table diluted with less contaminated water from deeper in the well. This could yield pumped samples with the concentrations shown on Figure 5.17. Although difficult to interpret, the data from well 299-W14-13 indicate that concentrations measured from pumped samples may not represent actual concentrations in the aquifer.

\subsubsection{Geographical Distribution of Contaminants}

This section summarizes the areal distribution of contaminants in groundwater at WMA TX-TY. Spatial variation in contaminant concentrations may provide some clues about source areas. Because concentrations change over time, a time period must be chosen to examine spatial distribution patterns. For this purpose, the most recent data (average of five sampling events) was chosen. Data were first grouped by geographic location and tabulated as shown in Table 5.7. Data were then plotted and inspected for distribution patterns or groupings. Contour maps of contaminant concentrations were drawn to identify spatial patterns that might be indicative of source areas. The maps are shown in the series of Figures 5.18 through 5.22.

Contamination in two areas near the TX and TY tank farms warrants consideration: east and downgradient of 241-TX and 241-TY tank farms, and south of 241-TX tank farm. The contaminants of interest east of WMA TX-TY are technetium-99, iodine-129, nitrate, tritium, and chromium. The contaminant of interest south of TX tank farm is technetium-99.

Carbon tetrachloride is a contaminant both east and south of the TX tank farm. The maximum carbon tetrachloride found in the area in 2002 was $5,800 \mu \mathrm{g} / \mathrm{L}$ (average of fiscal year 2002 samples) in well 299-W15-1, south of the TX tank farm (Hartman et al. 2003). The carbon tetrachloride is believed to be from pre-1973 waste from the Plutonium Finishing Plant. The major identified sources are the 216-Z-9 trench, the 216-Z-1A tile field, and the 216-Z-18 crib. 
The part of the carbon tetrachloride plume exceeding 2,000 $\mu \mathrm{g} / \mathrm{L}$ extends west of WMA TX-TY. This part of the plume is intercepted by well 299-W15-40 which averaged 2,400 $\mu \mathrm{g} / \mathrm{L}$ carbon tetrachloride in 2003. Extraction wells for the 200-ZP-1 pump-and-treat in the area may be responsible for the increased carbon tetrachloride in the well and are probably responsible for increased technetium-99 in nearby well 299-W15-41.

Table 5.7. Average Concentration of Mobile Contaminants in Groundwater in the Vicinity of the TX-TY WMA for the Time Period August 2002 to August 2003

\begin{tabular}{|c|c|c|c|c|c|c|c|}
\hline WELLS & $\begin{array}{c}\mathrm{NO}_{3} \\
(\mu \mathrm{g} / \mathrm{L})\end{array}$ & $\begin{array}{c}\mathbf{F} \\
(\mu \mathrm{g} / \mathrm{L})\end{array}$ & $\begin{array}{c}\mathrm{Cr}^{(2)} \\
(\mu \mathrm{g} / \mathrm{L})\end{array}$ & $\begin{array}{c}\mathbf{C C l}_{4} \\
(\mu \mathrm{g} / \mathrm{L})\end{array}$ & $\begin{array}{c}\text { Tc-99 } \\
(\mathrm{pCi} / \mathrm{g})\end{array}$ & $\begin{array}{c}{ }^{\mathbf{3}} \mathbf{H} \\
(\mathbf{p C i} / \mathbf{g})\end{array}$ & $\begin{array}{c}\text { I-129 } \\
(\mathrm{pCi} / \mathrm{g})\end{array}$ \\
\hline \multicolumn{8}{|c|}{ West (Upgradient) Side of WMA TX-TY } \\
\hline 299-W15-40 & $94,940^{(1)}(5)$ & $330(5)$ & $14.7(5)$ & $2,400(3)$ & $72.7(5)$ & $4,224(5)$ & $\mathrm{NA}^{(3)}$ \\
\hline $299-W 15-765$ & $146,600(5)$ & $332(5)$ & $22.0(5)$ & $3,200(2)$ & $83.7 \quad(5)$ & $4,722(5)$ & $\mathrm{ND}^{(4)}$ \\
\hline \multicolumn{8}{|c|}{ East (Downgradient) Side of WMA TX-TY } \\
\hline W10-26 & $103,433(6)$ & $1,533(6)$ & $8.6(6)$ & NA & $99.8(6)$ & $8,200(6)$ & ND \\
\hline W10-27 & $103,050(4)$ & $972 \quad(4)$ & $5.2(2)$ & NA & $117.9(4)$ & $12,850(4)$ & NA \\
\hline W14-5 & $94,640(5)$ & $1,260(5)$ & $5.2(1)$ & NA & $247(5)$ & $1,113(5)$ & NA \\
\hline W14-6 & $98,940(5)$ & $1,060(5)$ & ND & NA & $282(5)$ & $603(5)$ & NA \\
\hline W14-13 & $426,000(5)$ & $768(5)$ & $498.4(5)$ & NA & $7,474(5)$ & $1,820,000(5)$ & $33(3)$ \\
\hline W14-14 & $93,620(5)$ & $1,010(5)$ & ND & $360(1)$ & $250(5)$ & $2,724(5)$ & ND \\
\hline W14-15 & $79,500(5)$ & $1,200(5)$ & $62.4(5)$ & NA & $509(5)$ & $27,800(5)$ & $2.3(1)$ \\
\hline W14-16 & $77,200(5)$ & $572(5)$ & ND & NA & $216.6(5)$ & $2,190(5)$ & ND \\
\hline W14-17 & $158,000(5)$ & $582(5)$ & ND & NA & $474(5)$ & $636(5)$ & ND \\
\hline W14-18 & $121,333(6)$ & $273(6)$ & $4.3(1)$ & NA & $409.8(6)$ & $8,301 \quad(6)$ & ND \\
\hline W14-19 & $100,100(3)$ & $1,067(3)$ & ND & NA & $265 \quad(3)$ & $2,807 \quad(3)$ & ND \\
\hline \multicolumn{8}{|c|}{ South of WMA TX-TY } \\
\hline 299-W15-41 & $68,060(5)$ & $579(5)$ & $6.2(4)$ & $1.300(1)$ & $611.8(5)$ & $5,942(5)$ & ND \\
\hline 299-W15-44 & $95,300(3)$ & $433(3)$ & $11.3(3)$ & $2,900(1)$ & $107.4(3)$ & $4,610(3)$ & ND \\
\hline 299-W15-763 & $37,400(6)$ & $607(6)$ & $4.9(4)$ & NA & $86.2(6)$ & $2,033(6)$ & NA \\
\hline $\begin{array}{ll}\text { (1) } & \text { Numbers in } \\
\text { (2) } & \text { Filtered san } \\
\text { (3) } & \text { Not Analyz } \\
\text { (4) } & \text { Not Detect }\end{array}$ & $\begin{array}{l}\text { enthesis are the } \\
\text { s. }\end{array}$ & umber of de & & & & & \\
\hline
\end{tabular}




\subsubsection{Contamination East of WMA TX-TY}

Figure 5.18 shows a plume map for chromium at the end August 2003. The figure shows that chromium was detected in one downgradient well (299-W14-13) above the drinking water standard of $100 \mu \mathrm{g} / \mathrm{L}$. The concentration of chromium in the well in August 2003 was $540 \mu \mathrm{g} / \mathrm{L}$. Given the current direction of groundwater flow, one potential source for the chromium is the 241-TY tank farm. However, about 1,060 kilograms of chromium were disposed to the TY cribs located about $65 \mathrm{~m}$ northeast of the well (Simpson et al. 2001). Since the general dip of the strata in the area is toward the west or southwest, it is possible that contamination from the cribs migrated through the vadose zone toward well 299-W14-13. In the past, water from a tanker truck filling station, located about $140 \mathrm{~m}$ up dip of the TY cribs, was seen leaking onto the ground from the fill spout. Water was seen to pool on the ground and run about $100 \mathrm{~m}$ down slope (toward the TX and TY tank farms) in a ditch along the side of the gravel road. Infiltration of this water could have mobilized contamination in the vadose zone beneath the TY cribs and moved the contamination down dip toward well 299-W14-13.

Also, Fecht et al. (1977) state that gross gamma logs obtained prior to 1977 showed contamination at the 216-T-28 crib extended from near the surface to the water table and that breakthrough to groundwater could have occurred at the site. They also state that waste from the crib was noted in a well 299-W14-1, located $38 \mathrm{~m}$ south of the crib so that considerable lateral spreading had occurred in the vadose zone beneath the TY cribs. Therefore, we cannot currently assign an origin for the elevated chromium in well 299-W14-13 to a particular facility.

Figure 5.19 shows a plume map for technetium-99 at the end of August 2003. Technetium-99 was detected in one downgradient well (299-W14-13) above the drinking water standard of $900 \mathrm{pCi} / \mathrm{L}$. Given the current direction of groundwater flow, one potential source for the technetium-99 is single-shell tanks in WMA TX-TY. However, three other sources also may have contributed some technetium-99 to the groundwater east of WMA TX-TY. As mentioned above, Fecht et al. (1977) state that considerable lateral spreading of discharged water and contaminants occurred south of the 216-T-28 crib and that breakthrough to the groundwater could have occurred at that site. The $216-\mathrm{T}-28 \mathrm{crib}$ received about 10.9 curies of technetium-99 (Kincaid et al. 1998). Thus, some of the technetium in the groundwater east of TX-TY today may be from the 216-T-28 crib.

The 216-T-19 tile field is also a potential source for some of the technetium-99 east of WMA TX-TY. The tile field received 455 million liters of primarily steam condensate from the 242-T evaporator (DOE 1992), which contained 9.89 curies of technetium-99. Groundwater flow was toward the northeast from the tile field (thus towards) the location of well 299-W14-13 during the last approximately 25 years that the tile field was used.

Finally, a fourth potential source for some of the technetium-99 east of the WMA is leaks from the 242-T evaporator building. The evaporator is approximately $70 \mathrm{~m}$ upgradient of well 299-W14-13. Given a groundwater flow rate of $0.19 \mathrm{~m} / \mathrm{d}$ (from aquifer tests, Table 5.3) in well 299-W14-13, a pre-1997 (when flow direction changed toward the east) leak from the evaporator would just recently be intercepted by the well. However, if the slower, Darcy velocities from Table 5.4 are used, an evaporator leak would not yet have reached the well. This indicates that leaks from the 242 Evaporator might be contributing to contamination at well 299-W14-13 today but would not have contributed to the plume encountered by well 299-W14-12 in the early 1990s. 
The plume maps for chromium and technetium-99 (see Figure 5.18 and 19) show that the contaminant plumes are relatively small and centered near well 299-W14-13. Concentrations of both contaminants drop sharply both to the north in well 299-W14-18 and to the south in well 299-W14-15, although concentrations of technetium-99 have been increasing slightly in both wells over the past two years. Technetium-99 concentrations increased from 189 to $468 \mathrm{pCi} / \mathrm{L}$ in well 299-W14-18 since the end of 2001 and from 380 to $472 \mathrm{pCi} / \mathrm{L}$ in well 299-W14-15 since the end of 2000 . These wells may be on the edge of the plume apparently centered at well 299-W14-13.

Well 299-W14-17 is about 125 m downgradient (south east) of well 299-W14-13. Given a flow rate of $0.19 \mathrm{~m}$ per day, the technetium-99 seen at well 299-W14-13 is expected to have traveled about $70 \mathrm{~m}$ toward well 299-W14-17 since the 1997 change in flow direction. Technetium-99 concentrations have decreased in well 299-W14-17, from $576 \mathrm{pCi} / \mathrm{L}$ to $456 \mathrm{pCi} / \mathrm{L}$, during the last two years. Thus, the technetium-99 plume at well 299-W14-13 does not appear to have spread to the downgradient well, 299-W14-17, at this time.

Figure 5.20 shows a plume map for nitrate at the end of August 2003. Almost all wells in the groundwater monitoring network at WMA TX-TY, including the upgradient wells, have had nitrate concentrations greater than the MCL of $45,000 \mu \mathrm{g} / \mathrm{L}$ throughout most of their sampling life. The highest nitrate concentrations have been at well 299-W14-13. This well has had nitrate concentrations greater than those in the regional plume since it was drilled in late 1998. Before that time, nitrate in well 299-W14-12 (now dry, but adjacent to well 299-W14-13) was between 450,000 and 550,000 $\mu \mathrm{g} / \mathrm{L}$ since it was drilled in 1992. Subsequently, nitrate in well 299-W14-12 decreased to about 200,000 $\mu \mathrm{g} / \mathrm{L}$ in 1997 before increasing to about $580,000 \mu \mathrm{g} / \mathrm{L}$ when it went dry in late 1998 (see Figure 5.10).

Nitrate in the area of wells 299-W14-12 and 299-W14-13 is probably from several sources including a regional nitrate plume from Plutonium Finishing Plant disposal sites. Other potential sources are those mentioned above as potential sources for chromium and technetium-99.

An area of relatively low nitrate concentration, north of well 299-W14-13, has existed since at least the mid-1990s (Figure 5.20). The cause for the low nitrate in the area is not known. Dilution by liquids disposed to the 216-T-26 through 216-T-28 cribs does not appear to be probable because 1,000,000 kilograms of nitrate were in the waste stream sent to the 216-T-26 crib (DOE 1992).

Figure 5.21 shows a plume map for tritium at the end of August 2003. Tritium was detected in one downgradient well (299-W14-13) above the drinking water standard of 20,000 pCi/L. Like nitrate, tritium most likely has several sources that include WMA TX-TY and several cribs and trenches in the area. Hodges (1998) used tritium/technetium-99 ratios to show that contamination in the area of the now dry well 299-W14-12 was probably a mixture of regional contamination and tank waste.

Two other contaminants, cobalt-60 and iodine-129, have been found at WMA TX-TY. Cobalt-60 was found in four wells prior to 1982. Cobalt-60 was highly variable in well 299-W14-2, located at the 216-T-28 crib; between 1971 and 1976, it reached a maximum of $75 \mathrm{pCi} / \mathrm{L}$ in 1971. Since that time, cobalt-60 decreased to between 10 and $25 \mathrm{pCi} / \mathrm{L}$ (between 1976 and 1981) and has been undetectable since 1982.

Well 299-W14-5, located east of the TX tank farm, showed highly variable cobalt-60 concentrations between in 1975 and 1976 with the highest concentration reaching $52 \mathrm{pCi} / \mathrm{L}$. Cobalt-60 concentrations 
decreased to less than detectable in the well after 1977. Cobalt-60 concentrations were also high in well 299-W14-6, south of well 299-W14-5, in 1975 (68 pCi/L). Subsequently, the well was not sampled for 10 years and cobalt-60 has been undetected in the well since 1988.

Well 299-W15-4, located south of the TX tank farm, also showed high concentrations of cobalt-60 between 1971 and 1976 with the maximum reaching 42 pCi/L. Like well 299-W14-6, well 299-W15-4 was not sampled between 1976 and 1987 after which cobalt-60 was essentially undetected in groundwater samples.

Cobalt-60 was found in well 299-W14-12 during the entire life of the well, between 1992 and 1999. The cobalt-60 concentration was $28 \mathrm{pCi} / \mathrm{L}$ in late 1992 and decreased to about $4 \mathrm{pCi} / \mathrm{L}$ in early 1996. Cobalt-60 increased to $16 \mathrm{pCi} / \mathrm{L}$ in 1999 when the well was last sampled before it went dry. Cobalt-60 has not been found in replacement well 299-W14-13.

Apparently, there was an early 1970s cobalt-60 plume in the area east and south of the TX tank farm. That plume either dissipated or passed through the area in the late 1970s. A second plume, isolated to well 299-W14-12, was noted during the 1990s but has not been found in any other wells at the WMA.

Iodine-129 was found in well 299-W14-2 at the 218-T-28 crib between 1996 and December 2000 when the well was went dry. Concentrations were quite variable during this time and the last concentration measured in the well was $64 \mathrm{pCi} / \mathrm{L}$. This was the highest iodine- 129 concentration seen in the well.

Iodine-129 has also been found in well 299-W14-12 and its replacement well 299-W14-13. Iodine129 reached about $28 \mathrm{pCi} / \mathrm{L}$ in well 299-W14-12 in 1992 before decreasing to undetectable levels in 1996. Iodine-129 began to increase in the well in the last two samples obtained before the well went dry. The last concentration was $16.4 \mathrm{pCi} / \mathrm{L}$ iodine-129. Iodine- 129 concentrations have varied between 16 and $50 \mathrm{pCi} / \mathrm{L}$ in replacement well 299-W14-13.

The source of the iodine-129 east of the TX tank farm is not known for certain. One possible source is the 216-T-26 through 216-T-28 cribs which received up to $0.0725 \mathrm{Ci}$ of iodine-129 during their operation (Kincaid et al. 1998). It is also possible that the SSTs in the WMA could be the source of the iodine-129. 


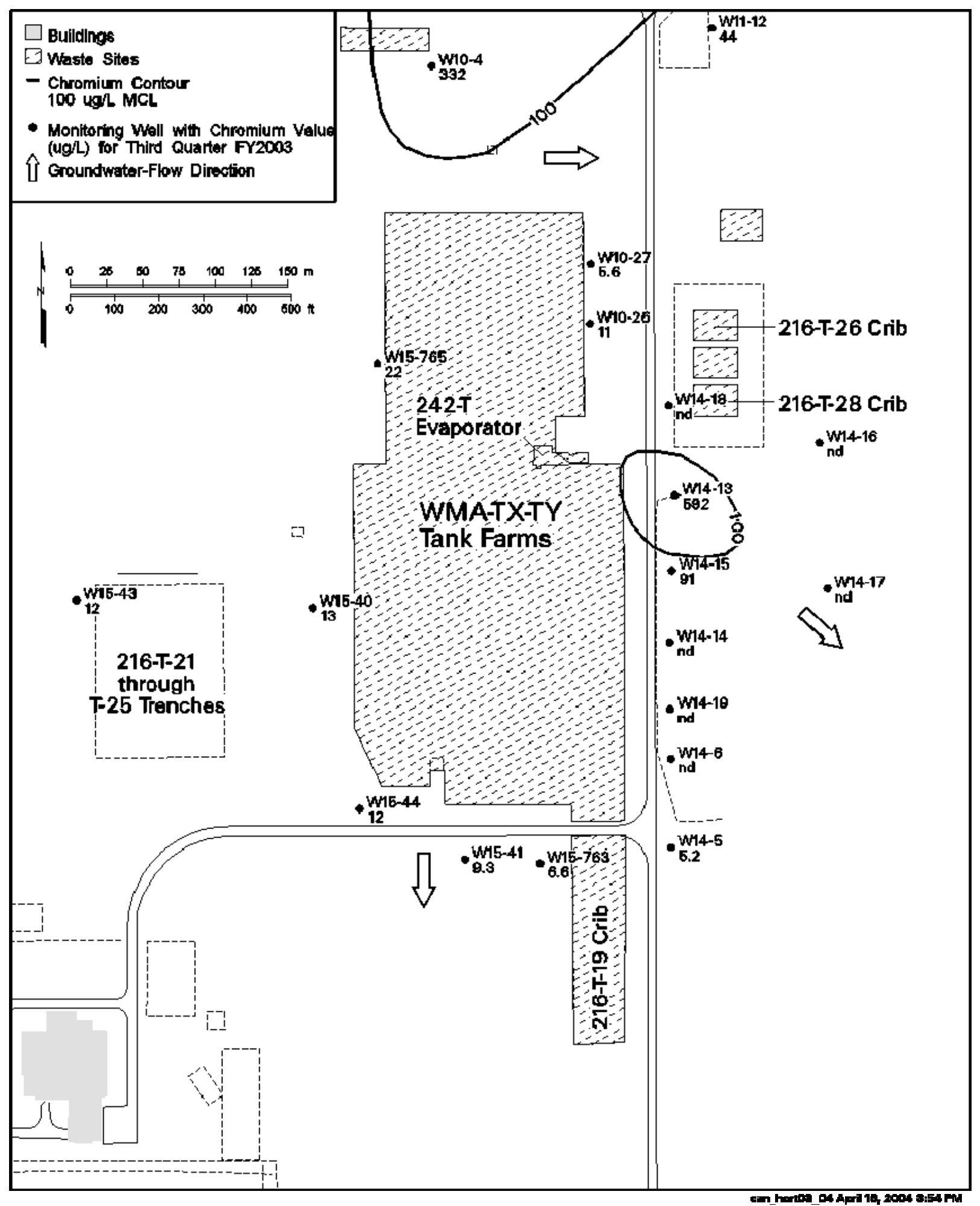

Figure 5.18. Chromium Plume Map at WMA TX-TY for the Fourth Quarter of Calendar Year 2002 


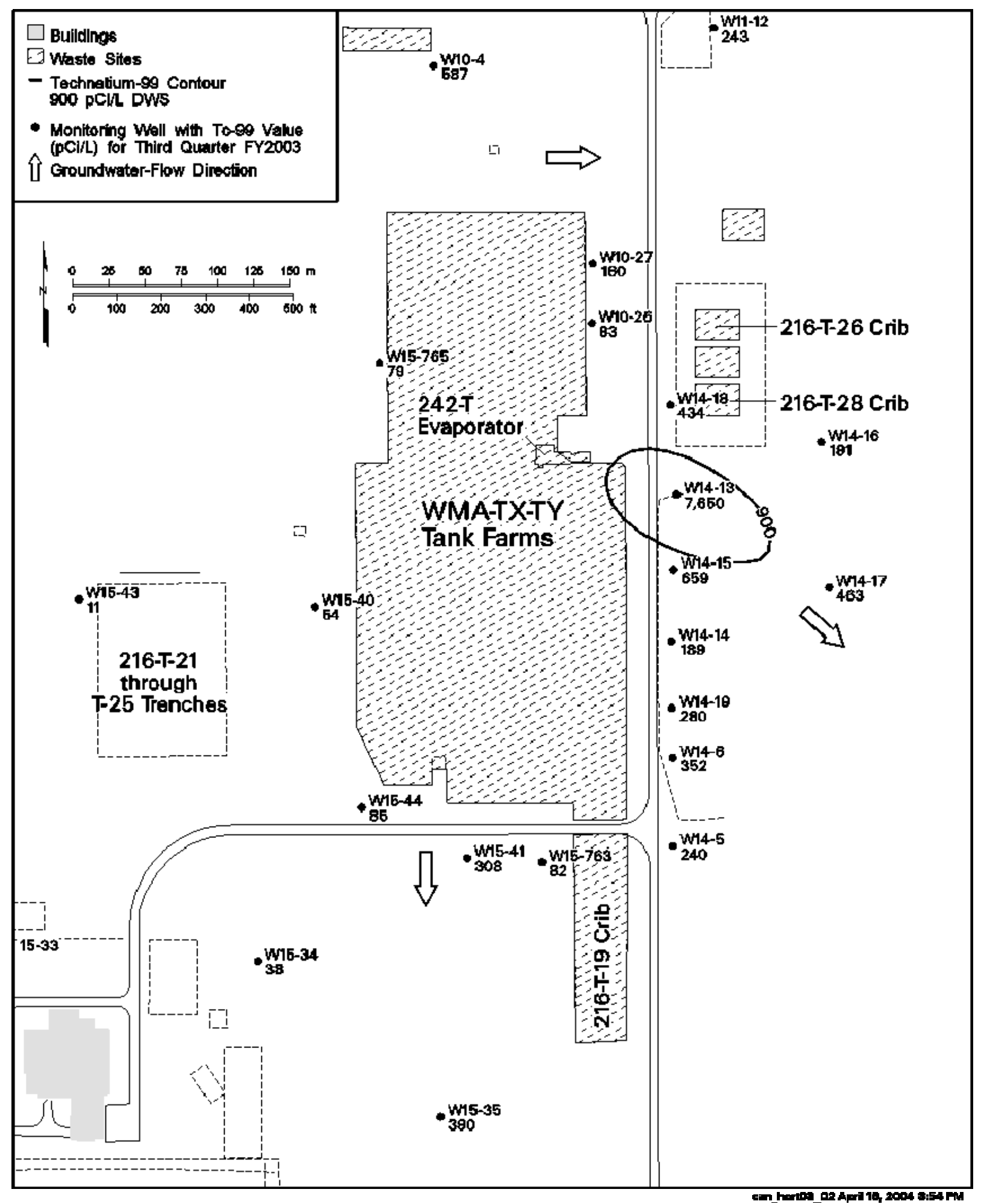

Figure 5.19. Technetium-99 Plume Map at WMA TX-TY for the Fourth Quarter of Calendar Year 2002 


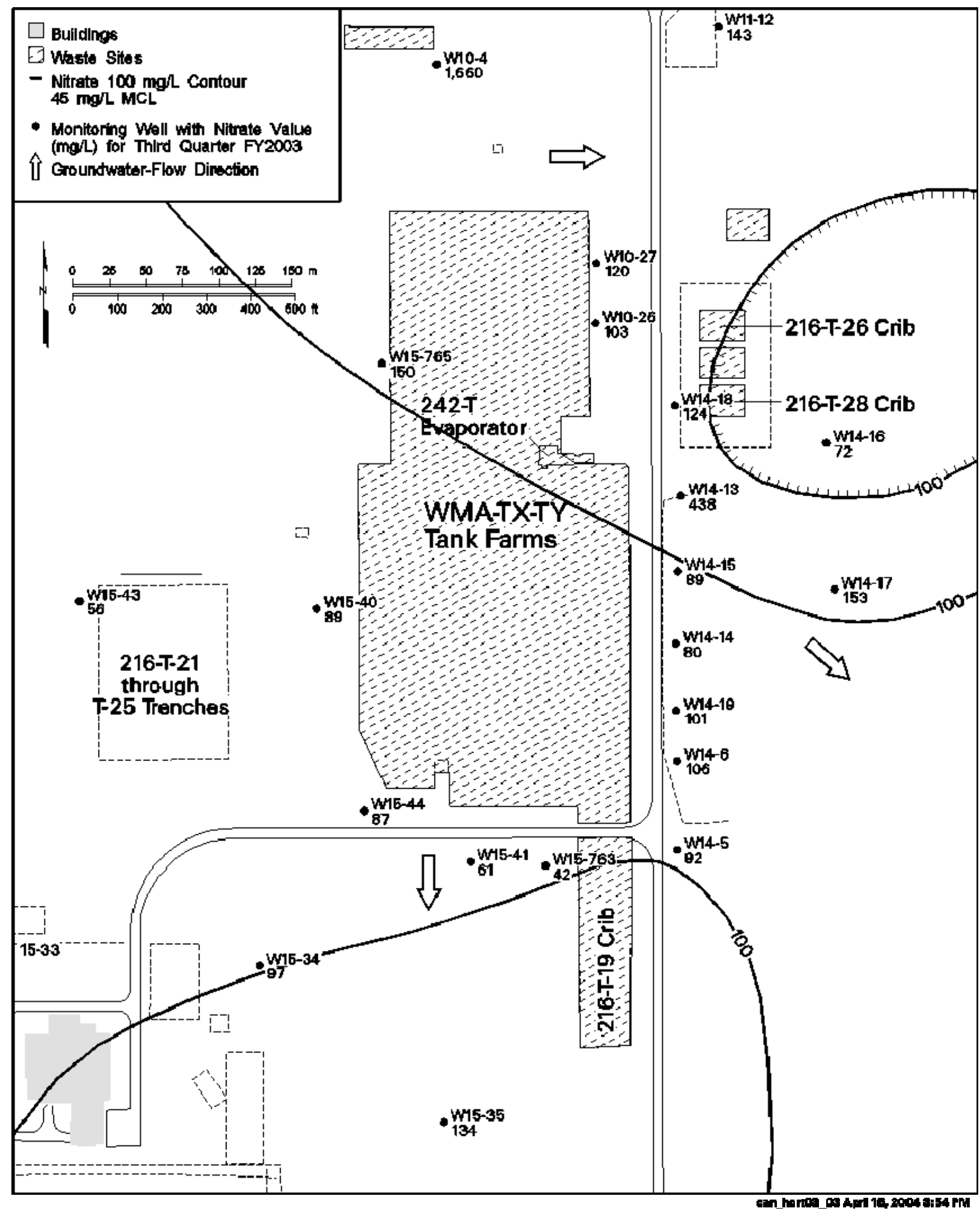

Figure 5.20. Nitrate Plume Map at WMA TX-TY for the Fourth Quarter of Calendar Year 2002 


\subsubsection{Southern Boundary of Waste Management Area TX-TY}

The 200-ZP-1 pump-and-treat operation began in 1994 with one extraction well. The operation was expanded to three wells in 1996 and, finally, to six extraction wells in August 1997. The first distinct effects of the pump-and-treat operation on groundwater flow direction beneath WMA TX-TY was observed on the June 1998 water-table map (Hartman 1999). Well 299-W15-22, located at the southwest corner of the WMA, and originally drilled as an upgradient well, was the closest to the 200-ZP-1 pumpand-treat extraction wells before it went dry in 1998. Technetium-99 began to increase in this well in May 1997, exceeded the maximum contaminant level in August 1997, and reached a high of 3,680 pCi/L in May 1998. The well was last sampled in August 1998.

Well 299-W15-4 is an older pre-RCRA well originally drilled to monitor the 216-T-19 crib at the southeast corner of the WMA. Prior to May 1998, the well was sampled only on an annual basis; however, available data indicate that technetium-99 started to increase in this well in mid-1997 and reached a peak value of $980 \mathrm{pCi} / \mathrm{L}$ in July 1999. The last sampling in October 1999 yielded a value of $640 \mathrm{pCi} / \mathrm{L}$ technetium-99. Chromium began to increase in well 299-W15-4 in 1999, but the peak concentration of chromium $(20 \mu \mathrm{g} / \mathrm{L})$ was below the maximum contaminant level in the last samples from the well before it went dry.

Well 299-W15-763 was completed as a replacement well for 299-W15-4 in 2001. The first routine sample from this well, taken in May 2001, indicated a technetium-99 level of $57 \mathrm{pCi} / \mathrm{L}$. The most recent sample taken from this well contained $123 \mathrm{pCi} / \mathrm{L}$ technetium-99. Technetium-99 concentrations in this well are anomalously low when compared to other wells in the area. The geologist's log noted cemented zones in the screened interval of this well. Thus, changes in lithology may account for the difference between technetium- 99 concentrations in this and adjacent wells.

Well 299-W15-41 was completed in January 2000 and was first sampled in March 2000. The initial sampling yielded a technetium- 99 concentration of $1,980 \mathrm{pCi} / \mathrm{L}$. Concentrations of technetium- 99 have subsequently decreased to about $328 \mathrm{pCi} / \mathrm{L}$ since August 2002. No significant concentrations of chromium have been found in samples from this well.

Technetium-99 in wells along the southern boundary of WMA TX-TY started to increase approximately one year after Phase II of the 200-ZP-1 pump-and-treat operation began. (Phase II, consisting of three extraction wells, began the use of the closest extraction wells to the WMA, wells 299-W15-34 and 299-W15-35.) Given the southerly groundwater flow direction imposed on the southern portion of the WMA by the pump-and-treat operation, the most reasonable explanation for the increasing technetium-99 is that groundwater contaminated with technetium-99 is being drawn from beneath the WMA into the pump-and-treat system. Alternatively, technetium-99 may be originating from the 216-T-19 crib and tile field (DOE 2002b). Given the changing groundwater flow direction along the southern boundary of the WMA, the few available monitoring wells, and the lack in continuity of monitoring data due to dry wells and new wells, it is currently impossible to fully evaluate this problem.

\subsection{Comparison of Groundwater Vadose Zone Porewater Compositions at the TX Tank Farm}

As mentioned previously, borehole C3830 was drilled to investigate a possible leak from tank TX-105, borehole C3831 was drilled to investigate possible leaks from TX-107 (used for many 
intra-tank farm transfers), and borehole C3832 was drilled to investigate a possible leak from tank TX-104. All potential leaks were estimated to have occurred in the 1975 to 1977 time frame. The leak from tank TX-107 is presumed to be the largest leak and was probably at least 30,200 liters (8,000 gallons) (Crumpler 2002).

The travel time of the leaked fluids through the vadose zone to the unconfined aquifer is difficult to estimate because it depends on several variables including density of the leaked fluid, leak volume and leak rate, recharge rate since the leaks, details of stratigraphy, contaminant distribution coefficients, and presence (or not) of preferential pathway to groundwater. Several estimated travel times through the vadose zone have been made (e.g., Ward et al. 1997, WHC 1990), but none are specific to the TX tank farm or the leaks from tank TX-107.

As a first approximation, a travel time through the vadose zone is estimated here following the method of one dimensional analysis used in Appendix B of WHC (1990). The approximation assumes:

1. the entire tank leak of 30,200 liters occurred within one month,

2. the leak occurred over an area of 410 square meters (this estimate is the cross section area of a singleshell tank bottom in TX tank farm and is probably much larger than the actual area of the leak. A smaller leak area would result in a faster flux and shorter travel time),

3. a stratigraphy similar to borehole 299-W15-7 (from Wood et al. 2001),

4. saturated moisture contents of 0.5 for gravel and coarse sand and 0.4 for silt and caliche (from WHC 1990, Appendix B),

5. saturated hydraulic conductivities of $0.005 \mathrm{~cm} / \mathrm{sec}$ for gravel, $0.001 \mathrm{~cm} / \mathrm{sec}$ for coarse sand, $0.0004 \mathrm{~cm} / \mathrm{sec}$ for silt, and $0.00005 \mathrm{~cm} / \mathrm{sec}$ for caliche (from WHC 1990, Appendix B),

6. unsaturated moisture contents of $0.06 \mathrm{~m}^{3} / \mathrm{m}^{3}$ for gravel, $0.09 \mathrm{~m}^{3} / \mathrm{m}^{3}$ for coarse sand, $0.18 \mathrm{~m}^{3} / \mathrm{m}^{3}$ for silt, and $0.23 \mathrm{~m}^{3} / \mathrm{m}^{3}$ for caliche, and

7. a retardation factor of 1 (i.e., a contaminant with no adsorption or reaction with the sediment surface adsorption sites).

Using the above assumptions, a travel time through the vadose zone to the water table is estimated to be five to six years. This is probably much too quick because there is no allowance for lateral spreading and generalized moisture curves for the Hanford Site were used. This estimate is used here, however.

Given 1) a leak from tank TX-107 in 1977, 2) a travel time from tank TX-107 to the vadose zone of five years, 3) a groundwater flow direction of north to north-northeast in the late 1970s (i.e., from tank TX-107 toward wells 299-W14-1, 299-W14-2, and 299-W14-12), and 4) a groundwater flow rate of $0.05 \mathrm{~m} / \mathrm{d}$ (a reasonable estimate from the data in Table 5.4 although flow rates may have been faster in the late 1970s because of a steeper $U$ pond groundwater mound), a highly mobile contaminant should have reached well 299-W14-2 after 17 years, or about 1994 (five years in the vadose zone and 12 years in the groundwater). 


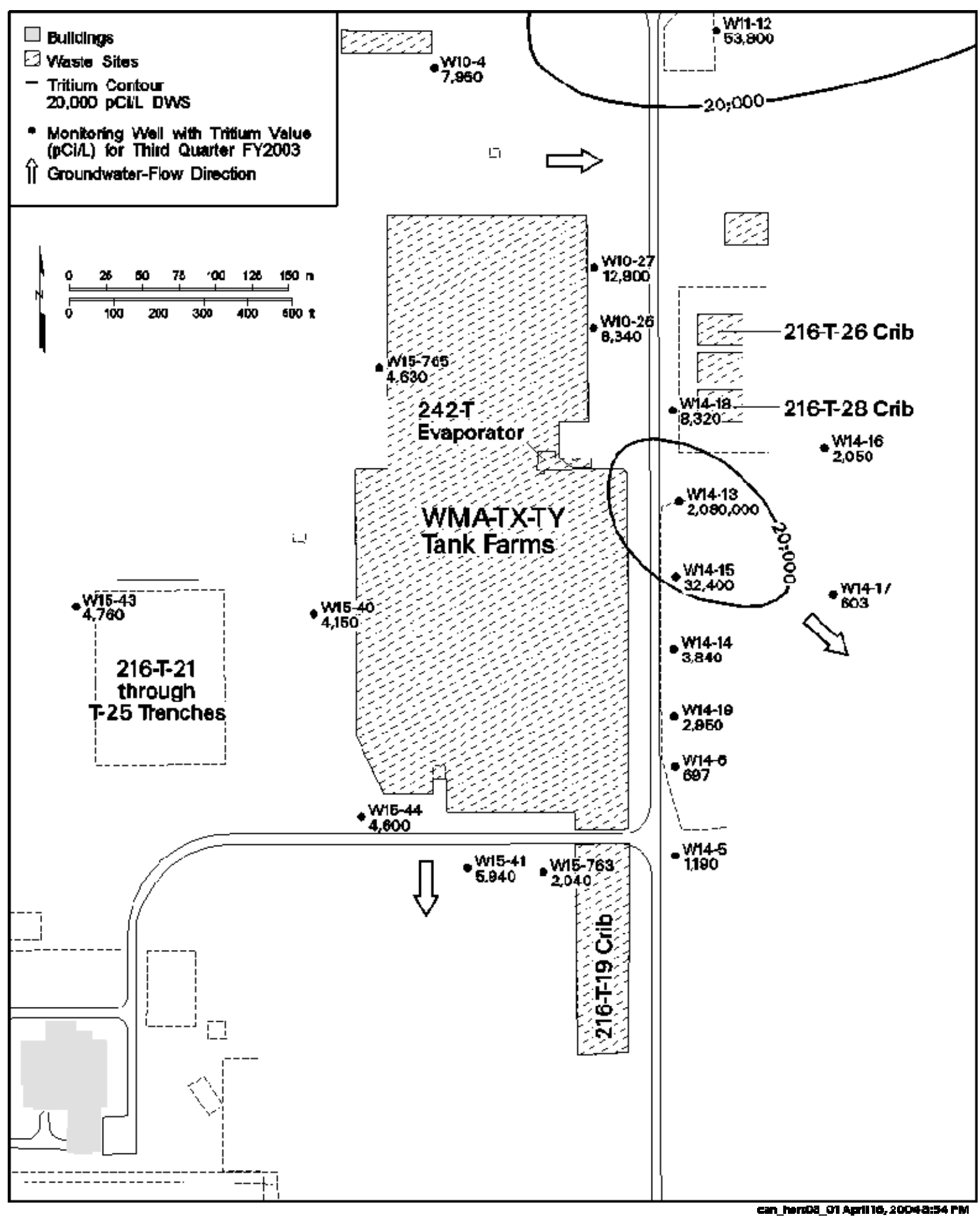

Figure 5.21. Tritium Plume Map at WMA TX-TY for the Fourth Quarter of Calendar Year 2002 
The data in Section 4 and in situ desorption $\mathrm{K}_{\mathrm{d}} \mathrm{s}$ calculated in Section 6.5 show that the more mobile contaminants in the porewater from boreholes C3830 through C3832 are cobalt-60, technetium-99, nitrate, sulfate $\left(\mathrm{SO}_{4}{ }^{2-}\right)$ and uranium $(\mathrm{U})$, which is less mobile than the others. Therefore, it is these constituents that would be expected in the groundwater if tank fluids have entered the groundwater.

A plume of cobalt-60, strontium-90, and nitrate passed well 299-W14-2 between 1971 and about 1980 (see Figure 5.22). A cobalt-60, nitrate, and tritium plume also passed through the area of wells 299-W14-5 and 299-W15-4 during the early to mid-1970s. These latter two wells are to the east and south, respectively, of the TX tank farm and not downgradient of the TX-107 tank during the 1970s and 1980s. This early cobalt-60, nitrate, tritium (and strontium-90) plume appears to have begun passing through the area a few years before the reported tank T-107 leak.

A cobalt-60, chromium, nitrate, technetium-99, and tritium plume passed well 299-W14-12 in the early- to mid- 1990s (Figures 5.9 through 5.12 and Figure 5.23). This is approximately the time estimated for the fluids from tank TX-107 to reach the well. To test whether this plume (and the earlier 1970s plume) may have been from tank TX-107, several ratios of contaminant concentration in groundwater from well 299-W14-12 were compared to the same concentration ratios in the vadose zone porewater from borehole C3831.

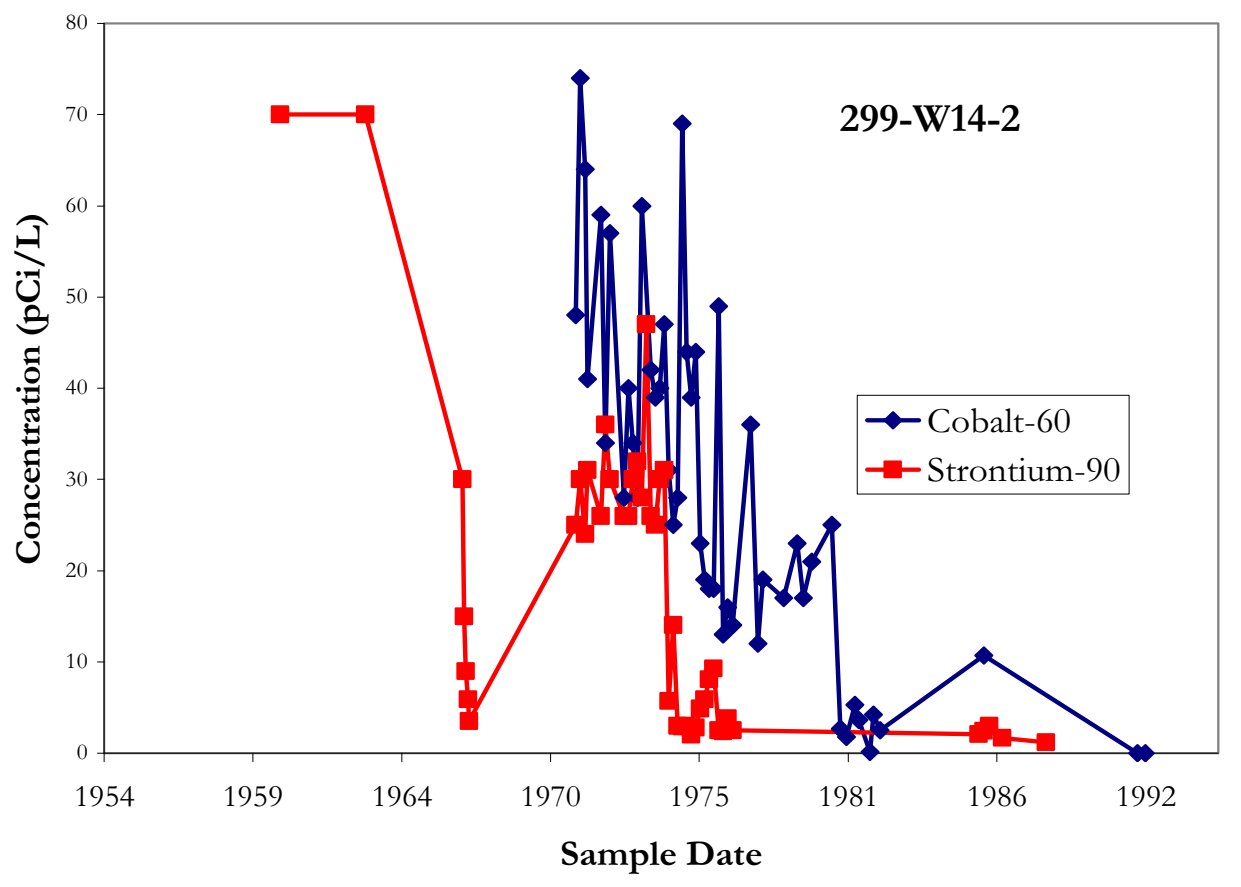

Figure 5.22. Cobalt-60 and Strontium-90 Concentrations in Well 299-W14-2 


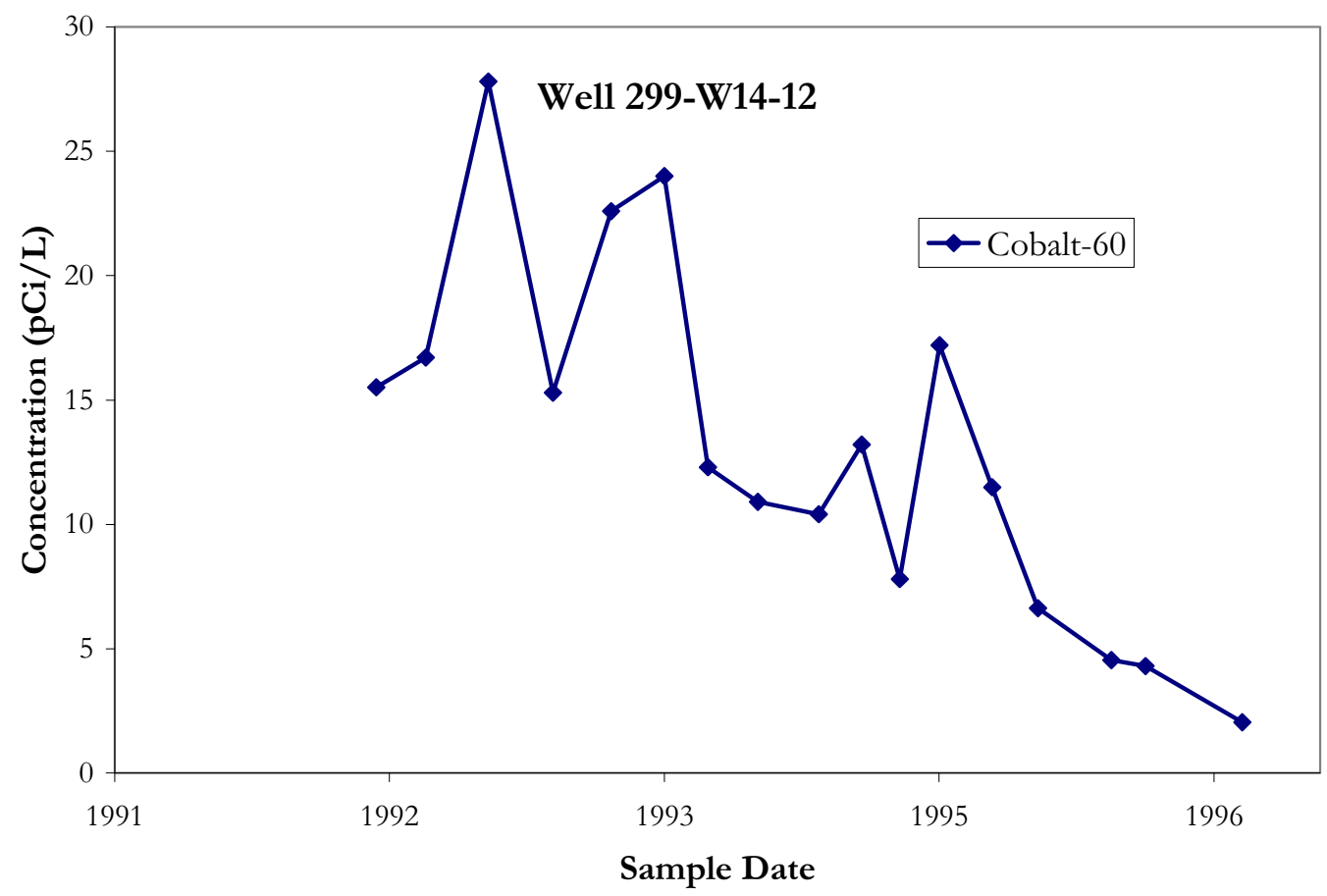

Figure 5.23. Cobalt-60 Concentrations in Well 299-W14-12

Several geochemical parameters were used to compare the porewater composition to groundwater composition. The first attempts to relate the groundwater and porewater compositions used the ratio of the concentration of various geochemical components (technetium-99, calcium, fluoride, chromium, sulfate, and sodium [Na]) to the concentration of nitrate. The ratios for porewater are given in Table 5.8; contaminant ratios for groundwater, using all available data with no laboratory qualifiers since about 1960, are shown in Table 5.9.

The agreement between the two data sets is not good. Some ratios for groundwater are larger than those for the vadose zone porewater $\left(\mathrm{Cr} / \mathrm{NO}_{3}{ }^{-}, \mathrm{F}_{/} \mathrm{NO}_{3}{ }^{-}\right)$and others are smaller than the vadose zone porewater $\left(\mathrm{Tc}-99 / \mathrm{NO}_{3}{ }^{-}, \mathrm{Na} / \mathrm{NO}_{3}{ }^{-}\right)$. The lack of agreement between the groundwater ratios and the contaminated borehole sediment porewater rations suggests that the groundwater contamination has been influenced by fluids from nearby cribs and trenches. The ratios of most mobile species in the vadose zone porewaters should remain stable as tank fluids percolate through the sediment because the only reaction between the tank waste and the vadose zone sediment should be dilution as dispersion and mixing occurs with native porewater. That is, the concentrations of mobile constituents will change proportionately to each other and their ratios will remain constant as the fluids descend towards the water table. The ratio for Tc-99/ $\mathrm{NO}_{3}{ }^{-}$, shown in Table 5.8 as a function of depth, shows a fairly constant value $(0.16 \pm 0.04 \mathrm{pCi} / \mu \mathrm{g})$ between the depths of 69.6 and $115.1 \mathrm{ft}$ bgs in borehole C3831 and $0.12 \pm 0.03 \mathrm{pCi} / \mu \mathrm{g}$ between depths of 70.0 and $110.0 \mathrm{ft}$ bgs in borehole C3832 (not shown in Table 5.80). Based on chemical composition data presented in Simpson et al. (2001), the Tc-99/ $\mathrm{NO}_{3}{ }^{-}$ratio for liquids that leaked from TX-107 was $6.07 \mathrm{E}-01 \mathrm{pCi} / \mu \mathrm{g}$, whereas the $\mathrm{Tc}-99 / \mathrm{NO}_{3}{ }^{-}$ratio of the liquids disposed to the nearby $216-\mathrm{T}-19$ tile field and 216-T-28 crib were $6.89 \mathrm{E}-04$ and $8.45 \mathrm{E}-04 \mathrm{pCi} / \mathrm{mg}$, respectively. Based on the large difference in $\mathrm{Tc}-99 / \mathrm{NO}_{3}{ }^{-}$ratio of the liquids that leaked from the tank and the low values for nearby cribs and tile fields and the proximity of the boreholes to TX tanks, it is likely that the 
boreholes intercepted only tank leak fluids. But because the boreholes met refusal in the Cold Creek lower subunit and the groundwater Tc-99/ $\mathrm{NO}_{3}{ }^{-}$ratios are much lower, it is difficult to determine whether fluids that leaked from TX tanks, especially TX104, TX105 and TX107 that were investigated with the three boreholes (C3832, C3830, and C3831, respectively), has reached the groundwater below the TX-TY WMA.

A second attempt was made to compare groundwater and the contaminated borehole sediment porewater compositions by eliminating nitrate (an anion common to both tank waste and liquid disposed to nearby cribs and trenches) from the ratios. These results are shown in Tables 5.10 and 5.11 for porewater and groundwater, respectively. Comparison of the data in the two tables shows that the groundwater and porewater compositions are very different. If the porewater composition represents the composition of tank waste, then the contamination in the groundwater either is not tank waste or is a mixture of tank waste and other contaminant sources such that the nature of the tank waste is no longer recognizable.

In summary, there is no current similarity between the present or past groundwater contamination and current porewater compositions from the contaminated borehole sediments. Therefore, we cannot link the contaminants in the groundwater, currently or during the era of contaminant introduction into the vadose zone, to the porewaters currently in the borehole sediments, which are known to be derived from liquids that leaked from tank TX-107. 
Table 5.8. Contaminant Concentration Ratios for Vadose Zone Porewater from Borehole C3831 as a Function of Depth and From Tank TX-107 Fluids

\begin{tabular}{|c|c|c|c|c|c|c|}
\hline Depth & $\begin{array}{c}\mathrm{Tc}-99 / \mathrm{NO}_{3}^{-} \\
(\mathrm{pCi} / \mu \mathrm{g})\end{array}$ & $\begin{array}{l}\mathrm{Cr} / \mathrm{NO}_{3}^{-} \\
(\mu \mathrm{g} / \mu \mathrm{g})\end{array}$ & $\begin{array}{c}\mathrm{F} / \mathrm{NO}_{3}^{-} \\
(\mathrm{mg} / \mathrm{mg})\end{array}$ & $\begin{array}{l}\mathrm{Na} / \mathrm{NO}_{3}^{-} \\
(\mathrm{mg} / \mathrm{mg})\end{array}$ & $\begin{array}{l}\mathrm{Ca} / \mathrm{NO}_{3}^{-} \\
(\mathrm{mg} / \mathrm{mg})\end{array}$ & $\begin{array}{c}\mathrm{SO}_{4}{ }^{2-} / \mathrm{NO}_{3}{ }^{-} \\
(\mathrm{mg} / \mathrm{mg})\end{array}$ \\
\hline 15.97 & 0.040 & 0.000195 & 0.750404 & 12.65 & 4.045 & 2.68 \\
\hline 21.93 & 0.067 & 0.000136 & 0.192436 & 10.06 & 2.070 & 4.16 \\
\hline 28.90 & 0.022 & 0.000362 & 0.535111 & 15.87 & 2.512 & 6.84 \\
\hline 46.06 & 0.051 & 0.002111 & 0.113569 & 11.44 & 6.893 & 14.56 \\
\hline 52.03 & 0.026 & 0.000260 & 0.400169 & 16.66 & 1.347 & 2.77 \\
\hline 53.18 & 0.053 & 0.000051 & 0.007275 & 0.74 & 0.126 & 0.14 \\
\hline 59.94 & 0.120 & 0.000028 & 0.000597 & 0.44 & 0.004 & 0.05 \\
\hline 61.15 & 0.245 & 0.000129 & 0.001159 & 0.77 & 0.002 & 0.06 \\
\hline 67.53 & 0.217 & 0.000891 & 0.016630 & 2.21 & 0.013 & 0.44 \\
\hline 67.53 & 0.206 & 0.000647 & 0.016965 & 2.21 & 0.009 & 0.43 \\
\hline 68.21 & 0.092 & 0.000745 & 0.007523 & 1.14 & 0.020 & 0.30 \\
\hline 69.60 & 0.179 & 0.000886 & 0.012407 & 1.44 & 0.021 & 0.41 \\
\hline 74.99 & 0.158 & 0.000013 & 0.001109 & 0.29 & 0.115 & 0.15 \\
\hline 77.67 & 0.128 & 0.000009 & 0.003699 & 0.27 & 0.124 & 0.22 \\
\hline 78.72 & 0.141 & 0.000008 & 0.001260 & 0.20 & 0.169 & 0.17 \\
\hline 85.99 & 0.078 & 0.000003 & 0.000274 & 0.07 & 0.205 & 0.08 \\
\hline 89.39 & 0.172 & 0.000010 & 0.003615 & 0.26 & 0.245 & 0.24 \\
\hline 93.99 & 0.216 & 0.000010 & 0.001160 & 0.17 & 0.171 & 0.10 \\
\hline 98.07 & 0.142 & 0.000013 & 0.001971 & 0.20 & 0.215 & 0.18 \\
\hline 101.29 & 0.139 & 0.000016 & 0.002684 & 0.20 & 0.244 & 0.19 \\
\hline 102.65 & 0.145 & 0.000011 & 0.002220 & 0.13 & 0.175 & 0.15 \\
\hline 114.44 & 0.198 & 0.000007 & 0.005453 & 0.17 & 0.276 & 0.44 \\
\hline 114.44 & 0.194 & 0.000007 & 0.005719 & 0.18 & 0.285 & 0.45 \\
\hline 115.06 & 0.187 & 0.000007 & 0.004727 & 0.15 & 0.272 & 0.47 \\
\hline \multicolumn{7}{|c|}{ Tank TX-107 } \\
\hline $\begin{array}{l}\text { from Simpson } \\
\text { et al. } 2001\end{array}$ & 0.60686 & 0.01728 & 0.00619 & 0.931 & 0.00450 & 0.0781 \\
\hline
\end{tabular}


Table 5.9. Contaminant Concentration Ratios for Groundwater Samples from Well 299-W14-12

\begin{tabular}{|c|c|c|c|c|c|}
\hline Sample Date & $\begin{array}{c}\mathrm{Tc}_{-99 / \mathrm{NO}_{3}}^{-} \\
(\mathrm{pCi} / \mu \mathrm{g})\end{array}$ & $\begin{array}{c}\mathrm{Cr} / \mathrm{NO}_{3}{ }^{-} \\
(\mu \mathrm{g} / \mu \mathrm{g})\end{array}$ & $\begin{array}{c}\mathrm{F} \mathrm{NO}_{3}^{-} \\
(\mathrm{mg} / \mathrm{mg})\end{array}$ & $\begin{array}{l}\mathrm{Na} / \mathrm{NO}_{3}{ }^{-} \\
(\mathrm{mg} / \mathrm{mg})\end{array}$ & $\begin{array}{c}\mathrm{SO}_{4}{ }^{2-} / \mathrm{NO}_{3} \\
(\mathrm{mg} / \mathrm{mg})\end{array}$ \\
\hline $4 / 21 / 1992$ & 0.0187 & 0.0932 & 0.227273 & 0.054545 & 0.170455 \\
\hline 7/20/1992 & 0.0219 & 0.1146 & 0.104167 & 0.052083 & 0.175 \\
\hline $11 / 11 / 1992$ & 0.0251 & 0.1132 & 0.188679 & 0.04717 & 0.177358 \\
\hline $3 / 9 / 1993$ & 0.0243 & 0.1091 & 0.181818 & 0.054545 & 0.190909 \\
\hline $6 / 23 / 1993$ & 0.0161 & 0.1064 & 0.191489 & 0.051064 & 0.204255 \\
\hline $9 / 28 / 1993$ & 0.0235 & 0.0981 & 1.019231 & 0.046154 & 0.184615 \\
\hline $12 / 16 / 1993$ & 0.0181 & 0.1000 & 0.230769 & 0.064103 & 0.192308 \\
\hline 3/17/1994 & 0.0009 & 0.0846 & 0.25641 & 0.064103 & 0.194872 \\
\hline 7/6/1994 & 0.0207 & 0.0951 & 0.268293 & 0.060976 & 0.185366 \\
\hline $9 / 22 / 1994$ & 0.0226 & 0.0974 & 0.282051 & 0.066667 & 0.189744 \\
\hline $11 / 30 / 1994$ & 0.0210 & 0.0633 & 0.333333 & 0.09 & 0.216667 \\
\hline 2/10/1995 & 0.0221 & 0.0644 & 0.222222 & 0.064444 & 0.186667 \\
\hline $5 / 17 / 1995$ & 0.0250 & 0.1000 & 1 & 0.086111 & 0.202778 \\
\hline $8 / 8 / 1995$ & 0.0173 & 0.0714 & 0.285714 & 0.085714 & 0.16 \\
\hline $12 / 20 / 1995$ & 0.0121 & 0.0600 & 0.44 & 0.112 & 0.212 \\
\hline $2 / 20 / 1996$ & 0.0091 & 0.0252 & 0.34 & 0.104 & 0.168 \\
\hline $5 / 16 / 1996$ & 0.0055 & 0.0109 & 0.395455 & 0.109091 & 0.172727 \\
\hline $8 / 14 / 1996$ & 0.0013 & 0.0056 & 0.666667 & 0.15 & 0.2 \\
\hline $11 / 13 / 1996$ & 0.0053 & 0.0028 & 0.309179 & 0.13913 & 0.199517 \\
\hline $2 / 10 / 1997$ & 0.0494 & 0.0192 & 1.757322 & 0.155263 & 0.197368 \\
\hline $5 / 14 / 1997$ & 0.0037 & 0.0034 & 0.345263 & 0.123932 & 0.181951 \\
\hline $11 / 17 / 1997$ & 0.0045 & 0.0021 & 0.275122 & 0.117308 & 0.163248 \\
\hline $2 / 17 / 1998$ & 0.0062 & 0.0050 & 0.228205 & 0.102059 & 0.153077 \\
\hline $6 / 25 / 1998$ & 0.0068 & 0.0012 & 0.215 & 0.084597 & 0.130294 \\
\hline $8 / 20 / 1998$ & 0.0070 & 0.0071 & 0.158235 & 0.068448 & 0.140831 \\
\hline $1 / 28 / 1999$ & 0.0107 & 0.0079 & 0.156235 & 0.054545 & 0.131034 \\
\hline
\end{tabular}


Table 5.10. Contaminant Concentration Ratios for Vadose Zone Porewater from Borehole C3831 as a Function of Depth and From Tank TX-107 Fluids

\begin{tabular}{|c|c|c|c|}
\hline $\begin{array}{l}\text { Depth } \\
\text { (ft bgs) }\end{array}$ & $\begin{array}{l}\text { Tc-99/Na } \\
(\mathrm{pCi} / \mathrm{mg})\end{array}$ & $\begin{array}{l}\mathrm{Tc}-99 / \mathrm{Cr} \\
(\mathrm{pCi} / \mu \mathrm{g})\end{array}$ & $\begin{array}{c}\text { Tc-99/F } \\
(\mathrm{pCi} / \mathrm{mg})\end{array}$ \\
\hline 15.97 & NA & 205.58 & 0.0535 \\
\hline 21.93 & NA & 494.35 & 0.3505 \\
\hline 28.90 & NA & 60.93 & 0.0412 \\
\hline 46.06 & NA & 23.97 & 0.4457 \\
\hline 52.03 & NA & 100.16 & 0.0651 \\
\hline 53.18 & 71.82 & 1049.40 & 7.2894 \\
\hline 59.94 & 269.51 & 4324.19 & 200.4449 \\
\hline 61.15 & 319.25 & 1900.35 & 211.1818 \\
\hline 67.53 & 98.04 & 243.45 & 13.0383 \\
\hline 67.53 & 93.27 & 318.84 & 12.1571 \\
\hline 68.21 & 80.43 & 123.43 & 12.2241 \\
\hline 69.60 & 124.58 & 201.83 & 14.4209 \\
\hline 74.99 & 543.95 & 12343.34 & 142.0491 \\
\hline 77.67 & 466.31 & 14549.63 & 34.5223 \\
\hline 78.72 & 713.76 & 18447.11 & 112.0922 \\
\hline 85.99 & 1129.53 & 29744.82 & 285.4978 \\
\hline 89.39 & 673.34 & 17654.06 & 47.5097 \\
\hline 93.99 & 1267.05 & 21941.02 & 186.2815 \\
\hline 98.07 & 727.64 & 10753.58 & 72.0698 \\
\hline 101.29 & 705.57 & 8859.07 & 51.7009 \\
\hline 102.65 & 1092.68 & 13424.60 & 65.4806 \\
\hline 114.44 & 1180.43 & 28930.93 & 36.3368 \\
\hline 114.44 & 1109.97 & 26803.72 & 33.9935 \\
\hline 115.06 & 1226.87 & 27104.64 & 39.4654 \\
\hline \multicolumn{4}{|c|}{ Tank T-107 Leak } \\
\hline from Simpson et al. 2001 & 0.0007 & 35.1145 & 0.09810 \\
\hline
\end{tabular}


Table 5.11. Contaminant Concentration Ratios for Groundwater Samples from Well 299-W14-12

\begin{tabular}{|c|c|c|c|}
\hline Date & $\begin{array}{l}\mathrm{Tc}-99 / \mathrm{Na} \\
\text { (pCi/mg) }\end{array}$ & $\begin{array}{l}\mathrm{Tc}-99 / \mathrm{Cr} \\
(\mathrm{pCi} / \mu \mathrm{g})\end{array}$ & $\begin{array}{c}\text { Tc-99/F } \\
(\mathrm{pCi} / \mathrm{mg})\end{array}$ \\
\hline $4 / 21 / 1992$ & 0.3433 & NA & 8.2400 \\
\hline $7 / 20 / 1992$ & 0.4200 & 19.0909 & 21.0000 \\
\hline 11/11/1992 & 0.5320 & 22.1667 & 13.3000 \\
\hline $3 / 9 / 1993$ & 0.4458 & 22.2917 & 13.3750 \\
\hline $6 / 23 / 1993$ & 0.3154 & 15.1400 & 8.4111 \\
\hline 9/28/1993 & 0.5083 & 23.9216 & 2.3019 \\
\hline $12 / 16 / 1993$ & 0.2816 & 18.0513 & 7.8222 \\
\hline $3 / 17 / 1994$ & 0.0148 & 1.1182 & 0.3690 \\
\hline 7/6/1994 & 0.3396 & 21.7692 & 7.7182 \\
\hline $9 / 22 / 1994$ & 0.3385 & 23.1579 & 8.0000 \\
\hline $11 / 30 / 1994$ & 0.2330 & 33.1053 & 6.2900 \\
\hline $2 / 10 / 1995$ & 0.3431 & 34.3103 & 9.9500 \\
\hline $5 / 17 / 1995$ & 0.2903 & 25.0000 & 2.5000 \\
\hline 8/8/1995 & 0.2020 & 24.2400 & 6.0600 \\
\hline $12 / 20 / 1995$ & 0.1077 & 20.0993 & 2.7408 \\
\hline $2 / 20 / 1996$ & 0.0873 & 36.0397 & 2.6712 \\
\hline $5 / 16 / 1996$ & 0.0503 & 50.3333 & 1.3885 \\
\hline $8 / 14 / 1996$ & 0.0084 & 22.7040 & 0.1892 \\
\hline $11 / 13 / 1996$ & 0.0378 & 191.2281 & 1.7031 \\
\hline $2 / 10 / 1997$ & 0.0442 & 256.5217 & 2.8095 \\
\hline $5 / 14 / 1997$ & 0.0241 & 109.2308 & 1.0823 \\
\hline $8 / 12 / 1997$ & NA & NA & 0.0000 \\
\hline $8 / 26 / 1997$ & 0.0376 & 180.0000 & \\
\hline 11/17/1997 & 0.0366 & 220.8333 & 1.9850 \\
\hline 2/17/1998 & 0.0525 & 123.0769 & 2.8623 \\
\hline $6 / 25 / 1998$ & 0.0663 & 547.6190 & 4.2751 \\
\hline $8 / 20 / 1998$ & 0.0832 & 98.9691 & 4.5070 \\
\hline $1 / 28 / 1999$ & 0.1562 & 135.9649 & 15.9794 \\
\hline
\end{tabular}




\subsection{Summary and Conclusions}

In this section, we present summary information about our interpretation of the TX borehole sediment characterization data. Conclusions are included to aid in making decisions on what interim actions and future studies are needed to make sound waste-management decisions at TX tank farm.

\subsection{Drilling and Sampling Summary at the TX Tank Farm}

Three boreholes were placed inside the TX Tank Farm area for the specific purpose of collecting core samples for physical and chemical characterization. Boreholes C3830, C3831, and C3832 were drilled via the closed-end probe method within the TX Tank Farm. Core samples, 1.25-ft-long by 2.5-in.-diameter, were collected at predetermined intervals within these boreholes. Each core contained two, 0.5-ft-long stainless-steel liners that contained sediment. An uncontaminated borehole (299-W10-27) was drilled outside the northeast corner of TY Tank Farm using a different sampling procedure. Two, 4-in.-diameter, 1-ft-long lexan-lined core samples were recovered from each 2.5-ft-long splitspoon in 299-W10-27. Sampling above $50 \mathrm{ft}$ was limited to core-barrel grab samples every $5 \mathrm{ft}$, between 50 and $132 \mathrm{ft}$ bgs near continuous core was collected while below $132 \mathrm{ft}$ bgs grab samples were collected every $5 \mathrm{ft}$ from the hard-tool drill cuttings. An additional three splitspoon cores were collected between hard-tooled intervals from the saturated zone within Ringold Formation member of Wooded Island (formerly called Unit E) gravels.

Borehole C3830 was located approximately $40 \mathrm{ft}(12.2 \mathrm{~m})$ southwest of single-shell tank 241-TX-105 to a total depth of $116.75 \mathrm{ft}(35.6 \mathrm{~m}) \mathrm{bgs}$; the hole was terminated when refusal was encountered near the top of the lower Cold Creek unit (caliche). During drilling, a total of 18 splitspoon core samples were collected intermittently between August 20, 2002 and early September 2002. In all, about $25 \mathrm{ft}$ of core was obtained from $\mathrm{C} 3830$, or about $22 \%$ of the total length of the hole. No samples or drill cuttings were collected between the 18 core runs because the hole was advanced in a closed configuration using a solid, removable tip.

Borehole C3831 was drilled and sampled using the driven-probe technique between July 1 and August 7, 2002. The borehole was located approximately $40 \mathrm{ft}(12 \mathrm{~m})$ southwest of single-shell tank 241-TX-107. During drilling, a total of 20 splitspoon core samples were collected intermittently starting at a depth of $15 \mathrm{ft}$ bgs. The hole was terminated when refusal was encountered at $115.4 \mathrm{ft}$ bgs in the caliche within the lower Cold Creek unit. In all, $26.74 \mathrm{ft}$ of core was obtained from C3831, which accounts for about $23 \%$ of the total length of the hole. No samples or drill cuttings were collected between the 20 core runs because the hole was advanced in a closed configuration using a solid, removable tip.

Borehole C3832 was drilled and sampled using the driven-probe technique between May 2 and June 3, 2002. The borehole is located about $20 \mathrm{ft}(6 \mathrm{~m})$ south-southeast of single-shell tank 241-TX-104. During drilling, a total of 19 splitspoon core samples were collected intermittently starting at a depth of about $16 \mathrm{ft}$ bgs. In all, $27.09 \mathrm{ft}$ of core was collected, which accounts for about $23 \%$ of the total length of the hole. The hole was terminated when refusal was encountered at $115.9 \mathrm{ft}$ bgs in the caliche within the lower Cold Creek unit. No samples or drill cuttings were collected between the 19 core runs because the hole was advanced in a closed configuration using a solid, removable tip. 
Each of the 6-in. long liners from all three boreholes were opened in the chemistry lab and geologically described during the subsampling process to obtain aliquots used in the various characterization activities. The geology between core samples was inferred and interpreted based on the geophysical log and blow-count data.

\subsection{Conceptual Model for TX Tank Farm Geology}

Three primary stratigraphic units were encountered in each of the three boreholes: 1) backfill material, 2) the Hanford formation, and 3) the Cold Creek unit. The deeper Ringold Formation was only penetrated in the "clean" borehole 299-W10-27. Table 6.1 summarizes the contacts between the various stratigraphic units in the three boreholes and "clean" borehole.

For all three boreholes, the backfill consists of predominantly grayish-brown, very poorly to moderately sorted, massive, gravelly sand to slightly gravelly sand, which is unconsolidated and weakly to strongly calcareous. This unit appears to be rather homogeneous and lacks lithologic variation suggested by relatively uniform geophysical logs and blow-count data. Near the bottom of the backfill at C3831 near $46 \mathrm{ft}$ bgs, a finer-grained 1-ft thick layer of laminated silty sand occurred. In the backfill at C3832, several feet or more of wet to moist, cohesive, well-sorted, strongly calcareous, dark grayish-brown, silty-fine sand was present at the base of the backfill sequence. Free water was reported in this material during core sampling. Fine-grained sand and silt was occasionally placed at and toward the base of the backfill within the TX Tank Farm, apparently to improve traction for construction vehicles (DOE-GJO 1997). This observation may explain the fine-grained and wetter nature of the backfill sediments at boreholes C3831 and C3832.

Below the backfill in all three boreholes lies the Hanford formation, which is divided into three informal units (H1, H2, and H3). However, at two of the boreholes the H1 unit was completely removed during excavation and then later used as backfill. We infer that a thin remnant of the $\mathrm{H} 1 \mathrm{unit}$ exists between 45 and $47 \mathrm{ft}$ bgs at borehole C3832. Further, at the three boreholes there is no indication that $\mathrm{H} 3$ unit materials are present above the contact with Cold Creek units. Therefore below the TX tanks, the stratigraphy is dominated by the Hanford formation $\mathrm{H} 2$ unit. The Hanford formation $\mathrm{H} 2$ unit consists of predominantly fine-to-coarse-grained sand with an overall gray to brownish-gray color. This sand has the appearance of "salt and pepper", with the "pepper" fraction consisting of basaltic rock fragments, and the "salt" fraction consisting of mostly quartz and feldspar grains (as discussed in Section 2.1.3). The H2 sands are sometimes capped or interbedded with thin beds of silty-fine sand to silt. The fine- to coarsesand beds are loose, massive to laminated, moderately to well-sorted, and weakly to moderately calcareous. Finer-grained beds are generally well sorted, cohesive, massive to laminated, yellowish to olive-brown, and moderately to strongly calcareous. 
Table 6.1. Stratigraphic Units and Contacts (ft bgs)

\begin{tabular}{|l|c|c|c|c||}
\hline \multicolumn{1}{|c|}{ Hole } & 299-W10-27 & C3830 (TX-105) & C3831 (TX-107) & C3832 (TX-104) \\
\hline Recent Eolian & 0 to 4.5 & - & - & - \\
\hline Backfill & - & 0 to 52 & 0 to 52.3 & 0 to 45 \\
\hline $\mathrm{H} 1$ & 4.5 to 41.5 & gone & gone & 45 to 47 \\
\hline $\mathrm{H} 2$ & 41.5 to 89.4 & 52 to 100.4 & 52.3 to 102.2 & 47 to 103 \\
\hline $\mathrm{CCU}_{\mathrm{u}}$ & 89.4 to 98 & 100.4 to 111 & 102.2 to 106 & 103 to 110.4 \\
\hline $\mathrm{CCU}_{1}$ & 98 to 112 & 111 to bottom & 106 to bottom & 110.4 to bottom \\
\hline $\mathrm{R}_{\mathrm{tf}}$ & 112 to 124 & Hole stopped & Hole stopped & Hole stopped \\
\hline $\mathrm{R}_{\mathrm{wi}}$ & 124 to hole bottom & Hole stopped & Hole stopped & Hole stopped \\
\hline $\begin{array}{l}\mathrm{H} 1=\text { Hanford formation Unit } 1-\text { gravel dominated cataclysmic flood deposits. } \\
\mathrm{H} 2=\text { Hanford formation Unit } 2-\text { sand dominated cataclysmic flood deposits. } \\
\mathrm{CCU}_{\mathrm{u}}=\text { Cold Creek Unit upper subunit - well-sorted silt and/or fine sand of eolian and/or fluvial origin. } \\
\mathrm{CCU}_{1}=\text { Cold Creek Unit lower subunit - calic paleosol sequences. } \\
\mathrm{R}_{\mathrm{tf}}=\text { Ringold Formation member of Taylor Flat }- \text { generally fluvial sands and silts. } \\
\mathrm{R}_{\mathrm{wi}}=\text { Ringold Formation member of Wooded Island - fluvial sand and gravel. }\end{array}$ \\
\hline
\end{tabular}

At borehole C3830, based on cores and the field moisture, spectral gamma, and blow-count logs, we infer there are four, thin fine-grained layers in the $\mathrm{H} 2$ unit. At borehole $\mathrm{C} 3831$ we infer that there are at least eight fine-grained layers in the $\mathrm{H} 2$ unit. At C3831, a clastic dike was observed within the Hanford formation $\mathrm{H} 2$ unit at about $60 \mathrm{ft}$ bgs. The clastic dike is characterized by compact and cohesive, sub-vertically laminated, grayish-brown sand to dark gray silt and clay. A few small pebbles are also present within the dike, which is moderately calcareous. The clastic dike shows higher moisture content compared to adjacent strata, probably as a result of the presence of more fine grained material, which tends to retain more moisture. The contamination profile at $\mathrm{C} 3831$ suggests that fluids may have been captured by this clastic dike and preferentially transported along the dike. That is, at C3831 there are no signs of tank fluids above the depth where the borehole intercepted the clastic dike and the contamination is present from the intercept depth to near the bottom of the hole. There are at least eight, thin fine-grained interbeds in the $\mathrm{H} 2$ unit at borehole $\mathrm{C} 3832$. These thin fine-grained lenses found at all three boreholes within the $\mathrm{H} 2$ sands may impact the flow of leaked fluids and effected irregular and horizontal flow.

The upper Cold Creek unit, $\mathrm{CCU}_{\mathrm{u}}$, at borehole C3830 is 10.6-ft thick. Six samples of the upper CCU were collected for physical and chemical characterization at three different depths within the upper CCU. Sediments from this unit are compact and well-sorted silt to silty-fine sand, which range from laminated to massive, and are moderately to strongly calcareous. This unit has an average gravimetric moisture content of $11.0 \%$. At borehole $\mathrm{C} 3831$, the $\mathrm{CCU}_{\mathrm{u}}$ is compact and well-sorted silt to silty-fine sands, which range from laminated to massive, and are moderately to strongly calcareous. The upper CCU in C3831 is relatively thin (only 3.8-ft thick). The upper CCU in C3832 is 7.4-ft thick and consists of compacted and well-sorted, mottled to laminated, moderately to strongly calcareous, yellowish-brown to olive-brown, silt to silty-fine sand. The top of the upper CCU, especially at $\mathrm{C} 3832$, is defined by a dramatic decrease in grain size and an increase in the total gamma activity. 
We define the top of the lower CCU as the top of the first pedogenically altered, carbonate-rich, cemented zone, that is accompanied by a sudden drop in natural-gamma activity. The lower Cold Creek unit, $\mathrm{CCU}_{1}$, was sparsely sampled in boreholes $\mathrm{C} 3830$ and $\mathrm{C} 3831$ but five samples were obtained out of borehole C3832. Sediments from this unit are slightly moist (gravimetric moisture content 11 to 13\%), mottled and cemented, pinkish-gray, very poorly sorted sand, silt, and olive-colored clay, some with a few small pebbles of angular basalt and others with pedogenic calcium carbonate stringers and nodules. All the samples are very strongly calcareous. The lower CCU represents a highly weathered paleosurface that developed unconformably on top of the Ringold Formation (Brown 1959, 1960) following a period of downcutting and degradation within the central Pasco Basin. The overall thickness of the lower CCU beneath the TX Tank Farm is generally 10-20 ft and dips to the southwest about one degree (Wood et al. 2001). In the vicinity of the TX Tank Farm, multiple, calcic-rich zones in the $\mathrm{CCU}_{1}$ subunit may be separated by relatively non-calcareous, un-cemented material, indicating some rapid accumulations occurred periodically between periods of soil development.

Deeper sediments were only sampled in the "clean" borehole, 299-W10-27, but based on other boreholes studied in the past, we offer the following geologic description. Generally, only fluvial gravel and sand facies are represented in the Ringold Formation vadose zone beneath the TX Tank Farm. The Ringold Formation member of Taylor Flat $\left(\mathrm{R}_{\mathrm{tf}}\right)$ within the T-TX-TY WMA (also referred to as the upper Ringold unit) consists of interstratified, well-bedded fine to coarse sand to silt belonging to a mixture of fluvial-sand and overbank facies associations. Post-Ringold Formation erosion has locally stripped away this member, including all the area beneath TX Tank Farm. Below the Ringold Formation Taylor Flat Member is the Ringold Formation Wooded Island Member ([ $\left.\mathrm{R}_{\mathrm{wi}}\right]$, also referred to as the Ringold Unit E) that consists predominantly of the fluvial-gravel facies association with occasional thin beds of the fluvial sand and/or the overbank facies associations. $R_{w i}$ within the TX Tank Farm averages about 85-m (275 ft) thick and the top of the unit dips very gently to the southwest. The water table lies within $\mathrm{R}_{\mathrm{wi}}$ gravels at about 220 -ft $(67 \mathrm{~m})$ depth, about halfway between basalt bedrock and the ground surface.

\subsection{Stratigraphy and Moisture Content}

In general, heterogeneities including fine-grained thin lenses in the Hanford formation and the relatively thick Cold Creek unit likely cause anisotropy in water flow. Increased moisture was found to correlate with each of the fine-grained thin lenses intercepted by the coring and other fine-grained lenses are inferred to be present in the Hanford formation $\mathrm{H} 2$ unit based on the field neutron logging profiles. Recall that only about $25 \%$ of the profiles in the boreholes were cored. Several findings and hypotheses on the relationship between moisture content and water and contaminant flow that are gleaned from the characterization efforts reported herein include:

- Relatively high moisture contents occur in the Cold Creek unit in all three boreholes, especially for the lower CCU (i.e., caliche).

- Average moisture content for the Hanford formation H2 unit in "clean" borehole, 299-W10-27, is significantly less than in the three boreholes. This may be attributed to either:

1. greater artificial recharge to the vadose zone associated with the boreholes (i.e., tank leaks, tank dome water diversion/shedding), 
2. sample bias. Moisture samples from the H2 unit at 299-W10-27 were collected at regular 1-ft intervals, whereas the borehole intervals were pre-selected based on suspected contamination (i.e., high moisture), or

3. higher natural recharge beneath the tank farms due to the removal of surface vegetation and placement of gravel, which significantly reduces or eliminates near-surface transpiration of moisture back to the atmosphere.

\subsection{Vertical Extent of Contamination}

The following paragraphs describe measurements of various parameters that help us determine the extent of vertical migration of tank or ancillary equipment leaks. We used several parameters including moisture content, $\mathrm{pH}$, electrical conductivity, nitrate, technetium-99, sodium, and uranium concentrations in water and acid extract as indicators to determine the leading edge of the plume. The concentrations of water-extractable (for mobile constituents) and acid-extractable or directly measured constituents in the sediment (for sorbing constituents) were used to delineate the total inventory of constituents within the plume. For technetium-99, the water-extractable data were judged to be a more accurate indication of past tank leaks than acid-extractable concentrations. In this section, we discuss all of the parameters measured except uranium and sodium.

Based on evaluating all these measurements, we conclude that the borehole data do not establish the vertical extent of tank contamination, especially in boreholes C3831 and C3832, because contamination was found at the bottom of these boreholes.

The first parameter, moisture content, is a direct measure of the mass of water in the vadose zone sediment. One would logically assume that wetter than normal conditions would represent the existence of leaked tank liquor but, as found at most of the boreholes studied to date, the moisture content in the three boreholes is indicative mainly of grain size.

The second parameter measured was the $\mathrm{pH}$ of water extracts of the vadose zone sediment. Based on the assumption that tank fluids are generally caustic and often very caustic ( $>1 \mathrm{M}$ free hydroxide), elevated $\mathrm{pH}$ profiles should be indicative of the zones impacted by leaked fluids. The $\mathrm{pH}$ profiles for sediments from the three boreholes show slightly elevated $\mathrm{pH}$ in borehole $\mathrm{C} 3831$, at $61 \mathrm{ft}$ bgs, that is indicative of alkaline tank fluid interactions. But the $\mathrm{pH}$ data at all other depths in borehole $\mathrm{C} 3831$ and at all depths in boreholes $\mathrm{C} 3830$ and $\mathrm{C} 3832$ show no indication of elevated $\mathrm{pH}$ values. Based on observations at other tank farms ( $\mathrm{SX}$ and $\mathrm{BX}$ ) where it is certain that caustic wastes are in the vadose zone, yet water extract $\mathrm{pH}$ values never exceed 10, we have concluded that $\mathrm{pH}$ is not a very sensitive parameter to use for evaluating the extent of plume migration in the vadose zone. A paper that provides a technically based conceptualization of the evolution of $\mathrm{pH}$ in sediments in contact with caustic fluids is in publication (see Wan et al. 2004).

The third parameter that was assessed to estimate the vertical extent of the leaked plume was dilutioncorrected water extract electrical conductivity (EC). The EC depth profiles for the three boreholes do show elevated EC in comparison to the background sediments from borehole 299-W10-27. There is slightly elevated EC in the $\mathrm{C} 3830$ borehole sediments from $59.4 \mathrm{ft}$ bgs to the bottom of the borehole samples. The highest dilution-corrected porewater $\mathrm{EC}$ is equivalent to a pore solution of $0.12 \mathrm{M} \mathrm{KCl}$, the salt solution used to calibrate the conductivity probe. 
There is also evidence of elevated EC starting at $60 \mathrm{ft}$ bgs all the way to the bottom of the borehole at C3831. Somewhere between the two C3831 samples at 53.2 and $59.9 \mathrm{ft}$ bgs, the EC of the 1:1 water extract increases to between 10 and 13 times the background sediment. At $\sim 86 \mathrm{ft}$ bgs in C3831 there is a second peak of high EC at about 11 times the background sediment water extract. Below $86 \mathrm{ft}$ bgs to the bottom of the $\mathrm{C} 3831$ borehole at $115 \mathrm{ft}$ bgs, the EC averages about 3 times higher than that in background sediments. When compared to the EC at borehole C3830 and C3832, the values at C3831 are unequivocally higher and indicative of the presence of saline tank-related fluids. The highest dilution-corrected porewater EC value for borehole $\mathrm{C} 3831$, between $60-61 \mathrm{ft} \mathrm{bgs}$, is equivalent to a pore solution of $0.4 \mathrm{M} \mathrm{KCl}$.

The EC values at C3832 are lower in the $\mathrm{H} 2$ unit and slightly larger than those at C3830 in the Cold Creek units and unequivocally lower than the EC values at borehole $\mathrm{C} 3831$ in both the $\mathrm{H} 2$ and $\mathrm{CCU}_{\mathrm{u}}$ units. The highest values of dilution-corrected porewater EC in borehole $\mathrm{C} 3832$ occur in two zones, between 61 to $63 \mathrm{ft}$ bgs and 110.3 to the bottom of the hole at $115.5 \mathrm{ft}$ bgs. The $\mathrm{C} 3832$ dilution-corrected $\mathrm{EC}$ values for these two zones are equivalent to a pore solution of 0.042 and $0.051 \mathrm{M} \mathrm{KCl}$. The maximum dilution-corrected EC at borehole $\mathrm{C} 3832$ in the $\mathrm{H} 2$ unit is $4.54 \mathrm{mS} / \mathrm{cm}$, lower than the dilution-corrected EC at borehole $\mathrm{C} 3830(12.5 \mathrm{mS} / \mathrm{cm})$. The highest dilution-corrected EC at borehole $\mathrm{C} 3832$ occurs in the $\mathrm{CCU}_{1}$ unit with a value of $6.27 \mathrm{mS} / \mathrm{cm}$.

Because the three boreholes could not be pushed through the $\mathrm{CCU}_{1}$ unit to deeper depths, it is difficult to judge whether the vadose zone plumes of saline fluids stopped at the caliche layer as was found at the SX tank farm (see Serne et al. 2002b, 2002d). It does seem that the more elevated portions of the EC profile at borehole $\mathrm{C} 3830$ currently resides at the bottom of a fine-grained thin lens in the $\mathrm{H} 2$ unit at $87 \mathrm{ft}$ bgs. At $\mathrm{C} 3831$, we lack good sample coverage in the fine-grained $\mathrm{CCU}_{\mathrm{u}}$ mud unit and the caliche unit to ascertain whether the salt plume has significantly descended into the Cold Creek sediments. There is strong indication at borehole $\mathrm{C} 3832$ that the saline plume has descended into the Cold Creek unit at least to the bottom of the borehole.

Despite the evidence that elevated EC values may be present in all three boreholes to their depth of refusal, the concentrations are not large. For example, the maximum dilution-corrected EC at borehole C3832 is $6.27 \mathrm{mS} / \mathrm{cm}$; at borehole C3830, the maximum is $12.5 \mathrm{mS} / \mathrm{cm}$; at borehole C3831, the maximum is $43.3 \mathrm{mS} / \mathrm{cm}$. The leaks near the SX108-109 and BX-102 tanks had peak vadose zone porewater concentrations that were equivalent to much more concentrated waste fluids, 524 to 1774 and $77 \mathrm{mS} / \mathrm{cm}$, respectively. At 299-E33-46 near tank B-110 the dilution-corrected EC was $15.1 \mathrm{mS} / \mathrm{cm}$, and at 299-W23-19 near tank SX-115, which contained dilute waste, the dilution-corrected EC was $33 \mathrm{mS} / \mathrm{cm}$.

The fourth parameter evaluated to define the vertical extent of contamination was nitrate. The nitrate water extract values for borehole $\mathrm{C} 3830$ are elevated from $67 \mathrm{ft}$ bgs to the deepest sample obtained. The nitrate water extract values are 10 to 50 times larger than for the background sediments in similar uncontaminated lithologies in borehole 299-W10-27. The nitrate water extract values for borehole C3831 are elevated compared to the background sediments from $53 \mathrm{ft} \mathrm{bgs}$ to the deepest sample obtained. The nitrate water extract values in C3831 borehole sediments are 20 to 300 times larger than for the background sediments between the depths of 53 and $86 \mathrm{ft}$ bgs. The nitrate concentrations in the borehole C3831 are also $\sim 5$ to 10 times larger than those at similar depths in borehole C3830. The nitrate water extract values for borehole C 3832 are elevated compared to the background sediments from $76 \mathrm{ft}$ bgs to the deepest sample obtained. The nitrate concentrations in the borehole C3832 are the same as those at 
borehole $\mathrm{C} 3830$ in the $\mathrm{H} 2$ sediments down to $97 \mathrm{ft}$ bgs, but higher than the $\mathrm{C} 3830$ sediments below $97 \mathrm{ft}$ bgs. Both C3832 and C3830 sediments contain $\sim 5$ to 10 times less nitrate than the sediments in borehole C3831. Thus, as found for the EC data, it is difficult to judge whether the vadose zone nitrate plumes were successfully stopped at the caliche layer as was found at the SX tank farm. It does appear that the nitrate plume in borehole C3832 may be a diluted and a deeper extension of the plume at C3831.

The fifth indicator species often used to define the vertical extent of contamination is technetium-99 in water extract samples. For the boreholes at the TX tank farm, the technetium-99 concentrations are not high enough to get a good indication on the vertical extent of tank related waste. The technetium-99 concentration levels are discussed in Section 6.6.

In summary, the moisture content, $\mathrm{pH}$, electrical conductivity, nitrate, and technetium-99 profiles versus depth do not clearly identify the leading edge of the plume. The profiles do collectively suggest that tank-related fluids in borehole $\mathrm{C} 3832$ have traveled deeper than at the other two boreholes and that the C3832 plume's most saline concentrations have reached the caliche in the Cold Creek lower subunit to a depth of at least $116 \mathrm{ft}$ bgs.

\subsection{Detailed Characterization to Elucidate Controlling Geochemical Processes}

The more detailed characterization activities of the cores from 299-W10-27 and the three boreholes added some insight on the processes that control the observed vertical distribution of contaminants and on the migration potential of key contaminants in the future. The porewaters, calculated by dilution correction of the 1:1 water extracts, in the sediment from the boreholes in the Hanford formation unit (H2) were dominated by sodium, nitrate, and bicarbonate for sediments with obvious signs of tank fluids. The most concentrated porewaters in the $\mathrm{H} 2$ and Cold Creek units for the three boreholes are shown in Table 6.2 in units of meq/L. Also included in the table for comparison are the maximum porewater concentrations found in other characterization work previously reported for the BX, B, and SX Tank Farms.

For borehole $\mathrm{C} 3830$, the most saline calculated porewater resides in the $\mathrm{H} 2$ unit and has a chemical composition of sodium $(0.032 \mathrm{~N})$, calcium $(0.042 \mathrm{~N})$, magnesium $(0.018 \mathrm{~N})$, potassium $(0.005 \mathrm{~N})$, nitrate $(0.040 \mathrm{~N})$, bicarbonate $(0.034 \mathrm{~N})$, sulfate $(0.020 \mathrm{~N})$, and chloride $(0.008 \mathrm{~N})$. The most saline calculated porewater in borehole $\mathrm{C} 3831$ is also present in the $\mathrm{H} 2$ sediments and is significantly more saline than the porewaters in $\mathrm{C} 3830$ and $\mathrm{C} 3832$. The maximum calculated porewater concentration in borehole $\mathrm{C} 3831$ has sodium $(0.418 \mathrm{~N})$, potassium $(0.005 \mathrm{~N})$, calcium $(0.001 \mathrm{~N})$, magnesium $(0.0002 \mathrm{~N})$, nitrate $(0.202 \mathrm{~N})$, bicarbonate $(0.191 \mathrm{~N})$, sulfate $(0.015 \mathrm{~N})$, phosphate $(0.008 \mathrm{~N})$, and chloride $(0.006 \mathrm{~N})$. A much more dilute, yet still tank-influenced porewater that consists of a more alkaline earth dominated system, is found in the borehole C3831 Cold Creek unit's sediments. The calculated porewater ionic strength in borehole $\mathrm{C} 3832$ sediments is more dilute than either of the other two boreholes but has more salinity in the Cold Creek sediments than in the $\mathrm{H} 2$ sediments. This suggests that the source of the fluids may be more distant from this borehole. That is, a plume descending within dipping strata with several finegrained lens migrates in a "stair-step fashion" that would yield a pattern in vertical boreholes where contamination would be found deeper in the downgradient borehole. This stair-step pattern is observed when comparing boreholes C3831 and C3832 where some of the constituents' distributions in borehole C3831 suggest that the plume that is observed in both C3831 and C3832 could be from tank TX-107. 
However, as discussed below not all constituents have distributions between the two boreholes that fit this hypothesis (see water-extractable uranium discussion). Further, the vertical distribution of contaminants at borehole $\mathrm{C} 3831$ may be controlled by the clastic dike that was intercepted at $60 \mathrm{ft}$ bgs.

As shown in Table 6.2, the calculated porewaters in the TX boreholes are much less concentrated than porewaters found in the vadose zone sediments from either the BX and SX WMAs.

The water-extractable major cations' distributions in the three borehole sediments suggest that an ion-exchange process dominates the porewater/sediment interactions where tank fluid passed by or currently exists. The depth profiles for the divalent alkaline earth cations (calcium, magnesium, and strontium) versus sodium show remarkable similarities in all three boreholes. All show depleted divalent (alkaline earth) cation concentrations in the shallow Hanford formation $\mathrm{H} 2$ sediments below the tank bottoms. Conversely, the water-extractable sodium concentrations in this zone are elevated. At borehole C3830, the distribution of the divalent alkaline earth cations (magnesium, calcium, and strontium but not barium) and the monovalent cation potassium show low water-extractable quantities between 54 to 58 and 67 to $72 \mathrm{ft}$ bgs with the lowest values of all at $67 \mathrm{ft}$ bgs. Conversely, the distribution of water-extractable sodium is higher than the mass that is water leachable from uncontaminated sediments in the whole profile excepting at the $59.35 \mathrm{ft}$ depth. The water-extractable sodium peak value occurs at $65 \mathrm{ft}$ bgs and the peak nitrate and EC value occur at $\sim 77 \mathrm{ft} \mathrm{bgs.} \mathrm{These} \mathrm{trends} \mathrm{suggest} \mathrm{that} \mathrm{tank} \mathrm{fluids} \mathrm{that} \mathrm{are} \mathrm{high} \mathrm{in}$ sodium (and nitrate based on the anion data) did seep into the vadose zone near this borehole. The water-extractable masses of all cations in the $59.35 \mathrm{ft}$ bgs sample are very similar to uncontaminated background sediments. There is a fine-grained lens near this depth that may have forced the tank fluids to flow laterally around this zone.

At borehole C3831, the distribution of the divalent alkaline earth cations (magnesium, calcium, and strontium but not barium) shows low water-extractable quantities between 61 and $70 \mathrm{ft}$ bgs. High divalent cation water extracts are found below in a narrow zone between 78.7 and $86 \mathrm{ft}$ bgs. Conversely, the distribution of water-extractable sodium is very high between the depths of 60 and $75 \mathrm{bgs}$. The water-extractable sodium values in borehole $\mathrm{C} 3831$ sediments are higher than the values in the uncontaminated sediments from borehole 299-W10-27 over the whole borehole profile. These trends suggest that tank fluids that are high in sodium and nitrate did seep into the vadose zone near this borehole. The sodium pushed the natural divalent cations and some of the natural potassium off the sediment cation exchange sites in the sediments between 61 and at least $70 \mathrm{ft}$ bgs. Right below the leading edge of the sodium plume one finds elevated levels of divalent cations that were displaced. We observe the highest levels of water-extractable divalent cations in the samples between 78.7 and $86 \mathrm{ft}$ bgs. At borehole $\mathrm{C} 3831$, the water-extractable magnesium, calcium, strontium, barium, potassium, and sodium in the sediments from $75 \mathrm{ft}$ bgs to the bottom of the borehole are larger than the background sediment in borehole 299-W10-27 by a factor of 3 to 5 and borehole C 3830 sediments by a factor of 2 . This probably is an indication that either more volume of fluid and/or higher concentration tank fluids are present in the C3831 sediments from $75 \mathrm{ft}$ bgs to the bottom of the borehole than are present in the sediments obtained from borehole C3830. 


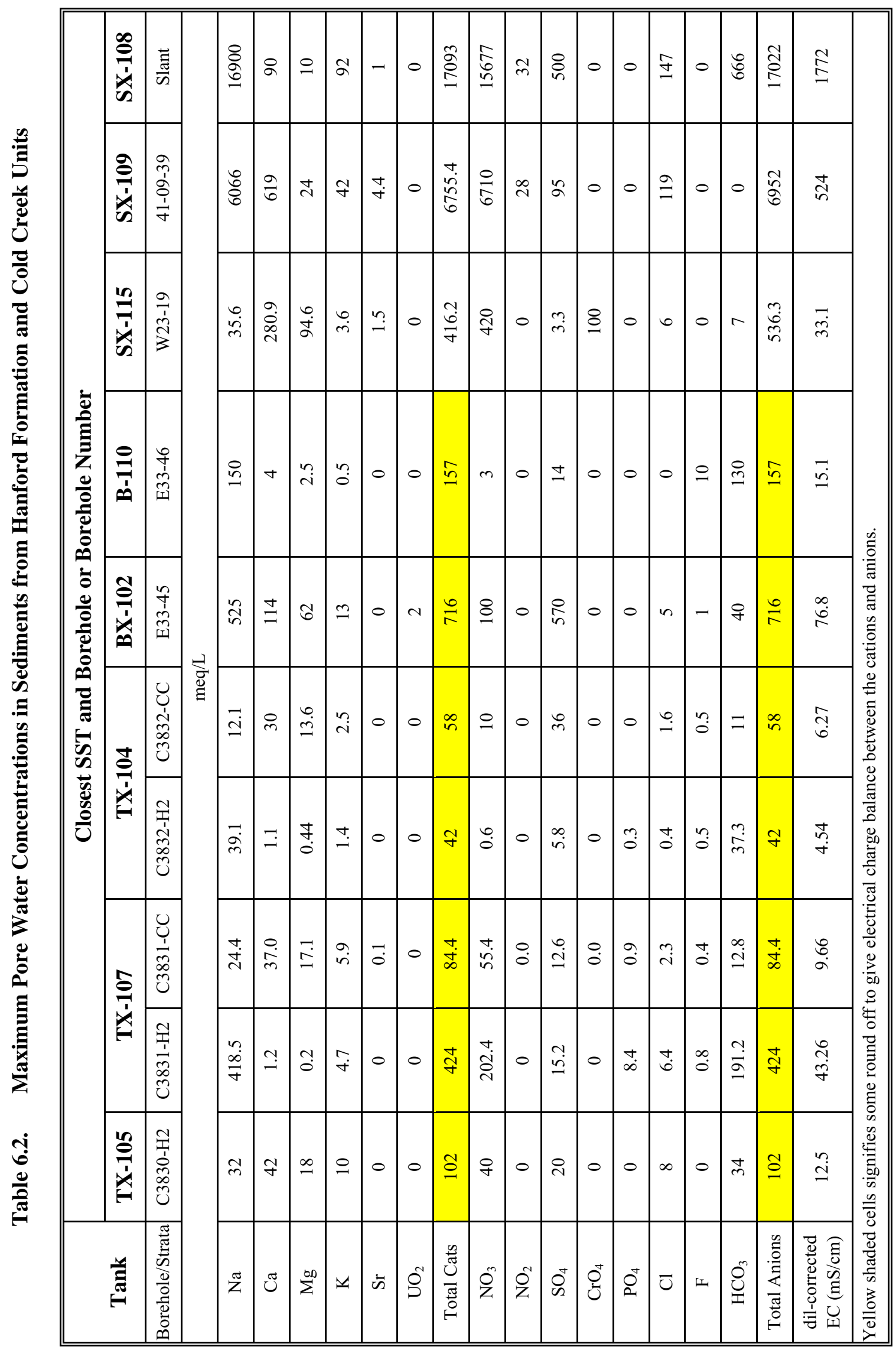


At borehole $\mathrm{C} 3832$, the distribution of the divalent alkaline earth cations (magnesium, calcium, and strontium, but not barium) shows low water-extractable quantities between 63 and $97 \mathrm{ft}$ bgs excepting the sample at $77 \mathrm{ft}$ bgs. High divalent cation water extracts are found below in the Cold Creek unit.

Conversely, the distribution of water-extractable sodium is elevated between the depths of 63 and 77 bgs. The water-extractable sodium values in borehole C3832 sediments are higher than the values in the uncontaminated sediments from borehole 299-W10-27 over the whole borehole profile including the backfill above the tank. These trends suggest that tank fluids that contained sodium did seep into the vadose zone near this borehole. The sodium pushed the natural divalent cations and some of the natural potassium off the sediment cation exchange sites between 63 to at least $76 \mathrm{ft} \mathrm{bgs,} \mathrm{if} \mathrm{not} \mathrm{all} \mathrm{the} \mathrm{way} \mathrm{to} \mathrm{the}$ bottom of the $\mathrm{H} 2$ unit at $102 \mathrm{ft}$ bgs. Right below the leading edge of the sodium plume there are elevated levels of divalent cations that were displaced. We observe the highest levels of water-extractable divalent cations in the $\mathrm{C} 3832$ samples below the Hanford formation $\mathrm{H} 2$ contact with the Cold Creek upper subunit to the bottom of the borehole. At borehole $\mathrm{C} 3832$, the water-extractable magnesium, calcium, strontium, potassium, and sodium concentrations in the sediments in both Cold Creek units (from $105 \mathrm{ft}$ bgs to the bottom of the borehole) are greater than for the background sediment in borehole 299-W10-27 and also borehole $\mathrm{C} 3830$ sediments by a factor of 2 to 5. This likely is an indication that a larger volume of tank fluids passed through the $\mathrm{C} 3832$ sediments to the bottom of the borehole than passed through the vadose zone at borehole 3830. The water-extractable sodium concentrations at borehole C3831 are larger than at C3832 and it is possible that the plume from a leak at tank TX-107 could have been intercepted by both C3831 and C3832 boreholes. The sodium concentrations in borehole C3832 in almost all instances are more dilute down to the bottom of the $\mathrm{H} 2$ unit but are larger in the Cold Creek sediments that lay below. This distribution is compatible with a scenario where the source of the fluid is closer to borehole C3831 and descends with some dilution with existing vadose zone porewater towards borehole C3832. There is such a southwesterly dip to the Cold Creek units and older strata below the TX Tank Farm. 


\subsection{Estimates of Contaminant Inventory and Sorption-Desorption Values}

In this section, we discuss our measurements and data synthesis used to quantify the inventory of key risk contaminants and our estimates of their adsorption-desorption tendencies. We did not perform any site-specific sorption or desorption studies per se because none of the contaminants were present at large enough concentrations to make testing practical. Further, because contaminant levels at TX are much lower than concentrations needed at other tank farms to cause predicted future risk concerns, detailed desorption testing did not appear to be necessary. However, by combining the data from the dilutioncorrected 1:1 water extracts, which represent the porewater, with the concentrations measured on the sediment, we can estimate the desorption $\mathrm{K}_{\mathrm{d}}$ values for contaminants of interest. For a contaminant that has very little water-soluble mass such as cesium-137, the in situ desorption $\mathrm{K}_{\mathrm{d}}$ can be approximated as the mass in the total sample per gram of dry sediment divided by the mass in the porewater per milliliter. For a contaminant that is quite soluble in the water extract (this is approximately equivalent to stating that the contaminant resides mainly in the porewater within the sediment), one needs to subtract the amount that was present in the porewater from the total amount present in the moist sediment sample to obtain a value for the amount that would remain on the solid at equilibrium with the pore fluid.

We will first describe our inventory estimates and then address the mobility status of contaminants presently found in the TX vadose zone sediments. Tables 6.3 through 6.5 provide our best estimate of the inventory of potentially mobile contaminants found in each of the three boreholes. Potential contaminants of concern that have been selected for discussion include technetium-99, uranium, cobalt-60, chromium(VI), and nitrate.

The concentrations of technetium-99 found in the sediment are very close to our detection limit, but the others are present at high enough concentrations that we are comfortable that precise and accurate data were obtained. For the technetium-99 inventory we suggest that the water extract data is most accurate and should be used to estimate technetium-99 inventory versus depth. However, we do present the technetium-99 acid extract data as the worst-case maximum inventory estimate. We assume that all technetium is water soluble in the sediments, as found during our characterization studies at BX and the SX WMAs (Serne et al. 2002b, 2002c, 2002d, and 2002e), and that the acid-extract data are biased high and are generally of suspect quality.

For uranium and chromium, we have found that one must separate the natural background concentrations from Hanford added material in discussing risk potential. The natural uranium and chromium are almost entirely resistant to water leaching and to becoming mobile, whereas the material added by Hanford activities is somewhat mobile. We thus recommend using the water-extractable uranium and chromium data as representative of the concentrations that could enter the water table for future risk calculations. However, we present the acid-extractable chromium and uranium inventories to allow very conservative risk calculations to be performed that assume all acid-extractable masses could ultimately become released to percolating recharge waters. For the cobalt- 60 , we present the total activity present in the sediments.

For nitrate, as for technetium-99, we assume that the water extract concentrations represent the total inventory. We have no other method to measure nitrate besides the water extract method. We use $8 \mathrm{M}$ nitric acid as our technique to measure the total amount of a constituent that is acid leachable. Thus, the nitric acid leachant overwhelms any nitrate present in the sediment. We have also designated in the 
tables, using yellow shading, samples that may contain Hanford-related wastes as opposed to samples that are likely uncontaminated natural sediments.

Semi-quantitative estimates of desorption $\mathrm{K}_{\mathrm{d}}$ values for the potential contaminants identified in Tables 6.3 through 6.5 can be calculated using the inventory estimates (mass or activity per gram of sediment) divided by the estimated porewater concentration of the constituent. These values are found in Tables 4.30, 4.45, 4.60 (acid extract) and 4.27, 4.42, and 4.57 (porewaters), respectively. Table 6.6 shows the estimated desorption $\mathrm{K}_{\mathrm{d}}$ values for the sediment cores obtained from each of the three boreholes. In Table 6.6, the depths where the bulk of the contamination is present are highlighted in red (bold) type and the desorption $\mathrm{K}_{\mathrm{d}}$ values that suggest contamination being present at even very low concentrations are highlighted in yellow (darker) shading. The faint blue (lighter) shading in Table 6.6 designates data that are more dominated by natural constituents or impacted by low precision analytical values. From the table one can see two trends. First where there are significant concentrations of contaminants in the sediments (between 67 to 87, 61 to 70, and 61 to $110 \mathrm{ft}$ bgs, at C3830, 3831, 3832, respectively), the $\mathrm{K}_{\mathrm{d}}$ values for uranium, chromium, and technetium-99 are smaller than their values at shallower and deeper depths. This is caused both by there being more saline porewaters (competing ions) and higher contributions of waste species for chromium and uranium being present, which are generally more water leachable than naturally present species. The changes in $K_{d}$ values for technetium- 99 outside the zone of significant contamination are likely more a function of imprecision in the acid versus water extract analytical results. The other trend is that the desorption $K_{d}$ values for technetium- 99 in the main portion of the vadose zone plumes is very close to $0 \mathrm{~mL} / \mathrm{g}$, while the desorption $\mathrm{K}_{\mathrm{d}}$ value for uranium and chromium in the main portion of the plumes vary between 0 to $2 \mathrm{~mL} / \mathrm{g}$, and 7 to $70 \mathrm{~mL} / \mathrm{g}$. 


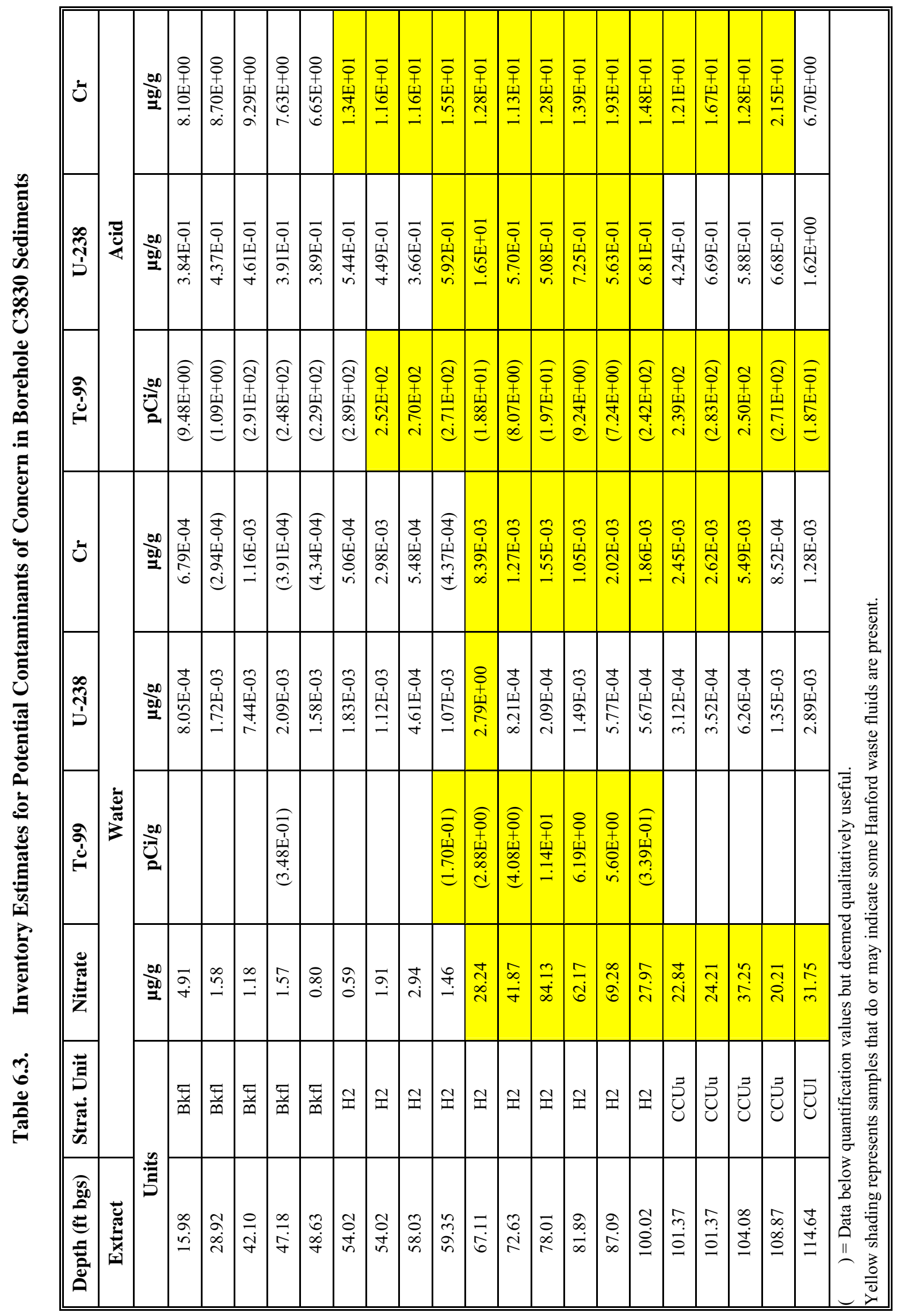


Table 6.4. Inventory Estimates for Potential Contaminants of Concern in Borehole C3831 Sediments

\begin{tabular}{|c|c|c|c|c|c|c|c|c|c|}
\hline $\begin{array}{c}\text { Depth } \\
\text { (ft bgs) }\end{array}$ & $\begin{array}{c}\text { Strat. } \\
\text { Unit }\end{array}$ & Nitrate & Tc-99 & U-238 & $\mathrm{Cr}$ & Tc-99 & U-238 & $\mathrm{Cr}$ & Co-60 \\
\hline \multicolumn{2}{|l|}{ Extract } & \multicolumn{4}{|c|}{ Water } & \multicolumn{3}{|c|}{ Acid } & Direct \\
\hline \multicolumn{2}{|c|}{ Units } & $\mu \mathrm{g} / \mathrm{g}$ & $\mathrm{pCi} / \mathrm{g}$ & $\mu \mathrm{g} / \mathrm{g}$ & $\mu \mathrm{g} / \mathrm{g}$ & $\mathrm{pCi} / \mathrm{g}$ & $\mu \mathrm{g} / \mathrm{g}$ & $\mu g / g$ & $\mathrm{pCi} / \mathrm{g}$ \\
\hline 15.97 & Bkfl & 1.7 & & $2.44 \mathrm{E}-03$ & $3.32 \mathrm{E}-04$ & & $5.18 \mathrm{E}-01$ & $9.47 \mathrm{E}+00$ & $<0.107$ \\
\hline 21.93 & Bkfl & 3.27 & & $1.35 \mathrm{E}-03$ & $4.47 \mathrm{E}-04$ & & $4.58 \mathrm{E}-01$ & $1.05 \mathrm{E}+02$ & $<0.089$ \\
\hline 28.90 & Bkfl & 2.31 & & $3.84 \mathrm{E}-03$ & 8.37E-04 & & $5.10 \mathrm{E}-01$ & $8.37 \mathrm{E}+00$ & $<0.134$ \\
\hline 46.06 & Bkfl & 3.35 & & $4.14 \mathrm{E}-03$ & $7.08 \mathrm{E}-03$ & & $5.06 \mathrm{E}-01$ & $6.51 \mathrm{E}+00$ & $<0.105$ \\
\hline 52.03 & Bkfl & 1.95 & & $2.87 \mathrm{E}-03$ & $5.09 \mathrm{E}-04$ & & $6.66 \mathrm{E}-01$ & $1.63 \mathrm{E}+01$ & $<0.107$ \\
\hline 53.18 & $\mathrm{H} 2$ & 55.44 & $2.94 \mathrm{E}+00$ & $9.46 \mathrm{E}-04$ & $2.80 \mathrm{E}-03$ & $(2.43 \mathrm{E}+01)$ & 5.94E-01 & $1.11 \mathrm{E}+01$ & 1.521 \\
\hline 59.94 & $\mathrm{H} 2$ & 667.32 & 7.99E +01 & $3.05 \mathrm{E}-03$ & $1.85 \mathrm{E}-02$ & $1.94 \mathrm{E}+02$ & $4.58 \mathrm{E}-01$ & $1.22 \mathrm{E}+01$ & 40.120 \\
\hline 61.15 & $\mathrm{H} 2$ & 560.84 & $1.37 \mathrm{E}+02$ & $4.02 \mathrm{E}-02$ & 7.23E-02 & $1.94 \mathrm{E}+02$ & $5.47 \mathrm{E}-01$ & $1.08 \mathrm{E}+01$ & 26.713 \\
\hline 67.53 & $\mathrm{H} 2$ & 72.93 & $1.58 \mathrm{E}+01$ & $3.07 \mathrm{E}-02$ & $6.50 \mathrm{E}-02$ & $(3.68 \mathrm{E}+01)$ & $6.37 \mathrm{E}-01$ & $1.24 \mathrm{E}+01$ & 28.124 \\
\hline 67.53 & $\mathrm{H} 2$ & 87.67 & $1.81 \mathrm{E}+01$ & $1.62 \mathrm{E}-02$ & $5.67 \mathrm{E}-02$ & $(4.15 \mathrm{E}+01)$ & $6.50 \mathrm{E}-01$ & $1.74 \mathrm{E}+01$ & 20.230 \\
\hline 68.21 & $\mathrm{H} 2$ & 91.28 & $8.39 \mathrm{E}+00$ & $5.90 \mathrm{E}-02$ & $6.80 \mathrm{E}-02$ & $(6.23 \mathrm{E}+01)$ & $8.54 \mathrm{E}-01$ & $1.36 \mathrm{E}+01$ & 38.557 \\
\hline 69.60 & $\mathrm{H} 2$ & 60.53 & $1.08 \mathrm{E}+01$ & $2.31 \mathrm{E}-02$ & $5.37 \mathrm{E}-02$ & $(5.44 \mathrm{E}+01)$ & $6.76 \mathrm{E}-01$ & $1.23 \mathrm{E}+01$ & 50.877 \\
\hline 74.99 & $\mathrm{H} 2$ & 350.18 & $5.52 \mathrm{E}+01$ & $1.71 \mathrm{E}-03$ & $4.47 \mathrm{E}-03$ & $(7.02 \mathrm{E}+01)$ & $6.60 \mathrm{E}-01$ & $1.47 \mathrm{E}+01$ & 7.337 \\
\hline 77.67 & $\mathrm{H} 2$ & 154.81 & $1.98 \mathrm{E}+01$ & $6.62 \mathrm{E}-04$ & $1.36 \mathrm{E}-03$ & $(3.98 \mathrm{E}+01)$ & $6.13 \mathrm{E}-01$ & $1.56 \mathrm{E}+01$ & 3.693 \\
\hline 78.72 & $\mathrm{H} 2$ & 287.03 & $4.05 \mathrm{E}+01$ & $1.15 \mathrm{E}-03$ & $2.20 \mathrm{E}-03$ & $(7.76 \mathrm{E}+01)$ & $6.34 \mathrm{E}-01$ & $1.18 \mathrm{E}+01$ & 2.068 \\
\hline 85.99 & $\mathrm{H} 2$ & 846.66 & $6.61 \mathrm{E}+01$ & $1.93 \mathrm{E}-03$ & $2.22 \mathrm{E}-03$ & $1.99 \mathrm{E}+02$ & $6.03 \mathrm{E}-01$ & $1.33 \mathrm{E}+01$ & 3.647 \\
\hline 89.39 & $\mathrm{H} 2$ & 98 & $1.68 \mathrm{E}+01$ & 7.29E-04 & $9.53 \mathrm{E}-04$ & $(3.16 \mathrm{E}+01)$ & $4.90 \mathrm{E}-01$ & $1.34 \mathrm{E}+01$ & 0.452 \\
\hline 93.99 & $\mathrm{H} 2$ & 252.96 & $5.46 \mathrm{E}+01$ & 8.67E-04 & $2.49 \mathrm{E}-03$ & $9.03 \mathrm{E}+01$ & $5.50 \mathrm{E}-01$ & $1.23 \mathrm{E}+01$ & 2.708 \\
\hline 98.07 & $\mathrm{H} 2$ & 202.78 & $2.88 \mathrm{E}+01$ & $1.23 \mathrm{E}-03$ & $2.68 \mathrm{E}-03$ & $(6.40 \mathrm{E}+01)$ & $5.97 \mathrm{E}-01$ & $1.31 \mathrm{E}+01$ & 1.005 \\
\hline 101.29 & $\mathrm{H} 2$ & 127.18 & $1.76 \mathrm{E}+01$ & 7.65E-04 & $1.99 \mathrm{E}-03$ & $(2.66 \mathrm{E}+01)$ & $5.55 \mathrm{E}-01$ & $1.08 \mathrm{E}+01$ & 1.408 \\
\hline 102.65 & $\mathrm{CCU}_{\mathrm{u}}$ & 222.42 & $3.23 \mathrm{E}+01$ & $1.28 \mathrm{E}-03$ & $2.41 \mathrm{E}-03$ & $(4.71 \mathrm{E}+01)$ & $6.28 \mathrm{E}-01$ & $1.04 \mathrm{E}+01$ & 0.582 \\
\hline 114.44 & $\mathrm{CCU}_{1}$ & 175.96 & $3.49 \mathrm{E}+01$ & 2.03E-03 & $1.21 \mathrm{E}-03$ & $(5.66 \mathrm{E}+01)$ & $1.22 \mathrm{E}+00$ & $6.33 \mathrm{E}+00$ & 0.694 \\
\hline 114.44 & $\mathrm{CCU}_{1}$ & 169.8 & $3.30 \mathrm{E}+01$ & $1.99 \mathrm{E}-03$ & $1.23 \mathrm{E}-03$ & $(4.59 \mathrm{E}+01)$ & $8.12 \mathrm{E}-01$ & $1.08 \mathrm{E}+01$ & 0.579 \\
\hline 115.06 & $\mathrm{CCU}_{1}$ & 204.28 & $3.81 \mathrm{E}+01$ & $2.07 \mathrm{E}-03$ & $1.41 \mathrm{E}-03$ & $(4.76 \mathrm{E}+01)$ & $8.46 \mathrm{E}-01$ & $6.88 \mathrm{E}+00$ & 0.570 \\
\hline
\end{tabular}


Table 6.5. Inventory Estimates for Potential Contaminants of Concern in Borehole C3832 Sediments

\begin{tabular}{|c|c|c|c|c|c|c|c|c|}
\hline $\begin{array}{c}\text { Depth } \\
\text { (ft bgs) }\end{array}$ & $\begin{array}{c}\text { Strat. } \\
\text { Unit }\end{array}$ & Nitrate & Tc-99 & U-238 & $\mathrm{Cr}$ & Tc-99 & U-238 & $\mathrm{Cr}$ \\
\hline \multicolumn{3}{|l|}{ Extract } & \multicolumn{3}{|l|}{ Water } & \multicolumn{3}{|c|}{ Acid } \\
\hline Units & & $\mu \mathrm{g} / \mathrm{g}$ & $\mathrm{pCi} / \mathrm{g}$ & $\mu g / g$ & $\mu \mathrm{g} / \mathrm{g}$ & $\mathrm{pCi} / \mathrm{g}$ & $\mu \mathrm{g} / \mathrm{g}$ & $\mu g / g$ \\
\hline 17.26 & backfill & 0.43 & & $1.70 \mathrm{E}-03$ & $(1.29 \mathrm{E}-04)$ & $(3.83 \mathrm{E}+01)$ & $3.97 \mathrm{E}-01$ & $1.69 \mathrm{E}+01$ \\
\hline 29.14 & backfill & 1.02 & & $9.88 \mathrm{E}-04$ & $(1.45 \mathrm{E}-04)$ & $(3.33 \mathrm{E}+01)$ & $4.20 \mathrm{E}-01$ & $1.30 \mathrm{E}+01$ \\
\hline 37.14 & backfill & 1.63 & & $2.24 \mathrm{E}-03$ & $5.15 \mathrm{E}-04$ & $(1.98 \mathrm{E}+01)$ & $3.84 \mathrm{E}-01$ & $1.15 \mathrm{E}+01$ \\
\hline 45.19 & backfill & 3.2 & & $4.81 \mathrm{E}-03$ & (4.98E-04) & $(1.31 \mathrm{E}+01)$ & 4.72E-01 & $1.11 \mathrm{E}+01$ \\
\hline 52.01 & $\mathrm{H} 2$ & 1.28 & & $8.77 \mathrm{E}-04$ & $(3.58 \mathrm{E}-04)$ & $(1.85 \mathrm{E}+01)$ & $5.54 \mathrm{E}-01$ & $1.51 \mathrm{E}+01$ \\
\hline 54.10 & $\mathrm{H} 2$ & 3.13 & & $4.44 \mathrm{E}-03$ & $(4.27 \mathrm{E}-04)$ & $(1.47 \mathrm{E}+01)$ & $7.05 \mathrm{E}-01$ & $1.67 \mathrm{E}+01$ \\
\hline 61.17 & $\mathrm{H} 2$ & 2.33 & & $1.72 \mathrm{E}-02$ & (4.93E-04) & $(1.21 \mathrm{E}+01)$ & $1.02 \mathrm{E}+00$ & $1.51 \mathrm{E}+01$ \\
\hline 62.96 & $\mathrm{H} 2$ & 1.85 & & $1.46 \mathrm{E}-01$ & $5.48 \mathrm{E}-04$ & $(1.47 \mathrm{E}+01)$ & $2.85 \mathrm{E}+00$ & $1.31 \mathrm{E}+01$ \\
\hline 69.99 & $\mathrm{H} 2$ & 2.62 & $(1.87 \mathrm{E}-01)$ & $1.81 \mathrm{E}+00$ & $1.36 \mathrm{E}-03$ & $(1.28 \mathrm{E}+01)$ & $1.46 \mathrm{E}+01$ & $2.22 \mathrm{E}+01$ \\
\hline 76.34 & $\mathrm{H} 2$ & 14.6 & $2.35 \mathrm{E}+00$ & $2.82 \mathrm{E}-01$ & $1.21 \mathrm{E}-03$ & $(3.11 \mathrm{E}+01)$ & $5.82 \mathrm{E}+00$ & $3.10 \mathrm{E}+01$ \\
\hline 76.34 & $\mathrm{H} 2$ & 21.08 & $2.29 \mathrm{E}+00$ & $1.32 \mathrm{E}-01$ & 7.49E-04 & $(2.19 \mathrm{E}+01)$ & $8.55 \mathrm{E}+00$ & $2.00 \mathrm{E}+01$ \\
\hline 77.04 & $\mathrm{H} 2$ & 79.04 & $7.16 \mathrm{E}+00$ & $1.26 \mathrm{E}+00$ & $9.66 \mathrm{E}-03$ & $(3.34 \mathrm{E}+01)$ & $1.22 \mathrm{E}+01$ & $1.39 \mathrm{E}+01$ \\
\hline 79.81 & $\mathrm{H} 2$ & 19.42 & $2.34 \mathrm{E}+00$ & $1.26 \mathrm{E}+00$ & $1.79 \mathrm{E}-02$ & $(1.94 \mathrm{E}+01)$ & $6.94 \mathrm{E}+00$ & $1.32 \mathrm{E}+01$ \\
\hline 84.01 & $\mathrm{H} 2$ & 25.12 & $1.76 \mathrm{E}+00$ & $5.57 \mathrm{E}-01$ & $2.85 \mathrm{E}-02$ & $(2.04 \mathrm{E}+01)$ & $1.09 \mathrm{E}+01$ & $1.81 \mathrm{E}+01$ \\
\hline 88.06 & $\mathrm{H} 2$ & 11.39 & $1.80 \mathrm{E}+00$ & $4.71 \mathrm{E}-01$ & $1.50 \mathrm{E}-03$ & $(1.21 \mathrm{E}+01)$ & $4.29 \mathrm{E}+00$ & $1.57 \mathrm{E}+01$ \\
\hline 94.05 & $\mathrm{H} 2$ & 3.93 & $(5.22 \mathrm{E}-01)$ & $5.90 \mathrm{E}-01$ & $3.95 \mathrm{E}-03$ & $(1.03 \mathrm{E}+01)$ & $2.39 \mathrm{E}+00$ & $1.64 \mathrm{E}+01$ \\
\hline 96.69 & $\mathrm{H} 2$ & 13.25 & $1.46 \mathrm{E}+00$ & $1.06 \mathrm{E}+00$ & $2.81 \mathrm{E}-03$ & $(1.32 \mathrm{E}+01)$ & $6.02 \mathrm{E}+00$ & $1.69 \mathrm{E}+01$ \\
\hline 105.01 & $\mathrm{CCUu}$ & 57.27 & $6.51 \mathrm{E}+00$ & $2.65 \mathrm{E}+00$ & $1.90 \mathrm{E}-03$ & $(1.63 \mathrm{E}+01)$ & $2.73 \mathrm{E}+01$ & $2.35 \mathrm{E}+01$ \\
\hline 110.28 & \multirow{2}{*}{$\mathrm{CCU}_{\mathrm{u}}$} & 72.48 & $1.08 \mathrm{E}+01$ & $2.60 \mathrm{E}+00$ & $9.10 \mathrm{E}-04$ & $(2.57 \mathrm{E}+01)$ & $3.07 \mathrm{E}+01$ & $2.06 \mathrm{E}+01$ \\
\hline 110.28 & & 97.36 & $1.18 \mathrm{E}+01$ & $2.61 \mathrm{E}+00$ & $1.03 \mathrm{E}-03$ & $(3.25 \mathrm{E}+01)$ & $3.05 \mathrm{E}+01$ & $3.18 \mathrm{E}+01$ \\
\hline 111.02 & $\mathrm{CCU}_{1}$ & 84.18 & $5.11 \mathrm{E}+00$ & 4.82E-03 & $9.28 \mathrm{E}-04$ & $(2.92 \mathrm{E}+01)$ & $1.40 \mathrm{E}+01$ & $1.09 \mathrm{E}+01$ \\
\hline 114.85 & $\mathrm{CCU}_{1}$ & 58.84 & $1.07 \mathrm{E}+01$ & $3.15 \mathrm{E}-03$ & $1.92 \mathrm{E}-03$ & $(3.39 \mathrm{E}+01)$ & $1.40 \mathrm{E}+01$ & $8.82 \mathrm{E}+00$ \\
\hline 115.54 & $\mathrm{CCU}_{1}$ & 48.09 & $2.50 \mathrm{E}+00$ & $1.18 \mathrm{E}-01$ & $9.11 \mathrm{E}-04$ & $(4.27 \mathrm{E}+01)$ & $1.90 \mathrm{E}+01$ & $3.18 \mathrm{E}+01$ \\
\hline
\end{tabular}




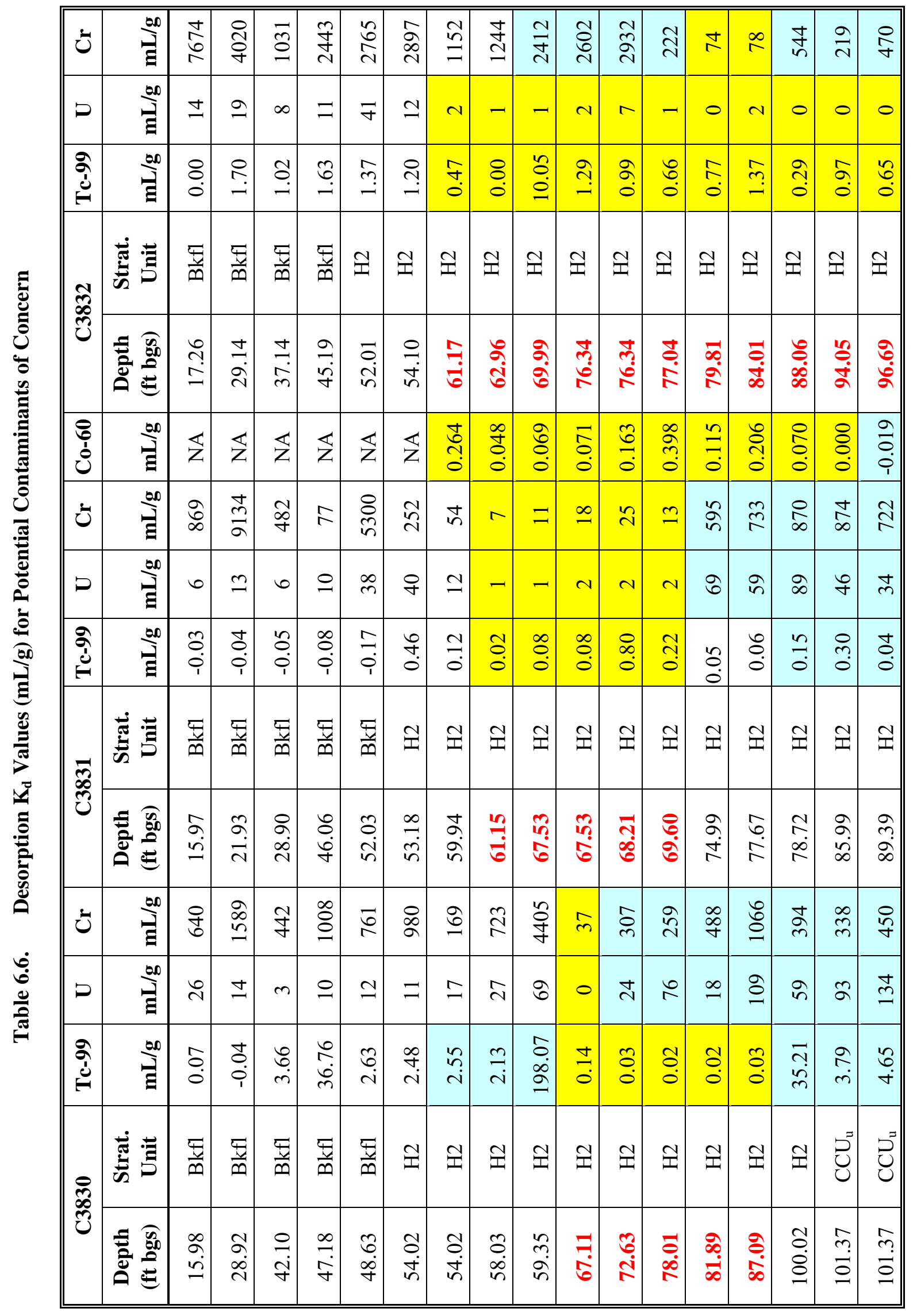




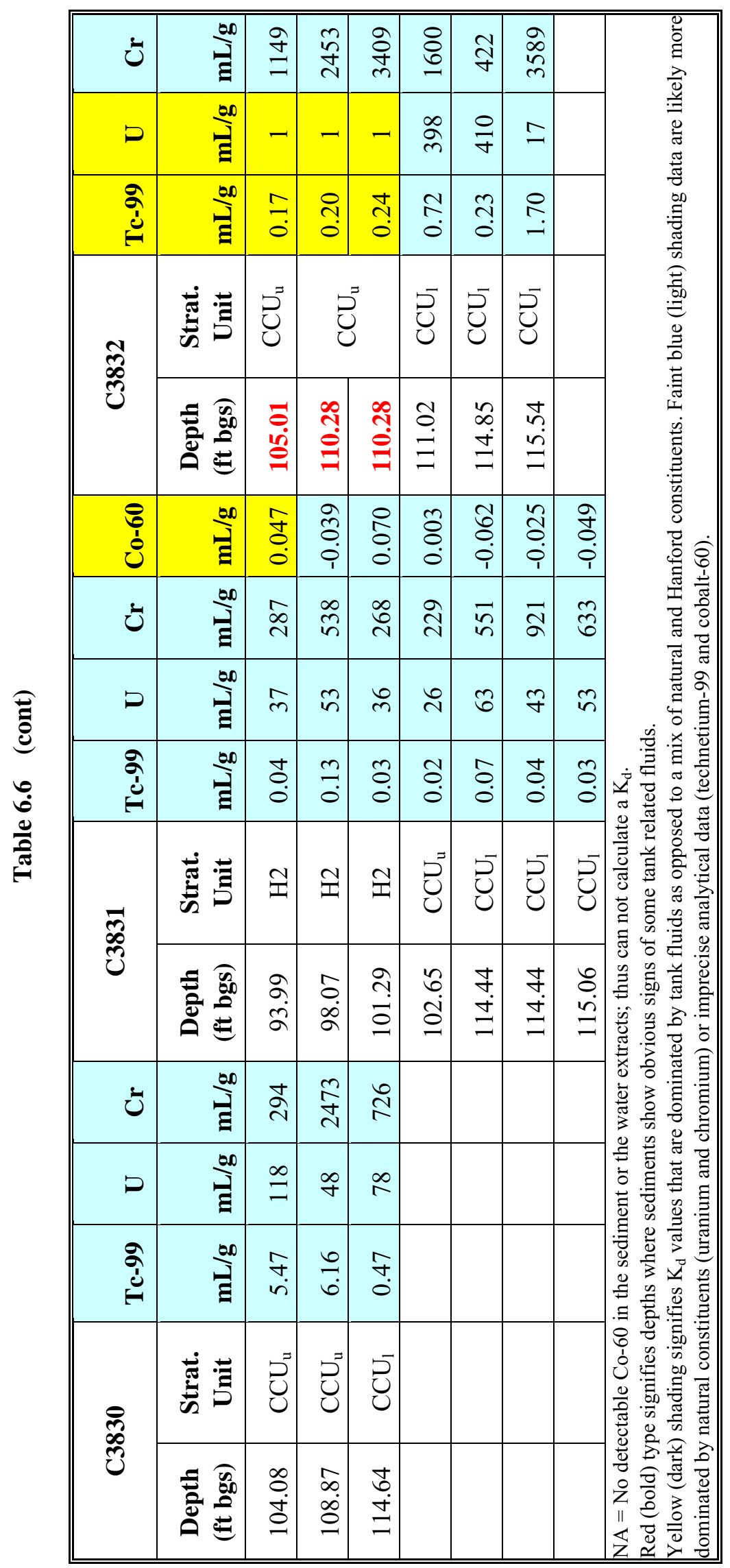


In borehole $\mathrm{C} 3831$ where cobalt- 60 was present, the desorption $\mathrm{K}_{\mathrm{d}}$ values, as determined by direct gamma energy analysis from the direct counting of the moist sediment and water extracts, are fairly low $(0.00$ to $0.4 \mathrm{~mL} / \mathrm{g})$. Thus, cobalt-60 in these vadose zone sediments would be considered quite mobile. The in situ desorption $K_{d}$ results suggest that of the potential contaminants, technetium- 99 is the most mobile, with cobalt-60 slightly less mobile or of equal mobility to technetium-99. Uranium is considerably less mobile, and chromium the least mobile.

For conservative modeling purposes we recommend using $\mathrm{K}_{\mathrm{d}}$ values of $0 \mathrm{~mL} / \mathrm{g}$ for nitrate and technetium-99, a value of $0.05 \mathrm{~mL} / \mathrm{g}$ for cobalt- 60 , a value of $1 \mathrm{~mL} / \mathrm{g}$ for uranium, and $10 \mathrm{~mL} / \mathrm{g}$ for chromium to represent the entire vadose zone profile from the bottoms of the tanks to the water table. The technetium in situ desorption $\mathrm{K}_{\mathrm{d}}$ value of zero is consistent with a wealth of literature that finds essentially no technetium adsorption onto Hanford Site sediment (Kaplan and Serne 1995; Kaplan and Serne 2000). The cobalt-60 results suggest that some complex that perhaps has a net negative charge is altering the cobalt's inherent cationic nature. Cobalt-60 has been found in the Hanford groundwater at several places, especially in the 1950 s, and can still be measured in a few locations, most notably in the northern 200 East Area.

\subsection{Other Geochemical Characterization Observations}

The comparison of the percentage of a constituent that is water extractable versus acid extractable from the contaminated sediment and the total mass that is acid leachable can be used to infer contamination for Hanford tank constituents such as sodium, sulfate, uranium, chromium, and other trace metals that occur naturally in the environment.

For borehole C3830, the acid extract data suggest that variations in mass leached per gram of sediment versus depth are lithology-related more so than an indication of tank fluid contamination. That is, for most constituents there are no signs of elevated values of acid-leachable constituents in borehole C3830 sediments, excepting acid-extractable sulfur (assumed to represent sulfate) and technetium-99. The acid-extractable sulfate profile in borehole C3830 sediments averages about 4 to 7 times higher than in comparable uncontaminated sediments from borehole 299-W10-27. The acid-extractable technetium-99 profile in the $\mathrm{C} 3830$ borehole sediments is elevated from $42 \mathrm{ft}$ bgs to $109 \mathrm{ft}$ bgs by a factor of 4 over the distribution of acid-extractable technetium-99 in the background sediment, which was a measure of our detection limit. The deepest sample obtained in borehole C3830 within the Cold Creek caliche does not have this slightly elevated acid-extractable technetium-99, suggesting that the bulk of the technetium-99 vadose zone plume has not migrated to the bottom of the borehole.

The only other indication of tank contamination at borehole C3830 is the high water- and acid-extractable uranium value for the sample at $67.11 \mathrm{ft}$ bgs. As mentioned in Sections 4.2.4, 4.3.4, and 4.4.4, contaminated sediments generally exhibit high ratios for water- to acid-extractable constituents when compared to uncontaminated sediment ratios. The percentage of the acid-extractable uranium that is also water extractable for the sample at $67.11 \mathrm{ft}$ bgs is $17 \%$ while all other uranium water extracts for sediments below the tank, leached less than $0.5 \%$ of the acid-extractable uranium. The water-extractable sodium percentage for the sample at $67.11 \mathrm{ft} \mathrm{bgs}$ is also $17 \%$ of the sodium that is acid extractable, which also is slightly higher than for uncontaminated sediments.

Comparing the acid extract data for borehole C3831 with similar lithologies in the uncontaminated borehole, 299-W10-27, suggest most of the variation in mass leached per gram of sediment versus depth 
is lithology related. Again, for most constituents there are no signs of elevated values of acid-leachable constituents in borehole C3831 sediments excepting acid-extractable sulfur (assumed to represent sulfate), sodium (between the depths of 61 and $67.5 \mathrm{ft} \mathrm{bgs),} \mathrm{molybdenum} \mathrm{(between} 67.5$ and $70 \mathrm{ft}$ bgs), and ruthenium and technetium-99 throughout most of the profile. The acid-extractable sulfate profile in borehole $\mathrm{C} 3831$ sediments averages about 4 to 7 times higher than in comparable uncontaminated sediments from borehole 299-W10-27. The acid-extractable sulfur (measured as sulfate) for boreholes C3830 and C3831 are similar. Borehole C3831 shows high acid-leachable technetium-99 and ruthenium throughout the profile and larger acid-extractable sodium and molybdenum in thin zones between 67.5 and 70 and 61 to $67.5 \mathrm{ft}$ bgs, respectively, than borehole C3830. The comparison of water to acid extracts for borehole C3831 sediments suggests that there are unnaturally high percentages of water-leachable uranium, chromium, and molybdenum between the depths of 61 and $70 \mathrm{ft}$ bgs. The water- to acidextractable sodium percentage is unnaturally high between the depths of 53 and $86 \mathrm{ft}$ bgs, suggesting sodium-enriched fluids or readily acid-soluble solids reside in the pores of the vadose zone sediments in this zone. The presence of elevated water and acid-extractable quantities of technetium- 99 and ruthenium between $60 \mathrm{ft}$ bgs and the bottom of the borehole at $115 \mathrm{ft}$ bgs suggests the presence of Hanford waste fluids in the vadose zone at these depths in borehole C3831. Thus the leading edge of contamination extends beyond the bottom of the borehole.

Acid-extractable technetium-99 in borehole C3832 also appears to be slightly above the background sediments but is the same as in borehole C3831 and somewhat lower than acid-extractable technetium-99 in borehole $\mathrm{C} 3830$. The comparison of water to acid extracts for borehole C3832 sediments suggests that there are unnaturally high percentages of water-leachable technetium-99 and uranium-238 between 76 and 115 , and 61 to $110.3 \mathrm{ft} \mathrm{bgs}$, respectively. There is also slightly high water-extractable sodium between 63 and $77 \mathrm{ft}$ bgs. The total mass of tank fluids that are present in borehole C3832 sediments and the percentages that are water leachable versus the concentrations that are acid leachable are lower for most constituents than at borehole C3831.

The two data sets suggest that the tank-related fluids in borehole C3832 may, in fact, be the leading edge of fluids that leaked from tank TX-107, which were first intercepted by borehole C3831. If so, then it also appears that the vadose zone plume dips to the southwest between boreholes C3831 and 3832, which is supported by discussions in Section 2.0. However, the uranium water and acid extract data for sediments at boreholes C3831 and C3832 do not fit our hypothesis that a plume of saline fluids has leaked from tank TX-107 and migrated and descended to deeper depths to the southwest. Unlike many other constituents, the uranium data for borehole C3831 sediments (closer to TX-107) show significantly lower water- and acid-leachable uranium than the sediments from C3832 (farther from TX-107 and down dip). Unless a mechanism can be hypothesized that allows uranium to leak from tank TX-107, without showing significant interactions with the sediments until migrating to the southwest where it is captured by the C3832 borehole, the uranium data suggest separate sources of contamination with different leak events. There are greater acid-extractable concentrations of uranium at borehole $\mathrm{C} 3832 \mathrm{from} 61.2 \mathrm{ft}$ bgs all the way to the bottom of the borehole than at either of the other two boreholes, C3830 and C3831. Acidextractable uranium concentrations vary from 1 to $30 \mathrm{ug} / \mathrm{g}$ over this interval and are significantly greater than values in borehole $\mathrm{C} 3831$.

As part of our characterization strategy for contaminated sediments, other parameters that can control contaminant migration were measured. For the TX tank farm characterization only calcium carbonate content was measured. Particle size measurements were performed only on uncontaminated sediment from selected samples from borehole 299-W10-27; however, photographs in Appendix A and the field 
moisture log, blow counts, and laboratory moisture contents identify that several fine-grained thin lenses are present within the Hanford formation $\mathrm{H} 2$ unit that can promote lateral spreading of leaked fluids. The upper and lower portions of the Cold Creek unit also contain a high percentage of fines that can lead to perching conditions and/or lateral spreading of percolating fluids.

There are highly calcareous zones associated with the lower Cold Creek subunit in each of the three boreholes and the background borehole at depths that range from 98 to 112,111 to the bottom of the borehole, 106 to the bottom of the borehole, and 110.4 to the bottom of the borings at 299-W10-27, C3830, C3831, and C3832, respectively. The caliche at borehole C3832 has the most calcium-carbonate equivalent solid of the three boreholes and the uncontaminated background sediment from 299-W10-27, based on available samples. The calcium-carbonate content in the Cold Creek lower subunit ranges from 20 to $34 \%$ at borehole $\mathrm{C} 3830,22 \%$ at $299-\mathrm{W} 10-27$, and $38 \%$ at borehole C3831, to 38 to $46 \%$ at borehole C3832. As found in most vadose sediments from the Hanford Reservation, there is very little $(<0.1 \%$ by weight) organic carbon in the vadose zone sediments. The borehole C3831 backfill sample at $46.1 \mathrm{ft}$ bgs appears to have elevated inorganic carbon ( $10.3 \mathrm{wt} \%$ as calcium carbonate) and some $(0.4 \mathrm{wt} \%)$ organic carbon. Aside from this backfill sample, carbon values for total, inorganic, and organic carbon are low and quite similar in the backfill and Hanford formation sediments from C3830, C3831, and C3832.

The matric potential data from a portion of the vadose zone profile at 299-W10-27 (zone where cores were collected were entirely within the Hanford formation $\mathrm{H} 2$ unit) show water potentials are generally much less than the gravity potential. The last sample taken at $123.5 \mathrm{ft}$ bgs appears to have a matric potential larger than the theoretical line, which represents the profile for matric potential in a sediment profile that is neither draining nor drier than (actively evapotranspiring) equilibrium. Matric potential values less than the gravity unit gradient suggest a draining profile. The water potential data from 299-W10-27's H2 unit, the unit where most of the contaminants reside in the TX boreholes, are consistent with a draining profile.

\subsection{Description of TX-TY Upper Unconfined Aquifer}

The suprabasalt aquifer is separated into the uppermost unconfined aquifer and the underlying Ringold Formation confined aquifer beneath WMA TX-TY by the silt and clay deposits of the Ringold Formation lower mud unit. Currently, the unconfined aquifer is about $55 \mathrm{~m}$ thick at well 299-W14-14, east of WMA TX-TY. The unconfined aquifer consists of sandy gravels and gravelly sands of the Ringold Formation member of Wooded Island unit E. Water levels beneath WMA TX-TY were raised as much as $13.5 \mathrm{~m}$ above the pre-Hanford natural water table because of artificial recharge from liquid waste disposal operations active since the mid-1940s. The largest volumes of discharge were to the 216-T pond system and the 216-U-10 pond. The increase in water-table elevation was most rapid from 1949 to 1956 and was somewhat stabilized between the late 1960s and the late 1980s. Water levels began to decline in the late 1980s.

Accompanying the changes in water level were changes in groundwater flow direction. Pre-Hanford Site groundwater flow direction was toward the east; it changed toward the south in the late 1940s and early 1950s. This shift resulted from disposal of large volumes of liquid to the 216-T pond. Around 1956, groundwater flow direction changed again and started flowing towards the north due to the increasing influence of the groundwater mound under 216-U pond. Discharges to 216-T pond ended in 1976 but continued at 216-U pond until 1984. Consequently, the flow direction changed again around 1996 when all discharges to the ground ceased and the influence of the $216-\mathrm{U}$ pond mound on the 
groundwater beneath the TX and TY tank farms diminished. Around 1996, the groundwater flow direction began to return toward the east or southeast. Today, groundwater contamination beneath the WMA and surrounding area is generally migrating easterly. Hydrologic data show that the groundwater flow direction becomes increasingly more southerly toward the south of WMA TX-TY. Groundwater beneath this part of the WMA is influenced by the extraction wells of the 200-ZP-1 pump-and-treat system. Extraction wells W15-33, W15-34, and W15-35 for the 200-ZP-1 pump-and-treat operation are $300 \mathrm{~m}$ southwest of WMA TX tank farm fenceline.

Results of the tracer dilution test show downward, vertical hydraulic gradients within the upper portion of the aquifer in wells 299-W10-26, 299-W14-13, and 299-W14-14. These three wells have fairly homogeneous lithology throughout the screened interval and comprehensive drawdown data do not indicate substantial variations in hydraulic conductivity. The existence of vertical flow in a well does not necessarily reflect actual groundwater flow conditions within the surrounding aquifer, but its presence implies a vertical flow gradient within the well screens and has implications pertaining to the representativeness of groundwater samples collected from the wells. The vertical gradient detected in these wells along the eastern edge of the TX and TY tank farms may have an impact on contaminant distribution patterns in the area.

A second finding of the hydrologic test data is the suggestion of higher hydraulic conductivities at certain depths within the screened interval of some wells relative to other depths. Aquifer tests in well 299-W15-41, located just south of the TX tank farm, indicate that the middle and lower parts of the screened interval have higher permeability than the upper part. However, development pumping data (which is not as definitive as aquifer testing) indicates that the upper part of the screened interval in nearby well 299-W15-763 has higher permeability than the lower parts. Thus, apparent differences in hydraulic conductivity do not appear to correlate from well to well. Taken as a whole, the geologist's logs, geophysical logs, development pumping data, and the hydrologic testing data all indicate heterogeneity in aquifer properties within the screened intervals of several individual wells and among wells at WMA TX-TY.

\subsection{Existing Groundwater Contamination}

Groundwater at the TX and TY tank farms contains elevated concentrations of carbon tetrachloride, chromium, iodine-129, nitrate, technetium-99, and tritium. This contamination appears to result from the mixing of wastes from a number of past waste-disposal activities, including the disposal of waste process water, and steam condensate at nearby cribs and trenches, disposal of plutonium processing waste at cribs and trenches associated with the Plutonium Finishing Plant, and leaks from single-shell tanks and transfer lines within the TX and TY tank farms.

Contamination in two areas near the TX and TY tank farms warrants consideration: east and downgradient of 241-TX and 241-TY tank farms, and south of 241- TX tank farm. The contaminants of interest east of WMA TX-TY are technetium-99, iodine-129, nitrate, tritium, chromium, and carbon tetrachloride. The contaminants of interest south of TX tank farm are technetium-99 and carbon tetrachloride. 
The maximum carbon tetrachloride found in the area of WMA TX-TY in 2002 was $5,800 \mu \mathrm{g} / \mathrm{L}$ in well 299-W15-1, south of the TX tank farm. The carbon tetrachloride is believed to be from pre-1973 waste from the Plutonium Finishing Plant. The major identified sources are the 216-Z-9 trench, the 216-Z-1A tile field, and the 216-Z-18 crib.

East of WMA TX-TY, chromium occurs in one downgradient well (299-W14-13) above the drinking water standard. In August 2003, the concentration was $540 \mu \mathrm{g} / \mathrm{L}$. Given the current direction of groundwater flow, one potential source for the chromium is the 241-TY tank farm. However, about 1,060 kilograms of chromium were disposed to the TY cribs located about $65 \mathrm{~m}$ northeast of the well. Since the general dip of the strata in the area is toward the west or southwest, it is possible that contamination from the cribs migrated through the vadose zone toward well 299-W14-13. Further, a tanker truck filling station, located about $140 \mathrm{~m}$ up dip of the TY cribs, was seen leaking onto the ground from the fill spout in the 1990s. Water was seen to pool on the ground and run about $100 \mathrm{~m}$ down slope (toward the TX and TY tank farms) in a ditch along the side of the gravel road. Infiltration of this water could have mobilized contamination in the vadose zone beneath the TY cribs and moved the contamination down dip toward well 299-W14-13. Furthermore, in the 1970s, contamination at the 216-T-28 crib extended from near the surface to the water table and thus breakthrough to groundwater could have occurred at the 216-T-28 crib site. Therefore, we can not currently assign an origin for the elevated chromium in well 299-W14-13 to a particular facility.

Technetium-99 was detected in this downgradient well (299-W14-13) above the drinking water standard. Given the current direction of groundwater flow, one potential source for the technetium-99 is single shell tanks in WMA TX-TY. However, three other sources, 216-T-28 crib, 216-T-19 tile field, and the 242-T evaporator building, also may have contributed some technetium-99 to the groundwater east of WMA TX-TY. Current groundwater plume maps for chromium and technetium-99 show that the contaminant plumes are relatively small and centered near well 299-W14-13. Concentrations of both contaminants drop sharply to the north in well 299-W14-18 and to the south in well 299-W14-15.

Almost all wells in the groundwater monitoring network at WMA TX-TY, including the upgradient wells, have had nitrate concentrations greater than the MCL of $45 \mathrm{mg} / \mathrm{L}$ throughout most of their sampling life. The highest nitrate concentrations $(580 \mathrm{mg} / \mathrm{L})$ have been at well 299-W14-13. This well has had nitrate concentrations greater than those in the regional plume since it was drilled in late 1998. Besides the regional source of nitrate from the Plutonium Finishing Plant and disposal to U Pond, other potential contaminant sources are those mentioned above as potential sources for chromium and technetium-99. Tritium has also been above the drinking water standard in well 299-W14-13. Like nitrate, tritium most likely has several sources that include WMA TX-TY and several cribs and trenches in the area.

South of the TX-TY WMA the key contaminants are technetium-99 and carbon tetrachloride. The groundwater in this area is currently impacted (since June 1998) by the 200-ZP-1 pump-and-treat operation. Technetium-99 concentrations in wells along the southern boundary of WMA TX-TY started to increase about 1 year after Phase II of the 200-ZP-1 pump-and-treat operation began. (Phase II, consisting of three extraction wells, began the use of the closest extraction wells to the WMA, wells 299-W15-34 and 299-W15-35.) Given the southerly groundwater flow direction imposed on the southern portion of the WMA by the pump-and-treat operation, the most reasonable explanation for the increasing technetium-99 is that groundwater contaminated with technetium-99 is being drawn from beneath the WMA into the pump-and-treat system. Alternatively, technetium-99 may be originating from the 
216-T-19 crib and tile field. Given the changing groundwater flow direction along the southern boundary of the WMA, the few available monitoring wells, and the lack in continuity of monitoring data due to dry wells and new wells, it is currently impossible to fully evaluate this problem.

\subsection{Complexities in Groundwater Data (Vertical and Temporal Variations)}

The groundwater data are complicated by signs that vertical stratification in contaminant and common solutes is present in many wells. Significant differences in specific conductance, technetium-99, chromium, nitrate, and tritium with depth were found in some monitoring wells. After purging some TX-TY wells, the pumped samples do not appear to be representative of ambient water because purging the well causes mixing of strata with different contaminant concentrations. Thus, interpreting the contaminant distribution in wells such as the most contaminated well in the WMA (299-W14-13) is very difficult because groundwater at the well contains high concentrations of several contaminants that show different vertical concentration profiles and probably come from several sources in the area.

Well pair 299-W14-12 and 299-W14-13 is at the northeast corner of the TX tank farm on the downgradient side of WMA TX-TY and currently has the highest concentration of technetium-99, tritium, iodine-129, fluoride, nitrate, and chromium of any well in the TX and TY tank farm monitoring network. This and other wells also show a time-varying contaminant distribution over the last 50 years. Technetium-99 in the area of the well pair 299-W14-12/13 began decreasing from a maximum of $\sim 13,500 \mathrm{pCi} / \mathrm{L}$ in 1993 and continued to decrease until about January 1997. At that time, technetium-99 began to increase until early 2000 when technetium-99 concentrations climbed to $\sim 8,000 \mathrm{pCi} / \mathrm{L}$. In early 2000 , technetium-99 began to decrease and dropped to about $3,300 \mathrm{pCi} / \mathrm{L}$ in early 2001 , at which time the concentration began to increase again. The latest increase continued until February 2003 and reached $8,740 \mathrm{pCi} / \mathrm{L}$. The results for nitrate in well pair 299-W14-12/13 show a trend similar to that seen for technetium-99. Nitrate began to decrease from a maximum of about $540,000 \mu \mathrm{g} / \mathrm{L}$ in 1993 to about $200,000 \mu \mathrm{g} / \mathrm{L}$ in early 1997 . Nitrate then began to increase until early 2000 when concentrations reached $\sim 440,000 \mu \mathrm{g} / \mathrm{L}$. Nitrate began to decrease a second time until early 2001 , at which time it began a second increasing trend that lasted through the beginning of 2003. Since that time, the nitrate concentration has decreased somewhat. Analytical results for tritium in well pair 299-W14-12/13 show a different trend in vertical distribution than that seen for technetium-99 and nitrate, but show the same trends with time. The chromium data suggest a different vertical distribution of chromium in the aquifer than the distributions of nitrate, technetium-99, and tritium. The data from the well pair indicate that the concentration of chromium is low at the top of the aquifer and increases at some depth below the water table but, again, the chromium distribution with time tracks the same as technetium, nitrate, and tritium. The similar trends with time suggest that these contaminants are from the same source. If so, they should not be fractionated differently in the aquifer versus depth. Thus, there is some discrepancy among the data as to the interpretation of the vertical distribution data.

Samples collected from several wells during drilling indicate an increase in nitrate concentration with increasing depth in the aquifer. A few wells show a second zone of high nitrate concentration near the water table. The shallow zone of high nitrate is interpreted to be from nearby local sources whereas the deeper, and more widespread, zone of high nitrate represents a regional plume from past practice discharges, probably from the Plutonium Finishing Plant that were disposed of to U pond. Depth distributions of tritium and carbon tetrachloride in well 299-W14-14 showed maximums at about $40 \mathrm{~m}$ 
below the water table, suggesting that significant concentrations of these contaminants may exist in the confined Ringold Formation aquifer.

\subsection{Vadose Zone Porewater and Groundwater Chemical Ratio Comparisons}

Selected concentration ratios of mobile contaminants in a) the vadose zone sediments sampled by the three boreholes, $b$ ) the TX-TY groundwater contaminant plumes and c) specific single-shell tanks, cribs and trenches at the time of suspected leaks and disposal campaigns, respectively, were used to assess whether there are indications that the groundwater contamination is related to current vadose zone contamination and can be associated with a specific facility or a specific tank leak.

Our initial attempts to relate the groundwater and porewater compositions used the ratios of the concentrations of technetium-99, calcium, fluoride, chromium, sulfate, and sodium to the concentration of nitrate. The agreement between the vadose zone porewater and contaminated groundwater data sets is not good. Some ratios for groundwater are larger than those for the vadose zone porewater $\left(\mathrm{Cr} / \mathrm{NO}_{3}{ }^{-}, \mathrm{F}^{-} \mathrm{NO}_{3}{ }^{-}\right)$ and other groundwater ratios are smaller than the vadose zone porewater ratios (Tc-99/ $\left.\mathrm{NO}_{3}{ }^{-}, \mathrm{Na} / \mathrm{NO}_{3}{ }^{-}\right)$. The lack of agreement between the groundwater ratios and the contaminated borehole sediment porewater ratios suggests that the groundwater contamination has been influenced by fluids from nearby cribs and trenches. The ratios of most mobile species in the vadose zone porewaters should remain stable as tank fluids percolate through the sediment because the only reaction between the tank waste and the vadose zone sediment mobile constituents should be dilution, as dispersion and mixing occurs with native porewater.

Based on the large difference in Tc-99/ $\mathrm{NO}_{3}{ }^{-}$ratio of the liquids that leaked from the TX tanks, the low values for nearby cribs and tile fields, and the proximity of the three boreholes to TX tanks, it is likely that the three boreholes intercepted only tank leak fluids. However, because the three boreholes did not sample below the upper Cold Creek subunit, we do not know whether tank fluids leaked from TX tanks, especially TX104, TX105 and TX107, have reached the groundwater below the TX-TY WMA. Comparison of the mobile constituent ratios for these two fluids shows that the groundwater and porewater compositions are very different. If the contaminated vadose zone sediment porewater composition represents the composition of tank waste, then the contamination in the groundwater either is not tank waste or it is a mixture of tank waste and other contaminant sources such that the nature of the tank waste is no longer recognizable.

In summary, there is no current similarity between the present or past groundwater contamination and current porewater compositions from the contaminated borehole sediments. Therefore, we cannot link the contaminants in the groundwater, currently or during the era of contamination introduction in the vadose zone, to the porewaters currently in the borehole sediments, which are known to be derived from the liquids that leaked from tanks in the TX tank farm, especially tank TX-107. 


\subsection{References}

Alexander DJ, SD Evelo, VG Johnson, and MD Sweeney. 1995. Groundwater Impact Assessment Report for the 216-T-4-2 Ditch. WHC-EP-0815, Westinghouse Hanford Company, Richland, Washington.

American Society of Agronomy (ASA). 1986a. "Hydrometer Method." Chapter 15-5 in Methods of Soil Analysis-Part 1, 2nd edition of Physical and Mineralogical Methods, SSSA Book Series No. 5, ed. A Klute, pp. 404-408. Soil Science Society of America, Madison, Wisconsin.

American Society of Agronomy (ASA). 1986b. "Pynchnometer Method." Chapter 14-3 in Methods of Soil Analysis-Part 1, 2nd edition of Physical and Mineralogical Methods, SSSA Book Series No. 5, ed. A Klute, pp. 378-379. Soil Science Society of America, Madison, Wisconsin.

American Society of Agronomy (ASA). 1996a. Methods of Soil Analysis-Part 3, Chemical Methods, SSSA Book Series 5, ed. DL Sparks, Soil Science Society of America, Madison, Wisconsin.

American Society of Agronomy (ASA). 1996b. "Elemental Analysis by XRF Spectroscopy." Chapter 7 in Methods of Soil Analysis-Part 3, Chemical Methods, SSSA Book Series 5, ed. DL Sparks, pp. 161-223. Soil Science Society of America, Madison, Wisconsin.

American Society for Testing and Materials (ASTM) D4129-88. 1988. Standard Test Method for Total and Organic Carbon in Water by High Temperature Oxidation and by Coulometric Detection. American Society for Testing and Materials, West Conshohocken, Pennsylvania.

American Society for Testing and Materials (ASTM) D2488-93. 1993. Standard Practice for Description and Identification of Soils (Visual-Manual Procedure). American Society for Testing and Materials, West Conshohocken, Pennsylvania.

American Society for Testing and Materials (ASTM) D2216-98. 1998. Test Method for Laboratory Determination of Water (Moisture) Content of Soil and Rock by Mass. American Society for Testing and Materials, West Conshohocken, Pennsylvania.

American Society for Testing and Materials (ASTM) D5298-94. 2002. Test Method for Measurement of Soil Potential (Suction) Using Filter Paper. American Society for Testing and Materials, West Conshohocken, Pennsylvania.

Baker VR, BN Bjornstad, AJ Busacca, KR Fecht, EP Kiver, UL Moody, JG Rigby, DF Stradling, and AM Tallman. 1991. "Quaternary Geology of the Columbia Plateau." In Quaternary Nonglacial Geology: Conterminous U.S. Geology of North America, ed. RB Morisson, K-2:215-250. Geological Society of America, Boulder, Colorado.

Baker VR and RC Bunker. 1985, "Cataclysmic Late-Pleistocene Flooding from Glacial Lake Missoula: A Review." Quaternary Science Reviews, 4:1-41. 
Bergeron MP and SK Wurstner. 2000. Groundwater Flow and Transport Calculations Supporting the Immobilized Low-Activity Waste Disposal Facility Performance Assessment. PNNL-13400, Pacific Northwest National Laboratory, Richland, Washington.

Bjornstad BN. 1984. Suprabasalt Stratigraphy Within and Adjacent to the Reference Repository Location. SD-BWI-DP-039, Rockwell Hanford Operations, Richland, Washington.

Bjornstad BN. 1990. Geohydrology of the 218-W-5 Burial Ground. PNL-7336, Pacific Northwest Laboratory, Richland, Washington.

Bjornstad BN, KR Fecht, and CJ Pluhar. 2001. "Long History of Pre-Wisconsin, Ice-Age, Cataclysmic Floods: Evidence from Southeastern Washington State.” Journal of Geology, 109:695-713.

Bjornstad BN, GV Last, SP Reidel, DG Horton, KR Fecht, GA Smith, and KA Lindsey. 2002. "Characterization and Proposed Formalization (Hanford formation) for Ice Age Flood Deposits Within the Pacific Northwest." In Geological Society of America, Abstracts with Programs, p. A-24, Geological Society of America, Boulder, Colorado.

Bjornstad BN, GV Last, and DG Horton. 2003. Hydrogeology of the Hanford Site Vadose Zone, 4th Symposium on the Hydrogeology of Washington State, Program Abstracts, Olympia, Washington.

Black RF. 1979. Clastic Dikes of the Pasco Basin, Southeastern Washington. RHO-BWI-C-64, Rockwell Hanford Operations, Richland, Washington.

Brown DJ. 1959. Subsurface Geology of the Hanford Separation Areas. HW-61780, General Electric Company, Richland, Washington.

Brown DJ. 1960. An Eolian Deposit Beneath the 200 West Area. HW-67549, General Electric Company, Richland, Washington.

Brown RE. 1970. Interrelationships of Geologic Formations and Processes Affecting Ecology as Exposed at Rattlesnake Springs. BNWL-B-29, Battelle Northwest Laboratory, Richland, Washington.

Caggiano JA and SM Goodwin. 1991. Interim Status Groundwater Monitoring Plan for the Single-Shell Tanks. WHC-SD-EN-AP-012, Westinghouse Hanford Company, Richland, Washington.

Connelly MP, BH Ford, and JV Borghese. 1992a. Hydrogeologic Model for the 200 West Groundwater Aggregate Area. WHC-SD-EN-TI-014, Westinghouse Hanford Company, Richland, Washington.

Connelly MP, JV Borghese, CD Delaney, BH Ford, JW Lindberg, and SJ Trent. 1992b. Hydrogeologic Model for the 200 East Groundwater Aggregate Area. WHC-SD-EN-TI-019, Westinghouse Hanford Company, Richland, Washington.

Crumpler JD. 2002. Site Specific SST Phase 1 RFI/CMS Work Plan Addendum for WMAs T and TX-TY. RPP-7578, Rev. 2, CH2M HILL Hanford Group, Inc., Richland, Washington. 
Deka RN M Wairiu, PW Mtakwa, CE Mullins, EM Veenendaal, and J Towend. 1995. "Use and Accuracy of the Filter Paper Method for Measuring Soil Matric Potential." European J. of Soil Sci. 46:233-238.

Delaney CD, KA Lindsey, and SP Reidel. 1991. Geology and Hydrology of the Hanford Site: A Standardized Text for Use in Westinghouse Hanford Company Documents and Reports. WHC-SC-ERTI-003, Westinghouse Hanford Company, Richland, Washington.

DOE (U.S. Department of Energy). 1984. Draft Environmental Assessment, Reference Repository Location, Hanford Site, Washington, DOE/RW-0017, U.S. Department of Energy, Washington, D.C.

DOE (U.S. Department of Energy). 1988. Consultation Draft Site Characterization Plan, Reference Repository Location, Hanford Site, Washington. DOE/RW-0164, U. S. Department of Energy, Office of Civilian Radioactive Waste Management, Washington, D. C.

DOE (U.S. Department of Energy). 1992. T Plant Source Aggregate Area Management Report. DOE/RL 91-61, U. S. Department of Energy, Richland Operations Office, Richland, Washington.

DOE (U.S. Department of Energy). 1999. Phase 1 RCRA Facility Investigation/Corrective Measures Study Work Plan for the SST Waste Management Areas. DOE/RL-99-36, Rev. 0, U.S. Department of Energy, Richland Operations Office, Richland, Washington.

DOE (U.S. Department of Energy). 2002a. Standardized Stratigraphic Nomenclature for Post-RingoldFormation Sediments Within the Pasco Basin. DOE/RL-2002-39, U.S. Department of Energy, Richland Operations Office, Richland Washington.

DOE (U.S. Department of Energy). 2002b. Fiscal Year 2001 Annual Summary Report for the 200-UP-1 and 200-ZP-1 Operable Unit Pump-and-Treat Operations. DOE/RL-2001-53, U. S. Department of Energy, Richland Operations Office, Richland, Washington.

DOE-GJO (U.S. Department of Energy-Grand Junction Office). 1997. Hanford Tank Farms Vadose Zone, TX Tank Farm Report. GJO-HAN-11, prepared by U.S. Department of Energy-Grand Junction Office for U.S. Department of Energy, Richland Operations Office, Richland Washington.

EPA (U.S. Environmental Protection Agency). 1986. Test Methods for Evaluating Solid Waste: Physical/Chemical Methods, $S W-846,3^{\text {rd }}$ ed. U.S. Environmental Protection Agency, Office of Solid Waste and Emergency Response, Washington, D.C., [Online manual]. Available URL: http://www.epa.gov/epaoswer/hazwaste/test/sw846.htm

EPA Method 300.0A. 1984. Test Method for the Determination of Inorganic Anions in Water by Ion Chromatography. EPA-600/4-84-017, U.S. Environmental Protection Agency, Washington, D.C.

EPA Method 3050B. 2000a. "Acid Digestion of Sediments, Sludges, and Soils." Test Methods for Evaluating Solid Waste, Physical/Chemical Methods. EPA Publication SW-846, [Online manual]. Available URL: http://www.epa.gov/epaoswer/hazwaste/test/sw846.htm 
EPA Method 6010B. 2000b. "Inductively Coupled Plasma-Atomic Emission Spectrometry." Test Methods for Evaluating Solid Waste, Physical/Chemical Methods. EPA Publication SW-846, [Online manual]. Available URL: http://www.epa.gov/epaoswer/hazwaste/test/sw846.htm

EPA Method 6020. 2000c. "Inductively Coupled Plasma-Mass Spectrometry." Test Methods for Evaluating Solid Waste, Physical/Chemical Methods. EPA Publication SW-846, [Online manual]. Available URL: http://www.epa.gov/epaoswer/hazwaste/test/sw846.htm

Fecht KR and DC Weekes. 1996. Geologic Field Inspection of the Sedimentary Sequence at the Environmental Restoration Disposal Facility. BHI-00230, Bechtel Hanford, Inc., Richland, Washington.

Fecht KR, BN Bjornstad, DG Horton, GV Last, SP Reidel, and KA Lindsey. 1999. Clastic Injection Dikes of the Pasco Basin and Vicinity: Geologic Atlas Series. BHI-01103, Rev. 0, Bechtel Hanford Company, Richland, Washington.

Fecht KR, GV Last, and KR Price, 1977. Evaluation of Scintillation Probe Profiles from 200 Area Crib Monitoring Wells, Volume III. ARH-ST-156, Atlantic Richfield Hanford Company, Richland, Washington.

Flint RF. 1938. "Origin of the Cheney-Palouse Scabland Tract.” Geological Society of America Bulletin, 49:461-524.

Folk RL. 1968. Petrology of Sedimentary Rocks. Hemphill, Austin, Texas.

Gardner MG, KD Reynolds, and DE Skoglie. 2002a. Completion Report for Probe Hole C3831 (TX-107) TX Tank Farm 200 West Area. RPP-12293, Rev. 0, Prepared for the Office of River Protection, CH2M HILL Hanford Group, Inc., Richland, Washington.

Gardner MG, KD Reynolds, and DE Skoglie. 2002b. Completion Report for Probe Hole C3832 (TX-104) TX Tank Farm 200 West Area. RPP-12017, Rev. 0-A, Prepared for the Office of River Protection, CH2M HILL Hanford Group, Inc., Richland, Washington.

Gee GW. 1987. Recharge at the Hanford Site. Status Report. PNL-6403, Pacific Northwest Laboratory, Richland, Washington.

Gee GW, MJ Fayer, ML Rockhold, and MD Campbell. 1992. "Variations in Recharge at the Hanford Site," NW Sci. 66:237-250.

Hartman MJ, ed. 1999. Hanford Site Groundwater Monitoring for Fiscal Year 1998. PNNL-12086, Pacific Northwest National Laboratory, Richland, Washington.

Hartman MJ, LF Morasch, and WD Webber, eds. 2003. Hanford Site Groundwater Monitoring for Fiscal Year 2002. PNNL-14187, Pacific Northwest National Laboratory, Richland, Washington.

Hodges FN, 1998. Results of Phase 1 Groundwater Quality Assessment for Single-Shell Tank Waste Management Areas T and TX-TY at the Hanford Site. PNNL-11809, Pacific Northwest National Laboratory, Richland, Washington. 
Hodges FN and CJ Chou, 2001. RCRA Assessment Plan for Single-Shell Tank Waste Management Area TX-TY at the Hanford Site. PNNL-12072, Pacific Northwest National Laboratory, Richland, Washington.

Horton DG. 2002. Groundwater Conditions at Single-Shell Tank Waste Management Area TX-TY (January 1998 through December 2001). PNNL-14099, Pacific Northwest National Laboratory, Richland, Washington.

Horton DG. 2003. Data Package for Calendar Year 2002 RCRA Groundwater Monitoring Wells at Single-Shell Tank Waste Management Area TX-TY. PNNL-14249, Pacific Northwest National Laboratory, Richland, Washington.

Johnson VG and CJ Chou, 2001. RCRA Groundwater Quality Assessment Report for Waste Management Area S-SX (November 1997 through April 2000). PNNL-13441, Pacific Northwest National Laboratory, Richland, Washington.

Johnson VG, TE Jones, SP Reidel, and MI Wood. 1999. Subsurface Physical Conditions of the S-SX Waste Management Area. HNF-4936, Lockheed Martin Hanford Corporation, Richland, Washington.

Kaplan DI and RJ Serne. 1995. Distribution Coefficient Values Describing Iodine, Neptunium, Selenium, Technetium, and Uranium Sorption to Hanford Sediment. PNL-10379, Supplement 1, Pacific Northwest Laboratory, Richland, Washington.

Kaplan DI and RJ Serne. 2000. Geochemical Data Package for the Hanford Immobilized Low-Activity Tank Waste Performance Assessment (ILAW-PA). PNNL-13037, Rev.1, Pacific Northwest National Laboratory, Richland, Washington.

Kincaid CT, MP Bergeron, CR Cole, MD Freshley, VG Johnson, DI Kaplan, RJ Serne, GP Streile, DL Strenge, PD Thorne, LW Vail, GA Whyatt, and SK Wurstner. 1998. Composite Analysis for LowLevel Waste Disposal in the 200 Area Plateau of the Hanford Site. PNNL-11800, Pacific Northwest National Laboratory, Richland, Washington.

Kipp RL and RD Mudd, 1974. Selected Water Table Contour Maps and Well Hydrographs for the Hanford Reservation, 1944-1973. BNWL-B-360, Pacific Northwest Laboratories, Richland, Washington.

Last GV, ed. 1994. 216-U-10 Pond and 216-Z-19 Ditch Characterization Studies. WHC-EP-0707 (formerly RHO-ST-45), Westinghouse Hanford Company, Richland, Washington.

Last GV, BN Bjornstad, MP Bergeron, DW Wallace, DR Newcomer, JA Schramke, MA Chamness, CS Cline, SP Airhart, and JS Wilbur. 1989. Hydrogeology of the 200 Areas Low-Level Burial Grounds An Interim Report. PNL-6820, 2 volumes, Pacific Northwest Laboratory, Richland, Washington. 
Lindenmeier CW, RJ Serne, BN Bjornstad, GW Gee, HT Schaef, DC Lanigan, MJ Lindberg, RE Clayton, VL LeGore, IV Kutnyakov, SR Baum, KN Geiszler, KMM Valenta, TS Vickerman, and LJ Royack. 2002. Characterization of Vadose Zone Sediment: RCRA Borehole 299-E33-338 Located Near the B-BX-BY Waste Management Area, PNNL-14121, Pacific Northwest National Laboratory, Richland, Washington.

Lindsey KA. 1995. Miocene-to Pliocene-Aged Suprabasalt Sediments of the Hanford Site, South-Central Washington, BHI-00184, Bechtel Hanford Inc., Richland, Washington.

Lindsey KA. 1996. Miocene-Pliocene Ringold Formation and Associated Deposits of the Ancestral Columbia River System, South-Central Washington and North-Central Oregon, Washington. Department of Natural Resources, Division of Geology and Earth Resources Open-File Report 96-8, Olympia, Washington, $45 \mathrm{p}$.

Lindsey KA, BN Bjornstad, JW Lindberg, and KM Hoffman. 1992a. Geologic Setting of the 200 East Area: An Update. WHC-SD-EN-TI-012, Westinghouse Hanford Company, Richland, Washington.

Lindsey KA, MP Connelly, and BN Bjornstad. 1992b. Geologic Setting of the 200 West Area - An Update. WHC-SD-EN-TI-008, Westinghouse Hanford Company, Richland, Washington.

Lindsey KA, SE Kos, and KD Reynolds. 2000. Vadose Zone Geology of the Boreholes 299-W22-50 and 299-W23-19 S-SX Waste Management Area, Hanford Site, South-Central Washington. RPP-6149, Rev. 0, prepared for the Office of River Protection, CH2M HILL Group, Inc., Richland, Washington.

Lindsey KA, SE Kos, and KD Reynolds. 2001. Vadose Zone Geology of Boreholes 299-W10-27 and 299-W11-39 T-TX-TY Waste Management Area, Hanford Site, South-Central Washington. RPP-8531, Rev. 0, prepared for the Office of River Protection, CH2M HILL Group, Inc., Richland, Washington.

Lindsey KA, SP Reidel, KR Fecht, JL Slate, AG Law, and AM Tallman. 1994a. "Geohydrologic Setting of the Hanford Site, South-Central Washington.” In Geologic Field Trips in the Pacific Northwest, eds. DA Swanson and RA Hagerud, pp. 1C-1 to 1C-16. Geological Society of America Meeting, Geological Society of America, Boulder, Colorado.

Lindsey KA, JL Slate, GK Jaeger, KJ Swett, and RB Mercer. 1994b. Geologic Setting of the Low-Level Burial Grounds. WHC-SD-EN-TI-290, Rev. 0, Westinghouse Hanford Company, Richland, Washington.

Maxfield HL. 1979. Handbook 200 Areas Waste Sites, Volume II. RHO-CD-673, Rockwell Hanford Operations, Richland, Washington.

Moody UL. 1987. Late Quaternary Stratigraphy of the Channeled Scabland and Adjacent Areas, Ph.D. Thesis, University of Idaho, Moscow, Idaho.

Myers CW and SM Price, eds. 1979. Geologic Studies of the Columbia Plateau - A Status Report. RHO-BWI-ST-4, Rockwell Hanford Operations, Richland, Washington.

O'Connor JE. 1993. Hydrology, Hydraulics, and Geomorphology of the Bonneville Flood. Special Paper \#274, Geological Society of America, Boulder, Colorado, 83 p. 
Or D and JM Wraith. 2002. "Soil Water Content and Water Potential Relationships." In Soil Physics Companion, ed. AW Warrick, pp. 49-84, CRC Press, Boca Raton, Florida.

Pacific Northwest Laboratory (PNL). 1990a. Procedures for Groundwater Investigations. PNL-MA-567-DO-1, Pacific Northwest Laboratory, Richland, Washington.

Pacific Northwest Laboratory (PNL). 1990b. Procedures for Groundwater Investigations. PNL-MA-567-SFA-2, Pacific Northwest Laboratory, Richland, Washington.

Pacific Northwest National Laboratory (PNNL). 1997. Gamma Energy Analysis Operation and Instrument Verification Using the Genie2000 ${ }^{T M}$ Support Software. PNNL-RRL-01, Pacific Northwest National Laboratory, Richland, Washington.

Pacific Northwest National Laboratory (PNNL). 1998. Inductively Coupled Plasma Mass Spectrometric (ICP-MS) Analysis. PNNL-AGG-415, Pacific Northwest National Laboratory, Richland, Washington.

Pacific Northwest National Laboratory (PNNL). 1999. Visual Description and Classification of Potentially Contaminated Borehole Samples. PNL Procedure D9T81-99-GVL-1, Pacific Northwest National Laboratory, Richland, Washington, 6 p.

Pacific Northwest National Laboratory (PNNL). 2000. Liquid Scintillation Counting and Instrument Verification Using the 1400 DSM ${ }^{\mathrm{TM}}$ Support Software. PNNL-AGG-002, Pacific Northwest National Laboratory, Richland, Washington.

Pacific Northwest National Laboratory (PNNL). 2004. [Online listing of borehole geophysical logs for Well 299W10-27; as accessed March 8, 2004.] Available URL:

http://boreholelogs.pnl.gov/200WEST/W10027

Price WH and KR Fecht. 1976. Geology of the 241-TX Tank Farm. ARH-LD-136, Atlantic Richfield Hanford Company, Richland, Washington.

Reidel SP and KR Fecht. 1994. Geologic Map of the Priest Rapids 1:100,000 Quadrangle, Washington. Washington Division of Geology and Earth Resources Open-File Report 94-13, 22 p.

Reidel SP, KA Lindsey, and KR Fecht. 1992. Field Trip Guide to the Hanford Site. WHC-MR-0391, Westinghouse Hanford Company, Richland, Washington.

Reineck HE and IB Singh. 1975. Depositional Sedimentary Environments. 439p. Springer-Verlag, New York.

Reynolds KD. 2003. Completion Report for Probe Hole C3830 (TX-105) TX Tank Farm 200 West Area. RPP-13741, Prepared for the Office of River Protection, CH2M HILL Hanford Group, Inc., Richland, Washington.

Rhoades JD. 1996. "Salinity: Electrical Conductivity and Total Dissolved Solids." In Methods of Soil Analysis Part 3, ed. JM Bigham, pp. 417-435. American Society of Agronomy, Madison, Wisconsin. 
Salvador A, ed. 1994. International Stratigraphic Guide. $2^{\text {nd }}$ ed. International Union of Geological Sciences and the Geological Society of America, Boulder, Colorado.

Serne RJ, HT Schaef, BN Bjornstad, BA Williams, DC Lanigan, DG Horton, RE Clayton, VL LeGore, MJ O'Hara, CF Brown, KE Parker, IV Kutnyakov, JN Serne, AV Mitroshkov, GV Last, SC Smith, CW Lindenmeier, JM Zachara, and DS Burke. 2002a. Characterization of Vadose Zone Sediment: Uncontaminated RCRA Borehole Core Samples and Composite Samples. PNNL-13757-1, Pacific Northwest National Laboratory, Richland, Washington.

Serne RJ, HT Schaef, BN Bjornstad, DC Lanigan, GW Gee, CW Lindenmeier, RE Clayton, VL LeGore, MJ O'Hara, CF Brown, RD Orr, G.V Last, IV Kutnyakov, DS Burke, TC Wilson, and BA Williams. 2002b. Characterization of Vadose Zone Sediment: Borehole 299-W23-19 [SX-115] in the S-SX Waste Management Area. PNNL-13757-2, Pacific Northwest National Laboratory, Richland, Washington.

Serne RJ, GV Last, HT Schaef, DC Lanigan, CW Lindenmeier, CC Ainsworth, RE Clayton, VL LeGore, MJ O'Hara, CF Brown, RD Orr, IV Kutnyakov, TC Wilson, KB Wagnon, BA Williams, and DB Burke. 2002c. Characterization of Vadose Zone Sediment, Part 4: Slant Borehole SX-108 in the S-SX Waste Management Area. PNNL-13757-4, Pacific Northwest National Laboratory, Richland, Washington.

Serne RJ, GV Last, GW Gee, HT Schaef, DC Lanigan, CW Lindenmeier, RE Clayton, VL LeGore, RD Orr, MJ O'Hara, CF Brown, DS Burke, AT Owen, IV Kutnyakov, and TC Wilson. 2002d. Characterization of Vadose Zone Sediment: Borehole 41-09-39 in the S-SX Waste Management Area. PNNL-13757-3, Pacific Northwest National Laboratory, Richland, Washington.

Serne RJ, GV Last, GW Gee, HT Schaef, DC Lanigan, CW Lindenmeier, MJ Lindberg, RE Clayton, VL LeGore, RD Orr, IV Kutnyakov, SR Baum, KN Geiszler, CF Brown, MM Valenta, and TS Vickerman. 2002e. Characterization of Vadose Zone Sediment: Borehole 299-E33-45 Near BX-102 in the $B-B X-B Y$ Waste Management Area, PNNL-14083, Pacific Northwest National Laboratory, Richland, Washington.

Serne RJ, BN Bjornstad, GW Gee, HT Schaef, DC Lanigan, CW Lindenmeier, RD Orr, VL LeGore, RE Clayton, MJ Lindberg, IV Kutnyakov, SR Baum, KN Geiszler, MM Valenta, TS Vickerman, and LJ Royack. 2002f. Characterization of Vadose Zone Sediment: Borehole 299-E33-46 Near B-110 in the $B-B X-B Y$ Waste Management Area, PNNL-14119, Pacific Northwest National Laboratory, Richland, Washington.

Shaw J, M Munro-Stasuik, B Sawyer, C Beaney, JE Lesemann, A Musacchio, B Rains, and RR Young. 1999. "The Channeled Scabland: Back to Bretz," Geology, 27:605-608.

Simpson BC, RA Corbin, and SF Agnew, 2001. Hanford Soil Inventory Model. BHI-01496 Rev. 0, Bechtel Hanford, Inc., Richland, Washington.

Slate JL. 1996. "Buried Carbonate Paleosols Developed in Pliocene-Pleistocene Deposits of the Pasco Basin, South-Central Washington.” USA: Quaternary International, 34-36:191-196.

Slate JL. 2000. Nature and Variability of the Plio-Pleistocene Unit in the 200 West Area of the Hanford Site. BHI-01203, Rev. 0, Bechtel Hanford, Inc., Richland, Washington. 
Smith GA. 1993. "Missoula Flood Dynamics and Magnitudes Inferred from Sedimentology of SlackWater Deposits on the Columbia Plateau." Geological Society of America Bulletin, 195:77-100.

Spane FA, Jr., PD Thorne, and DR Newcomer. 2001a. Results of Detailed Hydrologic Characterization Tests - Fiscal Year 1999. PNNL-13378, Pacific Northwest National Laboratory, Richland, Washington.

Spane FA, Jr., PD Thorne, and DR Newcomer. 2001b. Results of Detailed Hydrologic Characterization Tests - Fiscal Year 2000. PNNL-13514, Pacific Northwest National Laboratory, Richland, Washington.

Spane FA, Jr., PD Thorne, and DR Newcomer. 2002. Results of Detailed Hydrologic Characterization Tests - Fiscal Year 2001. PNNL-14113, Pacific Northwest National Laboratory, Richland, Washington.

Spane FA, Jr., PD Thorne, and DR Newcomer. 2003. Results of Detailed Hydrologic Characterization Tests - Fiscal Year 2002. PNNL-14186, Pacific Northwest National Laboratory, Richland, Washington.

Tallman AM, KR Fecht, MC Marratt, and GV Last. 1979. Geology of the Separations Areas, Hanford Site, South-Central Washington. RHO-ST-23, Rockwell Hanford Operations, Richland, Washington.

Tallman AM, JT Lillie, and KR Fecht. 1981. "Suprabasalt Sediment of the Cold Creek Syncline Area," In Subsurface Geology of the Cold Creek Syncline, eds. CW Myers and SM Price, RHO-BWI-ST-14, Rockwell Hanford Operations, Richland, Washington.

USGS (United States Geological Survey). 2001. "Alkalinity and Acid Neutralizing Capacity.” National Field Manual for the Collection of Water-Quality Data, $2^{\text {nd }}$ ed., eds. SA Rounds and FD Wilde. March 23, 2004 Available URL:

http://water.usgs.gov/owq/FieldManual/Chapter6/section6.6/html/section6.6.htm

Waldrop WR and HS Pearson. 2000. Results of Field Tests with the Electromagnetic Borehole Flowmeter at the Pacific Northwest National Laboratory, Richland, WA. QEC-T-132, Quantum Engineering Corporation, London, Tennessee.

Wan J, JT Larsen, TK Tokunaga, and Z Zheng. 2004. " $\mathrm{pH}$ Neutralization and Zonation in Alkaline-Saline Tank Waste Plumes.” Environ. Sci. Technol. 38:1321-1329.

Ward AL, GW Gee, and MD White. 1997. A Comprehensive Analysis of Contaminant Transport in the Vadose Zone Beneath Tank SX-109. PNNL-11463, Pacific Northwest National Laboratory, Richland, Washington.

Webster GD and JW Crosby. 1982. Stratigraphic Investigation of the Skagit/Hanford Nuclear Project, Volume 4, Puget Sound Power and Light Company, Bellevue, Washington.

Wentworth CK. 1922. "A grade scale and class terms for clastic sediments.” Journal of Geology, 30:377-392.

WHC 1990. 1990. Liquid Effluent Study Final Project Report. WHC-EP-0367, Westinghouse Hanford Company, Richland, Washington. 
Williams BA, BN Bjornstad, R Schalla, and WD Webber. 2002. Revised Hydrogeology for the Suprabasalt Aquifer System, 200-West Area and Vicinity, Hanford Site, Washington. PNNL-13858, Pacific Northwest National Laboratory, Richland, Washington.

Wood MI, R Schalla, BN Bjornstad, and FN Hodges. 2001. Subsurface Conditions Description of the T and TX-TY Waste Management Areas. RPP-7123, Rev. 0, CH2M HILL Hanford Group, Inc., Richland, Washington.

Wood MI, TE Jones, R Schalla, BN Bjornstad, and FN Hodges. 2001. Subsurface Conditions Description of the T and TX-TY Waste Management Areas. RPP-7123, Rev. 0. CH2M HILL Hanford Group, Inc., Richland, Washington. 


\section{APPENDIX A. CORE PHOTOGRAPHS}
A.1 C3125 (299-W10-27)
A.2 C3830
A.3 C3831
A.4 C3832 
APPENDIX A.1

C3125 (299-W10-27)

SPLITSPOON CORE

SAMPLE PHOTOGRAPHS 


\section{Contents}

Appendix A.1 C3125 (299-W10-27) Splitspoon Core Sample Photographs....

A-1.1

\section{Figures}

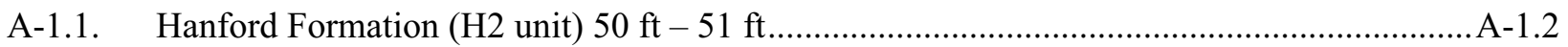

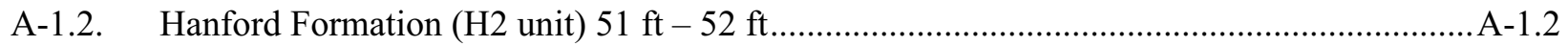

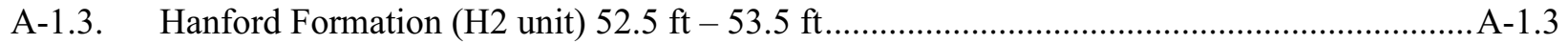

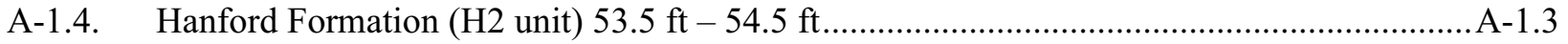

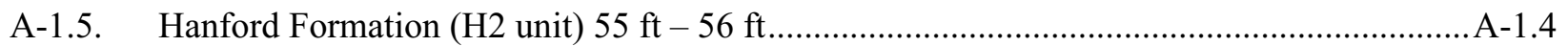

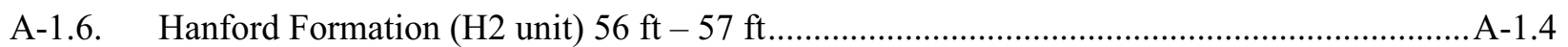

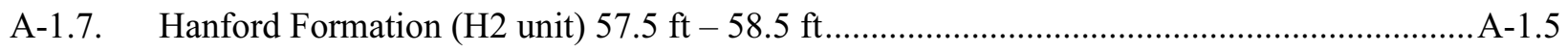

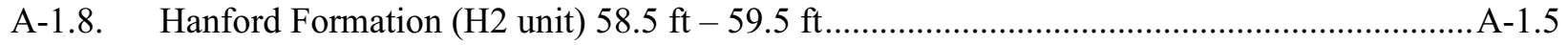

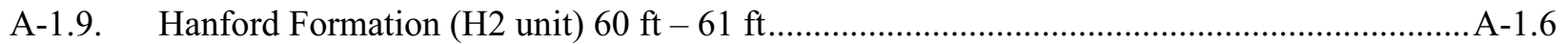

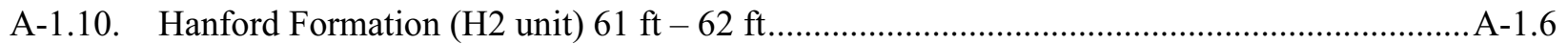

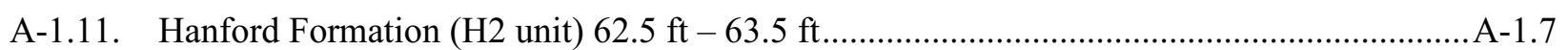

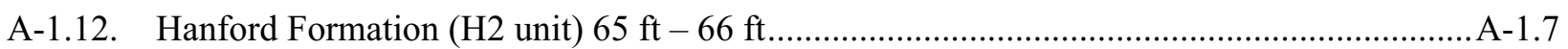

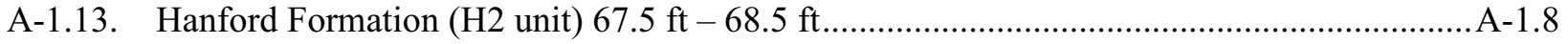

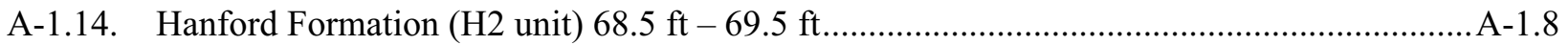

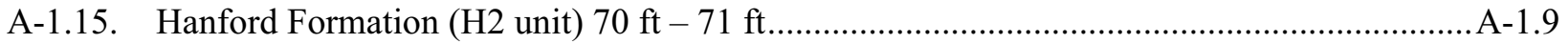

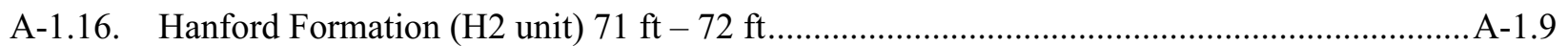

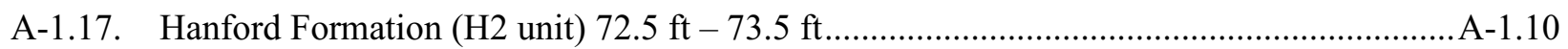

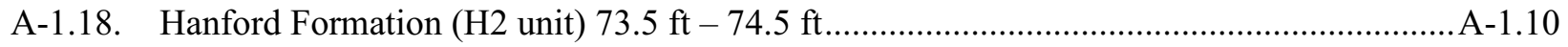

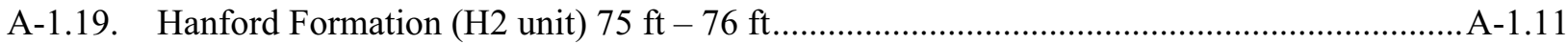

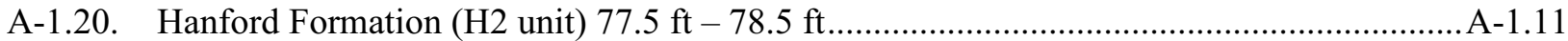

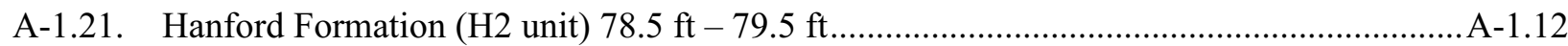

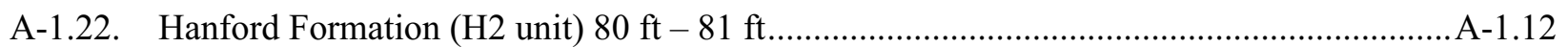

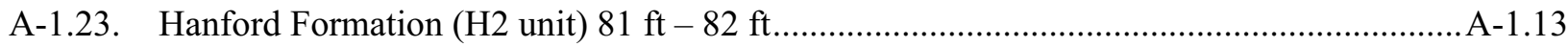

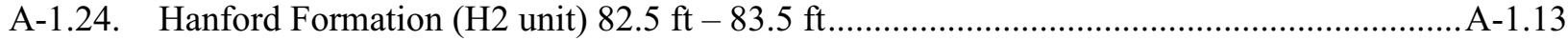

A-1.25. Hanford Formation (H2 unit) $83.5 \mathrm{ft}-84.5 \mathrm{ft}$............................................................A-1.14

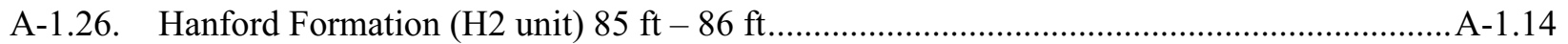

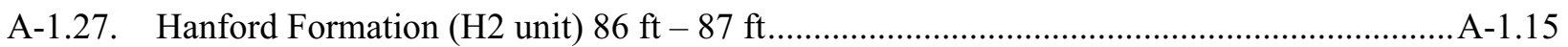




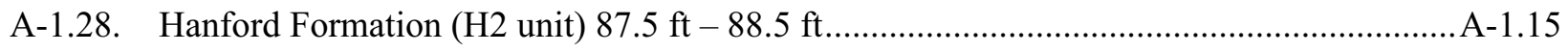

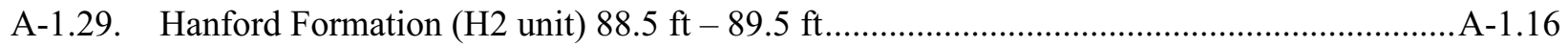

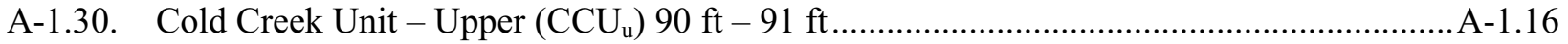

A-1.31. Cold Creek Unit - Upper $\left(\mathrm{CCU}_{\mathrm{u}}\right) 92.5 \mathrm{ft}-93.5 \mathrm{ft}$........................................................ A-1.17

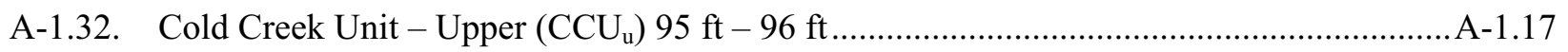

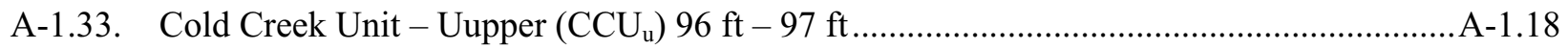

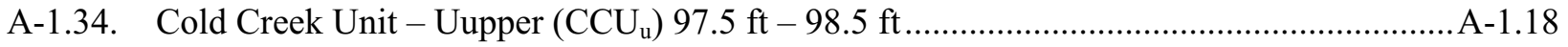

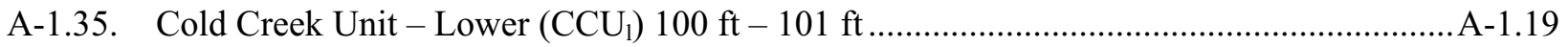

A-1.36. Cold Creek Unit - Lower $\left(\mathrm{CCU}_{1}\right) 102.5 \mathrm{ft}-103.5 \mathrm{ft}$...................................................A-1.19

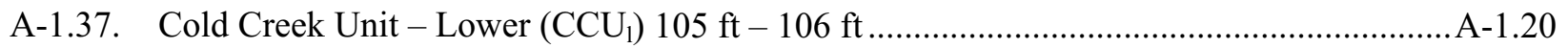

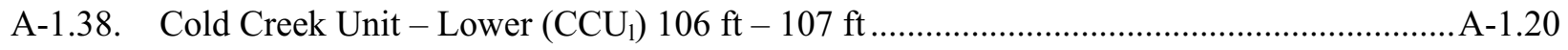

A-1.39. Cold Creek Unit - Lower $\left(\mathrm{CCU}_{1}\right) 107.5 \mathrm{ft}-108.5 \mathrm{ft}$..................................................

A-1.40. Cold Creek Unit - Lower $\left(\mathrm{CCU}_{1}\right) 110 \mathrm{ft}-111 \mathrm{ft}$........................................................... A-1.21

A-1.41. Ringold Formation - Member of Taylor Flat $\left(\mathrm{R}_{\mathrm{tf}}\right) 112.5 \mathrm{ft}-113.5 \mathrm{ft}$......................... A-1.22

A-1.42. Ringold Formation - Member of Taylor Flat $\left(\mathrm{R}_{\mathrm{tf}}\right) 113.5 \mathrm{ft}-114.5 \mathrm{ft}$..........................A-1.22

A-1.43. Ringold Formation - Member of Taylor Flat $\left(\mathrm{R}_{\mathrm{tf}}\right) 115 \mathrm{ft}-116 \mathrm{ft}$................................ A-1.23

A-1.44. Ringold Formation - Member of Taylor Flat $\left(\mathrm{R}_{\mathrm{tf}}\right) 116 \mathrm{ft}-117 \mathrm{ft}$.............................. A-1.23

A-1.45. Ringold Formation - Member of Taylor Flat $\left(\mathrm{R}_{\mathrm{tf}}\right) 117.5 \mathrm{ft}-118.5 \mathrm{ft}$......................... A-1.24

A-1.46. Ringold Formation - Member of Taylor Flat $\left(\mathrm{R}_{\mathrm{tf}}\right) 120 \mathrm{ft}-121 \mathrm{ft}$................................ A-1.24

A-1.47. Ringold Formation - Member of Wooded Island $\left(\mathrm{R}_{\mathrm{wi}}\right) 122.5 \mathrm{ft}-123.5 \mathrm{ft} \ldots \ldots \ldots \ldots \ldots \ldots \ldots . . . . . . . . . .25$

A-1.48. Ringold Formation - Member of Wooded Island $\left(\mathrm{R}_{\mathrm{wi}}\right) 123.5 \mathrm{ft}-124.5 \mathrm{ft}$..................... A-1.25

A-1.49. Ringold Formation - Member of Wooded Island $\left(\mathrm{R}_{\mathrm{wi}}\right) 125 \mathrm{ft}-126 \mathrm{ft}$...........................A-1.26

A-1.50. Ringold Formation - Member of Wooded Island $\left(\mathrm{R}_{\mathrm{wi}}\right) 127.5 \mathrm{ft}-128.5 \mathrm{ft}$......................A-1.26

A-1.51. Ringold Formation - Member of Wooded Island $\left(\mathrm{R}_{\mathrm{wi}}\right) 129.5 \mathrm{ft}-130.5 \mathrm{ft} \ldots \ldots \ldots \ldots \ldots \ldots \ldots . . . . . . . .27$

A-1.52. Ringold Formation - Member of Wooded Island $\left(\mathrm{R}_{\mathrm{wi}}\right) 130.5 \mathrm{ft}-131.5 \mathrm{ft} \ldots \ldots \ldots \ldots \ldots \ldots \ldots . . . . . . . . . . .27$ 


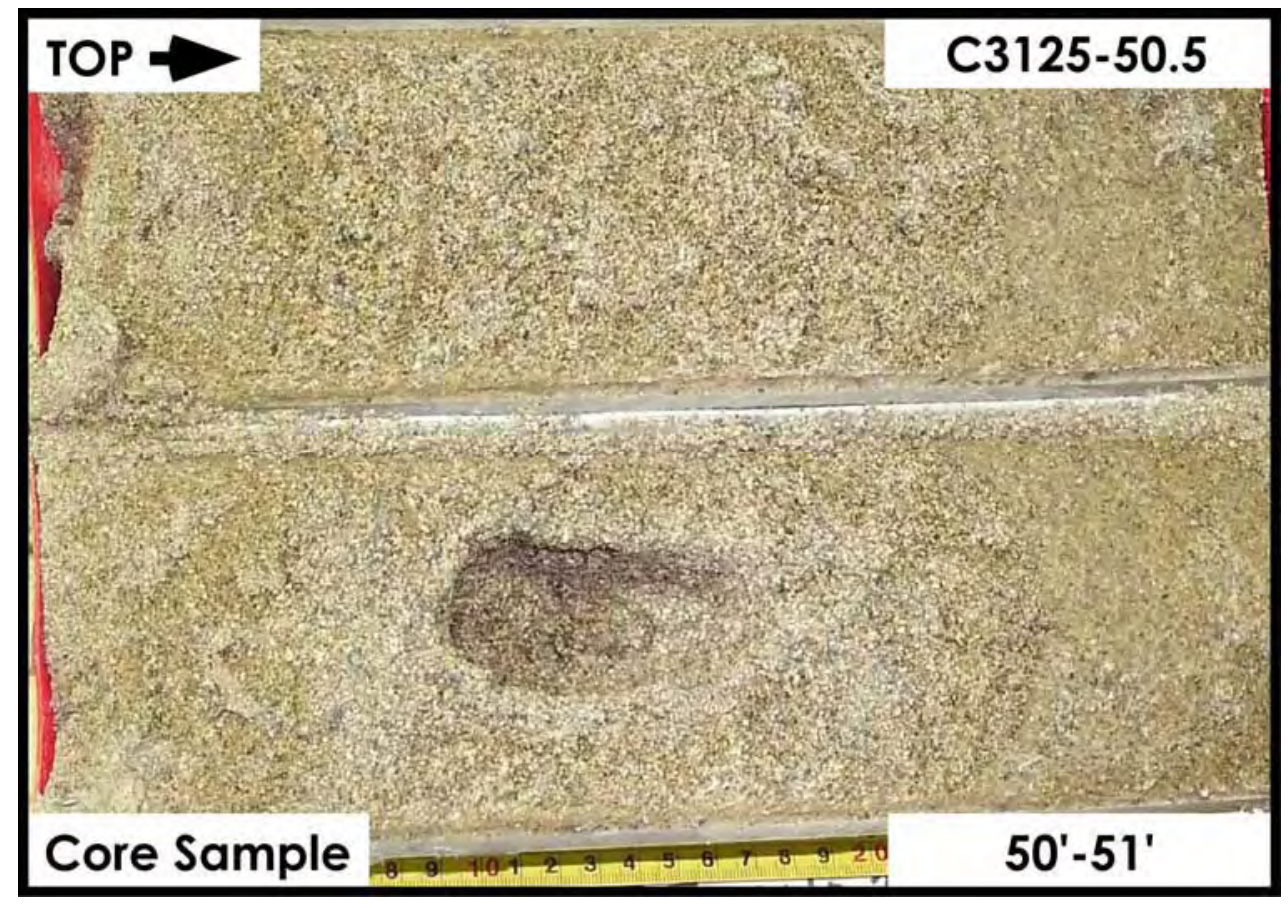

Figure A-1.1. Hanford Formation (H2 unit) $50 \mathrm{ft}-51 \mathrm{ft}$

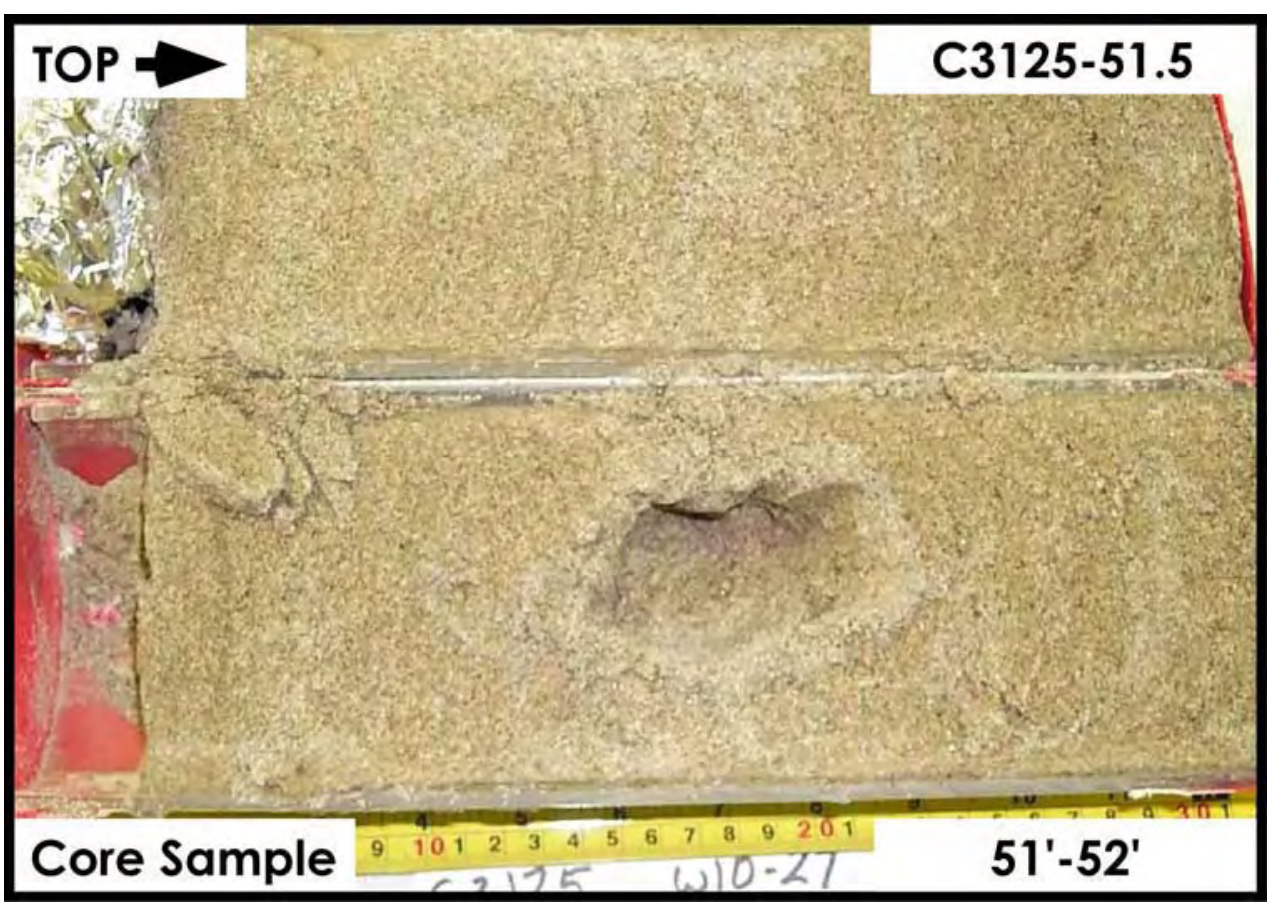

Figure A-1.2. Hanford Formation (H2 unit) $51 \mathrm{ft}-52 \mathrm{ft}$ 


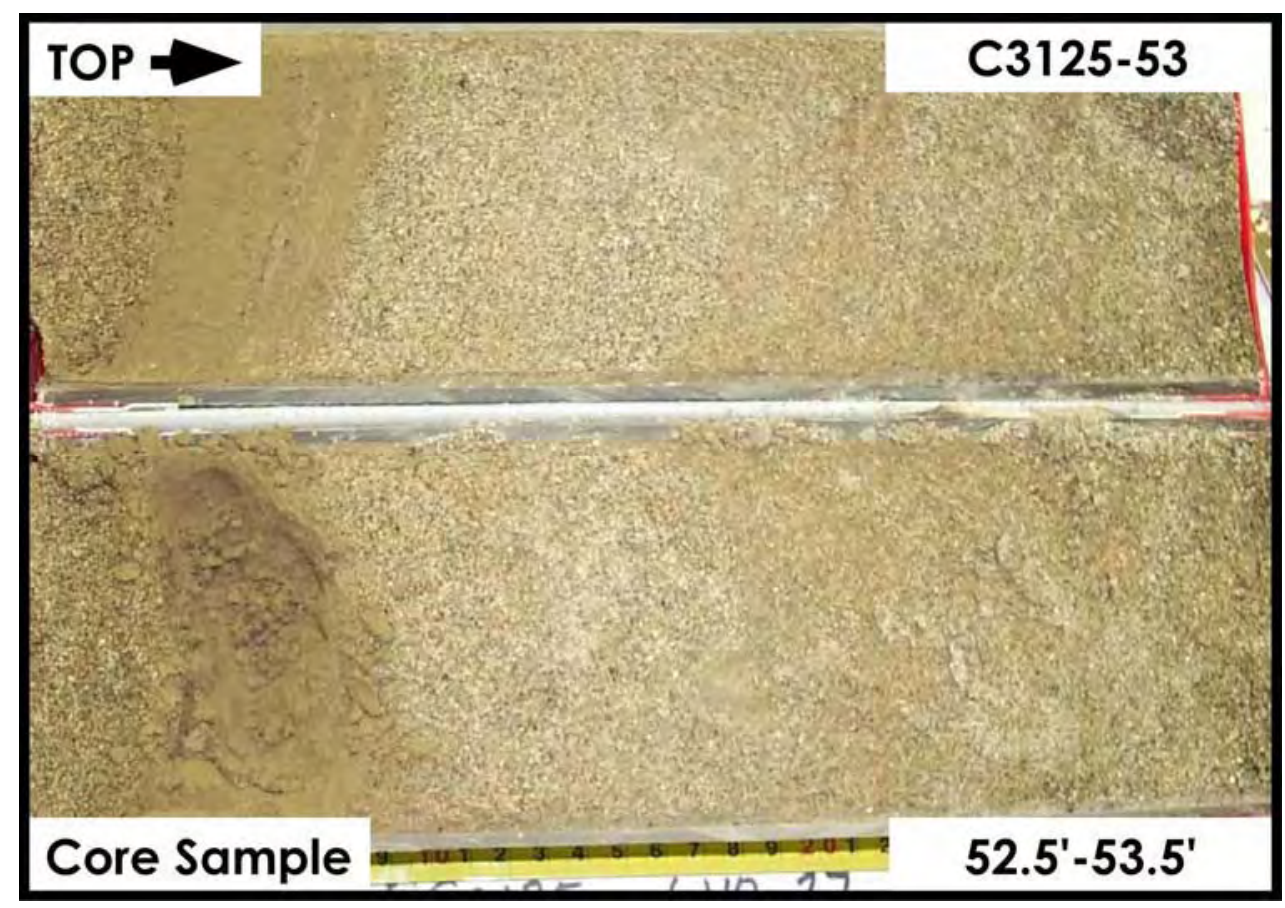

Figure A-1.3. Hanford Formation (H2 unit) $52.5 \mathrm{ft}-53.5 \mathrm{ft}$

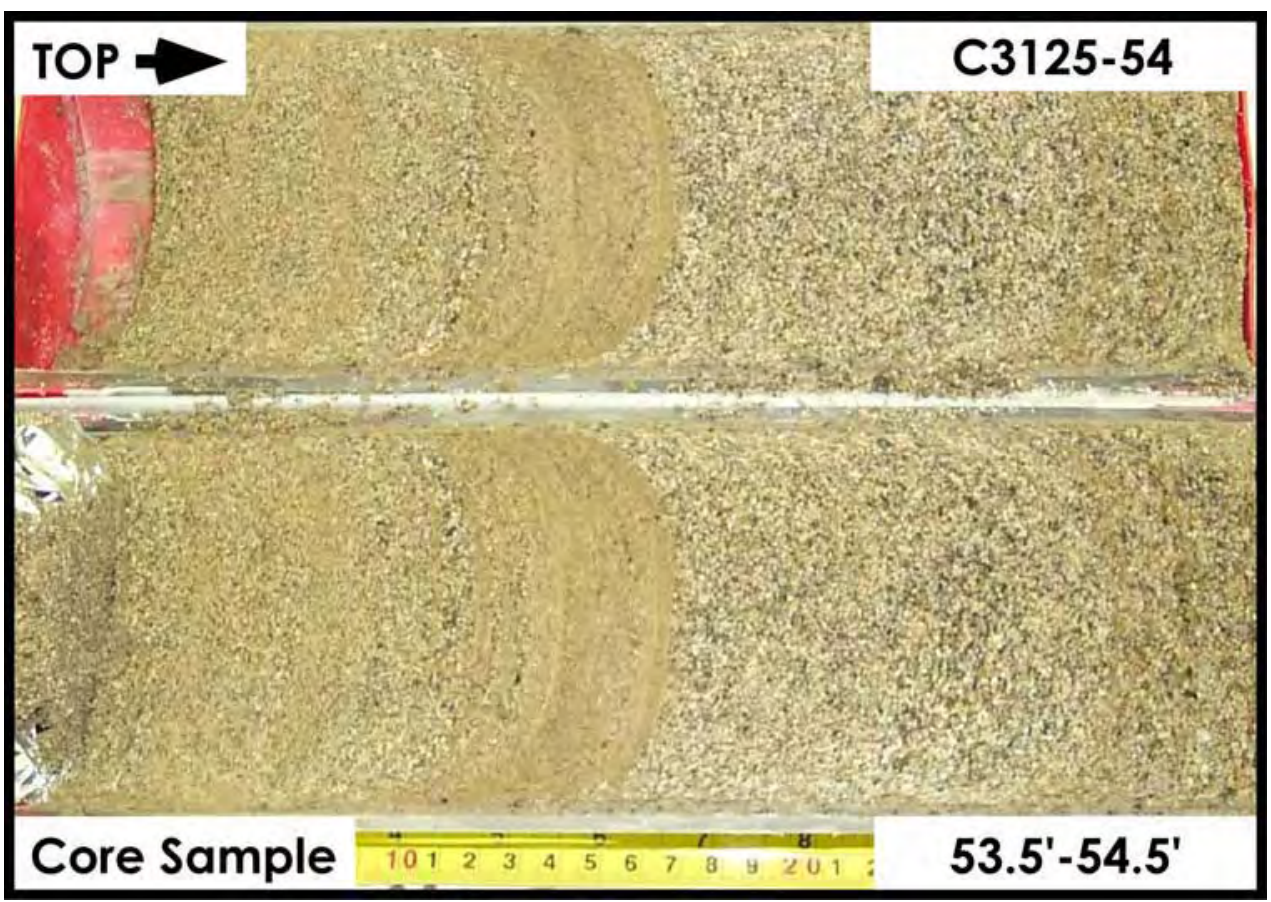

Figure A-1.4. Hanford Formation (H2 unit) $53.5 \mathrm{ft}-54.5 \mathrm{ft}$ 


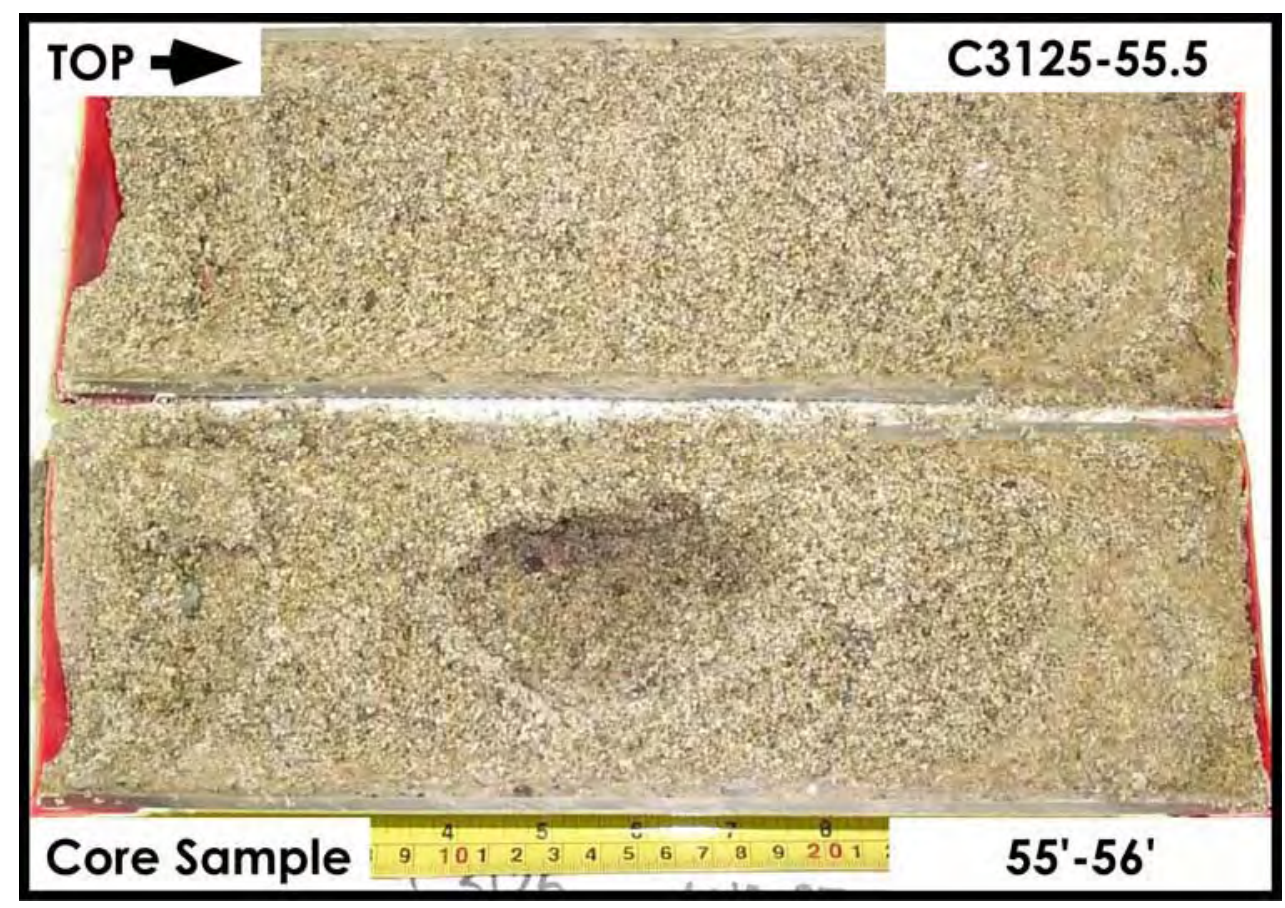

Figure A-1.5. Hanford Formation (H2 unit) $55 \mathrm{ft}-56 \mathrm{ft}$

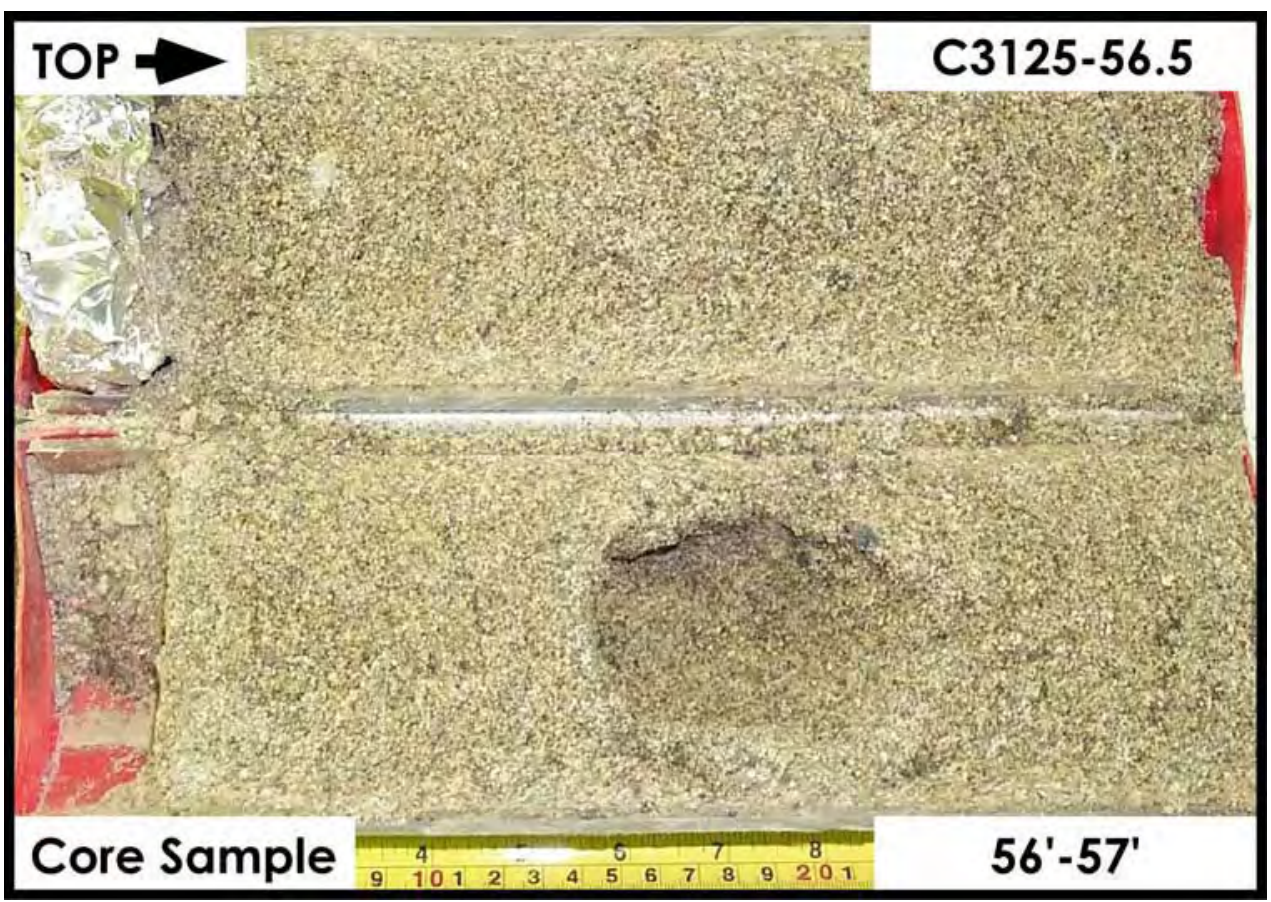

Figure A-1.6. Hanford Formation (H2 unit) $56 \mathrm{ft}-57 \mathrm{ft}$ 


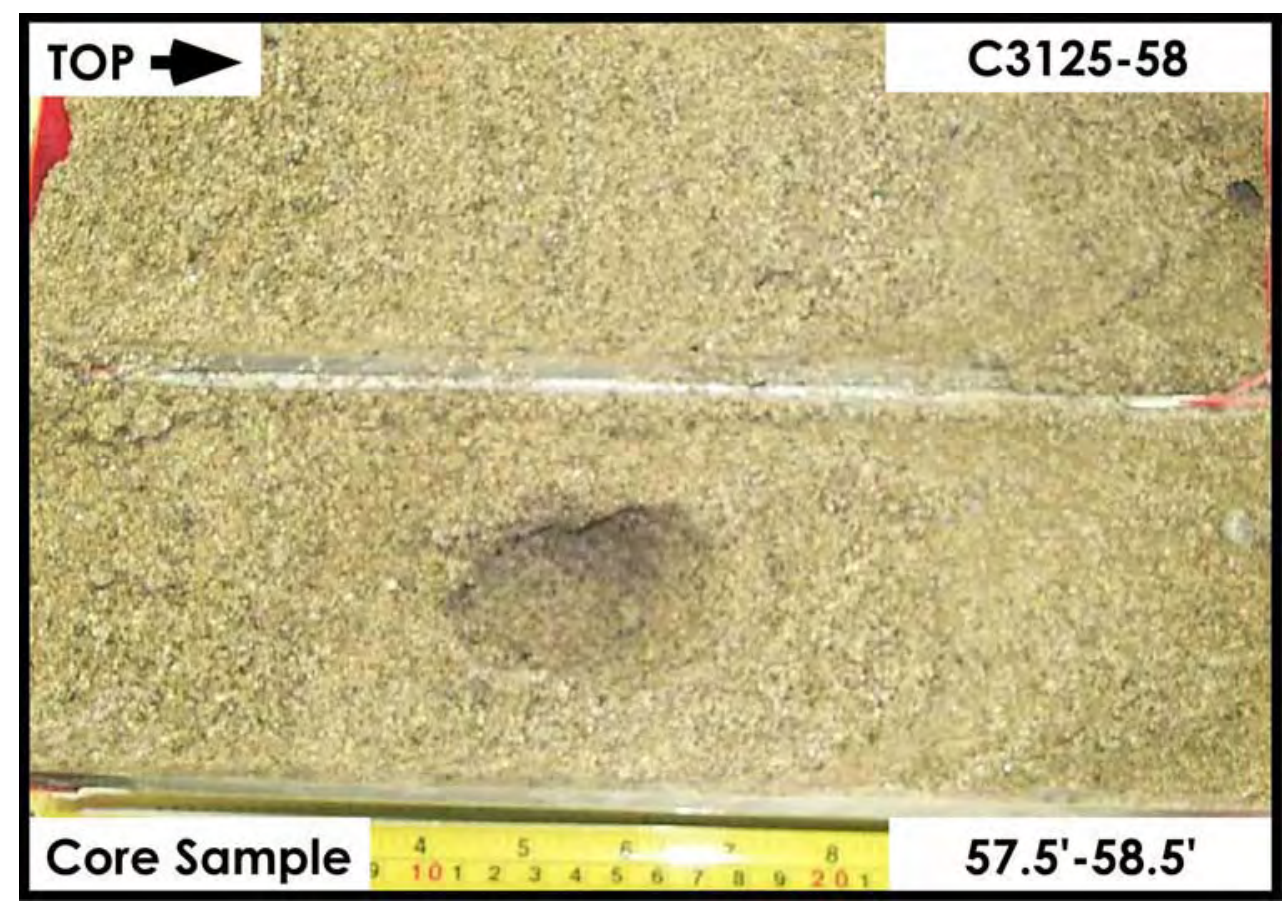

Figure A-1.7. Hanford Formation (H2 unit) $57.5 \mathrm{ft}-\mathbf{5 8 . 5} \mathrm{ft}$

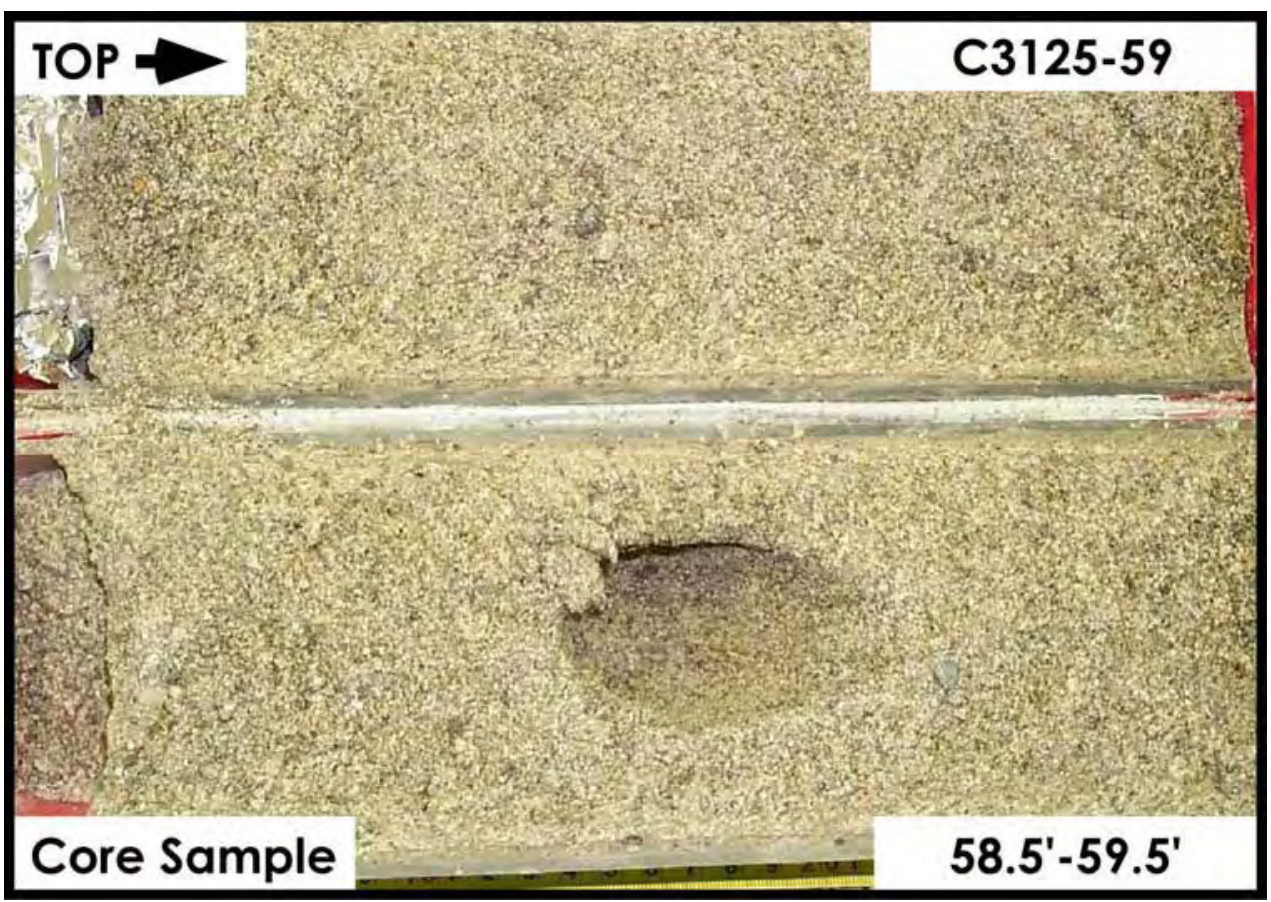

Figure A-1.8. Hanford Formation (H2 unit) $58.5 \mathrm{ft}-59.5 \mathrm{ft}$ 


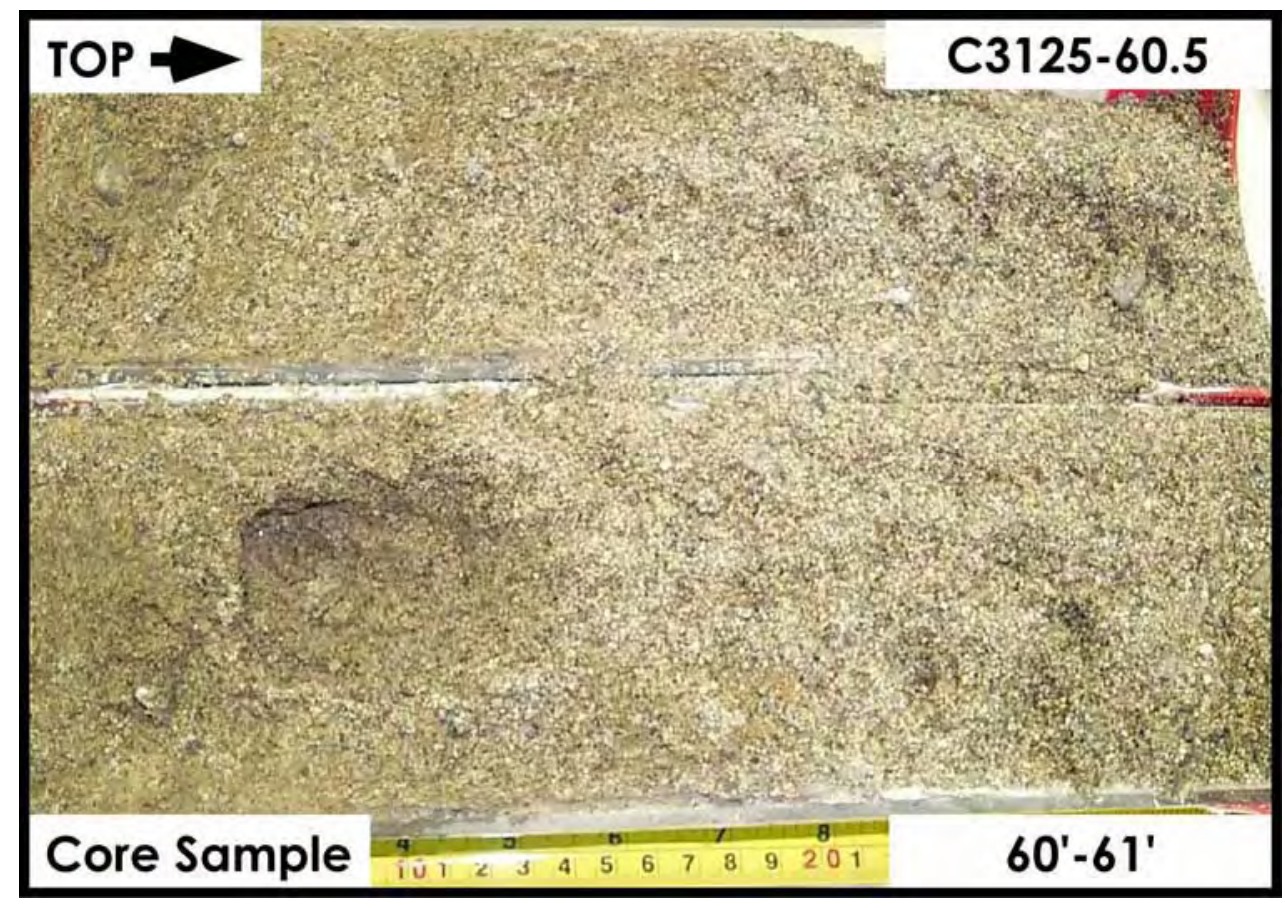

Figure A-1.9. Hanford Formation (H2 unit) $60 \mathrm{ft}-61 \mathrm{ft}$

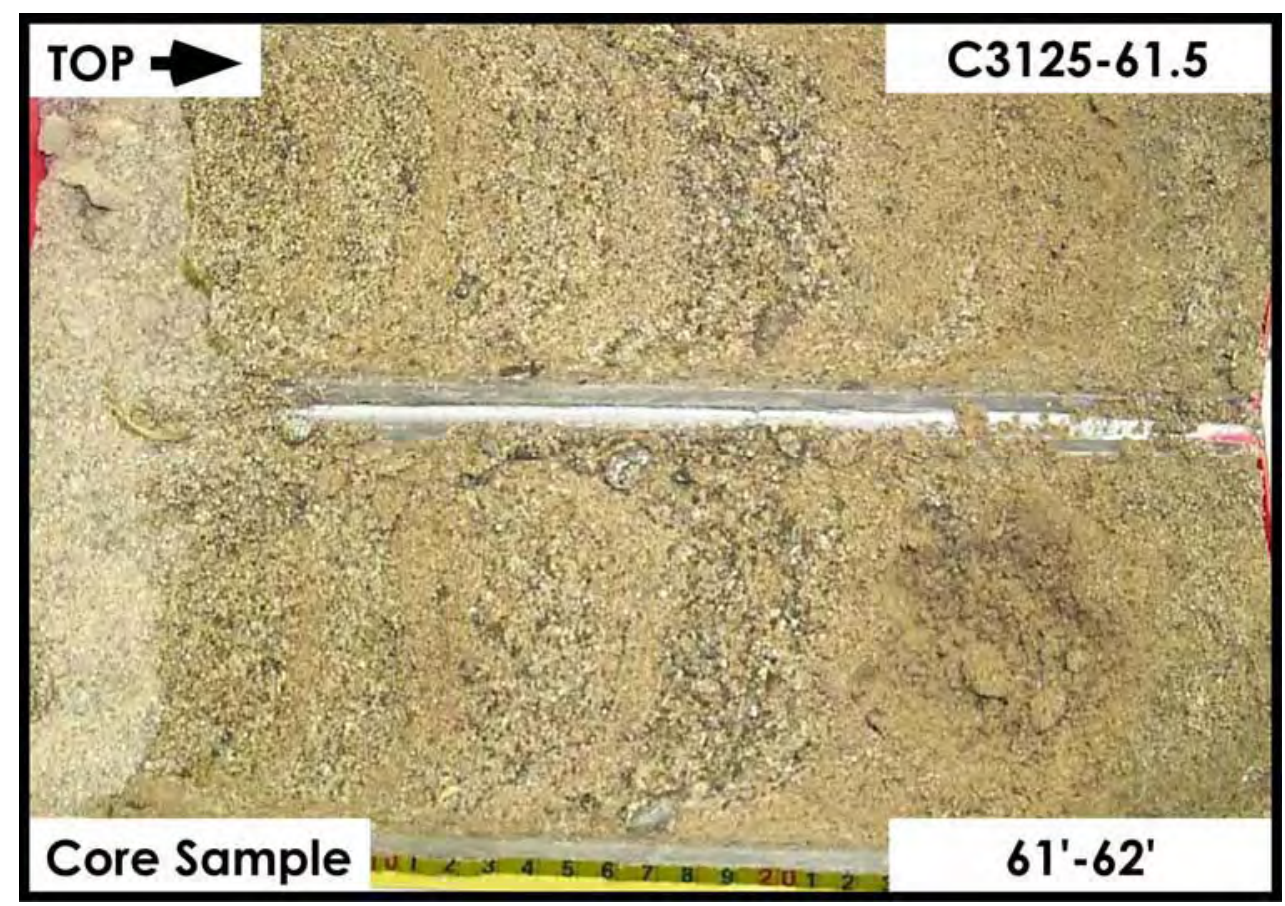

Figure A-1.10. Hanford Formation (H2 unit) $61 \mathrm{ft}-62 \mathrm{ft}$ 


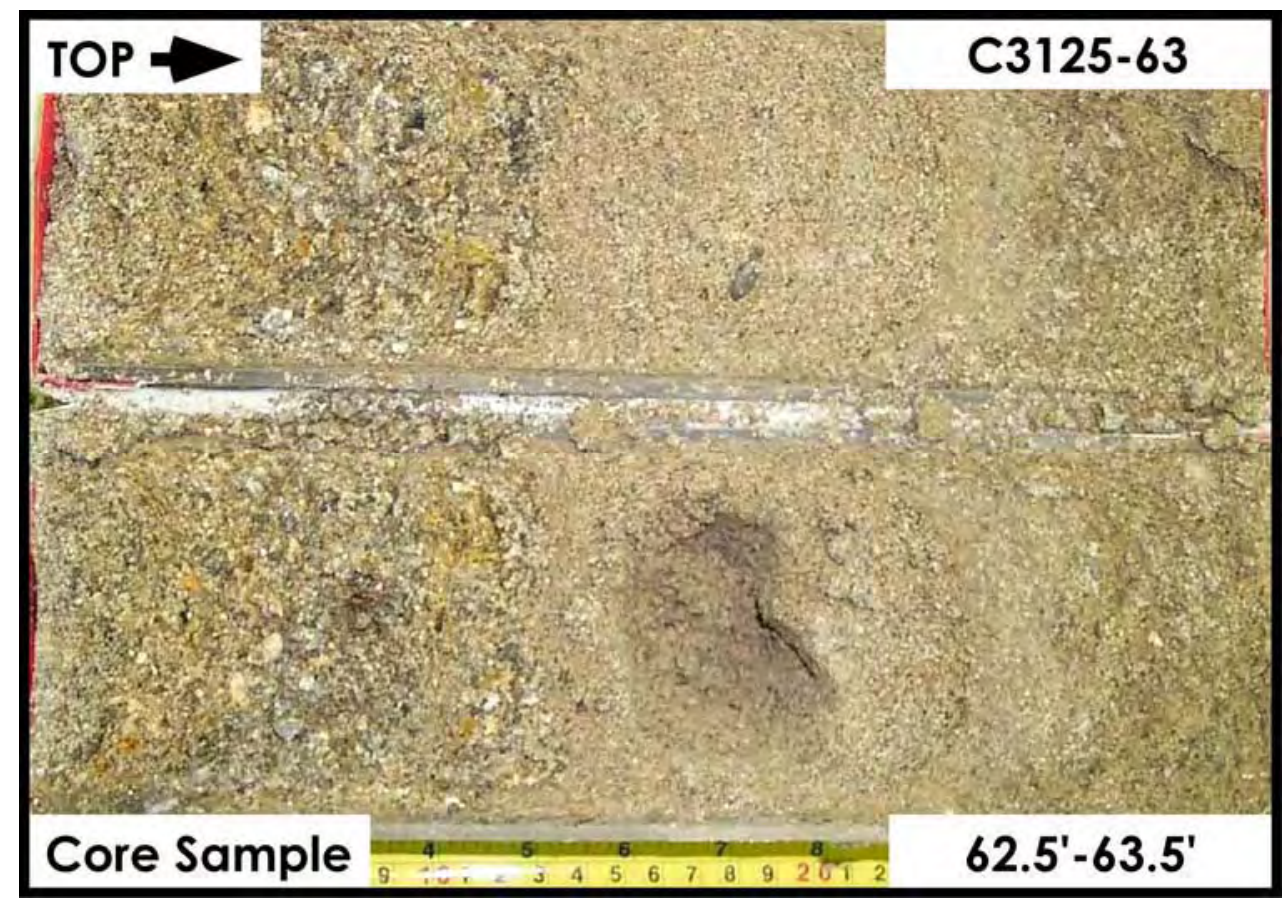

Figure A-1.11. Hanford Formation (H2 unit) $62.5 \mathrm{ft}-63.5 \mathrm{ft}$

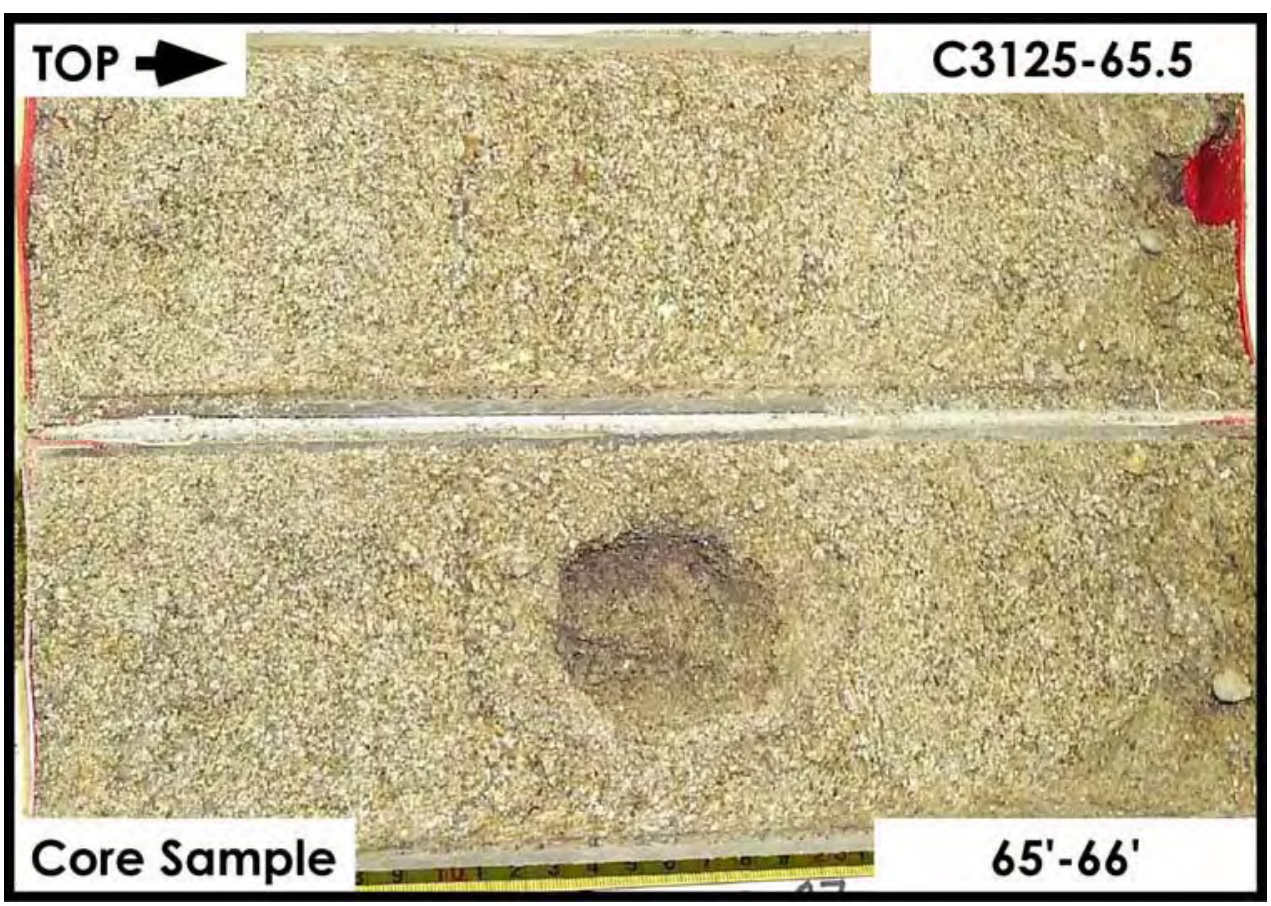

Figure A-1.12. Hanford Formation (H2 unit) $65 \mathrm{ft}-66 \mathrm{ft}$ 


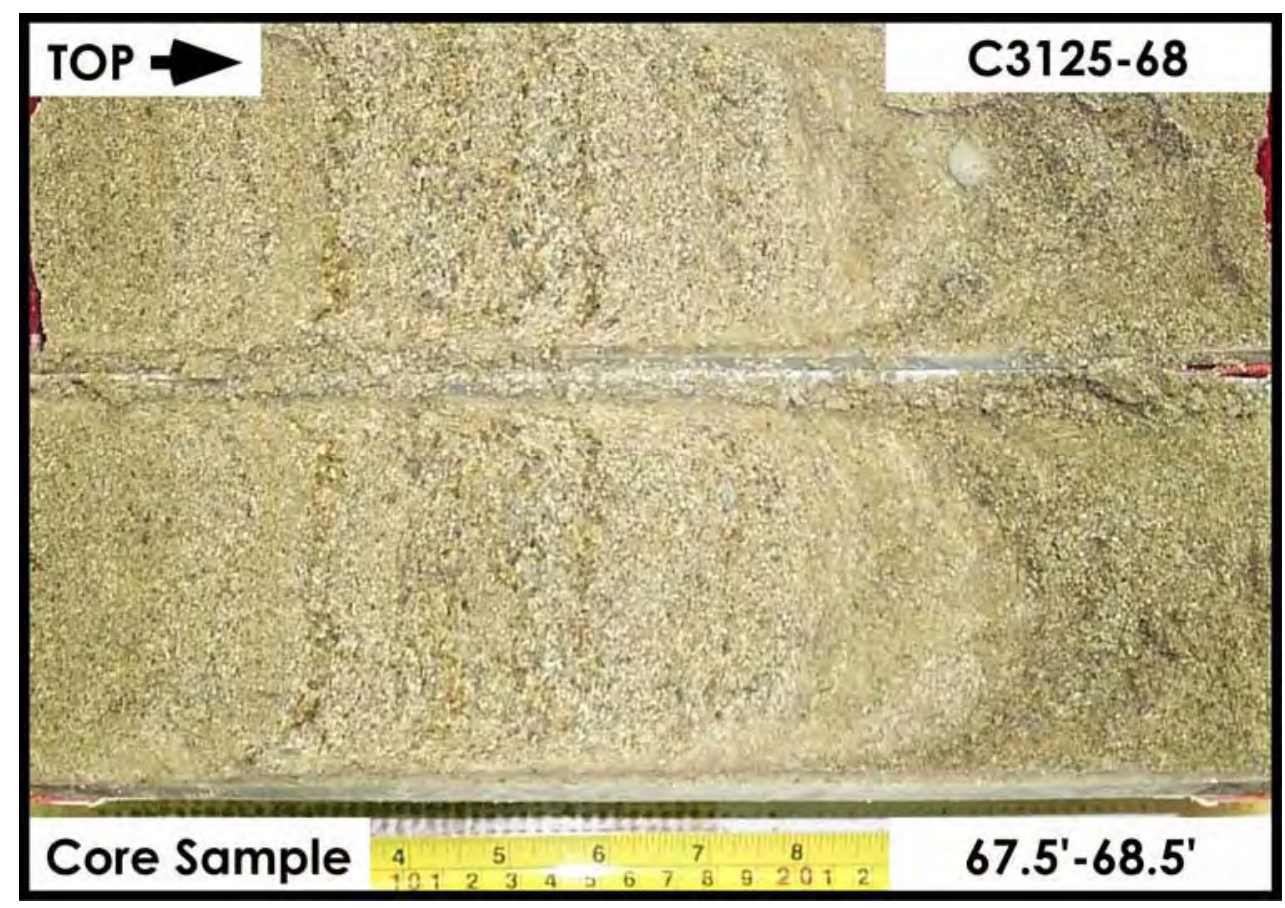

Figure A-1.13. Hanford Formation (H2 unit) $67.5 \mathrm{ft}-68.5 \mathrm{ft}$

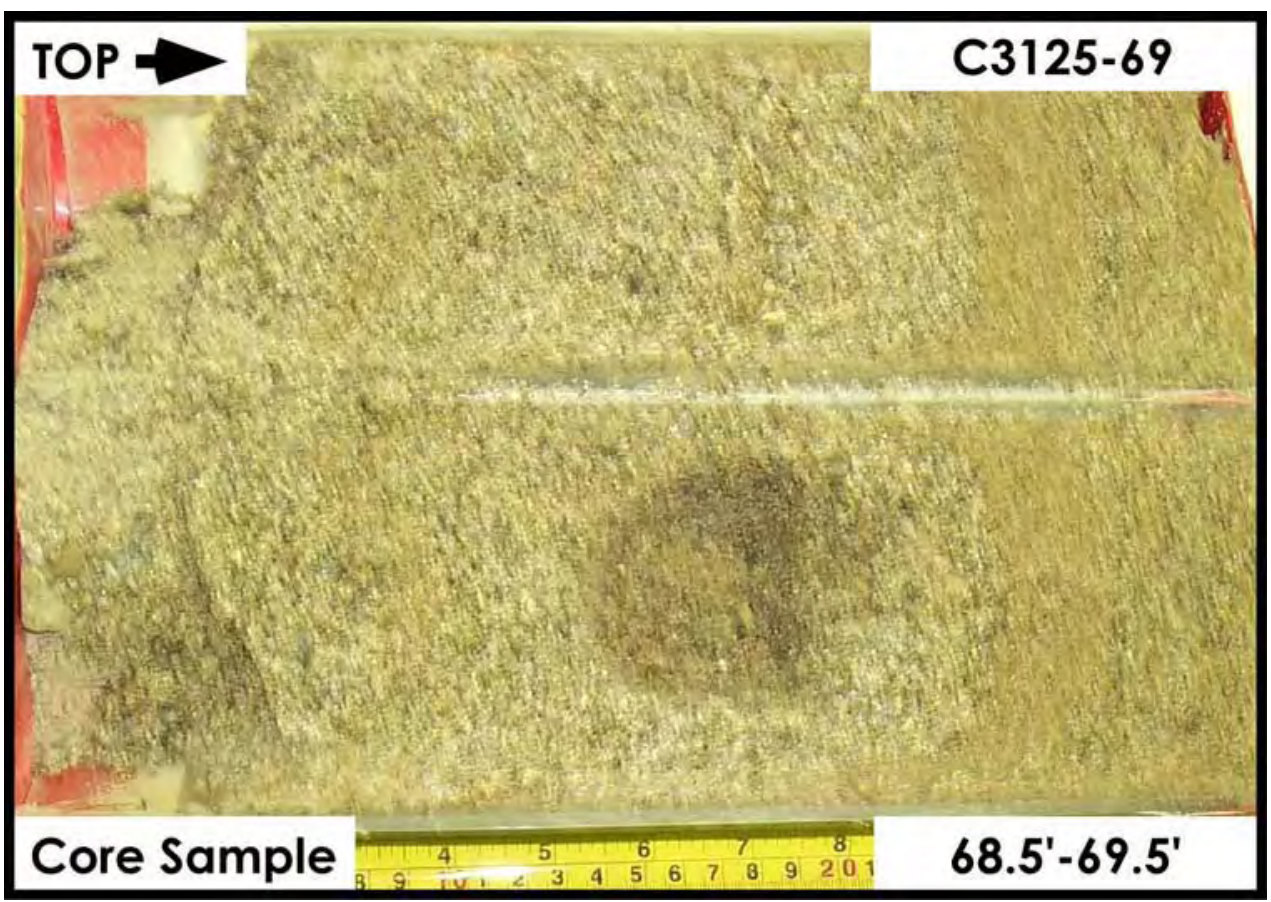

Figure A-1.14. Hanford Formation (H2 unit) $68.5 \mathrm{ft}-69.5 \mathrm{ft}$ 


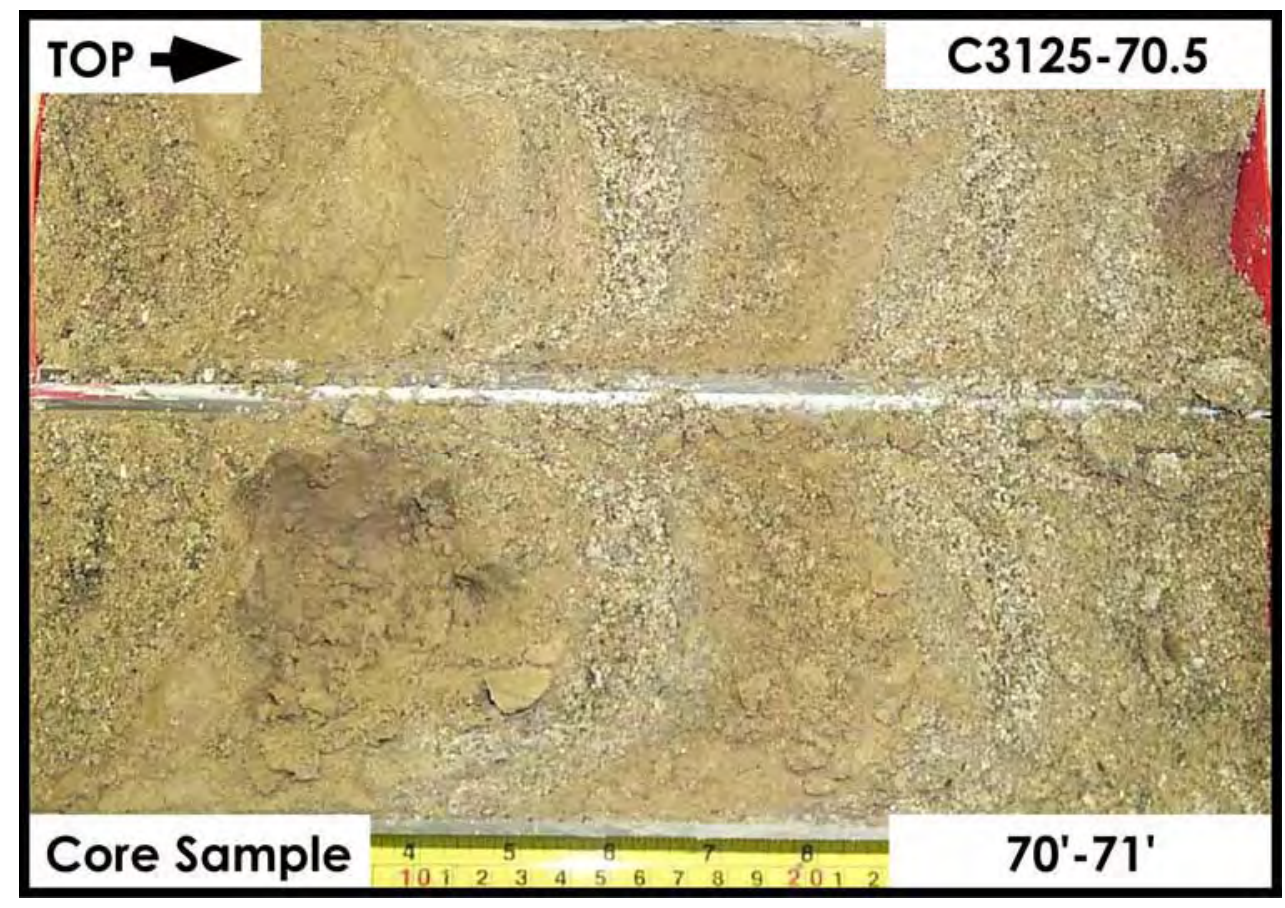

Figure A-1.15. Hanford Formation (H2 unit) $70 \mathrm{ft}-71 \mathrm{ft}$

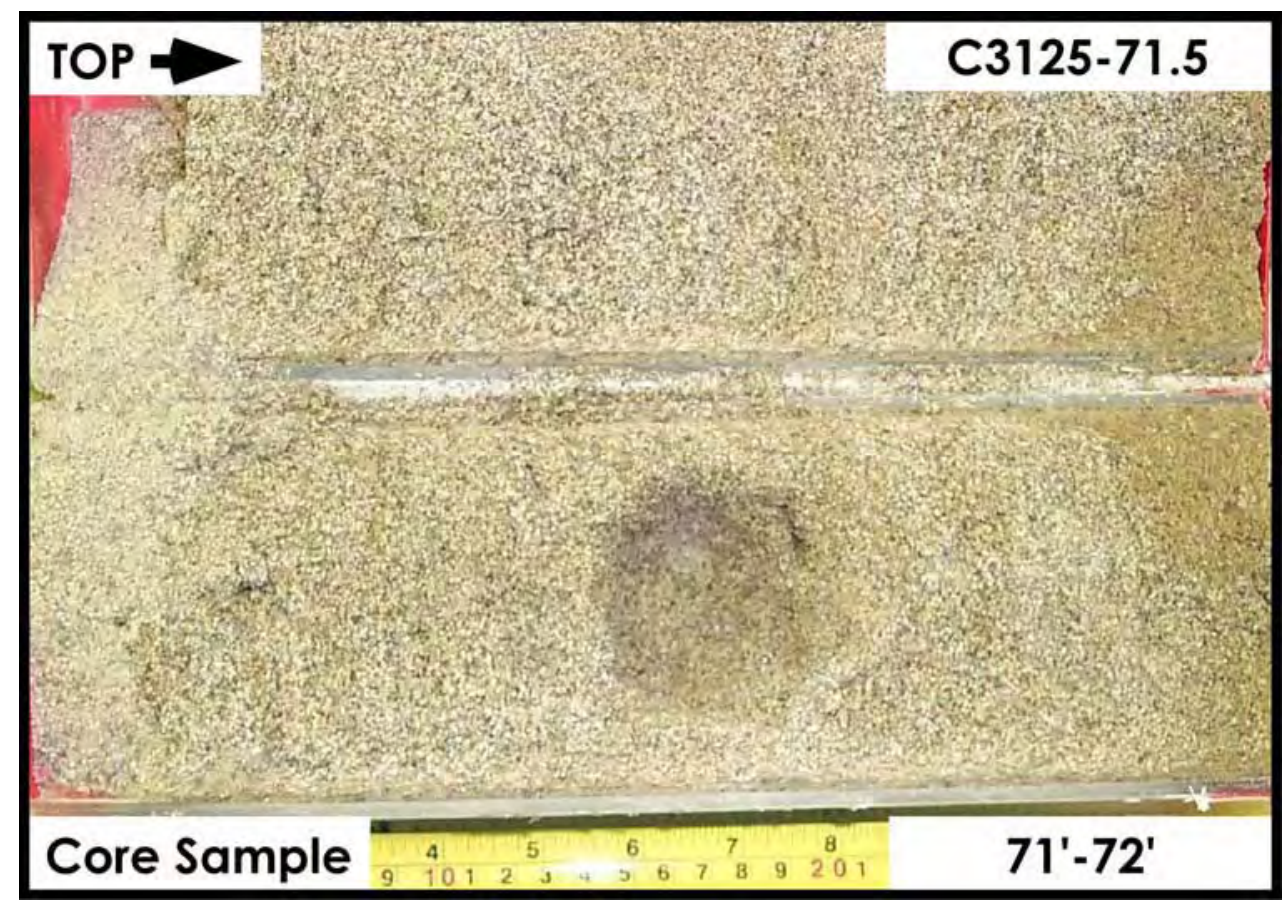

Figure A-1.16. Hanford Formation (H2 unit) $71 \mathrm{ft}-72 \mathrm{ft}$ 


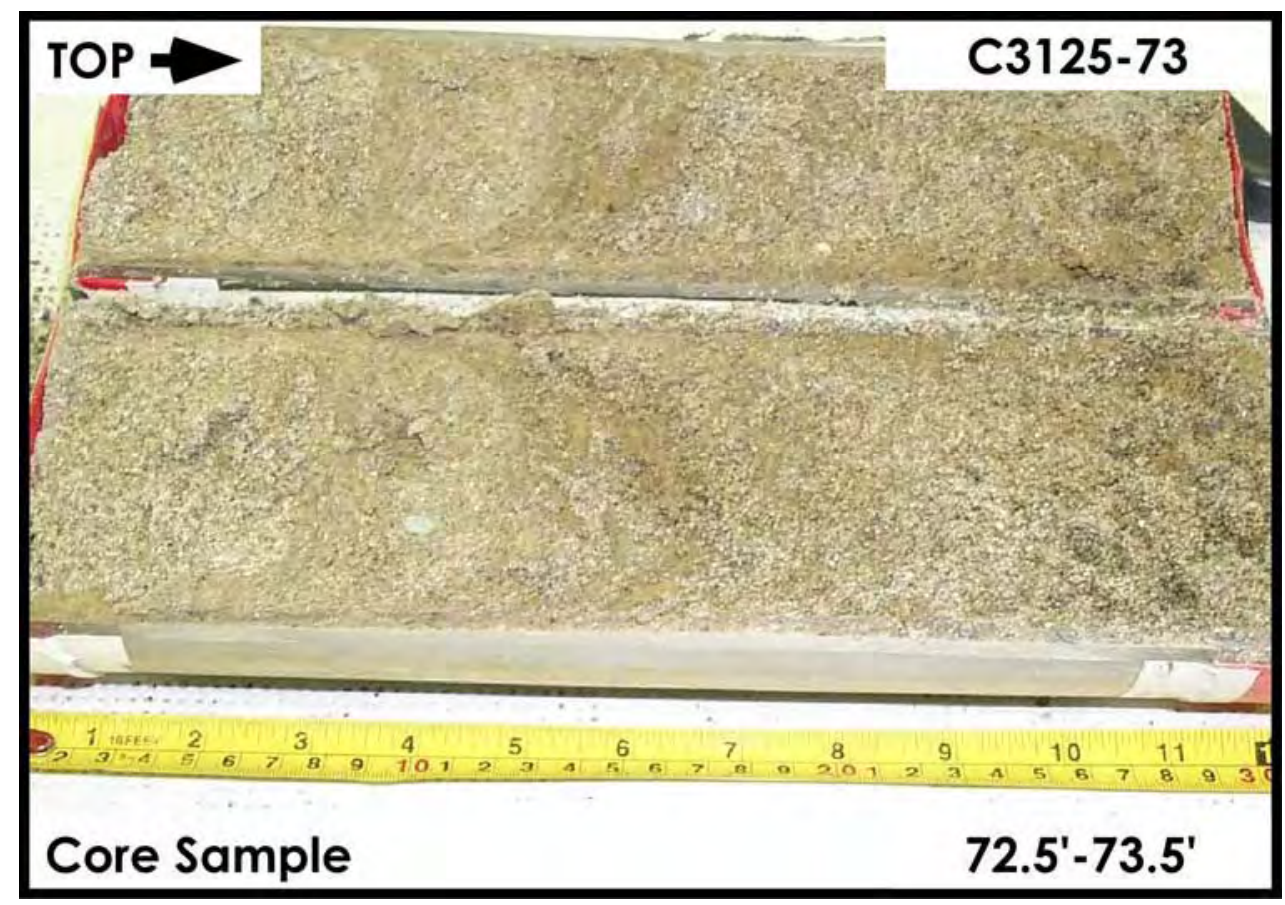

Figure A-1.17. Hanford Formation (H2 unit) $72.5 \mathrm{ft}-73.5 \mathrm{ft}$

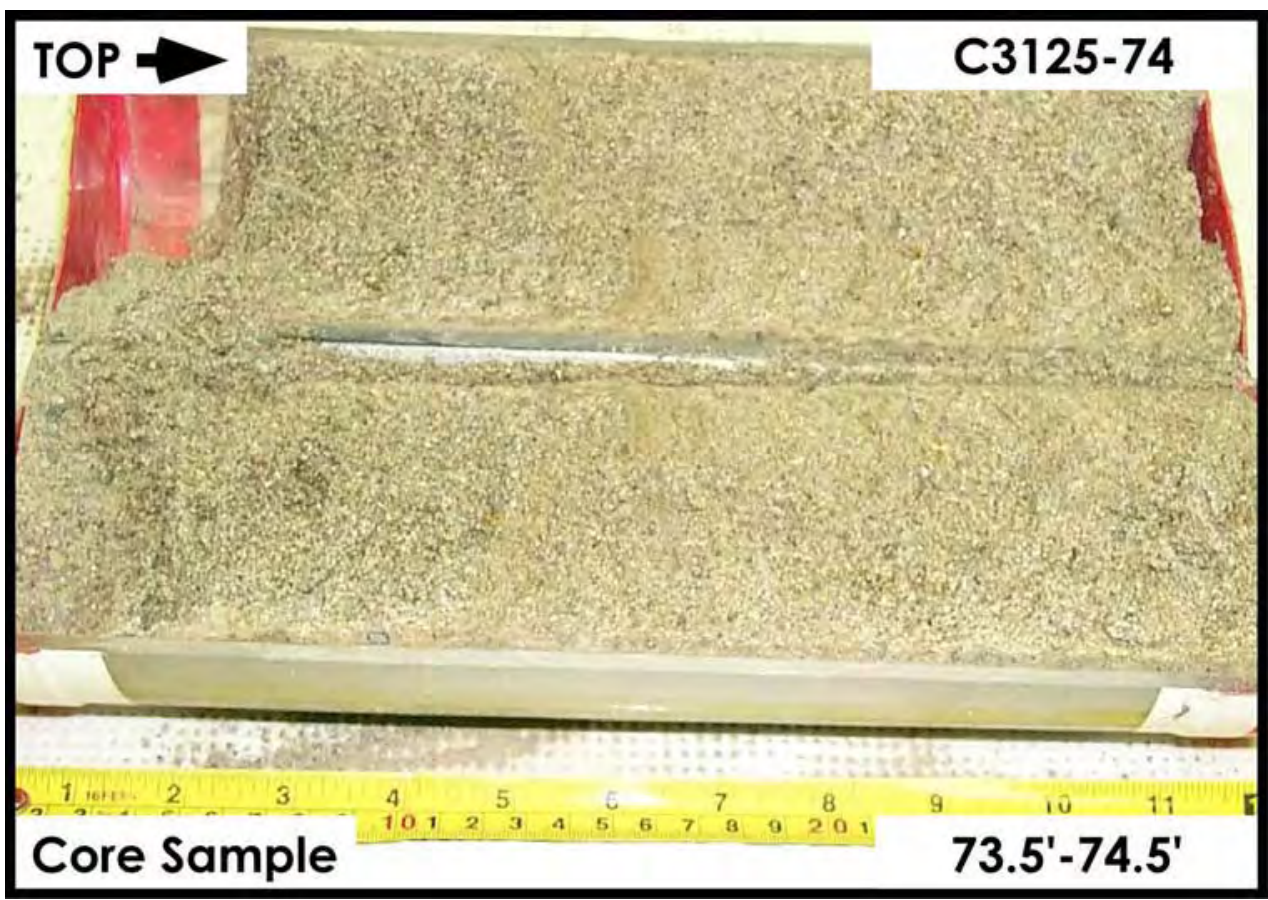

Figure A-1.18. Hanford Formation (H2 unit) $73.5 \mathrm{ft}-74.5 \mathrm{ft}$ 


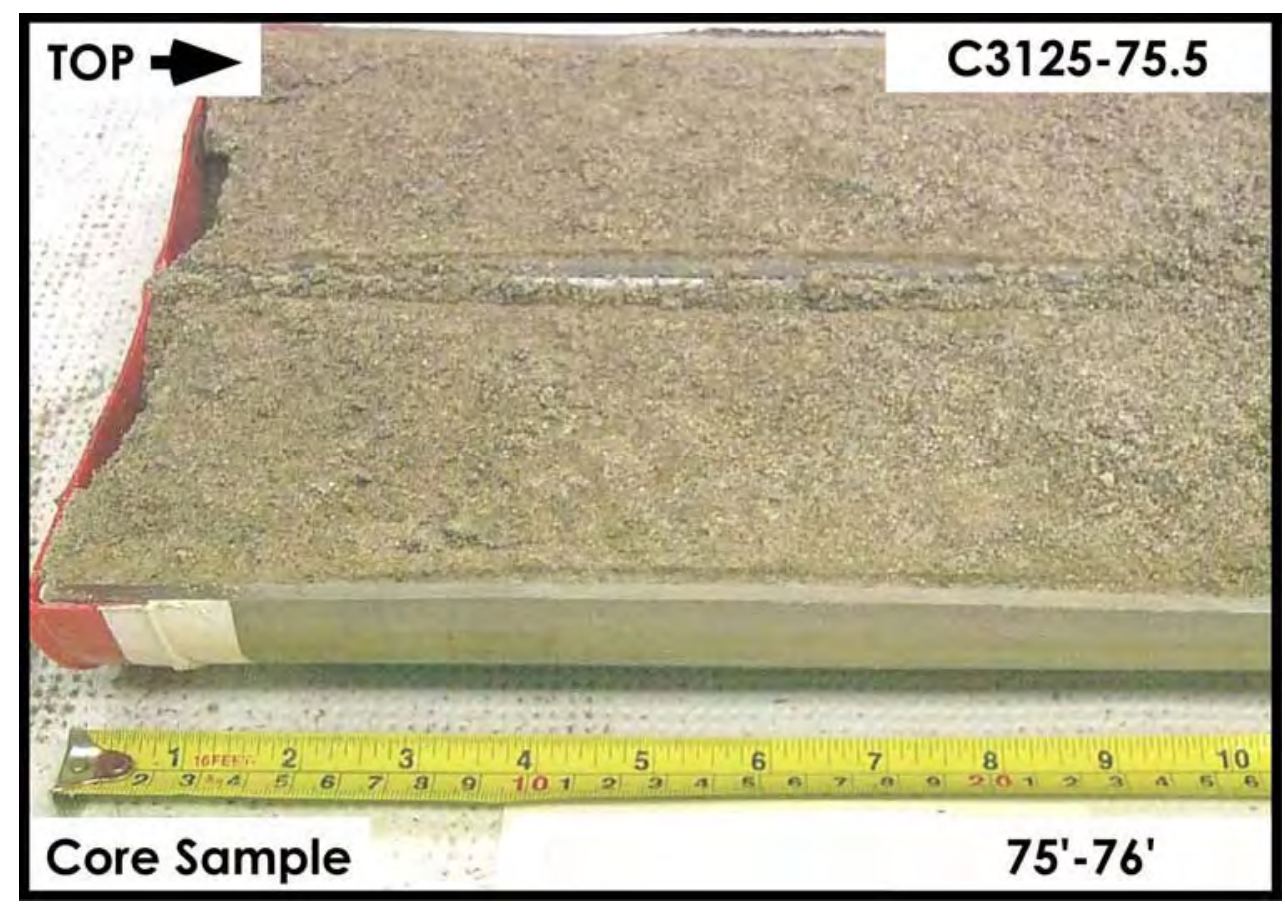

Figure A-1.19. Hanford Formation (H2 unit) $75 \mathrm{ft}-76 \mathrm{ft}$

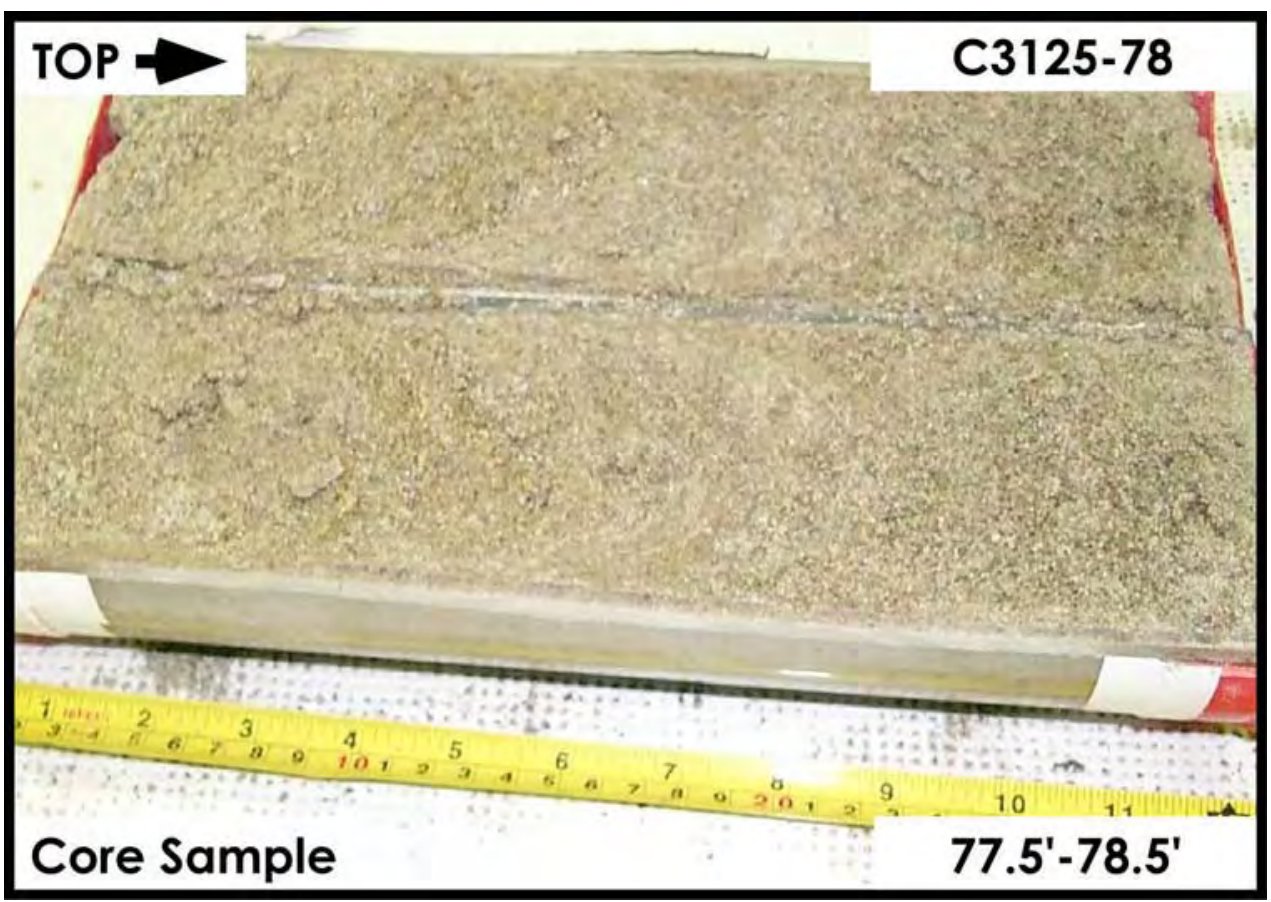

Figure A-1.20. Hanford Formation (H2 unit) $77.5 \mathrm{ft}-78.5 \mathrm{ft}$ 


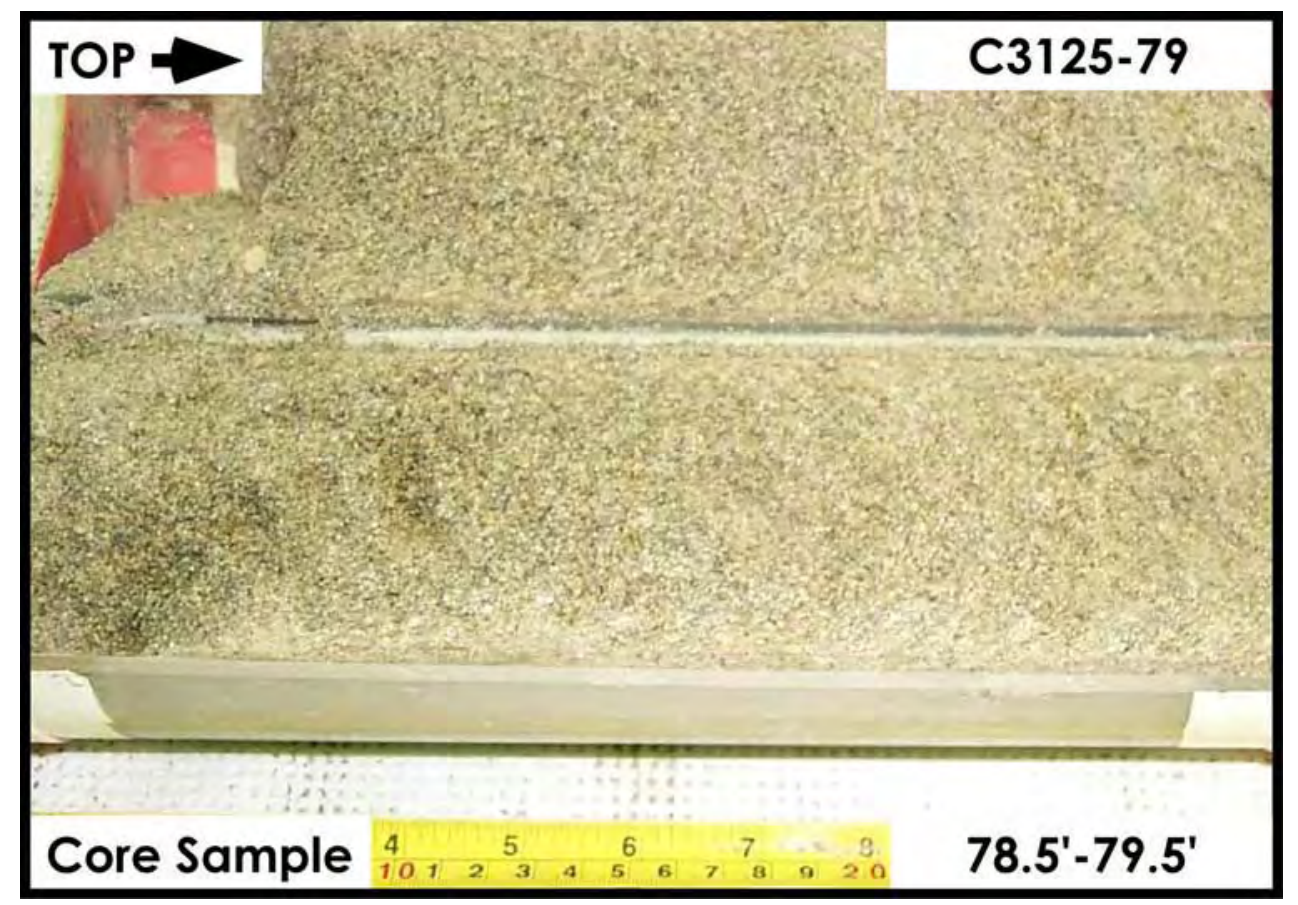

Figure A-1.21. Hanford Formation (H2 unit) $78.5 \mathrm{ft}-79.5 \mathrm{ft}$

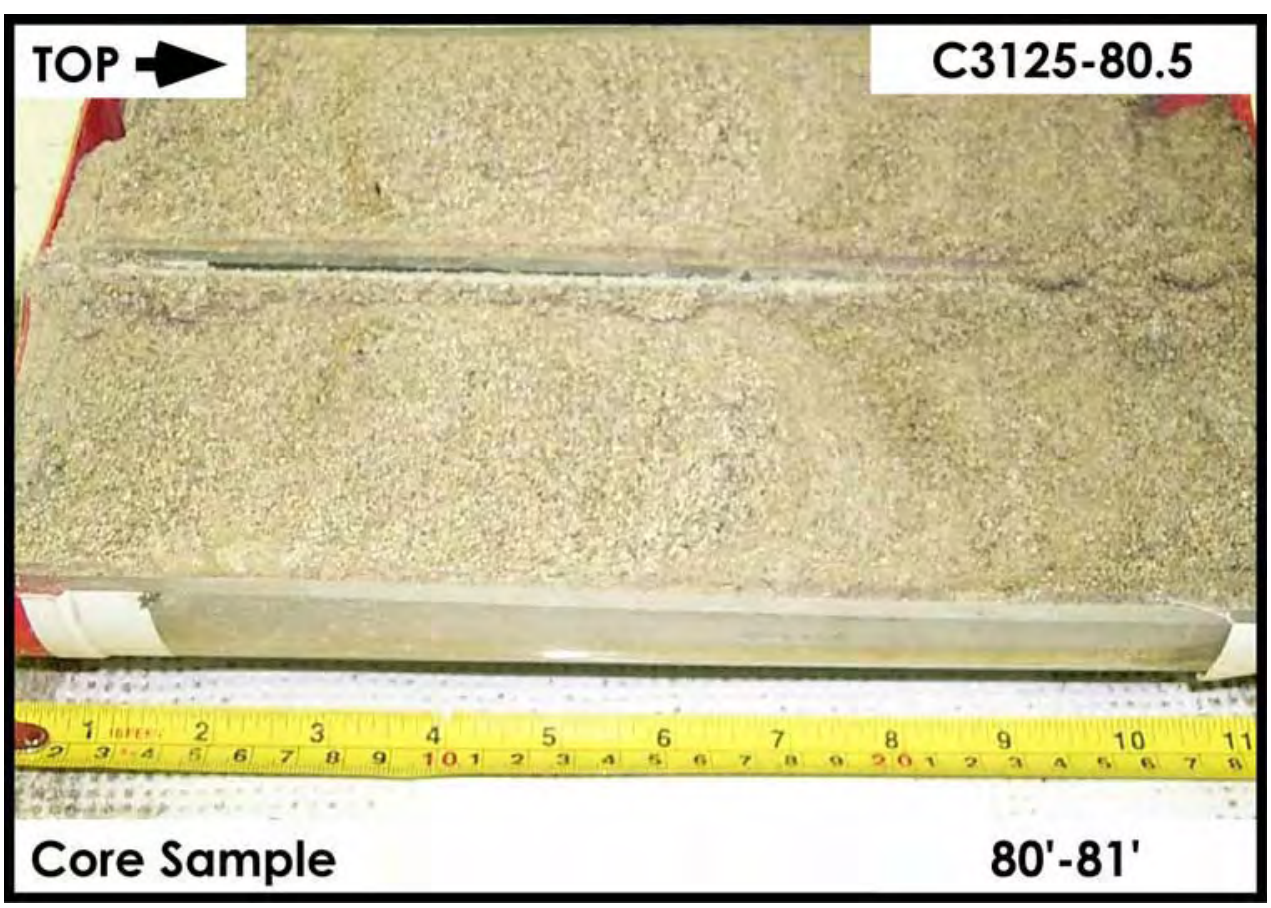

Figure A-1.22. Hanford Formation (H2 unit) $80 \mathrm{ft}-81 \mathrm{ft}$ 


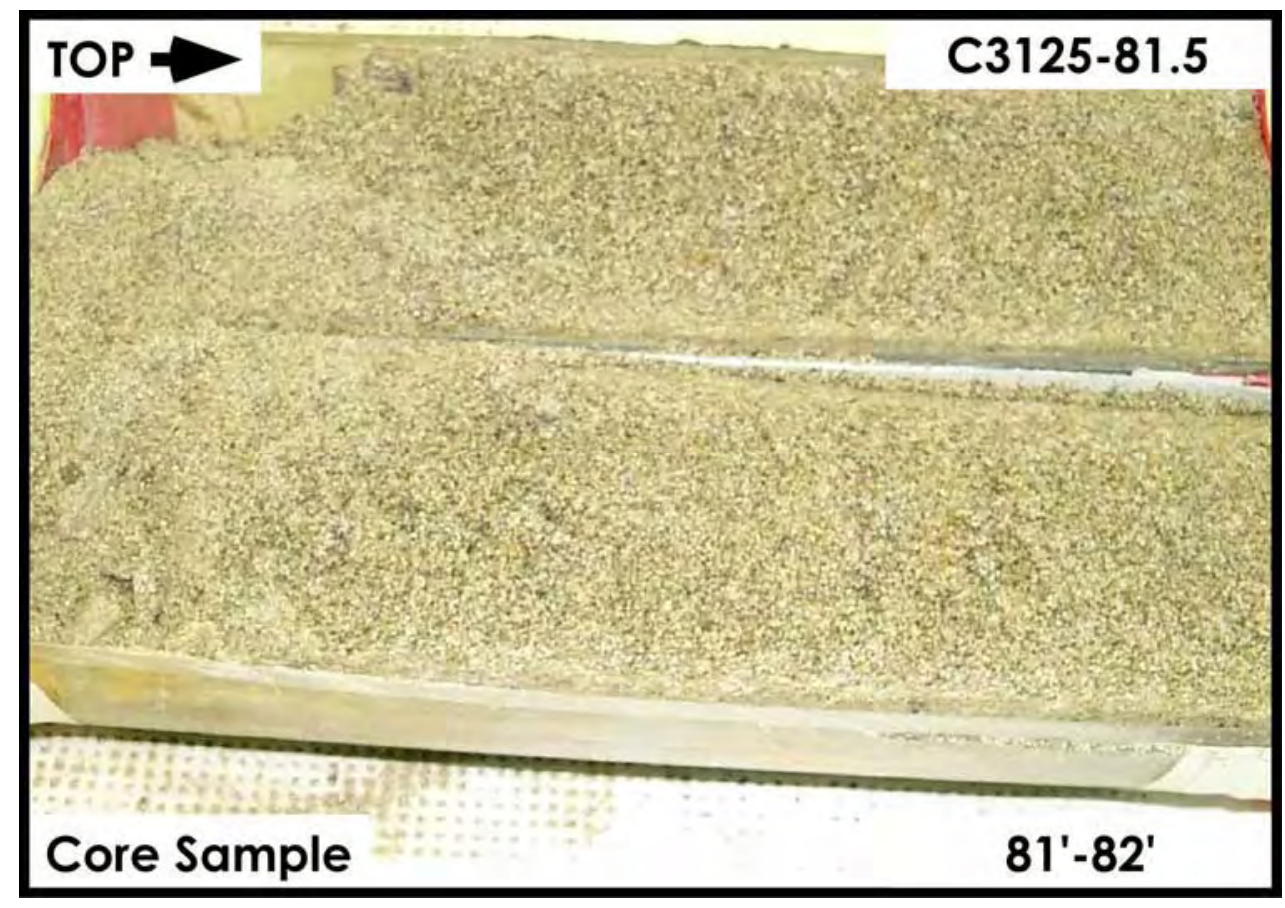

Figure A-1.23. Hanford Formation (H2 unit) $81 \mathrm{ft}-82 \mathrm{ft}$

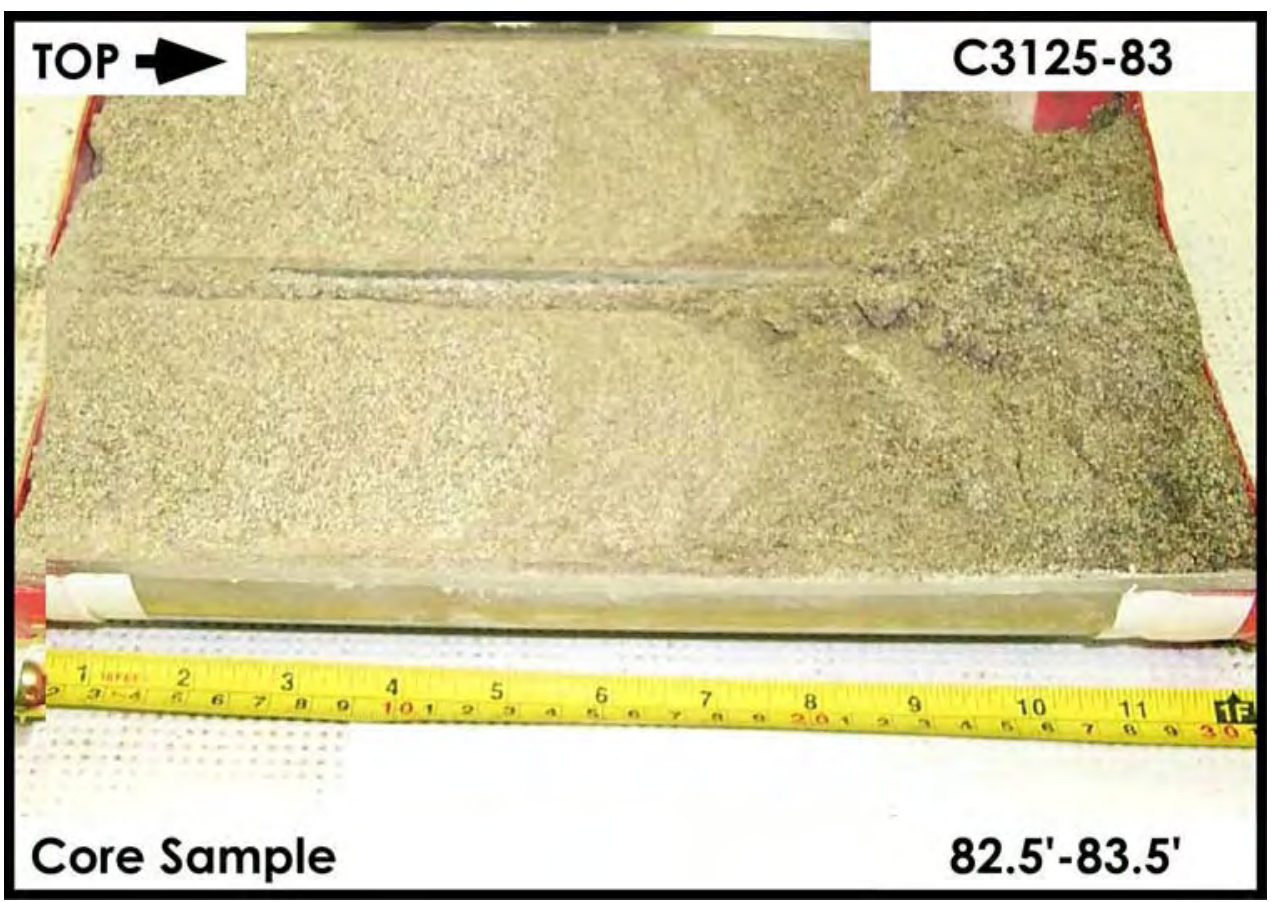

Figure A-1.24. Hanford Formation (H2 unit) $82.5 \mathrm{ft}-83.5 \mathrm{ft}$ 


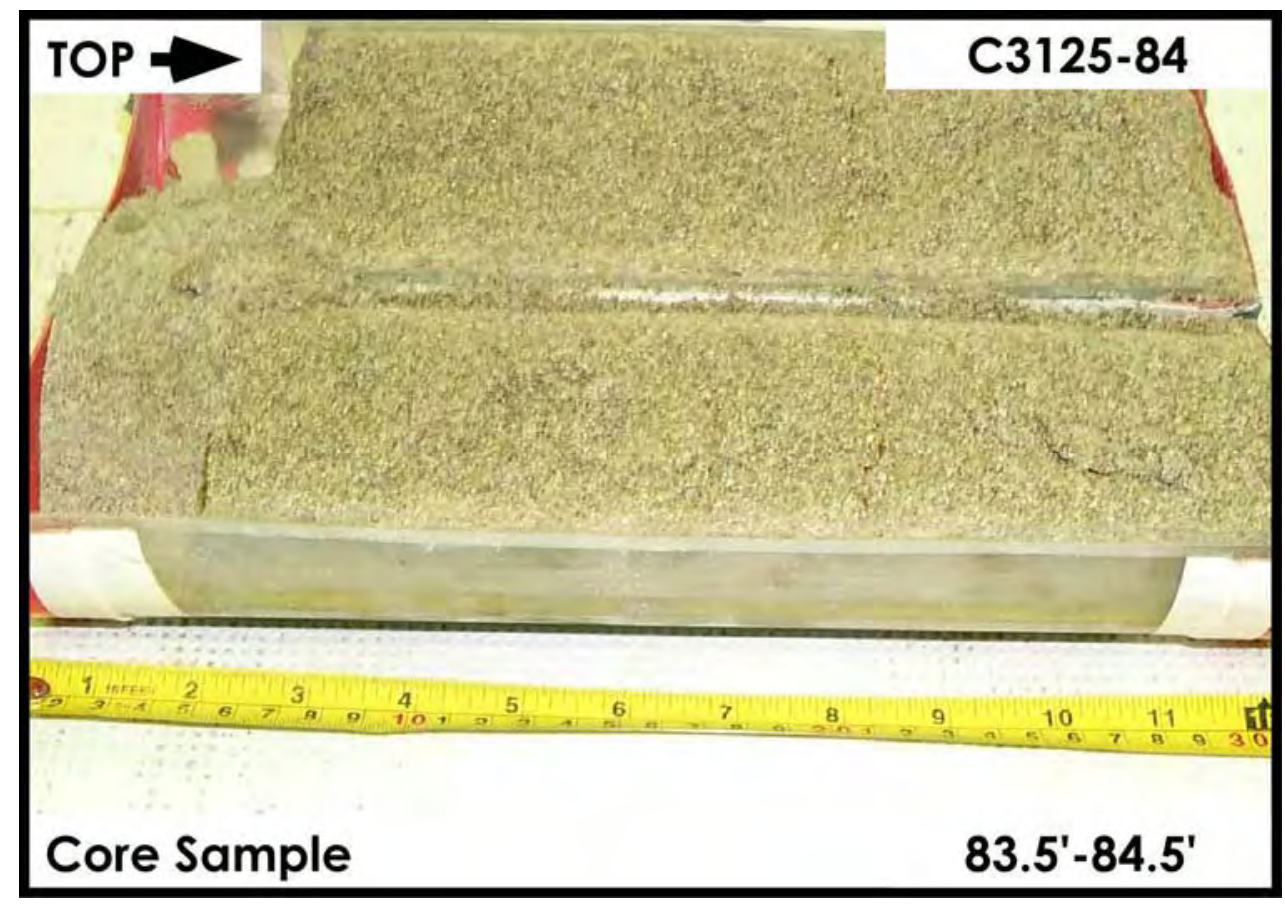

Figure A-1.25. Hanford Formation (H2 unit) $83.5 \mathrm{ft}-84.5 \mathrm{ft}$

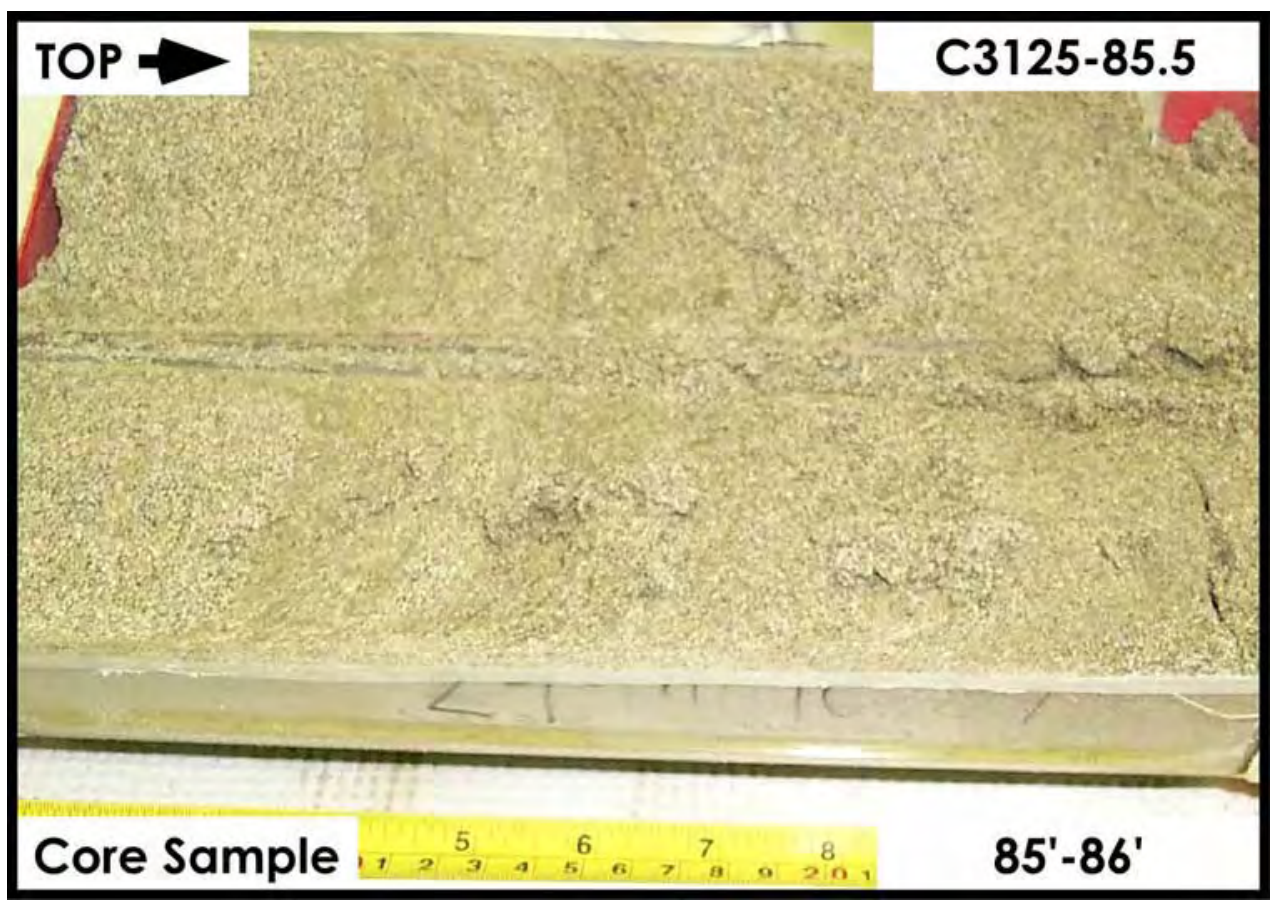

Figure A-1.26. Hanford Formation (H2 unit) $85 \mathrm{ft}-86 \mathrm{ft}$ 


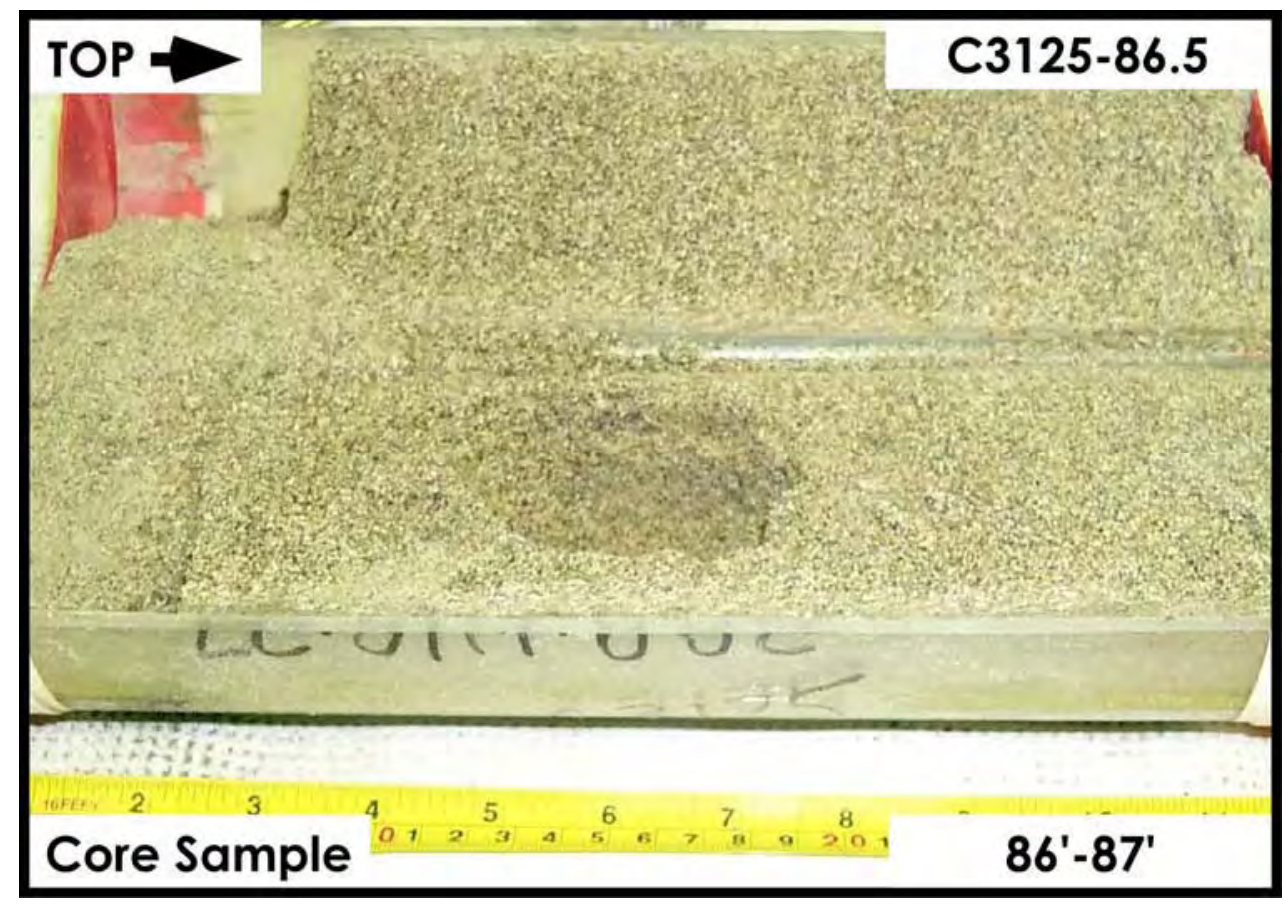

Figure A-1.27. Hanford Formation (H2 unit) $86 \mathrm{ft}-87 \mathrm{ft}$

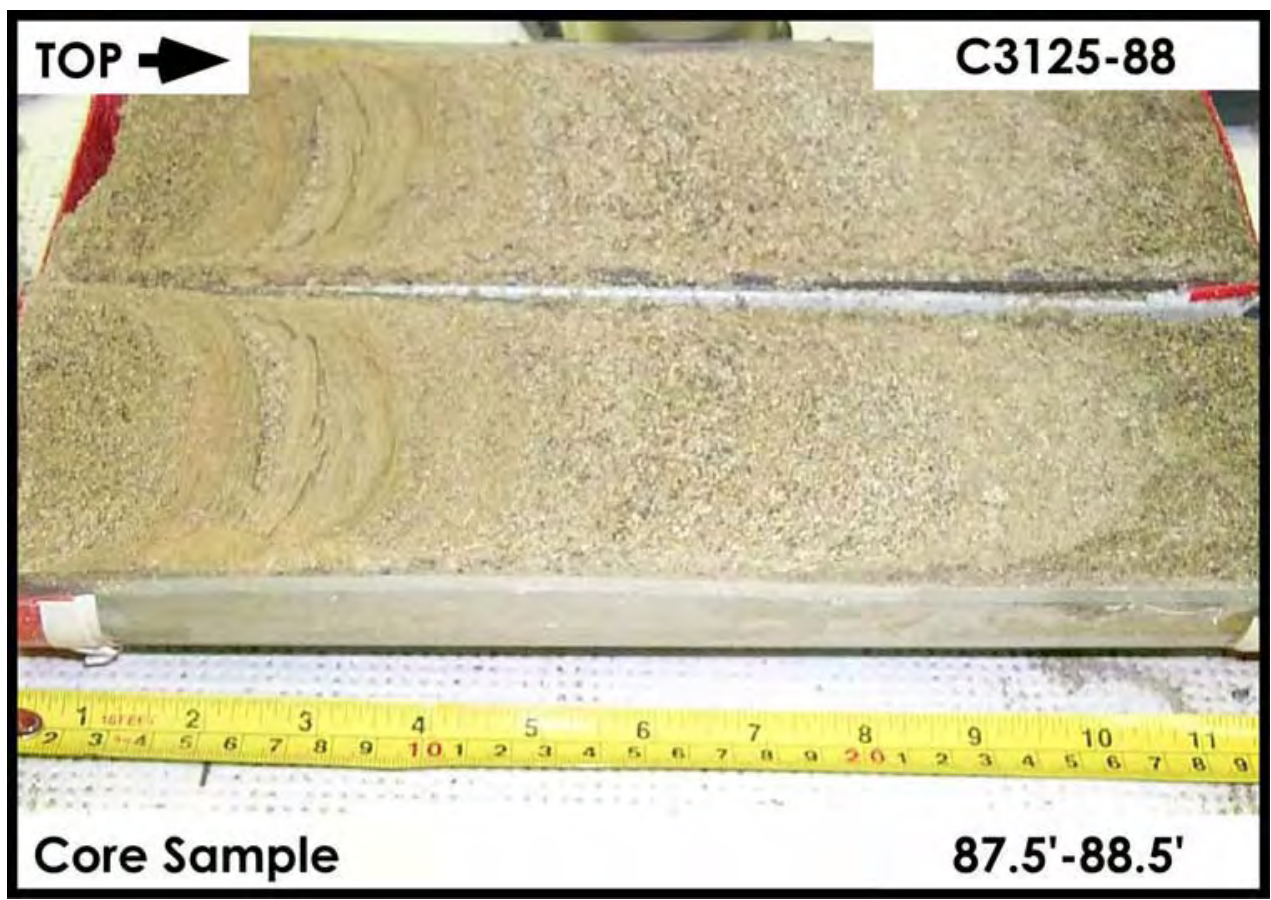

Figure A-1.28. Hanford Formation (H2 unit) $87.5 \mathrm{ft}-88.5 \mathrm{ft}$ 


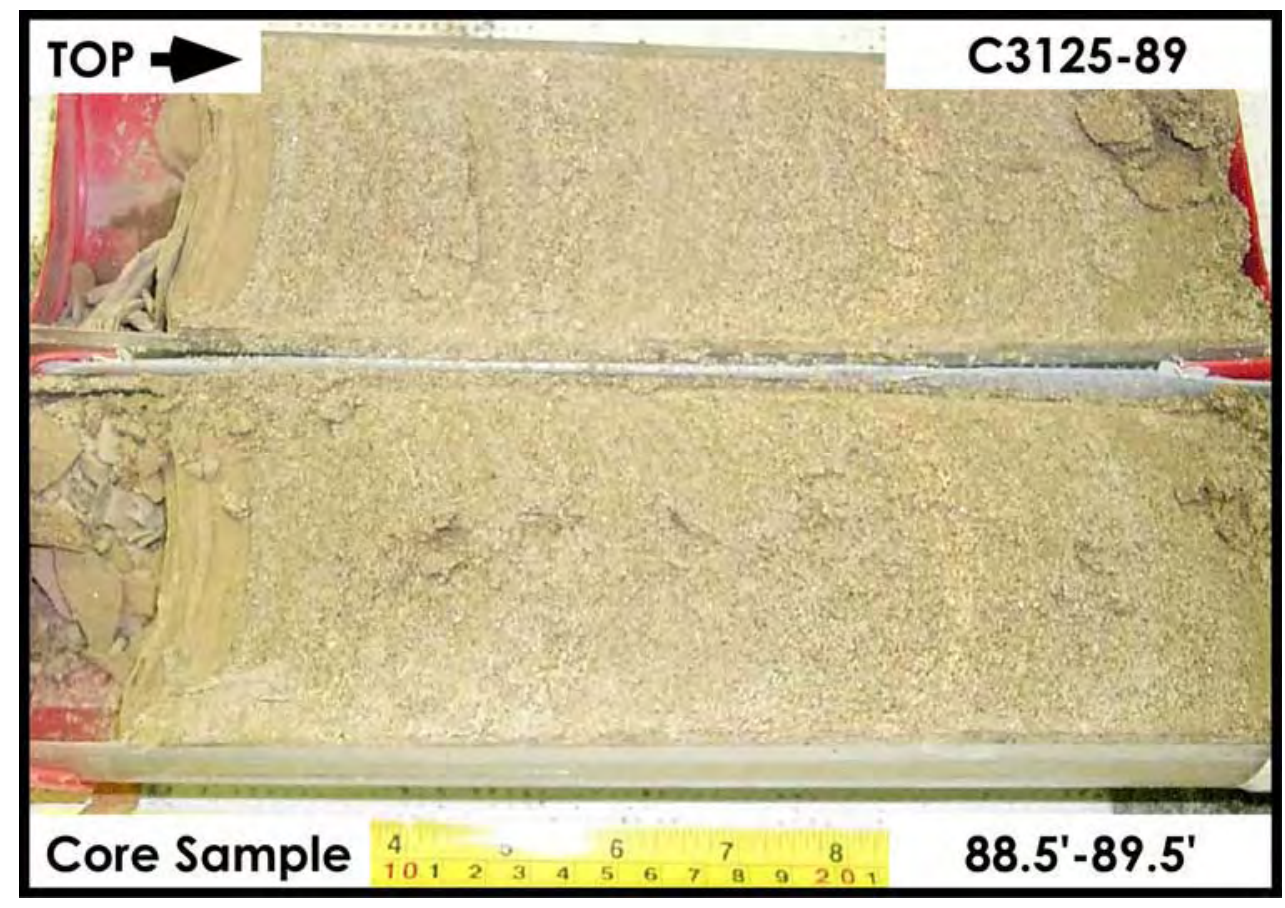

Figure A-1.29. Hanford Formation (H2 unit) $88.5 \mathrm{ft}-89.5 \mathrm{ft}$

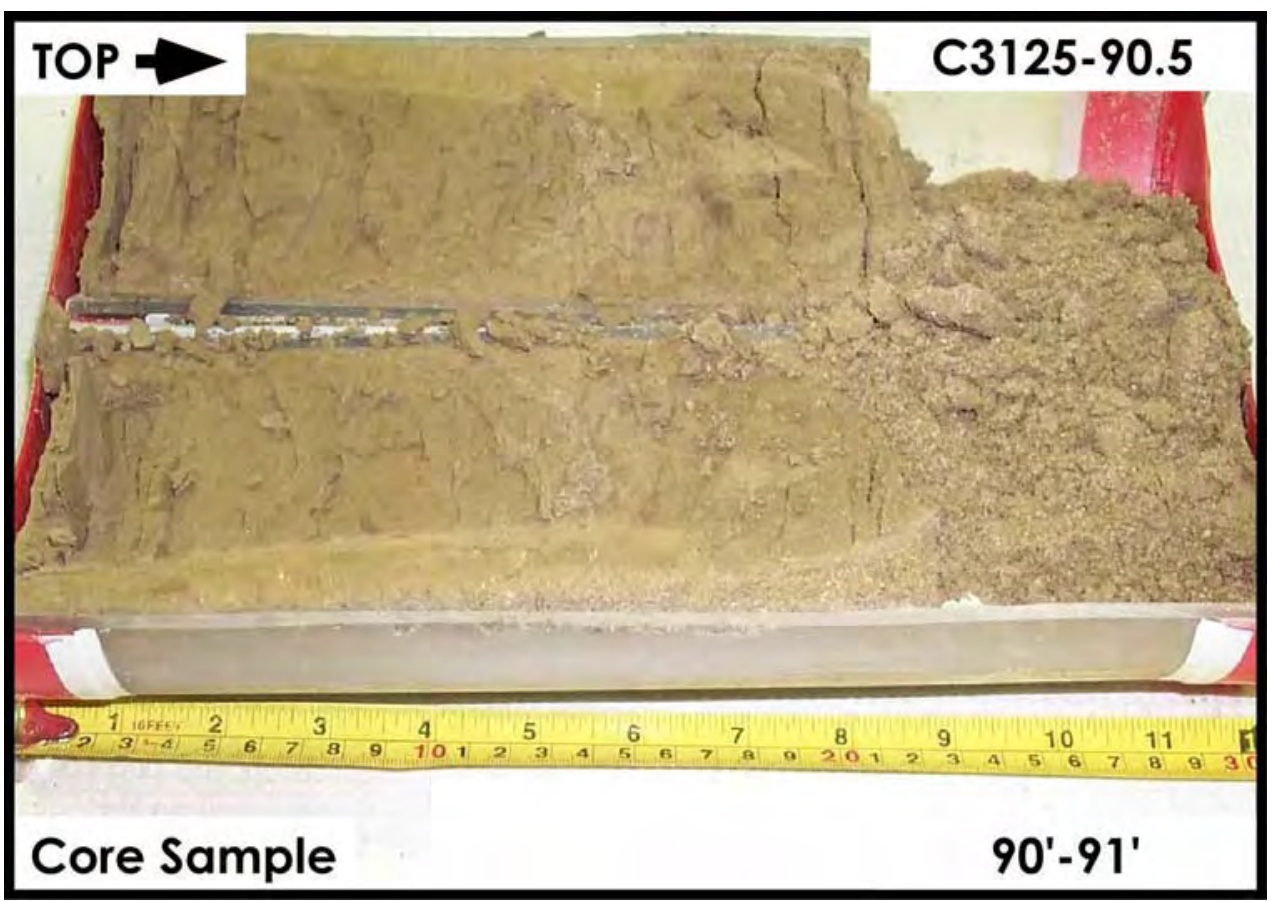

Figure A-1.30. Cold Creek Unit - Upper $\left(\mathrm{CCU}_{\mathrm{u}}\right) 90 \mathrm{ft}-91 \mathrm{ft}$ 


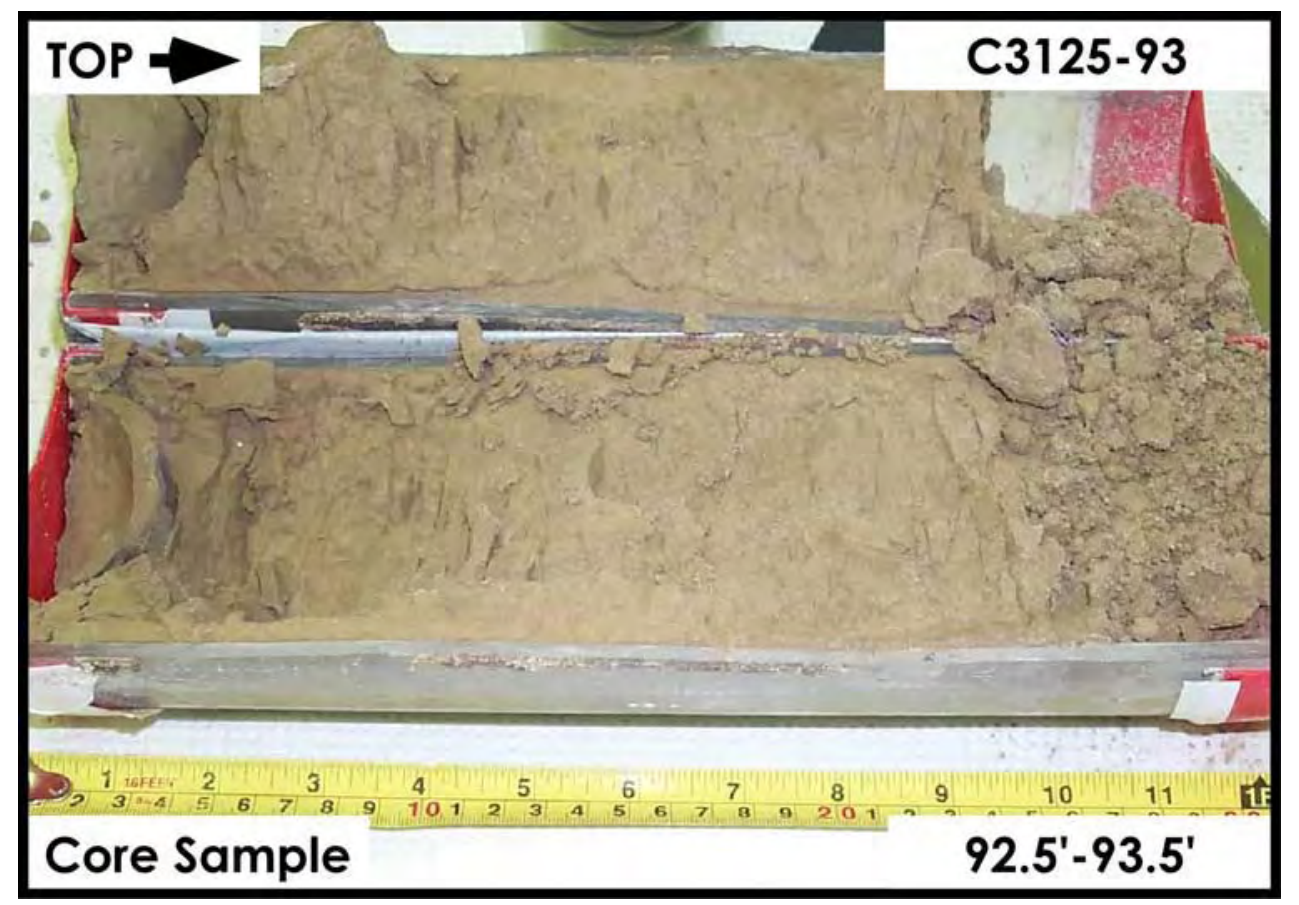

Figure A-1.31. Cold Creek Unit - Upper $\left(\mathrm{CCU}_{\mathrm{u}}\right) 92.5 \mathrm{ft}-93.5 \mathrm{ft}$

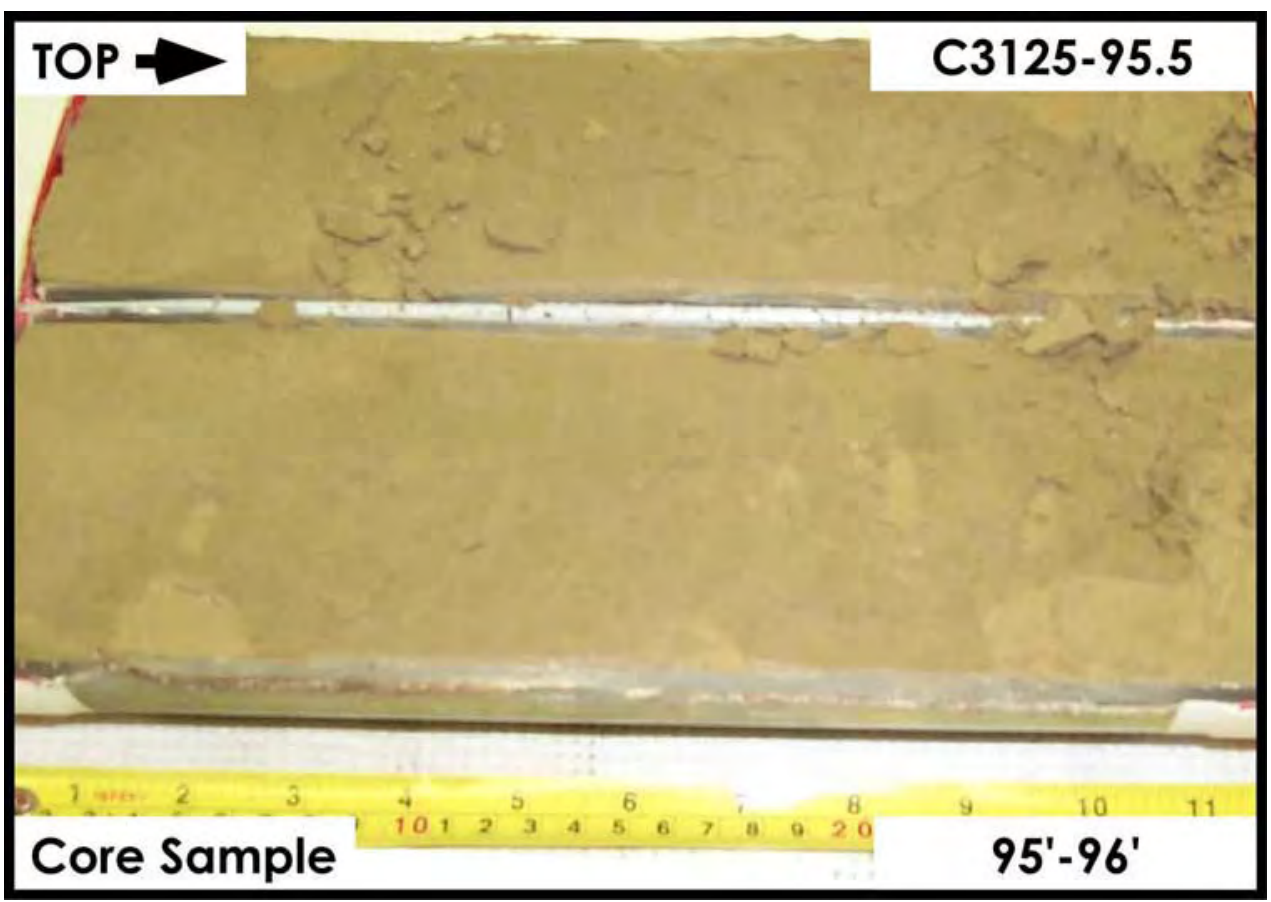

Figure A-1.32. Cold Creek Unit - Upper $\left(\mathrm{CCU}_{\mathrm{u}}\right) 95 \mathrm{ft}-96 \mathrm{ft}$ 


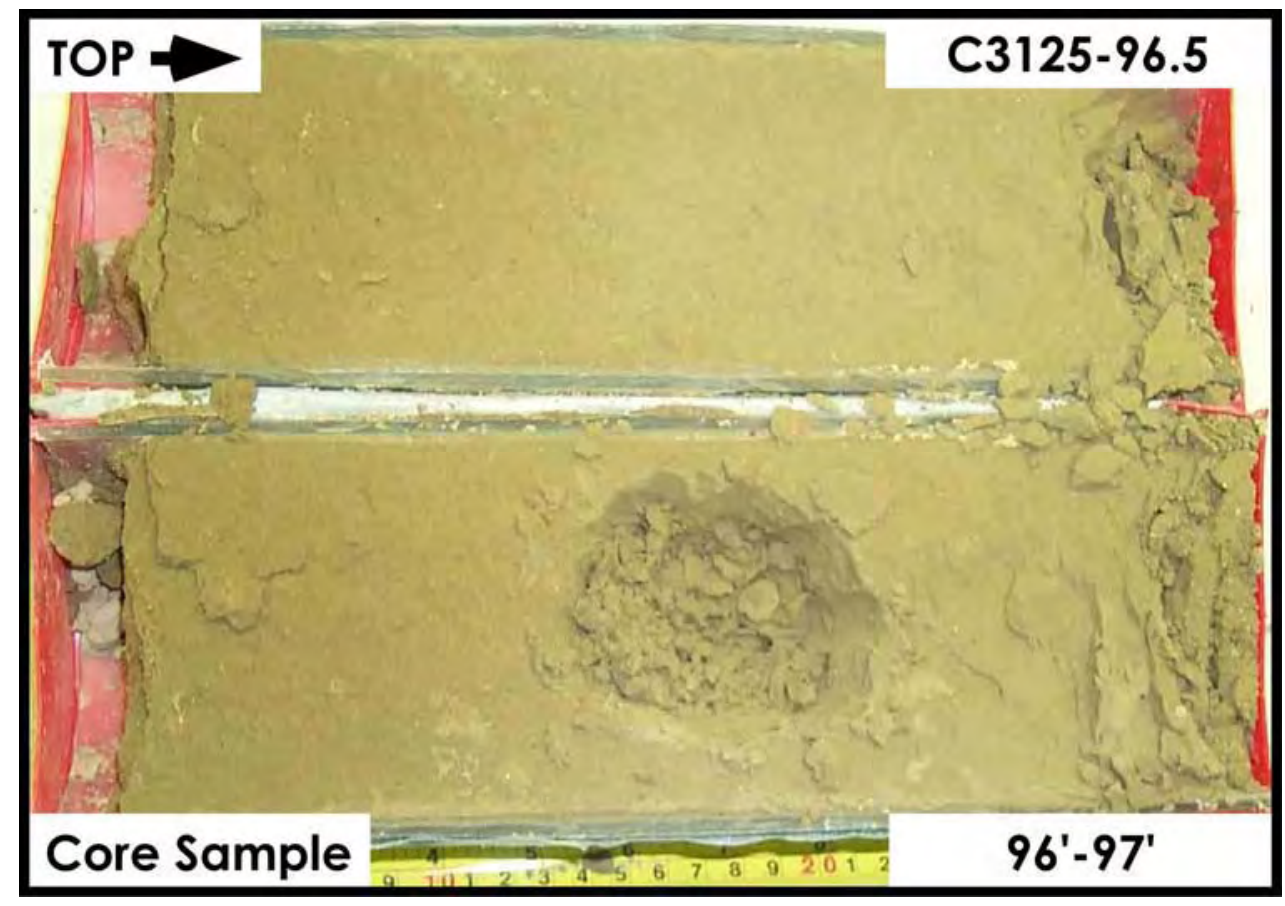

Figure A-1.33. Cold Creek Unit - Upper $\left(\mathrm{CCU}_{\mathrm{u}}\right) 96 \mathrm{ft}-97 \mathrm{ft}$

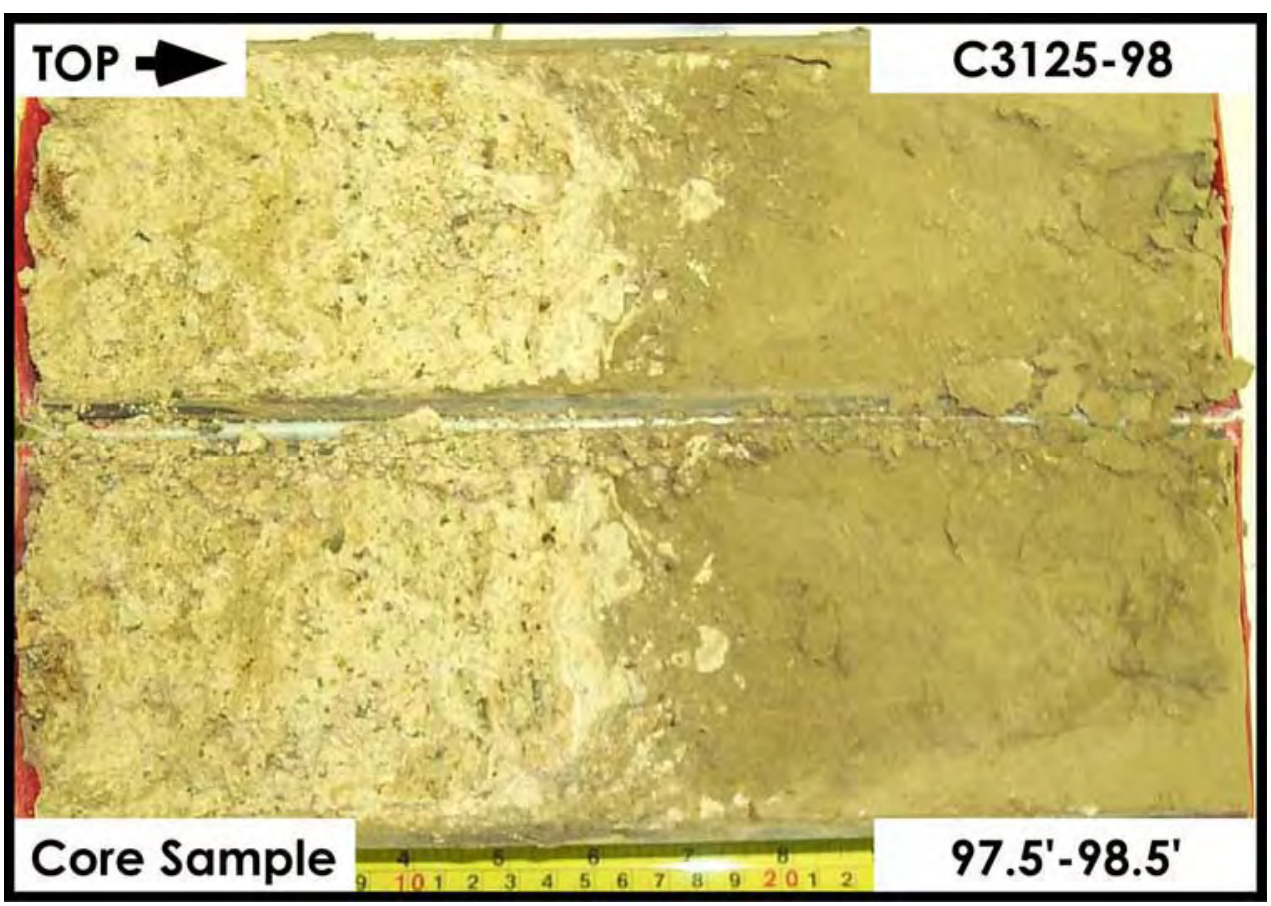

Figure A-1.34. Cold Creek Unit - Upper $\left(\mathrm{CCU}_{\mathrm{u}}\right) 97.5 \mathrm{ft}-98.5 \mathrm{ft}$ 


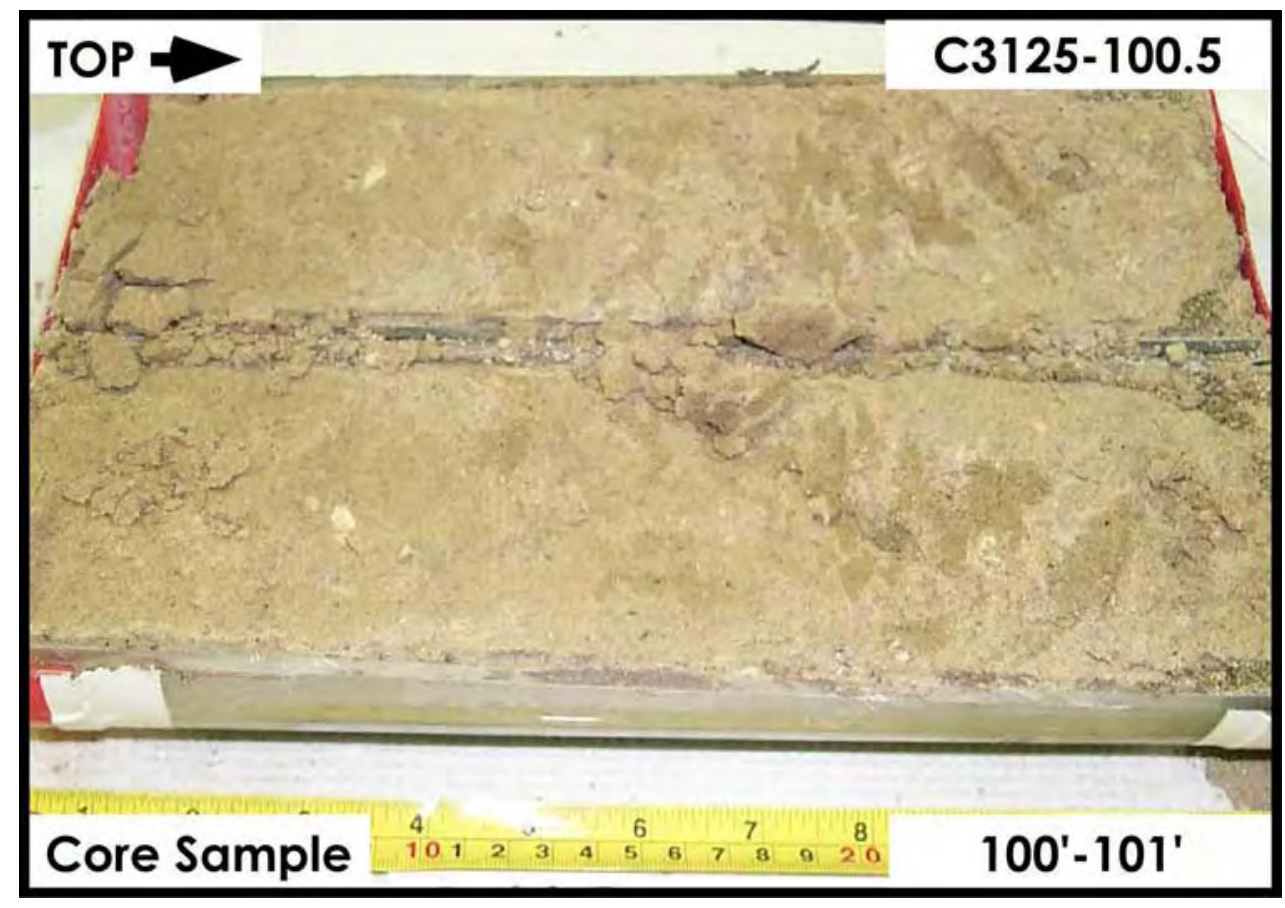

Figure A-1.35. Cold Creek Unit - Lower $\left(\mathrm{CCU}_{1}\right) 100 \mathrm{ft}-101 \mathrm{ft}$

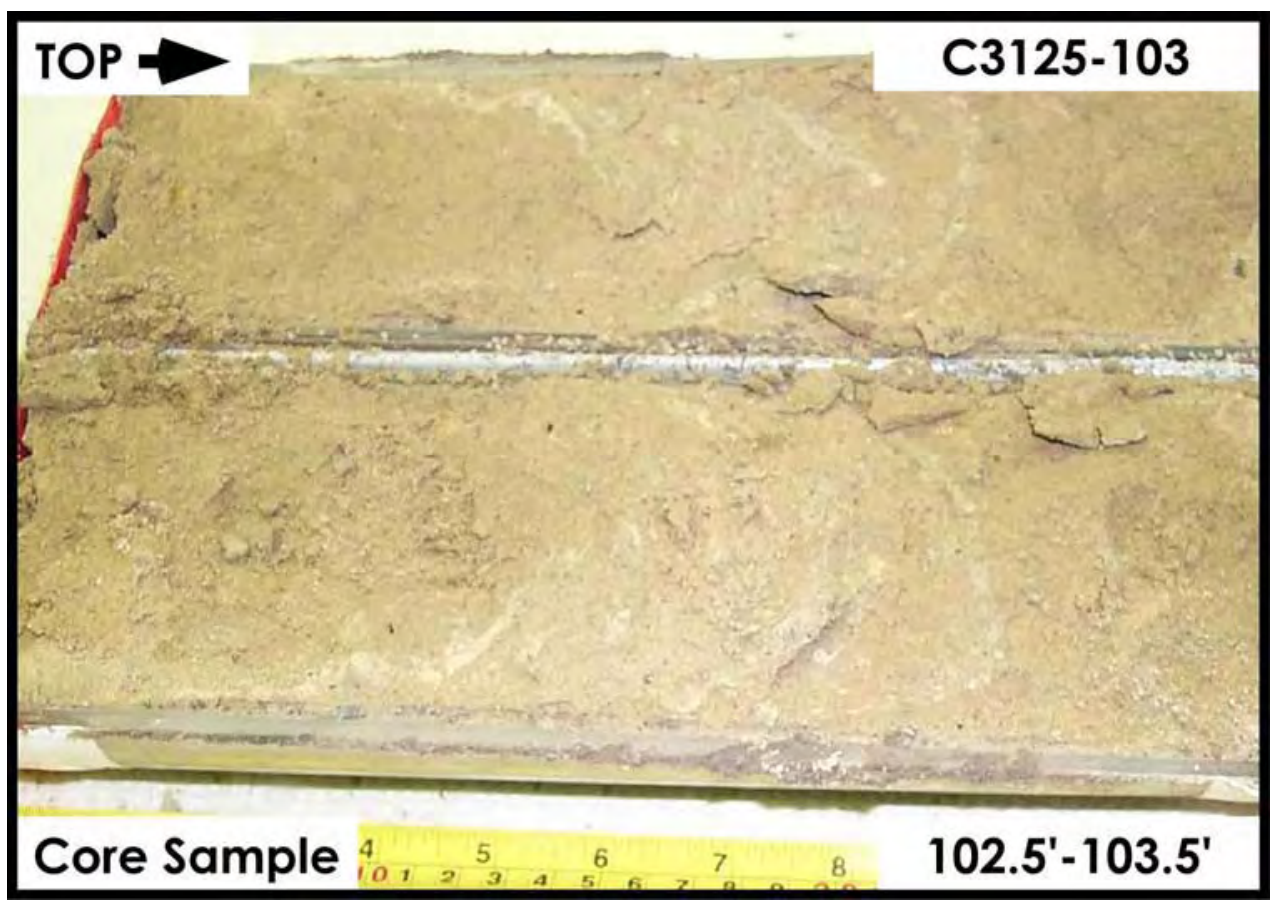

Figure A-1.36. Cold Creek Unit - Lower $\left(\mathrm{CCU}_{\mathrm{l}}\right) \mathbf{1 0 2 . 5} \mathrm{ft}-\mathbf{1 0 3 . 5} \mathrm{ft}$ 


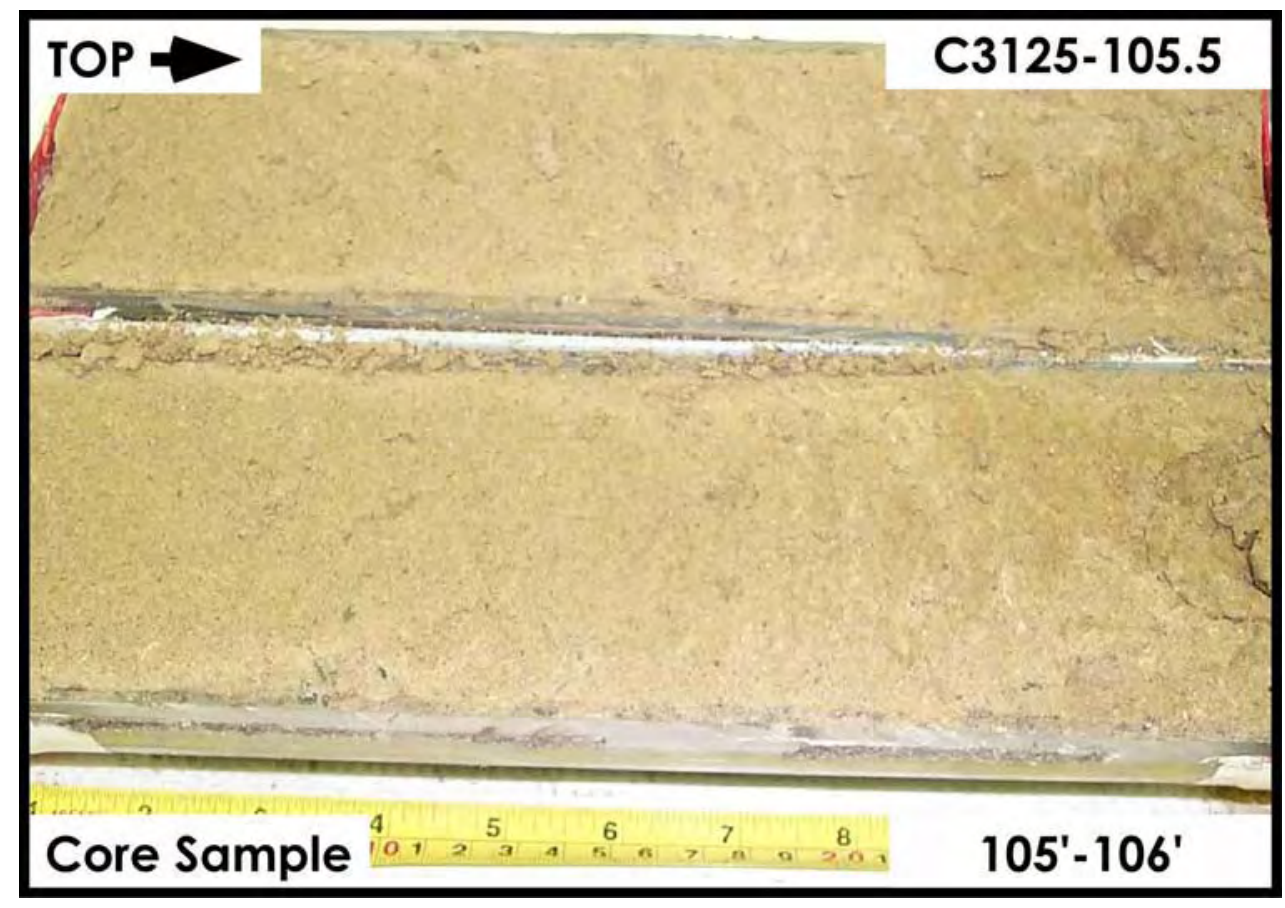

Figure A-1.37. Cold Creek Unit - Lower $\left(\mathrm{CCU}_{\mathrm{I}}\right) 105 \mathrm{ft}-106 \mathrm{ft}$

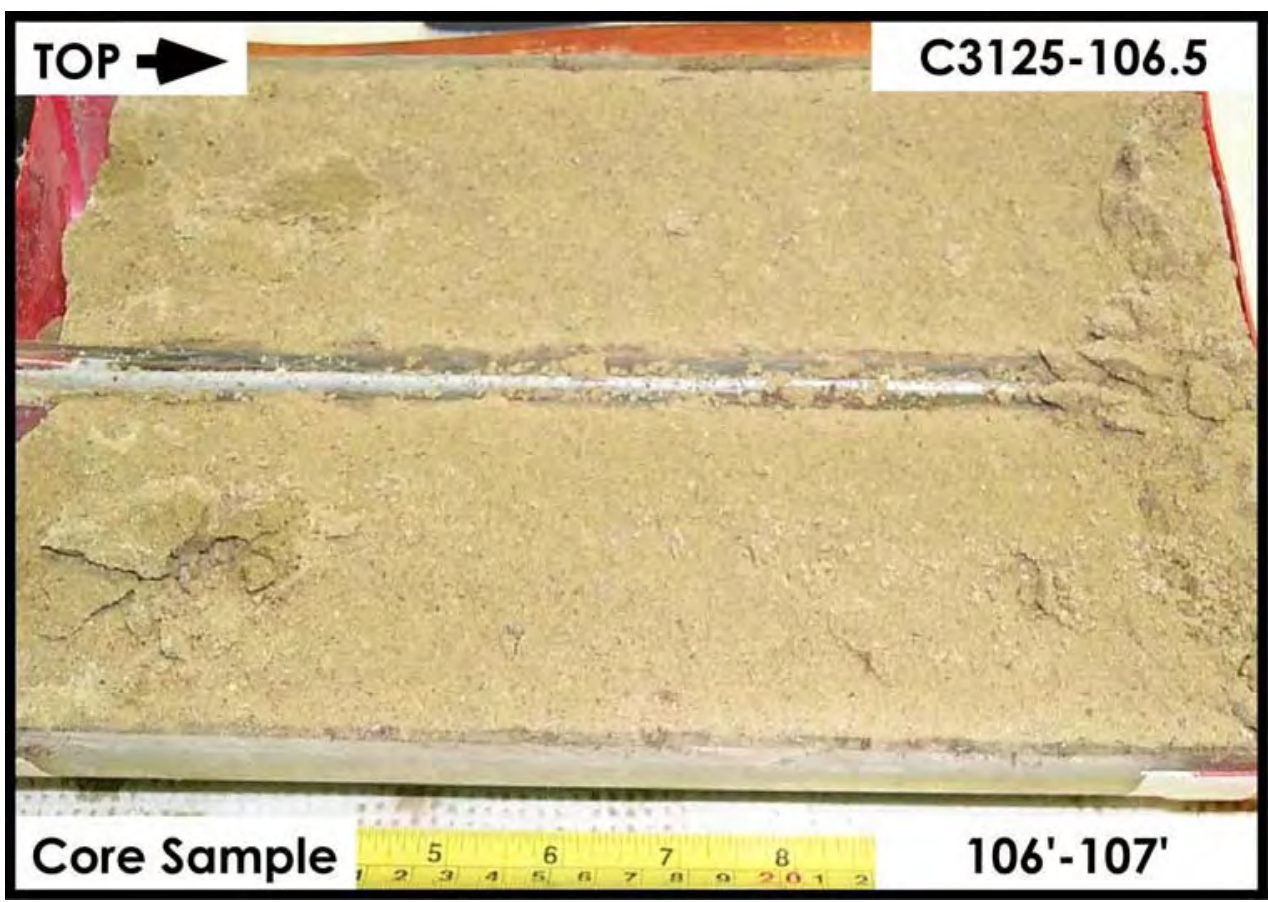

Figure A-1.38. Cold Creek Unit - Lower $\left(\mathrm{CCU}_{\mathrm{l}}\right) 106 \mathrm{ft}$ - $107 \mathrm{ft}$ 


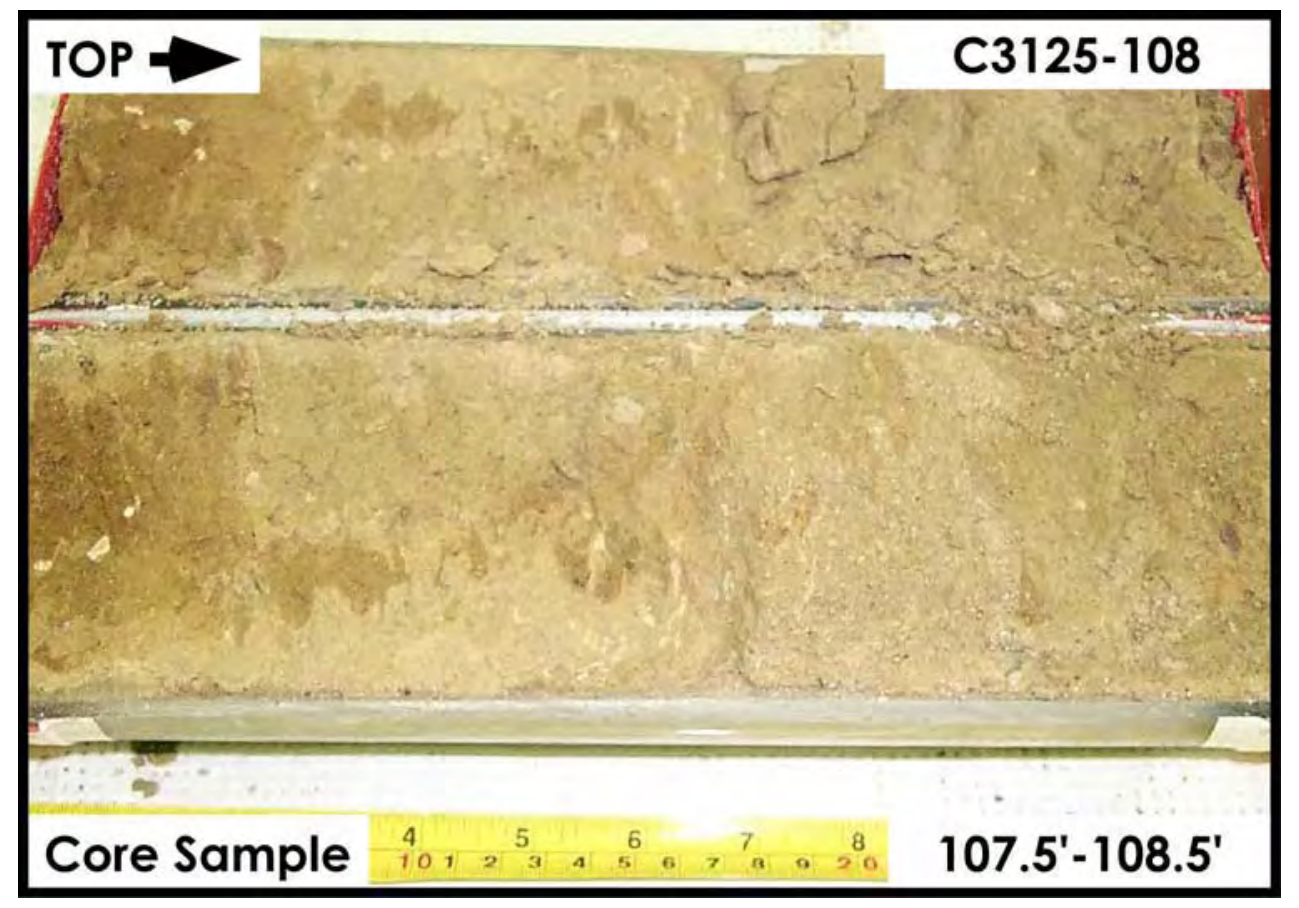

Figure A-1.39. Cold Creek Unit - Lower $\left(\mathrm{CCU}_{\mathrm{I}}\right) \mathbf{1 0 7 . 5} \mathrm{ft}-108.5 \mathrm{ft}$

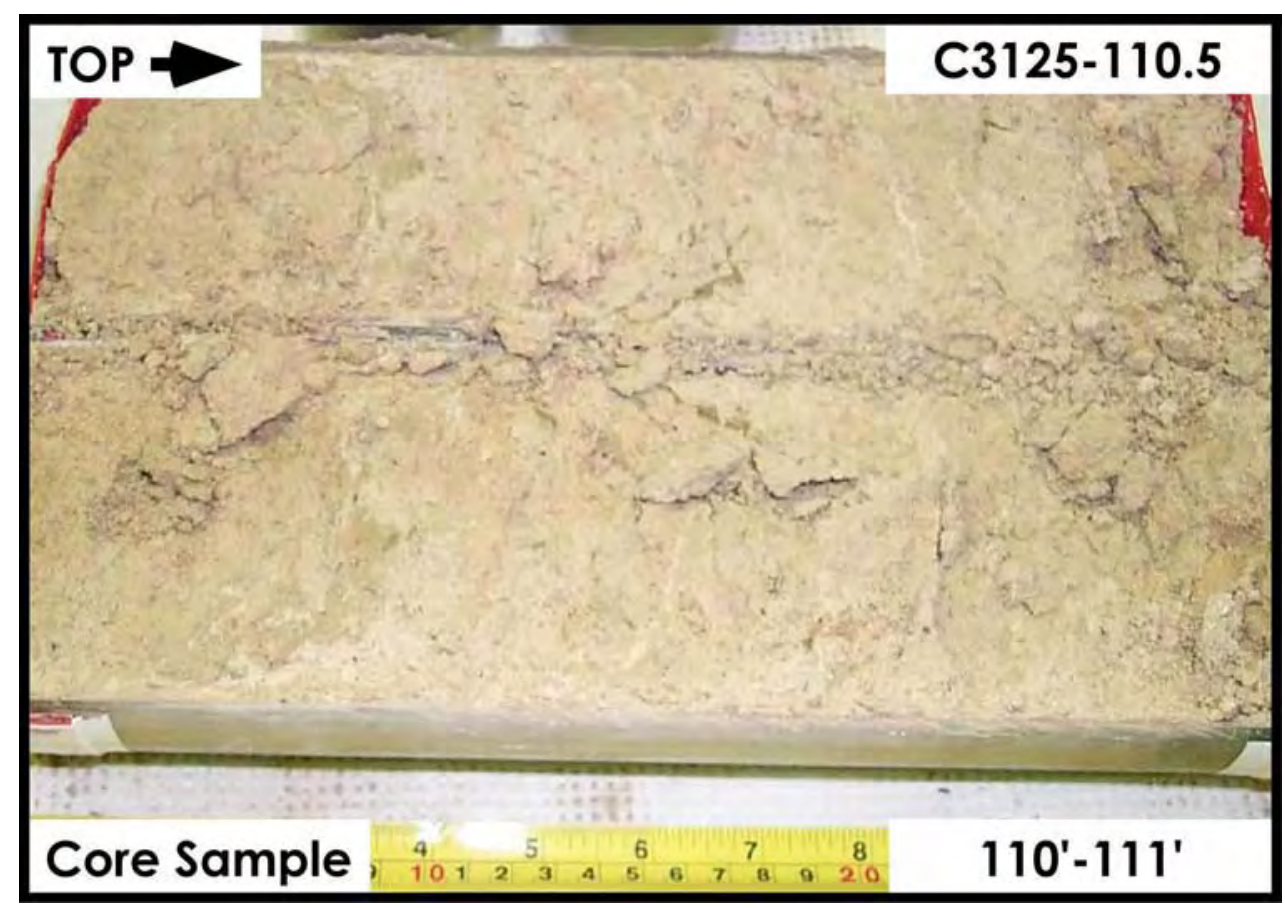

Figure A-1.40. Cold Creek Unit - Lower $\left(C_{C} U_{l}\right) 110 \mathrm{ft}-111 \mathrm{ft}$ 


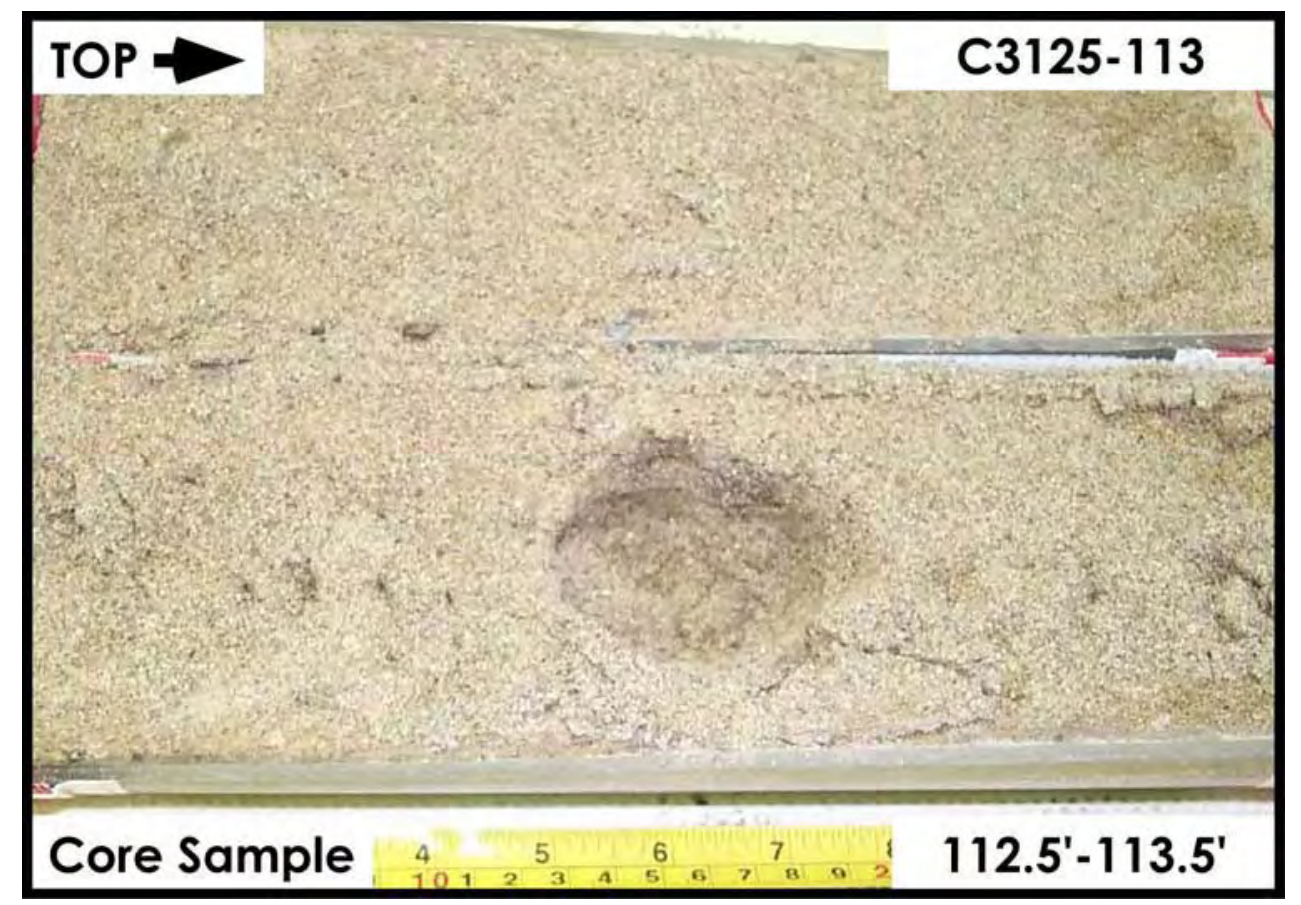

Figure A-1.41. Ringold Formation - Member of Taylor Flat $\left(R_{t f}\right) 112.5 \mathrm{ft}-113.5 \mathrm{ft}$

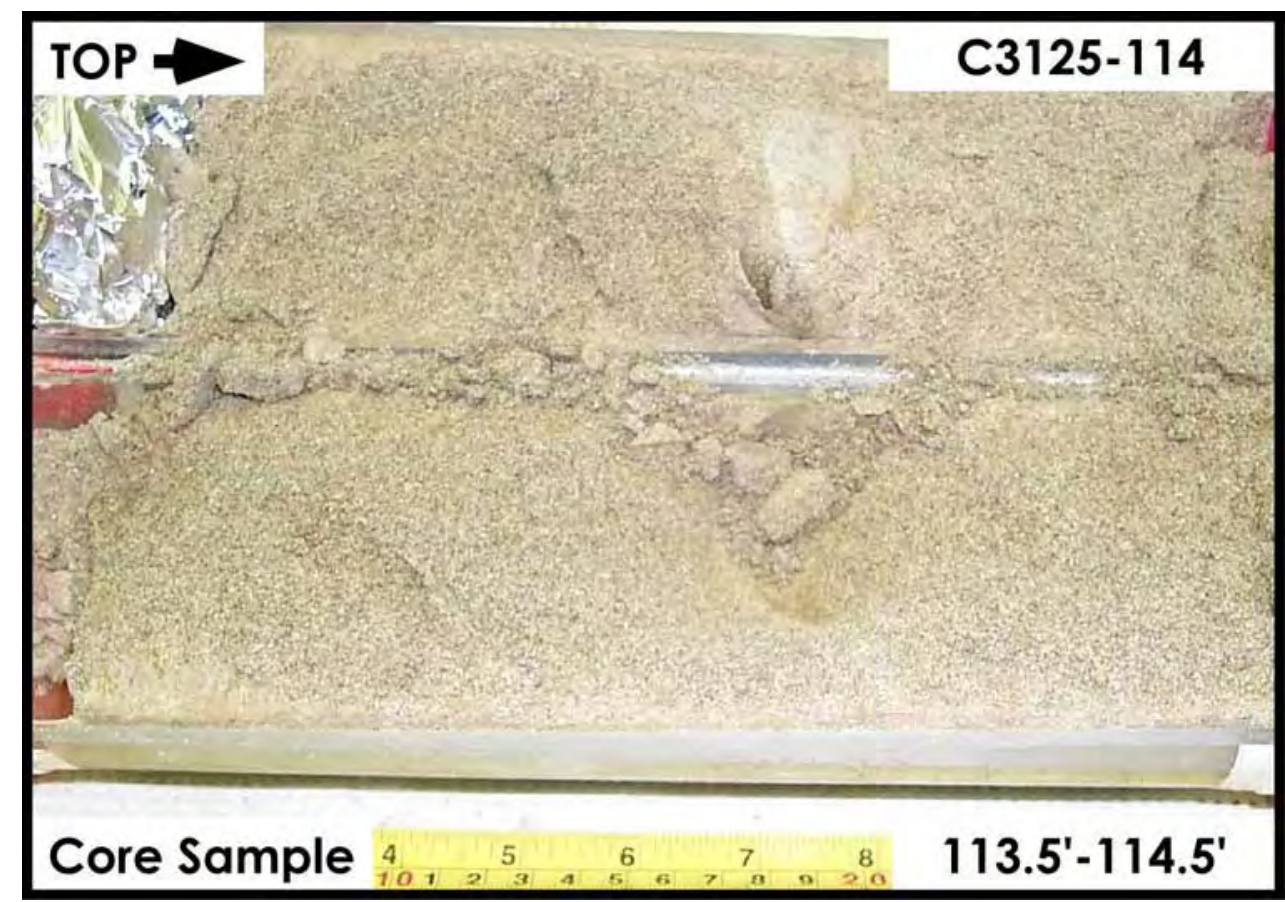

Figure A-1.42. Ringold Formation - Member of Taylor Flat $\left(R_{t f}\right) 113.5 \mathrm{ft}-114.5 \mathrm{ft}$ 


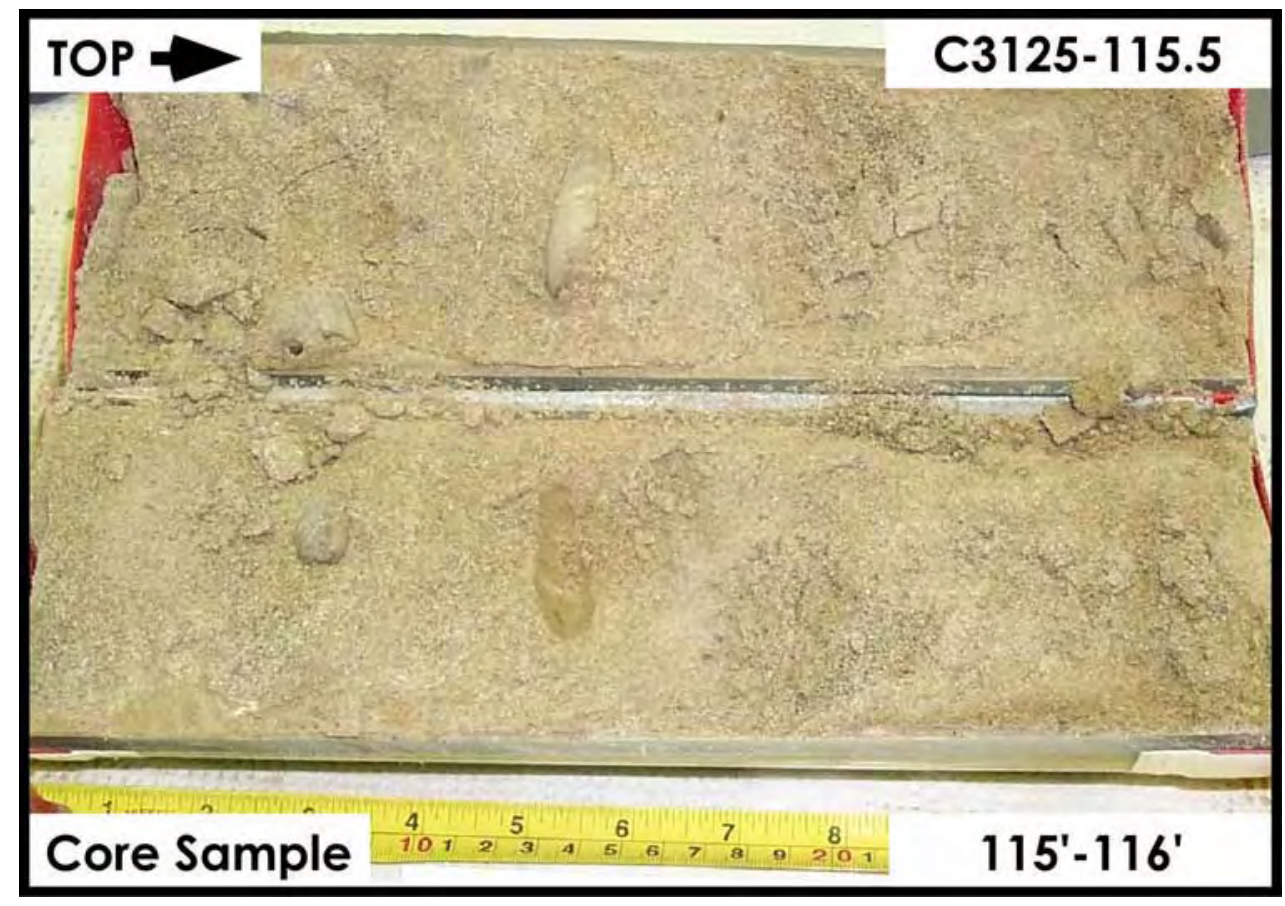

Figure A-1.43. Ringold Formation - Member of Taylor Flat $\left(R_{t f}\right) 115 \mathrm{ft}-116 \mathrm{ft}$

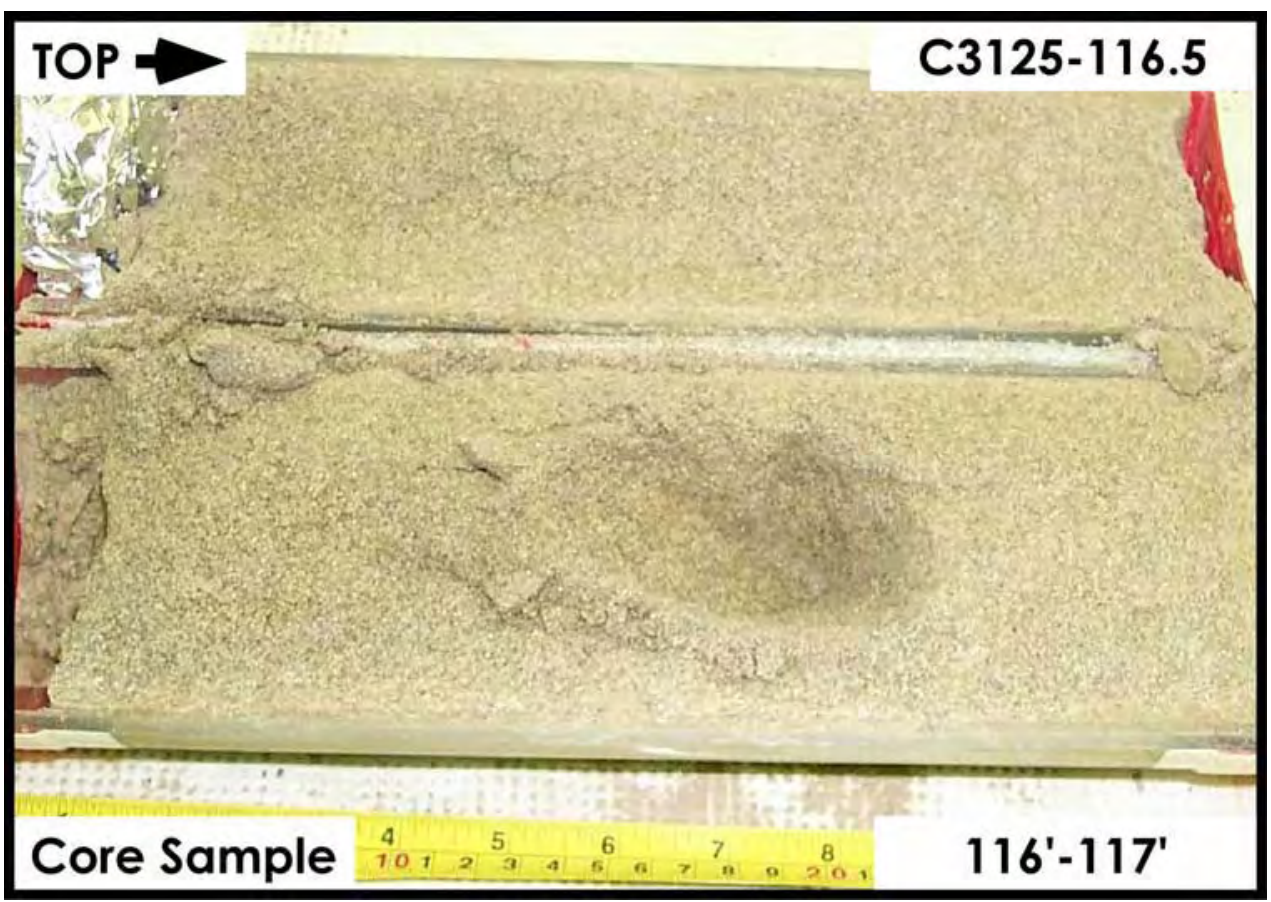

Figure A-1.44. Ringold Formation - Member of Taylor Flat $\left(R_{t f}\right) 116 \mathrm{ft}-117 \mathrm{ft}$ 


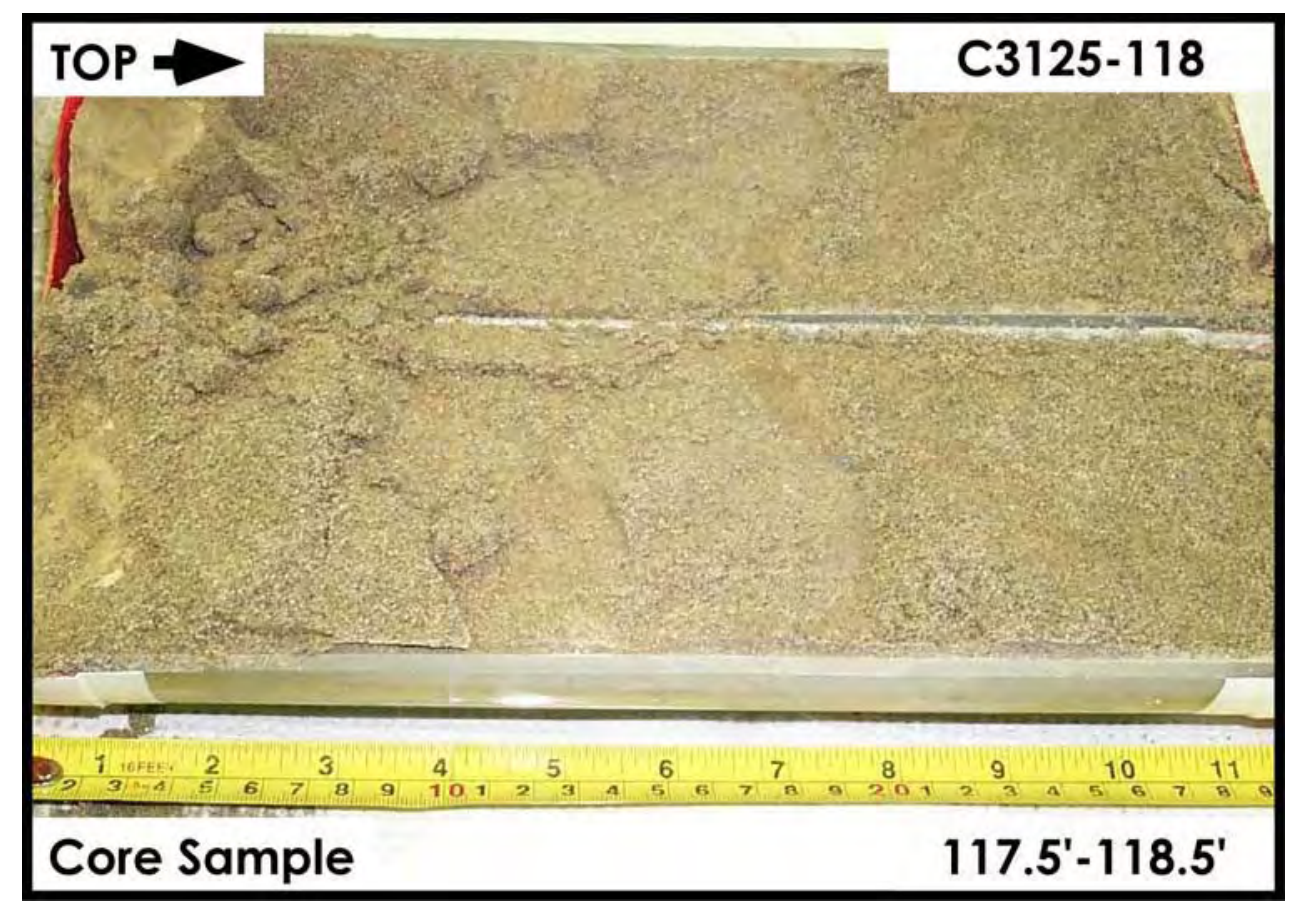

Figure A-1.45. Ringold Formation - Member of Taylor Flat $\left(R_{t f}\right) 117.5 \mathrm{ft}-118.5 \mathrm{ft}$

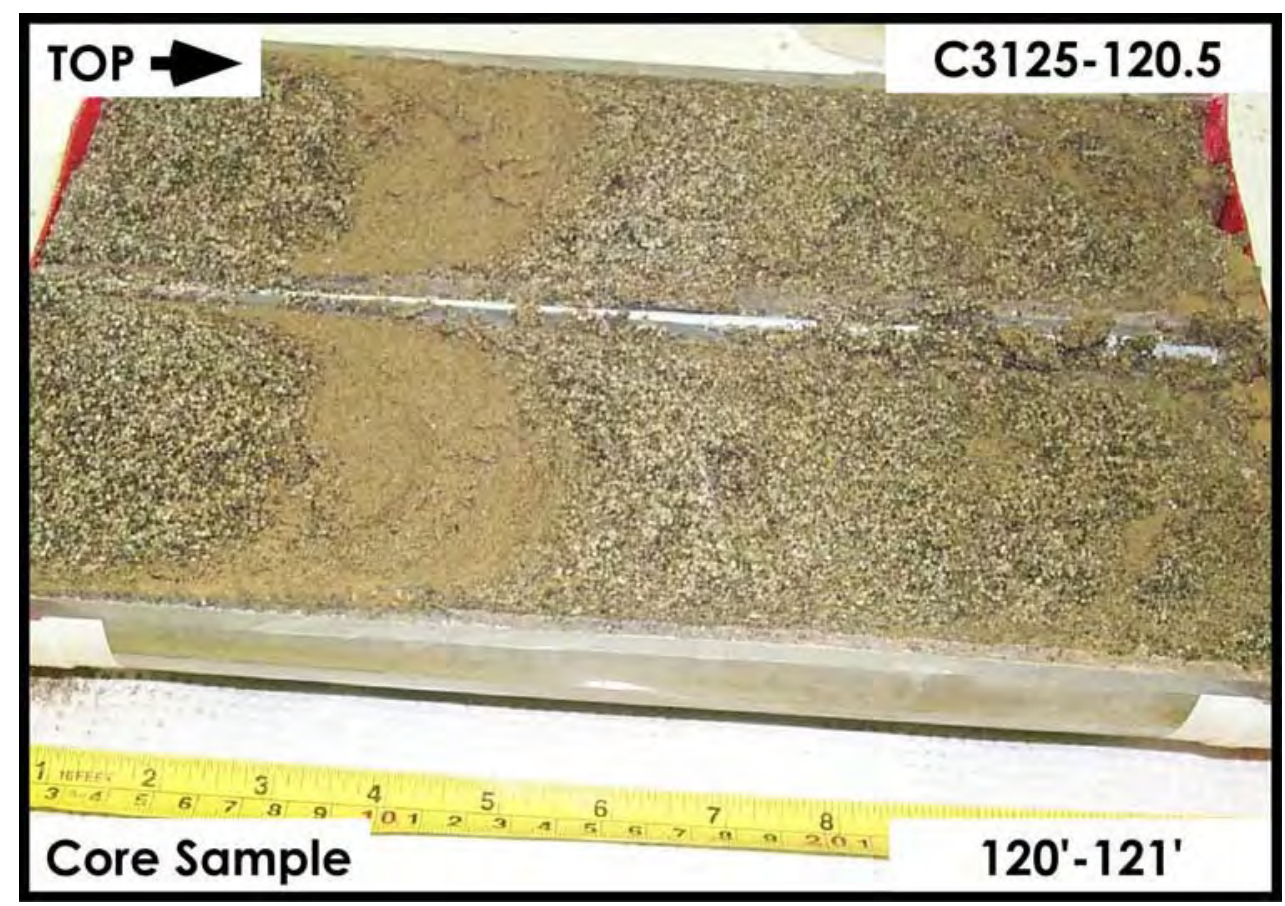

Figure A-1.46. Ringold Formation - Member of Taylor Flat $\left(R_{t f}\right) 120 \mathrm{ft}-121 \mathrm{ft}$ 


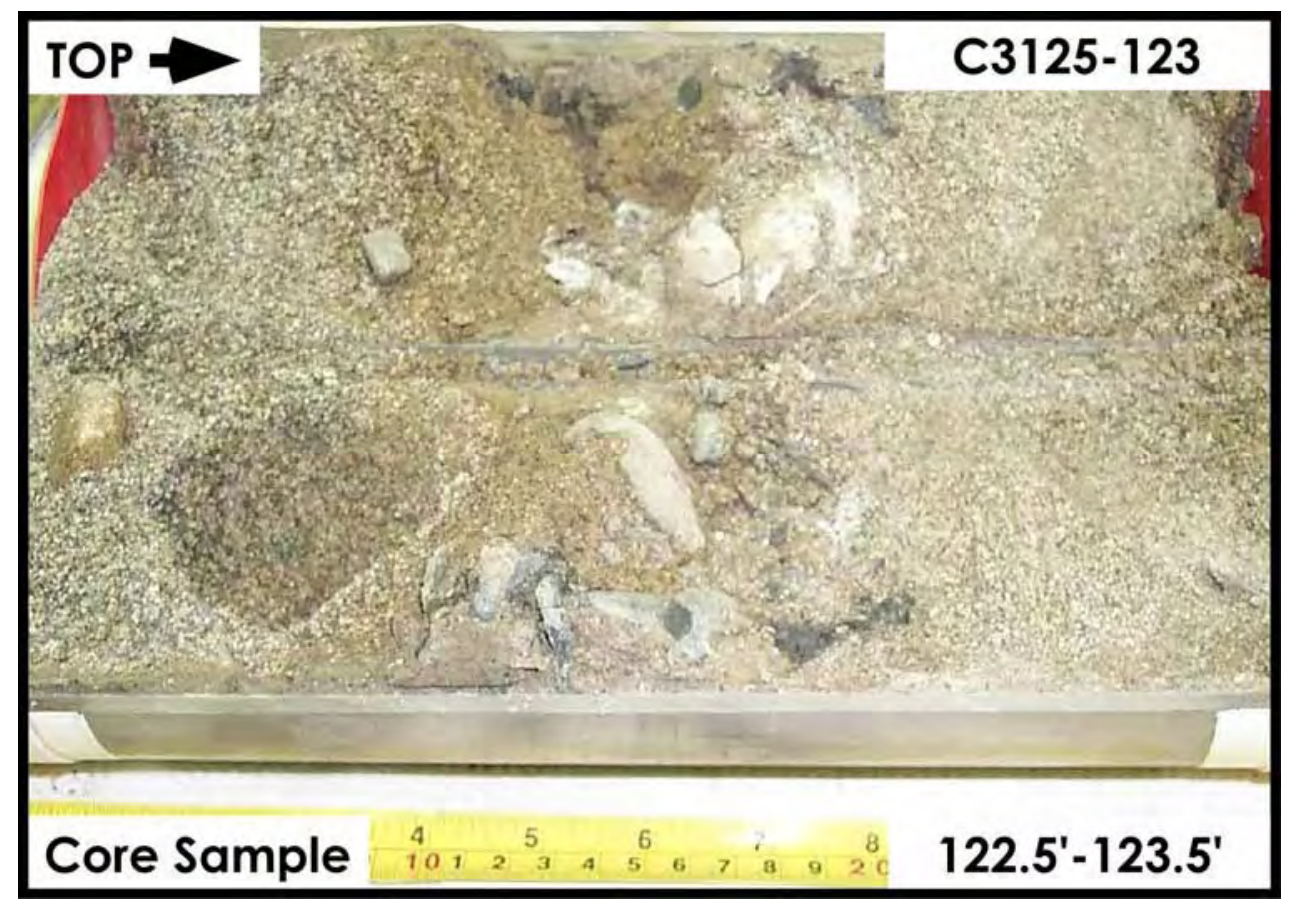

Figure A-1.47. Ringold Formation - Member of Wooded Island $\left(R_{w i}\right) 122.5 \mathrm{ft}-123.5 \mathrm{ft}$

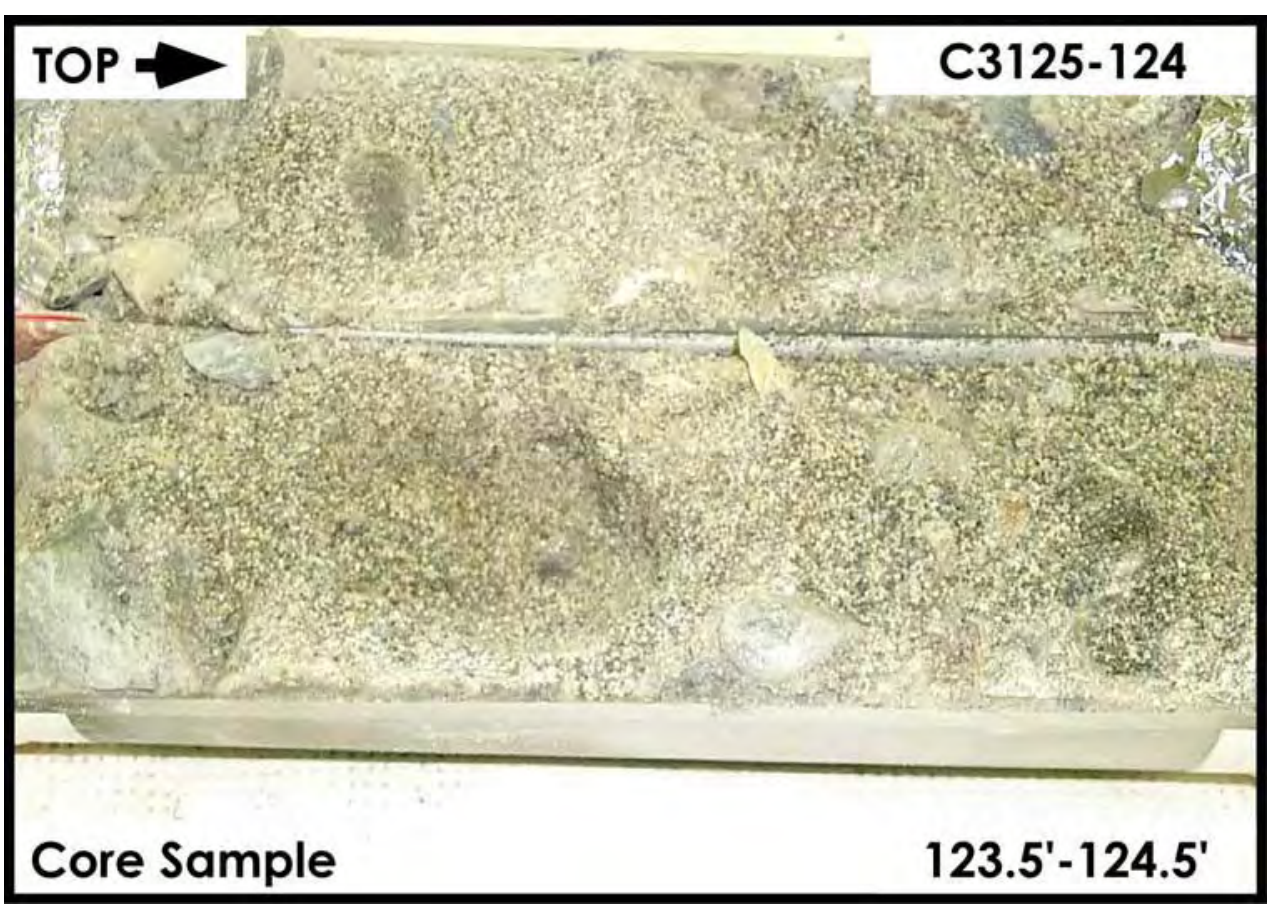

Figure A-1.48. Ringold Formation - Member of Wooded Island $\left(R_{w i}\right) 123.5 \mathrm{ft}-124.5 \mathrm{ft}$ 


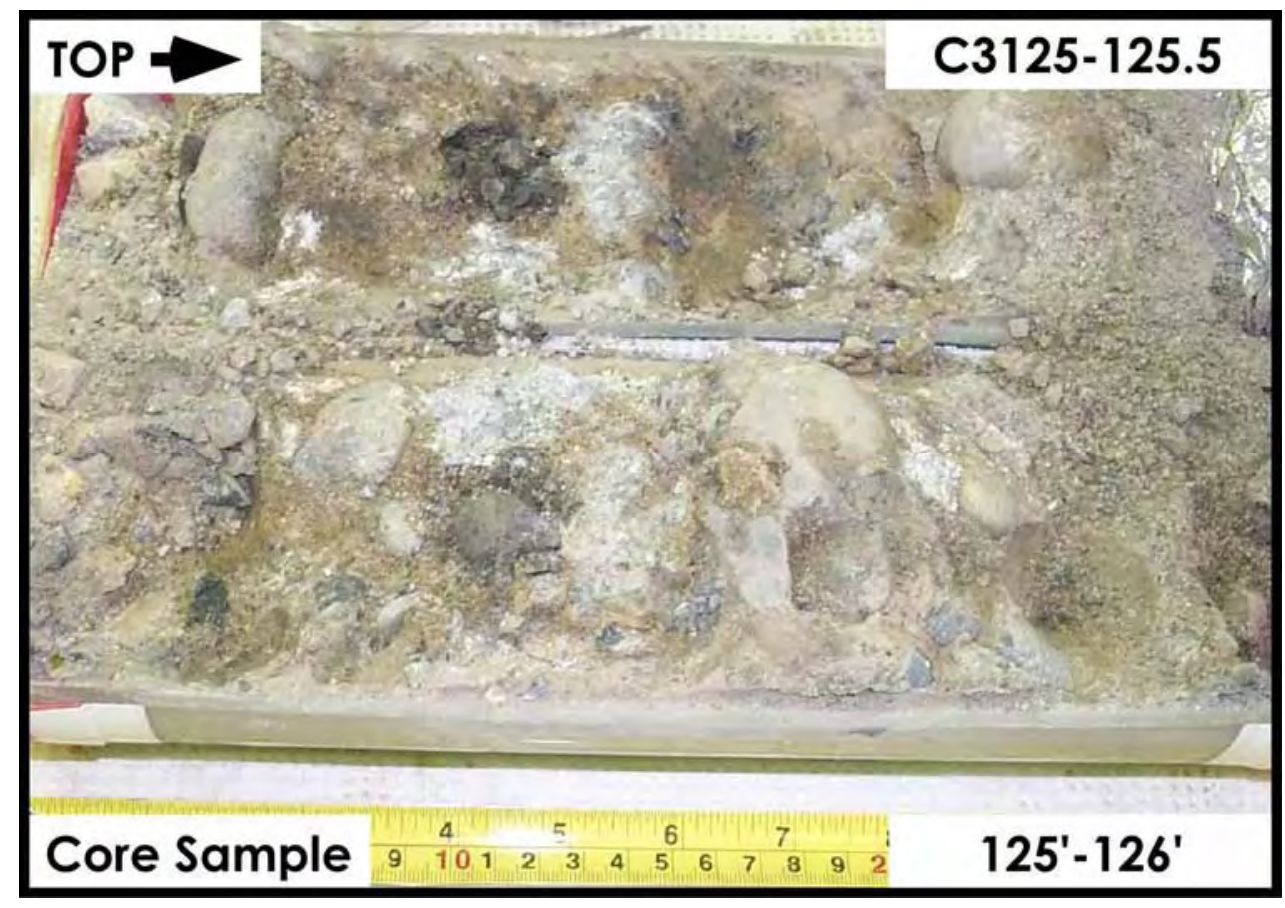

Figure A-1.49. Ringold Formation - Member of Wooded Island $\left(R_{w i}\right) 125 \mathrm{ft}-126 \mathrm{ft}$

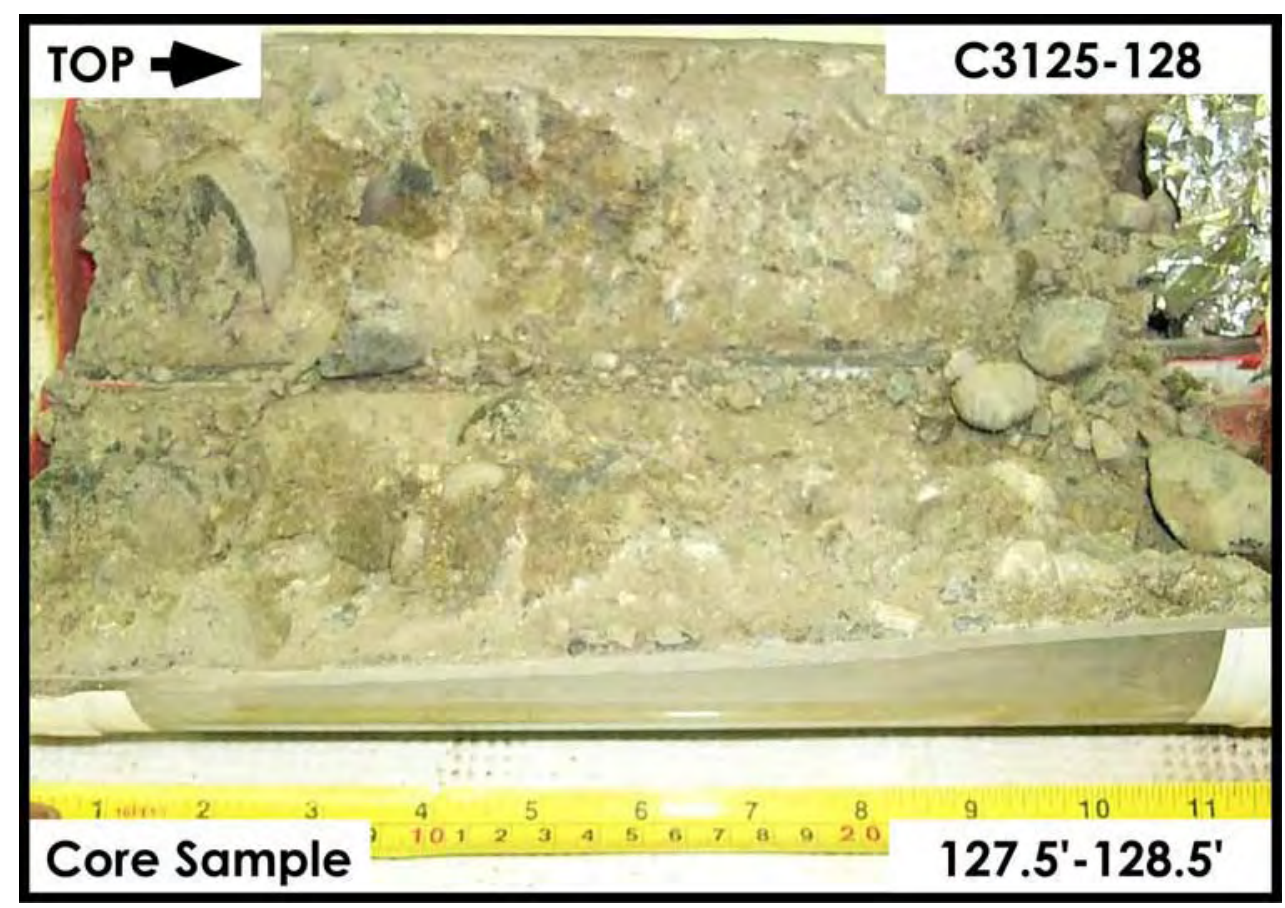

Figure A-1.50. Ringold Formation - Member of Wooded Island $\left(R_{w i}\right) 127.5 \mathrm{ft}-128.5 \mathrm{ft}$ 


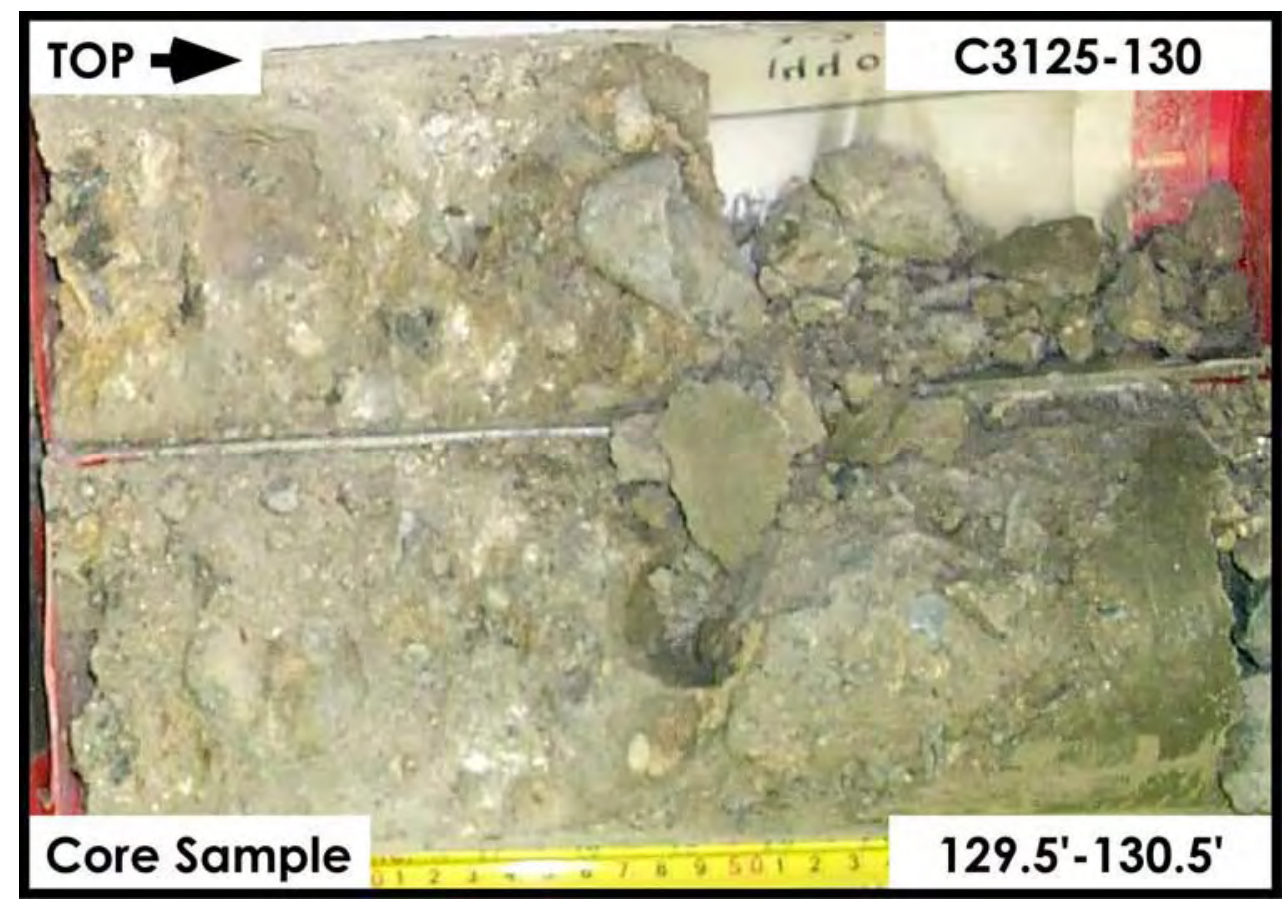

Figure A-1.51. Ringold Formation - Member of Wooded Island $\left(R_{w i}\right) 129.5 \mathrm{ft}-130.5 \mathrm{ft}$

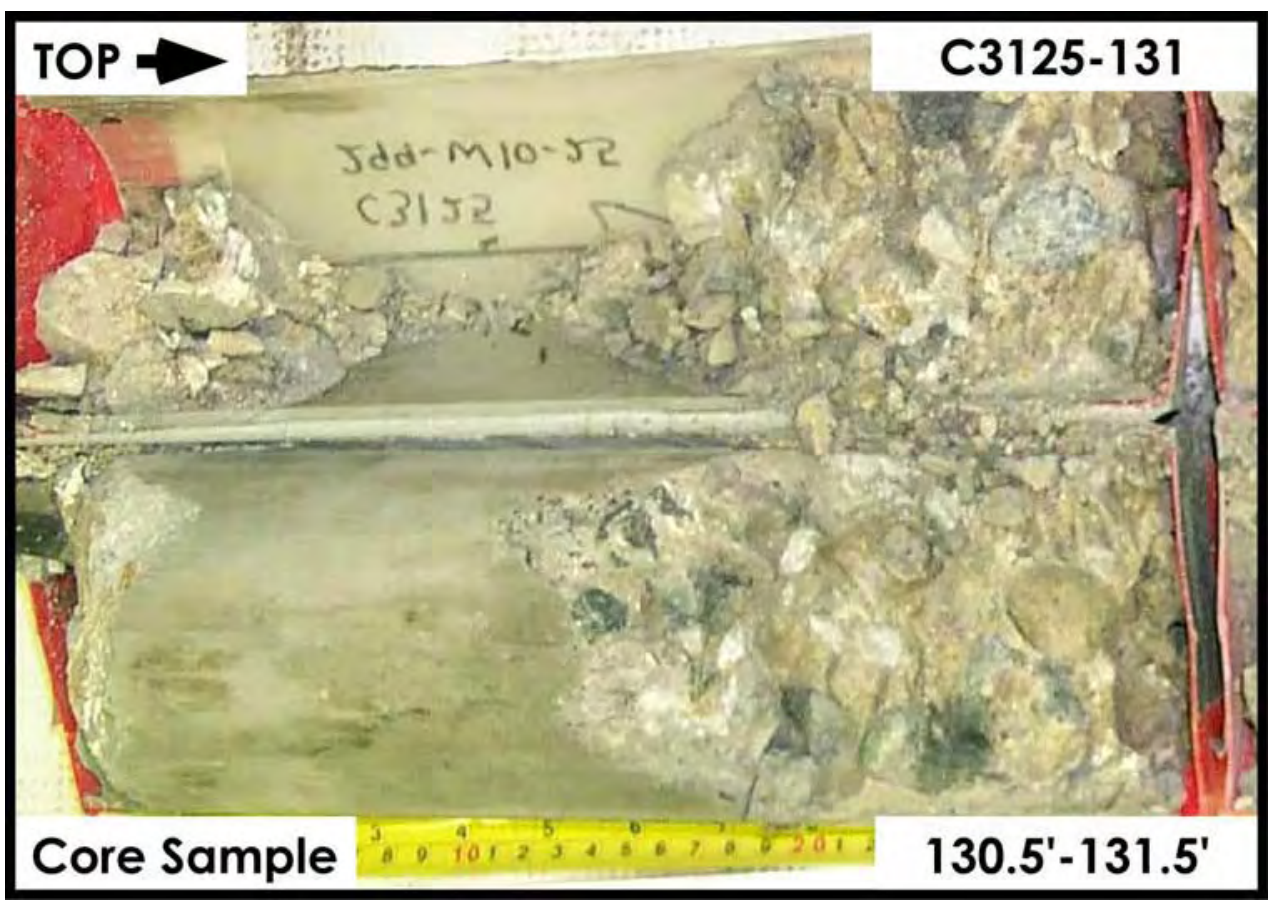

Figure A-1.52. Ringold Formation - Member of Wooded Island $\left(R_{w i}\right) 130.5 \mathrm{ft}-131.5 \mathrm{ft}$ 
APPENDIX A.2

C3830 (TX-105)

SPLITSPOON CORE

SAMPLE PHOTOGRAPHS 


\section{Contents}

Appendix A .2 C3830 (TX-105) Splitspoon Core Sample Photographs

\section{Figures}

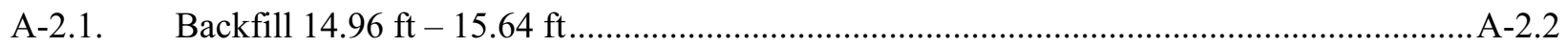

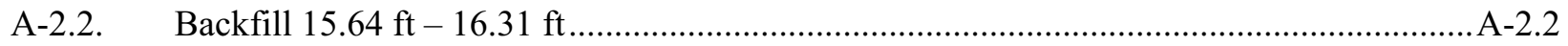

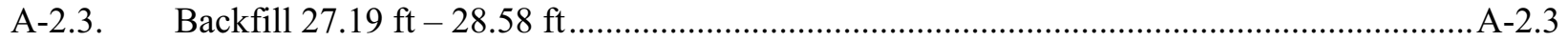

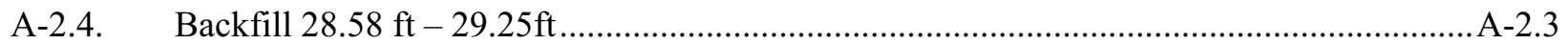

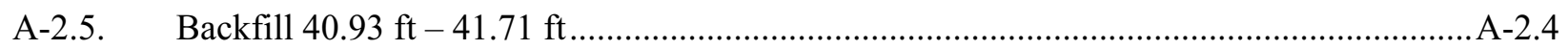

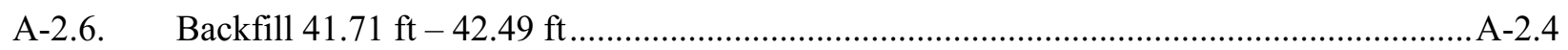

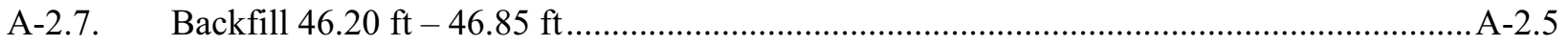

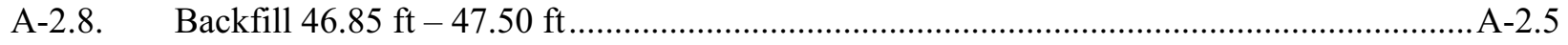

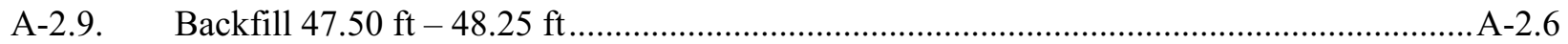

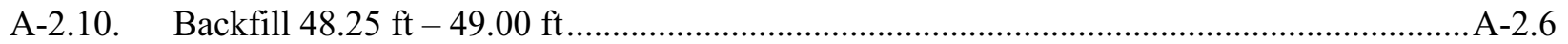

A-2.11. Hanford Formation (H2 unit) $52.98 \mathrm{ft}-53.67 \mathrm{ft}$....................................................... A-2.7

A-2.12. Hanford Formation (H2 unit) $53.67 \mathrm{ft}-54.36 \mathrm{ft}$...................................................... A-2.7

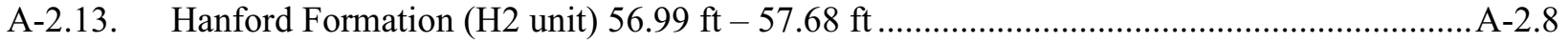

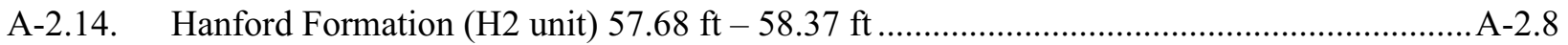

A-2.15. Hanford Formation (H2 unit) $58.29 \mathrm{ft}-59.00 \mathrm{ft}$........................................................ A-2.9

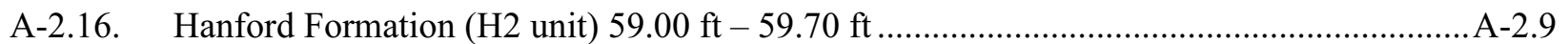

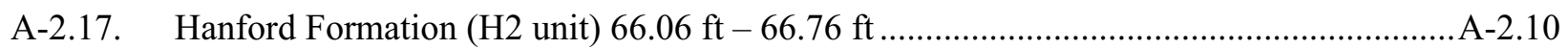

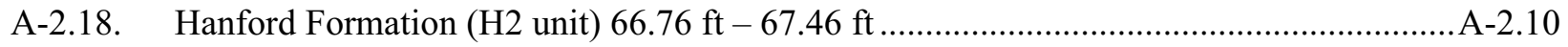

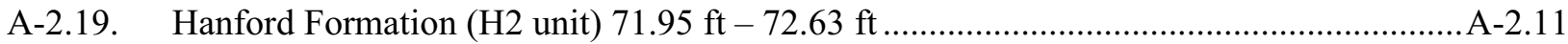

A-2.20. Hanford Formation (H2 unit) $72.63 \mathrm{ft}-73.30 \mathrm{ft}$....................................................... A-2.11

A-2.21. Hanford Formation (H2 unit) $76.98 \mathrm{ft}-77.67 \mathrm{ft}$..........................................................A-2.12

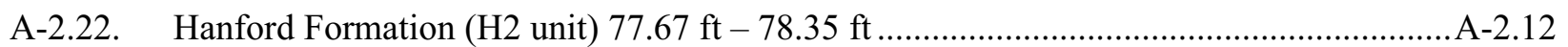

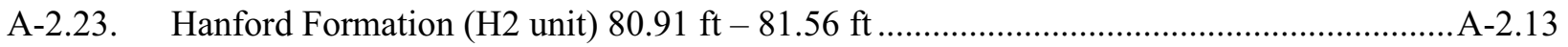

A-2.24. Hanford Formation (H2 unit) $81.56 \mathrm{ft}-82.21 \mathrm{ft}$.............................................................

A-2.25. Hanford Formation (H2 unit) $86.11 \mathrm{ft}-86.76 \mathrm{ft}$......................................................A-2.14

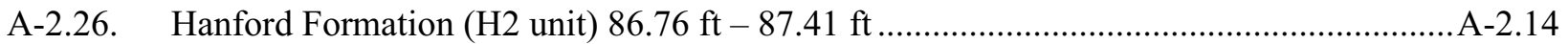

A-2.27. Hanford Formation (H2 unit) $98.97 \mathrm{ft}-99.67 \mathrm{ft}$..........................................................A-2.15 
A-2.28. Hanford Formation (H2 unit) $99.67 \mathrm{ft}-100.36 \mathrm{ft}$..................................................... A-2.15

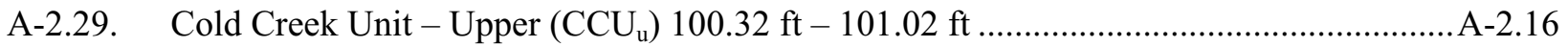

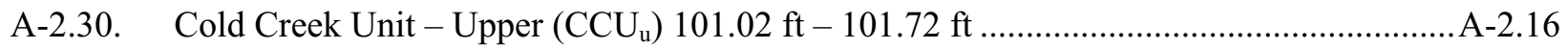

A-2.31. Cold Creek Unit - Upper $\left(\mathrm{CCU}_{\mathrm{u}}\right) 102.99 \mathrm{ft}-103.72 \mathrm{ft}$............................................... A-2.17

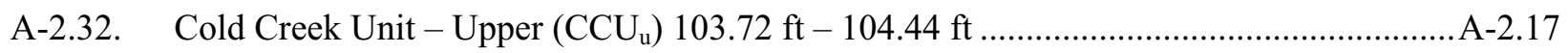

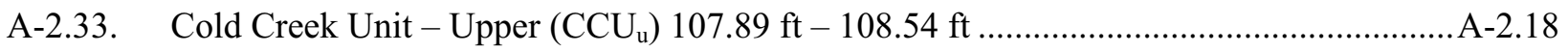

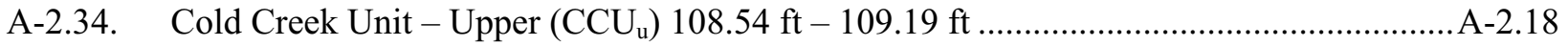

A-2.35. Cold Creek Unit - Lower $\left(\mathrm{CCU}_{1}\right) 113.55 \mathrm{ft}-114.25 \mathrm{ft}$............................................. A-2.19

A-2.36. Cold Creek Unit - Lower $\left(\mathrm{CCU}_{1}\right) 114.25 \mathrm{ft}-115.00 \mathrm{ft}$................................................A-2.19 


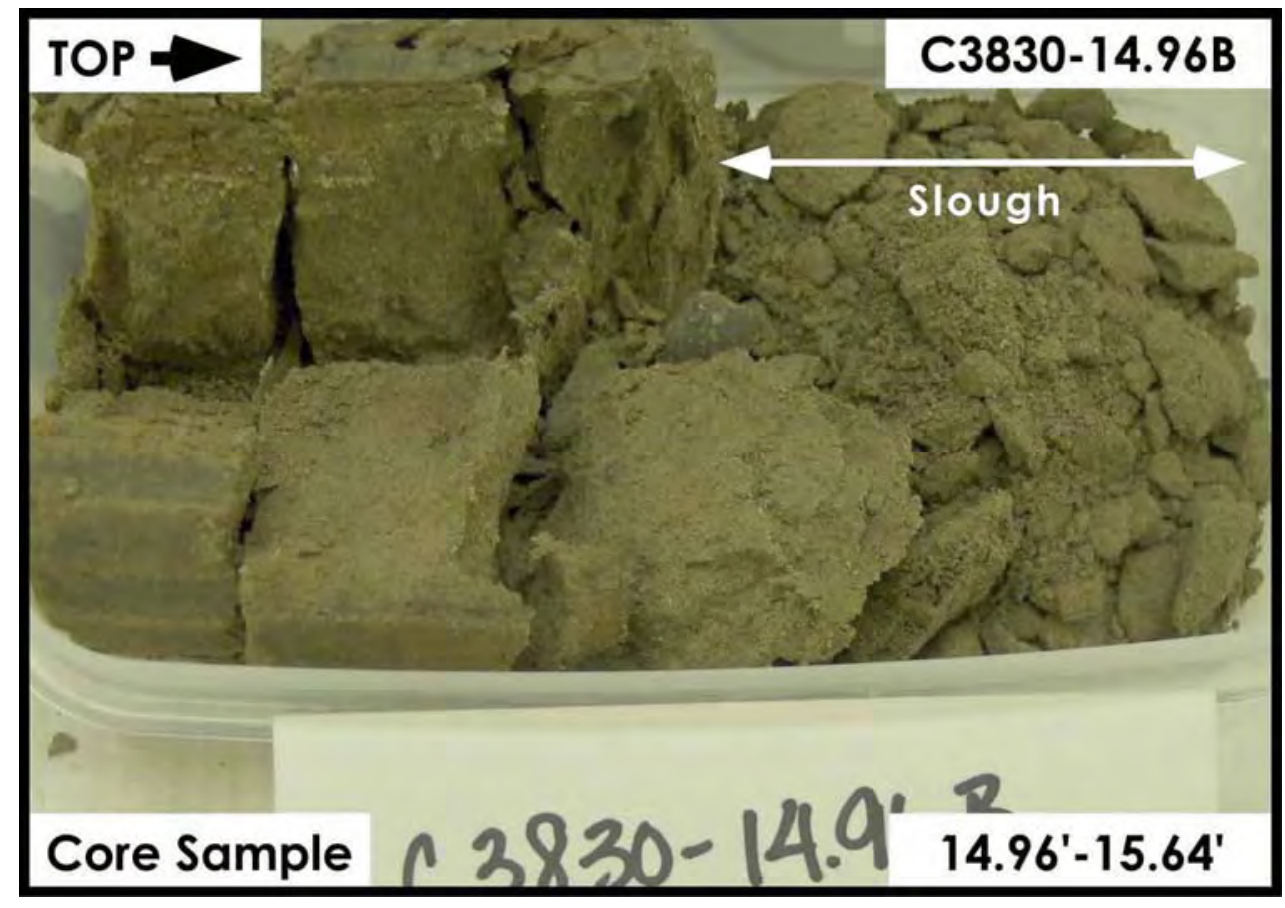

Figure A-2.1. Backfill $14.96 \mathrm{ft}-\mathbf{1 5 . 6 4} \mathrm{ft}$

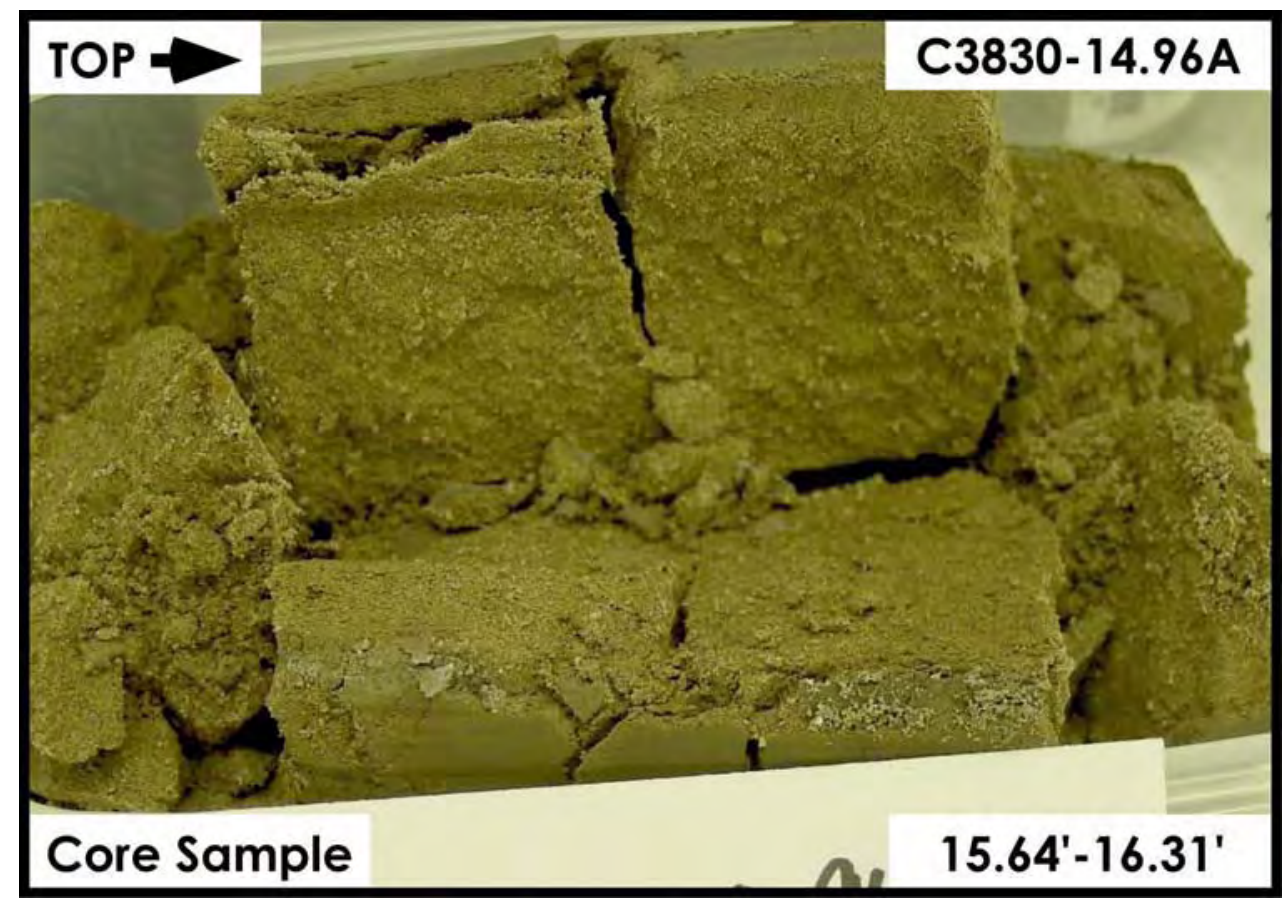

Figure A-2.2. Backfill $15.64 \mathrm{ft}-\mathbf{1 6 . 3 1} \mathrm{ft}$ 


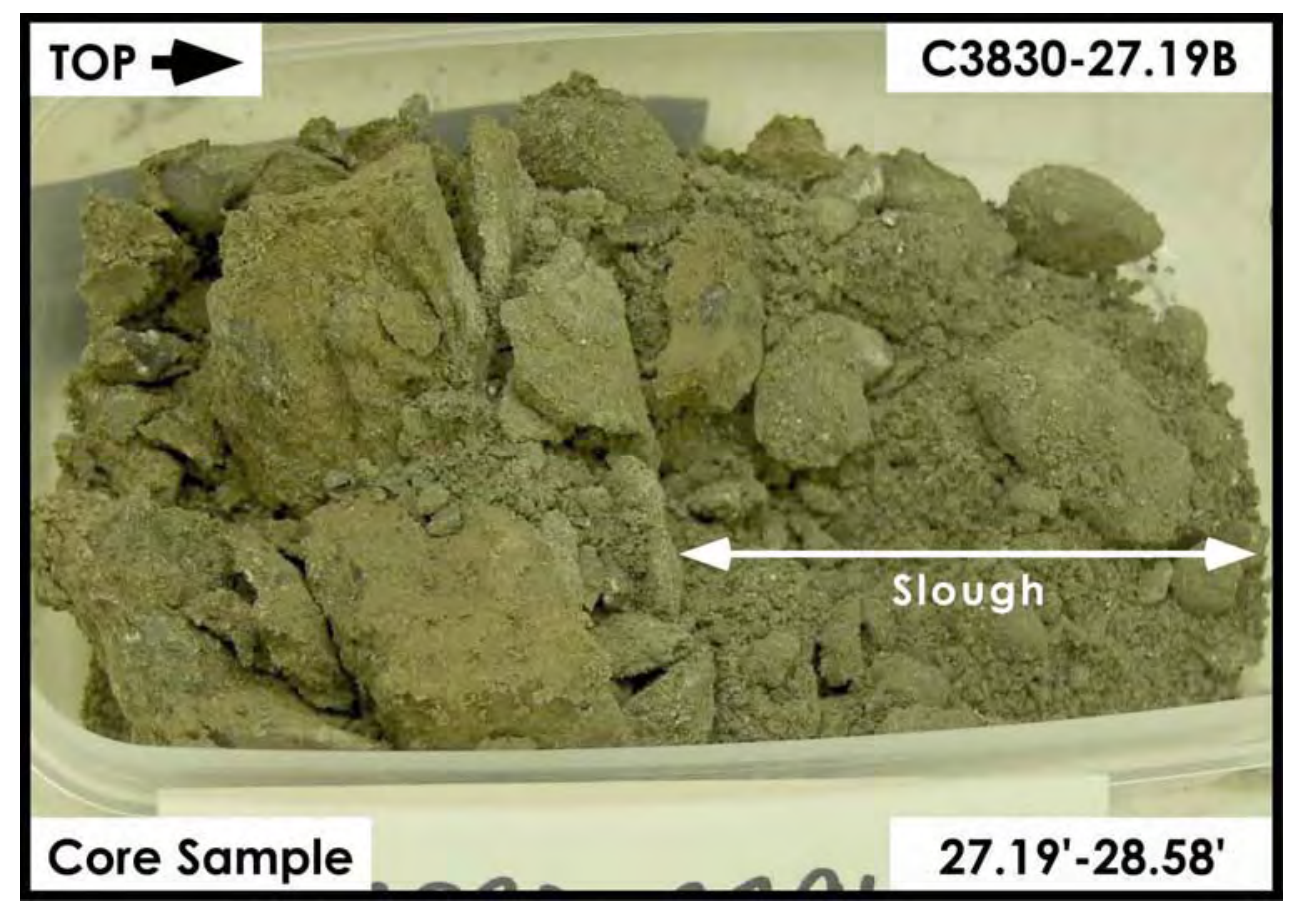

Figure A-2.3. Backfill $27.19 \mathrm{ft}-\mathbf{2 8 . 5 8} \mathrm{ft}$

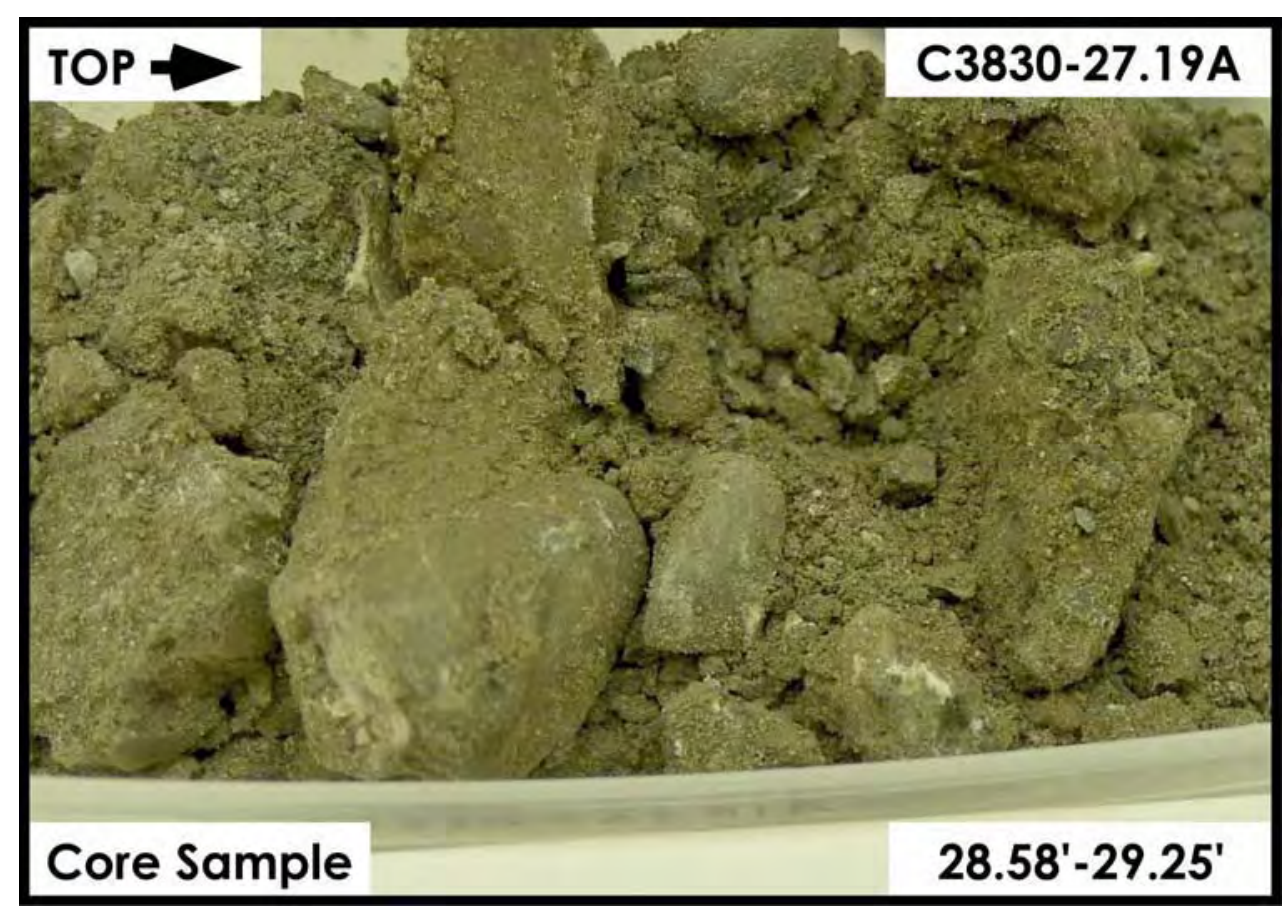

Figure A-2.4. Backfill $28.58 \mathrm{ft}-\mathbf{2 9 . 2 5 f t}$ 


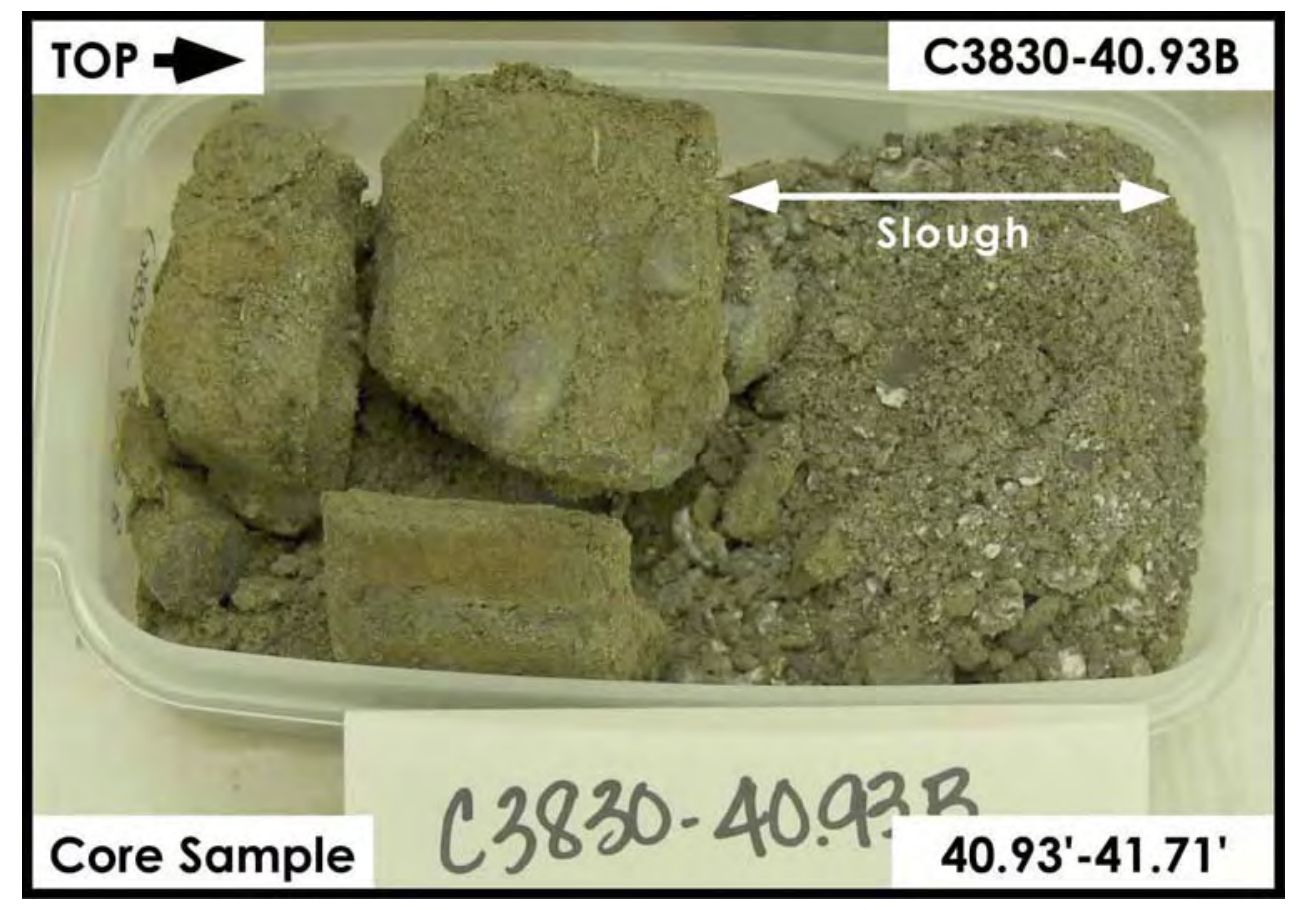

Figure A-2.5. Backfill $40.93 \mathrm{ft}-\mathbf{4 1 . 7 1} \mathrm{ft}$

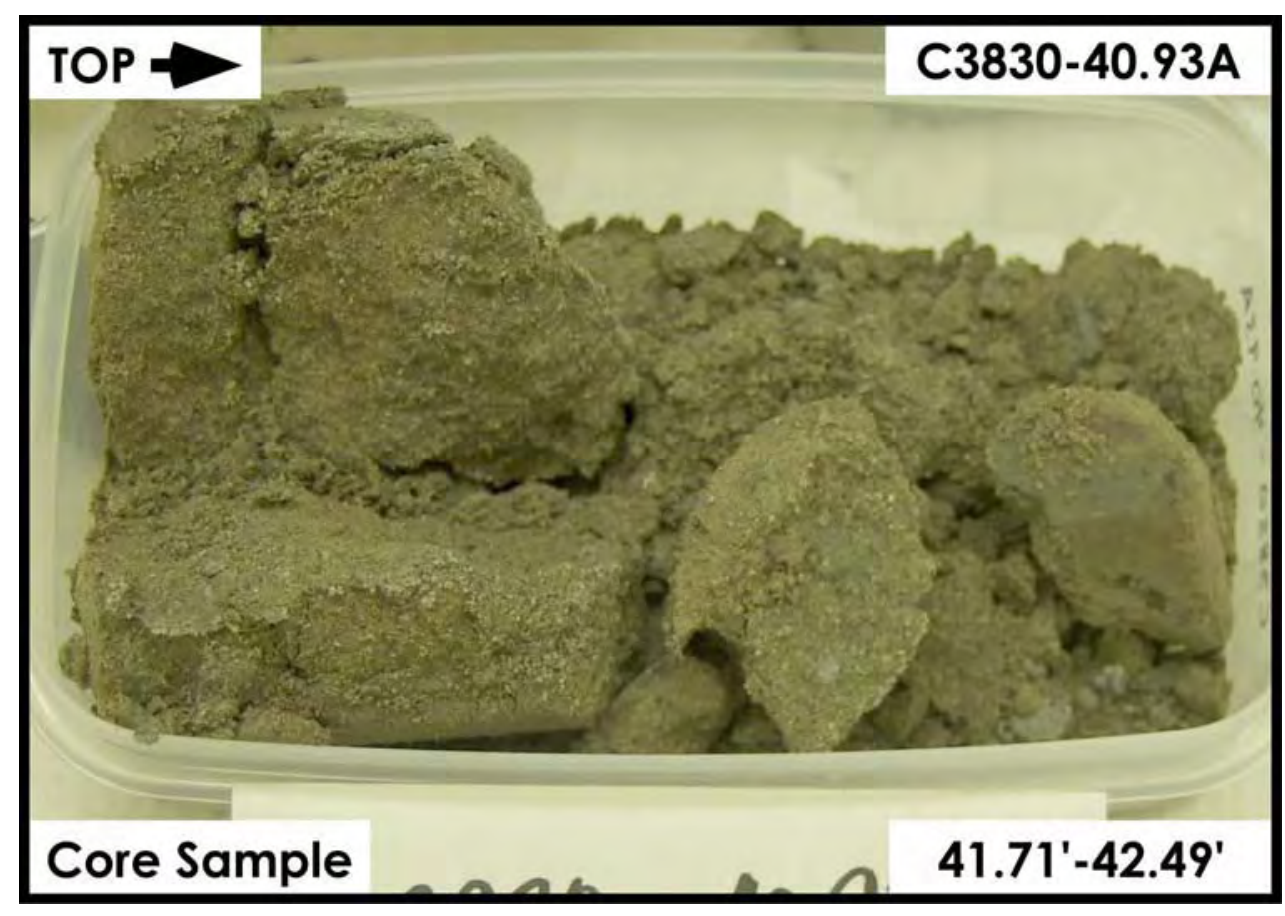

Figure A-2.6. Backfill $41.71 \mathrm{ft}-\mathbf{4 2 . 4 9} \mathrm{ft}$ 


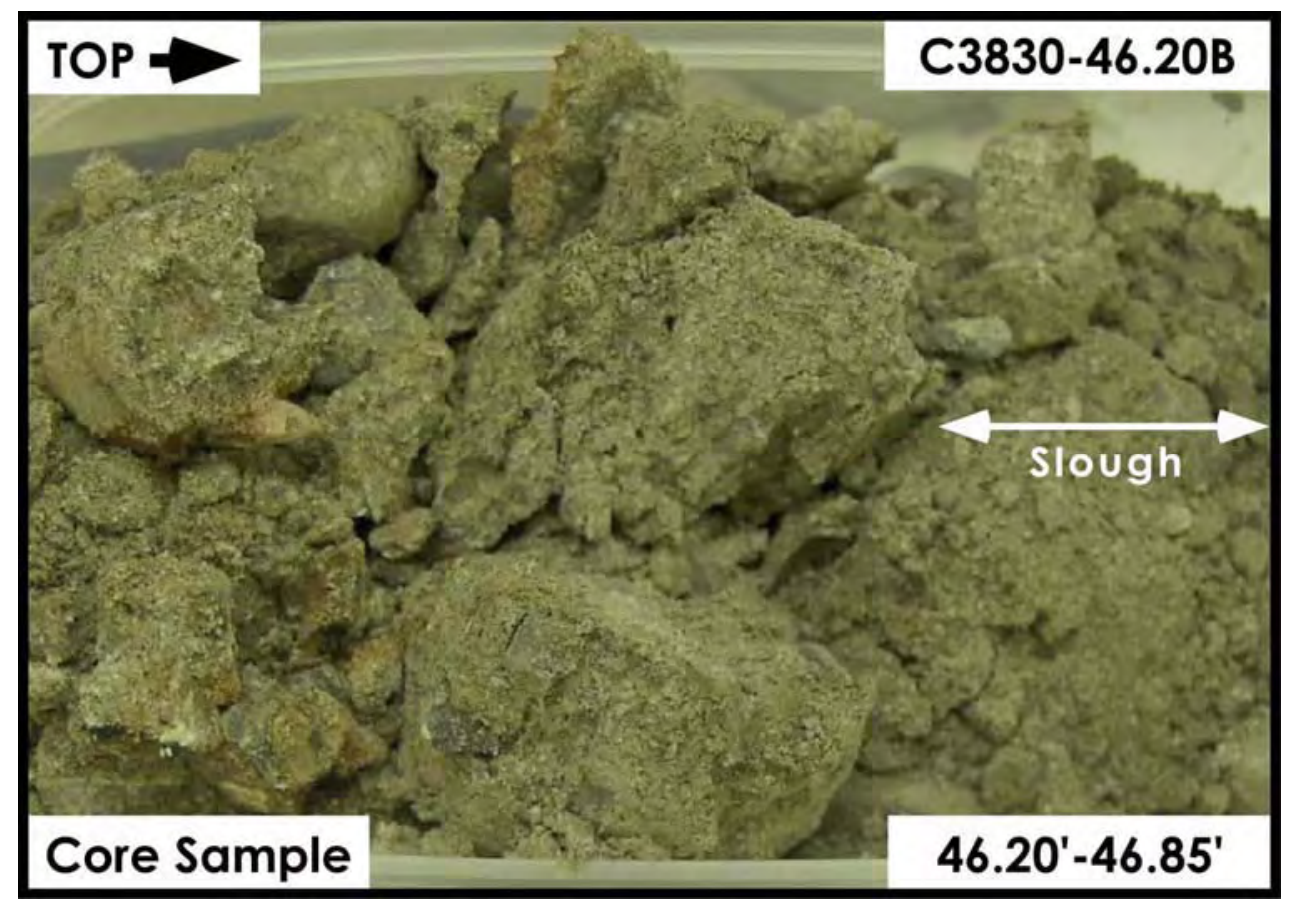

Figure A-2.7. Backfill $46.20 \mathrm{ft}-\mathbf{4 6 . 8 5} \mathrm{ft}$

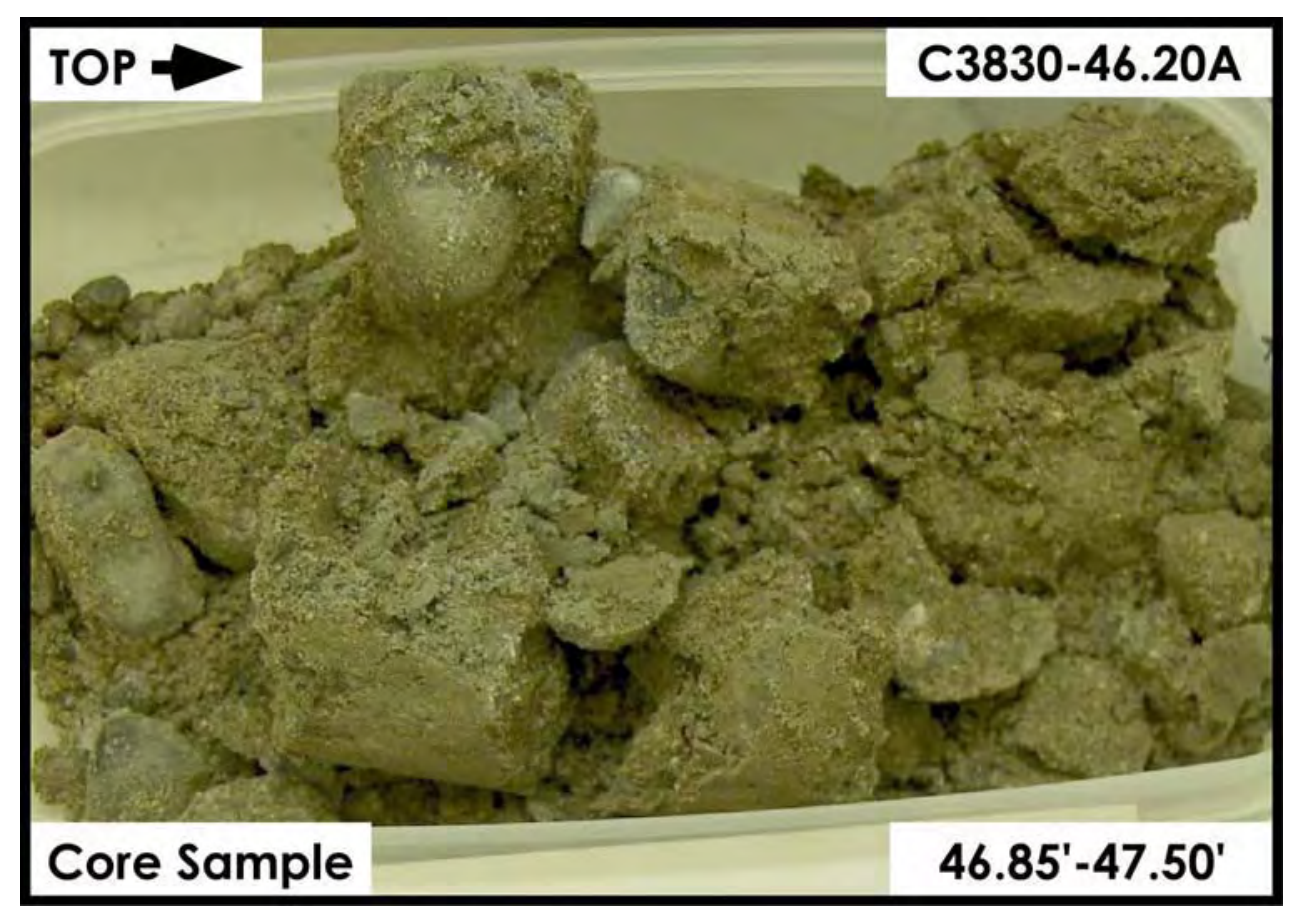

Figure A-2.8. Backfill $46.85 \mathrm{ft}-\mathbf{4 7 . 5 0} \mathrm{ft}$ 


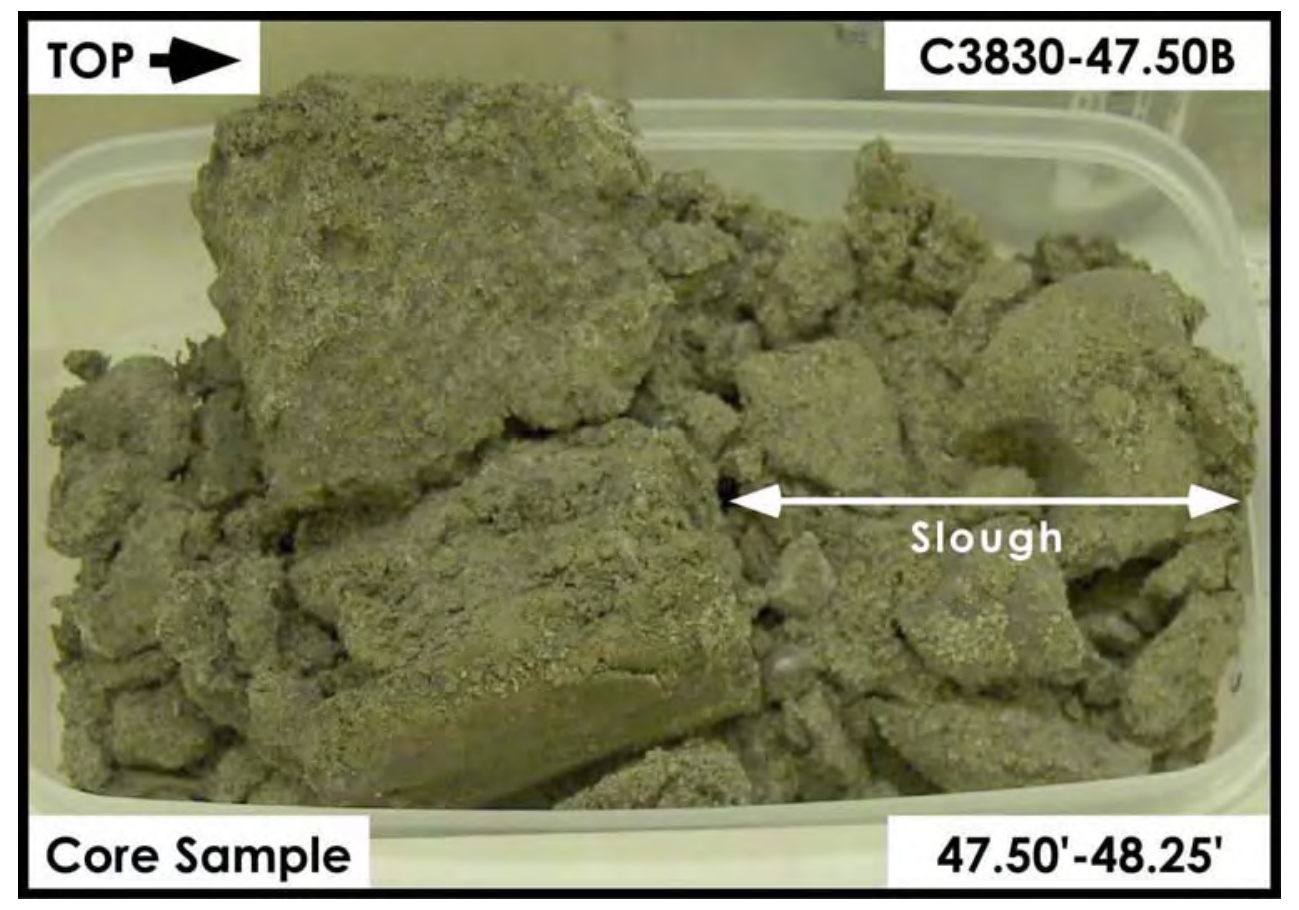

Figure A-2.9. Backfill $47.50 \mathrm{ft}-\mathbf{4 8 . 2 5} \mathrm{ft}$

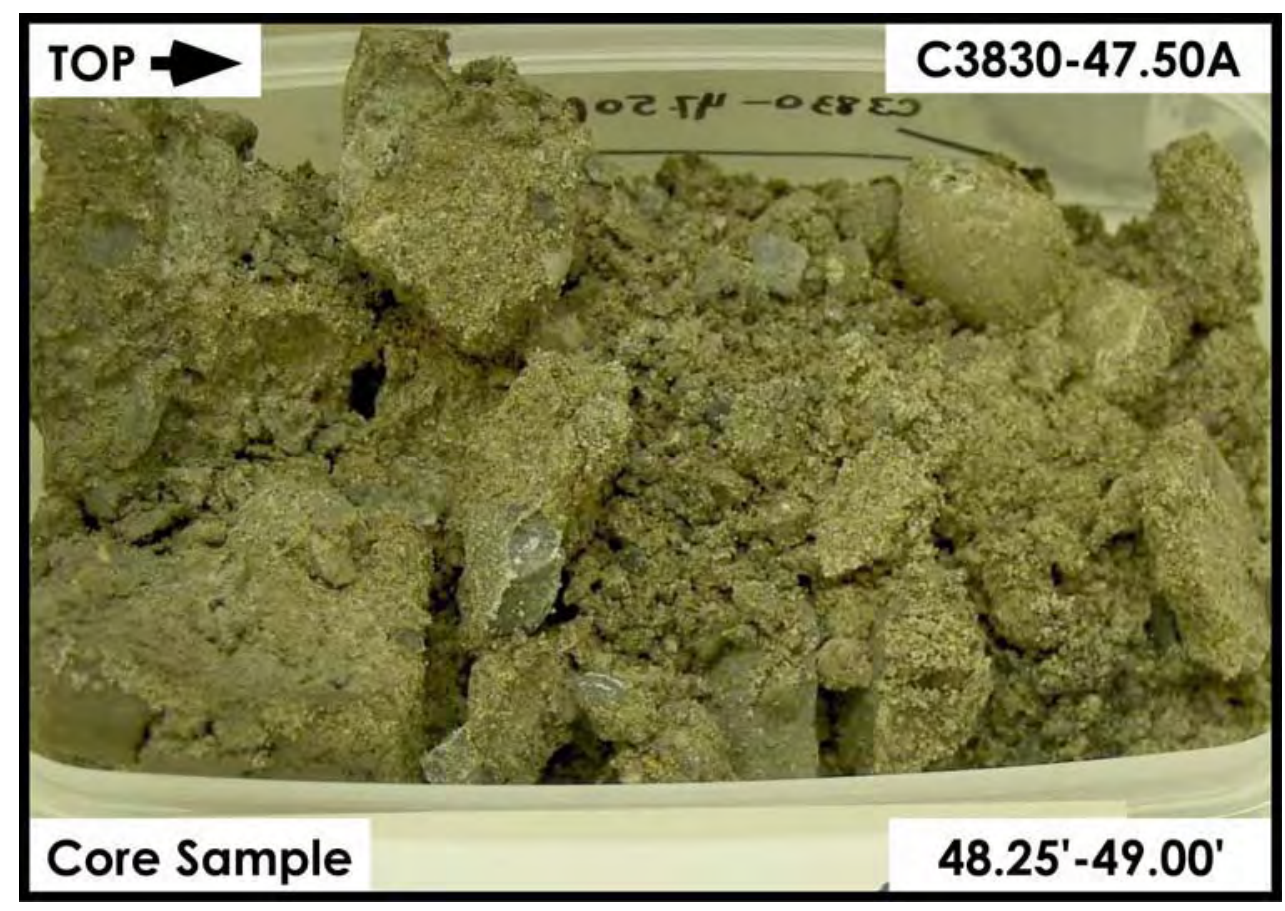

Figure A-2.10. Backfill $48.25 \mathrm{ft}-\mathbf{4 9 . 0 0} \mathrm{ft}$ 


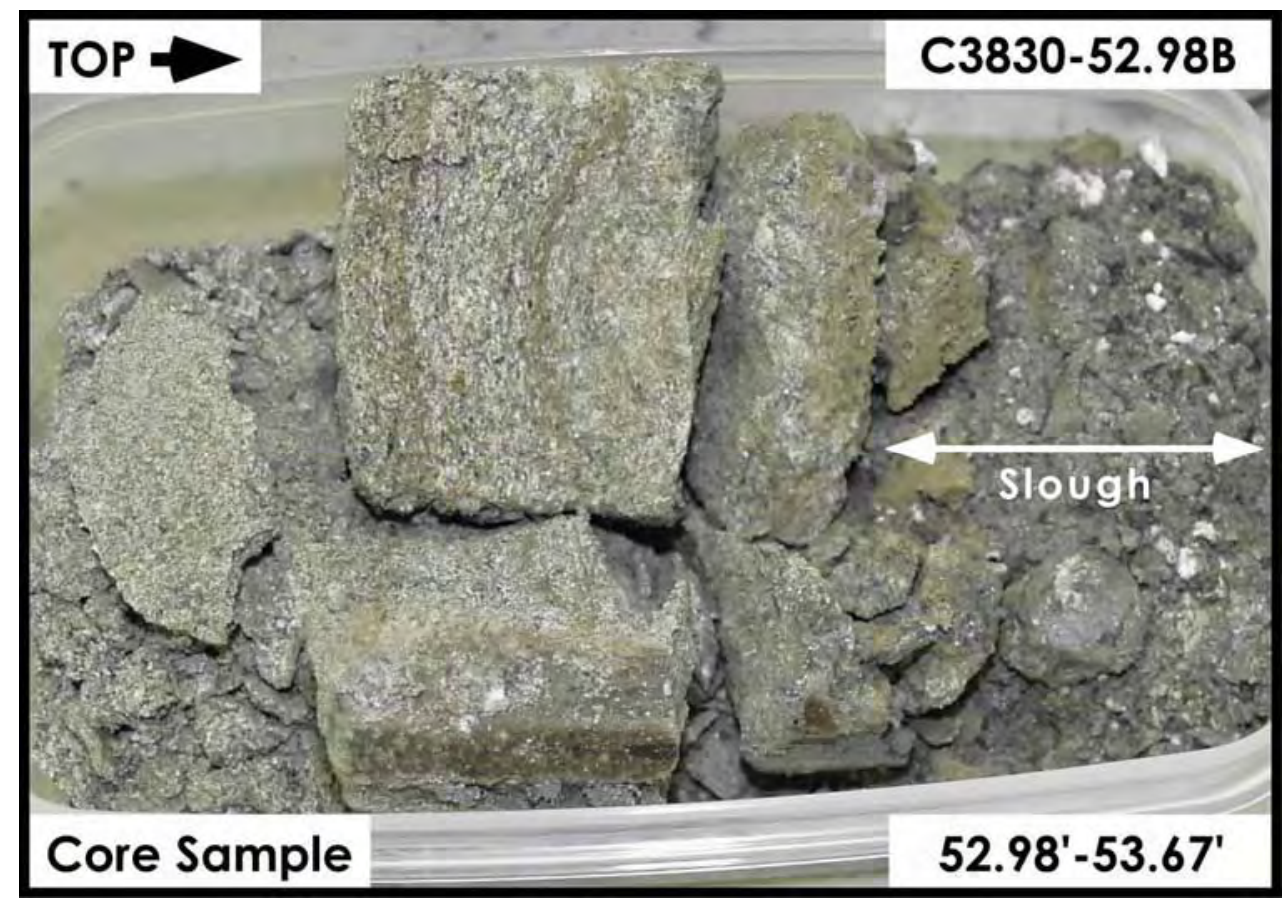

Figure A-2.11. Hanford Formation (H2 unit) $52.98 \mathrm{ft}-53.67 \mathrm{ft}$

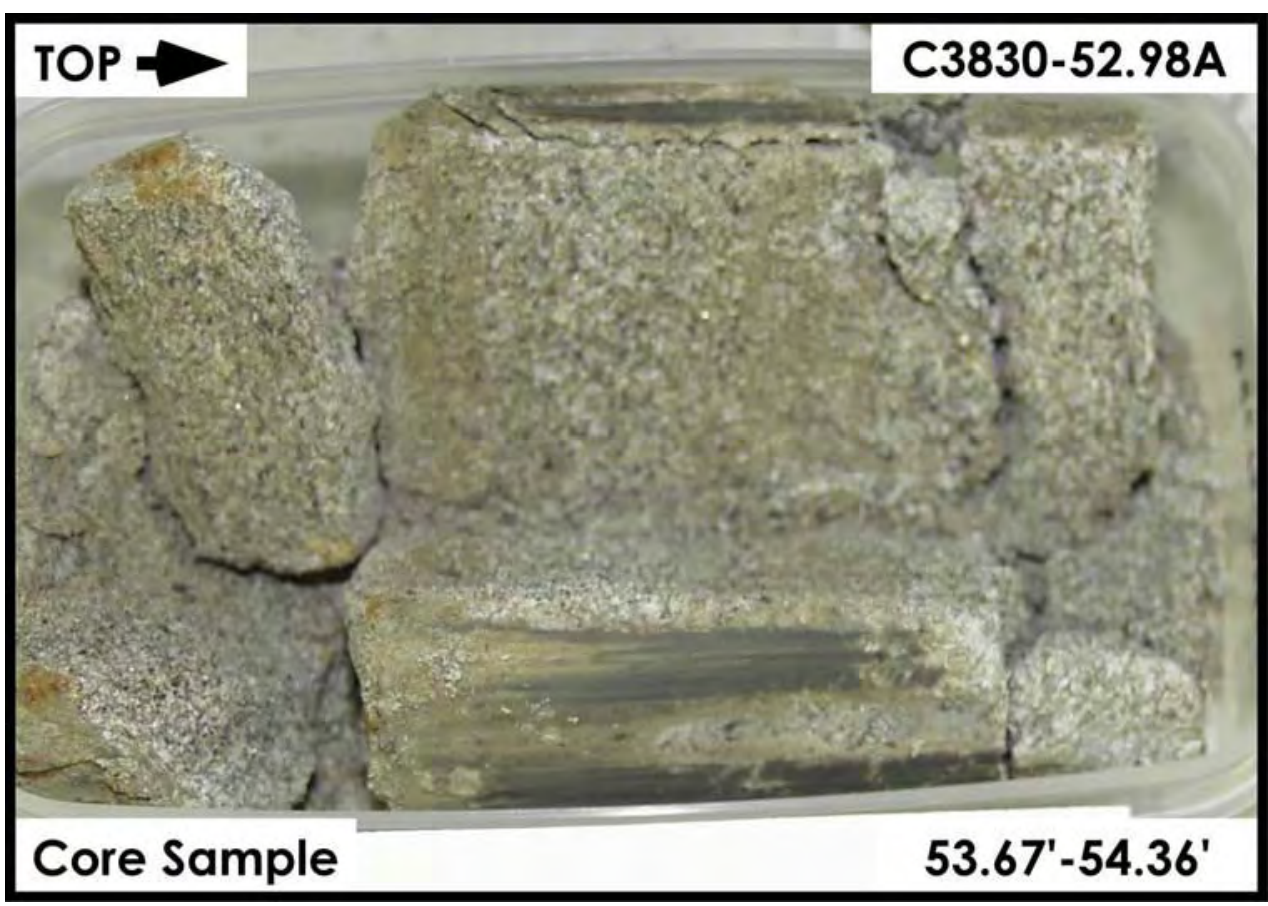

Figure A-2.12. Hanford Formation (H2 unit) $53.67 \mathrm{ft}-54.36 \mathrm{ft}$ 


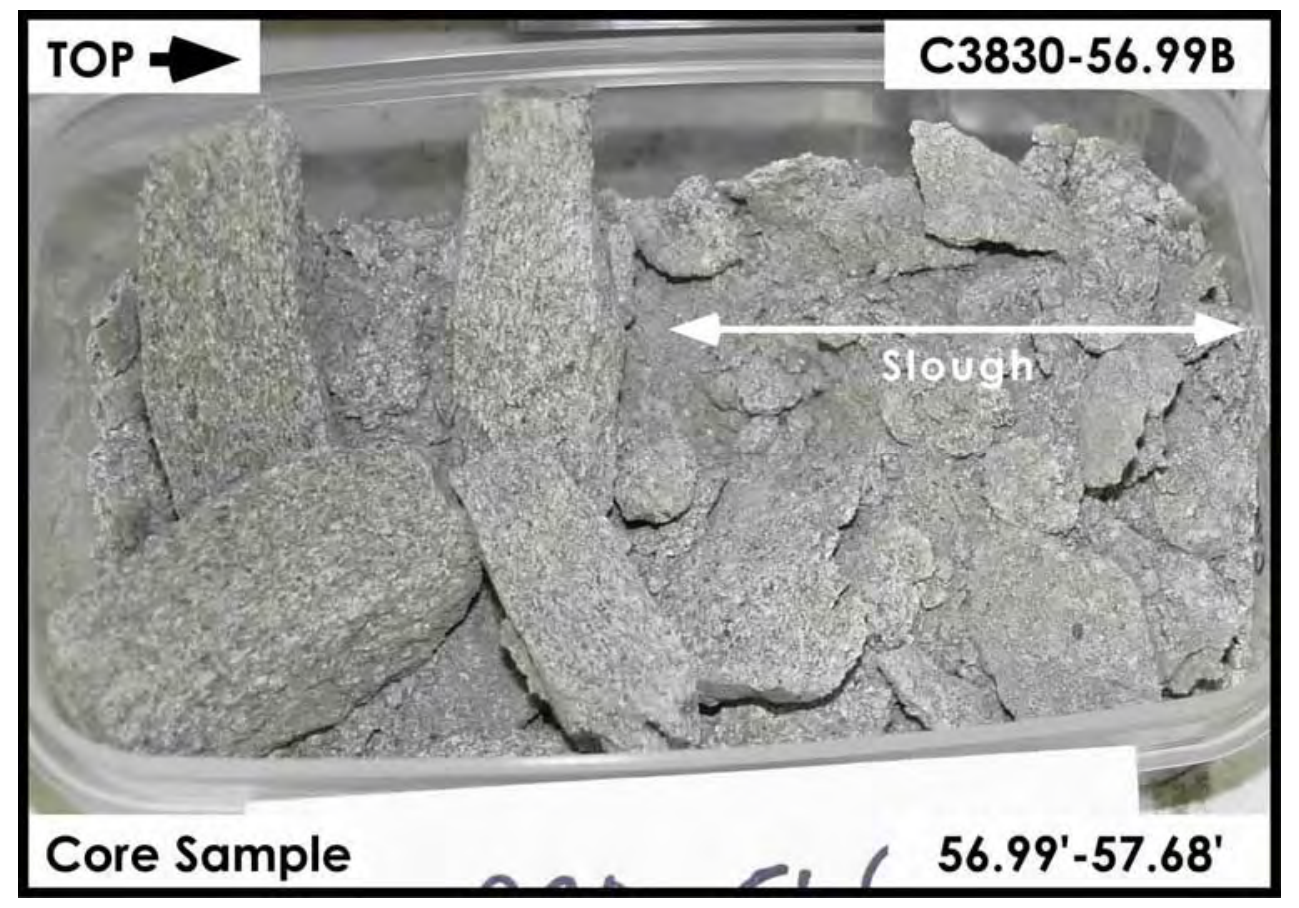

Figure A-2.13. Hanford Formation (H2 unit) $56.99 \mathrm{ft}-\mathbf{5 7 . 6 8} \mathrm{ft}$

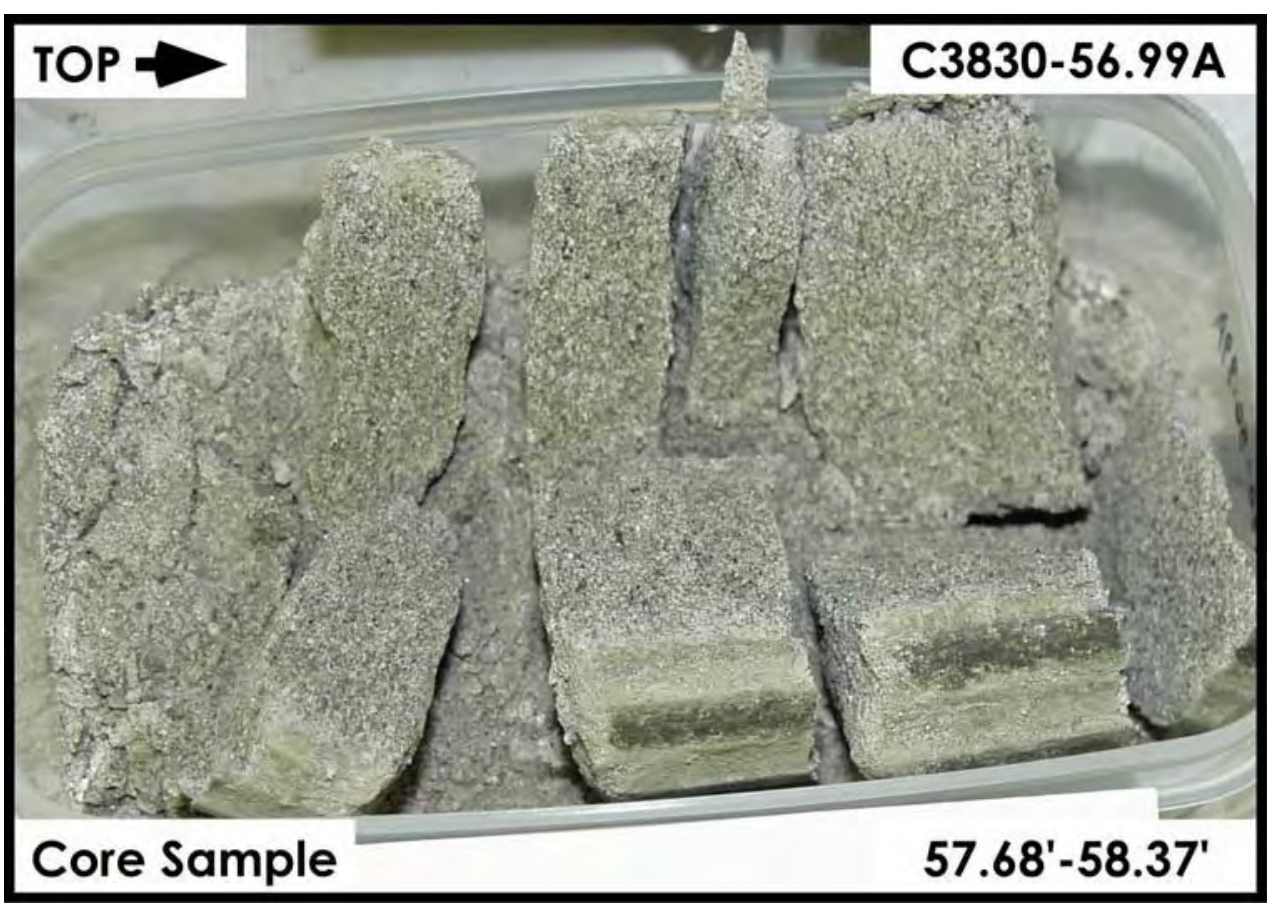

Figure A-2.14. Hanford Formation (H2 unit) $57.68 \mathrm{ft}-\mathbf{5 8 . 3 7} \mathrm{ft}$ 


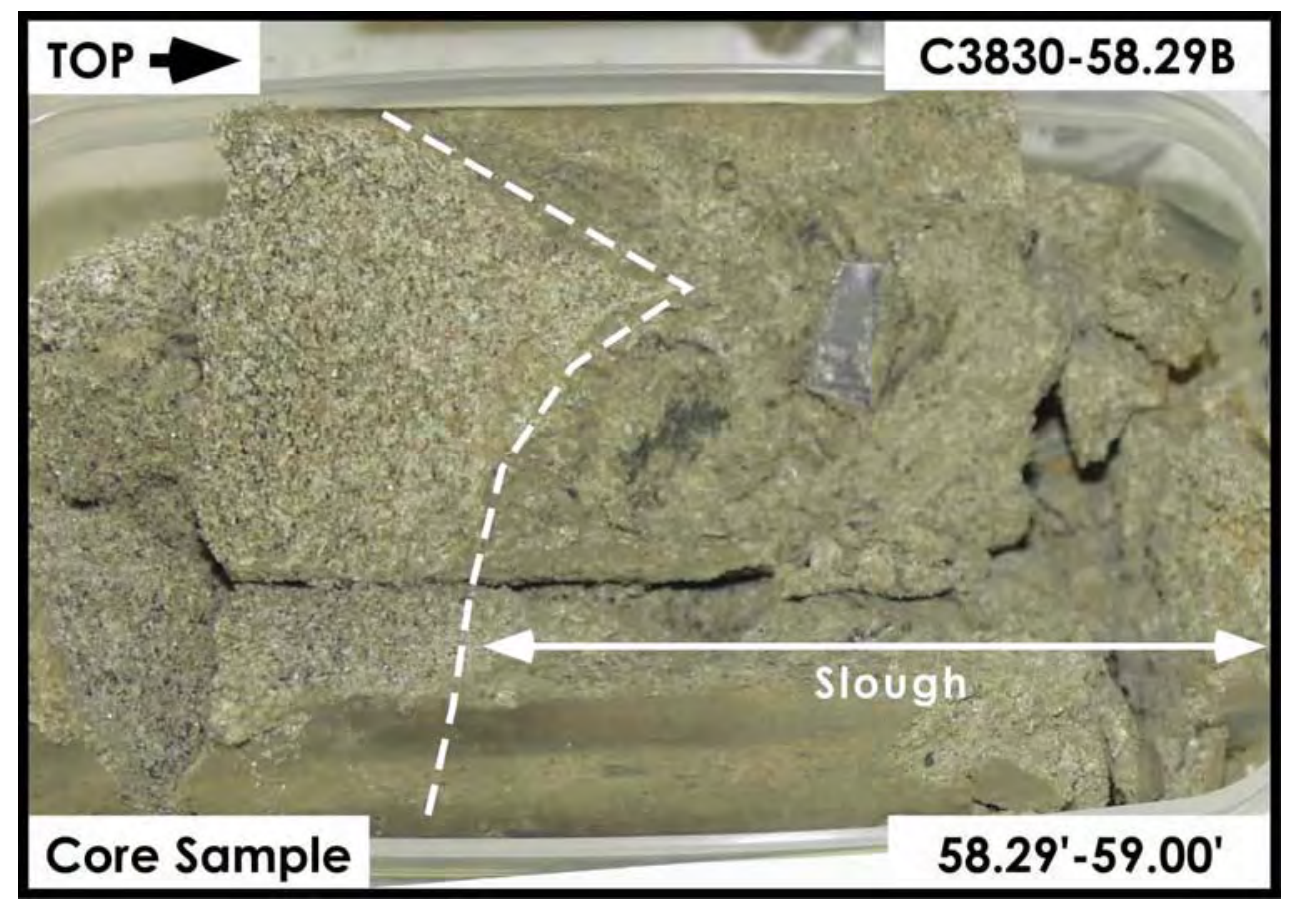

Figure A-2.15. Hanford Formation (H2 unit) $58.29 \mathrm{ft}-\mathbf{5 9 . 0 0} \mathrm{ft}$

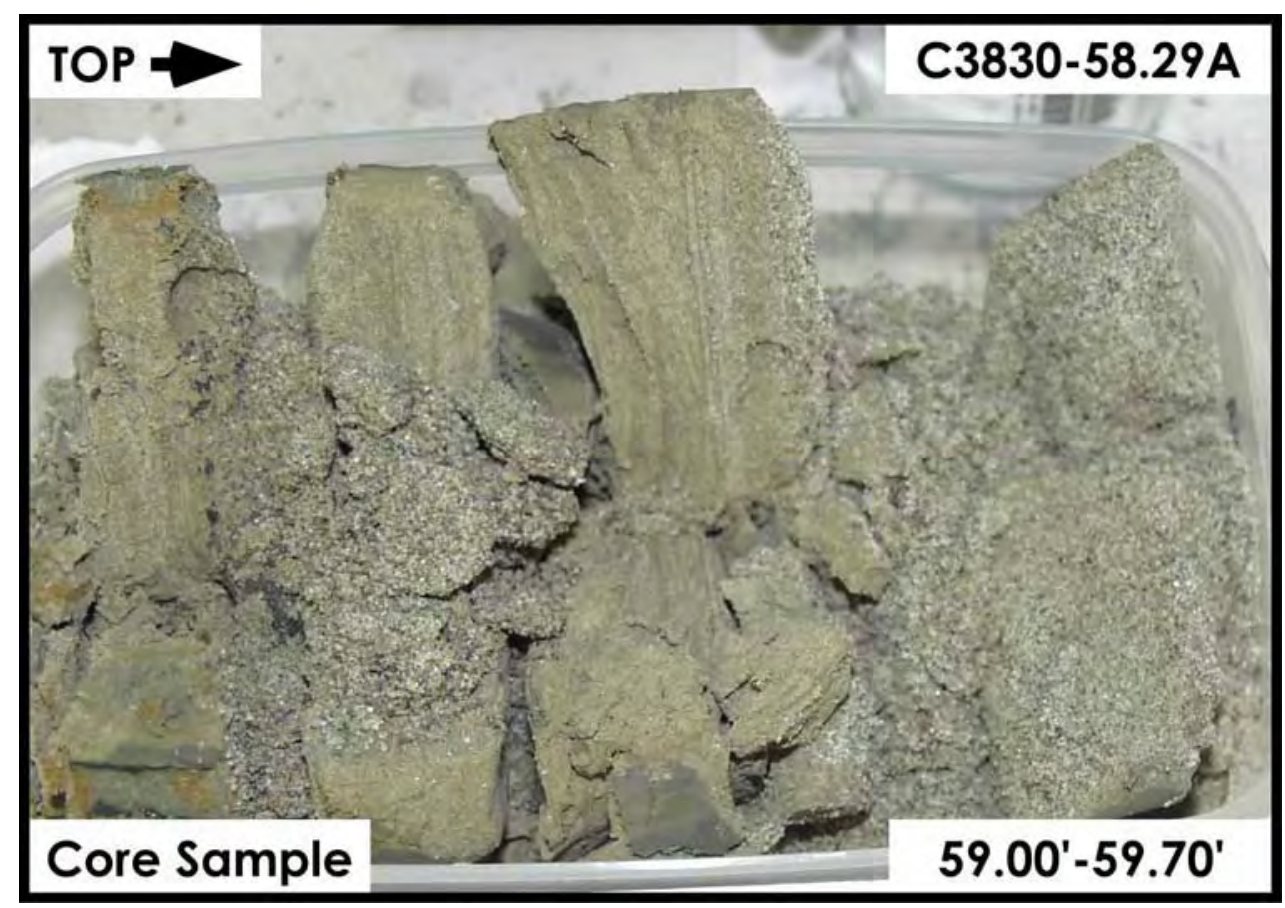

Figure A-2.16. Hanford Formation (H2 unit) $59.00 \mathrm{ft}-\mathbf{5 9 . 7 0} \mathrm{ft}$ 


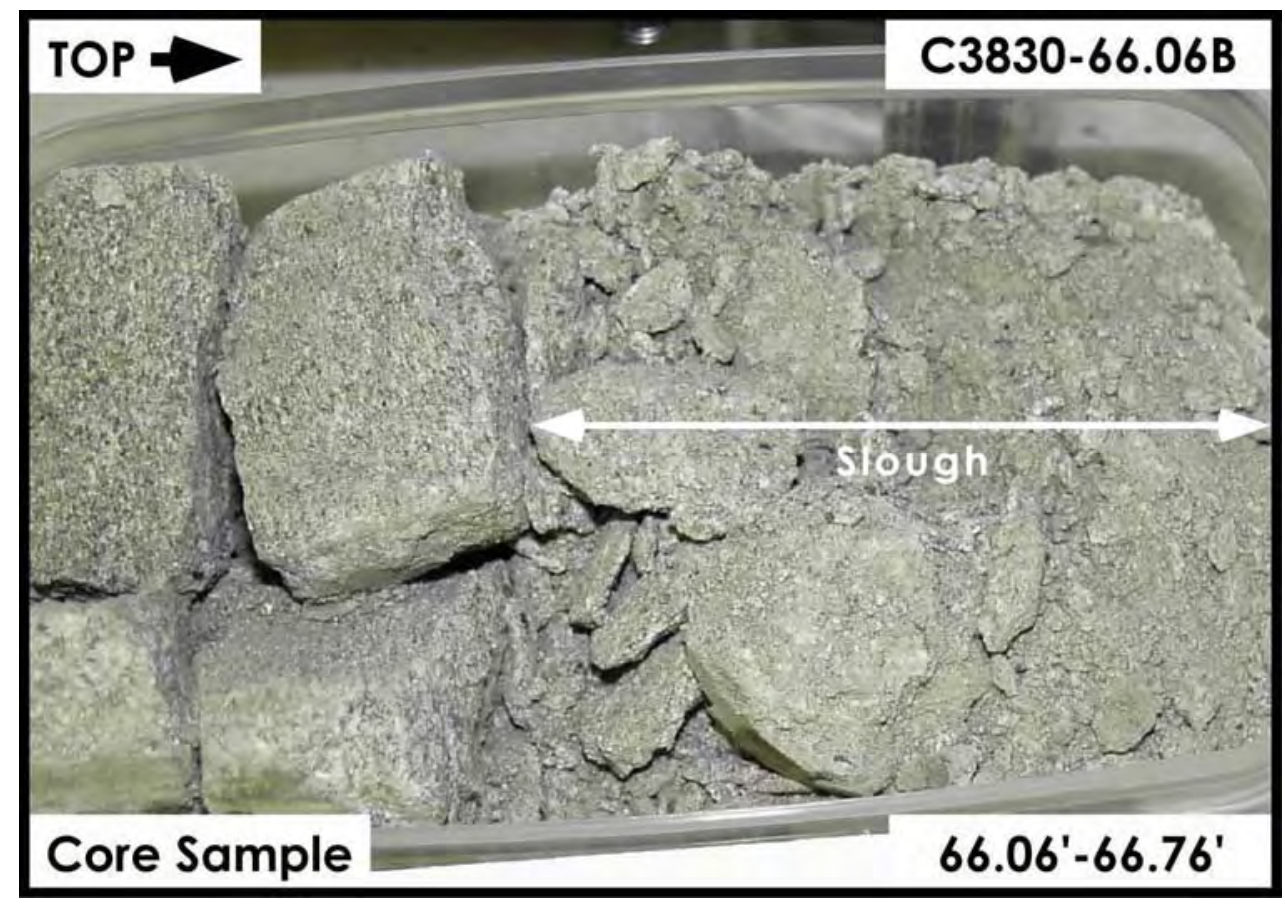

Figure A-2.17. Hanford Formation (H2 unit) $66.06 \mathrm{ft}-66.76 \mathrm{ft}$

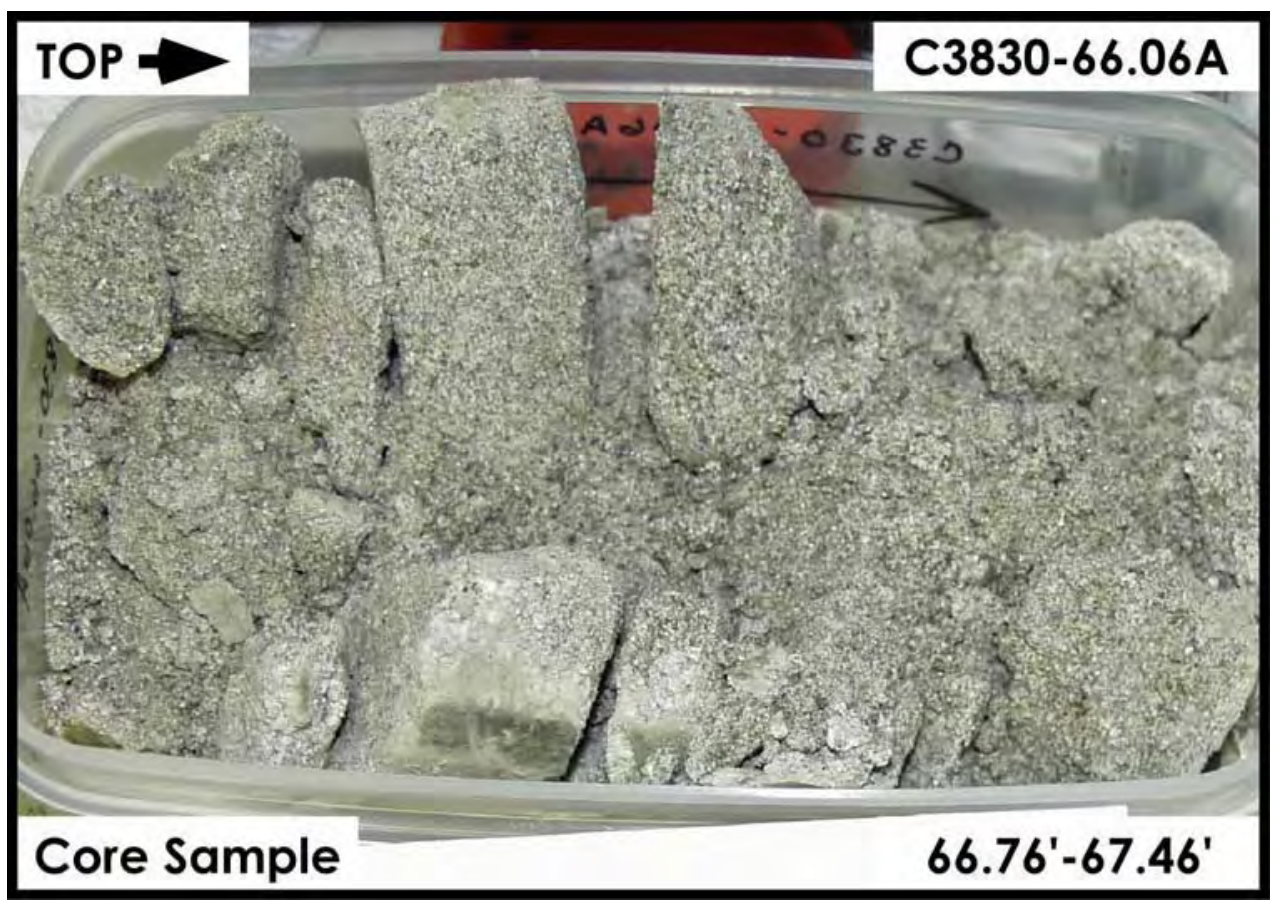

Figure A-2.18. Hanford Formation (H2 unit) $66.76 \mathrm{ft}-67.46 \mathrm{ft}$ 


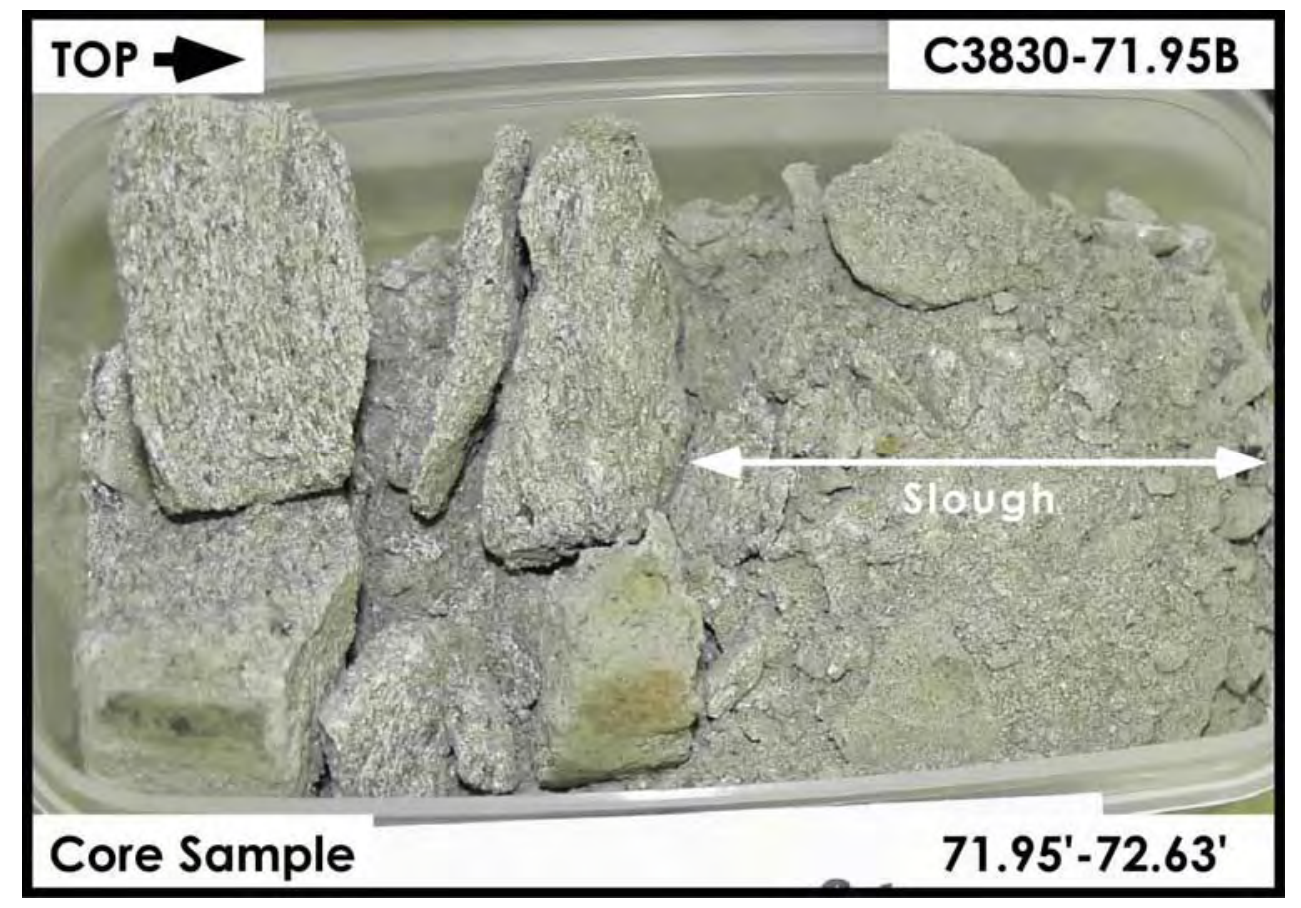

Figure A-2.19. Hanford Formation (H2 unit) $71.95 \mathrm{ft}-72.63 \mathrm{ft}$

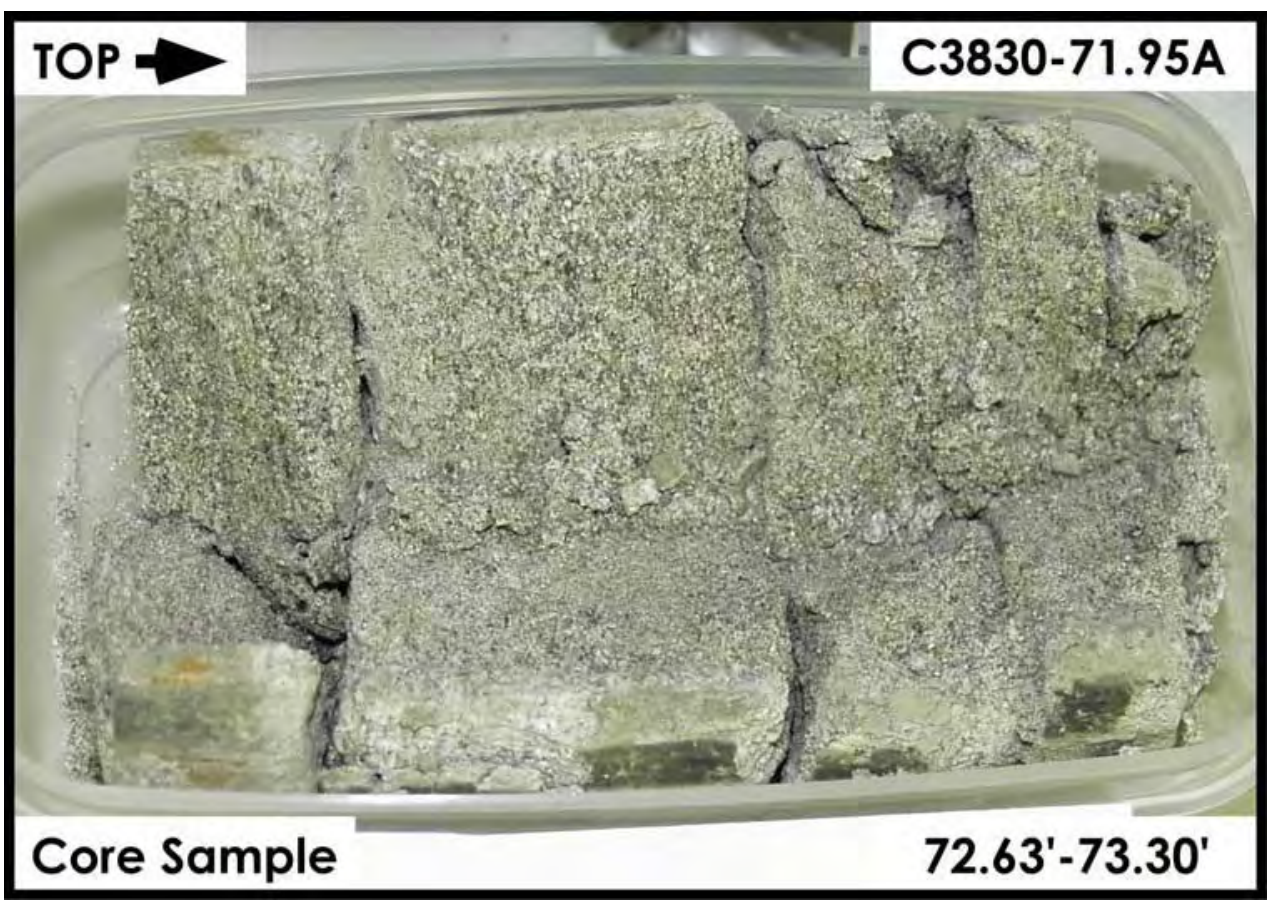

Figure A-2.20. Hanford Formation (H2 unit) $72.63 \mathrm{ft}-73.30 \mathrm{ft}$ 


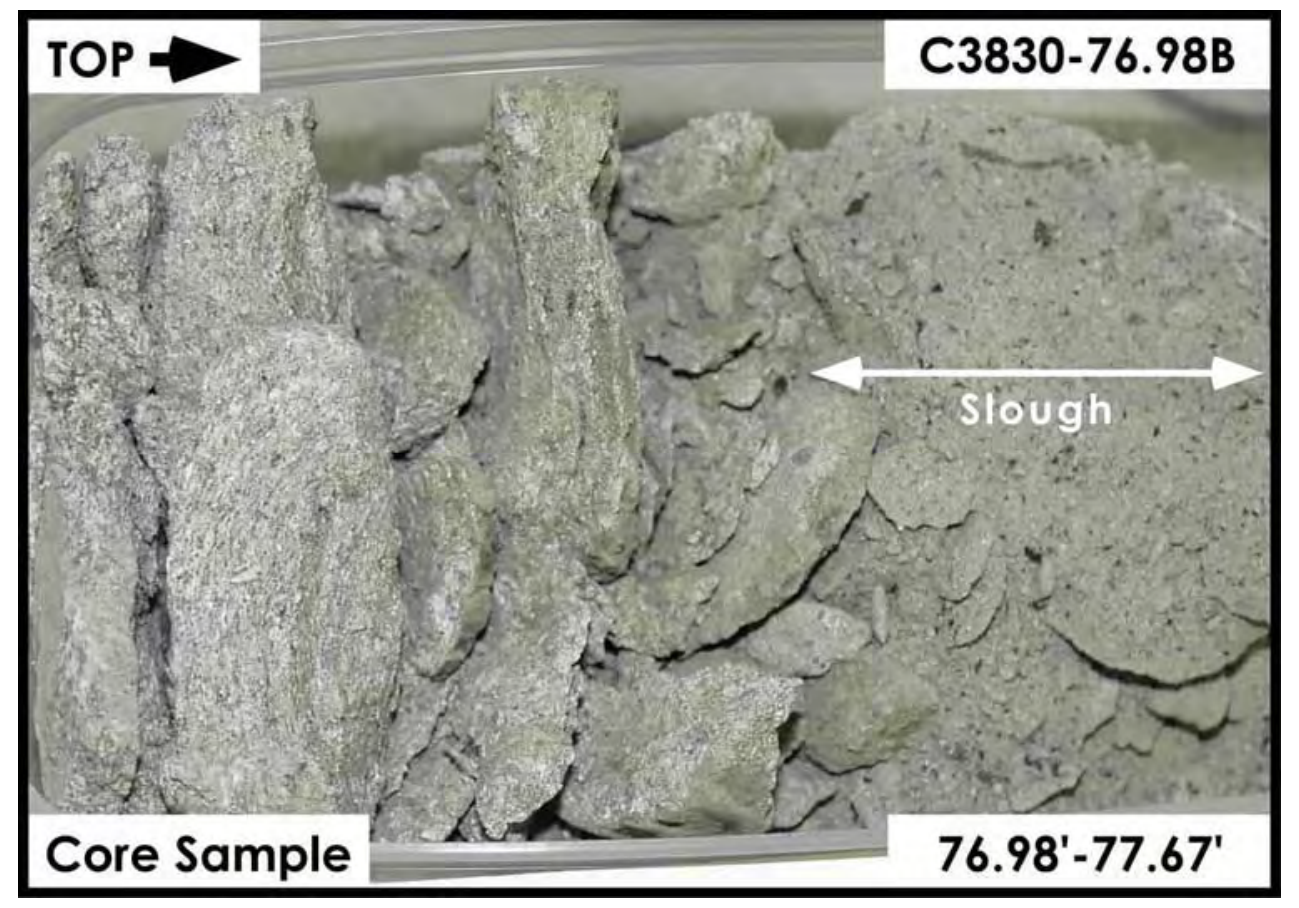

Figure A-2.21. Hanford Formation (H2 unit) $76.98 \mathrm{ft}-77.67 \mathrm{ft}$

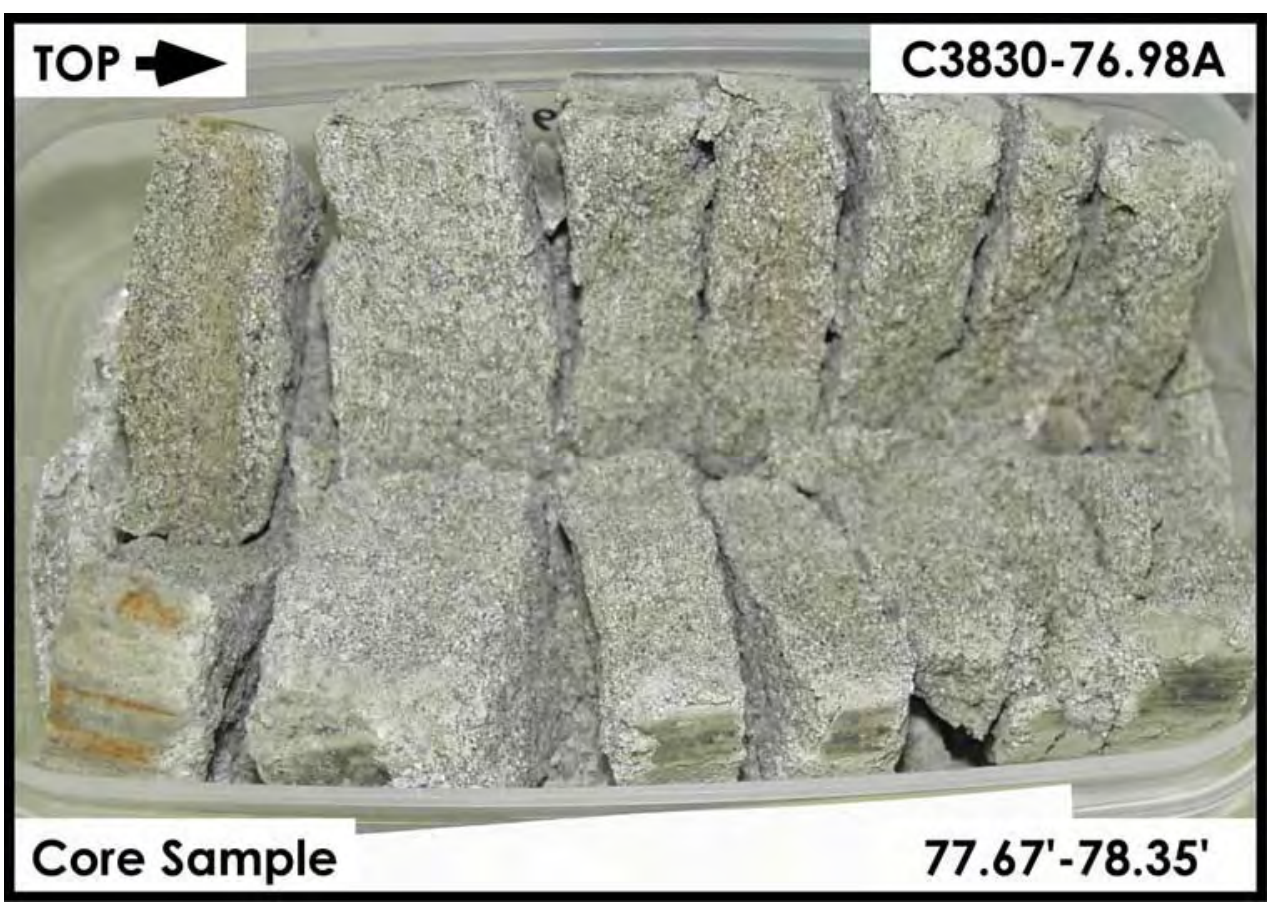

Figure A-2.22. Hanford Formation (H2 unit) $77.67 \mathrm{ft}-78.35 \mathrm{ft}$ 


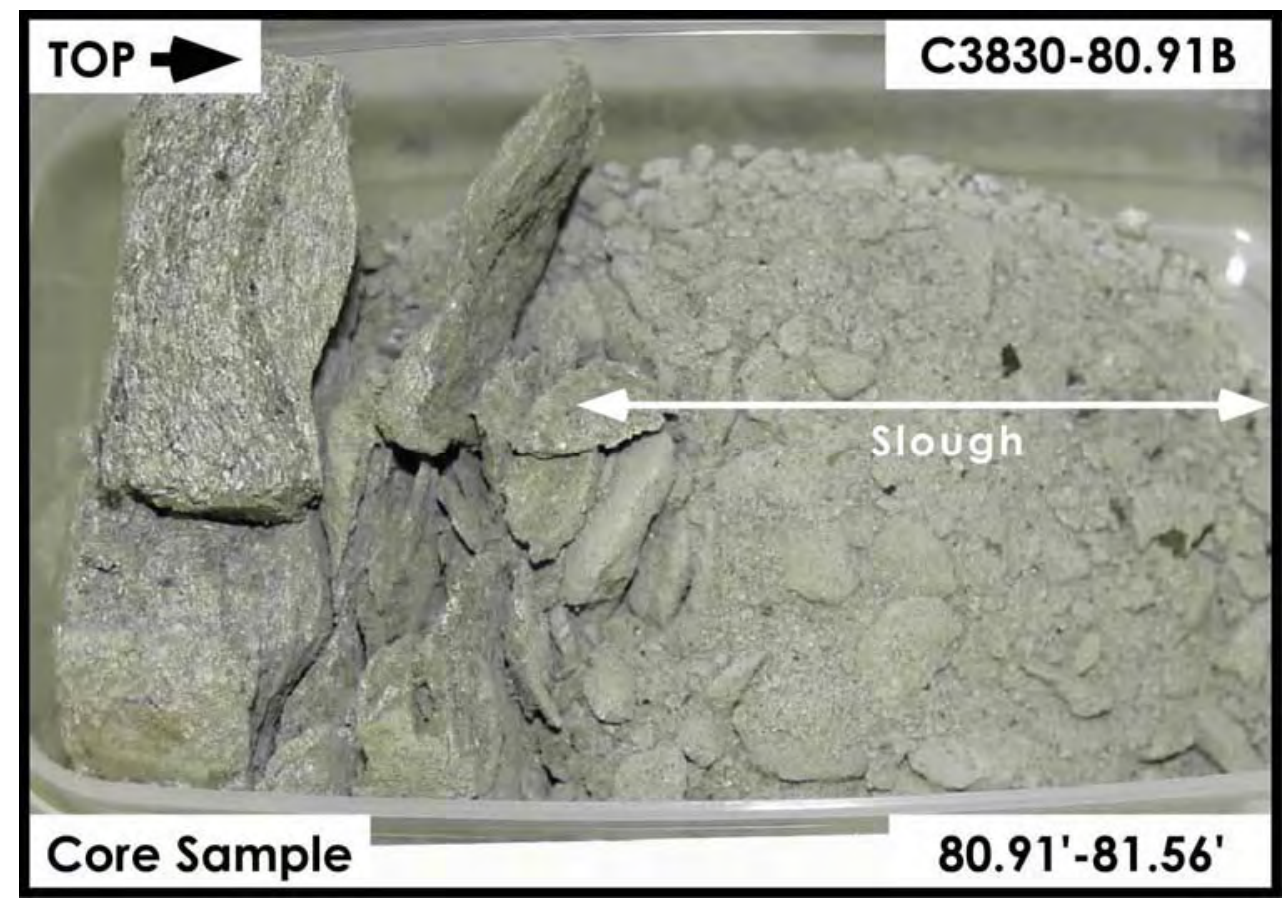

Figure A-2.23. Hanford Formation (H2 unit) $80.91 \mathrm{ft}-81.56 \mathrm{ft}$

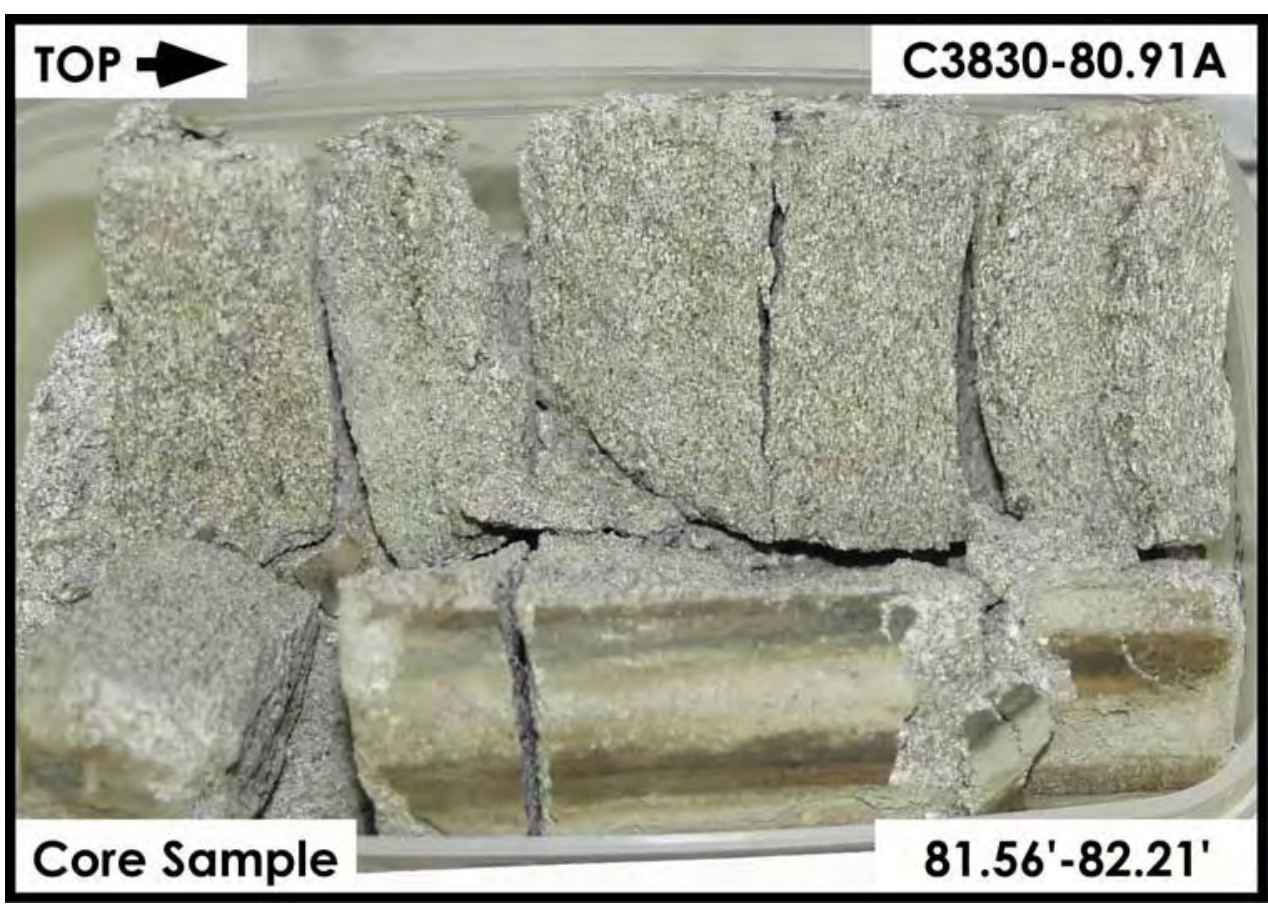

Figure A-2.24. Hanford Formation (H2 unit) $81.56 \mathrm{ft}-82.21 \mathrm{ft}$ 


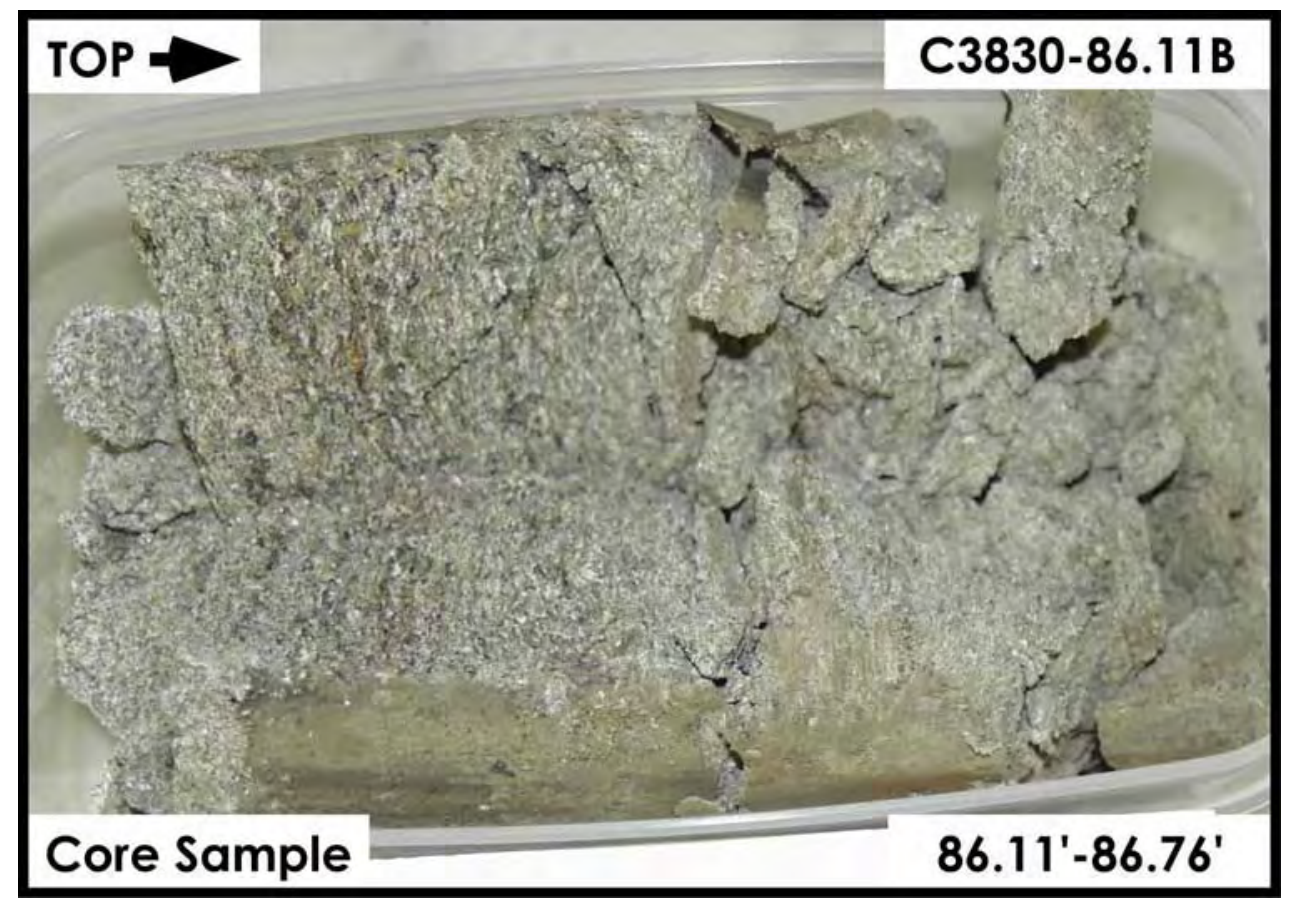

Figure A-2.25. Hanford Formation (H2 unit) $86.11 \mathrm{ft}-86.76 \mathrm{ft}$

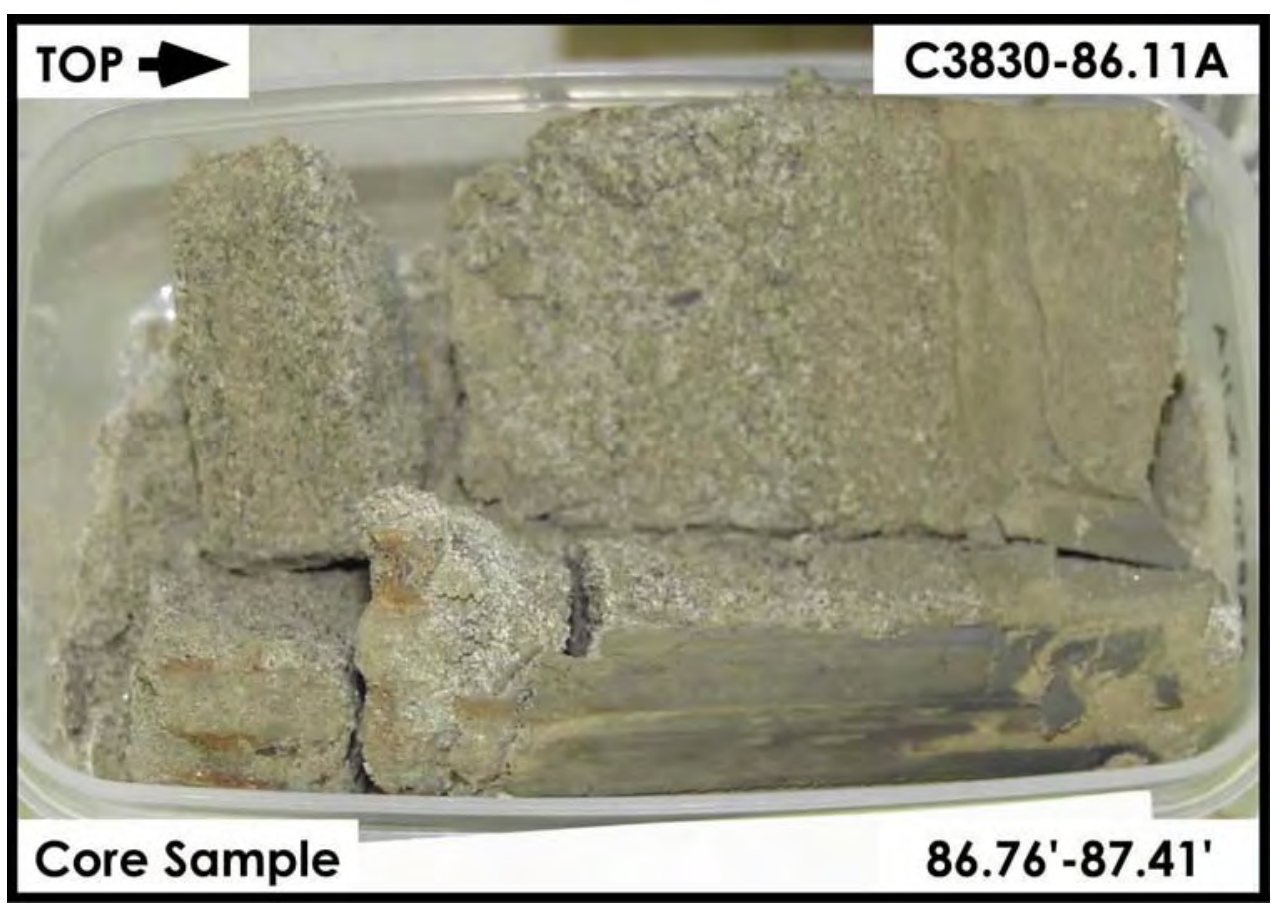

Figure A-2.26. Hanford Formation (H2 unit) $86.76 \mathrm{ft}-87.41 \mathrm{ft}$ 


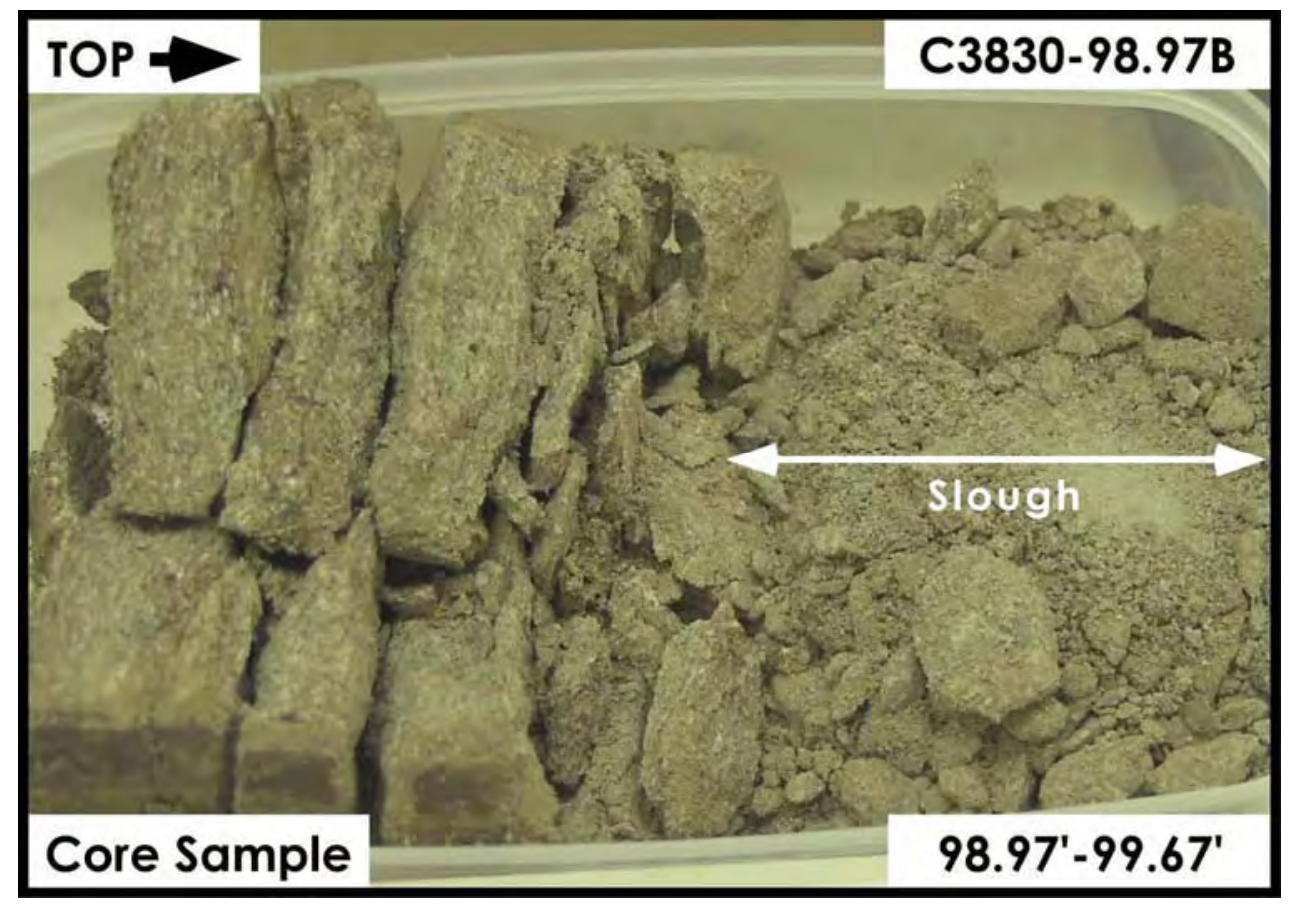

Figure A-2.27. Hanford Formation (H2 unit) $98.97 \mathrm{ft}-99.67 \mathrm{ft}$

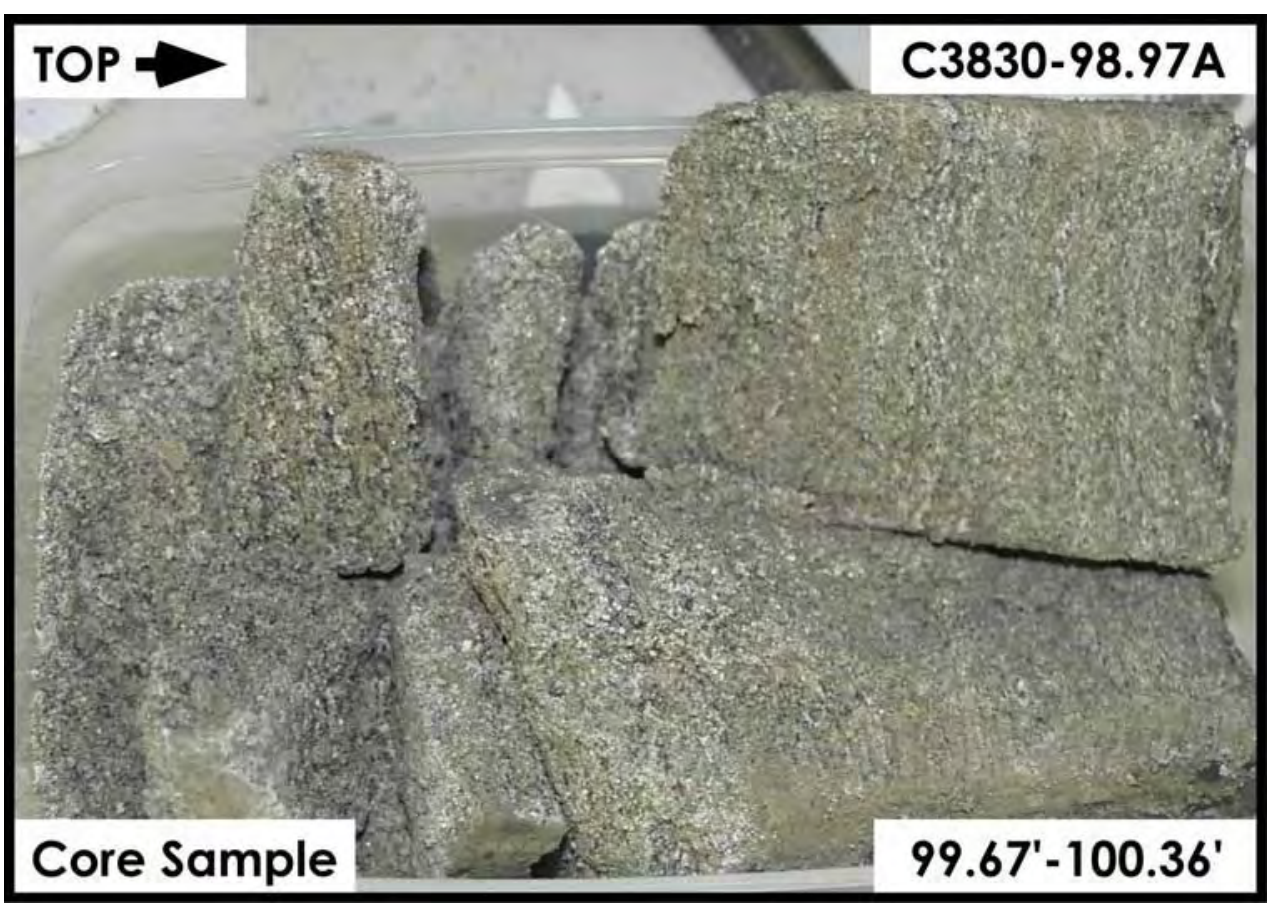

Figure A-2.28. Hanford Formation (H2 unit) $99.67 \mathrm{ft}-100.36 \mathrm{ft}$ 


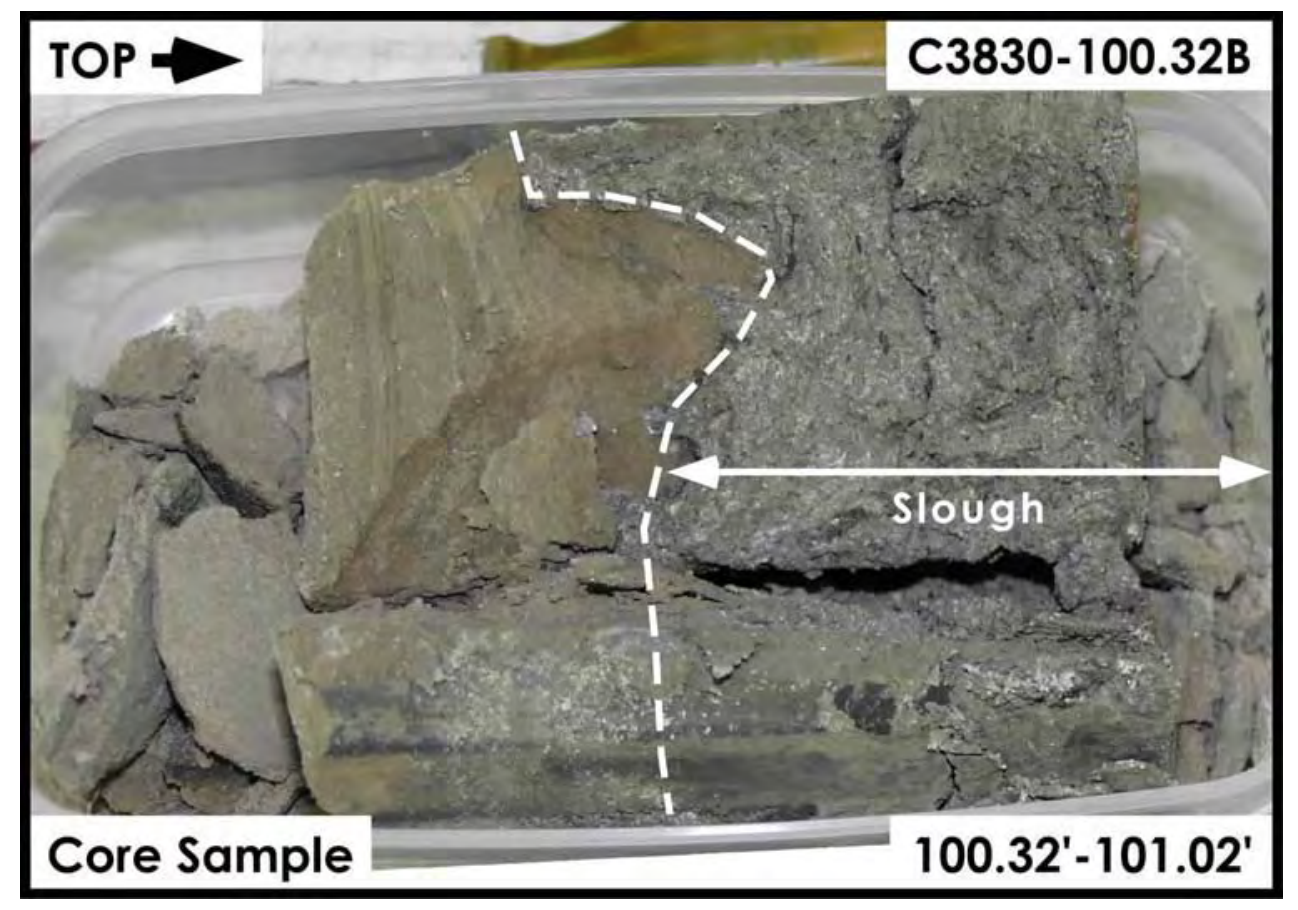

Figure A-2.29. Cold Creek Unit - Upper $\left(\mathrm{CCU}_{\mathrm{u}}\right) \mathbf{1 0 0 . 3 2} \mathrm{ft}-101.02 \mathrm{ft}$

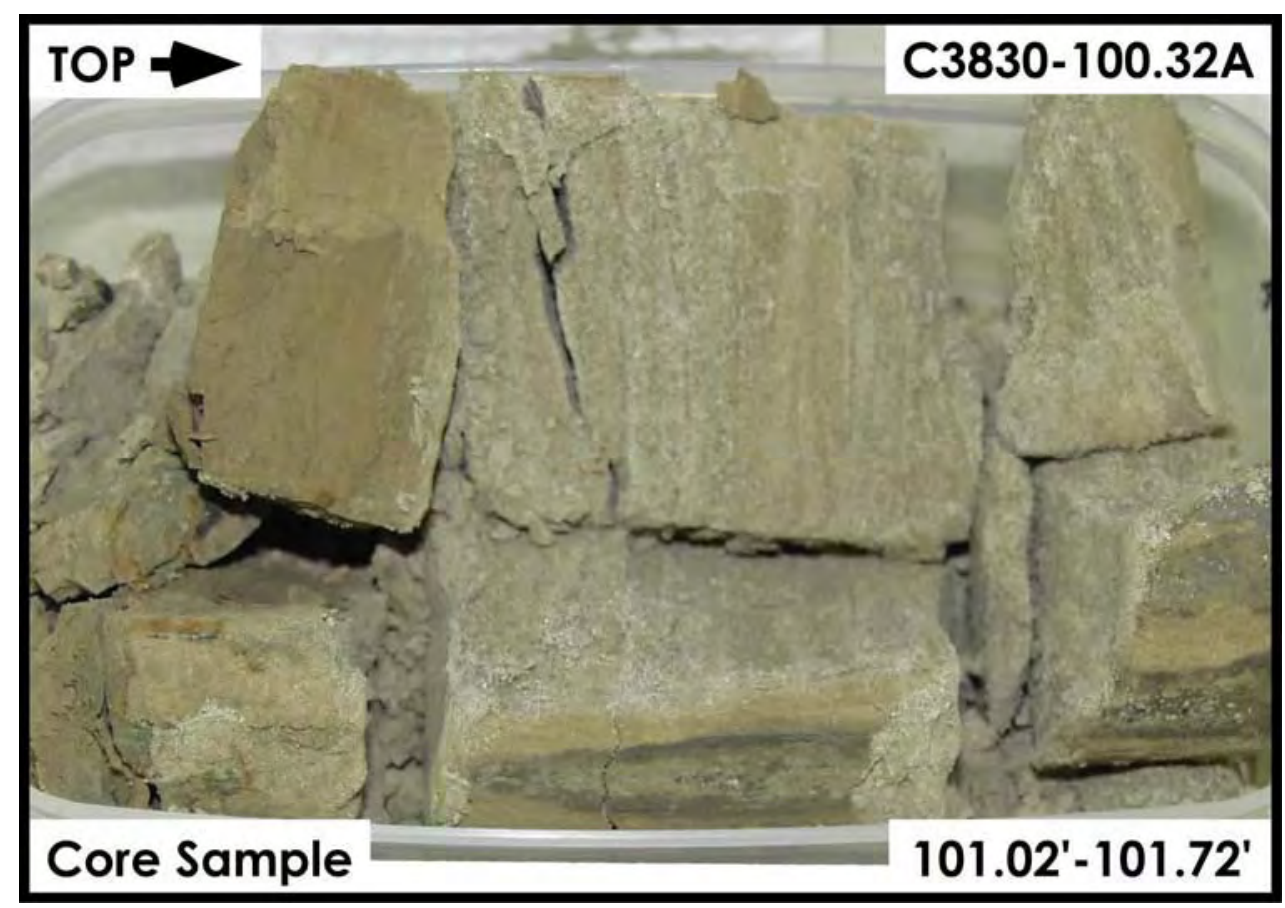

Figure A-2.30. Cold Creek Unit - Upper $\left(\mathrm{CCU}_{\mathrm{u}}\right) \mathbf{1 0 1 . 0 2} \mathrm{ft}-101.72 \mathrm{ft}$ 


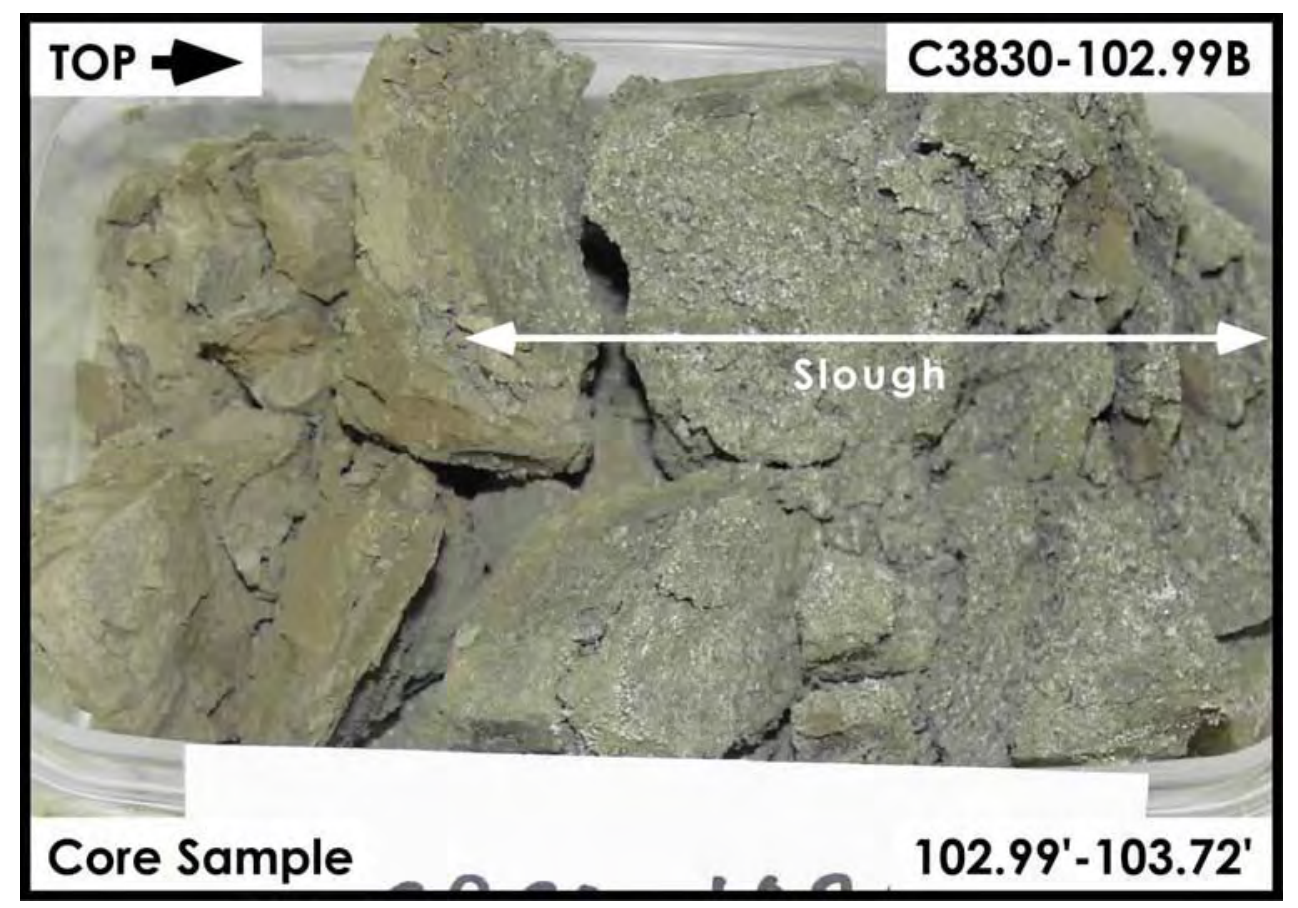

Figure A-2.31. Cold Creek Unit - Upper $\left(\mathrm{CCU}_{\mathrm{u}}\right) \mathbf{1 0 2 . 9 9} \mathrm{ft}-103.72 \mathrm{ft}$

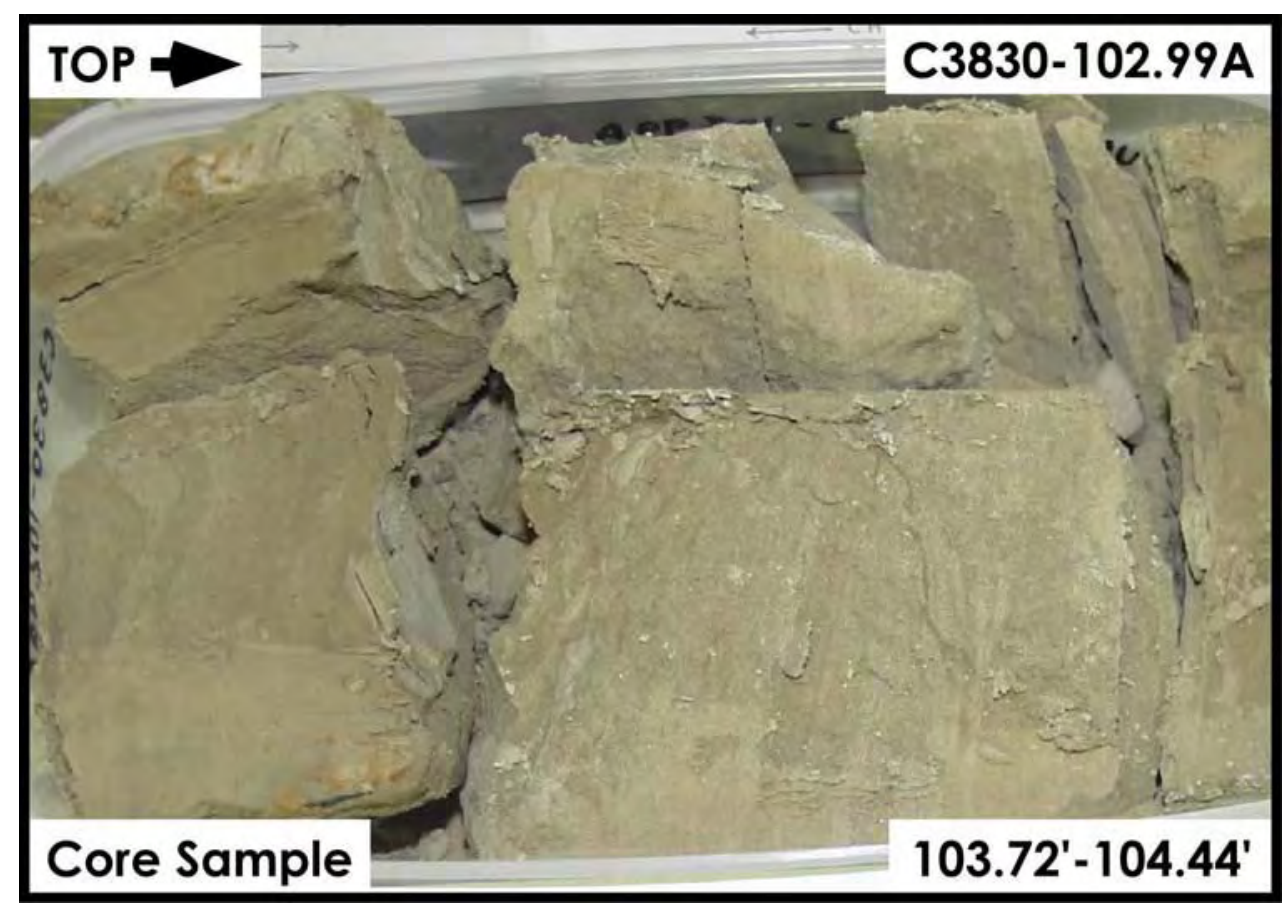

Figure A-2.32. Cold Creek Unit - Upper $\left(\mathrm{CCU}_{\mathrm{u}}\right) \mathbf{1 0 3 . 7 2} \mathrm{ft}-104.44 \mathrm{ft}$ 


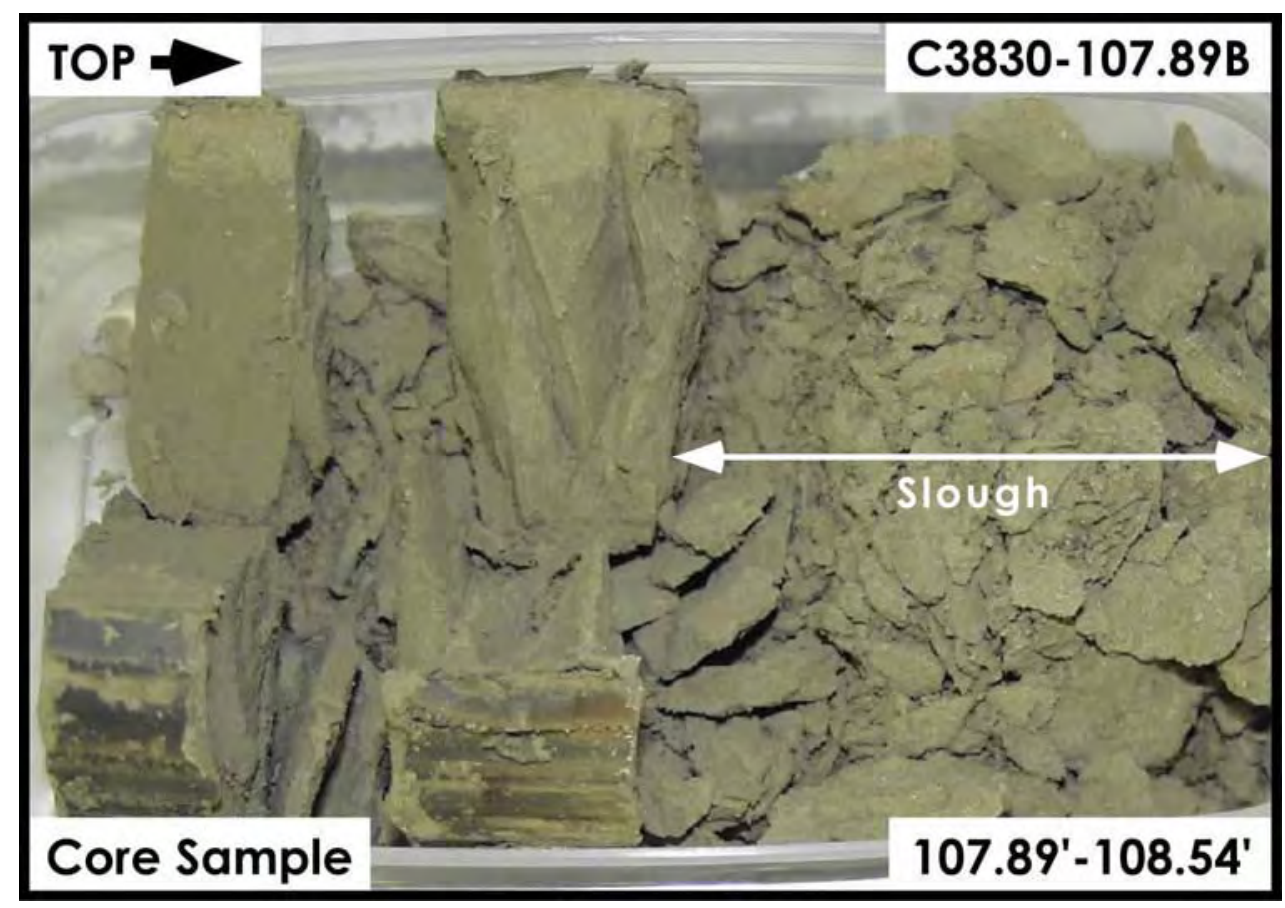

Figure A-2.33. Cold Creek Unit - Upper $\left(\mathrm{CCU}_{\mathrm{u}}\right) \mathbf{1 0 7 . 8 9} \mathrm{ft}-\mathbf{1 0 8 . 5 4} \mathrm{ft}$

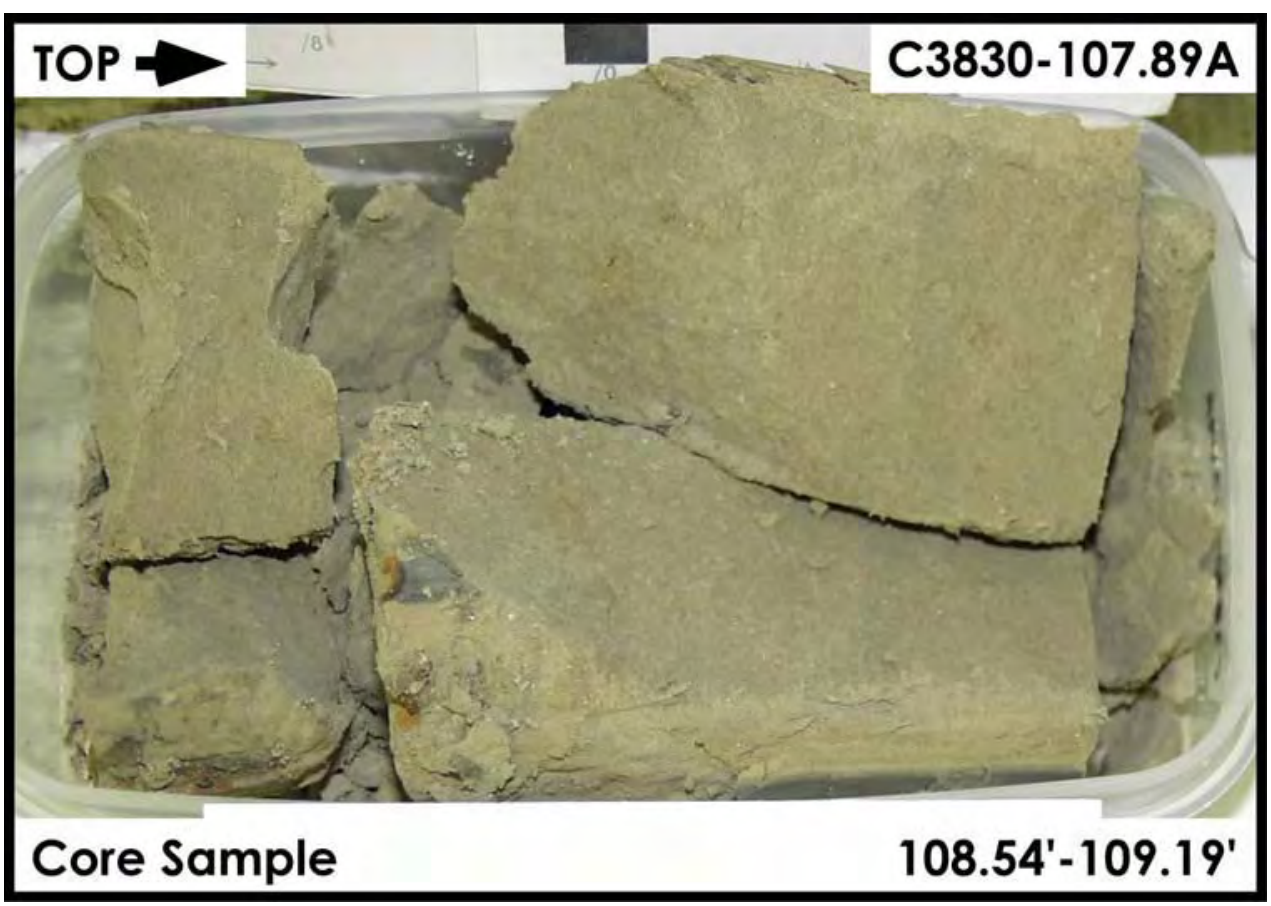

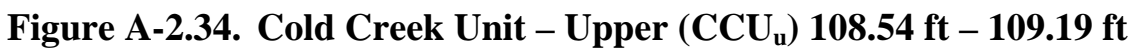




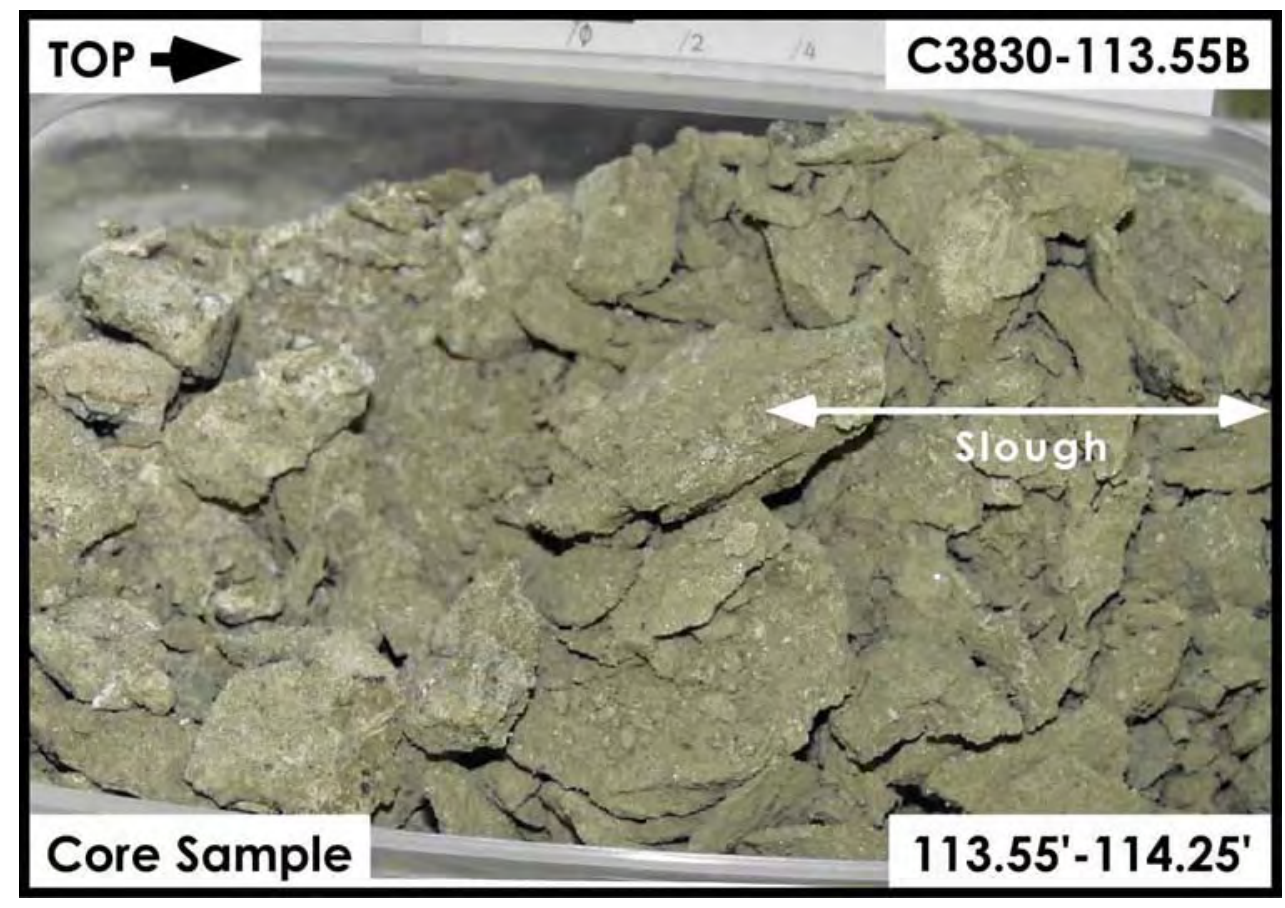

Figure A-2.35. Cold Creek Unit - Lower $\left(\mathrm{CCU}_{\mathrm{l}}\right) \mathbf{1 1 3 . 5 5} \mathrm{ft}-\mathbf{1 1 4 . 2 5} \mathrm{ft}$

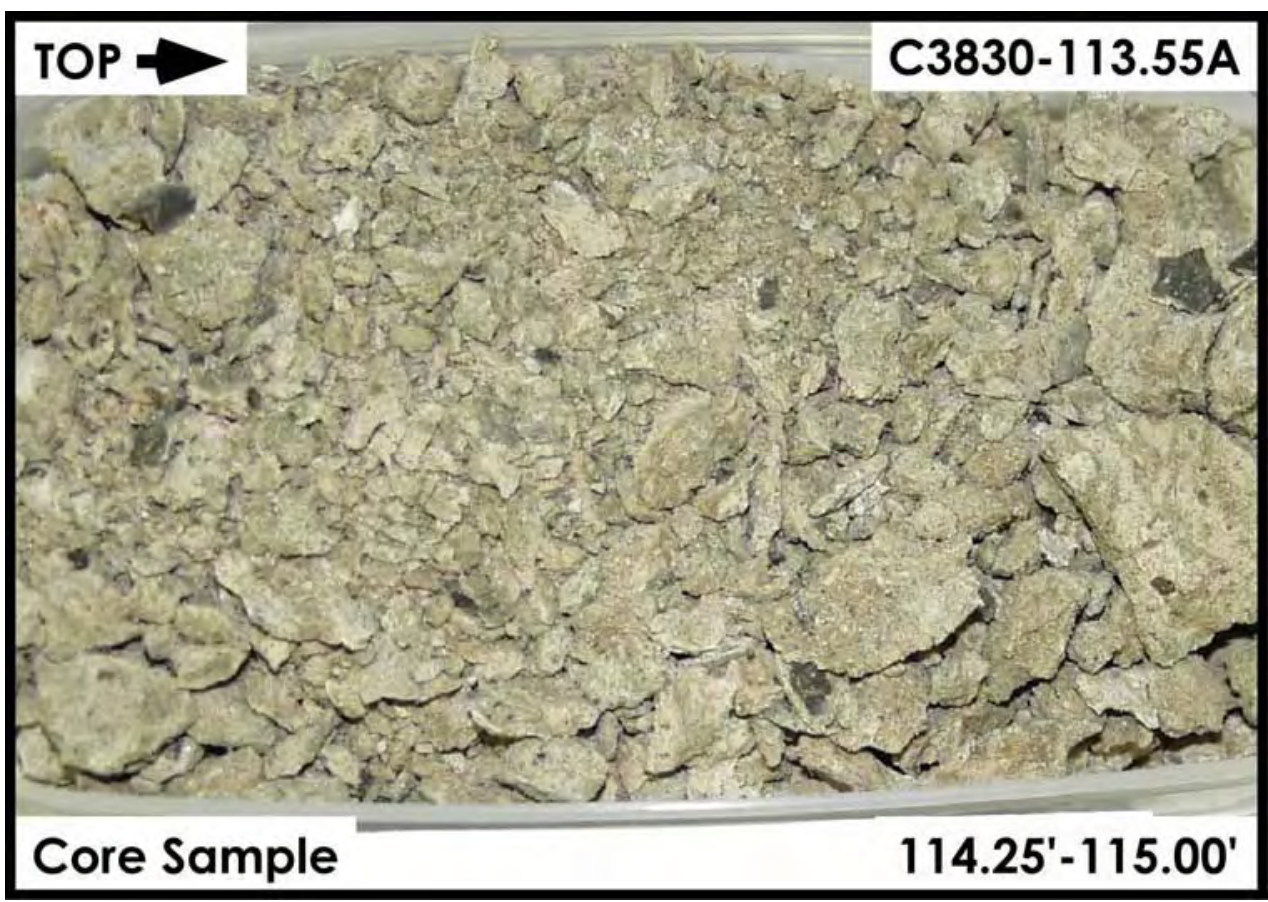

Figure A-2.36. Cold Creek Unit - Lower $\left(\mathrm{CCU}_{\mathrm{l}}\right) \mathbf{1 1 4 . 2 5} \mathrm{ft}-\mathbf{1 1 5 . 0 0} \mathrm{ft}$ 
APPENDIX A.3

C3831 (TX-107)

SPLITSPOON CORE

SAMPLE PHOTOGRAPHS 


\section{Contents}

Appendix A.3 C3831(TX-107) Splitspoon Core Sample Photographs

A-3.1

\section{Figures}

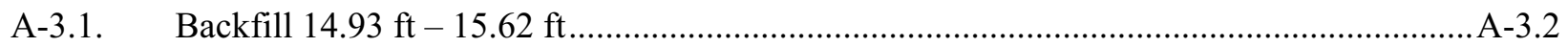

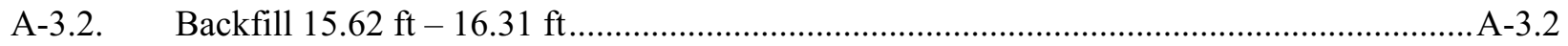

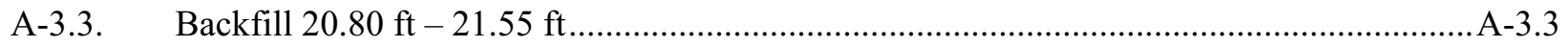

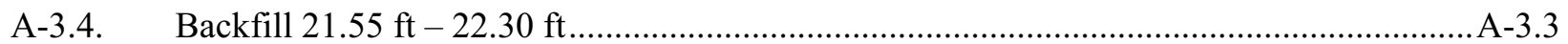

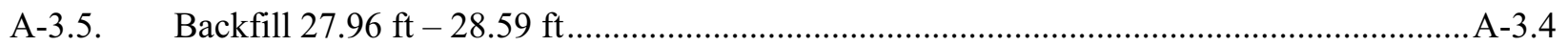

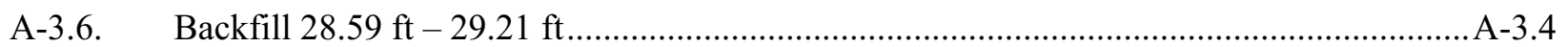

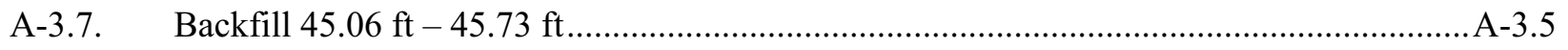

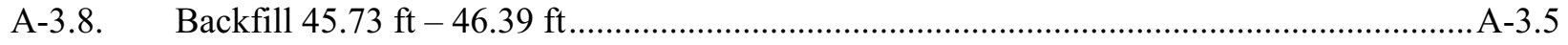

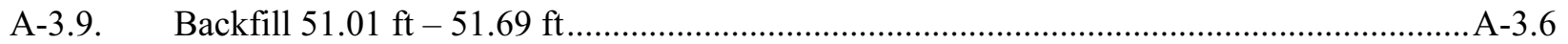

A-3.10. Backfill/Hanford Formation (H2 unit) $51.69 \mathrm{ft}-52.36 \mathrm{ft}$..................................................

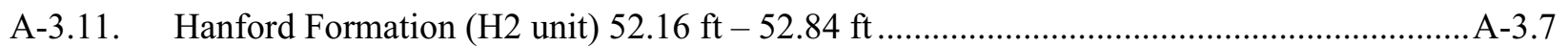

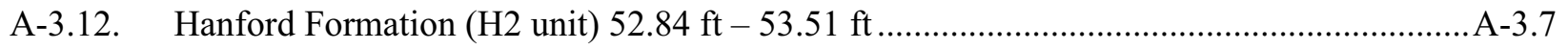

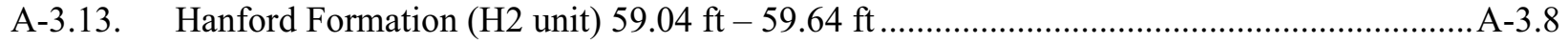

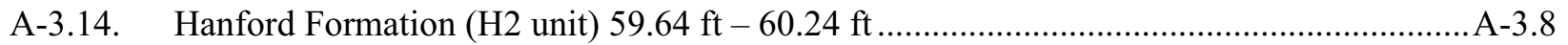

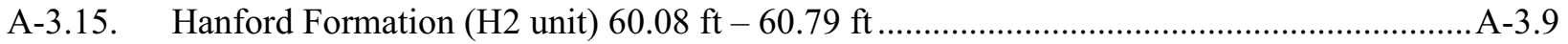

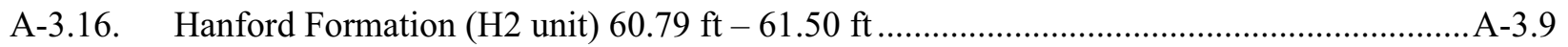

A-3.17. Hanford Formation (H2 unit) $67.19 \mathrm{ft}-67.87 \mathrm{ft}$......................................................

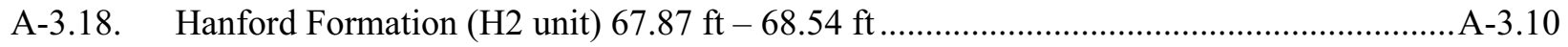

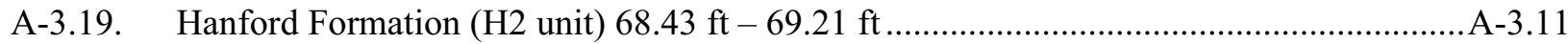

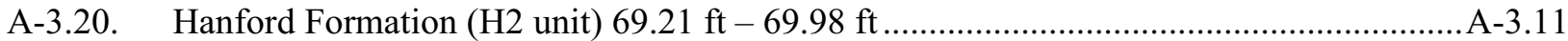

A-3.21. Hanford Formation (H2 unit) $74.04 \mathrm{ft}-74.67 \mathrm{ft}$.............................................................

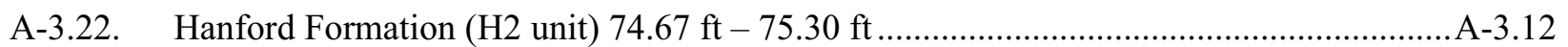

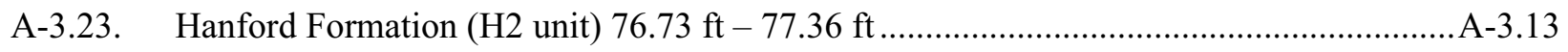

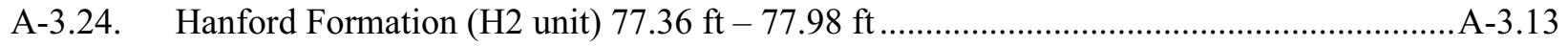

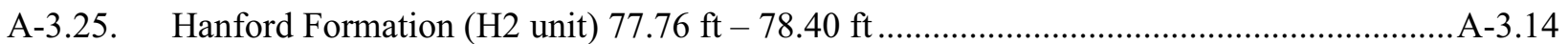

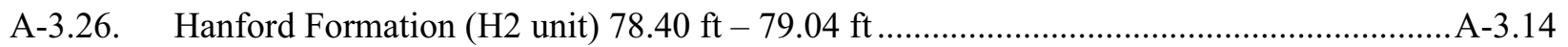

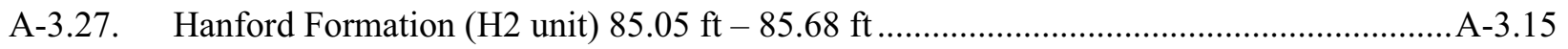




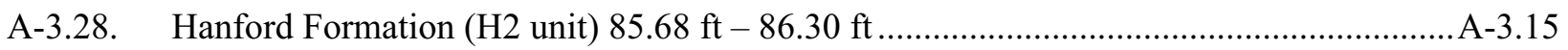

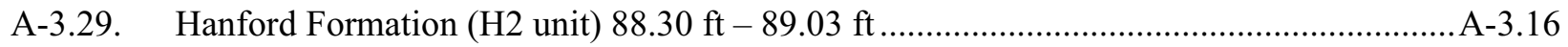

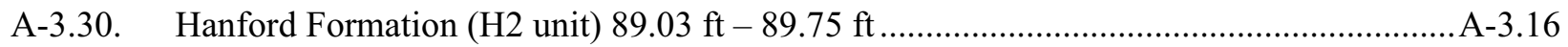

A-3.31. Hanford Formation (H2 unit) $93.05 \mathrm{ft}-93.68 \mathrm{ft}$.........................................................A-3.17

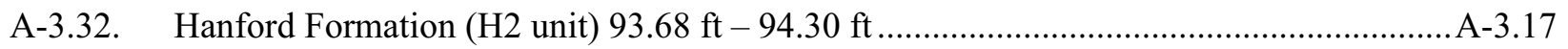

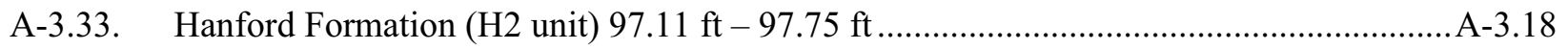

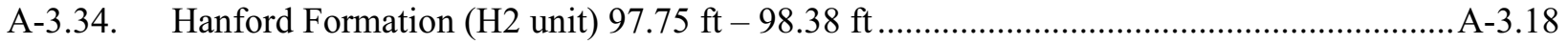

A-3.35. Hanford Formation (H2 unit) $100.20 \mathrm{ft}-100.93 \mathrm{ft}$.......................................................A-3.19

A-3.36. Hanford Formation (H2 unit) $100.93 \mathrm{ft}-101.65 \mathrm{ft}$.....................................................A-3.19

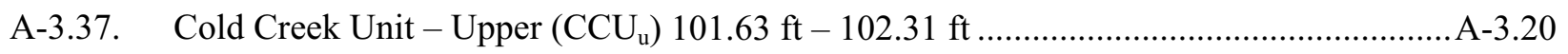

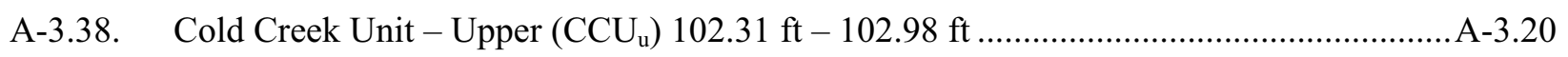

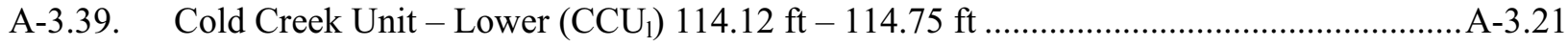

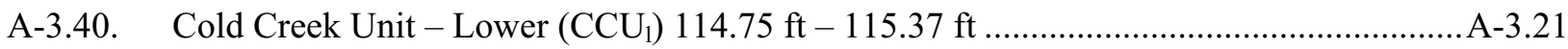




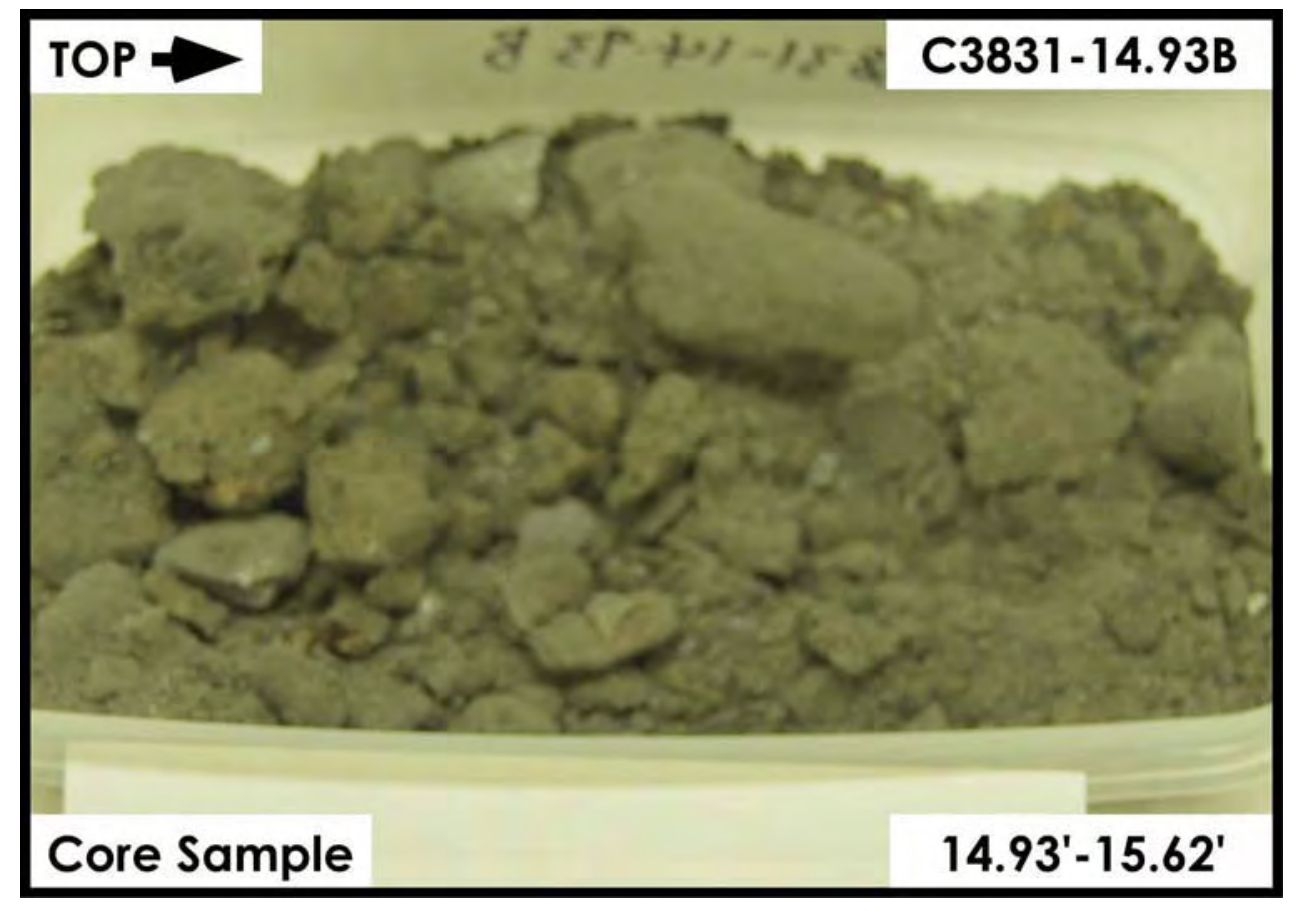

Figure A-3.1. Backfill $14.93 \mathrm{ft}-\mathbf{1 5 . 6 2} \mathbf{f t}$

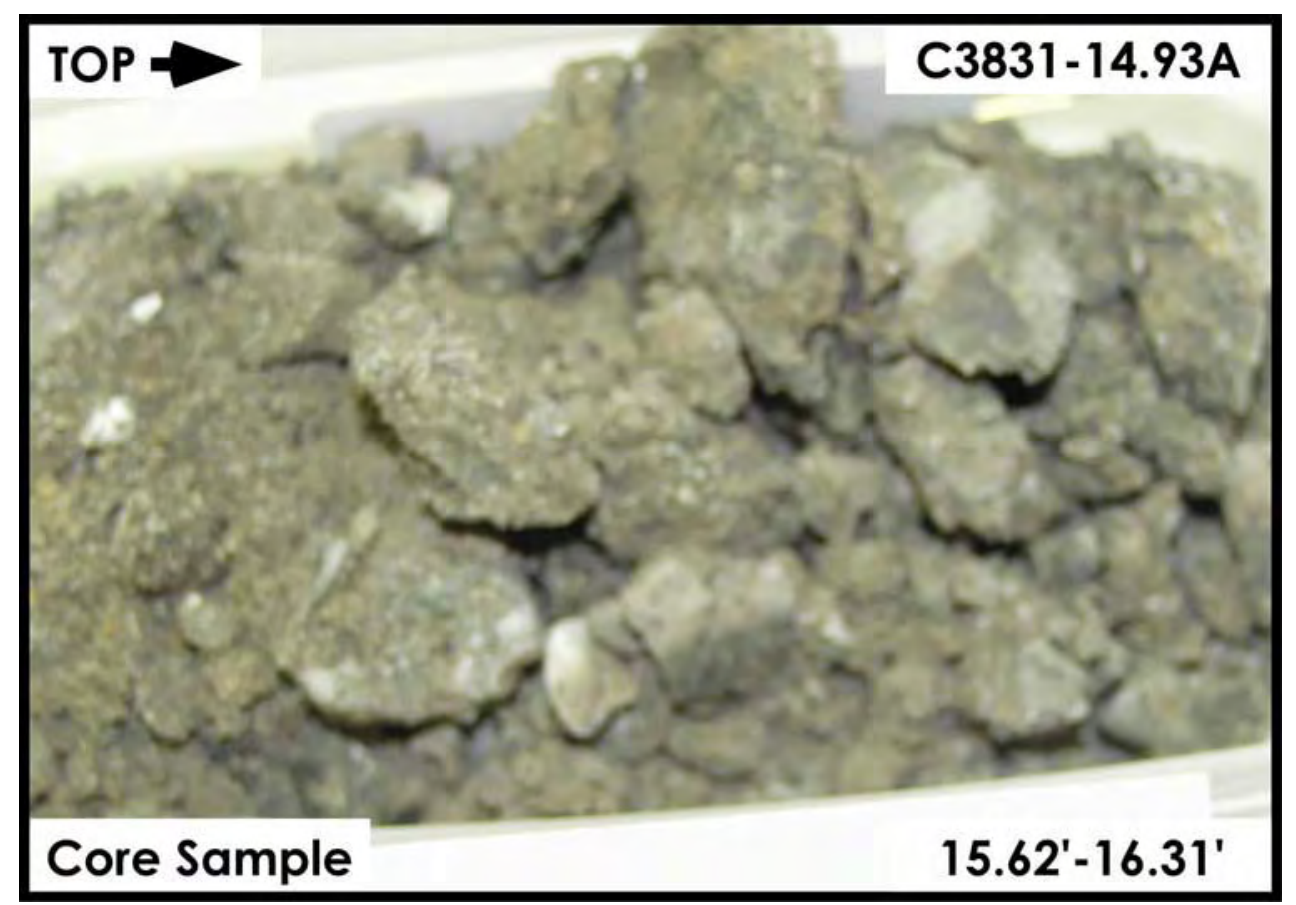

Figure A-3.2. Backfill $15.62 \mathrm{ft}-\mathbf{1 6 . 3 1} \mathrm{ft}$ 


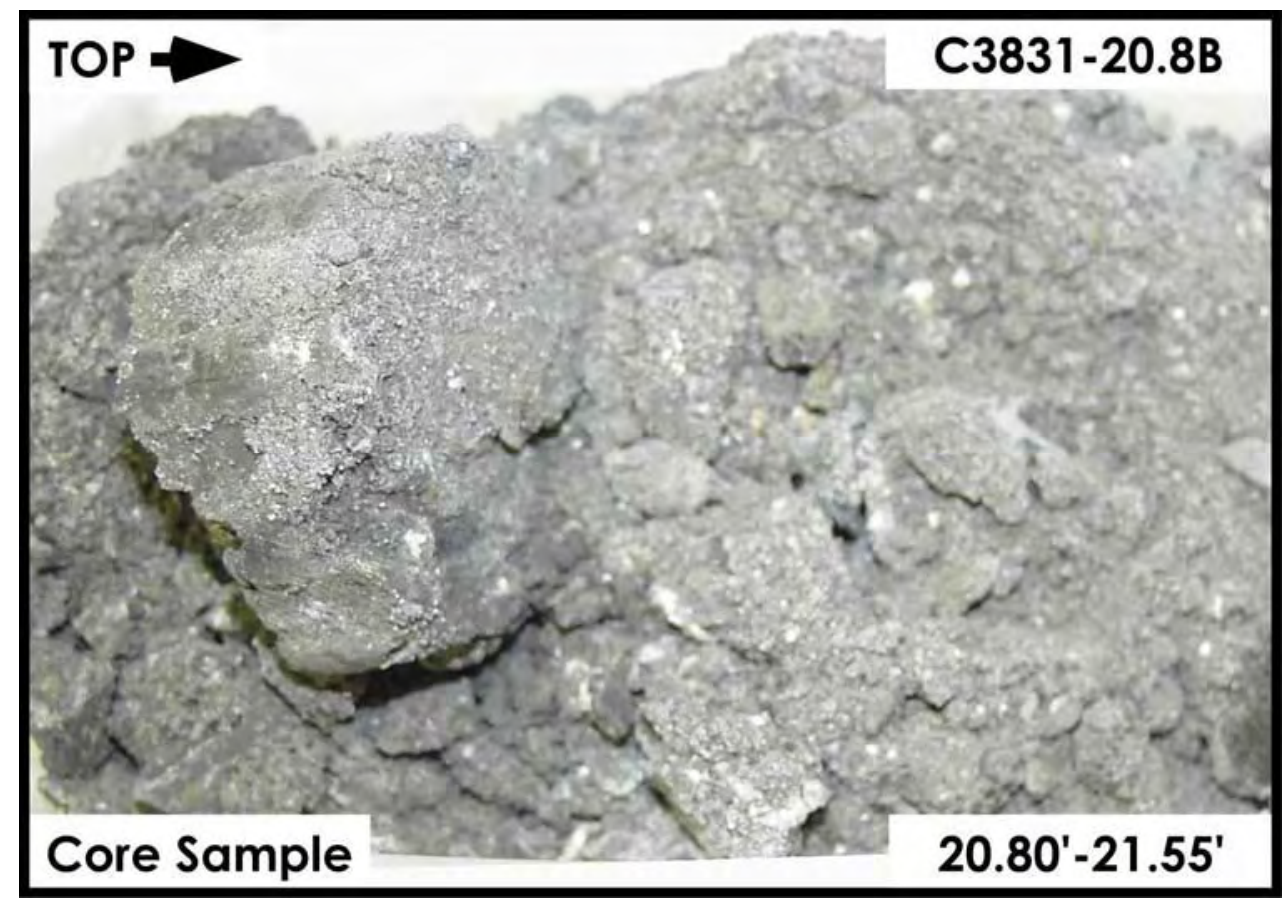

Figure A-3.3. Backfill $20.80 \mathrm{ft}-\mathbf{2 1 . 5 5} \mathrm{ft}$

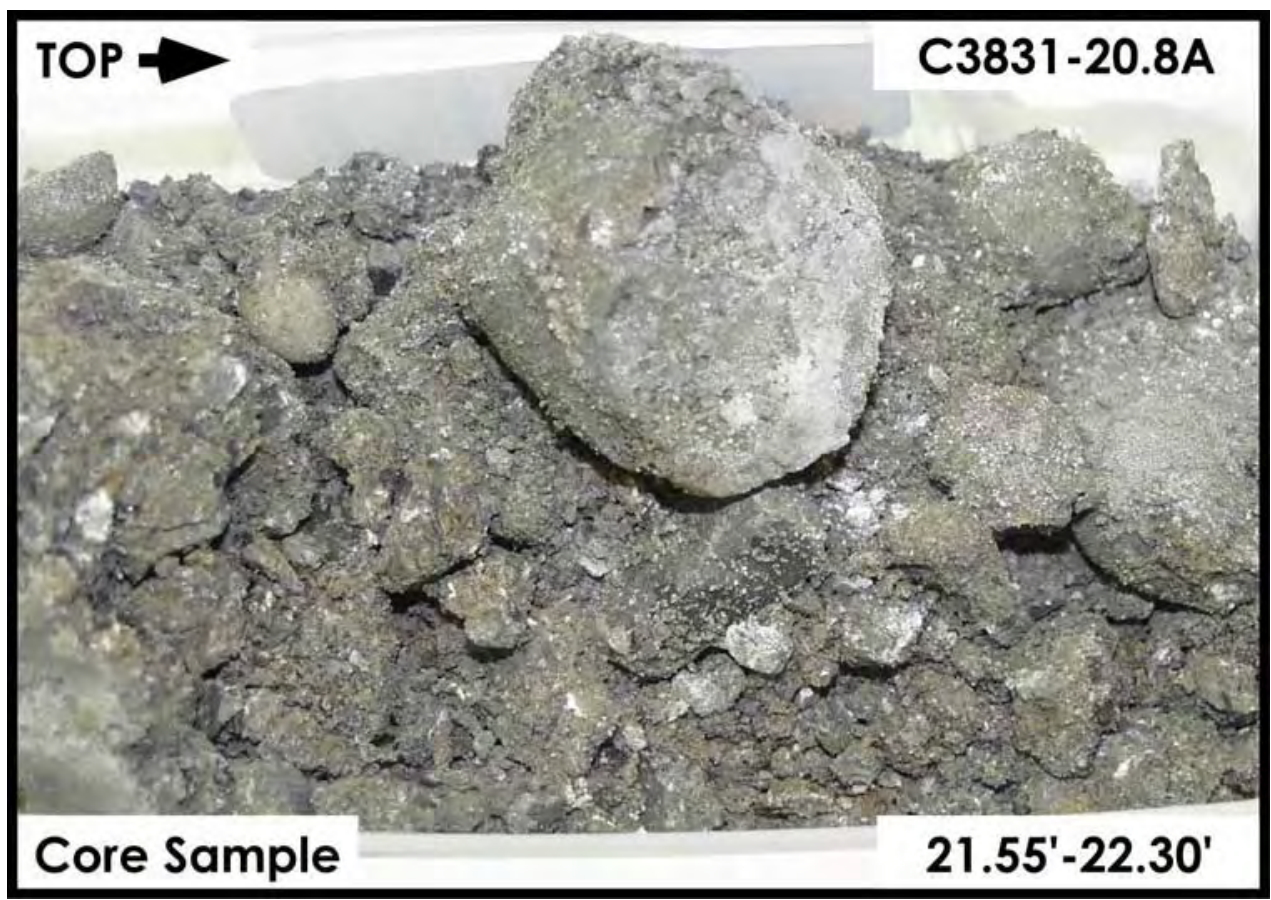

Figure A-3.4. Backfill $21.55 \mathrm{ft}-\mathbf{2 2 . 3 0} \mathrm{ft}$ 


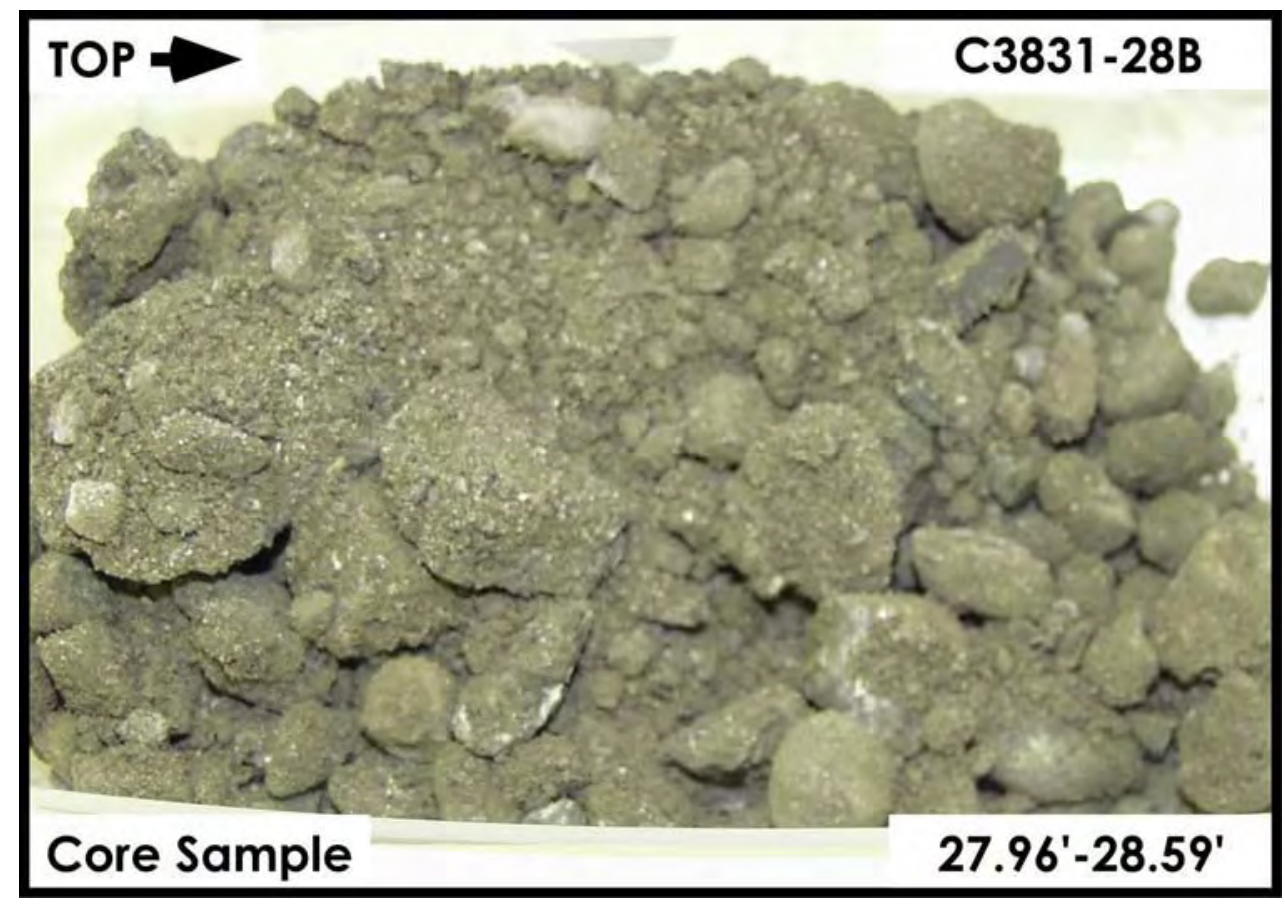

Figure A-3.5. Backfill $27.96 \mathrm{ft}-\mathbf{2 8 . 5 9} \mathrm{ft}$

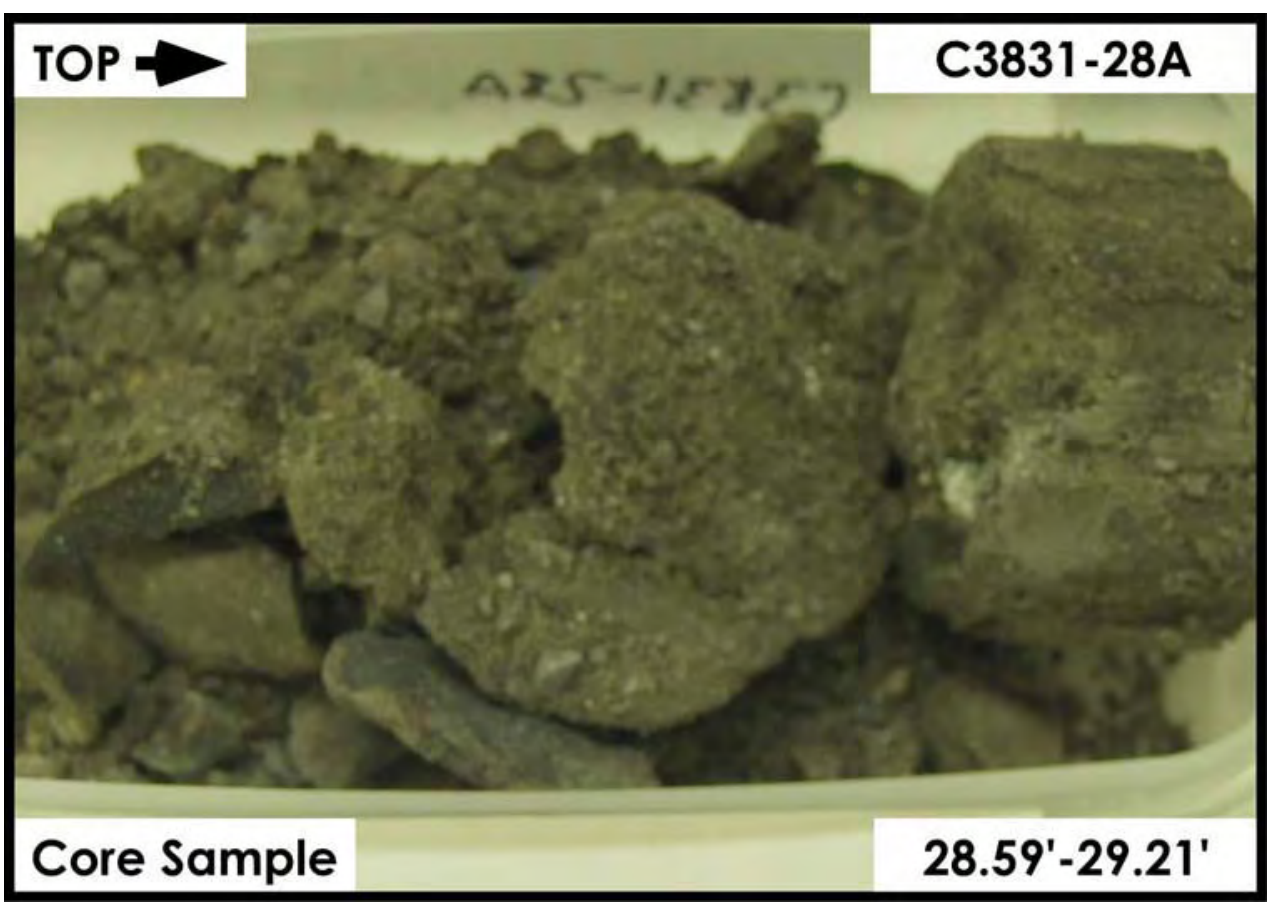

Figure A-3.6. Backfill $28.59 \mathrm{ft}-\mathbf{2 9 . 2 1} \mathrm{ft}$ 


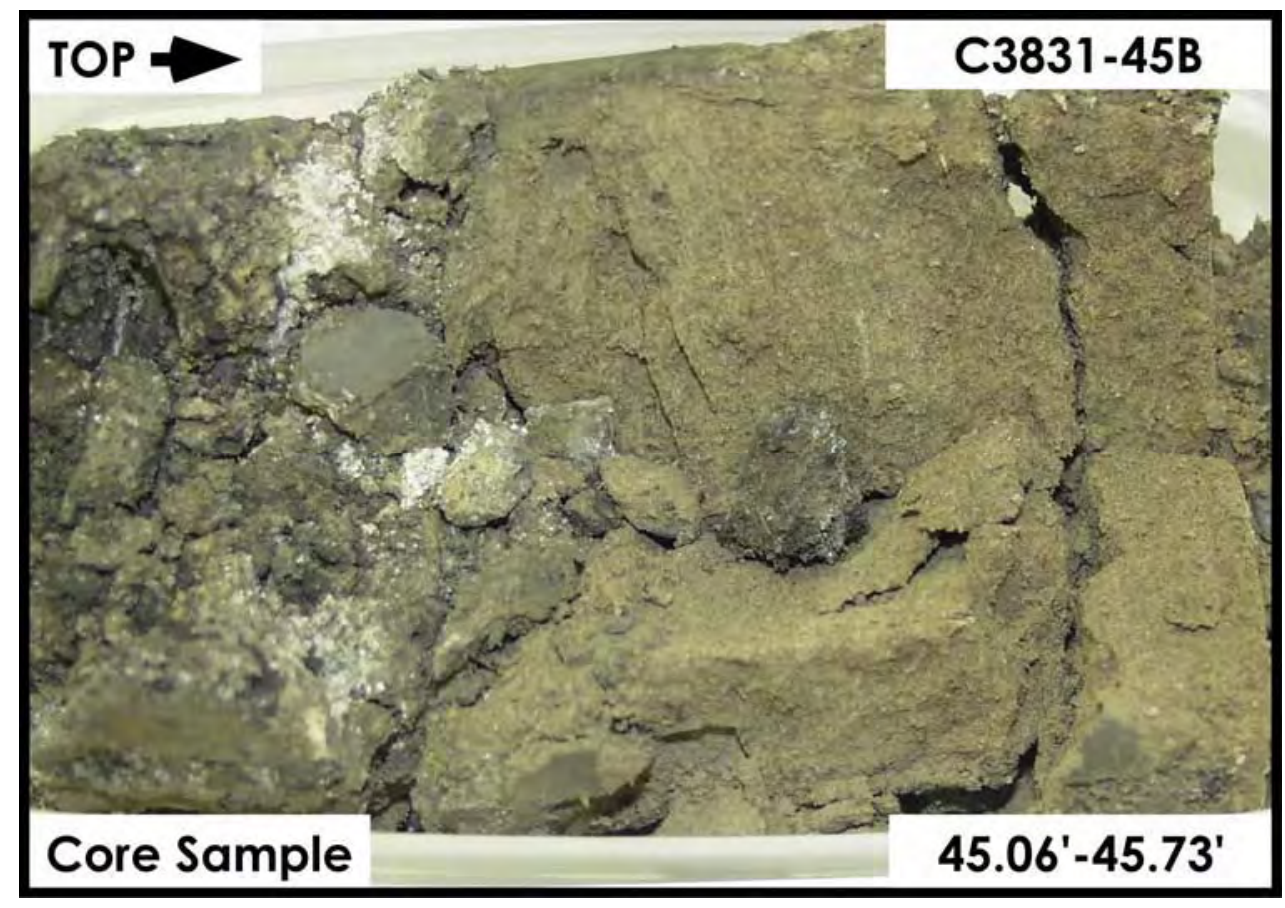

Figure A-3.7. Backfill $45.06 \mathrm{ft}-\mathbf{4 5 . 7 3} \mathrm{ft}$

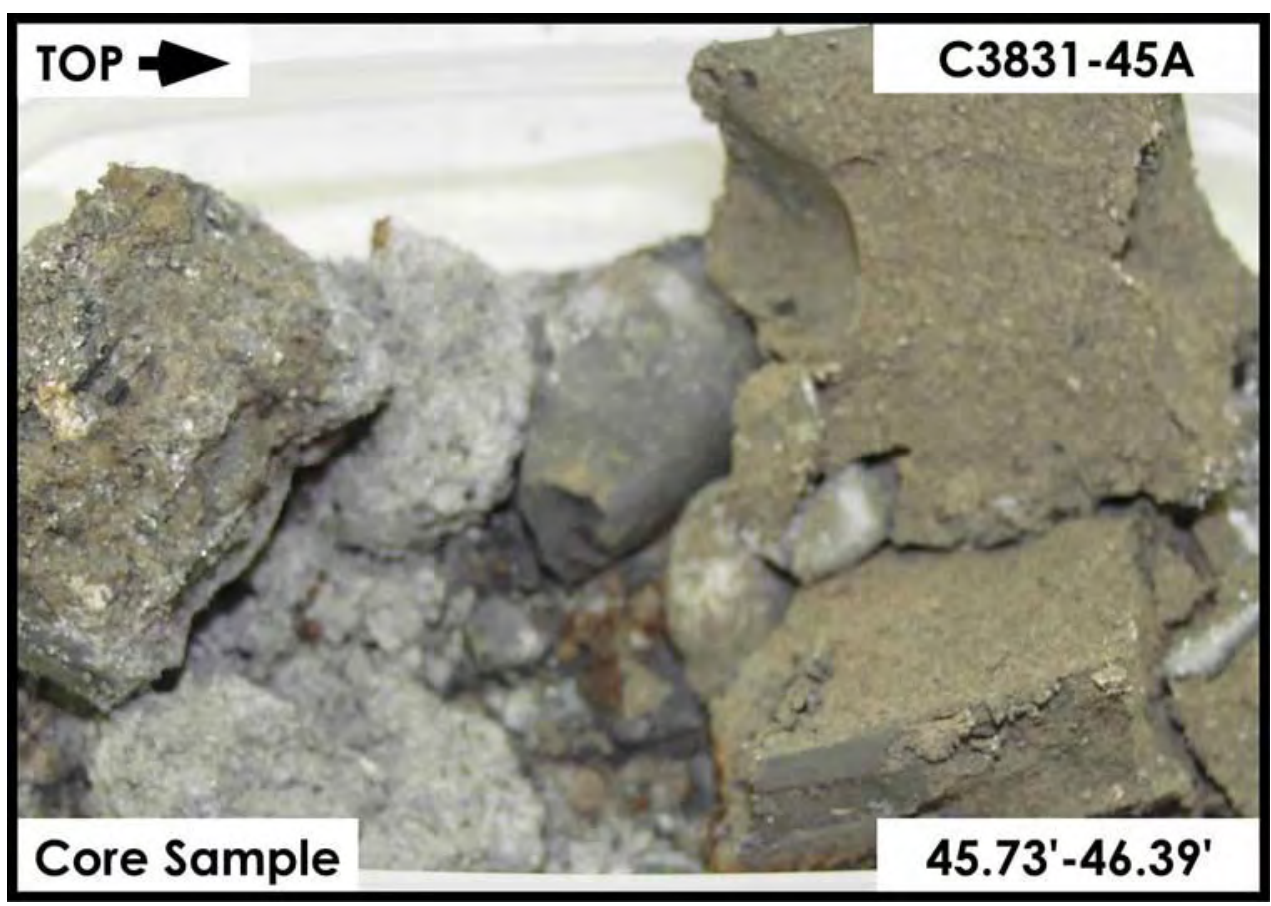

Figure A-3.8. Backfill $45.73 \mathrm{ft}-\mathbf{4 6 . 3 9} \mathrm{ft}$ 


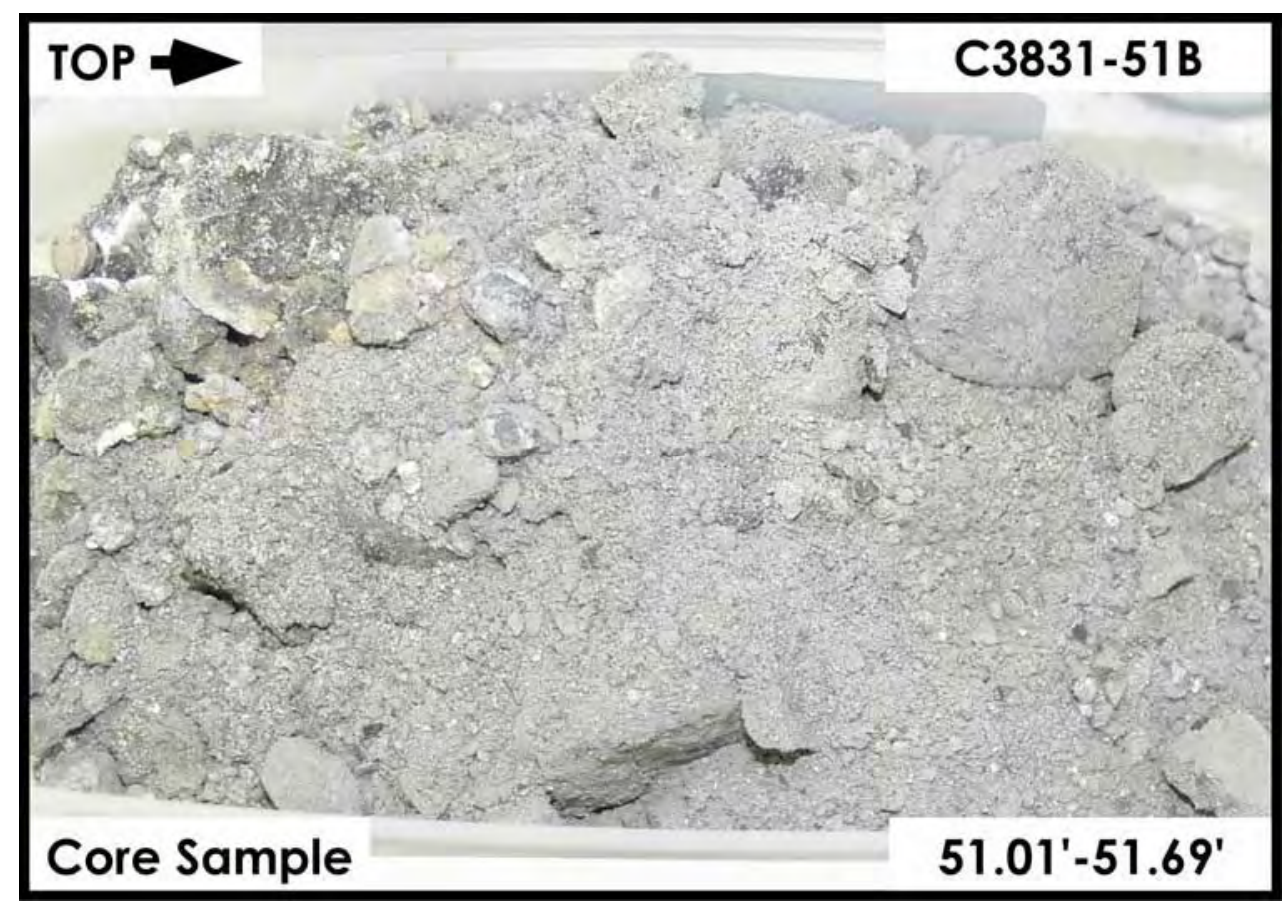

Figure A-3.9. Backfill $51.01 \mathrm{ft}-\mathbf{5 1 . 6 9} \mathrm{ft}$

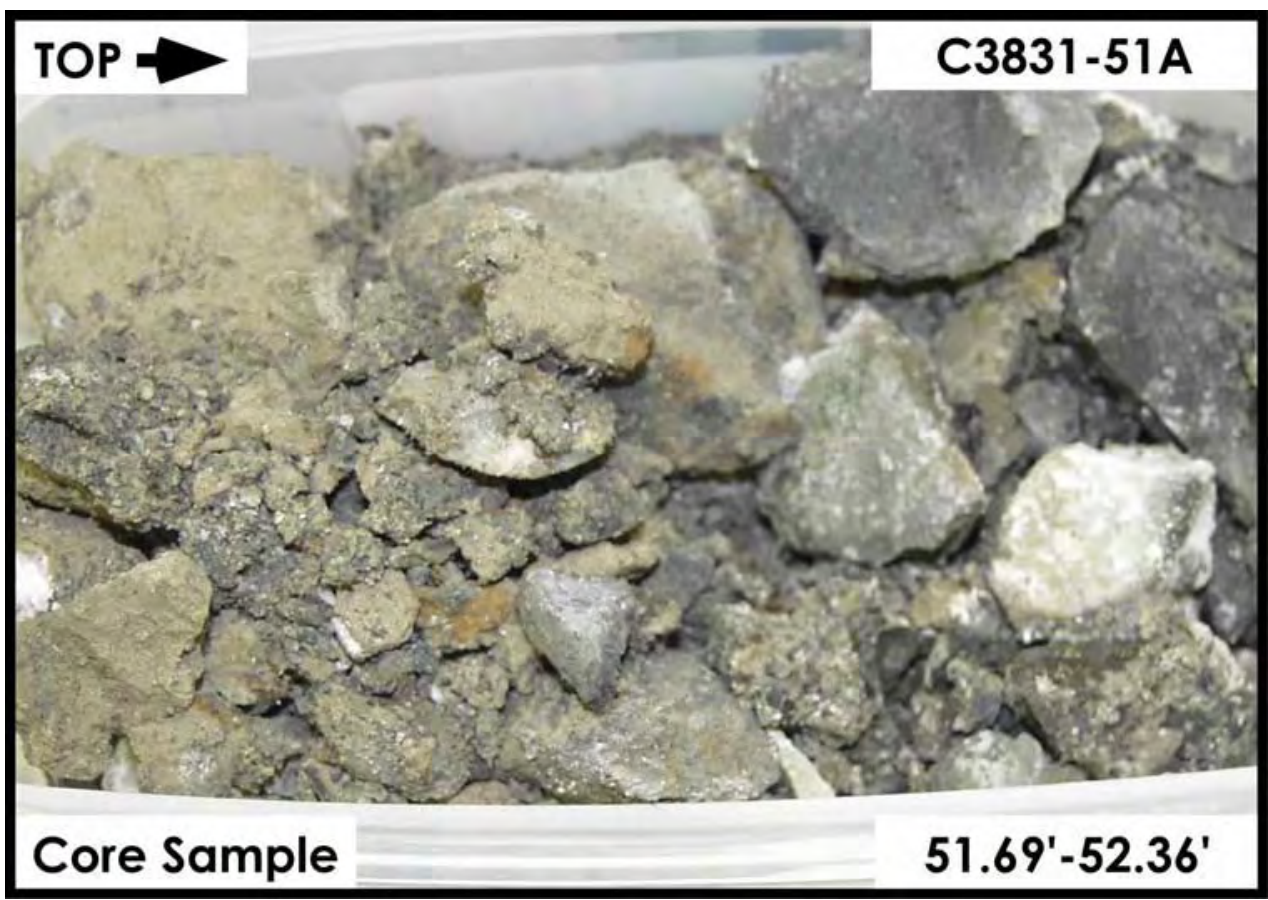

Figure A-3.10. Backfill/Hanford Formation (H2 unit) $51.69 \mathrm{ft}-52.36 \mathrm{ft}$ 


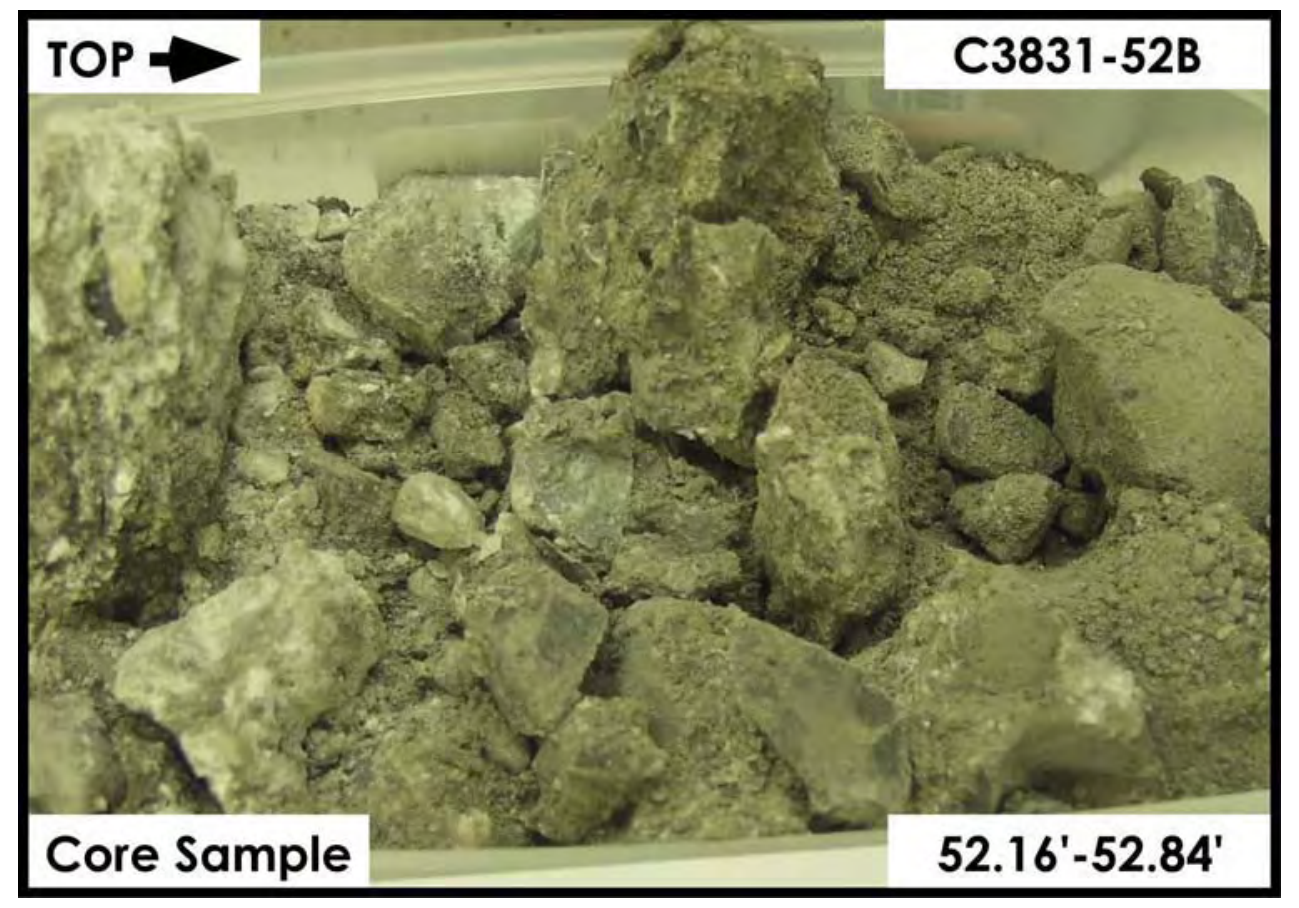

Figure A-3.11. Hanford Formation (H2 unit) $52.16 \mathrm{ft}-\mathbf{5 2 . 8 4} \mathrm{ft}$

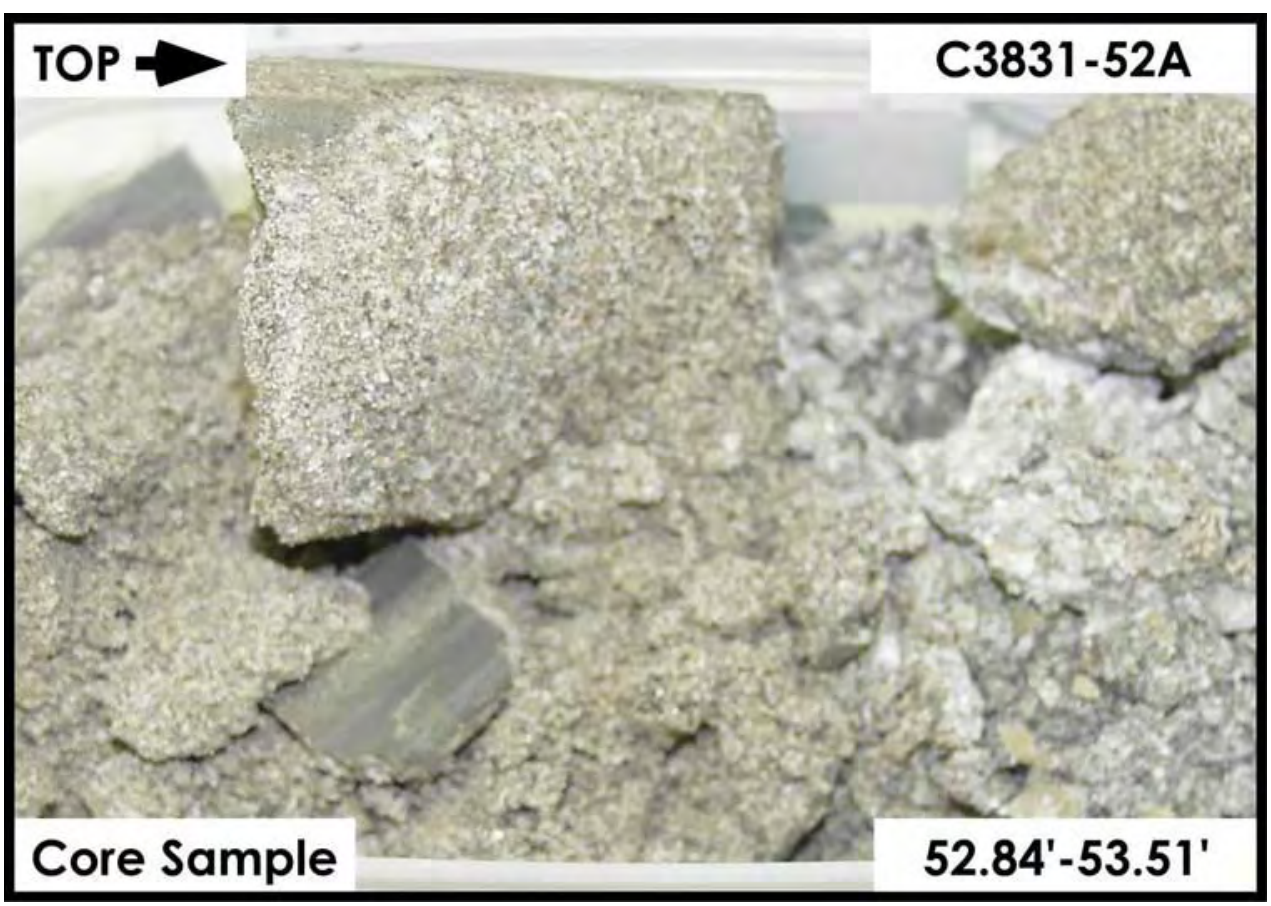

Figure A-3.12. Hanford Formation (H2 unit) $52.84 \mathrm{ft}-53.51 \mathrm{ft}$ 


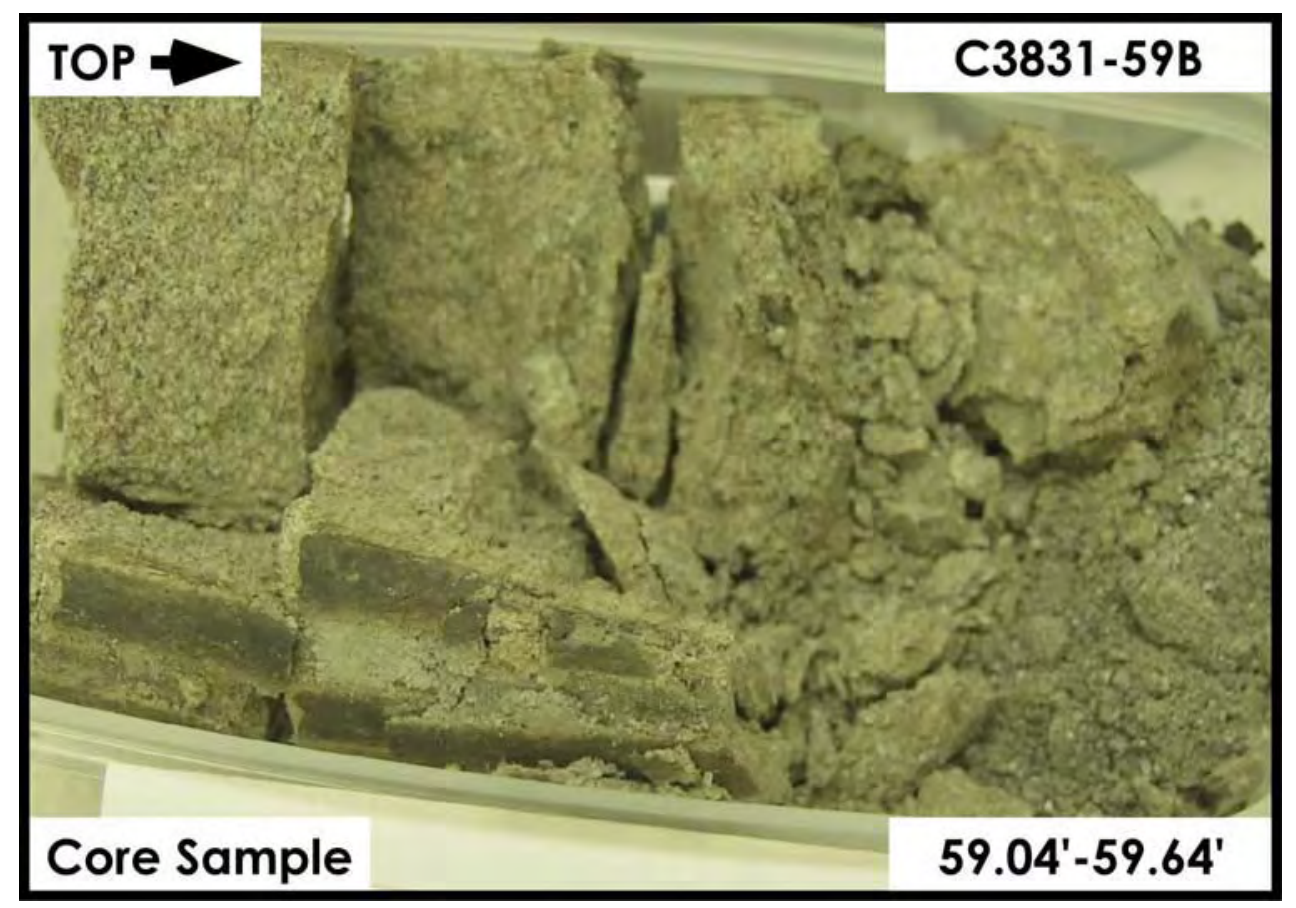

Figure A-3.13. Hanford Formation (H2 unit) $59.04 \mathrm{ft}-\mathbf{5 9 . 6 4} \mathrm{ft}$

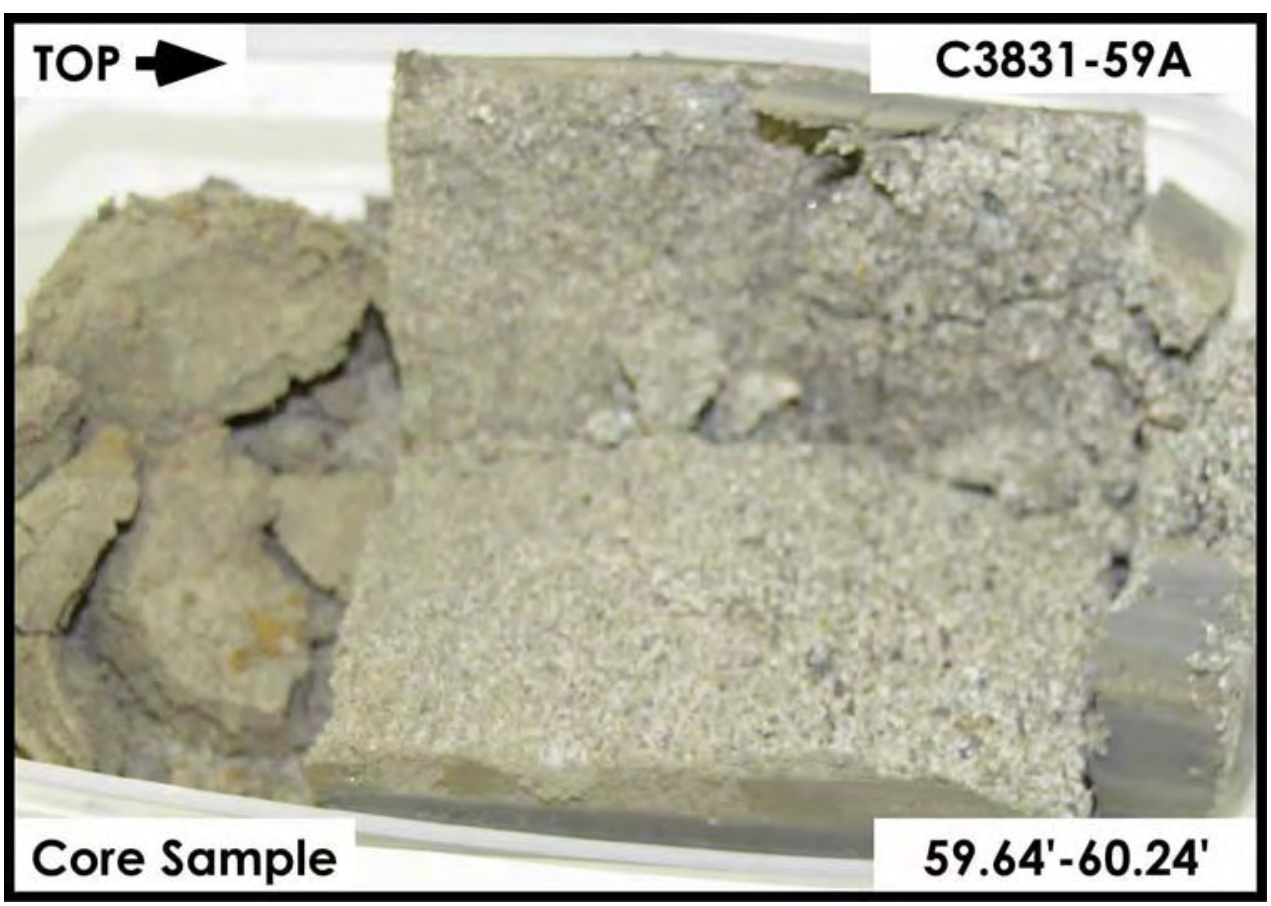

Figure A-3.14. Hanford Formation (H2 unit) $59.64 \mathrm{ft}-60.24 \mathrm{ft}$ 


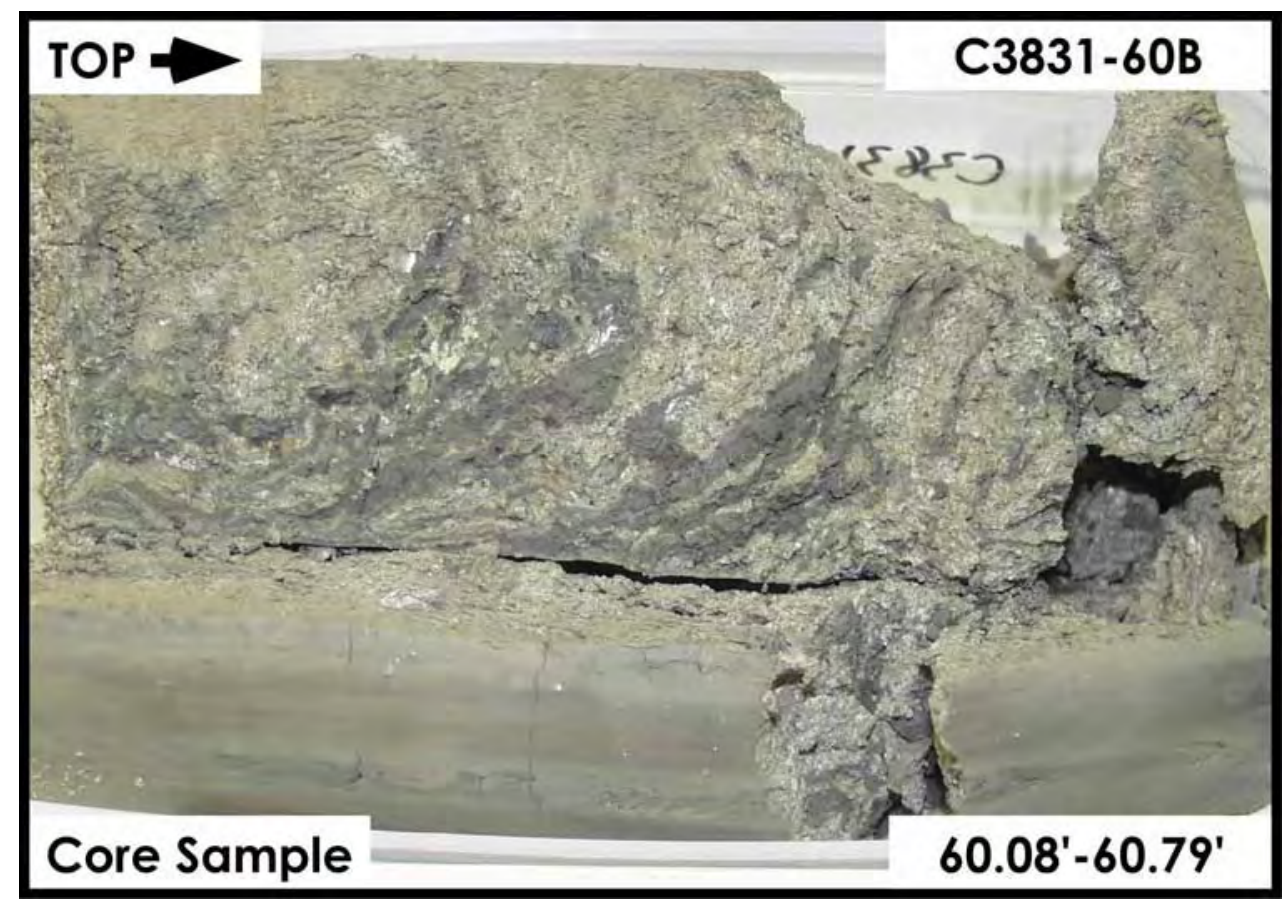

Figure A-3.15. Hanford Formation (H2 unit) $60.08 \mathrm{ft}-60.79 \mathrm{ft}$

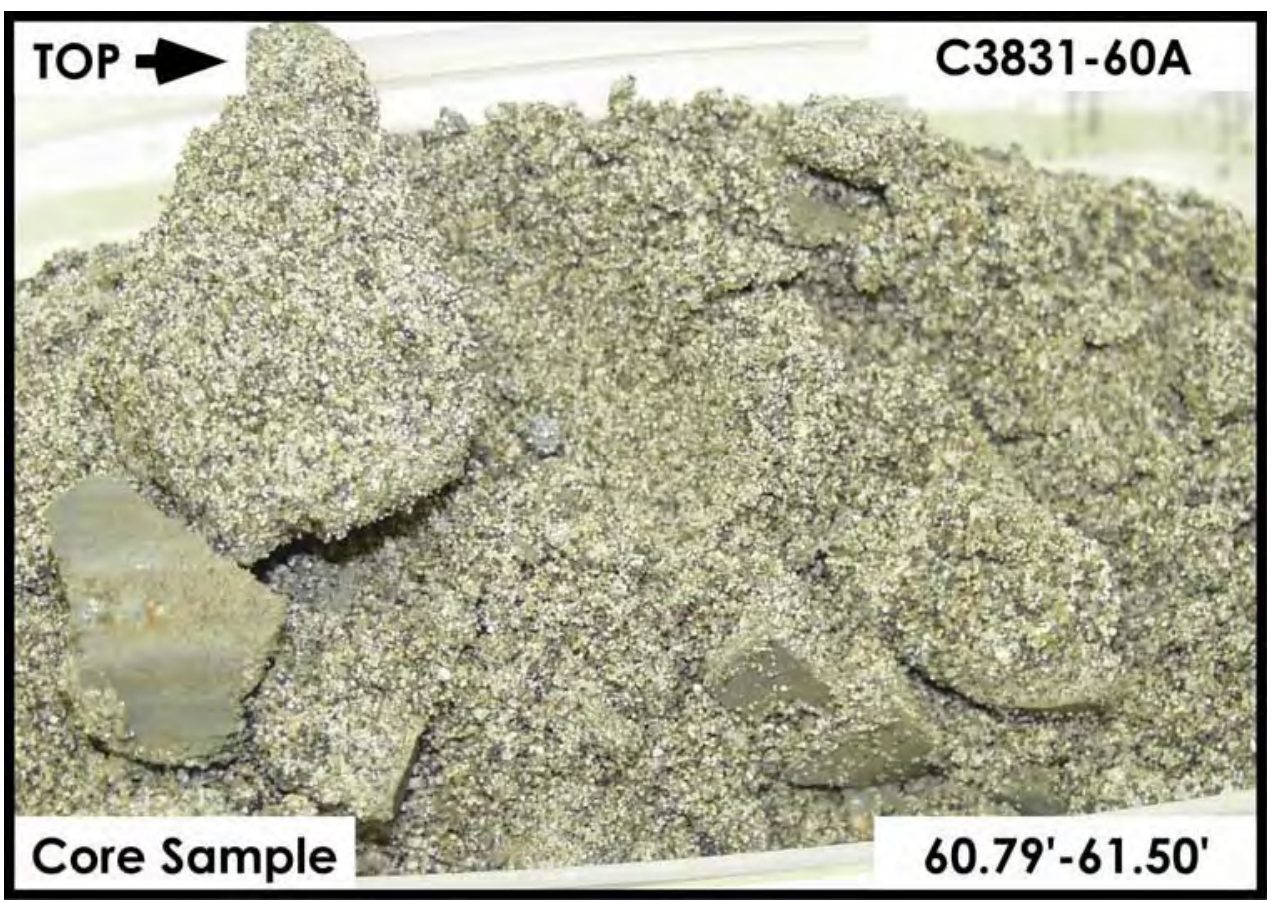

Figure A-3.16. Hanford Formation (H2 unit) $60.79 \mathrm{ft}-61.50 \mathrm{ft}$ 


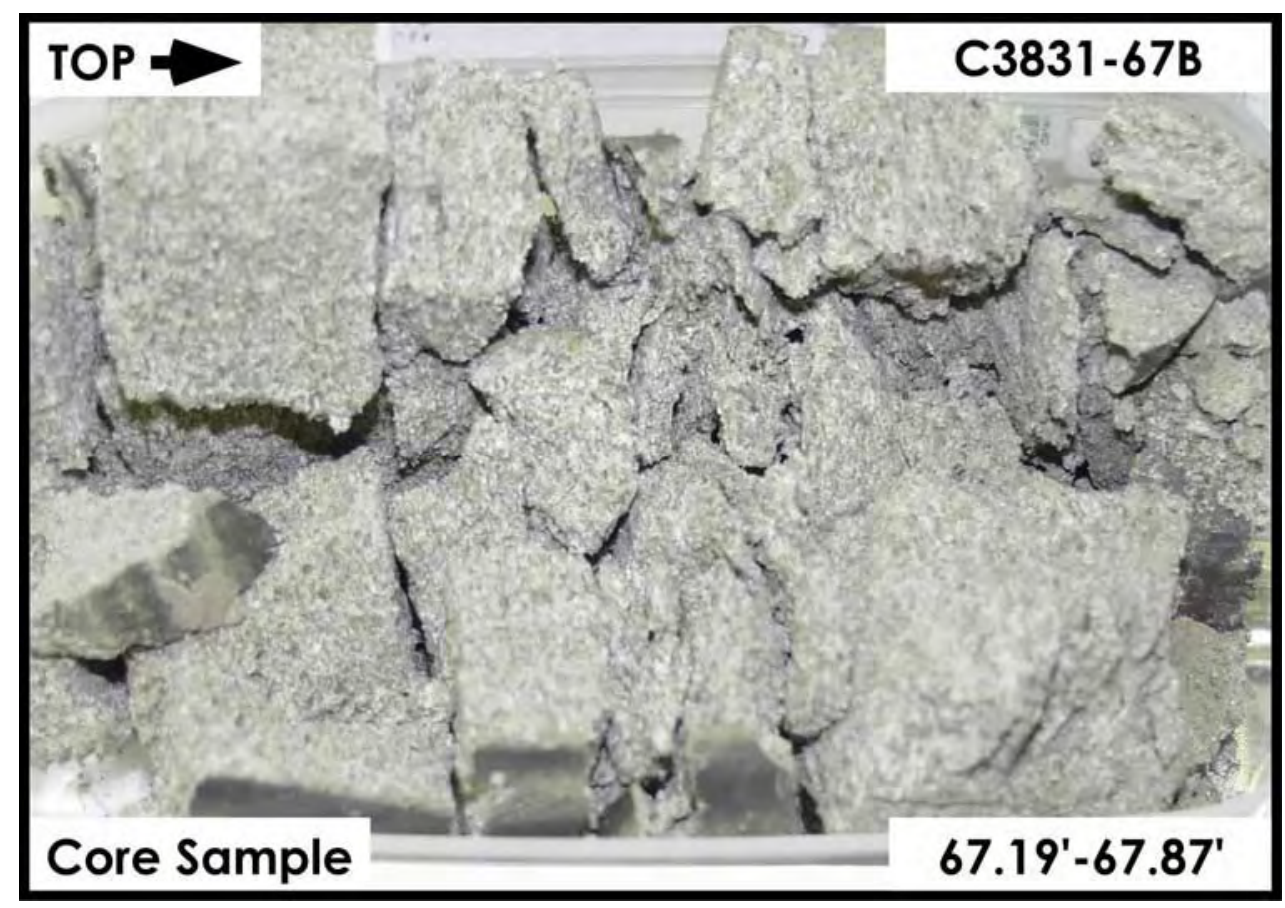

Figure A-3.17. Hanford Formation (H2 unit) $67.19 \mathrm{ft}-67.87 \mathrm{ft}$

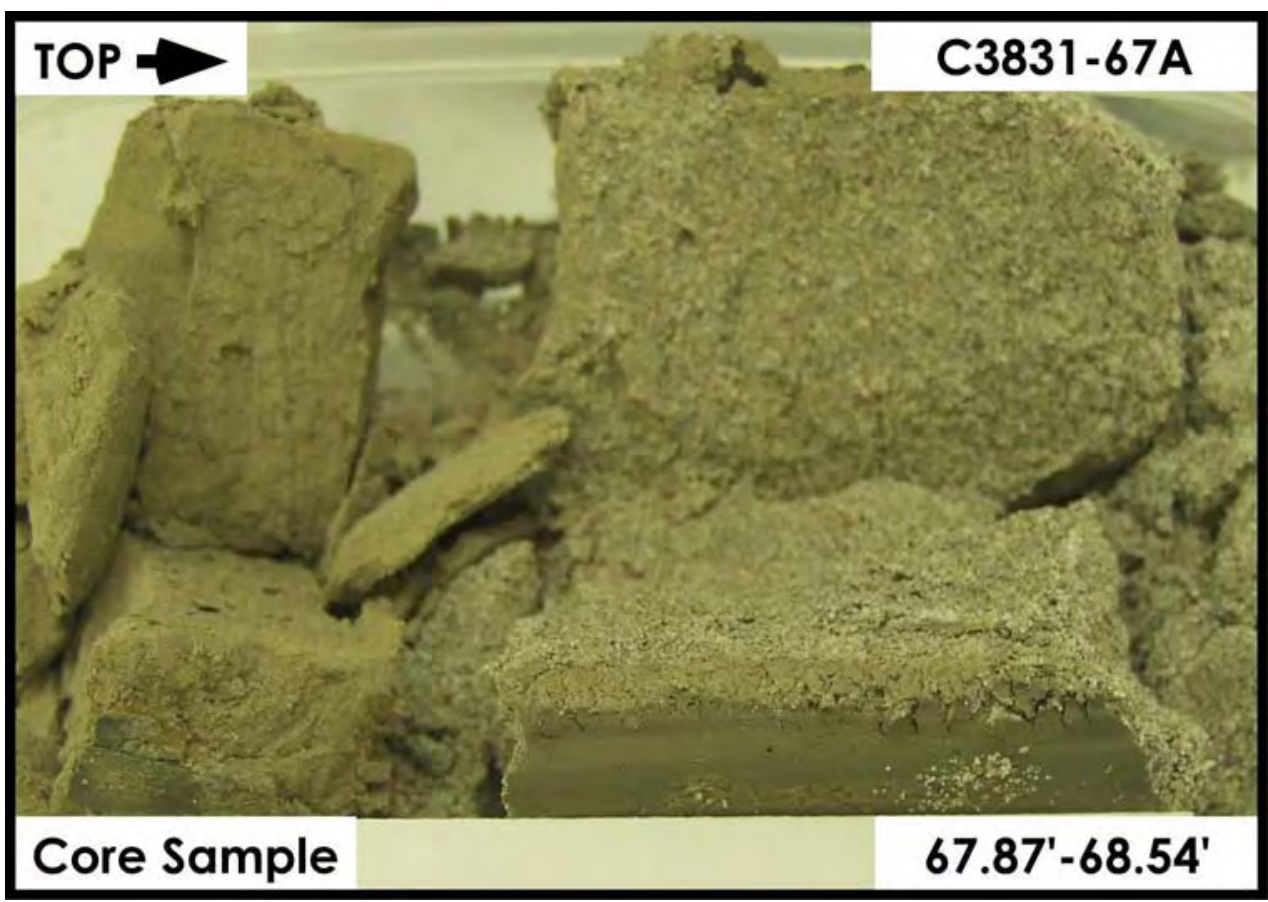

Figure A-3.18. Hanford Formation (H2 unit) $67.87 \mathrm{ft}-68.54 \mathrm{ft}$ 


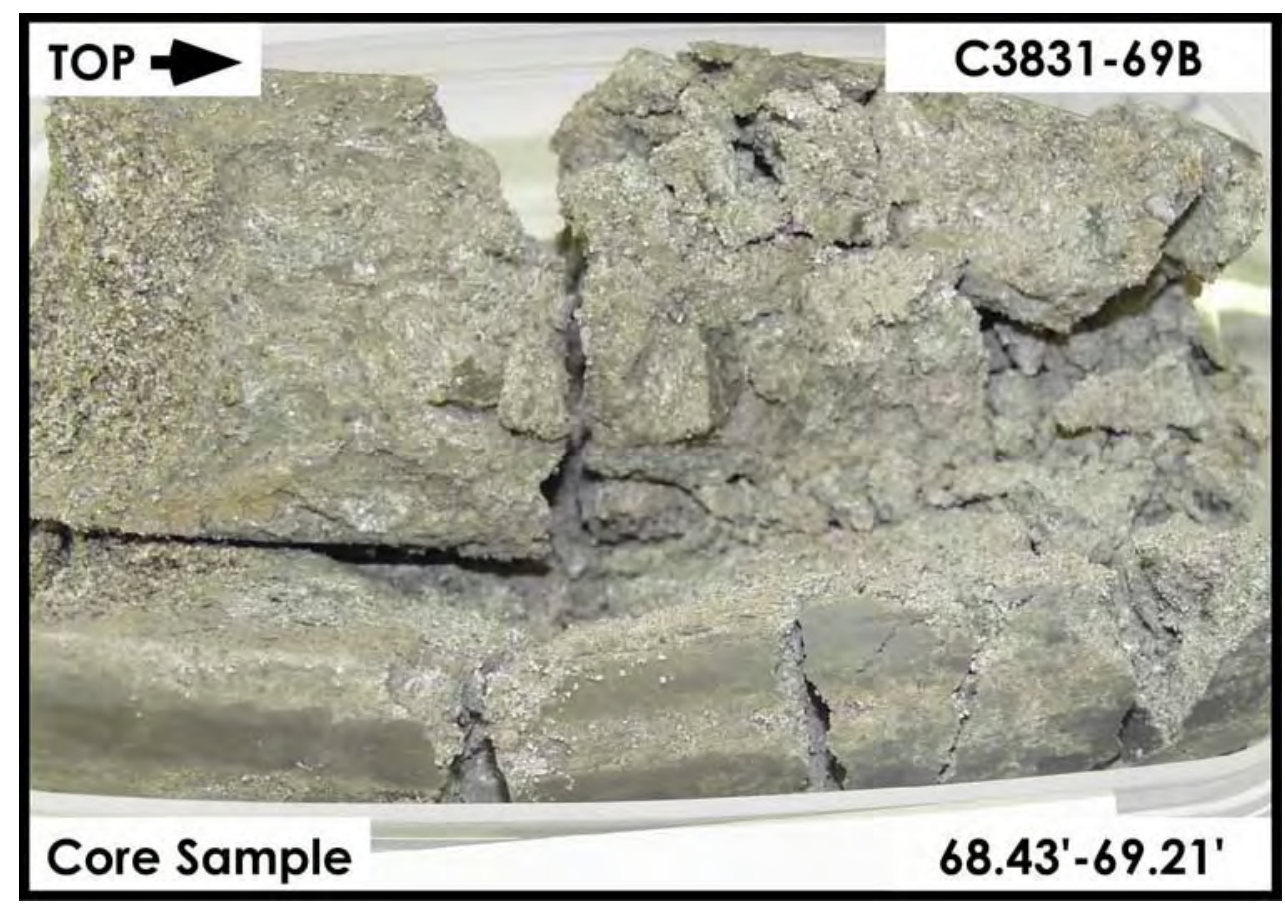

Figure A-3.19. Hanford Formation (H2 unit) $68.43 \mathrm{ft}-69.21 \mathrm{ft}$

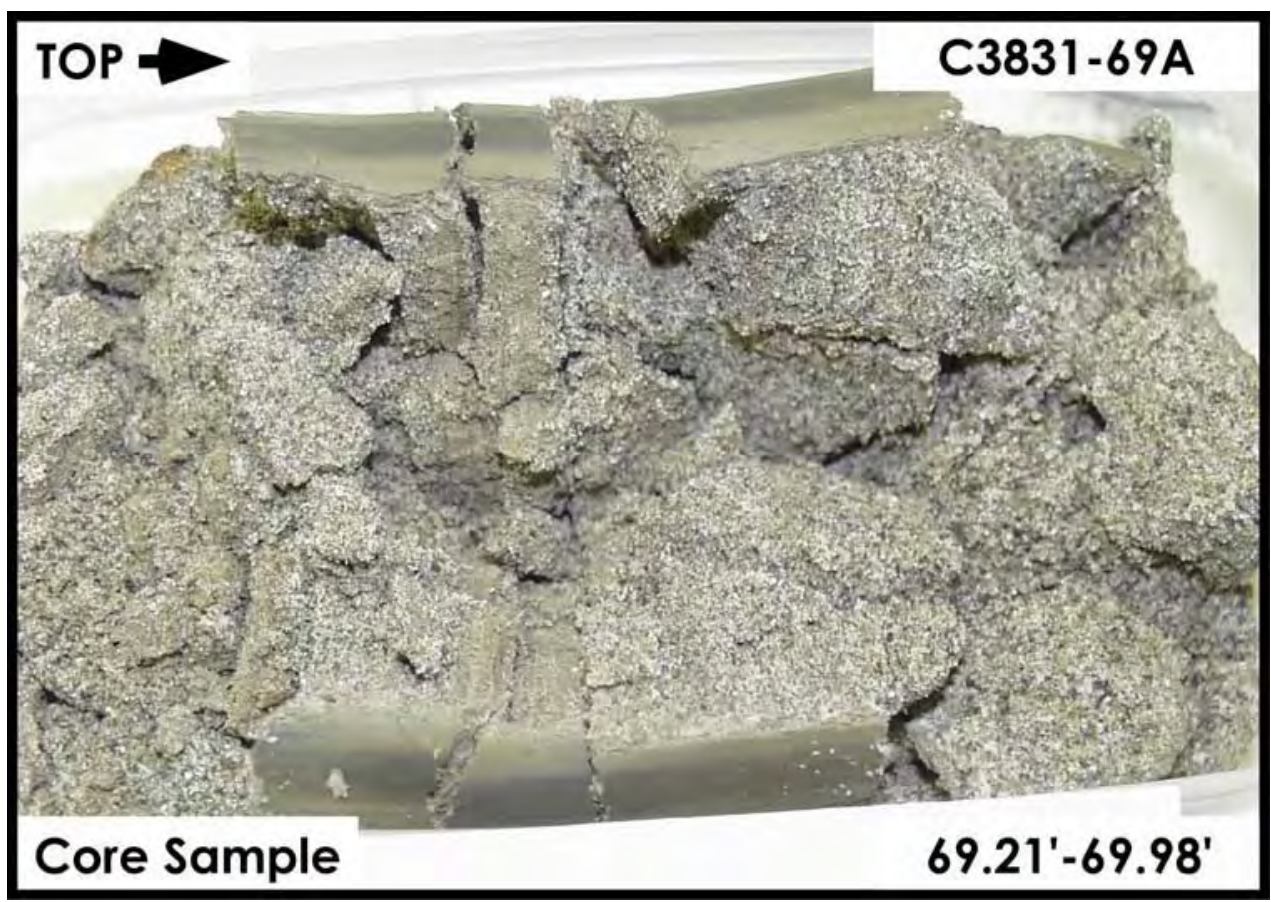

Figure A-3.20. Hanford Formation (H2 unit) $69.21 \mathrm{ft}-69.98 \mathrm{ft}$ 


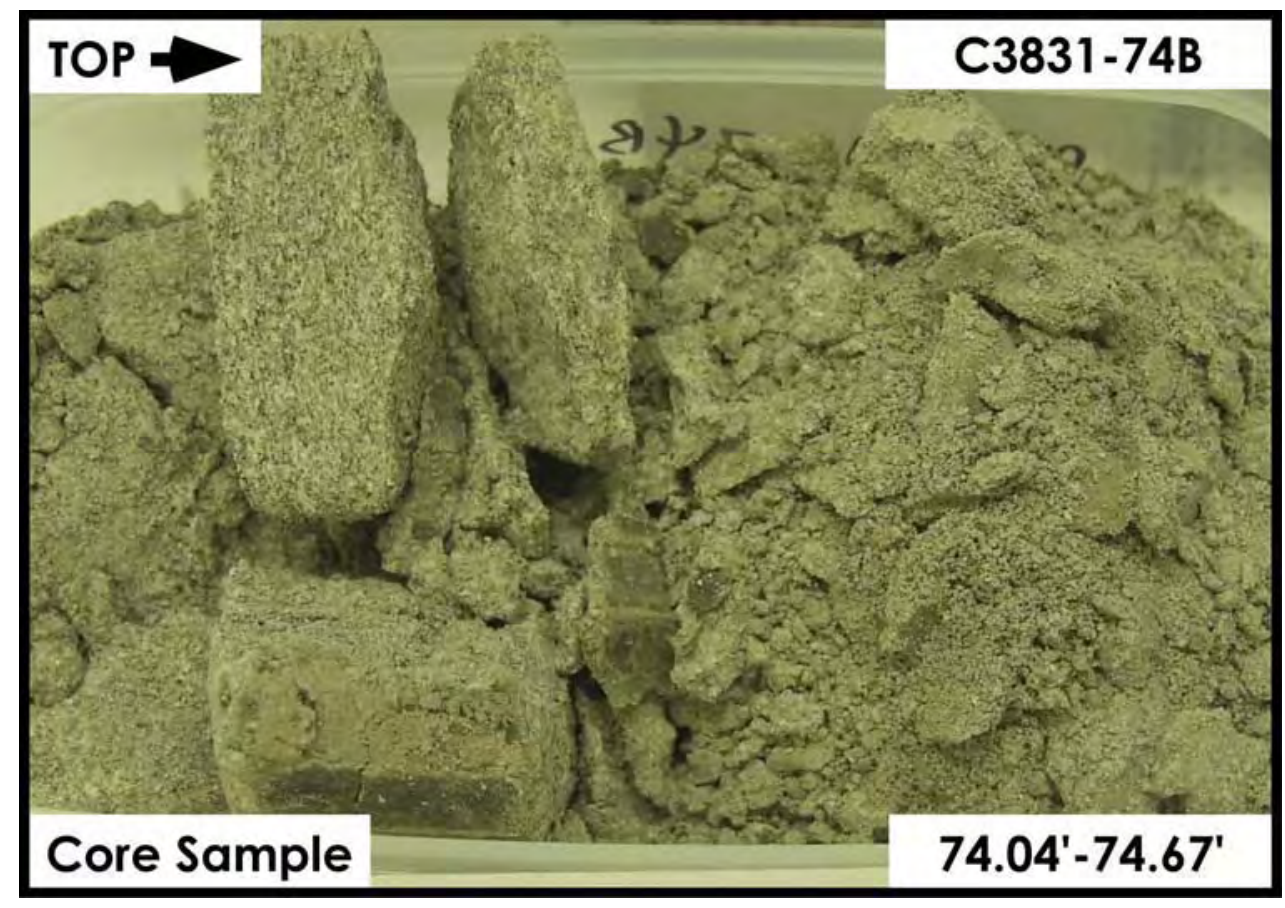

Figure A-3.21. Hanford Formation (H2 unit) $74.04 \mathrm{ft}-\mathbf{7 4 . 6 7} \mathbf{f t}$

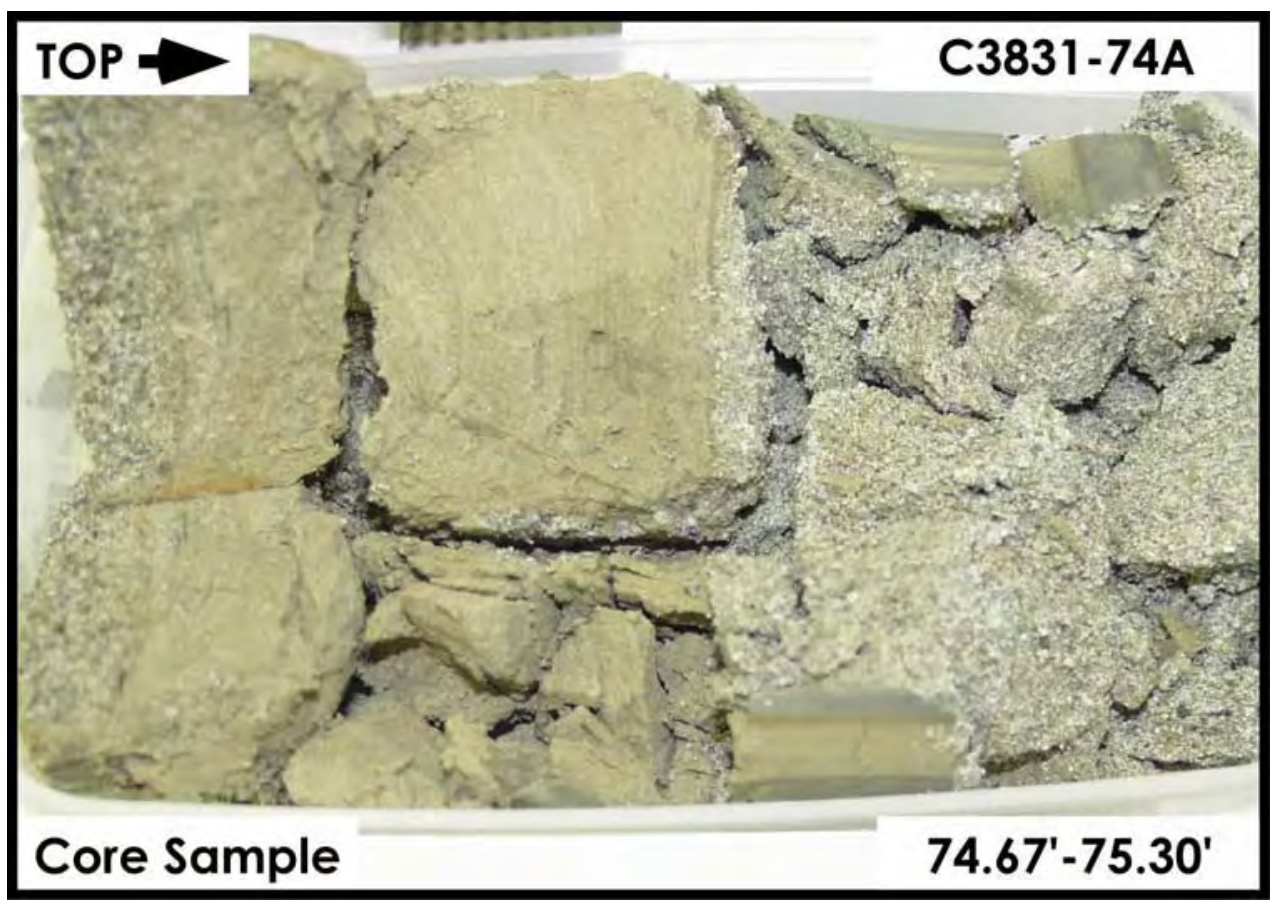

Figure A-3.22. Hanford Formation (H2 unit) $74.67 \mathrm{ft}-75.30 \mathrm{ft}$ 


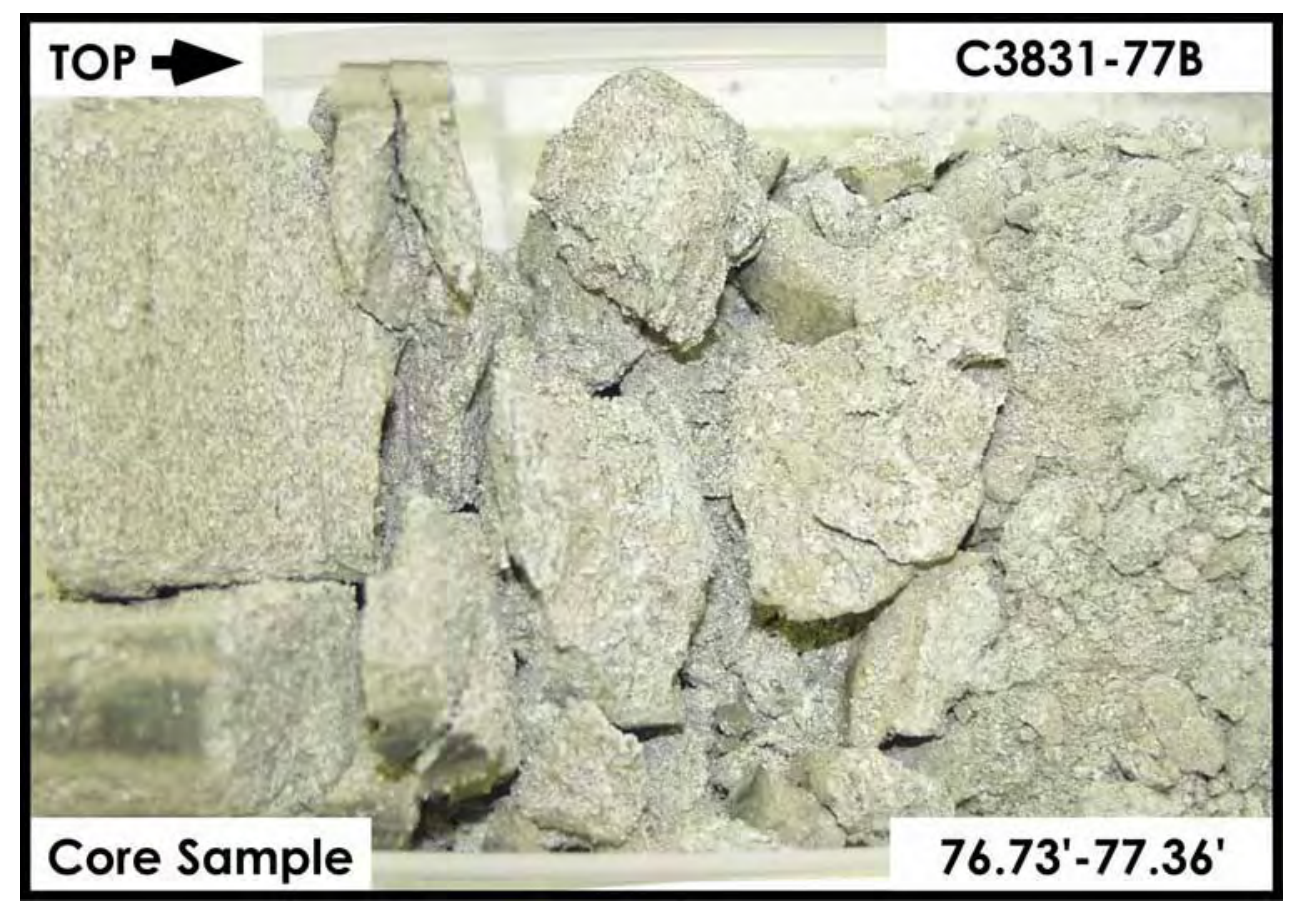

Figure A-3.23. Hanford Formation (H2 unit) $76.73 \mathrm{ft}-77.36 \mathrm{ft}$

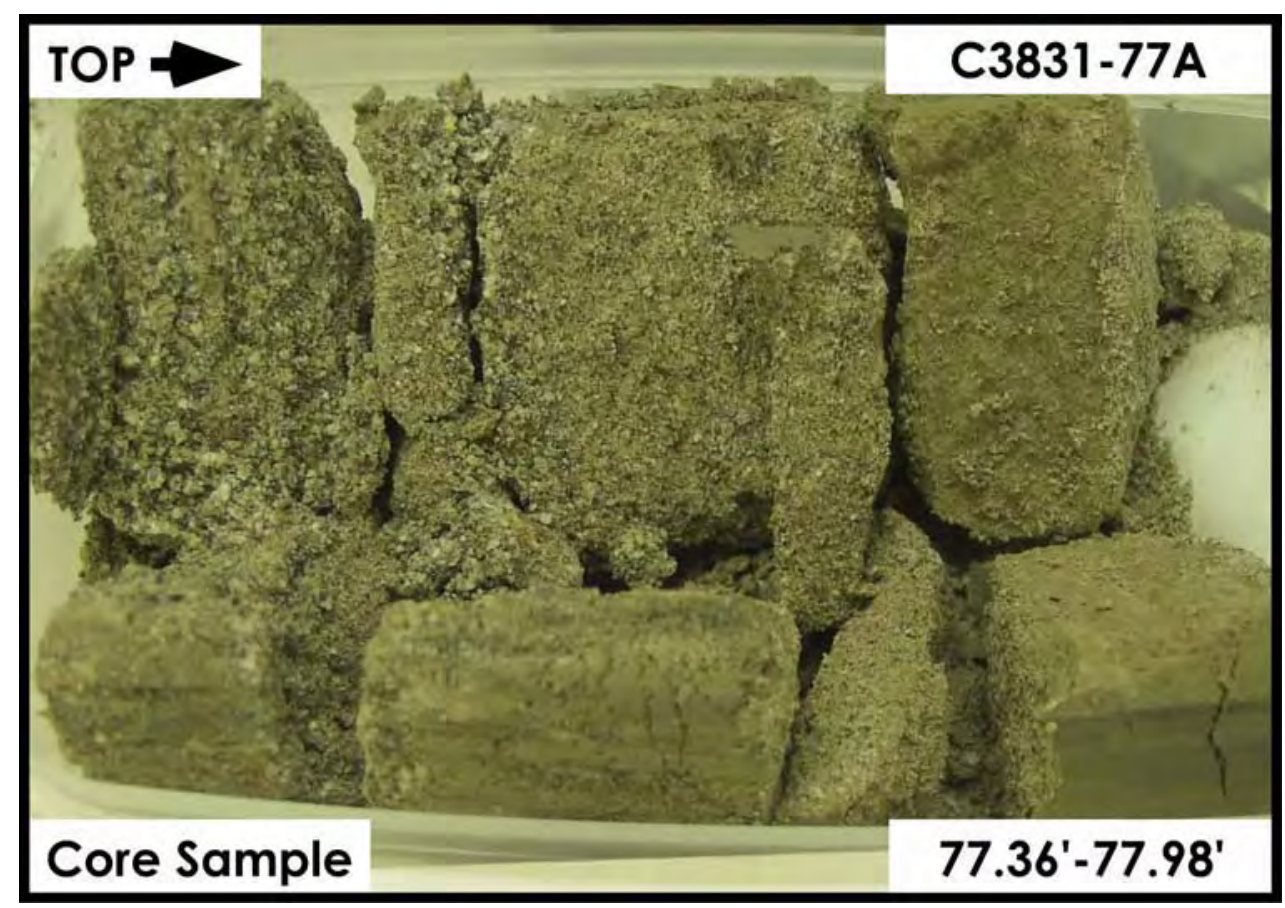

Figure A-3.24. Hanford Formation (H2 unit) $77.36 \mathrm{ft}-77.98 \mathrm{ft}$ 


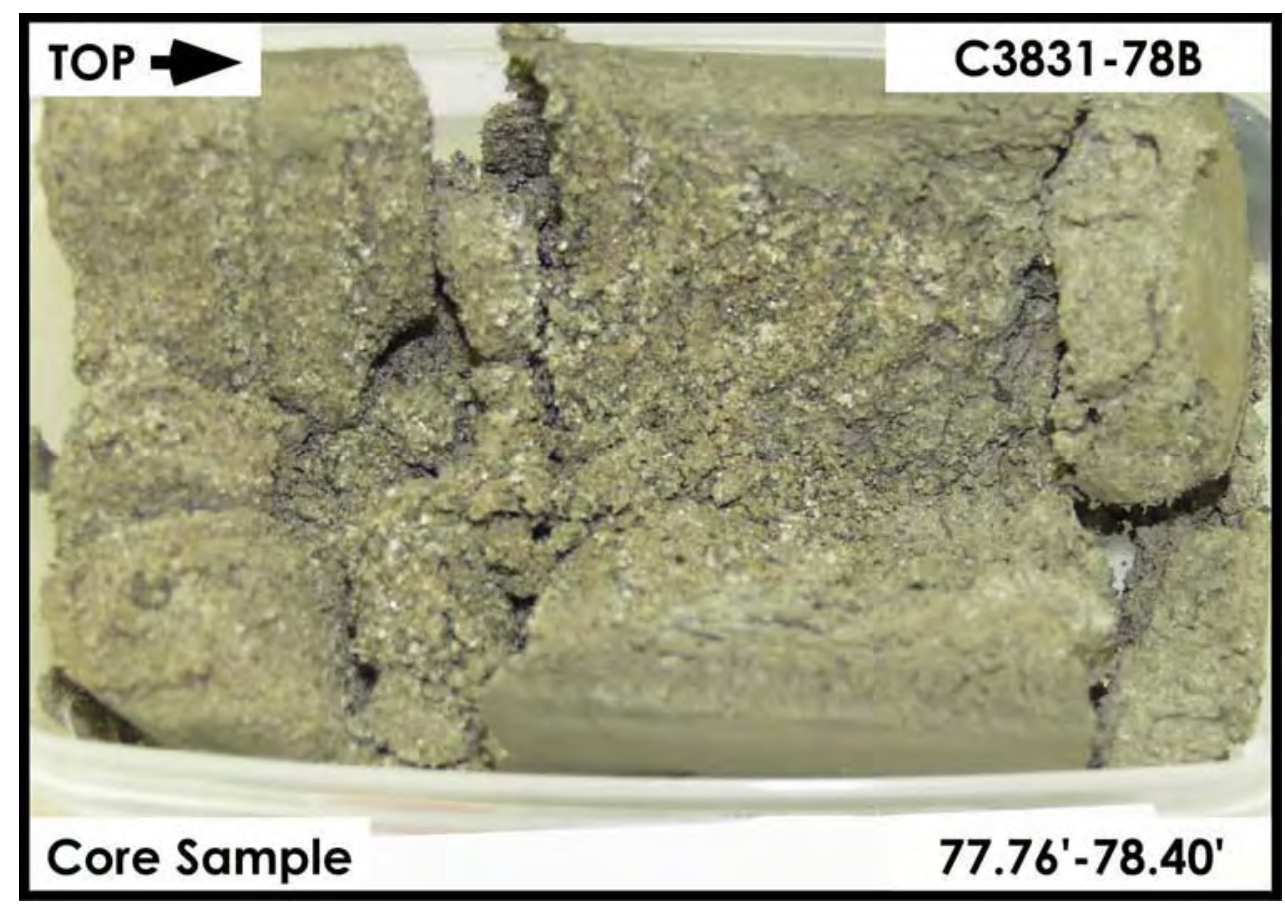

Figure A-3.25. Hanford Formation (H2 unit) $77.76 \mathrm{ft}-78.40 \mathrm{ft}$

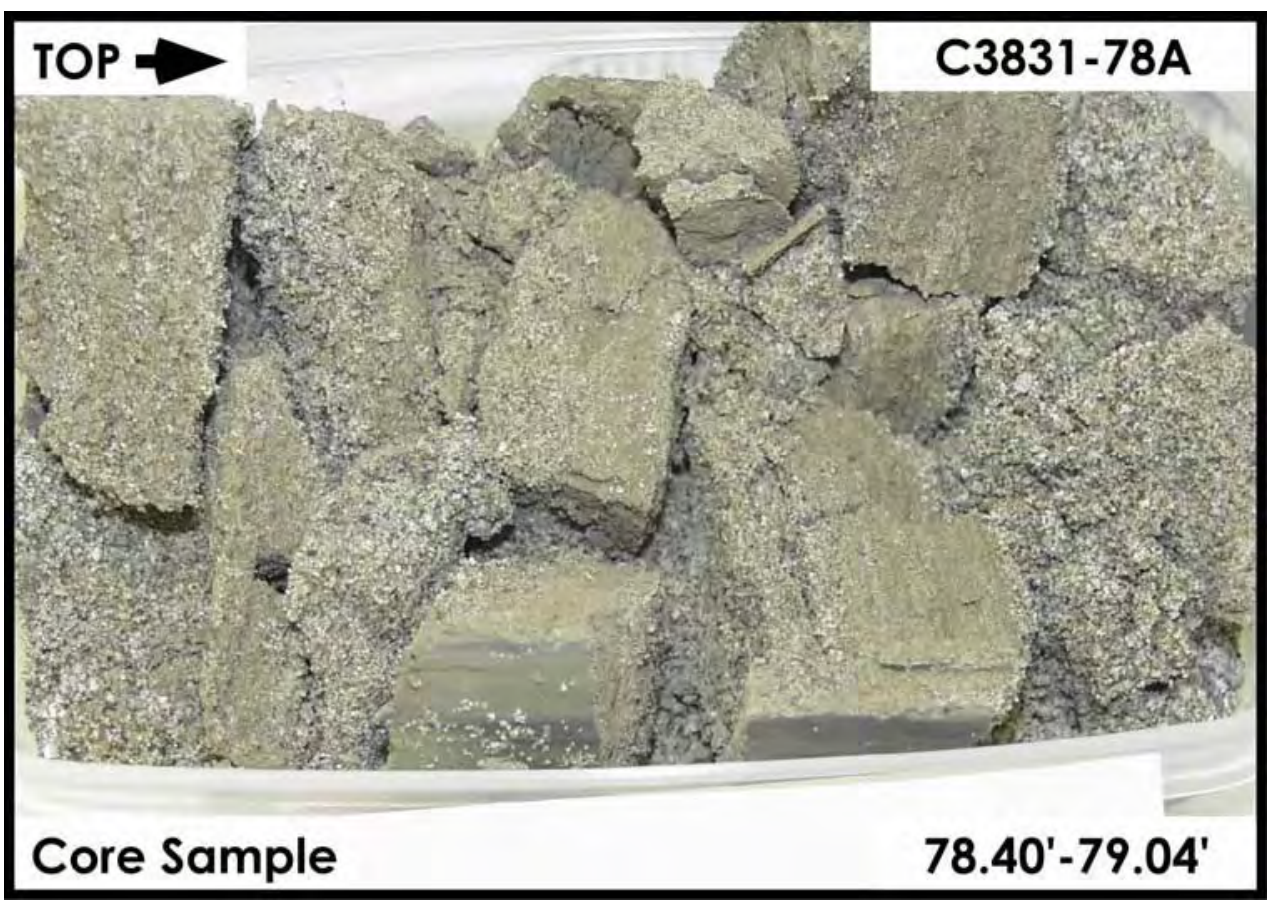

Figure A-3.26. Hanford Formation (H2 unit) $78.40 \mathrm{ft} \mathbf{- 7 9 . 0 4} \mathbf{f t}$ 


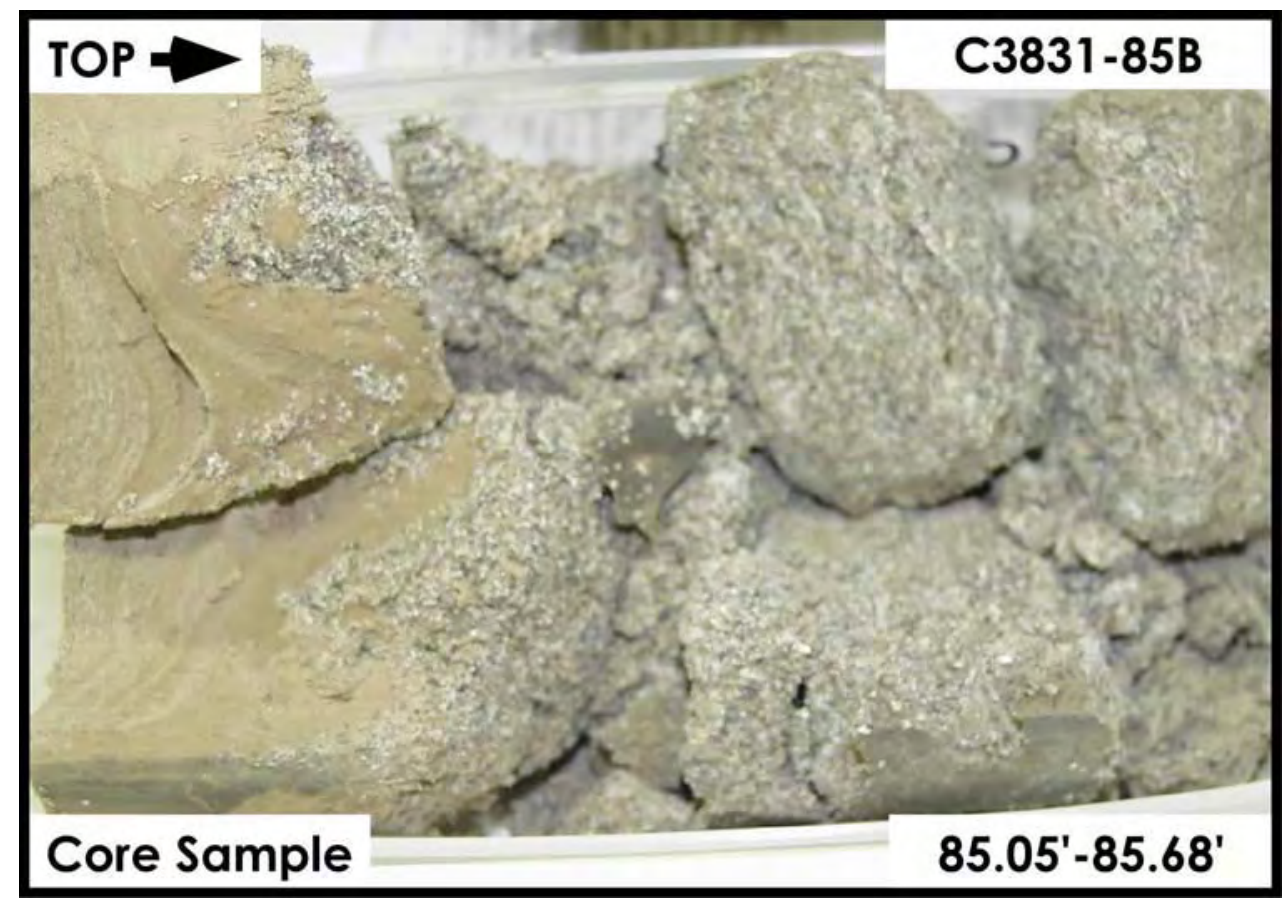

Figure A-3.27. Hanford Formation (H2 unit) $85.05 \mathrm{ft}-85.68 \mathrm{ft}$

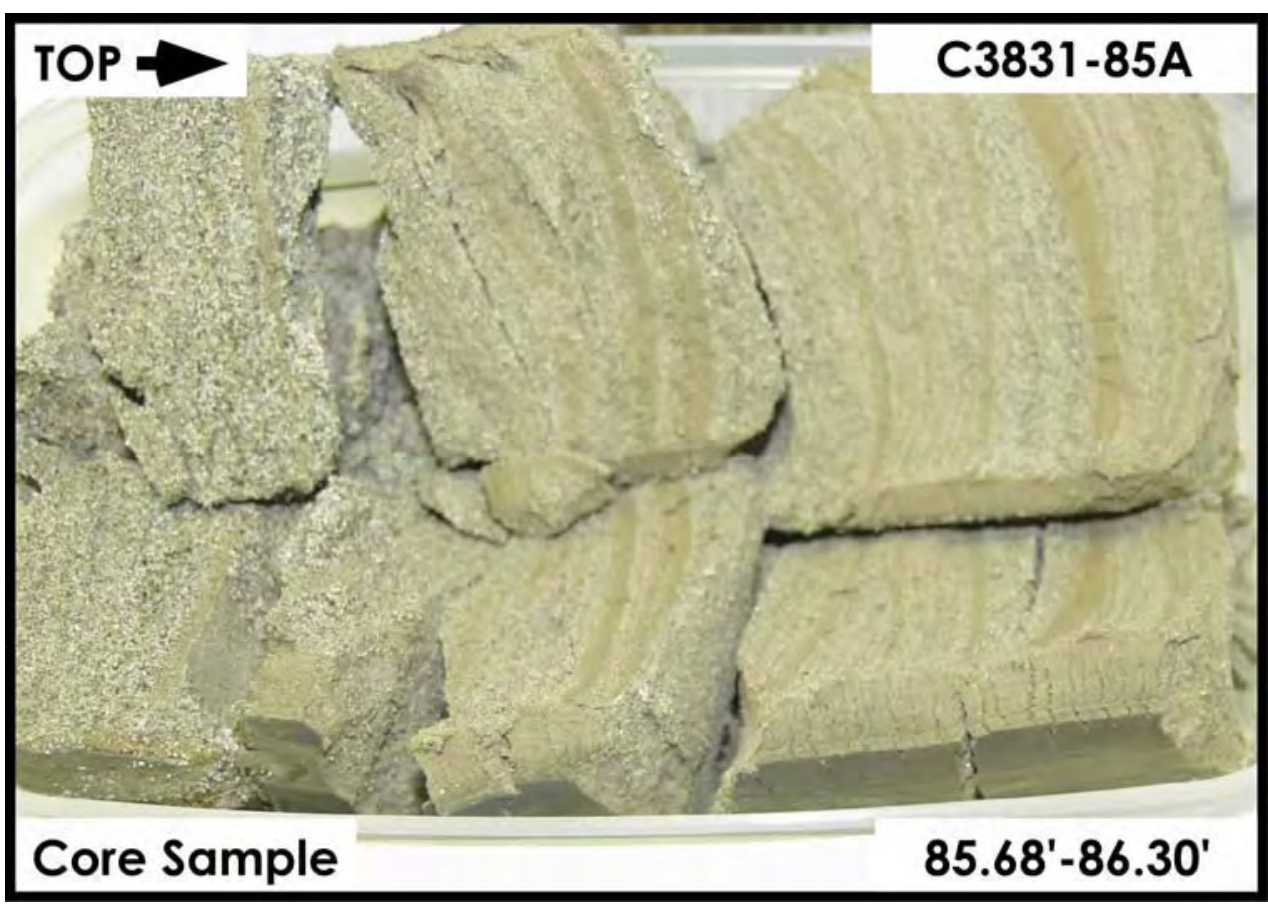

Figure A-3.28. Hanford Formation (H2 unit) $85.68 \mathrm{ft}-86.30 \mathrm{ft}$ 


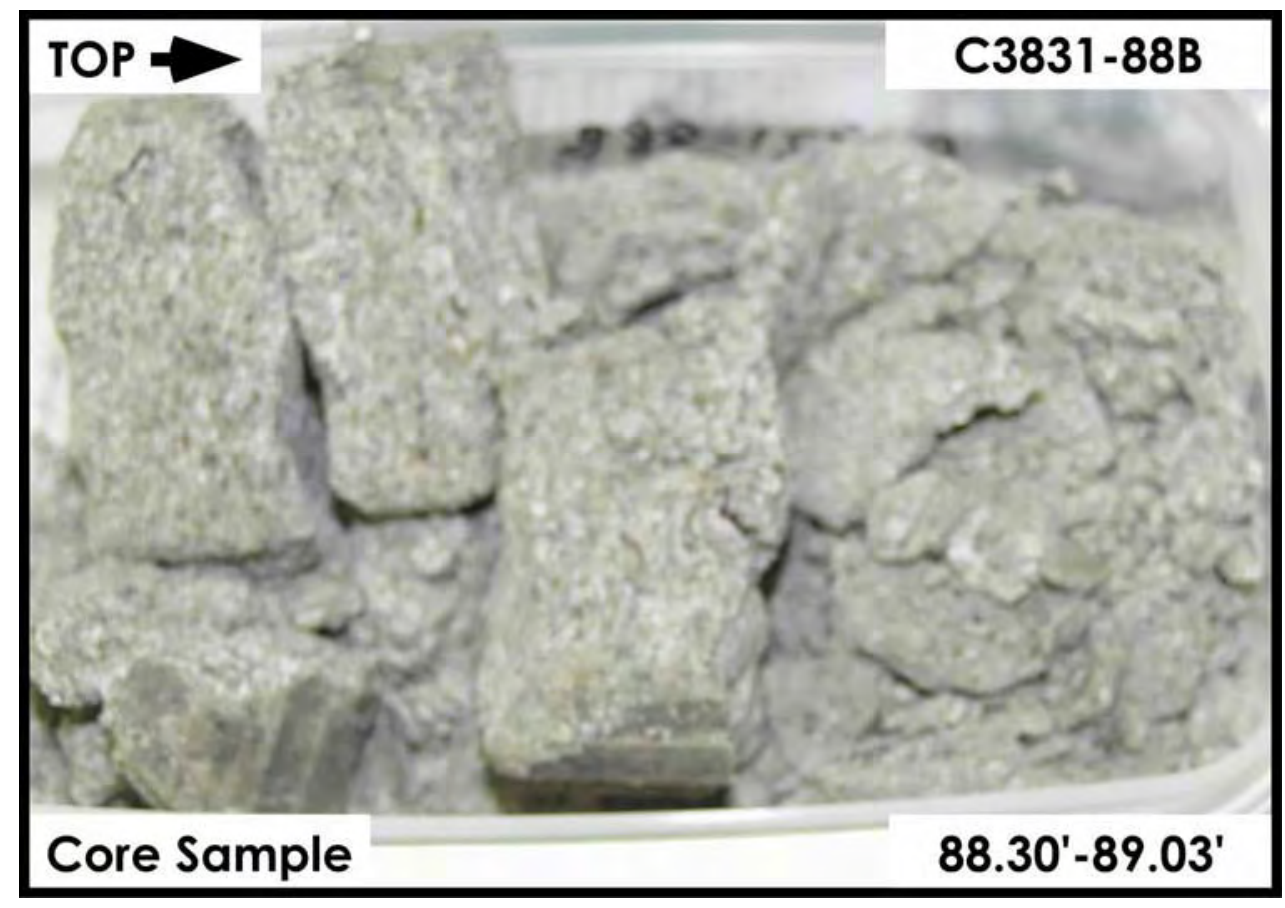

Figure A-3.29. Hanford Formation (H2 unit) $88.30 \mathrm{ft}-\mathbf{8 9 . 0 3} \mathrm{ft}$

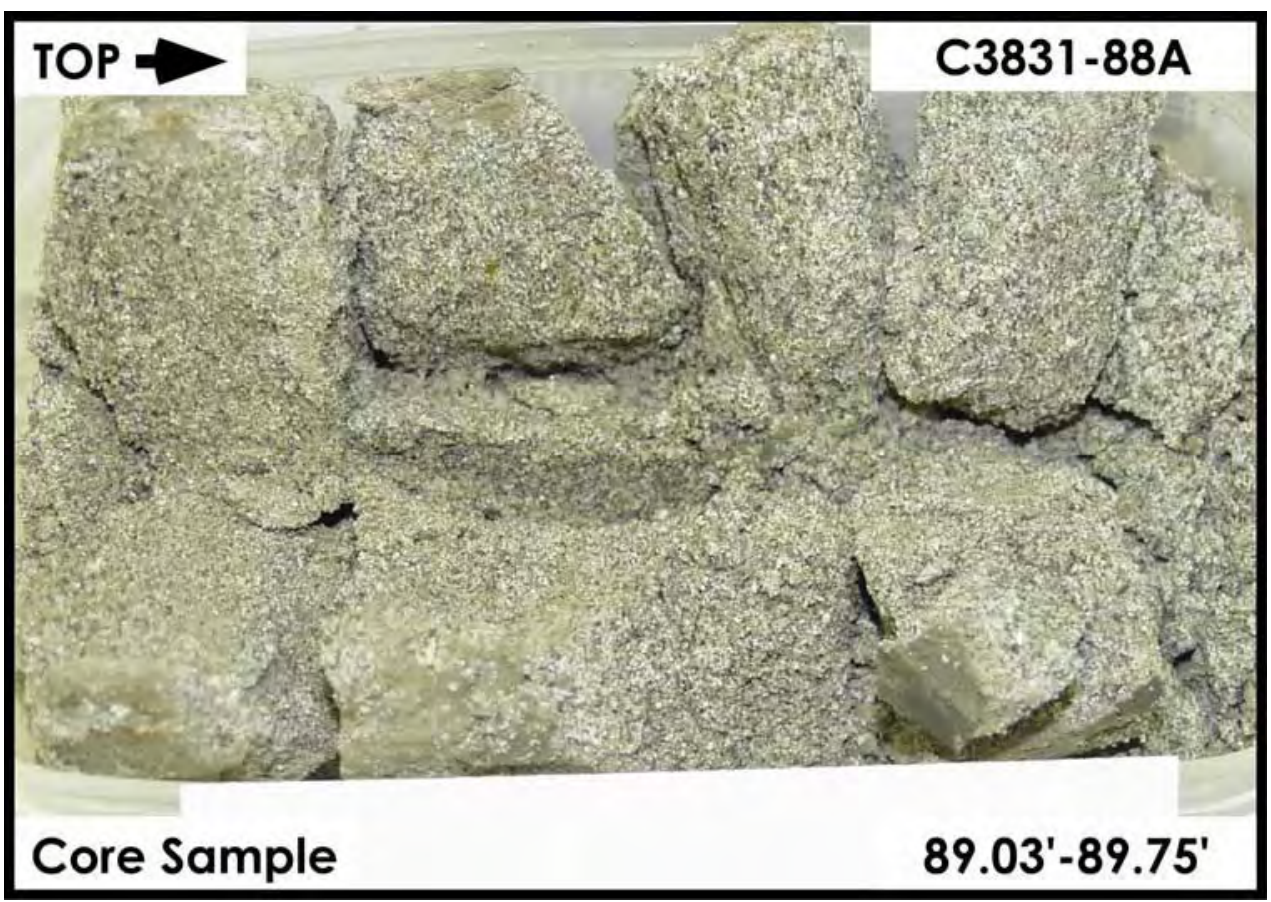

Figure A-3.30. Hanford Formation (H2 unit) $89.03 \mathrm{ft}-89.75 \mathrm{ft}$ 


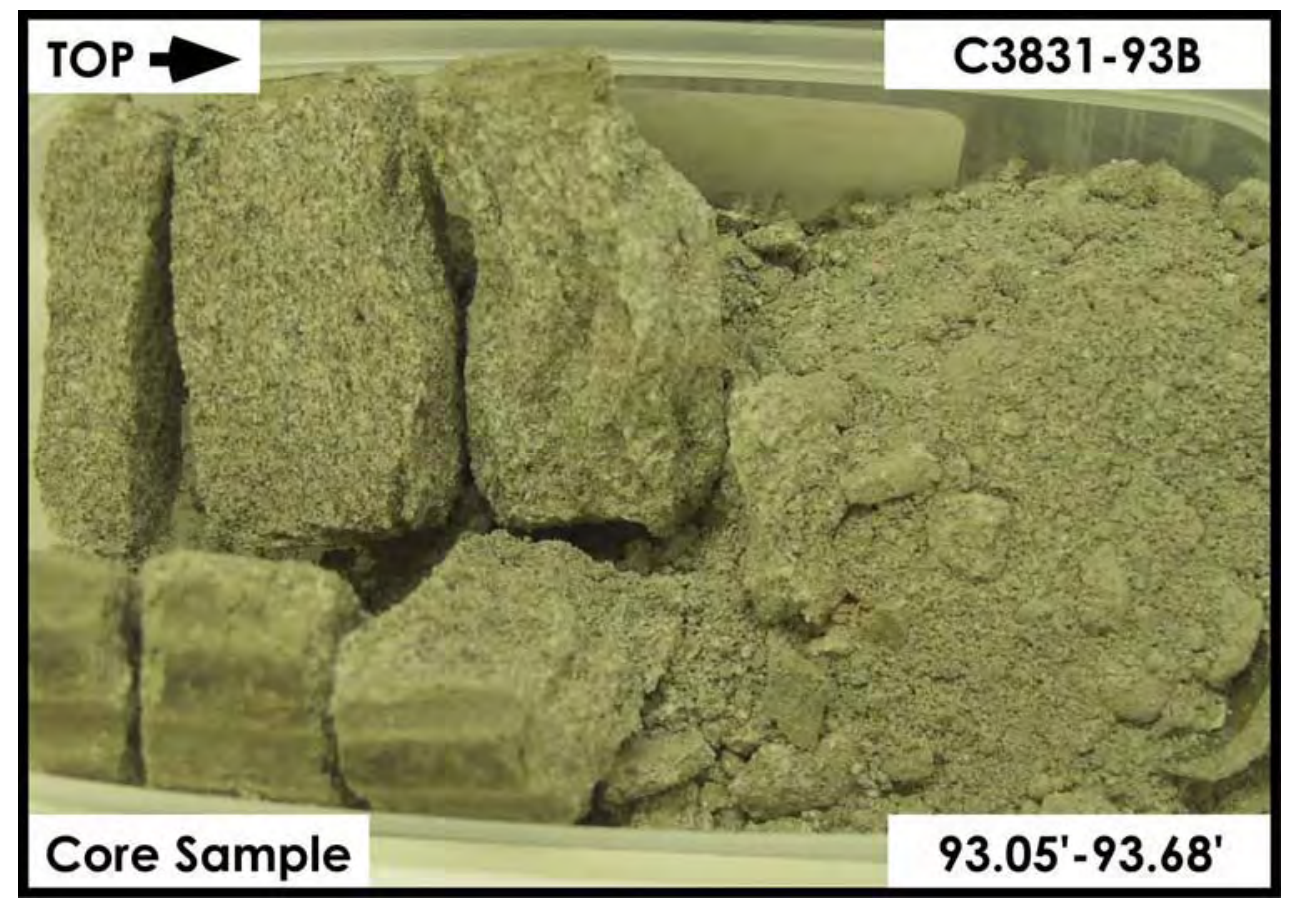

Figure A-3.31. Hanford Formation (H2 unit) $93.05 \mathrm{ft}-93.68 \mathrm{ft}$

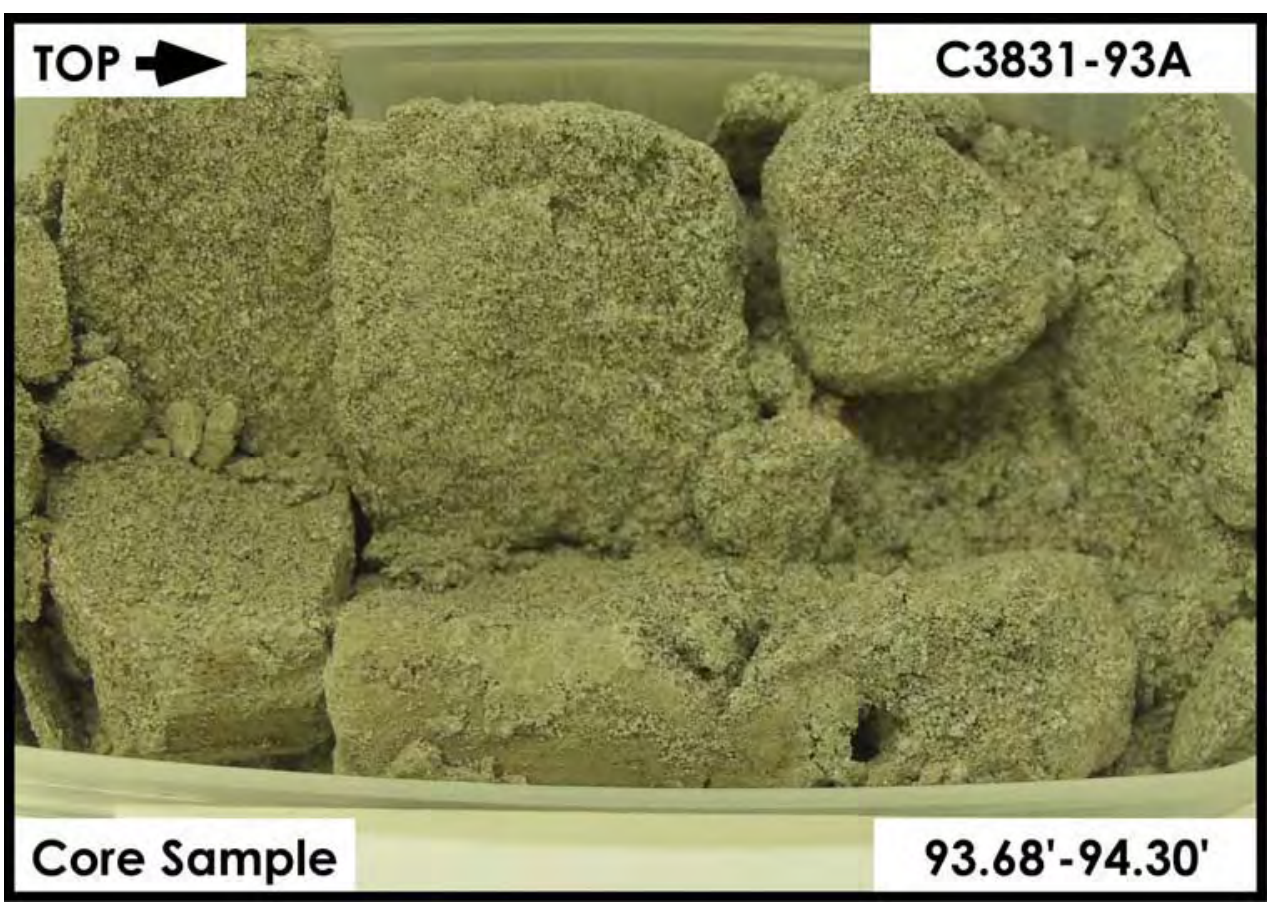

Figure A-3.32. Hanford Formation (H2 unit) $93.68 \mathrm{ft}-94.30 \mathrm{ft}$ 


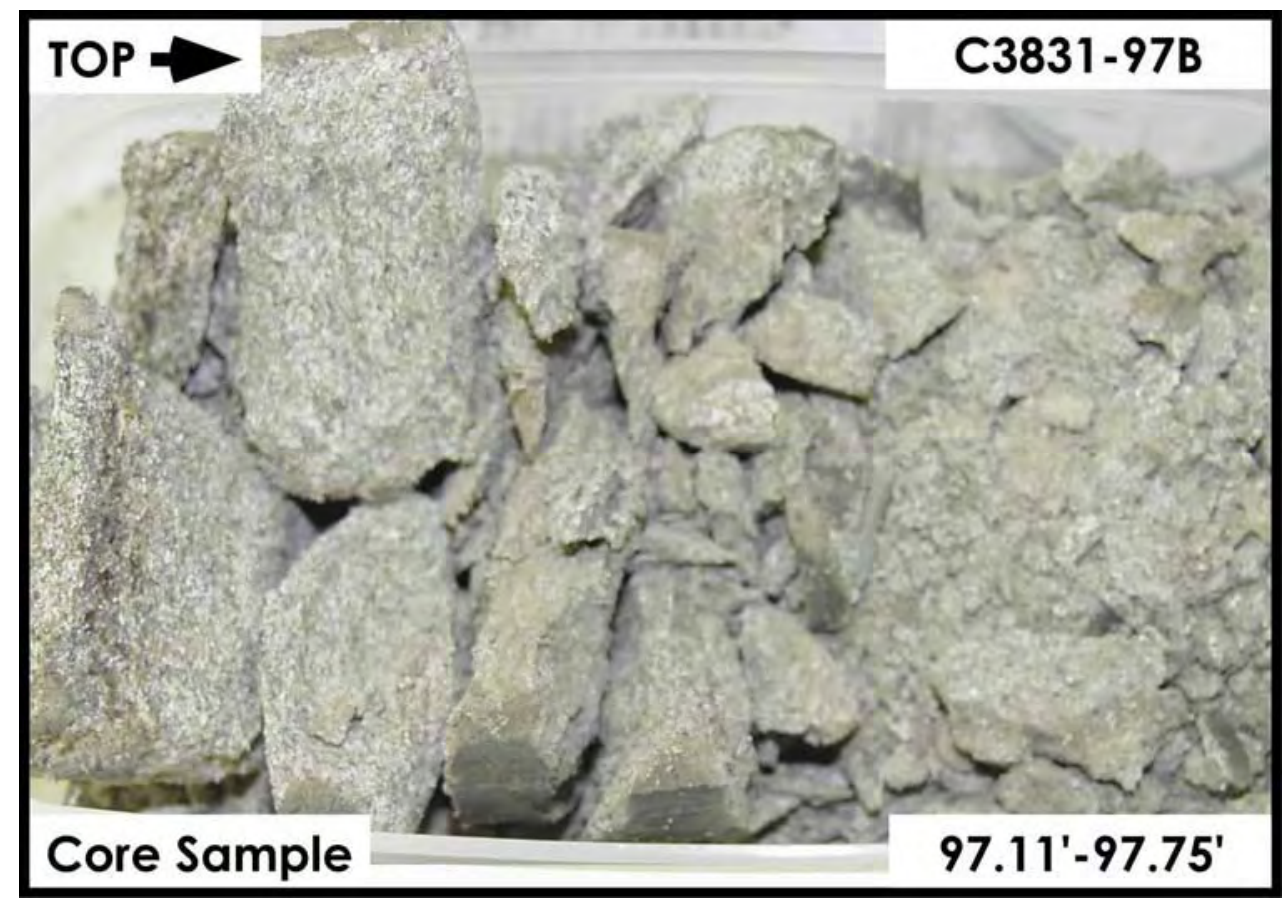

Figure A-3.33. Hanford Formation (H2 unit) $97.11 \mathrm{ft}-97.75 \mathrm{ft}$

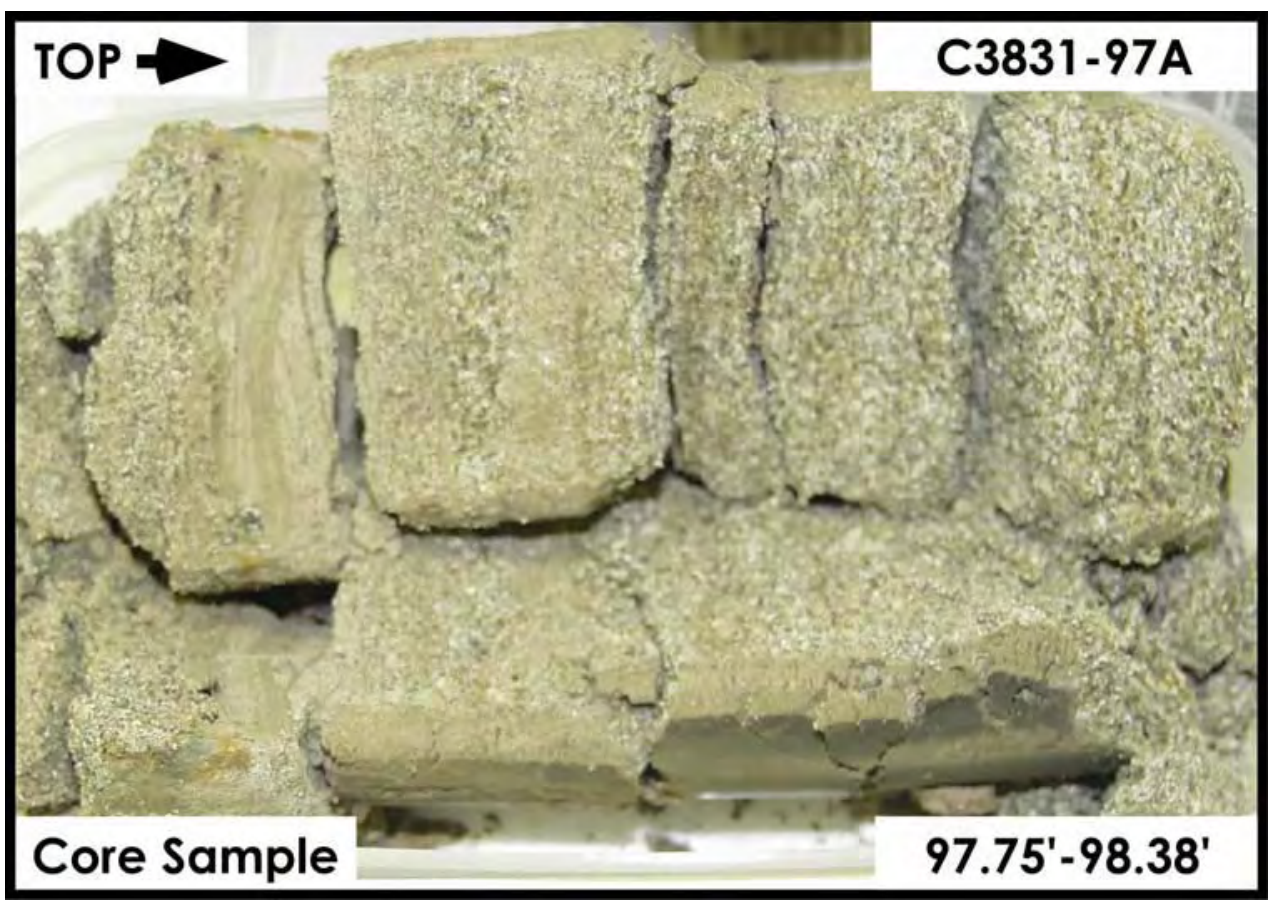

Figure A-3.34. Hanford Formation (H2 unit) $97.75 \mathrm{ft}$ - $98.38 \mathrm{ft}$ 


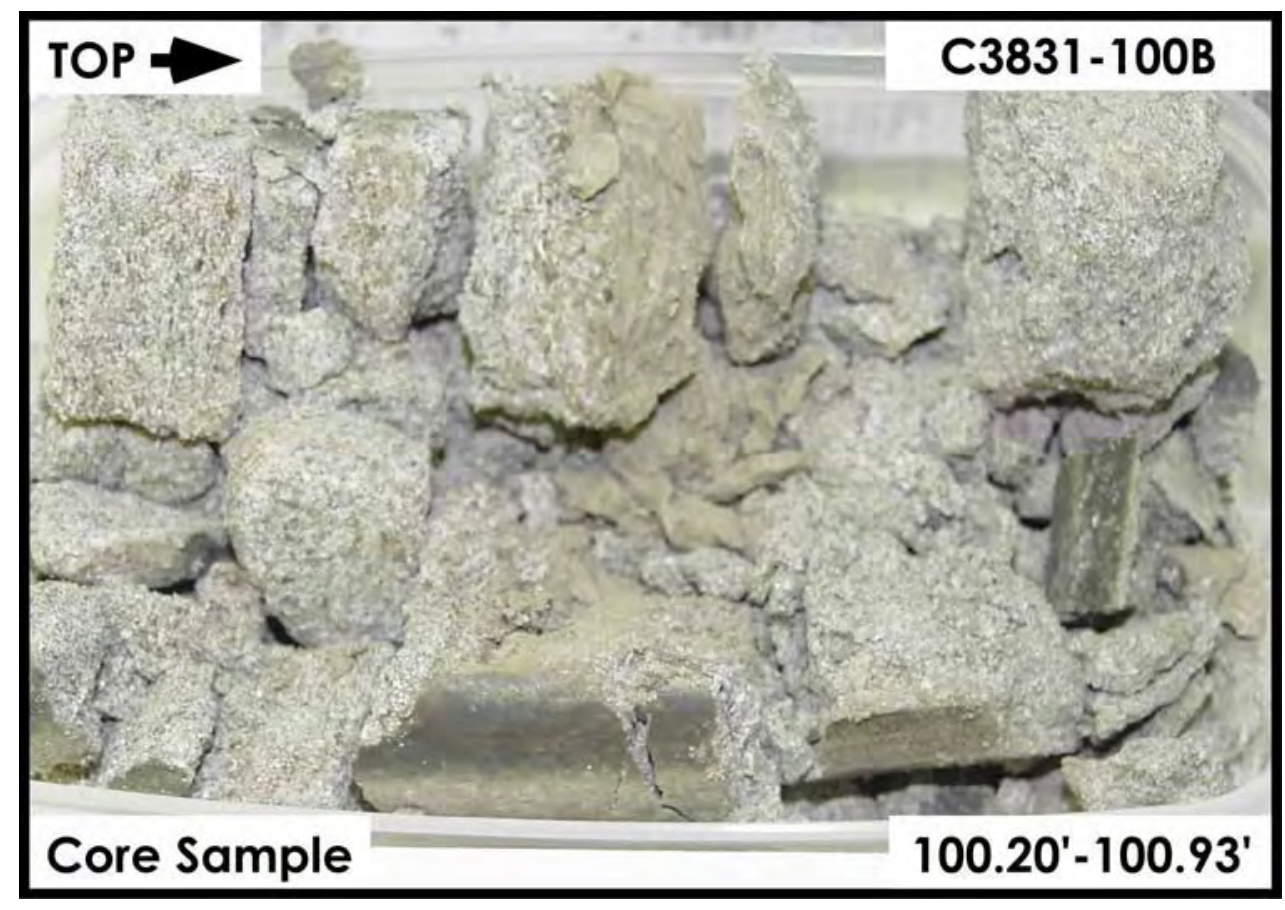

Figure A-3.35. Hanford Formation (H2 unit) $100.20 \mathrm{ft}-100.93 \mathrm{ft}$

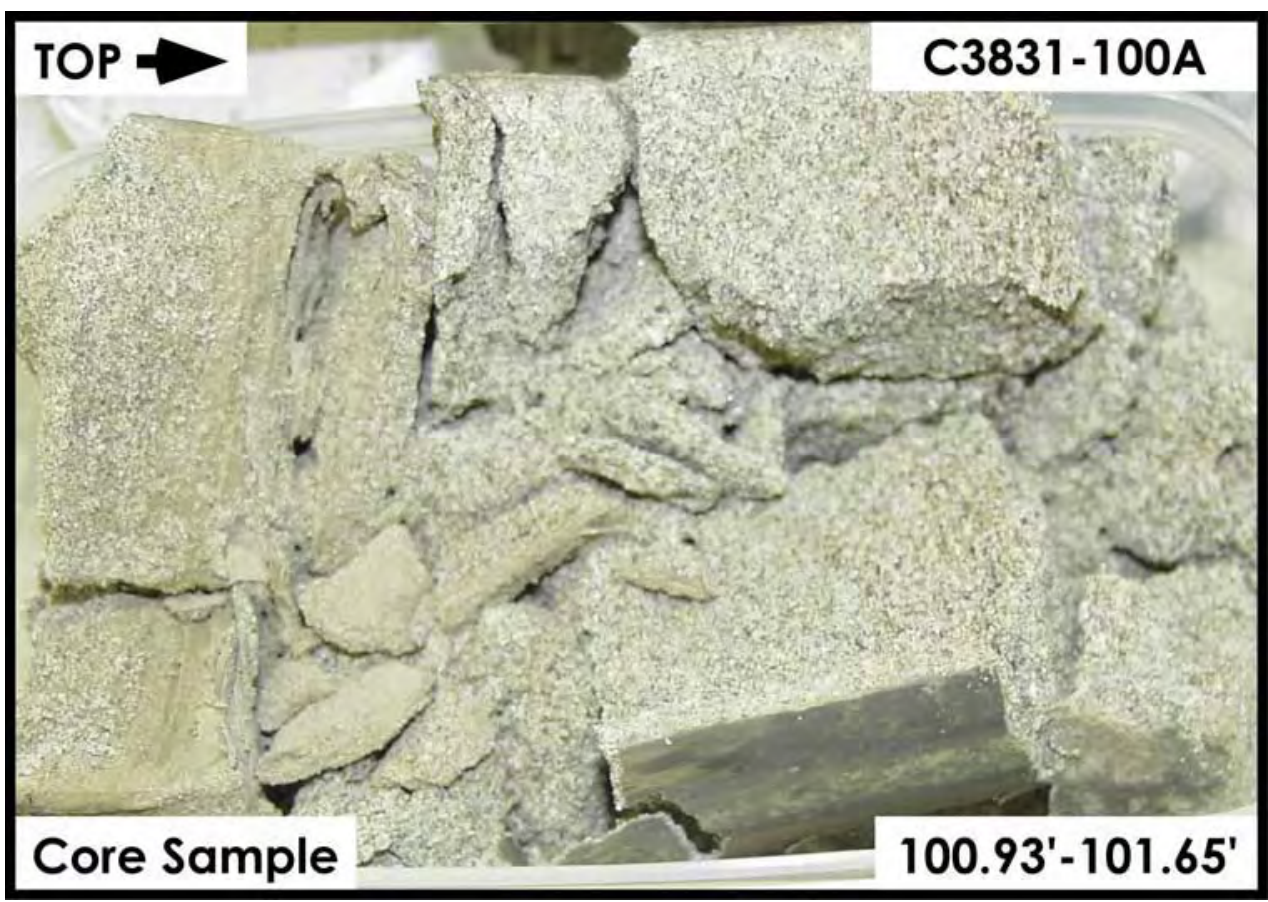

Figure A-3.36. Hanford Formation (H2 unit) $100.93 \mathrm{ft}-101.65 \mathrm{ft}$ 


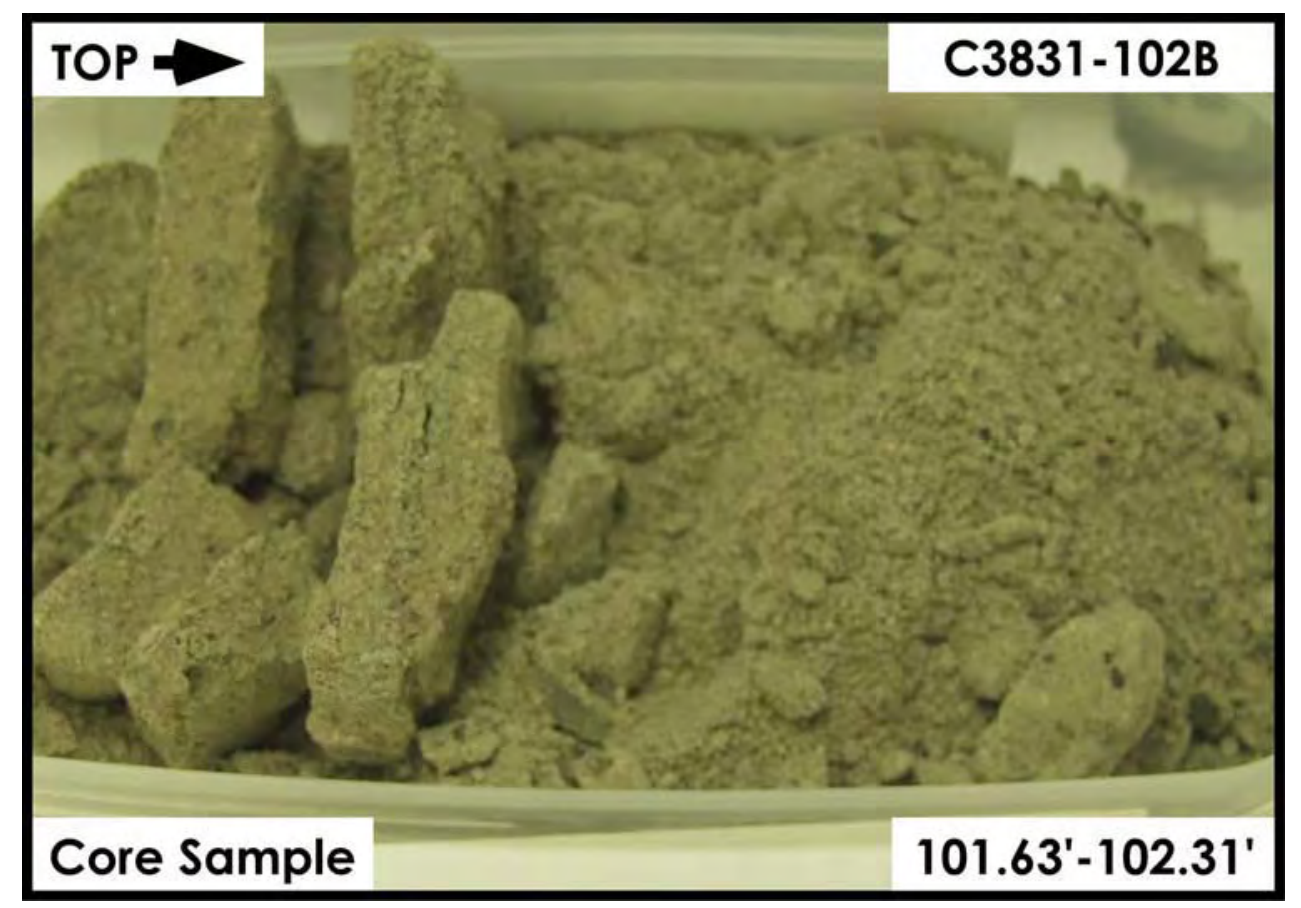

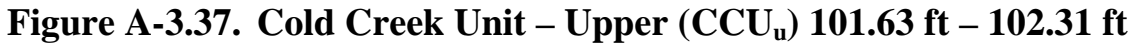

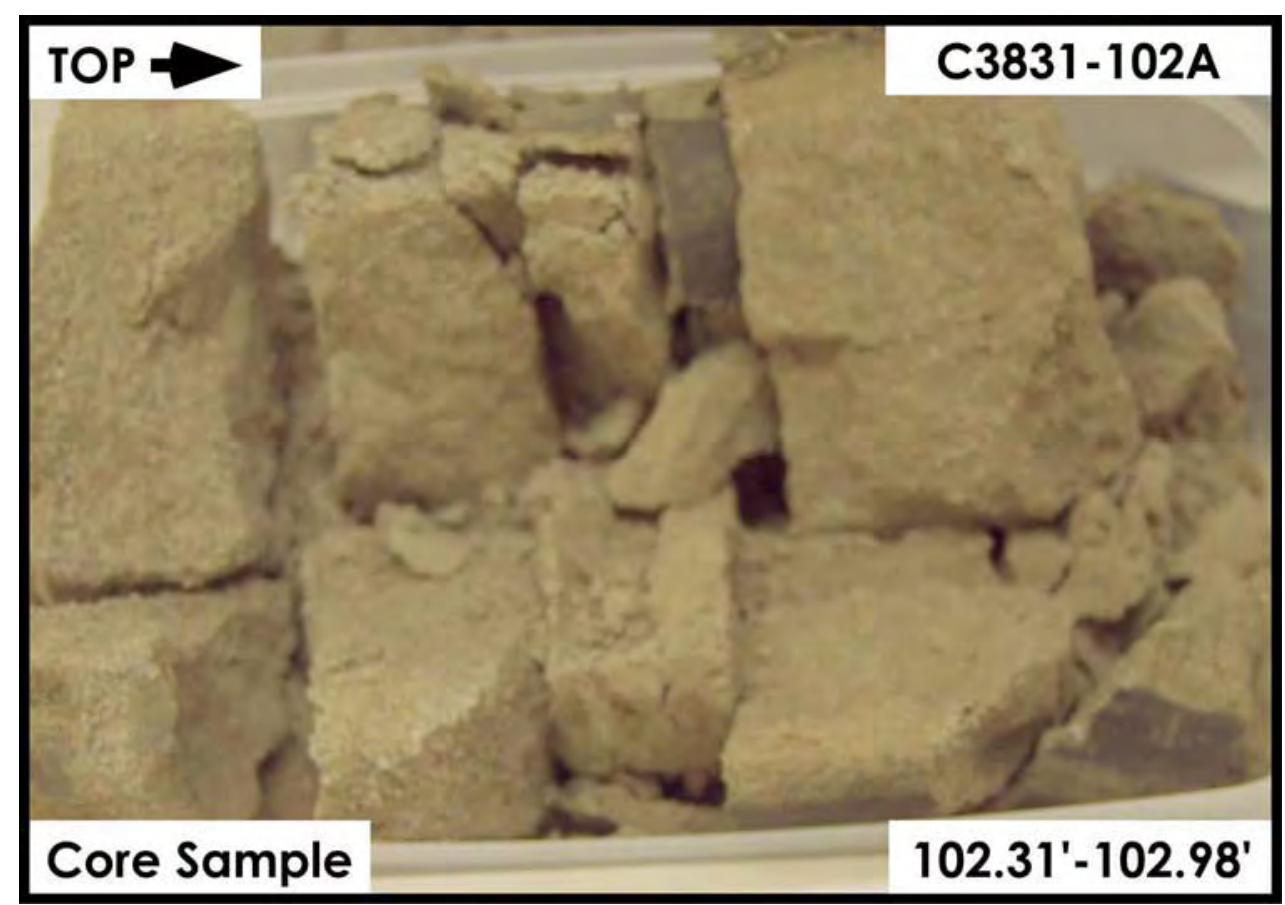

Figure A-3.38. Cold Creek Unit - Upper $\left(\mathrm{CCU}_{\mathrm{u}}\right) \mathbf{1 0 2 . 3 1} \mathrm{ft}-102.98 \mathrm{ft}$ 


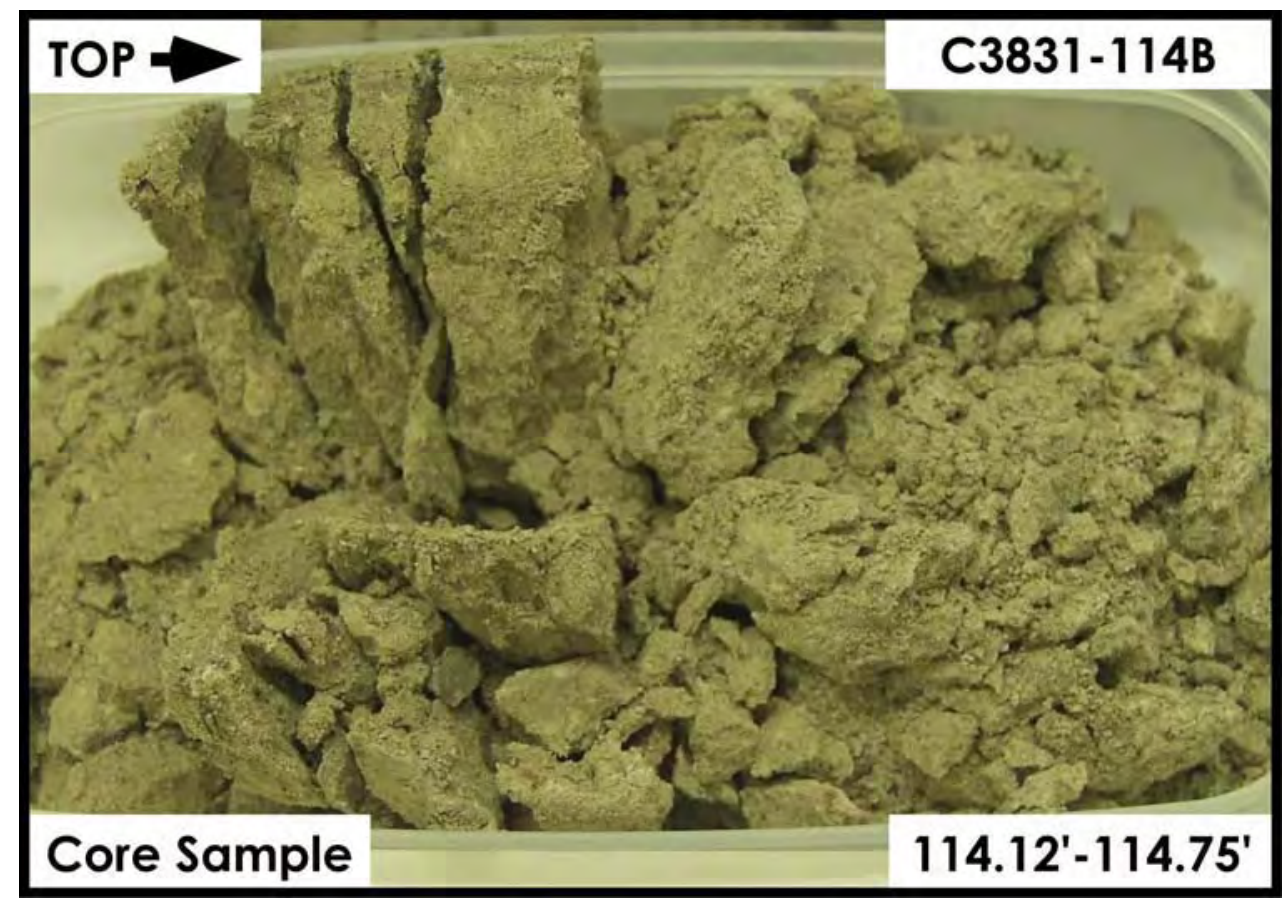

Figure A-3.39. Cold Creek Unit - Lower $\left(\mathrm{CCU}_{\mathrm{l}}\right) \mathbf{1 1 4 . 1 2} \mathrm{ft}-\mathbf{1 1 4 . 7 5} \mathrm{ft}$

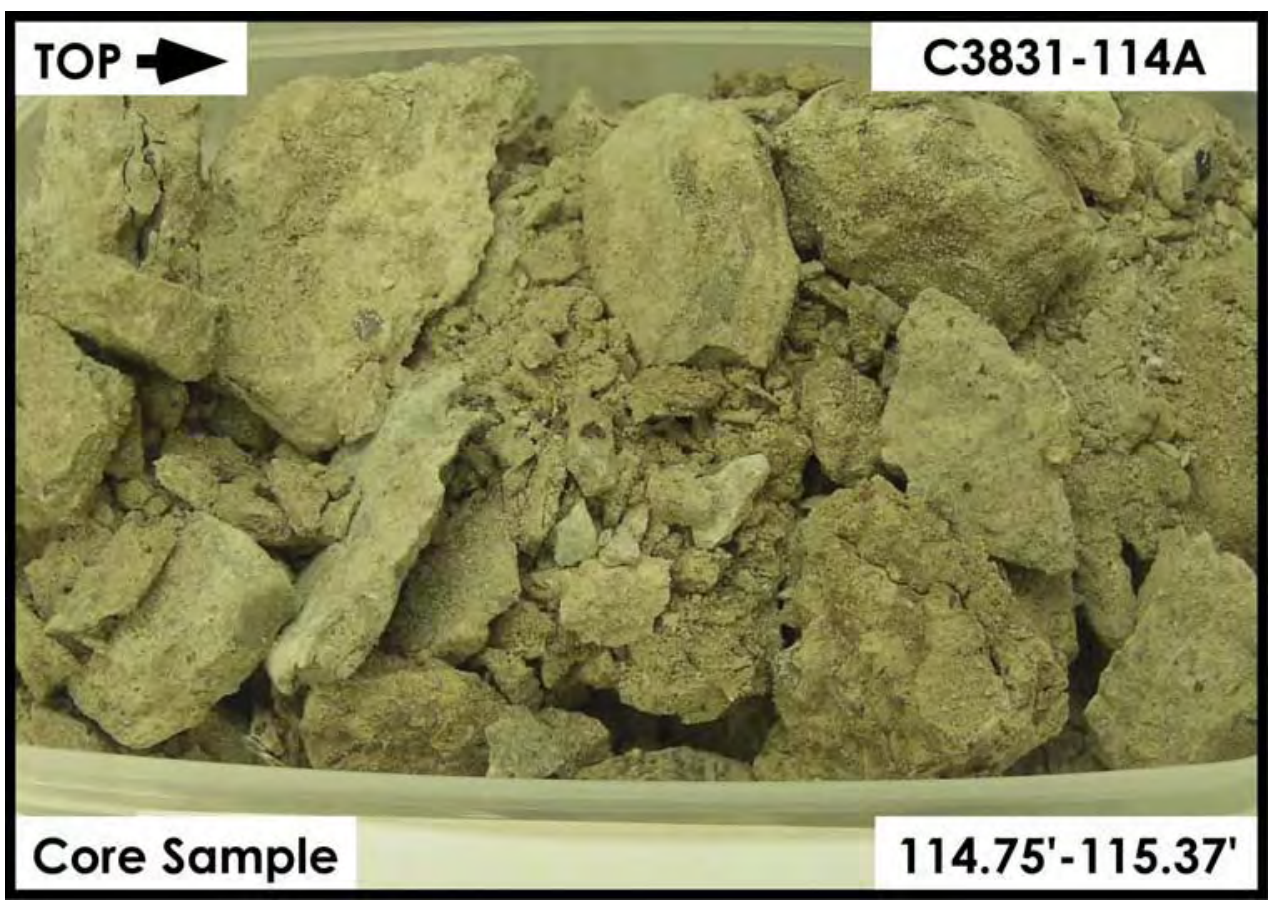

Figure A-3.40. Cold Creek Unit - Lower $\left(\mathrm{CCU}_{\mathrm{l}}\right) \mathbf{1 1 4 . 7 5} \mathrm{ft}-\mathbf{1 1 5 . 3 7} \mathrm{ft}$ 
Appendix A.4

C3832 (TX-104)

SPLITSPOON CORE

SAMPLE PHOTOGRAPHS 


\section{Contents}

Appendix A.4 C3832 (TX-104) Splitspoon Core Sample Photographs

A-4.1

\section{Figures}

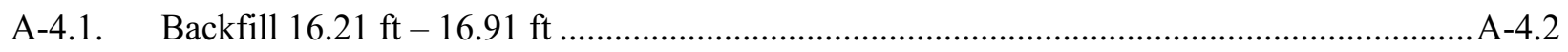

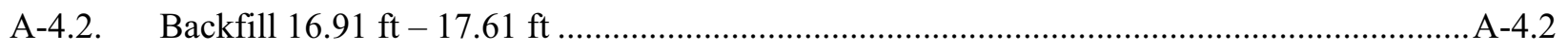

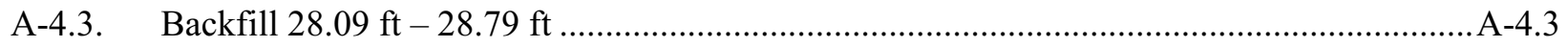

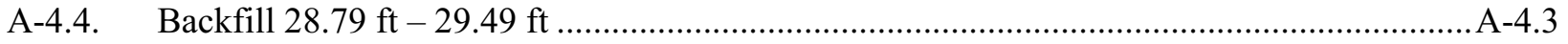

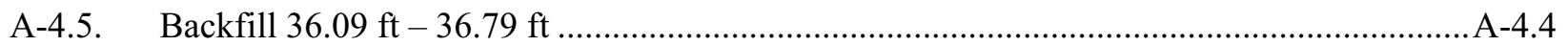

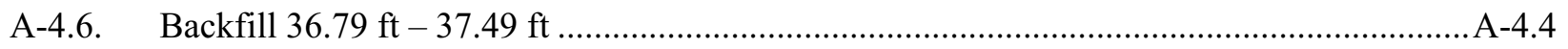

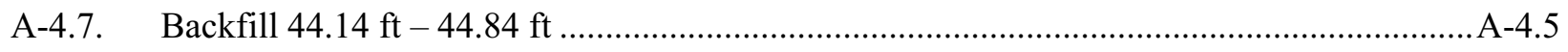

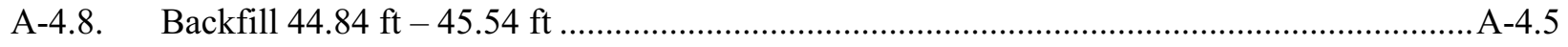

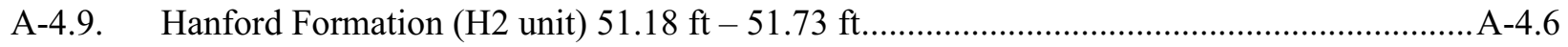

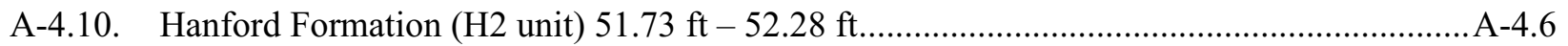

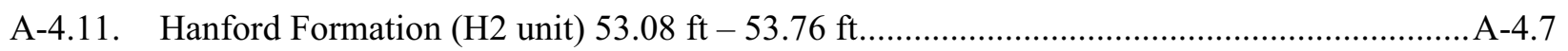

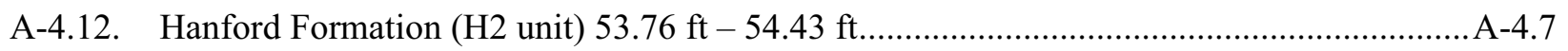

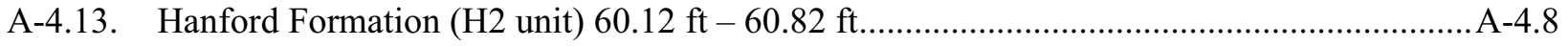

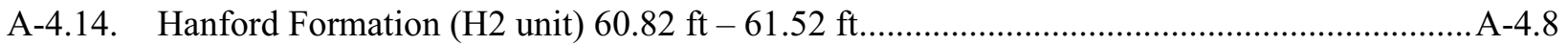

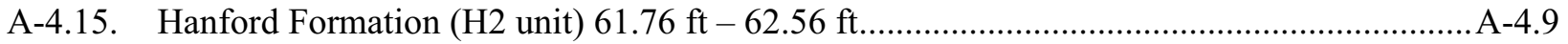

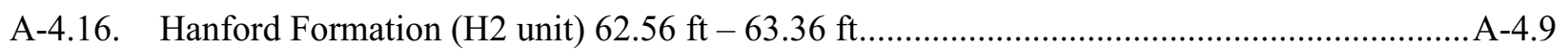

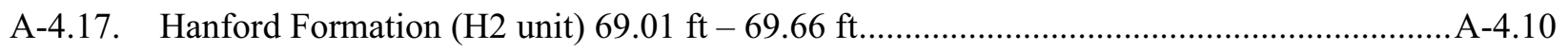

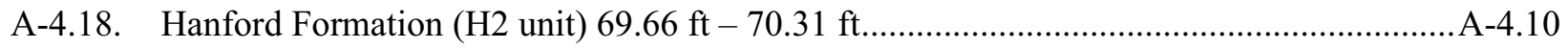

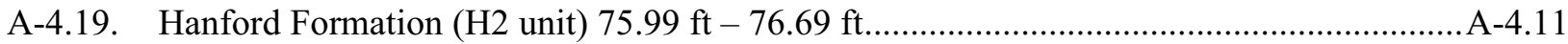

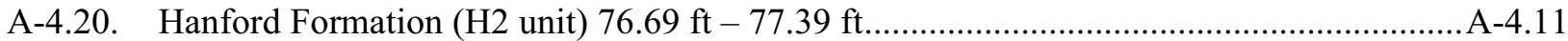

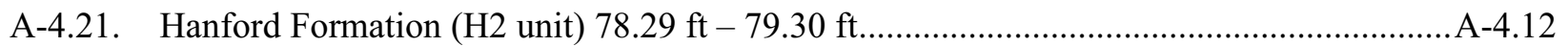

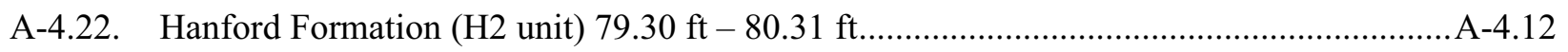

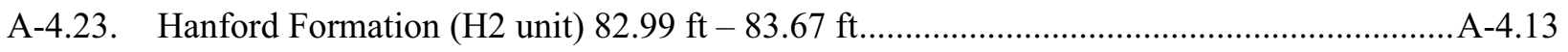

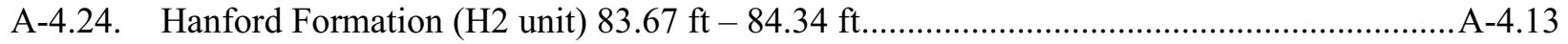

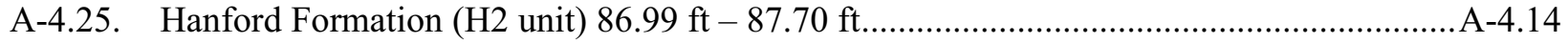

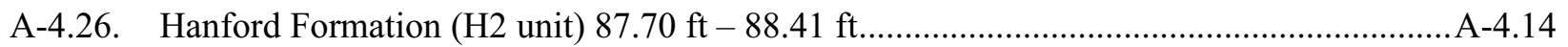

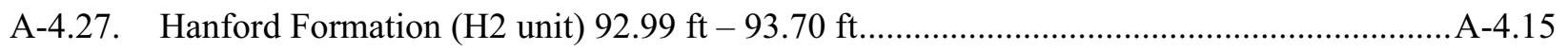




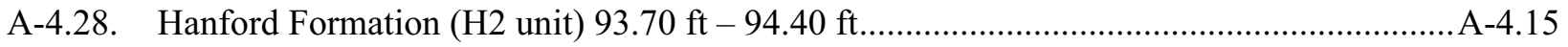

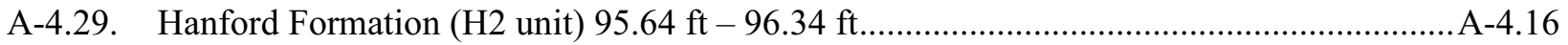

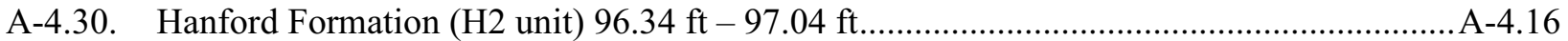

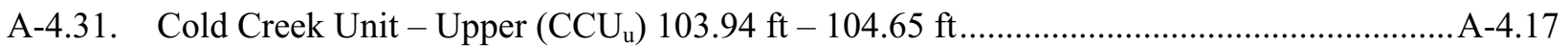

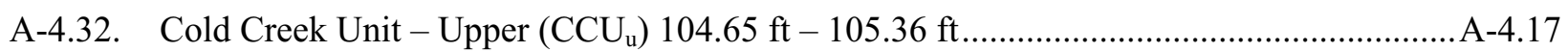

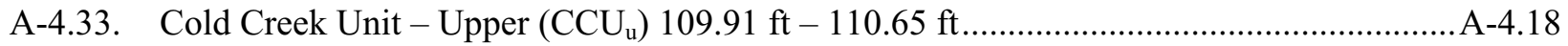

A-4.34. Cold Creek Unit - Lower $\left(\mathrm{CCU}_{1}\right) 110.65 \mathrm{ft}-111.38 \mathrm{ft}$................................................. A-4.18

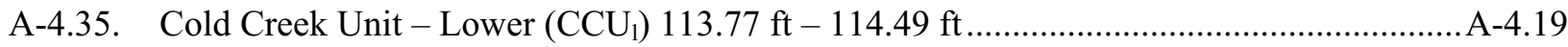

A-4.36. Cold Creek Unit - Lower $\left(\mathrm{CCU}_{1}\right) 114.49 \mathrm{ft}-115.20 \mathrm{ft}$................................................... A-4.19

A-4.37. Cold Creek Unit - Lower $\left(\mathrm{CCU}_{1}\right) 114.47 \mathrm{ft}-115.18 \mathrm{ft}$...................................................A-4.20

A-4.38. Cold Creek Unit - Lower $\left(\mathrm{CCU}_{1}\right) 115.18 \mathrm{ft}-115.89 \mathrm{ft}$.................................................. A-4.20 


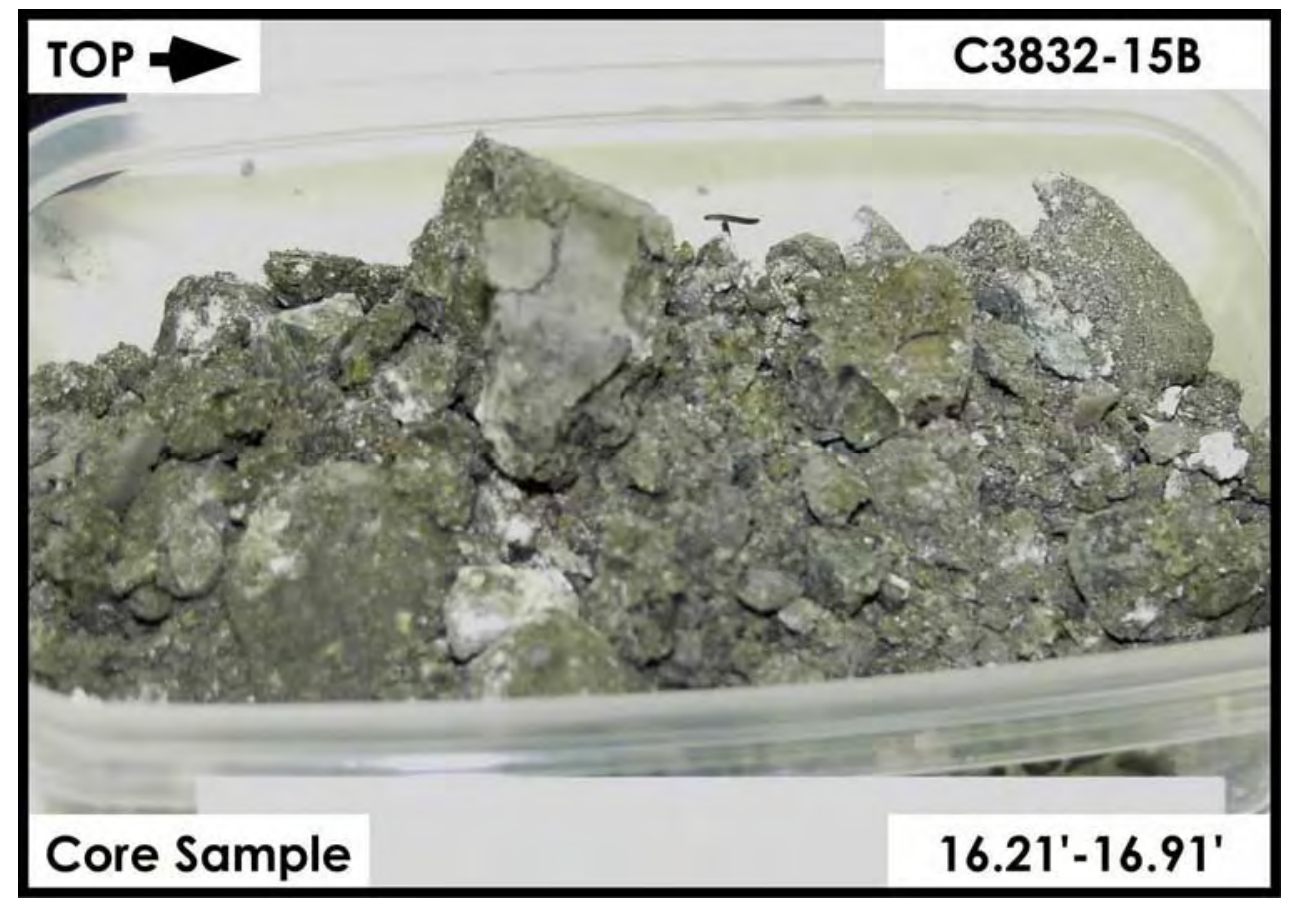

Figure A-4.1. Backfill $16.21 \mathrm{ft}-\mathbf{1 6 . 9 1} \mathrm{ft}$

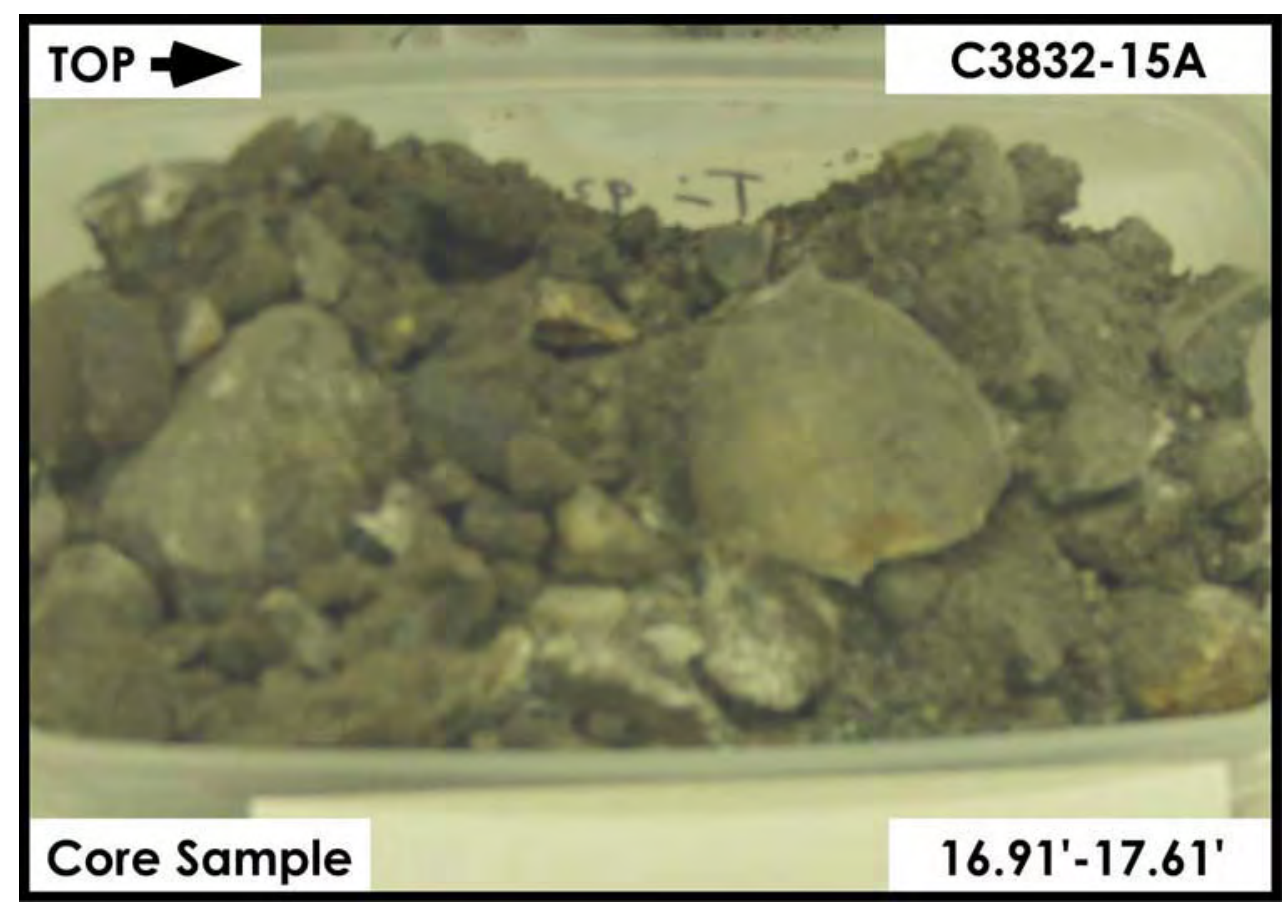

Figure A-4.2. Backfill $16.91 \mathrm{ft}-\mathbf{1 7 . 6 1} \mathrm{ft}$ 


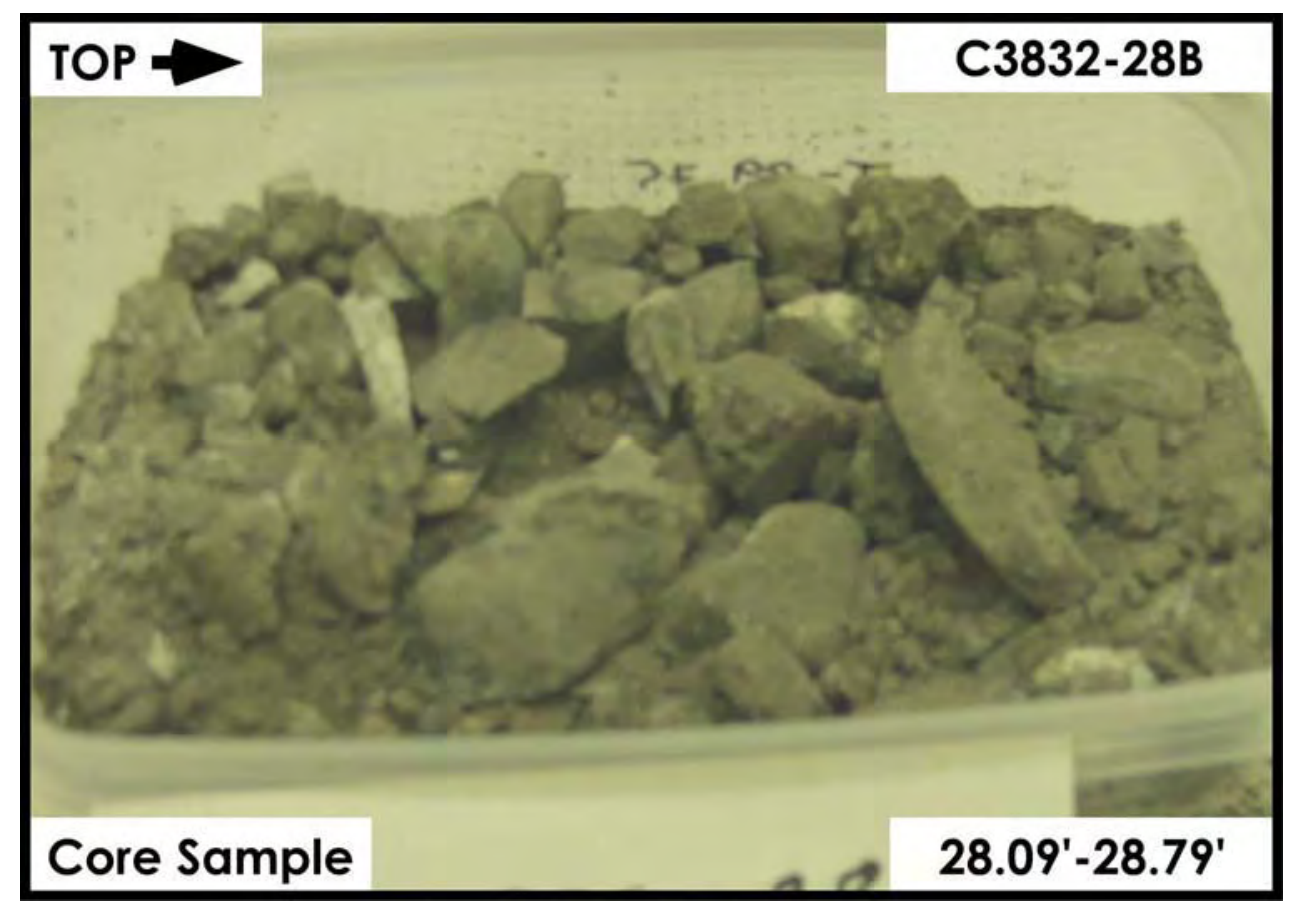

Figure A-4.3. Backfill $28.09 \mathrm{ft}-\mathbf{2 8 . 7 9} \mathrm{ft}$

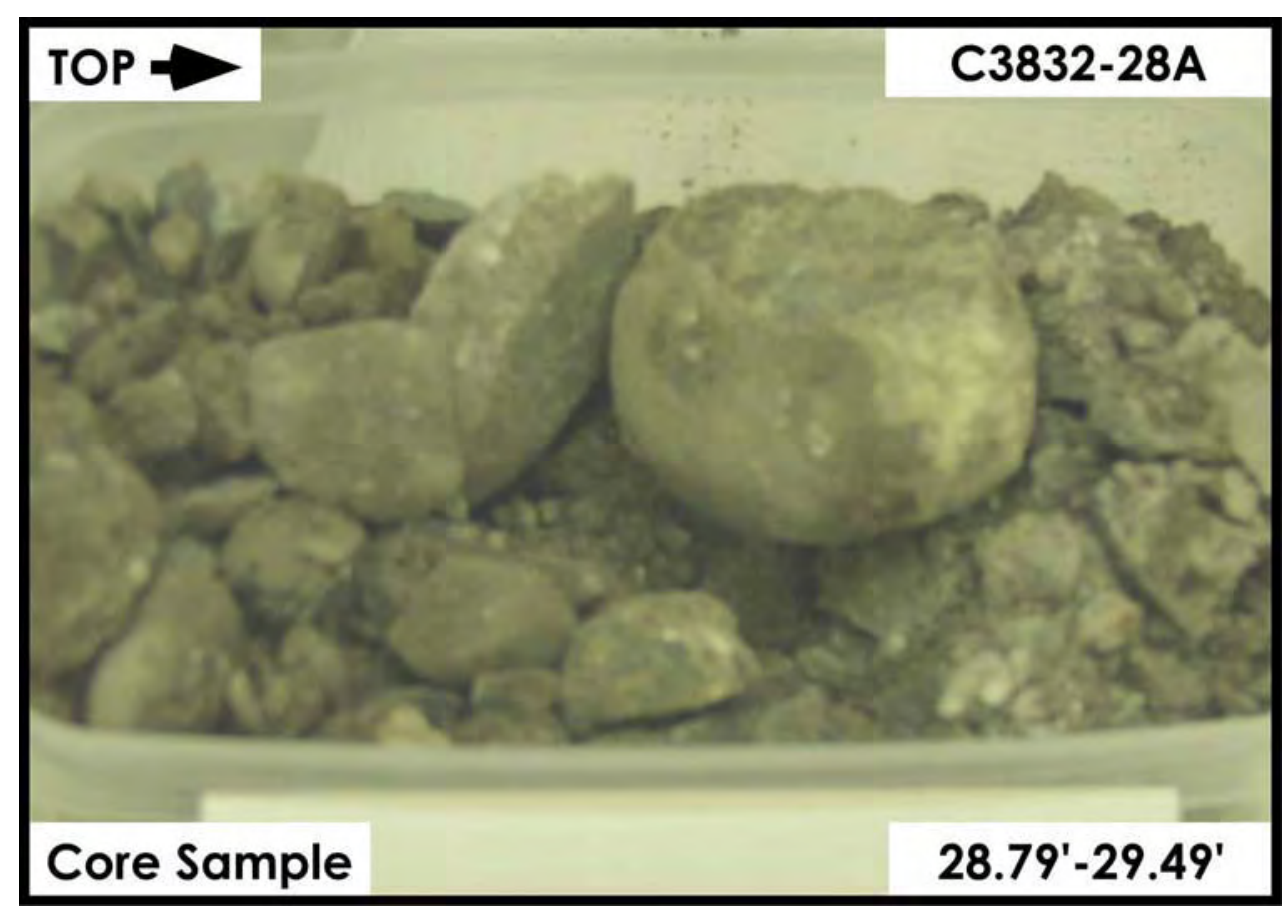

Figure A-4.4. Backfill $28.79 \mathrm{ft}-29.49 \mathrm{ft}$ 


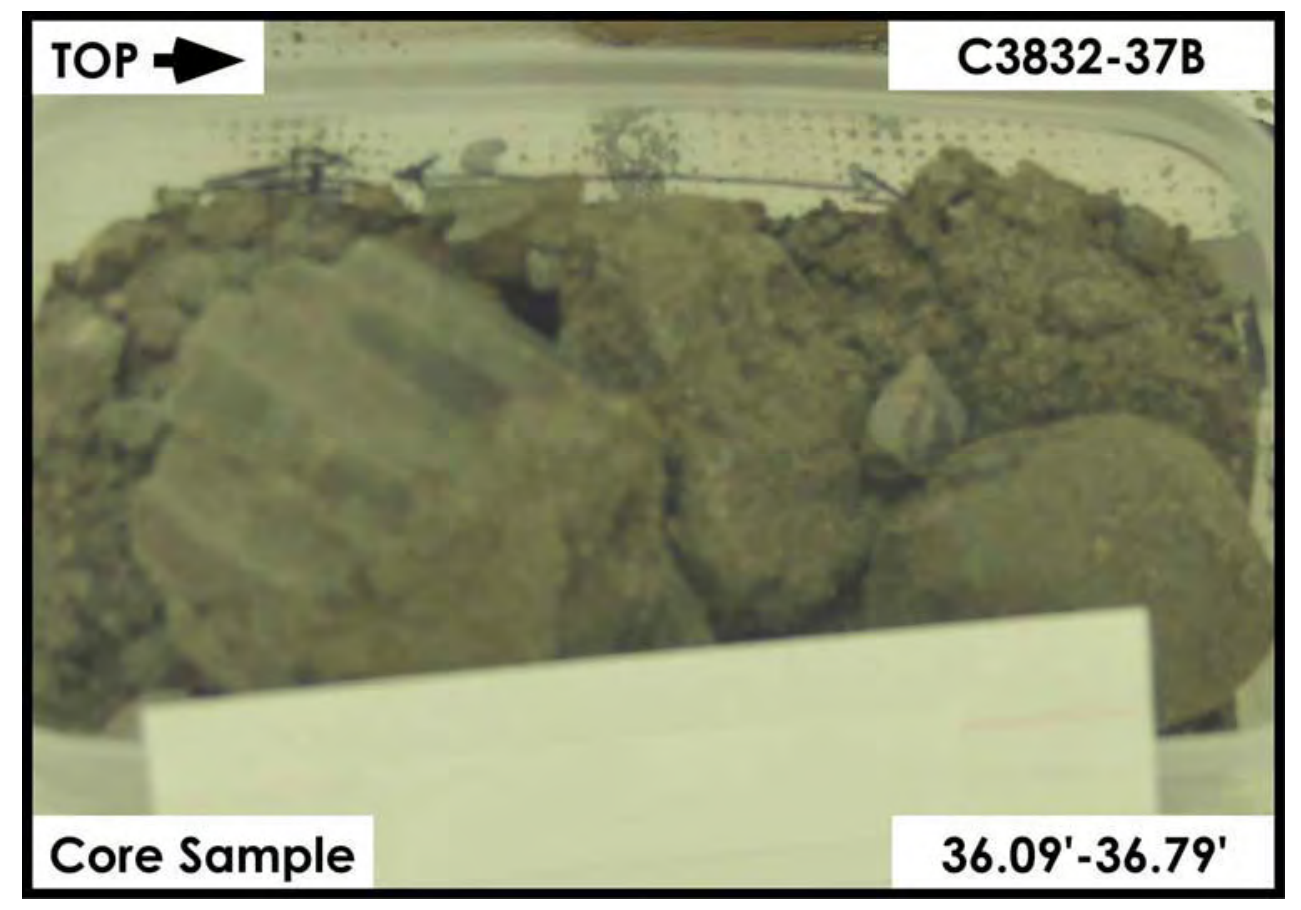

Figure A-4.5. Backfill $36.09 \mathrm{ft}-36.79 \mathrm{ft}$

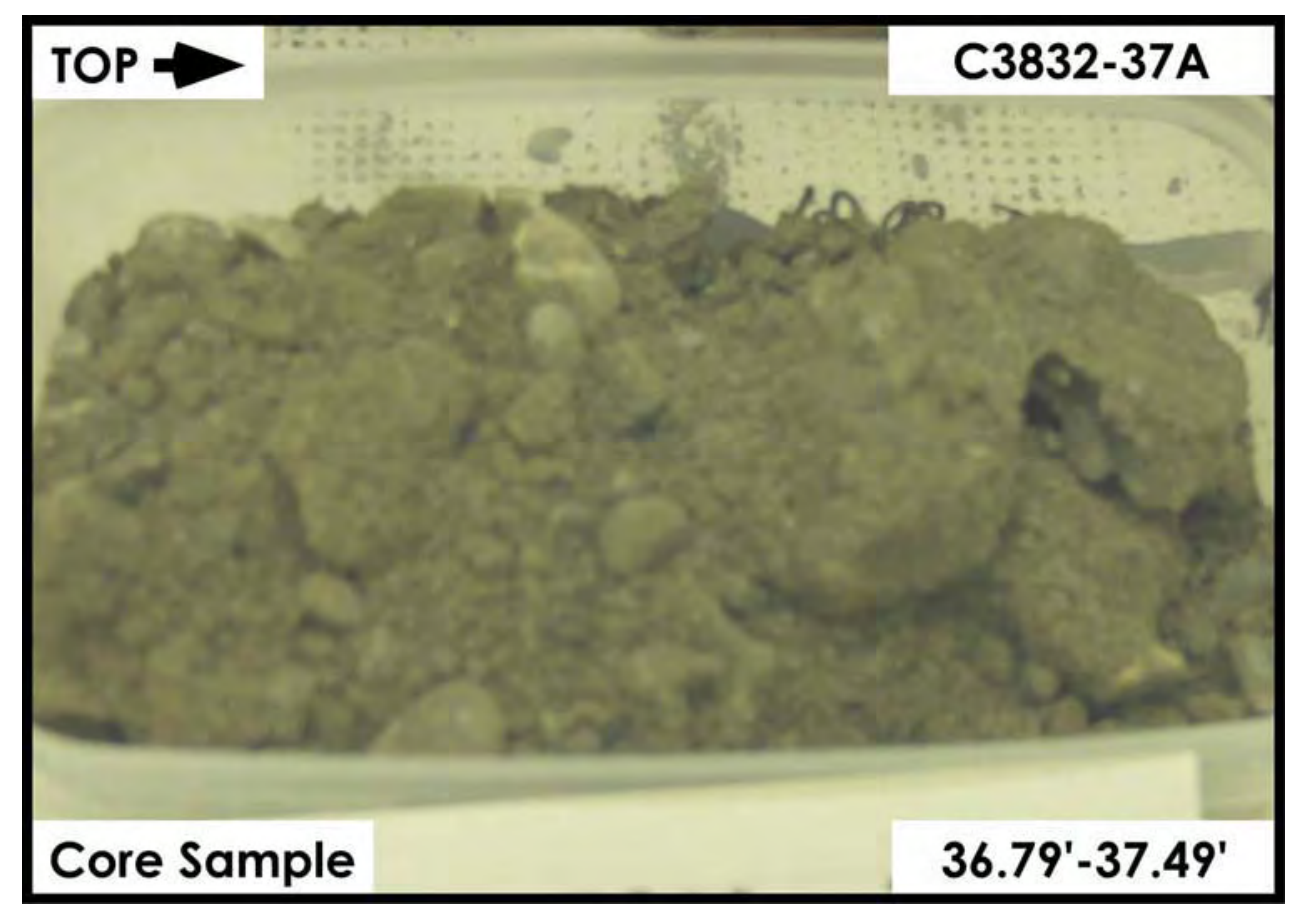

Figure A-4.6. Backfill $36.79 \mathrm{ft}-37.49 \mathrm{ft}$ 


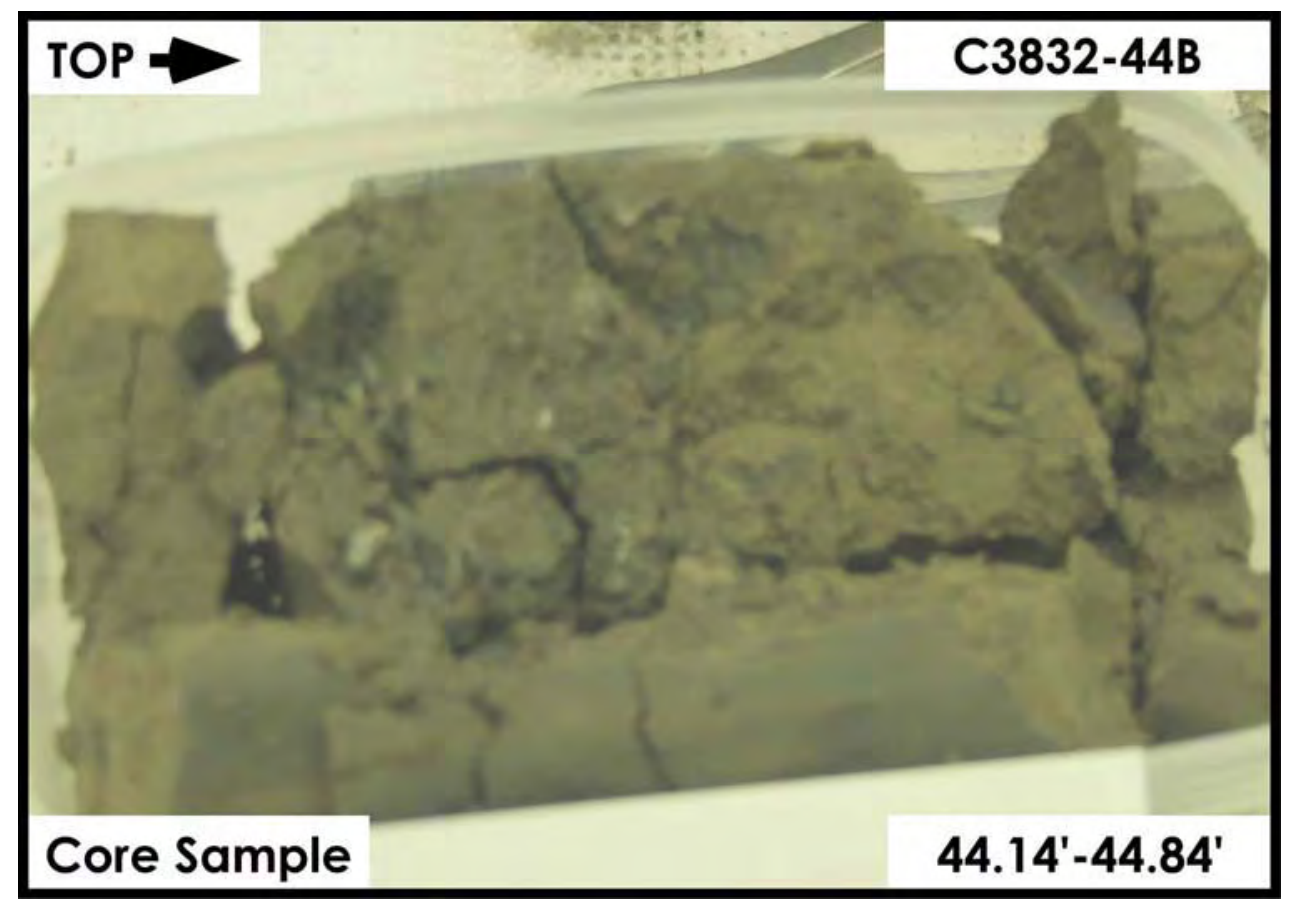

Figure A-4.7. Backfill $44.14 \mathrm{ft}-\mathbf{4 4 . 8 4} \mathrm{ft}$

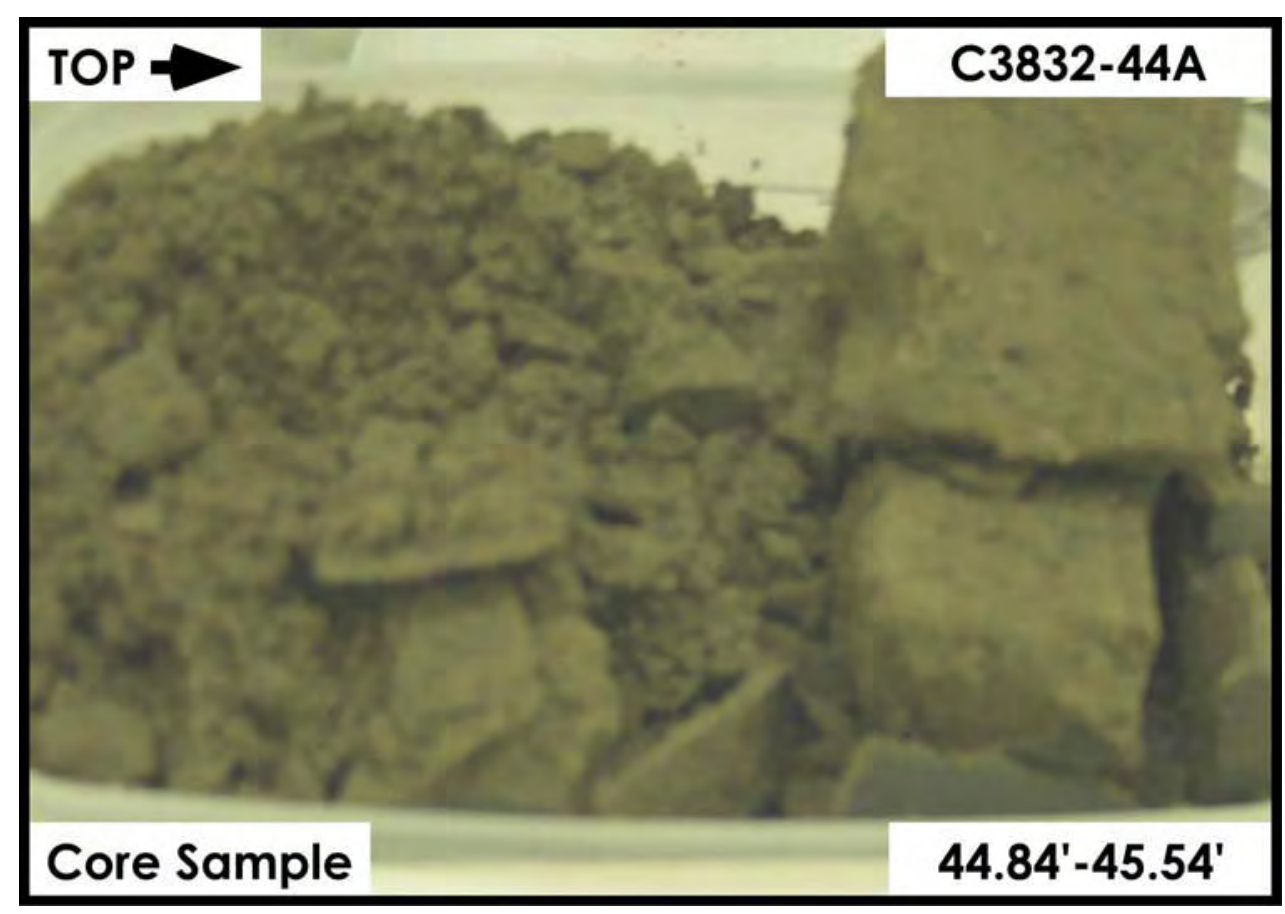

Figure A-4.8. Backfill $44.84 \mathrm{ft}-\mathbf{4 5 . 5 4} \mathrm{ft}$ 


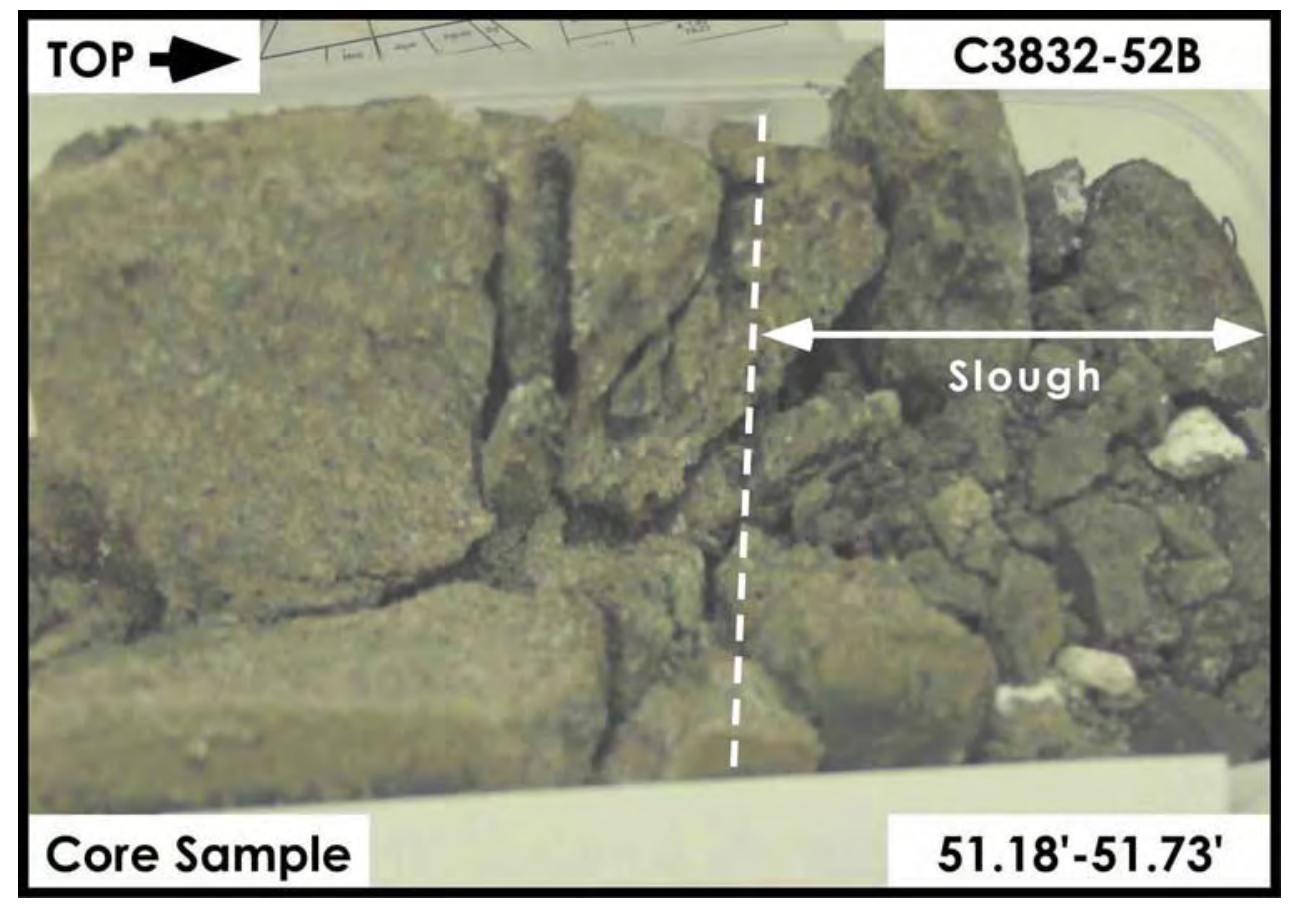

Figure A-4.9. Hanford Formation (H2 unit) $51.18 \mathrm{ft}-\mathbf{5 1 . 7 3} \mathrm{ft}$

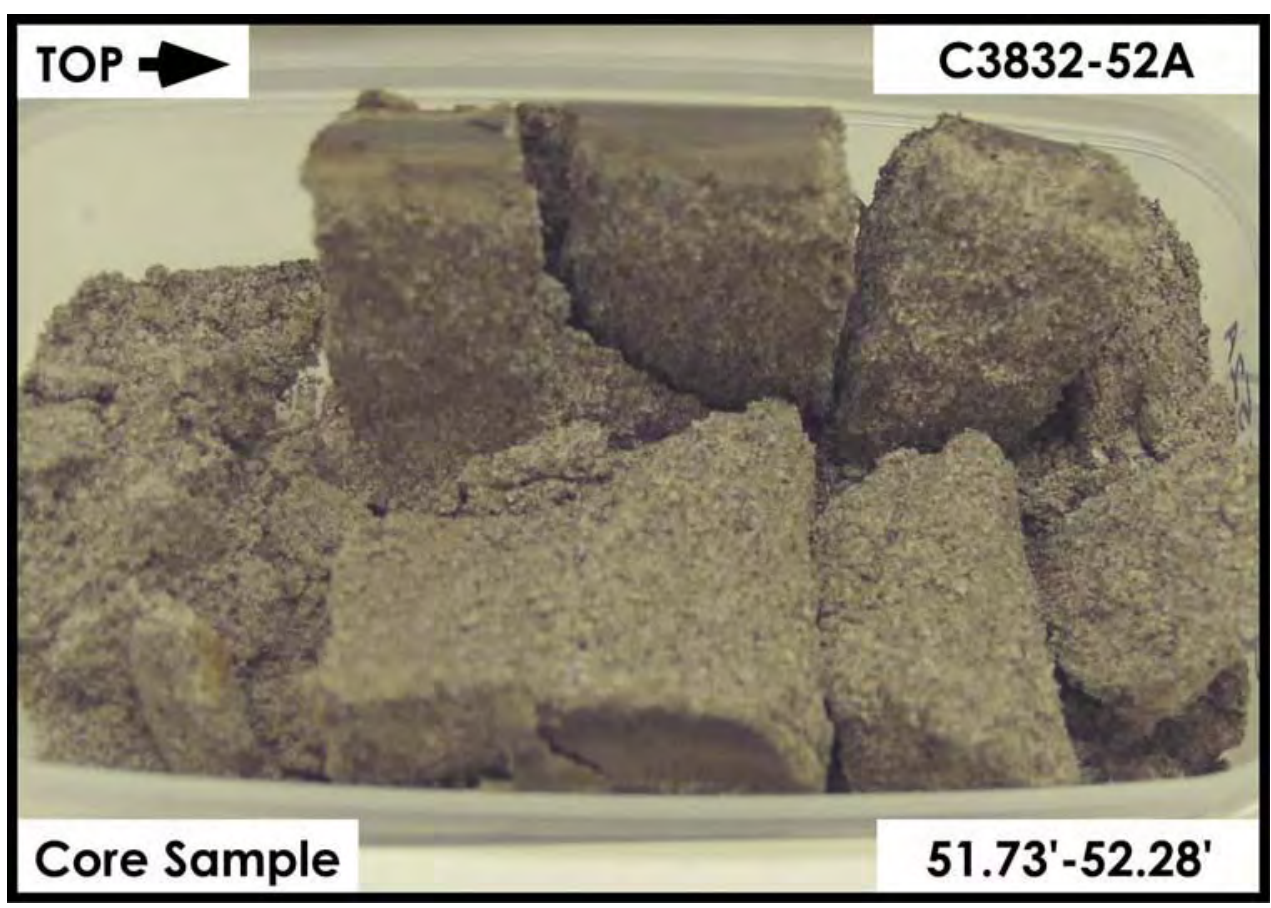

Figure A-4.10. Hanford Formation (H2 unit) $51.73 \mathrm{ft}-52.28 \mathrm{ft}$ 


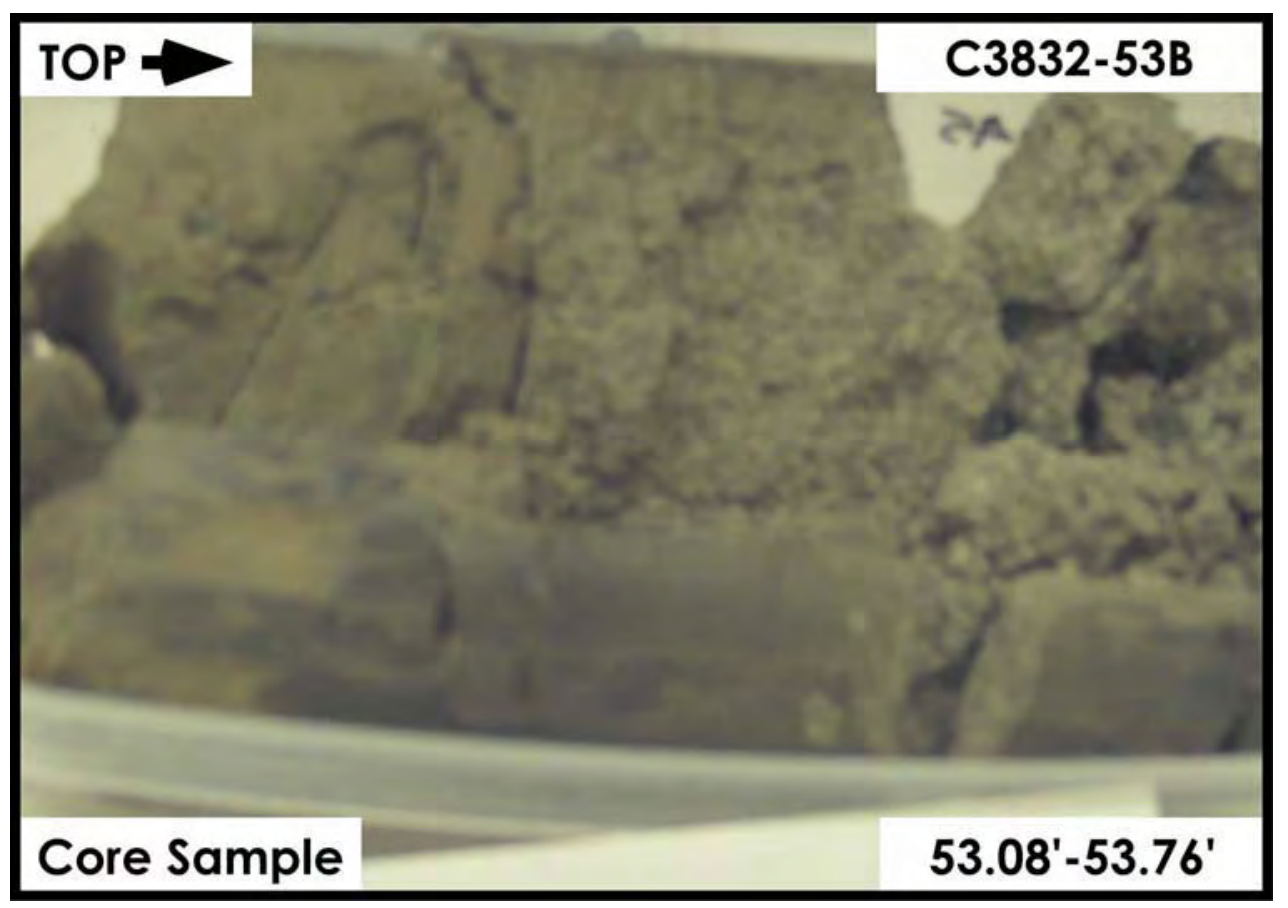

Figure A-4.11. Hanford Formation (H2 unit) $53.08 \mathrm{ft}-\mathbf{5 3 . 7 6} \mathrm{ft}$

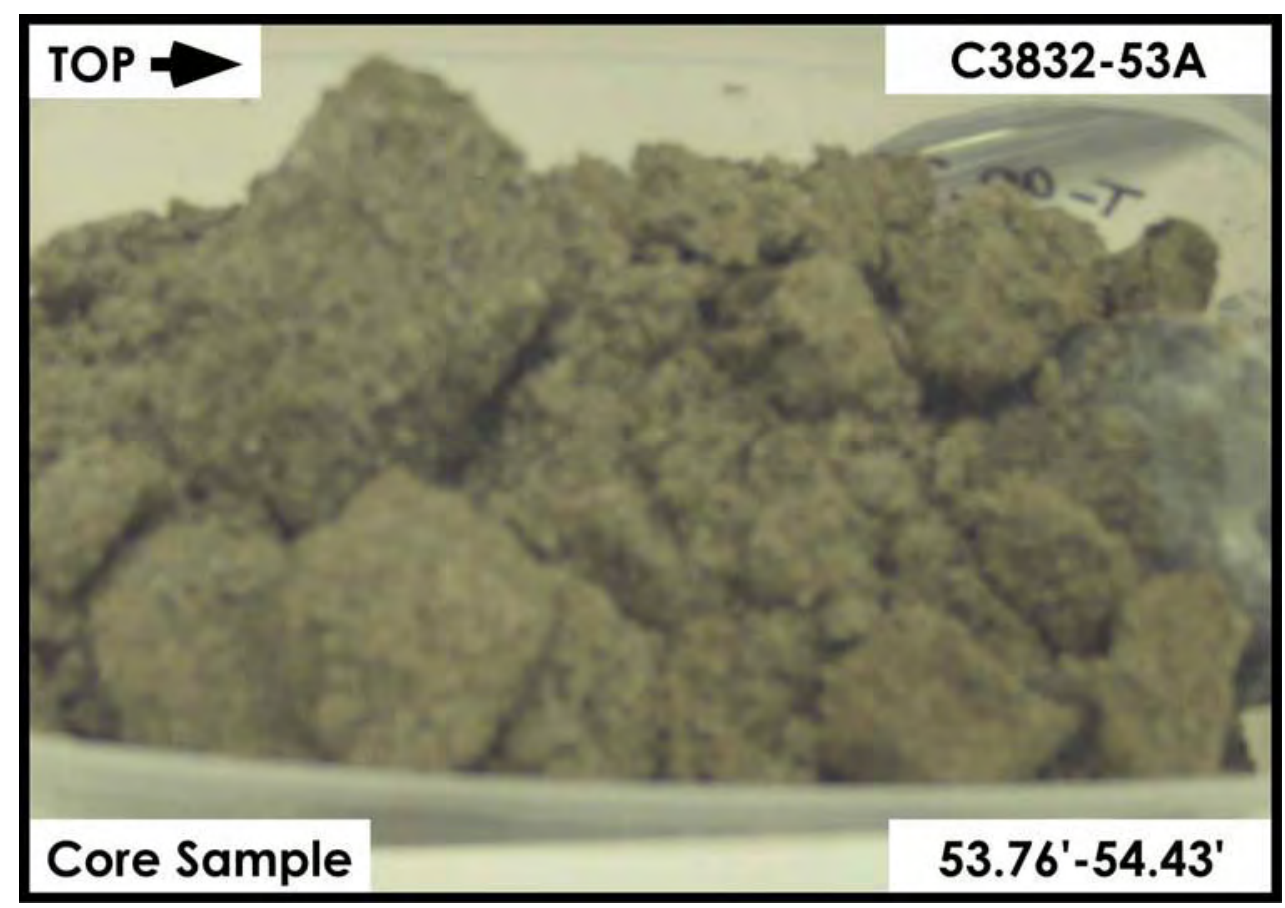

Figure A-4.12. Hanford Formation (H2 unit) $53.76 \mathrm{ft}-54.43 \mathrm{ft}$ 


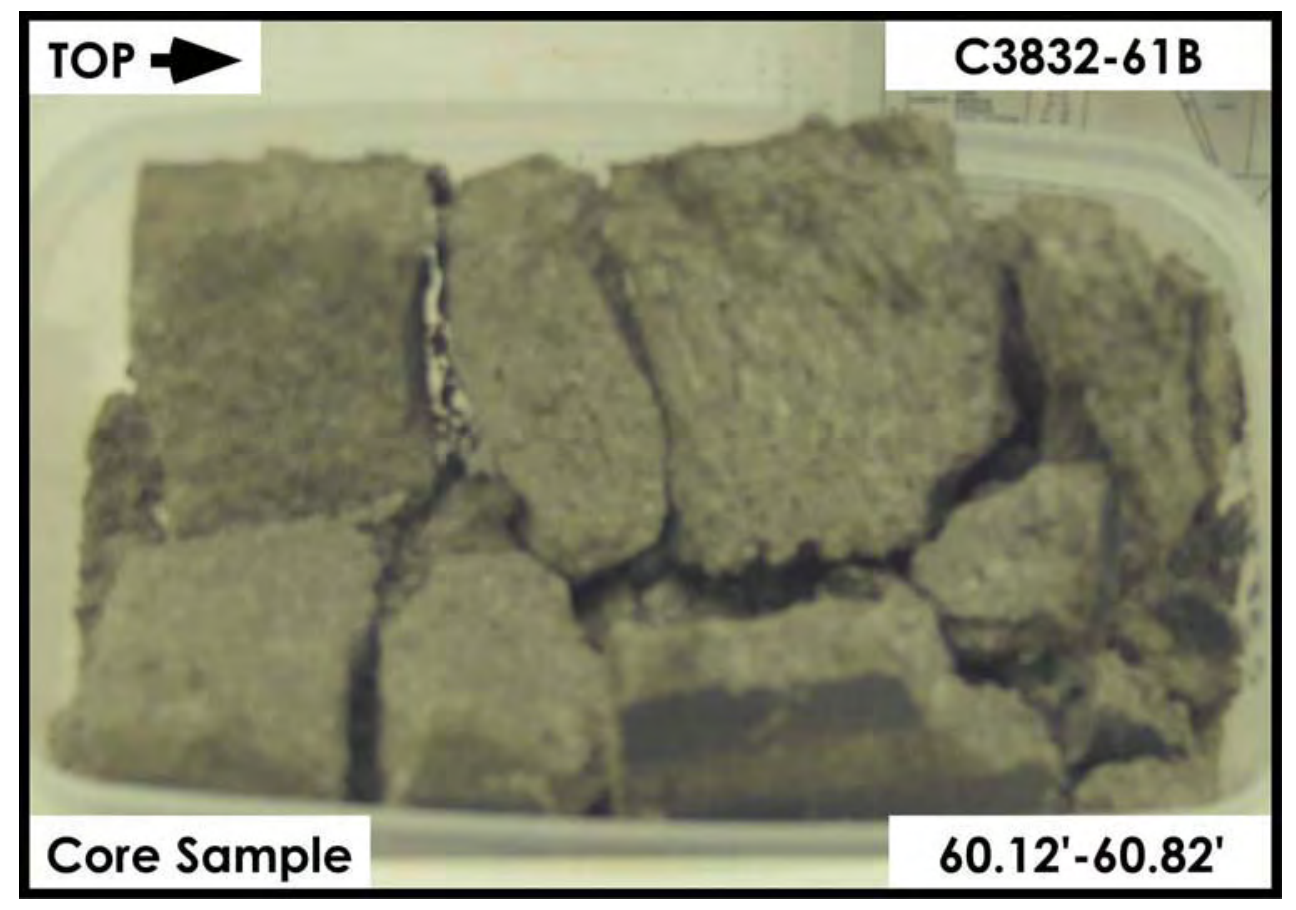

Figure A-4.13. Hanford Formation (H2 unit) $60.12 \mathrm{ft}-60.82 \mathrm{ft}$

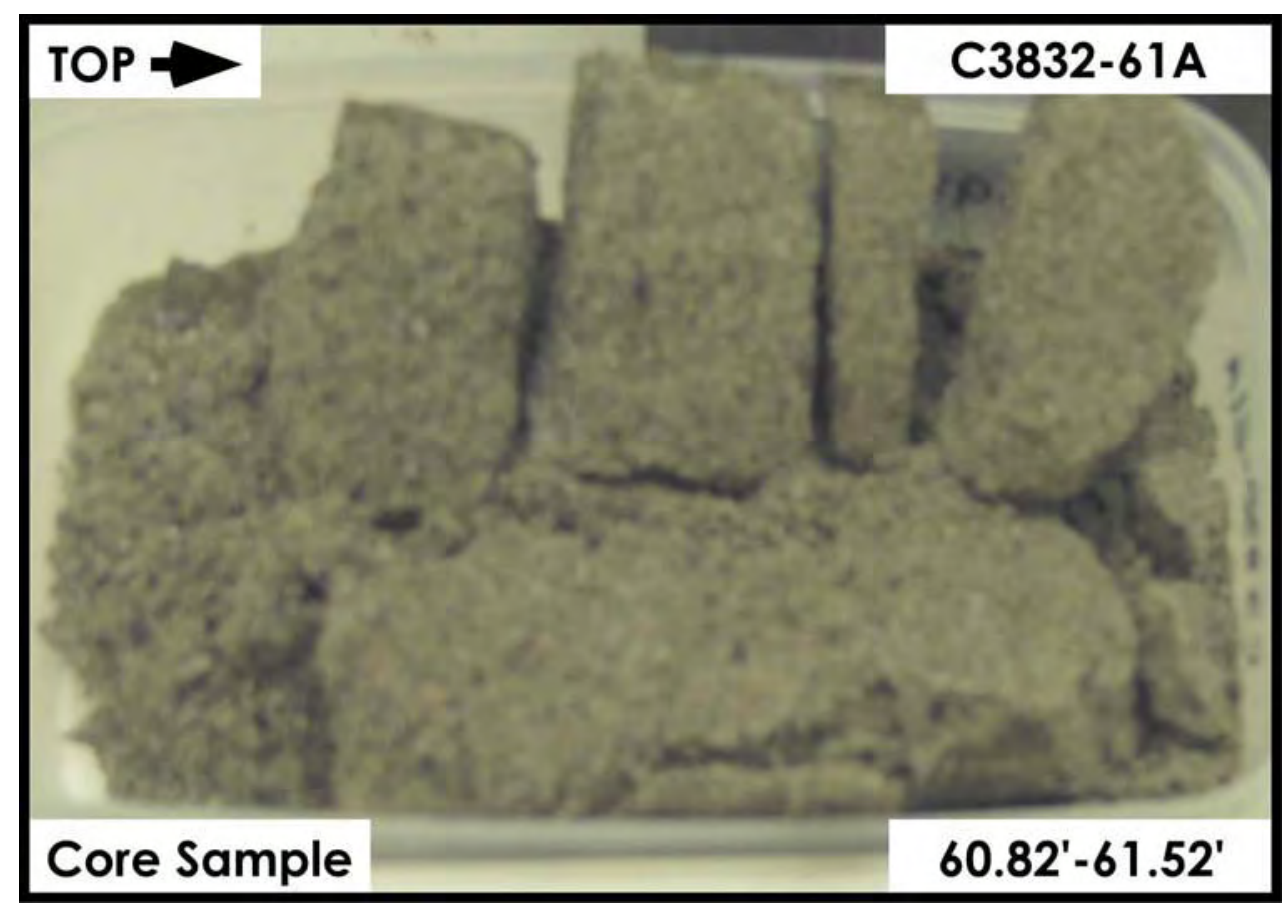

Figure A-4.14. Hanford Formation (H2 unit) $60.82 \mathrm{ft}-61.52 \mathrm{ft}$ 


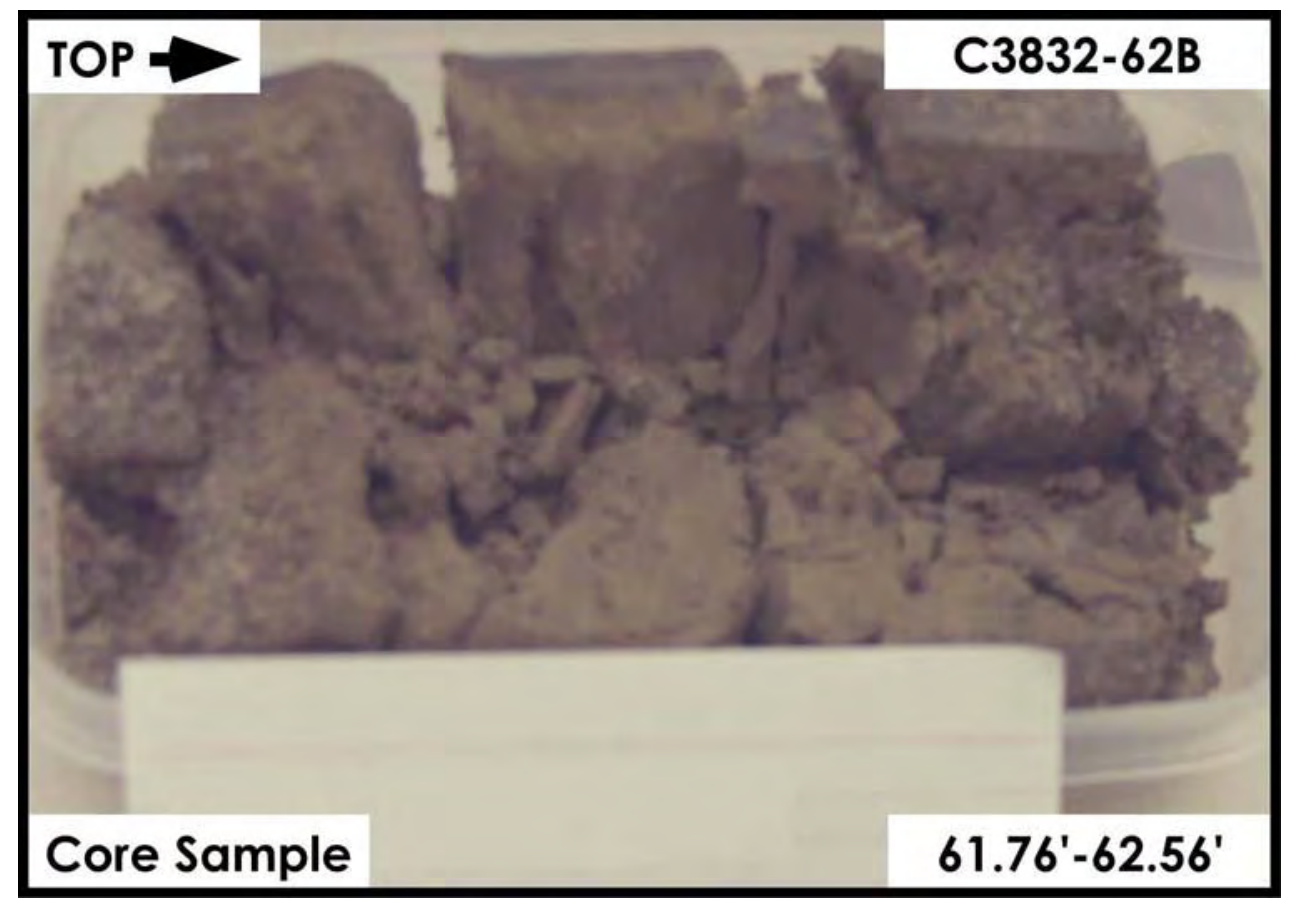

Figure A-4.15. Hanford Formation (H2 unit) $61.76 \mathrm{ft}-62.56 \mathrm{ft}$

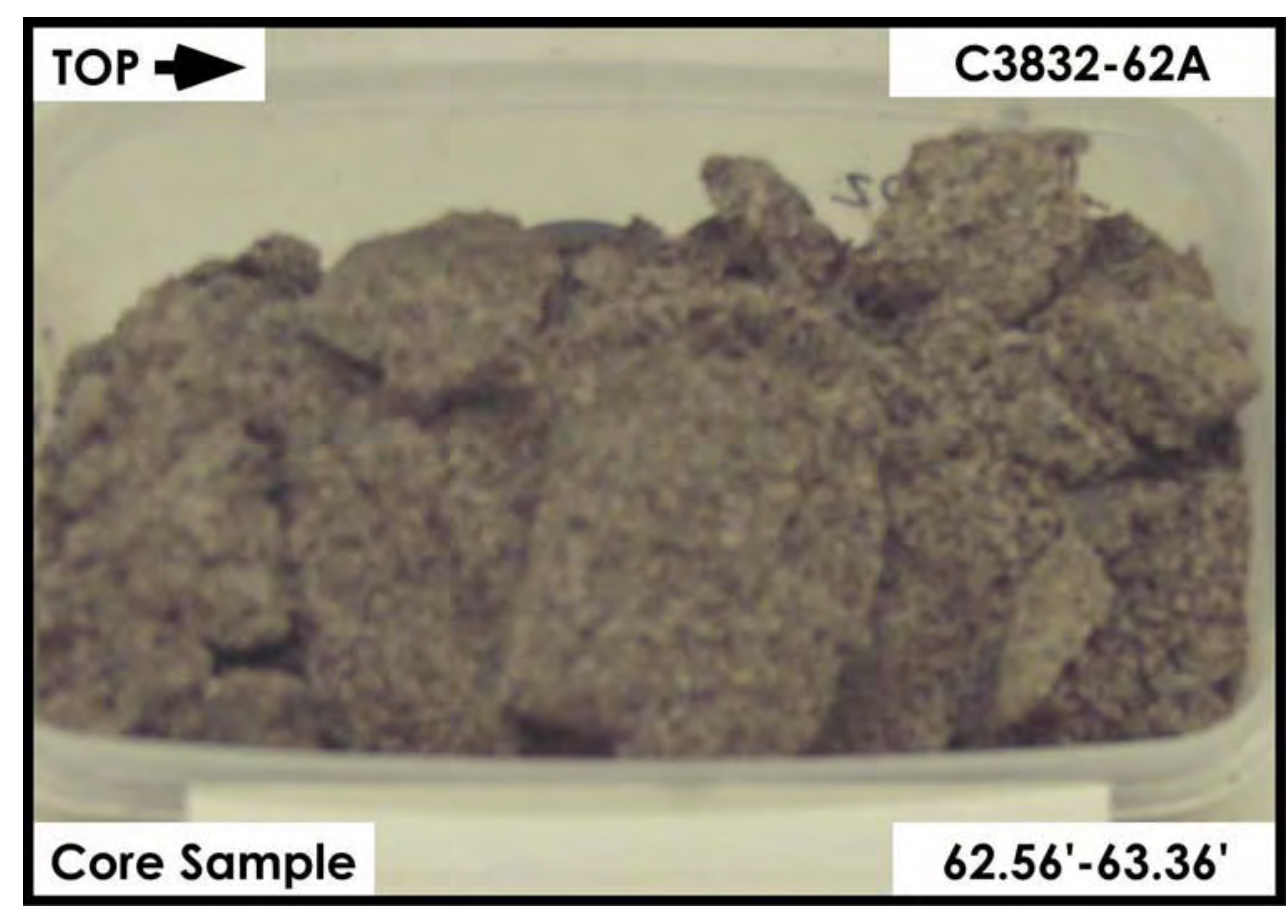

Figure A-4.16. Hanford Formation (H2 unit) $62.56 \mathrm{ft}-63.36 \mathrm{ft}$ 


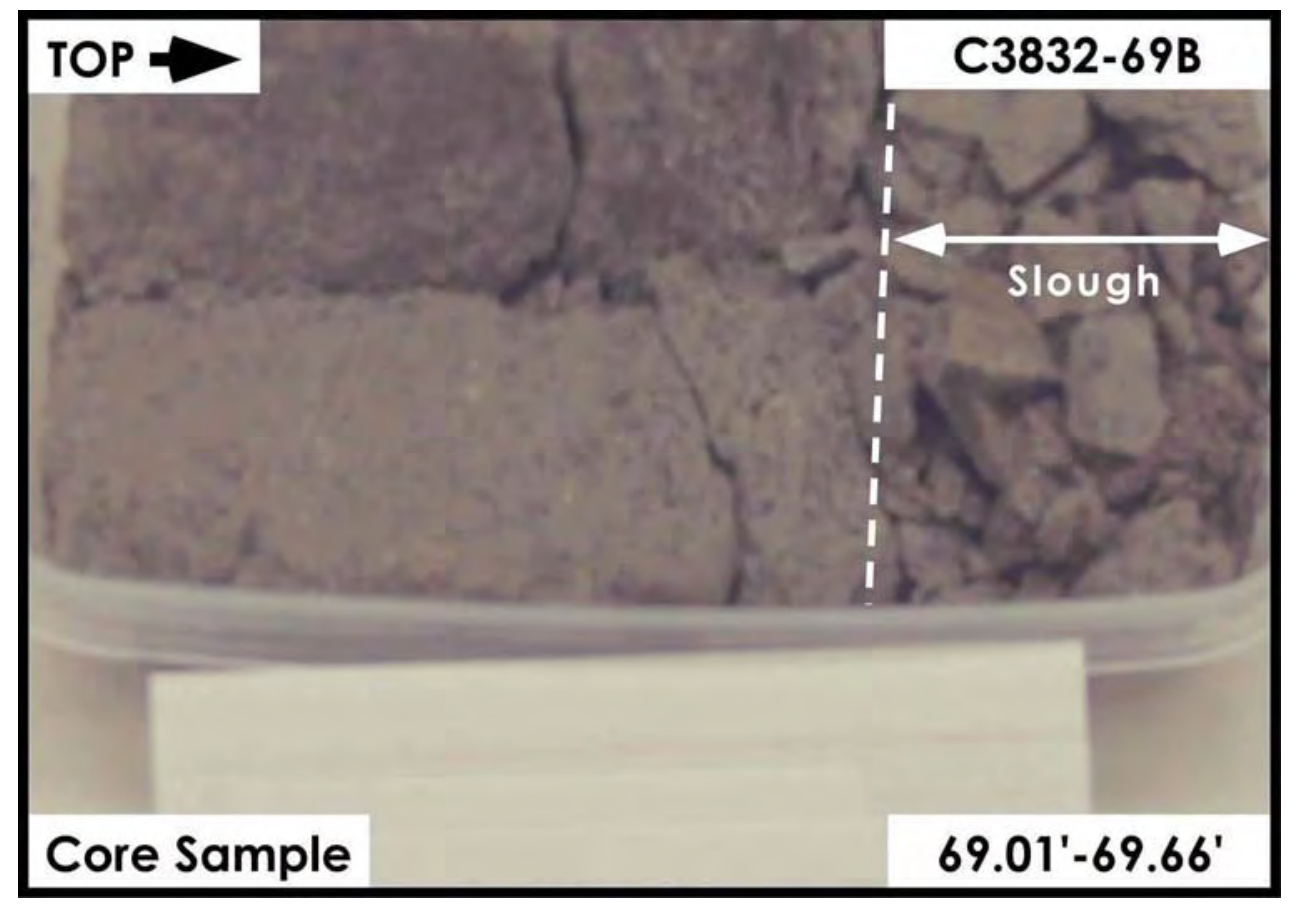

Figure A-4.17. Hanford Formation (H2 unit) $69.01 \mathrm{ft}-69.66 \mathrm{ft}$

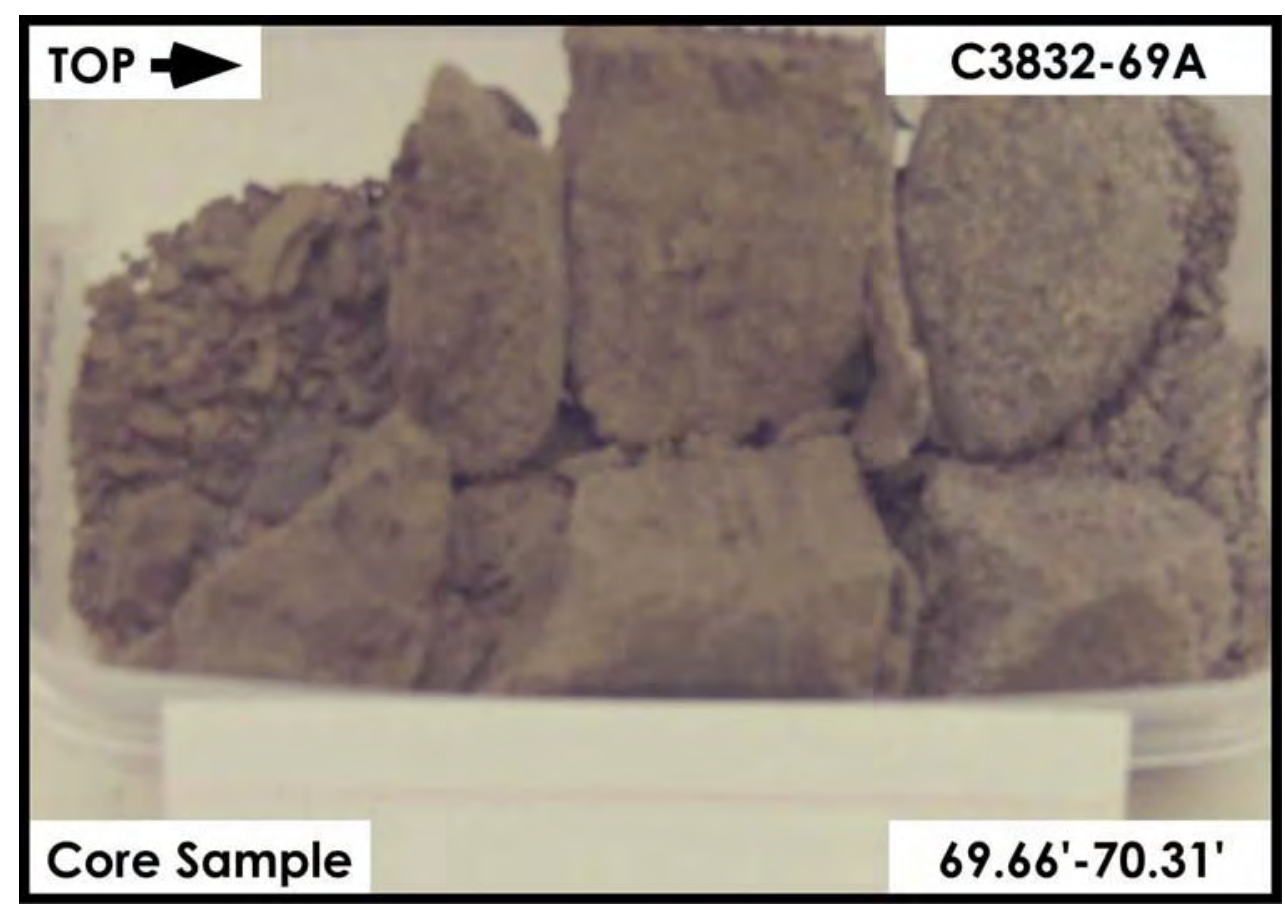

Figure A-4.18. Hanford Formation (H2 unit) $69.66 \mathrm{ft}-70.31 \mathrm{ft}$ 


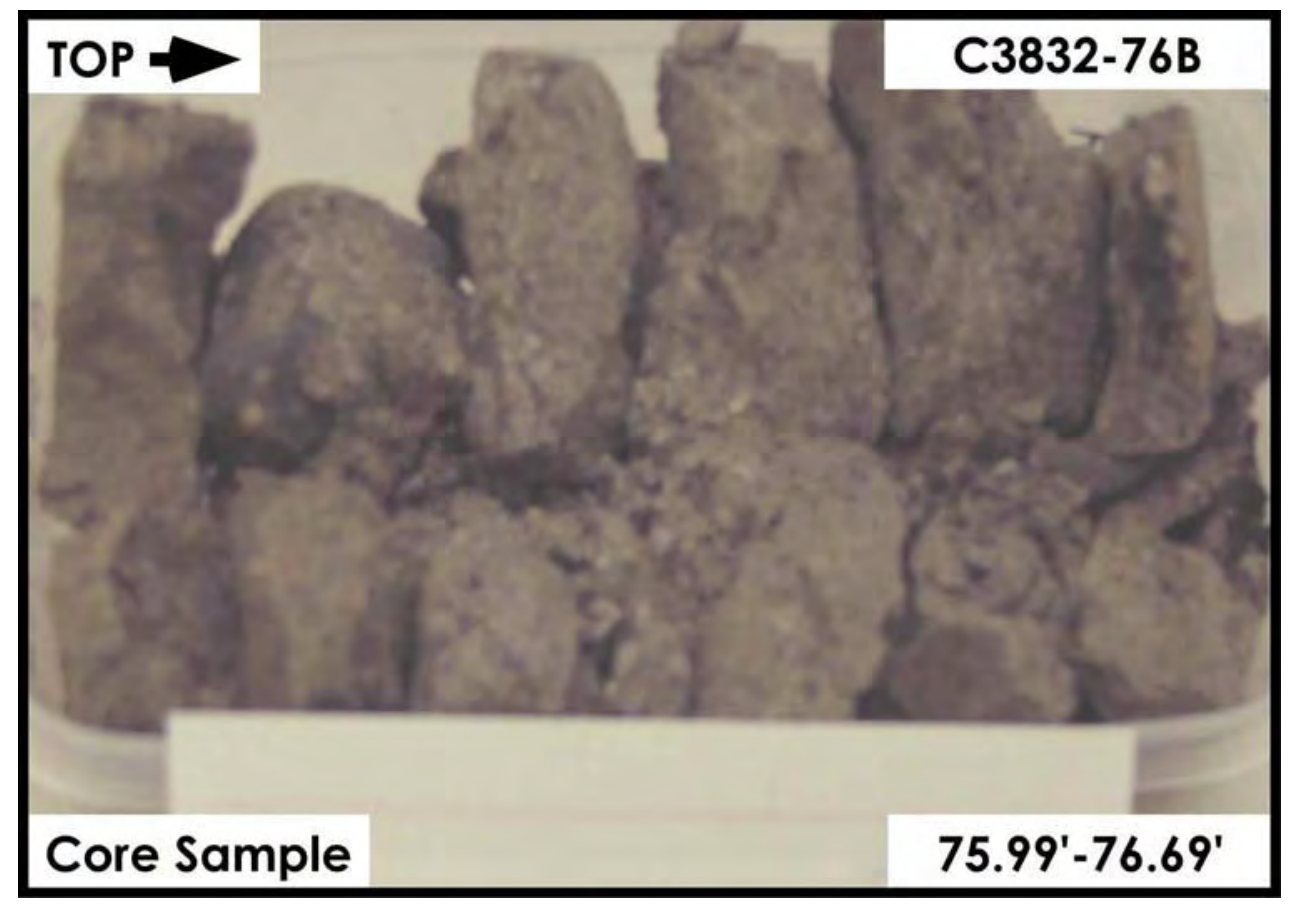

Figure A-4.19. Hanford Formation (H2 unit) $75.99 \mathrm{ft}-76.69 \mathrm{ft}$

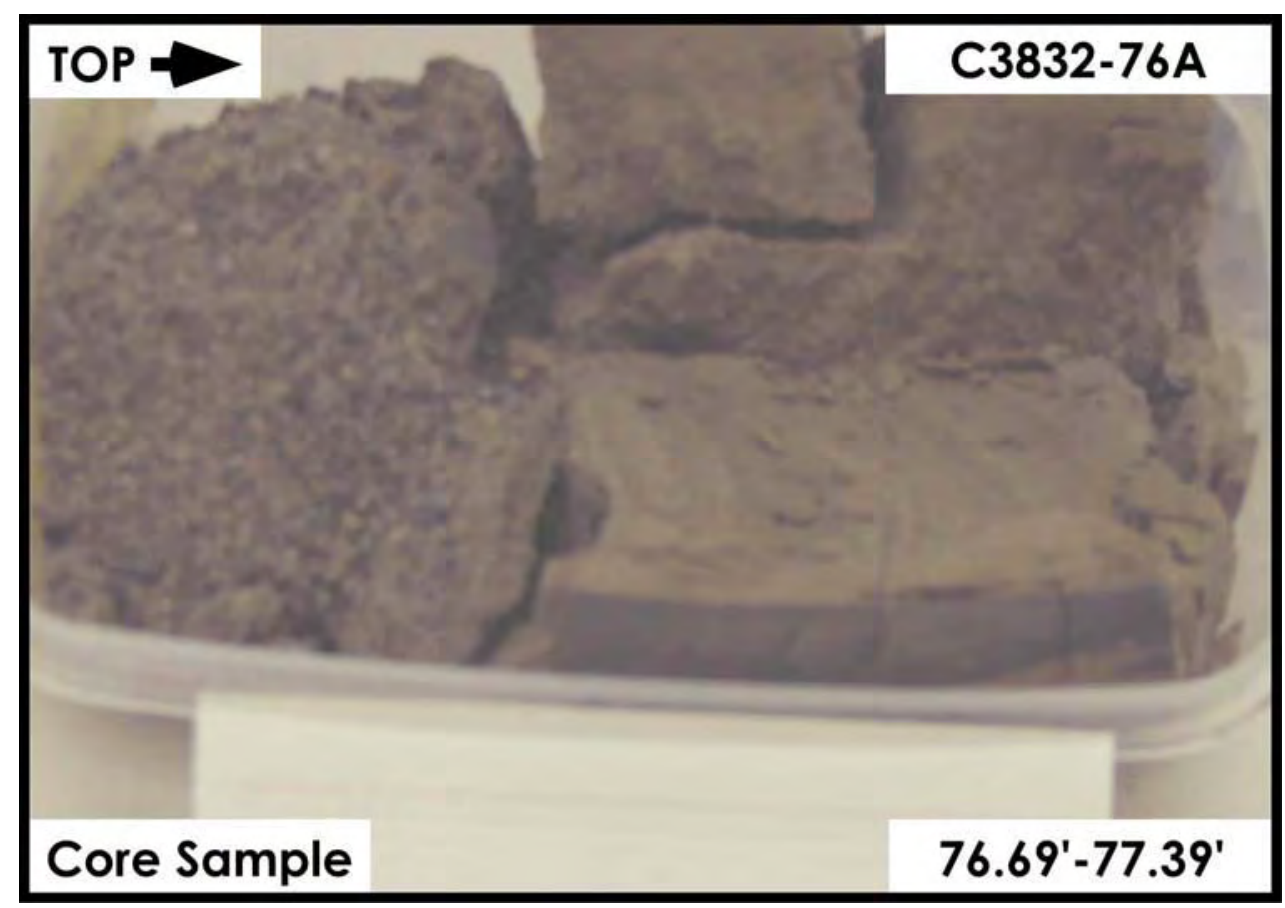

Figure A-4.20. Hanford Formation (H2 unit) $76.69 \mathrm{ft}-77.39 \mathrm{ft}$ 


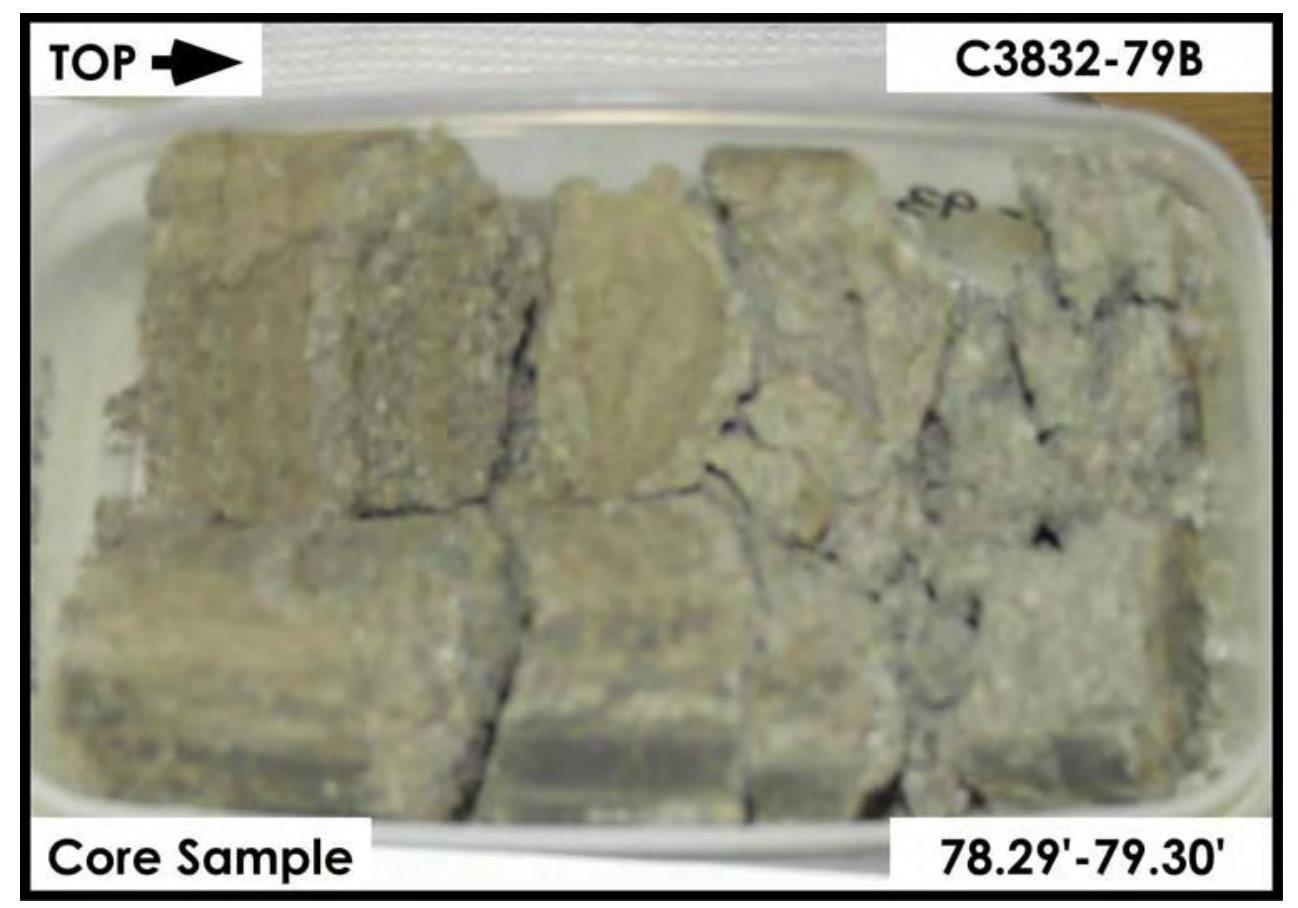

Figure A-4.21. Hanford Formation (H2 unit) $78.29 \mathrm{ft}-79.30 \mathrm{ft}$

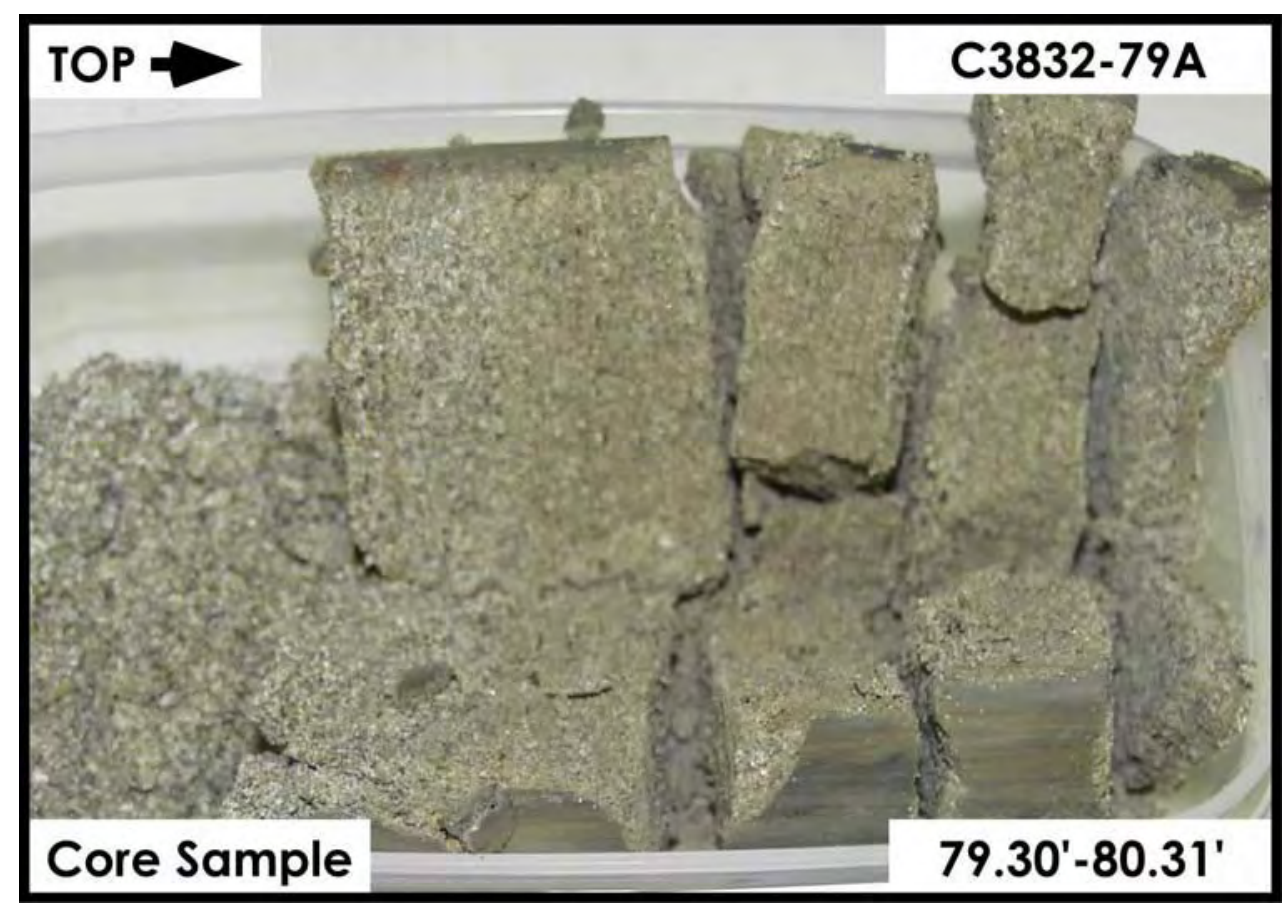

Figure A-4.22. Hanford Formation (H2 unit) $79.30 \mathrm{ft}-\mathbf{8 0 . 3 1} \mathrm{ft}$ 


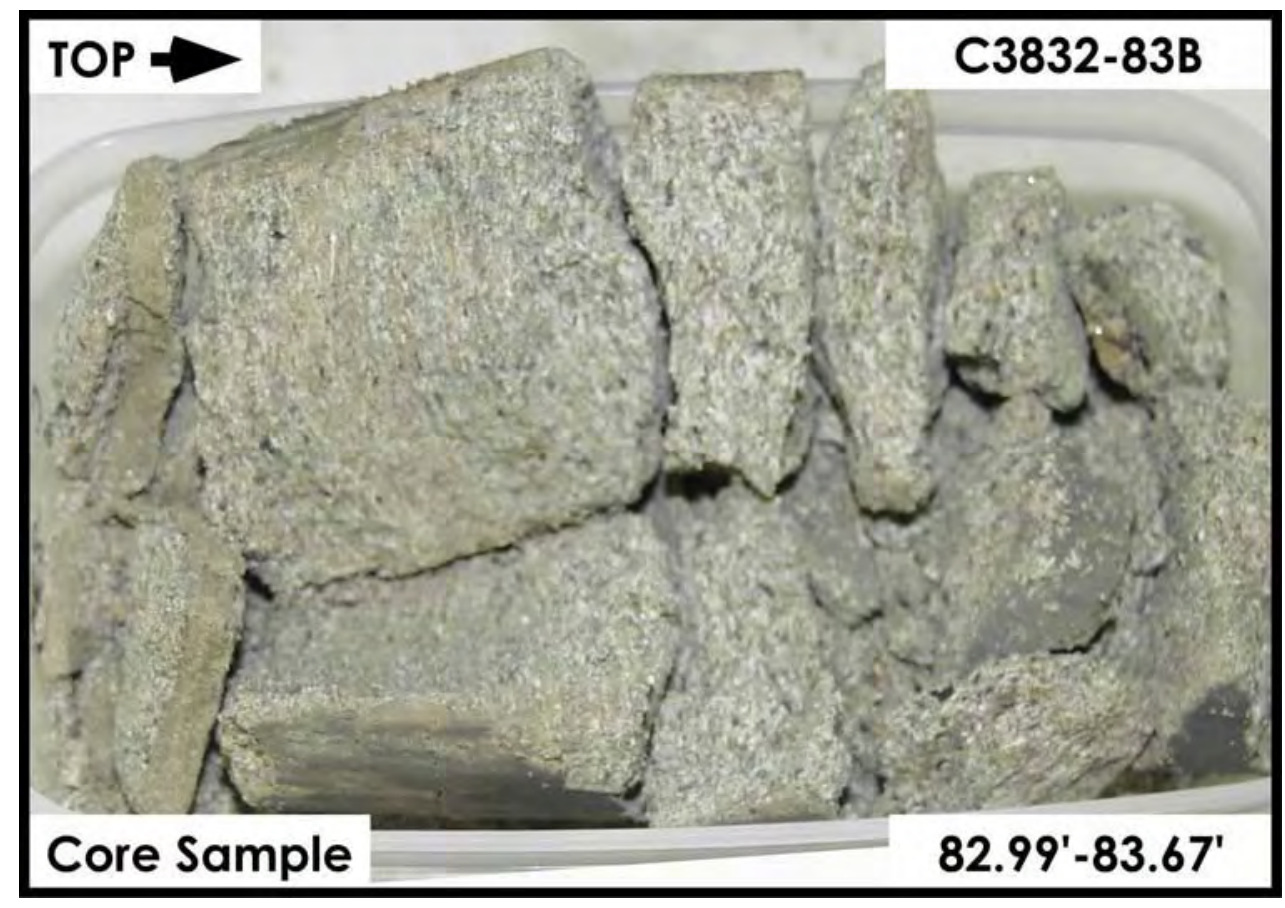

Figure A-4.23. Hanford Formation (H2 unit) $82.99 \mathrm{ft}-83.67 \mathrm{ft}$

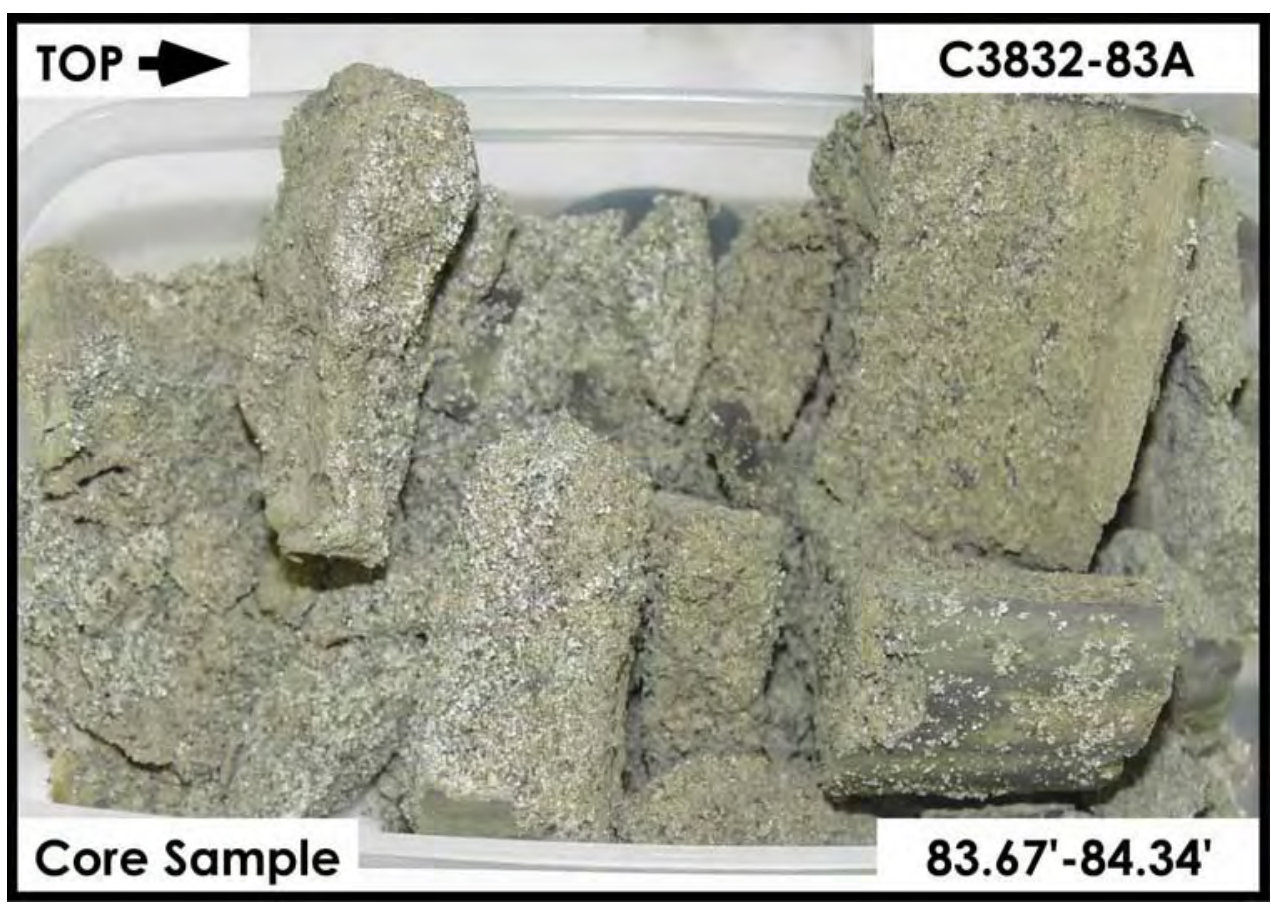

Figure A-4.24. Hanford Formation (H2 unit) $83.67 \mathrm{ft}-84.34 \mathrm{ft}$ 


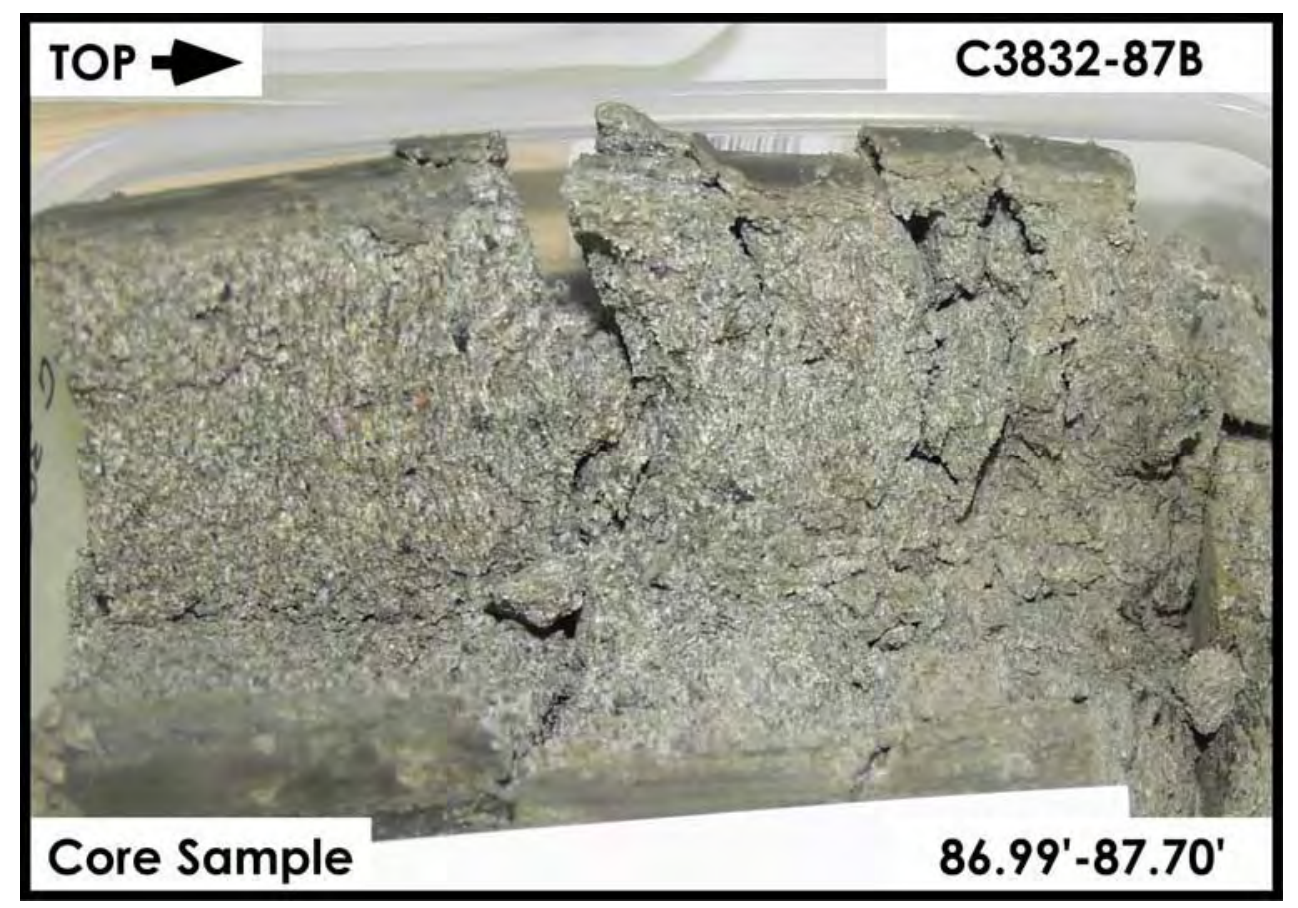

Figure A-4.25. Hanford Formation (H2 unit) $86.99 \mathrm{ft}-87.70 \mathrm{ft}$

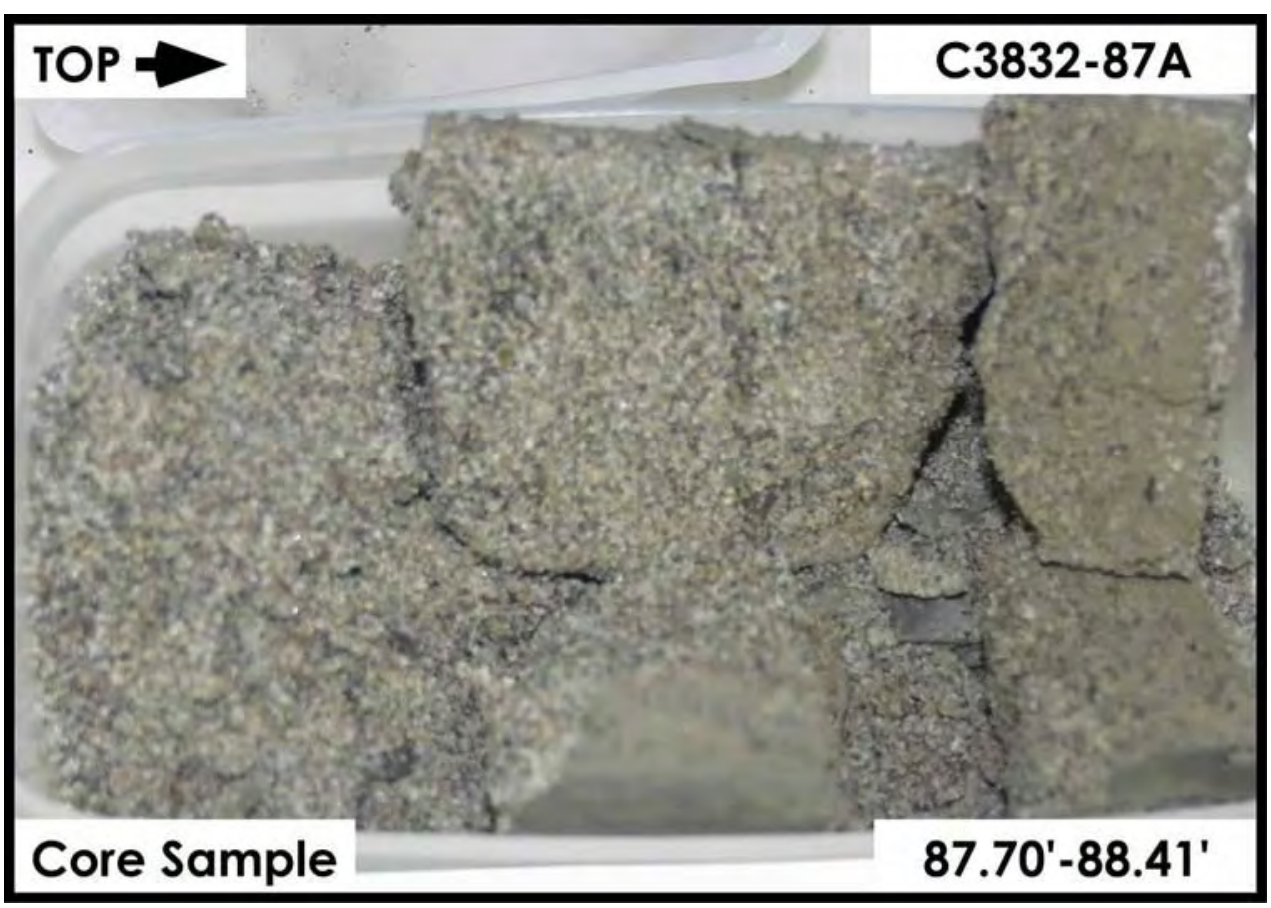

Figure A-4.26. Hanford Formation (H2 unit) $87.70 \mathrm{ft}-\mathbf{8 8 . 4 1} \mathrm{ft}$ 


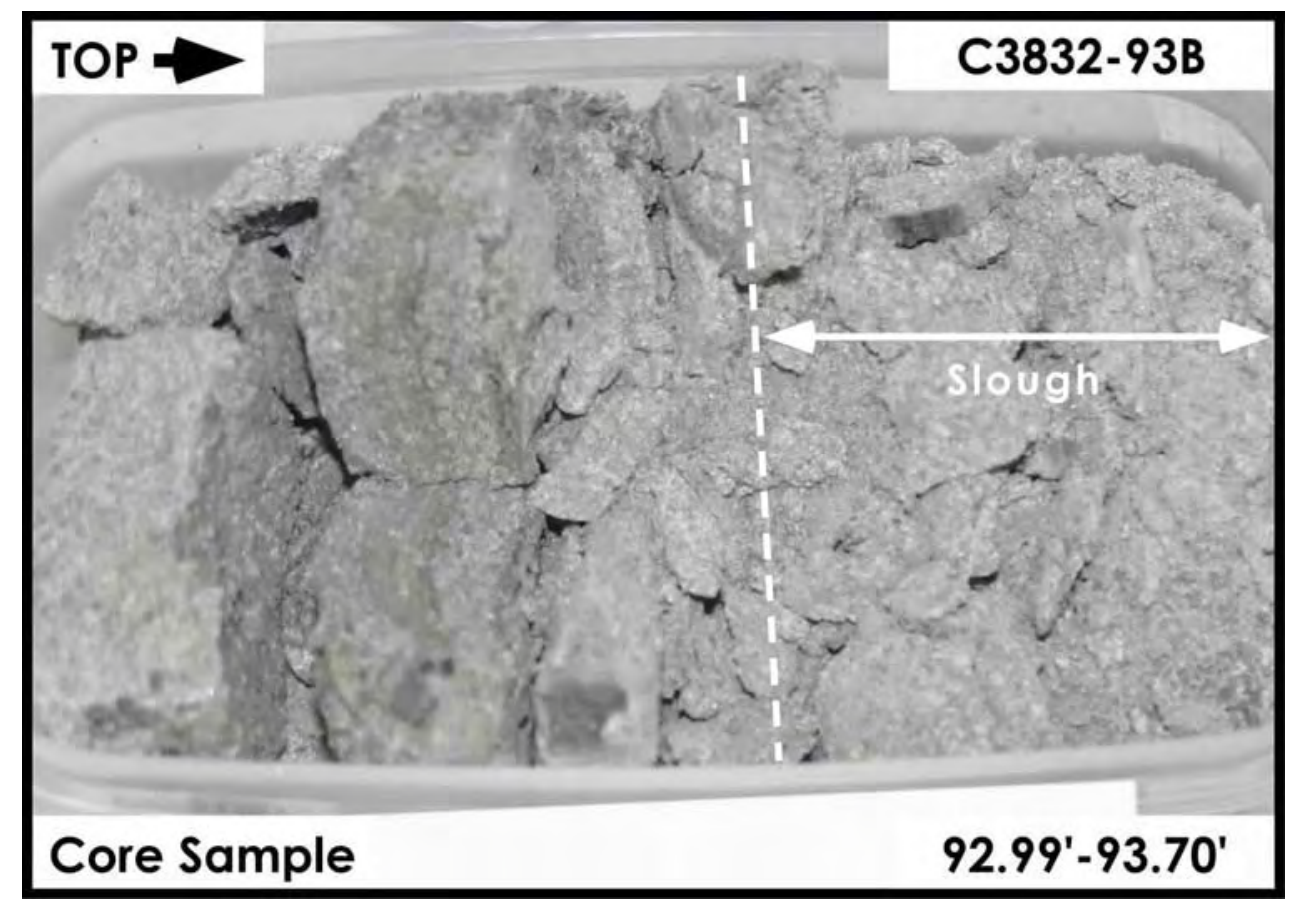

Figure A-4.27. Hanford Formation (H2 unit) $92.99 \mathrm{ft}-93.70 \mathrm{ft}$

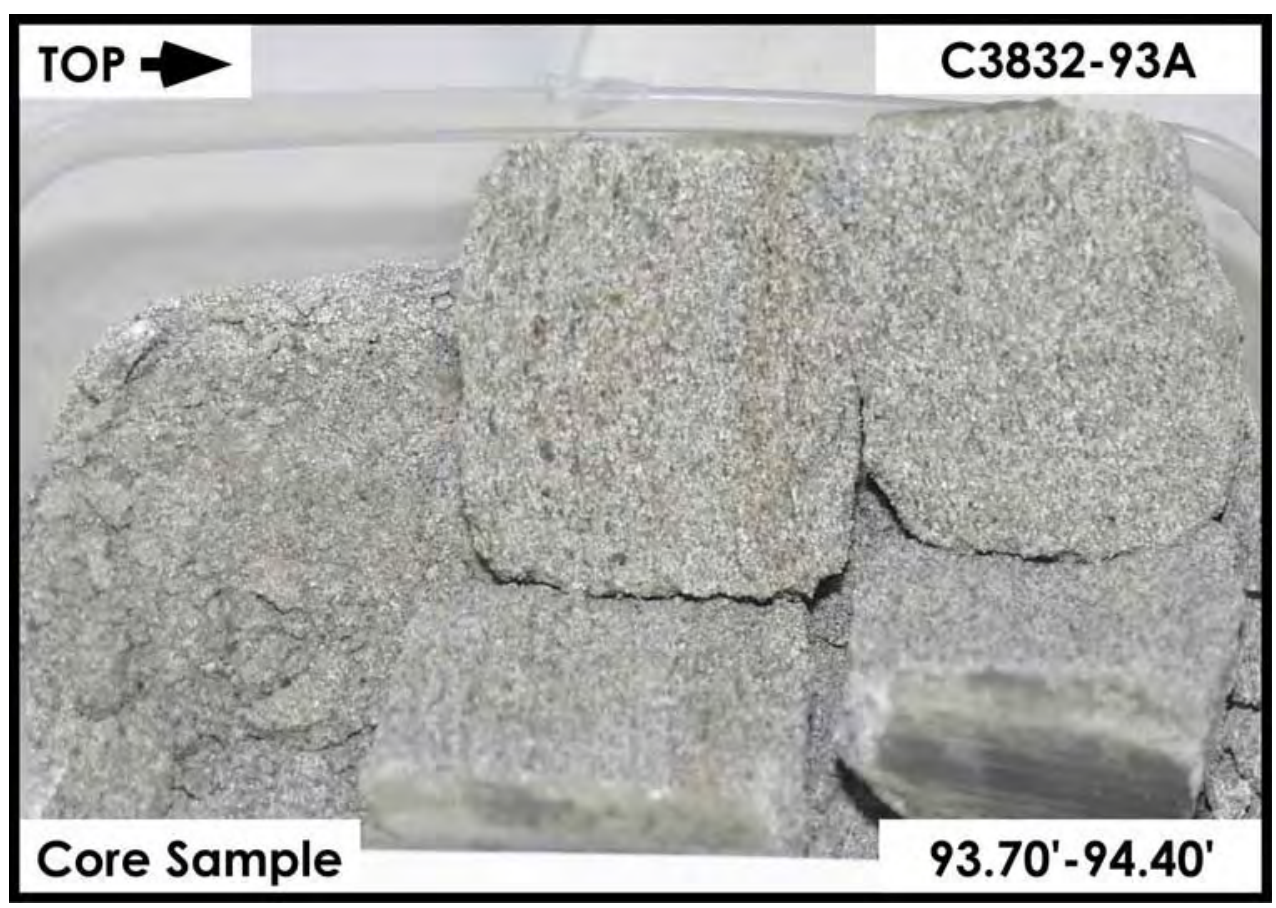

Figure A-4.28. Hanford Formation (H2 unit) $93.70 \mathrm{ft}-94.40 \mathrm{ft}$ 


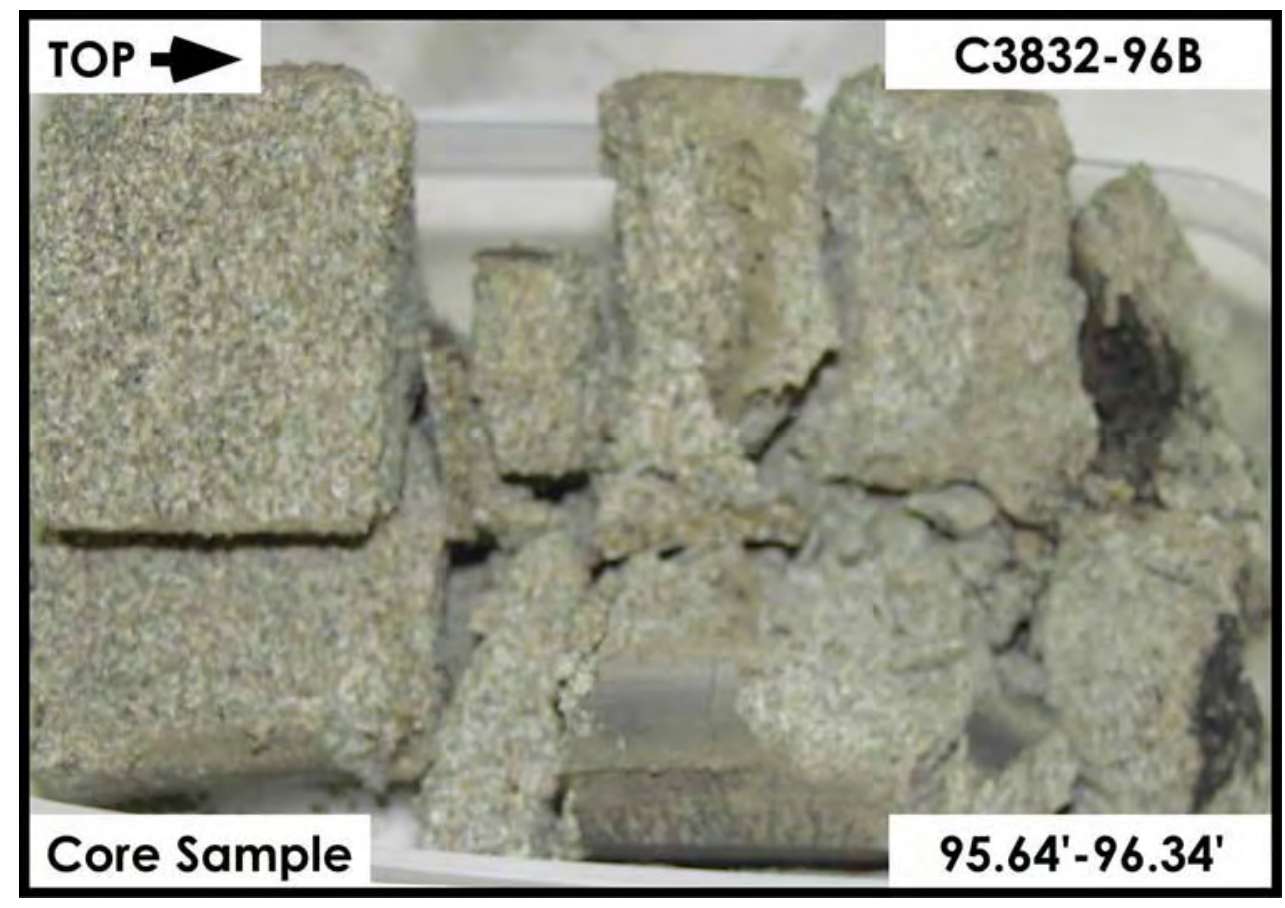

Figure A-4.29. Hanford Formation (H2 unit) $95.64 \mathrm{ft}-96.34 \mathrm{ft}$

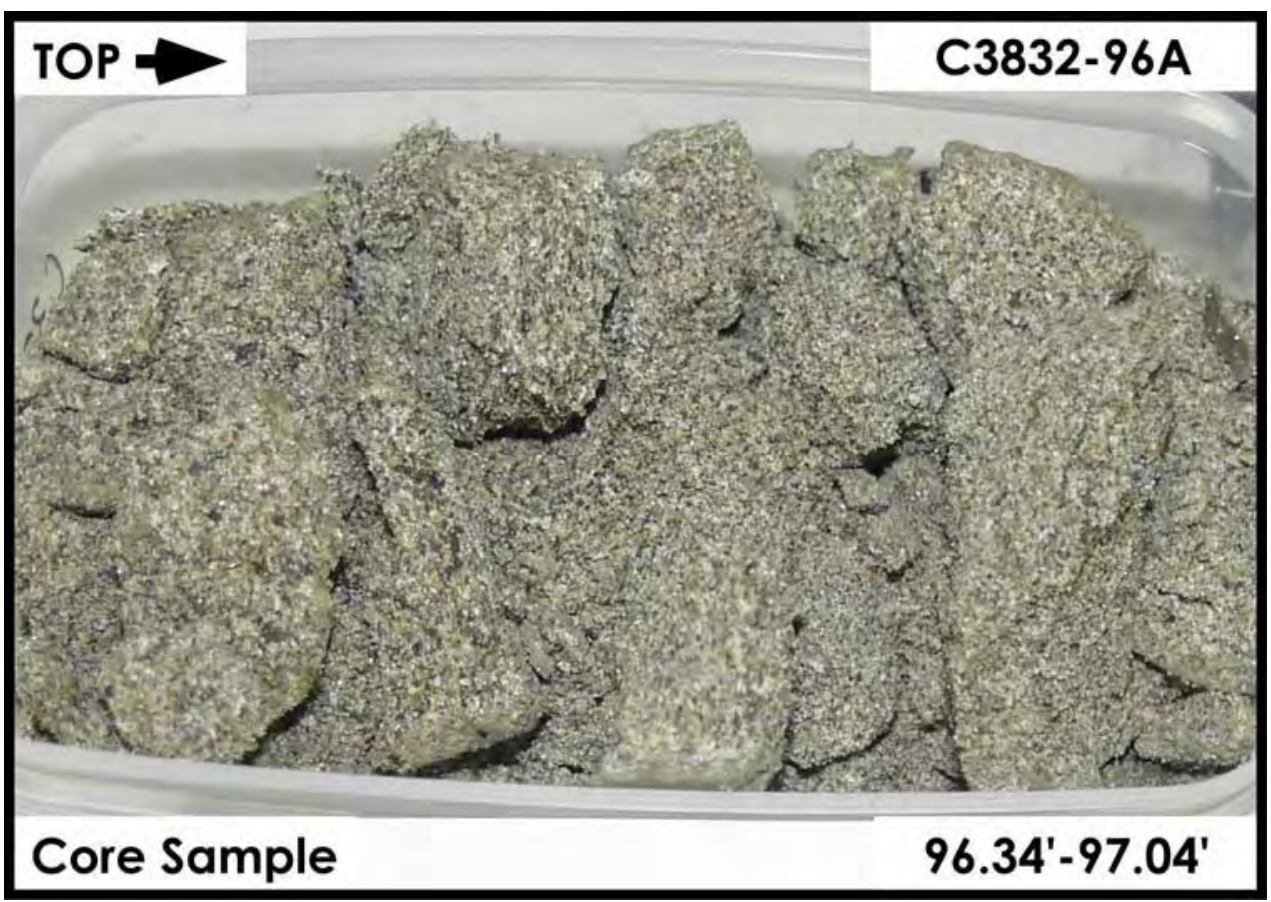

Figure A-4.30. Hanford Formation (H2 unit) $96.34 \mathrm{ft}$ - $97.04 \mathrm{ft}$ 


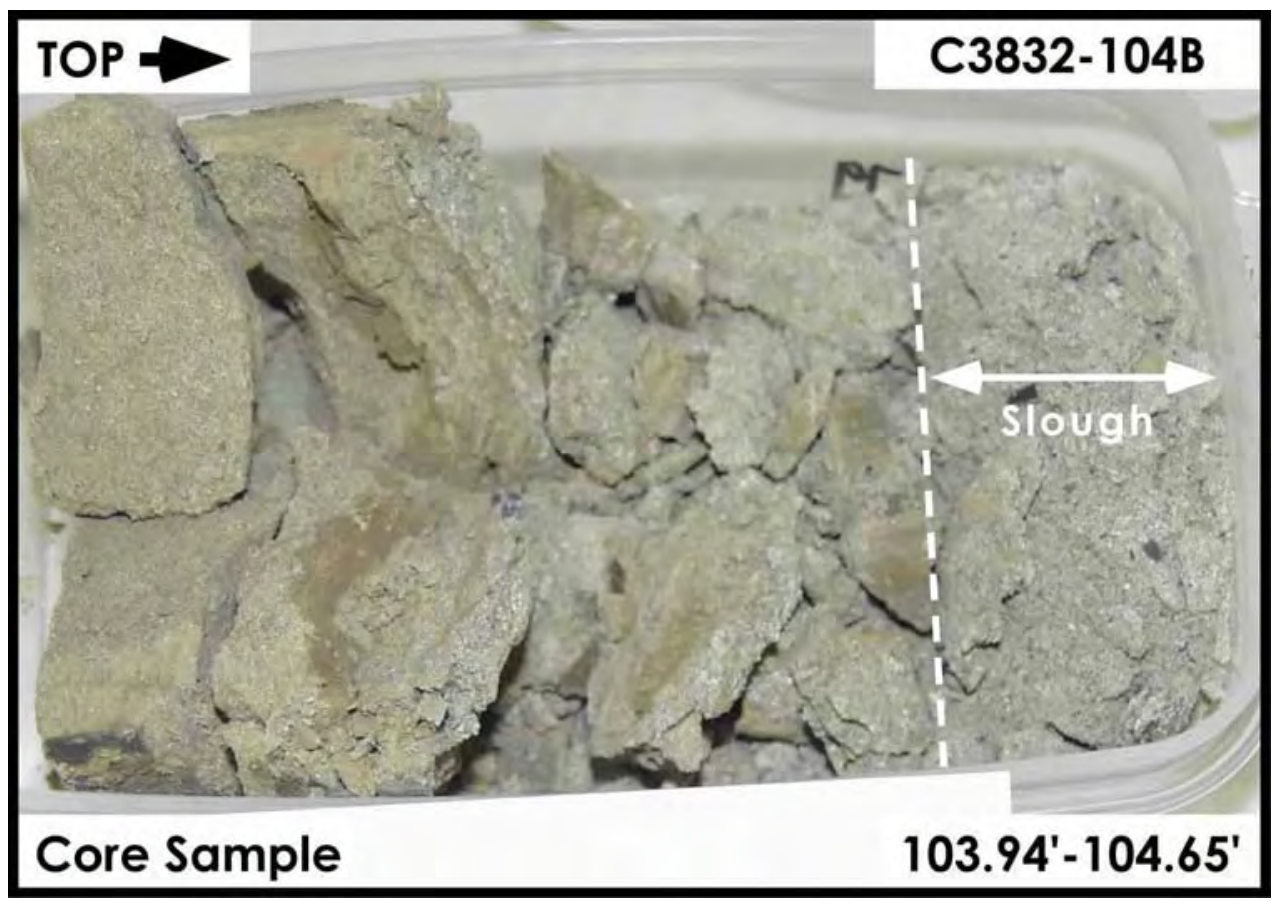

Figure A-4.31. Cold Creek Unit - Upper $\left(\mathrm{CCU}_{\mathrm{u}}\right) \mathbf{1 0 3 . 9 4} \mathrm{ft}-104.65 \mathrm{ft}$

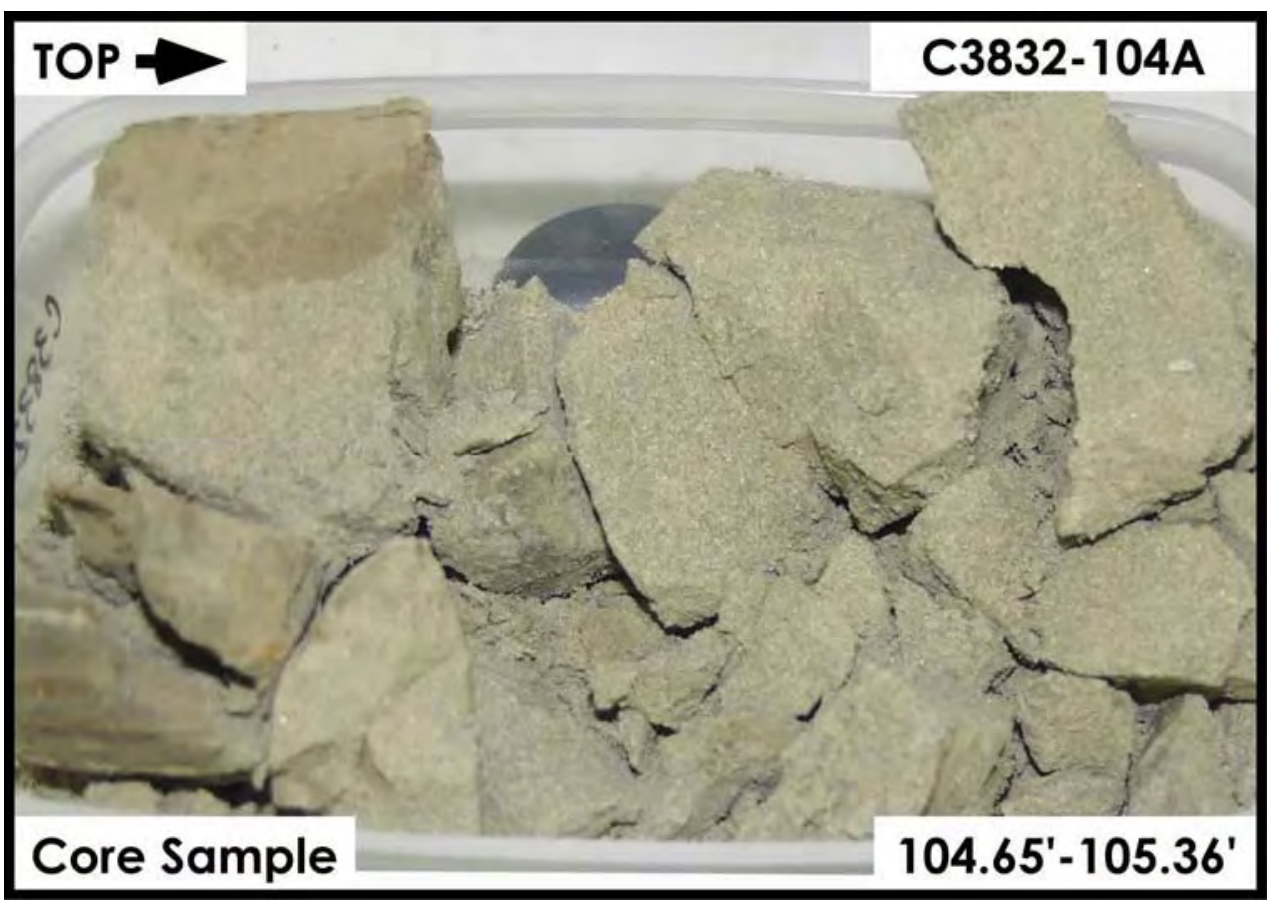

Figure A-4.32. Cold Creek Unit - Upper $\left(\mathrm{CCU}_{\mathrm{u}}\right) \mathbf{1 0 4 . 6 5} \mathrm{ft}-105.36 \mathrm{ft}$ 


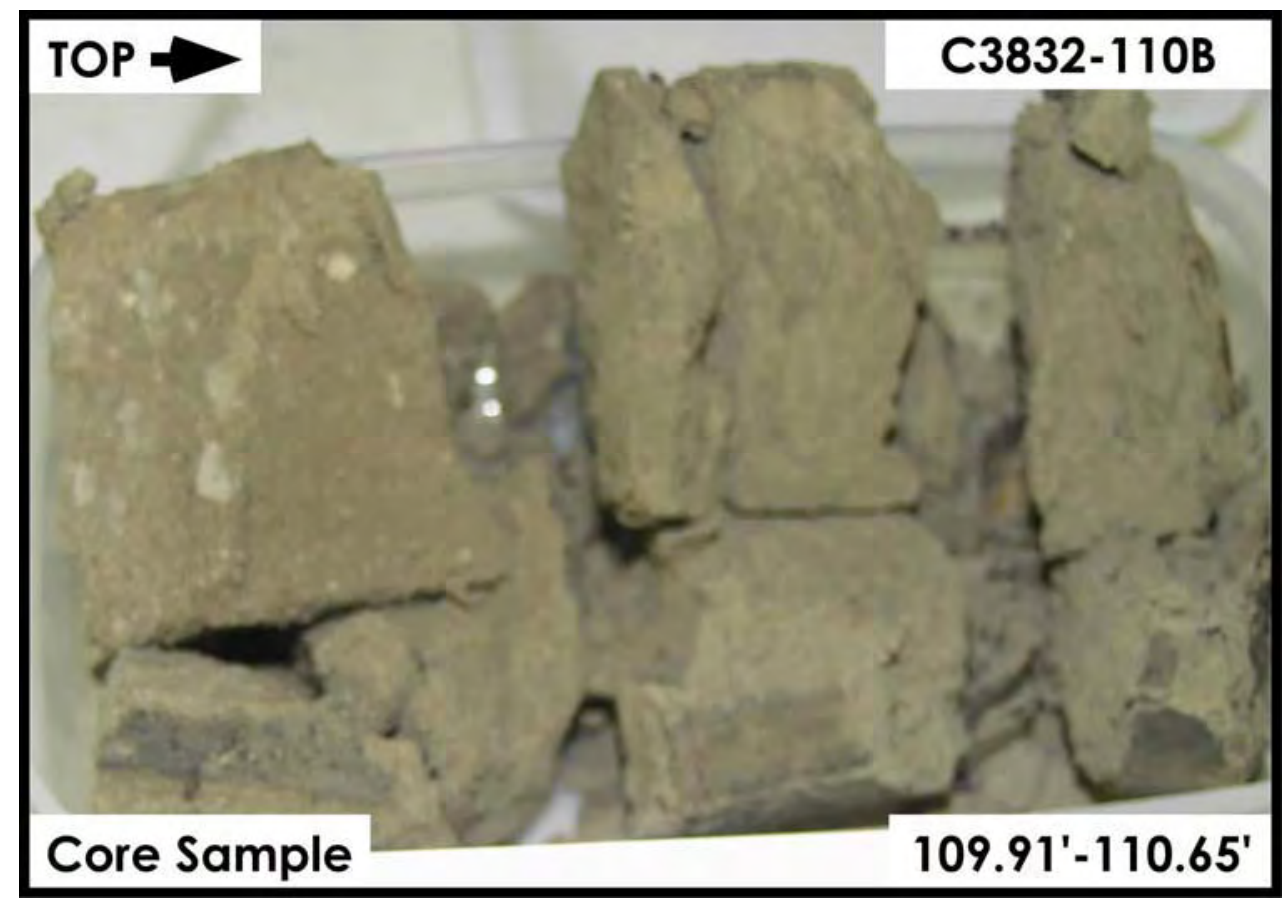

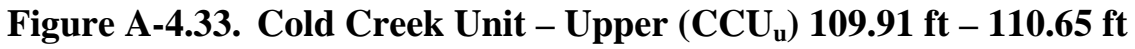

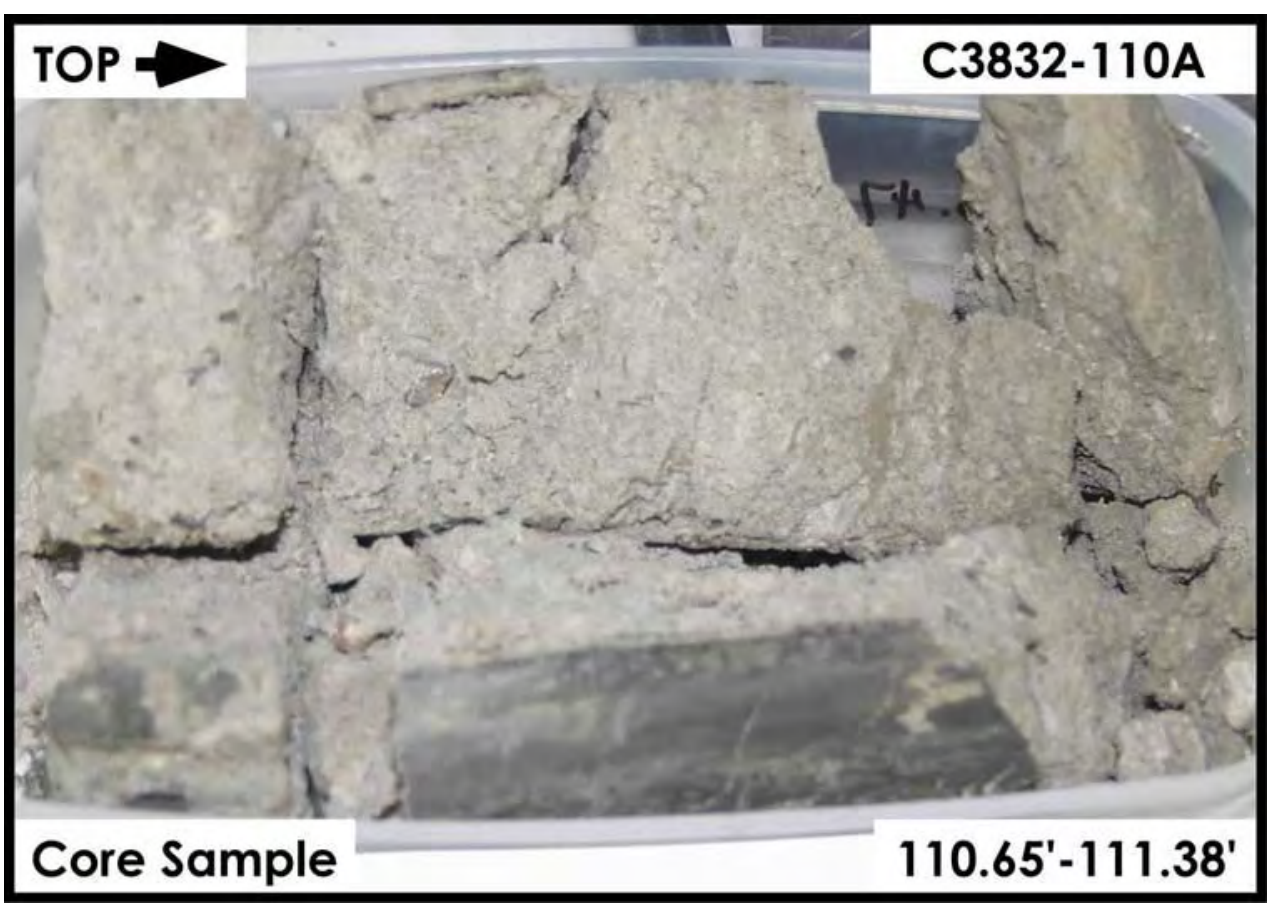

Figure A-4.34. Cold Creek Unit - Lower $\left(\mathrm{CCU}_{\mathrm{l}}\right) \mathbf{1 1 0 . 6 5} \mathrm{ft}-\mathbf{1 1 1 . 3 8} \mathrm{ft}$ 


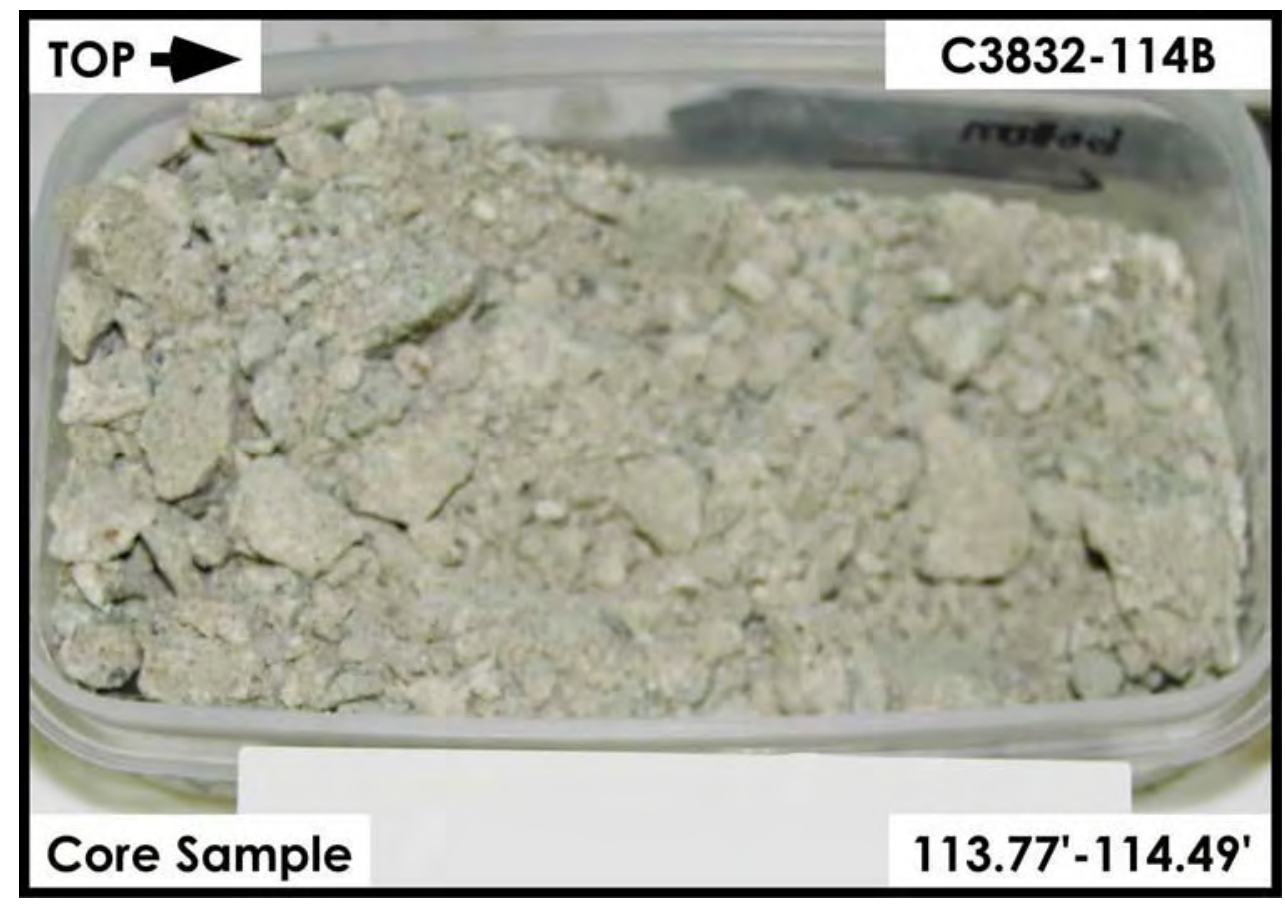

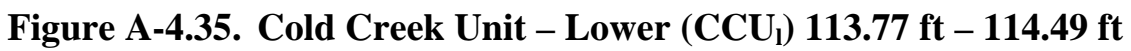

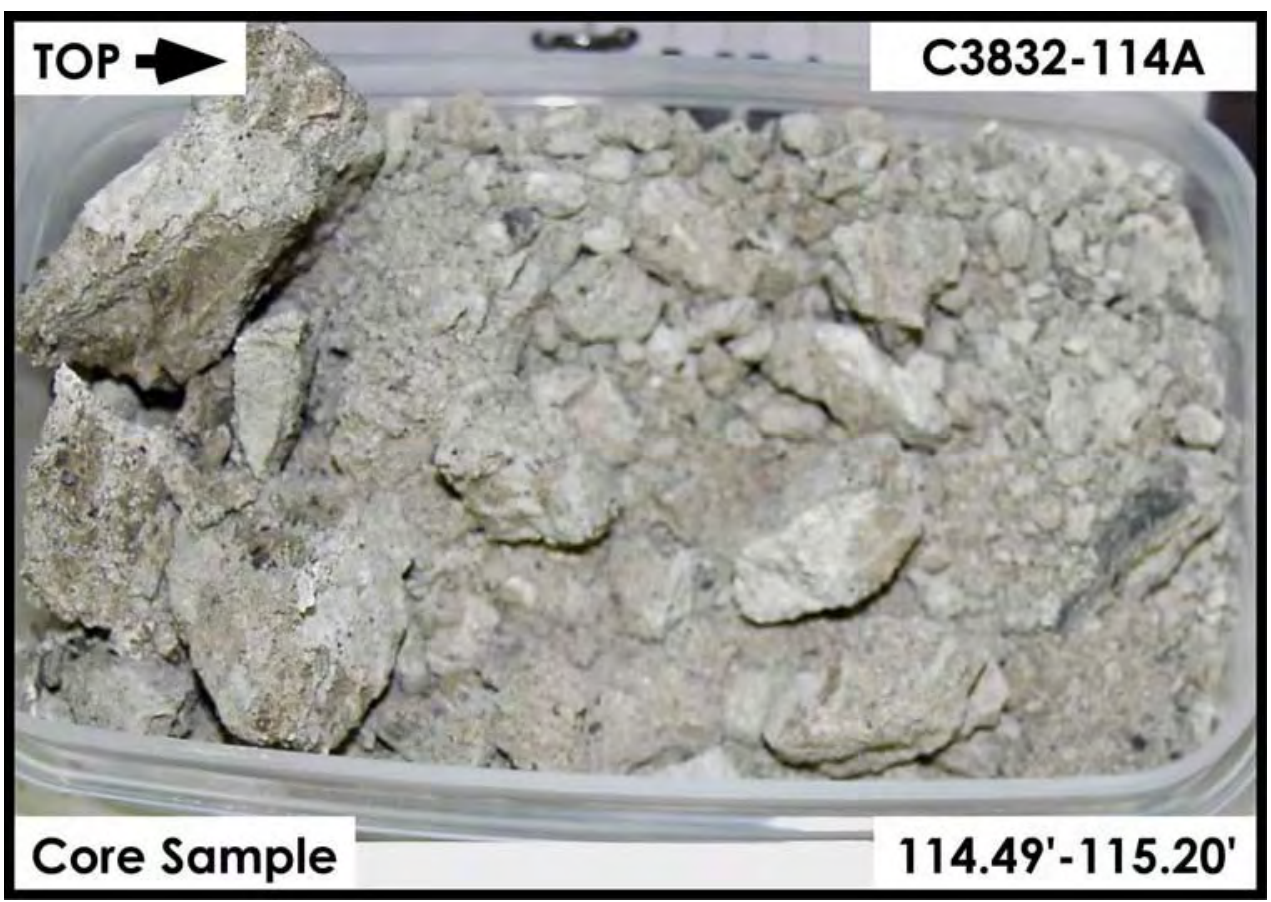

Figure A-4.36. Cold Creek Unit - Lower $\left(\mathrm{CCU}_{\mathrm{l}}\right) \mathbf{1 1 4 . 4 9} \mathrm{ft}-\mathbf{1 1 5 . 2 0} \mathrm{ft}$ 


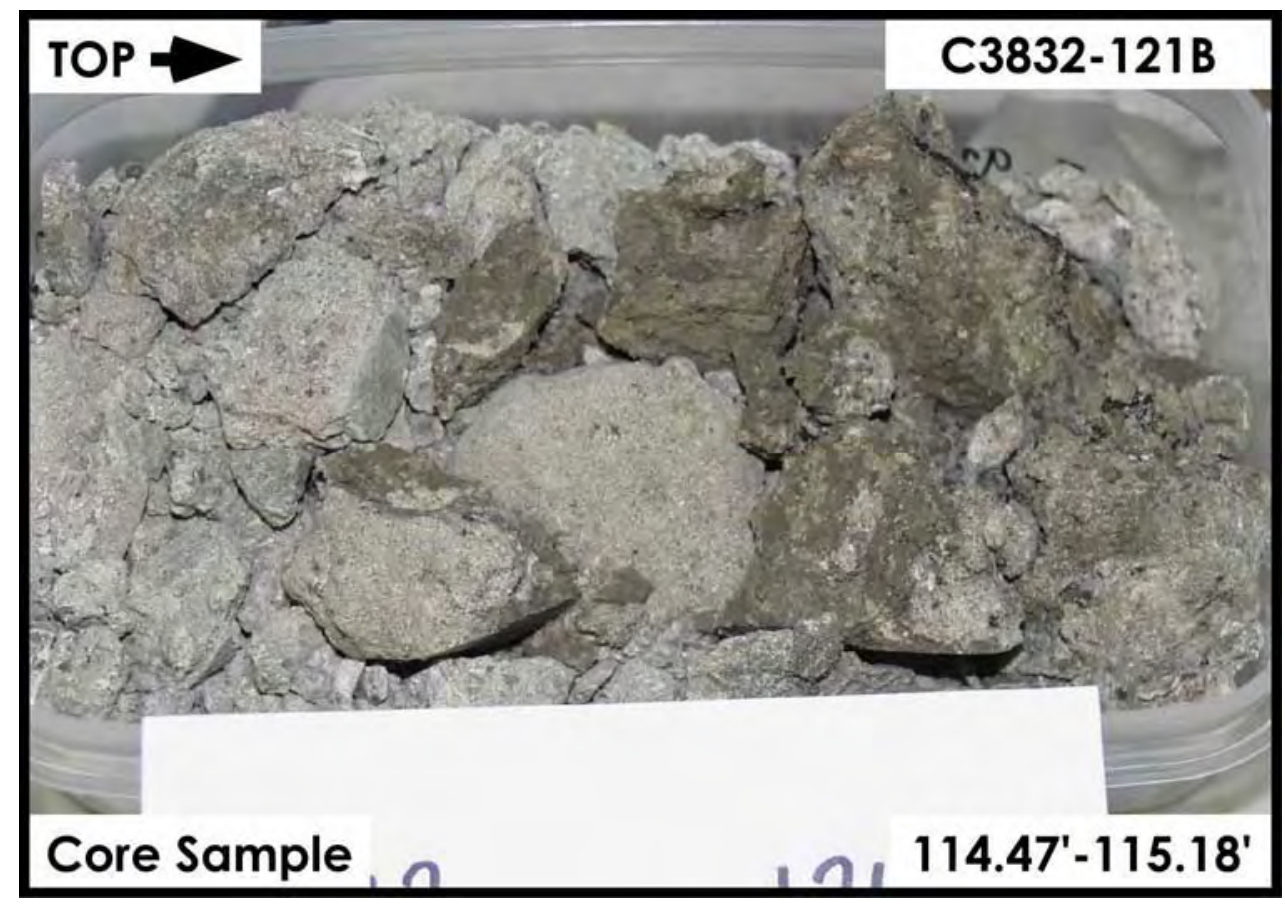

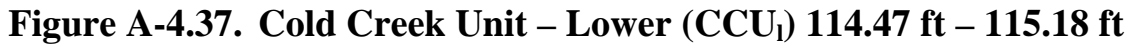

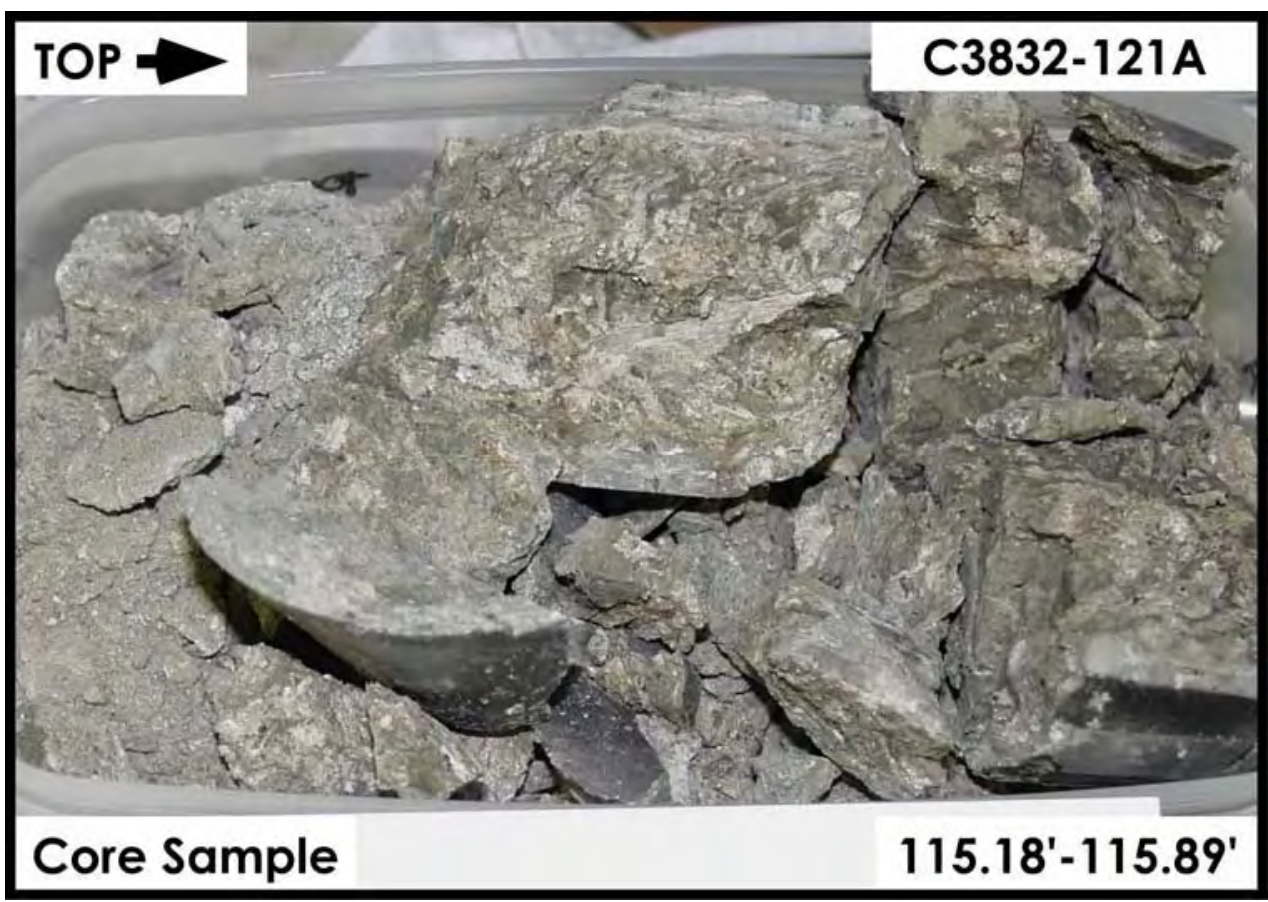

Figure A-4.38. Cold Creek Unit - Lower $\left(\mathrm{CCU}_{\mathrm{l}}\right) 115.18 \mathrm{ft}-115.89 \mathrm{ft}$ 


\section{APPENDIX B. CORE LOGS*}

\section{B.1 C3830 \\ B.2 C3831 \\ B.3 C3832}

*Core Logs for 299-W10-27 are presented in Lindsey et al. (2001). 


\title{
APPENDIX B.1
}

C3830 (TX-105)

\section{GEOLOGIC DESCRIPTION OF CORE OBTAINED}

\author{
DURING OPENING IN LAB
}




\section{Contents}

APPENDIX B.1 C3830 (TX-105) Geologic Description of Core...

B-1.1

B-1.i 


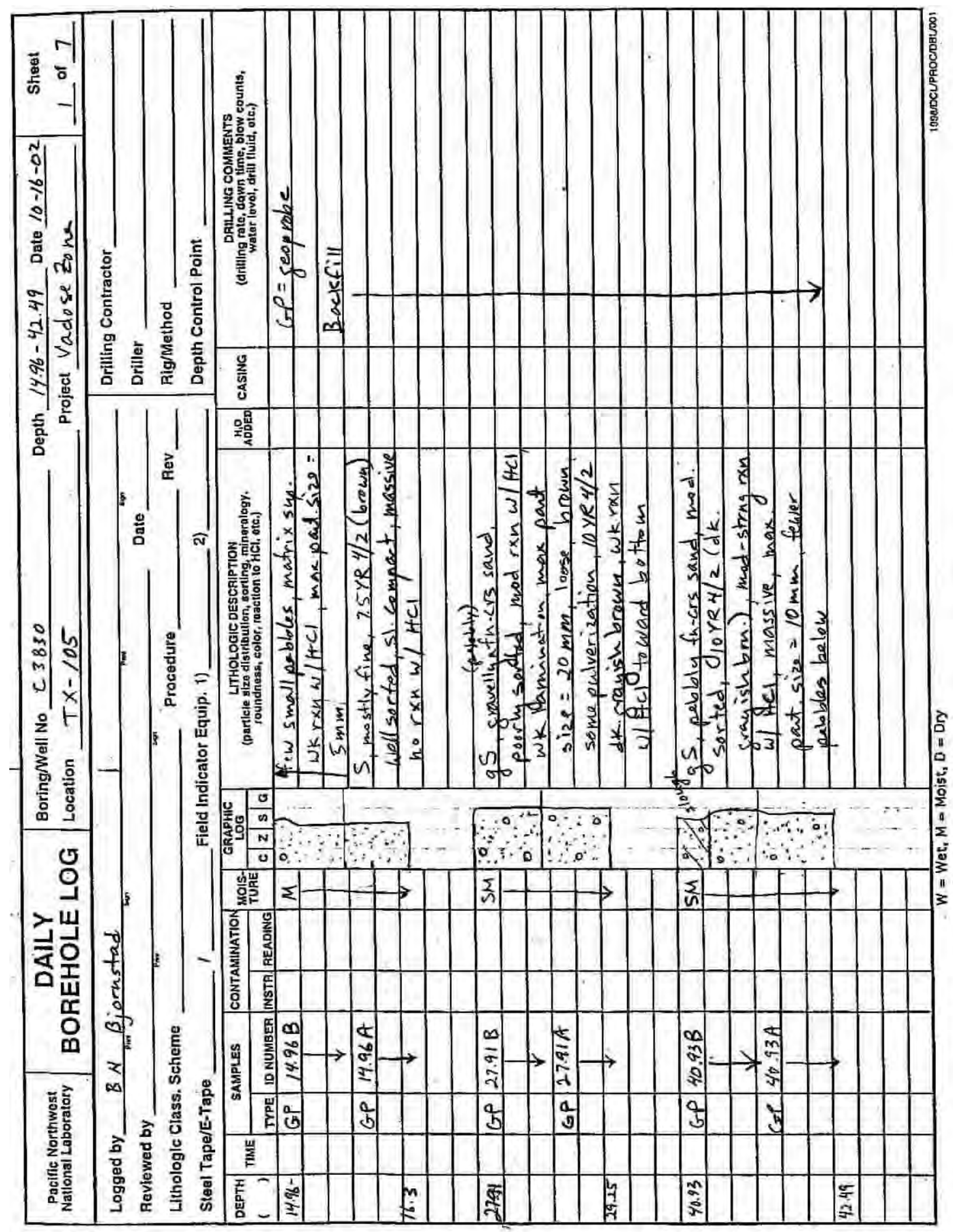




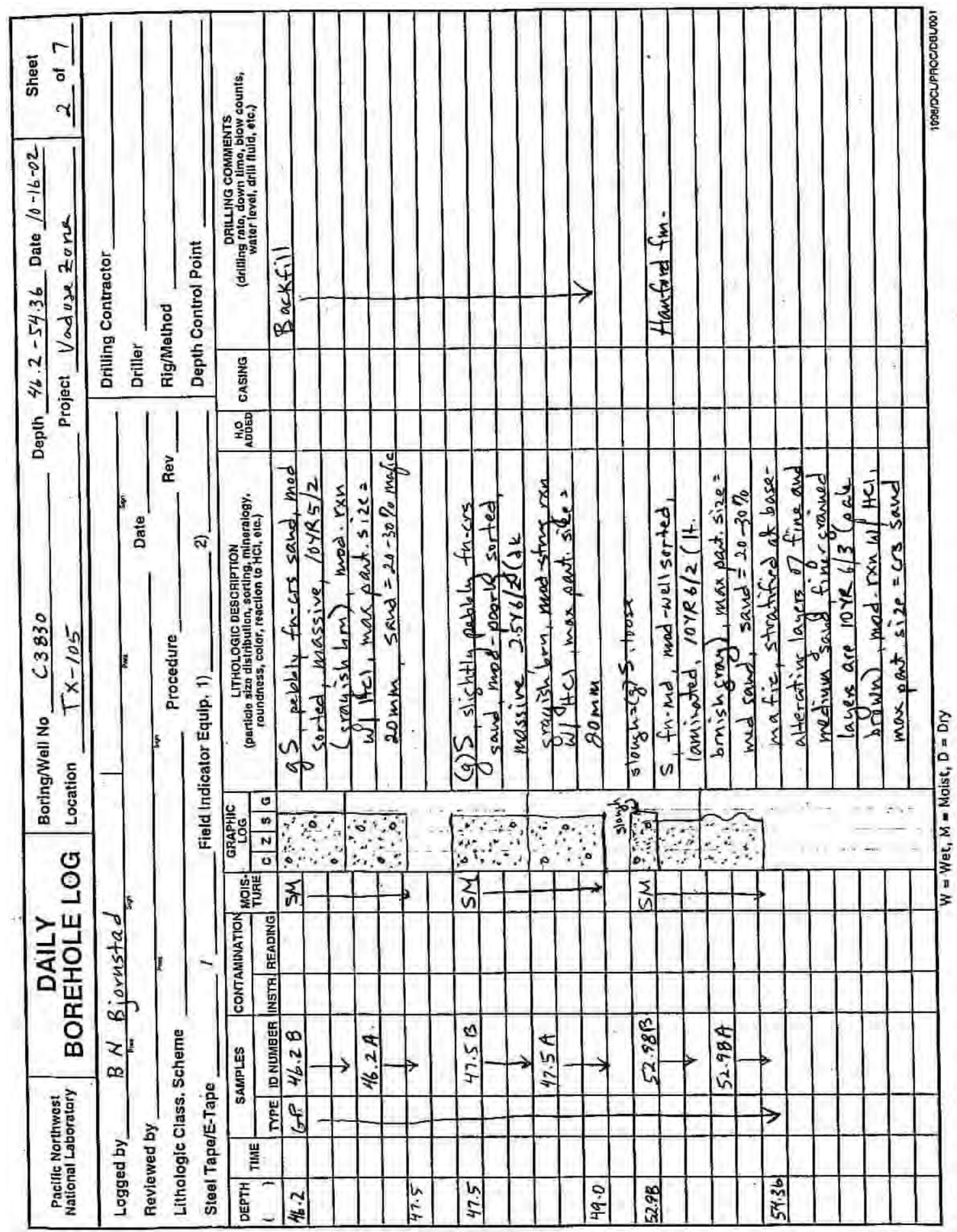




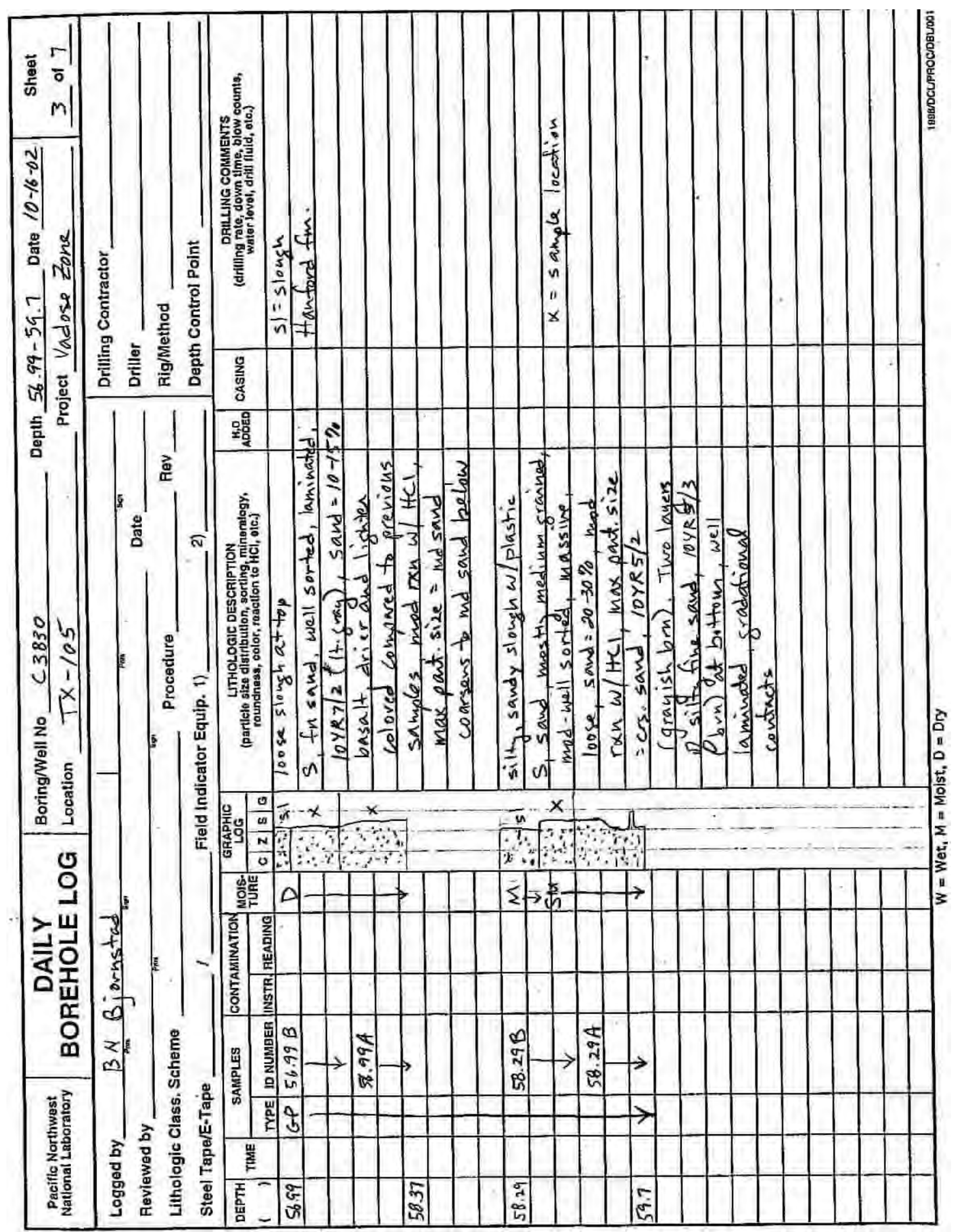




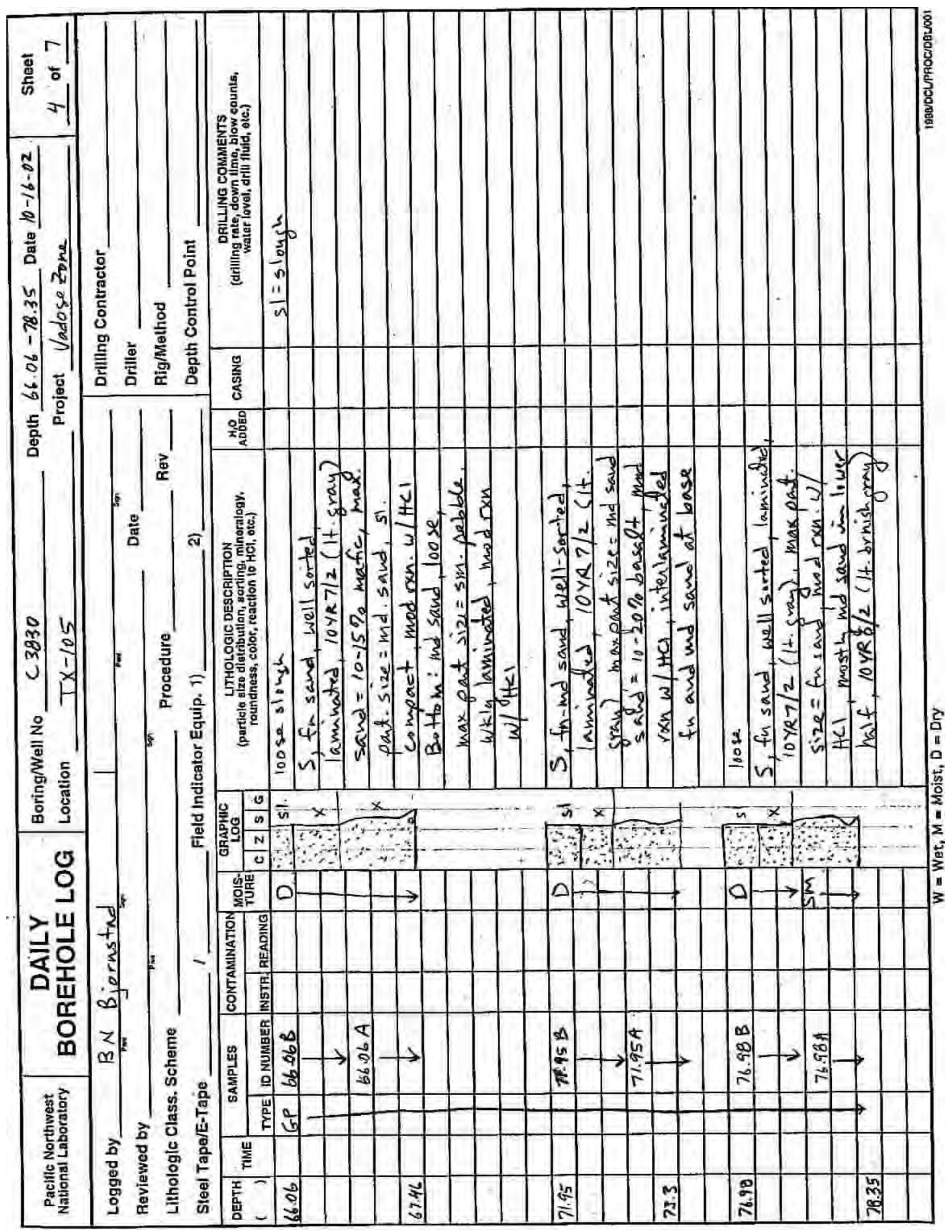




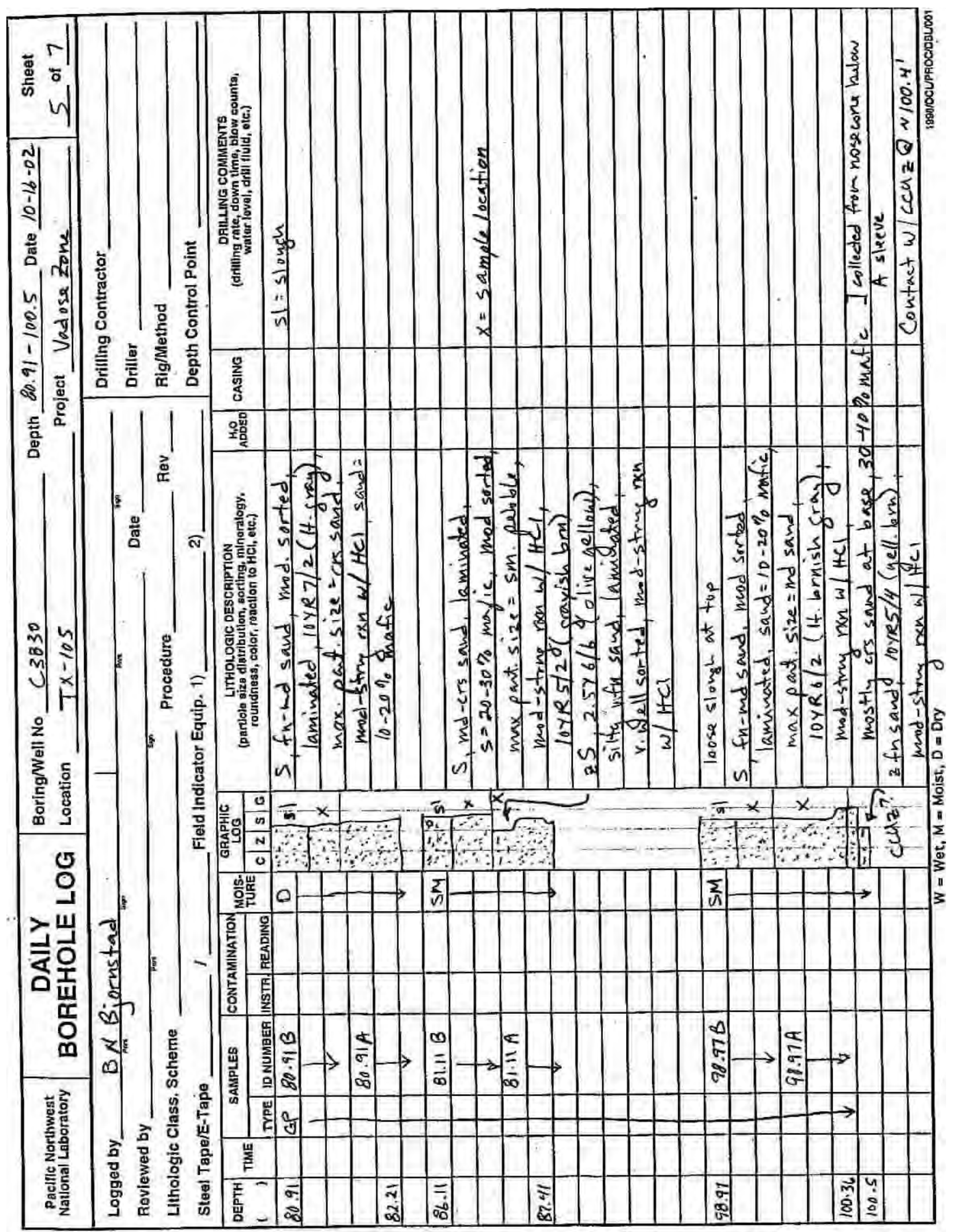




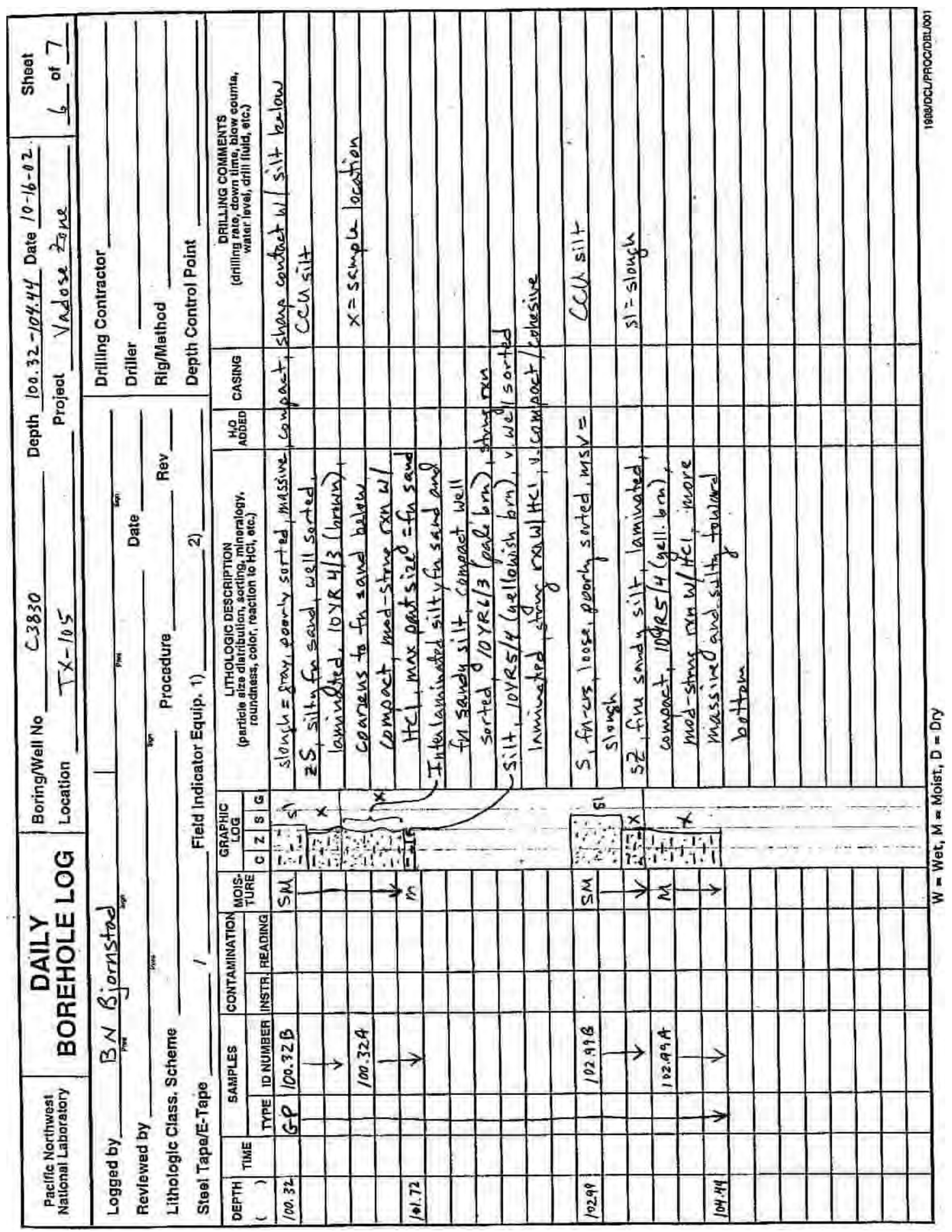




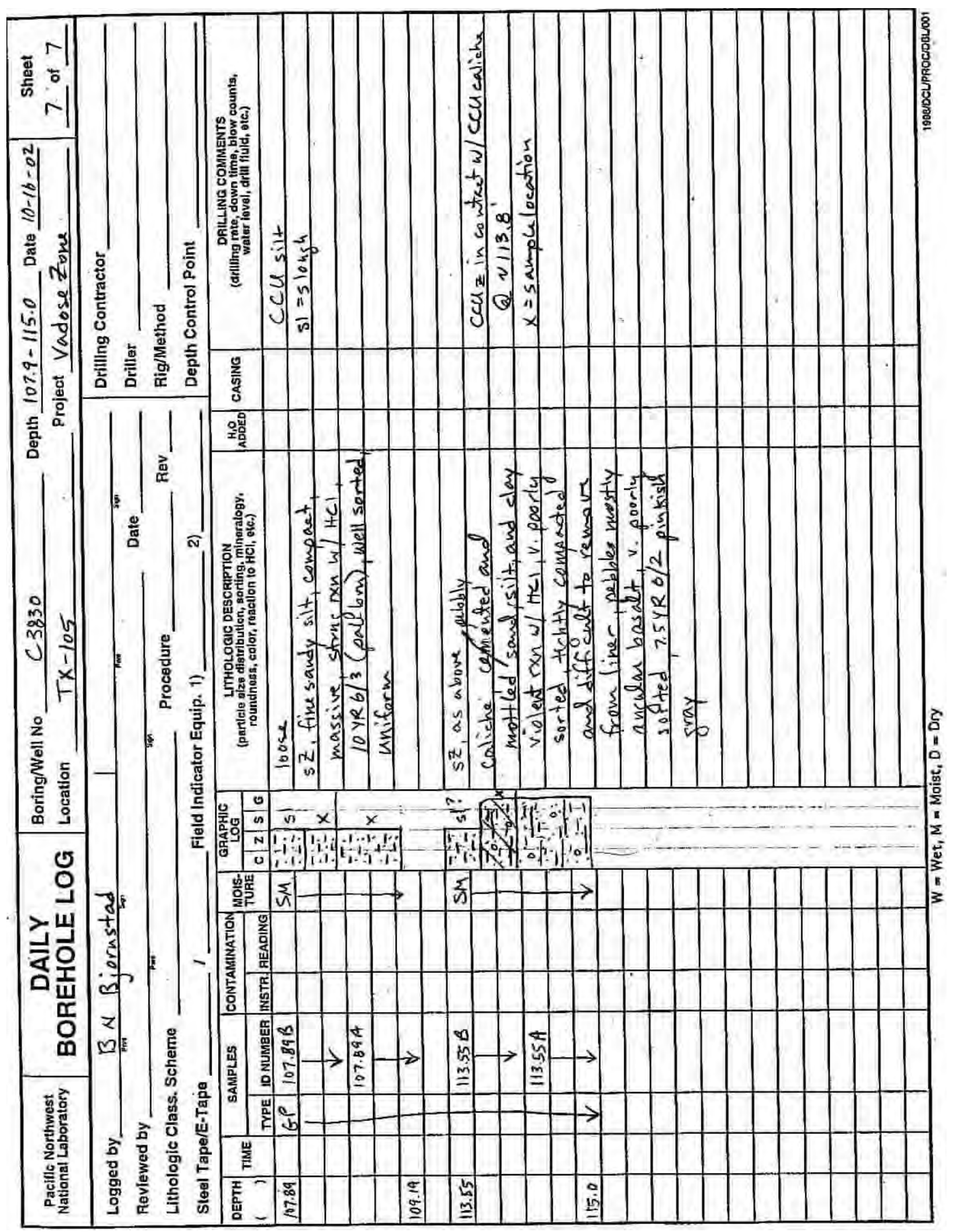


APPENDIX B.2

C3831 (TX-107)

\section{GEOLOGIC DESCRIPTION OF CORE OBTAINED}

\section{DURING OPENING IN LAB}




\section{Contents}

APPENDIX B.2 C3831 (TX-107) Geologic Description of Core...

B-2.1

B-2.i 


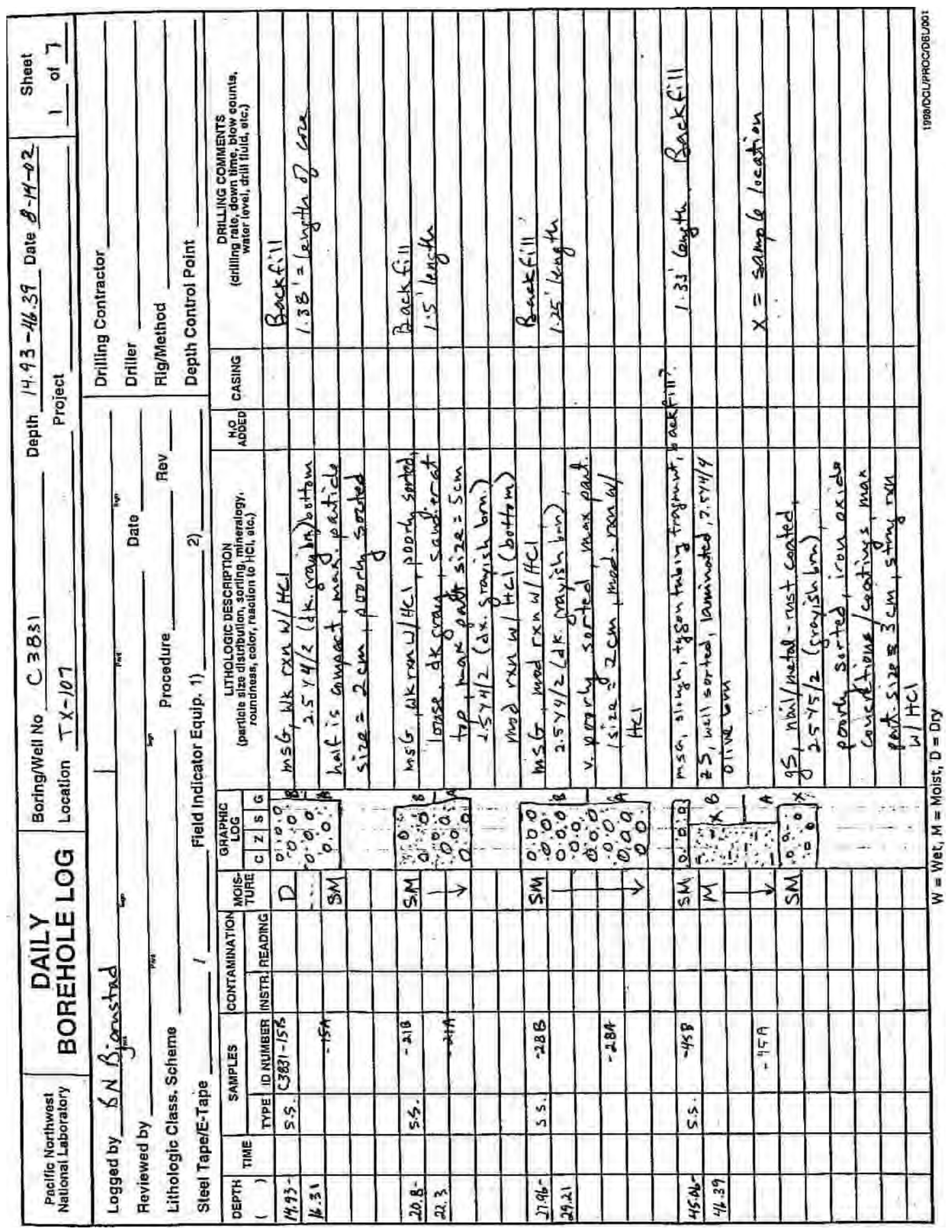




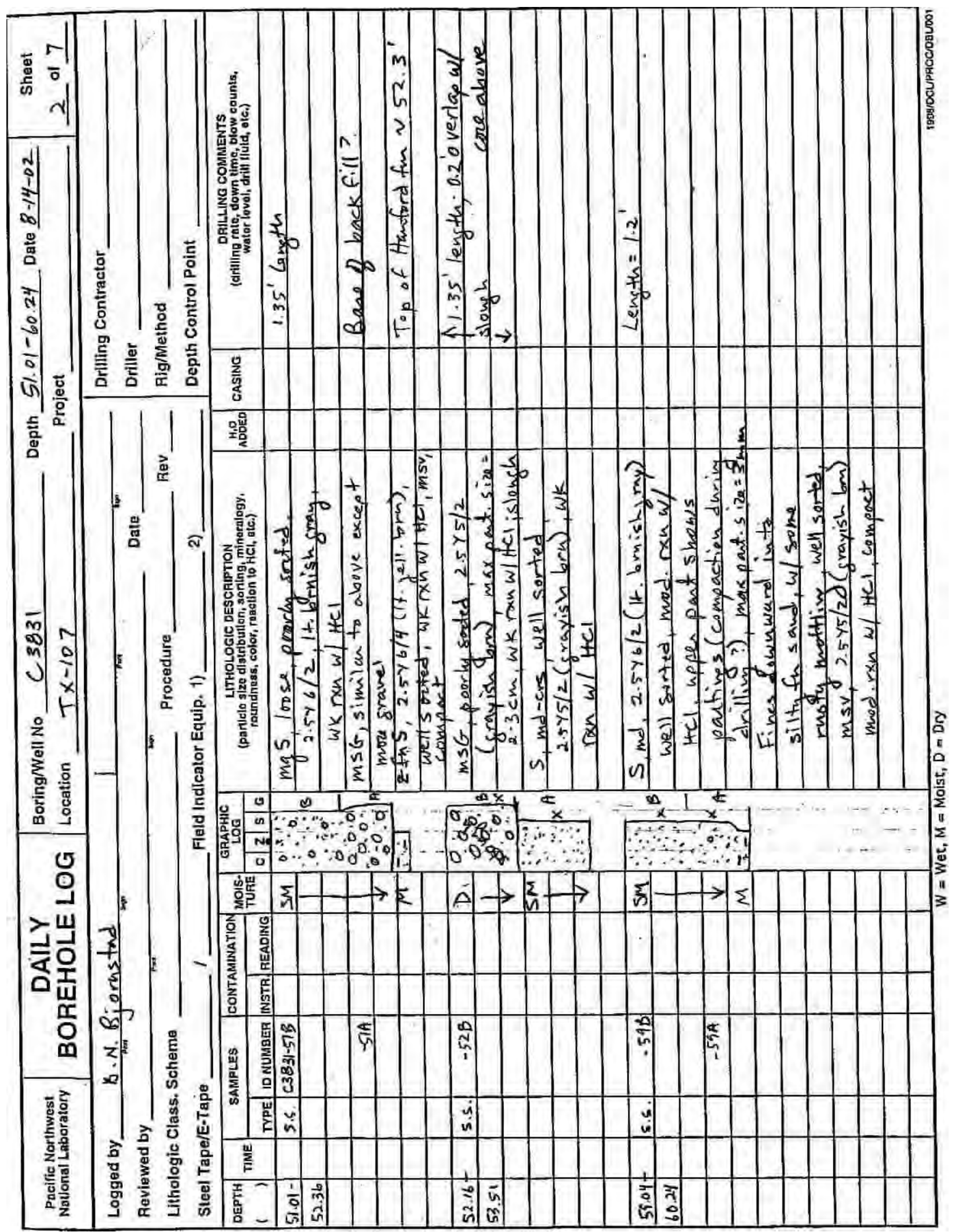




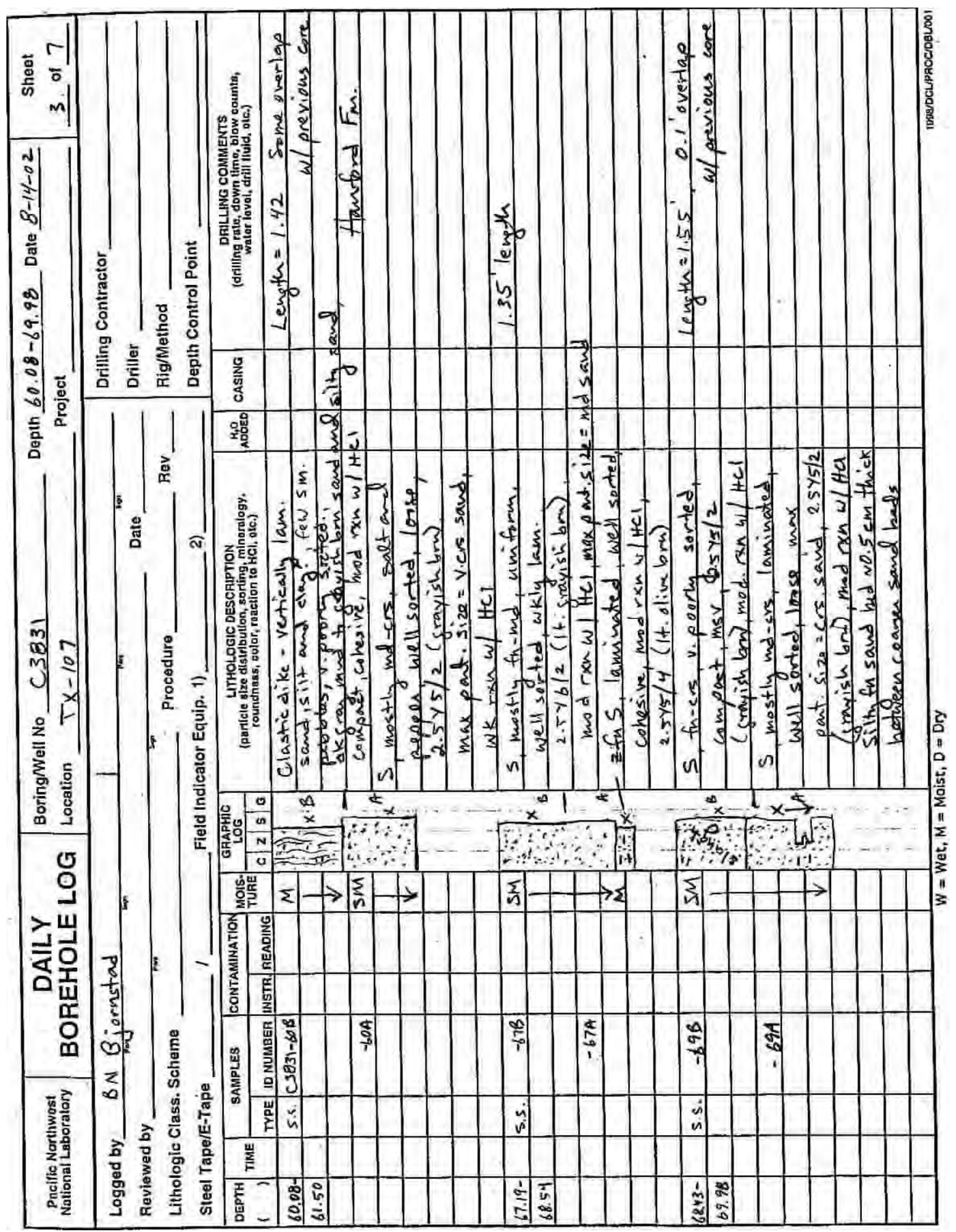




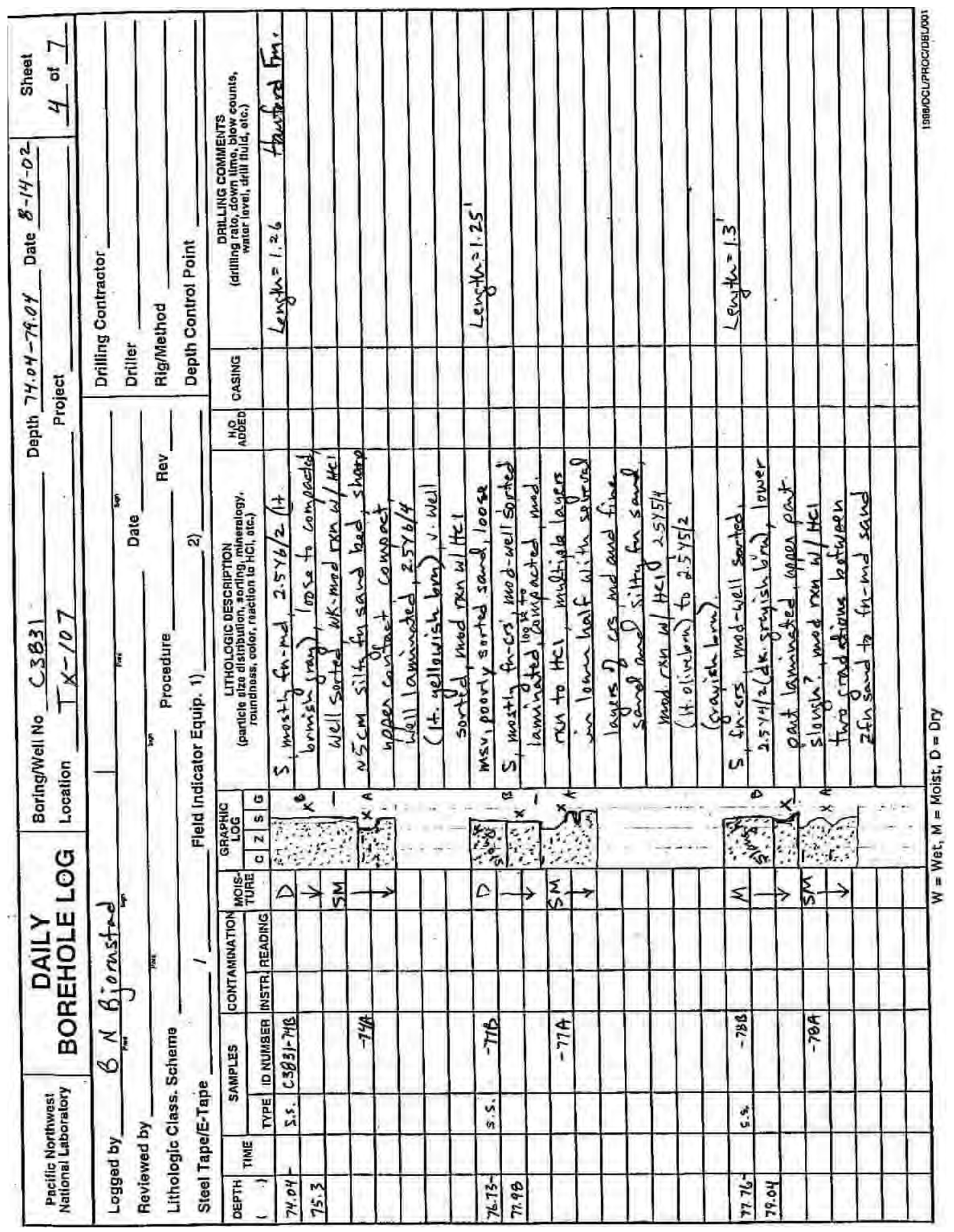




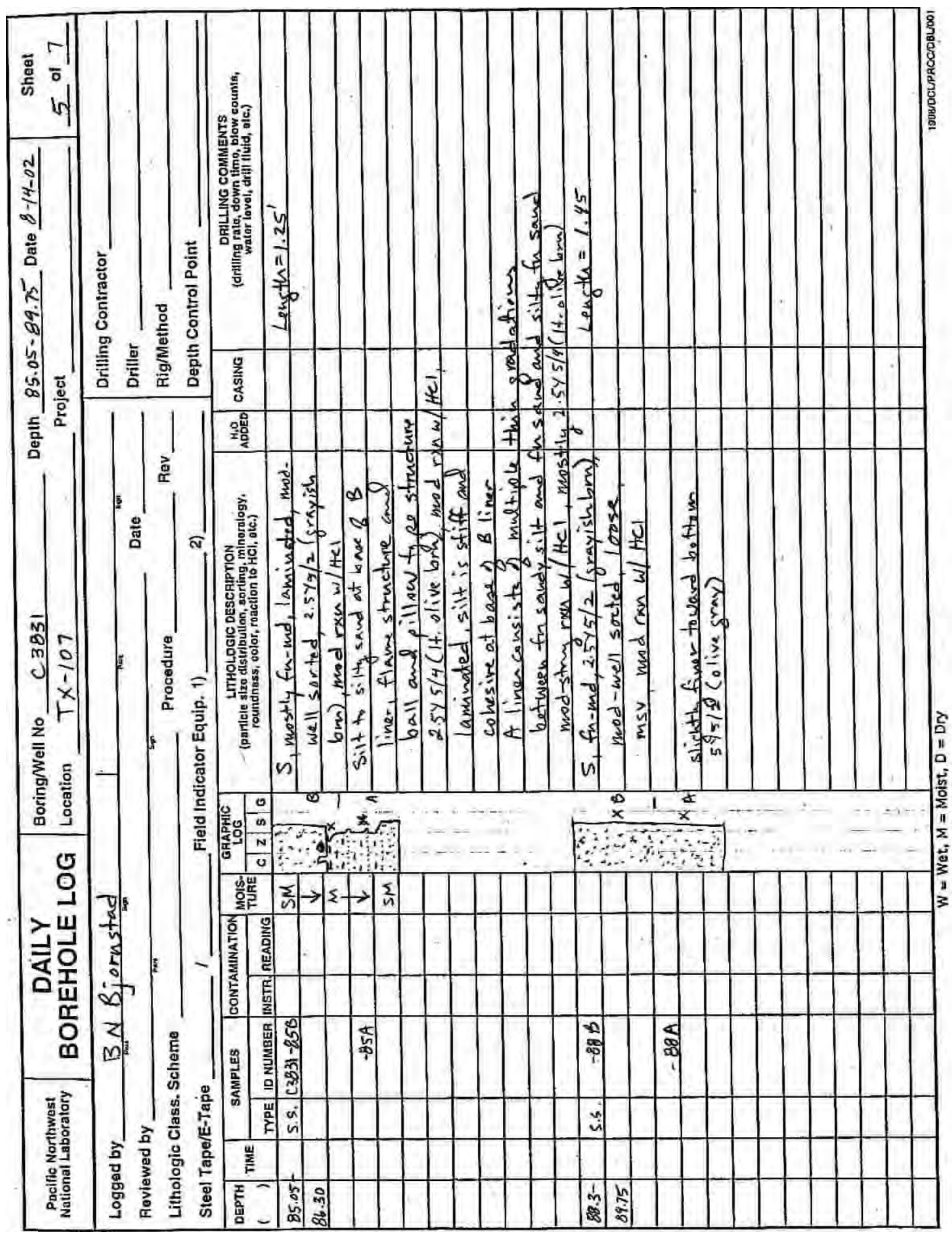




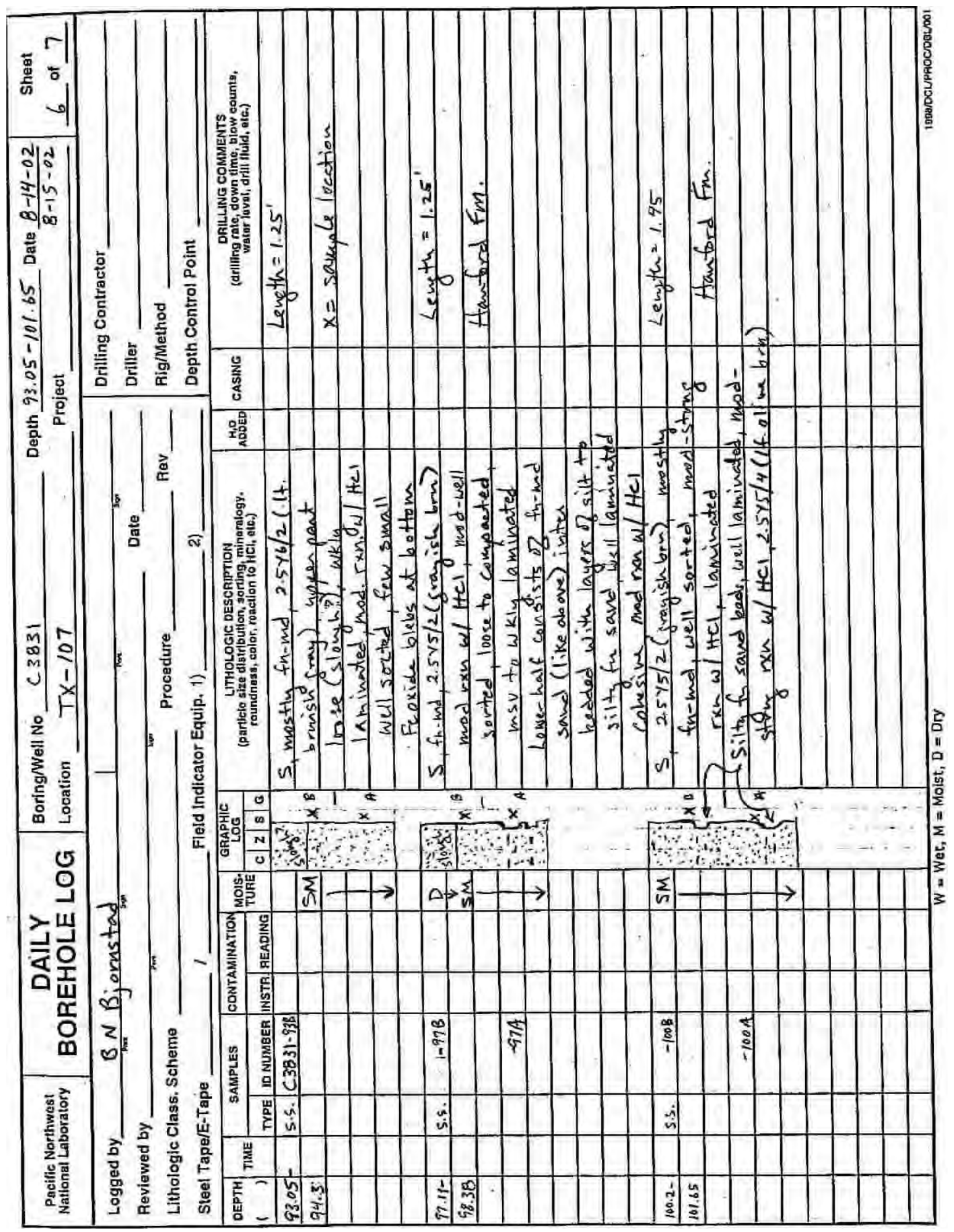




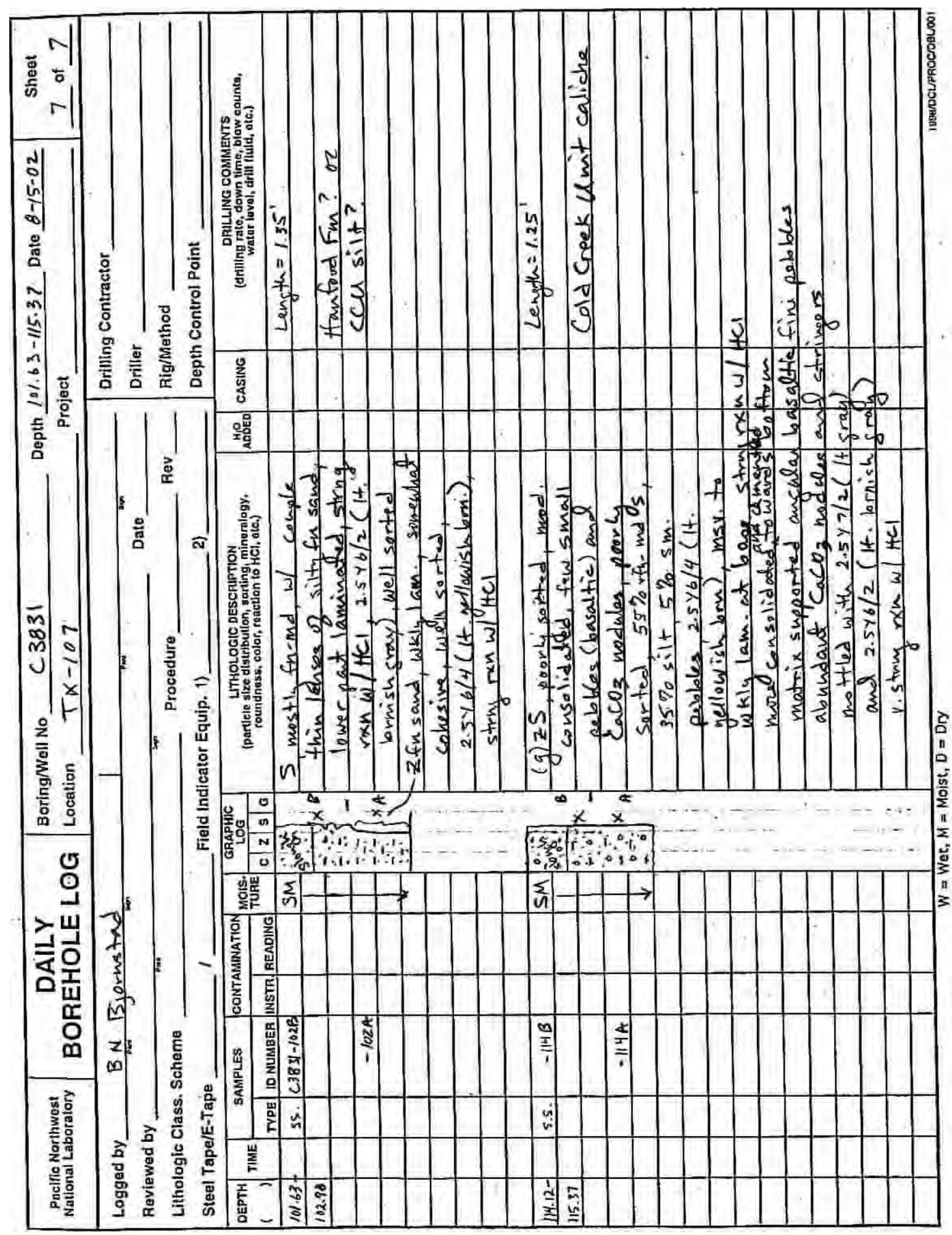


Appendix B.3

C3832 (TX-104)

\section{GEOLOGIC DESCRIPTION OF CORE OBTAINED}

\section{DURING OPENING IN LAB}




\section{Contents}

Appendix B.3 Core 3832 (TX-104) Geologic Description of Core ................................................... B-3.1 


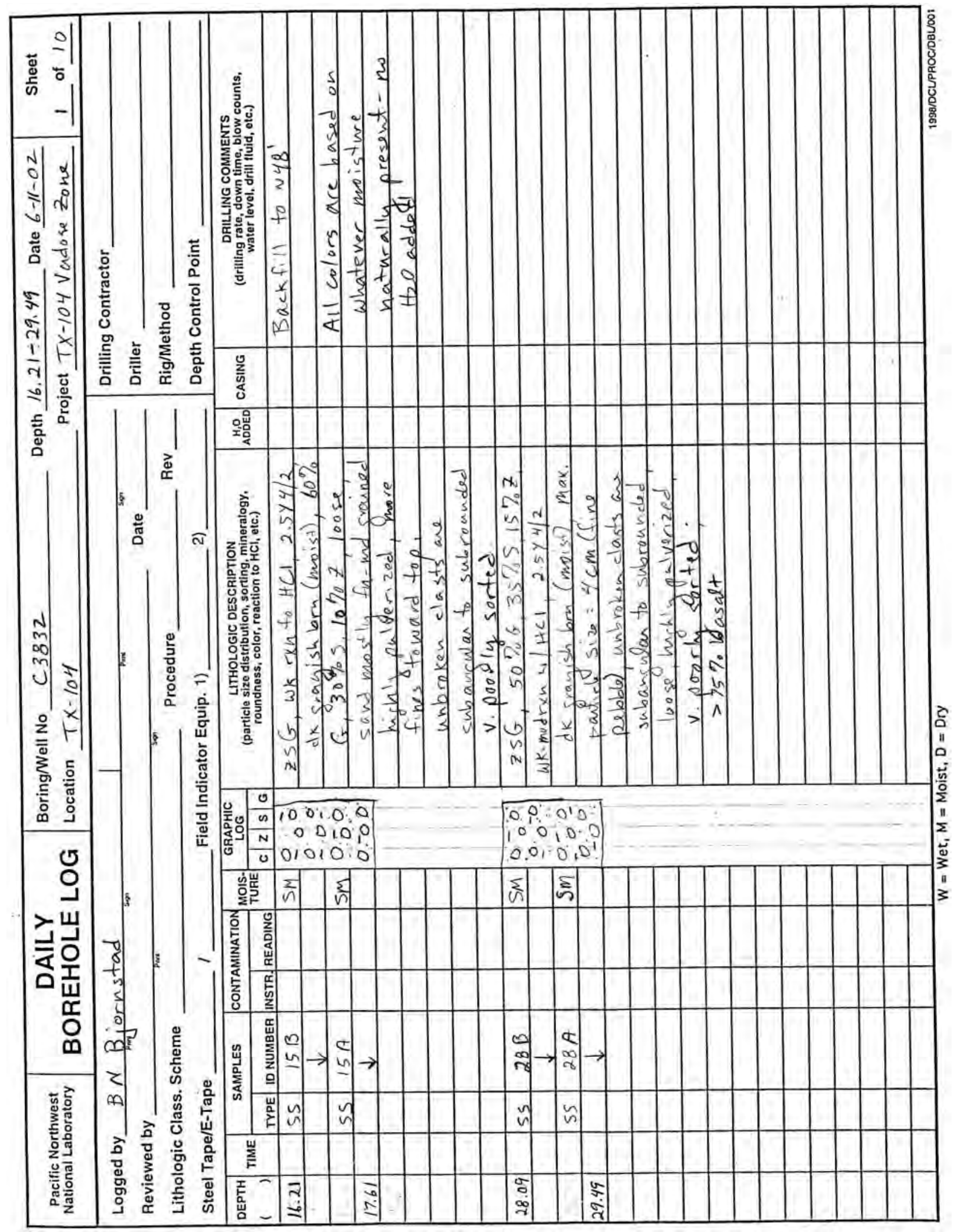




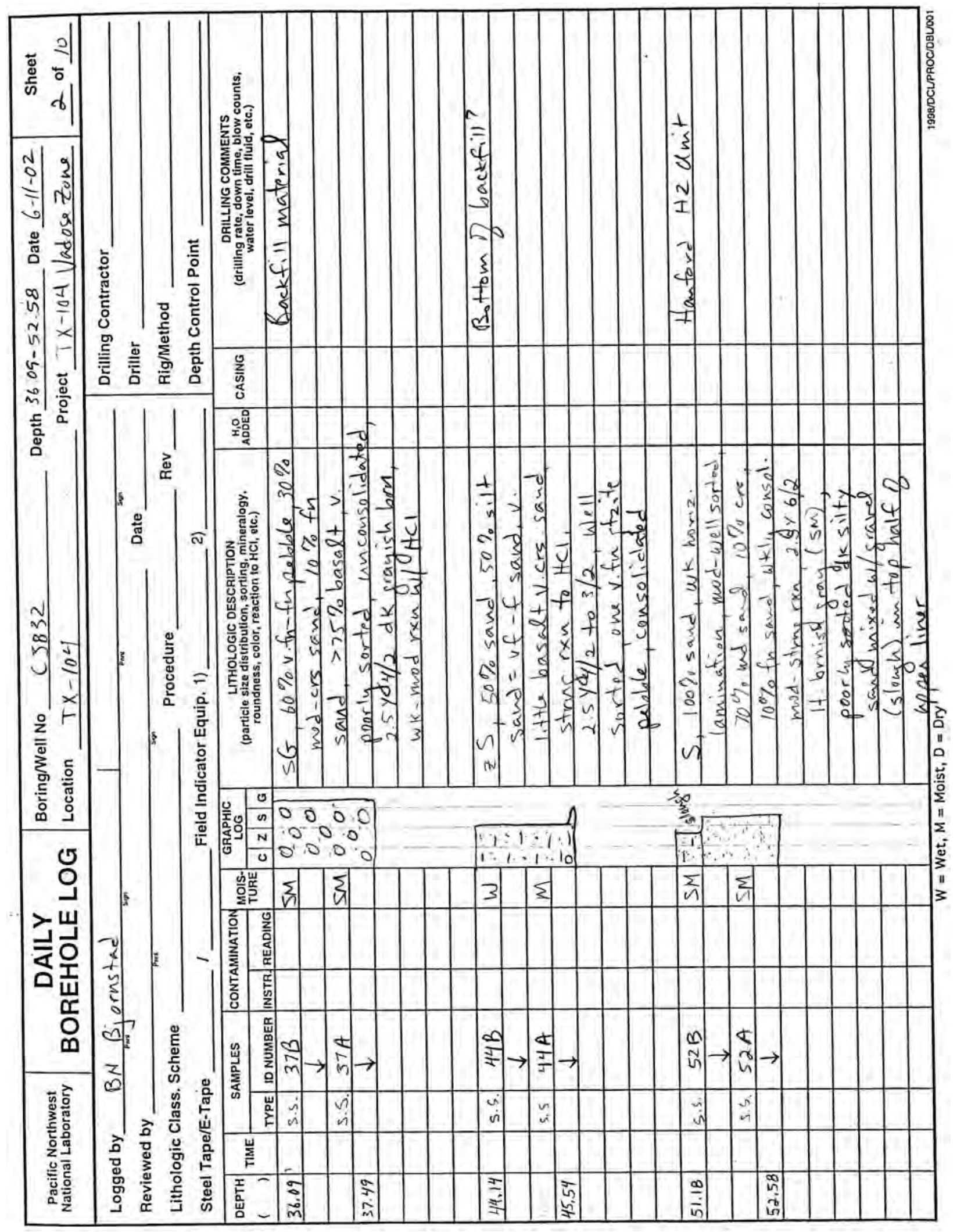




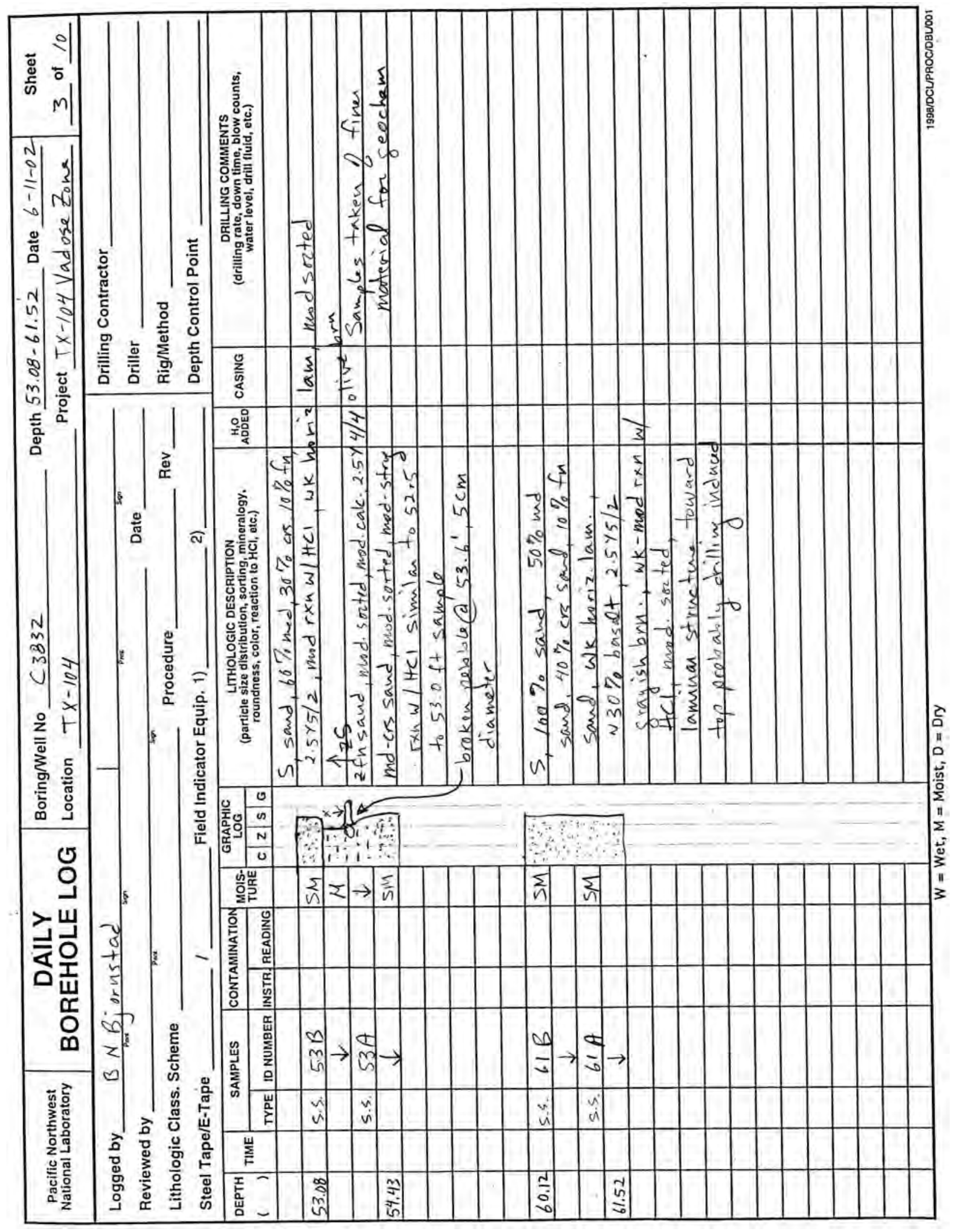




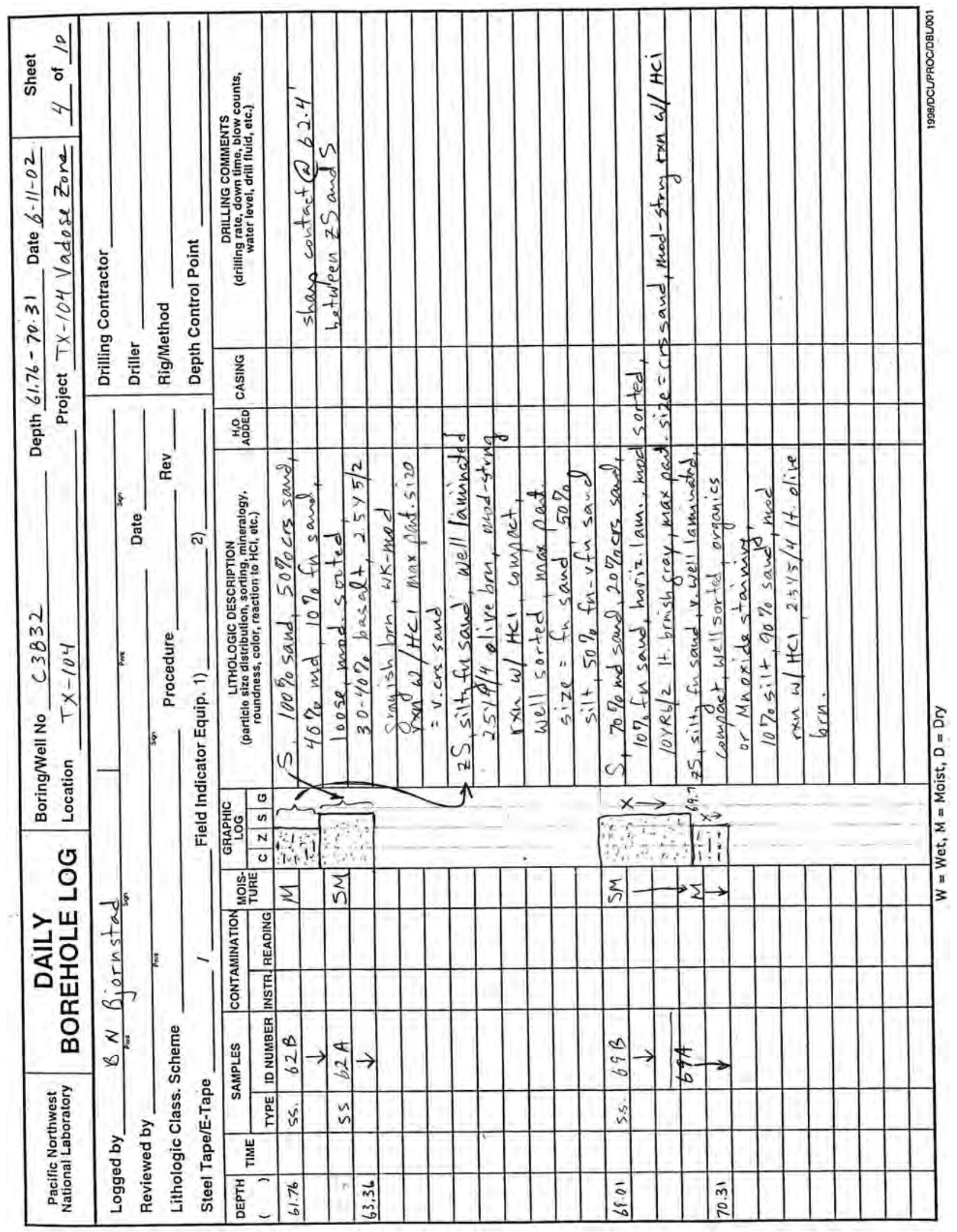




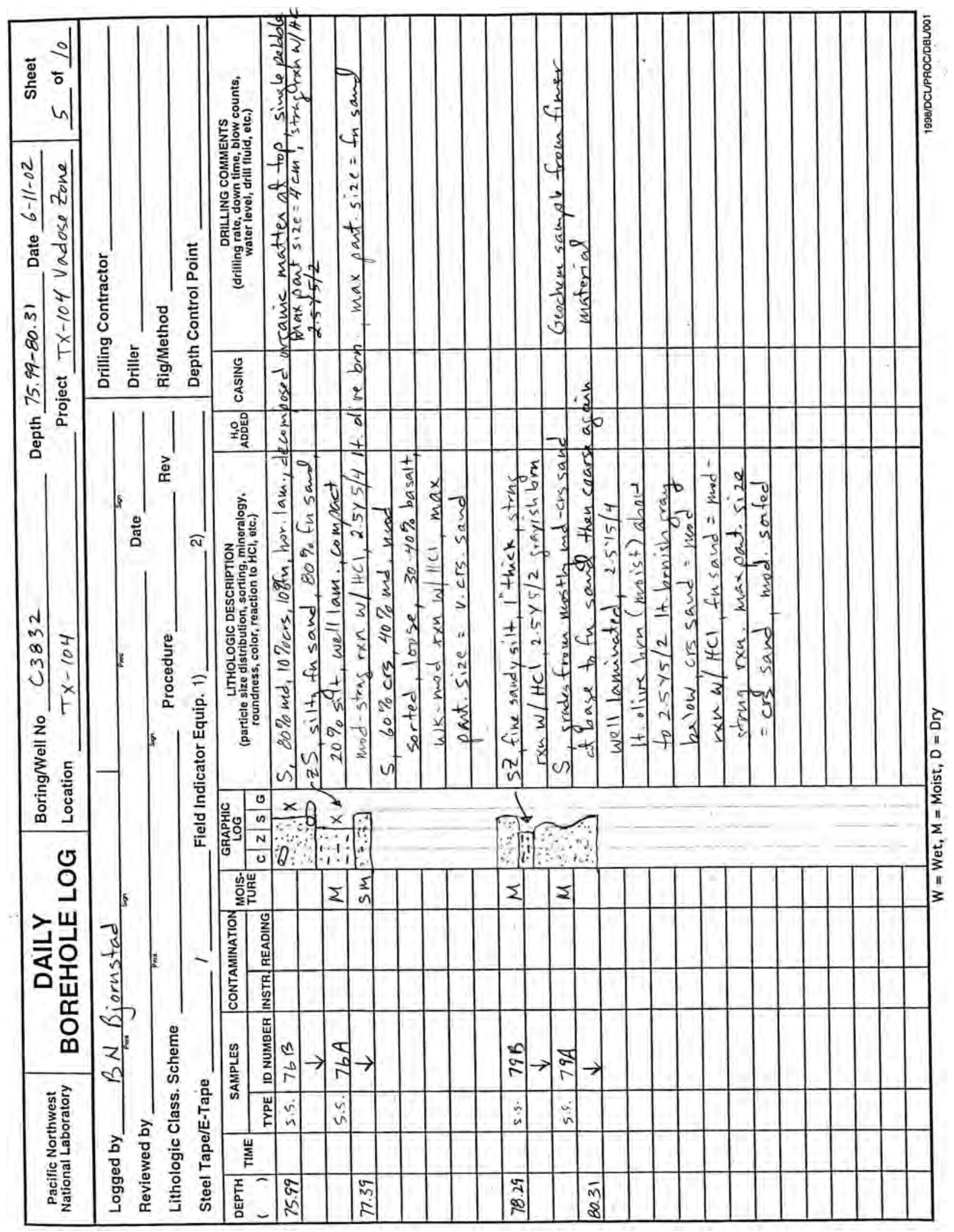




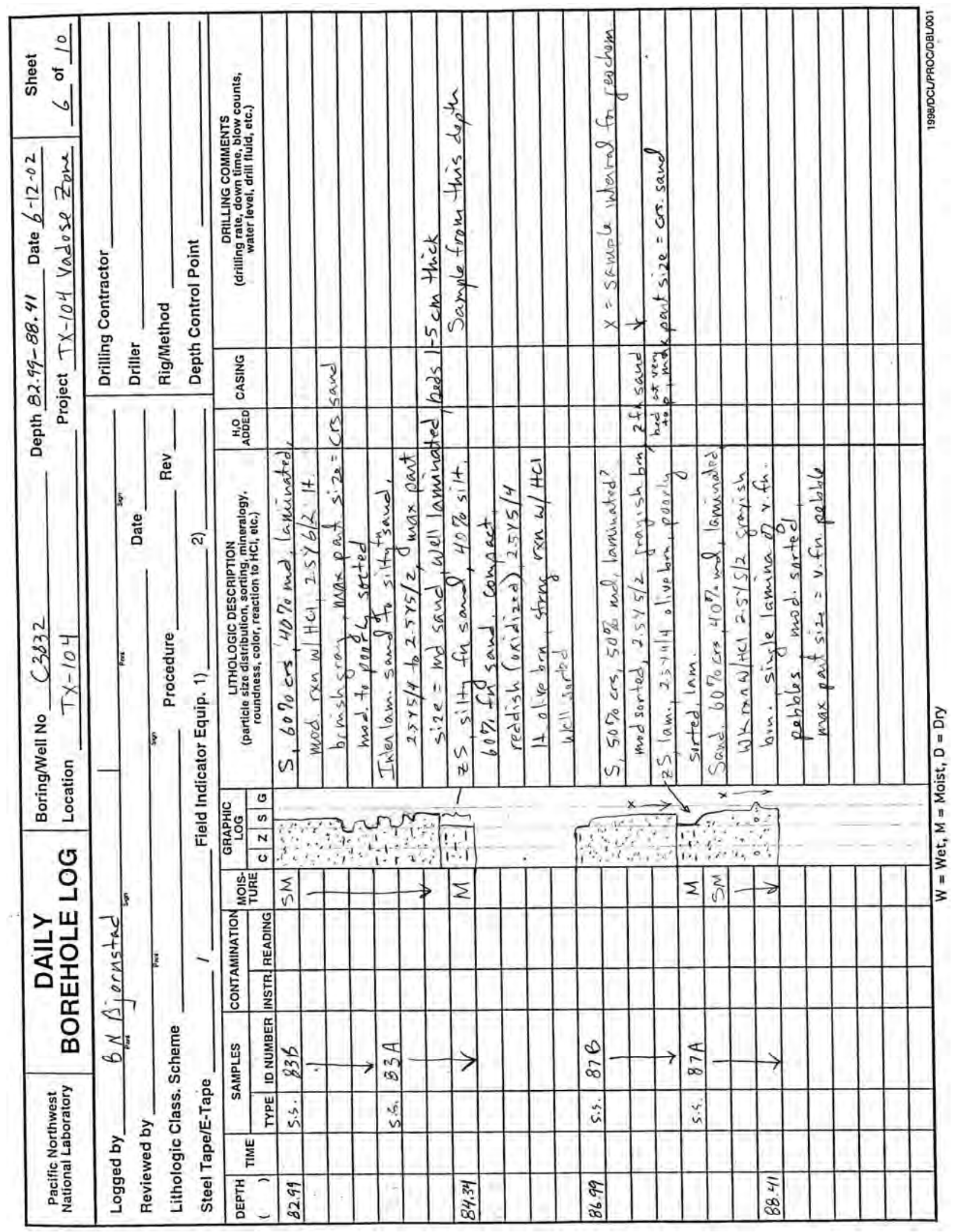




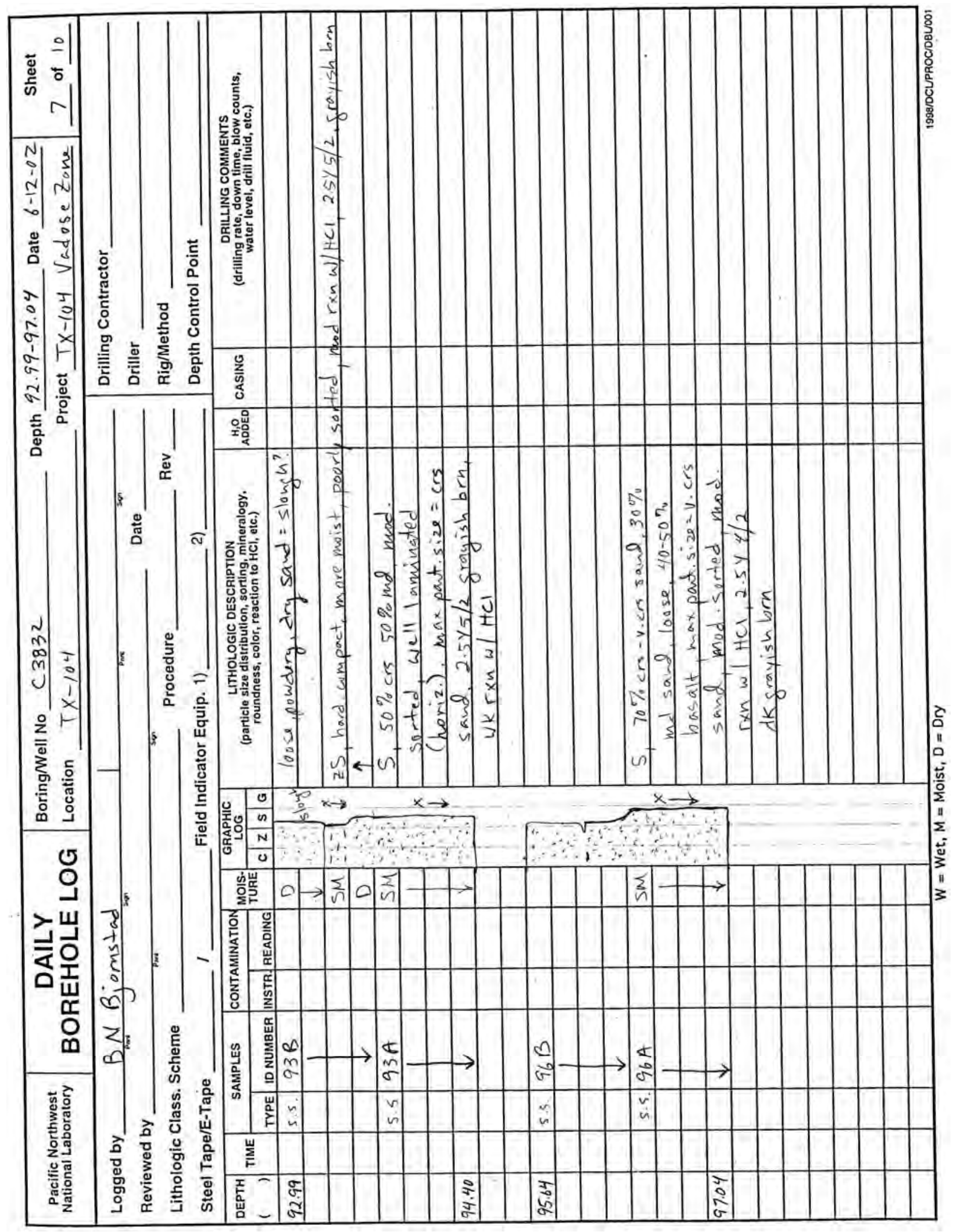




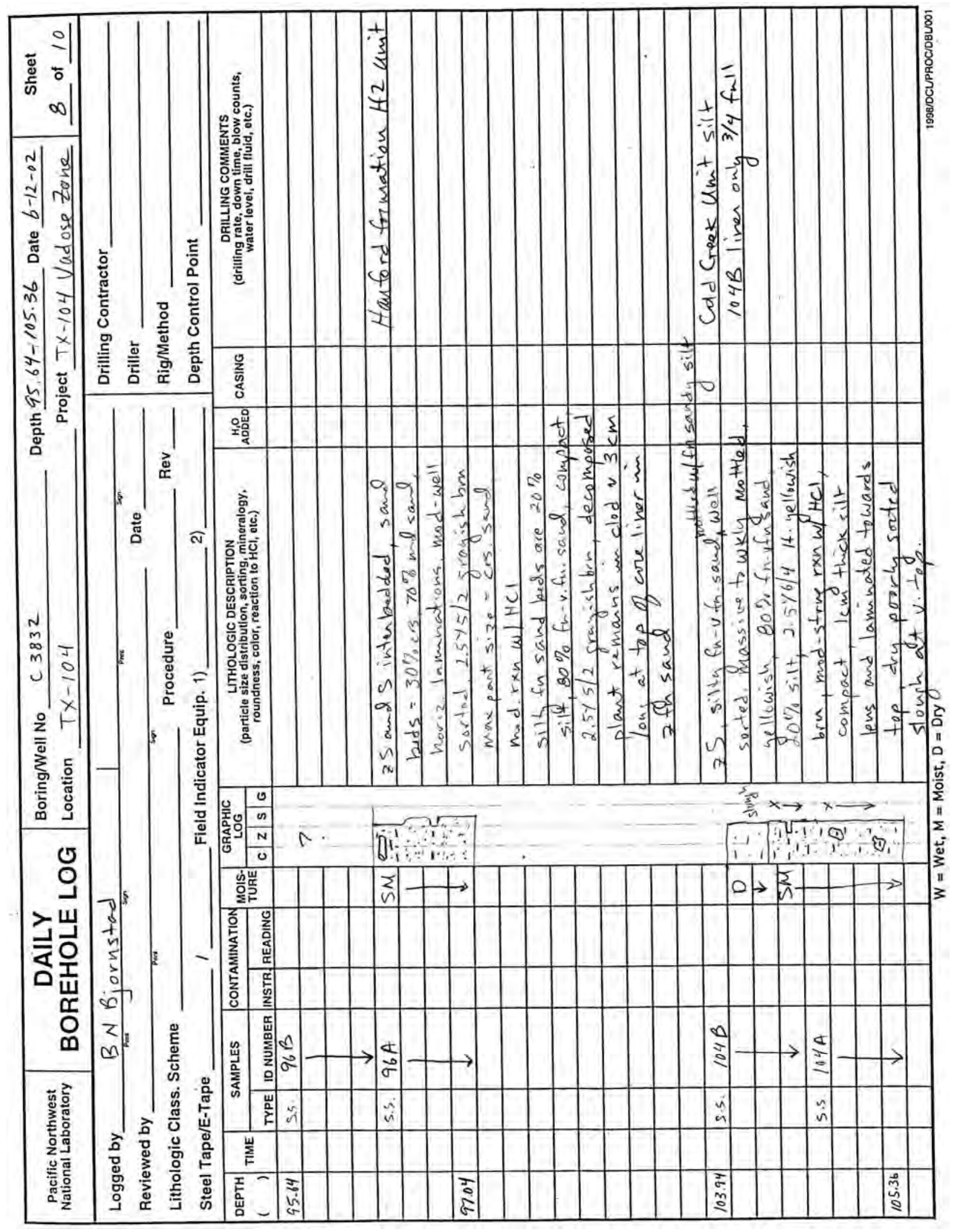




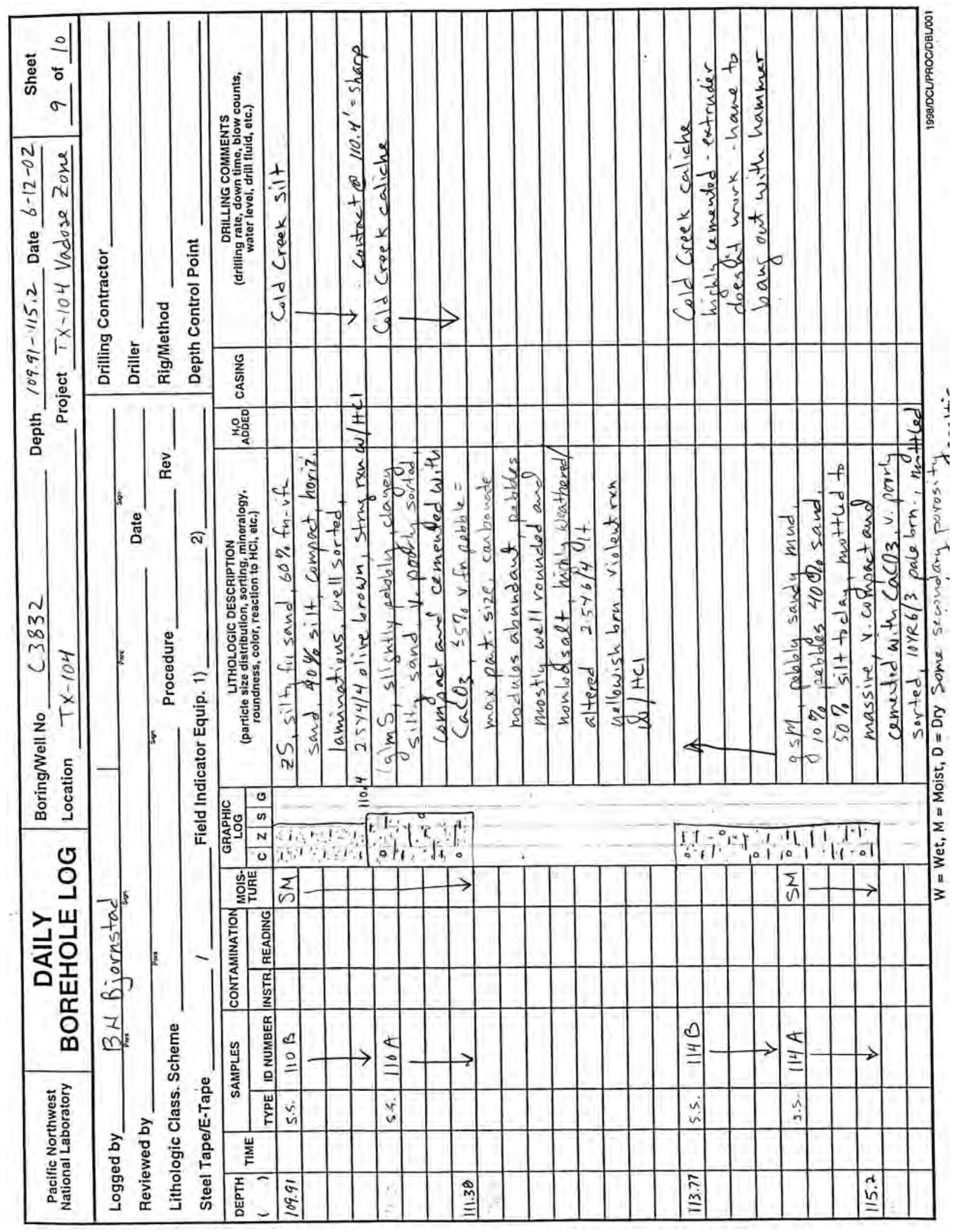




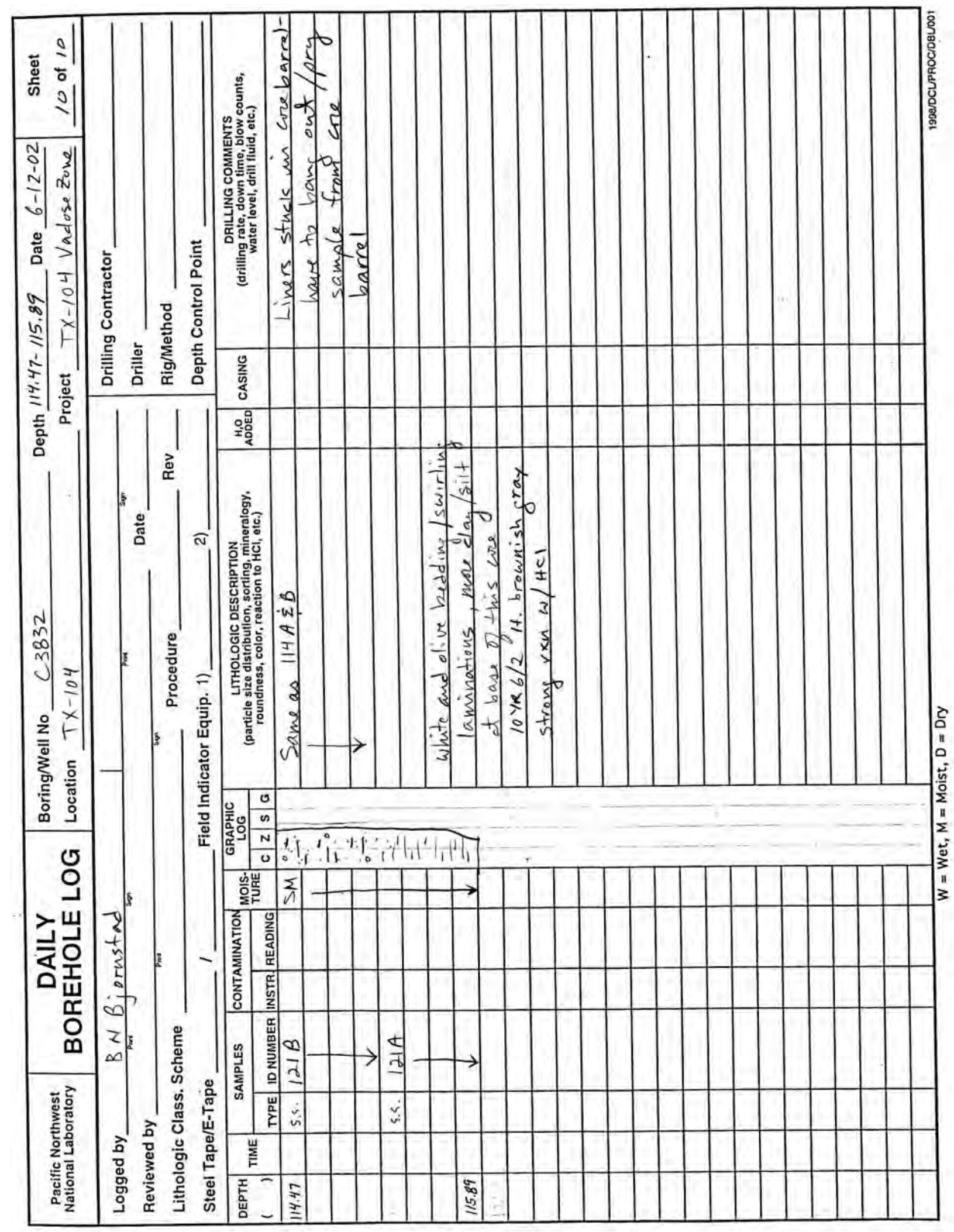


PNNL-14594

\section{Distribution}

No. of

\section{Copies}

\section{OFFSITE}

Steve Airhart

Freestone Environmental Services

1933 Jadwin Ave.

Suite 135

Richland, WA 99352

Dr. Harry Babad

2540 Cordoba Court

Richland, WA 99352-1609

Pat Brady

Geochemistry Department, 6118

Sandia National Laboratories

P.O. Box 5800

Albuquerque, New Mexico 87185-0750

Charles R. Bryan

Sandia National Laboratories

4100 National Parks Highway

Carlsbad, N.M. 88220

Susan Carroll

Lawrence Livermore National Laboratory

Mail Stop L-219

Livermore, CA 94550

John N. Christensen

Center for Isotope Geochemistry

Lawrence Berkeley National Laboratory

1 Cyclotron Road Bldg, Mail Stop 70A4418

Berkeley, CA 94720-8179

Jon Chorover

Associate Professor - Environmental

Chemistry

Department of Soil, Water and

Environmental Science

Shantz 429, Building \#38

University of Arizona

Tucson, AZ 85721-0038
No. of

Copies

Dave G. Coles

Coles Environmental Consulting

750 South Rosemont Rd

West Linn, OR 97068

Mark Conrad

Department of Earth and Planetary Sciences

University of California Berkeley

Berkeley, CA 94720

Dr. James A. Davis

U.S. Geological Survey

MS-465

345 Middlefield Rd.

Menlo Park, CA 94025

Donald J. DePaolo

Geology \& Geophysics Dept., MC4767

University of California

Berkeley, CA 94720-4767

Dirk A. Dunning

Oregon Office of Energy

625 Mariona St. N. E.

Salem, OR 97301-3742

Mark Ewanic

MSE Technology Applications, Inc.

200 Technology Way

Butte, MT 59701

Markus Flury

Department of Crop and Soil Sciences

Washington State University

Pullman, WA 99164

Amy P. Gamerdinger

2122 E. Hawthorne

Tucson, AZ 85719

Distr.1 
No. of

\section{Copies}

Jim Harsh

Department of Crop \& Soil Sciences

Washington State University

Johnson Hall - Room 249

Pullman WA 99164-6420

Victoria Johnson

Kennedy/Jenks Consultants, Inc. 1020 N. Center Parkway, Suite F

Kennewick, WA 99336

Dr. Cliff Johnston

Soil Chemistry and Mineralogy

1150 Lily Hall

Purdue University

West Lafayette, IN 47907-1150

Dr. Daniel I. Kaplan

Westinghouse Savannah River Company

Bldg. 774-43A, Rm 215

Aiken, SC 29808

Dr. Peter C. Lichtner

Los Alamos Natl. Lab

P.O. Box 1663

Los Alamos, NM 87545

Kevin A. Lindsey

Kennedy / Jenks Consultants, Inc. 1020 N. Center Parkway, Suite F

Kennewick, WA 99336

Patrick Longmire

Los Alamos National Laboratory

Mail Stop J534

P.O. Box 1663

Los Alamos, NM 87545

Kate Maher

The Center for Isotope Geochemistry

301 McCone Hall

University of California, Berkeley

Berkeley, CA 94702-4746
No. of

$\underline{\text { Copies }}$

John M. Matuszek

82 McGuffey Lane

Delmar, NY 12054

Melanie A. Mayes

Environmental Sciences Division

Oak Ridge National Laboratory

P.O. Box 2008

[Bethel Valley Road for FedEX/UPS

delivery]

Oak Ridge, TN 37831-6038

Jean Moran

Isotopic Tracers and Transport Group

Analytical and Nuclear Chemistry Division

Lawrence Livermore National Laboratory

L-231, P.O. Box 808

Livermore, CA 94550

Dr. Kathryn L. Nagy

Department of Earth and Environmental

Sciences

University of Illinois at Chicago (MC-186)

845 West Taylor Street

Chicago, IL 60607-7059

Heino Nitsche

Director, Center for Advanced

Environmental and Nuclear Studies

Lawrence Berkeley National Laboratory

1 Cyclotron Road

MS 70A-1150

Berkeley, CA 94720

Phil Reed

U.S. Nuclear Regulatory Commission Office of Nuclear Regulatory Research

Division of Systems Analysis and

Regulatory Effectiveness

Radiation Protection, Env. Risk and Waste Management Branch

Mail Stop: T9-F31

Washington, DC 20555-0001

Distr. 2 
PNNL-14594

No. of

Copies

Richard J. Reeder

Dept. of Geosciences

State University of New York at

Stony Brook

Stony Brook, NY 11794-2100

Al Robinson

68705, E 715 PRNE

Richland WA, 99352

Phil Rogers

13 Mountain Oak

Littleton, CO 80127

Sherry D. Samson

Research Assistant Professor

Department of Earth and

Environmental Sciences

University of Illinois at Chicago (MC186)

845 W. Taylor St.

Chicago, IL 60607-7059

Dawn A. Shaughnessy

Glenn T. Seaborg Center

Lawrence Berkeley National Laboratory

1 Cyclotron Road

MS 70A-1150

Berkeley, CA 94720

Doug Sherwood

Rivers Edge Environmental

1616 Riverside Drive

West Richland, WA 99353

David K. Shuh

Lawrence Berkeley National Lab

1 Cyclotron Road

Mail Stop 70A-1150

Berkeley, CA 94720

James "Buck" Sisson

Idaho National Engineering and

Environmental Laboratory

P.O. Box 1625, MS-2107

Idaho Falls, ID 83415-2107
No. of

Copies

Robert W. Smith, Ph.D.

Professor of Subsurface Science

Adjunct Professor of Geological Sciences

University of Idaho at Idaho Falls

1776 Science Center Drive

Idaho Falls, ID 83402

Stan Sobczyk

242 N. Laurel St.

Genesee, ID 83832-9760

Carl I. Steefel

Earth Sciences Division

Lawrence Berkeley National Laboratory

1 Cyclotron Road, Mail Stop 90R1116

Berkeley, CA 94720

Dr. Samuel J. Traina, Director

Sierra Nevada Research Institute

University of California, Merced

P.O. Box 2039

Merced, CA 95344

Dr. T. T. Chuck Vandergraaf

P.O. Box 857

Pinawa, Manitoba ROE 1LO

Canada

Dr. Jiamin Wan

Lawrence Berkeley National Laboratory

1 Cyclotron Rd. MS 70-0127A

Berkeley, CA 94720

Mr. Ronald G. Wilhelm

Office of Radiation and Indoor Air

401 M Street, S.W.,

Mail Code 6603J

Washington, D.C. 20460

W. Alexander Williams

U.S. Department of Energy

Office of Environmental Restoration

EM-33

19901 Germantown Road

Germantown, MD 20874-1290

Distr.3 
No. of

Copies

\section{ONSITE}

4 DOE Office of River Protection

P. E. LaMont

H6-60

R. W. Lober

S. A. Wiegman

R. B. Yasek

8 DOE Richland Operations Office

B. L. Foley

J. P. Hanson

R. D. Hildebrand

K. A. Kapsi

J. G. Morse

K. M. Thompson

DOE Public Reading Room (2)

Bechtel Hanford, Inc.

K. R. Fecht

H0-02

22 CH2M HILL Hanford Group, Inc.
A. Amonette
Technical Writer's Ink
F. J. Anderson
R. Calmus
M. P. Connelly
J.G. Field
T. E. Jones (2)
A. J. Knepp
S. L. Lambert
Lambert Engineering
J. E. Laurenz
F. M. Mann (5)
W. J. McMahon
C. W. Miller
D. A. Myers (3)
G. Parsons
T. L. Sams
E6-35
E6-35
H6-05
E6-35
H6-62
E6-35
H6-60
E6-35
H6-62
E6-35
E6-35
H6-35
E6-35
H6-19
H6-05

H6-60

H6-60

A6-38

A5-13

A6-38

A5-13

A6-38

A6-38

H2-53
No. of

Copies

3 Duratek Federal Services, Inc., Northwest Operations
M. G. Gardner
H1-11
K. D. Reynolds
H1-11
D. E. Skoglie
H1-11

6 Fluor Hanford, Inc.

M. W. Benecke E6-35

T. W. Fogwell E6-35

B. H. Ford E6-35

J. G. Hogan H1-11

V. G. Johnson E6-35

M. I. Wood H8-44

N. Ceto

B5-01

D. A. Faulk

E6-17

E6-17

\section{Pacific Northwest National Laboratory}

S. R. Baum

P7-22

B. N. Bjornstad (3)

K6-81

T. M. Brouns

K9-69

C. F. Brown

P7-22

R. W. Bryce

E6-35

K. J. Cantrell

K6-81

R.. E. Clayton

P7-22

W. J. Deutsch

K6-81

P. E. Dresel

K6-96

K. M. Geisler

P7-22

M. J. Fayer

K9-33

A. R. Felmy

K8-96

V. L. Freedman

K9-36

M. D. Freshley

K9-33

J. S. Fruchter

K6-96

G. W. Gee

K9-33

D. G. Horton (3)

K6-81

Distr.4 
No. of

Copies
J. P. Icenhour
C. T. Kincaid
K. M. Krupka
I. V. Kutnyakov
G. V. Last (2)
V. L. LeGore
M. J. Lindberg
C. W. Lindenmeier (2)
W. J. Martin
S. V. Mattigod
B. P. McGrail
P. D. Meyer
C. J. Murray
S. M. Narbutovskih
R. D. Orr
E. M. Pierce
Nik Qafoku
S. P. Reidel
R. J. Serne (20)
H. T. Schaef
W. Um

No. of

Copies

K6-81

E6-35

K6-81

P7-22

K6-81

P7-22

P7-22

P7-22

K6-81

K6-81

K6-81

BPO

K6-81

K6-96

K6-81

K6-81

K3-61

K6-81

P7-22

K6-81

P7-22
M. Valenta

P7-22

T. S. Vickerman

P7-22

A. L. Ward

K9-33

B. A. Williams

K6-81

S. B. Yabusaki

K9-36

J. M. Zachara

K8-96

F. Zhang

Information Release Office (2)

K9-33

S.M. Stoller

R. G. McCain

B2-62

6 Washington State Department of Ecology

$\begin{array}{ll}\text { S. Dahl-Crumpler } & \text { HO-57 } \\ \text { J. A. Caggiano } & \text { HO-57 } \\ \text { F. Hodges } & \text { HO-57 } \\ \text { A. D. Huckaby } & \text { HO-57 } \\ \text { B. Rochette } & \text { HO-57 } \\ \text { J. Yokel } & \text { HO-57 }\end{array}$

